\title{
Materials and Fuels Complex Facilities Radioactive Waste Management Basis and DOE Manual 435.1-1 Compliance Tables
}

September 2011

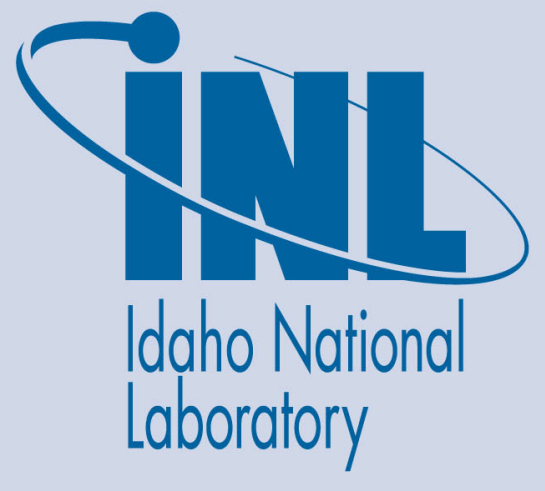

The INL is a U.S. Department of Energy National Laboratory operated by Battelle Energy Alliance 


\section{DISCLAIMER}

This information was prepared as an account of work sponsored by an agency of the U.S. Government. Neither the U.S. Government nor any agency thereof, nor any of their employees, makes any warranty, expressed or implied, or assumes any legal liability or responsibility for the accuracy, completeness, or usefulness, of any information, apparatus, product, or process disclosed, or represents that its use would not infringe privately owned rights. References herein to any specific commercial product, process, or service by trade name, trade mark, manufacturer, or otherwise, does not necessarily constitute or imply its endorsement, recommendation, or favoring by the U.S. Government or any agency thereof. The views and opinions of authors expressed herein do not necessarily state or reflect those of the U.S. Government or any agency thereof. 
INL/EXT-10-19791

Revision 2

\section{Materials and Fuels Complex Facilities Radioactive Waste Management Basis and DOE Manual 435.1-1 Compliance Tables}

September 2011

Idaho National Laboratory Idaho Falls, Idaho 83415

http://www.inl.gov

Prepared for the

U.S. Department of Energy

Office of Neclear Energy

Under DOE Idaho Operations Office

Contract DE-AC07-05ID14517 



\begin{abstract}
Department of Energy Order 435.1, "Radioactive Waste Management," along with its associated manual and guidance, requires development and maintenance of a radioactive waste management basis for each radioactive waste management facility, operation, and activity. This document presents a radioactive waste management basis for Idaho National Laboratory's Materials and Fuels Complex facilities that manage radioactive waste. The radioactive waste management basis for a facility comprises existing laboratory-wide and facility-specific documents. Department of Energy Manual 435.1-1, "Radioactive Waste Management Manual," facility compliance tables also are presented for the facilities. The tables serve as a tool for developing the radioactive waste management basis.
\end{abstract}




\section{CONTENTS}

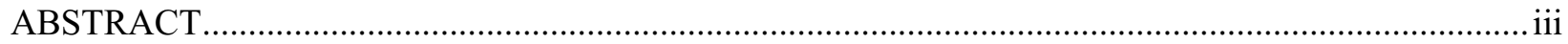

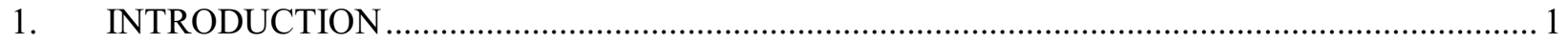

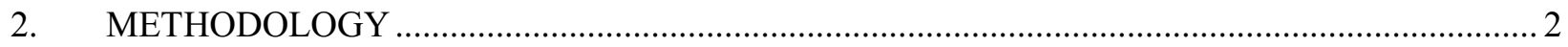

3. SCOPE

4. FACILITY RADIOACTIVE WASTE MANAGEMENT BASIS AND DOE MANUAL

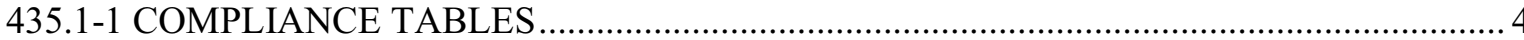

4.1 MFC-702, Plant Services Equipment Storage Building.................................................... 4

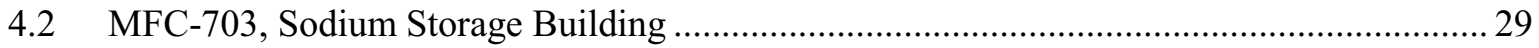

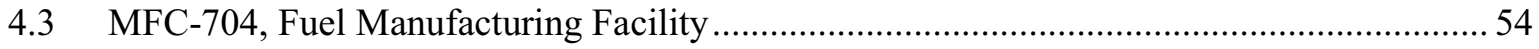

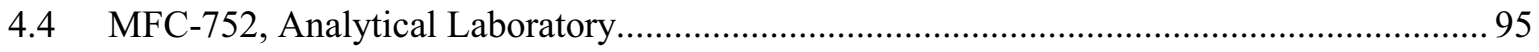

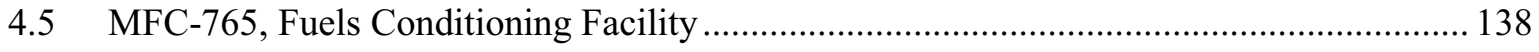

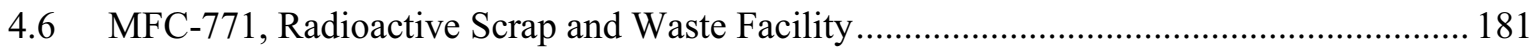

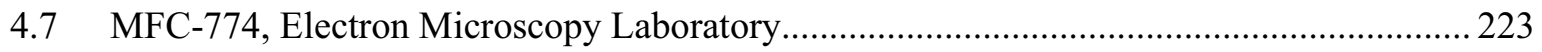

4.8 MFC-775, Zero Power Physics Reactor Workroom ..................................................... 248

4.9 MFC-784, Zero Power Physics Reactor Material Control Building .................................. 272

4.10 MFC-785, Hot Fuel Examination Facility ....................................................................... 296

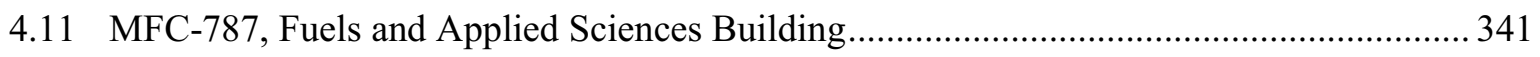

4.12 MFC-792A, Space and Security Power Systems Facility ................................................... 366

4.13 MFC-793, Sodium Components Maintenance Shop (including Metal RCRA

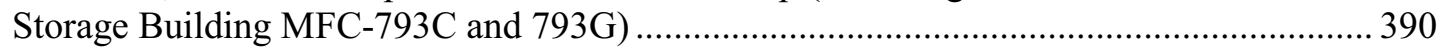

4.14 MFC-794, Contaminated Equipment Storage Building .................................................. 416

4.15 MFC-798, Radioactive Liquid Waste Treatment Facility.................................................. 441

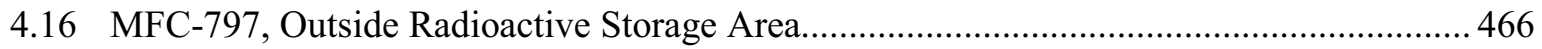

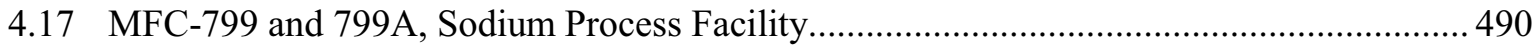

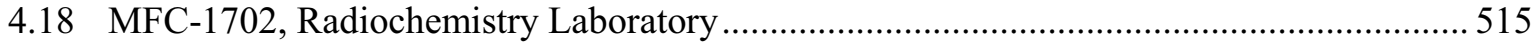

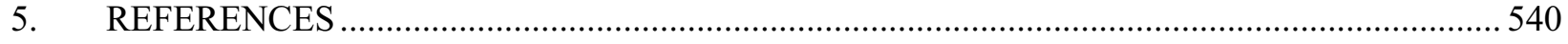




\section{TABLES}

1. MFC-702, Plant Services Equipment Storage Building, DOE Manual 435.1-1 low-level waste requirements and facility compliance information

2. MFC-703, Sodium Storage Building, DOE Manual 435.1-1 low-level waste requirements and facility compliance information

3. MFC-704, Fuel Manufacturing Facility, DOE Manual 435.1-1 transuranic waste requirements and facility compliance information .55

4. MFC-704, Fuel Manufacturing Facility, DOE Manual 435.1-1 low-level waste requirements and facility compliance information 72

5. MFC-752, Analytical Laboratory, DOE Manual 435.1-1 transuranic waste requirements and facility compliance information.....

6. MFC-752, Analytical Laboratory, DOE Manual 435.1-1 low-level waste requirements and facility compliance information.

7. MFC-765, Fuels Conditioning Facility, DOE Manual 435.1-1 transuranic waste requirements and facility compliance information

8. MFC-765, Fuels Conditioning Facility, DOE Manual 435.1-1 Low-level waste requirements and facility compliance information

9. MFC-771, Radioactive Scrap and Waste Facility, DOE Manual 435.1-1 transuranic waste requirements and facility compliance information

10. MFC-771, Radioactive Scrap and Waste Facility, DOE Manual 435.1-1 low-level waste requirements and facility compliance information

11. MFC-774, Electron Microscopy Laboratory, DOE Manual 435.1-1 low-level waste requirements and facility compliance information

12. MFC-775, Zero Power Physics Reactor Workroom, DOE Manual 435.1-1 low-level waste requirements and facility compliance information

13. MFC-784, Zero Power Physics Reactor Material Control Building, DOE Manual 435.1-1 low-level waste requirements and facility compliance information.

14. MFC-785, Hot Fuel Examination Facility, DOE Manual 435.1-1 transuranic waste requirements and facility compliance information

15. MFC-785, Hot Fuel Examination Facility, DOE Manual 435.1-1 low-level waste requirements and facility compliance information

16. MFC-787, Fuels and Applied Sciences Building, DOE Manual 435.1-1 low-level waste requirements and facility compliance information 
17. MFC-792A, Space and Security Power Systems Facility, DOE Manual 435.1-1 low-level waste requirements and facility compliance information

18. MFC-793, Sodium Components Maintenance Shop, DOE M 435.1-1 low-level waste requirements and facility compliance information

19. MFC-794, Contaminated Equipment Storage Building, DOE Manual 435.1-1 low-level waste requirements and facility compliance information.

20. MFC-798, Radioactive Liquid Waste Treatment Facility, DOE Manual 435.1-1 low-level waste requirements and Facility compliance information

21. MFC-797, Outside Radioactive Storage Area, DOE Manual 435.1-1 low-level waste requirements and facility compliance information.....

22. MFC-799 and MFC-799A, Sodium Process Facility, DOE Manual 435.1-1 low-level waste requirements and facility compliance information

23. MFC-1702, Radiochemistry Laboratory, DOE Manual 435.1-1 low-level waste requirements and facility compliance information 516 


\section{Materials and Fuels Complex Facilities Radioactive Waste Management Basis and DOE Manual 435.1-1 Compliance Tables}

\section{INTRODUCTION}

The U.S. Department of Energy (DOE) ensures that DOE radioactive waste is managed in a manner that is protective of worker and public health and the environment through DOE Order 435.1, "Radioactive Waste Management," and its associated manual (DOE Manual 435.1-1, "Radioactive Waste Management Manual") and guidance (DOE Guide 435.1-1, "Implementation Guide for Use with DOE M 435.1-1"). As required by DOE Manual 435.1-1, I.F.(2), field element managers are responsible for ensuring that a radioactive waste management basis (RWMB) is developed and maintained for each DOE radioactive waste management facility, operation, and activity. The RWMB must do the following:

- Reference or define the conditions under which the facility may operate based on the radioactive waste management documentation

- Include the applicable elements indentified in the specific waste type chapters of the manual (DOE Manual 435.1-1)

- Be developed using the graded approach process.

The specific waste type chapters of DOE Manaul 435.1-1 are high-level waste (Chapter II), transuranic (TRU) waste (Chapter III), and low-level waste (LLW) (Chapter IV). The RWMB is required to consist of "physical and administrative controls to ensure the protection of workers, the public, and the environment." For TRU waste and LLW, the RWMB is to include the following specific waste management controls:

- For generators, the waste certification program

- For treatment facilities and storage facilities, the waste acceptance requirements and the waste certification program

- For disposal facilities, the performance assessment, composite analysis, disposal authorization statement, closure plan, waste acceptance requirements, and monitoring plan.

Similar waste management controls are specified for high-level waste generators and high-level waste pretreatment, treatment, and storage facilities.

However, consistent with the graded approach provided in the DOE guidance, the required elements of the RWMB vary with the type of waste management operation or facility and the types of hazards associated with the facility. Therefore, the elements that are included in the guidance for each waste type chapter of the manual are not to be considered a complete list of elements. For example, the elements determined to be applicable to the RWMB for a facility may include the facility safety basis; authorization basis; operational procedures; radiation protection controls and procedures; waste characterization and certification plan; waste acceptance criteria; waste tracking and records management; waste storage and staging requirements; facility monitoring; quality assurance; and regulatory permits and appropriate documentation for permitted facilities.

The purpose of this document is to present a RWMB for Materials and Fuels Complex (MFC) facilities that manage radioactive waste and DOE Manual 435.1-1 facility compliance information tables for the MFC facilities. The facility RWMB comprises existing laboratory-wide and facility-specific documents. The DOE M 435.1-1 facility compliance information tables show how each facility meets the DOE Manual 435.1-1 requirement for a waste type and serve as a tool to develop the RWMB. The tables provide information that BEA and facility management officials can use to apply the graded approach 
emphasized in DOE Order 435.1 and its associated manual and guidance. This document is intended to support the summary RWMB (PLN-3654) for the facilities managing radioactive waste at MFC. The summary RWMB is to be submitted to the DOE field element manager for approval.

\section{METHODOLOGY}

The following methodology was used to prepare preliminary RWMB and facility compliance information tables for MFC:

- A kick-off meeting was held with MFC officials. At this meeting, a preliminary list of MFC facilities that should be included in this effort was verified. Based on the information obtained at this meeting, the list of facilities was revised. The MFC officials also provided the point of contact (POC) for each facility that could provide facility radioactive waste management information.

- Interviews were conducted with the primary POCs to discuss radioactive waste management procedures and programs at each facility. The interviews were conducted March 30 and April 2, 2010 .

- Based on the information received from the interviews and analysis of the procedures cited by the facility POCs and found through the Electronic Document Management System, initial draft tables describing facility-level compliance with DOE Manual 435.1-1 requirements for each facility and each waste type managed at the facility were developed.

- A series of review meetings were then conducted with the facility POCs and BEA management officials. These review meetings served as the verification of the information presented in the initial draft tables, which were based on the information obtained from the POC interviews and analysis of documents from the Electronic Document Management System. The meetings also allowed the BEA management officials to discuss and make decisions regarding the potential compliance issues identified in the tables. The BEA management officials determined areas where BEA would take further actions and also areas where further actions were not necessary (e.g., issues where the BEA management officials decided that sufficient compliance was provided by INL-wide procedures or programs). The review meetings were held between May 25 and May 28, 2010.

- The tables were revised based on the input received during the review meetings.

- For each facility, a preliminary RWMB and a list of areas requiring further BEA and facility management actions were developed based on information from the revised tables.

In developing and reviewing the compliance information and preliminary RWMB, the graded approach that DOE specifies for developing the RWMB and that is emphasized throughout the DOE Guide 435.1-1 guidance was used. The guidance also states that, when possible, existing processes, programs, and documentation should be considered as possible ways to comply with DOE Manual 435.1-1 requirements (DOE Guide 435.1-1).

Both the manual and associated guidance were considered in developing and reviewing the preliminary RWMB. DOE Manual 435.1-1 describes the requirements and establishes specific responsibilities for implementing DOE Order 435.1 for the management of DOE high-level waste, TRU waste, LLW, and the radioactive component of mixed waste. DOE Guide 435.1-1 was developed to aid in implementing DOE Manual 435.1-1 requirements. The guide aids in understanding what is necessary to attain compliance, facilitates effective and efficient implementation of the requirements, and offers acceptable ways to implement the requirements. The guide is not meant to be viewed as additional or mandatory requirements. The guide emphasizes consideration of situation-specific attributes and application of the graded approach to dictate the rigor applied to implementation (DOE Guide 435.1-1 and DOE Manual 435.1-1). 


\section{SCOPE}

The following MFC facilities were identified as managing radioactive waste and are included in this study:

- $\quad$ MFC-702, Plant Services Equipment Storage Building

- $\quad$ MFC-703, Sodium Storage Building

- $\quad$ MFC-704, Fuel Manufacturing Facility (FMF)

- MFC-752, Analytical Laboratory

- $\quad$ MFC-765, Fuels Conditioning Facility (FCF)

- $\quad$ MFC-771, Radioactive Scrap and Waste Facility (RSWF)

- $\quad$ MFC-774, Electron Microscopy Laboratory

- $\quad$ MFC-775, Zero Power Physics Reactro (ZPPR) Workroom

- $\quad$ MFC-785, Hot Fuel Examination Facility (HFEF)

- $\quad$ MFC-787, Fuels and Applied Sciences Building

- MFC-792A, Space and Security Power Systems Facility

- MFC-793, Sodium Components Maintenance Shop (including Metal Resource Conservation and Recovery Act [RCRA] Storage Building MFC-793C and 793G)

- $\quad$ MFC-794, Contaminated Equipment Storage Building

- MFC-798, Radioactive Liquid Waste Treatment Facility (RLWTF)

- MFC-797, Outside Radioactive Storage Area

- $\quad$ MFC-799 and 799A, Sodium Process Facility

- $\quad$ MFC-1702, Radiochemistry Laboratory.

The facilities below were identified prior to the kick-off meeting as facilities that manage radioactive waste. However, information obtained during the kick-off meeting held with facility representatives or during subsequent POC interviews confirmed that radioactive waste management activities are not conducted at these facilities. Therefore, compliance information tables were not developed for these facilities:

- $\quad$ MFC-720, Transient Reactor Experiment and Test (TREAT) Transient Reactor Test Facility

- MFC-721, TREAT Transient Reactor Test Facility

- MFC-723, TREAT Transient Reactor Test Facility Warehouse

- $\quad$ MFC-724, TREAT Transient Reactor Test Facility

- $\quad$ MFC-780, Laundry Sorting Building

- $\quad$ MFC-784, ZPPR - Material Control

- $\quad$ MFC-792, Space and Security Power Systems Facility

- $\quad$ MFC-774, ZPPR Counting Lab B

- MFC-NFRSA and SFRSA North Fenced Radioactive Storage Area and South Fenced Radioactive Storage Area. 


\section{FACILITY RADIOACTIVE WASTE MANAGEMENT BASIS AND DOE MANUAL 435.1-1 COMPLIANCE TABLES}

This section presents the RWMB and DOE Manual 435.1-1 compliance tables for the following MFC facilities:

- $\quad$ MFC-702, Plant Services Equipment Storage Building (Subsection 5.1)

- $\quad$ MFC-703, Sodium Storage Building (Subsection 5.2)

- $\quad$ MFC-704, FMF (Subsection 5.3)

- $\quad$ MFC-752, Analytical Laboratory (Subsection 5.4)

- $\quad$ MFC-765, FCF (Subsection 5.5)

- $\quad$ MFC-771, RSWF (Subsection 5.6)

- MFC-774, Electron Microscopy Laboratory (Subsection 5.7)

- $\quad$ MFC-775, ZPPR Workroom (Subsection 5.8)

- $\quad$ MFC-785, HFEF (Subsection 5.9)

- $\quad$ MFC-787, Fuels and Applied Sciences Building (Subsection 5.10)

- $\quad$ MFC-792A, Space and Security Power Systems Facility (Subsection 5.11)

- MFC-793, Sodium Components Maintenance Shop (including Metal RCRA Storage Building MFC-793C and 793G) (Subsection 5.12)

- $\quad$ MFC-794, Contaminated Equipment Storage Building (Subsection 5.13)

- $\quad$ MFC-798, RLWTF (Subsection 5.14)

- $\quad$ MFC-797, Outside Radioactive Storage Area (Subsection 5.15)

- $\quad$ MFC-799 and 799A, Sodium Process Facility (Subsection 5.16)

- $\quad$ MFC-1702, Radiochemistry Laboratory (Subsection 5.17).

For each MFC facility, a brief facility overview is provided. The overview includes a facility description, the facility's safety basis classification, the radioactive waste management activities and waste types for the facility, a list of the RWMB documents and programs for the facility, and a list of the compliance requirements needing further BEA management action.

The DOE Manual 435.1-1 compliance information table for each radioactive waste type managed at each MFC facility also is provided for each facility. Each table shows the DOE Manual 435.1-1 requirement, facility compliance information for each requirement, and compliance issues for consideration by INL, BEA, and facility management, as appropriate. In some cases, excerpts from the DOE Guide 435.1-1 guidance associated with the DOE Manual 435.1-1 requirement are included. These excerpts are included to provide additional context and information about the requirement. However, the complete guidance citation should be consulted for decision-making.

\subsection{MFC-702, Plant Services Equipment Storage Building}

1. Facility description: Radiologically contaminated laundry used at MFC facilities is collected in MFC-702 and readied for shipment to a commercial laundry vendor. The laundry consists primarily of used cloth coveralls and cloth hoods and may contain some used full-face respirators. The laundry is typically packaged in the facilities in double poly bags, transferred to MFC-702, and placed in a metal shipping bin. Some of the personal protective laundry is used in facilities as a precautionary 
measure during radiological work where engineered contamination controls are used. This typically ensures that the laundry does not get radiologically contaminated. In contaminated areas, the laundry is normally used as an under layer protected by a disposable coverall, such that the likelihood of contamination on the laundry is mitigated but not eliminated. This application is used most frequently in FCF and HFEF.

2. Hazard category: "Other"

3. Radioactive waste managed at this facility: Contact-handled $(\mathrm{CH}) \mathrm{LLW}$ is generated and staged in this facility subsequent to routine facility operations.

4. RWMB documents/programs:

a. Safety basis/hazard analysis:

- ECAR-789, "Hazard Categorization of the Materials and Fuels Complex Laundry Facility MFC-702"

- EDF-7234, "Evaluation of Source Terms in MFC-Building 702"

b. Laboratory-wide:

- Form 441.A34, "INL Radiological Control Required Surveys"

- LI-435, "Waste Management Routine Field Activities"

- LRD-15001, "Radiological Control Manual"

- LWP-13840, "Management of Issues, Observations, and Noteworthy Practices"

- LWP-14002, "Timeout and Stop Work Authority"

- LWP-15011, "Radioactive Material Areas and Radioactive Storage Areas"

- LWP-17000, "Waste Management"

- MCP-139, "Radiological Surveys"

- MCP-17000, "Waste Generator Services Waste Management"

- MCP-17500, "Waste Generator Services Certification of Waste Shipments to the Nevada Test Site"

- PDD-17000, "Waste Management Program"

- PLN-114, "INL Emergency Plan/RCRA Contingency Plan"

- PLN-522, "Quality Assurance Program Plan for the Waste Management/Waste Certification Program"

c. Facility-specific:

- AWP-2.13, "Radiological Material Inventory Control and Facility Hazard Categorization"

- TSD-OI-004, "Waste and Material Acceptance for Storage/Treatment and Radioactive Material Inventory Control."

LLW is managed at this facility. Table 1 presents the facility compliance information for Chapter IV, "Low-level Waste Requirements."

Table 1. MFC-702, Plant Services Equipment Storage Building, DOE Manual 435.1-1 low-level waste requirements and facility compliance information.

\begin{tabular}{|c|c|}
\hline \multicolumn{2}{|c|}{ MFC-702, Plant Services Equipment Storage Building } \\
\hline Chapter IV, LLW Requirements & Facility Compliance Information \\
\hline A. Definition of Low-Level Waste. Low-level & This requirement provides the criteria for determining \\
\hline
\end{tabular}


Table 1. (continued).

\begin{tabular}{|c|c|}
\hline \multicolumn{2}{|c|}{ MFC-702, Plant Services Equipment Storage Building } \\
\hline Chapter IV, LLW Requirements & Facility Compliance Information \\
\hline $\begin{array}{l}\text { radioactive waste is radioactive waste that is not high- } \\
\text { level radioactive waste, spent nuclear fuel, transuranic } \\
\text { waste, byproduct material (as defined in section 11e.(2) } \\
\text { of the Atomic Energy Act of 1954, as amended), or } \\
\text { naturally occurring radioactive material. } \\
\text { (From DOE G } 435.1-1 \text { Chapter IV: Low-level } \\
\text { radioactive waste is defined by what it is not. The } \\
\text { guidance on definitions in Chapters II and III should be } \\
\text { consulted first for making a determination on how to } \\
\text { properly manage a suspect waste stream.) }\end{array}$ & $\begin{array}{l}\text { which DOE radioactive waste is to be managed as LLW } \\
\text { in accordance with DOE Manual } 435.1-1 \text {, Chapter IV. } \\
\text { Radioactive waste managed at this facility under the } \\
\text { requirements of this chapter is not managed under the } \\
\text { requirements of DOE Manual } 435.1-1 \text {, Chapter II or } \\
\text { Chapter III. }\end{array}$ \\
\hline $\begin{array}{l}\text { B. Management of Specific Wastes. The following } \\
\text { provide for management of specific wastes as low-level } \\
\text { waste in accordance with the requirements in this } \\
\text { Chapter: }\end{array}$ & See (1), (2), (3), and (4) below. \\
\hline $\begin{array}{l}\text { (1) Mixed Low-Level Waste. Low-level waste } \\
\text { determined to contain both source, special nuclear, or } \\
\text { byproduct material subject to the Atomic Energy Act of } \\
1954 \text {, as amended, and a hazardous component subject } \\
\text { to the Resource Conservation and Recovery Act } \\
\text { (RCRA), as amended, shall be managed in accordance } \\
\text { with the requirements of RCRA and DOE O 435.1, } \\
\text { Radioactive Waste Management, and this Manual. }\end{array}$ & $\begin{array}{l}\text { Not applicable (NA); this facility does not manage } \\
\text { RCRA-regulated mixed LLW. }\end{array}$ \\
\hline $\begin{array}{l}\text { (2) TSCA-Regulated Waste. Low-level waste } \\
\text { containing polychlorinated biphenyls, asbestos, or } \\
\text { other such regulated toxic components shall be } \\
\text { managed in accordance with requirements derived from } \\
\text { the Toxic Substances Control Act, as amended, DOE O } \\
\text { 435.1, Radioactive Waste Management, and this } \\
\text { Manual. }\end{array}$ & $\begin{array}{l}\text { NA; this facility does not manage TSCA-regulated } \\
\text { waste. }\end{array}$ \\
\hline $\begin{array}{l}\text { (3) Accelerator-Produced Waste. Radioactive waste } \\
\text { produced as a result of operations of DOE accelerators } \\
\text { is low-level waste and shall be managed in accordance } \\
\text { with DOE O } 435.1 \text {, Radioactive Waste Management, } \\
\text { and this Manual, and all applicable Federal or State } \\
\text { requirements. }\end{array}$ & $\begin{array}{l}\text { NA; this facility does not manage accelerator-produced } \\
\text { waste. }\end{array}$ \\
\hline $\begin{array}{l}\text { (4) 11e.(2) and Naturally Occurring Radioactive } \\
\text { Material. Small quantities of } 11 \text { e.(2) byproduct } \\
\text { material and naturally occurring radioactive material } \\
\text { may be managed as low-level waste provided they can } \\
\text { be managed to meet the requirements for low-level } \\
\text { waste disposal in Section IV.P of this Manual. }\end{array}$ & $\begin{array}{l}\text { NA; this facility does not manage naturally occurring } \\
\text { radioactive material. }\end{array}$ \\
\hline $\begin{array}{l}\text { C. Complex-Wide Low-Level Waste Management } \\
\text { Program. A complex-wide program and plan shall be } \\
\text { developed as described under Responsibilities, 2.B and } \\
\text { 2.D, in Chapter I of this Manual. }\end{array}$ & $\begin{array}{l}\text { DOE Manual } 435.1-1 \text { §I.2.B and §I.2.D apply to the } \\
\text { Assistant Secretary for Environmental Management and } \\
\text { the Deputy Assistant Secretary for Waste Management, } \\
\text { respectively. }\end{array}$ \\
\hline $\begin{array}{l}\text { D. Radioactive Waste Management Basis. Low-level } \\
\text { waste facilities, operations, and activities shall have a }\end{array}$ & $\begin{array}{l}\text { The RWMB provides the regulatory framework for } \\
\text { management of radioactive waste at INL. It specifically }\end{array}$ \\
\hline
\end{tabular}


Table 1. (continued).

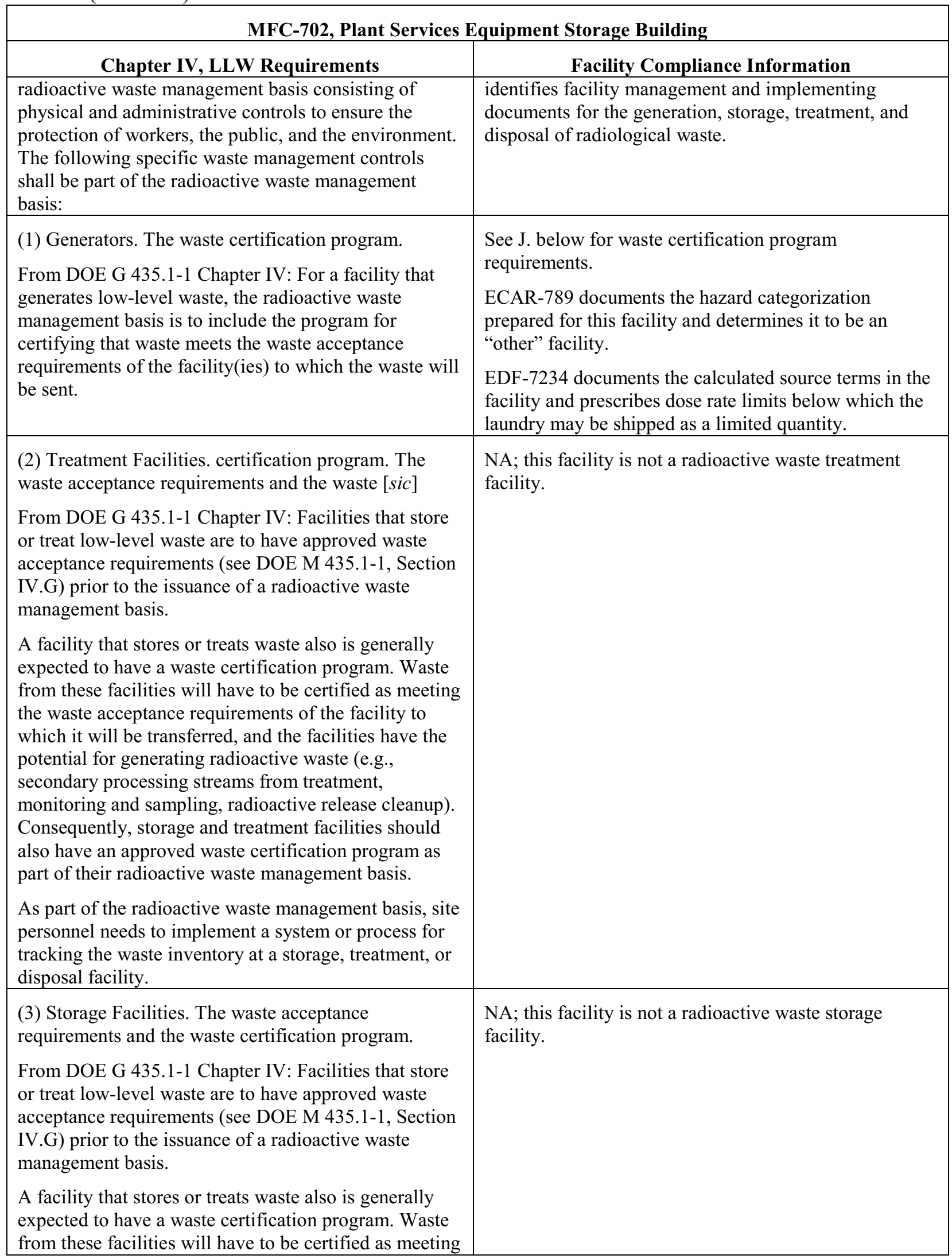


Table 1. (continued).

\begin{tabular}{|c|c|}
\hline \multicolumn{2}{|c|}{ MFC-702, Plant Services Equipment Storage Building } \\
\hline Chapter IV, LLW Requirements & Facility Compliance Information \\
\hline $\begin{array}{l}\text { the waste acceptance requirements of the facility to } \\
\text { which it will be transferred, and the facilities have the } \\
\text { potential for generating radioactive waste (e.g., } \\
\text { secondary processing streams from treatment, } \\
\text { monitoring and sampling, radioactive release cleanup). } \\
\text { Consequently, storage and treatment facilities should } \\
\text { also have an approved waste certification program as } \\
\text { part of their radioactive waste management basis. }\end{array}$ & \\
\hline $\begin{array}{l}\text { As part of the radioactive waste management basis, site } \\
\text { personnel needs to implement a system or process for } \\
\text { tracking the waste inventory at a storage, treatment, or } \\
\text { disposal facility. }\end{array}$ & \\
\hline $\begin{array}{l}\text { (4) Disposal Facilities. The performance assessment, } \\
\text { composite analysis, disposal authorization statement, } \\
\text { closure plan, waste acceptance requirements, and } \\
\text { monitoring plan. }\end{array}$ & $\begin{array}{l}\mathrm{NA} \text {; this facility is not a radioactive waste disposal } \\
\text { facility. }\end{array}$ \\
\hline $\begin{array}{l}\text { E. Contingency Actions. The following requirements } \\
\text { are in addition to those in Chapter I of this Manual } \\
\text { [DOE M 435.1-1 §I.1.E(5)]. }\end{array}$ & $\begin{array}{l}\text { DOE Manual } 435.1-1 \S \mathrm{I} .1 . \mathrm{E}(5) \text { addresses the sitewide } \\
\text { emergency management system. The INL plan is } \\
\text { provided in PLN-114. }\end{array}$ \\
\hline $\begin{array}{l}\text { (1) Contingency Storage. For off-normal or emergency } \\
\text { situations involving high activity or high hazard liquid } \\
\text { low-level waste storage or treatment, spare capacity } \\
\text { with adequate capabilities shall be maintained to } \\
\text { receive the largest volume of liquid contained in any } \\
\text { one storage tank or treatment facility. Tanks or other } \\
\text { facilities that are designated low-level waste } \\
\text { contingency storage shall be maintained in an } \\
\text { operational condition when waste is present and shall } \\
\text { meet the requirements of DOE O } 435.1 \text {, Radioactive } \\
\text { Waste Management, and this Manual. }\end{array}$ & NA; this facility does not store liquid LLW. \\
\hline $\begin{array}{l}\text { From DOE G } 435.1-1 \text { Chapter IV: Compliance with } \\
\text { these requirements is demonstrated if adequate spare } \\
\text { capacity and transfer equipment exists for emergency } \\
\text { transfers of all high activity and high hazard liquid } \\
\text { low-level waste. In addition, the capability to perform } \\
\text { emergency transfers is demonstrated by having waste } \\
\text { transfer routings identified, operational procedures to } \\
\text { direct transfers, staff trained to the procedures, and } \\
\text { records showing that the spare capacity and transfer } \\
\text { capability are kept in operating condition. }\end{array}$ & \\
\hline $\begin{array}{l}\text { (2) Transfer Equipment. Pipelines and auxiliary } \\
\text { facilities necessary for the transfer of high activity or } \\
\text { high hazard liquid low-level waste to contingency } \\
\text { storage shall be maintained in an operational condition } \\
\text { when waste is present and shall meet the requirements } \\
\text { of DOE O 435.1, Radioactive Waste Management, and } \\
\text { this Manual. }\end{array}$ & NA; this facility does not transfer LLW. \\
\hline From DOE G 435.1-1 Chapter IV: Compliance with & \\
\hline
\end{tabular}


Table 1. (continued).

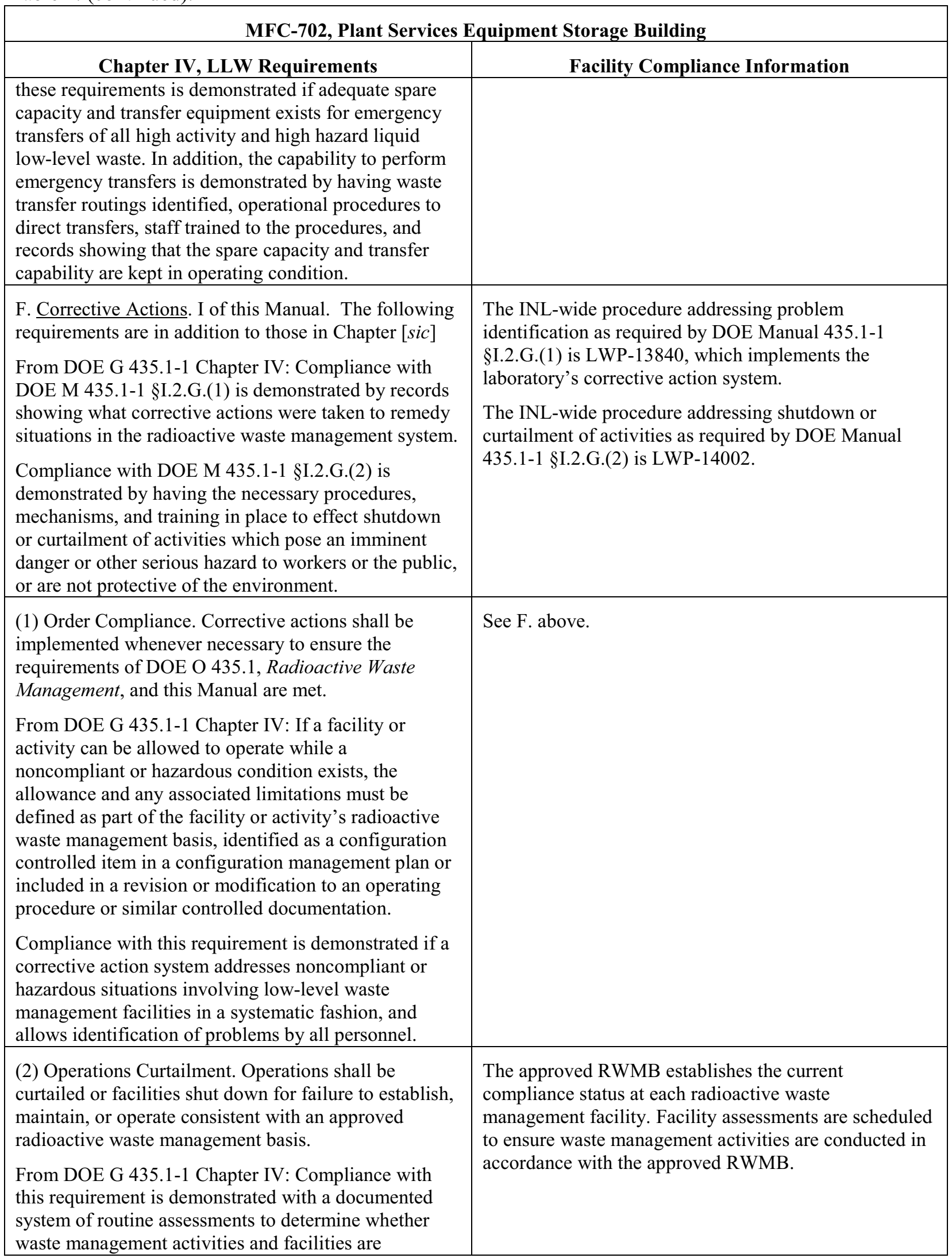


Table 1. (continued).

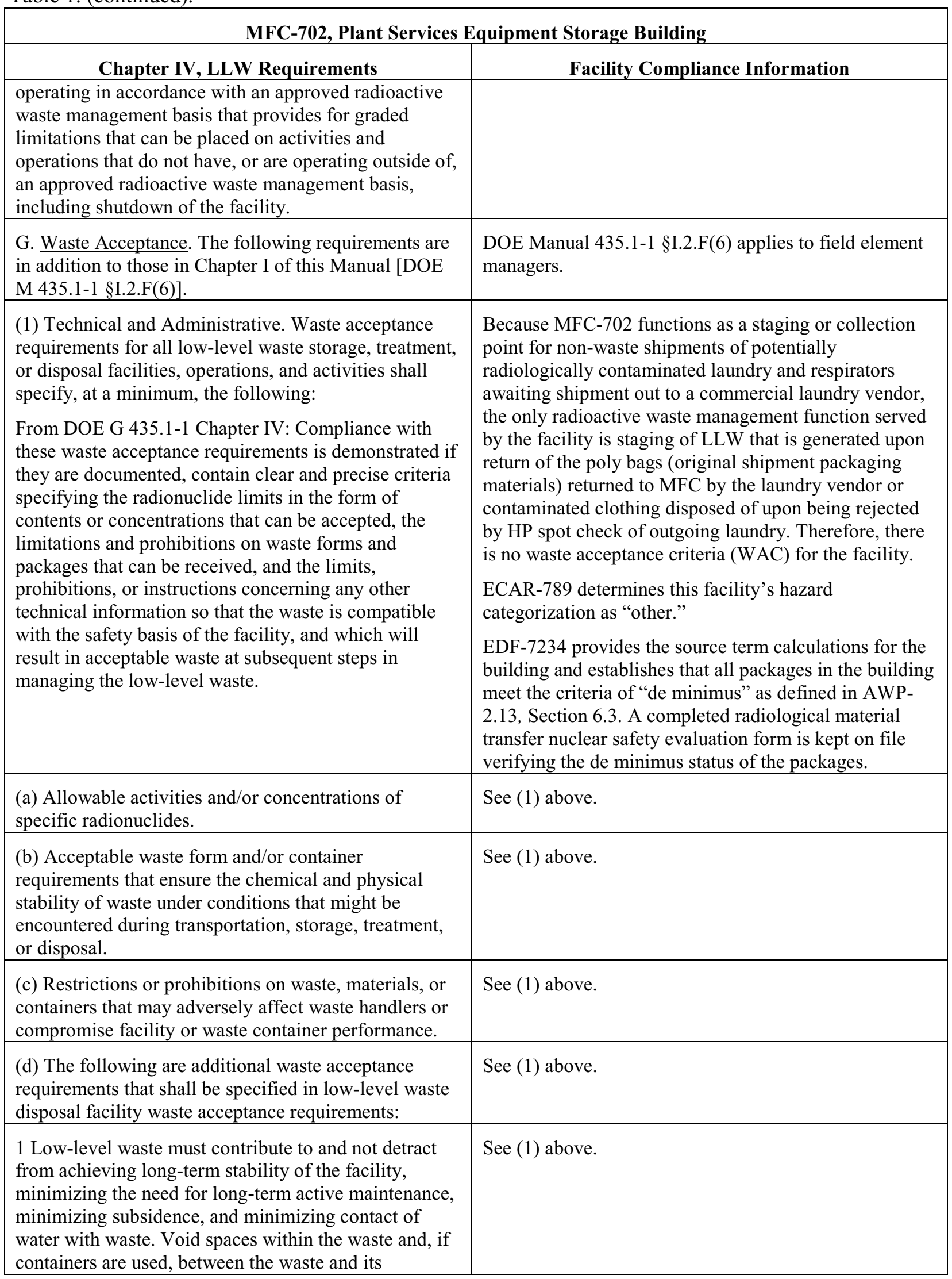


Table 1. (continued).

\begin{tabular}{|c|c|}
\hline \multicolumn{2}{|c|}{ MFC-702, Plant Services Equipment Storage Building } \\
\hline Chapter IV, LLW Requirements & Facility Compliance Information \\
\hline container shall be reduced to the extent practical. & \\
\hline $\begin{array}{l}2 \text { Liquid low-level waste or low-level waste containing } \\
\text { free liquid must be converted into a form that contains } \\
\text { as little freestanding liquid as is reasonably achievable, } \\
\text { but in no case shall the liquid exceed } 1 \text { percent of the } \\
\text { waste volume when the low-level waste is in a disposal } \\
\text { container, or } 0.5 \text { percent of the waste volume after it is } \\
\text { processed to a stable form. }\end{array}$ & See (1) above. \\
\hline $\begin{array}{l}3 \text { Low-level waste must not be readily capable of } \\
\text { detonation or of explosive decomposition or reaction at } \\
\text { anticipated pressures and temperatures, or of explosive } \\
\text { reaction with water. Pyrophoric materials contained in } \\
\text { waste shall be treated, prepared, and packaged to be } \\
\text { nonflammable. }\end{array}$ & See (1) above. \\
\hline $\begin{array}{l}4 \text { Low-level waste must not contain, or be capable of } \\
\text { generating by radiolysis or biodegradation, quantities } \\
\text { of toxic gases, vapors, or fumes harmful to the public } \\
\text { or workers or disposal facility personnel, or harmful to } \\
\text { the long-term structural stability of the disposal site. }\end{array}$ & See (1) above. \\
\hline $\begin{array}{l}5 \text { Low-level waste in a gaseous form must be packaged } \\
\text { such that the pressure does not exceed } 1.5 \text { atmospheres } \\
\text { absolute at } 20 \text { C. [ sic }]\end{array}$ & See (1) above. \\
\hline $\begin{array}{l}\text { (e) The basis, procedures, and levels of authority } \\
\text { required for granting exceptions to the waste } \\
\text { acceptance requirements, which shall be contained in } \\
\text { each facility's waste acceptance documentation. Each } \\
\text { exception request shall be documented, including its } \\
\text { disposition as approved or not approved. }\end{array}$ & See (1) above. \\
\hline $\begin{array}{l}\text { From DOE G } 435.1-1 \text { Chapter IV: Waste acceptance } \\
\text { requirements are acceptable if they are documented and } \\
\text { contain a clear description of the procedure and bases } \\
\text { for obtaining an exception or deviation to the } \\
\text { acceptance criteria for low-level waste to be received at } \\
\text { the facility. }\end{array}$ & \\
\hline $\begin{array}{l}\text { (2) Evaluation and Acceptance. The receiving facility } \\
\text { shall evaluate waste for acceptance, including } \\
\text { confirmation that the technical and administrative } \\
\text { requirements have been met. A process for the } \\
\text { disposition of non-conforming wastes shall be } \\
\text { established. }\end{array}$ & See (1) above. \\
\hline $\begin{array}{l}\text { From DOE G 435.1-1 Chapter IV: Compliance with } \\
\text { the waste acceptance requirements for a low-level } \\
\text { waste management facility is demonstrated if they } \\
\text { include a process for evaluation and acceptance of } \\
\text { incoming waste to ensure the acceptance criteria of the } \\
\text { facility receiving the waste are met that includes one of } \\
\text { or a combination of: (1) testing, sampling, and analysis }\end{array}$ & \\
\hline
\end{tabular}


Table 1. (continued).

\begin{tabular}{|c|c|}
\hline \multicolumn{2}{|c|}{ MFC-702, Plant Services Equipment Storage Building } \\
\hline Chapter IV, LLW Requirements & Facility Compliance Information \\
\hline $\begin{array}{l}\text { of representative samples of waste upon receipt; (2) } \\
\text { testing, sampling, and analysis of split samples of } \\
\text { waste taken at the generator site; ( } 3 \text { ) evaluation of } \\
\text { testing, sampling, and analysis of data provided by the } \\
\text { generator, or (4) audits, reviews, surveillance, or } \\
\text { observations of generator waste certification programs } \\
\text { and characterization activities. Additionally, acceptable } \\
\text { waste acceptance requirements for a storage, treatment } \\
\text { or disposal facility will have documented procedures } \\
\text { and actions to be taken if a waste that does not conform } \\
\text { to the waste acceptance criteria is received at the } \\
\text { facility. }\end{array}$ & \\
\hline $\begin{array}{l}\text { H. Waste Generation Planning. The following } \\
\text { requirements are in addition to those in Chapter I of } \\
\text { this Manual [DOE M 435.1-1 §I.2.F(7)]. }\end{array}$ & $\begin{array}{l}\text { DOE Manual 435.1-1 §I.2.F(7) applies to field element } \\
\text { managers. }\end{array}$ \\
\hline $\begin{array}{l}\text { (1) Life-Cycle Planning. Prior to waste generation, } \\
\text { planning shall be performed to address the entire life } \\
\text { cycle for all low-level waste streams. }\end{array}$ & $\begin{array}{l}\text { PDD- } 17000 \text { and LWP- } 17000 \text { provide direction to the } \\
\text { waste generators for waste generation planning to } \\
\text { address the entire life cycle. }\end{array}$ \\
\hline $\begin{array}{l}\text { From DOE G 435.1-1 Chapter IV: Compliance with } \\
\text { this planning requirement is demonstrated by the } \\
\text { individual sites establishing a process for evaluating } \\
\text { the life-cycle of low-level waste prior to its generation, } \\
\text { including the identification of low-level wastes with no } \\
\text { path to disposal and appropriate records justifying the } \\
\text { newly generated low-level waste stream(s), and site } \\
\text { personnel possessing planning information showing the } \\
\text { location(s) where low-level waste will be stored, } \\
\text { treated, and/or disposed along with a confirmation that } \\
\text { the personnel managing the facilities agree that the } \\
\text { low-level waste may be managed at those facilities. }\end{array}$ & \\
\hline $\begin{array}{l}\text { (2) Waste with No Identified Path to Disposal. Low- } \\
\text { level waste streams with no identified path to disposal } \\
\text { shall be generated only in accordance with approved } \\
\text { conditions which, at a minimum, shall address: }\end{array}$ & $\begin{array}{l}\text { This facility is not generating radioactive waste that } \\
\text { does not have an identified path to disposal. }\end{array}$ \\
\hline (a) Programmatic need to generate the waste; & See (2) above. \\
\hline $\begin{array}{l}\text { (b) Characteristics and issues preventing the disposal of } \\
\text { the waste; }\end{array}$ & See (2) above. \\
\hline $\begin{array}{l}\text { (c) Safe storage of the waste until disposal can be } \\
\text { achieved; and }\end{array}$ & See (2) above. \\
\hline $\begin{array}{l}\text { (d) Activities and plans for achieving final disposal of } \\
\text { the waste. }\end{array}$ & See (2) above. \\
\hline $\begin{array}{l}\text { I. Waste Characterization. Low-level waste shall be } \\
\text { characterized using direct or indirect methods, and the } \\
\text { characterization documented in sufficient detail to } \\
\text { ensure safe management and compliance with the } \\
\text { waste acceptance requirements of the facility receiving }\end{array}$ & $\begin{array}{l}\text { MCP-17000 } \S 4 \text { specifies the requirements for preparing } \\
\text { an Integrated Waste Tracking System (IWTS) profile } \\
\text { that captures waste characterization information. }\end{array}$ \\
\hline
\end{tabular}


Table 1. (continued).

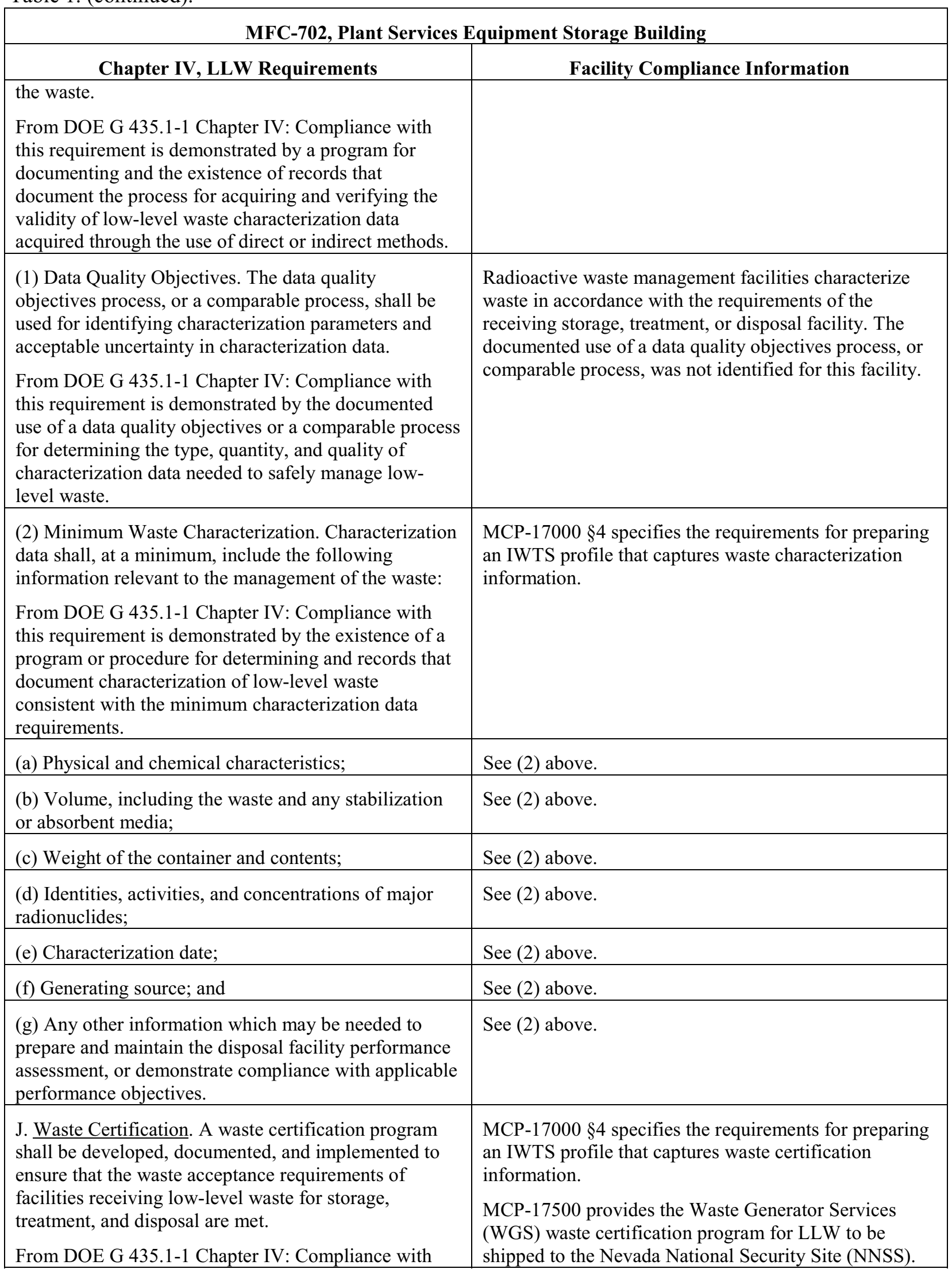


Table 1. (continued).

\begin{tabular}{|c|c|}
\hline \multicolumn{2}{|c|}{ MFC-702, Plant Services Equipment Storage Building } \\
\hline Chapter IV, LLW Requirements & Facility Compliance Information \\
\hline $\begin{array}{l}\text { the development and documentation portion of the } \\
\text { certification requirement is demonstrated by a waste } \\
\text { certification plan that identifies the organizations } \\
\text { involved, assigns responsibilities for implementing the } \\
\text { program, and describes or references the quality } \\
\text { assurance, training, procurement controls, records } \\
\text { management, and procedures to be used by the } \\
\text { program. Acceptable performance for implementing } \\
\text { the program is demonstrated when appropriate } \\
\text { personnel are trained and follow the procedures that } \\
\text { govern their part of the waste certification. } \\
\text { Additionally, acceptable performance is demonstrated } \\
\text { if the waste certification plan and procedures are } \\
\text { current and controlled in accordance with a document } \\
\text { controls program, and records related to certification } \\
\text { (e.g., certification statements, training records, } \\
\text { procurement records, characterization records, } \\
\text { container records) are generated and managed in } \\
\text { accordance with the established site program. }\end{array}$ & $\begin{array}{l}\text { Container procurement is addressed in MCP-17000 } \\
\S 4.6 \text {. } \\
\text { Waste certification is performed and tracked using } \\
\text { IWTS. Documentation of the IWTS Program is } \\
\text { available electronically only. } \\
\text { PLN-522 requires waste technical specialists and waste } \\
\text { disposition specialists to complete the appropriate } \\
\text { training/qualification before being granted approval } \\
\text { authority for profiles within the IWTS Program. The } \\
\text { waste certification official, alternate waste certification } \\
\text { official, and NNSS packaging certifiers must complete } \\
\text { the appropriate training/qualifications to disposition } \\
\text { waste to NNSS. }\end{array}$ \\
\hline $\begin{array}{l}\text { (1) Certification Program. The waste certification } \\
\text { program shall designate the officials who have the } \\
\text { authority to certify and release waste for shipment; and } \\
\text { specify what documentation is required for waste } \\
\text { generation, characterization, shipment, and } \\
\text { certification. The program shall provide requirements } \\
\text { for auditability, retrievability, and storage of required } \\
\text { documentation and specify the records retention period. } \\
\text { From DOE G } 435.1-1 \text { Chapter IV: Compliance with } \\
\text { this requirement is demonstrated by a program or } \\
\text { procedure for record keeping and records showing that } \\
\text { low-level waste is certified as having met the waste } \\
\text { acceptance criteria of the facility to which it was } \\
\text { transferred and that the certification statement is } \\
\text { supported by additional records regarding the waste } \\
\text { source, characterization, and container. }\end{array}$ & See J. above. \\
\hline $\begin{array}{l}\text { (2) Certification before Transfer. Low-level waste shall } \\
\text { be certified as meeting waste acceptance requirements } \\
\text { before it is transferred to the facility receiving the } \\
\text { waste. } \\
\text { From DOE G } 435.1-1 \text { Chapter IV: Compliance with } \\
\text { this requirement is demonstrated by the presence of a } \\
\text { certification program which includes procedures } \\
\text { requiring a signed certification statement prior to the } \\
\text { release of waste for transfer, and by dated records } \\
\text { showing that waste was certified before being } \\
\text { transferred. }\end{array}$ & See J. above. \\
\hline $\begin{array}{l}\text { (3) Maintaining Certification. Low-level waste that has } \\
\text { been certified as meeting the waste acceptance } \\
\text { requirements for transfer to a storage, treatment, or }\end{array}$ & See J. above. \\
\hline
\end{tabular}


Table 1. (continued).

\begin{tabular}{|c|c|}
\hline \multicolumn{2}{|c|}{ MFC-702, Plant Services Equipment Storage Building } \\
\hline Chapter IV, LLW Requirements & Facility Compliance Information \\
\hline $\begin{array}{l}\text { disposal facility shall be managed in a manner that } \\
\text { maintains its certification status. }\end{array}$ & \\
\hline $\begin{array}{l}\text { From DOE G } 435.1-1 \text { Chapter IV: Compliance with } \\
\text { this requirement is demonstrated by a program or } \\
\text { procedure reflecting this requirement is present and site } \\
\text { personnel are able to show that the storage of low-level } \\
\text { waste containers is in a facility or manner where the } \\
\text { containers would not be damaged by normal weather } \\
\text { events, and cannot be accessed by unauthorized } \\
\text { personnel. Further, each container can be traced to its } \\
\text { certification and the information supporting that } \\
\text { certification. }\end{array}$ & \\
\hline $\begin{array}{l}\text { K. Waste Transfer. A documented process shall be } \\
\text { established and implemented for transferring } \\
\text { responsibility for management of low-level waste and }\end{array}$ & $\begin{array}{l}\text { MCP- } 17000 \text { specifies the requirements for preparing an } \\
\text { IWTS profile, which captures waste certification data, } \\
\text { transfer information and associated authorizations. }\end{array}$ \\
\hline $\begin{array}{l}\text { for ensuring avallability of relevant data. The following } \\
\text { requirements are in addition to those in Chapter I of } \\
\text { this Manual. }\end{array}$ & $\begin{array}{l}\text { MCP-17500 provides the WGS waste certification } \\
\text { program for LLW to be shipped to NTS }\end{array}$ \\
\hline $\begin{array}{l}\text { From DOE G } 435.1-1 \text { Chapter IV: Compliance with } \\
\text { this requirement is demonstrated if facilities have } \\
\text { procedures for the receipt of waste and the transfer of } \\
\text { waste, as appropriate, which address the acquisition of } \\
\text { waste and container data and the transfer of ownership, } \\
\text { respectively. Further evidence of acceptable } \\
\text { performance is facility records showing that data on the } \\
\text { waste containers is available and accurate, and that } \\
\text { documented transfer of responsibility occurs. }\end{array}$ & $\begin{array}{l}\text { TSD-OI- } 004 \text { specifies requirements and provides } \\
\text { instructions for accepting LLW and mixed LLW at the } \\
\text { MFC treatment, storage, and disposal facilities. }\end{array}$ \\
\hline $\begin{array}{l}\text { (1) Authorization. Low-level waste shall not be } \\
\text { transferred to a storage, treatment, or disposal facility } \\
\text { until personnel responsible for the facility receiving the } \\
\text { waste authorize the transfer. }\end{array}$ & See K. above. \\
\hline $\begin{array}{l}\text { From DOE G } 435.1-1 \text { Chapter IV: Compliance with } \\
\text { this requirement is demonstrated by sites having } \\
\text { procedures that require a confirmation of authorization } \\
\text { before releasing waste for transfer, and records } \\
\text { showing that transfers are made in accordance with } \\
\text { written authorizations. }\end{array}$ & \\
\hline $\begin{array}{l}\text { (2) Data. Waste characterization data, container } \\
\text { information, and generation, storage, treatment, and } \\
\text { transportation information for low-level waste shall be } \\
\text { transferred with or be traceable to the waste. }\end{array}$ & See K. above. \\
\hline $\begin{array}{l}\text { From DOE G } 435.1-1 \text { Chapter IV: Compliance with } \\
\text { this requirement is demonstrated if there are procedures } \\
\text { requiring that characterization and container data be } \\
\text { provided and maintained for each low-level waste } \\
\text { transfer and documented records of transfers show that } \\
\text { the information is being provided. }\end{array}$ & \\
\hline
\end{tabular}


Table 1. (continued).

\begin{tabular}{|c|c|}
\hline \multicolumn{2}{|c|}{ MFC-702, Plant Services Equipment Storage Building } \\
\hline Chapter IV, LLW Requirements & Facility Compliance Information \\
\hline $\begin{array}{l}\text { L. Packaging and Transportation. The following } \\
\text { requirements are in addition to those in Chapter I of } \\
\text { this Manual [DOE M 435.1-1 §I.1.E(11)]. }\end{array}$ & $\begin{array}{l}\text { DOE Manual 435.1-1 §I.1.E(11) applies to field element } \\
\text { managers. }\end{array}$ \\
\hline $\begin{array}{l}\text { (1) Packaging. If containers are used: } \\
\text { From DOE G 435.1-1 Chapter IV: Compliance with } \\
\text { the packaging requirement is demonstrated by: (1) } \\
\text { procedures which document proper packaging } \\
\text { protocols; and (2) no trends of routine repackaging of } \\
\text { low-level waste that is packaged after issuance of DOE } \\
\text { O } 435.1 \text {. Successful performance of this requirement is } \\
\text { also demonstrated by a record of containers for which } \\
\text { failure has not routinely occurred under management } \\
\text { conditions. It is recognized that there may be failed } \\
\text { containers for waste previously placed in storage. For } \\
\text { those containers, the goal is to only have to repackage } \\
\text { the waste one time after it is retrieved and } \\
\text { characterized. Further, acceptable performance is } \\
\text { demonstrated by containers of waste having marking } \\
\text { and labeling that allows correlation with waste } \\
\text { characterization data and container information. }\end{array}$ & MCP-17000 $§ 4$ addresses packaging requirements. \\
\hline $\begin{array}{l}\text { (a) Low-level waste shall be packaged in a manner that } \\
\text { provides containment and protection for the duration of } \\
\text { the anticipated storage period and until disposal is } \\
\text { achieved or until the waste has been removed from the } \\
\text { container. }\end{array}$ & See (1) above. \\
\hline $\begin{array}{l}\text { (b) When waste is packaged, vents or other measures } \\
\text { shall be provided if the potential exists for pressurizing } \\
\text { or generating flammable or explosive concentrations of } \\
\text { gases within the waste container. }\end{array}$ & See (1) above. \\
\hline $\begin{array}{l}\text { (c) Containers of low-level waste shall be marked such } \\
\text { that their contents can be identified. }\end{array}$ & See (1) above. \\
\hline $\begin{array}{l}\text { (2) Transportation. To the extent practical, the volume } \\
\text { of waste and number of low-level waste shipments } \\
\text { shall be minimized. }\end{array}$ & $\begin{array}{l}\text { NA; waste is not shipped to an offsite facility for final } \\
\text { disposition from this facility. }\end{array}$ \\
\hline $\begin{array}{l}\text { From DOE G } 435.1-1 \text { Chapter IV: Compliance with } \\
\text { this requirement can be demonstrated by a combination } \\
\text { of site procedures directing the efficient use of waste } \\
\text { container capacity and documentation showing that } \\
\text { low-level waste shipments are systematically planned } \\
\text { and optimized to the extent practical. }\end{array}$ & \\
\hline $\begin{array}{l}\text { M. Site Evaluation and Facility Design. The following } \\
\text { requirements are in addition to those in Chapter I of } \\
\text { this Manual. }\end{array}$ & $\begin{array}{l}\text { NA; this requirement addresses new radioactive waste } \\
\text { management facilities. }\end{array}$ \\
\hline
\end{tabular}


Table 1. (continued).

\begin{tabular}{|c|c|}
\hline \multicolumn{2}{|c|}{ MFC-702, Plant Services Equipment Storage Building } \\
\hline Chapter IV, LLW Requirements & Facility Compliance Information \\
\hline $\begin{array}{l}\text { (1) Site Evaluation. Proposed locations for low-level } \\
\text { waste facilities shall be evaluated to identify relevant } \\
\text { features that should be avoided or must be considered } \\
\text { in facility design and analyses. }\end{array}$ & See M. above. \\
\hline $\begin{array}{l}\text { (a) Each site proposed for a new low-level waste } \\
\text { facility or expansion of an existing low-level waste } \\
\text { facility shall be evaluated considering environmental } \\
\text { characteristics, geotechnical characteristics, and human } \\
\text { activities, including for a low-level waste disposal } \\
\text { facility, the capability of the site to demonstrate, at a } \\
\text { minimum, whether it is: }\end{array}$ & See M. above. \\
\hline $\begin{array}{l}1 \text { Located to accommodate the projected volume of } \\
\text { waste to be received; }\end{array}$ & See M. above. \\
\hline $\begin{array}{l}2 \text { Located in a flood plain, a tectonically active area, or } \\
\text { in the zone of water table fluctuation; and }\end{array}$ & See M. above. \\
\hline $\begin{array}{l}3 \text { Located where radionuclide migration pathways are } \\
\text { predictable and erosion and surface runoff can be } \\
\text { controlled. }\end{array}$ & See M. above. \\
\hline $\begin{array}{l}\text { (b) Proposed sites with environmental characteristics, } \\
\text { geotechnical characteristics, and human activities for } \\
\text { which adequate protection cannot be provided through } \\
\text { facility design shall be deemed unsuitable for the } \\
\text { location of the facility. }\end{array}$ & See M. above. \\
\hline $\begin{array}{l}\text { (c) Low-level waste disposal facilities shall be sited to } \\
\text { achieve long-term stability and to minimize, to the } \\
\text { extent practical, the need for active maintenance } \\
\text { following final closure. }\end{array}$ & See M. above. \\
\hline $\begin{array}{l}\text { (2) Low-Level Waste Treatment and Storage Facility } \\
\text { Design. The following facility requirements and } \\
\text { general design criteria, at a minimum, apply: }\end{array}$ & See M. above. \\
\hline $\begin{array}{l}\text { (a) Confinement. Low-level waste systems and } \\
\text { components shall be designed to maintain waste } \\
\text { confinement. }\end{array}$ & See M. above. \\
\hline (b) Ventilation. & See M. above. \\
\hline $\begin{array}{l}1 \text { Design of low-level waste treatment and storage } \\
\text { facilities shall include ventilation, if applicable, } \\
\text { through an appropriate filtration system to maintain the } \\
\text { release of radioactive material in airborne effluents } \\
\text { within the requirements and guidelines specified in } \\
\text { applicable requirements. }\end{array}$ & See M. above. \\
\hline $\begin{array}{l}2 \text { When conditions exist for generating gases in } \\
\text { flammable or explosive concentrations, ventilation } \\
\text { systems or other measures shall be provided to keep the } \\
\text { gases in a non-flammable and nonexplosive condition. } \\
\text { Where concentrations of explosive or flammable gases }\end{array}$ & See M. above. \\
\hline
\end{tabular}


Table 1. (continued).

\begin{tabular}{|c|c|}
\hline \multicolumn{2}{|c|}{ MFC-702, Plant Services Equipment Storage Building } \\
\hline Chapter IV, LLW Requirements & Facility Compliance Information \\
\hline $\begin{array}{l}\text { are expected to approach the lower flammability limit, } \\
\text { measures shall be taken to prevent deflagration or } \\
\text { detonation. }\end{array}$ & \\
\hline $\begin{array}{l}\text { (c) Consideration of Decontamination and } \\
\text { Decommissioning. Areas in new and modifications to } \\
\text { existing low-level waste management facilities that are } \\
\text { subject to contamination with radioactive or other } \\
\text { hazardous materials shall be designed to facilitate } \\
\text { decontamination. For such facilities a proposed } \\
\text { decommissioning method or a conversion method } \\
\text { leading to reuse shall be described. }\end{array}$ & See M. above. \\
\hline $\begin{array}{l}\text { (d) Instrumentation and Control Systems. Engineering } \\
\text { controls shall be incorporated in the design and } \\
\text { engineering of low-level waste treatment and storage } \\
\text { facilities to provide volume inventory data and to } \\
\text { prevent spills, leaks, and overflows from tanks or } \\
\text { confinement systems. }\end{array}$ & See M. above. \\
\hline $\begin{array}{l}\text { (e) Monitoring. Monitoring and/or leak detection } \\
\text { capabilities shall be incorporated in the design and } \\
\text { engineering of low-level waste treatment and storage } \\
\text { facilities to provide rapid identification of failed } \\
\text { confinement and/or other abnormal conditions. }\end{array}$ & See M. above. \\
\hline $\begin{array}{l}\text { (3) Low-Level Waste Disposal Facility Design. The } \\
\text { following facility requirements and general design } \\
\text { criteria, at a minimum, apply: }\end{array}$ & See M. above. \\
\hline $\begin{array}{l}\text { (a) Confinement. Low-level waste systems and } \\
\text { components shall be designed to maintain waste } \\
\text { confinement. }\end{array}$ & See M. above. \\
\hline (b) Ventilation. & \\
\hline $\begin{array}{l}1 \text { Design of low-level waste disposal facilities shall } \\
\text { include ventilation, if applicable, through an } \\
\text { appropriate filtration system to maintain the release of } \\
\text { radioactive material in airborne effluents within the } \\
\text { requirements and guidelines specified in applicable } \\
\text { requirements. }\end{array}$ & See M. above. \\
\hline $\begin{array}{l}2 \text { When conditions exist for generating gases in } \\
\text { flammable or explosive concentrations, ventilation } \\
\text { systems or other measures shall be provided to keep the } \\
\text { gases in a nonflammable and non-explosive condition. } \\
\text { Where concentrations of explosive or flammable gases } \\
\text { are expected to approach the lower flammability limit, } \\
\text { measures shall be taken to prevent deflagration or } \\
\text { detonation. }\end{array}$ & See M. above. \\
\hline $\begin{array}{l}\text { (c) Stability. Low-level waste disposal facilities shall } \\
\text { be designed to achieve long-term stability and to } \\
\text { minimize to the extent practical, the need for active }\end{array}$ & See M. above. \\
\hline
\end{tabular}


Table 1. (continued).

\begin{tabular}{|c|c|}
\hline \multicolumn{2}{|c|}{ MFC-702, Plant Services Equipment Storage Building } \\
\hline Chapter IV, LLW Requirements & Facility Compliance Information \\
\hline maintenance following final closure. & \\
\hline $\begin{array}{l}\text { (d) Control of Water. Low-level waste disposal } \\
\text { facilities shall be designed to minimize to the extent } \\
\text { practical, the contact of waste with water during and } \\
\text { after disposal. }\end{array}$ & See M. above. \\
\hline $\begin{array}{l}\text { N. Storage and Staging. The following requirements } \\
\text { are in addition to those in Chapter I of this Manual } \\
\text { [DOE M 435.1-1 §I.2.F(13)]. }\end{array}$ & $\begin{array}{l}\text { DOE Manual 435.1-1 §I.2.F(13) applies to field element } \\
\text { managers. }\end{array}$ \\
\hline $\begin{array}{l}\text { (1) Storage Prohibitions. Low-level waste in storage } \\
\text { shall not be readily capable of detonation, explosive } \\
\text { decomposition, reaction at anticipated pressures and } \\
\text { temperatures, or explosive reaction with water. Prior to } \\
\text { storage, pyrophoric materials shall be treated, prepared, } \\
\text { and packaged to be nonflammable. }\end{array}$ & $\begin{array}{l}\text { NA; this facility does not store LLW. See N. (7) below } \\
\text { for staging requirements. }\end{array}$ \\
\hline $\begin{array}{l}\text { From DOE G } 435.1-1 \text { Chapter IV: Compliance with } \\
\text { this requirement is demonstrated by having waste } \\
\text { acceptance requirements which prohibit low-level } \\
\text { waste that is ignitable or explosive from being accepted } \\
\text { for storage unless it has been treated, and procedures } \\
\text { for properly preparing such materials for safe storage. }\end{array}$ & \\
\hline $\begin{array}{l}\text { (2) Storage Limit. Low-level waste that has an } \\
\text { identified path to disposal shall not be stored longer } \\
\text { than one year prior to disposal, except for storage for } \\
\text { decay, or as otherwise authorized by the Field Element } \\
\text { Manager. }\end{array}$ & See (1) above. \\
\hline $\begin{array}{l}\text { From DOE G } 435.1-1 \text { Chapter IV: Storage longer than } \\
\text { one year can be justified if the conditions for such } \\
\text { storage are approved by the Field Element Manager as } \\
\text { part of the radioactive waste management basis for the } \\
\text { facility. }\end{array}$ & \\
\hline $\begin{array}{l}\text { Storage for radioactive decay for a period greater than } \\
1 \text { year for waste that has an identified path to disposal } \\
\text { is allowed. Adequate justification and the supporting } \\
\text { information for storage for decay is to be documented } \\
\text { in the radioactive waste management basis for the } \\
\text { facility in which the storage will take place. }\end{array}$ & \\
\hline $\begin{array}{l}\text { Mixed waste. Under the Federal Facility Compliance } \\
\text { Act of } 1992 \text {, DOE sites were required to develop Site } \\
\text { Treatment Plans to bring stored mixed low-level waste } \\
\text { into compliance with these requirements. The Site } \\
\text { Treatment Plan needs to be consulted and any mixed } \\
\text { low-level waste stored for the purpose of accumulation } \\
\text { to facilitate treatment must meet Resource } \\
\text { Conservation and Recovery Act storage requirements. } \\
\text { There could be several ways within different scenarios } \\
\text { that this requirement can be met, as illustrated by the } \\
\text { examples below, however, there are basically four }\end{array}$ & \\
\hline
\end{tabular}


Table 1. (continued).

\begin{tabular}{|c|c|}
\hline \multicolumn{2}{|c|}{ MFC-702, Plant Services Equipment Storage Building } \\
\hline Chapter IV, LLW Requirements & Facility Compliance Information \\
\hline $\begin{array}{l}\text { ways to show compliance with the requirement and } \\
\text { include appropriate provisions in the radioactive waste } \\
\text { management basis for the facility in which it is stored. }\end{array}$ & \\
\hline $\begin{array}{l}\text { Legacy waste. As discussed above, the intention of the } \\
\text { requirement is not to force malicious compliance or } \\
\text { heroic actions which would result in increased risk or } \\
\text { safety concerns. Rather, the intention is that waste in } \\
\text { storage longer than one year receives additional } \\
\text { attention to ensure that the public, the workers, and the } \\
\text { environment are protected from the hazards of the } \\
\text { waste, and that progress is being made to dispose of the } \\
\text { waste. There could be several ways within different } \\
\text { scenarios that this requirement can be met, as } \\
\text { illustrated by the examples below, however, there are } \\
\text { basically four ways to show compliance with the } \\
\text { requirement: }\end{array}$ & \\
\hline $\begin{array}{l}\text { 1) the radioactive waste management basis allows for } \\
\text { storage for no more than one year. }\end{array}$ & \\
\hline $\begin{array}{l}\text { 2) the radioactive waste management basis allows for } \\
\text { storage for no more than one year, or for storage for } \\
\text { decay only for periods greater than a year, which are } \\
\text { specified on a radionuclide basis. }\end{array}$ & \\
\hline $\begin{array}{l}\text { 3) the radioactive waste management basis allows for } \\
\text { storage for more than one year, up to a specified period } \\
\text { of time based on a documented technical evaluation } \\
\text { that the waste can be stored in a manner that does not } \\
\text { cause changes to the waste or waste packages that is } \\
\text { detrimental to the safe storage of the waste, the final } \\
\text { disposal of the waste or to meeting the disposal } \\
\text { performance objectives. }\end{array}$ & \\
\hline $\begin{array}{l}\text { 4) the radioactive waste management basis allows for } \\
\text { storage for decay (with specifics) and for storage for } \\
\text { more than one year for other low-level waste, up to a } \\
\text { specified period of time based on a documented } \\
\text { technical evaluation that the waste can be stored in a } \\
\text { manner that does not cause changes to the waste or } \\
\text { waste packages that is detrimental to the safe storage of } \\
\text { the waste, the final disposal of the waste or to meeting } \\
\text { the disposal performance objectives. }\end{array}$ & \\
\hline $\begin{array}{l}\text { Compliance with this requirement is demonstrated by } \\
\text { the existence of a radioactive waste management basis } \\
\text { for the storage facility approved by the Field Element } \\
\text { Manager that includes the time frames that waste are } \\
\text { allowed to be stored, the necessary justifications for } \\
\text { storage for decay, and the necessary technical } \\
\text { evaluations if storage is to extend significantly beyond } \\
\text { the one-year time frame. }\end{array}$ & \\
\hline (3) Storage Integrity. Low-level waste shall be stored & See (1) above. \\
\hline
\end{tabular}


Table 1. (continued).

\begin{tabular}{|c|c|}
\hline \multicolumn{2}{|c|}{ MFC-702, Plant Services Equipment Storage Building } \\
\hline Chapter IV, LLW Requirements & Facility Compliance Information \\
\hline $\begin{array}{l}\text { in a location and manner that protects the integrity of } \\
\text { waste for the expected time of storage and minimizes } \\
\text { worker exposure. }\end{array}$ & \\
\hline $\begin{array}{l}\text { From DOE G } 435.1-1 \text { Chapter IV: However, in making } \\
\text { a decision to use a facility for storage and in } \\
\text { developing a radioactive waste management basis for } \\
\text { the activity, particular attention to protection of } \\
\text { workers is needed. }\end{array}$ & \\
\hline $\begin{array}{l}\text { Compliance with this requirement is demonstrated if } \\
\text { sites have storage capabilities for low-level waste that } \\
\text { provide protection to waste containers so that their } \\
\text { integrity will not be damaged through physical or } \\
\text { chemical (corrosion) processes and that keep personnel } \\
\text { from spending extended periods of time in the areas } \\
\text { where low-level waste is stored. }\end{array}$ & \\
\hline (4) Waste Characterization for Storage. & See (1) above. \\
\hline $\begin{array}{l}\text { (a) Low-level waste that does not have an identified } \\
\text { path to disposal shall be characterized as necessary to } \\
\text { meet the data quality objectives and minimum } \\
\text { characterization requirements of this Chapter, to ensure } \\
\text { safe storage, and to facilitate disposal. }\end{array}$ & See (1) above. \\
\hline $\begin{array}{l}\text { (b) Characterization information for all low-level waste } \\
\text { in storage shall be maintained as a record in accordance } \\
\text { with the requirements for Records Management in } \\
\text { Chapter I of this Manual. }\end{array}$ & See (1) above. \\
\hline $\begin{array}{l}\text { From DOE G } 435.1-1 \text { Chapter IV: Compliance with } \\
\text { this requirement is demonstrated by documented } \\
\text { procedures for managing waste characterization and } \\
\text { container information on low-level waste as a Federal } \\
\text { record. The records are managed per the applicable } \\
\text { policies and procedures for records management } \\
\text { referenced in DOE O } 200.1 \text { and established at the } \\
\text { applicable Field Element. }\end{array}$ & \\
\hline $\begin{array}{l}\text { (5) Container Inspection. A process shall be developed } \\
\text { and implemented for inspecting and maintaining } \\
\text { containers of low-level waste to ensure container } \\
\text { integrity is not compromised. }\end{array}$ & $\begin{array}{l}\text { LI- } 435 \text { requires quarterly inspections of radioactive } \\
\text { waste containers if waste is stored outdoors or has been } \\
\text { in storage for greater than } 1 \text { year. }\end{array}$ \\
\hline $\begin{array}{l}\text { From DOE G } 435.1-1 \text { Chapter IV: Compliance with } \\
\text { this requirement is demonstrated by: (1) a documented } \\
\text { process for waste container inspection and } \\
\text { maintenance; and (2) documentation for all waste } \\
\text { container inspections and maintenance actions } \\
\text { performed. }\end{array}$ & \\
\hline $\begin{array}{l}\text { (6) Storage Management. Low-level waste storage } \\
\text { shall be managed to identify and segregate low-level } \\
\text { waste from mixed low-level waste. }\end{array}$ & See (1) above. \\
\hline
\end{tabular}


Table 1. (continued).

\begin{tabular}{|c|c|}
\hline \multicolumn{2}{|c|}{ MFC-702, Plant Services Equipment Storage Building } \\
\hline Chapter IV, LLW Requirements & Facility Compliance Information \\
\hline $\begin{array}{l}\text { (7) Staging. Staging of low-level waste shall be for the } \\
\text { purpose of the accumulation of such quantities of waste } \\
\text { as necessary to facilitate transportation, treatment, and } \\
\text { disposal. Staging longer than } 90 \text { days shall meet the } \\
\text { requirements for storage above and in Chapter I of this } \\
\text { Manual. }\end{array}$ & $\begin{array}{l}\text { Routine LLW, such as personnel protective equipment, } \\
\text { is accumulated at this facility for disposal. MCP-17000, } \\
\text { Appendix F, "Container Start Date and Storage } \\
\text { Prohibitions," restricts staging LLW to } 90 \text { days } \\
\text { maximum at any generator or treatment facility prior to } \\
\text { acceptance by a storage facility. }\end{array}$ \\
\hline $\begin{array}{l}\text { From DOE G 435.1-1 Chapter IV: The staging of low- } \\
\text { level waste needs to be addressed in the radioactive } \\
\text { waste management basis for the facility that is } \\
\text { performing the staging. Generators, treatment facilities, } \\
\text { and disposal facilities that stage waste must ensure that } \\
\text { the action of staging is included and authorized as part } \\
\text { of their radioactive waste management basis for the } \\
\text { affected facilities, operations, or activities. }\end{array}$ & $\begin{array}{l}\text { As stated in DOE Guide } 435.1-1 \text { §IV.N.(7), staging } \\
\text { waste in accordance with this requirement allows waste } \\
\text { to be accumulated without being considered storage and } \\
\text { being bound by the associated storage requirements. }\end{array}$ \\
\hline $\begin{array}{l}\text { Staging longer than } 90 \text { days must be justified, the } \\
\text { conditions for such storage met, and these practices } \\
\text { approved by the Field Element Manager as part of the } \\
\text { radioactive waste management basis for the facility. }\end{array}$ & \\
\hline $\begin{array}{l}\text { Compliance with this requirement is demonstrated by a } \\
\text { staging program that limits the temporary storage of } \\
\text { waste to only circumstances allowed in the } \\
\text { requirement, including justifications for any staging } \\
\text { that exceeds the } 90 \text {-day period, which is documented in } \\
\text { the radioactive waste management basis for the facility. }\end{array}$ & \\
\hline $\begin{array}{l}\text { O. Treatment. Low-level waste treatment to provide } \\
\text { more stable waste forms and to improve the long-term } \\
\text { performance of a low-level waste disposal facility shall } \\
\text { be implemented as necessary to meet the performance } \\
\text { objectives of the disposal facility. }\end{array}$ & NA; this facility does not treat LLW. \\
\hline $\begin{array}{l}\text { From DOE G } 435.1-1 \text { Chapter IV: Compliance with } \\
\text { this requirement is demonstrated when a treatment } \\
\text { facility or process ensures that treated waste will meet } \\
\text { the minimum waste form requirements of DOE M } \\
435.1 \text { and meet additional disposal facility-specific } \\
\text { waste acceptance requirements for additional stability } \\
\text { or long-term performance of facilities that will receive } \\
\text { the treated waste. }\end{array}$ & \\
\hline $\begin{array}{l}\text { P. Disposal. Low-level waste disposal facilities shall } \\
\text { meet the following requirements. }\end{array}$ & NA; this facility does not dispose of LLW. \\
\hline $\begin{array}{l}\text { (1) Performance Objectives. Low-level waste disposal } \\
\text { facilities shall be sited, designed, operated, maintained, } \\
\text { and closed so that a reasonable expectation exists that } \\
\text { the following performance objectives will be met for } \\
\text { waste disposed of after September 26, } 1988 \text { : }\end{array}$ & See P. above. \\
\hline
\end{tabular}


Table 1. (continued).

\begin{tabular}{|c|c|}
\hline \multicolumn{2}{|c|}{ MFC-702, Plant Services Equipment Storage Building } \\
\hline Chapter IV, LLW Requirements & Facility Compliance Information \\
\hline $\begin{array}{l}\text { (a) Dose to representative members of the public shall } \\
\text { not exceed } 25 \mathrm{mrem}(0.25 \mathrm{mSv}) \text { in a year total } \\
\text { effective dose equivalent from all exposure pathways, } \\
\text { excluding the dose from radon and its progeny in air. }\end{array}$ & See P. above. \\
\hline $\begin{array}{l}\text { (b) Dose to representative members of the public via } \\
\text { the air pathway shall not exceed } 10 \text { mrem }(0.10 \mathrm{mSv}) \\
\text { in a year total effective dose equivalent, excluding the } \\
\text { dose from radon and its progeny. }\end{array}$ & See P. above. \\
\hline $\begin{array}{l}\text { (c) Release of radon shall be less than an average flux } \\
\text { of } 20 \mathrm{pCi} / \mathrm{m}^{2} / \mathrm{s}\left(0.74 \mathrm{~Bq} / \mathrm{m}^{2} / \mathrm{s}\right) \text { at the surface of the } \\
\text { disposal facility. Alternatively, a limit of } 0.5 \mathrm{pCi} / 1 \\
(0.0185 \mathrm{~Bq} / \mathrm{l}) \text { of air may be applied at the boundary of } \\
\text { the facility. }\end{array}$ & See P. above. \\
\hline $\begin{array}{l}\text { (2) Performance Assessment. A site-specific } \\
\text { radiological performance assessment shall be prepared } \\
\text { and maintained for DOE low-level waste disposed of } \\
\text { after September } 26,1988 \text {. The performance assessment } \\
\text { shall include calculations for a } 1,000 \text { year period after } \\
\text { closure of potential doses to representative future } \\
\text { members of the public and potential releases from the } \\
\text { facility to provide a reasonable expectation that the } \\
\text { performance objectives identified in this Chapter are } \\
\text { not exceeded as a result of operation and closure of the } \\
\text { facility. }\end{array}$ & See P. above. \\
\hline $\begin{array}{l}\text { (a) Analyses performed to demonstrate compliance } \\
\text { with the performance objectives in this Chapter, and to } \\
\text { establish limits on concentrations of radionuclides for } \\
\text { disposal based on the performance measures for } \\
\text { inadvertent intruders in this Chapter shall be based on } \\
\text { reasonable activities in the critical group of exposed } \\
\text { individuals. Unless otherwise specified, the assumption } \\
\text { of average living habits and exposure conditions in } \\
\text { representative critical groups of individuals projected } \\
\text { to receive the highest doses is appropriate. The } \\
\text { likelihood of inadvertent intruder scenarios may be } \\
\text { considered in interpreting the results of the analyses } \\
\text { and establishing radionuclide concentrations, if } \\
\text { adequate justification is provided. }\end{array}$ & See P. above. \\
\hline $\begin{array}{l}\text { (b) The point of compliance shall correspond to the } \\
\text { point of highest projected dose or concentration beyond } \\
\text { a } 100 \text { meter buffer zone surrounding the disposed } \\
\text { waste. A larger or smaller buffer zone may be used if } \\
\text { adequate justification is provided. }\end{array}$ & See P. above. \\
\hline $\begin{array}{l}\text { (c) Performance assessments shall address reasonably } \\
\text { foreseeable natural processes that might disrupt barriers } \\
\text { against release and transport of radioactive materials. }\end{array}$ & See P. above. \\
\hline
\end{tabular}


Table 1. (continued).

\begin{tabular}{|c|c|}
\hline \multicolumn{2}{|c|}{ MFC-702, Plant Services Equipment Storage Building } \\
\hline Chapter IV, LLW Requirements & Facility Compliance Information \\
\hline $\begin{array}{l}\text { (d) Performance assessments shall use DOE-approved } \\
\text { dose coefficients (dose conversion factors) for internal } \\
\text { and external exposure of reference adults. }\end{array}$ & See P. above. \\
\hline $\begin{array}{l}\text { (e) The performance assessment shall include a } \\
\text { sensitivity/uncertainty analysis. }\end{array}$ & See P. above. \\
\hline $\begin{array}{l}\text { (f) Performance assessments shall include a } \\
\text { demonstration that projected releases of radionuclides } \\
\text { to the environment shall be maintained as low as } \\
\text { reasonably achievable (ALARA). }\end{array}$ & See P. above. \\
\hline $\begin{array}{l}\text { (g) For purposes of establishing limits on radionuclides } \\
\text { that may be disposed of near-surface, the performance } \\
\text { assessment shall include an assessment of impacts to } \\
\text { water resources. }\end{array}$ & See P. above. \\
\hline $\begin{array}{l}\text { (h) For purposes of establishing limits on the } \\
\text { concentration of radionuclides that may be disposed of } \\
\text { near-surface, the performance assessment shall include } \\
\text { an assessment of impacts calculated for a hypothetical } \\
\text { person assumed to inadvertently intrude for a } \\
\text { temporary period into the low-level waste disposal } \\
\text { facility. For intruder analyses, institutional controls } \\
\text { shall be assumed to be effective in deterring intrusion } \\
\text { for at least } 100 \text { years following closure. The intruder } \\
\text { analyses shall use performance measures for chronic } \\
\text { and acute exposure scenarios, respectively, of } 100 \\
\text { mrem }(1 \mathrm{mSv}) \text { in a year and } 500 \text { mrem }(5 \mathrm{mSv}) \text { total } \\
\text { effective dose equivalent excluding radon in air. }\end{array}$ & See P. above. \\
\hline $\begin{array}{l}\text { (3) Composite Analysis. For disposal facilities which } \\
\text { received waste after September } 26,1988 \text {, a site-specific } \\
\text { radiological composite analysis shall be prepared and } \\
\text { maintained that accounts for all sources of radioactive } \\
\text { material that may be left at the DOE site and may } \\
\text { interact with the low- level waste disposal facility, } \\
\text { contributing to the dose projected to a hypothetical } \\
\text { member of the public from the existing or future } \\
\text { disposal facilities. Performance measures shall be } \\
\text { consistent with DOE requirements for protection of the } \\
\text { public and environment and evaluated for a } 1,000 \text { year } \\
\text { period following disposal facility closure. The } \\
\text { composite analysis results shall be used for planning, } \\
\text { radiation protection activities, and future use } \\
\text { commitments to minimize the likelihood that current } \\
\text { low- level waste disposal activities will result in the } \\
\text { need for future corrective or remedial actions to } \\
\text { adequately protect the public and the environment. }\end{array}$ & See P. above. \\
\hline $\begin{array}{l}\text { (4) Performance Assessment and Composite Analysis } \\
\text { Maintenance. The performance assessment and } \\
\text { composite analysis shall be maintained to evaluate } \\
\text { changes that could affect the performance, design, and }\end{array}$ & See P. above. \\
\hline
\end{tabular}


Table 1. (continued).

\begin{tabular}{|c|c|}
\hline \multicolumn{2}{|c|}{ MFC-702, Plant Services Equipment Storage Building } \\
\hline Chapter IV, LLW Requirements & Facility Compliance Information \\
\hline $\begin{array}{l}\text { operating bases for the facility. Performance } \\
\text { assessment and composite analysis maintenance shall } \\
\text { include the conduct of research, field studies, and } \\
\text { monitoring needed to address uncertainties or gaps in } \\
\text { existing data. The performance assessment shall be } \\
\text { updated to support the final facility closure. Additional } \\
\text { iterations of the performance assessment and composite } \\
\text { analysis shall be conducted as necessary during the } \\
\text { post-closure period. }\end{array}$ & \\
\hline $\begin{array}{l}\text { (a) Performance assessments and composite analyses } \\
\text { shall be reviewed and revised when changes in waste } \\
\text { forms or containers, radionuclide inventories, facility } \\
\text { design and operations, closure concepts, or the } \\
\text { improved understanding of the performance of the } \\
\text { waste disposal facility in combination with the features } \\
\text { of the site on which it is located alter the conclusions or } \\
\text { the conceptual model(s) of the existing performance } \\
\text { assessment or composite analysis. }\end{array}$ & See P. above. \\
\hline $\begin{array}{l}\text { (b) A determination of the continued adequacy of the } \\
\text { performance assessment and composite analysis shall } \\
\text { be made on an annual basis, and shall consider the } \\
\text { results of data collection and analysis from research, } \\
\text { field studies, and monitoring. }\end{array}$ & See P. above. \\
\hline $\begin{array}{l}\text { (c) Annual summaries of low-level waste disposal } \\
\text { operations shall be prepared with respect to the } \\
\text { conclusions and recommendations of the performance } \\
\text { assessment and composite analysis and a determination } \\
\text { of the need to revise the performance assessment or } \\
\text { composite analysis. }\end{array}$ & See P. above. \\
\hline $\begin{array}{l}\text { (5) Disposal Authorization. A disposal authorization } \\
\text { statement shall be obtained prior to construction of a } \\
\text { new low-level waste disposal facility. Field Elements } \\
\text { with existing low-level waste disposal facilities shall } \\
\text { obtain a disposal authorization statement in accordance } \\
\text { with the schedule in the Complex-Wide Low-Level } \\
\text { Waste Management Program Plan. The disposal } \\
\text { authorization statement shall be issued based on a } \\
\text { review of the facility's performance assessment, } \\
\text { composite analysis, performance assessment and } \\
\text { composite analysis maintenance, preliminary closure } \\
\text { plan, and preliminary monitoring plan. The disposal } \\
\text { authorization statement shall specify the limits and } \\
\text { conditions on construction, design, operations, and } \\
\text { closure of the low-level waste facility based on these } \\
\text { reviews. A disposal authorization statement is a part of } \\
\text { the radioactive waste management basis for a disposal } \\
\text { facility. Failure to obtain a disposal authorization } \\
\text { statement by the implementation date of this Order } \\
\text { shall result in shutdown of the disposal facility. }\end{array}$ & See P. above. \\
\hline
\end{tabular}


Table 1. (continued).

\begin{tabular}{|c|c|}
\hline \multicolumn{2}{|c|}{ MFC-702, Plant Services Equipment Storage Building } \\
\hline Chapter IV, LLW Requirements & Facility Compliance Information \\
\hline $\begin{array}{l}\text { (6) Disposal Facility Operations. The disposal facility } \\
\text { design and operation must be consistent with the } \\
\text { disposal facility closure plan and lead to disposal } \\
\text { facility closure that provides a reasonable expectation } \\
\text { that performance objectives will be met. Low-level } \\
\text { waste shall be disposed in such a manner that achieves } \\
\text { the performance objectives stated in this Chapter, } \\
\text { consistent with the disposal facility radiological } \\
\text { performance assessment. Additional requirements } \\
\text { include: }\end{array}$ & See P. above. \\
\hline $\begin{array}{l}\text { (a) Operating procedures shall be developed and } \\
\text { implemented for low-level waste disposal facilities that } \\
\text { protect the public, workers, and the environment; } \\
\text { ensure the security of the facility; minimize subsidence } \\
\text { during and after waste emplacement; achieve long-term } \\
\text { stability and minimize the need for long-term active } \\
\text { maintenance; and meet the requirements of the } \\
\text { closure/post-closure plan. }\end{array}$ & See P. above. \\
\hline $\begin{array}{l}\text { (b) Permanent identification markers for disposal } \\
\text { excavations and monitoring wells shall be emplaced. }\end{array}$ & See P. above. \\
\hline $\begin{array}{l}\text { (c) Low-level waste placement into disposal units shall } \\
\text { minimize voids between waste containers. Voids } \\
\text { within disposal units shall be filled to the extent } \\
\text { practical. Uncontainerized bulk waste shall also be } \\
\text { placed in a manner that minimizes voids and } \\
\text { subsidence. }\end{array}$ & See P. above. \\
\hline $\begin{array}{l}\text { (d) Operations are to be conducted so that active waste } \\
\text { disposal operations will not have an adverse effect on } \\
\text { any other disposal units. }\end{array}$ & See P. above. \\
\hline $\begin{array}{l}\text { (e) Operations shall include a process for tracking and } \\
\text { documenting low-level waste placement in the facility } \\
\text { by generator source. }\end{array}$ & See P. above. \\
\hline $\begin{array}{l}\text { (7) Alternate Requirements for Low-Level Waste } \\
\text { Disposal Facility Design and Operation. Requirements } \\
\text { other than those set forth in this Section for the design } \\
\text { and operation of a low-level waste disposal facility } \\
\text { may be approved on a specific basis if a reasonable } \\
\text { expectation is demonstrated that the disposal } \\
\text { performance objectives will be met. }\end{array}$ & See P. above. \\
\hline $\begin{array}{l}\text { Q. Closure. The following requirements are in addition } \\
\text { to those in Chapter I of this Manual. }\end{array}$ & NA; this facility does not dispose of LLW. \\
\hline $\begin{array}{l}\text { (1) Disposal Facility Closure Plans. A preliminary } \\
\text { closure plan shall be developed and submitted to } \\
\text { Headquarters for review with the performance } \\
\text { assessment and composite analysis. The closure plan } \\
\text { shall be updated following issuance of the disposal }\end{array}$ & See Q. above. \\
\hline
\end{tabular}


Table 1. (continued).

\begin{tabular}{|c|c|}
\hline \multicolumn{2}{|c|}{ MFC-702, Plant Services Equipment Storage Building } \\
\hline Chapter IV, LLW Requirements & Facility Compliance Information \\
\hline $\begin{array}{l}\text { authorization statement to incorporate conditions } \\
\text { specified in the disposal authorization statement. } \\
\text { Closure plans shall: }\end{array}$ & \\
\hline $\begin{array}{l}\text { (a) Be updated as required during the operational life of } \\
\text { the facility. }\end{array}$ & See Q. above. \\
\hline $\begin{array}{l}\text { (b) Include a description of how the disposal facility } \\
\text { will be closed to achieve long-term stability and } \\
\text { minimize the need for active maintenance following } \\
\text { closure and to ensure compliance with the requirements } \\
\text { of DOE 5400.5, Radiation Protection of the Public and } \\
\text { the Environment. }\end{array}$ & See Q. above. \\
\hline $\begin{array}{l}\text { (c) Include the total expected inventory of wastes to be } \\
\text { disposed of at the facility over the operational life of } \\
\text { the facility. }\end{array}$ & See Q. above. \\
\hline $\begin{array}{l}\text { (2) Disposal Facility Closure. Closure of a disposal } \\
\text { facility shall occur within a five-year period after it is } \\
\text { filled to capacity, or after the facility is otherwise } \\
\text { determined to be no longer needed. }\end{array}$ & See Q. above. \\
\hline $\begin{array}{l}\text { (a) Prior to facility closure, the final inventory of the } \\
\text { low-level waste disposed in the facility shall be } \\
\text { prepared and incorporated in the performance } \\
\text { assessment and composite analysis which shall be } \\
\text { updated to support the closure of the facility. }\end{array}$ & See Q. above. \\
\hline $\begin{array}{l}\text { (b) A final closure plan shall be prepared based on the } \\
\text { final inventory of waste disposed in the facility, the } \\
\text { plan implemented, and the updated performance } \\
\text { assessment and composite analysis prepared in support } \\
\text { of the facility closure. }\end{array}$ & See Q. above. \\
\hline $\begin{array}{l}\text { (c) Institutional control measures shall be integrated } \\
\text { into land use and stewardship plans and programs, and } \\
\text { shall continue until the facility can be released pursuant } \\
\text { to DOE 5400.5, Radiation Protection of the Public and } \\
\text { the Environment. }\end{array}$ & See Q. above. \\
\hline $\begin{array}{l}\text { (d) The location and use of the facility shall be filed } \\
\text { with the local authorities responsible for land use and } \\
\text { zoning. }\end{array}$ & See Q. above. \\
\hline $\begin{array}{l}\text { R. Monitoring. The following requirements are in } \\
\text { addition to those in Chapter I of this Manual [DOE M } \\
435.1-1 \text { §I.1.E(7)]. }\end{array}$ & $\begin{array}{l}\text { DOE Manual 435.1-1 §I.1.E(7) applies to field element } \\
\text { managers. }\end{array}$ \\
\hline $\begin{array}{l}\text { (1) All Waste Facilities. Parameters that shall be } \\
\text { sampled or monitored, at a minimum, include: } \\
\text { temperature, pressure (for closed systems), } \\
\text { radioactivity in ventilation exhaust and liquid effluent } \\
\text { streams, and flammable or explosive mixtures of gases. } \\
\text { Facility monitoring programs shall include verification } \\
\text { that passive and active control systems have not failed. }\end{array}$ & $\begin{array}{l}\text { Monitoring requirements at INL radioactive waste } \\
\text { management facilities are tailored for the specific } \\
\text { facility to enable timely indication of developing } \\
\text { problems. Existing radiological control procedures and } \\
\text { assessments are followed/completed to monitor waste } \\
\text { facilities. }\end{array}$ \\
\hline
\end{tabular}


Table 1. (continued).

\begin{tabular}{|c|c|}
\hline \multicolumn{2}{|c|}{ MFC-702, Plant Services Equipment Storage Building } \\
\hline Chapter IV, LLW Requirements & Facility Compliance Information \\
\hline $\begin{array}{l}\text { From DOE G 435.1-1 Chapter IV: The minimum } \\
\text { parameters specified in the requirement were selected } \\
\text { based on their potential significance for anticipating } \\
\text { and identifying undesirable conditions at low-level } \\
\text { waste management facilities. Each facility's radioactive } \\
\text { waste management basis should include an evaluation } \\
\text { of the applicability and significance of the minimum } \\
\text { parameters. This evaluation also needs to consider } \\
\text { additional parameters to be sampled or monitored to } \\
\text { ensure the protection of the public health, the } \\
\text { environment, and the workers. If a minimum parameter } \\
\text { specified in the requirement is deemed to be not } \\
\text { applicable in any way to the active operation of that } \\
\text { facility, then that justification should be included in the } \\
\text { radioactive waste management basis and when } \\
\text { approved constitutes an exemption to the manual. }\end{array}$ & $\begin{array}{l}\text { LRD-15001 and MCP-139 specify methods and } \\
\text { frequency of radiological control surveys of all } \\
\text { radiological areas. MCP-139 specifies the use of } \\
\text { Form } 441 . A 34 \text {. This form is referred to as the "routine } \\
\text { sheet" and is to be used by facility radiological control } \\
\text { foremen to list radiological areas that are to be surveyed, } \\
\text { the survey periods, and methods. }\end{array}$ \\
\hline $\begin{array}{l}\text { Verification activities are part of the radioactive waste } \\
\text { management basis as a condition for operation and } \\
\text { documented appropriately. }\end{array}$ & \\
\hline $\begin{array}{l}\text { Compliance with this requirement is demonstrated if } \\
\text { monitoring or sampling for the stated parameters is } \\
\text { performed for all facilities with a precision, accuracy, } \\
\text { and frequency consistent with timely identification of } \\
\text { developing problems and a justification exists in the } \\
\text { approved radioactive waste management basis for those } \\
\text { specified parameters which are not monitored or } \\
\text { sampled. }\end{array}$ & \\
\hline $\begin{array}{l}\text { (2) Liquid Waste Storage Facilities. For facilities } \\
\text { storing liquid low-level waste, the following shall also } \\
\text { be monitored: liquid level and/or waste volume, and } \\
\text { significant waste chemistry parameters. }\end{array}$ & NA; this facility does not store liquid LLW. \\
\hline $\begin{array}{l}\text { (3) Disposal Facilities. A preliminary monitoring plan } \\
\text { for a low-level waste disposal facility shall be prepared } \\
\text { and submitted to Headquarters for review with the } \\
\text { performance assessment and composite analysis. The } \\
\text { monitoring plan shall be updated within one year } \\
\text { following issuance of the disposal authorization } \\
\text { statement to incorporate and implement conditions } \\
\text { specified in the disposal authorization statement. }\end{array}$ & NA; this facility does not dispose of LLW. \\
\hline $\begin{array}{l}\text { (a) The site-specific performance assessment and } \\
\text { composite analysis shall be used to determine the } \\
\text { media, locations, radionuclides, and other substances to } \\
\text { be monitored. }\end{array}$ & See (3) above. \\
\hline $\begin{array}{l}\text { (b) The environmental monitoring program shall be } \\
\text { designed to include measuring and evaluating releases, } \\
\text { migration of radionuclides, disposal unit subsidence, } \\
\text { and changes in disposal facility and disposal site } \\
\text { parameters which may affect long-term performance. }\end{array}$ & See (3) above. \\
\hline
\end{tabular}


Table 1. (continued).

\begin{tabular}{|l|l|}
\hline \multicolumn{2}{|c|}{ MFC-702, Plant Services Equipment Storage Building } \\
\hline \multicolumn{1}{|c|}{ Chapter IV, LLW Requirements } & \multicolumn{1}{|c|}{ Facility Compliance Information } \\
\hline $\begin{array}{l}\text { (c) The environmental monitoring programs shall be } \\
\text { capable of detecting changing trends in performance to } \\
\text { allow application of any necessary corrective action } \\
\text { prior to exceeding the performance objectives in this } \\
\text { Chapter. }\end{array}$ & See (3) above. \\
\hline
\end{tabular}

\subsection{MFC-703, Sodium Storage Building}

1. Facility description: MFC-703 consists of one building used for container storage. The Sodium Storage Building is a prefabricated steel frame building with uninsulated metal wall and roof panels. The wall and roof panels are nestable ribbed-type panels of painted steel. Steel flashing, closures, and trim provide weather-tight construction and finishing to the building. End laps in roofing and side walls, in addition to all flashing and vertical joints of siding, are sealed with continuous beads of sealant or sealant tape. Ridge vents and wall louvers, providing building passive ventilation, are designed to prevent moisture influx into the building.

MFC-703 is $50 \times 100 \mathrm{ft}$ with a nominal eave height of $12 \mathrm{ft}(10 \mathrm{ft}$ clear at the inside haunch connection of the structural frame). The building was placed on a 6-in. reinforced-concrete slab elevated slightly above grade ensuring that any precipitation drains away from the building. Access into the building is limited to two personnel doors and one $14 \times 12$-ft overhead door for forklift access on the east end. The doors are maintained closed and locked except when access is necessary for inspection or other routine activities. The electrical system in the Sodium Storage Building consists of a $480-\mathrm{V}$, three-phase power service transformed to $120 / 208-\mathrm{V}$ power for lighting, receptacles, overhead door motor, and the fire alarm and detection system.

2. Hazard category: Less-than-hazard-category-3 facility (LTHC3)

3. Radioactive waste managed at this facility: CH LLW and liquid mixed CH LLW are stored at this facility.

4. RWMB documents/programs:

a. Safety basis/hazard analysis:

- EDF-7030, "Inventory Analysis of Radiological Facilities at the Materials and Fuels Complex (MFC)"

b. Laboratory-wide:

- Form 441.A34, "INL Radiological Control Required Surveys"

- FRM-323, "TSD Facilities Material Acceptance Checksheet"

- LI-435, "Waste Management Routine Field Activities"

- LRD-15001, "Radiological Control Manual"

- LWP-13840, "Management of Issues, Observations, and Noteworthy Practices"

- LWP-14002, "Timeout and Stop Work Authority"

- LWP-15011, "Radioactive Material Areas and Radioactive Storage Areas"

- MCP-139, "Radiological Surveys"

- MCP-17000, "Waste Generator Services Waste Management" 
- MCP-17410, "Management of Waste Storage Areas"

- MCP-17500, "Waste Generator Services Certification of Waste Shipments to the Nevada Test Site"

- PDD-17000, "Waste Management Program"

- PLN-114, "INL Emergency Plan/RCRA Contingency Plan"

- PLN-522, "Quality Assurance Program Plan for the Waste Management/Waste Certification Program"

c. Facility-specific:

- PER-116, "HWMA/RCRA Storage and Treatment Permit for the Materials and Fuels Complex"

- SD-38.1.1, "Treatment, Storage, and Disposal Facilities (TSDF) Environmental Compliance"

- TSD-OI-004, "Waste and Material Acceptance for Storage/Treatment and Radioactive Material Inventory Control."

LLW is managed at this facility. Table 2 presents the facility compliance information for Chapter IV, "Low-level Waste Requirements."

Table 2. MFC-703, Sodium Storage Building, DOE Manual 435.1-1 low-level waste requirements and facility compliance information.

\begin{tabular}{|c|c|}
\hline \multicolumn{2}{|c|}{ MFC-703, Sodium Storage Building } \\
\hline Chapter IV, LLW Requirements & Facility Compliance Information \\
\hline $\begin{array}{l}\text { A. Definition of Low-Level Waste. Low-level } \\
\text { radioactive waste is radioactive waste that is not high- } \\
\text { level radioactive waste, spent nuclear fuel, transuranic } \\
\text { waste, byproduct material (as defined in section 11e.( } 2 \text { ) } \\
\text { of the Atomic Energy Act of 1954, as amended), or } \\
\text { naturally occurring radioactive material. } \\
\text { (From DOE G } 435.1-1 \text { Chapter IV: Low-level } \\
\text { radioactive waste is defined by what it is not. The } \\
\text { guidance on definitions in Chapters II and III should be } \\
\text { consulted first for making a determination on how to } \\
\text { properly manage a suspect waste stream.) }\end{array}$ & $\begin{array}{l}\text { This requirement provides the criteria for determining } \\
\text { which DOE radioactive waste is to be managed as } \\
\text { LLW in accordance with DOE Manual } 435.1-1 \text {, } \\
\text { Chapter IV. } \\
\text { Radioactive waste managed at this facility under the } \\
\text { requirements of this chapter is not managed under the } \\
\text { requirements of DOE Manual } 435.1-1 \text {, Chapter II or } \\
\text { Chapter III. }\end{array}$ \\
\hline $\begin{array}{l}\text { B. Management of Specific Wastes. The following } \\
\text { provide for management of specific wastes as low-level } \\
\text { waste in accordance with the requirements in this } \\
\text { Chapter: }\end{array}$ & See below. \\
\hline $\begin{array}{l}\text { (1) Mixed Low-Level Waste. Low-level waste } \\
\text { determined to contain both source, special nuclear, or } \\
\text { byproduct material subject to the Atomic Energy Act of } \\
\text { 1954, as amended, and a hazardous component subject } \\
\text { to the Resource Conservation and Recovery Act } \\
\text { (RCRA), as amended, shall be managed in accordance } \\
\text { with the requirements of RCRA and DOE O 435.1, } \\
\text { Radioactive Waste Management, and this Manual. }\end{array}$ & $\begin{array}{l}\text { This facility has a Hazardous Waste Management Act } \\
\text { (HWMA)/RCRA permit to store mixed waste (PER- } \\
\text { 116). This facility stores mixed LLW only. }\end{array}$ \\
\hline $\begin{array}{l}\text { (2) TSCA-Regulated Waste. Low-level waste } \\
\text { containing polychlorinated biphenyls, asbestos, or other } \\
\text { such regulated toxic components shall be managed in }\end{array}$ & $\begin{array}{l}\text { NA; this facility does not manage TSCA-regulated } \\
\text { waste. }\end{array}$ \\
\hline
\end{tabular}


Table 2. (continued).

MFC-703, Sodium Storage Building

\begin{tabular}{l}
\hline \multicolumn{1}{|c|}{ Chapter IV, LLW Requirements } \\
\hline accordance with requirements derived from the Toxic \\
Substances Control Act, as amended, DOE O 435.1, \\
Radioactive Waste Management, and this Manual. \\
\hline (3) Accelerator-Produced Waste. Radioactive waste \\
produced as a result of operations of DOE accelerators \\
is low-level waste and shall be managed in accordance \\
with DOE O 435.1, Radioactive Waste Management, \\
and this Manual, and all applicable Federal or State \\
requirements.
\end{tabular}

(4) 11e.(2) and Naturally Occurring Radioactive Material. Small quantities of 11e.(2) byproduct material and naturally occurring radioactive material may be managed as low-level waste provided they can be managed to meet the requirements for low-level waste disposal in Section IV.P of this Manual.

C. Complex-Wide Low-Level Waste Management Program. A complex-wide program and plan shall be developed as described under Responsibilities, 2.B and 2.D, in Chapter I of this Manual.

D. Radioactive Waste Management Basis. Low-level waste facilities, operations, and activities shall have a radioactive waste management basis consisting of physical and administrative controls to ensure the protection of workers, the public, and the environment. The following specific waste management controls shall be part of the radioactive waste management basis:

(1) Generators. The waste certification program.

From DOE G 435.1-1 Chapter IV: For a facility that generates low-level waste, the radioactive waste management basis is to include the program for certifying that waste meets the waste acceptance requirements of the facility(ies) to which the waste will be sent.

(2) Treatment Facilities. certification program. The waste acceptance requirements and the waste [sic]

From DOE G 435.1-1 Chapter IV: Facilities that store or treat low-level waste are to have approved waste acceptance requirements (see DOE M 435.1-1, Section IV.G) prior to the issuance of a radioactive waste management basis.

A facility that stores or treats waste also is generally expected to have a waste certification program. Waste from these facilities will have to be certified as meeting the waste acceptance requirements of the facility to which it will be transferred, and the facilities have the
NA; this facility does not manage accelerator-produced waste.

Facility Compliance Information

NA; this facility does not manage naturally occurring radioactive material.

Not a facility-specific requirement. DOE Manual 435.1-1 §I.2.B and §I.2.D apply to the Assistant Secretary for Environmental Management and the Deputy Assistant Secretary for Waste Management, respectively.

The RWMB provides the regulatory framework for management of radioactive waste at INL. It specifically identifies facility management and implementing documents for the generation, storage, treatment, and disposal of radiological waste.

This facility is a LTHC3 facility (EDF-7030).

NA; this facility does not generate LLW.

NA; this facility does not treat LLW. 
Table 2. (continued).

MFC-703, Sodium Storage Building

\begin{tabular}{|l|}
\hline \multicolumn{1}{|c|}{ Chapter IV, LLW Requirements } \\
\hline potential for generating radioactive waste (e.g., \\
secondary processing streams from treatment, \\
monitoring and sampling, radioactive release cleanup). \\
Consequently, storage and treatment facilities should \\
also have an approved waste certification program as \\
part of their radioactive waste management basis. \\
As part of the radioactive waste management basis, site \\
personnel needs to implement a system or process for \\
tracking the waste inventory at a storage, treatment, or \\
disposal facility.
\end{tabular}

(3) Storage Facilities. The waste acceptance requirements and the waste certification program.

From DOE G 435.1-1 Chapter IV: Facilities that store or treat low-level waste are to have approved waste acceptance requirements (see DOE M 435.1-1, Section IV.G) prior to the issuance of a radioactive waste management basis.

A facility that stores or treats waste also is generally expected to have a waste certification program. Waste from these facilities will have to be certified as meeting the waste acceptance requirements of the facility to which it will be transferred, and the facilities have the potential for generating radioactive waste (e.g., secondary processing streams from treatment, monitoring and sampling, radioactive release cleanup). Consequently, storage and treatment facilities should also have an approved waste certification program as part of their radioactive waste management basis.

As part of the radioactive waste management basis, site personnel needs to implement a system or process for tracking the waste inventory at a storage, treatment, or disposal facility.

(4) Disposal Facilities. The performance assessment, composite analysis, disposal authorization statement, closure plan, waste acceptance requirements, and monitoring plan.

E. Contingency Actions. The following requirements are in addition to those in Chapter I of this Manual [DOE M 435.1-1 §I.1.E(5)].

(1) Contingency Storage. For off-normal or emergency situations involving high activity or high hazard liquid low-level waste storage or treatment, spare capacity with adequate capabilities shall be maintained to receive the largest volume of liquid contained in any

See G. and J. below.

MCP-17000 §4 specifies the use of IWTS, which tracks the waste inventory.

TSD-OI-004 \$3.2.1 addresses the use of IWTS to track waste inventory.
$\mathrm{NA}$; this facility is not a disposal facility.

Not a facility-specific requirement. DOE Manual 435.1-1 §I.1.E(5) addresses the sitewide emergency management system. The INL plan is provided in PLN-114.

The HWMA/RCRA permit also includes a contingency plan (PER-116, Attachment 7, §G).

NA; this facility does not store liquid waste in tanks. 
Table 2. (continued).

\section{MFC-703, Sodium Storage Building}

\begin{tabular}{|c|c|}
\hline Chapter IV, LLW Requirements & Facility Compliance Information \\
\hline \multicolumn{2}{|l|}{$\begin{array}{l}\text { one storage tank or treatment facility. Tanks or other } \\
\text { facilities that are designated low-level waste } \\
\text { contingency storage shall be maintained in an } \\
\text { operational condition when waste is present and shall } \\
\text { meet the requirements of DOE O 435.1, Radioactive } \\
\text { Waste Management, and this Manual. }\end{array}$} \\
\hline \multicolumn{2}{|l|}{$\begin{array}{l}\text { From DOE G 435.1-1 Chapter IV: Compliance with } \\
\text { these requirements is demonstrated if adequate spare } \\
\text { capacity and transfer equipment exists for emergency } \\
\text { transfers of all high activity and high hazard liquid low- } \\
\text { level waste. In addition, the capability to perform } \\
\text { emergency transfers is demonstrated by having waste } \\
\text { transfer routings identified, operational procedures to } \\
\text { direct transfers, staff trained to the procedures, and } \\
\text { records showing that the spare capacity and transfer } \\
\text { capability are kept in operating condition. }\end{array}$} \\
\hline $\begin{array}{l}\text { (2) Transfer Equipment. Pipelines and auxiliary } \\
\text { facilities necessary for the transfer of high activity or } \\
\text { high hazard liquid low-level waste to contingency } \\
\text { storage shall be maintained in an operational condition } \\
\text { when waste is present and shall meet the requirements } \\
\text { of DOE O } 435.1 \text {, Radioactive Waste Management, and } \\
\text { this Manual. }\end{array}$ & NA; this facility does not store liquid waste in tanks. \\
\hline \multicolumn{2}{|l|}{$\begin{array}{l}\text { From DOE G 435.1-1 Chapter IV: Compliance with } \\
\text { these requirements is demonstrated if adequate spare } \\
\text { capacity and transfer equipment exists for emergency } \\
\text { transfers of all high activity and high hazard liquid low- } \\
\text { level waste. In addition, the capability to perform } \\
\text { emergency transfers is demonstrated by having waste } \\
\text { transfer routings identified, operational procedures to } \\
\text { direct transfers, staff trained to the procedures, and } \\
\text { records showing that the spare capacity and transfer } \\
\text { capability are kept in operating condition. }\end{array}$} \\
\hline \multirow{4}{*}{$\begin{array}{l}\text { F. Corrective Actions. I of this Manual. The following } \\
\text { requirements are in addition to those in Chapter [sic] } \\
\text { From DOE G 435.1-1 Chapter IV: Compliance with } \\
\text { DOE M 435.1-1 §I.2.G.(1) is demonstrated by records } \\
\text { showing what corrective actions were taken to remedy } \\
\text { situations in the radioactive waste management system. } \\
\text { Compliance with DOE M 435.1-1 §I.2.G.(2) is } \\
\text { demonstrated by having the necessary procedures, } \\
\text { mechanisms, and training in place to effect shutdown } \\
\text { or curtailment of activities which pose an imminent } \\
\text { danger or other serious hazard to workers or the public, } \\
\text { or are not protective of the environment. }\end{array}$} & $\begin{array}{l}\text { The INL-wide procedure addressing problem } \\
\text { identification as required by DOE Manual } 435.1-1\end{array}$ \\
\hline & \\
\hline & $\begin{array}{l}\text { The INL-wide procedure addressing shutdown or } \\
\text { curtailment of activities as required by DOE Manual }\end{array}$ \\
\hline & \\
\hline $\begin{array}{l}\text { (1) Order Compliance. Corrective actions shall be } \\
\text { implemented whenever necessary to ensure the } \\
\text { requirements of DOE O } 435.1 \text {, Radioactive Waste }\end{array}$ & $\begin{array}{l}\text { See F. above. } \\
\text { This facility is has a HWMA/RCRA permit to store }\end{array}$ \\
\hline
\end{tabular}


Table 2. (continued).

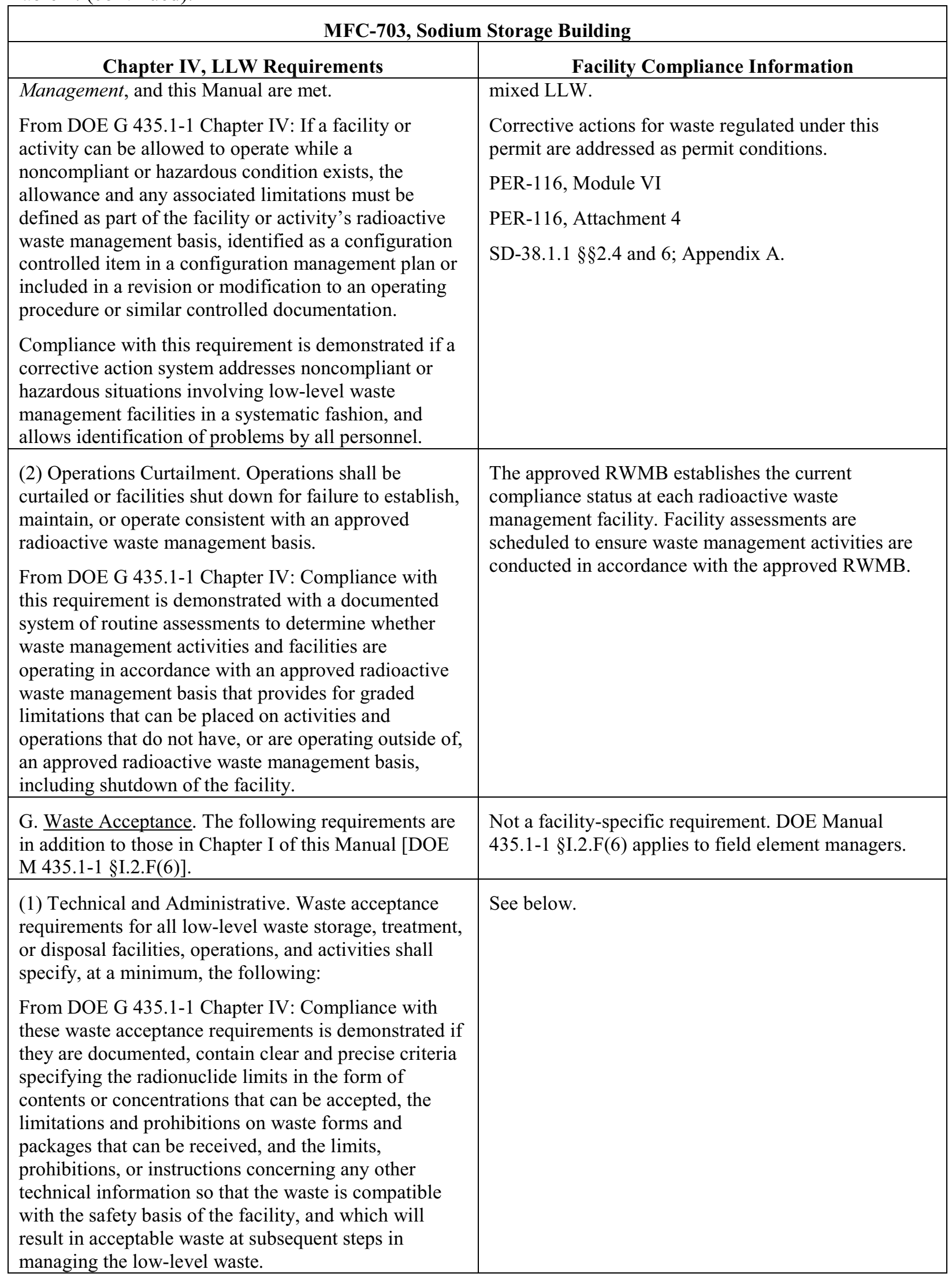


Table 2. (continued).

\begin{tabular}{|c|c|}
\hline \multicolumn{2}{|c|}{ MFC-703, Sodium Storage Building } \\
\hline Chapter IV, LLW Requirements & Facility Compliance Information \\
\hline $\begin{array}{l}\text { (a) Allowable activities and/or concentrations of } \\
\text { specific radionuclides. }\end{array}$ & $\begin{array}{l}\text { MCP-17000 } \\
\text { TSD-OI-004 } \S 3.2 .\end{array}$ \\
\hline $\begin{array}{l}\text { (b) Acceptable waste form and/or container } \\
\text { requirements that ensure the chemical and physical } \\
\text { stability of waste under conditions that might be } \\
\text { encountered during transportation, storage, treatment, } \\
\text { or disposal. }\end{array}$ & $\begin{array}{l}\text { MCP-17000 } \\
\text { TSD-OI-004 } \S 3.3 \text { and } 3.4 \\
\text { PER-116, Module II.C and III } \\
\text { PER-116, Attachment } 1 \S \S B-2(a) \text { and } \S D-1(a) ; \\
\text { Attachment } 2 \S C-2(a) \\
\text { SD-38.1.1, Appendix A and Appendix H. }\end{array}$ \\
\hline $\begin{array}{l}\text { (c) Restrictions or prohibitions on waste, materials, or } \\
\text { containers that may adversely affect waste handlers or } \\
\text { compromise facility or waste container performance. }\end{array}$ & $\begin{array}{l}\text { MCP-17000 } \\
\text { TSD-OI-004 } 33.2 \\
\text { PER-116, Module II.C and III } \\
\text { PER-116, Attachment } 1 \S \S B-2(a) \text { and D-1(a); } \\
\text { Attachment } 2 \S C-2(a) \\
\text { SD-38.1.1, Appendix A and Appendix H. }\end{array}$ \\
\hline $\begin{array}{l}\text { (d) The following are additional waste acceptance } \\
\text { requirements that shall be specified in low-level waste } \\
\text { disposal facility waste acceptance requirements: }\end{array}$ & NA; this facility is not a LLW disposal facility. \\
\hline $\begin{array}{l}1 \text { Low-level waste must contribute to and not detract } \\
\text { from achieving long-term stability of the facility, } \\
\text { minimizing the need for long-term active maintenance, } \\
\text { minimizing subsidence, and minimizing contact of } \\
\text { water with waste. Void spaces within the waste and, if } \\
\text { containers are used, between the waste and its container } \\
\text { shall be reduced to the extent practical. }\end{array}$ & See (d) above. \\
\hline $\begin{array}{l}2 \text { Liquid low-level waste or low-level waste containing } \\
\text { free liquid must be converted into a form that contains } \\
\text { as little freestanding liquid as is reasonably achievable, } \\
\text { but in no case shall the liquid exceed } 1 \text { percent of the } \\
\text { waste volume when the low-level waste is in a disposal } \\
\text { container, or } 0.5 \text { percent of the waste volume after it is } \\
\text { processed to a stable form. }\end{array}$ & See (d) above. \\
\hline $\begin{array}{l}3 \text { Low-level waste must not be readily capable of } \\
\text { detonation or of explosive decomposition or reaction at } \\
\text { anticipated pressures and temperatures, or of explosive } \\
\text { reaction with water. Pyrophoric materials contained in } \\
\text { waste shall be treated, prepared, and packaged to be } \\
\text { nonflammable. }\end{array}$ & See (d) above. \\
\hline $\begin{array}{l}4 \text { Low-level waste must not contain, or be capable of } \\
\text { generating by radiolysis or biodegradation, quantities } \\
\text { of toxic gases, vapors, or fumes harmful to the public } \\
\text { or workers or disposal facility personnel, or harmful to } \\
\text { the long-term structural stability of the disposal site. }\end{array}$ & See (d) above. \\
\hline
\end{tabular}


Table 2. (continued).

\begin{tabular}{|c|c|}
\hline \multicolumn{2}{|c|}{ MFC-703, Sodium Storage Building } \\
\hline Chapter IV, LLW Requirements & Facility Compliance Information \\
\hline $\begin{array}{l}5 \text { Low-level waste in a gaseous form must be packaged } \\
\text { such that the pressure does not exceed } 1.5 \text { atmospheres } \\
\text { absolute at } 20 \mathrm{C} \text {. [ sic] }\end{array}$ & See (d) above. \\
\hline $\begin{array}{l}\text { (e) The basis, procedures, and levels of authority } \\
\text { required for granting exceptions to the waste } \\
\text { acceptance requirements, which shall be contained in } \\
\text { each facility's waste acceptance documentation. Each } \\
\text { exception request shall be documented, including its } \\
\text { disposition as approved or not approved. } \\
\text { From DOE G } 435.1-1 \text { Chapter IV: Waste acceptance } \\
\text { requirements are acceptable if they are documented and } \\
\text { contain a clear description of the procedure and bases } \\
\text { for obtaining an exception or deviation to the } \\
\text { acceptance criteria for low-level waste to be received at } \\
\text { the facility. }\end{array}$ & $\begin{array}{l}\text { Exceptions to the waste acceptance requirements are } \\
\text { not permitted. }\end{array}$ \\
\hline $\begin{array}{l}\text { (2) Evaluation and Acceptance. The receiving facility } \\
\text { shall evaluate waste for acceptance, including } \\
\text { confirmation that the technical and administrative } \\
\text { requirements have been met. A process for the } \\
\text { disposition of non-conforming wastes shall be } \\
\text { established. } \\
\text { From DOE G 435.1-1 Chapter IV: Compliance with the } \\
\text { waste acceptance requirements for a low-level waste } \\
\text { management facility is demonstrated if they include a } \\
\text { process for evaluation and acceptance of incoming } \\
\text { waste to ensure the acceptance criteria of the facility } \\
\text { receiving the waste are met that includes one of or a } \\
\text { combination of: (1) testing, sampling, and analysis of } \\
\text { representative samples of waste upon receipt; (2) } \\
\text { testing, sampling, and analysis of split samples of } \\
\text { waste taken at the generator site; (3) evaluation of } \\
\text { testing, sampling, and analysis of data provided by the } \\
\text { generator, or (4) audits, reviews, surveillance, or } \\
\text { observations of generator waste certification programs } \\
\text { and characterization activities. Additionally, acceptable } \\
\text { waste acceptance requirements for a storage, treatment } \\
\text { or disposal facility will have documented procedures } \\
\text { and actions to be taken if a waste that does not conform } \\
\text { to the waste acceptance criteria is received at the } \\
\text { facility. }\end{array}$ & $\begin{array}{l}\text { MCP-17000 } \\
\text { TSD-OI-004 §3 } \\
\text { PER-116, Module II.C and III } \\
\text { PER-116, Attachment } 1 \text { §D-1(b); Attachment } 2 \text { §- } \\
\text { 2(a) } \\
\text { SD-38.1.1, Appendix A and Appendix H } \\
\text { Meeting permit and safety basis constraints are } \\
\text { checked using: } \\
\quad \text { FRM-323 } \\
\text { IWTS material and waste characterization profile } \\
\text { Nonconforming waste is not permitted. }\end{array}$ \\
\hline $\begin{array}{l}\text { H. Waste Generation Planning. The following } \\
\text { requirements are in addition to those in Chapter I of } \\
\text { this Manual [DOE M 435.1-1 §I.2.F(7)]. }\end{array}$ & $\begin{array}{l}\text { Not a facility-specific requirement. DOE Manual } \\
435.1-1 \S I .2 . F(7) \text { applies to field element managers. }\end{array}$ \\
\hline $\begin{array}{l}\text { (1) Life-Cycle Planning. Prior to waste generation, } \\
\text { planning shall be performed to address the entire life } \\
\text { cycle for all low-level waste streams. } \\
\text { From DOE G 435.1-1 Chapter IV: Compliance with }\end{array}$ & NA; LLW is not generated at this facility. \\
\hline
\end{tabular}


Table 2. (continued).

MFC-703, Sodium Storage Building

\begin{tabular}{|c|c|}
\hline Chapter IV, LLW Requirements & Facility Compliance Information \\
\hline $\begin{array}{l}\text { this planning requirement is demonstrated by the } \\
\text { individual sites establishing a process for evaluating the } \\
\text { life-cycle of low-level waste prior to its generation, } \\
\text { including the identification of low-level wastes with no } \\
\text { path to disposal and appropriate records justifying the } \\
\text { newly generated low-level waste stream(s), and site } \\
\text { personnel possessing planning information showing the } \\
\text { location(s) where low-level waste will be stored, } \\
\text { treated, and/or disposed along with a confirmation that } \\
\text { the personnel managing the facilities agree that the } \\
\text { low-level waste may be managed at those facilities. }\end{array}$ & \\
\hline $\begin{array}{l}\text { (2) Waste with No Identified Path to Disposal. Low- } \\
\text { level waste streams with no identified path to disposal } \\
\text { shall be generated only in accordance with approved } \\
\text { conditions which, at a minimum, shall address: }\end{array}$ & $\begin{array}{l}\text { NA; this facility is not generating LLW that does not } \\
\text { have an identified path to disposal. }\end{array}$ \\
\hline (a) Programmatic need to generate the waste; & See (2) above. \\
\hline $\begin{array}{l}\text { (b) Characteristics and issues preventing the disposal of } \\
\text { the waste; }\end{array}$ & See (2) above. \\
\hline $\begin{array}{l}\text { (c) Safe storage of the waste until disposal can be } \\
\text { achieved; and }\end{array}$ & See (2) above. \\
\hline $\begin{array}{l}\text { (d) Activities and plans for achieving final disposal of } \\
\text { the waste. }\end{array}$ & See (2) above. \\
\hline $\begin{array}{l}\text { I. Waste Characterization. Low-level waste shall be } \\
\text { characterized using direct or indirect methods, and the } \\
\text { characterization documented in sufficient detail to } \\
\text { ensure safe management and compliance with the } \\
\text { waste acceptance requirements of the facility receiving } \\
\text { the waste. } \\
\text { From DOE G } 435.1-1 \text { Chapter IV: Compliance with } \\
\text { this requirement is demonstrated by a program for } \\
\text { documenting and the existence of records that } \\
\text { document the process for acquiring and verifying the } \\
\text { validity of low-level waste characterization data } \\
\text { acquired through the use of direct or indirect methods. }\end{array}$ & $\begin{array}{l}\text { MCP-17000 } \\
\text { TSD-OI-004 } \$ 3.2 .6 \text { and Appendix C } \\
\text { PER-116, Module II.C } \\
\text { PER-116, Attachment } 2 \\
\text { SD-38.1.1, Appendix A and Appendix H. }\end{array}$ \\
\hline $\begin{array}{l}\text { (1) Data Quality Objectives. The data quality } \\
\text { objectives process, or a comparable process, shall be } \\
\text { used for identifying characterization parameters and } \\
\text { acceptable uncertainty in characterization data. } \\
\text { From DOE G } 435.1-1 \text { Chapter IV: Compliance with } \\
\text { this requirement is demonstrated by the documented } \\
\text { use of a data quality objectives or a comparable process } \\
\text { for determining the type, quantity, and quality of } \\
\text { characterization data needed to safely manage low- } \\
\text { level waste. }\end{array}$ & $\begin{array}{l}\text { Radioactive waste management facilities characterize } \\
\text { waste in accordance with the requirements of the } \\
\text { receiving storage, treatment, or disposal facility. The } \\
\text { documented use of a data quality objectives process, or } \\
\text { comparable process, was not identified for this facility. }\end{array}$ \\
\hline $\begin{array}{l}\text { (2) Minimum Waste Characterization. Characterization } \\
\text { data shall, at a minimum, include the following }\end{array}$ & $\begin{array}{l}\text { MCP- } 17000 \text {, including } \S \S 4.2,4.3 \text {, and } 4.4 \text {, provides } \\
\text { waste characterization requirements. Information on }\end{array}$ \\
\hline
\end{tabular}


Table 2. (continued).

\section{MFC-703, Sodium Storage Building}

Chapter IV, LLW Requirements

information relevant to the management of the waste:

From DOE G 435.1-1 Chapter IV: Compliance with this requirement is demonstrated by the existence of a program or procedure for determining and records that document characterization of low-level waste consistent with the minimum characterization data requirements.
Facility Compliance Information

absorbent media is required in $\S \S 4.5$ and 4.7 .

MCP-17000 also specifies the use of IWTS that documents characterization data in an IWTS profile.

TSD-OI-004 §3.2.6 and Appendix C

PER-116, Module II.C

PER-116, Attachment 2

SD-38.1.1, Appendix A and Appendix H

FRM-323

IWTS material and waste characterization profile.

(a) Physical and chemical characteristics;

(b) Volume, including the waste and any stabilization or absorbent media;

(c) Weight of the container and contents;

(d) Identities, activities, and concentrations of major radionuclides;

(e) Characterization date;

(f) Generating source; and

(g) Any other information which may be needed to prepare and maintain the disposal facility performance assessment, or demonstrate compliance with applicable performance objectives.

J. Waste Certification. A waste certification program shall be developed, documented, and implemented to ensure that the waste acceptance requirements of facilities receiving low-level waste for storage, treatment, and disposal are met.

From DOE G 435.1-1 Chapter IV: Compliance with the development and documentation portion of the certification requirement is demonstrated by a waste certification plan that identifies the organizations involved, assigns responsibilities for implementing the program, and describes or references the quality assurance, training, procurement controls, records management, and procedures to be used by the program. Acceptable performance for implementing the program is demonstrated when appropriate personnel are trained and follow the procedures that govern their part of the waste certification.

Additionally, acceptable performance is demonstrated if the waste certification plan and procedures are current and controlled in accordance with a document controls program, and records related to certification (e.g., certification statements, training records,
See I. and (2) above.

See I. and (2) above.

See I. and (2) above.

See I. and (2) above.

See I. and (2) above.

See I. and (2) above.

See I. and (2) above.

MCP-17000 cites a waste certification program for LLW destined for NNSS. For waste destined for locations other than NNSS, the waste disposition specialist is responsible for certifying the waste stream by ensuring the waste, as characterized, falls within the limitations of the waste acceptance criteria of the treatment, storage, or disposal facility $(\$ 2)$.

Container procurement is addressed in MCP-17000 $\$ 4.6$.

MCP-17500 provides the WGS waste certification program for LLW to be shipped to NNSS.

Waste certification is performed and tracked using IWTS. Documentation of the IWTS Program is available electronically only.

PLN-522 requires waste technical specialists and waste disposition specialists to complete the appropriate training/qualification before being granted approval authority for profiles within the IWTS Program. The waste certification official, alternate waste certification official, and NNSS packaging certifiers must complete the appropriate training/qualifications to disposition 
Table 2. (continued).

MFC-703, Sodium Storage Building

\begin{tabular}{|c|}
\hline Chapter IV, LLW Requirements \\
\hline $\begin{array}{l}\text { procurement records, characterization records, } \\
\text { container records) are generated and managed in } \\
\text { accordance with the established site program. }\end{array}$ \\
\hline $\begin{array}{l}\text { (1) Certification Program. The waste certification } \\
\text { program shall designate the officials who have the } \\
\text { authority to certify and release waste for shipment; and } \\
\text { specify what documentation is required for waste } \\
\text { generation, characterization, shipment, and } \\
\text { certification. The program shall provide requirements } \\
\text { for auditability, retrievability, and storage of required } \\
\text { documentation and specify the records retention period. }\end{array}$ \\
\hline $\begin{array}{l}\text { From DOE G 435.1-1 Chapter IV: Compliance with } \\
\text { this requirement is demonstrated by a program or } \\
\text { procedure for record keeping and records showing that } \\
\text { low-level waste is certified as having met the waste } \\
\text { acceptance criteria of the facility to which it was } \\
\text { transferred and that the certification statement is } \\
\text { supported by additional records regarding the waste } \\
\text { source, characterization, and container. }\end{array}$ \\
\hline
\end{tabular}

(2) Certification before Transfer. Low-level waste shall be certified as meeting waste acceptance requirements before it is transferred to the facility receiving the waste.

From DOE G 435.1-1 Chapter IV: Compliance with this requirement is demonstrated by the presence of a certification program which includes procedures requiring a signed certification statement prior to the release of waste for transfer, and by dated records showing that waste was certified before being transferred.

(3) Maintaining Certification. Low-level waste that has been certified as meeting the waste acceptance requirements for transfer to a storage, treatment, or disposal facility shall be managed in a manner that maintains its certification status.

From DOE G 435.1-1 Chapter IV: Compliance with this requirement is demonstrated by a program or procedure reflecting this requirement is present and site personnel are able to show that the storage of low-level waste containers is in a facility or manner where the containers would not be damaged by normal weather events, and cannot be accessed by unauthorized personnel. Further, each container can be traced to its

See J. above. MCP-17500 $\$ 4.3 .6$ addresses controls for certification before transfer for LLW to be disposed of at NNSS.
See J. above. Pre-certification checklists are cited in MCP-17000 and MCP-17500. Surveillances alsoare addressed in MCP-17500.

LWP-15011 $\S 5$ provides general radioactive storage area requirements. 
Table 2. (continued).

MFC-703, Sodium Storage Building

\begin{tabular}{|c|c|}
\hline $\begin{array}{l}\text { Chapter IV, LLW Requirements } \\
\text { certification and the information supporting that } \\
\text { certification. }\end{array}$ & Facility Compliance Information \\
\hline $\begin{array}{l}\text { K. Waste Transfer. A documented process shall be } \\
\text { established and implemented for transferring } \\
\text { responsibility for management of low-level waste and } \\
\text { for ensuring availability of relevant data. The following } \\
\text { requirements are in addition to those in Chapter I of } \\
\text { this Manual. } \\
\text { From DOE G 435.1-1 Chapter IV: Compliance with } \\
\text { this requirement is demonstrated if facilities have } \\
\text { procedures for the receipt of waste and the transfer of } \\
\text { waste, as appropriate, which address the acquisition of } \\
\text { waste and container data and the transfer of ownership, } \\
\text { respectively. Further evidence of acceptable } \\
\text { performance is facility records showing that data on the } \\
\text { waste containers is available and accurate, and that } \\
\text { documented transfer of responsibility occurs. }\end{array}$ & $\begin{array}{l}\text { MCP- } 17000 \S 4.8 .15 \text { specifies requirements for } \\
\text { interfacility transfers. } \\
\text { MCP-17500 } \S 4 \text { addresses LLW to be transferred to } \\
\text { NNSS. } \\
\text { TSD-OI-004 } \S \S 3.2,3.4,3.7,3.8 \text {, and } 4 \text {. }\end{array}$ \\
\hline $\begin{array}{l}\text { (1) Authorization. Low-level waste shall not be } \\
\text { transferred to a storage, treatment, or disposal facility } \\
\text { until personnel responsible for the facility receiving the } \\
\text { waste authorize the transfer. } \\
\text { From DOE G } 435.1-1 \text { Chapter IV: Compliance with } \\
\text { this requirement is demonstrated by sites having } \\
\text { procedures that require a confirmation of authorization } \\
\text { before releasing waste for transfer, and records } \\
\text { showing that transfers are made in accordance with } \\
\text { written authorizations. }\end{array}$ & See K. above. \\
\hline $\begin{array}{l}\text { (2) Data. Waste characterization data, container } \\
\text { information, and generation, storage, treatment, and } \\
\text { transportation information for low-level waste shall be } \\
\text { transferred with or be traceable to the waste. } \\
\text { From DOE G 435.1-1 Chapter IV: Compliance with } \\
\text { this requirement is demonstrated if there are procedures } \\
\text { requiring that characterization and container data be } \\
\text { provided and maintained for each low-level waste } \\
\text { transfer and documented records of transfers show that } \\
\text { the information is being provided. }\end{array}$ & See K. above. \\
\hline $\begin{array}{l}\text { L. Packaging and Transportation. The following } \\
\text { requirements are in addition to those in Chapter I of } \\
\text { this Manual [DOE M 435.1-1 §I.1.E(11)]. }\end{array}$ & See (1) and (2) below. \\
\hline $\begin{array}{l}\text { (1) Packaging. If containers are used: } \\
\text { From DOE G 435.1-1 Chapter IV: Compliance with the } \\
\text { packaging requirement is demonstrated by: (1) } \\
\text { procedures which document proper packaging } \\
\text { protocols; and (2) no trends of routine repackaging of } \\
\text { low-level waste that is packaged after issuance of DOE } \\
\text { O 435.1. Successful performance of this requirement is }\end{array}$ & $\begin{array}{l}\text { MCP-17000 } \S 4 \text { addresses packaging requirements. } \\
\text { TSD-OI-004 } § 3.3 \text {. }\end{array}$ \\
\hline
\end{tabular}


Table 2. (continued).

MFC-703, Sodium Storage Building

\begin{tabular}{|c|c|}
\hline Chapter IV, LLW Requirements & Facility Compliance Information \\
\hline $\begin{array}{l}\text { also demonstrated by a record of containers for which } \\
\text { failure has not routinely occurred under management } \\
\text { conditions. It is recognized that there may be failed } \\
\text { containers for waste previously placed in storage. For } \\
\text { those containers, the goal is to only have to repackage } \\
\text { the waste one time after it is retrieved and } \\
\text { characterized. Further, acceptable performance is } \\
\text { demonstrated by containers of waste having marking } \\
\text { and labeling that allows correlation with waste } \\
\text { characterization data and container information. }\end{array}$ & \\
\hline $\begin{array}{l}\text { (a) Low-level waste shall be packaged in a manner that } \\
\text { provides containment and protection for the duration of } \\
\text { the anticipated storage period and until disposal is } \\
\text { achieved or until the waste has been removed from the } \\
\text { container. }\end{array}$ & See (1) above. \\
\hline $\begin{array}{l}\text { (b) When waste is packaged, vents or other measures } \\
\text { shall be provided if the potential exists for pressurizing } \\
\text { or generating flammable or explosive concentrations of } \\
\text { gases within the waste container. }\end{array}$ & See (1) above. \\
\hline $\begin{array}{l}\text { (c) Containers of low-level waste shall be marked such } \\
\text { that their contents can be identified. }\end{array}$ & See (1) above. \\
\hline $\begin{array}{l}\text { (2) Transportation. To the extent practical, the volume } \\
\text { of waste and number of low-level waste shipments } \\
\text { shall be minimized. }\end{array}$ & $\begin{array}{l}\text { MCP-17000 } \S 4 \text { addresses transportation. The waste } \\
\text { disposition specialist coordinates with packaging and } \\
\text { transportation personnel for waste shipped offsite from } \\
\text { this facility. }\end{array}$ \\
\hline $\begin{array}{l}\text { this requirement can be demonstrated by a combination } \\
\text { of site procedures directing the efficient use of waste } \\
\text { container capacity and documentation showing that } \\
\text { low-level waste shipments are systematically planned } \\
\text { and optimized to the extent practical. }\end{array}$ & $\begin{array}{l}\text { MCP-17500 specifies waste certification official and } \\
\text { waste disposition specialist responsibilities and } \\
\text { coordination with packaging and transportation } \\
\text { personnel for waste shipped directly to NNSS from this } \\
\text { facility. }\end{array}$ \\
\hline $\begin{array}{l}\text { M. Site Evaluation and Facility Design. The following } \\
\text { requirements are in addition to those in Chapter I of } \\
\text { this Manual. }\end{array}$ & $\begin{array}{l}\mathrm{NA} \text {; this requirement addresses new radioactive waste } \\
\text { management facilities or modifications to existing } \\
\text { facilities. }\end{array}$ \\
\hline $\begin{array}{l}\text { (1) Site Evaluation. Proposed locations for low-level } \\
\text { waste facilities shall be evaluated to identify relevant } \\
\text { features that should be avoided or must be considered } \\
\text { in facility design and analyses. }\end{array}$ & See M. above. \\
\hline $\begin{array}{l}\text { (a) Each site proposed for a new low-level waste } \\
\text { facility or expansion of an existing low-level waste } \\
\text { facility shall be evaluated considering environmental } \\
\text { characteristics, geotechnical characteristics, and human } \\
\text { activities, including for a low-level waste disposal } \\
\text { facility, the capability of the site to demonstrate, at a } \\
\text { minimum, whether it is: }\end{array}$ & See M. above. \\
\hline $\begin{array}{l}1 \text { Located to accommodate the projected volume of } \\
\text { waste to be received; }\end{array}$ & See M. above. \\
\hline
\end{tabular}


Table 2. (continued).

MFC-703, Sodium Storage Building

\begin{tabular}{|c|c|}
\hline Chapter IV, LLW Requirements & Facility Compliance Information \\
\hline $\begin{array}{l}2 \text { Located in a flood plain, a tectonically active area, or } \\
\text { in the zone of water table fluctuation; and }\end{array}$ & See M. above. \\
\hline $\begin{array}{l}3 \text { Located where radionuclide migration pathways are } \\
\text { predictable and erosion and surface runoff can be } \\
\text { controlled. }\end{array}$ & See M. above. \\
\hline $\begin{array}{l}\text { (b) Proposed sites with environmental characteristics, } \\
\text { geotechnical characteristics, and human activities for } \\
\text { which adequate protection cannot be provided through } \\
\text { facility design shall be deemed unsuitable for the } \\
\text { location of the facility. }\end{array}$ & See M. above. \\
\hline $\begin{array}{l}\text { (c) Low-level waste disposal facilities shall be sited to } \\
\text { achieve long-term stability and to minimize, to the } \\
\text { extent practical, the need for active maintenance } \\
\text { following final closure. }\end{array}$ & See M. above. \\
\hline $\begin{array}{l}\text { (2) Low-Level Waste Treatment and Storage Facility } \\
\text { Design. The following facility requirements and } \\
\text { general design criteria, at a minimum, apply: }\end{array}$ & See M. above. \\
\hline $\begin{array}{l}\text { (a) Confinement. Low-level waste systems and } \\
\text { components shall be designed to maintain waste } \\
\text { confinement. }\end{array}$ & See M. above. \\
\hline (b) Ventilation. & See M. above. \\
\hline $\begin{array}{l}1 \text { Design of low-level waste treatment and storage } \\
\text { facilities shall include ventilation, if applicable, } \\
\text { through an appropriate filtration system to maintain the } \\
\text { release of radioactive material in airborne effluents } \\
\text { within the requirements and guidelines specified in } \\
\text { applicable requirements. }\end{array}$ & See M. above. \\
\hline $\begin{array}{l}2 \text { When conditions exist for generating gases in } \\
\text { flammable or explosive concentrations, ventilation } \\
\text { systems or other measures shall be provided to keep the } \\
\text { gases in a non-flammable and nonexplosive condition. } \\
\text { Where concentrations of explosive or flammable gases } \\
\text { are expected to approach the lower flammability limit, } \\
\text { measures shall be taken to prevent deflagration or } \\
\text { detonation. }\end{array}$ & See M. above. \\
\hline $\begin{array}{l}\text { (c) Consideration of Decontamination and } \\
\text { Decommissioning. Areas in new and modifications to } \\
\text { existing low-level waste management facilities that are } \\
\text { subject to contamination with radioactive or other } \\
\text { hazardous materials shall be designed to facilitate } \\
\text { decontamination. For such facilities a proposed } \\
\text { decommissioning method or a conversion method } \\
\text { leading to reuse shall be described. }\end{array}$ & See M. above. \\
\hline $\begin{array}{l}\text { (d) Instrumentation and Control Systems. Engineering } \\
\text { controls shall be incorporated in the design and }\end{array}$ & See M. above. \\
\hline
\end{tabular}


Table 2. (continued).

MFC-703, Sodium Storage Building

\begin{tabular}{|l|l|}
\hline \multicolumn{1}{|c|}{ Chapter IV, LLW Requirements } & Facility Compliance Information \\
\hline engineering of low-level waste treatment and storage & \\
facilities to provide volume inventory data and to & \\
prevent spills, leaks, and overflows from tanks or & \\
confinement systems. & \\
\hline
\end{tabular}

(e) Monitoring. Monitoring and/or leak detection capabilities shall be incorporated in the design and engineering of low-level waste treatment and storage facilities to provide rapid identification of failed confinement and/or other abnormal conditions.

(3) Low-Level Waste Disposal Facility Design. The following facility requirements and general design criteria, at a minimum, apply:

(a) Confinement. Low-level waste systems and components shall be designed to maintain waste confinement.

\section{(b) Ventilation.}

1 Design of low-level waste disposal facilities shall include ventilation, if applicable, through an appropriate filtration system to maintain the release of radioactive material in airborne effluents within the requirements and guidelines specified in applicable requirements.

2 When conditions exist for generating gases in flammable or explosive concentrations, ventilation systems or other measures shall be provided to keep the gases in a nonflammable and non-explosive condition. Where concentrations of explosive or flammable gases are expected to approach the lower flammability limit, measures shall be taken to prevent deflagration or detonation.

(c) Stability. Low-level waste disposal facilities shall be designed to achieve long-term stability and to minimize to the extent practical, the need for active maintenance following final closure.

(d) Control of Water. Low-level waste disposal facilities shall be designed to minimize to the extent practical, the contact of waste with water during and after disposal.

N. Storage and Staging. The following requirements are in addition to those in Chapter I of this Manual [DOE M 435.1-1 §I.2.F(13)].

(1) Storage Prohibitions. Low-level waste in storage shall not be readily capable of detonation, explosive decomposition, reaction at anticipated pressures and temperatures, or explosive reaction with water. Prior to storage, pyrophoric materials shall be treated, prepared,
See M. above.

See M. above.

See M. above.

See M. above.

See M. above.

See M. above.

See M. above.

See M. above.

Not a facility-specific requirement. DOE Manual

435.1-1 §I.2.F(13) applies to field element managers.

MCP-17000

TSD-OI-004 $\$ 3.2$

PER-116, Module II.C and III 
Table 2. (continued).

MFC-703, Sodium Storage Building

\begin{tabular}{|l|}
\hline \multicolumn{1}{|c|}{ Chapter IV, LLW Requirements } \\
\hline and packaged to be nonflammable. \\
From DOE G 435.1-1 Chapter IV: Compliance with \\
this requirement is demonstrated by having waste \\
acceptance requirements which prohibit low-level \\
waste that is ignitable or explosive from being accepted \\
for storage unless it has been treated, and procedures \\
for properly preparing such materials for safe storage.
\end{tabular}

(2) Storage Limit. Low-level waste that has an identified path to disposal shall not be stored longer than one year prior to disposal, except for storage for decay, or as otherwise authorized by the Field Element Manager.

From DOE G 435.1-1 Chapter IV: Storage longer than one year can be justified if the conditions for such storage are approved by the Field Element Manager as part of the radioactive waste management basis for the facility.

Storage for radioactive decay for a period greater than 1 year for waste that has an identified path to disposal is allowed. Adequate justification and the supporting information for storage for decay is to be documented in the radioactive waste management basis for the facility in which the storage will take place.

Mixed waste. Under the Federal Facility Compliance Act of 1992, DOE sites were required to develop Site Treatment Plans to bring stored mixed low-level waste into compliance with these requirements. The Site Treatment Plan needs to be consulted and any mixed low-level waste stored for the purpose of accumulation to facilitate treatment must meet Resource

Conservation and Recovery Act storage requirements. There could be several ways within different scenarios that this requirement can be met, as illustrated by the examples below, however, there are basically four ways to show compliance with the requirement and include appropriate provisions in the radioactive waste management basis for the facility in which it is stored.

Legacy waste. As discussed above, the intention of the requirement is not to force malicious compliance or heroic actions which would result in increased risk or safety concerns. Rather, the intention is that waste in storage longer than one year receives additional attention to ensure that the public, the workers, and the environment are protected from the hazards of the waste, and that progress is being made to dispose of the waste. There could be several ways within different scenarios that this requirement can be met, as

Facility Compliance Information

PER-116, Attachment $1 \S \mathrm{D}-1(\mathrm{a})$; Attachment 2 $\S \mathrm{C}-2(\mathrm{a})$

SD-38.1.1, Appendix A and Appendix H

The HWMA/RCRA permit (PER-116, Module III.B.5) allows ignitable (D001) and reactive (D003) hazardous waste to be stored and specifies the conditions under which the waste can be stored safely.

MCP-17000 $\$ 4.8 .16$ addresses storage time limits and waste that is to be stored longer than 1 year.

MCP-17000, Appendix F, addresses storage time limits.

Storage longer than 1 year for mixed waste is allowable under the Site Treatment Plan. 
Table 2. (continued).

\section{MFC-703, Sodium Storage Building}

\begin{tabular}{|c|c|}
\hline Chapter IV, LLW Requirements & Facility Compliance Information \\
\hline $\begin{array}{l}\text { illustrated by the examples below, however, there are } \\
\text { basically four ways to show compliance with the } \\
\text { requirement: }\end{array}$ & \\
\hline $\begin{array}{l}\text { 1) the radioactive waste management basis allows for } \\
\text { storage for no more than one year. }\end{array}$ & \\
\hline $\begin{array}{l}\text { 2) the radioactive waste management basis allows for } \\
\text { storage for no more than one year, or for storage for } \\
\text { decay only for periods greater than a year, which are } \\
\text { specified on a radionuclide basis. }\end{array}$ & \\
\hline $\begin{array}{l}\text { 3) the radioactive waste management basis allows for } \\
\text { storage for more than one year, up to a specified period } \\
\text { of time based on a documented technical evaluation } \\
\text { that the waste can be stored in a manner that does not } \\
\text { cause changes to the waste or waste packages that is } \\
\text { detrimental to the safe storage of the waste, the final } \\
\text { disposal of the waste or to meeting the disposal } \\
\text { performance objectives. }\end{array}$ & \\
\hline $\begin{array}{l}\text { 4) the radioactive waste management basis allows for } \\
\text { storage for decay (with specifics) and for storage for } \\
\text { more than one year for other low-level waste, up to a } \\
\text { specified period of time based on a documented } \\
\text { technical evaluation that the waste can be stored in a } \\
\text { manner that does not cause changes to the waste or } \\
\text { waste packages that is detrimental to the safe storage of } \\
\text { the waste, the final disposal of the waste or to meeting } \\
\text { the disposal performance objectives. }\end{array}$ & \\
\hline $\begin{array}{l}\text { Compliance with this requirement is demonstrated by } \\
\text { the existence of a radioactive waste management basis } \\
\text { for the storage facility approved by the Field Element } \\
\text { Manager that includes the time frames that waste are } \\
\text { allowed to be stored, the necessary justifications for } \\
\text { storage for decay, and the necessary technical } \\
\text { evaluations if storage is to extend significantly beyond } \\
\text { the one-year time frame. }\end{array}$ & \\
\hline (3) Storage Integrity. Low-level waste shall be stored in & МCP-17000 \\
\hline $\begin{array}{l}\text { a location and manner that protects the integrity of } \\
\text { waste for the expected time of storage and minimizes }\end{array}$ & TSD-OI-004 $\S 3.3$ and 3.4 \\
\hline worker exposure. & PER-116, Module III \\
\hline From DOE G 435.1-1 Chapter IV: However, in making & PER-116, Attachment 1, §D-1(a) \\
\hline $\begin{array}{l}\text { developing a radioactive waste management basis for } \\
\text { the activity, particular attention to protection of } \\
\text { workers is needed. }\end{array}$ & SD-38.1.1, Appendix A and Appendix H. \\
\hline $\begin{array}{l}\text { Compliance with this requirement is demonstrated if } \\
\text { sites have storage capabilities for low-level waste that } \\
\text { provide protection to waste containers so that their } \\
\text { integrity will not be damaged through physical or }\end{array}$ & \\
\hline
\end{tabular}


Table 2. (continued).

MFC-703, Sodium Storage Building

\begin{tabular}{|l|}
\hline \multicolumn{1}{|c|}{ Chapter IV, LLW Requirements } \\
\hline $\begin{array}{l}\text { chemical (corrosion) processes and that keep personnel } \\
\text { from spending extended periods of time in the areas } \\
\text { where low-level waste is stored. }\end{array}$ \\
(4) Waste Characterization for Storage. \\
(a) Low-level waste that does not have an identified \\
path to disposal shall be characterized as necessary to \\
meet the data quality objectives and minimum \\
characterization requirements of this Chapter, to ensure \\
safe storage, and to facilitate disposal.
\end{tabular}

(b) Characterization information for all low-level waste in storage shall be maintained as a record in accordance with the requirements for Records Management in Chapter I of this Manual.

From DOE G 435.1-1 Chapter IV: Compliance with this requirement is demonstrated by documented procedures for managing waste characterization and container information on low-level waste as a Federal record. The records are managed per the applicable policies and procedures for records management referenced in DOE O 200.1 and established at the applicable Field Element.

(5) Container Inspection. A process shall be developed and implemented for inspecting and maintaining containers of low-level waste to ensure container integrity is not compromised.

From DOE G 435.1-1 Chapter IV: Compliance with this requirement is demonstrated by: (1) a documented process for waste container inspection and maintenance; and (2) documentation for all waste container inspections and maintenance actions performed.
See below.

This facility does not store LLW that does not have an identified path to disposal.

MCP-17000

TSD-OI-004 $\S 3.8$ and 4

PER-116, Module III

PER-116, Attachment $1 \S \mathrm{D}$ and Attachment 2

SD-38.1.1, Appendix A and Appendix H.

MCP-17000

For mixed LLW:

TSD-OI-004 $\S 3.4 .7$ and 4.3

PER-116, Module III

PER-116, Attachment 4 (this attachment includes examples of facility-specific inspection forms to be used)

SD-38.1.1, Appendix A and Appendix H

LWP-15011 does not include a requirement for inspection.

This facility does not store LLW that is not mixed LLW. LI-435 requires quarterly inspections of radioactive waste containers if waste is stored outdoors or has been in storage for greater than one year.

(6) Storage Management. Low-level waste storage shall be managed to identify and segregate low-level waste from mixed low-level waste.

(7) Staging. Staging of low-level waste shall be for the purpose of the accumulation of such quantities of waste as necessary to facilitate transportation, treatment, and disposal. Staging longer than 90 days shall meet the requirements for storage above and in Chapter I of this Manual.
NA; LLW is not stored at this facility.

NA; LLW is not staged at this facility. 
Table 2. (continued).

\begin{tabular}{|c|c|}
\hline \multicolumn{2}{|c|}{ MFC-703, Sodium Storage Building } \\
\hline Chapter IV, LLW Requirements & Facility Compliance Information \\
\hline $\begin{array}{l}\text { From DOE G } 435.1-1 \text { Chapter IV: The staging of low- } \\
\text { level waste needs to be addressed in the radioactive } \\
\text { waste management basis for the facility that is } \\
\text { performing the staging. Generators, treatment facilities, } \\
\text { and disposal facilities that stage waste must ensure that } \\
\text { the action of staging is included and authorized as part } \\
\text { of their radioactive waste management basis for the } \\
\text { affected facilities, operations, or activities. }\end{array}$ & \\
\hline $\begin{array}{l}\text { Staging longer than } 90 \text { days must be justified, the } \\
\text { conditions for such storage met, and these practices } \\
\text { approved by the Field Element Manager as part of the } \\
\text { radioactive waste management basis for the facility. }\end{array}$ & \\
\hline $\begin{array}{l}\text { Compliance with this requirement is demonstrated by a } \\
\text { staging program that limits the temporary storage of } \\
\text { waste to only circumstances allowed in the } \\
\text { requirement, including justifications for any staging } \\
\text { that exceeds the } 90 \text {-day period, which is documented in } \\
\text { the radioactive waste management basis for the facility. }\end{array}$ & \\
\hline $\begin{array}{l}\text { O. Treatment. Low-level waste treatment to provide } \\
\text { more stable waste forms and to improve the long-term } \\
\text { performance of a low-level waste disposal facility shall } \\
\text { be implemented as necessary to meet the performance } \\
\text { objectives of the disposal facility. }\end{array}$ & NA; treatment is not performed in this facility. \\
\hline $\begin{array}{l}\text { From DOE G } 435.1-1 \text { Chapter IV: Compliance with } \\
\text { this requirement is demonstrated when a treatment } \\
\text { facility or process ensures that treated waste will meet } \\
\text { the minimum waste form requirements of DOE M } \\
435.1 \text { and meet additional disposal facility-specific } \\
\text { waste acceptance requirements for additional stability } \\
\text { or long-term performance of facilities that will receive } \\
\text { the treated waste. }\end{array}$ & \\
\hline $\begin{array}{l}\text { P. Disposal. Low-level waste disposal facilities shall } \\
\text { meet the following requirements. }\end{array}$ & NA; LLW is not disposed of in this facility. \\
\hline $\begin{array}{l}\text { (1) Performance Objectives. Low-level waste disposal } \\
\text { facilities shall be sited, designed, operated, maintained, } \\
\text { and closed so that a reasonable expectation exists that } \\
\text { the following performance objectives will be met for } \\
\text { waste disposed of after September } 26,1988 \text { : }\end{array}$ & See P. above. \\
\hline $\begin{array}{l}\text { (a) Dose to representative members of the public shall } \\
\text { not exceed } 25 \mathrm{mrem}(0.25 \mathrm{mSv}) \text { in a year total effective } \\
\text { dose equivalent from all exposure pathways, excluding } \\
\text { the dose from radon and its progeny in air. }\end{array}$ & See P. above. \\
\hline $\begin{array}{l}\text { (b) Dose to representative members of the public via } \\
\text { the air pathway shall not exceed } 10 \mathrm{mrem}(0.10 \mathrm{mSv}) \\
\text { in a year total effective dose equivalent, excluding the } \\
\text { dose from radon and its progeny. }\end{array}$ & See P. above. \\
\hline
\end{tabular}


Table 2. (continued).

MFC-703, Sodium Storage Building

Chapter IV, LLW Requirements

(c) Release of radon shall be less than an average flux of $20 \mathrm{pCi} / \mathrm{m}^{2} / \mathrm{s}\left(0.74 \mathrm{~Bq} / \mathrm{m}^{2} / \mathrm{s}\right)$ at the surface of the disposal facility. Alternatively, a limit of $0.5 \mathrm{pCi} / 1$ $(0.0185 \mathrm{~Bq} / \mathrm{l})$ of air may be applied at the boundary of the facility.

(2) Performance Assessment. A site-specific radiological performance assessment shall be prepared and maintained for DOE low-level waste disposed of after September 26, 1988. The performance assessment shall include calculations for a 1,000 year period after closure of potential doses to representative future members of the public and potential releases from the facility to provide a reasonable expectation that the performance objectives identified in this Chapter are not exceeded as a result of operation and closure of the facility.

(a) Analyses performed to demonstrate compliance with the performance objectives in this Chapter, and to establish limits on concentrations of radionuclides for disposal based on the performance measures for inadvertent intruders in this Chapter shall be based on reasonable activities in the critical group of exposed individuals. Unless otherwise specified, the assumption of average living habits and exposure conditions in representative critical groups of individuals projected to receive the highest doses is appropriate. The likelihood of inadvertent intruder scenarios may be considered in interpreting the results of the analyses and establishing radionuclide concentrations, if adequate justification is provided.

(b) The point of compliance shall correspond to the point of highest projected dose or concentration beyond a 100 meter buffer zone surrounding the disposed waste. A larger or smaller buffer zone may be used if adequate justification is provided.

(c) Performance assessments shall address reasonably foreseeable natural processes that might disrupt barriers against release and transport of radioactive materials.

(d) Performance assessments shall use DOE-approved dose coefficients (dose conversion factors) for internal and external exposure of reference adults.

(e) The performance assessment shall include a sensitivity/uncertainty analysis.

(f) Performance assessments shall include a demonstration that projected releases of radionuclides to the environment shall be maintained as low as reasonably achievable (ALARA).
Facility Compliance Information

See P. above.

See P. above.

See P. above.

See P. above.

See P. above.

See P. above.

See P. above.

See P. above. 
Table 2. (continued).

MFC-703, Sodium Storage Building

\begin{tabular}{|l|l|}
\hline \multicolumn{1}{|c|}{ Chapter IV, LLW Requirements } & \multicolumn{1}{|c|}{ Facility Compliance Information } \\
\hline $\begin{array}{l}\text { (g) For purposes of establishing limits on radionuclides } \\
\text { that may be disposed of near-surface, the performance } \\
\text { assessment shall include an assessment of impacts to } \\
\text { water resources. }\end{array}$ & See P. above. \\
\hline
\end{tabular}

(h) For purposes of establishing limits on the

See P. above.

concentration of radionuclides that may be disposed of near-surface, the performance assessment shall include an assessment of impacts calculated for a hypothetical person assumed to inadvertently intrude for a temporary period into the low-level waste disposal facility. For intruder analyses, institutional controls shall be assumed to be effective in deterring intrusion for at least 100 years following closure. The intruder analyses shall use performance measures for chronic and acute exposure scenarios, respectively, of 100 mrem $(1 \mathrm{mSv})$ in a year and $500 \mathrm{mrem}(5 \mathrm{mSv})$ total effective dose equivalent excluding radon in air.

(3) Composite Analysis. For disposal facilities which received waste after September 26, 1988, a site-specific radiological composite analysis shall be prepared and maintained that accounts for all sources of radioactive material that may be left at the DOE site and may interact with the low- level waste disposal facility, contributing to the dose projected to a hypothetical member of the public from the existing or future disposal facilities. Performance measures shall be consistent with DOE requirements for protection of the public and environment and evaluated for a 1,000 year period following disposal facility closure. The composite analysis results shall be used for planning, radiation protection activities, and future use commitments to minimize the likelihood that current low- level waste disposal activities will result in the need for future corrective or remedial actions to adequately protect the public and the environment.

(4) Performance Assessment and Composite Analysis Maintenance. The performance assessment and composite analysis shall be maintained to evaluate changes that could affect the performance, design, and operating bases for the facility. Performance assessment and composite analysis maintenance shall include the conduct of research, field studies, and monitoring needed to address uncertainties or gaps in existing data. The performance assessment shall be updated to support the final facility closure. Additional iterations of the performance assessment and composite analysis shall be conducted as necessary during the post-closure period.

See P. above.

See P. above. 
Table 2. (continued).

MFC-703, Sodium Storage Building

Chapter IV, LLW Requirements

Facility Compliance Information

(a) Performance assessments and composite analyses shall be reviewed and revised when changes in waste forms or containers, radionuclide inventories, facility design and operations, closure concepts, or the improved understanding of the performance of the waste disposal facility in combination with the features of the site on which it is located alter the conclusions or the conceptual model(s) of the existing performance assessment or composite analysis.

(b) A determination of the continued adequacy of the performance assessment and composite analysis shall be made on an annual basis, and shall consider the results of data collection and analysis from research, field studies, and monitoring.

(c) Annual summaries of low-level waste disposal operations shall be prepared with respect to the conclusions and recommendations of the performance assessment and composite analysis and a determination of the need to revise the performance assessment or composite analysis.

(5) Disposal Authorization. A disposal authorization statement shall be obtained prior to construction of a new low-level waste disposal facility. Field Elements with existing low-level waste disposal facilities shall obtain a disposal authorization statement in accordance with the schedule in the Complex-Wide Low-Level Waste Management Program Plan. The disposal authorization statement shall be issued based on a review of the facility's performance assessment, composite analysis, performance assessment and composite analysis maintenance, preliminary closure plan, and preliminary monitoring plan. The disposal authorization statement shall specify the limits and conditions on construction, design, operations, and closure of the low-level waste facility based on these reviews. A disposal authorization statement is a part of the radioactive waste management basis for a disposal facility. Failure to obtain a disposal authorization statement by the implementation date of this Order shall result in shutdown of the disposal facility.

(6) Disposal Facility Operations. The disposal facility

See P. above.

See P. above.

See P. above. design and operation must be consistent with the disposal facility closure plan and lead to disposal facility closure that provides a reasonable expectation that performance objectives will be met. Low-level waste shall be disposed in such a manner that achieves the performance objectives stated in this Chapter, consistent with the disposal facility radiological performance assessment. Additional requirements

See P. above. 
Table 2. (continued).

\begin{tabular}{|c|c|}
\hline \multicolumn{2}{|c|}{ MFC-703, Sodium Storage Building } \\
\hline Chapter IV, LLW Requirements & Facility Compliance Information \\
\hline include: & \\
\hline $\begin{array}{l}\text { (a) Operating procedures shall be developed and } \\
\text { implemented for low-level waste disposal facilities that } \\
\text { protect the public, workers, and the environment; } \\
\text { ensure the security of the facility; minimize subsidence } \\
\text { during and after waste emplacement; achieve long-term } \\
\text { stability and minimize the need for long-term active } \\
\text { maintenance; and meet the requirements of the } \\
\text { closure/post-closure plan. }\end{array}$ & See P. above. \\
\hline $\begin{array}{l}\text { (b) Permanent identification markers for disposal } \\
\text { excavations and monitoring wells shall be emplaced. }\end{array}$ & See P. above. \\
\hline $\begin{array}{l}\text { (c) Low-level waste placement into disposal units shall } \\
\text { minimize voids between waste containers. Voids within } \\
\text { disposal units shall be filled to the extent practical. } \\
\text { Uncontainerized bulk waste shall also be placed in a } \\
\text { manner that minimizes voids and subsidence. }\end{array}$ & See P. above. \\
\hline $\begin{array}{l}\text { (d) Operations are to be conducted so that active waste } \\
\text { disposal operations will not have an adverse effect on } \\
\text { any other disposal units. }\end{array}$ & See P. above. \\
\hline $\begin{array}{l}\text { (e) Operations shall include a process for tracking and } \\
\text { documenting low-level waste placement in the facility } \\
\text { by generator source. }\end{array}$ & See P. above. \\
\hline $\begin{array}{l}\text { (7) Alternate Requirements for Low-Level Waste } \\
\text { Disposal Facility Design and Operation. Requirements } \\
\text { other than those set forth in this Section for the design } \\
\text { and operation of a low-level waste disposal facility } \\
\text { may be approved on a specific basis if a reasonable } \\
\text { expectation is demonstrated that the disposal } \\
\text { performance objectives will be met. }\end{array}$ & See P. above. \\
\hline $\begin{array}{l}\text { Q. Closure. The following requirements are in addition } \\
\text { to those in Chapter I of this Manual. }\end{array}$ & NA; LLW is not disposed of in this facility. \\
\hline $\begin{array}{l}\text { (1) Disposal Facility Closure Plans. A preliminary } \\
\text { closure plan shall be developed and submitted to } \\
\text { Headquarters for review with the performance } \\
\text { assessment and composite analysis. The closure plan } \\
\text { shall be updated following issuance of the disposal } \\
\text { authorization statement to incorporate conditions } \\
\text { specified in the disposal authorization statement. } \\
\text { Closure plans shall: }\end{array}$ & See Q. above. \\
\hline $\begin{array}{l}\text { (a) Be updated as required during the operational life of } \\
\text { the facility. }\end{array}$ & See Q. above. \\
\hline $\begin{array}{l}\text { (b) Include a description of how the disposal facility } \\
\text { will be closed to achieve long-term stability and } \\
\text { minimize the need for active maintenance following } \\
\text { closure and to ensure compliance with the requirements } \\
\text { of DOE 5400.5, Radiation Protection of the Public and }\end{array}$ & See Q. above. \\
\hline
\end{tabular}


Table 2. (continued).

\begin{tabular}{|c|c|}
\hline \multicolumn{2}{|c|}{ MFC-703, Sodium Storage Building } \\
\hline Chapter IV, LLW Requirements & Facility Compliance Information \\
\hline the Environment. & \\
\hline $\begin{array}{l}\text { (c) Include the total expected inventory of wastes to be } \\
\text { disposed of at the facility over the operational life of } \\
\text { the facility. }\end{array}$ & See Q. above. \\
\hline $\begin{array}{l}\text { (2) Disposal Facility Closure. Closure of a disposal } \\
\text { facility shall occur within a five-year period after it is } \\
\text { filled to capacity, or after the facility is otherwise } \\
\text { determined to be no longer needed. }\end{array}$ & See Q. above. \\
\hline $\begin{array}{l}\text { (a) Prior to facility closure, the final inventory of the } \\
\text { low-level waste disposed in the facility shall be } \\
\text { prepared and incorporated in the performance } \\
\text { assessment and composite analysis which shall be } \\
\text { updated to support the closure of the facility. }\end{array}$ & See Q. above. \\
\hline $\begin{array}{l}\text { (b) A final closure plan shall be prepared based on the } \\
\text { final inventory of waste disposed in the facility, the } \\
\text { plan implemented, and the updated performance } \\
\text { assessment and composite analysis prepared in support } \\
\text { of the facility closure. }\end{array}$ & See Q. above. \\
\hline $\begin{array}{l}\text { (c) Institutional control measures shall be integrated } \\
\text { into land use and stewardship plans and programs, and } \\
\text { shall continue until the facility can be released pursuant } \\
\text { to DOE } 5400.5, \text { Radiation Protection of the Public and } \\
\text { the Environment. }\end{array}$ & See Q. above. \\
\hline $\begin{array}{l}\text { (d) The location and use of the facility shall be filed } \\
\text { with the local authorities responsible for land use and } \\
\text { zoning. }\end{array}$ & See Q. above. \\
\hline $\begin{array}{l}\text { R. Monitoring. The following requirements are in } \\
\text { addition to those in Chapter I of this Manual [DOE M } \\
\text { 435.1-1 §I.1.E(7)]. }\end{array}$ & See (1), (2), and (3) below. \\
\hline $\begin{array}{l}\text { (1) All Waste Facilities. Parameters that shall be } \\
\text { sampled or monitored, at a minimum, include: } \\
\text { temperature, pressure (for closed systems), } \\
\text { radioactivity in ventilation exhaust and liquid effluent } \\
\text { streams, and flammable or explosive mixtures of gases. } \\
\text { Facility monitoring programs shall include verification } \\
\text { that passive and active control systems have not failed. } \\
\text { From DOE G 435.1-1 Chapter IV: The minimum } \\
\text { parameters specified in the requirement were selected } \\
\text { based on their potential significance for anticipating } \\
\text { and identifying undesirable conditions at low-level } \\
\text { waste management facilities. Each facility's radioactive } \\
\text { waste management basis should include an evaluation } \\
\text { of the applicability and significance of the minimum } \\
\text { parameters. This evaluation also needs to consider } \\
\text { additional parameters to be sampled or monitored to } \\
\text { ensure the protection of the public health, the }\end{array}$ & $\begin{array}{l}\text { Monitoring requirements at INL radioactive waste } \\
\text { management facilities are tailored for the specific } \\
\text { facility to enable timely indication of developing } \\
\text { problems. Existing radiological control procedures and } \\
\text { assessments are followed/completed to monitor waste } \\
\text { facilities. } \\
\text { PER-116, Attachment } 1 \S \mathrm{D} \text { and Attachment } 4 \S \mathrm{F} \\
\text { describe facility monitoring and inspection } \\
\text { requirements. } \\
\text { LRD-15001 and MCP-139 specify methods and } \\
\text { frequency of radiological control surveys of all } \\
\text { radiological areas. MCP-139 specifies the use of } \\
\text { Form } 441 . \text { A34. This form is referred to as the "routine } \\
\text { sheet" and is to be used by facility radiological control } \\
\text { foremen to list radiological areas that are to be } \\
\text { surveyed, the survey periods, and methods. }\end{array}$ \\
\hline
\end{tabular}


Table 2. (continued).

MFC-703, Sodium Storage Building

\begin{tabular}{|c|c|}
\hline Chapter IV, LLW Requirements & Facility Compliance Information \\
\hline $\begin{array}{l}\text { environment, and the workers. If a minimum parameter } \\
\text { specified in the requirement is deemed to be not } \\
\text { applicable in any way to the active operation of that } \\
\text { facility, then that justification should be included in the } \\
\text { radioactive waste management basis and when } \\
\text { approved constitutes an exemption to the manual. }\end{array}$ & \\
\hline $\begin{array}{l}\text { Verification activities are part of the radioactive waste } \\
\text { management basis as a condition for operation and } \\
\text { documented appropriately. }\end{array}$ & \\
\hline $\begin{array}{l}\text { Compliance with this requirement is demonstrated if } \\
\text { monitoring or sampling for the stated parameters is } \\
\text { performed for all facilities with a precision, accuracy, } \\
\text { and frequency consistent with timely identification of } \\
\text { developing problems and a justification exists in the } \\
\text { approved radioactive waste management basis for those } \\
\text { specified parameters which are not monitored or } \\
\text { sampled. }\end{array}$ & \\
\hline $\begin{array}{l}\text { (2) Liquid Waste Storage Facilities. For facilities } \\
\text { storing liquid low-level waste, the following shall also } \\
\text { be monitored: liquid level and/or waste volume, and } \\
\text { significant waste chemistry parameters. }\end{array}$ & NA; liquid LLW waste is not stored at this facility. \\
\hline $\begin{array}{l}\text { (3) Disposal Facilities. A preliminary monitoring plan } \\
\text { for a low-level waste disposal facility shall be prepared } \\
\text { and submitted to Headquarters for review with the } \\
\text { performance assessment and composite analysis. The } \\
\text { monitoring plan shall be updated within one year } \\
\text { following issuance of the disposal authorization } \\
\text { statement to incorporate and implement conditions } \\
\text { specified in the disposal authorization statement. }\end{array}$ & NA; LLW is not disposed of in this facility. \\
\hline $\begin{array}{l}\text { (a) The site-specific performance assessment and } \\
\text { composite analysis shall be used to determine the } \\
\text { media, locations, radionuclides, and other substances to } \\
\text { be monitored. }\end{array}$ & See (3) above. \\
\hline $\begin{array}{l}\text { (b) The environmental monitoring program shall be } \\
\text { designed to include measuring and evaluating releases, } \\
\text { migration of radionuclides, disposal unit subsidence, } \\
\text { and changes in disposal facility and disposal site } \\
\text { parameters which may affect long-term performance. }\end{array}$ & See (3) above. \\
\hline $\begin{array}{l}\text { (c) The environmental monitoring programs shall be } \\
\text { capable of detecting changing trends in performance to } \\
\text { allow application of any necessary corrective action } \\
\text { prior to exceeding the performance objectives in this } \\
\text { Chapter. }\end{array}$ & See (3) above. \\
\hline
\end{tabular}




\subsection{MFC-704, Fuel Manufacturing Facility}

1. Facility description: FMF was constructed in 1986 for the purpose of housing binary (i.e., uranium and zirconium) fuel and its associated manufacturing equipment to sustain a fuel manufacturing operation for Experimental Breeder Reactor (EBR)-II. EBR-II fuel is no longer manufactured in FMF. Activities conducted as part of the FMF mission include (1) processing fuel currently stored at MFC for use elsewhere in the DOE complex, (2) research and development on new fabrication methods for high-density, low-enrichment fuel forms, (3) fuel fabrication for the Fuel Cycle Research and Development Program to investigate options for actinide transmutation fuels and targets, and (4) storage of uranium and TRU elements, including plutonium and neptunium.

FMF operations associated with the aforementioned activities include receipt, storage, handling, inspection, and processing of uranium, plutonium, and other TRU materials. There are five gloveboxes and two operational hoods in FMF. Processing of plutonium-bearing and other TRU materials is performed in the Advanced Fuel Cycle Initiative glovebox and the waste characterization glovebox. Processing of uranium-bearing materials can be performed in all gloveboxes. These include the Advanced Fuel Cycle Iniative, waste characterization, uranium handling, highly enriched uranium, and special nuclear material gloveboxes. Radioactive material is stored in the FMF vault in five storage arrangements: (1) EBR-II subassemblies in a vertical rack, (2) neptunium oxide containers stored in horizontal tubes in a shielded, modular array, (3) uranium, plutonium, and other TRU materials (typically highly enriched uranium fuel and scrap material) in containers of various shapes and sizes stored within modules in racks, (4) long element storage rack, and (5) radioactive material stored in shipping containers on the vault floor.

2. Hazard category: Hazard Category 2 Nuclear Facility

3. Radioactive waste managed at this facility: $\mathrm{CH}$ TRU and mixed $\mathrm{CH}$ TRU waste are generated and stored at this facility. CH LLW and MLLW is generated and staged in this facility subsequent to routine facility operations.

\section{RWMB documents/programs:}

a. Safety Basis/Hazards Analysis:

- IAG-262, "INL Authorization Agreement for the Materials and Fuels Complex (MFC) Fuel Manufacturing Facility (FMF)"

- LST-303, "Safety Basis List for the Materials and Fuels Complex (MFC) Fuel Manufacturing Facility (FMF)"

- SAR-404, "Safety Analysis Report for the Fuel Manufacturing Facility"

b. Laboratory-wide:

- Form 435.83, "Idaho National Laboratory Contact-Handled Transuranic Waste Disposition TSR-Related (Checklist - Requirements - Certification)"

- Form 441.A34, "INL Radiological Control Required Surveys"

- LI-435, "Waste Management Routine Field Activities"

- LRD-15001, "Radiological Control Manual"

- LWP-13840, "Management of Issues, Observations, and Noteworthy Practices"

- LWP-14002, "Timeout and Stop Work Authority"

- LWP-8300, "Transuranic Waste Handling"

- LWP-15011, "Radioactive Material Areas and Radioactive Storage Areas"

- LWP-17000, "Waste Management" 
- MCP-139, "Radiological Surveys"

- MCP-17000, "Waste Generator Services Waste Management"

- MCP-17410, "Management of Waste Storage Areas"

- MCP-17500, "Waste Generator Services Certification of Waste Shipments to the Nevada Test Site"

- PDD-17000, "Waste Management Program"

- PLN-114, "INL Emergency Plan/RCRA Contingency Plan"

- PLN-522, "Quality Assurance Program Plan for the Waste Management/Waste Certification Program"

- PLN-8300, "Materials and Fuels Complex Contact-Handled TRU Waste Certification Program Plan"

c. Facility-specific:

- ANL-NT-192, "The Defense Programs Origin of Transuranic Waste at Argonne National Laboratory-West, H. F. McFarlane, 11/1/2001"

- FMF-OI-015, "General Facility Waste"

- INL/EXT-10-17600, "Process Knowledge Summary Report for Materials and Fuels Complex Contact-handled Transuranic Waste"

- LST-337, "Approved Container/Payload List For Inter-Facility Transfer Operations At MFC"

- RSWF-OI-003, "Material Acceptance for Storage"

- RSWF-OI-004, "Administrative Requirements/Process for Material Transfers"

- TSD-OI-004, "Waste and Material Acceptance for Storage/Treatment and Radioactive Material Inventory Control"

- TSM-OI-003, "Transfer of Hazardous Material in Non-DOT-Certified Packaging between MFC Nuclear Facilities"

TRU waste and LLW are managed at this facility. Table 3shows the facility compliance information for DOE Manual 435.1-1 Chapter III, "Transuranic Waste Requirements," and Table 4 presents the facility compliance information for Chapter IV, "Low-level Waste Requirements."

Table 3. MFC-704, Fuel Manufacturing Facility, DOE Manual 435.1-1 transuranic waste requirements and facility compliance information.

\begin{tabular}{|l|l|}
\hline \multicolumn{2}{|c|}{ Facility Name: MFC-704, Fuel Manufacturing Facility } \\
\hline \multicolumn{1}{|c|}{ Chapter III, TRU Waste Requirements } & \multicolumn{1}{c|}{ Facility Compliance Information } \\
\hline $\begin{array}{l}\text { A. Definition of Transuranic Waste. Transuranic } \\
\text { waste is radioactive waste containing more than 100 } \\
\text { nanocuries (3700 becquerels) of alpha-emitting } \\
\text { transuranic isotopes per gram of waste, with half-lives } \\
\text { greater than 20 years, except for: }\end{array}$ & $\begin{array}{l}\text { This requirement proves the criteria for determining } \\
\text { which DOE radioactive wastes are to be managed as } \\
\text { TRU waste in accordance with DOE Manual 435.1-1, } \\
\text { Chapter III. } \\
\begin{array}{l}\text { From DOE G 435.1-1 Chapter III: The determination } \\
\text { of transuranic waste should be made at the time of } \\
\text { waste certification, that is, each time the waste is } \\
\text { transferred to another person or facility.) }\end{array}\end{array}$ \\
\hline See J. below. \\
\hline (1) High-level radioactive waste; & See A. above. \\
\hline (2) Waste that the Secretary of Energy has & See A. above. \\
\hline
\end{tabular}


Table 3. (continued).

Facility Name: MFC-704, Fuel Manufacturing Facility

\begin{tabular}{|c|}
\hline Chapter III, TRU Waste Requirements \\
\hline $\begin{array}{l}\text { determined, with the concurrence of the Administrator } \\
\text { of the Environmental Protection Agency, does not } \\
\text { need the degree of isolation required by the } 40 \text { CFR } \\
\text { Part } 191 \text { disposal regulations; or }\end{array}$ \\
\hline
\end{tabular}

(3) Waste that the Nuclear Regulatory Commission has approved for disposal on a case-by-case basis in accordance with 10 CFR Part 61.

\section{B. Management of Specific Wastes. The following} provide for management of specific wastes as transuranic waste in accordance with the requirements in this Chapter:

From DOE G 435.1-1 Chapter III:

Compliance with these requirements is demonstrated if RCRA, state-hazardous, and TSCA-regulated radioactive wastes are being managed in compliance with applicable requirements and agreements or in accordance with a consent order, and consistent with the Transuranic Waste Requirements of DOE M 435.1-1.)

(1) Mixed Transuranic Waste. Transuranic waste determined to contain both a hazardous component subject to the Resource Conservation and Recovery Act (RCRA), as amended, and a radioactive component subject to the Atomic Energy Act of 1954, as amended, shall be managed in accordance with the requirements of RCRA and DOE O 435.1, Radioactive Waste Management, and this Manual.

See A. above. Facility Compliance Information

See (1), (2), and (3) below.

MFC-704 generates mixed TRU waste.

This facility manages mixed TRU waste in satellite accumulation areas (SAAs). Management of SAAs is addressed in MCP-17410 and overall management of mixed waste is addressed in MCP-17000.

FMF-OI-015 addresses management of the mixed TRU waste generated in this facility.

LWP-8300 defines the requirements and establishes the process associated with generation, handling, characterization, and storage of $\mathrm{CH}$, mixed, and remote-handled $(\mathrm{RH})$ TRU waste.

(2) TSCA-Regulated Waste. Transuranic waste containing polychlorinated biphenyls, asbestos, or other such regulated toxic components shall be managed in accordance with requirements derived from the Toxic Substances Control Act, as amended, DOE O 435.1, Radioactive Waste Management, and this Manual.

(3) Pre-1970 Transuranic Waste. Transuranic waste disposed of prior to implementation of the 1970 Atomic Energy Commission Immediate Action Directive regarding retrievable storage of transuranic waste is not subject to the requirements of DOE $\mathrm{O}$ 435.1, Radioactive Waste Management, and this Manual.

C. Complex-Wide Transuranic Waste Management Program. A complex-wide program and plan shall be

NA; TSCA-regulated TRU waste is not managed at this facility.

NA; pre-1970 TRU waste is not managed at this facility.

Not a facility-specific requirement. DOE Manual 435.1-
1 §I.2.B and §I.2.D apply to the Assistant Secretary for


Table 3. (continued).

Facility Name: MFC-704, Fuel Manufacturing Facility

\begin{tabular}{|l|l|}
\hline \multicolumn{1}{|c|}{ Chapter III, TRU Waste Requirements } \\
\hline $\begin{array}{l}\text { developed as described under Responsibilities, 2.B } \\
\text { and 2.D, in Chapter I of this Manual. }\end{array}$ \\
From DOE G 435.1-1 Chapter III: \\
$\begin{array}{l}\text { Compliance with this requirement is demonstrated by } \\
\text { the presence of a Complex-Wide Transuranic Waste } \\
\text { Management Program which includes the appropriate } \\
\text { interfaces, technical information, data inputs, and } \\
\text { other elements described in Chapter I of this Manual. }\end{array}$ \\
\hline D. Radioactive Waste Management Basis.
\end{tabular}

Transuranic waste facilities, operations, and activities shall have a radioactive waste management basis consisting of physical and administrative controls to ensure the protection of workers, the public, and the environment. The following specific waste management controls shall be part of the radioactive waste management basis:

From DOE G 435.1-1 Chapter III:

Compliance with this requirement is demonstrated if, the radioactive waste management basis is documented and signed by the Field Element manager or a designee (see DOE M 435.1-1, Section I.1.A, Delegation of Authority) for each transuranic waste management facility, operation, or activity. Using a graded approach, it may be possible to include multiple activities under a single radioactive waste management basis, but it should be possible to objectively identify which activities are covered. Further, the radioactive waste management basis includes or references the controls that are established on a facility-specific basis to address the unique waste management requirements and circumstances for each facility, operation, and/or activity.)

(1) Generators. The waste certification program.

From DOE G 435.1-1 Chapter III:

For a facility that generates transuranic waste, the radioactive waste management basis is to include the program for certifying that waste meets the waste acceptance requirements of the facility(ies) to which the waste will be sent.

(2) Treatment Facilities. certification program. The waste acceptance requirements and the waste [ $\mathrm{sic}]$

From DOE G 435.1-1 Chapter III:

Facilities that store or treat ransuranic waste are to have approved waste acceptance requirements (see DOE M 435.1-1, Section III.G) prior to the issuance of a radioactive waste management basis. The waste

The RWMB provides the regulatory framework for management of radioactive waste at INL. It specifically identifies facility management and implementing documents for the generation, storage, treatment, and disposal of radiological waste. Environmental Management and the Deputy Assistant
Secretary for Waste Management, respectively. 
Table 3. (continued).

Facility Name: MFC-704, Fuel Manufacturing Facility

\begin{abstract}
Chapter III, TRU Waste Requirements acceptance requirements will usually suffice as documentation of the radiological, physical, and chemical limitations on waste that can be safely received at the facility, provided they are developed correctly with consideration of the hazards of the waste to be managed, and are kept up to date. Controls on the radiological, physical and chemical limitations need to include considerations of the potential effects of radiolysis.

A facility that stores or treats waste is generally expected to have a waste certification program. Waste from these facilities will have to be certified as meeting the waste acceptance requirements of the facility to which it will be transferred and the facilities have the potential for generating radioactive waste (e.g., secondary processing streams from treatment, monitoring and sampling, radioactive release cleanup). Consequently, storage and treatment facilities should also have an approved waste certification program as part of their radioactive waste management basis.
\end{abstract}

As part of the radioactive waste management basis, site personnel should implement a system or process for tracking the waste inventory at a storage, treatment, or disposal facility.

(3) Storage Facilities. The waste acceptance requirements and the waste certification program.

From DOE G 435.1-1 Chapter III:

Facilities that store or treat transuranic waste are to have approved waste acceptance requirements (see DOE M 435.1-1, Section III.G) prior to the issuance of a radioactive waste management basis. The waste acceptance requirements will usually suffice as documentation of the radiological, physical, and chemical limitations on waste that can be safely received at the facility, provided they are developed correctly with consideration of the hazards of the waste to be managed, and are kept up to date. Controls on the radiological, physical and chemical limitations need to include considerations of the potential effects of radiolysis.

A facility that stores or treats waste is generally expected to have a waste certification program. Waste from these facilities will have to be certified as meeting the waste acceptance requirements of the facility to which it will be transferred and the facilities have the potential for generating radioactive waste (e.g., secondary processing streams from treatment,
See G. and J. below for waste acceptance and waste certification program requirements.

LWP-8300 and PLN-8300 specifies documentation and packaging. LWP-8300 addresses the use of the IWTS to track waste inventory. 
Table 3. (continued).

Facility Name: MFC-704, Fuel Manufacturing Facility

\begin{tabular}{l}
\hline \multicolumn{1}{|c|}{ Chapter III, TRU Waste Requirements } \\
\hline monitoring and sampling, radioactive release \\
cleanup). Consequently, storage and treatment \\
facilities should also have an approved waste \\
certification program as part of their radioactive waste \\
management basis. \\
As part of the radioactive waste management basis, \\
site personnel should implement a system or process \\
for tracking the waste inventory at a storage, \\
treatment, or disposal facility. \\
\hline
\end{tabular}

(4) Disposal Facilities. The performance assessment, disposal authorization statement, waste acceptance requirements, and monitoring plan.

E. Contingency Actions. The following requirements are in addition to those in Chapter I of this Manual.

From DOE G 435.1-1 Chapter III:

Compliance with these requirements is demonstrated by having adequate spare capacity and transfer equipment exists for emergency transfers of all liquid transuranic waste. In addition, the capability to perform emergency transfers is demonstrated by having waste transfer routings identified, operational procedures to direct transfers, staff trained to the procedures, and records showing that the spare capacity and transfer capability are kept in operating condition.

(1) Contingency Storage. For off-normal or emergency situations involving liquid transuranic waste storage or treatment, spare capacity with adequate capabilities shall be maintained to receive the largest volume of liquid contained in any one storage tank or treatment facility. Tanks or other facilities that are designated transuranic waste contingency storage shall be maintained in an operational condition when waste is present and shall meet the requirements of DOE O 435.1, Radioactive Waste Management, and this Manual.

(2) Transfer Equipment. Pipelines and auxiliary facilities necessary for the transfer of liquid waste to contingency storage shall be maintained in an operational condition when waste is present and shall meet the requirements of DOE $\mathrm{O} 435.1$, Radioactive Waste Management, and this Manual.

F. Corrective Actions. I of this Manual. The following requirements are in addition to those in Chapter [sic]
NA; this facility is not a disposal facility.

DOE Manual 435.1-1 §I.1.E(5) addresses the sitewide emergency management system. The INL plan is provided in PLN-114.
NA; this facility does not store liquid TRU waste.
Facility Compliance Information

NA

Facility Compliance Information


Table 3. (continued).

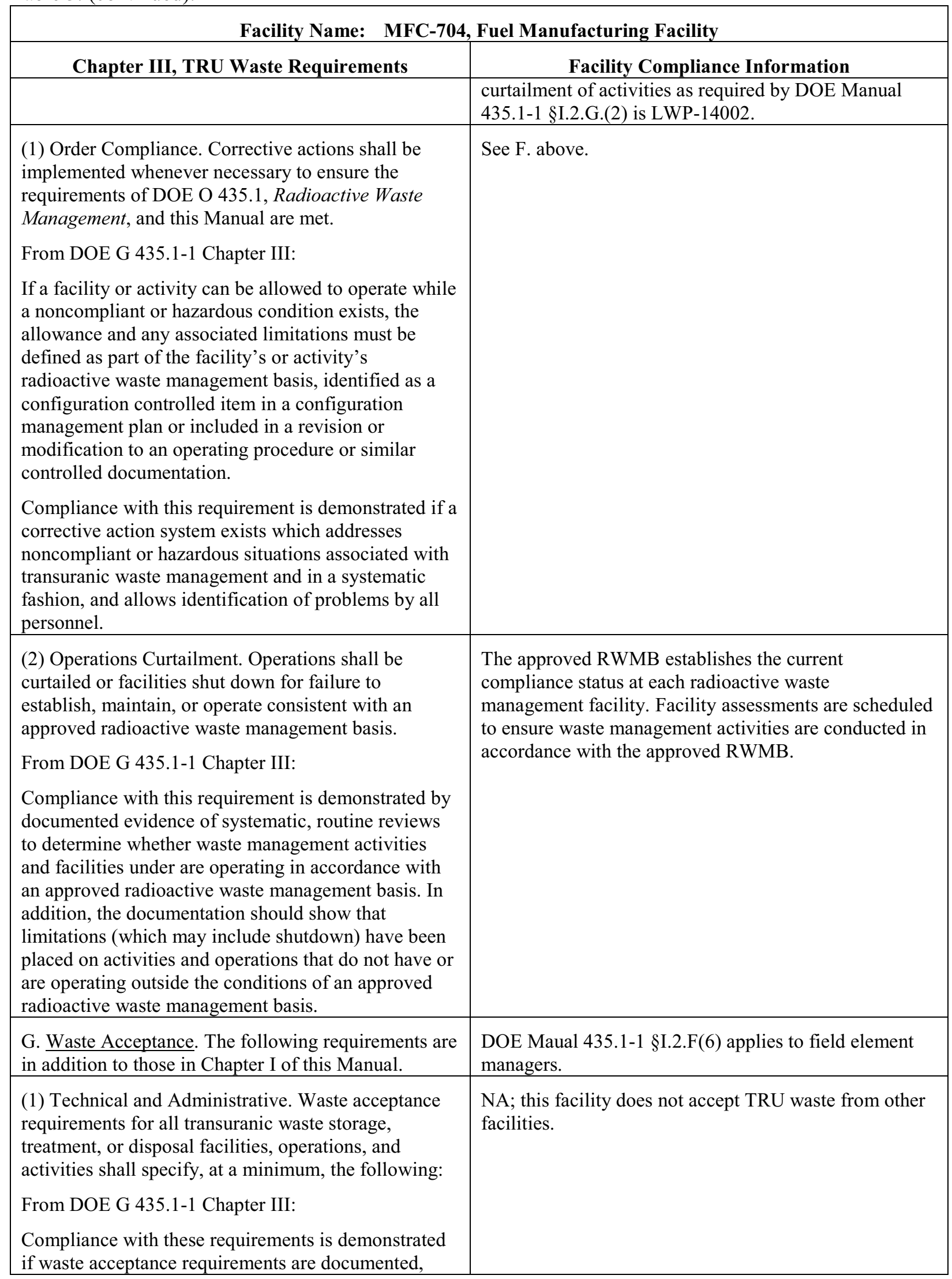


Table 3. (continued).

Facility Name: MFC-704, Fuel Manufacturing Facility

\begin{tabular}{l} 
Chapter III, TRU Waste Requirements \\
\hline contain clear and precise criteria specifying the \\
radionuclide limits in the form of contents or \\
concentrations that can be accepted, the limitations \\
and prohibitions on waste forms and packages that \\
can be received, and the limits, prohibitions, or \\
instructions concerning any other technical \\
information so that the waste is compatible with the \\
safety basis of the facility, and which will result in \\
acceptable waste at subsequent steps in managing the \\
transuranic waste. Waste acceptance requirements are \\
to also contain a clear description of the process and \\
bases for obtaining an exception or deviation to the \\
acceptance criteria for transuranic waste to be \\
received \\
at the facility.
\end{tabular}

(a) Allowable activities and/or concentrations of specific radionuclides;

(b) Acceptable waste form and/or container requirements that ensure the chemical and physical stability of waste under conditions that might be encountered during transportation, storage, treatment, or disposal;

(c) Restrictions or prohibitions on waste, materials, or containers that may adversely affect waste handlers or compromise facility or waste container performance;

(d) Requirement to identify transuranic waste as defense or non-defense, and limitations on acceptance; and

(e) The basis, procedures, and levels of authority required for granting exceptions to the waste acceptance requirements, which shall be contained in each facility's waste acceptance documentation. Each exception request shall be documented, including its disposition as approved or not approved.

(2) Evaluation and Acceptance. The receiving facility shall evaluate waste for acceptance, including confirmation that technical and administrative requirements have been met. A process for the disposition of non-conforming wastes shall be established.

From DOE G 435.1-1 Chapter III:

Compliance with these requirements is demonstrated if there is a procedure or process for evaluating and accepting incoming waste which ensures the acceptance criteria of the facility receiving the waste are met by one or a combination of: (1) testing, sampling, and analysis of representative samples of

See (1) above.

See (1) above.

See (1) above.

See (1) above. Facility Compliance Information

See (1) above.

See (1) above.

See (1) above.

(1)


Table 3. (continued).

Facility Name: MFC-704, Fuel Manufacturing Facility

\begin{tabular}{|l|}
\hline \multicolumn{1}{|c|}{ Chapter III, TRU Waste Requirements } \\
\hline incoming waste upon receipt; (2) testing, sampling, \\
and analysis of samples of waste taken at the \\
generator facility; (3) evaluation of testing, sampling, \\
and analysis of data provided by the generator; or (4) \\
audits, reviews, or surveillances of generator waste \\
certification programs and characterization activities. \\
Additionally, acceptable waste acceptance \\
requirements for a storage, treatment, or disposal \\
facility will have documented procedures and actions \\
to be taken if a waste that does not conform to the \\
waste acceptance criteria is received at the facility. \\
\hline $\begin{array}{l}\text { H. Waste Generation Planning. The following } \\
\text { requirements are in addition to those in Chapter I of } \\
\text { this Manual. }\end{array}$ \\
\hline
\end{tabular}

(1) Life-Cycle Planning. Prior to waste generation, planning shall be performed to address the entire life cycle for all transuranic waste streams.

From DOE G 435.1-1 Chapter III:

Compliance with this planning requirement is demonstrated by the individual sites establishing a process for evaluating the life-cycle of [transuranic] waste prior to its generation, including the identification of [transuranic] wastes with no path to disposal and appropriate records justifying the newly generated [transuranic] waste stream(s), and site personnel possessing planning information showing the location(s) where [transuranic] waste will be stored, treated, and/or disposed along with a confirmation that the personnel managing the facilities agree that the [transuranic] waste may be managed at those facilities.

(2) Waste with No Identified Path to Disposal. Transuranic waste streams with no identified path to disposal shall be generated only in accordance with approved conditions which, at a minimum, shall address:

From DOE G 435.1-1 Chapter III:

Compliance with requirement is demonstrated by the waste generation organization having documentation concerning the decision to generate a transuranic waste stream that does not have an identified path to disposal. This documentation needs to include the cognizant Field Element Manager or designee approval to generate the waste, an explanation of the need for the process that generates the transuranic waste, a discussion of the reason it cannot be disposed of, the proposed management plan for the waste, and an up-to-date schedule of activities being pursued to
DOE Manual 435.1-1 §I.2.F(7) applies to field element managers.

PDD-17000 and LWP-17000 provide direction to the waste generators for waste generation planning to address the entire life cycle.
NA; this facility does not generate TRU waste with no identified path to disposal. 
Table 3. (continued).

Facility Name: MFC-704, Fuel Manufacturing Facility

\begin{tabular}{l} 
Chapter III, TRU Waste Requirements \\
\hline resolve constraints to the disposal of the subject \\
waste. Consistent with the use of a graded approach \\
for applying DOE M 435.1-1 requirements, the \\
schedule and plans for disposing of nondefense waste \\
can defer to the complex-wide resolution of the issue.)
\end{tabular}

(a) Programmatic need to generate the waste;

(b) Characteristics and issues preventing the disposal of the waste;

(c) Safe storage of the waste until disposal can be achieved; and

(d) Activities and plans for achieving final disposal of the waste.

I. Waste Characterization. Transuranic waste shall be characterized using direct or indirect methods, and the characterization documented in sufficient detail to ensure safe management and compliance with the waste acceptance requirements of the facility receiving the waste.

From DOE G 435.1-1 Chapter III:

Compliance with this requirement is demonstrated by a program for documenting and the existence of records that document the process for acquiring and verifying the validity of transuranic waste characterization data acquired through the use of direct or indirect methods.

(1) Data Quality Objectives. The data quality objectives process, or a comparable process, shall be used for identifying characterization parameters and acceptable uncertainty in characterization data.

From DOE G 435.1-1 Chapter III:

Compliance with this requirement is demonstrated by the documented use of a data quality objectives or a comparable process for determining the type, quantity, and quality of characterization data needed to safely manage transuranic waste.

(2) Minimum Waste Characterization.

Characterization data shall, at a minimum, include the following information relevant to the management of the waste:

From DOE G 435.1-1 Chapter III:
See (2) above.

Facility Compliance Information

See (2) above.

See (2) above.

See (2) above.

LWP-8300 $§ 4.2$ provides general INL-wide

requirements for containerization and characterization documentation requirements.

FMF-OI-015 addresses characterization requirements for TRU and mixed TRUwaste generated in this facility.

TRU waste transferred for onsite storage to MFC-771, RSWF, is characterized in accordance with RSWF-OI003 .

MCP-17000 $\$ 4$ specifies the requirements for preparing an IWTS profile that captures waste characterization information.

When certified in accordance with the RSWF WAC, MFC TRU waste is, to the extent possible, in compliance with the WAC for various treatment or disposal facilities that could be the ultimate destination of the waste (RSWF-OI-003).

Radioactive waste management facilities characterize waste in accordance with the requirements of the receiving storage, treatment, or disposal facility. The documented use of a data quality objectives process, or comparable process, was not identified for this facility.

LWP-8300 § 4.2 provides general INL-wide requirements for containerization and characterization documentation requirements.

MCP-17000 $\S 4$ specifies the requirements for preparing an IWTS profile that captures waste characterization information. FMF-OI-015 addresses characterization 
Table 3. (continued).

Facility Name: MFC-704, Fuel Manufacturing Facility

\begin{tabular}{|c|c|}
\hline Chapter III, TRU Waste Requirements & Facility Compliance Information \\
\hline $\begin{array}{l}\text { Compliance with this requirement is demonstrated by } \\
\text { the existence of a program or procedures for } \\
\text { determining and records that document } \\
\text { characterization of transuranic waste consistent with } \\
\text { the minimum characterization data requirements.) }\end{array}$ & $\begin{array}{l}\text { requirements for TRU waste. } \\
\text { TRU waste transferred for onsite storage to MFC-771, } \\
\text { RSWF, is characterized in accordance with RSWF-OI- } \\
003 \S 4.1 .7 \text { and Appendix A }\end{array}$ \\
\hline (a) Physical and chemical characteristics; & See (2) above. \\
\hline $\begin{array}{l}\text { (b) Volume, including the waste and any stabilization } \\
\text { or absorbent media; }\end{array}$ & See (2) above. \\
\hline (c) Weight of the container and contents; & See (2) above. \\
\hline $\begin{array}{l}\text { (d) Identities, activities, and concentrations of major } \\
\text { radionuclides; }\end{array}$ & See (2) above. \\
\hline (e) Characterization date; & See (2) above. \\
\hline (f) Generating source; & See (2) above. \\
\hline (g) Packaging date; and & See (2) above. \\
\hline $\begin{array}{l}\text { (h) Any other information which may be needed to } \\
\text { prepare and maintain the disposal facility performance } \\
\text { assessment or demonstrate compliance with } \\
\text { applicable performance objectives. }\end{array}$ & See (2) above. \\
\hline $\begin{array}{l}\text { J. Waste Certification. A waste certification program } \\
\text { shall be developed, documented, and implemented to } \\
\text { ensure that the waste acceptance requirements of } \\
\text { facilities receiving transuranic waste for storage, } \\
\text { treatment, or disposal are met. } \\
\text { From DOE G 435.1-1 Chapter III: } \\
\text { Compliance with the development and documentation } \\
\text { portion of the certification requirement is } \\
\text { demonstrated by a waste certification plan that } \\
\text { identifies the organizations involved, assigns } \\
\text { responsibilities for implementing the program, and } \\
\text { describes or references the quality assurance, training, } \\
\text { procurement controls, records management, and } \\
\text { procedures to be used by the program. Acceptable } \\
\text { performance for implementing the program is } \\
\text { demonstrated when the appropriate personnel are } \\
\text { trained, and have and follow the procedures that } \\
\text { govern their part of the waste certification process. } \\
\text { Acceptable performance also requires that the waste } \\
\text { certification plan and procedures are current and } \\
\text { controlled in accordance with a document control } \\
\text { program, and records related to certification (e.g., } \\
\text { certification statements, training records, procurement } \\
\text { records, characterization records, container records) } \\
\text { are generated and managed in accordance with the } \\
\text { established site program. }\end{array}$ & $\begin{array}{l}\text { PLN- } 8300 \text { provides MFC-wide certification of CH TRU } \\
\text { waste. } \\
\text { LWP- } 8300 \text { provides general INL-wide requirements for } \\
\text { containerization and characterization documentation } \\
\text { requirements. } \\
\text { TRU waste transferred for onsite storage to MFC-771, } \\
\text { RSWF, is certified in accordance with RSWF-OI-003 } \\
\S 3 \text {. } \\
\text { MCP-17000 specifies the requirements for preparing an } \\
\text { IWTS profile that captures waste certification } \\
\text { information. } \\
\text { When certified in accordance with the RSWF WAC, } \\
\text { MFC TRU waste is, to the extent possible, in } \\
\text { compliance with the WAC for various treatment or } \\
\text { disposal facilities that could be the ultimate destination } \\
\text { of the waste (RSWF-OI-003). Procedural documentation } \\
\text { other than this statement regarding certification of TRU } \\
\text { waste destined for Waste Isolation Pilot Plant (WIPP) } \\
\text { disposition was not found. }\end{array}$ \\
\hline
\end{tabular}


Table 3. (continued).

Facility Name: MFC-704, Fuel Manufacturing Facility

\begin{tabular}{|c|c|}
\hline Chapter III, TRU Waste Requirements & Facility Compliance Information \\
\hline $\begin{array}{l}\text { (1) Certification Program. The waste certification } \\
\text { program shall designate the officials who have the } \\
\text { authority to certify and release waste for shipment; } \\
\text { and specify what documentation is required for waste } \\
\text { generation, characterization, shipment, and } \\
\text { certification. The program shall provide requirements } \\
\text { for auditability, retrievability, and storage of required } \\
\text { documentation and specify the records retention } \\
\text { period. } \\
\text { From DOE G } 435.1-1 \text { Chapter III: } \\
\text { Compliance with this requirement is demonstrated by } \\
\text { a program or procedure for record keeping and } \\
\text { records showing that each container of waste is } \\
\text { certified as having met the waste acceptance criteria } \\
\text { of the facility to which it was transferred and the } \\
\text { certification statement is supported by additional } \\
\text { records regarding the waste source, characterization, } \\
\text { and container. }\end{array}$ & See J. above. \\
\hline $\begin{array}{l}\text { (2) Certification before Transfer. Transuranic waste } \\
\text { shall be certified as meeting waste acceptance } \\
\text { requirements before it is transferred to the facility } \\
\text { receiving the waste. } \\
\text { From DOE G } 435.1-1 \text { Chapter III: } \\
\text { Compliance with this requirement is demonstrated by } \\
\text { the presence of a certification program which includes } \\
\text { procedures requiring a signed certification statement } \\
\text { prior to the release of waste for transfer, and by dated } \\
\text { records showing that waste was certified before being } \\
\text { transferred. }\end{array}$ & See J. above. \\
\hline $\begin{array}{l}\text { (3) Maintaining Certification. Transuranic waste that } \\
\text { has been certified as meeting the waste acceptance } \\
\text { requirements for transfer to a storage, treatment, or } \\
\text { disposal facility shall be managed in a manner that } \\
\text { maintains its certification status. } \\
\text { From DOE G } 435.1-1 \text { Chapter III: } \\
\text { Compliance with this requirement is demonstrated by } \\
\text { the existence of a program or procedure reflecting this } \\
\text { requirement and site personnel able to show that the } \\
\text { storage of containers of waste is in a facility or } \\
\text { manner where the containers are not damaged by } \\
\text { normal weather events, and cannot be accessed by } \\
\text { unauthorized personnel. Further, each container can } \\
\text { be traced to its certification and the information } \\
\text { supporting that certification. }\end{array}$ & See J. above. \\
\hline $\begin{array}{l}\text { K. Waste Transfer. A documented process shall be } \\
\text { established and implemented for transferring }\end{array}$ & $\begin{array}{l}\text { RSWF-OI-003 specifies requirements and provides } \\
\text { instructions for accepting mixed waste, radioactive }\end{array}$ \\
\hline
\end{tabular}


Table 3. (continued).

Facility Name: MFC-704, Fuel Manufacturing Facility

\begin{tabular}{l}
\hline \multicolumn{1}{|c|}{ Chapter III, TRU Waste Requirements } \\
\hline responsibility for management of transuranic waste \\
and for ensuring availability of relevant data. The \\
following requirements are in addition to those in \\
Chapter I of this Manual. \\
From DOE G 435.1-1 Chapter III: \\
Compliance with this requirement is demonstrated if \\
facilities have procedures for the receipt of waste and \\
the transfer of waste, as appropriate, which address \\
the acquisition of waste and container data and the \\
transfer of ownership, respectively. Further evidence \\
of acceptable performance is facility records showing \\
that data on the waste containers are available and \\
accurate, and that documented transfer of \\
responsibility occurs.
\end{tabular}

sonsibility occurs.
Facility Compliance Information

waste, and radioactive material for storage at RSWF. Appendix A serves as the record document to be maintained for each container going to that facility.

RSWF-OI-004 provides the administrative requirements/process used by RSWF management for approving material transfer activities into and out of RSWF.

TSD-OI-004 specifies requirements and provides instructions for accepting $\mathrm{CH}$ TRU and mixed $\mathrm{CH}$ TRU waste at the MFC treatment, storage, and disposal facilities.

LWP-8300 $\S 4.3$ provides instruction on containerization of $\mathrm{CH}$ TRU waste going to the Advanced Mixed Waste Treatment Plant and prescribes the use of Form 435.83 as the documented record of container data and transfer.

PLN-8300 provides MFC-wide certification of $\mathrm{CH}$ TRU waste.

(1) Authorization. Transuranic waste shall not be transferred to a storage, treatment, or disposal facility until personnel responsible for the facility receiving the waste authorize the transfer.

From DOE G 435.1-1 Chapter III:

Compliance with this requirement is demonstrated by sites having procedures that require a confirmation of authorization before releasing waste for transfer, and records showing that transfers are made in accordance with written authorizations.

(2) Data. Waste characterization data, container information, and generation, storage, treatment, and transportation information for transuranic waste shall be transferred with or be traceable to the waste.

From DOE G 435.1-1 Chapter III:

Compliance with this requirement is demonstrated if there are procedures requiring that characterization and container data be provided and maintained for each waste transfer and documented records of transfers show that the information is being provided.

L. Packaging and Transportation. The following requirements are in addition to those in Chapter I of this Manual.

(1) Packaging.

From DOE G 435.1-1 Chapter III:

Compliance with the packaging requirement is
See K. above.

See K. above.

See (1)(a) through (2) below.
See (1)(a) through (2) below. 
Table 3. (continued).

Facility Name: MFC-704, Fuel Manufacturing Facility

\begin{tabular}{|c|}
\hline Chapter III, TRU Waste Requirements \\
\hline $\begin{array}{l}\text { demonstrated by procedures which document proper } \\
\text { packaging protocols, including documented evidence } \\
\text { that, where feasible, non-defense transuranic waste } \\
\text { has been packaged separately from defense } \\
\text { transuranic waste and by never having to repackage } \\
\text { transuranic waste that is packaged after issuance of } \\
\text { DOE O } 435.1 \text { in order to maintain containment. } \\
\text { However, the above protocol may not be satisfied by } \\
\text { containers that were placed in storage prior to } \\
\text { issuance of the DOE O } 435.1 \text {. For those containers, } \\
\text { the goal is to only have to repackage the waste one } \\
\text { time after it is retrieved and characterized. Further, } \\
\text { acceptable performance is demonstrated by containers } \\
\text { of waste having marking and labeling that allows } \\
\text { correlation with waste characterization data and } \\
\text { container information. Successful performance of this } \\
\text { requirement is also demonstrated by a record of } \\
\text { container performance in which failure has not } \\
\text { routinely occurred. }\end{array}$ \\
\hline
\end{tabular}

(a) Transuranic waste shall be packaged in a manner that provides containment and protection for the duration of the anticipated storage period and until disposal is achieved or until the waste is removed from the container.
LWP-8300 $\S 4.2$ and 4.3 address packaging ventilation requirements for TRU waste.

PLN-8300 addresses this requirement for CH TRU waste generated at this facility.

FMF-OI-015§5.2.1.2 provides instructions for packaging of $\mathrm{CH}$ TRU.

RSWF-OI-003 provides for use of Appendix A as a record of the ventilated or other pressurization protection packaging.

TSM-OI-003 prescribes the appropriate packaging for intra-facility movements of TRU waste.

LST-337 prescribes the appropriate container as approved by waste type.

LWP-8300 $\S \$ 4.2$ and 4.3 address packaging ventilation requirements for TRU waste.

PLN-8300 addresses this requirement for CH TRU waste generated at this facility.

FMF-OI-015 $\$ 5.2 .1 .2$ provides instructions for packaging of $\mathrm{CH}$ TRU.

RSWF-OI-003 provides for use of Appendix A as a record of the ventilated or other pressurization protection packaging.

TSM-OI-003 prescribes the appropriate packaging for intra-facility movements of TRU waste.

LST-337 prescribes the appropriate container as approved by waste type. 
Table 3. (continued).

Facility Name: MFC-704, Fuel Manufacturing Facility

\begin{tabular}{l} 
Chapter III, TRU Waste Requirements \\
\hline the facility itself may mitigate the hazards associated \\
with the accumulation of gases. For above-grade \\
storage of transuranic waste containers, the \\
radioactive waste management basis needs to include \\
controls which mitigate the hazards associated with \\
the accumulation of gases by restricting access to the \\
storage area and providing equipment to protect \\
against fire or explosion.
\end{tabular}

(c) When transuranic waste is packaged, defense waste shall be packaged separately from non-defense waste, if feasible.

(d) Containers of transuranic waste shall be marked such that their contents can be identified.

INL/EXT-10-17600 $§ 3$ addresses the defense determination requirement based on ANL-NT-192.

LWP-8300 $§ 4.3 .1 .7$ provides instructions on properly marking/labeling TRU waste containers.

PLN-8300 addresses this requirement for CH TRU waste generated at this facility.

FMF-OI-015 $§ 5.2 .1 .2$ provides instructions for packaging of $\mathrm{CH}$ TRU.

RSWF-OI-003 specifies requirements and provides instructions for accepting mixed waste, radioactive waste, and radioactive material for storage at RSWF. Appendix A serves as the record document to be maintained for each container going to that facility.

(2) Transportation. To the extent practical, the volume of waste and number of transuranic waste shipments shall be minimized.

From DOE G 435.1-1 Chapter III:

Compliance with this requirement can be demonstrated by a combination of site procedures directing the efficient use of waste container capacity and documentation showing that transuranic waste shipments are systematically planned and make optimal use of the shipment system (e.g., TRUPACT II) to the extent practical.

M. Site Evaluation and Facility Design. The following requirements are in addition to those in Chapter I of this Manual.

(1) Site Evaluation. Proposed locations for transuranic waste facilities shall be evaluated to identify relevant features that should be avoided or must be considered in facility design and analyses.

(a) Each site proposed for a new transuranic waste facility or expansion of an existing transuranic waste facility shall be evaluated considering environmental characteristics, geotechnical characteristics, and human activities.
NA; waste is not shipped to an offsite facility for final disposition from this facility

NA; this requirement addresses new radioactive waste management facilities.

See M. above

See M. above 
Table 3. (continued).

Facility Name: MFC-704, Fuel Manufacturing Facility

\begin{tabular}{|l|}
\hline \multicolumn{1}{|c|}{ Chapter III, TRU Waste Requirements } \\
\hline (b) Proposed sites with environmental characteristics, \\
geotechnical characteristics, and human activities for \\
which adequate protection cannot be provided through \\
facility design shall be deemed unsuitable for the \\
location of the facility.
\end{tabular}

(2) Facility Design. The following facility requirements and general design criteria, at a minimum, apply:

(a) Confinement. Transuranic waste systems and
components shall be designed to maintain waste
confinement.
(b) Ventilation.
1 Design of transuranic waste treatment and storage
facilities shall include ventilation, if applicable,
through an appropriate filtration system to maintain
the release of radioactive material in airborne
effluents within the requirements and guidelines
specified in applicable requirements.

2 When conditions exist for generating gases in flammable or explosive concentrations in treatment or storage facilities, ventilation or other measures shall be provided to keep the gases in a non-flammable and non-explosive condition. Where concentrations of explosive or flammable gases are expected to approach the lower flammability limit, measures shall be taken to prevent deflagration or detonation.

(c) Consideration of Decontamination and Decommissioning. Areas in new and modifications to existing transuranic waste management facilities that are subject to contamination with radioactive or other hazardous materials shall be designed to facilitate decontamination. For such facilities a proposed decommissioning method or a conversion method leading to reuse shall be described.

(d) Instrumentation and Control Systems. Engineering controls shall be incorporated in the design and engineering of transuranic waste treatment and storage facilities to provide volume inventory data and to prevent spills, leaks, and overflows from tanks or confinement systems.

(e) Monitoring. Monitoring and/or leak detection capabilities shall be incorporated in the design and engineering of transuranic waste storage, treatment, and disposal facilities to provide rapid identification of failed confinement and/or other abnormal conditions.

See M. above Facility Compliance Information

See M. above

See M. above

See M. above

See M. above

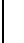

See M. above

See M. above

See M. above 
Table 3. (continued).

Facility Name: MFC-704, Fuel Manufacturing Facility

\begin{tabular}{l}
\hline \multicolumn{1}{|c|}{ Chapter III, TRU Waste Requirements } \\
\hline N. Storage. The following requirements are in \\
addition to those in Chapter I of this Manual. \\
(1) Storage Prohibitions. Transuranic waste in storage \\
shall not be readily capable of detonation, explosive \\
decomposition, reaction at anticipated pressures and \\
temperatures, or explosive reaction with water. Prior \\
to storage, pyrophoric materials shall be treated, \\
prepared, and packaged to be nonflammable. \\
From DOE G 435.1-1 Chapter III: \\
Compliance with this requirement is demonstrated by \\
having waste acceptance requirements which prohibit \\
waste that is ignitable or explosive from being \\
accepted for storage unless it has been treated. \\
\hline
\end{tabular}

(2) Storage Integrity. Transuranic waste shall be stored in a location and manner that protects the integrity of waste for the expected time of storage and minimizes worker exposure.

From DOE G 435.1-1 Chapter III:

Compliance with this requirement is demonstrated if sites have storage capabilities for transuranic waste that provide protection of waste containers so that their integrity will not be damaged through physical or chemical (corrosion) processes and that keep personnel from spending extended periods of time in the areas where transuranic waste is stored.

(3) Container Inspection. A process shall be developed and implemented for inspecting and maintaining containers of transuranic waste to ensure container integrity is not compromised.

\section{From DOE G 435.1-1 Chapter III:}

Compliance with this requirement is demonstrated by a documented process for waste container inspection and maintenance at every facility managing transuranic waste, and documentation for all waste container inspections and maintenance actions performed.

(4) Retrievable Earthen-Covered Storage. Plans for the removal of transuranic waste from retrievable earthen-covered storage facilities shall be established and maintained. Prior to commencing waste retrieval activities, each waste storage site shall be evaluated to determine relevant information on types, quantities, and location of radioactive and hazardous chemicals as necessary to protect workers during the retrieval process.
Facility Compliance Information

See below.

NA; this facility does not have WAC for TRU waste because the facility does not accept TRU waste from other facilities.

For the TRU waste generated at this facility, LWP-8300 and PLN-8300 address meeting receiving facility WAC and procedures.

The mixed TRU waste at this facility is accumulated in SAAs and TAAs, respectively.

MCP-17000 and MCP-17410 $\$ 4.4$ addresses conditions under which waste should be accumulated.

LWP-15011 $\S 5$ provides general radioactive storage area requirements.

LI-435 requires quarterly inspections of radioactive waste containers if waste is stored outdoors or has been in storage for greater than 1 year.

Inspections are performed for TAAs and SAAs as required by WGS procedures (MCP-17000 and MCP17410).

NA; this facility is not an earthen-covered storage facility. 
Table 3. (continued).

Facility Name: MFC-704, Fuel Manufacturing Facility

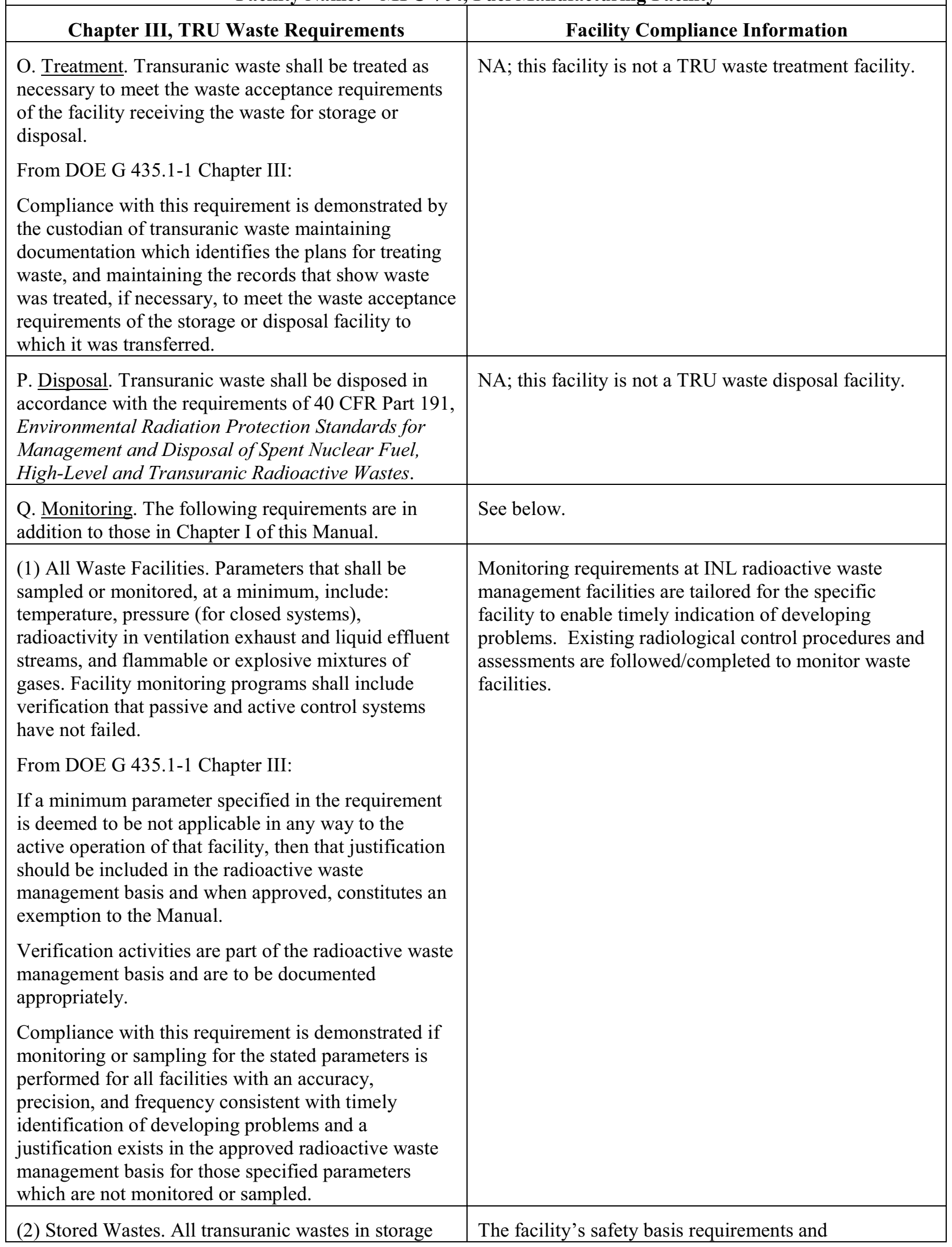


Table 3. (continued).

Facility Name: MFC-704, Fuel Manufacturing Facility

\begin{tabular}{|c|c|}
\hline Chapter III, TRU Waste Requirements & Facility Compliance Information \\
\hline $\begin{array}{l}\text { shall be monitored, as prescribed by the appropriate } \\
\text { facility safety analysis, to ensure the wastes are } \\
\text { maintained in safe condition. } \\
\text { From DOE G 435.1-1 Chapter III: } \\
\text { Compliance with this requirement is demonstrated if } \\
\text { the monitoring requirements in the facility procedures } \\
\text { include, at a minimum, monitoring the systems and } \\
\text { parameters as indicated by the safety analysis. }\end{array}$ & $\begin{array}{l}\text { implementing documents are identified in SAR- } 404 . \\
\text { This facility is a Hazard Category } 2 \text { Nuclear Facility. }\end{array}$ \\
\hline $\begin{array}{l}\text { (3) Liquid Waste Storage Facilities. For facilities } \\
\text { storing liquid transuranic waste, the following shall } \\
\text { also be monitored: liquid level and/or waste volume, } \\
\text { and significant waste chemistry parameters. } \\
\text { From DOE G 435.1-1 Chapter III: } \\
\text { Compliance with this requirement is demonstrated by } \\
\text { developing operational procedures for monitoring } \\
\text { liquid transuranic waste storage tank liquid level, } \\
\text { waste volume, and tank chemistry so that waste } \\
\text { volume or chemistry changes are detected in a time } \\
\text { frame that will allow implementation of corrective } \\
\text { measures to limit public and worker doses and to } \\
\text { mitigate unplanned releases of stored liquid waste. }\end{array}$ & NA; this facility does not store liquid TRU waste. \\
\hline
\end{tabular}

Table 4. MFC-704, Fuel Manufacturing Facility, DOE Manual 435.1-1 low-level waste requirements and facility compliance information.

\begin{tabular}{|c|c|}
\hline \multicolumn{2}{|c|}{ MFC-704, Fuel Manufacturing Facility } \\
\hline Chapter IV, LLW Requirements & Facility Compliance Information \\
\hline $\begin{array}{l}\text { A. Definition of Low-Level Waste. Low-level } \\
\text { radioactive waste is radioactive waste that is not high- } \\
\text { level radioactive waste, spent nuclear fuel, transuranic } \\
\text { waste, byproduct material (as defined in section 11e.(2) } \\
\text { of the Atomic Energy Act of 1954, as amended), or } \\
\text { naturally occurring radioactive material. } \\
\text { From DOE G } 435.1-1 \text { Chapter IV: Low-level } \\
\text { radioactive waste is defined by what it is not. The } \\
\text { guidance on definitions in Chapters II and III should be } \\
\text { consulted first for making a determination on how to } \\
\text { properly manage a suspect waste stream.) }\end{array}$ & $\begin{array}{l}\text { This requirement provides the criteria for determining } \\
\text { which DOE radioactive waste is to be managed as } \\
\text { LLW in accordance with DOE Manual 435.1-1 } \\
\text { Chapter IV. } \\
\text { Radioactive waste managed at this facility under the } \\
\text { requirements of this chapter is not managed under the } \\
\text { requirements of DOE Manual } 435.1-1 \text { Chapter II or } \\
\text { Chapter III. }\end{array}$ \\
\hline $\begin{array}{l}\text { B. Management of Specific Wastes. The following } \\
\text { provide for management of specific wastes as low-level } \\
\text { waste in accordance with the requirements in this } \\
\text { Chapter: }\end{array}$ & See (1), (2), (3), and (4) below. \\
\hline $\begin{array}{l}\text { (1) Mixed Low-Level Waste. Low-level waste } \\
\text { determined to contain both source, special nuclear, or } \\
\text { byproduct material subject to the Atomic Energy Act of } \\
\text { 1954, as amended, and a hazardous component subject }\end{array}$ & $\begin{array}{l}\text { This facility manages mixed LLW in SAAs. } \\
\text { Management of SAAs is addressed in MCP-17410, and } \\
\text { overall management of mixed waste is addressed in } \\
\text { MCP-17000. }\end{array}$ \\
\hline
\end{tabular}


Table 4. (continued).

\begin{tabular}{|c|c|}
\hline \multicolumn{2}{|c|}{ MFC-704, Fuel Manufacturing Facility } \\
\hline Chapter IV, LLW Requirements & Facility Compliance Information \\
\hline $\begin{array}{l}\text { to the Resource Conservation and Recovery Act } \\
\text { (RCRA), as amended, shall be managed in accordance } \\
\text { with the requirements of RCRA and DOE O 435.1, } \\
\text { Radioactive Waste Management, and this Manual. }\end{array}$ & $\begin{array}{l}\text { LI } 1219-07-M F C ~ \S 2 \text {, Table } 2.03 \text { and } \S 5 \text { address } \\
\text { generation of mixed LLW and accumulation in an } \\
\text { SAA. } \\
\text { Individual projects also would have project-specific } \\
\text { laboratory instructions that would address the } \\
\text { management of mixed LLW in accordance with RCRA } \\
\text { regulations. }\end{array}$ \\
\hline $\begin{array}{l}\text { (2) TSCA-Regulated Waste. Low-level waste } \\
\text { containing polychlorinated biphenyls, asbestos, or other } \\
\text { such regulated toxic components shall be managed in } \\
\text { accordance with requirements derived from the Toxic } \\
\text { Substances Control Act, as amended, DOE O 435.1, } \\
\text { Radioactive Waste Management, and this Manual. }\end{array}$ & $\begin{array}{l}\text { NA; this facility does not manage TSCA-regulated } \\
\text { waste. }\end{array}$ \\
\hline $\begin{array}{l}\text { (3) Accelerator-Produced Waste. Radioactive waste } \\
\text { produced as a result of operations of DOE accelerators } \\
\text { is low-level waste and shall be managed in accordance } \\
\text { with DOE O 435.1, Radioactive Waste Management, } \\
\text { and this Manual, and all applicable Federal or State } \\
\text { requirements. }\end{array}$ & $\begin{array}{l}\text { NA; this facility does not manage accelerator-produced } \\
\text { waste. }\end{array}$ \\
\hline $\begin{array}{l}\text { (4) } 11 \mathrm{e} \text {.(2) and Naturally Occurring Radioactive } \\
\text { Material. Small quantities of } 11 \mathrm{e} \text {.(2) byproduct } \\
\text { material and naturally occurring radioactive material } \\
\text { may be managed as low-level waste provided they can } \\
\text { be managed to meet the requirements for low-level } \\
\text { waste disposal in Section IV.P of this Manual. }\end{array}$ & $\begin{array}{l}\mathrm{NA} \text {; this facility does not manage naturally occurring } \\
\text { radioactive material. }\end{array}$ \\
\hline $\begin{array}{l}\text { C. Complex-Wide Low-Level Waste Management } \\
\text { Program. A complex-wide program and plan shall be } \\
\text { developed as described under Responsibilities, 2.B and } \\
\text { 2.D, in Chapter I of this Manual. }\end{array}$ & $\begin{array}{l}\text { DOE Manual } 435.1-1 \S \text { II.2.B and } \S I .2 . D \text { apply to the } \\
\text { Assistant Secretary for Environmental Management } \\
\text { and the Deputy Assistant Secretary for Waste } \\
\text { Management, respectively. }\end{array}$ \\
\hline $\begin{array}{l}\text { D. Radioactive Waste Management Basis. Low-level } \\
\text { waste facilities, operations, and activities shall have a } \\
\text { radioactive waste management basis consisting of } \\
\text { physical and administrative controls to ensure the } \\
\text { protection of workers, the public, and the environment. } \\
\text { The following specific waste management controls } \\
\text { shall be part of the radioactive waste management } \\
\text { basis: }\end{array}$ & $\begin{array}{l}\text { The RWMB provides the regulatory framework for } \\
\text { management of radioactive waste at INL. It specifically } \\
\text { identifies facility management and implementing } \\
\text { documents for the generation, storage, treatment, and } \\
\text { disposal of radiological waste. }\end{array}$ \\
\hline $\begin{array}{l}\text { (1) Generators. The waste certification program. } \\
\text { From DOE G } 435.1-1 \text { Chapter IV: For a facility that } \\
\text { generates low-level waste, the radioactive waste } \\
\text { management basis is to include the program for } \\
\text { certifying that waste meets the waste acceptance } \\
\text { requirements of the facility(ies) to which the waste will } \\
\text { be sent. }\end{array}$ & $\begin{array}{l}\text { See J. below for waste certification program } \\
\text { requirements. } \\
\text { SAR- } 404 \text { establishes the safety basis documentation } \\
\text { for the facility and determines it to be a Hazard } \\
\text { Category } 2 \text { nuclear facility. }\end{array}$ \\
\hline $\begin{array}{l}\text { (2) Treatment Facilities. certification program. The } \\
\text { waste acceptance requirements and the waste }[\text { sic }]\end{array}$ & NA; waste is not treated at this facility. \\
\hline
\end{tabular}


Table 4. (continued).

\begin{tabular}{|c|c|}
\hline \multicolumn{2}{|c|}{ MFC-704, Fuel Manufacturing Facility } \\
\hline Chapter IV, LLW Requirements & Facility Compliance Information \\
\hline $\begin{array}{l}\text { From DOE G } 435.1-1 \text { Chapter IV: Facilities that store } \\
\text { or treat low-level waste are to have approved waste } \\
\text { acceptance requirements (see DOE M } 435.1-1 \text {, Section } \\
\text { IV.G) prior to the issuance of a radioactive waste } \\
\text { management basis. }\end{array}$ & \\
\hline $\begin{array}{l}\text { A facility that stores or treats waste also is generally } \\
\text { expected to have a waste certification program. Waste } \\
\text { from these facilities will have to be certified as meeting } \\
\text { the waste acceptance requirements of the facility to } \\
\text { which it will be transferred, and the facilities have the } \\
\text { potential for generating radioactive waste (e.g., } \\
\text { secondary processing streams from treatment, } \\
\text { monitoring and sampling, radioactive release cleanup). } \\
\text { Consequently, storage and treatment facilities should } \\
\text { also have an approved waste certification program as } \\
\text { part of their radioactive waste management basis. }\end{array}$ & \\
\hline $\begin{array}{l}\text { As part of the radioactive waste management basis, site } \\
\text { personnel needs to implement a system or process for } \\
\text { tracking the waste inventory at a storage, treatment, or } \\
\text { disposal facility. }\end{array}$ & \\
\hline $\begin{array}{l}\text { (3) Storage Facilities. The waste acceptance } \\
\text { requirements and the waste certification program. }\end{array}$ & NA; this facility does not store LLW. \\
\hline $\begin{array}{l}\text { From DOE G } 435.1-1 \text { Chapter IV: Facilities that store } \\
\text { or treat low-level waste are to have approved waste } \\
\text { acceptance requirements (see DOE M } 435.1-1 \text {, Section } \\
\text { IV.G) prior to the issuance of a radioactive waste } \\
\text { management basis. }\end{array}$ & \\
\hline $\begin{array}{l}\text { A facility that stores or treats waste also is generally } \\
\text { expected to have a waste certification program. Waste } \\
\text { from these facilities will have to be certified as meeting } \\
\text { the waste acceptance requirements of the facility to } \\
\text { which it will be transferred, and the facilities have the } \\
\text { potential for generating radioactive waste (e.g., } \\
\text { secondary processing streams from treatment, } \\
\text { monitoring and sampling, radioactive release cleanup). } \\
\text { Consequently, storage and treatment facilities should } \\
\text { also have an approved waste certification program as } \\
\text { part of their radioactive waste management basis. }\end{array}$ & \\
\hline $\begin{array}{l}\text { As part of the radioactive waste management basis, site } \\
\text { personnel needs to implement a system or process for } \\
\text { tracking the waste inventory at a storage, treatment, or } \\
\text { disposal facility. }\end{array}$ & \\
\hline $\begin{array}{l}\text { (4) Disposal Facilities. The performance assessment, } \\
\text { composite analysis, disposal authorization statement, } \\
\text { closure plan, waste acceptance requirements, and } \\
\text { monitoring plan. }\end{array}$ & NA; this facility is not a disposal facility. \\
\hline E. Contingency Actions. The following requirements & DOE Manual 435.1-1 §I.1.E(5) addresses the sitewide \\
\hline
\end{tabular}


Table 4. (continued).

\begin{tabular}{|c|c|}
\hline \multicolumn{2}{|c|}{ MFC-704, Fuel Manufacturing Facility } \\
\hline Chapter IV, LLW Requirements & Facility Compliance Information \\
\hline $\begin{array}{l}\text { are in addition to those in Chapter I of this Manual } \\
\text { [DOE M 435.1-1 §I.1.E(5)]. }\end{array}$ & $\begin{array}{l}\text { emergency management system. The INL plan is } \\
\text { provided in PLN-114. }\end{array}$ \\
\hline $\begin{array}{l}\text { (1) Contingency Storage. For off-normal or emergency } \\
\text { situations involving high activity or high hazard liquid } \\
\text { low-level waste storage or treatment, spare capacity } \\
\text { with adequate capabilities shall be maintained to } \\
\text { receive the largest volume of liquid contained in any } \\
\text { one storage tank or treatment facility. Tanks or other } \\
\text { facilities that are designated low-level waste } \\
\text { contingency storage shall be maintained in an } \\
\text { operational condition when waste is present and shall } \\
\text { meet the requirements of DOE O 435.1, Radioactive } \\
\text { Waste Management, and this Manual. }\end{array}$ & NA; this facility does not store liquid LLW. \\
\hline $\begin{array}{l}\text { From DOE G } 435.1-1 \text { Chapter IV: Compliance with } \\
\text { these requirements is demonstrated if adequate spare } \\
\text { capacity and transfer equipment exists for emergency } \\
\text { transfers of all high activity and high hazard liquid low- } \\
\text { level waste. In addition, the capability to perform } \\
\text { emergency transfers is demonstrated by having waste } \\
\text { transfer routings identified, operational procedures to } \\
\text { direct transfers, staff trained to the procedures, and } \\
\text { records showing that the spare capacity and transfer } \\
\text { capability are kept in operating condition. }\end{array}$ & \\
\hline $\begin{array}{l}\text { (2) Transfer Equipment. Pipelines and auxiliary } \\
\text { facilities necessary for the transfer of high activity or } \\
\text { high hazard liquid low-level waste to contingency } \\
\text { storage shall be maintained in an operational condition } \\
\text { when waste is present and shall meet the requirements } \\
\text { of DOE O } 435.1 \text {, Radioactive Waste Management, and } \\
\text { this Manual. }\end{array}$ & NA; this facility does not store or treat liquid LLW. \\
\hline \multicolumn{2}{|l|}{$\begin{array}{l}\text { From DOE G } 435.1-1 \text { Chapter IV: Compliance with } \\
\text { these requirements is demonstrated if adequate spare } \\
\text { capacity and transfer equipment exists for emergency } \\
\text { transfers of all high activity and high hazard liquid low- } \\
\text { level waste. In addition, the capability to perform } \\
\text { emergency transfers is demonstrated by having waste } \\
\text { transfer routings identified, operational procedures to } \\
\text { direct transfers, staff trained to the procedures, and } \\
\text { records showing that the spare capacity and transfer } \\
\text { capability are kept in operating condition. }\end{array}$} \\
\hline \multirow{4}{*}{$\begin{array}{l}\text { F. Corrective Actions. I of this Manual. The following } \\
\text { requirements are in addition to those in Chapter [sic] } \\
\text { From DOE G 435.1-1 Chapter IV: Compliance with } \\
\text { DOE M 435.1-1 §I.2.G.(1) is demonstrated by records } \\
\text { showing what corrective actions were taken to remedy } \\
\text { situations in the radioactive waste management system. } \\
\text { Compliance with DOE M 435.1-1 §I.2.G.(2) is } \\
\text { demonstrated by having the necessary procedures, }\end{array}$} & $\begin{array}{l}\text { The INL-wide procedure addressing problem } \\
\text { identification as required by DOE Manual } 435.1-1\end{array}$ \\
\hline & $\begin{array}{l}\text { §I.2.G.(1) is LWP-13840, which implements the } \\
\text { laboratory's corrective action system. }\end{array}$ \\
\hline & $\begin{array}{l}\text { The INL-wide procedure addressing shutdown or } \\
\text { curtailment of activities as required by DOE Manual }\end{array}$ \\
\hline & 435.1-1 §I.2.G.(2) is LWP-14002. \\
\hline
\end{tabular}


Table 4. (continued).

\begin{tabular}{|c|c|}
\hline \multicolumn{2}{|c|}{ MFC-704, Fuel Manufacturing Facility } \\
\hline Chapter IV, LLW Requirements & Facility Compliance Information \\
\hline $\begin{array}{l}\text { mechanisms, and training in place to effect shutdown } \\
\text { or curtailment of activities which pose an imminent } \\
\text { danger or other serious hazard to workers or the public, } \\
\text { or are not protective of the environment. }\end{array}$ & \\
\hline $\begin{array}{l}\text { (1) Order Compliance. Corrective actions shall be } \\
\text { implemented whenever necessary to ensure the } \\
\text { requirements of DOE O } 435.1 \text {, Radioactive Waste } \\
\text { Management, and this Manual are met. }\end{array}$ & See F. above. \\
\hline $\begin{array}{l}\text { From DOE G 435.1-1 Chapter IV: If a facility or } \\
\text { activity can be allowed to operate while a } \\
\text { noncompliant or hazardous condition exists, the } \\
\text { allowance and any associated limitations must be } \\
\text { defined as part of the facility or activity's radioactive } \\
\text { waste management basis, identified as a configuration } \\
\text { controlled item in a configuration management plan or } \\
\text { included in a revision or modification to an operating } \\
\text { procedure or similar controlled documentation. }\end{array}$ & \\
\hline $\begin{array}{l}\text { Compliance with this requirement is demonstrated if a } \\
\text { corrective action system addresses noncompliant or } \\
\text { hazardous situations involving low-level waste } \\
\text { management facilities in a systematic fashion, and } \\
\text { allows identification of problems by all personnel. }\end{array}$ & \\
\hline $\begin{array}{l}\text { (2) Operations Curtailment. Operations shall be } \\
\text { curtailed or facilities shut down for failure to establish, } \\
\text { maintain, or operate consistent with an approved } \\
\text { radioactive waste management basis. }\end{array}$ & $\begin{array}{l}\text { The approved RWMB establishes the current } \\
\text { compliance status at each radioactive waste } \\
\text { management facility. Facility assessments are } \\
\text { scheduled to ensure waste management activities are }\end{array}$ \\
\hline $\begin{array}{l}\text { From DOE G } 435.1-1 \text { Chapter IV: Compliance with } \\
\text { this requirement is demonstrated with a documented } \\
\text { system of routine assessments to determine whether } \\
\text { waste management activities and facilities are } \\
\text { operating in accordance with an approved radioactive } \\
\text { waste management basis that provides for graded } \\
\text { limitations that can be placed on activities and } \\
\text { operations that do not have, or are operating outside of, } \\
\text { an approved radioactive waste management basis, } \\
\text { including shutdown of the facility. }\end{array}$ & conducted in accordance with the approved RWMB. \\
\hline $\begin{array}{l}\text { G. Waste Acceptance. The following requirements are } \\
\text { in addition to those in Chapter I of this Manual [DOE } \\
\text { M 435.1-1 §I.2.F(6)]. }\end{array}$ & $\begin{array}{l}\text { DOE Manual 435.1-1 §I.2.F(6) applies to field element } \\
\text { managers. }\end{array}$ \\
\hline $\begin{array}{l}\text { (1) Technical and Administrative. Waste acceptance } \\
\text { requirements for all low-level waste storage, treatment, } \\
\text { or disposal facilities, operations, and activities shall } \\
\text { specify, at a minimum, the following: }\end{array}$ & $\begin{array}{l}\text { NA; this facility does not accept LLW from other } \\
\text { facilities. }\end{array}$ \\
\hline $\begin{array}{l}\text { From DOE G } 435.1-1 \text { Chapter IV: Compliance with } \\
\text { these waste acceptance requirements is demonstrated if } \\
\text { they are documented, contain clear and precise criteria } \\
\text { specifying the radionuclide limits in the form of }\end{array}$ & \\
\hline
\end{tabular}


Table 4. (continued).

MFC-704, Fuel Manufacturing Facility

\begin{tabular}{l} 
Chapter IV, LLW Requirements \\
\hline \multicolumn{1}{|c|}{ contents or concentrations that can be accepted, the } \\
limitations and prohibitions on waste forms and \\
packages that can be received, and the limits, \\
prohibitions, or instructions concerning any other \\
technical information so that the waste is compatible \\
with the safety basis of the facility, and which will \\
result in acceptable waste at subsequent steps in \\
managing the low-level waste.)
\end{tabular}

(a) Allowable activities and/or concentrations of specific radionuclides.

(b) Acceptable waste form and/or container requirements that ensure the chemical and physical stability of waste under conditions that might be encountered during transportation, storage, treatment, or disposal.

(c) Restrictions or prohibitions on waste, materials, or containers that may adversely affect waste handlers or compromise facility or waste container performance.

(d) The following are additional waste acceptance requirements that shall be specified in low-level waste disposal facility waste acceptance requirements:

1 Low-level waste must contribute to and not detract from achieving long-term stability of the facility, minimizing the need for long-term active maintenance, minimizing subsidence, and minimizing contact of water with waste. Void spaces within the waste and, if containers are used, between the waste and its container shall be reduced to the extent practical.

2 Liquid low-level waste or low-level waste containing free liquid must be converted into a form that contains as little freestanding liquid as is reasonably achievable, but in no case shall the liquid exceed 1 percent of the waste volume when the low-level waste is in a disposal container, or 0.5 percent of the waste volume after it is processed to a stable form.

3 Low-level waste must not be readily capable of detonation or of explosive decomposition or reaction at anticipated pressures and temperatures, or of explosive reaction with water. Pyrophoric materials contained in waste shall be treated, prepared, and packaged to be nonflammable.

4 Low-level waste must not contain, or be capable of generating by radiolysis or biodegradation, quantities of toxic gases, vapors, or fumes harmful to the public or workers or disposal facility personnel, or harmful to the long-term structural stability of the disposal site.
Facility Compliance Information

See (1) above.

See (1) above.

See (1) above.

See (1) above.

See (1) above.

See (1) above.

See (1) above.

See (1) above. 
Table 4. (continued).

\begin{tabular}{|c|c|}
\hline \multicolumn{2}{|c|}{ MFC-704, Fuel Manufacturing Facility } \\
\hline Chapter IV, LLW Requirements & Facility Compliance Information \\
\hline $\begin{array}{l}5 \text { Low-level waste in a gaseous form must be packaged } \\
\text { such that the pressure does not exceed } 1.5 \text { atmospheres } \\
\text { absolute at } 20 \mathrm{C} \text {. [ sic }]\end{array}$ & See (1) above. \\
\hline $\begin{array}{l}\text { (e) The basis, procedures, and levels of authority } \\
\text { required for granting exceptions to the waste } \\
\text { acceptance requirements, which shall be contained in } \\
\text { each facility's waste acceptance documentation. Each } \\
\text { exception request shall be documented, including its } \\
\text { disposition as approved or not approved. }\end{array}$ & See (1) above. \\
\hline $\begin{array}{l}\text { From DOE G } 435.1-1 \text { Chapter IV: Waste acceptance } \\
\text { requirements are acceptable if they are documented and } \\
\text { contain a clear description of the procedure and bases } \\
\text { for obtaining an exception or deviation to the } \\
\text { acceptance criteria for low-level waste to be received at } \\
\text { the facility. }\end{array}$ & \\
\hline $\begin{array}{l}\text { (2) Evaluation and Acceptance. The receiving facility } \\
\text { shall evaluate waste for acceptance, including } \\
\text { confirmation that the technical and administrative } \\
\text { requirements have been met. A process for the } \\
\text { disposition of non-conforming wastes shall be } \\
\text { established. }\end{array}$ & See (1) above. \\
\hline $\begin{array}{l}\text { From DOE G 435.1-1 Chapter IV: Compliance with the } \\
\text { waste acceptance requirements for a low-level waste } \\
\text { management facility is demonstrated if they include a } \\
\text { process for evaluation and acceptance of incoming } \\
\text { waste to ensure the acceptance criteria of the facility } \\
\text { receiving the waste are met that includes one of or a } \\
\text { combination of: (1) testing, sampling, and analysis of } \\
\text { representative samples of waste upon receipt; (2) } \\
\text { testing, sampling, and analysis of split samples of } \\
\text { waste taken at the generator site; ( } 3 \text { ) evaluation of } \\
\text { testing, sampling, and analysis of data provided by the } \\
\text { generator, or (4) audits, reviews, surveillance, or } \\
\text { observations of generator waste certification programs } \\
\text { and characterization activities. Additionally, acceptable } \\
\text { waste acceptance requirements for a storage, treatment } \\
\text { or disposal facility will have documented procedures } \\
\text { and actions to be taken if a waste that does not conform } \\
\text { to the waste acceptance criteria is received at the } \\
\text { facility. }\end{array}$ & \\
\hline $\begin{array}{l}\text { H. Waste Generation Planning. The following } \\
\text { requirements are in addition to those in Chapter I of } \\
\text { this Manual [DOE M 435.1-1 } \S \operatorname{I} 2 . \mathrm{F}(7)] \text {. }\end{array}$ & $\begin{array}{l}\text { DOE Manual 435.1-1 } \S \mathrm{I} \cdot 2 . \mathrm{F}(7) \text { applies to field element } \\
\text { managers. }\end{array}$ \\
\hline $\begin{array}{l}\text { (1) Life-Cycle Planning. Prior to waste generation, } \\
\text { planning shall be performed to address the entire life } \\
\text { cycle for all low-level waste streams. } \\
\text { From DOE G 435.1-1 Chapter IV: Compliance with }\end{array}$ & $\begin{array}{l}\text { PDD- } 17000 \text { and LWP- } 17000 \text { provide direction to the } \\
\text { waste generators for waste generation planning to } \\
\text { address the entire life cycle. }\end{array}$ \\
\hline
\end{tabular}


Table 4. (continued).

MFC-704, Fuel Manufacturing Facility

\begin{tabular}{|c|c|}
\hline Chapter IV, LLW Requirements & Facility Compliance Information \\
\hline $\begin{array}{l}\text { this planning requirement is demonstrated by the } \\
\text { individual sites establishing a process for evaluating the } \\
\text { life-cycle of low-level waste prior to its generation, } \\
\text { including the identification of low-level wastes with no } \\
\text { path to disposal and appropriate records justifying the } \\
\text { newly generated low-level waste stream(s), and site } \\
\text { personnel possessing planning information showing the } \\
\text { location(s) where low-level waste will be stored, } \\
\text { treated, and/or disposed along with a confirmation that } \\
\text { the personnel managing the facilities agree that the } \\
\text { low-level waste may be managed at those facilities. }\end{array}$ & \\
\hline $\begin{array}{l}\text { (2) Waste with No Identified Path to Disposal. Low- } \\
\text { level waste streams with no identified path to disposal } \\
\text { shall be generated only in accordance with approved } \\
\text { conditions which, at a minimum, shall address: }\end{array}$ & $\begin{array}{l}\text { This facility is not generating radioactive waste that } \\
\text { does not have an identified path to disposal. }\end{array}$ \\
\hline (a) Programmatic need to generate the waste; & See (2) above. \\
\hline $\begin{array}{l}\text { (b) Characteristics and issues preventing the disposal of } \\
\text { the waste; }\end{array}$ & See (2) above. \\
\hline $\begin{array}{l}\text { (c) Safe storage of the waste until disposal can be } \\
\text { achieved; and }\end{array}$ & See (2) above. \\
\hline $\begin{array}{l}\text { (d) Activities and plans for achieving final disposal of } \\
\text { the waste. }\end{array}$ & See (2) above. \\
\hline $\begin{array}{l}\text { I. Waste Characterization. Low-level waste shall be } \\
\text { characterized using direct or indirect methods, and the } \\
\text { characterization documented in sufficient detail to } \\
\text { ensure safe management and compliance with the } \\
\text { waste acceptance requirements of the facility receiving } \\
\text { the waste. } \\
\text { From DOE G } 435.1-1 \text { Chapter IV: Compliance with } \\
\text { this requirement is demonstrated by a program for } \\
\text { documenting and the existence of records that } \\
\text { document the process for acquiring and verifying the } \\
\text { validity of low-level waste characterization data } \\
\text { acquired through the use of direct or indirect methods. }\end{array}$ & $\begin{array}{l}\text { MCP-17000 } \S 4 \text { specifies the requirements for } \\
\text { preparing an IWTS profile that captures waste } \\
\text { characterization information. } \\
\text { FMF-OI- } 015 \text { provides very general discussion of waste } \\
\text { characterization being conducted by use of process } \\
\text { knowledge, nondestructive analysis, or chemical and } \\
\text { radiochemical analyses, all of which are conducted at } \\
\text { the Analytical Laboratory. }\end{array}$ \\
\hline $\begin{array}{l}\text { (1) Data Quality Objectives. The data quality } \\
\text { objectives process, or a comparable process, shall be } \\
\text { used for identifying characterization parameters and } \\
\text { acceptable uncertainty in characterization data. } \\
\text { From DOE G } 435.1-1 \text { Chapter IV: Compliance with } \\
\text { this requirement is demonstrated by the documented } \\
\text { use of a data quality objectives or a comparable process } \\
\text { for determining the type, quantity, and quality of } \\
\text { characterization data needed to safely manage low- } \\
\text { level waste. }\end{array}$ & $\begin{array}{l}\text { Radioactive waste management facilities characterize } \\
\text { waste in accordance with the requirements of the } \\
\text { receiving storage, treatment, or disposal facility. The } \\
\text { documented use of a data quality objectives process, or } \\
\text { comparable process, was not identified for this facility. }\end{array}$ \\
\hline $\begin{array}{l}\text { (2) Minimum Waste Characterization. Characterization } \\
\text { data shall, at a minimum, include the following }\end{array}$ & $\begin{array}{l}\text { MCP-17000 } \S 4 \text { specifies the requirements for } \\
\text { preparing an IWTS profile that captures waste }\end{array}$ \\
\hline
\end{tabular}


Table 4. (continued).

\section{MFC-704, Fuel Manufacturing Facility}

Chapter IV, LLW Requirements

information relevant to the management of the waste:

From DOE G 435.1-1 Chapter IV: Compliance with this requirement is demonstrated by the existence of a program or procedure for determining and records that document characterization of low-level waste consistent with the minimum characterization data requirements.)

\begin{tabular}{l}
\hline (a) Physical and chemical characteristics; \\
(b) Volume, including the waste and any stabilization \\
or absorbent media; \\
\hline (c) Weight of the container and contents; \\
\hline $\begin{array}{l}\text { (d) Identities, activities, and concentrations of major } \\
\text { radionuclides; }\end{array}$ \\
\hline (e) Characterization date; \\
\hline (f) Generating source; and \\
\hline $\begin{array}{l}\text { (g) Any other information which may be needed to } \\
\text { prepare and maintain the disposal facility performance } \\
\text { assessment, or demonstrate compliance with applicabl } \\
\text { performance objectives. }\end{array}$ \\
\hline $\begin{array}{l}\text { J. Waste Certification. A waste certification program } \\
\text { shall be developed, documented, and implemented to } \\
\text { ensure that the waste acceptance requirements of } \\
\text { facilities receiving low-level waste for storage, } \\
\text { treatment, and disposal are met. }\end{array}$
\end{tabular}

From DOE G 435.1-1 Chapter IV: Compliance with the development and documentation portion of the certification requirement is demonstrated by a waste certification plan that identifies the organizations involved, assigns responsibilities for implementing the program, and describes or references the quality assurance, training, procurement controls, records management, and procedures to be used by the program. Acceptable performance for implementing the program is demonstrated when appropriate personnel are trained and follow the procedures that govern their part of the waste certification.

Additionally, acceptable performance is demonstrated if the waste certification plan and procedures are current and controlled in accordance with a document controls program, and records related to certification (e.g., certification statements, training records, procurement records, characterization records, container records) are generated and managed in accordance with the established site program.
Facility Compliance Information

characterization information.

FMF-OI-015 provides very general discussion of waste characterization being conducted by use of process knowledge, non-destructive analysis, or chemical and radiochemical analyses, all of which are conducted at the Analytical Laboratory.

See (2) above.

See (2) above.

See (2) above.

See (2) above.

See (2) above.

See (2) above.

See (2) above.

MCP-17000 $§ 4$ specifies the requirements for preparing an IWTS profile that captures waste certification information.

MCP-17500 provides the WGS waste certification program for LLW to be shipped to NNSS.

Container procurement is addressed in MCP-17000 $\S 4.6$.

Waste certification is performed and tracked using IWTS. Documentation of the IWTS Program is available electronically only.

PLN-522 requires waste technical specialists and waste disposition specialists to complete the appropriate training/qualification before being granted approval authority for profiles within the IWTS Program. The waste certification official, alternate waste certification official, and NNSS packaging certifiers must complete the appropriate training/qualifications to disposition waste to NNSS. 
Table 4. (continued).

\begin{tabular}{|c|c|}
\hline \multicolumn{2}{|c|}{ MFC-704, Fuel Manufacturing Facility } \\
\hline Chapter IV, LLW Requirements & Facility Compliance Information \\
\hline $\begin{array}{l}\text { program shall designate the officials who have the } \\
\text { authority to certify and release waste for shipment; and } \\
\text { specify what documentation is required for waste } \\
\text { generation, characterization, shipment, and } \\
\text { certification. The program shall provide requirements } \\
\text { for auditability, retrievability, and storage of required } \\
\text { documentation and specify the records retention period. }\end{array}$ & \\
\hline $\begin{array}{l}\text { From DOE G } 435.1-1 \text { Chapter IV: Compliance with } \\
\text { this requirement is demonstrated by a program or } \\
\text { procedure for record keeping and records showing that } \\
\text { low-level waste is certified as having met the waste } \\
\text { acceptance criteria of the facility to which it was } \\
\text { transferred and that the certification statement is } \\
\text { supported by additional records regarding the waste } \\
\text { source, characterization, and container. }\end{array}$ & \\
\hline $\begin{array}{l}\text { (2) Certification before Transfer. Low-level waste shall } \\
\text { be certified as meeting waste acceptance requirements } \\
\text { before it is transferred to the facility receiving the } \\
\text { waste. }\end{array}$ & See J. above. \\
\hline $\begin{array}{l}\text { From DOE G } 435.1-1 \text { Chapter IV: Compliance with } \\
\text { this requirement is demonstrated by the presence of a } \\
\text { certification program which includes procedures } \\
\text { requiring a signed certification statement prior to the } \\
\text { release of waste for transfer, and by dated records } \\
\text { showing that waste was certified before being } \\
\text { transferred. }\end{array}$ & \\
\hline $\begin{array}{l}\text { (3) Maintaining Certification. Low-level waste that has } \\
\text { been certified as meeting the waste acceptance } \\
\text { requirements for transfer to a storage, treatment, or } \\
\text { disposal facility shall be managed in a manner that } \\
\text { maintains its certification status. }\end{array}$ & See J. above. \\
\hline $\begin{array}{l}\text { From DOE G } 435.1-1 \text { Chapter IV: Compliance with } \\
\text { this requirement is demonstrated by a program or } \\
\text { procedure reflecting this requirement is present and site } \\
\text { personnel are able to show that the storage of low-level } \\
\text { waste containers is in a facility or manner where the } \\
\text { containers would not be damaged by normal weather } \\
\text { events, and cannot be accessed by unauthorized } \\
\text { personnel. Further, each container can be traced to its } \\
\text { certification and the information supporting that } \\
\text { certification. }\end{array}$ & \\
\hline $\begin{array}{l}\text { K. Waste Transfer. A documented process shall be } \\
\text { established and implemented for transferring } \\
\text { responsibility for management of low-level waste and }\end{array}$ & $\begin{array}{l}\text { MCP-17000 specifies the requirements for preparing } \\
\text { an IWTS profile that captures waste certification data, } \\
\text { transfer information, and associated authorizations. }\end{array}$ \\
\hline $\begin{array}{l}\text { for ensuring availability of relevant data. The following } \\
\text { requirements are in addition to those in Chapter I of } \\
\text { this Manual. }\end{array}$ & $\begin{array}{l}\text { MCP-17500 provides the WGS waste certification } \\
\text { program for LLW to be shipped to NNSS. }\end{array}$ \\
\hline From DOE G 435.1-1 Chapter IV: Compliance with & TSD-OI-004 specifies requirements and provides \\
\hline
\end{tabular}


Table 4. (continued).

\begin{tabular}{|c|c|}
\hline \multicolumn{2}{|c|}{ MFC-704, Fuel Manufacturing Facility } \\
\hline Chapter IV, LLW Requirements & Facility Compliance Information \\
\hline $\begin{array}{l}\text { this requirement is demonstrated if facilities have } \\
\text { procedures for the receipt of waste and the transfer of } \\
\text { waste, as appropriate, which address the acquisition of } \\
\text { waste and container data and the transfer of ownership, } \\
\text { respectively. Further evidence of acceptable } \\
\text { performance is facility records showing that data on the } \\
\text { waste containers is available and accurate, and that } \\
\text { documented transfer of responsibility occurs. }\end{array}$ & $\begin{array}{l}\text { instructions for accepting LLW and mixed LLW at the } \\
\text { MFC treatment, storage, and disposal facilities. }\end{array}$ \\
\hline $\begin{array}{l}\text { (1) Authorization. Low-level waste shall not be } \\
\text { transferred to a storage, treatment, or disposal facility } \\
\text { until personnel responsible for the facility receiving the } \\
\text { waste authorize the transfer. }\end{array}$ & See K. above. \\
\hline $\begin{array}{l}\text { From DOE G } 435.1-1 \text { Chapter IV: Compliance with } \\
\text { this requirement is demonstrated by sites having } \\
\text { procedures that require a confirmation of authorization } \\
\text { before releasing waste for transfer, and records } \\
\text { showing that transfers are made in accordance with } \\
\text { written authorizations. }\end{array}$ & \\
\hline $\begin{array}{l}\text { (2) Data. Waste characterization data, container } \\
\text { information, and generation, storage, treatment, and } \\
\text { transportation information for low-level waste shall be } \\
\text { transferred with or be traceable to the waste. }\end{array}$ & See K. above. \\
\hline $\begin{array}{l}\text { From DOE G } 435.1-1 \text { Chapter IV: Compliance with } \\
\text { this requirement is demonstrated if there are procedures } \\
\text { requiring that characterization and container data be } \\
\text { provided and maintained for each low-level waste } \\
\text { transfer and documented records of transfers show that } \\
\text { the information is being provided. }\end{array}$ & \\
\hline $\begin{array}{l}\text { L. Packaging and Transportation. The following } \\
\text { requirements are in addition to those in Chapter I of } \\
\text { this Manual [DOE M 435.1-1 §I.1.E(11)]. }\end{array}$ & $\begin{array}{l}\text { DOE Manual 435.1-1 §I.1.E(11) applies to field } \\
\text { element managers. }\end{array}$ \\
\hline (1) Packaging. If containers are used: & MCP-17000 $§ 4$ addresses packaging requirements. \\
\hline $\begin{array}{l}\text { From DOE G 435.1-1 Chapter IV: Compliance with the } \\
\text { packaging requirement is demonstrated by: (1) } \\
\text { procedures which document proper packaging } \\
\text { protocols; and (2) no trends of routine repackaging of } \\
\text { low-level waste that is packaged after issuance of DOE } \\
\text { O } 435.1 \text {. Successful performance of this requirement is } \\
\text { also demonstrated by a record of containers for which } \\
\text { failure has not routinely occurred under management } \\
\text { conditions. It is recognized that there may be failed } \\
\text { containers for waste previously placed in storage. For } \\
\text { those containers, the goal is to only have to repackage } \\
\text { the waste one time after it is retrieved and } \\
\text { characterized. Further, acceptable performance is } \\
\text { demonstrated by containers of waste having marking } \\
\text { and labeling that allows correlation with waste } \\
\text { characterization data and container information.) }\end{array}$ & \\
\hline
\end{tabular}


Table 4. (continued).

\begin{tabular}{|c|c|}
\hline \multicolumn{2}{|c|}{ MFC-704, Fuel Manufacturing Facility } \\
\hline Chapter IV, LLW Requirements & Facility Compliance Information \\
\hline $\begin{array}{l}\text { (a) Low-level waste shall be packaged in a manner that } \\
\text { provides containment and protection for the duration of } \\
\text { the anticipated storage period and until disposal is } \\
\text { achieved or until the waste has been removed from the } \\
\text { container. }\end{array}$ & See (1) above. \\
\hline $\begin{array}{l}\text { (b) When waste is packaged, vents or other measures } \\
\text { shall be provided if the potential exists for pressurizing } \\
\text { or generating flammable or explosive concentrations of } \\
\text { gases within the waste container. }\end{array}$ & See (1) above. \\
\hline $\begin{array}{l}\text { (c) Containers of low-level waste shall be marked such } \\
\text { that their contents can be identified. }\end{array}$ & See (1) above. \\
\hline $\begin{array}{l}\text { (2) Transportation. To the extent practical, the volume } \\
\text { of waste and number of low-level waste shipments } \\
\text { shall be minimized. }\end{array}$ & $\begin{array}{l}\text { NA; waste is not shipped to an offsite facility for final } \\
\text { disposition from this facility. }\end{array}$ \\
\hline $\begin{array}{l}\text { From DOE G } 435.1-1 \text { Chapter IV: Compliance with } \\
\text { this requirement can be demonstrated by a combination } \\
\text { of site procedures directing the efficient use of waste } \\
\text { container capacity and documentation showing that } \\
\text { low-level waste shipments are systematically planned } \\
\text { and optimized to the extent practical. }\end{array}$ & \\
\hline $\begin{array}{l}\text { M. Site Evaluation and Facility Design. The following } \\
\text { requirements are in addition to those in Chapter I of } \\
\text { this Manual. }\end{array}$ & $\begin{array}{l}\mathrm{NA} \text {; this requirement addresses new radioactive waste } \\
\text { management facilities. }\end{array}$ \\
\hline $\begin{array}{l}\text { (1) Site Evaluation. Proposed locations for low-level } \\
\text { waste facilities shall be evaluated to identify relevant } \\
\text { features that should be avoided or must be considered } \\
\text { in facility design and analyses. }\end{array}$ & See M. above. \\
\hline $\begin{array}{l}\text { (a) Each site proposed for a new low-level waste } \\
\text { facility or expansion of an existing low-level waste } \\
\text { facility shall be evaluated considering environmental } \\
\text { characteristics, geotechnical characteristics, and human } \\
\text { activities, including for a low-level waste disposal } \\
\text { facility, the capability of the site to demonstrate, at a } \\
\text { minimum, whether it is: }\end{array}$ & See M. above. \\
\hline $\begin{array}{l}1 \text { Located to accommodate the projected volume of } \\
\text { waste to be received; }\end{array}$ & See M. above. \\
\hline $\begin{array}{l}2 \text { Located in a flood plain, a tectonically active area, or } \\
\text { in the zone of water table fluctuation; and }\end{array}$ & See M. above. \\
\hline $\begin{array}{l}3 \text { Located where radionuclide migration pathways are } \\
\text { predictable and erosion and surface runoff can be } \\
\text { controlled. }\end{array}$ & See M. above. \\
\hline $\begin{array}{l}\text { (b) Proposed sites with environmental characteristics, } \\
\text { geotechnical characteristics, and human activities for } \\
\text { which adequate protection cannot be provided through } \\
\text { facility design shall be deemed unsuitable for the }\end{array}$ & See M. above. \\
\hline
\end{tabular}


Table 4. (continued).

\begin{tabular}{|c|c|}
\hline \multicolumn{2}{|c|}{ MFC-704, Fuel Manufacturing Facility } \\
\hline Chapter IV, LLW Requirements & Facility Compliance Information \\
\hline location of the facility. & \\
\hline $\begin{array}{l}\text { (c) Low-level waste disposal facilities shall be sited to } \\
\text { achieve long-term stability and to minimize, to the } \\
\text { extent practical, the need for active maintenance } \\
\text { following final closure. }\end{array}$ & See M. above. \\
\hline $\begin{array}{l}\text { (2) Low-Level Waste Treatment and Storage Facility } \\
\text { Design. The following facility requirements and } \\
\text { general design criteria, at a minimum, apply: }\end{array}$ & See M. above. \\
\hline $\begin{array}{l}\text { (a) Confinement. Low-level waste systems and } \\
\text { components shall be designed to maintain waste } \\
\text { confinement. }\end{array}$ & See M. above. \\
\hline (b) Ventilation. & See M. above. \\
\hline $\begin{array}{l}1 \text { Design of low-level waste treatment and storage } \\
\text { facilities shall include ventilation, if applicable, } \\
\text { through an appropriate filtration system to maintain the } \\
\text { release of radioactive material in airborne effluents } \\
\text { within the requirements and guidelines specified in } \\
\text { applicable requirements. }\end{array}$ & See M. above. \\
\hline $\begin{array}{l}2 \text { When conditions exist for generating gases in } \\
\text { flammable or explosive concentrations, ventilation } \\
\text { systems or other measures shall be provided to keep the } \\
\text { gases in a non-flammable and nonexplosive condition. } \\
\text { Where concentrations of explosive or flammable gases } \\
\text { are expected to approach the lower flammability limit, } \\
\text { measures shall be taken to prevent deflagration or } \\
\text { detonation. }\end{array}$ & See M. above. \\
\hline $\begin{array}{l}\text { (c) Consideration of Decontamination and } \\
\text { Decommissioning. Areas in new and modifications to } \\
\text { existing low-level waste management facilities that are } \\
\text { subject to contamination with radioactive or other } \\
\text { hazardous materials shall be designed to facilitate } \\
\text { decontamination. For such facilities a proposed } \\
\text { decommissioning method or a conversion method } \\
\text { leading to reuse shall be described. }\end{array}$ & See M. above. \\
\hline $\begin{array}{l}\text { (d) Instrumentation and Control Systems. Engineering } \\
\text { controls shall be incorporated in the design and } \\
\text { engineering of low-level waste treatment and storage } \\
\text { facilities to provide volume inventory data and to } \\
\text { prevent spills, leaks, and overflows from tanks or } \\
\text { confinement systems. }\end{array}$ & See M. above. \\
\hline $\begin{array}{l}\text { (e) Monitoring. Monitoring and/or leak detection } \\
\text { capabilities shall be incorporated in the design and } \\
\text { engineering of low-level waste treatment and storage } \\
\text { facilities to provide rapid identification of failed } \\
\text { confinement and/or other abnormal conditions. }\end{array}$ & See M. above. \\
\hline (3) Low-Level Waste Disposal Facility Design. The & See M. above. \\
\hline
\end{tabular}


Table 4. (continued).

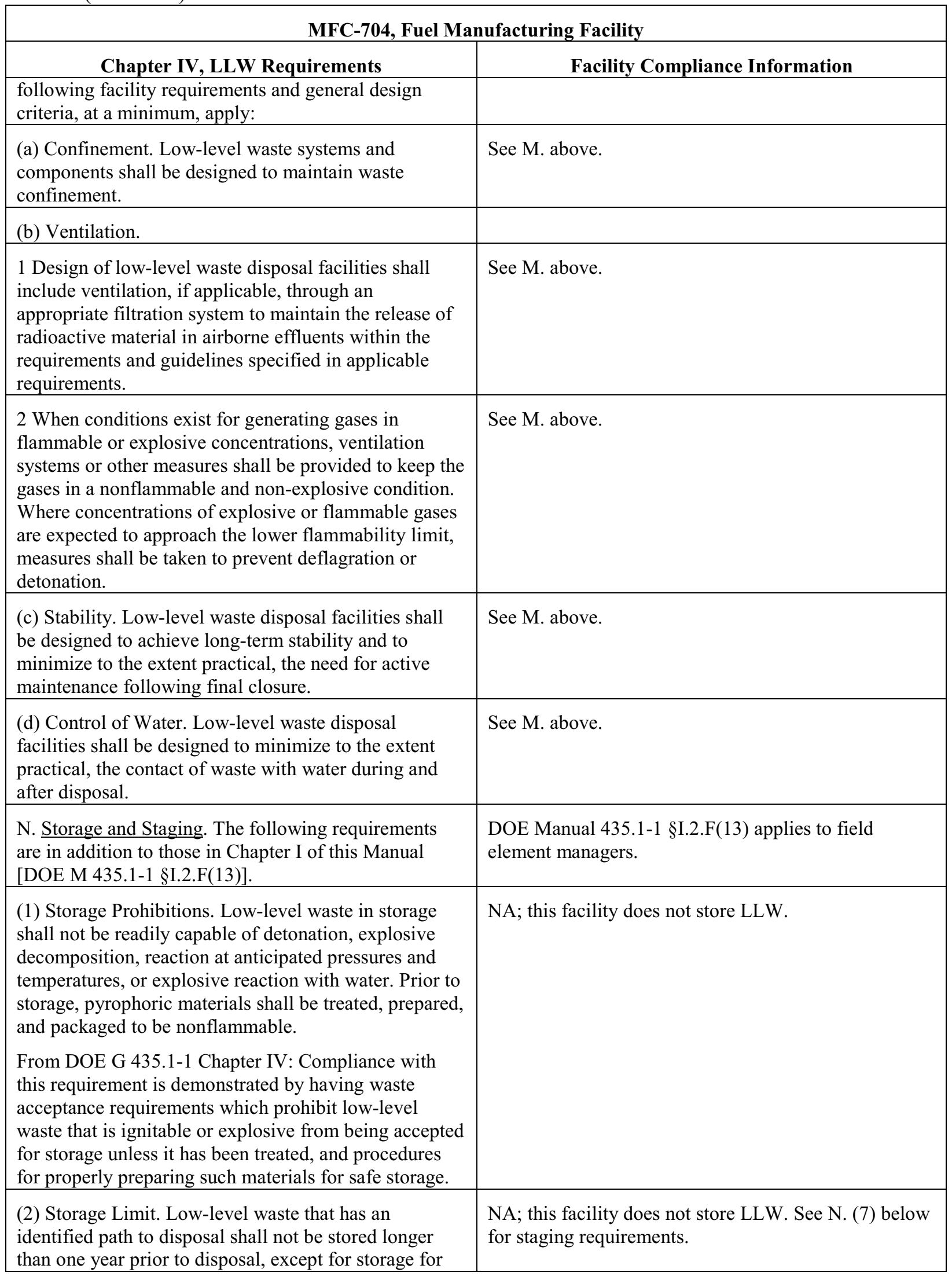


Table 4. (continued).

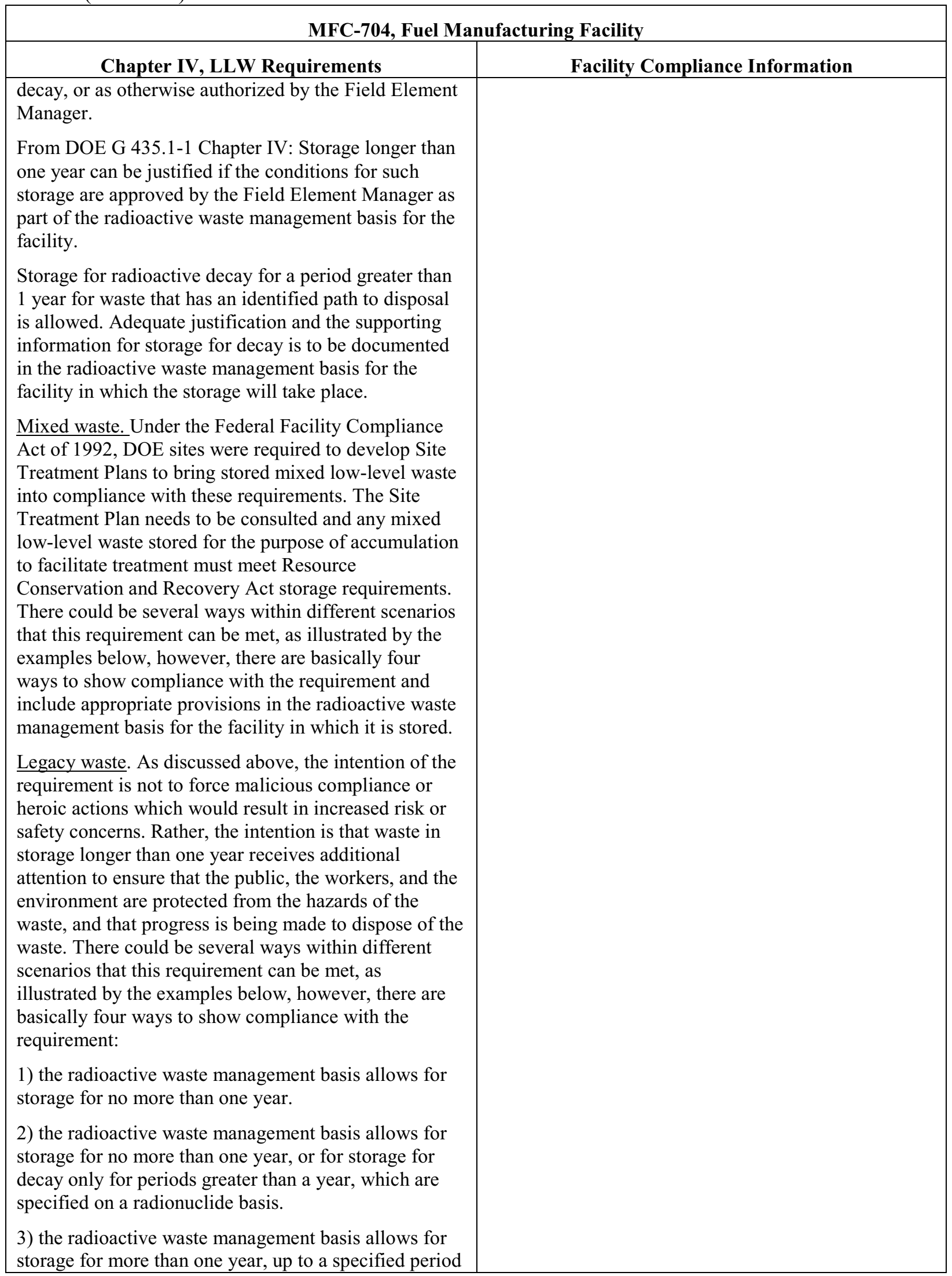


Table 4. (continued).

\begin{tabular}{|c|c|}
\hline \multicolumn{2}{|c|}{ MFC-704, Fuel Manufacturing Facility } \\
\hline Chapter IV, LLW Requirements & Facility Compliance Information \\
\hline $\begin{array}{l}\text { of time based on a documented technical evaluation } \\
\text { that the waste can be stored in a manner that does not } \\
\text { cause changes to the waste or waste packages that is } \\
\text { detrimental to the safe storage of the waste, the final } \\
\text { disposal of the waste or to meeting the disposal } \\
\text { performance objectives. }\end{array}$ & \\
\hline $\begin{array}{l}\text { 4) the radioactive waste management basis allows for } \\
\text { storage for decay (with specifics) and for storage for } \\
\text { more than one year for other low-level waste, up to a } \\
\text { specified period of time based on a documented } \\
\text { technical evaluation that the waste can be stored in a } \\
\text { manner that does not cause changes to the waste or } \\
\text { waste packages that is detrimental to the safe storage of } \\
\text { the waste, the final disposal of the waste or to meeting } \\
\text { the disposal performance objectives. }\end{array}$ & \\
\hline $\begin{array}{l}\text { Compliance with this requirement is demonstrated by } \\
\text { the existence of a radioactive waste management basis } \\
\text { for the storage facility approved by the Field Element } \\
\text { Manager that includes the time frames that waste are } \\
\text { allowed to be stored, the necessary justifications for } \\
\text { storage for decay, and the necessary technical } \\
\text { evaluations if storage is to extend significantly beyond } \\
\text { the one-year time frame. }\end{array}$ & \\
\hline $\begin{array}{l}\text { (3) Storage Integrity. Low-level waste shall be stored in } \\
\text { a location and manner that protects the integrity of } \\
\text { waste for the expected time of storage and minimizes } \\
\text { worker exposure. }\end{array}$ & $\begin{array}{l}\text { NA; this facility does not store LLW. See N. (7) below } \\
\text { for staging requirements. }\end{array}$ \\
\hline $\begin{array}{l}\text { However, in making a decision to use a facility for } \\
\text { storage and in developing a radioactive waste } \\
\text { management basis for the activity, particular attention } \\
\text { to protection of workers is needed. }\end{array}$ & \\
\hline $\begin{array}{l}\text { From DOE G } 435.1-1 \text { Chapter IV: Compliance with } \\
\text { this requirement is demonstrated if sites have storage } \\
\text { capabilities for low-level waste that provide protection } \\
\text { to waste containers so that their integrity will not be } \\
\text { damaged through physical or chemical (corrosion) } \\
\text { processes and that keep personnel from spending } \\
\text { extended periods of time in the areas where low-level } \\
\text { waste is stored. }\end{array}$ & \\
\hline (4) Waste Characterization for Storage. & $\begin{array}{l}\text { NA; this facility does not store LLW. See N. (7) below } \\
\text { for staging requirements. }\end{array}$ \\
\hline $\begin{array}{l}\text { (a) Low-level waste that does not have an identified } \\
\text { path to disposal shall be characterized as necessary to } \\
\text { meet the data quality objectives and minimum } \\
\text { characterization requirements of this Chapter, to ensure } \\
\text { safe storage, and to facilitate disposal. }\end{array}$ & $\begin{array}{l}\text { NA; this facility does not store LLW. See N. (7) below } \\
\text { for staging requirements. }\end{array}$ \\
\hline (b) Characterization information for all low-level waste & NA; this facility does not store LLW. See N. (7) below \\
\hline
\end{tabular}


Table 4. (continued).

\begin{tabular}{|c|c|}
\hline \multicolumn{2}{|c|}{ MFC-704, Fuel Manufacturing Facility } \\
\hline Chapter IV, LLW Requirements & Facility Compliance Information \\
\hline $\begin{array}{l}\text { in storage shall be maintained as a record in accordance } \\
\text { with the requirements for Records Management in } \\
\text { Chapter I of this Manual. }\end{array}$ & for staging requirements. \\
\hline $\begin{array}{l}\text { From DOE G 435.1-1 Chapter IV: Compliance with } \\
\text { this requirement is demonstrated by documented } \\
\text { procedures for managing waste characterization and } \\
\text { container information on low-level waste as a Federal } \\
\text { record. The records are managed per the applicable } \\
\text { policies and procedures for records management } \\
\text { referenced in DOE O } 200.1 \text { and established at the } \\
\text { applicable Field Element. }\end{array}$ & \\
\hline $\begin{array}{l}\text { (5) Container Inspection. A process shall be developed } \\
\text { and implemented for inspecting and maintaining } \\
\text { containers of low-level waste to ensure container } \\
\text { integrity is not compromised. }\end{array}$ & $\begin{array}{l}\text { LI- } 435 \text { requires quarterly inspections of radioactive } \\
\text { waste containers if waste is stored outdoors or has been } \\
\text { in storage for greater than } 1 \text { year. }\end{array}$ \\
\hline $\begin{array}{l}\text { From DOE G } 435.1-1 \text { Chapter IV: Compliance with } \\
\text { this requirement is demonstrated by: (1) a documented } \\
\text { process for waste container inspection and } \\
\text { maintenance; and (2) documentation for all waste } \\
\text { container inspections and maintenance actions } \\
\text { performed. }\end{array}$ & \\
\hline $\begin{array}{l}\text { (6) Storage Management. Low-level waste storage shall } \\
\text { be managed to identify and segregate low-level waste } \\
\text { from mixed low-level waste. }\end{array}$ & $\begin{array}{l}\text { NA; this facility does not store LLW. See N. (7) below } \\
\text { for staging requirements. }\end{array}$ \\
\hline $\begin{array}{l}\text { (7) Staging. Staging of low-level waste shall be for the } \\
\text { purpose of the accumulation of such quantities of waste } \\
\text { as necessary to facilitate transportation, treatment, and } \\
\text { disposal. Staging longer than } 90 \text { days shall meet the } \\
\text { requirements for storage above and in Chapter I of this }\end{array}$ & $\begin{array}{l}\text { Routine LLW, such as personnel protective equipment, } \\
\text { is accumulated at this facility for disposal. } \\
\text { MCP-17000, Appendix F, restricts staging LLW to } \\
90 \text { days maximum at any generator or treatment } \\
\text { facility prior to acceptance by a storage facility. }\end{array}$ \\
\hline $\begin{array}{l}\text { From DOE G 435.1-1 Chapter IV: The staging of low- } \\
\text { level waste needs to be addressed in the radioactive } \\
\text { waste management basis for the facility that is } \\
\text { performing the staging. Generators, treatment facilities, } \\
\text { and disposal facilities that stage waste must ensure that } \\
\text { the action of staging is included and authorized as part } \\
\text { of their radioactive waste management basis for the } \\
\text { affected facilities, operations, or activities. }\end{array}$ & $\begin{array}{l}\text { As stated in DOE Guide } 435.1-1 \text { §IV.N.( } 7 \text { ), staging } \\
\text { waste in accordance with this requirement allows waste } \\
\text { to be accumulated without being considered storage } \\
\text { and being bound by the associated storage } \\
\text { requirements. }\end{array}$ \\
\hline $\begin{array}{l}\text { Staging longer than } 90 \text { days must be justified, the } \\
\text { conditions for such storage met, and these practices } \\
\text { approved by the Field Element Manager as part of the } \\
\text { radioactive waste management basis for the facility. }\end{array}$ & \\
\hline $\begin{array}{l}\text { Compliance with this requirement is demonstrated by a } \\
\text { staging program that limits the temporary storage of } \\
\text { waste to only circumstances allowed in the } \\
\text { requirement, including justifications for any staging } \\
\text { that exceeds the } 90 \text {-day period, which is documented in }\end{array}$ & \\
\hline
\end{tabular}


Table 4. (continued).

\begin{tabular}{|c|c|}
\hline \multicolumn{2}{|c|}{ MFC-704, Fuel Manufacturing Facility } \\
\hline Chapter IV, LLW Requirements & Facility Compliance Information \\
\hline the radioactive waste management basis for the facility. & \\
\hline $\begin{array}{l}\text { O. Treatment. Low-level waste treatment to provide } \\
\text { more stable waste forms and to improve the long-term } \\
\text { performance of a low-level waste disposal facility shall } \\
\text { be implemented as necessary to meet the performance } \\
\text { objectives of the disposal facility. }\end{array}$ & NA; this facility does not treat LLW. \\
\hline $\begin{array}{l}\text { From DOE G } 435.1-1 \text { Chapter IV: Compliance with } \\
\text { this requirement is demonstrated when a treatment } \\
\text { facility or process ensures that treated waste will meet } \\
\text { the minimum waste form requirements of DOE M } \\
435.1 \text { and meet additional disposal facility-specific } \\
\text { waste acceptance requirements for additional stability } \\
\text { or long-term performance of facilities that will receive } \\
\text { the treated waste. }\end{array}$ & \\
\hline $\begin{array}{l}\text { P. Disposal. Low-level waste disposal facilities shall } \\
\text { meet the following requirements. }\end{array}$ & NA; this facility does not dispose of LLW. \\
\hline $\begin{array}{l}\text { (1) Performance Objectives. Low-level waste disposal } \\
\text { facilities shall be sited, designed, operated, maintained, } \\
\text { and closed so that a reasonable expectation exists that } \\
\text { the following performance objectives will be met for } \\
\text { waste disposed of after September } 26,1988 \text { : }\end{array}$ & See P. above. \\
\hline $\begin{array}{l}\text { (a) Dose to representative members of the public shall } \\
\text { not exceed } 25 \mathrm{mrem}(0.25 \mathrm{mSv}) \text { in a year total effective } \\
\text { dose equivalent from all exposure pathways, excluding } \\
\text { the dose from radon and its progeny in air. }\end{array}$ & See P. above. \\
\hline $\begin{array}{l}\text { (b) Dose to representative members of the public via } \\
\text { the air pathway shall not exceed } 10 \text { mrem }(0.10 \mathrm{mSv}) \\
\text { in a year total effective dose equivalent, excluding the } \\
\text { dose from radon and its progeny. }\end{array}$ & See P. above. \\
\hline $\begin{array}{l}\text { (c) Release of radon shall be less than an average flux } \\
\text { of } 20 \mathrm{pCi} / \mathrm{m}^{2} / \mathrm{s}\left(0.74 \mathrm{~Bq} / \mathrm{m}^{2} / \mathrm{s}\right) \text { at the surface of the } \\
\text { disposal facility. Alternatively, a limit of } 0.5 \mathrm{pCi} / 1 \\
(0.0185 \mathrm{~Bq} / \mathrm{l}) \text { of air may be applied at the boundary of } \\
\text { the facility. }\end{array}$ & See P. above. \\
\hline $\begin{array}{l}\text { (2) Performance Assessment. A site-specific } \\
\text { radiological performance assessment shall be prepared } \\
\text { and maintained for DOE low-level waste disposed of } \\
\text { after September 26, } 1988 \text {. The performance assessment } \\
\text { shall include calculations for a } 1,000 \text { year period after } \\
\text { closure of potential doses to representative future } \\
\text { members of the public and potential releases from the } \\
\text { facility to provide a reasonable expectation that the } \\
\text { performance objectives identified in this Chapter are } \\
\text { not exceeded as a result of operation and closure of the } \\
\text { facility. }\end{array}$ & See P. above. \\
\hline (a) Analyses performed to demonstrate compliance & See P. above. \\
\hline
\end{tabular}


Table 4. (continued).

\begin{tabular}{|c|c|}
\hline \multicolumn{2}{|c|}{ MFC-704, Fuel Manufacturing Facility } \\
\hline Chapter IV, LLW Requirements & Facility Compliance Information \\
\hline $\begin{array}{l}\text { with the performance objectives in this Chapter, and to } \\
\text { establish limits on concentrations of radionuclides for } \\
\text { disposal based on the performance measures for } \\
\text { inadvertent intruders in this Chapter shall be based on } \\
\text { reasonable activities in the critical group of exposed } \\
\text { individuals. Unless otherwise specified, the assumption } \\
\text { of average living habits and exposure conditions in } \\
\text { representative critical groups of individuals projected } \\
\text { to receive the highest doses is appropriate. The } \\
\text { likelihood of inadvertent intruder scenarios may be } \\
\text { considered in interpreting the results of the analyses } \\
\text { and establishing radionuclide concentrations, if } \\
\text { adequate justification is provided. }\end{array}$ & \\
\hline $\begin{array}{l}\text { (b) The point of compliance shall correspond to the } \\
\text { point of highest projected dose or concentration beyond } \\
\text { a } 100 \text { meter buffer zone surrounding the disposed } \\
\text { waste. A larger or smaller buffer zone may be used if } \\
\text { adequate justification is provided. }\end{array}$ & See P. above. \\
\hline $\begin{array}{l}\text { (c) Performance assessments shall address reasonably } \\
\text { foreseeable natural processes that might disrupt barriers } \\
\text { against release and transport of radioactive materials. }\end{array}$ & See P. above. \\
\hline $\begin{array}{l}\text { (d) Performance assessments shall use DOE-approved } \\
\text { dose coefficients (dose conversion factors) for internal } \\
\text { and external exposure of reference adults. }\end{array}$ & See P. above. \\
\hline $\begin{array}{l}\text { (e) The performance assessment shall include a } \\
\text { sensitivity/uncertainty analysis. }\end{array}$ & See P. above. \\
\hline $\begin{array}{l}\text { (f) Performance assessments shall include a } \\
\text { demonstration that projected releases of radionuclides } \\
\text { to the environment shall be maintained as low as } \\
\text { reasonably achievable (ALARA). }\end{array}$ & See P. above. \\
\hline $\begin{array}{l}\text { (g) For purposes of establishing limits on radionuclides } \\
\text { that may be disposed of near-surface, the performance } \\
\text { assessment shall include an assessment of impacts to } \\
\text { water resources. }\end{array}$ & See P. above. \\
\hline $\begin{array}{l}\text { (h) For purposes of establishing limits on the } \\
\text { concentration of radionuclides that may be disposed of } \\
\text { near-surface, the performance assessment shall include } \\
\text { an assessment of impacts calculated for a hypothetical } \\
\text { person assumed to inadvertently intrude for a } \\
\text { temporary period into the low-level waste disposal } \\
\text { facility. For intruder analyses, institutional controls } \\
\text { shall be assumed to be effective in deterring intrusion } \\
\text { for at least } 100 \text { years following closure. The intruder } \\
\text { analyses shall use performance measures for chronic } \\
\text { and acute exposure scenarios, respectively, of } 100 \\
\text { mrem ( } 1 \text { mSv) in a year and } 500 \text { mrem ( } 5 \mathrm{mSv}) \text { total } \\
\text { effective dose equivalent excluding radon in air. }\end{array}$ & See P. above. \\
\hline
\end{tabular}


Table 4. (continued).

MFC-704, Fuel Manufacturing Facility

\begin{tabular}{|c|c|}
\hline Chapter IV, LLW Requirements & Facility Compliance Information \\
\hline $\begin{array}{l}\text { (3) Composite Analysis. For disposal facilities which } \\
\text { received waste after September } 26,1988 \text {, a site-specific } \\
\text { radiological composite analysis shall be prepared and } \\
\text { maintained that accounts for all sources of radioactive } \\
\text { material that may be left at the DOE site and may } \\
\text { interact with the low- level waste disposal facility, } \\
\text { contributing to the dose projected to a hypothetical } \\
\text { member of the public from the existing or future } \\
\text { disposal facilities. Performance measures shall be } \\
\text { consistent with DOE requirements for protection of the } \\
\text { public and environment and evaluated for a } 1,000 \text { year } \\
\text { period following disposal facility closure. The } \\
\text { composite analysis results shall be used for planning, } \\
\text { radiation protection activities, and future use } \\
\text { commitments to minimize the likelihood that current } \\
\text { low- level waste disposal activities will result in the } \\
\text { need for future corrective or remedial actions to } \\
\text { adequately protect the public and the environment. }\end{array}$ & See P. above. \\
\hline $\begin{array}{l}\text { (4) Performance Assessment and Composite Analysis } \\
\text { Maintenance. The performance assessment and } \\
\text { composite analysis shall be maintained to evaluate } \\
\text { changes that could affect the performance, design, and } \\
\text { operating bases for the facility. Performance } \\
\text { assessment and composite analysis maintenance shall } \\
\text { include the conduct of research, field studies, and } \\
\text { monitoring needed to address uncertainties or gaps in } \\
\text { existing data. The performance assessment shall be } \\
\text { updated to support the final facility closure. Additional } \\
\text { iterations of the performance assessment and composite } \\
\text { analysis shall be conducted as necessary during the } \\
\text { post-closure period. }\end{array}$ & See P. above. \\
\hline $\begin{array}{l}\text { (a) Performance assessments and composite analyses } \\
\text { shall be reviewed and revised when changes in waste } \\
\text { forms or containers, radionuclide inventories, facility } \\
\text { design and operations, closure concepts, or the } \\
\text { improved understanding of the performance of the } \\
\text { waste disposal facility in combination with the features } \\
\text { of the site on which it is located alter the conclusions or } \\
\text { the conceptual model(s) of the existing performance } \\
\text { assessment or composite analysis. }\end{array}$ & See P. above. \\
\hline $\begin{array}{l}\text { (b) A determination of the continued adequacy of the } \\
\text { performance assessment and composite analysis shall } \\
\text { be made on an annual basis, and shall consider the } \\
\text { results of data collection and analysis from research, } \\
\text { field studies, and monitoring. }\end{array}$ & See P. above. \\
\hline $\begin{array}{l}\text { (c) Annual summaries of low-level waste disposal } \\
\text { operations shall be prepared with respect to the } \\
\text { conclusions and recommendations of the performance } \\
\text { assessment and composite analysis and a determination }\end{array}$ & See P. above. \\
\hline
\end{tabular}


Table 4. (continued).

\begin{tabular}{|c|c|}
\hline \multicolumn{2}{|c|}{ MFC-704, Fuel Manufacturing Facility } \\
\hline Chapter IV, LLW Requirements & Facility Compliance Information \\
\hline $\begin{array}{l}\text { of the need to revise the performance assessment or } \\
\text { composite analysis. }\end{array}$ & \\
\hline $\begin{array}{l}\text { (5) Disposal Authorization. A disposal authorization } \\
\text { statement shall be obtained prior to construction of a } \\
\text { new low-level waste disposal facility. Field Elements } \\
\text { with existing low-level waste disposal facilities shall } \\
\text { obtain a disposal authorization statement in accordance } \\
\text { with the schedule in the Complex-Wide Low-Level } \\
\text { Waste Management Program Plan. The disposal } \\
\text { authorization statement shall be issued based on a } \\
\text { review of the facility's performance assessment, } \\
\text { composite analysis, performance assessment and } \\
\text { composite analysis maintenance, preliminary closure } \\
\text { plan, and preliminary monitoring plan. The disposal } \\
\text { authorization statement shall specify the limits and } \\
\text { conditions on construction, design, operations, and } \\
\text { closure of the low-level waste facility based on these } \\
\text { reviews. A disposal authorization statement is a part of } \\
\text { the radioactive waste management basis for a disposal } \\
\text { facility. Failure to obtain a disposal authorization } \\
\text { statement by the implementation date of this Order } \\
\text { shall result in shutdown of the disposal facility. }\end{array}$ & See P. above. \\
\hline $\begin{array}{l}\text { (6) Disposal Facility Operations. The disposal facility } \\
\text { design and operation must be consistent with the } \\
\text { disposal facility closure plan and lead to disposal } \\
\text { facility closure that provides a reasonable expectation } \\
\text { that performance objectives will be met. Low-level } \\
\text { waste shall be disposed in such a manner that achieves } \\
\text { the performance objectives stated in this Chapter, } \\
\text { consistent with the disposal facility radiological } \\
\text { performance assessment. Additional requirements } \\
\text { include: }\end{array}$ & See P. above. \\
\hline $\begin{array}{l}\text { (a) Operating procedures shall be developed and } \\
\text { implemented for low-level waste disposal facilities that } \\
\text { protect the public, workers, and the environment; } \\
\text { ensure the security of the facility; minimize subsidence } \\
\text { during and after waste emplacement; achieve long-term } \\
\text { stability and minimize the need for long-term active } \\
\text { maintenance; and meet the requirements of the } \\
\text { closure/post-closure plan. }\end{array}$ & See P. above. \\
\hline $\begin{array}{l}\text { (b) Permanent identification markers for disposal } \\
\text { excavations and monitoring wells shall be emplaced. }\end{array}$ & See P. above. \\
\hline $\begin{array}{l}\text { (c) Low-level waste placement into disposal units shall } \\
\text { minimize voids between waste containers. Voids within } \\
\text { disposal units shall be filled to the extent practical. } \\
\text { Uncontainerized bulk waste shall also be placed in a } \\
\text { manner that minimizes voids and subsidence. }\end{array}$ & See P. above. \\
\hline (d) Operations are to be conducted so that active waste & See P. above. \\
\hline
\end{tabular}


Table 4. (continued).

\begin{tabular}{|c|c|}
\hline \multicolumn{2}{|c|}{ MFC-704, Fuel Manufacturing Facility } \\
\hline Chapter IV, LLW Requirements & Facility Compliance Information \\
\hline $\begin{array}{l}\text { disposal operations will not have an adverse effect on } \\
\text { any other disposal units. }\end{array}$ & \\
\hline $\begin{array}{l}\text { (e) Operations shall include a process for tracking and } \\
\text { documenting low-level waste placement in the facility } \\
\text { by generator source. }\end{array}$ & See P. above. \\
\hline $\begin{array}{l}\text { (7) Alternate Requirements for Low-Level Waste } \\
\text { Disposal Facility Design and Operation. Requirements } \\
\text { other than those set forth in this Section for the design } \\
\text { and operation of a low-level waste disposal facility } \\
\text { may be approved on a specific basis if a reasonable } \\
\text { expectation is demonstrated that the disposal } \\
\text { performance objectives will be met. }\end{array}$ & See P. above. \\
\hline $\begin{array}{l}\text { Q. Closure. The following requirements are in addition } \\
\text { to those in Chapter I of this Manual. }\end{array}$ & NA; this facility does not dispose of LLW. \\
\hline $\begin{array}{l}\text { (1) Disposal Facility Closure Plans. A preliminary } \\
\text { closure plan shall be developed and submitted to } \\
\text { Headquarters for review with the performance } \\
\text { assessment and composite analysis. The closure plan } \\
\text { shall be updated following issuance of the disposal } \\
\text { authorization statement to incorporate conditions } \\
\text { specified in the disposal authorization statement. } \\
\text { Closure plans shall: }\end{array}$ & See Q. above. \\
\hline $\begin{array}{l}\text { (a) Be updated as required during the operational life of } \\
\text { the facility. }\end{array}$ & See Q. above. \\
\hline $\begin{array}{l}\text { (b) Include a description of how the disposal facility } \\
\text { will be closed to achieve long-term stability and } \\
\text { minimize the need for active maintenance following } \\
\text { closure and to ensure compliance with the requirements } \\
\text { of DOE 5400.5, Radiation Protection of the Public and } \\
\text { the Environment. }\end{array}$ & See Q. above. \\
\hline $\begin{array}{l}\text { (c) Include the total expected inventory of wastes to be } \\
\text { disposed of at the facility over the operational life of } \\
\text { the facility. }\end{array}$ & See Q. above. \\
\hline $\begin{array}{l}\text { (2) Disposal Facility Closure. Closure of a disposal } \\
\text { facility shall occur within a five-year period after it is } \\
\text { filled to capacity, or after the facility is otherwise } \\
\text { determined to be no longer needed. }\end{array}$ & See Q. above. \\
\hline $\begin{array}{l}\text { (a) Prior to facility closure, the final inventory of the } \\
\text { low-level waste disposed in the facility shall be } \\
\text { prepared and incorporated in the performance } \\
\text { assessment and composite analysis which shall be } \\
\text { updated to support the closure of the facility. }\end{array}$ & See Q. above. \\
\hline $\begin{array}{l}\text { (b) A final closure plan shall be prepared based on the } \\
\text { final inventory of waste disposed in the facility, the } \\
\text { plan implemented, and the updated performance } \\
\text { assessment and composite analysis prepared in support }\end{array}$ & See Q. above. \\
\hline
\end{tabular}


Table 4. (continued).

\begin{tabular}{|c|c|}
\hline \multicolumn{2}{|c|}{ MFC-704, Fuel Manufacturing Facility } \\
\hline Chapter IV, LLW Requirements & Facility Compliance Information \\
\hline of the facility closure. & \\
\hline $\begin{array}{l}\text { (c) Institutional control measures shall be integrated } \\
\text { into land use and stewardship plans and programs, and } \\
\text { shall continue until the facility can be released pursuant } \\
\text { to DOE } 5400.5 \text {, Radiation Protection of the Public and } \\
\text { the Environment. }\end{array}$ & See Q. above. \\
\hline $\begin{array}{l}\text { (d) The location and use of the facility shall be filed } \\
\text { with the local authorities responsible for land use and } \\
\text { zoning. }\end{array}$ & See Q. above. \\
\hline $\begin{array}{l}\text { R. Monitoring. The following requirements are in } \\
\text { addition to those in Chapter I of this Manual [DOE M } \\
435.1-1 \text { §I.1.E(7)]. }\end{array}$ & $\begin{array}{l}\text { DOE Manual 435.1-1 §I.1.E(7) applies to field element } \\
\text { managers. }\end{array}$ \\
\hline $\begin{array}{l}\text { (1) All Waste Facilities. Parameters that shall be } \\
\text { sampled or monitored, at a minimum, include: } \\
\text { temperature, pressure (for closed systems), } \\
\text { radioactivity in ventilation exhaust and liquid effluent } \\
\text { streams, and flammable or explosive mixtures of gases. } \\
\text { Facility monitoring programs shall include verification } \\
\text { that passive and active control systems have not failed. }\end{array}$ & $\begin{array}{l}\text { Monitoring requirements at INL radioactive waste } \\
\text { management facilities are tailored for the specific } \\
\text { facility to enable timely indication of developing } \\
\text { problems. Existing radiological control procedures and } \\
\text { assessments are followed/completed to monitor waste } \\
\text { facilities. }\end{array}$ \\
\hline $\begin{array}{l}\text { From DOE G 435.1-1 Chapter IV: The minimum } \\
\text { parameters specified in the requirement were selected } \\
\text { based on their potential significance for anticipating } \\
\text { and identifying undesirable conditions at low-level } \\
\text { waste management facilities. Each facility's radioactive } \\
\text { waste management basis should include an evaluation } \\
\text { of the applicability and significance of the minimum } \\
\text { parameters. This evaluation also needs to consider } \\
\text { additional parameters to be sampled or monitored to } \\
\text { ensure the protection of the public health, the } \\
\text { environment, and the workers. If a minimum parameter } \\
\text { specified in the requirement is deemed to be not } \\
\text { applicable in any way to the active operation of that } \\
\text { facility, then that justification should be included in the } \\
\text { radioactive waste management basis and when } \\
\text { approved constitutes an exemption to the manual. }\end{array}$ & \\
\hline $\begin{array}{l}\text { Verification activities are part of the radioactive waste } \\
\text { management basis as a condition for operation and } \\
\text { documented appropriately. }\end{array}$ & \\
\hline $\begin{array}{l}\text { Compliance with this requirement is demonstrated if } \\
\text { monitoring or sampling for the stated parameters is } \\
\text { performed for all facilities with a precision, accuracy, } \\
\text { and frequency consistent with timely identification of } \\
\text { developing problems and a justification exists in the } \\
\text { approved radioactive waste management basis for those } \\
\text { specified parameters which are not monitored or } \\
\text { sampled. }\end{array}$ & \\
\hline (2) Liquid Waste Storage Facilities. For facilities & NA; liquid LLW is not stored in this facility. \\
\hline
\end{tabular}


Table 4. (continued).

\begin{tabular}{|l|l|}
\hline \multicolumn{2}{|c|}{ MFC-704, Fuel Manufacturing Facility } \\
\hline \multicolumn{1}{|c|}{ Chapter IV, LLW Requirements } & \multicolumn{1}{|c|}{ Facility Compliance Information } \\
\hline $\begin{array}{l}\text { storing liquid low-level waste, the following shall also } \\
\text { be monitored: liquid level and/or waste volume, and } \\
\text { significant waste chemistry parameters. }\end{array}$ & \\
\hline $\begin{array}{l}\text { (3) Disposal Facilities. A preliminary monitoring plan } \\
\text { for a low-level waste disposal facility shall be prepared } \\
\text { and submitted to Headquarters for review with the } \\
\text { performance assessment and composite analysis. The } \\
\text { monitoring plan shall be updated within one year } \\
\text { following issuance of the disposal authorization } \\
\text { statement to incorporate and implement conditions } \\
\text { specified in the disposal authorization statement. }\end{array}$ & \\
\hline $\begin{array}{l}\text { (a) The site-specific performance assessment and } \\
\text { composite analysis shall be used to determine the } \\
\text { media, locations, radionuclides, and other substances to } \\
\text { be monitored. }\end{array}$ & \\
\hline $\begin{array}{l}\text { (b) The environmental monitoring program shall be } \\
\text { designed to include measuring and evaluating releases, } \\
\text { migration of radionuclides, disposal unit subsidence, } \\
\text { and changes in disposal facility and disposal site } \\
\text { parameters which may affect long-term performance. }\end{array}$ & See (3) above. \\
\hline $\begin{array}{l}\text { (c) The environmental monitoring programs shall be } \\
\text { capable of detecting changing trends in performance to } \\
\text { allow application of any necessary corrective action } \\
\text { prior to exceeding the performance objectives in this } \\
\text { Chapter. }\end{array}$ & See (3) above. \\
\hline
\end{tabular}

\subsection{MFC-752, Analytical Laboratory}

1. Facility description: MFC-752, Analytical Laboratory, is located in the A and B wings of the Laboratory and Office Building 752, with one room in the C wing. However, MFC-752's administrative offices are in the $\mathrm{L}$ wing and Room C-126. The Analytical Laboratory also occupies a portion of the Laboratory and Office Building beneath the A and B wings. The construction of the foundation, floor, and hot cells is reinforced concrete. The building construction is concrete masonry exterior walls and concrete masonry or metal stud and gypsum board interior walls.

The main features of the A wing are the six hot cells and attached gloveboxes, one general purpose laboratory (C-123), an equipment decontamination room (A-126), two vaults (A-116) for storage of radioactive materials, and two glovebox systems (A-102). The B wing contains the chemical, casting, and nondestructive assay laboratories. 


\section{a. Hot Cells}

The basic purpose of the hot cells is to provide a shielded laboratory environment for analysis of nuclear fuels and other irradiated material. The hot cells provide the primary confinement for all highly radioactive materials introduced into the facility for analysis or characterization. Analyses are performed behind leaded glass shielding windows using state-of-the-art leader/follower manipulators in order to protect personnel, the process, and the environment.

The primary wall for the six interconnected hot cells is constructed of 2-ft-thick high density concrete. In the back of the four center cells is a 3 -ft-wide (stepped to $4 \mathrm{ft}$ ) by 6 -ft 8 -in.-high shielding door. At the east and west end cells are 5-ft 6-in.-wide (stepped to $6 \mathrm{ft} 6$ in.) by 6 -ft 8 -in.-high shielding doors. Inside each shielding door is a steel splash door for sealing the cells. The gasket seal between the splash door and the cell wall is broken when the splash door is opened, allowing cell entry. The cell wall thickness reduces to $1 \mathrm{ft}$ above the doors on the back and on the ends at a height of $7 \mathrm{ft} 11 \mathrm{in}$. Adjacent to the four rear cell doors, the wall thickness is $2 \mathrm{ft} 6 \mathrm{in}$. The concrete ceiling is $10 \mathrm{in}$. thick. There is a 2-ft-thick shielded viewing window in the front of each cell with a viewing area of $25.5 \mathrm{in}$. (front) to $31 \mathrm{in.}$ (back) in height and $36 \mathrm{in.}$ (front) to 48 in. (back) in width. Two sealed manipulators are located inside the cell just behind the viewing windows. Attached to the back of Cell 6 is a shielded glovebox. Access from the hot cell to the glovebox is an 8-in. penetration through the hot cell wall.

The hot cells are operated at a pressure negative with respect to the surrounding rooms and at ambient temperature.

The hot cell design includes features that facilitate decontamination and eventual decommissioning and dismantling. To the extent practicable, corners are rounded and exposed sheet metal surfaces of the hot cells are free of sharp edges, cracks, pits, grooves, and other irregularities that could trap contaminants. The interior is a painted surface that can be decontaminated.

Interior lighting for the hot cells is provided by fixtures mounted to the exterior of the hot cells. An easy access unit design permits routine maintenance and lamp change without breaching the cell boundary.

b. Hot Cell Service Area

Behind the hot cells is the hot cell service area (A-101a). This area provides access to the hot cells. Equipment and reagent needed in the cells are transferred into the cells from the service entry through a shielded transfer port in Cell 6. Radioactive waste and samples are removed through a shielded transfer port in Cell 1 via a 4-in. pneumatic transfer system line that terminates in a shielded cask in the Laboratory and Office Building, or via a 2-in. pneumatic transfer system line that goes to FCF and then on to HFEF. Samples are transferred into the hot cells through a pneumatic transfer system from FCF or from HFEF by intermediate transfer to FCF or via the Cell 6 transfer port. Some samples may be transferred directly to the hot cells.

c. Manipulator Repair Room

A 10-ft by 12-ft room located adjacent to the hot cells is equipped to support repair of the leader/follower manipulators. The room is set up similar to the hot cells such that the manipulator can be pulled and inserted into the repair room via a port for repair.

d. Vaults

North of the hot cell service area is an area containing vaults. The vaults are used for storage of radioactive and hazardous waste.

e. B-Wing Laboratories

The main features of the B wing are general chemistry laboratories, analytical instrument laboratories, gloveboxes, counting rooms, and chemical storage. B-147, formerly known as the Experimental Fuels Laboratory, contains an inert atmosphere glovebox where actinide-bearing 
materials are fabricated and tested. The laboratories are designed with laboratory air hoods and contain a variety of scientific equipment. Typical equipment may include, but is not limited to, spectrophotometers, spectrometers, chromatographs, ion selective electrodes, diffractometers, fluorometers, elemental analyzers, and other Analytical Laboratory equipment, such as hot plates and balances. The general chemistry laboratories perform analyses on nonradioactive samples or samples containing relatively low levels of radioactivity.

2. Hazard category: Hazard category 3 non-reactor nuclear facility

3. Radioactive waste managed at this facility: Routine CH LLW and liquid mixed LLW are generated and staged at this facility. CH TRU waste and RH TRU waste are generated and stored at this facility.

\section{RWMB documents/programs:}

a. Safety basis/hazard analysis:

- W0660-0055-KH, "Analytical Laboratory Safety Analysis Report"

- LST-329, "Analytical Laboratory Nuclear Safety Basis Implementation Matrix”

b. Laboratory-wide:

- Form 441.A34, "INL Radiological Control Required Surveys"

- LI-435, "Waste Management Routine Field Activities"

- LRD-15001, "Radiological Control Manual"

- LWP-8000, Environmental Instructions for Facilities, Processes, Materials, and Equipment

- LWP-8300, "Transuranic Waste Handling”

- LWP-13840, "Management of Issues, Observations, and Noteworthy Practices"

- LWP-14002, "Timeout and Stop Work Authority"

- LWP-15011, "Radioactive Material Areas and Radioactive Storage Areas"

- LWP-17000, "Waste Management"

- MCP-139, "Radiological Surveys"

- MCP-17000, "Waste Generator Services Waste Management"

- MCP-17410, "Management of Waste Storage Areas"

- MCP-17500, "Waste Generator Services Certification of Waste Shipments to the Nevada Test Site"

- PDD-17000, "Waste Management Program"

- PLN-114, "INL Emergency Plan/RCRA Contingency Plan"

- PLN-522, "Quality Assurance Program Plan for the Waste Management/Waste Certification Program"

- PLN-8300, "Materials and Fuels Complex Contact-Handled TRU Waste Certification Program Plan"

c. Facility-specific:

- AL-0634-OI-001, "Radioactive Liquid Waste System"

- AL-5000-LI-003, "Contact-Handled Transuranic Waste Handling"

- AL-7000-OI-001, "Facility Conditions"

- ANL-NT-192, "The Defense Programs Origin of Transuranic Waste at Argonne National Laboratory-West, H. F. McFarlane, 11/1/2001" 
- INL/EXT-10-17600, Process Knowledge Summary Report for Materials and Fuels Complex Contact-handled Transuranic Waste

- PER-116, "HWMA/RCRA Storage and Treatment Permit for the Materials and Fuels Complex"

- PLN-2495, "Waste Analysis Plan for the Idaho National Laboratory Materials and Fuels Complex Analytical Laboratory Elementary Neutralization Unit"

- RL-OI-1, "Radioactive-Liquid-Waste Collection"

- SD-38.1.1, "Treatment, Storage, and Disposal Facilities (TSDF) Environmental Compliance"

- TSD-OI-004, "Waste and Material Acceptance for Storage/Treatment and Radioactive Material Inventory Control"

- W0640-0047-KP, "Hot Cell Waste Preparation and Sample Collection for Disposal/Return"

- W0660-0035-AP, “General Laboratory Waste."

TRU waste and LLW are managed at this facility. Table 5 shows the facility compliance information for DOE Manual 435.1-1 Chapter III, "Transuranic Waste Requirements," and Table 6 presents the facility compliance information for Chapter IV, "Low-level Waste Requirements."

Table 5. MFC-752, Analytical Laboratory, DOE Manual 435.1-1 transuranic waste requirements and facility compliance information.

\begin{tabular}{|l|l|}
\hline \multicolumn{2}{|c|}{ MFC-752, Analytical Laboratory } \\
\hline \multicolumn{1}{|c|}{ Chapter III, Transuranic Waste Requirements } & \multicolumn{1}{c|}{ Facility Compliance Information } \\
\hline $\begin{array}{l}\text { A. Definition of Transuranic Waste. Transuranic waste } \\
\text { is radioactive waste containing more than 100 } \\
\text { nanocuries (3700 becquerels) of alpha-emitting } \\
\text { transuranic isotopes per gram of waste, with half-lives } \\
\text { greater than 20 years, except for: }\end{array}$ & $\begin{array}{l}\text { This requirement proves the criteria for determining } \\
\text { which DOE radioactive waste is to be managed as TRU } \\
\text { waste in accordance with DOE Manual 435.1-1, } \\
\text { Chapter III. }\end{array}$ \\
$\begin{array}{l}\text { (From DOE G 435.1-1 Chapter III: The determination } \\
\text { of transuranic waste should be made at the time of } \\
\text { waste certification, that is, each time the waste is } \\
\text { transferred to another person or facility.) }\end{array}$ & See J. below. \\
\hline \begin{tabular}{l} 
(1) High-level radioactive waste; \\
\hline $\begin{array}{l}\text { (2) Waste that the Secretary of Energy has determined, } \\
\text { with the concurrence of the Administrator of the }\end{array}$
\end{tabular} & See A. above. \\
$\begin{array}{l}\text { Environmental Protection Agency, does not need the } \\
\text { degree of isolation required by the 40 CFR Part 191 } \\
\text { disposal regulations; or }\end{array}$ & \\
\hline $\begin{array}{l}\text { (3) Waste that the Nuclear Regulatory Commission } \\
\text { has approved for disposal on a case-by-case basis in } \\
\text { accordance with 10 CFR Part 61. }\end{array}$ & See A. above. \\
\hline $\begin{array}{l}\text { B. Management of Specific Wastes. The following } \\
\text { provide for management of specific wastes as } \\
\text { transuranic waste in accordance with the requirements } \\
\text { in this Chapter: }\end{array}$ & See below. \\
$\begin{array}{l}\text { From DOE G 435.1-1 Chapter III: Compliance with } \\
\text { these requirements is demonstrated if RCRA, state- } \\
\text { hazardous, and TSCA-regulated radioactive wastes are } \\
\text { being managed in compliance with applicable }\end{array}$ & \\
\hline
\end{tabular}


Table 5. (continued).

\section{MFC-752, Analytical Laboratory}

Chapter III, Transuranic Waste Requirements Facility Compliance Information

requirements and agreements or in accordance with a consent order, and consistent with the Transuranic Waste Requirements of DOE M 435.1-1.

(1) Mixed Transuranic Waste. Transuranic waste determined to contain both a hazardous component subject to the Resource Conservation and Recovery Act (RCRA), as amended, and a radioactive component subject to the Atomic Energy Act of 1954, as amended, shall be managed in accordance with the requirements of RCRA and DOE O 435.1, Radioactive Waste Management, and this Manual.

(2) TSCA-Regulated Waste. Transuranic waste containing polychlorinated biphenyls, asbestos, or other such regulated toxic components shall be managed in accordance with requirements derived from the Toxic Substances Control Act, as amended, DOE O 435.1, Radioactive Waste Management, and this Manual.

(3) Pre-1970 Transuranic Waste. Transuranic waste disposed of prior to implementation of the 1970 Atomic Energy Commission Immediate Action Directive regarding retrievable storage of transuranic waste is not subject to the requirements of DOE O 435.1, Radioactive Waste Management, and this Manual.

C. Complex-Wide Transuranic Waste Management Program. A complex-wide program and plan shall be developed as described under Responsibilities, 2.B and 2.D, in Chapter I of this Manual.

From DOE G 435.1-1 Chapter III: Compliance with this requirement is demonstrated by the presence of a Complex-Wide Transuranic Waste Management Program which includes the appropriate interfaces, technical information, data inputs, and other elements described in Chapter I of this Manual.

D. Radioactive waste management basis. Transuranic waste facilities, operations, and activities shall have a radioactive waste management basis consisting of physical and administrative controls to ensure the protection of workers, the public, and the environment. The following specific waste management controls shall be part of the radioactive waste management basis:

From DOE G 435.1-1 Chapter III: Compliance with this requirement is demonstrated if, the radioactive waste management basis is documented and signed by the Field Element manager or a designee (see DOE M 435.1-1, Section I.1.A, Delegation of Authority) for
Mixed TRU waste is managed at this facility.

Compliance with RCRA regulations is addressed by WGS in its waste management services role in MCP-17000.

NA; TSCA-regulated TRU waste is not managed at this facility.

NA; pre-1970 TRU waste is not managed at this facility.

Not a facility-specific requirement. DOE Manual 435.1-1 $\S I .2 . B$ and §I.2.D apply to the Assistant Secretary for Environmental Management and the Deputy Assistant Secretary for Waste Management, respectively.

The RWMB provides the regulatory framework for management of radioactive waste at INL. It specifically identifies facility management and implementing documents for the generation, storage, treatment, and disposal of radiological waste. This facility is a Hazard Category 3 non-reactor nuclear facility (W0660-0055$\mathrm{KH})$. The facility's safety basis requirements and implementing documents are identified in LST-329. 
Table 5. (continued).

MFC-752, Analytical Laboratory

Chapter III, Transuranic Waste Requirements Facility Compliance Information each transuranic waste management facility, operation, or activity. Using a graded approach, it may be possible to include multiple activities under a single radioactive waste management basis, but it should be possible to objectively identify which activities are covered. Further, the radioactive waste management basis includes or references the controls that are established on a facility-specific basis to address the unique waste management requirements and circumstances for each facility, operation, and/or activity.

(1) Generators. The waste certification program.

See J. below.

From DOE G 435.1-1 Chapter III: For a facility that generates transuranic waste, the radioactive waste management basis is to include the program for certifying that waste meets the waste acceptance requirements of the facility(ies) to which the waste will be sent. 
Table 5. (continued).

\section{MFC-752, Analytical Laboratory}

Chapter III, Transuranic Waste Requirements

(2) Treatment Facilities. certification program. The waste acceptance requirements and the waste [sic]

From DOE G 435.1-1 Chapter III: Facilities that store or treat transuranic waste are to have approved waste acceptance requirements (see DOE M 435.1-1, Section III.G) prior to the issuance of a radioactive waste management basis. The waste acceptance requirements will usually suffice as documentation of the radiological, physical, and chemical limitations on waste that can be safely received at the facility, provided they are developed correctly with consideration of the hazards of the waste to be managed, and are kept up to date. Controls on the radiological, physical and chemical limitations need to include considerations of the potential effects of radiolysis.

A facility that stores or treats waste is generally expected to have a waste certification program. Waste from these facilities will have to be certified as meeting the waste acceptance requirements of the facility to which it will be transferred and the facilities have the potential for generating radioactive waste (e.g., secondary processing streams from treatment, monitoring and sampling, radioactive release cleanup). Consequently, storage and treatment facilities should also have an approved waste certification program as part of their radioactive waste management basis.

As part of the radioactive waste management basis, site personnel should implement a system or process for tracking the waste inventory at a storage, treatment, or disposal facility.

(3) Storage Facilities. The waste acceptance requirements and the waste certification program.

From DOE G 435.1-1 Chapter III: Facilities that store or treat transuranic waste are to have approved waste acceptance requirements (see DOE M 435.1-1, Section III.G) prior to the issuance of a radioactive waste management basis. The waste acceptance requirements will usually suffice as documentation of the radiological, physical, and chemical limitations on waste that can be safely received at the facility, provided they are developed correctly with consideration of the hazards of the waste to be managed, and are kept up to date. Controls on the radiological, physical and chemical limitations need to include considerations of the potential effects of radiolysis.

A facility that stores or treats waste is generally
NA; LLW is not treated at this facility.
See G. and J. below for waste acceptance and waste certification program requirements.

AL-5000-LI-003 specifies documentation and packaging in accordance with LWP-8300 and PLN-8300.

LWP-8300 addresses the use of the IWTS to track waste inventory. 
Table 5. (continued).

MFC-752, Analytical Laboratory

\begin{tabular}{|c|c|}
\hline Chapter III, Transuranic Waste Requirements & Facility Compliance Information \\
\hline $\begin{array}{l}\text { expected to have a waste certification program. Waste } \\
\text { from these facilities will have to be certified as } \\
\text { meeting the waste acceptance requirements of the } \\
\text { facility to which it will be transferred and the facilities } \\
\text { have the potential for generating radioactive waste } \\
\text { (e.g., secondary processing streams from treatment, } \\
\text { monitoring and sampling, radioactive release cleanup). } \\
\text { Consequently, storage and treatment facilities should } \\
\text { also have an approved waste certification program as } \\
\text { part of their radioactive waste management basis. }\end{array}$ & \\
\hline $\begin{array}{l}\text { As part of the radioactive waste management basis, } \\
\text { site personnel should implement a system or process } \\
\text { for tracking the waste inventory at a storage, treatment, } \\
\text { or disposal facility. }\end{array}$ & \\
\hline $\begin{array}{l}\text { (4) Disposal Facilities. The performance assessment, } \\
\text { disposal authorization statement, waste acceptance } \\
\text { requirements, and monitoring plan. }\end{array}$ & NA; this facility is not a disposal facility. \\
\hline $\begin{array}{l}\text { E. Contingency Actions. The following requirements } \\
\text { are in addition to those in Chapter I of this Manual. } \\
\text { From DOE G 435.1-1 Chapter III: Compliance with } \\
\text { these requirements is demonstrated by having adequate } \\
\text { spare capacity and transfer equipment exists for } \\
\text { emergency transfers of all liquid transuranic waste. In } \\
\text { addition, the capability to perform emergency transfers } \\
\text { is demonstrated by having waste transfer routings } \\
\text { identified, operational procedures to direct transfers, } \\
\text { staff trained to the procedures, and records showing } \\
\text { that the spare capacity and transfer capability are kept } \\
\text { in operating condition. }\end{array}$ & $\begin{array}{l}\text { Not a facility-specific requirement. DOE Manual 435.1-1 } \\
\text { I.1.E(5) addresses the sitewide emergency management } \\
\text { system. The INL plan is provided in PLN-114. }\end{array}$ \\
\hline $\begin{array}{l}\text { (1) Contingency Storage. For off-normal or emergency } \\
\text { situations involving liquid transuranic waste storage or } \\
\text { treatment, spare capacity with adequate capabilities } \\
\text { shall be maintained to receive the largest volume of } \\
\text { liquid contained in any one storage tank or treatment } \\
\text { facility. Tanks or other facilities that are designated } \\
\text { transuranic waste contingency storage shall be } \\
\text { maintained in an operational condition when waste is } \\
\text { present and shall meet the requirements of DOE O } \\
\text { 435.1, Radioactive Waste Management, and this } \\
\text { Manual. }\end{array}$ & $\begin{array}{l}\text { NA; this facility does not store or treat liquid TRU waste } \\
\text { in tanks. }\end{array}$ \\
\hline $\begin{array}{l}\text { (2) Transfer Equipment. Pipelines and auxiliary } \\
\text { facilities necessary for the transfer of liquid waste to } \\
\text { contingency storage shall be maintained in an } \\
\text { operational condition when waste is present and shall } \\
\text { meet the requirements of DOE O } 435.1 \text {, Radioactive } \\
\text { Waste Management, and this Manual. }\end{array}$ & $\begin{array}{l}\text { NA; this facility does not store or treat liquid TRU waste } \\
\text { in tanks. }\end{array}$ \\
\hline $\begin{array}{l}\text { F. Corrective Actions. I of this Manual. The following } \\
\text { requirements are in addition to those in Chapter [sic] }\end{array}$ & $\begin{array}{l}\text { The INL-wide procedure addressing problem } \\
\text { identification as required by DOE Manual } 435.1-1\end{array}$ \\
\hline
\end{tabular}


Table 5. (continued).

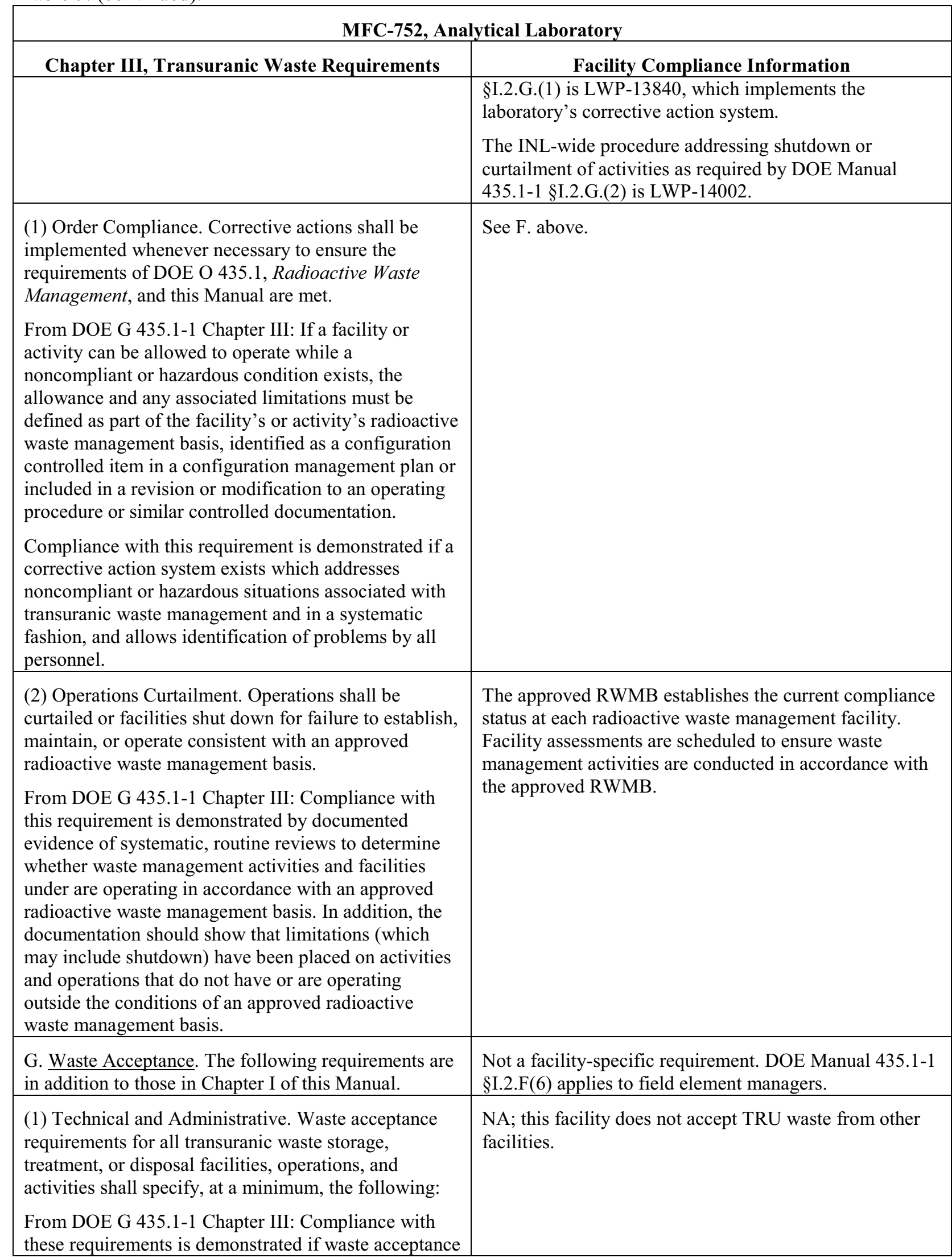


Table 5. (continued).

MFC-752, Analytical Laboratory

\begin{tabular}{|c|c|}
\hline Chapter III, Transuranic Waste Requirements & Facility Compliance Information \\
\hline $\begin{array}{l}\text { requirements are documented, contain clear and } \\
\text { precise criteria specifying the radionuclide limits in the } \\
\text { form of contents or concentrations that can be } \\
\text { accepted, the limitations and prohibitions on waste } \\
\text { forms and packages that can be received, and the } \\
\text { limits, prohibitions, or instructions concerning any } \\
\text { other technical information so that the waste is } \\
\text { compatible with the safety basis of the facility, and } \\
\text { which will result in acceptable waste at subsequent } \\
\text { steps in managing the transuranic waste. Waste } \\
\text { acceptance requirements are to also contain a clear } \\
\text { description of the process and bases for obtaining an } \\
\text { exception or deviation to the acceptance criteria for } \\
\text { transuranic waste to be received } \\
\text { at the facility. }\end{array}$ & \\
\hline $\begin{array}{l}\text { (a) Allowable activities and/or concentrations of } \\
\text { specific radionuclides; }\end{array}$ & See (1) above. \\
\hline $\begin{array}{l}\text { (b) Acceptable waste form and/or container } \\
\text { requirements that ensure the chemical and physical } \\
\text { stability of waste under conditions that might be } \\
\text { encountered during transportation, storage, treatment, } \\
\text { or disposal; }\end{array}$ & See (1) above. \\
\hline $\begin{array}{l}\text { (c) Restrictions or prohibitions on waste, materials, or } \\
\text { containers that may adversely affect waste handlers or } \\
\text { compromise facility or waste container performance; }\end{array}$ & See (1) above. \\
\hline $\begin{array}{l}\text { (d) Requirement to identify transuranic waste as } \\
\text { defense or non-defense, and limitations on acceptance; } \\
\text { and }\end{array}$ & See (1) above. \\
\hline $\begin{array}{l}\text { (e) The basis, procedures, and levels of authority } \\
\text { required for granting exceptions to the waste } \\
\text { acceptance requirements, which shall be contained in } \\
\text { each facility's waste acceptance documentation. Each } \\
\text { exception request shall be documented, including its } \\
\text { disposition as approved or not approved. }\end{array}$ & See (1) above. \\
\hline $\begin{array}{l}\text { (2) Evaluation and Acceptance. The receiving facility } \\
\text { shall evaluate waste for acceptance, including } \\
\text { confirmation that technical and administrative } \\
\text { requirements have been met. A process for the } \\
\text { disposition of non-conforming wastes shall be } \\
\text { established. } \\
\text { From DOE G 435.1-1 Chapter III: Compliance with } \\
\text { these requirements is demonstrated if there is a } \\
\text { procedure or process for evaluating and accepting } \\
\text { incoming waste which ensures the acceptance criteria } \\
\text { of the facility receiving the waste are met by one or a } \\
\text { combination of: (1) testing, sampling, and analysis of } \\
\text { representative samples of incoming waste upon }\end{array}$ & $\begin{array}{l}\text { NA; this facility does not accept TRU waste from other } \\
\text { facilities. }\end{array}$ \\
\hline
\end{tabular}


Table 5. (continued).

\section{MFC-752, Analytical Laboratory}

Chapter III, Transuranic Waste Requirements Facility Compliance Information

receipt; (2) testing, sampling, and analysis of samples of waste taken at the generator facility; (3) evaluation of testing, sampling, and analysis of data provided by the generator; or (4) audits, reviews, or surveillances of generator waste certification programs and characterization activities. Additionally, acceptable waste acceptance requirements for a storage, treatment, or disposal facility will have documented procedures and actions to be taken if a waste that does not conform to the waste acceptance criteria is received at the facility.

H. Waste Generation Planning. The following requirements are in addition to those in Chapter I of this Manual.

(1) Life-Cycle Planning. Prior to waste generation, planning shall be performed to address the entire life cycle for all transuranic waste streams.

From DOE G 435.1-1 Chapter III: Compliance with this planning requirement is demonstrated by the individual sites establishing a process for evaluating the life-cycle of [transuranic] waste prior to its generation, including the identification of [transuranic] wastes with no path to disposal and appropriate records justifying the newly generated [transuranic] waste stream(s), and site personnel possessing planning information showing the location(s) where [transuranic] waste will be stored, treated, and/or disposed along with a confirmation that the personnel managing the facilities agree that the [transuranic] waste may be managed at those facilities.

(2) Waste with No Identified Path to Disposal. Transuranic waste streams with no identified path to disposal shall be generated only in accordance with approved conditions which, at a minimum, shall address:

From DOE G 435.1-1 Chapter III: Compliance with requirement is demonstrated by the waste generation organization having documentation concerning the decision to generate a transuranic waste stream that does not have an identified path to disposal. This documentation needs to include the cognizant Field Element Manager or designee approval to generate the waste, an explanation of the need for the process that generates the transuranic waste, a discussion of the reason it cannot be disposed of, the proposed management plan for the waste, and an up-to-date schedule of activities being pursued to resolve constraints to the disposal of the subject waste. Consistent with the use of a graded approach for

Not a facility-specific requirement. DOE Manual 435.1-1 $\S$ I.2.F(7) applies to field element managers.

PDD-17000 and LWP-17000 provide direction to the waste generators for waste generation planning to address the entire life cycle.
NA; this facility is not generating TRU waste that does not have an identified path to disposal. 
Table 5. (continued).

\section{MFC-752, Analytical Laboratory}

Chapter III, Transuranic Waste Requirements Facility Compliance Information applying DOE M 435.1-1 requirements, the schedule and plans for disposing of nondefense waste can defer to the complex-wide resolution of the issue.

(a) Programmatic need to generate the waste;

(b) Characteristics and issues preventing the disposal of the waste;

(c) Safe storage of the waste until disposal can be achieved; and

(d) Activities and plans for achieving final disposal of the waste.

I. Waste Characterization. Transuranic waste shall be characterized using direct or indirect methods, and the characterization documented in sufficient detail to ensure safe management and compliance with the waste acceptance requirements of the facility receiving the waste.

From DOE G 435.1-1 Chapter III: Compliance with this requirement is demonstrated by a program for documenting and the existence of records that document the process for acquiring and verifying the validity of transuranic waste characterization data acquired through the use of direct or indirect methods.

(1) Data Quality Objectives. The data quality objectives process, or a comparable process, shall be used for identifying characterization parameters and acceptable uncertainty in characterization data.

From DOE G 435.1-1 Chapter III: Compliance with this requirement is demonstrated by the documented use of a data quality objectives or a comparable process for determining the type, quantity, and quality of characterization data needed to safely manage transuranic waste.

(2) Minimum Waste Characterization. Characterization data shall, at a minimum, include the following information relevant to the management of the waste:

From DOE G 435.1-1 Chapter III: Compliance with this requirement is demonstrated by the existence of a program or procedures for determining and records that document characterization of transuranic waste consistent with the minimum characterization data requirements.
See (2) above.

See (2) above.

See (2) above.

See (2) above.

W0660-0035-AP $\S \S 3.4$ and 3.5

W0640-0047-KP $\S 3.2$

AL-5000-LI-003, which specifies documentation and packaging in accordance with LWP-8300 ( $\$ 4$ addresses waste characterization) and PLN-8300 ( $\$ 2.9$ addresses waste characterization).

This facility also is managing several drums of RH TRU waste. LWP-8300 states that RH TRU waste must meet receiving facility WAC and procedures. Disposition of the RH TRU is being coordinated with the DOE Environmental Management (EM) contractor. The waste acceptance criteria will be established by the EM contractor by a project agreement. Acceptable knowledge and characterization information will be provided to demonstrate compliance with these criteria.

Radioactive waste management facilities characterize waste in accordance with the requirements of the receiving storage, treatment, or disposal facility. The documented use of a data quality objectives process, or comparable process, was not identified for this facility. 
Table 5. (continued).

MFC-752, Analytical Laboratory

Chapter III, Transuranic Waste Requirements

(a) Physical and chemical characteristics;

(b) Volume, including the waste and any stabilization or absorbent media;

(c) Weight of the container and contents;

(d) Identities, activities, and concentrations of major radionuclides;

\begin{tabular}{|l|}
\hline (e) Characterization date; \\
\hline (f) Generating source; \\
\hline (g) Packaging date; and \\
\hline
\end{tabular}

(h) Any other information which may be needed to prepare and maintain the disposal facility performance assessment or demonstrate compliance with applicable performance objectives.

J. Waste Certification. A waste certification program shall be developed, documented, and implemented to ensure that the waste acceptance requirements of facilities receiving transuranic waste for storage, treatment, or disposal are met.

From DOE G 435.1-1 Chapter III: Compliance with the development and documentation portion of the certification requirement is demonstrated by a waste certification plan that identifies the organizations involved, assigns responsibilities for implementing the program, and describes or references the quality assurance, training, procurement controls, records management, and procedures to be used by the program. Acceptable performance for implementing the program is demonstrated when the appropriate personnel are trained, and have and follow the procedures that govern their part of the waste certification process. Acceptable performance also requires that the waste certification plan and procedures are current and controlled in accordance with a document control program, and records related to certification (e.g., certification statements, training records, procurement records, characterization records, container records) are generated and managed in accordance with the established site program.

(1) Certification Program. The waste certification program shall designate the officials who have the authority to certify and release waste for shipment; and specify what documentation is required for waste generation, characterization, shipment, and certification. The program shall provide requirements for auditability, retrievability, and storage of required

\section{Facility Compliance Information}

See I. above.

See I. above.

See I. above.

See I. above.

See I. above.

See I. above.

See I. above.

See I. above.

Certification of the CH TRU managed at this facility is performed in conjunction with WGS in accordance with AL-5000-LI-003, which specifies documentation and packaging in accordance with LWP-8300 and PLN-8300.

This facility also is managing several drums of RH TRU waste. LWP-8300 states that RH TRU waste must meet receiving facility $\mathrm{WAC}$ and procedures. Disposition of the RH TRU is being coordinated with the EM contractor. The WAC will be established by the EM contractor by a project agreement. Acceptable knowledge and characterization information will be provided to demonstrate compliance with these criteria. 
Table 5. (continued).

\section{MFC-752, Analytical Laboratory}

\begin{tabular}{|c|c|}
\hline \multicolumn{2}{|c|}{ MFC-752, Analytical Laboratory } \\
\hline Chapter III, Transuranic Waste Requirements & Facility Compliance Information \\
\hline $\begin{array}{l}\text { documentation and specify the records retention } \\
\text { period. }\end{array}$ & \\
\hline $\begin{array}{l}\text { From DOE G 435.1-1 Chapter III: Compliance with } \\
\text { this requirement is demonstrated by a program or } \\
\text { procedure for record keeping and records showing that } \\
\text { each container of waste is certified as having met the } \\
\text { waste acceptance criteria of the facility to which it was } \\
\text { transferred and the certification statement is supported } \\
\text { by additional records regarding the waste source, } \\
\text { characterization, and container. }\end{array}$ & \\
\hline $\begin{array}{l}\text { (2) Certification before Transfer. Transuranic waste } \\
\text { shall be certified as meeting waste acceptance } \\
\text { requirements before it is transferred to the facility } \\
\text { receiving the waste. }\end{array}$ & See J. above. \\
\hline $\begin{array}{l}\text { From DOE G } 435.1-1 \text { Chapter III: Compliance with } \\
\text { this requirement is demonstrated by the presence of a } \\
\text { certification program which includes procedures } \\
\text { requiring a signed certification statement prior to the } \\
\text { release of waste for transfer, and by dated records } \\
\text { showing that waste was certified before being } \\
\text { transferred. }\end{array}$ & \\
\hline $\begin{array}{l}\text { (3) Maintaining Certification. Transuranic waste that } \\
\text { has been certified as meeting the waste acceptance } \\
\text { requirements for transfer to a storage, treatment, or } \\
\text { disposal facility shall be managed in a manner that } \\
\text { maintains its certification status. }\end{array}$ & $\begin{array}{l}\text { See J. above. } \\
\text { LWP- } 15011 \S 5 \text { provides general radioactive storage area } \\
\text { requirements. }\end{array}$ \\
\hline $\begin{array}{l}\text { From DOE G } 435.1-1 \text { Chapter III: Compliance with } \\
\text { this requirement is demonstrated by the existence of a } \\
\text { program or procedure reflecting this requirement and } \\
\text { site personnel able to show that the storage of } \\
\text { containers of waste is in a facility or manner where the } \\
\text { containers are not damaged by normal weather events, } \\
\text { and cannot be accessed by unauthorized personnel. } \\
\text { Further, each container can be traced to its certification } \\
\text { and the information supporting that certification. }\end{array}$ & \\
\hline K. Waste Transfer. A documented process shall be & AL-5000-LI-003 $§ 5.4$ \\
\hline $\begin{array}{l}\text { established and implemented for transferring } \\
\text { responsibility for management of transuranic waste } \\
\text { and for ensuring availability of relevant data. The } \\
\text { following requirements are in addition to those in }\end{array}$ & $\begin{array}{l}\text { PLN- } 8300 \$ 2.11 \text { states that MFC storage facilities or the } \\
\text { Advanced Mixed Waste Treatment Project needs to } \\
\text { approve material profiles and containers for shipment. }\end{array}$ \\
\hline $\begin{array}{l}\text { From DOE G 435.1-1 Chapter III: Compliance with } \\
\text { this requirement is demonstrated if facilities have } \\
\text { procedures for the receipt of waste and the transfer of } \\
\text { waste, as appropriate, which address the acquisition of } \\
\text { waste and container data and the transfer of ownership, } \\
\text { respectively. Further evidence of acceptable } \\
\text { performance is facility records showing that data on }\end{array}$ & $\begin{array}{l}\text { This facility also is managing several drums of RH TRU } \\
\text { waste. LWP- } 8300 \text { states that RH TRU waste must meet } \\
\text { receiving facility WAC and procedures. Disposition of } \\
\text { the RH TRU is being coordinated with the EM } \\
\text { contractor. A waste-specific agreement will be developed } \\
\text { to transfer management responsibility to the EM } \\
\text { contractor for this waste. }\end{array}$ \\
\hline
\end{tabular}


Table 5. (continued).

MFC-752, Analytical Laboratory

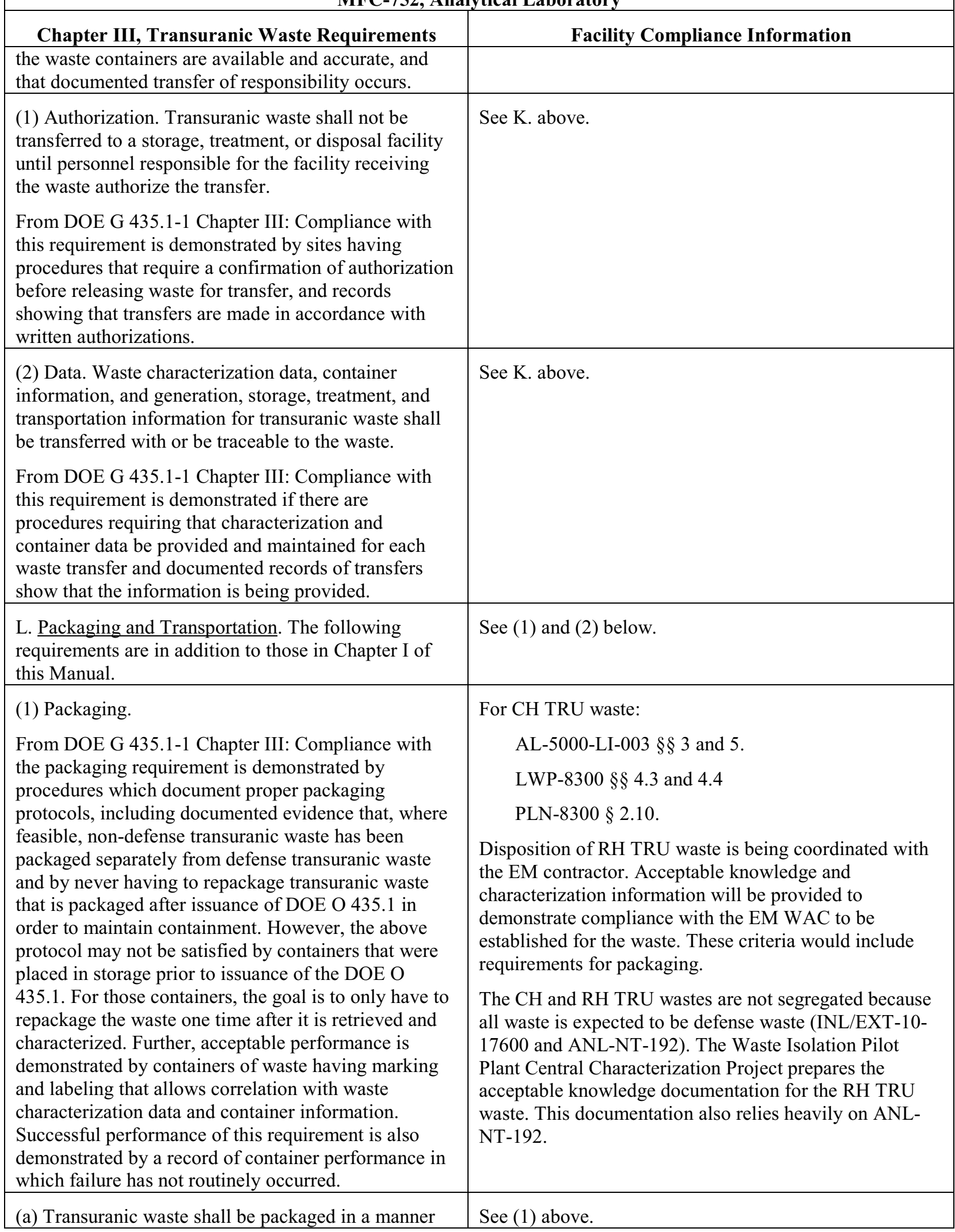


Table 5. (continued).

\section{MFC-752, Analytical Laboratory}

\begin{tabular}{|c|c|}
\hline Chapter III, Transuranic Waste Requirements & Facility Compliance Information \\
\hline $\begin{array}{l}\text { that provides containment and protection for the } \\
\text { duration of the anticipated storage period and until } \\
\text { disposal is achieved or until the waste is removed from } \\
\text { the container. }\end{array}$ & \\
\hline $\begin{array}{l}\text { (b) Vents or other mechanisms to prevent } \\
\text { pressurization of containers or generation of } \\
\text { flammable or explosive concentrations of gases shall } \\
\text { be installed on containers of newly-generated waste at } \\
\text { the time the waste is packaged. Containers of currently } \\
\text { stored waste shall meet this requirement as soon as } \\
\text { practical unless analyses demonstrate that the waste } \\
\text { can otherwise be managed safely. }\end{array}$ & See (1) above. \\
\hline $\begin{array}{l}\text { From DOE G 435.1-1 Chapter III: In developing the } \\
\text { radioactive waste management basis, site personnel } \\
\text { need to consider the hazards associated with drums of } \\
\text { transuranic waste which have not been provided with } \\
\text { vents or been proven to not need vents through an } \\
\text { approved safety analysis. For unvented containers in } \\
\text { earthen-covered storage, the facility itself may } \\
\text { mitigate the hazards associated with the accumulation } \\
\text { of gases. For above-grade storage of transuranic waste } \\
\text { containers, the radioactive waste management basis } \\
\text { needs to include controls which mitigate the hazards } \\
\text { associated with the accumulation of gases by } \\
\text { restricting access to the storage area and providing } \\
\text { equipment to protect against fire or explosion. }\end{array}$ & \\
\hline $\begin{array}{l}\text { (c) When transuranic waste is packaged, defense waste } \\
\text { shall be packaged separately from non-defense waste, } \\
\text { if feasible. }\end{array}$ & See (1) above. \\
\hline $\begin{array}{l}\text { (d) Containers of transuranic waste shall be marked } \\
\text { such that their contents can be identified. }\end{array}$ & See (1) above. \\
\hline $\begin{array}{l}\text { (2) Transportation. To the extent practical, the volume } \\
\text { of waste and number of transuranic waste shipments } \\
\text { shall be minimized. }\end{array}$ & $\begin{array}{l}\text { NA; waste is not shipped to an offsite facility for final } \\
\text { disposition from this facility. }\end{array}$ \\
\hline $\begin{array}{l}\text { From DOE G } 435.1-1 \text { Chapter III: Compliance with } \\
\text { this requirement can be demonstrated by a } \\
\text { combination of site procedures directing the efficient } \\
\text { use of waste container capacity and documentation } \\
\text { showing that transuranic waste shipments are } \\
\text { systematically planned and make optimal use of the } \\
\text { shipment system (e.g., TRUPACT II) to the extent } \\
\text { practical. }\end{array}$ & \\
\hline $\begin{array}{l}\text { M. Site Evaluation and Facility Design. The following } \\
\text { requirements are in addition to those in Chapter I of } \\
\text { this Manual. }\end{array}$ & $\begin{array}{l}\text { NA; this requirement addresses new radioactive waste } \\
\text { management facilities or modifications to existing } \\
\text { facilities. }\end{array}$ \\
\hline
\end{tabular}


Table 5. (continued).

MFC-752, Analytical Laboratory

Chapter III, Transuranic Waste Requirements

(1) Site Evaluation. Proposed locations for transuranic waste facilities shall be evaluated to identify relevant features that should be avoided or must be considered in facility design and analyses.

(a) Each site proposed for a new transuranic waste facility or expansion of an existing transuranic waste facility shall be evaluated considering environmental characteristics, geotechnical characteristics, and human activities.

(b) Proposed sites with environmental characteristics, geotechnical characteristics, and human activities for which adequate protection cannot be provided through facility design shall be deemed unsuitable for the location of the facility.

(2) Facility Design. The following facility requirements and general design criteria, at a minimum, apply:

(a) Confinement. Transuranic waste systems and components shall be designed to maintain waste confinement.

(b) Ventilation.

1 Design of transuranic waste treatment and storage facilities shall include ventilation, if applicable, through an appropriate filtration system to maintain the release of radioactive material in airborne effluents within the requirements and guidelines specified in applicable requirements.

2 When conditions exist for generating gases in flammable or explosive concentrations in treatment or storage facilities, ventilation or other measures shall be provided to keep the gases in a non-flammable and non-explosive condition. Where concentrations of explosive or flammable gases are expected to approach the lower flammability limit, measures shall be taken to prevent deflagration or detonation.

(c) Consideration of Decontamination and Decommissioning. Areas in new and modifications to existing transuranic waste management facilities that are subject to contamination with radioactive or other hazardous materials shall be designed to facilitate decontamination. For such facilities a proposed decommissioning method or a conversion method leading to reuse shall be described.

(d) Instrumentation and Control Systems. Engineering controls shall be incorporated in the design and engineering of transuranic waste treatment and storage
Facility Compliance Information

See M. above.

See M. above.

See M. above.

See M. above.

See M. above.

See M. above.

See M. above.

See M. above.

See M. above.

See M. above. 
Table 5. (continued).

\section{MFC-752, Analytical Laboratory}

Chapter III, Transuranic Waste Requirements Facility Compliance Information

facilities to provide volume inventory data and to prevent spills, leaks, and overflows from tanks or confinement systems.

(e) Monitoring. Monitoring and/or leak detection capabilities shall be incorporated in the design and engineering of transuranic waste storage, treatment, and disposal facilities to provide rapid identification of failed confinement and/or other abnormal conditions.

N. Storage. The following requirements are in addition to those in Chapter I of this Manual.

(1) Storage Prohibitions. Transuranic waste in storage shall not be readily capable of detonation, explosive decomposition, reaction at anticipated pressures and temperatures, or explosive reaction with water. Prior to storage, pyrophoric materials shall be treated, prepared, and packaged to be nonflammable.

From DOE G 435.1-1 Chapter III: Compliance with this requirement is demonstrated by having waste acceptance requirements which prohibit waste that is ignitable or explosive from being accepted for storage unless it has been treated.

(2) Storage Integrity. Transuranic waste shall be stored in a location and manner that protects the integrity of waste for the expected time of storage and minimizes worker exposure.

From DOE G 435.1-1 Chapter III: Compliance with this requirement is demonstrated if sites have storage capabilities for transuranic waste that provide protection of waste containers so that their integrity will not be damaged through physical or chemical (corrosion) processes and that keep personnel from spending extended periods of time in the areas where transuranic waste is stored.

(3) Container Inspection. A process shall be developed and implemented for inspecting and maintaining containers of transuranic waste to ensure container integrity is not compromised.

From DOE G 435.1-1 Chapter III: Compliance with this requirement is demonstrated by a documented process for waste container inspection and maintenance at every facility managing transuranic waste, and documentation for all waste container inspections and maintenance actions performed.

(4) Retrievable Earthen-Covered Storage. Plans for the removal of transuranic waste from retrievable earthencovered storage facilities shall be established and maintained. Prior to commencing waste retrieval

See M. above.

See below.

NA; this facility does not have WAC for TRU waste because the facility does not accept TRU waste from other facilities.

For the TRU waste generated at this facility, LWP-8300 and PLN-8300 address meeting receiving facility WAC and procedures.

The mixed TRU waste at this facility is accumulated in SAAs and TAAs, respectively.

MCP-17000 and MCP-17410 $§ 4.4$ addresses conditions under which waste should be accumulated.

LWP-15011 $\$ 5$ provides general radioactive storage area requirements.

LI-435 requires quarterly inspections of radioactive waste containers if waste is stored outdoors or has been in storage for greater than 1 year.

Inspections are performed for TAAs and SAAs as required by WGS procedures (MCP-17000 and MCP17410).

NA; this facility is not an earthen-covered storage facility. 
Table 5. (continued).

\section{MFC-752, Analytical Laboratory}

Chapter III, Transuranic Waste Requirements Facility Compliance Information

activities, each waste storage site shall be evaluated to determine relevant information on types, quantities, and location of radioactive and hazardous chemicals as necessary to protect workers during the retrieval process.

O. Treatment. Transuranic waste shall be treated as necessary to meet the waste acceptance requirements of the facility receiving the waste for storage or disposal.

From DOE G 435.1-1 Chapter III: Compliance with this requirement is demonstrated by the custodian of transuranic waste maintaining documentation which identifies the plans for treating waste, and maintaining the records that show waste was treated, if necessary, to meet the waste acceptance requirements of the storage or disposal facility to which it was transferred.

P. Disposal. Transuranic waste shall be disposed in accordance with the requirements of 40 CFR Part 191, Environmental Radiation Protection Standards for Management and Disposal of Spent Nuclear Fuel, High-Level and Transuranic Radioactive Wastes.

Q. Monitoring. The following requirements are in addition to those in Chapter I of this Manual.

(1) All Waste Facilities. Parameters that shall be sampled or monitored, at a minimum, include: temperature, pressure (for closed systems), radioactivity in ventilation exhaust and liquid effluent streams, and flammable or explosive mixtures of gases. Facility monitoring programs shall include verification that passive and active control systems have not failed.

From DOE G 435.1-1 Chapter III: If a minimum parameter specified in the requirement is deemed to be not applicable in any way to the active operation of that facility, then that justification should be included in the radioactive waste management basis and when approved, constitutes an exemption to the Manual.

Verification activities are part of the radioactive waste management basis and are to be documented appropriately.

Compliance with this requirement is demonstrated if monitoring or sampling for the stated parameters is performed for all facilities with an accuracy, precision, and frequency consistent with timely identification of developing problems and a justification exists in the approved radioactive waste management basis for those specified parameters which are not monitored or
NA; TRU waste is not treated at this facility.

NA; TRU waste is not disposed of at this facility.

See (1), (2), and (3) below.

General facility monitoring is addressed in AL-7000-OI001. However, a specific monitoring program for radioactive waste and the assessment of monitoring parameters were not identified.

Monitoring requirements at INL radioactive waste management facilities are tailored for the specific facility to enable timely indication of developing problems. Existing radiological control procedures and assessments are followed/completed to monitor waste facilities. LRD-15001 and MCP-139 specify methods and frequency of radiological control surveys of all radiological areas. MCP-139 specifies the use of Form 441.A34. This form is referred to as the "routine sheet" and is to be used by facility radiological control foremen to list radiological areas that are to be surveyed, the survey periods, and methods. 
Table 5. (continued).

MFC-752, Analytical Laboratory

\begin{tabular}{|c|c|}
\hline $\begin{array}{l}\text { Chapter III, Transuranic Waste Requirements } \\
\text { sampled }\end{array}$ & Facility Compliance Information \\
\hline sampled. & \\
\hline $\begin{array}{l}\text { (2) Stored Wastes. All transuranic wastes in storage } \\
\text { shall be monitored, as prescribed by the appropriate } \\
\text { facility safety analysis, to ensure the wastes are } \\
\text { maintained in safe condition. }\end{array}$ & $\begin{array}{l}\text { The facility's safety basis requirements and } \\
\text { implementing documents are identified in LST- } 329 \text {. This } \\
\text { facility is a Hazard Category } 3 \text { non-reactor nuclear } \\
\text { facility (W0660-0055-KH). }\end{array}$ \\
\hline $\begin{array}{l}\text { From DOE G } 435.1-1 \text { Chapter III: Compliance with } \\
\text { this requirement is demonstrated if the monitoring } \\
\text { requirements in the facility procedures include, at a } \\
\text { minimum, monitoring the systems and parameters as } \\
\text { indicated by the safety analysis. }\end{array}$ & \\
\hline $\begin{array}{l}\text { (3) Liquid Waste Storage Facilities. For facilities } \\
\text { storing liquid transuranic waste, the following shall } \\
\text { also be monitored: liquid level and/or waste volume, } \\
\text { and significant waste chemistry parameters. }\end{array}$ & NA; liquid TRU waste is not stored at this facility. \\
\hline $\begin{array}{l}\text { From DOE G } 435.1-1 \text { Chapter III: Compliance with } \\
\text { this requirement is demonstrated by developing } \\
\text { operational procedures for monitoring liquid } \\
\text { transuranic waste storage tank liquid level, waste } \\
\text { volume, and tank chemistry so that waste volume or } \\
\text { chemistry changes are detected in a time frame that } \\
\text { will allow implementation of corrective measures to } \\
\text { limit public and worker doses and to mitigate } \\
\text { unplanned releases of stored liquid waste. }\end{array}$ & \\
\hline
\end{tabular}

Table 6. MFC-752, Analytical Laboratory, DOE Manual 435.1-1 low-level waste requirements and facility compliance information.

\begin{tabular}{|c|c|}
\hline \multicolumn{2}{|c|}{ Facility Name: MFC-752, Analytical Laboratory } \\
\hline Chapter IV, LLW Requirements & Facility Compliance Information \\
\hline $\begin{array}{l}\text { A. Definition of Low-Level Waste. Low-level } \\
\text { radioactive waste is radioactive waste that is not high- } \\
\text { level radioactive waste, spent nuclear fuel, transuranic } \\
\text { waste, byproduct material (as defined in section 11e.( } 2 \text { ) } \\
\text { of the Atomic Energy Act of 1954, as amended), or } \\
\text { naturally occurring radioactive material. } \\
\text { (From DOE G } 435.1-1 \text { Chapter IV: Low-level } \\
\text { radioactive waste is defined by what it is not. The } \\
\text { guidance on definitions in Chapters II and III should be } \\
\text { consulted first for making a determination on how to } \\
\text { properly manage a suspect waste stream.) }\end{array}$ & $\begin{array}{l}\text { This requirement provides the criteria for determining } \\
\text { which DOE radioactive waste is to be managed as } \\
\text { LLW in accordance with DOE Manual } 435.1-1 \text {, } \\
\text { Chapter IV. } \\
\text { Radioactive waste managed at this facility under the } \\
\text { requirements of this chapter is not managed under the } \\
\text { requirements of DOE Manual 435.1-1, Chapter II or } \\
\text { Chapter III. }\end{array}$ \\
\hline $\begin{array}{l}\text { B. Management of Specific Wastes. The following } \\
\text { provide for management of specific wastes as low-level } \\
\text { waste in accordance with the requirements in this } \\
\text { Chapter: }\end{array}$ & See below. \\
\hline $\begin{array}{l}\text { (1) Mixed Low-Level Waste. Low-level waste } \\
\text { determined to contain both source, special nuclear, or }\end{array}$ & This facility manages mixed LLW. \\
\hline
\end{tabular}


Table 6. (continued).

Facility Name: MFC-752, Analytical Laboratory

\begin{tabular}{|c|}
\hline Chapter IV, LLW Requirements \\
\hline $\begin{array}{l}\text { byproduct material subject to the Atomic Energy Act of } \\
\text { 1954, as amended, and a hazardous component subject } \\
\text { to the Resource Conservation and Recovery Act } \\
\text { (RCRA), as amended, shall be managed in accordance } \\
\text { with the requirements of RCRA and DOE O 435.1, } \\
\text { Radioactive Waste Management, and this Manual. }\end{array}$ \\
\hline $\begin{array}{l}\text { (2) TSCA-Regulated Waste. Low-level waste } \\
\text { containing polychlorinated biphenyls, asbestos, or } \\
\text { other such regulated toxic components shall be } \\
\text { managed in accordance with requirements derived from } \\
\text { the Toxic Substances Control Act, as amended, DOE O } \\
\text { 435.1, Radioactive Waste Management, and this } \\
\text { Manual. }\end{array}$ \\
\hline
\end{tabular}

(3) Accelerator-Produced Waste. Radioactive waste produced as a result of operations of DOE accelerators is low-level waste and shall be managed in accordance with DOE O 435.1, Radioactive Waste Management, and this Manual, and all applicable Federal or State requirements.

(4) 11e.(2) and Naturally Occurring Radioactive Material. Small quantities of 11e.(2) byproduct material and naturally occurring radioactive material may be managed as low-level waste provided they can be managed to meet the requirements for low-level waste disposal in Section IV.P of this Manual.

C. Complex-Wide Low-Level Waste Management Program. A complex-wide program and plan shall be developed as described under Responsibilities, 2.B and 2.D, in Chapter I of this Manual.

D. Radioactive Waste Management Basis. Low-level waste facilities, operations, and activities shall have a radioactive waste management basis consisting of physical and administrative controls to ensure the protection of workers, the public, and the environment. The following specific waste management controls shall be part of the radioactive waste management basis:

(1) Generators. The waste certification program.

From DOE G 435.1-1 Chapter IV: For a facility that generates low-level waste, the radioactive waste management basis is to include the program for certifying that waste meets the waste acceptance requirements of the facility(ies) to which the waste will be sent.

(2) Treatment Facilities. certification program. The waste acceptance requirements and the waste [sic]

\section{Facility Compliance Information}

Compliance with RCRA regulations is addressed by WGS in its waste management services role in MCP-17000.

This facility manages TSCA-regulated waste.

Compliance with TSCA regulations is addressed by WGS in its waste management services role in MCP-17000.

NA; this facility does not manage accelerator-produced waste.

NA; this facility does not manage naturally occurring radioactive material.

Not a facility-specific requirement. DOE Manual 435.1-1 §I.2.B and §I.2.D apply to the Assistant Secretary for Environmental Management and the Deputy Assistant Secretary for Waste Management, respectively.

The RWMB provides the regulatory framework for management of radioactive waste at INL. It specifically identifies facility management and implementing documents for the generation, storage, treatment, and disposal of radiological waste. This facility is a Hazard Category 3 non-reactor nuclear facility (W0660-0055KH.) The facility's safety basis requirements and implementing documents are identified in LST-329.

See J. below.

NA; LLW is not treated at this facility.

Containerized elementary neutralization is performed 
Table 6. (continued).

Facility Name: MFC-752, Analytical Laboratory

\begin{tabular}{l}
\hline \multicolumn{1}{|c|}{ Chapter IV, LLW Requirements } \\
\hline From DOE G 435.1-1 Chapter IV: Facilities that store \\
or treat low-level waste are to have approved waste \\
acceptance requirements (see DOE M 435.1-1, Section \\
IV.G) prior to the issuance of a radioactive waste \\
management basis. \\
A facility that stores or treats waste also is generally \\
expected to have a waste certification program. Waste \\
from these facilities will have to be certified as meeting \\
the waste acceptance requirements of the facility to \\
which it will be transferred, and the facilities have the \\
potential for generating radioactive waste (e.g., \\
secondary processing streams from treatment, \\
monitoring and sampling, radioactive release cleanup). \\
Consequently, storage and treatment facilities should \\
also have an approved waste certification program as \\
part of their radioactive waste management basis.
\end{tabular}

As part of the radioactive waste management basis, site personnel needs to implement a system or process for tracking the waste inventory at a storage, treatment, or disposal facility.

(3) Storage Facilities. The waste acceptance requirements and the waste certification program.

From DOE G 435.1-1 Chapter IV: Facilities that store or treat low-level waste are to have approved waste acceptance requirements (see DOE M 435.1-1, Section IV.G) prior to the issuance of a radioactive waste management basis.

A facility that stores or treats waste also is generally expected to have a waste certification program. Waste from these facilities will have to be certified as meeting the waste acceptance requirements of the facility to which it will be transferred, and the facilities have the potential for generating radioactive waste (e.g., secondary processing streams from treatment, monitoring and sampling, radioactive release cleanup). Consequently, storage and treatment facilities should also have an approved waste certification program as part of their radioactive waste management basis.

As part of the radioactive waste management basis, site personnel needs to implement a system or process for tracking the waste inventory at a storage, treatment, or disposal facility.

(4) Disposal Facilities. The performance assessment, composite analysis, disposal authorization statement, closure plan, waste acceptance requirements, and monitoring plan.

\section{Facility Compliance Information}

at this facility as provided by LWP-8000. As stated in $\$ 4.118$, elementary neutralization of corrosive hazardous waste may take place at any location at which the waste is generated or stored, and neither a generator treatment plan nor a permit is required. Solidification of liquid LLW for the purpose of staging (not for treating the radioactive constituents) also may be performed. Therefore, this facility is not considered to be a treatment facility.

NA; this facility stages waste in accordance with N.(7) to facilitate treatment or disposal.

NA; this facility is not a disposal facility. 
Table 6. (continued).

Facility Name: MFC-752, Analytical Laboratory

\begin{tabular}{l}
\hline \multicolumn{1}{|c|}{ Chapter IV, LLW Requirements } \\
\hline E. Contingency Actions. The following requirements \\
are in addition to those in Chapter I of this Manual \\
[DOE M 435.1-1 §I.1.E(5)].
\end{tabular}

(1) Contingency Storage. For off-normal or emergency situations involving high activity or high hazard liquid low-level waste storage or treatment, spare capacity with adequate capabilities shall be maintained to receive the largest volume of liquid contained in any one storage tank or treatment facility. Tanks or other facilities that are designated low-level waste contingency storage shall be maintained in an operational condition when waste is present and shall meet the requirements of DOE O 435.1, Radioactive Waste Management, and this Manual.

From DOE G 435.1-1 Chapter IV: Compliance with these requirements is demonstrated if adequate spare capacity and transfer equipment exists for emergency transfers of all high activity and high hazard liquid low-level waste. In addition, the capability to perform emergency transfers is demonstrated by having waste transfer routings identified, operational procedures to direct transfers, staff trained to the procedures, and records showing that the spare capacity and transfer capability are kept in operating condition.

(2) Transfer Equipment. Pipelines and auxiliary facilities necessary for the transfer of high activity or high hazard liquid low-level waste to contingency storage shall be maintained in an operational condition when waste is present and shall meet the requirements of DOE O 435.1, Radioactive Waste Management, and this Manual.

From DOE G 435.1-1 Chapter IV: Compliance with these requirements is demonstrated if adequate spare capacity and transfer equipment exists for emergency transfers of all high activity and high hazard liquid low-level waste. In addition, the capability to perform emergency transfers is demonstrated by having waste transfer routings identified, operational procedures to direct transfers, staff trained to the procedures, and records showing that the spare capacity and transfer capability are kept in operating condition.

F. Corrective Actions. I of this Manual. The following requirements are in addition to those in Chapter [sic]

From DOE G 435.1-1 Chapter IV: Compliance with DOE M 435.1-1 §I.2.G.(1) is demonstrated by records showing what corrective actions were taken to remedy situations in the radioactive waste management system.

Not a facility-specific requirement. DOE Manual 435.1-1 §I.1.E(5) addresses the sitewide emergency management system. The INL plan is provided in PLN-114.

NA; liquid LLW is not stored or treated in a tank system at this facility.

However, AL-0634-OI-001 addresses the facility's evaporator feed tanks, which are used for the recirculation, sampling, and pumping of suspect liquid waste to RLWTF. The contents of the tanks can be transferred to an onsite tank truck. These transfers would be directed by a work order.

This tank system is being replaced. In the interim, carboys are being used for the disposal of suspect liquid waste to RLWTF in accordance with AL-0634OI-002.
NA; liquid LLW is not stored or treated in a tank system at this facility.

However, AL-0634-OI-001 addresses the facility's evaporator feed tanks, which are used for recirculation, sampling, and pumping of suspect liquid waste to RLWTF. The contents of the tanks can be transferred to an onsite tank truck. These transfers would be directed by a work order.

This tank system is being replaced. In the interim, carboys are being used for disposal of suspect liquid waste to RLWTF in accordance with AL-0634-OI-002.
The INL-wide procedure addressing problem identification as required by DOE Manual 435.1-1 §I.2.G.(1) is LWP-13840, which implements the laboratory's corrective action system.

The INL-wide procedure addressing shutdown or curtailment of activities as required by DOE 
Table 6. (continued).

Facility Name: MFC-752, Analytical Laboratory

\begin{tabular}{|l|l|}
\hline \multicolumn{1}{|c|}{ Chapter IV, LLW Requirements } \\
\hline $\begin{array}{l}\text { Compliance with DOE M 435.1-1 §I.2.G.(2) is } \\
\text { demonstrated by having the necessary procedures, } \\
\text { mechanisms, and training in place to effect shutdown } \\
\text { or curtailment of activities which pose an imminent } \\
\text { danger or other serious hazard to workers or the public, } \\
\text { or are not protective of the environment. }\end{array}$ \\
\hline
\end{tabular}

(1) Order Compliance. Corrective actions shall be implemented whenever necessary to ensure the requirements of DOE O 435.1, Radioactive Waste Management, and this Manual are met.

From DOE G 435.1-1 Chapter IV: If a facility or activity can be allowed to operate while a noncompliant or hazardous condition exists, the allowance and any associated limitations must be defined as part of the facility or activity's radioactive waste management basis, identified as a configuration controlled item in a configuration management plan or included in a revision or modification to an operating procedure or similar controlled documentation.

Compliance with this requirement is demonstrated if a corrective action system addresses noncompliant or hazardous situations involving low-level waste management facilities in a systematic fashion, and allows identification of problems by all personnel.

(2) Operations Curtailment. Operations shall be curtailed or facilities shut down for failure to establish, maintain, or operate consistent with an approved radioactive waste management basis.

From DOE G 435.1-1 Chapter IV: Compliance with this requirement is demonstrated with a documented system of routine assessments to determine whether waste management activities and facilities are operating in accordance with an approved radioactive waste management basis that provides for graded limitations that can be placed on activities and operations that do not have, or are operating outside of, an approved radioactive waste management basis, including shutdown of the facility.

G. Waste Acceptance. The following requirements are in addition to those in Chapter I of this Manual [DOE M 435.1-1 §I.2.F(6)].

(1) Technical and Administrative. Waste acceptance requirements for all low-level waste storage, treatment, or disposal facilities, operations, and activities shall specify, at a minimum, the following:

From DOE G 435.1-1 Chapter IV: Compliance with these waste acceptance requirements is demonstrated if

The approved RWMB establishes the current compliance status at each radioactive waste management facility. Facility assessments are scheduled to ensure waste management activities are conducted in accordance with the approved RWMB.
Not a facility-specific requirement. DOE Manual 435.1-1 §I.2.F(6) applies to field element managers.

NA; this facility generates LLW but does not receive radioactive waste from other sources. 
Table 6. (continued).

Facility Name: MFC-752, Analytical Laboratory

\begin{tabular}{|c|c|}
\hline Chapter IV, LLW Requirements & Facility Compliance Information \\
\hline $\begin{array}{l}\text { they are documented, contain clear and precise criteria } \\
\text { specifying the radionuclide limits in the form of } \\
\text { contents or concentrations that can be accepted, the } \\
\text { limitations and prohibitions on waste forms and } \\
\text { packages that can be received, and the limits, } \\
\text { prohibitions, or instructions concerning any other } \\
\text { technical information so that the waste is compatible } \\
\text { with the safety basis of the facility, and which will } \\
\text { result in acceptable waste at subsequent steps in } \\
\text { managing the low-level waste. }\end{array}$ & \\
\hline $\begin{array}{l}\text { (a) Allowable activities and/or concentrations of } \\
\text { specific radionuclides. }\end{array}$ & See (1) above. \\
\hline $\begin{array}{l}\text { (b) Acceptable waste form and/or container } \\
\text { requirements that ensure the chemical and physical } \\
\text { stability of waste under conditions that might be } \\
\text { encountered during transportation, storage, treatment, } \\
\text { or disposal. }\end{array}$ & See (1) above. \\
\hline $\begin{array}{l}\text { (c) Restrictions or prohibitions on waste, materials, or } \\
\text { containers that may adversely affect waste handlers or } \\
\text { compromise facility or waste container performance. }\end{array}$ & See (1) above. \\
\hline $\begin{array}{l}\text { (d) The following are additional waste acceptance } \\
\text { requirements that shall be specified in low-level waste } \\
\text { disposal facility waste acceptance requirements: }\end{array}$ & NA; this facility is not a LLW disposal facility. \\
\hline $\begin{array}{l}1 \text { Low-level waste must contribute to and not detract } \\
\text { from achieving long-term stability of the facility, } \\
\text { minimizing the need for long-term active maintenance, } \\
\text { minimizing subsidence, and minimizing contact of } \\
\text { water with waste. Void spaces within the waste and, if } \\
\text { containers are used, between the waste and its } \\
\text { container shall be reduced to the extent practical. }\end{array}$ & See (d) above. \\
\hline $\begin{array}{l}2 \text { Liquid low-level waste or low-level waste containing } \\
\text { free liquid must be converted into a form that contains } \\
\text { as little freestanding liquid as is reasonably achievable, } \\
\text { but in no case shall the liquid exceed } 1 \text { percent of the } \\
\text { waste volume when the low-level waste is in a disposal } \\
\text { container, or } 0.5 \text { percent of the waste volume after it is } \\
\text { processed to a stable form. }\end{array}$ & See (d) above. \\
\hline $\begin{array}{l}3 \text { Low-level waste must not be readily capable of } \\
\text { detonation or of explosive decomposition or reaction at } \\
\text { anticipated pressures and temperatures, or of explosive } \\
\text { reaction with water. Pyrophoric materials contained in } \\
\text { waste shall be treated, prepared, and packaged to be } \\
\text { nonflammable. }\end{array}$ & See (d) above. \\
\hline
\end{tabular}


Table 6. (continued).

Facility Name: MFC-752, Analytical Laboratory

\begin{tabular}{|c|c|}
\hline Chapter IV, LLW Requirements & Facility Compliance Information \\
\hline $\begin{array}{l}4 \text { Low-level waste must not contain, or be capable of } \\
\text { generating by radiolysis or biodegradation, quantities } \\
\text { of toxic gases, vapors, or fumes harmful to the public } \\
\text { or workers or disposal facility personnel, or harmful to } \\
\text { the long-term structural stability of the disposal site. }\end{array}$ & See (d) above. \\
\hline $\begin{array}{l}5 \text { Low-level waste in a gaseous form must be packaged } \\
\text { such that the pressure does not exceed } 1.5 \text { atmospheres } \\
\text { absolute at } 20 \text { C. [ sic] }\end{array}$ & See (d) above. \\
\hline $\begin{array}{l}\text { (e) The basis, procedures, and levels of authority } \\
\text { required for granting exceptions to the waste } \\
\text { acceptance requirements, which shall be contained in } \\
\text { each facility's waste acceptance documentation. Each } \\
\text { exception request shall be documented, including its } \\
\text { disposition as approved or not approved. }\end{array}$ & $\begin{array}{l}\text { NA; this facility does not accept waste from other } \\
\text { facilities. }\end{array}$ \\
\hline $\begin{array}{l}\text { From DOE G } 435.1-1 \text { Chapter IV: Waste acceptance } \\
\text { requirements are acceptable if they are documented and } \\
\text { contain a clear description of the procedure and bases } \\
\text { for obtaining an exception or deviation to the } \\
\text { acceptance criteria for low-level waste to be received at } \\
\text { the facility. }\end{array}$ & \\
\hline $\begin{array}{l}\text { (2) Evaluation and Acceptance. The receiving facility } \\
\text { shall evaluate waste for acceptance, including } \\
\text { confirmation that the technical and administrative } \\
\text { requirements have been met. A process for the } \\
\text { disposition of non-conforming wastes shall be } \\
\text { established. }\end{array}$ & $\begin{array}{l}\text { NA; this facility does not accept waste from other } \\
\text { facilities. }\end{array}$ \\
\hline $\begin{array}{l}\text { From DOE G 435.1-1 Chapter IV: Compliance with } \\
\text { the waste acceptance requirements for a low-level } \\
\text { waste management facility is demonstrated if they } \\
\text { include a process for evaluation and acceptance of } \\
\text { incoming waste to ensure the acceptance criteria of the } \\
\text { facility receiving the waste are met that includes one of } \\
\text { or a combination of: (1) testing, sampling, and analysis } \\
\text { of representative samples of waste upon receipt; (2) } \\
\text { testing, sampling, and analysis of split samples of } \\
\text { waste taken at the generator site; ( } 3 \text { ) evaluation of } \\
\text { testing, sampling, and analysis of data provided by the } \\
\text { generator, or (4) audits, reviews, surveillance, or } \\
\text { observations of generator waste certification programs } \\
\text { and characterization activities. Additionally, acceptable } \\
\text { waste acceptance requirements for a storage, treatment } \\
\text { or disposal facility will have documented procedures } \\
\text { and actions to be taken if a waste that does not conform } \\
\text { to the waste acceptance criteria is received at the } \\
\text { facility. }\end{array}$ & \\
\hline $\begin{array}{l}\text { H. Waste Generation Planning. The following } \\
\text { requirements are in addition to those in Chapter I of } \\
\text { this Manual [DOE M 435.1-1 §I.2.F(7)]. }\end{array}$ & $\begin{array}{l}\text { Not a facility-specific requirement. DOE Manual } \\
435.1-1 \text { §I.2.F(7) applies to field element managers. }\end{array}$ \\
\hline
\end{tabular}


Table 6. (continued).

Facility Name: MFC-752, Analytical Laboratory

\begin{tabular}{|c|c|}
\hline Chapter IV, LLW Requirements & Facility Compliance Information \\
\hline $\begin{array}{l}\text { (1) Life-Cycle Planning. Prior to waste generation, } \\
\text { planning shall be performed to address the entire life } \\
\text { cycle for all low-level waste streams. }\end{array}$ & $\begin{array}{l}\text { PDD- } 17000 \text { and LWP-17000 provide direction to the } \\
\text { waste generators for waste generation planning to } \\
\text { address the entire life cycle. }\end{array}$ \\
\hline $\begin{array}{l}\text { From DOE G 435.1-1 Chapter IV: Compliance with } \\
\text { this planning requirement is demonstrated by the } \\
\text { individual sites establishing a process for evaluating } \\
\text { the life-cycle of low-level waste prior to its generation, } \\
\text { including the identification of low-level wastes with no } \\
\text { path to disposal and appropriate records justifying the } \\
\text { newly generated low-level waste stream(s), and site } \\
\text { personnel possessing planning information showing the } \\
\text { location(s) where low-level waste will be stored, } \\
\text { treated, and/or disposed along with a confirmation that } \\
\text { the personnel managing the facilities agree that the } \\
\text { low-level waste may be managed at those facilities. }\end{array}$ & \\
\hline $\begin{array}{l}\text { (2) Waste with No Identified Path to Disposal. Low- } \\
\text { level waste streams with no identified path to disposal } \\
\text { shall be generated only in accordance with approved } \\
\text { conditions which, at a minimum, shall address: }\end{array}$ & $\begin{array}{l}\text { NA; this facility is not generating LLW that does not } \\
\text { have an identified path to disposal. }\end{array}$ \\
\hline (a) Programmatic need to generate the waste; & See (2) above. \\
\hline $\begin{array}{l}\text { (b) Characteristics and issues preventing the disposal of } \\
\text { the waste; }\end{array}$ & See (2) above. \\
\hline $\begin{array}{l}\text { (c) Safe storage of the waste until disposal can be } \\
\text { achieved; and }\end{array}$ & See (2) above. \\
\hline $\begin{array}{l}\text { (d) Activities and plans for achieving final disposal of } \\
\text { the waste. }\end{array}$ & See (2) above. \\
\hline $\begin{array}{l}\text { I. Waste Characterization. Low-level waste shall be } \\
\text { characterized using direct or indirect methods, and the } \\
\text { characterization documented in sufficient detail to } \\
\text { ensure safe management and compliance with the } \\
\text { waste acceptance requirements of the facility receiving } \\
\text { the waste. }\end{array}$ & $\begin{array}{l}\text { MCP-17000 addresses waste characterization. } \\
\text { W0660-0035-AP } \S 3.4 \text { and } 3.5 \\
\text { W0640-0047-KP } \S 3.2 \\
\text { PLN-2495 } § 4\end{array}$ \\
\hline $\begin{array}{l}\text { From DOE G 435.1-1 Chapter IV: Compliance with } \\
\text { this requirement is demonstrated by a program for } \\
\text { documenting and the existence of records that } \\
\text { document the process for acquiring and verifying the } \\
\text { validity of low-level waste characterization data } \\
\text { acquired through the use of direct or indirect methods. }\end{array}$ & \\
\hline
\end{tabular}


Table 6. (continued).

Facility Name: MFC-752, Analytical Laboratory

\begin{tabular}{l}
\hline \multicolumn{1}{|c|}{ Chapter IV, LLW Requirements } \\
\hline (1) Data Quality Objectives. The data quality \\
objectives process, or a comparable process, shall be \\
used for identifying characterization parameters and \\
acceptable uncertainty in characterization data. \\
From DOE G 435.1-1 Chapter IV: Compliance with \\
this requirement is demonstrated by the documented \\
use of a data quality objectives or a comparable process \\
for determining the type, quantity, and quality of \\
characterization data needed to safely manage low- \\
level waste.
\end{tabular}

(2) Minimum Waste Characterization. Characterization data shall, at a minimum, include the following information relevant to the management of the waste:

From DOE G 435.1-1 Chapter IV: Compliance with this requirement is demonstrated by the existence of a program or procedure for determining and records that document characterization of low-level waste consistent with the minimum characterization data requirements.

(a) Physical and chemical characteristics;
(b) Volume, including the waste and any stabilization
or absorbent media;

(c) Weight of the container and contents;

(d) Identities, activities, and concentrations of major radionuclides;

(e) Characterization date;
(f) Generating source; and

(g) Any other information which may be needed to prepare and maintain the disposal facility performance assessment, or demonstrate compliance with applicable performance objectives.

J. Waste Certification. A waste certification program shall be developed, documented, and implemented to ensure that the waste acceptance requirements of facilities receiving low-level waste for storage, treatment, and disposal are met.

From DOE G 435.1-1 Chapter IV: Compliance with the development and documentation portion of the certification requirement is demonstrated by a waste certification plan that identifies the organizations involved, assigns responsibilities for implementing the program, and describes or references the quality assurance, training, procurement controls, records management, and procedures to be used by the

\section{Facility Compliance Information}

Radioactive waste management facilities characterize waste in accordance with the requirements of the receiving storage, treatment, or disposal facility. The documented use of a data quality objectives process, or comparable process, was not identified for this facility.

PLN-2495 $\S 5$ specifies the data quality objectives for verification sampling. However, documentation of the data quality objectives process and results is not provided or referenced.

MCP-17000, including $\S \S 4.2,4.3$, and 4.4, provides waste characterization requirements. Information on absorbent media is required in $\S \S 4.5$ and 4.7. MCP-17000 also specifies the use of IWTS, which documents characterization data in an IWTS profile.

See I. and (2) above.

See I. and (2) above.

See I. and (2) above.

See I. and (2) above. See I. and (2) above.

See I. and (2) above.

See I. and (2) above.

MCP-17000 cites a waste certification program for LLW destined for NNSS. For waste destined for locations other than NNSS, the waste disposition specialist is responsible for certifying the waste stream by ensuring the waste, as characterized, falls within the limitations of the waste acceptance criteria of the treatment, storage, or disposal facility $(\$ 2)$.

Container procurement is addressed in $\mathrm{MCP}-17000$ $\S 4.6$.

MCP-17500 provides the WGS waste certification program for LLW to be shipped to NNSS.

Waste certification is performed and tracked using 
Table 6. (continued).

Facility Name: MFC-752, Analytical Laboratory

Chapter IV, LLW Requirements

program. Acceptable performance for implementing the program is demonstrated when appropriate personnel are trained and follow the procedures that govern their part of the waste certification.

Additionally, acceptable performance is demonstrated if the waste certification plan and procedures are current and controlled in accordance with a document controls program, and records related to certification (e.g., certification statements, training records, procurement records, characterization records, container records) are generated and managed in accordance with the established site program.

(1) Certification Program. The waste certification program shall designate the officials who have the authority to certify and release waste for shipment; and specify what documentation is required for waste generation, characterization, shipment, and certification. The program shall provide requirements for auditability, retrievability, and storage of required documentation and specify the records retention period.

From DOE G 435.1-1 Chapter IV: Compliance with this requirement is demonstrated by a program or procedure for record keeping and records showing that low-level waste is certified as having met the waste acceptance criteria of the facility to which it was transferred and that the certification statement is supported by additional records regarding the waste source, characterization, and container.

(2) Certification before Transfer. Low-level waste shall be certified as meeting waste acceptance requirements before it is transferred to the facility receiving the waste.

From DOE G 435.1-1 Chapter IV: Compliance with this requirement is demonstrated by the presence of a certification program which includes procedures requiring a signed certification statement prior to the release of waste for transfer, and by dated records showing that waste was certified before being transferred.

(3) Maintaining Certification. Low-level waste that has been certified as meeting the waste acceptance requirements for transfer to a storage, treatment, or disposal facility shall be managed in a manner that maintains its certification status.

From DOE G 435.1-1 Chapter IV: Compliance with this requirement is demonstrated by a program or
Facility Compliance Information

IWTS. Documentation of the IWTS Program is available electronically only.

PLN-522 requires waste technical specialists and waste disposition specialists to complete the appropriate training/qualification before being granted approval authority for profiles within the IWTS Program. The waste certification official, alternate waste certification official, and NNSS packaging certifiers must complete the appropriate training/qualifications to disposition waste to NNSS.

Liquid LLW is sent to RLWTF in accordance with AL-0634-OI-001 and AL-0634-OI-002, which require compliance with RLWTF waste acceptance criteria.

See J. above. MCP- $17500 \S \S 2$ and 5 address certification records for shipments to NNSS.
See J. above. MCP-17500 §4.3.6 addresses controls for certification before transfer for LLW to be disposed of at NNSS.
See J. above. Pre-certification checklists are cited in MCP-17000 and MCP-17500. Surveillances also are addressed in MCP-17500.

LWP-15011 §5 provides general radioactive storage area requirements. 
Table 6. (continued).

Facility Name: MFC-752, Analytical Laboratory

\begin{tabular}{|c|c|}
\hline $\begin{array}{l}\text { Chapter IV, LLW Requirements } \\
\text { procedure reflecting this requirement is present and site } \\
\text { personnel are able to show that the storage of low-level } \\
\text { waste containers is in a facility or manner where the } \\
\text { containers would not be damaged by normal weather } \\
\text { events, and cannot be accessed by unauthorized } \\
\text { personnel. Further, each container can be traced to its } \\
\text { certification and the information supporting that } \\
\text { certification. }\end{array}$ & Facility Compliance Information \\
\hline $\begin{array}{l}\text { K. Waste Transfer. A documented process shall be } \\
\text { established and implemented for transferring } \\
\text { responsibility for management of low-level waste and } \\
\text { for ensuring availability of relevant data. The following } \\
\text { requirements are in addition to those in Chapter I of } \\
\text { this Manual. } \\
\text { From DOE G 435.1-1 Chapter IV: Compliance with } \\
\text { this requirement is demonstrated if facilities have } \\
\text { procedures for the receipt of waste and the transfer of } \\
\text { waste, as appropriate, which address the acquisition of } \\
\text { waste and container data and the transfer of ownership, } \\
\text { respectively. Further evidence of acceptable } \\
\text { performance is facility records showing that data on the } \\
\text { waste containers is available and accurate, and that } \\
\text { documented transfer of responsibility occurs. }\end{array}$ & $\begin{array}{l}\text { W0640-0047-KP } \S 5.8 \\
\text { W0660-0035-AP } \S \S 3.8 \text { and } 3.9 \\
\text { PLN-2495 } \S 3.2 \text { and } 6 \\
\text { Liquid LLW is sent to RLWTF in accordance with } \\
\text { AL-0634-OI-001 and AL-0634-OI-002, which require } \\
\text { compliance with RLWTF WAC. } \\
\text { RL-OI-1 specifies the RLWTF requirements for } \\
\text { receiving transferred waste. } \\
\text { MCP-17000 } \$ 4.8 .15 \text { specifies requirements for } \\
\text { interfacility transfers. } \\
\text { TSD-OI-004 includes the MFC-703, MFC-793, and } \\
\text { MFC-797 requirements for receiving transferred waste. } \\
\text { MCP-17500 } \$ 4 \text { addresses LLW to be transferred to } \\
\text { NNSS. }\end{array}$ \\
\hline $\begin{array}{l}\text { (1) Authorization. Low-level waste shall not be } \\
\text { transferred to a storage, treatment, or disposal facility } \\
\text { until personnel responsible for the facility receiving the } \\
\text { waste authorize the transfer. } \\
\text { From DOE G } 435.1-1 \text { Chapter IV: Compliance with } \\
\text { this requirement is demonstrated by sites having } \\
\text { procedures that require a confirmation of authorization } \\
\text { before releasing waste for transfer, and records } \\
\text { showing that transfers are made in accordance with } \\
\text { written authorizations. }\end{array}$ & See K. above. \\
\hline $\begin{array}{l}\text { (2) Data. Waste characterization data, container } \\
\text { information, and generation, storage, treatment, and } \\
\text { transportation information for low-level waste shall be } \\
\text { transferred with or be traceable to the waste. } \\
\text { From DOE G 435.1-1 Chapter IV: Compliance with } \\
\text { this requirement is demonstrated if there are procedures } \\
\text { requiring that characterization and container data be } \\
\text { provided and maintained for each low-level waste } \\
\text { transfer and documented records of transfers show that } \\
\text { the information is being provided. }\end{array}$ & See K. above. \\
\hline $\begin{array}{l}\text { L. Packaging and Transportation. The following } \\
\text { requirements are in addition to those in Chapter I of } \\
\text { this Manual [DOE M 435.1-1 §I.1.E(11)]. }\end{array}$ & See (1) and (2) below. \\
\hline
\end{tabular}


Table 6. (continued).

Facility Name: MFC-752, Analytical Laboratory

\begin{tabular}{l} 
Chapter IV, LLW Requirements \\
\hline (1) Packaging. If containers are used: \\
From DOE G 435.1-1 Chapter IV: Compliance with \\
the packaging requirement is demonstrated by: (1) \\
procedures which document proper packaging \\
protocols; and (2) no trends of routine repackaging of \\
low-level waste that is packaged after issuance of DOE \\
O 435.1. Successful performance of this requirement is \\
also demonstrated by a record of containers for which \\
failure has not routinely occurred under management \\
conditions. It is recognized that there may be failed \\
containers for waste previously placed in storage. For \\
those containers, the goal is to only have to repackage \\
the waste one time after it is retrieved and \\
characterized. Further, acceptable performance is \\
demonstrated by containers of waste having marking \\
and labeling that allows correlation with waste \\
characterization data and container information.
\end{tabular}

(a) Low-level waste shall be packaged in a manner that provides containment and protection for the duration of the anticipated storage period and until disposal is achieved or until the waste has been removed from the container.

(b) When waste is packaged, vents or other measures shall be provided if the potential exists for pressurizing or generating flammable or explosive concentrations of gases within the waste container.

(c) Containers of low-level waste shall be marked such that their contents can be identified.

(2) Transportation. To the extent practical, the volume of waste and number of low-level waste shipments shall be minimized.

From DOE G 435.1-1 Chapter IV: Compliance with this requirement can be demonstrated by a combination of site procedures directing the efficient use of waste container capacity and documentation showing that low-level waste shipments are systematically planned and optimized to the extent practical.

M. Site Evaluation and Facility Design. The following requirements are in addition to those in Chapter I of this Manual.

(1) Site Evaluation. Proposed locations for low-level waste facilities shall be evaluated to identify relevant features that should be avoided or must be considered in facility design and analyses.

(a) Each site proposed for a new low-level waste facility or expansion of an existing low-level waste
Facility Compliance Information

W0660-0035-AP $\S 3.8$

W0640-0047-KP $§ 5$

MCP-17000 $\$ 4$ addresses packaging requirements.

See (1) above.

See (1) above.

See (1) above.

MCP-17000 $\S 4$ addresses transportation. The waste disposition specialist coordinates with packaging and transportation personnel for waste shipped offsite from this facility.

Waste is shipped directly to NNSS from this facility. MCP-17500 specifies waste certification official and waste disposition specialist responsibilities and coordination with packaging and transportation personnel.

NA; this requirement addresses new radioactive waste management facilities or modifications to existing facilities.

See M. above.

See M. above. 
Table 6. (continued).

Facility Name: MFC-752, Analytical Laboratory

\begin{tabular}{|c|c|}
\hline Chapter IV, LLW Requirements & Facility Compliance Information \\
\hline $\begin{array}{l}\text { facility shall be evaluated considering environmental } \\
\text { characteristics, geotechnical characteristics, and human } \\
\text { activities, including for a low-level waste disposal } \\
\text { facility, the capability of the site to demonstrate, at a } \\
\text { minimum, whether it is: }\end{array}$ & \\
\hline $\begin{array}{l}1 \text { Located to accommodate the projected volume of } \\
\text { waste to be received; }\end{array}$ & See M. above. \\
\hline $\begin{array}{l}2 \text { Located in a flood plain, a tectonically active area, or } \\
\text { in the zone of water table fluctuation; and }\end{array}$ & See M. above. \\
\hline $\begin{array}{l}3 \text { Located where radionuclide migration pathways are } \\
\text { predictable and erosion and surface runoff can be } \\
\text { controlled. }\end{array}$ & See M. above. \\
\hline $\begin{array}{l}\text { (b) Proposed sites with environmental characteristics, } \\
\text { geotechnical characteristics, and human activities for } \\
\text { which adequate protection cannot be provided through } \\
\text { facility design shall be deemed unsuitable for the } \\
\text { location of the facility. }\end{array}$ & See M. above. \\
\hline $\begin{array}{l}\text { (c) Low-level waste disposal facilities shall be sited to } \\
\text { achieve long-term stability and to minimize, to the } \\
\text { extent practical, the need for active maintenance } \\
\text { following final closure. }\end{array}$ & See M. above. \\
\hline $\begin{array}{l}\text { (2) Low-Level Waste Treatment and Storage Facility } \\
\text { Design. The following facility requirements and } \\
\text { general design criteria, at a minimum, apply: }\end{array}$ & See M. above. \\
\hline $\begin{array}{l}\text { (a) Confinement. Low-level waste systems and } \\
\text { components shall be designed to maintain waste } \\
\text { confinement. }\end{array}$ & See M. above. \\
\hline (b) Ventilation. & See M. above. \\
\hline $\begin{array}{l}1 \text { Design of low-level waste treatment and storage } \\
\text { facilities shall include ventilation, if applicable, } \\
\text { through an appropriate filtration system to maintain the } \\
\text { release of radioactive material in airborne effluents } \\
\text { within the requirements and guidelines specified in } \\
\text { applicable requirements. }\end{array}$ & See M. above. \\
\hline $\begin{array}{l}2 \text { When conditions exist for generating gases in } \\
\text { flammable or explosive concentrations, ventilation } \\
\text { systems or other measures shall be provided to keep the } \\
\text { gases in a non-flammable and nonexplosive condition. } \\
\text { Where concentrations of explosive or flammable gases } \\
\text { are expected to approach the lower flammability limit, } \\
\text { measures shall be taken to prevent deflagration or } \\
\text { detonation. }\end{array}$ & See M. above. \\
\hline $\begin{array}{l}\text { (c) Consideration of Decontamination and } \\
\text { Decommissioning. Areas in new and modifications to } \\
\text { existing low-level waste management facilities that are }\end{array}$ & See M. above. \\
\hline
\end{tabular}


Table 6. (continued).

Facility Name: MFC-752, Analytical Laboratory

\begin{tabular}{|l|}
\hline \multicolumn{1}{|c|}{ Chapter IV, LLW Requirements } \\
\hline subject to contamination with radioactive or other \\
hazardous materials shall be designed to facilitate \\
decontamination. For such facilities a proposed \\
decommissioning method or a conversion method \\
leading to reuse shall be described. \\
\hline $\begin{array}{l}\text { (d) Instrumentation and Control Systems. Engineering } \\
\text { controls shall be incorporated in the design and } \\
\text { engineering of low-level waste treatment and storage } \\
\text { facilities to provide volume inventory data and to } \\
\text { prevent spills, leaks, and overflows from tanks or } \\
\text { confinement systems. }\end{array}$ \\
\hline
\end{tabular}

(e) Monitoring. Monitoring and/or leak detection capabilities shall be incorporated in the design and engineering of low-level waste treatment and storage facilities to provide rapid identification of failed confinement and/or other abnormal conditions.

(3) Low-Level Waste Disposal Facility Design. The following facility requirements and general design criteria, at a minimum, apply:

(a) Confinement. Low-level waste systems and components shall be designed to maintain waste confinement.

(b) Ventilation.

1 Design of low-level waste disposal facilities shall include ventilation, if applicable, through an appropriate filtration system to maintain the release of radioactive material in airborne effluents within the requirements and guidelines specified in applicable requirements.

2 When conditions exist for generating gases in flammable or explosive concentrations, ventilation systems or other measures shall be provided to keep the gases in a nonflammable and non-explosive condition. Where concentrations of explosive or flammable gases are expected to approach the lower flammability limit, measures shall be taken to prevent deflagration or detonation.

(c) Stability. Low-level waste disposal facilities shall be designed to achieve long-term stability and to minimize to the extent practical, the need for active maintenance following final closure.

(d) Control of Water. Low-level waste disposal facilities shall be designed to minimize to the extent practical, the contact of waste with water during and after disposal.
See M. above.

See M. above.

See M. above.

See M. above.

See M. above.

See M. above.

See M. above.

See M. above.

See M. above. 
Table 6. (continued).

Facility Name: MFC-752, Analytical Laboratory

\begin{tabular}{l}
\hline \multicolumn{1}{|c|}{ Chapter IV, LLW Requirements } \\
\hline N. Storage and Staging. The following requirements \\
are in addition to those in Chapter I of this Manual \\
{$[$ DOE M 435.1-1 §I.2.F(13)]. }
\end{tabular}

(1) Storage Prohibitions. Low-level waste in storage shall not be readily capable of detonation, explosive decomposition, reaction at anticipated pressures and temperatures, or explosive reaction with water. Prior to storage, pyrophoric materials shall be treated, prepared, and packaged to be nonflammable.

From DOE G 435.1-1 Chapter IV: Compliance with this requirement is demonstrated by having waste acceptance requirements which prohibit low-level waste that is ignitable or explosive from being accepted for storage unless it has been treated, and procedures for properly preparing such materials for safe storage.

(2) Storage Limit. Low-level waste that has an identified path to disposal shall not be stored longer than one year prior to disposal, except for storage for decay, or as otherwise authorized by the Field Element Manager.

From DOE G 435.1-1 Chapter IV: Storage longer than one year can be justified if the conditions for such storage are approved by the Field Element Manager as part of the radioactive waste management basis for the facility.

Storage for radioactive decay for a period greater than 1 year for waste that has an identified path to disposal is allowed. Adequate justification and the supporting information for storage for decay is to be documented in the radioactive waste management basis for the facility in which the storage will take place.

Mixed waste. Under the Federal Facility Compliance Act of 1992, DOE sites were required to develop Site Treatment Plans to bring stored mixed low-level waste into compliance with these requirements. The Site Treatment Plan needs to be consulted and any mixed low-level waste stored for the purpose of accumulation to facilitate treatment must meet Resource Conservation and Recovery Act storage requirements. There could be several ways within different scenarios that this requirement can be met, as illustrated by the examples below, however, there are basically four ways to show compliance with the requirement and include appropriate provisions in the radioactive waste management basis for the facility in which it is stored.

Legacy waste. As discussed above, the intention of the requirement is not to force malicious compliance or
Facility Compliance Information

Not a facility-specific requirement. DOE Manual 435.1-1 §I.2.F(13) applies to field element managers.

NA; LLW is not stored at this facility.

NA; LLW is not stored at this facility. 
Table 6. (continued).

Facility Name: MFC-752, Analytical Laboratory

\begin{tabular}{|c|c|}
\hline Chapter IV, LLW Requirements & Facility Compliance Information \\
\hline $\begin{array}{l}\text { heroic actions which would result in increased risk or } \\
\text { safety concerns. Rather, the intention is that waste in } \\
\text { storage longer than one year receives additional } \\
\text { attention to ensure that the public, the workers, and the } \\
\text { environment are protected from the hazards of the } \\
\text { waste, and that progress is being made to dispose of the } \\
\text { waste. There could be several ways within different } \\
\text { scenarios that this requirement can be met, as } \\
\text { illustrated by the examples below, however, there are } \\
\text { basically four ways to show compliance with the } \\
\text { requirement: }\end{array}$ & \\
\hline $\begin{array}{l}\text { 1) the radioactive waste management basis allows for } \\
\text { storage for no more than one year. }\end{array}$ & \\
\hline $\begin{array}{l}\text { 2) the radioactive waste management basis allows for } \\
\text { storage for no more than one year, or for storage for } \\
\text { decay only for periods greater than a year, which are } \\
\text { specified on a radionuclide basis. }\end{array}$ & \\
\hline $\begin{array}{l}\text { 3) the radioactive waste management basis allows for } \\
\text { storage for more than one year, up to a specified period } \\
\text { of time based on a documented technical evaluation } \\
\text { that the waste can be stored in a manner that does not } \\
\text { cause changes to the waste or waste packages that is } \\
\text { detrimental to the safe storage of the waste, the final } \\
\text { disposal of the waste or to meeting the disposal } \\
\text { performance objectives. }\end{array}$ & \\
\hline $\begin{array}{l}\text { 4) the radioactive waste management basis allows for } \\
\text { storage for decay (with specifics) and for storage for } \\
\text { more than one year for other low-level waste, up to a } \\
\text { specified period of time based on a documented } \\
\text { technical evaluation that the waste can be stored in a } \\
\text { manner that does not cause changes to the waste or } \\
\text { waste packages that is detrimental to the safe storage of } \\
\text { the waste, the final disposal of the waste or to meeting } \\
\text { the disposal performance objectives. }\end{array}$ & \\
\hline $\begin{array}{l}\text { Compliance with this requirement is demonstrated by } \\
\text { the existence of a radioactive waste management basis } \\
\text { for the storage facility approved by the Field Element } \\
\text { Manager that includes the time frames that waste are } \\
\text { allowed to be stored, the necessary justifications for } \\
\text { storage for decay, and the necessary technical } \\
\text { evaluations if storage is to extend significantly beyond } \\
\text { the one-year time frame. }\end{array}$ & \\
\hline $\begin{array}{l}\text { (3) Storage Integrity. Low-level waste shall be stored } \\
\text { in a location and manner that protects the integrity of } \\
\text { waste for the expected time of storage and minimizes } \\
\text { worker exposure. }\end{array}$ & NA; LLW is not stored at this facility. \\
\hline $\begin{array}{l}\text { From DOE G } 435.1-1 \text { Chapter IV: However, in making } \\
\text { a decision to use a facility for storage and in }\end{array}$ & \\
\hline
\end{tabular}


Table 6. (continued).

Facility Name: MFC-752, Analytical Laboratory

\begin{tabular}{|l|}
\hline \multicolumn{1}{|c|}{ Chapter IV, LLW Requirements } \\
\hline developing a radioactive waste management basis for \\
the activity, particular attention to protection of \\
workers is needed. \\
Compliance with this requirement is demonstrated if \\
sites have storage capabilities for low-level waste that \\
provide protection to waste containers so that their \\
integrity will not be damaged through physical or \\
chemical (corrosion) processes and that keep personnel \\
from spending extended periods of time in the areas \\
where low-level waste is stored.
\end{tabular}

(4) Waste Characterization for Storage.

NA; LLW is not stored at this facility.

(a) Low-level waste that does not have an identified path to disposal shall be characterized as necessary to meet the data quality objectives and minimum characterization requirements of this Chapter, to ensure safe storage, and to facilitate disposal.

(b) Characterization information for all low-level waste in storage shall be maintained as a record in accordance with the requirements for Records Management in Chapter I of this Manual.

From DOE G 435.1-1 Chapter IV: Compliance with this requirement is demonstrated by documented procedures for managing waste characterization and container information on low-level waste as a Federal record. The records are managed per the applicable policies and procedures for records management referenced in DOE O 200.1 and established at the applicable Field Element.

(5) Container Inspection. A process shall be developed and implemented for inspecting and maintaining containers of low-level waste to ensure container integrity is not compromised.

From DOE G 435.1-1 Chapter IV: Compliance with this requirement is demonstrated by: (1) a documented process for waste container inspection and maintenance; and (2) documentation for all waste container inspections and maintenance actions performed.

(6) Storage Management. Low-level waste storage shall be managed to identify and segregate low-level waste from mixed low-level waste.

(7) Staging. Staging of low-level waste shall be for the purpose of the accumulation of such quantities of waste as necessary to facilitate transportation, treatment, and disposal. Staging longer than 90 days shall meet the requirements for storage above and in Chapter I of this Manual.

See (4) above. Facility Compliance Information

See (4) above.

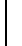

Facility Compliance Information

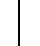

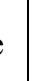

See (4) above.

LI-435 requires quarterly inspections of radioactive waste containers if waste is stored outdoors or has been in storage for greater than 1 year.

Inspections are performed for temporary accumulation areas and satellite accumulation areas as required by WGS procedures (MCP-17000 and MCP-17410).

NA; LLW is not stored at this facility.

LLW and mixed LLW is staged for the purpose of accumulation to facilitate treatment and disposal. Mixed LLW is staged in SAAs in accordance with MCP-17000 and MCP-17410. LLW is staged in temporary accumulation areas in accordance with MCP-17000 and MCP-17410. 
Table 6. (continued).

Facility Name: MFC-752, Analytical Laboratory

\begin{tabular}{|c|c|}
\hline Chapter IV, LLW Requirements & Facility Compliance Information \\
\hline $\begin{array}{l}\text { From DOE G 435.1-1 Chapter IV: The staging of low- } \\
\text { level waste needs to be addressed in the radioactive } \\
\text { waste management basis for the facility that is } \\
\text { performing the staging. Generators, treatment facilities, } \\
\text { and disposal facilities that stage waste must ensure that } \\
\text { the action of staging is included and authorized as part } \\
\text { of their radioactive waste management basis for the } \\
\text { affected facilities, operations, or activities. }\end{array}$ & $\begin{array}{l}\text { MCP-17000, Appendix F restricts staging LLW to } \\
90 \text { days maximum at any generator or treatment facility } \\
\text { prior to acceptance by a storage facility. }\end{array}$ \\
\hline $\begin{array}{l}\text { Staging longer than } 90 \text { days must be justified, the } \\
\text { conditions for such storage met, and these practices } \\
\text { approved by the Field Element Manager as part of the } \\
\text { radioactive waste management basis for the facility. }\end{array}$ & \\
\hline $\begin{array}{l}\text { Compliance with this requirement is demonstrated by a } \\
\text { staging program that limits the temporary storage of } \\
\text { waste to only circumstances allowed in the } \\
\text { requirement, including justifications for any staging } \\
\text { that exceeds the } 90 \text {-day period, which is documented in } \\
\text { the radioactive waste management basis for the facility. }\end{array}$ & \\
\hline $\begin{array}{l}\text { O. Treatment. Low-level waste treatment to provide } \\
\text { more stable waste forms and to improve the long-term } \\
\text { performance of a low-level waste disposal facility shall } \\
\text { be implemented as necessary to meet the performance } \\
\text { objectives of the disposal facility. }\end{array}$ & $\begin{array}{l}\text { NA; treatment is not performed in this facility. } \\
\text { Containerized elementary neutralization is performed } \\
\text { at this facility as provided by LWP- } 8000 \text {. As stated in } \\
\S 4.118 \text {, elementary neutralization of corrosive } \\
\text { hazardous waste may take place at any location where }\end{array}$ \\
\hline $\begin{array}{l}\text { From DOE G } 435.1-1 \text { Chapter IV: Compliance with } \\
\text { this requirement is demonstrated when a treatment } \\
\text { facility or process ensures that treated waste will meet } \\
\text { the minimum waste form requirements of DOE M } \\
435.1 \text { and meet additional disposal facility-specific } \\
\text { waste acceptance requirements for additional stability } \\
\text { or long-term performance of facilities that will receive } \\
\text { the treated waste. }\end{array}$ & $\begin{array}{l}\text { the waste is generated or stored and neither a generator } \\
\text { treatment plan nor a permit is required. Solidification } \\
\text { of liquid LLW for the purpose of staging (not for } \\
\text { treating the radioactive constituents) also may be } \\
\text { performed. Therefore, this facility is not considered to } \\
\text { be a treatment facility. }\end{array}$ \\
\hline $\begin{array}{l}\text { P. Disposal. Low-level waste disposal facilities shall } \\
\text { meet the following requirements. }\end{array}$ & NA; LLW is not disposed of in this facility. \\
\hline $\begin{array}{l}\text { (1) Performance Objectives. Low-level waste disposal } \\
\text { facilities shall be sited, designed, operated, maintained, } \\
\text { and closed so that a reasonable expectation exists that } \\
\text { the following performance objectives will be met for } \\
\text { waste disposed of after September } 26,1988 \text { : }\end{array}$ & See P. above. \\
\hline $\begin{array}{l}\text { (a) Dose to representative members of the public shall } \\
\text { not exceed } 25 \text { mrem }(0.25 \mathrm{mSv}) \text { in a year total } \\
\text { effective dose equivalent from all exposure pathways, } \\
\text { excluding the dose from radon and its progeny in air. }\end{array}$ & See P. above. \\
\hline $\begin{array}{l}\text { (b) Dose to representative members of the public via } \\
\text { the air pathway shall not exceed } 10 \mathrm{mrem}(0.10 \mathrm{mSv}) \\
\text { in a year total effective dose equivalent, excluding the } \\
\text { dose from radon and its progeny. }\end{array}$ & See P. above. \\
\hline
\end{tabular}


Table 6. (continued).

Facility Name: MFC-752, Analytical Laboratory

\section{Chapter IV, LLW Requirements}

(c) Release of radon shall be less than an average flux of $20 \mathrm{pCi} / \mathrm{m}^{2} / \mathrm{s}\left(0.74 \mathrm{~Bq} / \mathrm{m}^{2} / \mathrm{s}\right)$ at the surface of the disposal facility. Alternatively, a limit of $0.5 \mathrm{pCi} / 1$ $(0.0185 \mathrm{~Bq} / \mathrm{l})$ of air may be applied at the boundary of the facility.

(2) Performance Assessment. A site-specific radiological performance assessment shall be prepared and maintained for DOE low-level waste disposed of after September 26, 1988. The performance assessment shall include calculations for a 1,000 year period after closure of potential doses to representative future members of the public and potential releases from the facility to provide a reasonable expectation that the performance objectives identified in this Chapter are not exceeded as a result of operation and closure of the facility.

(a) Analyses performed to demonstrate compliance with the performance objectives in this Chapter, and to establish limits on concentrations of radionuclides for disposal based on the performance measures for inadvertent intruders in this Chapter shall be based on reasonable activities in the critical group of exposed individuals. Unless otherwise specified, the assumption of average living habits and exposure conditions in representative critical groups of individuals projected to receive the highest doses is appropriate. The likelihood of inadvertent intruder scenarios may be considered in interpreting the results of the analyses and establishing radionuclide concentrations, if adequate justification is provided.

(b) The point of compliance shall correspond to the point of highest projected dose or concentration beyond a 100 meter buffer zone surrounding the disposed waste. A larger or smaller buffer zone may be used if adequate justification is provided.

(c) Performance assessments shall address reasonably foreseeable natural processes that might disrupt barriers against release and transport of radioactive materials.

(d) Performance assessments shall use DOE-approved dose coefficients (dose conversion factors) for internal and external exposure of reference adults.

(e) The performance assessment shall include a sensitivity/uncertainty analysis.

(f) Performance assessments shall include a demonstration that projected releases of radionuclides to the environment shall be maintained as low as reasonably achievable (ALARA).

\section{Facility Compliance Information}

See P. above.

See P. above.

See P. above.

See P. above.

See P. above.

See P. above.

See P. above.

See P. above. 
Table 6. (continued).

Facility Name: MFC-752, Analytical Laboratory

\begin{tabular}{|l|}
\hline \multicolumn{1}{|c|}{ Chapter IV, LLW Requirements } \\
\hline (g) For purposes of establishing limits on radionuclides \\
that may be disposed of near-surface, the performance \\
assessment shall include an assessment of impacts to \\
water resources.
\end{tabular}

(h) For purposes of establishing limits on the concentration of radionuclides that may be disposed of near-surface, the performance assessment shall include an assessment of impacts calculated for a hypothetical person assumed to inadvertently intrude for a temporary period into the low-level waste disposal facility. For intruder analyses, institutional controls shall be assumed to be effective in deterring intrusion for at least 100 years following closure. The intruder analyses shall use performance measures for chronic and acute exposure scenarios, respectively, of 100 mrem $(1 \mathrm{mSv})$ in a year and $500 \mathrm{mrem}(5 \mathrm{mSv})$ total effective dose equivalent excluding radon in air.

(3) Composite Analysis. For disposal facilities which received waste after September 26, 1988, a site-specific radiological composite analysis shall be prepared and maintained that accounts for all sources of radioactive material that may be left at the DOE site and may interact with the low- level waste disposal facility, contributing to the dose projected to a hypothetical member of the public from the existing or future disposal facilities. Performance measures shall be consistent with DOE requirements for protection of the public and environment and evaluated for a 1,000 year period following disposal facility closure. The composite analysis results shall be used for planning, radiation protection activities, and future use commitments to minimize the likelihood that current low- level waste disposal activities will result in the need for future corrective or remedial actions to adequately protect the public and the environment.

(4) Performance Assessment and Composite Analysis Maintenance. The performance assessment and composite analysis shall be maintained to evaluate changes that could affect the performance, design, and operating bases for the facility. Performance assessment and composite analysis maintenance shall include the conduct of research, field studies, and monitoring needed to address uncertainties or gaps in existing data. The performance assessment shall be updated to support the final facility closure. Additional iterations of the performance assessment and composite analysis shall be conducted as necessary during the post-closure period.

See P. above.

See P. above. See P. above.

See P. above. Facility Compliance Information 
Table 6. (continued).

Facility Name: MFC-752, Analytical Laboratory

Chapter IV, LLW Requirements

(a) Performance assessments and composite analyses shall be reviewed and revised when changes in waste forms or containers, radionuclide inventories, facility design and operations, closure concepts, or the improved understanding of the performance of the waste disposal facility in combination with the features of the site on which it is located alter the conclusions or the conceptual model(s) of the existing performance assessment or composite analysis.

(b) A determination of the continued adequacy of the performance assessment and composite analysis shall be made on an annual basis, and shall consider the results of data collection and analysis from research, field studies, and monitoring.

(c) Annual summaries of low-level waste disposal operations shall be prepared with respect to the conclusions and recommendations of the performance assessment and composite analysis and a determination of the need to revise the performance assessment or composite analysis.

(5) Disposal Authorization. A disposal authorization statement shall be obtained prior to construction of a new low-level waste disposal facility. Field Elements with existing low-level waste disposal facilities shall obtain a disposal authorization statement in accordance with the schedule in the Complex-Wide Low-Level Waste Management Program Plan. The disposal authorization statement shall be issued based on a review of the facility's performance assessment, composite analysis, performance assessment and composite analysis maintenance, preliminary closure plan, and preliminary monitoring plan. The disposal authorization statement shall specify the limits and conditions on construction, design, operations, and closure of the low-level waste facility based on these reviews. A disposal authorization statement is a part of the radioactive waste management basis for a disposal facility. Failure to obtain a disposal authorization statement by the implementation date of this Order shall result in shutdown of the disposal facility.

(6) Disposal Facility Operations. The disposal facility design and operation must be consistent with the disposal facility closure plan and lead to disposal facility closure that provides a reasonable expectation that performance objectives will be met. Low-level waste shall be disposed in such a manner that achieves the performance objectives stated in this Chapter, consistent with the disposal facility radiological performance assessment. Additional requirements
Facility Compliance Information

See P. above.

See P. above.

See P. above.

See P. above.
See P. above. 
Table 6. (continued).

Facility Name: MFC-752, Analytical Laboratory

\begin{tabular}{l}
\hline \multicolumn{1}{|c|}{ Chapter IV, LLW Requirements } \\
\hline include: \\
\hline (a) Operating procedures shall be developed and \\
implemented for low-level waste disposal facilities that \\
protect the public, workers, and the environment; \\
ensure the security of the facility; minimize subsidence \\
during and after waste emplacement; achieve long-term \\
stability and minimize the need for long-term active \\
maintenance; and meet the requirements of the \\
closure/post-closure plan.
\end{tabular}

(b) Permanent identification markers for disposal excavations and monitoring wells shall be emplaced.

(c) Low-level waste placement into disposal units shall minimize voids between waste containers. Voids within disposal units shall be filled to the extent practical. Uncontainerized bulk waste shall also be placed in a manner that minimizes voids and subsidence.

(d) Operations are to be conducted so that active waste disposal operations will not have an adverse effect on any other disposal units.

(e) Operations shall include a process for tracking and documenting low-level waste placement in the facility by generator source.

(7) Alternate Requirements for Low-Level Waste Disposal Facility Design and Operation. Requirements other than those set forth in this Section for the design and operation of a low-level waste disposal facility may be approved on a specific basis if a reasonable expectation is demonstrated that the disposal performance objectives will be met.

Q. Closure. The following requirements are in addition to those in Chapter I of this Manual.

(1) Disposal Facility Closure Plans. A preliminary closure plan shall be developed and submitted to Headquarters for review with the performance assessment and composite analysis. The closure plan shall be updated following issuance of the disposal authorization statement to incorporate conditions specified in the disposal authorization statement. Closure plans shall:

(a) Be updated as required during the operational life of the facility.

(b) Include a description of how the disposal facility will be closed to achieve long-term stability and minimize the need for active maintenance following closure and to ensure compliance with the requirements

See P. above.

See P. above.

See P. above.

NA; LLW waste is not disposed of in this facility.

See Q. above.

See Q. above.

See Q. above. Facility Compliance Information

See P. above.

See P. above.

See P. above.

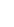

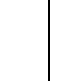


Table 6. (continued).

Facility Name: MFC-752, Analytical Laboratory

\begin{tabular}{|l|l|}
\hline \multicolumn{1}{|c|}{ Chapter IV, LLW Requirements } & Facility Compliance Information \\
\hline $\begin{array}{l}\text { of DOE 5400.5, Radiation Protection of the Public and } \\
\text { the Environment. }\end{array}$ \\
\hline
\end{tabular}

(c) Include the total expected inventory of wastes to be

See Q. above. disposed of at the facility over the operational life of the facility.

(2) Disposal Facility Closure. Closure of a disposal facility shall occur within a five-year period after it is filled to capacity, or after the facility is otherwise determined to be no longer needed.

(a) Prior to facility closure, the final inventory of the low-level waste disposed in the facility shall be prepared and incorporated in the performance assessment and composite analysis which shall be updated to support the closure of the facility.

(b) A final closure plan shall be prepared based on the final inventory of waste disposed in the facility, the plan implemented, and the updated performance assessment and composite analysis prepared in support of the facility closure.

(c) Institutional control measures shall be integrated into land use and stewardship plans and programs, and shall continue until the facility can be released pursuant to DOE 5400.5, Radiation Protection of the Public and the Environment.

(d) The location and use of the facility shall be filed with the local authorities responsible for land use and zoning.

R. Monitoring. The following requirements are in addition to those in Chapter I of this Manual [DOE M 435.1-1 §I.1.E(7)].

(1) All Waste Facilities. Parameters that shall be sampled or monitored, at a minimum, include: temperature, pressure (for closed systems), radioactivity in ventilation exhaust and liquid effluent streams, and flammable or explosive mixtures of gases. Facility monitoring programs shall include verification that passive and active control systems have not failed.

From DOE G 435.1-1 Chapter IV: The minimum parameters specified in the requirement were selected based on their potential significance for anticipating and identifying undesirable conditions at low-level waste management facilities. Each facility's radioactive waste management basis should include an evaluation of the applicability and significance of the minimum parameters. This evaluation also needs to consider additional parameters to be sampled or monitored to
See Q. above.

See Q. above.

See Q. above.

See Q. above.

See Q. above.

See (1), (2), (3) below.

General facility monitoring is addressed in AL-7000-

OI-001. However, a specific monitoring program for radioactive waste and the assessment of monitoring parameters were not identified.

Monitoring requirements at INL radioactive waste management facilities are tailored for the specific facility to enable timely indication of developing problems. Existing radiological control procedures and assessments are followed/completed to monitor waste facilities.

LRD-15001 and MCP-139 specify methods and frequency of radiological control surveys of all radiological areas. MCP-139 specifies the use of Form 441.A34. This form is referred to as the "routine sheet" and is to be used by facility radiological control foremen to list radiological areas that are to be 
Table 6. (continued).

Facility Name: MFC-752, Analytical Laboratory

\begin{tabular}{|c|c|}
\hline Chapter IV, LLW Requirements & Facility Compliance Information \\
\hline $\begin{array}{l}\text { ensure the protection of the public health, the } \\
\text { environment, and the workers. If a minimum parameter } \\
\text { specified in the requirement is deemed to be not } \\
\text { applicable in any way to the active operation of that } \\
\text { facility, then that justification should be included in the } \\
\text { radioactive waste management basis and when } \\
\text { approved constitutes an exemption to the manual. }\end{array}$ & surveyed, the survey periods, and methods. \\
\hline $\begin{array}{l}\text { Verification activities are part of the radioactive waste } \\
\text { management basis as a condition for operation and } \\
\text { documented appropriately. }\end{array}$ & \\
\hline $\begin{array}{l}\text { Compliance with this requirement is demonstrated if } \\
\text { monitoring or sampling for the stated parameters is } \\
\text { performed for all facilities with a precision, accuracy, } \\
\text { and frequency consistent with timely identification of } \\
\text { developing problems and a justification exists in the } \\
\text { approved radioactive waste management basis for those } \\
\text { specified parameters which are not monitored or } \\
\text { sampled. }\end{array}$ & \\
\hline $\begin{array}{l}\text { (2) Liquid Waste Storage Facilities. For facilities } \\
\text { storing liquid low-level waste, the following shall also } \\
\text { be monitored: liquid level and/or waste volume, and } \\
\text { significant waste chemistry parameters. }\end{array}$ & NA; liquid waste is not stored at this facility. \\
\hline $\begin{array}{l}\text { (3) Disposal Facilities. A preliminary monitoring plan } \\
\text { for a low-level waste disposal facility shall be prepared } \\
\text { and submitted to Headquarters for review with the } \\
\text { performance assessment and composite analysis. The } \\
\text { monitoring plan shall be updated within one year } \\
\text { following issuance of the disposal authorization } \\
\text { statement to incorporate and implement conditions } \\
\text { specified in the disposal authorization statement. }\end{array}$ & NA; LLW is not disposed of in this facility. \\
\hline $\begin{array}{l}\text { (a) The site-specific performance assessment and } \\
\text { composite analysis shall be used to determine the } \\
\text { media, locations, radionuclides, and other substances to } \\
\text { be monitored. }\end{array}$ & See (3) above. \\
\hline $\begin{array}{l}\text { (b) The environmental monitoring program shall be } \\
\text { designed to include measuring and evaluating releases, } \\
\text { migration of radionuclides, disposal unit subsidence, } \\
\text { and changes in disposal facility and disposal site } \\
\text { parameters which may affect long-term performance. }\end{array}$ & See (3) above. \\
\hline $\begin{array}{l}\text { (c) The environmental monitoring programs shall be } \\
\text { capable of detecting changing trends in performance to } \\
\text { allow application of any necessary corrective action } \\
\text { prior to exceeding the performance objectives in this } \\
\text { Chapter. }\end{array}$ & See (3) above. \\
\hline
\end{tabular}




\subsection{MFC-765, Fuels Conditioning Facility}

1. Facility description: Remote conditioning of spent metallic fuel from EBR-II is the principal operation conducted in FCF, which is located at MFC at INL. Before facility modifications and installations of new conditioning equipment, FCF was named the HFEF - South from 1969 through 1990.

FCF is an updated hot-cell facility meeting modern codes and standards for use by DOE to demonstrate the technical feasibility of the electrometallurgical technology for the conditioning of DOE spent fuel and to complete the treatment if the demonstration is successful. The present emphasis of the facility is treatment of the EBR-II spent driver-and blanket-fuel assemblies. DOE has identified the electrometallurgical treatment as a promising technology to treat EBR-II spent nuclear fuel.

2. Hazard category: Hazard Category 2 Nuclear Facility

3. Radioactive waste managed at this facility: CH TRU waste, mixed-TRU waste, and RH TRU waste are generated and stored at this facility. CH LLW, mixed LLW, RH LLW, mixed RH-LLW, and liquid LLW are generated and staged at this facility. The mixed LLW is accumulated in an SAA for disposition.

\section{RWMB documents/programs:}

a. Safety Basis/Hazards Analysis:

- F0000-0018-AK, "Final Safety Analysis Report for the Fuel Conditioning Facility"

- F0000-0026-ES, "Criticality Hazard Control Statement for the Fuel Conditioning Facility"

- IAG-263, "INL Authorization Agreement for the Materials and Fuels Complex (MFC) Fuel Conditioning Facility (FCF)"

- LST-304, "Safety Basis List for the Materials and Fuels Complex (MFC) Fuel Conditioning Facility (FCF)"

b. Laboratory-wide:

- Form 435.83, "Idaho National Laboratory Contact-Handled Transuranic Waste Disposition TSR Related (Checklist - Requirements - Certification)"

- Form 441.A34, "INL Radiological Control Required Surveys"

- LI-435, "Waste Management Routine Field Activities"

- LRD-15001, "Radiological Control Manual"

- LWP-8300, "Transuranic Waste Handling"

- LWP-13840, "Management of Issues, Observations, and Noteworthy Practices"

- LWP-14002, "Timeout and Stop Work Authority"

- LWP-15011, "Radioactive Material Areas and Radioactive Storage Areas"

- LWP-17000, "Waste Management"

- MCP-139, "Radiological Surveys"

- MCP-17000, "Waste Generator Services Waste Management"

- MCP-17410, "Management of Waste Storage Areas"

- MCP-17500, "Waste Generator Services Certification of Waste Shipments to the Nevada Test Site"

- PDD-17000, "Waste Management Program"

- PLN-114, "INL Emergency Plan/RCRA Contingency Plan" 
- PLN-522, "Quality Assurance Program Plan for the Waste Management/Waste Certification Program"

- PLN-8300, "Materials and Fuels Complex Contact-Handled TRU Waste Certification Program Plan"

c. Facility-specific:

- ANL-NT-192, "The Defense Programs Origin of Transuranic Waste at Argonne National Laboratory-West, H. F. McFarlane, 11/1/2001"

- CCN 210728, August 8, 2007, Mr. Brian R. Monson to Mr. David L. Wessman, "Manufacturing Process Unit Exemption for the Fuel Conditioning Facility at the Materials and Fuels Complex, Idaho National Laboratory"

- FCF-OI-1302, "Material Control and Accountability"

- FCF-OI-6523, "Radioactive Liquid Waste System"

- FCF-OI-6605, "In-Cell Waste Tracking and Logging"

- FCF-OI-6606, "In-Cell Radiological Smear Data Logging"

- FCF-OI-6614, "Contact-Handled Low-Level Waste Handling”

- FCF-OI-6620, "In Cell Indirect Waste Handling"

- INL/EXT-10-17600, Process Knowledge Summary Report for Materials and Fuels Complex Contact-handled Transuranic Waste

- LST-337, "Approved Container/Payload List for Inter-Facility Transfer Operations at MFC”

- RL-OI-1, "Radioactive Liquid Waste Collection"

- RSWF-OI-003, "Material Acceptance for Storage"

- RSWF-OI-004, "Administrative Requirements/Process for Material Transfers"

- TSD-OI-004, "Waste and Material Acceptance for Storage/Treatment and Radioactive Material Inventory Control"

- TSM-OI-003, Transfer of Hazardous Material in Non-DOT-Certified Packaging between MFC Nuclear Facilities."

TRU waste and LLW are managed at this facility. Table 7 shows the facility compliance information for DOE Manual 435.1-1 Chapter III, "Transuranic Waste Requirements," and Table 8 presents the facility compliance information for Chapter IV, "Low-level Waste Requirements."

Table 7. MFC-765, Fuels Conditioning Facility, DOE Manual 435.1-1 transuranic waste requirements and facility compliance information.

\begin{tabular}{|c|c|}
\hline \multicolumn{2}{|c|}{ Facility Name: MFC-765, Fuels Conditioning Facility } \\
\hline Chapter III, Transuranic Waste Requirements & Facility Compliance Information \\
\hline $\begin{array}{l}\text { A. Definition of Transuranic Waste. Transuranic } \\
\text { waste is radioactive waste containing more than } 100 \\
\text { nanocuries ( } 3700 \text { becquerels) of alpha-emitting } \\
\text { transuranic isotopes per gram of waste, with half-lives } \\
\text { greater than } 20 \text { years, except for: } \\
\text { (From DOE G } 435.1-1 \text { Chapter III: The determination } \\
\text { of transuranic waste should be made at the time of } \\
\text { waste certification, that is, each time the waste is } \\
\text { transferred to another person or facility.) }\end{array}$ & $\begin{array}{l}\text { This requirement proves the criteria for determining } \\
\text { which DOE radioactive waste is to be managed as TRU } \\
\text { waste in accordance with DOE Manual 435.1-1, } \\
\text { Chapter III. } \\
\text { See J. below. }\end{array}$ \\
\hline (1) High-level radioactive waste; & See A. above. \\
\hline
\end{tabular}


Table 7. (continued).

Facility Name: MFC-765, Fuels Conditioning Facility

\section{Chapter III, Transuranic Waste Requirements}

(2) Waste that the Secretary of Energy has determined, with the concurrence of the Administrator of the Environmental Protection Agency, does not need the degree of isolation required by the $40 \mathrm{CFR}$ Part 191 disposal regulations; or

(3) Waste that the Nuclear Regulatory Commission has approved for disposal on a case-by-case basis in accordance with 10 CFR Part 61.

B. Management of Specific Wastes. The following provide for management of specific wastes as transuranic waste in accordance with the requirements in this Chapter:

From DOE G 435.1-1 Chapter III:

Compliance with these requirements is demonstrated if RCRA, state-hazardous, and TSCA-regulated radioactive wastes are being managed in compliance with applicable requirements and agreements or in accordance with a consent order, and consistent with the Transuranic Waste Requirements of DOE M 435.1-1.)

(1) Mixed Transuranic Waste. Transuranic waste determined to contain both a hazardous component subject to the Resource Conservation and Recovery Act (RCRA), as amended, and a radioactive component subject to the Atomic Energy Act of 1954, as amended, shall be managed in accordance with the requirements of RCRA and DOE O 435.1, Radioactive Waste Management, and this Manual.

(2) TSCA-Regulated Waste. Transuranic waste containing polychlorinated biphenyls, asbestos, or other such regulated toxic components shall be managed in accordance with requirements derived from the Toxic Substances Control Act, as amended, DOE O 435.1, Radioactive Waste Management, and this Manual.

(3) Pre-1970 Transuranic Waste. Transuranic waste disposed of prior to implementation of the 1970 Atomic Energy Commission Immediate Action
See A. above.

See (1), (2), and (3) below.
Facility Compliance Information

See A. above.
This facility generates and stores mixed TRU waste.

CCN 210728, August 8, 2007, Mr. Brian R. Monson to

Mr. David L. Wessman, Manufacturing Process Unit

Exemption for the Fuel Conditioning Facility at the

Materials and Fuels Complex, Idaho National

Laboratory, provides the Idaho Department of

Environmental Quality concurrence with the MPU exemption of FCF operations from RCRA regulation.

LWP-8300 defines the requirements and establishes the process associated with generation, handling, characterization, and storage of $\mathrm{CH}$, mixed, and $\mathrm{RH}$ TRU waste.

FCF-OI-6620 establishes and implements administrative requirements and provides instructions for management of the in-cell mixed TRU wastes managed at this facility.

NA; TSCA-regulated TRU waste is not managed at this facility. 
Table 7. (continued).

Facility Name: MFC-765, Fuels Conditioning Facility

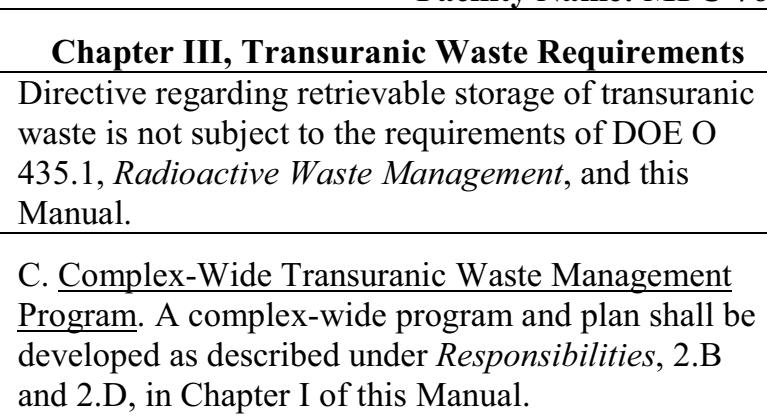

From DOE G 435.1-1 Chapter III:

Compliance with this requirement is demonstrated by the presence of a Complex-Wide Transuranic Waste Management Program which includes the appropriate interfaces, technical information, data inputs, and other elements described in Chapter I of this Manual.

D. Radioactive Waste Management Basis.

Transuranic waste facilities, operations, and activities shall have a radioactive waste management basis consisting of physical and administrative controls to ensure the protection of workers, the public, and the environment. The following specific waste management controls shall be part of the radioactive waste management basis:

From DOE G 435.1-1 Chapter III:

Compliance with this requirement is demonstrated if, the radioactive waste management basis is documented and signed by the Field Element manager or a designee (see DOE M 435.1-1, Section I.1.A, Delegation of Authority) for each transuranic waste management facility, operation, or activity. Using a graded approach, it may be possible to include multiple activities under a single radioactive waste management basis, but it should be possible to objectively identify which activities are covered. Further, the radioactive waste management basis includes or references the controls that are established on a facility-specific basis to address the unique waste management requirements and circumstances for each facility, operation, and/or activity.)

(1) Generators. The waste certification program.

From DOE G 435.1-1 Chapter III:

For a facility that generates transuranic waste, the radioactive waste management basis is to include the program for certifying that waste meets the waste acceptance requirements of the facility(ies) to which the waste will be sent.

Not a facility-specific requirement. DOE Manual 435.11 §I.2.B and §I.2.D apply to the Assistant Secretary for Environmental Management and the Deputy Assistant Secretary for Waste Management, respectively.

The RWMB provides the regulatory framework for management of radioactive waste at INL. It specifically identifies facility management and implementing documents for the generation, storage, treatment, and disposal of radiological waste.
See J. below for waste certification program requirements.

F0000-0018-AK serves as the safety basis documentation for the facility and establishes it as a Hazard Category 2 nuclear facility.

F0000-0026-ES provides the limits, boundaries, conditions, and rules under which activities involving fissionable materials are carried out. 
Table 7. (continued).

\begin{tabular}{|c|c|}
\hline \multicolumn{2}{|c|}{ Facility Name: MFC-765, Fuels Conditioning Facility } \\
\hline Chapter III, Transuranic Waste Requirements & Facility Compliance Information \\
\hline & $\begin{array}{l}\text { FCF-OI-1302 specifies material accountability } \\
\text { requirements for managing special nuclear material in } \\
\text { FCF and provides the instructions necessary to meet the } \\
\text { requirements using the Mass Tracking System database. }\end{array}$ \\
\hline $\begin{array}{l}\text { (2) Treatment Facilities. certification program. The } \\
\text { waste accentance requirements and the waste }[s i c]\end{array}$ & NA; waste is not treated at this facility. \\
\hline From DOE G 435.1-1 Chapter III: & \\
\hline $\begin{array}{l}\text { Facilities that store or treat ransuranic waste are to } \\
\text { have approved waste acceptance requirements (see } \\
\text { DOE M 435.1-1, Section III.G) prior to the issuance } \\
\text { of a radioactive waste management basis. The waste } \\
\text { acceptance requirements will usually suffice as } \\
\text { documentation of the radiological, physical, and } \\
\text { chemical limitations on waste that can be safely } \\
\text { received at the facility, provided they are developed } \\
\text { correctly with consideration of the hazards of the } \\
\text { waste to be managed, and are kept up to date. Controls } \\
\text { on the radiological, physical and chemical limitations } \\
\text { need to include considerations of the potential effects } \\
\text { of radiolysis. }\end{array}$ & \\
\hline $\begin{array}{l}\text { A facility that stores or treats waste is generally } \\
\text { expected to have a waste certification program. Waste } \\
\text { from these facilities will have to be certified as } \\
\text { meeting the waste acceptance requirements of the } \\
\text { facility to which it will be transferred and the facilities } \\
\text { have the potential for generating radioactive waste } \\
\text { (e.g., secondary processing streams from treatment, } \\
\text { monitoring and sampling, radioactive release } \\
\text { cleanup). Consequently, storage and treatment } \\
\text { facilities should also have an approved waste } \\
\text { certification program as part of their radioactive waste } \\
\text { management basis. }\end{array}$ & \\
\hline $\begin{array}{l}\text { As part of the radioactive waste management basis, } \\
\text { site personnel should implement a system or process } \\
\text { for tracking the waste inventory at a storage, } \\
\text { treatment, or disposal facility. }\end{array}$ & \\
\hline $\begin{array}{l}\text { (3) Storage Facilities. The waste acceptance } \\
\text { requirements and the waste certification program. }\end{array}$ & $\begin{array}{l}\text { See G. and J. below for waste acceptance and waste } \\
\text { certification program requirements. }\end{array}$ \\
\hline From DOE G 435.1-1 Chapter III: & F0000-0018-AK serves as the safety basis \\
\hline $\begin{array}{l}\text { Facilities that store or treat transuranic waste are to } \\
\text { have approved waste acceptance requirements (see }\end{array}$ & $\begin{array}{l}\text { documentation for the facility and establishes it as a } \\
\text { Hazard Category } 2 \text { nuclear facility. }\end{array}$ \\
\hline $\begin{array}{l}\text { DOE M 435.1-1, Section III.G) prior to the issuance } \\
\text { of a radioactive waste management basis. The waste } \\
\text { acceptance requirements will usually suffice as }\end{array}$ & $\begin{array}{l}\text { F0000-0026-ES provides the limits, boundaries, } \\
\text { conditions, and the rules under which activities } \\
\text { involving fissionable materials are carried out. }\end{array}$ \\
\hline $\begin{array}{l}\text { documentation of the radiological, physical, and } \\
\text { chemical limitations on waste that can be safely } \\
\text { received at the facility, provided they are developed }\end{array}$ & $\begin{array}{l}\text { FCF-OI-1302 specifies material accountability } \\
\text { requirements for managing special nuclear material in }\end{array}$ \\
\hline
\end{tabular}


Table 7. (continued).

Facility Name: MFC-765, Fuels Conditioning Facility

Chapter III, Transuranic Waste Requirements correctly with consideration of the hazards of the waste to be managed, and are kept up to date. Controls on the radiological, physical and chemical limitations need to include considerations of the potential effects of radiolysis.

A facility that stores or treats waste is generally expected to have a waste certification program. Waste from these facilities will have to be certified as meeting the waste acceptance requirements of the facility to which it will be transferred and the facilities have the potential for generating radioactive waste (e.g., secondary processing streams from treatment, monitoring and sampling, radioactive release cleanup). Consequently, storage and treatment facilities should also have an approved waste certification program as part of their radioactive waste management basis.

As part of the radioactive waste management basis, site personnel should implement a system or process for tracking the waste inventory at a storage, treatment, or disposal facility.

(4) Disposal Facilities. The performance assessment, disposal authorization statement, waste acceptance requirements, and monitoring plan.

E. Contingency Actions. The following requirements are in addition to those in Chapter I of this Manual.

From DOE G 435.1-1 Chapter III:

Compliance with these requirements is demonstrated by having adequate spare capacity and transfer equipment exists for emergency transfers of all liquid transuranic waste. In addition, the capability to perform emergency transfers is demonstrated by having waste transfer routings identified, operational procedures to direct transfers, staff trained to the procedures, and records showing that the spare capacity and transfer capability are kept in operating condition.

(1) Contingency Storage. For off-normal or emergency situations involving liquid transuranic waste storage or treatment, spare capacity with adequate capabilities shall be maintained to receive the largest volume of liquid contained in any one storage tank or treatment facility. Tanks or other facilities that are designated transuranic waste contingency storage shall be maintained in an operational condition when waste is present and shall meet the requirements of DOE O 435.1, Radioactive Waste Management, and this Manual.

\section{Facility Compliance Information}

FCF and provides the instructions necessary to meet the requirements using the Mass Tracking System database.

NA; this facility is not a disposal facility.

DOE Manual 435.1-1 §I.1.E(5) addresses the sitewide emergency management system. The INL plan is provided in PLN-114.

NA; this facility does not store or treat liquid TRU waste. 
Table 7. (continued).

Facility Name: MFC-765, Fuels Conditioning Facility

\section{Chapter III, Transuranic Waste Requirements}

(2) Transfer Equipment. Pipelines and auxiliary facilities necessary for the transfer of liquid waste to contingency storage shall be maintained in an operational condition when waste is present and shall meet the requirements of DOE O 435.1, Radioactive Waste Management, and this Manual.

F. Corrective Actions. I of this Manual. The following requirements are in addition to those in Chapter [sic]

(1) Order Compliance. Corrective actions shall be implemented whenever necessary to ensure the requirements of DOE O 435.1, Radioactive Waste Management, and this Manual are met.

From DOE G 435.1-1 Chapter III:

If a facility or activity can be allowed to operate while a noncompliant or hazardous condition exists, the allowance and any associated limitations must be defined as part of the facility's or activity's radioactive waste management basis, identified as a configuration controlled item in a configuration management plan or included in a revision or modification to an operating procedure or similar controlled documentation.

Compliance with this requirement is demonstrated if a corrective action system exists which addresses noncompliant or hazardous situations associated with transuranic waste management and in a systematic fashion, and allows identification of problems by all personnel.

(2) Operations Curtailment. Operations shall be curtailed or facilities shut down for failure to establish, maintain, or operate consistent with an approved radioactive waste management basis.

From DOE G 435.1-1 Chapter III:

Compliance with this requirement is demonstrated by documented evidence of systematic, routine reviews to determine whether waste management activities and facilities under are operating in accordance with an approved radioactive waste management basis. In addition, the documentation should show that limitations (which may include shutdown) have been placed on activities and operations that do not have or
The INL-wide procedure addressing problem identification as required by DOE Manual 435.1-1 §I.2.G.(1) is LWP-13840, which implements the laboratory's corrective action system.

The INL-wide procedure addressing shutdown or curtailment of activities as required by DOE Manual 435.1-1 §I.2.G.(2) is LWP-14002.

See F. above.
The approved RWMB establishes the current compliance status at each radioactive waste management facility. Facility assessments are scheduled to ensure waste management activities are conducted in accordance with the approved RWMB. 
Table 7. (continued).

Facility Name: MFC-765, Fuels Conditioning Facility

\begin{tabular}{|l|}
\hline \multicolumn{1}{|c|}{ Chapter III, Transuranic Waste Requirements } \\
\hline $\begin{array}{l}\text { are operating outside the conditions of an approved } \\
\text { radioactive waste management basis. }\end{array}$ \\
\hline $\begin{array}{l}\text { G. Waste Acceptance. The following requirements are } \\
\text { in addition to those in Chapter I of this Manual. }\end{array}$ \\
\hline
\end{tabular}

(1) Technical and Administrative. Waste acceptance requirements for all transuranic waste storage, treatment, or disposal facilities, operations, and activities shall specify, at a minimum, the following:

From DOE G 435.1-1 Chapter III:

Compliance with these requirements is demonstrated if waste acceptance requirements are documented, contain clear and precise criteria specifying the radionuclide limits in the form of contents or concentrations that can be accepted, the limitations and prohibitions on waste forms and packages that can be received, and the limits, prohibitions, or instructions concerning any other technical information so that the waste is compatible with the safety basis of the facility, and which will result in acceptable waste at subsequent steps in managing the transuranic waste. Waste acceptance requirements are to also contain a clear description of the process and bases for obtaining an exception or deviation to the acceptance criteria for transuranic waste to be received at the facility.

(a) Allowable activities and/or concentrations of specific radionuclides;

(b) Acceptable waste form and/or container requirements that ensure the chemical and physical stability of waste under conditions that might be encountered during transportation, storage, treatment, or disposal;

(c) Restrictions or prohibitions on waste, materials, or containers that may adversely affect waste handlers or compromise facility or waste container performance;

(d) Requirement to identify transuranic waste as defense or non-defense, and limitations on acceptance; and

(e) The basis, procedures, and levels of authority required for granting exceptions to the waste acceptance requirements, which shall be contained in each facility's waste acceptance documentation. Each exception request shall be documented, including its disposition as approved or not approved.

(2) Evaluation and Acceptance. The receiving facility shall evaluate waste for acceptance, including

DOE Manual 435.1-1 §I.2.F(6) applies to field element managers.

NA; this facility does not accept TRU waste from other facilities. Facility Compliance Information

rercen

racilities. 
Table 7. (continued).

Facility Name: MFC-765, Fuels Conditioning Facility

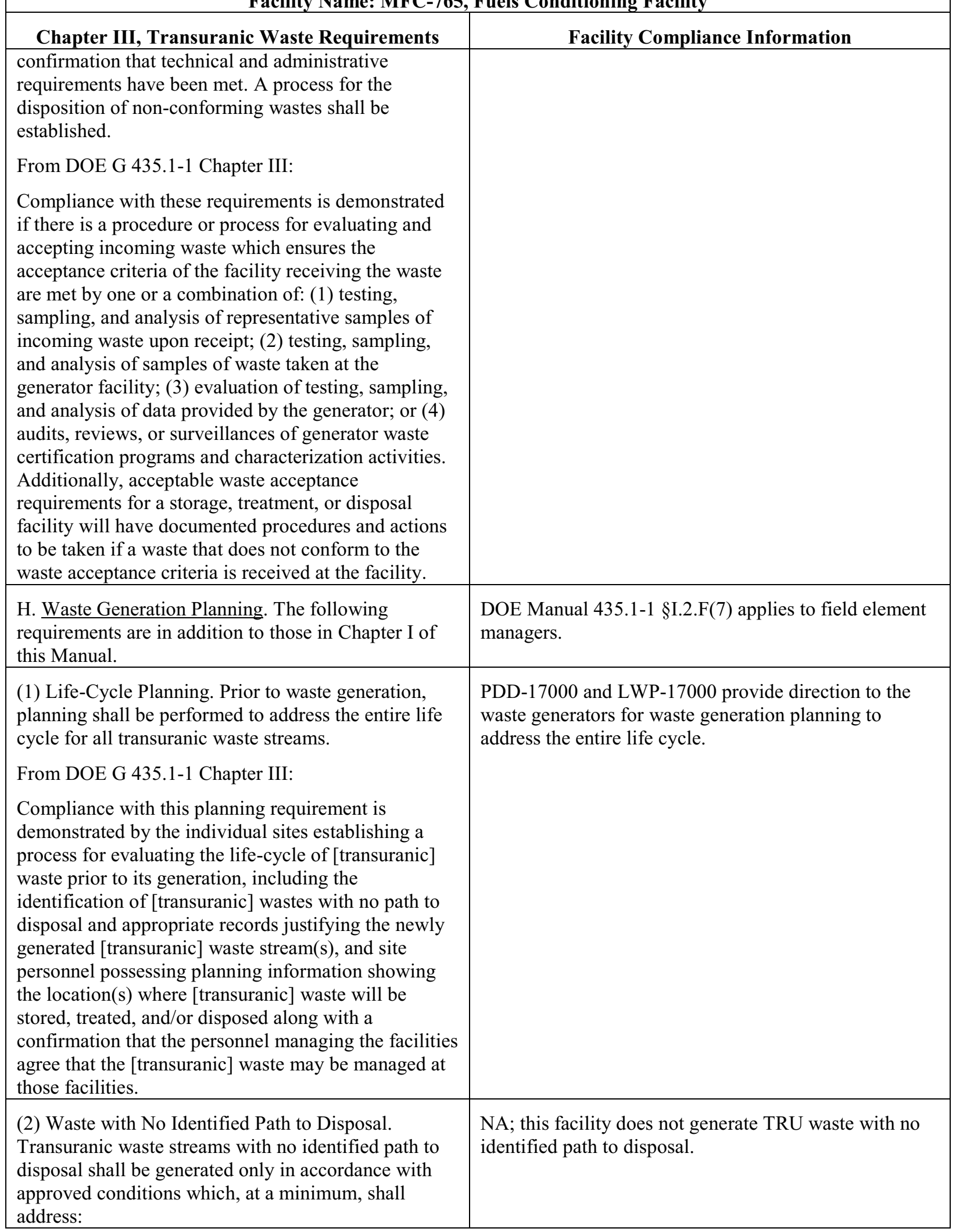


Table 7. (continued).

Facility Name: MFC-765, Fuels Conditioning Facility

Chapter III, Transuranic Waste Requirements
From DOE G 435.1-1 Chapter III:
Compliance with requirement is demonstrated by the
waste generation organization having documentation
concerning the decision to generate a transuranic
waste stream that does not have an identified path to
disposal. This documentation needs to include the
cognizant Field Element Manager or designee
approval to generate the waste, an explanation of the
need for the process that generates the transuranic
waste, a discussion of the reason it cannot be disposed
of, the proposed management plan for the waste, and
an up-to-date schedule of activities being pursued to
resolve constraints to the disposal of the subject
waste. Consistent with the use of a graded approach
for applying DOE M $435.1-1$ requirements, the
schedule and plans for disposing of nondefense waste
can defer to the complex-wide resolution of the issue.)

(a) Programmatic need to generate the waste;

See (2) above.

(b) Characteristics and issues preventing the disposal of the waste;

See (2) above.

(c) Safe storage of the waste until disposal can be achieved; and

(d) Activities and plans for achieving final disposal of the waste.

I. Waste Characterization. Transuranic waste shall be characterized using direct or indirect methods, and the characterization documented in sufficient detail to ensure safe management and compliance with the waste acceptance requirements of the facility receiving the waste.

From DOE G 435.1-1 Chapter III:

Compliance with this requirement is demonstrated by a program for documenting and the existence of records that document the process for acquiring and verifying the validity of transuranic waste characterization data acquired through the use of direct or indirect methods.
See (2) above.

See (2) above.

LWP-8300 $§ 4.2$ provides general INL-wide requirements for containerization and characterization documentation requirements.

FCF-OI-6620 addresses characterization requirements for $\mathrm{CH}$ TRU, mixed TRU, and RH TRU waste generated in the facility.

TRU waste transferred for onsite storage to MFC-771, RSWF, is characterized in accordance with RSWF-OI003.

MCP-17000 $\$ 4$ specifies the requirements for preparing an IWTS profile that captures waste characterization information.

When certified in accordance with the RSWF WAC, MFC TRU waste is, to the extent possible, in compliance with the WAC for various treatment or disposal facilities that could be the ultimate destination of the waste (RSWF-OI-003).

Radioactive waste management facilities characterize waste in accordance with the requirements of the receiving storage, treatment, or disposal facility. The documented use of a data quality objectives process, or 
Table 7. (continued).

Facility Name: MFC-765, Fuels Conditioning Facility

Chapter III, Transuranic Waste Requirements

From DOE G 435.1-1 Chapter III:

Compliance with this requirement is demonstrated by the documented use of a data quality objectives or a comparable process for determining the type, quantity, and quality of characterization data needed to safely manage transuranic waste.

(2) Minimum Waste Characterization.

Characterization data shall, at a minimum, include the following information relevant to the management of the waste:

From DOE G 435.1-1 Chapter III:

Compliance with this requirement is demonstrated by the existence of a program or procedures for determining and records that document characterization of transuranic waste consistent with the minimum characterization data requirements.)

(a) Physical and chemical characteristics;

(b) Volume, including the waste and any stabilization or absorbent media;

(c) Weight of the container and contents;

(d) Identities, activities, and concentrations of major radionuclides;

\begin{tabular}{|l|}
\hline (e) Characterization date; \\
\hline (f) Generating source;
\end{tabular}

(g) Packaging date; and

(h) Any other information which may be needed to prepare and maintain the disposal facility performance assessment or demonstrate compliance with applicable performance objectives.

J. Waste Certification. A waste certification program shall be developed, documented, and implemented to ensure that the waste acceptance requirements of
Facility Compliance Information

comparable process, was not identified for this facility.

LWP-8300 § 4.2 provides general INL-wide

requirements for containerization and characterization documentation requirements.

FCF-OI-6620 addresses characterization of in-cell, non-process, or indirect waste.

TRU waste transferred for onsite storage to MFC-771, RSWF, is characterized in accordance with RSWF-OI$003 \S 4.1 .7$ and Appendix A, Form 412.09.

MCP-17000 $\$ 4$ specifies the requirements for preparing an IWTS profile that captures waste characterization information.

FCF-OI-6605 addresses in-cell waste tracking and logging to identify discrete waste items and aid in characterization of waste. This document requires revision due to reference to DOE Order 5820.2A, which is now replaced by DOE Order 435.1.

FCF-OI-6606 provides instructions for recording the radiological smear data in the MTG system for use as a record in characterization of loose contamination levels associated with waste materials.

See (2) above.

See (2) above.

See (2) above.

See (2) above.

See (2) above.

See (2) above.

See (2) above.

See (2) above.

PLN-8300 provides MFC-wide certification of CH TRU waste.

LWP-8300 provides general INL-wide requirements for 
Table 7. (continued).

Facility Name: MFC-765, Fuels Conditioning Facility

Chapter III, Transuranic Waste Requirements

facilities receiving transuranic waste for storage, treatment, or disposal are met.

From DOE G 435.1-1 Chapter III:

Compliance with the development and documentation portion of the certification requirement is demonstrated by a waste certification plan that identifies the organizations involved, assigns responsibilities for implementing the program, and describes or references the quality assurance, training, procurement controls, records management, and procedures to be used by the program. Acceptable performance for implementing the program is demonstrated when the appropriate personnel are trained, and have and follow the procedures that govern their part of the waste certification process. Acceptable performance also requires that the waste certification plan and procedures are current and controlled in accordance with a document control program, and records related to certification (e.g., certification statements, training records, procurement records, characterization records, container records) are generated and managed in accordance with the established site program.

(1) Certification Program. The waste certification program shall designate the officials who have the authority to certify and release waste for shipment; and specify what documentation is required for waste generation, characterization, shipment, and certification. The program shall provide requirements for auditability, retrievability, and storage of required documentation and specify the records retention period.

From DOE G 435.1-1 Chapter III:

Compliance with this requirement is demonstrated by a program or procedure for record keeping and records showing that each container of waste is certified as having met the waste acceptance criteria of the facility to which it was transferred and the certification statement is supported by additional records regarding the waste source, characterization, and container.

(2) Certification before Transfer. Transuranic waste shall be certified as meeting waste acceptance requirements before it is transferred to the facility receiving the waste.

From DOE G 435.1-1 Chapter III:

Compliance with this requirement is demonstrated by
Facility Compliance Information containerization and characterization documentation requirements.

TRU waste transferred for on-site storage to RSWF is certified in accordance with RSWF-OI-003 $\S 3$.

MCP-17000 specifies the requirements for preparing an IWTS profile that captures waste certification information.

When certified in accordance with the RSWF WAC, MFC TRU waste is, to the extent possible, in compliance with the WAC for various treatment or disposal facilities that could be the ultimate destination of the waste (RSWF-OI-003). Procedural documentation other than this statement regarding certification of TRU waste destined for Waste Isolation Pilot Plant disposition was not found.

See J. above.

See J. above. 
Table 7. (continued).

Facility Name: MFC-765, Fuels Conditioning Facility

\begin{tabular}{l}
\hline \multicolumn{1}{|c|}{ Chapter III, Transuranic Waste Requirements } \\
\hline $\begin{array}{l}\text { the presence of a certification program which includes } \\
\text { procedures requiring a signed certification statement } \\
\text { prior to the release of waste for transfer, and by dated } \\
\text { records showing that waste was certified before being } \\
\text { transferred. }\end{array}$ \\
$\begin{array}{l}\text { (3) Maintaining Certification. Transuranic waste that } \\
\text { has been certified as meeting the waste acceptance } \\
\text { requirements for transfer to a storage, treatment, or } \\
\text { disposal facility shall be managed in a manner that } \\
\text { maintains its certification status. } \\
\text { From DOE G 435.1-1 Chapter III: } \\
\text { Compliance with this requirement is demonstrated by } \\
\text { the existence of a program or procedure reflecting this } \\
\text { requirement and site personnel able to show that the } \\
\text { storage of containers of waste is in a facility or } \\
\text { manner where the containers are not damaged by } \\
\text { normal weather events, and cannot be accessed by } \\
\text { unauthorized personnel. Further, each container can } \\
\text { be traced to its certification and the information } \\
\text { supporting that certification. }\end{array}$ \\
K. Waste Transfer. A documant
\end{tabular}

K. Waste Transfer. A documented process shall be established and implemented for transferring responsibility for management of transuranic waste and for ensuring availability of relevant data. The following requirements are in addition to those in Chapter I of this Manual.

From DOE G 435.1-1 Chapter III:

Compliance with this requirement is demonstrated if facilities have procedures for the receipt of waste and the transfer of waste, as appropriate, which address the acquisition of waste and container data and the transfer of ownership, respectively. Further evidence of acceptable performance is facility records showing that data on the waste containers are available and accurate, and that documented transfer of responsibility occurs.

See J. above. Facility Compliance Information

RSWF-OI-003 specifies requirements and provides instructions for accepting mixed waste, radioactive waste, and radioactive material for storage at RSWF. Appendix A serves as the record document to be maintained for each container going to that facility.

RSWF-OI-004 provides the administrative requirements/process used by RSWF management for approving material transfer activities into and out of RSWF.

TSD-OI-004 specifies requirements and provides instructions for accepting $\mathrm{CH}$ TRU and mixed $\mathrm{CH}$ TRU waste at the MFC treatment, storage, and disposal facilities.

LWP-8300 $§ 4.3$ provides instruction on containerization of $\mathrm{CH}$ TRU waste going to the Advanced Mixed Waste Treatment Plant and prescribes the use of Form 435.83 as the documented record of container data and transfer.

PLN-8300 provides MFC-wide certification of $\mathrm{CH}$ TRU waste.

MCP-17000 specifies the requirements for preparing an IWTS profile that captures waste certification data, transfer information, and associated authorizations.

See K. above.
(1) Authorization. Transuranic waste shall not be transferred to a storage, treatment, or disposal facility until personnel responsible for the facility receiving 
Table 7. (continued).

Facility Name: MFC-765, Fuels Conditioning Facility

Chapter III, Transuranic Waste Requirements
the waste authorize the transfer.
From DOE G 435.1-1 Chapter III:
Compliance with this requirement is demonstrated by
sites having procedures that require a confirmation of
authorization before releasing waste for transfer, and
records showing that transfers are made in accordance
with written authorizations.

(2) Data. Waste characterization data, container information, and generation, storage, treatment, and transportation information for transuranic waste shall be transferred with or be traceable to the waste.

From DOE G 435.1-1 Chapter III:

Compliance with this requirement is demonstrated if there are procedures requiring that characterization and container data be provided and maintained for each waste transfer and documented records of transfers show that the information is being provided.

L. Packaging and Transportation. The following requirements are in addition to those in Chapter I of this Manual.

\section{(1) Packaging.}

From DOE G 435.1-1 Chapter III:

Compliance with the packaging requirement is demonstrated by procedures which document proper packaging protocols, including documented evidence that, where feasible, non-defense transuranic waste has been packaged separately from defense transuranic waste and by never having to repackage transuranic waste that is packaged after issuance of DOE O 435.1 in order to maintain containment. However, the above protocol may not be satisfied by containers that were placed in storage prior to issuance of the DOE O 435.1. For those containers, the goal is to only have to repackage the waste one time after it is retrieved and characterized. Further, acceptable performance is demonstrated by containers of waste having marking and labeling that allows correlation with waste characterization data and container information. Successful performance of this requirement is also demonstrated by a record of container performance in which failure has not routinely occurred.

(a) Transuranic waste shall be packaged in a manner that provides containment and protection for the duration of the anticipated storage period and until disposal is achieved or until the waste is removed
See K. above. Facility Compliance Information

See (1)(a) through (2) below.

See (1)(a) through (2) below.
LWP-8300 and the various documents cited below address packaging requirements for TRU waste managed at this facility.

PLN-8300 addresses this requirement for CH TRU 
Table 7. (continued).

\begin{tabular}{|c|c|}
\hline \multicolumn{2}{|c|}{ Facility Name: MFC-765, Fuels Conditioning Facility } \\
\hline Chapter III, Transuranic Waste Requirements & Facility Compliance Information \\
\hline from the container. & $\begin{array}{l}\text { waste generated at this facility. } \\
\text { FCF-OI- } 6620 \S 2.2 .5 \text { requires all waste be packaged in } \\
\text { an approved waste receptacle. } \\
\text { RSWF-OI-003 specifies requirements and provides } \\
\text { instructions for accepting mixed waste, radioactive } \\
\text { waste, and radioactive material for storage at RSWF. } \\
\text { Appendix A serves as the record document to be } \\
\text { maintained for each container going to that facility. } \\
\text { TSM-OI-003 prescribes the appropriate packaging for } \\
\text { intra-facility movements of TRU waste. } \\
\text { LST-337 prescribes the appropriate container as } \\
\text { approved by waste type. }\end{array}$ \\
\hline $\begin{array}{l}\text { (b) Vents or other mechanisms to prevent } \\
\text { pressurization of containers or generation of } \\
\text { flammable or explosive concentrations of gases shall } \\
\text { be installed on containers of newly-generated waste at } \\
\text { the time the waste is packaged. Containers of } \\
\text { currently stored waste shall meet this requirement as } \\
\text { soon as practical unless analyses demonstrate that the } \\
\text { waste can otherwise be managed safely. } \\
\text { From DOE G 435.1-1 Chapter III: } \\
\text { In developing the radioactive waste management } \\
\text { basis, site personnel need to consider the hazards } \\
\text { associated with drums of transuranic waste which } \\
\text { have not been provided with vents or been proven to } \\
\text { not need vents through an approved safety analysis. } \\
\text { For unvented containers in earthen-covered storage, } \\
\text { the facility itself may mitigate the hazards associated } \\
\text { with the accumulation of gases. For above-grade } \\
\text { storage of transuranic waste containers, the } \\
\text { radioactive waste management basis needs to include } \\
\text { controls which mitigate the hazards associated with } \\
\text { the accumulation of gases by restricting access to the } \\
\text { storage area and providing equipment to protect } \\
\text { against fire or explosion. }\end{array}$ & $\begin{array}{l}\text { LWP- } 8300 \S \S 4.2 \text { and } 4.3 \text { address packaging ventilation } \\
\text { requirements for TRU waste. } \\
\text { PLN- } 8300 \text { addresses this requirement for TRU waste } \\
\text { generated at this facility. } \\
\text { FCF-OI- } 6620 \S 2.2 .5 \text { requires all waste be packaged in } \\
\text { an approved waste receptacle. } \\
\text { RSWF-OI- } 003 \text { provides for use of Appendix A as } \\
\text { record of the ventilated or other pressurization } \\
\text { protection packaging. } \\
\text { TSM-OI-003 prescribes the appropriate packaging for } \\
\text { intra-facility movements of TRU waste. } \\
\text { LST- } 337 \text { prescribes the appropriate container as } \\
\text { approved by waste type. }\end{array}$ \\
\hline $\begin{array}{l}\text { (c) When transuranic waste is packaged, defense } \\
\text { waste shall be packaged separately from non-defense } \\
\text { waste, if feasible. }\end{array}$ & $\begin{array}{l}\text { INL/EXT-10-17600 } \S 3 \text { addresses the defense } \\
\text { determination requirement based on ANL-NT-192. }\end{array}$ \\
\hline $\begin{array}{l}\text { (d) Containers of transuranic waste shall be marked } \\
\text { such that their contents can be identified. }\end{array}$ & $\begin{array}{l}\text { LWP- } 8300 \S 4.3 .1 .7 \text { provides instructions on properly } \\
\text { marking/labeling TRU waste containers. } \\
\text { PLN- } 8300 \text { addresses this requirement for CH TRU } \\
\text { waste generated at this facility. } \\
\text { RSWF-OI-003 specifies requirements and provides } \\
\text { instructions for accepting mixed waste, radioactive } \\
\text { waste, and radioactive material for storage at RSWF. } \\
\text { Appendix A serves as the record document to be }\end{array}$ \\
\hline
\end{tabular}


Table 7. (continued).

\begin{tabular}{|c|c|}
\hline \multicolumn{2}{|c|}{ Facility Name: MFC-765, Fuels Conditioning Facility } \\
\hline Chapter III, Transuranic Waste Requirements & Facility Compliance Information \\
\hline & maintained for each container going to that facility. \\
\hline $\begin{array}{l}\text { (2) Transportation. To the extent practical, the volume } \\
\text { of waste and number of transuranic waste shipments } \\
\text { shall be minimized. }\end{array}$ & $\begin{array}{l}\text { NA; waste is not shipped from this facility to an offsite } \\
\text { facility for final disposition. }\end{array}$ \\
\hline From DOE G 435.1-1 Chapter III: & \\
\hline $\begin{array}{l}\text { Compliance with this requirement can be } \\
\text { demonstrated by a combination of site procedures } \\
\text { directing the efficient use of waste container capacity } \\
\text { and documentation showing that transuranic waste } \\
\text { shipments are systematically planned and make } \\
\text { optimal use of the shipment system (e.g., TRUPACT } \\
\text { II) to the extent practical. }\end{array}$ & \\
\hline $\begin{array}{l}\text { M. Site Evaluation and Facility Design. The following } \\
\text { requirements are in addition to those in Chapter I of } \\
\text { this Manual. }\end{array}$ & $\begin{array}{l}\mathrm{NA} \text {; this requirement addresses new radioactive waste } \\
\text { management facilities. }\end{array}$ \\
\hline $\begin{array}{l}\text { (1) Site Evaluation. Proposed locations for transuranic } \\
\text { waste facilities shall be evaluated to identify relevant } \\
\text { features that should be avoided or must be considered } \\
\text { in facility design and analyses. }\end{array}$ & See M. above. \\
\hline $\begin{array}{l}\text { (a) Each site proposed for a new transuranic waste } \\
\text { facility or expansion of an existing transuranic waste } \\
\text { facility shall be evaluated considering environmental } \\
\text { characteristics, geotechnical characteristics, and } \\
\text { human activities. }\end{array}$ & See M. above. \\
\hline $\begin{array}{l}\text { (b) Proposed sites with environmental characteristics, } \\
\text { geotechnical characteristics, and human activities for } \\
\text { which adequate protection cannot be provided through } \\
\text { facility design shall be deemed unsuitable for the } \\
\text { location of the facility. }\end{array}$ & See M. above. \\
\hline $\begin{array}{l}\text { (2) Facility Design. The following facility } \\
\text { requirements and general design criteria, at a } \\
\text { minimum, apply: }\end{array}$ & See M. above. \\
\hline $\begin{array}{l}\text { (a) Confinement. Transuranic waste systems and } \\
\text { components shall be designed to maintain waste } \\
\text { confinement. }\end{array}$ & See M. above. \\
\hline \multicolumn{2}{|l|}{ (b) Ventilation. } \\
\hline $\begin{array}{l}1 \text { Design of transuranic waste treatment and storage } \\
\text { facilities shall include ventilation, if applicable, } \\
\text { through an appropriate filtration system to maintain } \\
\text { the release of radioactive material in airborne } \\
\text { effluents within the requirements and guidelines } \\
\text { specified in applicable requirements. }\end{array}$ & See M. above. \\
\hline $\begin{array}{l}2 \text { When conditions exist for generating gases in } \\
\text { flammable or explosive concentrations in treatment or } \\
\text { storage facilities, ventilation or other measures shall }\end{array}$ & See M. above. \\
\hline
\end{tabular}


Table 7. (continued).

Facility Name: MFC-765, Fuels Conditioning Facility

\begin{tabular}{|l|}
\hline \multicolumn{1}{|c|}{ Chapter III, Transuranic Waste Requirements } \\
\hline $\begin{array}{l}\text { be provided to keep the gases in a non-flammable and } \\
\text { non-explosive condition. Where concentrations of } \\
\text { explosive or flammable gases are expected to } \\
\text { approach the lower flammability limit, measures shall } \\
\text { be taken to prevent deflagration or detonation. }\end{array}$ \\
\hline
\end{tabular}

(c) Consideration of Decontamination and

Decommissioning. Areas in new and modifications to existing transuranic waste management facilities that are subject to contamination with radioactive or other hazardous materials shall be designed to facilitate decontamination. For such facilities a proposed decommissioning method or a conversion method leading to reuse shall be described.

(d) Instrumentation and Control Systems. Engineering controls shall be incorporated in the design and engineering of transuranic waste treatment and storage facilities to provide volume inventory data and to prevent spills, leaks, and overflows from tanks or confinement systems.

(e) Monitoring. Monitoring and/or leak detection capabilities shall be incorporated in the design and engineering of transuranic waste storage, treatment, and disposal facilities to provide rapid identification of failed confinement and/or other abnormal conditions.

N. Storage. The following requirements are in addition to those in Chapter I of this Manual.

(1) Storage Prohibitions. Transuranic waste in storage shall not be readily capable of detonation, explosive decomposition, reaction at anticipated pressures and temperatures, or explosive reaction with water. Prior to storage, pyrophoric materials shall be treated, prepared, and packaged to be nonflammable.

From DOE G 435.1-1 Chapter III:

Compliance with this requirement is demonstrated by having waste acceptance requirements which prohibit waste that is ignitable or explosive from being accepted for storage unless it has been treated.

(2) Storage Integrity. Transuranic waste shall be stored in a location and manner that protects the integrity of waste for the expected time of storage and minimizes worker exposure.

From DOE G 435.1-1 Chapter III:

Compliance with this requirement is demonstrated if sites have storage capabilities for transuranic waste that provide protection of waste containers so that
See M. above. Facility Compliance Information

See M. above.

See M. above.

Not a facility-specific requirement. DOE Manual 435.11 §I.2.F(13) applies to field element managers.

LWP-8300 $\$ 4.2$, addresses the storage prohibitions for TRU waste managed at INL. The documents cited below provide for proper documentation that this requirement is met upon containerization of this waste.

PLN-8300 provides MFC-wide certification of CH TRU waste.

FCF-OI-6620 § 2.2.4 addresses materials prohibited from acceptance as waste at this facility.

LWP-15011 $§ 5$ provides general radioactive storage area requirements.

LWP-8300 $\$ 4.2$ addresses the adequate storage requirements for TRU waste managed at INL. 
Table 7. (continued).

Facility Name: MFC-765, Fuels Conditioning Facility

\begin{tabular}{l} 
Chapter III, Transuranic Waste Requirements \\
\hline $\begin{array}{l}\text { their integrity will not be damaged through physical or } \\
\text { chemical (corrosion) processes and that keep } \\
\text { personnel from spending extended periods of time in } \\
\text { the areas where transuranic waste is stored. }\end{array}$ \\
(3) Container Inspection. A process shall be \\
developed and implemented for inspecting and \\
maintaining containers of transuranic waste to ensure \\
container integrity is not compromised. \\
From DOE G 435.1-1 Chapter III: \\
Compliance with this requirement is demonstrated by \\
a documented process for waste container inspection \\
and maintenance at every facility managing \\
transuranic waste, and documentation for all waste \\
container inspections and maintenance actions \\
performed.
\end{tabular}

(4) Retrievable Earthen-Covered Storage. Plans for the removal of transuranic waste from retrievable earthen-covered storage facilities shall be established and maintained. Prior to commencing waste retrieval activities, each waste storage site shall be evaluated to determine relevant information on types, quantities, and location of radioactive and hazardous chemicals as necessary to protect workers during the retrieval process.

O. Treatment. Transuranic waste shall be treated as necessary to meet the waste acceptance requirements of the facility receiving the waste for storage or disposal.

From DOE G 435.1-1 Chapter III:

Compliance with this requirement is demonstrated by the custodian of transuranic waste maintaining documentation which identifies the plans for treating waste, and maintaining the records that show waste was treated, if necessary, to meet the waste acceptance requirements of the storage or disposal facility to which it was transferred.

P. Disposal. Transuranic waste shall be disposed in accordance with the requirements of 40 CFR Part 191, Environmental Radiation Protection Standards for Management and Disposal of Spent Nuclear Fuel, High-Level and Transuranic Radioactive Wastes.

Q. Monitoring. The following requirements are in addition to those in Chapter I of this Manual.

(1) All Waste Facilities. Parameters that shall be sampled or monitored, at a minimum, include: temperature, pressure (for closed systems),
Facility Compliance Information

LI-435 requires quarterly inspections of radioactive waste containers if waste is stored outdoors or has been in storage for greater than 1 year.

NA; this facility is not an earthen-covered storage facility.

NA; this facility is not a TRU waste disposal facility.

NA; this facility is not a TRU waste treatment facility.

See below.

Monitoring requirements at INL radioactive waste management facilities are tailored for the specific facility to enable timely indication of developing 
Table 7. (continued).

Facility Name: MFC-765, Fuels Conditioning Facility

Chapter III, Transuranic Waste Requirements radioactivity in ventilation exhaust and liquid effluent streams, and flammable or explosive mixtures of gases. Facility monitoring programs shall include verification that passive and active control systems have not failed.

\section{From DOE G 435.1-1 Chapter III:}

If a minimum parameter specified in the requirement is deemed to be not applicable in any way to the active operation of that facility, then that justification should be included in the radioactive waste management basis and when approved, constitutes an exemption to the Manual.

Verification activities are part of the radioactive waste management basis and are to be documented appropriately.

Compliance with this requirement is demonstrated if monitoring or sampling for the stated parameters is performed for all facilities with an accuracy, precision, and frequency consistent with timely identification of developing problems and a justification exists in the approved radioactive waste management basis for those specified parameters which are not monitored or sampled.

(2) Stored Wastes. All transuranic wastes in storage shall be monitored, as prescribed by the appropriate facility safety analysis, to ensure the wastes are maintained in safe condition.

From DOE G 435.1-1 Chapter III:

Compliance with this requirement is demonstrated if the monitoring requirements in the facility procedures include, at a minimum, monitoring the systems and parameters as indicated by the safety analysis.

(3) Liquid Waste Storage Facilities. For facilities storing liquid transuranic waste, the following shall also be monitored: liquid level and/or waste volume, and significant waste chemistry parameters.

From DOE G 435.1-1 Chapter III:

Compliance with this requirement is demonstrated by developing operational procedures for monitoring liquid transuranic waste storage tank liquid level, waste volume, and tank chemistry so that waste volume or chemistry changes are detected in a time frame that will allow implementation of corrective measures to limit public and worker doses and to mitigate unplanned releases of stored liquid waste.
The facility's safety basis requirements and implementing documents are identified in F0000-0018AK and F0000-0026-ES. This facility is a Hazard Category 2 Nuclear Facility.

NA; this facility does not store liquid TRU waste. 
Table 8. MFC-765, Fuels Conditioning Facility, DOE Manual 435.1-1 Low-level waste requirements and facility compliance information.

\begin{tabular}{|c|c|}
\hline \multicolumn{2}{|c|}{ MFC-765, Fuels Conditioning Facility } \\
\hline Chapter IV, LLW Requirements & Facility Compliance Information \\
\hline $\begin{array}{l}\text { A. Definition of Low-Level Waste. Low-level } \\
\text { radioactive waste is radioactive waste that is not high- } \\
\text { level radioactive waste, spent nuclear fuel, transuranic } \\
\text { waste, byproduct material (as defined in section } 11 \mathrm{e} .(2) \\
\text { of the Atomic Energy Act of } 1954 \text {, as amended), or } \\
\text { naturally occurring radioactive material. }\end{array}$ & $\begin{array}{l}\text { This requirement proves the criteria for determining } \\
\text { which DOE radioactive waste is to be managed as } \\
\text { LLW in accordance with DOE Manual 435.1-1, } \\
\text { Chapter IV. } \\
\text { Radioactive waste managed at this facility under the } \\
\text { requirements of this chapter is not managed under the } \\
\text { requirements of DOE Manual } 435.1-1 \text {, Chapter II or } \\
\text { Chapter III. }\end{array}$ \\
\hline $\begin{array}{l}\text { B. Management of Specific Wastes. The following } \\
\text { provide for management of specific wastes as low-level } \\
\text { waste in accordance with the requirements in this } \\
\text { Chapter: }\end{array}$ & See (1), (2), (3), and (4) below. \\
\hline $\begin{array}{l}\text { (1) Mixed Low-Level Waste. Low-level waste } \\
\text { determined to contain source, special nuclear, or } \\
\text { byproduct material subject to the Atomic Energy Act of } \\
1954 \text {, as amended, and a hazardous component subject } \\
\text { to the Resource Conservation and Recovery Act } \\
\text { (RCRA), as amended, shall be managed in accordance } \\
\text { with the requirements of RCRA and DOE O } 435.1 \text {, } \\
\text { Radioactive Waste Management, and this Manual. }\end{array}$ & $\begin{array}{l}\text { This facility manages mixed LLW. The documents } \\
\text { cited below seem to demonstrate compliance with this } \\
\text { requirement. } \\
\text { CCN } 210728 \text {, August } 8,2007 \text {, Mr. Brian R. Monson to } \\
\text { Mr. David L. Wessman, "Manufacturing Process Unit } \\
\text { Exemption for the Fuel Conditioning Facility at the } \\
\text { Materials and Fuels Complex, Idaho National } \\
\text { Laboratory," provides the Idaho Department of } \\
\text { Environmental Quality concurrence with the MPU } \\
\text { exemption of FCF operations from RCRA regulation. } \\
\text { This facility manages mixed LLW in SAAs. } \\
\text { Management of SAAs is addressed in MCP-17410, and } \\
\text { overall management of mixed waste is addressed in } \\
\text { MCP-17000. } \\
\text { FCF-OI-6620 establishes and implements } \\
\text { administrative requirements and provides instructions } \\
\text { for management of the in-cell mixed TRU waste } \\
\text { managed at this facility. }\end{array}$ \\
\hline $\begin{array}{l}\text { (2) TSCA-Regulated Waste. Low-level waste } \\
\text { containing polychlorinated biphenyls, asbestos, or other } \\
\text { such regulated toxic components shall be managed in } \\
\text { accordance with requirements derived from the Toxic } \\
\text { Substances Control Act, as amended, DOE O } 435.1 \text {, } \\
\text { Radioactive Waste Management, and this Manual. }\end{array}$ & $\begin{array}{l}\text { NA; this facility does not manage TSCA-regulated } \\
\text { waste. }\end{array}$ \\
\hline $\begin{array}{l}\text { (3) Accelerator-Produced Waste. Radioactive waste } \\
\text { produced as a result of operations of DOE accelerators } \\
\text { is low-level waste and shall be managed in accordance } \\
\text { with DOE O } 435.1 \text {, Radioactive Waste Management, } \\
\text { and this Manual, and all applicable Federal or State } \\
\text { requirements. }\end{array}$ & $\begin{array}{l}\text { NA; this facility does not manage accelerator-produced } \\
\text { waste. }\end{array}$ \\
\hline $\begin{array}{l}\text { (4) } 11 \text { e.(2) and Naturally Occurring Radioactive } \\
\text { Material. Small quantities of } 11 \text { e.(2) byproduct } \\
\text { material and naturally occurring radioactive material }\end{array}$ & $\begin{array}{l}\text { NA; this facility does not manage naturally occurring } \\
\text { radioactive material. }\end{array}$ \\
\hline
\end{tabular}


Table 8. (continued).

MFC-765, Fuels Conditioning Facility

\begin{tabular}{|c|}
\hline Chapter IV, LLW Requirements \\
\hline $\begin{array}{l}\text { may be managed as low-level waste provided they can } \\
\text { be managed to meet the requirements for low-level } \\
\text { waste disposal in Section IV.P of this Manual. }\end{array}$ \\
\hline $\begin{array}{l}\text { C. Complex-Wide Low-Level Waste Management } \\
\text { Program. A complex-wide program and plan shall be } \\
\text { developed as described under Responsibilities, 2.B and } \\
\text { 2.D, in Chapter I of this Manual. }\end{array}$ \\
\hline $\begin{array}{l}\text { D. Radioactive Waste Management Basis. Low-level } \\
\text { waste facilities, operations, and activities shall have a } \\
\text { radioactive waste management basis consisting of } \\
\text { physical and administrative controls to ensure the } \\
\text { protection of workers, the public, and the environment. } \\
\text { The following specific waste management controls } \\
\text { shall be part of the radioactive waste management } \\
\text { basis: }\end{array}$ \\
\hline
\end{tabular}

(1) Generators. The waste certification program.

From DOE G 435.1-1 Chapter IV:

For a facility that generates low-level waste, the radioactive waste management basis is to include the program for certifying that waste meets the waste acceptance requirements of the facility(ies) to which the waste will be sent.

(2) Treatment Facilities. certification program. The waste acceptance requirements and the waste [sic]

From DOE G 435.1-1 Chapter IV:

Facilities that store or treat low-level waste are to have approved waste acceptance requirements (see DOE M 435.1-1, Section IV.G) prior to the issuance of a radioactive waste management basis.

A facility that stores or treats waste also is generally expected to have a waste certification program. Waste from these facilities will have to be certified as meeting the waste acceptance requirements of the facility to which it will be transferred, and the facilities have the potential for generating radioactive waste (e.g., secondary processing streams from treatment,

DOE Manual 435.1-1 §I.2.B and §I.2.D apply to the Assistant Secretary for Environmental Management and the Deputy Assistant Secretary for Waste Management, respectively.

The RWMB provides the regulatory framework for management of radioactive waste at INL. It specifically identifies facility management and implementing documents for the generation, storage, treatment, and disposal of radiological waste.

See J. below for waste certification program requirements.

F0000-0018-AK serves as the safety basis documentation for the facility and establishes it as a Hazard Category 2 nuclear facility.

F0000-0026-ES provides the limits, boundaries, conditions, and rules under which activities involving fissionable materials are carried out.

FCF-OI-6605 provides instructions for performing in-cell tracking and logging using the Mass Tracking System to document the contents and source term for each waste container.

FCF-OI-1302 specifies material accountability requirements for managing special nuclear material in FCF and provides the instructions necessary to meet the requirements using the Mass Tracking System database.

NA; waste is not treated at this facility. 
Table 8. (continued).

MFC-765, Fuels Conditioning Facility

\begin{tabular}{|l|}
\hline \multicolumn{1}{|c|}{ Chapter IV, LLW Requirements } \\
\hline monitoring and sampling, radioactive release cleanup). \\
Consequently, storage and treatment facilities should \\
also have an approved waste certification program as \\
part of their radioactive waste management basis. \\
As part of the radioactive waste management basis, site \\
personnel needs to implement a system or process for \\
tracking the waste inventory at a storage, treatment, or \\
disposal facility.
\end{tabular}

(3) Storage Facilities. The waste acceptance requirements and the waste certification program.

From DOE G 435.1-1 Chapter IV:

Facilities that store or treat low-level waste are to have approved waste acceptance requirements (see DOE M 435.1-1, Section IV.G) prior to the issuance of a radioactive waste management basis.

A facility that stores or treats waste also is generally expected to have a waste certification program. Waste from these facilities will have to be certified as meeting the waste acceptance requirements of the facility to which it will be transferred, and the facilities have the potential for generating radioactive waste (e.g., secondary processing streams from treatment, monitoring and sampling, radioactive release cleanup). Consequently, storage and treatment facilities should also have an approved waste certification program as part of their radioactive waste management basis.

As part of the radioactive waste management basis, site personnel needs to implement a system or process for tracking the waste inventory at a storage, treatment, or disposal facility.

(4) Disposal Facilities. The performance assessment, composite analysis, disposal authorization statement, closure plan, waste acceptance requirements, and monitoring plan.

E. Contingency Actions. The following requirements are in addition to those in Chapter I of this Manual [DOE M 435.1-1 §I.1.E(5)].

(1) Contingency Storage. For off-normal or emergency situations involving high activity or high hazard liquid low-level waste storage or treatment, spare capacity with adequate capabilities shall be maintained to receive the largest volume of liquid contained in any one storage tank or treatment facility. Tanks or other facilities that are designated low-level waste contingency storage shall be maintained in an operational condition when waste is present and shall meet the requirements of DOE O 435.1, Radioactive

NA; this facility does not store LLW.

NA; this facility is not a disposal facility.

DOE Manual 435.1-1 §I.1.E(5) addresses the sitewide emergency management system. The INL plan is provided in PLN-114.

NA; this facility does not store or treat liquid LLW. 
Table 8. (continued).

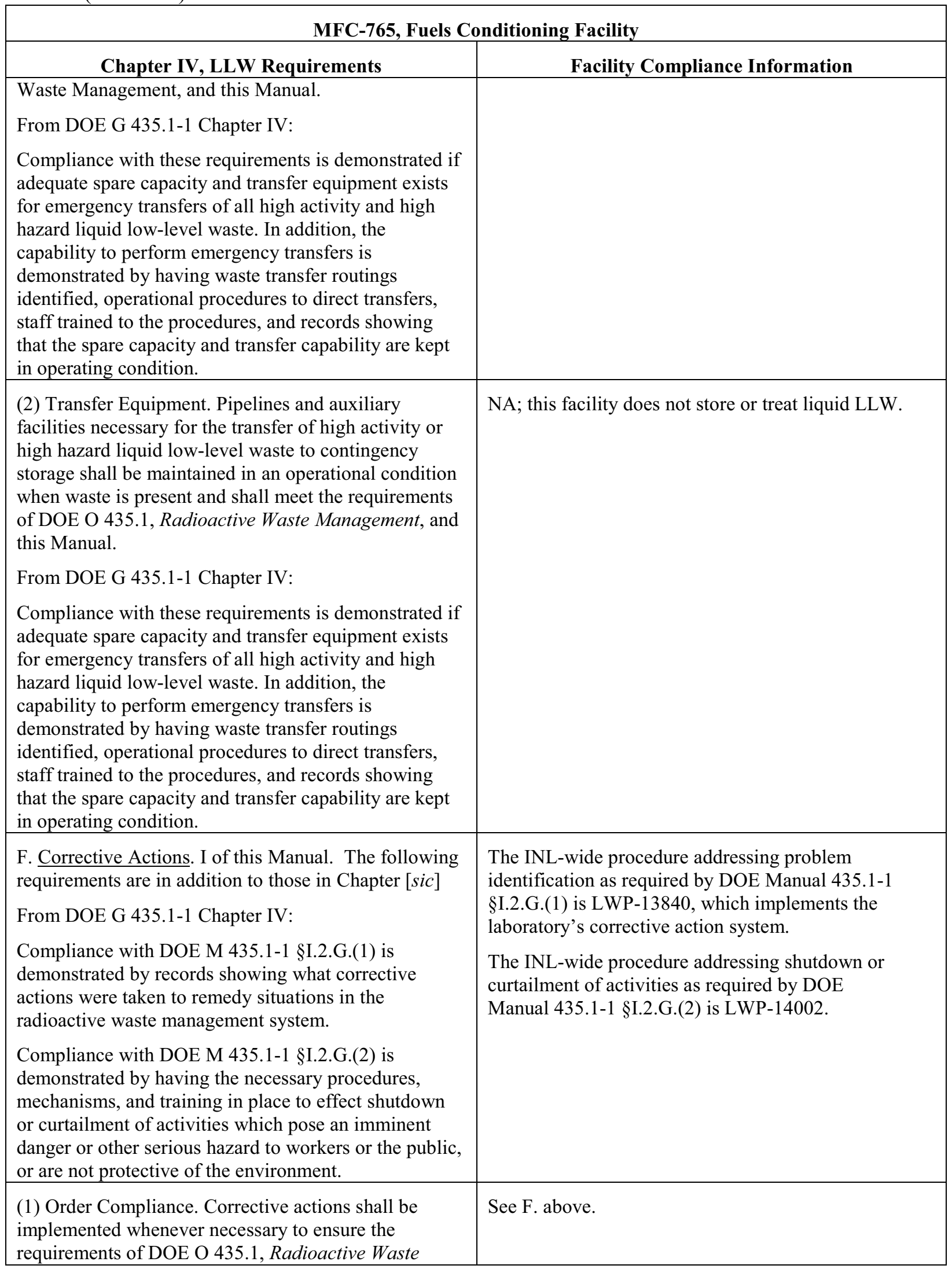


Table 8. (continued).

\begin{tabular}{|c|c|}
\hline \multicolumn{2}{|c|}{ MFC-765, Fuels Conditioning Facility } \\
\hline Chapter IV, LLW Requirements & Facility Compliance Information \\
\hline Management, and this Manual are met. & \\
\hline From DOE G 435.1-1 Chapter IV: & \\
\hline $\begin{array}{l}\text { If a facility or activity can be allowed to operate while } \\
\text { a noncompliant or hazardous condition exists, the } \\
\text { allowance and any associated limitations must be } \\
\text { defined as part of the facility or activity's radioactive } \\
\text { waste management basis, identified as a configuration } \\
\text { controlled item in a configuration management plan or } \\
\text { included in a revision or modification to an operating } \\
\text { procedure or similar controlled documentation. }\end{array}$ & \\
\hline $\begin{array}{l}\text { Compliance with this requirement is demonstrated if a } \\
\text { corrective action system addresses noncompliant or } \\
\text { hazardous situations involving low-level waste } \\
\text { management facilities in a systematic fashion, and } \\
\text { allows identification of problems by all personnel. }\end{array}$ & \\
\hline $\begin{array}{l}\text { (2) Operations Curtailment. Operations shall be } \\
\text { curtailed or facilities shut down for failure to establish, } \\
\text { maintain, or operate consistent with an approved } \\
\text { radioactive waste management basis. } \\
\text { From DOE G 435.1-1 Chapter IV: }\end{array}$ & $\begin{array}{l}\text { The approved RWMB establishes the current } \\
\text { compliance status at each radioactive waste } \\
\text { management facility. Facility assessments are } \\
\text { scheduled to ensure waste management activities are } \\
\text { conducted in accordance with the approved RWMB. }\end{array}$ \\
\hline $\begin{array}{l}\text { Compliance with this requirement is demonstrated with } \\
\text { a documented system of routine assessments to } \\
\text { determine whether waste management activities and } \\
\text { facilities are operating in accordance with an approved } \\
\text { radioactive waste management basis that provides for } \\
\text { graded limitations that can be placed on activities and } \\
\text { operations that do not have, or are operating outside of, } \\
\text { an approved radioactive waste management basis, } \\
\text { including shutdown of the facility. }\end{array}$ & \\
\hline $\begin{array}{l}\text { G. Waste Acceptance. The following requirements are } \\
\text { in addition to those in Chapter I of this Manual [DOE } \\
\mathrm{M} 435.1-1 \S \mathrm{I} \cdot 2 . \mathrm{F}(6)] \text {. }\end{array}$ & $\begin{array}{l}\text { DOE Manual 435.1-1 } \S \mathrm{I} \cdot 2 . \mathrm{F}(6) \text { applies to field element } \\
\text { managers. }\end{array}$ \\
\hline $\begin{array}{l}\text { (1) Technical and Administrative. Waste acceptance } \\
\text { requirements for all low-level waste storage, treatment, } \\
\text { or disposal facilities, operations, and activities shall } \\
\text { specify, at a minimum, the following: }\end{array}$ & $\begin{array}{l}\text { NA; this facility does not accept LLW from other } \\
\text { facilities. }\end{array}$ \\
\hline From DOE G 435.1-1 Chapter IV: & \\
\hline $\begin{array}{l}\text { Compliance with these waste acceptance requirements } \\
\text { is demonstrated if they are documented, contain clear } \\
\text { and precise criteria specifying the radionuclide limits in } \\
\text { the form of contents or concentrations that can be } \\
\text { accepted, the limitations and prohibitions on waste } \\
\text { forms and packages that can be received, and the limits, } \\
\text { prohibitions, or instructions concerning any other } \\
\text { technical information so that the waste is compatible } \\
\text { with the safety basis of the facility, and which will }\end{array}$ & \\
\hline
\end{tabular}


Table 8. (continued).

\begin{tabular}{|c|c|}
\hline \multicolumn{2}{|c|}{ MFC-765, Fuels Conditioning Facility } \\
\hline Chapter IV, LLW Requirements & Facility Compliance Information \\
\hline $\begin{array}{l}\text { result in acceptable waste at subsequent steps in } \\
\text { managing the low-level waste.) }\end{array}$ & \\
\hline $\begin{array}{l}\text { (a) Allowable activities and/or concentrations of } \\
\text { specific radionuclides. }\end{array}$ & See (1) above. \\
\hline $\begin{array}{l}\text { (b) Acceptable waste form and/or container } \\
\text { requirements that ensure the chemical and physical } \\
\text { stability of waste under conditions that might be } \\
\text { encountered during transportation, storage, treatment, } \\
\text { or disposal. }\end{array}$ & See (1) above. \\
\hline $\begin{array}{l}\text { (c) Restrictions or prohibitions on waste, materials, or } \\
\text { containers that may adversely affect waste handlers or } \\
\text { compromise facility or waste container performance. }\end{array}$ & See (1) above. \\
\hline $\begin{array}{l}\text { (d) The following are additional waste acceptance } \\
\text { requirements that shall be specified in low-level waste } \\
\text { disposal facility waste acceptance requirements: }\end{array}$ & See (1) above. \\
\hline $\begin{array}{l}1 \text { Low-level waste must contribute to and not detract } \\
\text { from achieving long-term stability of the facility, } \\
\text { minimizing the need for long-term active maintenance, } \\
\text { minimizing subsidence, and minimizing contact of } \\
\text { water with waste. Void spaces within the waste and, if } \\
\text { containers are used, between the waste and its container } \\
\text { shall be reduced to the extent practical. }\end{array}$ & See (1) above. \\
\hline $\begin{array}{l}2 \text { Liquid low-level waste or low-level waste containing } \\
\text { free liquid must be converted into a form that contains } \\
\text { as little freestanding liquid as is reasonably achievable, } \\
\text { but in no case shall the liquid exceed } 1 \text { percent of the } \\
\text { waste volume when the low-level waste is in a disposal } \\
\text { container, or } 0.5 \text { percent of the waste volume after it is } \\
\text { processed to a stable form. }\end{array}$ & See (1) above. \\
\hline $\begin{array}{l}3 \text { Low-level waste must not be readily capable of } \\
\text { detonation or of explosive decomposition or reaction at } \\
\text { anticipated pressures and temperatures, or of explosive } \\
\text { reaction with water. Pyrophoric materials contained in } \\
\text { waste shall be treated, prepared, and packaged to be } \\
\text { nonflammable. }\end{array}$ & See (1) above. \\
\hline $\begin{array}{l}4 \text { Low-level waste must not contain, or be capable of } \\
\text { generating by radiolysis or biodegradation, quantities } \\
\text { of toxic gases, vapors, or fumes harmful to the public } \\
\text { or workers or disposal facility personnel, or harmful to } \\
\text { the long-term structural stability of the disposal site. }\end{array}$ & See (1) above. \\
\hline $\begin{array}{l}5 \text { Low-level waste in a gaseous form must be packaged } \\
\text { such that the pressure does not exceed } 1.5 \text { atmospheres } \\
\text { absolute at } 20 \mathrm{C} \text {. [ sic] }\end{array}$ & See (1) above. \\
\hline $\begin{array}{l}\text { (e) The basis, procedures, and levels of authority } \\
\text { required for granting exceptions to the waste } \\
\text { acceptance requirements, which shall be contained in }\end{array}$ & See (1) above. \\
\hline
\end{tabular}


Table 8. (continued).

MFC-765, Fuels Conditioning Facility

\begin{tabular}{l}
\hline \multicolumn{1}{c}{ Chapter IV, LLW Requirements } \\
\hline each facility's waste acceptance documentation. Each \\
exception request shall be documented, including its \\
disposition as approved or not approved. \\
From DOE G 435.1-1 Chapter IV: \\
Waste acceptance requirements are acceptable if they \\
are documented and contain a clear description of the \\
procedure and bases for obtaining an exception or \\
deviation to the acceptance criteria for low-level waste \\
to be received at the facility.
\end{tabular}

(2) Evaluation and Acceptance. The receiving facility shall evaluate waste for acceptance, including confirmation that the technical and administrative requirements have been met. A process for the disposition of non-conforming wastes shall be established.

From DOE G 435.1-1 Chapter IV:

Compliance with the waste acceptance requirements for a low-level waste management facility is demonstrated if they include a process for evaluation and acceptance of incoming waste to ensure the acceptance criteria of the facility receiving the waste are met that includes one of or a combination of: (1) testing, sampling, and analysis of representative samples of waste upon receipt; (2) testing, sampling, and analysis of split samples of waste taken at the generator site; (3) evaluation of testing, sampling, and analysis of data provided by the generator, or (4) audits, reviews, surveillance, or observations of generator waste certification programs and characterization activities. Additionally, acceptable waste acceptance requirements for a storage, treatment or disposal facility will have documented procedures and actions to be taken if a waste that does not conform to the waste acceptance criteria is received at the facility.

H. Waste Generation Planning. The following requirements are in addition to those in Chapter I of this Manual [DOE M 435.1-1 §I.2.F(7)].

(1) Life-Cycle Planning. Prior to waste generation, planning shall be performed to address the entire life cycle for all low-level waste streams.

From DOE G 435.1-1 Chapter IV:

Compliance with this planning requirement is demonstrated by the individual sites establishing a process for evaluating the life-cycle of low-level waste prior to its generation, including the identification of low-level wastes with no path to disposal and
See (1) above. Facility Compliance Information
DOE Manual 435.1-1 §I.2.F(7) applies to field element managers.

PDD-17000 and LWP-17000 provide direction to the waste generators for waste generation planning to address the entire life cycle. 
Table 8. (continued).

MFC-765, Fuels Conditioning Facility

\begin{tabular}{l}
\hline \multicolumn{1}{|c|}{ Chapter IV, LLW Requirements } \\
\hline appropriate records justifying the newly generated low- \\
level waste stream(s), and site personnel possessing \\
planning information showing the location(s) where \\
low-level waste will be stored, treated, and/or disposed \\
along with a confirmation that the personnel managing \\
the facilities agree that the low-level waste may be \\
managed at those facilities.
\end{tabular}

(2) Waste with No Identified Path to Disposal. Lowlevel waste streams with no identified path to disposal shall be generated only in accordance with approved conditions which, at a minimum, shall address:

(a) Programmatic need to generate the waste;

(b) Characteristics and issues preventing the disposal of the waste;

(c) Safe storage of the waste until disposal can be achieved; and

(d) Activities and plans for achieving final disposal of the waste.

I. Waste Characterization. Low-level waste shall be characterized using direct or indirect methods, and the characterization documented in sufficient detail to ensure safe management and compliance with the waste acceptance requirements of the facility receiving the waste.

From DOE G 435.1-1 Chapter IV:

Compliance with this requirement is demonstrated by a program for documenting and the existence of records that document the process for acquiring and verifying the validity of low-level waste characterization data acquired through the use of direct or indirect methods.
(1) Data Quality Objectives. The data quality objectives process, or a comparable process, shall be used for identifying characterization parameters and acceptable uncertainty in characterization data.

From DOE G 435.1-1 Chapter IV:

Compliance with this requirement is demonstrated by
This facility is not generating radioactive waste that does not have an identified path to disposal.

See (2) above.

See (2) above.

See (2) above.

See (2) above.

MCP-17000 $§ 4$ specifies the requirements for preparing an IWTS profile that captures waste characterization information.

FCF-OI-6620 addresses characterization of in-cell, non-process, or indirect waste.

FCF-OI-6614 establishes and implements administrative requirements and provides instructions for characterization, documentation, packaging, labeling, and shipping of solid contact-handled LLW generated in this facility.

FCF-OI-6605 provides instructions for performing in-cell tracking and logging using the Mass Tracking System to document the contents and source term for each waste container.

Appendices A, B, and C of RL-OI-1 provide documented characterization of the liquid LLW generated at the decontamination spray chamber.

Characterization of the liquid LLW stream from the Decontamination Spray Chamber is done in accordance with FCF-OI-6523 § 5.3.1.

Radioactive waste management facilities characterize waste in accordance with the requirements of the receiving storage, treatment, or disposal facility. The documented use of a data quality objectives process, or comparable process, was not identified for this facility. 
Table 8. (continued).

MFC-765, Fuels Conditioning Facility

\begin{tabular}{l} 
Chapter IV, LLW Requirements \\
\hline \multicolumn{1}{|c|}{ the documented use of a data quality objectives or a } \\
comparable process for determining the type, quantity, \\
and quality of characterization data needed to safely \\
manage low-level waste.
\end{tabular}

(2) Minimum Waste Characterization. Characterization data shall, at a minimum, include the following information relevant to the management of the waste:

From DOE G 435.1-1 Chapter IV:

Compliance with this requirement is demonstrated by the existence of a program or procedure for determining and records that document characterization of low-level waste consistent with the minimum characterization data requirements.)
MCP-17000 $§ 4$ specifies the requirements for preparing an IWTS profile that captures waste characterization information.

FCF-OI-6620 addresses characterization of in-cell, non-process, or indirect waste.

FCF-OI-6614 establishes and implements administrative requirements and provides instructions for characterization, documentation, packaging, labeling, and shipping of solid contact-handled LLW generated in this facility.

FCF-OI-6605 provides instructions for performing in-cell tracking and logging using the Mass Tracking System to document the contents and source term for each waste container.

Appendices A, B, and C of RL-OI-1 provide documented characterization of the liquid LLW generated at the decontamination spray chamber.

Characterization of the liquid LLW stream from the Decontamination Spray Chamber is done in accordance with FCF-OI-6523 $§ 5.3 .1$.

See (2) above.

See (2) above.

(b) Volume, including the waste and any stabilization or absorbent media;

(c) Weight of the container and contents;

(d) Identities, activities, and concentrations of major radionuclides;

\section{(e) Characterization date;}

(f) Generating source; and

(g) Any other information which may be needed to prepare and maintain the disposal facility performance assessment, or demonstrate compliance with applicable performance objectives.

J. Waste Certification. A waste certification program shall be developed, documented, and implemented to ensure that the waste acceptance requirements of facilities receiving low-level waste for storage, treatment, and disposal are met.

From DOE G 435.1-1 Chapter IV:

Compliance with the development and documentation
MCP-17000 $§ 4$ specifies the requirements for preparing an IWTS profile that captures waste certification information.

MCP-17500 provides the WGS waste certification program for LLW to be shipped to NNSS.

Container procurement is addressed in MCP-17000 $\S 4.6$. 
Table 8. (continued).

MFC-765, Fuels Conditioning Facility

\begin{tabular}{|c|c|}
\hline Chapter IV, LLW Requirements & Facility Compliance Information \\
\hline $\begin{array}{l}\text { portion of the certification requirement is demonstrated } \\
\text { by a waste certification plan that identifies the } \\
\text { organizations involved, assigns responsibilities for } \\
\text { implementing the program, and describes or references } \\
\text { the quality assurance, training, procurement controls, } \\
\text { records management, and procedures to be used by the } \\
\text { program. Acceptable performance for implementing } \\
\text { the program is demonstrated when appropriate } \\
\text { personnel are trained and follow the procedures that } \\
\text { govern their part of the waste certification. } \\
\text { Additionally, acceptable performance is demonstrated } \\
\text { if the waste certification plan and procedures are } \\
\text { current and controlled in accordance with a document } \\
\text { controls program, and records related to certification } \\
\text { (e.g., certification statements, training records, } \\
\text { procurement records, characterization records, } \\
\text { container records) are generated and managed in } \\
\text { accordance with the established site program. }\end{array}$ & $\begin{array}{l}\text { RSWF-OI-003 specifies requirements and provides } \\
\text { instructions for accepting mixed waste, radioactive } \\
\text { waste, and radioactive material for storage at RSWF. } \\
\text { Appendix A serves as the record document to be } \\
\text { maintained for each container going to that facility. } \\
\text { Waste certification is performed and tracked using } \\
\text { IWTS. Documentation of the IWTS Program is } \\
\text { available electronically only. } \\
\text { PLN-522 requires waste technical specialists and waste } \\
\text { disposition specialists to complete the appropriate } \\
\text { training/qualification before being granted approval } \\
\text { authority for profiles within the IWTS Program. The } \\
\text { waste certification official, alternate waste certification } \\
\text { official, and NNSS packaging certifiers must complete } \\
\text { the appropriate training/qualifications to disposition } \\
\text { waste to NNSS. } \\
\text { The facility completes a Liquid Waste Generator } \\
\text { Certification Form which is featured as Appendices A } \\
\text { and C of RL-OI-1 to support certification of the liquid } \\
\text { LLW generated prior to transfer to RLWTF. }\end{array}$ \\
\hline $\begin{array}{l}\text { (1) Certification Program. The waste certification } \\
\text { program shall designate the officials who have the } \\
\text { authority to certify and release waste for shipment; and } \\
\text { specify what documentation is required for waste } \\
\text { generation, characterization, shipment, and } \\
\text { certification. The program shall provide requirements } \\
\text { for auditability, retrievability, and storage of required } \\
\text { documentation and specify the records retention period. } \\
\text { From DOE G 435.1-1 Chapter IV: } \\
\text { Compliance with this requirement is demonstrated by a } \\
\text { program or procedure for record keeping and records } \\
\text { showing that low-level waste is certified as having met } \\
\text { the waste acceptance criteria of the facility to which it } \\
\text { was transferred and that the certification statement is } \\
\text { supported by additional records regarding the waste } \\
\text { source, characterization, and container. }\end{array}$ & See J. above. \\
\hline $\begin{array}{l}\text { (2) Certification before Transfer. Low-level waste shall } \\
\text { be certified as meeting waste acceptance requirements } \\
\text { before it is transferred to the facility receiving the } \\
\text { waste. } \\
\text { From DOE G 435.1-1 Chapter IV: } \\
\text { Compliance with this requirement is demonstrated by } \\
\text { the presence of a certification program which includes } \\
\text { procedures requiring a signed certification statement } \\
\text { prior to the release of waste for transfer, and by dated } \\
\text { records showing that waste was certified before being }\end{array}$ & See J. above. \\
\hline
\end{tabular}


Table 8. (continued).

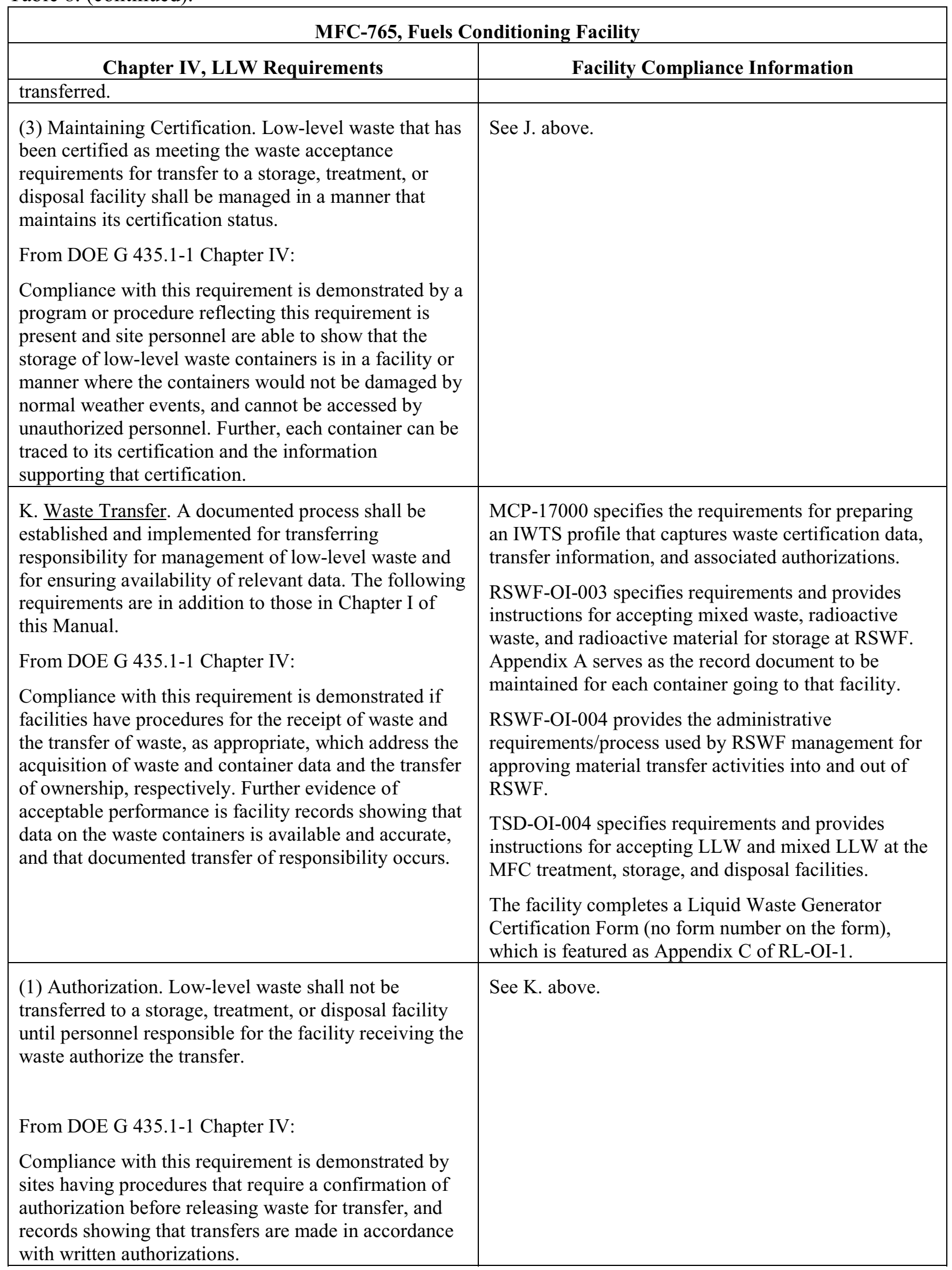


Table 8. (continued).

\begin{tabular}{|c|c|}
\hline \multicolumn{2}{|c|}{ MFC-765, Fuels Conditioning Facility } \\
\hline Chapter IV, LLW Requirements & Facility Compliance Information \\
\hline $\begin{array}{l}\text { (2) Data. Waste characterization data, container } \\
\text { information, and generation, storage, treatment, and } \\
\text { transportation information for low-level waste shall be } \\
\text { transferred with or be traceable to the waste. }\end{array}$ & See K. above. \\
\hline $\begin{array}{l}\text { Compliance with this requirement is demonstrated if } \\
\text { there are procedures requiring that characterization and } \\
\text { container data be provided and maintained for each } \\
\text { low-level waste transfer and documented records of } \\
\text { transfers show that the information is being provided. }\end{array}$ & \\
\hline $\begin{array}{l}\text { L. Packaging and Transportation. The following } \\
\text { requirements are in addition to those in Chapter I of } \\
\text { this Manual [DOE M 435.1-1 §I.1.E(11)]. }\end{array}$ & $\begin{array}{l}\text { DOE Manual 435.1-1 §I.1.E(11) applies to field } \\
\text { element managers. }\end{array}$ \\
\hline $\begin{array}{l}\text { (1) Packaging. If containers are used: } \\
\text { From DOE G 435.1-1 Chapter IV: } \\
\text { Compliance with the packaging requirement is } \\
\text { demonstrated by: (1) procedures which document } \\
\text { proper packaging protocols; and (2) no trends of } \\
\text { routine repackaging of low-level waste that is packaged } \\
\text { after issuance of DOE O } 435.1 \text {. Successful } \\
\text { performance of this requirement is also demonstrated } \\
\text { by a record of containers for which failure has not } \\
\text { routinely occurred under management conditions. It is } \\
\text { recognized that there may be failed containers for } \\
\text { waste previously placed in storage. For those } \\
\text { containers, the goal is to only have to repackage the } \\
\text { waste one time after it is retrieved and characterized. } \\
\text { Further, acceptable performance is demonstrated by } \\
\text { containers of waste having marking and labeling that } \\
\text { allows correlation with waste characterization data and } \\
\text { container information.) }\end{array}$ & MCP-17000 $§ 4$ addresses packaging requirements. \\
\hline $\begin{array}{l}\text { (a) Low-level waste shall be packaged in a manner that } \\
\text { provides containment and protection for the duration of } \\
\text { the anticipated storage period and until disposal is } \\
\text { achieved or until the waste has been removed from the } \\
\text { container. }\end{array}$ & See (1) above. \\
\hline $\begin{array}{l}\text { (b) When waste is packaged, vents or other measures } \\
\text { shall be provided if the potential exists for pressurizing } \\
\text { or generating flammable or explosive concentrations of } \\
\text { gases within the waste container. }\end{array}$ & See (1) above. \\
\hline $\begin{array}{l}\text { (c) Containers of low-level waste shall be marked such } \\
\text { that their contents can be identified. }\end{array}$ & See (1) above. \\
\hline $\begin{array}{l}\text { (2) Transportation. To the extent practical, the volume } \\
\text { of waste and number of low-level waste shipments } \\
\text { shall be minimized. }\end{array}$ & $\begin{array}{l}\text { NA; waste is not shipped to an offsite facility for final } \\
\text { disposition from this facility. }\end{array}$ \\
\hline
\end{tabular}


Table 8. (continued).

\begin{tabular}{|c|c|}
\hline \multicolumn{2}{|c|}{ MFC-765, Fuels Conditioning Facility } \\
\hline Chapter IV, LLW Requirements & Facility Compliance Information \\
\hline From DOE G 435.1-1 Chapter IV: & \\
\hline $\begin{array}{l}\text { Compliance with this requirement can be demonstrated } \\
\text { by a combination of site procedures directing the } \\
\text { efficient use of waste container capacity and } \\
\text { documentation showing that low-level waste shipments } \\
\text { are systematically planned and optimized to the extent } \\
\text { practical. }\end{array}$ & \\
\hline $\begin{array}{l}\text { M. Site Evaluation and Facility Design. The following } \\
\text { requirements are in addition to those in Chapter I of } \\
\text { this Manual. }\end{array}$ & $\begin{array}{l}\text { NA; this requirement addresses new radioactive waste } \\
\text { management facilities. }\end{array}$ \\
\hline $\begin{array}{l}\text { (1) Site Evaluation. Proposed locations for low-level } \\
\text { waste facilities shall be evaluated to identify relevant } \\
\text { features that should be avoided or must be considered } \\
\text { in facility design and analyses. }\end{array}$ & See M. above. \\
\hline $\begin{array}{l}\text { (a) Each site proposed for a new low-level waste } \\
\text { facility or expansion of an existing low-level waste } \\
\text { facility shall be evaluated considering environmental } \\
\text { characteristics, geotechnical characteristics, and human } \\
\text { activities, including for a low-level waste disposal } \\
\text { facility, the capability of the site to demonstrate, at a } \\
\text { minimum, whether it is: }\end{array}$ & See M. above. \\
\hline $\begin{array}{l}1 \text { Located to accommodate the projected volume of } \\
\text { waste to be received; }\end{array}$ & See M. above. \\
\hline $\begin{array}{l}2 \text { Located in a flood plain, a tectonically active area, or } \\
\text { in the zone of water table fluctuation; and }\end{array}$ & See M. above. \\
\hline $\begin{array}{l}3 \text { Located where radionuclide migration pathways are } \\
\text { predictable and erosion and surface runoff can be } \\
\text { controlled. }\end{array}$ & See M. above. \\
\hline $\begin{array}{l}\text { (b) Proposed sites with environmental characteristics, } \\
\text { geotechnical characteristics, and human activities for } \\
\text { which adequate protection cannot be provided through } \\
\text { facility design shall be deemed unsuitable for the } \\
\text { location of the facility. }\end{array}$ & See M. above. \\
\hline $\begin{array}{l}\text { (c) Low-level waste disposal facilities shall be sited to } \\
\text { achieve long-term stability and to minimize, to the } \\
\text { extent practical, the need for active maintenance } \\
\text { following final closure. }\end{array}$ & See M. above. \\
\hline $\begin{array}{l}\text { (2) Low-Level Waste Treatment and Storage Facility } \\
\text { Design. The following facility requirements and } \\
\text { general design criteria, at a minimum, apply: }\end{array}$ & See M. above. \\
\hline $\begin{array}{l}\text { (a) Confinement. Low-level waste systems and } \\
\text { components shall be designed to maintain waste } \\
\text { confinement. }\end{array}$ & See M. above. \\
\hline (b) Ventilation. & See M. above. \\
\hline
\end{tabular}


Table 8. (continued).

MFC-765, Fuels Conditioning Facility

\begin{tabular}{|c|c|}
\hline Chapter IV, LLW Requirements & Facility Compliance Information \\
\hline $\begin{array}{l}1 \text { Design of low-level waste treatment and storage } \\
\text { facilities shall include ventilation, if applicable, } \\
\text { through an appropriate filtration system to maintain the } \\
\text { release of radioactive material in airborne effluents } \\
\text { within the requirements and guidelines specified in } \\
\text { applicable requirements. }\end{array}$ & See M. above. \\
\hline $\begin{array}{l}2 \text { When conditions exist for generating gases in } \\
\text { flammable or explosive concentrations, ventilation } \\
\text { systems or other measures shall be provided to keep the } \\
\text { gases in a non-flammable and nonexplosive condition. } \\
\text { Where concentrations of explosive or flammable gases } \\
\text { are expected to approach the lower flammability limit, } \\
\text { measures shall be taken to prevent deflagration or } \\
\text { detonation. }\end{array}$ & See M. above. \\
\hline $\begin{array}{l}\text { (c) Consideration of Decontamination and } \\
\text { Decommissioning. Areas in new and modifications to } \\
\text { existing low-level waste management facilities that are } \\
\text { subject to contamination with radioactive or other } \\
\text { hazardous materials shall be designed to facilitate } \\
\text { decontamination. For such facilities a proposed } \\
\text { decommissioning method or a conversion method } \\
\text { leading to reuse shall be described. }\end{array}$ & See M. above. \\
\hline $\begin{array}{l}\text { (d) Instrumentation and Control Systems. Engineering } \\
\text { controls shall be incorporated in the design and } \\
\text { engineering of low-level waste treatment and storage } \\
\text { facilities to provide volume inventory data and to } \\
\text { prevent spills, leaks, and overflows from tanks or } \\
\text { confinement systems. }\end{array}$ & See M. above. \\
\hline $\begin{array}{l}\text { (e) Monitoring. Monitoring and/or leak detection } \\
\text { capabilities shall be incorporated in the design and } \\
\text { engineering of low-level waste treatment and storage } \\
\text { facilities to provide rapid identification of failed } \\
\text { confinement and/or other abnormal conditions. }\end{array}$ & See M. above. \\
\hline $\begin{array}{l}\text { (3) Low-Level Waste Disposal Facility Design. The } \\
\text { following facility requirements and general design } \\
\text { criteria, at a minimum, apply: }\end{array}$ & See M. above. \\
\hline $\begin{array}{l}\text { (a) Confinement. Low-level waste systems and } \\
\text { components shall be designed to maintain waste } \\
\text { confinement. }\end{array}$ & See M. above. \\
\hline \multicolumn{2}{|l|}{ (b) Ventilation. } \\
\hline $\begin{array}{l}1 \text { Design of low-level waste disposal facilities shall } \\
\text { include ventilation, if applicable, through an } \\
\text { appropriate filtration system to maintain the release of } \\
\text { radioactive material in airborne effluents within the } \\
\text { requirements and guidelines specified in applicable } \\
\text { requirements. }\end{array}$ & See M. above. \\
\hline
\end{tabular}


Table 8. (continued).

MFC-765, Fuels Conditioning Facility

\begin{tabular}{|l|}
\hline \multicolumn{1}{|c|}{ Chapter IV, LLW Requirements } \\
\hline 2 When conditions exist for generating gases in \\
flammable or explosive concentrations, ventilation \\
systems or other measures shall be provided to keep the \\
gases in a nonflammable and non-explosive condition. \\
Where concentrations of explosive or flammable gases \\
are expected to approach the lower flammability limit, \\
measures shall be taken to prevent deflagration or \\
detonation.
\end{tabular}

(c) Stability. Low-level waste disposal facilities shall be designed to achieve long-term stability and to minimize to the extent practical, the need for active maintenance following final closure.

(d) Control of Water. Low-level waste disposal facilities shall be designed to minimize to the extent practical, the contact of waste with water during and after disposal.

N. Storage and Staging. The following requirements are in addition to those in Chapter I of this Manual [DOE M 435.1-1 §I.2.F(13)].

(1) Storage Prohibitions. Low-level waste in storage shall not be readily capable of detonation, explosive decomposition, reaction at anticipated pressures and temperatures, or explosive reaction with water. Prior to storage, pyrophoric materials shall be treated, prepared, and packaged to be nonflammable.

From DOE G 435.1-1 Chapter IV:

Compliance with this requirement is demonstrated by having waste acceptance requirements which prohibit low-level waste that is ignitable or explosive from being accepted for storage unless it has been treated, and procedures for properly preparing such materials for safe storage.

(2) Storage Limit. Low-level waste that has an identified path to disposal shall not be stored longer than one year prior to disposal, except for storage for decay, or as otherwise authorized by the Field Element Manager.

From DOE G 435.1-1 Chapter IV:

Storage longer than one year can be justified if the conditions for such storage are approved by the Field Element Manager as part of the radioactive waste management basis for the facility.

Storage for radioactive decay for a period greater than 1 year for waste that has an identified path to disposal is allowed. Adequate justification and the supporting information for storage for decay is to be documented
See M. above.

See M. above.
See M. above.

Facility Compliance Information

See M. above. 
Table 8. (continued).

MFC-765, Fuels Conditioning Facility

in the radioactive waste management basis for the facility in which the storage will take place.

Mixed waste. Under the Federal Facility Compliance

Act of 1992, DOE sites were required to develop Site

Treatment Plans to bring stored mixed low-level waste

into compliance with these requirements. The Site

Treatment Plan needs to be consulted and any mixed

low-level waste stored for the purpose of accumulation

to facilitate treatment must meet Resource

Conservation and Recovery Act storage requirements.

There could be several ways within different scenarios

that this requirement can be met, as illustrated by the

examples below, however, there are basically four

ways to show compliance with the requirement and

include appropriate provisions in the radioactive waste

management basis for the facility in which it is stored.

Legacy waste. As discussed above, the intention of the requirement is not to force malicious compliance or heroic actions which would result in increased risk or safety concerns. Rather, the intention is that waste in storage longer than one year receives additional attention to ensure that the public, the workers, and the environment are protected from the hazards of the waste, and that progress is being made to dispose of the waste. There could be several ways within different scenarios that this requirement can be met, as illustrated by the examples below, however, there are basically four ways to show compliance with the requirement:

1) the radioactive waste management basis allows for storage for no more than one year.

2) the radioactive waste management basis allows for storage for no more than one year, or for storage for decay only for periods greater than a year, which are specified on a radionuclide basis.

3 ) the radioactive waste management basis allows for storage for more than one year, up to a specified period of time based on a documented technical evaluation that the waste can be stored in a manner that does not cause changes to the waste or waste packages that is detrimental to the safe storage of the waste, the final disposal of the waste or to meeting the disposal performance objectives.

4) the radioactive waste management basis allows for storage for decay (with specifics) and for storage for more than one year for other low-level waste, up to a specified period of time based on a documented technical evaluation that the waste can be stored in a 
Table 8. (continued).

MFC-765, Fuels Conditioning Facility

\begin{tabular}{l} 
Chapter IV, LLW Requirements \\
\hline manner that does not cause changes to the waste or \\
waste packages that is detrimental to the safe storage of \\
the waste, the final disposal of the waste or to meeting \\
the disposal performance objectives. \\
Compliance with this requirement is demonstrated by \\
the existence of a radioactive waste management basis \\
for the storage facility approved by the Field Element \\
Manager that includes the time frames that waste are \\
allowed to be stored, the necessary justifications for \\
storage for decay, and the necessary technical \\
evaluations if storage is to extend significantly beyond \\
the one-year time frame.
\end{tabular}

(3) Storage Integrity. Low-level waste shall be stored in a location and manner that protects the integrity of waste for the expected time of storage and minimizes worker exposure.

However, in making a decision to use a facility for storage and in developing a radioactive waste management basis for the activity, particular attention to protection of workers is needed.

From DOE G 435.1-1 Chapter IV:

Compliance with this requirement is demonstrated if sites have storage capabilities for low-level waste that provide protection to waste containers so that their integrity will not be damaged through physical or chemical (corrosion) processes and that keep personnel from spending extended periods of time in the areas where low-level waste is stored.

(4) Waste Characterization for Storage.

(a) Low-level waste that does not have an identified path to disposal shall be characterized as necessary to meet the data quality objectives and minimum characterization requirements of this Chapter, to ensure safe storage, and to facilitate disposal.

(b) Characterization information for all low-level waste in storage shall be maintained as a record in accordance with the requirements for Records Management in Chapter I of this Manual.

From DOE G 435.1-1 Chapter IV:

Compliance with this requirement is demonstrated by documented procedures for managing waste characterization and container information on low-level waste as a Federal record. The records are managed per the applicable policies and procedures for records management referenced in DOE O 200.1 and
NA; this facility does not store LLW. See N. (7) below for staging requirements.
NA; this facility does not store LLW. See N. (7) below for staging requirements.

NA; this facility does not store LLW. See N. (7) below for staging requirements.

NA; this facility does not store LLW. See N. (7) below for staging requirements. 
Table 8. (continued).

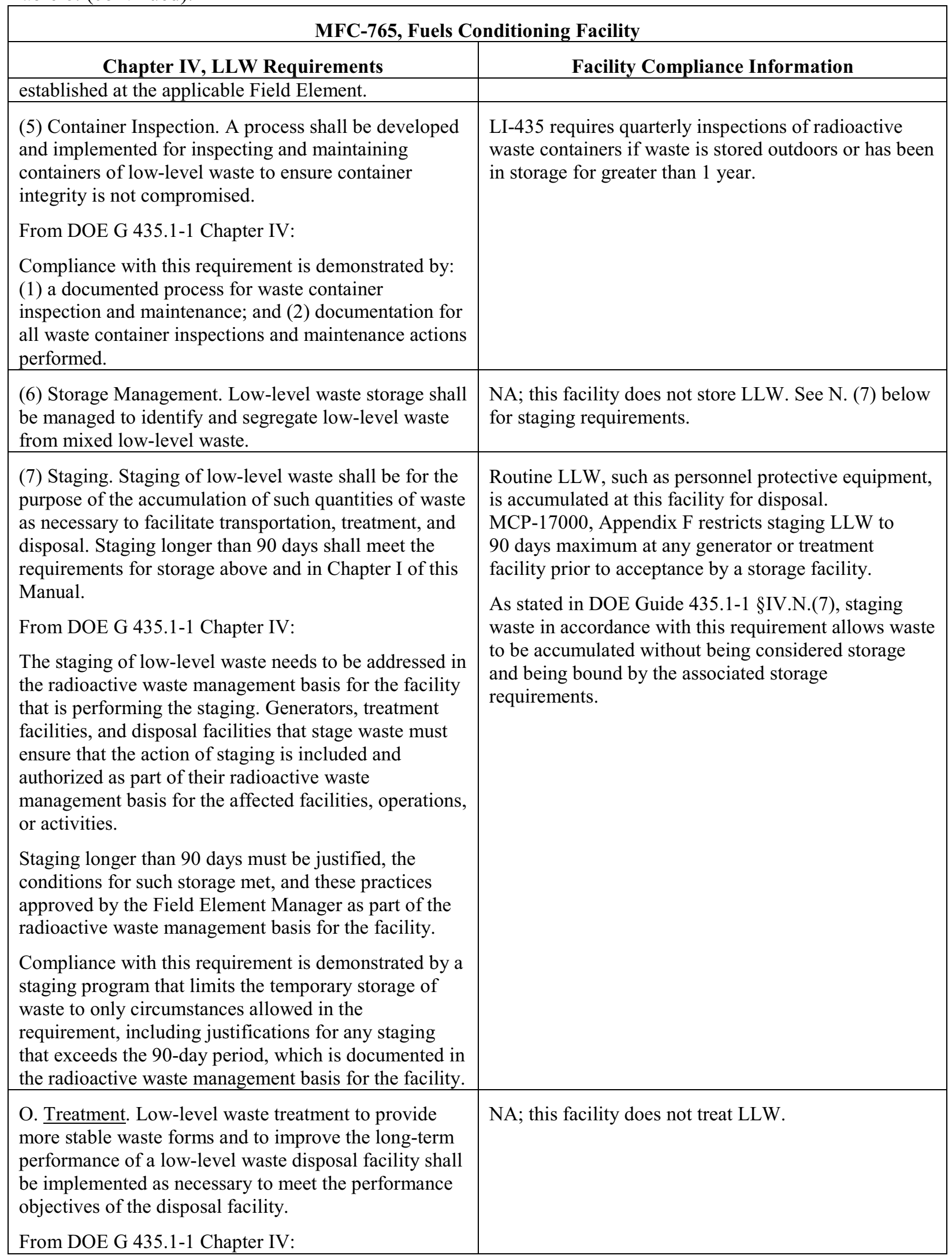


Table 8. (continued).

MFC-765, Fuels Conditioning Facility

\begin{tabular}{|l|}
\hline \multicolumn{1}{|c|}{ Chapter IV, LLW Requirements } \\
\hline Compliance with this requirement is demonstrated \\
when a treatment facility or process ensures that treated \\
waste will meet the minimum waste form requirements \\
of DOE M 435.1 and meet additional disposal facility- \\
specific waste acceptance requirements for additional \\
stability or long-term performance of facilities that will \\
receive the treated waste.
\end{tabular}

P. Disposal. Low-level waste disposal facilities shall meet the following requirements.

(1) Performance Objectives. Low-level waste disposal facilities shall be sited, designed, operated, maintained, and closed so that a reasonable expectation exists that the following performance objectives will be met for waste disposed of after September 26, 1988:

(a) Dose to representative members of the public shall not exceed $25 \mathrm{mrem}(0.25 \mathrm{mSv})$ in a year total effective dose equivalent from all exposure pathways, excluding the dose from radon and its progeny in air.

(b) Dose to representative members of the public via the air pathway shall not exceed $10 \mathrm{mrem}(0.10 \mathrm{mSv})$ in a year total effective dose equivalent, excluding the dose from radon and its progeny.

(c) Release of radon shall be less than an average flux of $20 \mathrm{pCi} / \mathrm{m}^{2} / \mathrm{s}\left(0.74 \mathrm{~Bq} / \mathrm{m}^{2} / \mathrm{s}\right)$ at the surface of the disposal facility. Alternatively, a limit of $0.5 \mathrm{pCi} / 1$ $(0.0185 \mathrm{~Bq} / \mathrm{l})$ of air may be applied at the boundary of the facility.

(2) Performance Assessment. A site-specific radiological performance assessment shall be prepared and maintained for DOE low-level waste disposed of after September 26, 1988. The performance assessment shall include calculations for a 1,000 year period after closure of potential doses to representative future members of the public and potential releases from the facility to provide a reasonable expectation that the performance objectives identified in this Chapter are not exceeded as a result of operation and closure of the facility.

(a) Analyses performed to demonstrate compliance with the performance objectives in this Chapter, and to establish limits on concentrations of radionuclides for disposal based on the performance measures for inadvertent intruders in this Chapter shall be based on reasonable activities in the critical group of exposed individuals. Unless otherwise specified, the assumption of average living habits and exposure conditions in representative critical groups of individuals projected

See P. above.

See P. above.

See P. above.

See P. above.

See P. above. Facility Compliance Information

NA; this facility does not dispose of LLW.

See P. above. 
Table 8. (continued).

MFC-765, Fuels Conditioning Facility

\begin{tabular}{|l}
\hline \multicolumn{1}{|c|}{ Chapter IV, LLW Requirements } \\
\hline to receive the highest doses is appropriate. The \\
likelihood of inadvertent intruder scenarios may be \\
considered in interpreting the results of the analyses \\
and establishing radionuclide concentrations, if \\
adequate justification is provided.
\end{tabular}

(b) The point of compliance shall correspond to the point of highest projected dose or concentration beyond a 100 meter buffer zone surrounding the disposed waste. A larger or smaller buffer zone may be used if adequate justification is provided.

(c) Performance assessments shall address reasonably foreseeable natural processes that might disrupt barriers against release and transport of radioactive materials.

(d) Performance assessments shall use DOE-approved dose coefficients (dose conversion factors) for internal and external exposure of reference adults.

(e) The performance assessment shall include a sensitivity/uncertainty analysis.

(f) Performance assessments shall include a demonstration that projected releases of radionuclides to the environment shall be maintained as low as reasonably achievable (ALARA).

(g) For purposes of establishing limits on radionuclides that may be disposed of near-surface, the performance assessment shall include an assessment of impacts to water resources.

(h) For purposes of establishing limits on the concentration of radionuclides that may be disposed of near-surface, the performance assessment shall include an assessment of impacts calculated for a hypothetical person assumed to inadvertently intrude for a temporary period into the low-level waste disposal facility. For intruder analyses, institutional controls shall be assumed to be effective in deterring intrusion for at least 100 years following closure. The intruder analyses shall use performance measures for chronic and acute exposure scenarios, respectively, of 100 mrem $(1 \mathrm{mSv})$ in a year and $500 \mathrm{mrem}(5 \mathrm{mSv})$ total effective dose equivalent excluding radon in air.

(3) Composite Analysis. For disposal facilities which received waste after September 26, 1988, a site-specific radiological composite analysis shall be prepared and maintained that accounts for all sources of radioactive material that may be left at the DOE site and may interact with the low- level waste disposal facility, contributing to the dose projected to a hypothetical member of the public from the existing or future
See P. above.

See P. above.

See P. above. Facility Compliance Information
See P. above.

See P. above.

See P. above.

See P. above.

See P. above. 
Table 8. (continued).

\begin{tabular}{|c|c|}
\hline \multicolumn{2}{|c|}{ MFC-765, Fuels Conditioning Facility } \\
\hline Chapter IV, LLW Requirements & Facility Compliance Information \\
\hline $\begin{array}{l}\text { disposal facilities. Performance measures shall be } \\
\text { consistent with DOE requirements for protection of the } \\
\text { public and environment and evaluated for a } 1,000 \text { year } \\
\text { period following disposal facility closure. The } \\
\text { composite analysis results shall be used for planning, } \\
\text { radiation protection activities, and future use } \\
\text { commitments to minimize the likelihood that current } \\
\text { low- level waste disposal activities will result in the } \\
\text { need for future corrective or remedial actions to } \\
\text { adequately protect the public and the environment. }\end{array}$ & \\
\hline $\begin{array}{l}\text { (4) Performance Assessment and Composite Analysis } \\
\text { Maintenance. The performance assessment and } \\
\text { composite analysis shall be maintained to evaluate } \\
\text { changes that could affect the performance, design, and } \\
\text { operating bases for the facility. Performance } \\
\text { assessment and composite analysis maintenance shall } \\
\text { include the conduct of research, field studies, and } \\
\text { monitoring needed to address uncertainties or gaps in } \\
\text { existing data. The performance assessment shall be } \\
\text { updated to support the final facility closure. Additional } \\
\text { iterations of the performance assessment and composite } \\
\text { analysis shall be conducted as necessary during the } \\
\text { post-closure period. }\end{array}$ & See P. above. \\
\hline $\begin{array}{l}\text { (a) Performance assessments and composite analyses } \\
\text { shall be reviewed and revised when changes in waste } \\
\text { forms or containers, radionuclide inventories, facility } \\
\text { design and operations, closure concepts, or the } \\
\text { improved understanding of the performance of the } \\
\text { waste disposal facility in combination with the features } \\
\text { of the site on which it is located alter the conclusions or } \\
\text { the conceptual model(s) of the existing performance } \\
\text { assessment or composite analysis. }\end{array}$ & See P. above. \\
\hline $\begin{array}{l}\text { (b) A determination of the continued adequacy of the } \\
\text { performance assessment and composite analysis shall } \\
\text { be made on an annual basis, and shall consider the } \\
\text { results of data collection and analysis from research, } \\
\text { field studies, and monitoring. }\end{array}$ & See P. above. \\
\hline $\begin{array}{l}\text { (c) Annual summaries of low-level waste disposal } \\
\text { operations shall be prepared with respect to the } \\
\text { conclusions and recommendations of the performance } \\
\text { assessment and composite analysis and a determination } \\
\text { of the need to revise the performance assessment or } \\
\text { composite analysis. }\end{array}$ & See P. above. \\
\hline $\begin{array}{l}\text { (5) Disposal Authorization. A disposal authorization } \\
\text { statement shall be obtained prior to construction of a } \\
\text { new low-level waste disposal facility. Field Elements } \\
\text { with existing low-level waste disposal facilities shall } \\
\text { obtain a disposal authorization statement in accordance } \\
\text { with the schedule in the Complex-Wide Low-Level }\end{array}$ & See P. above. \\
\hline
\end{tabular}


Table 8. (continued).

MFC-765, Fuels Conditioning Facility

\begin{tabular}{|l|}
\hline \multicolumn{1}{|c|}{ Chapter IV, LLW Requirements } \\
\hline Waste Management Program Plan. The disposal \\
authorization statement shall be issued based on a \\
review of the facility's performance assessment, \\
composite analysis, performance assessment and \\
composite analysis maintenance, preliminary closure \\
plan, and preliminary monitoring plan. The disposal \\
authorization statement shall specify the limits and \\
conditions on construction, design, operations, and \\
closure of the low-level waste facility based on these \\
reviews. A disposal authorization statement is a part of \\
the radioactive waste management basis for a disposal \\
facility. Failure to obtain a disposal authorization \\
statement by the implementation date of this Order \\
shall result in shutdown of the disposal facility.
\end{tabular}

(6) Disposal Facility Operations. The disposal facility design and operation must be consistent with the disposal facility closure plan and lead to disposal facility closure that provides a reasonable expectation that performance objectives will be met. Low-level waste shall be disposed in such a manner that achieves the performance objectives stated in this Chapter, consistent with the disposal facility radiological performance assessment. Additional requirements include:

(a) Operating procedures shall be developed and implemented for low-level waste disposal facilities that protect the public, workers, and the environment; ensure the security of the facility; minimize subsidence during and after waste emplacement; achieve long-term stability and minimize the need for long-term active maintenance; and meet the requirements of the closure/post-closure plan.

(b) Permanent identification markers for disposal excavations and monitoring wells shall be emplaced.

(c) Low-level waste placement into disposal units shall minimize voids between waste containers. Voids within disposal units shall be filled to the extent practical. Uncontainerized bulk waste shall also be placed in a manner that minimizes voids and subsidence.

(d) Operations are to be conducted so that active waste disposal operations will not have an adverse effect on any other disposal units.

(e) Operations shall include a process for tracking and documenting low-level waste placement in the facility by generator source.

(7) Alternate Requirements for Low-Level Waste Disposal Facility Design and Operation. Requirements other than those set forth in this Section for the design
See P. above. Facility Compliance Information

See P. above.

See P. above.

See P. above.

See P. above.

See P. above.

See P. above. 
Table 8. (continued).

MFC-765, Fuels Conditioning Facility

\begin{tabular}{l} 
Chapter IV, LLW Requirements \\
\hline $\begin{array}{l}\text { and operation of a low-level waste disposal facility } \\
\text { may be approved on a specific basis if a reasonable } \\
\text { expectation is demonstrated that the disposal } \\
\text { performance objectives will be met. }\end{array}$ \\
Q. Closure. The following requirements are in addition \\
to those in Chapter I of this Manual. \\
\hline $\begin{array}{l}\text { (1) Disposal Facility Closure Plans. A preliminary } \\
\text { closure plan shall be developed and submitted to } \\
\text { Headquarters for review with the performance } \\
\text { assessment and composite analysis. The closure plan } \\
\text { shall be updated following issuance of the disposal } \\
\text { authorization statement to incorporate conditions } \\
\text { specified in the disposal authorization statement. } \\
\text { Closure plans shall: }\end{array}$ \\
\hline
\end{tabular}

(a) Be updated as required during the operational life of the facility.

(b) Include a description of how the disposal facility will be closed to achieve long-term stability and minimize the need for active maintenance following closure and to ensure compliance with the requirements of DOE 5400.5, Radiation Protection of the Public and the Environment.

(c) Include the total expected inventory of wastes to be disposed of at the facility over the operational life of the facility.

(2) Disposal Facility Closure. Closure of a disposal facility shall occur within a five-year period after it is filled to capacity, or after the facility is otherwise determined to be no longer needed.

(a) Prior to facility closure, the final inventory of the low-level waste disposed in the facility shall be prepared and incorporated in the performance assessment and composite analysis which shall be updated to support the closure of the facility.

(b) A final closure plan shall be prepared based on the final inventory of waste disposed in the facility, the plan implemented, and the updated performance assessment and composite analysis prepared in support of the facility closure.

(c) Institutional control measures shall be integrated into land use and stewardship plans and programs, and shall continue until the facility can be released pursuant to DOE 5400.5, Radiation Protection of the Public and the Environment.
Facility Compliance Information

NA; this facility does not dispose of LLW.

See Q. above.

See Q. above.

See Q. above.

See Q. above.

See Q. above.

See Q. above.

See Q. above.

See Q. above. 
Table 8. (continued).

MFC-765, Fuels Conditioning Facility

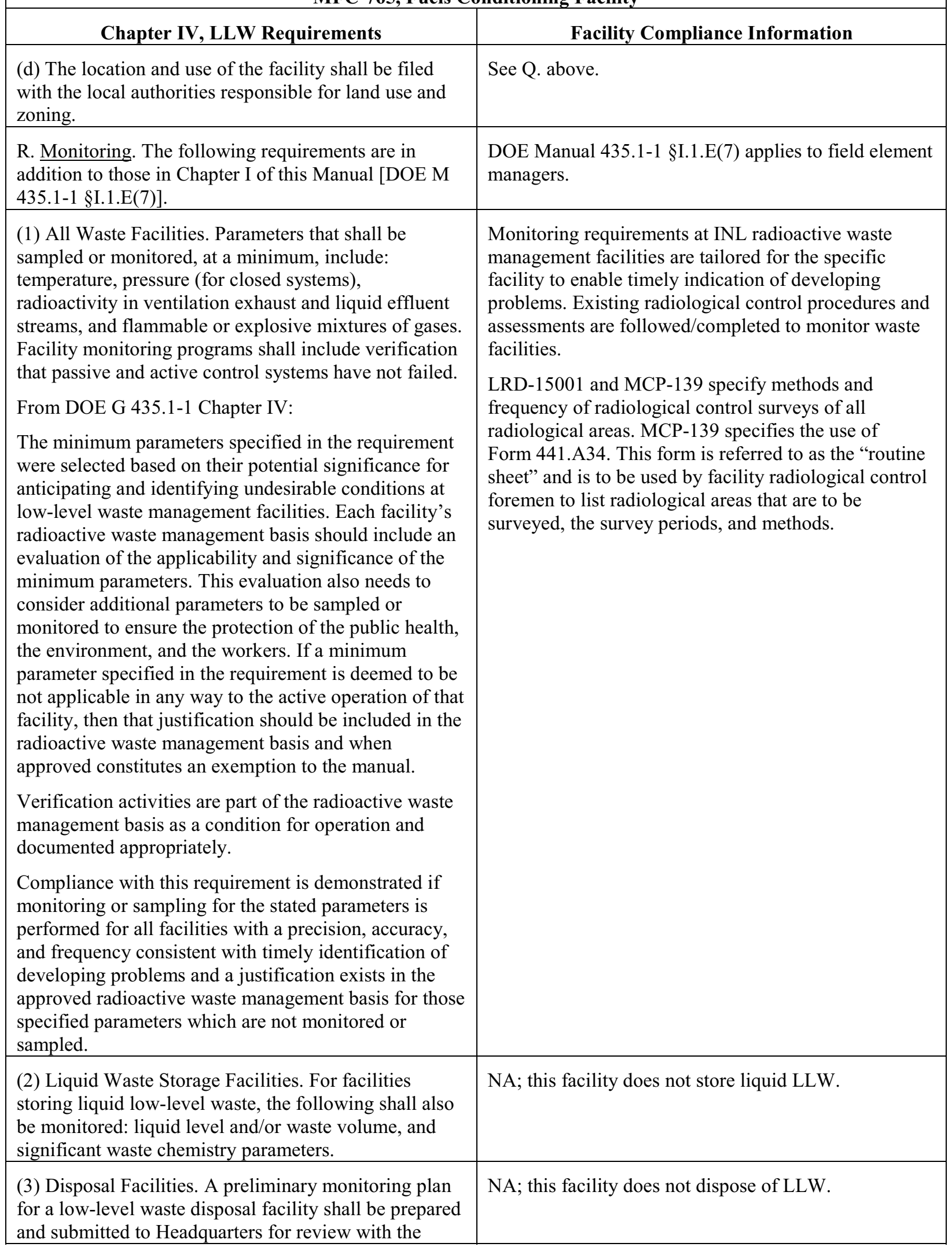


Table 8. (continued).

\begin{tabular}{|l|l|}
\hline \multicolumn{2}{|c|}{ MFC-765, Fuels Conditioning Facility } \\
\hline \multicolumn{1}{|c|}{ Chapter IV, LLW Requirements } & \multicolumn{1}{|c|}{ Facility Compliance Information } \\
\hline $\begin{array}{l}\text { performance assessment and composite analysis. The } \\
\text { monitoring plan shall be updated within one year } \\
\text { following issuance of the disposal authorization } \\
\text { statement to incorporate and implement conditions } \\
\text { specified in the disposal authorization statement. }\end{array}$ & \\
\hline $\begin{array}{l}\text { (a) The site-specific performance assessment and } \\
\text { composite analysis shall be used to determine the } \\
\text { media, locations, radionuclides, and other substances to } \\
\text { be monitored. }\end{array}$ & See (3) above. \\
\hline $\begin{array}{l}\text { (b) The environmental monitoring program shall be } \\
\text { designed to include measuring and evaluating releases, } \\
\text { migration of radionuclides, disposal unit subsidence, } \\
\text { and changes in disposal facility and disposal site } \\
\text { parameters which may affect long-term performance. }\end{array}$ & See (3) above. \\
\hline $\begin{array}{l}\text { (c) The environmental monitoring programs shall be } \\
\text { capable of detecting changing trends in performance to } \\
\text { allow application of any necessary corrective action } \\
\text { prior to exceeding the performance objectives in this } \\
\text { Chapter. }\end{array}$ & See (3) above. \\
\hline
\end{tabular}

\subsection{MFC-771, Radioactive Scrap and Waste Facility}

1. Facility description: RSWF, established in 1965 for storage of RH mixed waste, is outdoors. There are no permanent buildings. The facility is approximately $388 \times 448 \mathrm{ft}$ (4 acres) and is entirely enclosed by a fence. Sealed carbon-steel liners are buried vertically in the ground in bored holes such that the top of the liners protrude approximately $4 \mathrm{in}$. above ground. Prior to placing the liners in the storage area, several feet of gravel and soil were placed over the storage area and graded to slope gently from the centerline to the parallel sides, which were banked with gravel. This grade promotes run-off, reducing percolation, and serves to prevent run-on into the area.

RSWF is designed with a grid of 27 rows spaced $12 \mathrm{ft}$ apart with approximately 50 storage sites per row. The storage liners are arranged on 6-ft centers in the rows. The volume capacity, based on the size of the waste containers that are placed in storage, is approximately 53,000 gal. This assumes that approximately 1,320 of the liner sites are usable for mixed waste storage.

There are three primary sizes of storage liners containing HW/mixed waste currently located in RSWF. They are 16 in., 24 in., and 26 in. in diameter.

Waste is not placed directly in the carbon steel liners, but rather is placed in containers that are transferred into the liners. Shielding is provided by placing a 30 -in. concrete or 6 -in. steel shield plug in the liner and welding it to the top of the liner, as applicable.

2. Hazard category: Hazard Category 2 non-reactor nuclear facility

3. Radioactive waste managed at this facility: RH TRU, RH mixed TRU, RH LLW and RH mixed LLW are stored at this facility. 


\section{RWMB documents/programs:}

a. Safety basis/hazard analysis:

- SAR-407, "Safety Analysis Report for the Radioactive Scrap and Waste Facility (MFC-771)"

- LST-305, "Safety Basis List for the Materials and Fuels Complex (MFC) Radioactive Scrap and Waste Facility (RSWF)"

- IAG-264, "INL Authorization Agreement for the Materials and Fuels Complex (MFC) Radioactive Scrap and Waste Facility (RSWF)"

b. Laboratory-wide:

- Form 441.A34, "INL Radiological Control Required Surveys"

- LI-435, "Waste Management Routine Field Activities"

- LRD-15001, "Radiological Control Manual"

- LWP-8300, "Transuranic Waste Handling"

- LWP-13840, "Management of Issues, Observations, and Noteworthy Practices"

- LWP-14002, "Timeout and Stop Work Authority"

- LWP-15011, "Radioactive Material Areas and Radioactive Storage Areas"

- LWP-17000, "Waste Management"

- MCP-139, "Radiological Surveys"

- MCP-17000, "Waste Generator Services Waste Management"

- MCP-17500, "Waste Generator Services Certification of Waste Shipments to the Nevada Test Site"

- PDD-17000, "Waste Management Program"

- PLN-114, "INL Emergency Plan/RCRA Contingency Plan"

- PLN-522, "Quality Assurance Program Plan for the Waste Management/Waste Certification Program"

- PLN-8300, "Materials and Fuels Complex Contact-Handled TRU Waste Certification Program Plan"

c. Facility-specific:

- ANL-NT-192, "The Defense Programs Origin of Transuranic Waste at Argonne National Laboratory-West, H. F. McFarlane, 11/1/2001"

- RSWF-OI-003, "Material Acceptance for Storage"

- RSWF-OI-004, "Administrative Requirements/Process for Material Transfers"

- RSWF-OI-006, "Maintenance and Surveillance Requirements"

- INL/EXT-10-17600, Process Knowledge Summary Report for Materials and Fuels Complex Contact-handled Transuranic Waste

- PER-116, "HWMA/RCRA Storage and Treatment Permit for the Materials and Fuels Complex"

- SD-38.1.1, "Treatment, Storage, and Disposal Facilities (TSDF) Environmental Compliance"

- TSD-OI-004, "Waste and Material Acceptance for Storage/Treatment and Radioactive Material Inventory Control"

TRU waste and LLW are managed at this facility. Table 9 shows the facility compliance information for DOE Manual 435.1-1, Chapter III, "Transuranic Waste Requirements," and Table 10 presents the facility compliance information for Chapter IV, "Low-level Waste Requirements." 
Table 9. MFC-771, Radioactive Scrap and Waste Facility, DOE Manual 435.1-1 transuranic waste requirements and facility compliance information.

\begin{tabular}{|c|c|}
\hline \multicolumn{2}{|c|}{ MFC-771 Radioactive Scrap and Waste Facility } \\
\hline Chapter III. Transuranic Waste Requirements & Facility Compliance Information \\
\hline $\begin{array}{l}\text { A. Definition of Transuranic Waste. Transuranic waste } \\
\text { is radioactive waste containing more than } 100 \\
\text { nanocuries ( } 3700 \text { becquerels) of alpha-emitting } \\
\text { transuranic isotopes per gram of waste, with half-lives } \\
\text { greater than } 20 \text { years, except for: } \\
\text { (From DOE G } 435.1-1 \text { Chapter III: The determination } \\
\text { of transuranic waste should be made at the time of } \\
\text { waste certification, that is, each time the waste is } \\
\text { transferred to another person or facility.) }\end{array}$ & $\begin{array}{l}\text { This requirement proves the criteria for determining which DOE } \\
\text { radioactive waste is to be managed as TRU waste in accordance } \\
\text { with DOE Manual } 435.1-1 \text {, Chapter III. } \\
\text { See J. below. }\end{array}$ \\
\hline (1) High-level radioactive waste; & See A. above. \\
\hline $\begin{array}{l}\text { (2) Waste that the Secretary of Energy has determined, } \\
\text { with the concurrence of the Administrator of the } \\
\text { Environmental Protection Agency, does not need the } \\
\text { degree of isolation required by the } 40 \text { CFR Part } 191 \\
\text { disposal regulations; or }\end{array}$ & See A. above. \\
\hline $\begin{array}{l}\text { (3) Waste that the Nuclear Regulatory Commission } \\
\text { has approved for disposal on a case-by-case basis in } \\
\text { accordance with } 10 \text { CFR Part } 61 \text {. }\end{array}$ & See A. above. \\
\hline $\begin{array}{l}\text { B. Management of Specific Wastes. The following } \\
\text { provide for management of specific wastes as } \\
\text { transuranic waste in accordance with the requirements } \\
\text { in this Chapter: } \\
\text { From DOE G 435.1-1 Chapter III: Compliance with } \\
\text { these requirements is demonstrated if RCRA, state- } \\
\text { hazardous, and TSCA-regulated radioactive wastes are } \\
\text { being managed in compliance with applicable } \\
\text { requirements and agreements or in accordance with a } \\
\text { consent order, and consistent with the Transuranic } \\
\text { Waste Requirements of DOE M } 435.1-1 \text {. }\end{array}$ & See below. \\
\hline $\begin{array}{l}\text { (1) Mixed Transuranic Waste. Transuranic waste } \\
\text { determined to contain both a hazardous component } \\
\text { subject to the Resource Conservation and Recovery } \\
\text { Act (RCRA), as amended, and a radioactive } \\
\text { component subject to the Atomic Energy Act of } 1954 \text {, } \\
\text { as amended, shall be managed in accordance with the } \\
\text { requirements of RCRA and DOE O } 435.1 \text {, Radioactive } \\
\text { Waste Management, and this Manual. }\end{array}$ & $\begin{array}{l}\text { Mixed TRU waste is managed at this facility. } \\
\text { This facility has a HWMA/RCRA permit to store mixed waste } \\
\text { (PER-116). }\end{array}$ \\
\hline $\begin{array}{l}\text { (2) TSCA-Regulated Waste. Transuranic waste } \\
\text { containing polychlorinated biphenyls, asbestos, or } \\
\text { other such regulated toxic components shall be } \\
\text { managed in accordance with requirements derived } \\
\text { from the Toxic Substances Control Act, as amended, } \\
\text { DOE O } 435.1 \text {, Radioactive Waste Management, and } \\
\text { this Manual. }\end{array}$ & NA; TSCA-regulated TRU waste is not managed at this facility. \\
\hline
\end{tabular}


Table 9. (continued).

\begin{tabular}{|c|c|}
\hline \multicolumn{2}{|c|}{ MFC-771 Radioactive Scrap and Waste Facility } \\
\hline Chapter III. Transuranic Waste Requirements & Facility Compliance Information \\
\hline $\begin{array}{l}\text { (3) Pre-1970 Transuranic Waste. Transuranic waste } \\
\text { disposed of prior to implementation of the } 1970 \\
\text { Atomic Energy Commission Immediate Action } \\
\text { Directive regarding retrievable storage of transuranic } \\
\text { waste is not subject to the requirements of DOE O } \\
\text { 435.1, Radioactive Waste Management, and this } \\
\text { Manual. }\end{array}$ & NA; pre-1970 TRU waste is not managed at this facility. \\
\hline $\begin{array}{l}\text { C. Complex-Wide Transuranic Waste Management } \\
\text { Program. A complex-wide program and plan shall be } \\
\text { developed as described under Responsibilities, 2.B and } \\
\text { 2.D, in Chapter I of this Manual. } \\
\text { From DOE G } 435.1-1 \text { Chapter III: Compliance with } \\
\text { this requirement is demonstrated by the presence of a } \\
\text { Complex-Wide Transuranic Waste Management } \\
\text { Program which includes the appropriate interfaces, } \\
\text { technical information, data inputs, and other elements } \\
\text { described in Chapter I of this Manual. }\end{array}$ & $\begin{array}{l}\text { Not a facility-specific requirement. DOE Manual } 435.1-1 \S \text { I.2.B } \\
\text { and §I.2.D apply to the Assistant Secretary for Environmental } \\
\text { Management and the Deputy Assistant Secretary for Waste } \\
\text { Management, respectively. }\end{array}$ \\
\hline $\begin{array}{l}\text { D. Radioactive waste management basis. Transuranic } \\
\text { waste facilities, operations, and activities shall have a } \\
\text { nadioactive waste management basis consisting of } \\
\text { physical and administrative controls to ensure the } \\
\text { protection of workers, the public, and the environment. } \\
\text { The following specific waste management controls } \\
\text { shall be part of the radioactive waste management } \\
\text { basis: } \\
\text { From DOE G 435.1-1 Chapter III: Compliance with } \\
\text { this requirement is demonstrated if, the radioactive } \\
\text { waste management basis is documented and signed by } \\
\text { the Field Element manager or a designee (see DOE M } \\
435.1-1 \text {, Section I.1.A, Delegation of Authority) for } \\
\text { each transuranic waste management facility, operation, } \\
\text { or activity. Using a graded approach, it may be } \\
\text { possible to include multiple activities under a single } \\
\text { radioactive waste management basis, but it should be } \\
\text { possible to objectively identify which activities are } \\
\text { covered. Further, the radioactive waste management } \\
\text { basis includes or references the controls that are } \\
\text { established on a facility-specific basis to address the } \\
\text { unique waste management requirements and } \\
\text { circumstances for each facility, operation, and/or } \\
\text { activity. }\end{array}$ & $\begin{array}{l}\text { The RWMB provides the regulatory framework for management } \\
\text { of radioactive waste at INL. It specifically identifies facility } \\
\text { management and implementing documents for the generation, } \\
\text { storage, treatment, and disposal of radiological waste. } \\
\text { This facility is a Hazard Category } 2 \text { non-reactor nuclear facility } \\
\text { (SAR-407). The facility's safety basis list and approval are } \\
\text { identified in LST-305 and IAG-264. }\end{array}$ \\
\hline $\begin{array}{l}\text { (1) Generators. The waste certification program. } \\
\text { From DOE G } 435.1-1 \text { Chapter III: For a facility that } \\
\text { generates transuranic waste, the radioactive waste } \\
\text { management basis is to include the program for } \\
\text { certifying that waste meets the waste acceptance } \\
\text { requirements of the facility(ies) to which the waste } \\
\text { will be sent. }\end{array}$ & NA; this facility does not generate TRU waste. \\
\hline
\end{tabular}


Table 9. (continued).

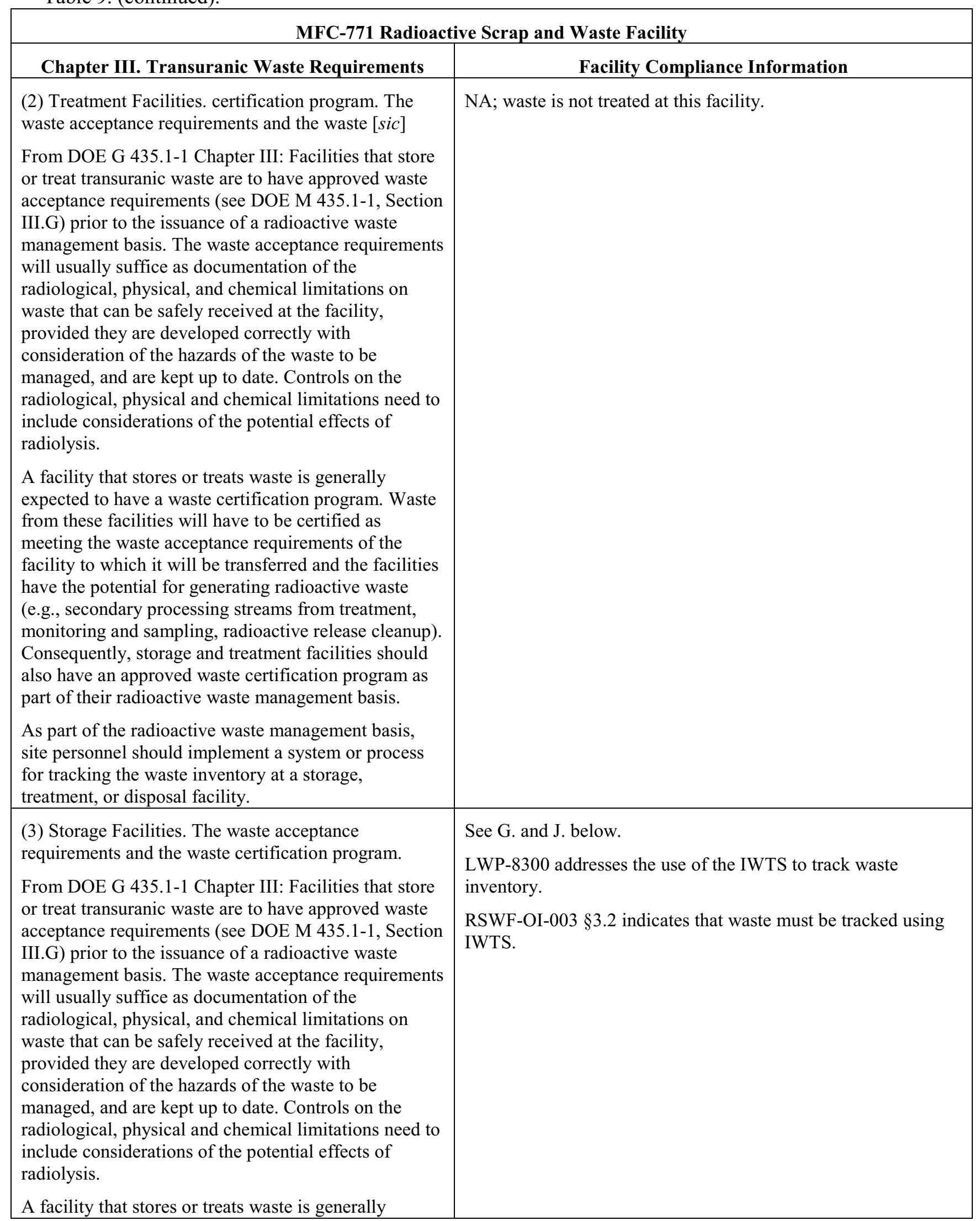


Table 9. (continued).

\begin{tabular}{|c|c|}
\hline \multicolumn{2}{|c|}{ MFC-771 Radioactive Scrap and Waste Facility } \\
\hline Chapter III. Transuranic Waste Requirements & Facility Compliance Information \\
\hline $\begin{array}{l}\text { expected to have a waste certification program. Waste } \\
\text { from these facilities will have to be certified as } \\
\text { meeting the waste acceptance requirements of the } \\
\text { facility to which it will be transferred and the facilities } \\
\text { have the potential for generating radioactive waste } \\
\text { (e.g., secondary processing streams from treatment, } \\
\text { monitoring and sampling, radioactive release cleanup). } \\
\text { Consequently, storage and treatment facilities should } \\
\text { also have an approved waste certification program as } \\
\text { part of their radioactive waste management basis. }\end{array}$ & \\
\hline $\begin{array}{l}\text { As part of the radioactive waste management basis, } \\
\text { site personnel should implement a system or process } \\
\text { for tracking the waste inventory at a storage, } \\
\text { treatment, or disposal facility. }\end{array}$ & \\
\hline $\begin{array}{l}\text { (4) Disposal Facilities. The performance assessment, } \\
\text { disposal authorization statement, waste acceptance } \\
\text { requirements, and monitoring plan. }\end{array}$ & NA; this facility is not a disposal facility. \\
\hline $\begin{array}{l}\text { E. Contingency Actions. The following requirements } \\
\text { are in addition to those in Chapter I of this Manual. } \\
\text { From DOE G 435.1-1 Chapter III: Compliance with } \\
\text { these requirements is demonstrated by having } \\
\text { adequate spare capacity and transfer equipment exists } \\
\text { for emergency transfers of all liquid transuranic waste. } \\
\text { In addition, the capability to perform emergency } \\
\text { transfers is demonstrated by having waste transfer } \\
\text { routings identified, operational procedures to direct } \\
\text { transfers, staff trained to the procedures, and records } \\
\text { showing that the spare capacity and transfer capability } \\
\text { are kept in operating condition. }\end{array}$ & $\begin{array}{l}\text { Not a facility-specific requirement. DOE Manual 435.1-1 } \\
\text { §I.1.E(5) addresses the sitewide emergency management } \\
\text { system. The INL plan is provided in PLN-114. } \\
\text { The HWMA/RCRA permit also includes a contingency plan } \\
\text { (PER-116, Attachment } 7, \S \mathrm{G} \text { ). }\end{array}$ \\
\hline $\begin{array}{l}\text { (1) Contingency Storage. For off-normal or emergency } \\
\text { situations involving liquid transuranic waste storage or } \\
\text { treatment, spare capacity with adequate capabilities } \\
\text { shall be maintained to receive the largest volume of } \\
\text { liquid contained in any one storage tank or treatment } \\
\text { facility. Tanks or other facilities that are designated } \\
\text { transuranic waste contingency storage shall be } \\
\text { maintained in an operational condition when waste is } \\
\text { present and shall meet the requirements of DOE O } \\
\text { 435.1, Radioactive Waste Management, and this } \\
\text { Manual. }\end{array}$ & $\begin{array}{l}\text { NA; this facility does not store or treat liquid TRU waste in } \\
\text { tanks. }\end{array}$ \\
\hline $\begin{array}{l}\text { (2) Transfer Equipment. Pipelines and auxiliary } \\
\text { facilities necessary for the transfer of liquid waste to } \\
\text { contingency storage shall be maintained in an } \\
\text { operational condition when waste is present and shall } \\
\text { meet the requirements of DOE O } 435.1 \text {, Radioactive } \\
\text { Waste Management, and this Manual. }\end{array}$ & $\begin{array}{l}\text { NA; this facility does not store or treat liquid TRU waste in } \\
\text { tanks. }\end{array}$ \\
\hline
\end{tabular}


Table 9. (continued).

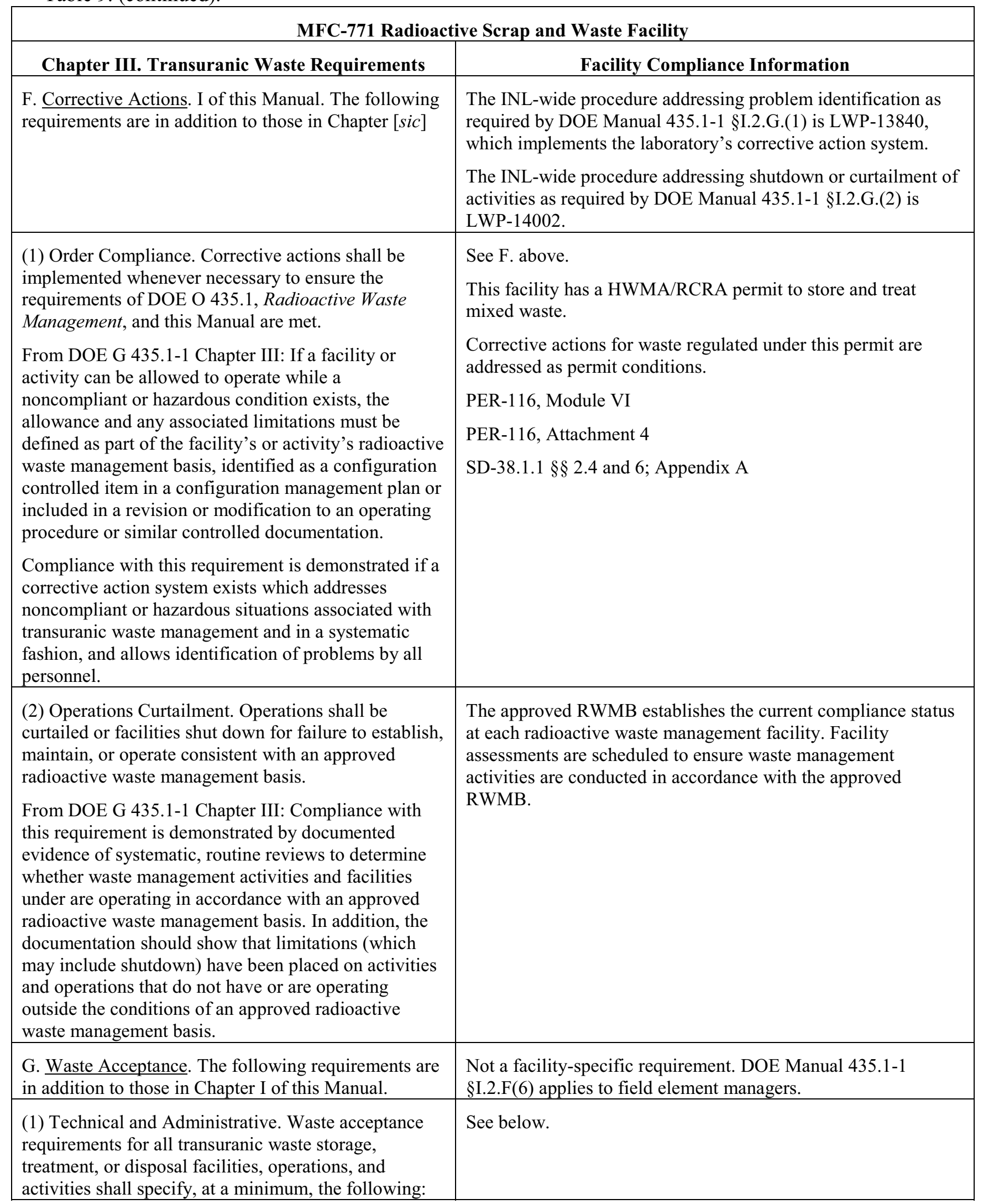


Table 9. (continued).

\begin{tabular}{|c|c|}
\hline \multicolumn{2}{|c|}{ MFC-771 Radioactive Scrap and Waste Facility } \\
\hline Chapter III. Transuranic Waste Requirements & Facility Compliance Information \\
\hline $\begin{array}{l}\text { From DOE G 435.1-1 Chapter III: Compliance with } \\
\text { these requirements is demonstrated if waste } \\
\text { acceptance requirements are documented, contain } \\
\text { clear and precise criteria specifying the radionuclide } \\
\text { limits in the form of contents or concentrations that } \\
\text { can be accepted, the limitations and prohibitions on } \\
\text { waste forms and packages that can be received, and } \\
\text { the limits, prohibitions, or instructions concerning any } \\
\text { other technical information so that the waste is } \\
\text { compatible with the safety basis of the facility, and } \\
\text { which will result in acceptable waste at subsequent } \\
\text { steps in managing the transuranic waste. Waste } \\
\text { acceptance requirements are to also contain a clear } \\
\text { description of the process and bases for obtaining an } \\
\text { exception or deviation to the acceptance criteria for } \\
\text { transuranic waste to be received } \\
\text { at the facility. }\end{array}$ & \\
\hline $\begin{array}{l}\text { (a) Allowable activities and/or concentrations of } \\
\text { specific radionuclides; }\end{array}$ & $\begin{array}{l}\text { LWP-8300 } \\
\text { RSWF-OI-003 § } 4\end{array}$ \\
\hline $\begin{array}{l}\text { (b) Acceptable waste form and/or container } \\
\text { requirements that ensure the chemical and physical } \\
\text { stability of waste under conditions that might be } \\
\text { encountered during transportation, storage, treatment, } \\
\text { or disposal; }\end{array}$ & $\begin{array}{l}\text { LWP-8300 } \\
\text { RSWF-OI-003 } \$ 4 \\
\text { PER-116, Module II.C and V } \\
\text { PER-116, Attachment 1, } \S \text { B-2(a), D-1(a); Attachment 2, § C- } \\
\text { 2(a) } \\
\text { SD-38.1.1, Appendix A and Appendix E }\end{array}$ \\
\hline $\begin{array}{l}\text { (c) Restrictions or prohibitions on waste, materials, or } \\
\text { containers that may adversely affect waste handlers or } \\
\text { compromise facility or waste container performance; }\end{array}$ & $\begin{array}{l}\text { LWP-8300 } \\
\text { RSWF-OI-003 } \$ 4 \\
\text { PER-116, Module II.C and V } \\
\text { PER-116, Attachment 1, §§ B-2(a), D-1(a); Attachment 2, § C- } \\
\text { 2(a) } \\
\text { SD-38.1.1, Appendix A and Appendix E }\end{array}$ \\
\hline $\begin{array}{l}\text { (d) Requirement to identify transuranic waste as } \\
\text { defense or non-defense, and limitations on acceptance; } \\
\text { and }\end{array}$ & $\begin{array}{l}\text { The remote-handled TRU waste is expected to be defense waste } \\
\text { (INL/EXT-10-17600 and ANL-NT-192). The Waste Isolation } \\
\text { Pilot Plant Central Characterization Project prepares the } \\
\text { acceptable knowledge documentation for the remote-handled } \\
\text { TRU waste. This documentation also relies heavily on } \\
\text { ANL-NT-192. }\end{array}$ \\
\hline $\begin{array}{l}\text { (e) The basis, procedures, and levels of authority } \\
\text { required for granting exceptions to the waste } \\
\text { acceptance requirements, which shall be contained in } \\
\text { each facility's waste acceptance documentation. Each } \\
\text { exception request shall be documented, including its } \\
\text { disposition as approved or not approved. }\end{array}$ & $\begin{array}{l}\text { A letter from the site manager granting permission to accept } \\
\text { waste that does not meet the waste acceptance requirements is } \\
\text { needed. However, this process is not documented. } \\
\text { COMPLIANCE CONSIDERATION } \\
\text { Evaluate whether this requirement needs to be addressed in the }\end{array}$ \\
\hline
\end{tabular}


Table 9. (continued).

\begin{tabular}{|c|c|}
\hline \multicolumn{2}{|c|}{ MFC-771 Radioactive Scrap and Waste Facility } \\
\hline Chapter III. Transuranic Waste Requirements & Facility Compliance Information \\
\hline & facility's WAC and procedure. \\
\hline (2) Evaluation and Acceptance. The receiving facility & LWP-8300 \\
\hline Shall evaluate waste for acceptance, including & RSWF-OI-003 § 3 \\
\hline requirements have been met. A process for the & PER-116, Module II.C and V \\
\hline $\begin{array}{l}\text { lisposition of non-contorming wastes snall be } \\
\text { established. }\end{array}$ & PER-116, Attachment $1 \S \mathrm{D}-1$ (b); Attachment $2 \S$ C-2(a) \\
\hline From DOE G 435.1-1 Chapter III: Compliance with & SD-38.1.1, Appendix A and Appendix E. \\
\hline & $\begin{array}{l}\text { Meeting permit and safety basis constraints are checked using } \\
\text { an IWTS Material and Waste Characterization Profile. }\end{array}$ \\
\hline incoming waste which ensures the acceptance criteria & COMPLIANCE CONSIDERATION \\
\hline $\begin{array}{l}\text { combination of: (1) testing, sampling, and analysis of } \\
\text { representative samples of incoming waste upon } \\
\text { receipt; (2) testing, sampling, and analysis of samples } \\
\text { of waste taken at the generator facility; (3) evaluation } \\
\text { of testing, sampling, and analysis of data provided by } \\
\text { the generator; or (4) audits, reviews, or surveillances } \\
\text { of generator waste certification programs and } \\
\text { characterization activities. Additionally, acceptable } \\
\text { waste acceptance requirements for a storage, } \\
\text { treatment, or disposal facility will have documented } \\
\text { procedures and actions to be taken if a waste that does } \\
\text { not conform to the waste acceptance criteria is } \\
\text { received at the facility. }\end{array}$ & $\begin{array}{l}\text { Evaluate whether non-conforming waste needs to be addressed } \\
\text { in the facility's WAC and procedure. }\end{array}$ \\
\hline $\begin{array}{l}\text { H. Waste Generation Planning. The following } \\
\text { requirements are in addition to those in Chapter I of } \\
\text { this Manual. }\end{array}$ & $\begin{array}{l}\text { Not a facility-specific requirement. DOE Manual 435.1-1 } \\
\S I .2 . F(7) \text { applies to field element managers. }\end{array}$ \\
\hline $\begin{array}{l}\text { (1) Life-Cycle Planning. Prior to waste generation, } \\
\text { planning shall be performed to address the entire life } \\
\text { cycle for all transuranic waste streams. }\end{array}$ & $\begin{array}{l}\text { PDD- } 17000 \text { and LWP- } 17000 \text { provide direction to the waste } \\
\text { generators for waste generation planning to address the entire } \\
\text { life cycle. }\end{array}$ \\
\hline $\begin{array}{l}\text { From DOE G 435.1-1 Chapter III: Compliance with } \\
\text { this planning requirement is demonstrated by the } \\
\text { individual sites establishing a process for evaluating } \\
\text { the life-cycle of [transuranic] waste prior to its } \\
\text { generation, including the identification of [transuranic] } \\
\text { wastes with no path to disposal and appropriate } \\
\text { records justifying the newly generated [transuranic] } \\
\text { waste stream(s), and site personnel possessing } \\
\text { planning information showing the location(s) where } \\
\text { [transuranic] waste will be stored, treated, and/or } \\
\text { disposed along with a confirmation that the personnel } \\
\text { managing the facilities agree that the [transuranic] } \\
\text { waste may be managed at those facilities. }\end{array}$ & \\
\hline $\begin{array}{l}\text { (2) Waste with No Identified Path to Disposal. } \\
\text { Transuranic waste streams with no identified path to } \\
\text { disposal shall be generated only in accordance with } \\
\text { approved conditions which, at a minimum, shall }\end{array}$ & $\begin{array}{l}\text { NA; this facility is not generating TRU waste that does not have } \\
\text { an identified path to disposal. }\end{array}$ \\
\hline
\end{tabular}


Table 9. (continued).

\begin{tabular}{|c|c|}
\hline \multicolumn{2}{|c|}{ MFC-771 Radioactive Scrap and Waste Facility } \\
\hline Chapter III. Transuranic Waste Requirements & Facility Compliance Information \\
\hline address: & \\
\hline $\begin{array}{l}\text { From DOE G } 435.1-1 \text { Chapter III: Compliance with } \\
\text { requirement is demonstrated by the waste generation } \\
\text { organization having documentation concerning the } \\
\text { decision to generate a transuranic waste stream that } \\
\text { does not have an identified path to disposal. This } \\
\text { documentation needs to include the cognizant Field } \\
\text { Element Manager or designee approval to generate the } \\
\text { waste, an explanation of the need for the process that } \\
\text { generates the transuranic waste, a discussion of the } \\
\text { reason it cannot be disposed of, the proposed } \\
\text { management plan for the waste, and an up-to-date } \\
\text { schedule of activities being pursued to resolve } \\
\text { constraints to the disposal of the subject waste. } \\
\text { Consistent with the use of a graded approach for } \\
\text { applying DOE M } 435.1-1 \text { requirements, the schedule } \\
\text { and plans for disposing of nondefense waste can defer } \\
\text { to the complex-wide resolution of the issue. }\end{array}$ & \\
\hline (a) Programmatic need to generate the waste; & See (2) above. \\
\hline $\begin{array}{l}\text { (b) Characteristics and issues preventing the disposal } \\
\text { of the waste; }\end{array}$ & See (2) above. \\
\hline $\begin{array}{l}\text { (c) Safe storage of the waste until disposal can be } \\
\text { achieved; and }\end{array}$ & See (2) above. \\
\hline $\begin{array}{l}\text { (d) Activities and plans for achieving final disposal of } \\
\text { the waste. }\end{array}$ & See (2) above. \\
\hline I. Waste Characterization. Transuranic waste shall be & LWP-8300 \\
\hline $\begin{array}{l}\text { characterized using direct or indirect methods, and the } \\
\text { characterization documented in sufficient detail to }\end{array}$ & RSWF-OI-003 $§ 4$ and Appendix A \\
\hline ensure safe management and compliance with the & PER-116, Module II.C \\
\hline $\begin{array}{l}\text { the waste. } \\
\text { the recenting }\end{array}$ & PER-116, Attachment 2 \\
\hline $\begin{array}{l}\text { From DOE G } 435.1-1 \text { Chapter III: Compliance with } \\
\text { this requirement is demonstrated by a program for } \\
\text { documenting and the existence of records that } \\
\text { document the process for acquiring and verifying the } \\
\text { validity of transuranic waste characterization data } \\
\text { acquired through the use of direct or indirect methods. }\end{array}$ & SD-38.1.1, Appendix A and Appendix E \\
\hline $\begin{array}{l}\text { (1) Data Quality Objectives. The data quality } \\
\text { objectives process, or a comparable process, shall be } \\
\text { used for identifying characterization parameters and } \\
\text { acceptable uncertainty in characterization data. }\end{array}$ & $\begin{array}{l}\text { Radioactive waste management facilities characterize waste in } \\
\text { accordance with the requirements of the receiving storage, } \\
\text { treatment, or disposal facility. The documented use of a data } \\
\text { quality objectives process, or comparable process, was not }\end{array}$ \\
\hline $\begin{array}{l}\text { From DOE G } 435.1-1 \text { Chapter III: Compliance with } \\
\text { this requirement is demonstrated by the documented } \\
\text { use of a data quality objectives or a comparable } \\
\text { process for determining the type, quantity, and quality } \\
\text { of characterization data needed to safely manage } \\
\text { transuranic waste. }\end{array}$ & \\
\hline
\end{tabular}


Table 9. (continued).

\begin{tabular}{|c|c|}
\hline \multicolumn{2}{|c|}{ MFC-771 Radioactive Scrap and Waste Facility } \\
\hline Chapter III. Transuranic Waste Requirements & Facility Compliance Information \\
\hline $\begin{array}{l}\text { (2) Minimum Waste Characterization. } \\
\text { Characterization data shall, at a minimum, include the } \\
\text { following information relevant to the management of } \\
\text { the waste: }\end{array}$ & $\begin{array}{l}\text { LWP-8300 } \\
\text { RSWF-OI-003 § 3, 4, and Appendix A } \\
\text { PER-116, Module II.C }\end{array}$ \\
\hline From DOE G 435.1-1 Chapter III: Compliance with & PER-116, Attachment 2 \\
\hline $\begin{array}{l}\text { program or procedures for determining and records } \\
\text { that document characterization of transuranic waste } \\
\text { consistent with the minimum characterization data } \\
\text { requirements. }\end{array}$ & $\begin{array}{l}\text { SD-38.1.1, Appendix A, Appendix E, and IWTS Material and } \\
\text { Waste Characterization Profile }\end{array}$ \\
\hline (a) Physical and chemical characteristics; & See I. and (2) above. \\
\hline $\begin{array}{l}\text { (b) Volume, including the waste and any stabilization } \\
\text { or absorbent media; }\end{array}$ & See I. and (2) above. \\
\hline (c) Weight of the container and contents; & See I. and (2) above. \\
\hline $\begin{array}{l}\text { (d) Identities, activities, and concentrations of major } \\
\text { radionuclides; }\end{array}$ & See I. and (2) above. \\
\hline (e) Characterization date; & See I. and (2) above. \\
\hline (f) Generating source; & See I. and (2) above. \\
\hline (g) Packaging date; and & See I. and (2) above. \\
\hline $\begin{array}{l}\text { (h) Any other information which may be needed to } \\
\text { prepare and maintain the disposal facility performance } \\
\text { assessment or demonstrate compliance with applicable } \\
\text { performance objectives. }\end{array}$ & See I. and (2) above. \\
\hline $\begin{array}{l}\text { J. Waste Certification. A waste certification program } \\
\text { shall be developed, documented, and implemented to } \\
\text { ensure that the waste acceptance requirements of } \\
\text { facilities receiving transuranic waste for storage, } \\
\text { treatment, or disposal are met. } \\
\text { From DOE G 435.1-1 Chapter III: Compliance with } \\
\text { the development and documentation portion of the } \\
\text { certification requirement is demonstrated by a waste } \\
\text { certification plan that identifies the organizations } \\
\text { involved, assigns responsibilities for implementing the } \\
\text { program, and describes or references the quality } \\
\text { assurance, training, procurement controls, records } \\
\text { management, and procedures to be used by the } \\
\text { program. Acceptable performance for implementing } \\
\text { the program is demonstrated when the appropriate } \\
\text { personnel are trained, and have and follow the } \\
\text { procedures that govern their part of the waste } \\
\text { certification process. Acceptable performance also } \\
\text { requires that the waste certification plan and } \\
\text { procedures are current and controlled in accordance } \\
\text { with a document control program, and records related } \\
\text { to certification (e.g., certification statements, training }\end{array}$ & $\begin{array}{l}\text { LWP-8300 } \\
\text { PER-116 } \\
\text { RSWF-OI-003 } \S 3,4 \text {, and Appendix A } \\
\text { RSWF-OI-003 } § 1 \text { states that "to the extent possible, the WAC } \\
\text { for RSWF complies with the WAC for various treatment or } \\
\text { disposal facilities that could be the ultimate destination of the } \\
\text { waste. Since there is not a disposal facility with waste } \\
\text { acceptance criteria for some of the types of waste stored at } \\
\text { RSWF, compliance with this procedure does not ensure } \\
\text { compliance with all transport systems or treatment/disposal } \\
\text { facility acceptance criteria." } \\
\text { RSWF-OI-004 }\end{array}$ \\
\hline
\end{tabular}


Table 9. (continued).

\begin{tabular}{|c|c|}
\hline \multicolumn{2}{|c|}{ MFC-771 Radioactive Scrap and Waste Facility } \\
\hline Chapter III. Transuranic Waste Requirements & Facility Compliance Information \\
\hline $\begin{array}{l}\text { records, procurement records, characterization records, } \\
\text { container records) are generated and managed in } \\
\text { accordance with the established site program. }\end{array}$ & \\
\hline $\begin{array}{l}\text { (1) Certification Program. The waste certification } \\
\text { program shall designate the officials who have the } \\
\text { authority to certify and release waste for shipment; and } \\
\text { specify what documentation is required for waste } \\
\text { generation, characterization, shipment, and } \\
\text { certification. The program shall provide requirements } \\
\text { for auditability, retrievability, and storage of required } \\
\text { documentation and specify the records retention } \\
\text { period. }\end{array}$ & See J. above. \\
\hline $\begin{array}{l}\text { From DOE G } 435.1-1 \text { Chapter III: Compliance with } \\
\text { this requirement is demonstrated by a program or } \\
\text { procedure for record keeping and records showing that } \\
\text { each container of waste is certified as having met the } \\
\text { waste acceptance criteria of the facility to which it was } \\
\text { transferred and the certification statement is supported } \\
\text { by additional records regarding the waste source, } \\
\text { characterization, and container. }\end{array}$ & \\
\hline $\begin{array}{l}\text { (2) Certification before Transfer. Transuranic waste } \\
\text { shall be certified as meeting waste acceptance } \\
\text { requirements before it is transferred to the facility } \\
\text { receiving the waste. }\end{array}$ & See J. above. \\
\hline $\begin{array}{l}\text { From DOE G 435.1-1 Chapter III: Compliance with } \\
\text { this requirement is demonstrated by the presence of a } \\
\text { certification program which includes procedures } \\
\text { requiring a signed certification statement prior to the } \\
\text { release of waste for transfer, and by dated records } \\
\text { showing that waste was certified before being } \\
\text { transferred. }\end{array}$ & \\
\hline $\begin{array}{l}\text { (3) Maintaining Certification. Transuranic waste that } \\
\text { has been certified as meeting the waste acceptance } \\
\text { requirements for transfer to a storage, treatment, or } \\
\text { disposal facility shall be managed in a manner that } \\
\text { maintains its certification status. }\end{array}$ & $\begin{array}{l}\text { See J. above. } \\
\text { LWP- } 15011 \S 5 \text { provides general radioactive storage area } \\
\text { requirements. }\end{array}$ \\
\hline $\begin{array}{l}\text { From DOE G } 435.1-1 \text { Chapter III: Compliance with } \\
\text { this requirement is demonstrated by the existence of a } \\
\text { program or procedure reflecting this requirement and } \\
\text { site personnel able to show that the storage of } \\
\text { containers of waste is in a facility or manner where the } \\
\text { containers are not damaged by normal weather events, } \\
\text { and cannot be accessed by unauthorized personnel. } \\
\text { Further, each container can be traced to its } \\
\text { certification and the information supporting that } \\
\text { certification. }\end{array}$ & \\
\hline
\end{tabular}


Table 9. (continued).

\begin{tabular}{|c|c|}
\hline \multicolumn{2}{|c|}{ MFC-771 Radioactive Scrap and Waste Facility } \\
\hline Chapter III. Transuranic Waste Requirements & Facility Compliance Information \\
\hline $\begin{array}{l}\text { K. Waste Transfer. A documented process shall be } \\
\text { established and implemented for transferring } \\
\text { responsibility for management of transuranic waste } \\
\text { and for ensuring availability of relevant data. The } \\
\text { following requirements are in addition to those in } \\
\text { Chapter I of this Manual. }\end{array}$ & RSWF-OI-004 \\
\hline $\begin{array}{l}\text { From DOE G } 435.1-1 \text { Chapter III: Compliance with } \\
\text { this requirement is demonstrated if facilities have } \\
\text { procedures for the receipt of waste and the transfer of } \\
\text { waste, as appropriate, which address the acquisition of } \\
\text { waste and container data and the transfer of } \\
\text { ownership, respectively. Further evidence of } \\
\text { acceptable performance is facility records showing } \\
\text { that data on the waste containers are available and } \\
\text { accurate, and that documented transfer of } \\
\text { responsibility occurs. }\end{array}$ & \\
\hline $\begin{array}{l}\text { (1) Authorization. Transuranic waste shall not be } \\
\text { transferred to a storage, treatment, or disposal facility } \\
\text { until personnel responsible for the facility receiving } \\
\text { the waste authorize the transfer. }\end{array}$ & See K. above. \\
\hline $\begin{array}{l}\text { From DOE G } 435.1-1 \text { Chapter III: Compliance with } \\
\text { this requirement is demonstrated by sites having } \\
\text { procedures that require a confirmation of authorization } \\
\text { before releasing waste for transfer, and records } \\
\text { showing that transfers are made in accordance with } \\
\text { written authorizations. }\end{array}$ & \\
\hline $\begin{array}{l}\text { (2) Data. Waste characterization data, container } \\
\text { information, and generation, storage, treatment, and } \\
\text { transportation information for transuranic waste shall } \\
\text { be transferred with or be traceable to the waste. }\end{array}$ & See K. above. \\
\hline $\begin{array}{l}\text { From DOE G } 435.1-1 \text { Chapter III: Compliance with } \\
\text { this requirement is demonstrated if there are } \\
\text { procedures requiring that characterization and } \\
\text { container data be provided and maintained for each } \\
\text { waste transfer and documented records of transfers } \\
\text { show that the information is being provided. }\end{array}$ & \\
\hline $\begin{array}{l}\text { L. Packaging and Transportation. The following } \\
\text { requirements are in addition to those in Chapter I of } \\
\text { this Manual. }\end{array}$ & See (1) and (2) below. \\
\hline (1) Packaging. & LWP-8300 \\
\hline From DOE G 435.1-1 Chapter III: Compliance with & RSWF-OI-003 $§ 4$ \\
\hline $\begin{array}{l}\text { the packaging requirement is demonstrated by } \\
\text { procedures which document proper packaging }\end{array}$ & PER-116, Module II.C and V \\
\hline protocols, including documented evidence that, where & PER-116, Attachment $1 \S \mathrm{D}-5$ \\
\hline $\begin{array}{l}\text { feasible, non-defense transuranic waste has been } \\
\text { packaged separately from defense transuranic waste }\end{array}$ & SD-38.1.1, Appendix A and Appendix E \\
\hline and by never having to repackage transuranic waste & The remote-handled TRU waste is not segregated because all of \\
\hline
\end{tabular}


Table 9. (continued).

\begin{tabular}{|c|c|}
\hline \multicolumn{2}{|c|}{ MFC-771 Radioactive Scrap and Waste Facility } \\
\hline Chapter III. Transuranic Waste Requirements & Facility Compliance Information \\
\hline $\begin{array}{l}\text { that is packaged after issuance of DOE O } 435.1 \text { in } \\
\text { order to maintain containment. However, the above } \\
\text { protocol may not be satisfied by containers that were } \\
\text { placed in storage prior to issuance of the DOE O } \\
435.1 \text {. For those containers, the goal is to only have to } \\
\text { repackage the waste one time after it is retrieved and } \\
\text { characterized. Further, acceptable performance is } \\
\text { demonstrated by containers of waste having marking } \\
\text { and labeling that allows correlation with waste } \\
\text { characterization data and container information. } \\
\text { Successful performance of this requirement is also } \\
\text { demonstrated by a record of container performance in } \\
\text { which failure has not routinely occurred. }\end{array}$ & $\begin{array}{l}\text { the waste is expected to be defense waste (INL/EXT-10-17600 } \\
\text { and ANL-NT-192). The Waste Isolation Pilot Plant Central } \\
\text { Characterization Project prepares the acceptable knowledge } \\
\text { documentation for the remote-handled TRU waste. This } \\
\text { documentation also relies heavily on ANL-NT-192. }\end{array}$ \\
\hline $\begin{array}{l}\text { (a) Transuranic waste shall be packaged in a manner } \\
\text { that provides containment and protection for the } \\
\text { duration of the anticipated storage period and until } \\
\text { disposal is achieved or until the waste is removed from } \\
\text { the container. }\end{array}$ & See (1) above. \\
\hline $\begin{array}{l}\text { (b) Vents or other mechanisms to prevent } \\
\text { pressurization of containers or generation of } \\
\text { flammable or explosive concentrations of gases shall } \\
\text { be installed on containers of newly-generated waste at } \\
\text { the time the waste is packaged. Containers of currently } \\
\text { stored waste shall meet this requirement as soon as } \\
\text { practical unless analyses demonstrate that the waste } \\
\text { can otherwise be managed safely. }\end{array}$ & $\begin{array}{l}\text { See (1) above. } \\
\text { The storage containers, including the absence of venting, have } \\
\text { been evaluated (SAR- } 407) \text {. }\end{array}$ \\
\hline $\begin{array}{l}\text { From DOE G 435.1-1 Chapter III: In developing the } \\
\text { radioactive waste management basis, site personnel } \\
\text { need to consider the hazards associated with drums of } \\
\text { transuranic waste which have not been provided with } \\
\text { vents or been proven to not need vents through an } \\
\text { approved safety analysis. For unvented containers in } \\
\text { earthen-covered storage, the facility itself may } \\
\text { mitigate the hazards associated with the accumulation } \\
\text { of gases. For above-grade storage of transuranic waste } \\
\text { containers, the radioactive waste management basis } \\
\text { needs to include controls which mitigate the hazards } \\
\text { associated with the accumulation of gases by } \\
\text { restricting access to the storage area and providing } \\
\text { equipment to protect against fire or explosion. }\end{array}$ & \\
\hline $\begin{array}{l}\text { (c) When transuranic waste is packaged, defense waste } \\
\text { shall be packaged separately from non-defense waste, } \\
\text { if feasible. }\end{array}$ & See (1) above. \\
\hline $\begin{array}{l}\text { (d) Containers of transuranic waste shall be marked } \\
\text { such that their contents can be identified. }\end{array}$ & See (1) above. \\
\hline $\begin{array}{l}\text { (2) Transportation. To the extent practical, the volume } \\
\text { of waste and number of transuranic waste shipments } \\
\text { shall be minimized. }\end{array}$ & NA; waste is not shipped for offsite disposal from this facility. \\
\hline
\end{tabular}


Table 9. (continued).

\begin{tabular}{|c|c|}
\hline \multicolumn{2}{|c|}{ MFC-771 Radioactive Scrap and Waste Facility } \\
\hline Chapter III. Transuranic Waste Requirements & Facility Compliance Information \\
\hline $\begin{array}{l}\text { From DOE G 435.1-1 Chapter III: Compliance with } \\
\text { this requirement can be demonstrated by a } \\
\text { combination of site procedures directing the efficient } \\
\text { use of waste container capacity and documentation } \\
\text { showing that transuranic waste shipments are } \\
\text { systematically planned and make optimal use of the } \\
\text { shipment system (e.g., TRUPACT II) to the extent } \\
\text { practical. }\end{array}$ & \\
\hline $\begin{array}{l}\text { M. Site Evaluation and Facility Design. The following } \\
\text { requirements are in addition to those in Chapter I of } \\
\text { this Manual. }\end{array}$ & $\begin{array}{l}\text { NA; this requirement addresses new radioactive waste } \\
\text { management facilities or modifications to existing facilities. }\end{array}$ \\
\hline $\begin{array}{l}\text { (1) Site Evaluation. Proposed locations for transuranic } \\
\text { waste facilities shall be evaluated to identify relevant } \\
\text { features that should be avoided or must be considered } \\
\text { in facility design and analyses. }\end{array}$ & See M. above. \\
\hline $\begin{array}{l}\text { (a) Each site proposed for a new transuranic waste } \\
\text { facility or expansion of an existing transuranic waste } \\
\text { facility shall be evaluated considering environmental } \\
\text { characteristics, geotechnical characteristics, and } \\
\text { human activities. }\end{array}$ & See M. above. \\
\hline $\begin{array}{l}\text { (b) Proposed sites with environmental characteristics, } \\
\text { geotechnical characteristics, and human activities for } \\
\text { which adequate protection cannot be provided through } \\
\text { facility design shall be deemed unsuitable for the } \\
\text { location of the facility. }\end{array}$ & See M. above. \\
\hline $\begin{array}{l}\text { (2) Facility Design. The following facility } \\
\text { requirements and general design criteria, at a } \\
\text { minimum, apply: }\end{array}$ & See M. above. \\
\hline $\begin{array}{l}\text { (a) Confinement. Transuranic waste systems and } \\
\text { components shall be designed to maintain waste } \\
\text { confinement. }\end{array}$ & See M. above. \\
\hline (b) Ventilation. & See M. above. \\
\hline $\begin{array}{l}1 \text { Design of transuranic waste treatment and storage } \\
\text { facilities shall include ventilation, if applicable, } \\
\text { through an appropriate filtration system to maintain } \\
\text { the release of radioactive material in airborne effluents } \\
\text { within the requirements and guidelines specified in } \\
\text { applicable requirements. }\end{array}$ & See M. above. \\
\hline $\begin{array}{l}2 \text { When conditions exist for generating gases in } \\
\text { flammable or explosive concentrations in treatment or } \\
\text { storage facilities, ventilation or other measures shall be } \\
\text { provided to keep the gases in a non-flammable and } \\
\text { non-explosive condition. Where concentrations of } \\
\text { explosive or flammable gases are expected to } \\
\text { approach the lower flammability limit, measures shall } \\
\text { be taken to prevent deflagration or detonation. }\end{array}$ & See M. above. \\
\hline
\end{tabular}


Table 9. (continued).

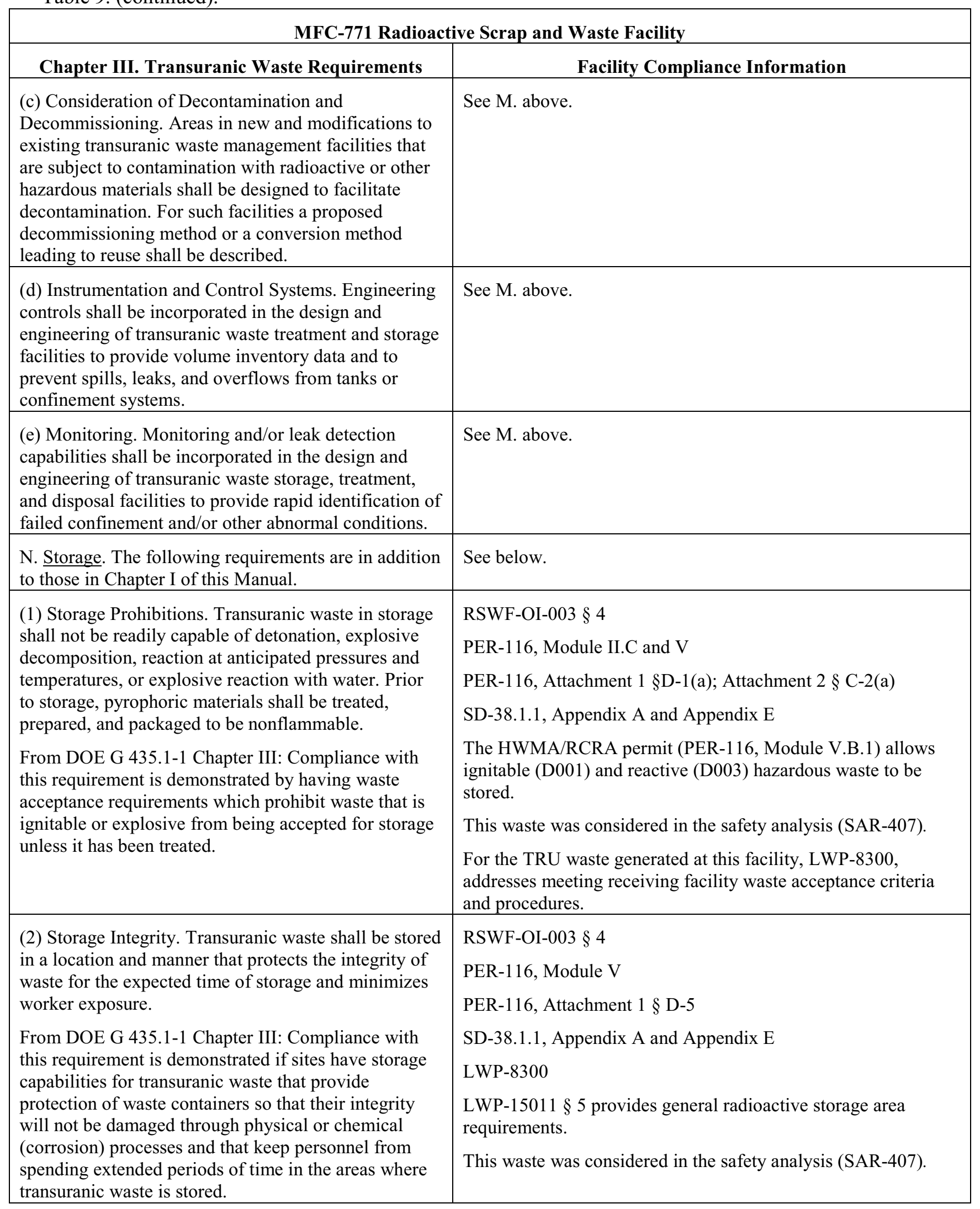


Table 9. (continued).

\begin{tabular}{|c|c|}
\hline \multicolumn{2}{|c|}{ MFC-771 Radioactive Scrap and Waste Facility } \\
\hline Chapter III. Transuranic Waste Requirements & Facility Compliance Information \\
\hline $\begin{array}{l}\text { (3) Container Inspection. A process shall be developed } \\
\text { and implemented for inspecting and maintaining } \\
\text { containers of transuranic waste to ensure container } \\
\text { integrity is not compromised. } \\
\text { From DOE G 435.1-1 Chapter III: Compliance with } \\
\text { this requirement is demonstrated by a documented } \\
\text { process for waste container inspection and } \\
\text { maintenance at every facility managing transuranic } \\
\text { waste, and documentation for all waste container } \\
\text { inspections and maintenance actions performed. }\end{array}$ & $\begin{array}{l}\text { LI-435 requires quarterly inspections of radioactive waste } \\
\text { containers if waste is stored outdoors or has been in storage for } \\
\text { greater than } 1 \text { year. } \\
\text { LWP-8300 } \\
\text { LWP-15011 does not include a requirement for inspection. } \\
\text { RSWF-OI-006 } § 2.3 \text { requires weekly inspection of the cathodic } \\
\text { protection system. } \\
\text { For mixed LLW: } \\
\text { PER-116, Module V.F } \\
\text { PER-116, Attachment } 4 \text {, F-2(b)(3); Attachment F-3 } \\
\text { SD-38.1.1, Appendix A and Appendix E. } \\
\text { Although the permit addresses mixed waste only, the inspection } \\
\text { of the cathodic protection system applies to the entire facility. } \\
\text { Therefore, with state agreement, the cathodic protection system } \\
\text { inspection provisions address all liners in the facility. }\end{array}$ \\
\hline $\begin{array}{l}\text { (4) Retrievable Earthen-Covered Storage. Plans for the } \\
\text { removal of transuranic waste from retrievable earthen- } \\
\text { covered storage facilities shall be established and } \\
\text { maintained. Prior to commencing waste retrieval } \\
\text { activities, each waste storage site shall be evaluated to } \\
\text { determine relevant information on types, quantities, } \\
\text { and location of radioactive and hazardous chemicals as } \\
\text { necessary to protect workers during the retrieval } \\
\text { process. }\end{array}$ & NA; this facility is not an earthen-covered storage facility. \\
\hline $\begin{array}{l}\text { O. Treatment. Transuranic waste shall be treated as } \\
\text { necessary to meet the waste acceptance requirements } \\
\text { of the facility receiving the waste for storage or } \\
\text { disposal. } \\
\text { From DOE G } 435.1-1 \text { Chapter III: Compliance with } \\
\text { this requirement is demonstrated by the custodian of } \\
\text { transuranic waste maintaining documentation which } \\
\text { identifies the plans for treating waste, and maintaining } \\
\text { the records that show waste was treated, if necessary, } \\
\text { to meet the waste acceptance requirements of the } \\
\text { storage or disposal facility to which it was transferred. }\end{array}$ & NA; treatment is not performed at this facility. \\
\hline $\begin{array}{l}\text { P. Disposal. Transuranic waste shall be disposed in } \\
\text { accordance with the requirements of } 40 \text { CFR Part 191, } \\
\text { Environmental Radiation Protection Standards for } \\
\text { Management and Disposal of Spent Nuclear Fuel, } \\
\text { High-Level and Transuranic Radioactive Wastes. }\end{array}$ & NA; TRU waste is not disposed of at this facility. \\
\hline $\begin{array}{l}\text { Q. Monitoring. The following requirements are in } \\
\text { addition to those in Chapter I of this Manual. }\end{array}$ & See (1), (2), and (3) below. \\
\hline (1) All Waste Facilities. Parameters that shall be & Monitoring requirements at INL radioactive waste management \\
\hline
\end{tabular}


Table 9. (continued).

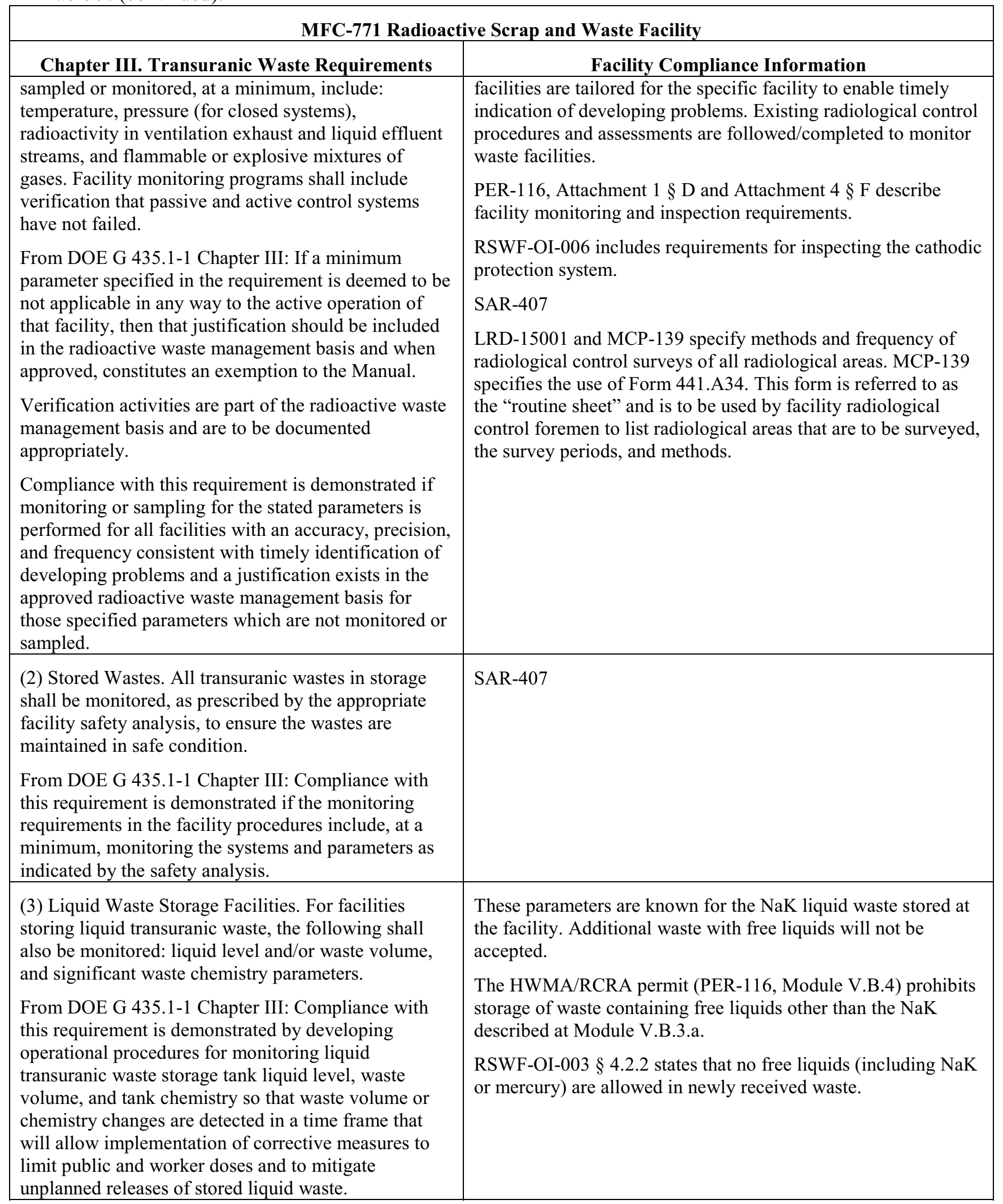


Table 10. MFC-771, Radioactive Scrap and Waste Facility, DOE Manual 435.1-1 low-level waste requirements and facility compliance information.

\begin{tabular}{|c|c|}
\hline \multicolumn{2}{|c|}{ MFC-771, Radioactive Scrap and Waste Facility } \\
\hline Chapter IV, LLW Requirements & Facility Compliance Information \\
\hline $\begin{array}{l}\text { A. Definition of Low-Level Waste. Low-level } \\
\text { radioactive waste is radioactive waste that is not high- } \\
\text { level radioactive waste, spent nuclear fuel, transuranic } \\
\text { waste, byproduct material (as defined in section } 11 \mathrm{e} .(2) \\
\text { of the Atomic Energy Act of } 1954 \text {, as amended), or } \\
\text { naturally occurring radioactive material. } \\
\text { (From DOE G } 435.1-1 \text { Chapter IV: Low-level } \\
\text { radioactive waste is defined by what it is not. The } \\
\text { guidance on definitions in Chapters II and III should be } \\
\text { consulted first for making a determination on how to } \\
\text { properly manage a suspect waste stream.) }\end{array}$ & $\begin{array}{l}\text { This requirement provides the criteria for determining } \\
\text { which DOE radioactive waste is to be managed as } \\
\text { LLW in accordance with DOE Manual } 435.1-1 \text {, } \\
\text { Chapter IV. } \\
\text { Radioactive waste managed at this facility under the } \\
\text { requirements of this chapter is not managed under the } \\
\text { requirements of DOE Manual } 435.1-1 \text {, Chapter II or } \\
\text { Chapter III. }\end{array}$ \\
\hline $\begin{array}{l}\text { B. Management of Specific Wastes. The following } \\
\text { provide for management of specific wastes as low-level } \\
\text { waste in accordance with the requirements in this } \\
\text { Chapter: }\end{array}$ & See below. \\
\hline $\begin{array}{l}\text { (1) Mixed Low-Level Waste. Low-level waste } \\
\text { determined to contain both source, special nuclear, or } \\
\text { byproduct material subject to the Atomic Energy Act of } \\
\text { 1954, as amended, and a hazardous component subject } \\
\text { to the Resource Conservation and Recovery Act } \\
\text { (RCRA), as amended, shall be managed in accordance } \\
\text { with the requirements of RCRA and DOE O 435.1, } \\
\text { Radioactive Waste Management, and this Manual. }\end{array}$ & $\begin{array}{l}\text { This facility is has a HWMA/RCRA permit to store } \\
\text { mixed waste (PER-116). }\end{array}$ \\
\hline $\begin{array}{l}\text { (2) TSCA-Regulated Waste. Low-level waste } \\
\text { containing polychlorinated biphenyls, asbestos, or } \\
\text { other such regulated toxic components shall be } \\
\text { managed in accordance with requirements derived from } \\
\text { the Toxic Substances Control Act, as amended, DOE O } \\
\text { 435.1, Radioactive Waste Management, and this } \\
\text { Manual. }\end{array}$ & $\begin{array}{l}\text { NA; this facility does not manage TSCA-regulated } \\
\text { waste. }\end{array}$ \\
\hline $\begin{array}{l}\text { (3) Accelerator-Produced Waste. Radioactive waste } \\
\text { produced as a result of operations of DOE accelerators } \\
\text { is low-level waste and shall be managed in accordance } \\
\text { with DOE O 435.1, Radioactive Waste Management, } \\
\text { and this Manual, and all applicable Federal or State } \\
\text { requirements. }\end{array}$ & $\begin{array}{l}\text { NA; this facility does not manage accelerator-produced } \\
\text { waste. }\end{array}$ \\
\hline $\begin{array}{l}\text { (4) } 11 \text { e.(2) and Naturally Occurring Radioactive } \\
\text { Material. Small quantities of } 11 \text { e.(2) byproduct } \\
\text { material and naturally occurring radioactive material } \\
\text { may be managed as low-level waste provided they can } \\
\text { be managed to meet the requirements for low-level } \\
\text { waste disposal in Section IV.P of this Manual. }\end{array}$ & $\begin{array}{l}\text { NA; this facility does not manage naturally occurring } \\
\text { radioactive material. }\end{array}$ \\
\hline
\end{tabular}


Table 10. (continued).

\section{MFC-771, Radioactive Scrap and Waste Facility}

\begin{tabular}{l}
\hline \multicolumn{1}{|c|}{ Chapter IV, LLW Requirements } \\
\hline C. Complex-Wide Low-Level Waste Management \\
$\underline{\text { Program. A complex-wide program and plan shall be }}$ \\
developed as described under Responsibilities, 2.B and \\
2.D, in Chapter I of this Manual.
\end{tabular}

D. Radioactive Waste Management Basis. Low-level waste facilities, operations, and activities shall have a radioactive waste management basis consisting of physical and administrative controls to ensure the protection of workers, the public, and the environment. The following specific waste management controls shall be part of the radioactive waste management basis:

Not a facility-specific requirement. DOE Manual 435.1-1 §I.2.B and §I.2.D apply to the Assistant Secretary for Environmental Management and the Deputy Assistant Secretary for Waste Management, respectively.

The RWMB provides the regulatory framework for management of radioactive waste at INL. It specifically identifies facility management and implementing documents for the generation, storage, treatment, and disposal of radiological waste.

This facility is a Hazard Category 2 non-reactor nuclear facility (SAR-407). The facility's safety basis list and approval are identified in LST-305.

IAG-264 documents DOE's approval of Battelle Energy Alliance's safety basis that is defined in LST305.

(1) Generators. The waste certification program.

NA; this facility does not generate LLW.

From DOE G 435.1-1 Chapter IV: For a facility that generates low-level waste, the radioactive waste management basis is to include the program for certifying that waste meets the waste acceptance requirements of the facility(ies) to which the waste will be sent.

(2) Treatment Facilities. certification program. The waste acceptance requirements and the waste $[\mathrm{sic}]$

From DOE G 435.1-1 Chapter IV: Facilities that store or treat low-level waste are to have approved waste acceptance requirements (see DOE M 435.1-1, Section IV.G) prior to the issuance of a radioactive waste management basis.

A facility that stores or treats waste also is generally expected to have a waste certification program. Waste from these facilities will have to be certified as meeting the waste acceptance requirements of the facility to which it will be transferred, and the facilities have the potential for generating radioactive waste (e.g., secondary processing streams from treatment, monitoring and sampling, radioactive release cleanup). Consequently, storage and treatment facilities should also have an approved waste certification program as part of their radioactive waste management basis.

As part of the radioactive waste management basis, site personnel needs to implement a system or process for tracking the waste inventory at a storage, treatment, or disposal facility.

(3) Storage Facilities. The waste acceptance
NA; waste is not treated at this facility. 
Table 10. (continued).

\section{MFC-771, Radioactive Scrap and Waste Facility}

\begin{abstract}
Chapter IV, LLW Requirements
requirements and the waste certification program.

From DOE G 435.1-1 Chapter IV: Facilities that store or treat low-level waste are to have approved waste acceptance requirements (see DOE M 435.1-1, Section IV.G) prior to the issuance of a radioactive waste management basis.

A facility that stores or treats waste also is generally expected to have a waste certification program. Waste from these facilities will have to be certified as meeting the waste acceptance requirements of the facility to which it will be transferred, and the facilities have the potential for generating radioactive waste (e.g., secondary processing streams from treatment, monitoring and sampling, radioactive release cleanup). Consequently, storage and treatment facilities should also have an approved waste certification program as part of their radioactive waste management basis.

As part of the radioactive waste management basis, site personnel needs to implement a system or process for tracking the waste inventory at a storage, treatment, or disposal facility.
\end{abstract}

(4) Disposal Facilities. The performance assessment, composite analysis, disposal authorization statement, closure plan, waste acceptance requirements, and monitoring plan.

E. Contingency Actions. The following requirements are in addition to those in Chapter I of this Manual [DOE M 435.1-1 §I.1.E(5)].

(1) Contingency Storage. For off-normal or emergency situations involving high activity or high hazard liquid low-level waste storage or treatment, spare capacity with adequate capabilities shall be maintained to receive the largest volume of liquid contained in any one storage tank or treatment facility. Tanks or other facilities that are designated low-level waste contingency storage shall be maintained in an operational condition when waste is present and shall meet the requirements of DOE O 435.1, Radioactive Waste Management, and this Manual.

From DOE G 435.1-1 Chapter IV: Compliance with these requirements is demonstrated if adequate spare capacity and transfer equipment exists for emergency transfers of all high activity and high hazard liquid low-level waste. In addition, the capability to perform

\section{Facility Compliance Information}

MCP-17000 § 4 specifies the use of IWTS, which tracks the waste inventory.

RSWF-OI-003 $\S 3.2$ indicates that waste must be traced using IWTS.

NA; this facility is not a disposal facility.

Not a facility-specific requirement. DOE Manual 435.1-1 §I.1.E(5) addresses the sitewide emergency management system. The INL plan is provided in PLN-114.

The HWMA/RCRA permit also includes a contingency plan (PER-116, Attachment 7 § G).

$\mathrm{NA}$; this facility does not store or treat liquid waste in tanks. 
Table 10. (continued).

MFC-771, Radioactive Scrap and Waste Facility

\begin{tabular}{l} 
Chapter IV, LLW Requirements \\
\hline emergency transfers is demonstrated by having waste \\
transfer routings identified, operational procedures to \\
direct transfers, staff trained to the procedures, and \\
records showing that the spare capacity and transfer \\
capability are kept in operating condition. \\
\hline (2) Transfer Equipment. Pipelines and auxiliary \\
facilities necessary for the transfer of high activity or \\
high hazard liquid low-level waste to contingency \\
storage shall be maintained in an operational condition \\
when waste is present and shall meet the requirements \\
of DOE O 435.1, Radioactive Waste Management, and \\
this Manual. \\
From DOE G $435.1-1$ Chapter IV: Compliance with \\
these requirements is demonstrated if adequate spare \\
capacity and transfer equipment exists for emergency \\
transfers of all high activity and high hazard liquid \\
low-level waste. In addition, the capability to perform \\
emergency transfers is demonstrated by having waste \\
transfer routings identified, operational procedures to \\
direct transfers, staff trained to the procedures, and \\
records showing that the spare capacity and transfer \\
capability are kept in operating condition.
\end{tabular}

F. Corrective Actions. I of this Manual. The following requirements are in addition to those in Chapter [sic]

From DOE G 435.1-1 Chapter IV: Compliance with DOE M 435.1-1 §I.2.G.(1) is demonstrated by records showing what corrective actions were taken to remedy situations in the radioactive waste management system.

Compliance with DOE M 435.1-1 §I.2.G.(2) is demonstrated by having the necessary procedures, mechanisms, and training in place to effect shutdown or curtailment of activities which pose an imminent danger or other serious hazard to workers or the public, or are not protective of the environment.

(1) Order Compliance. Corrective actions shall be implemented whenever necessary to ensure the requirements of DOE O 435.1, Radioactive Waste Management, and this Manual are met.

From DOE G 435.1-1 Chapter IV: If a facility or activity can be allowed to operate while a noncompliant or hazardous condition exists, the allowance and any associated limitations must be defined as part of the facility or activity's radioactive waste management basis, identified as a configuration controlled item in a configuration management plan or included in a revision or modification to an operating procedure or similar controlled documentation.
NA; this facility does not store or treat liquid waste in tanks.

The INL-wide procedure addressing problem identification as required by DOE Manual 435.1-1 $\S$ I.2.G.(1) is LWP-13840, which implements the laboratory's corrective action system.

The INL-wide procedure addressing shutdown or curtailment of activities as required by DOE Manual 435.1-1 §I.2.G.(2) is LWP-14002.

See F. above.

This facility has a HWMA/RCRA permit to store and treat mixed LLW.

Corrective actions for waste regulated under this permit are addressed as permit conditions.

PER-116, Module VI

PER-116, Attachment 4

SD-38.1.1 $\S 2.4,6$, and Appendix A 
Table 10. (continued).

MFC-771, Radioactive Scrap and Waste Facility

\begin{tabular}{|l|}
\hline \multicolumn{1}{|c|}{ Chapter IV, LLW Requirements } \\
\hline Compliance with this requirement is demonstrated if a \\
corrective action system addresses noncompliant or \\
hazardous situations involving low-level waste \\
management facilities in a systematic fashion, and \\
allows identification of problems by all personnel.
\end{tabular}

(2) Operations Curtailment. Operations shall be curtailed or facilities shut down for failure to establish, maintain, or operate consistent with an approved radioactive waste management basis.

From DOE G 435.1-1 Chapter IV: Compliance with this requirement is demonstrated with a documented system of routine assessments to determine whether waste management activities and facilities are operating in accordance with an approved radioactive waste management basis that provides for graded limitations that can be placed on activities and operations that do not have, or are operating outside of, an approved radioactive waste management basis, including shutdown of the facility.

G. Waste Acceptance. The following requirements are in addition to those in Chapter I of this Manual [DOE M 435.1-1 §I.2.F(6)].

(1) Technical and Administrative. Waste acceptance requirements for all low-level waste storage, treatment, or disposal facilities, operations, and activities shall specify, at a minimum, the following:

From DOE G 435.1-1 Chapter IV: Compliance with these waste acceptance requirements is demonstrated if they are documented, contain clear and precise criteria specifying the radionuclide limits in the form of contents or concentrations that can be accepted, the limitations and prohibitions on waste forms and packages that can be received, and the limits, prohibitions, or instructions concerning any other technical information so that the waste is compatible with the safety basis of the facility, and which will result in acceptable waste at subsequent steps in managing the low-level waste.

(a) Allowable activities and/or concentrations of specific radionuclides.

(b) Acceptable waste form and/or container requirements that ensure the chemical and physical stability of waste under conditions that might be encountered during transportation, storage, treatment, or disposal.

The approved RWMB establishes the current compliance status at each radioactive waste management facility. Facility assessments are scheduled to ensure waste management activities are conducted in accordance with the approved RWMB.

Not a facility-specific requirement. DOE Manual 435.1-1 §I.2.F(6) applies to field element managers.

See below.
MCP-17000

RSWF-OI- $003 \S 4$

MCP-17000

RSWF-OI-003 § 4

PER-116, Module II.C and V

PER-116, Attachment $1 \S \S$ B-2(a) and D-1(a); Attachment 2 \& C-2(a) 
Table 10. (continued).

\begin{tabular}{|c|c|}
\hline \multicolumn{2}{|c|}{ MFC-771, Radioactive Scrap and Waste Facility } \\
\hline Chapter IV, LLW Requirements & Facility Compliance Information \\
\hline & SD-38.1.1, Appendix A and Appendix E. \\
\hline (c) Restrictions or prohibitions on waste, materials, or & MCP-17000 \\
\hline containers that may adversely affect waste handlers or & RSWF-OI-003 § 4 \\
\hline & PER-116, Module II.C and V \\
\hline & $\begin{array}{l}\text { PER-116, Attachment } 1 \S \S \text { B-2(a) and D-1(a); } \\
\text { Attachment } 2 \S \text { C-2(a) }\end{array}$ \\
\hline & SD-38.1.1, Appendix A and Appendix E \\
\hline $\begin{array}{l}\text { (d) The following are additional waste acceptance } \\
\text { requirements that shall be specified in low-level waste } \\
\text { disposal facility waste acceptance requirements: }\end{array}$ & NA; this facility is not a LLW disposal facility. \\
\hline $\begin{array}{l}1 \text { Low-level waste must contribute to and not detract } \\
\text { from achieving long-term stability of the facility, } \\
\text { minimizing the need for long-term active maintenance, } \\
\text { minimizing subsidence, and minimizing contact of } \\
\text { water with waste. Void spaces within the waste and, if } \\
\text { containers are used, between the waste and its } \\
\text { container shall be reduced to the extent practical. }\end{array}$ & See (d) above. \\
\hline $\begin{array}{l}2 \text { Liquid low-level waste or low-level waste containing } \\
\text { free liquid must be converted into a form that contains } \\
\text { as little freestanding liquid as is reasonably achievable, } \\
\text { but in no case shall the liquid exceed } 1 \text { percent of the } \\
\text { waste volume when the low-level waste is in a disposal } \\
\text { container, or } 0.5 \text { percent of the waste volume after it is } \\
\text { processed to a stable form. }\end{array}$ & See (d) above. \\
\hline $\begin{array}{l}3 \text { Low-level waste must not be readily capable of } \\
\text { detonation or of explosive decomposition or reaction at } \\
\text { anticipated pressures and temperatures, or of explosive } \\
\text { reaction with water. Pyrophoric materials contained in } \\
\text { waste shall be treated, prepared, and packaged to be } \\
\text { nonflammable. }\end{array}$ & See (d) above. \\
\hline $\begin{array}{l}4 \text { Low-level waste must not contain, or be capable of } \\
\text { generating by radiolysis or biodegradation, quantities } \\
\text { of toxic gases, vapors, or fumes harmful to the public } \\
\text { or workers or disposal facility personnel, or harmful to } \\
\text { the long-term structural stability of the disposal site. }\end{array}$ & See (d) above. \\
\hline $\begin{array}{l}5 \text { Low-level waste in a gaseous form must be packaged } \\
\text { such that the pressure does not exceed } 1.5 \text { atmospheres } \\
\text { absolute at } 20 \mathrm{C} \text {. [ sic] }\end{array}$ & See (d) above. \\
\hline $\begin{array}{l}\text { (e) The basis, procedures, and levels of authority } \\
\text { required for granting exceptions to the waste } \\
\text { acceptance requirements, which shall be contained in } \\
\text { each facility's waste acceptance documentation. Each } \\
\text { exception request shall be documented, including its } \\
\text { disposition as approved or not approved. }\end{array}$ & $\begin{array}{l}\text { A letter from the site manager granting permission to } \\
\text { accept waste that does not meet the waste acceptance } \\
\text { requirements is needed. However, this process is not } \\
\text { documented. } \\
\text { COMPLIANCE CONSIDERATION }\end{array}$ \\
\hline
\end{tabular}


Table 10. (continued).

MFC-771, Radioactive Scrap and Waste Facility

\begin{tabular}{|c|}
\hline Chapter IV, LLW Requirements \\
\hline $\begin{array}{l}\text { From DOE G } 435.1-1 \text { Chapter IV: Waste acceptance } \\
\text { requirements are acceptable if they are documented and } \\
\text { contain a clear description of the procedure and bases } \\
\text { for obtaining an exception or deviation to the } \\
\text { acceptance criteria for low-level waste to be received at } \\
\text { the facility. }\end{array}$ \\
\hline
\end{tabular}

(2) Evaluation and Acceptance. The receiving facility shall evaluate waste for acceptance, including confirmation that the technical and administrative requirements have been met. A process for the disposition of non-conforming wastes shall be established.

From DOE G 435.1-1 Chapter IV: Compliance with the waste acceptance requirements for a low-level waste management facility is demonstrated if they include a process for evaluation and acceptance of incoming waste to ensure the acceptance criteria of the facility receiving the waste are met that includes one of or a combination of: (1) testing, sampling, and analysis of representative samples of waste upon receipt; (2) testing, sampling, and analysis of split samples of waste taken at the generator site; (3) evaluation of testing, sampling, and analysis of data provided by the generator, or (4) audits, reviews, surveillance, or observations of generator waste certification programs and characterization activities. Additionally, acceptable waste acceptance requirements for a storage, treatment or disposal facility will have documented procedures and actions to be taken if a waste that does not conform to the waste acceptance criteria is received at the facility.

H. Waste Generation Planning. The following requirements are in addition to those in Chapter I of this Manual [DOE M 435.1-1 §I.2.F(7)].

(1) Life-Cycle Planning. Prior to waste generation, planning shall be performed to address the entire life cycle for all low-level waste streams.

From DOE G 435.1-1 Chapter IV: Compliance with this planning requirement is demonstrated by the individual sites establishing a process for evaluating the life-cycle of low-level waste prior to its generation, including the identification of low-level wastes with no path to disposal and appropriate records justifying the newly generated low-level waste stream(s), and site personnel possessing planning information showing the location(s) where low-level waste will be stored, treated, and/or disposed along with a confirmation that the personnel managing the facilities agree that the
MCP-17000

RSWF-OI-003 $§ 3$

PER-116, Module II.C and V

PER-116, Attachment $1 \S$ D-1(b); Attachment $2 \S$ C2(a)

SD-38.1.1, Appendix A and Appendix E

Meeting permit and safety basis constraints are checked using an IWTS Material and Waste Characterization Profile.

\section{COMPLIANCE CONSIDERATION}

Evaluate whether non-conforming waste needs to be addressed in the facility's WAC and procedure.

Not a facility-specific requirement. DOE Manual 435.1-1 §I.2.F(7) applies to field element managers.

PDD-17000 and LWP-17000 provide direction to the waste generators for waste generation planning to address the entire life cycle. 
Table 10. (continued).

MFC-771, Radioactive Scrap and Waste Facility

\begin{tabular}{|l|}
\hline \multicolumn{1}{|c|}{ Chapter IV, LLW Requirements } \\
\hline low-level waste may be managed at those facilities. \\
\hline (2) Waste with No Identified Path to Disposal. Low- \\
level waste streams with no identified path to disposal \\
shall be generated only in accordance with approved \\
conditions which, at a minimum, shall address:
\end{tabular}

(a) Programmatic need to generate the waste;

(b) Characteristics and issues preventing the disposal of the waste;

(c) Safe storage of the waste until disposal can be achieved; and

(d) Activities and plans for achieving final disposal of the waste.

I. Waste Characterization. Low-level waste shall be characterized using direct or indirect methods, and the characterization documented in sufficient detail to ensure safe management and compliance with the waste acceptance requirements of the facility receiving the waste.

From DOE G 435.1-1 Chapter IV: Compliance with this requirement is demonstrated by a program for documenting and the existence of records that document the process for acquiring and verifying the validity of low-level waste characterization data acquired through the use of direct or indirect methods.

(1) Data Quality Objectives. The data quality objectives process, or a comparable process, shall be used for identifying characterization parameters and acceptable uncertainty in characterization data.

From DOE G 435.1-1 Chapter IV: Compliance with this requirement is demonstrated by the documented use of a data quality objectives or a comparable process for determining the type, quantity, and quality of characterization data needed to safely manage lowlevel waste.

(2) Minimum Waste Characterization. Characterization data shall, at a minimum, include the following information relevant to the management of the waste:

From DOE G 435.1-1 Chapter IV: Compliance with this requirement is demonstrated by the existence of a program or procedure for determining and records that document characterization of low-level waste consistent with the minimum characterization data requirements.
Facility Compliance Information

NA; this facility is not generating LLW that does not have an identified path to disposal.

See (2) above.

See (2) above.

See (2) above.

See (2) above.

MCP-17000

RSWF-OI-003 $§ 4$ and Appendix A

PER-116, Module II.C

PER-116, Attachment 2

SD-38.1.1, Appendix A and Appendix E

Radioactive waste management facilities characterize waste in accordance with the requirements of the receiving storage, treatment, or disposal facility. The documented use of a data quality objectives process, or comparable process, was not identified for this facility.

MCP-17000, including $\S \S 4.2,4.3$, and 4.4, provides waste characterization requirements. Information on absorbent media is required in $\S \S 4.5$ and 4.7.

MCP-17000 also specifies the use of IWTS, which documents characterization data in an IWTS profile.

RSWF-OI-003 §3, 4, and Appendix A

PER-116, Module II.C

PER-116, Attachment 2

SD-38.1.1, Appendix A and Appendix E 
Table 10. (continued).

\begin{tabular}{|c|c|}
\hline \multicolumn{2}{|c|}{ MFC-771, Radioactive Scrap and Waste Facility } \\
\hline Chapter IV, LLW Requirements & Facility Compliance Information \\
\hline & IWTS Material and Waste Characterization Profile \\
\hline (a) Physical and chemical characteristics; & See I. and (2) above. \\
\hline $\begin{array}{l}\text { (b) Volume, including the waste and any stabilization } \\
\text { or absorbent media; }\end{array}$ & See I. and (2) above. \\
\hline (c) Weight of the container and contents; & See I. and (2) above. \\
\hline $\begin{array}{l}\text { (d) Identities, activities, and concentrations of major } \\
\text { radionuclides; }\end{array}$ & See I. and (2) above. \\
\hline (e) Characterization date; & See I. and (2) above. \\
\hline (f) Generating source; and & See I. and (2) above. \\
\hline $\begin{array}{l}\text { (g) Any other information which may be needed to } \\
\text { prepare and maintain the disposal facility performance } \\
\text { assessment, or demonstrate compliance with applicable } \\
\text { performance objectives. }\end{array}$ & See I. and (2) above. \\
\hline $\begin{array}{l}\text { J. Waste Certification. A waste certification program } \\
\text { shall be developed, documented, and implemented to } \\
\text { ensure that the waste acceptance requirements of } \\
\text { facilities receiving low-level waste for storage, } \\
\text { treatment, and disposal are met. } \\
\text { From DOE G 435.1-1 Chapter IV: Compliance with } \\
\text { the development and documentation portion of the } \\
\text { certification requirement is demonstrated by a waste } \\
\text { certification plan that identifies the organizations } \\
\text { involved, assigns responsibilities for implementing the } \\
\text { program, and describes or references the quality } \\
\text { assurance, training, procurement controls, records } \\
\text { management, and procedures to be used by the } \\
\text { program. Acceptable performance for implementing } \\
\text { the program is demonstrated when appropriate } \\
\text { personnel are trained and follow the procedures that } \\
\text { govern their part of the waste certification. } \\
\text { Additionally, acceptable performance is demonstrated } \\
\text { if the waste certification plan and procedures are } \\
\text { current and controlled in accordance with a document } \\
\text { controls program, and records related to certification } \\
\text { (e.g., certification statements, training records, } \\
\text { procurement records, characterization records, } \\
\text { container records) are generated and managed in } \\
\text { accordance with the established site program. }\end{array}$ & $\begin{array}{l}\text { MCP-17000 cites a waste certification program for } \\
\text { LLW destined for NNSS. For waste destined for } \\
\text { locations other than NNSS, the waste disposition } \\
\text { specialist is responsible for certifying the waste stream } \\
\text { by ensuring the waste, as characterized, falls within the } \\
\text { limitations of the WAC of the treatment, storage, or } \\
\text { disposal facility ( } \$ 2 \text { ). } \\
\text { Container procurement is addressed in MCP-17000 } \\
\text { § } 4.6 \text {. } \\
\text { MCP-17500 provides the WGS waste certification } \\
\text { program for LLW to be shipped to NNSS. } \\
\text { Waste certification is performed and tracked using } \\
\text { IWTS. Documentation of the IWTS Program is } \\
\text { available electronically only. } \\
\text { PLN-522 requires waste technical specialists and waste } \\
\text { disposition specialists to complete the appropriate } \\
\text { training/qualification before being granted approval } \\
\text { authority for profiles within the IWTS Program. The } \\
\text { waste certification official, alternate waste certification } \\
\text { official, and NNSS packaging certifiers must complete } \\
\text { the appropriate training/qualifications to disposition } \\
\text { waste to NNSS. } \\
\text { RSWF-OI-003 § } 3,4 \text {, and Appendix A } \\
\text { RSWF-OI-003 } § 1 \text { states that "to the extent possible, } \\
\text { the WAC for RSWF complies with the WAC for } \\
\text { various treatment or disposal facilities that could be the } \\
\text { ultimate destination of the waste. Since there is not a } \\
\text { disposal facility with waste acceptance criteria for } \\
\text { some of the types of waste stored at RSWF, } \\
\text { compliance with this procedure does not ensure }\end{array}$ \\
\hline
\end{tabular}


Table 10. (continued).

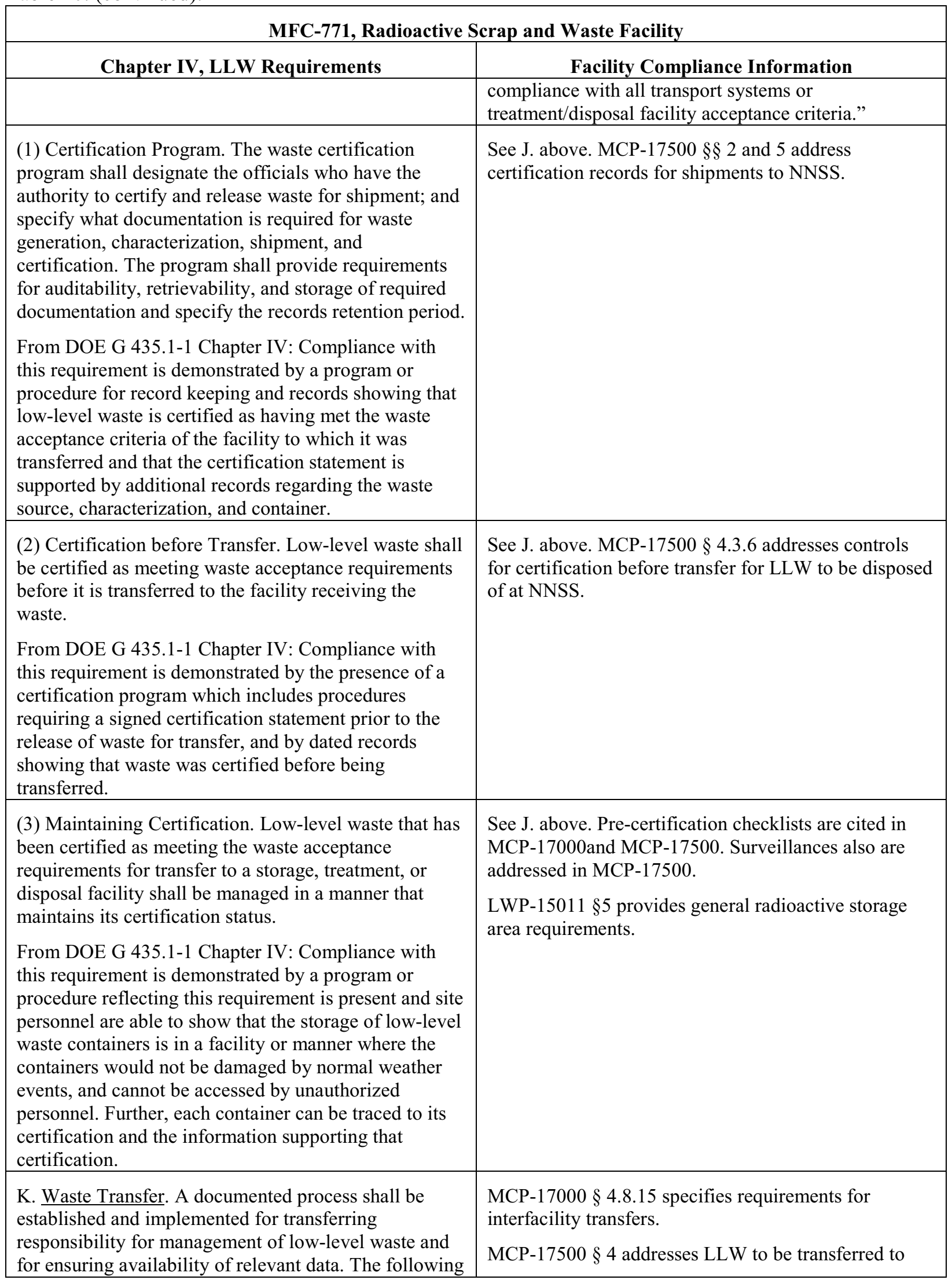


Table 10. (continued).

MFC-771, Radioactive Scrap and Waste Facility

\begin{tabular}{|c|c|}
\hline Chapter IV, LLW Requirements & Facility Compliance Information \\
\hline $\begin{array}{l}\text { requirements are in addition to those in Chapter I of } \\
\text { this Manual. } \\
\text { From DOE G 435.1-1 Chapter IV: Compliance with } \\
\text { this requirement is demonstrated if facilities have } \\
\text { procedures for the receipt of waste and the transfer of } \\
\text { waste, as appropriate, which address the acquisition of } \\
\text { waste and container data and the transfer of ownership, } \\
\text { respectively. Further evidence of acceptable } \\
\text { performance is facility records showing that data on the } \\
\text { waste containers is available and accurate, and that } \\
\text { documented transfer of responsibility occurs. }\end{array}$ & $\begin{array}{l}\text { NNSS. } \\
\text { RSWF-OI-004. }\end{array}$ \\
\hline $\begin{array}{l}\text { (1) Authorization. Low-level waste shall not be } \\
\text { transferred to a storage, treatment, or disposal facility } \\
\text { until personnel responsible for the facility receiving the } \\
\text { waste authorize the transfer. } \\
\text { From DOE G } 435.1-1 \text { Chapter IV: Compliance with } \\
\text { this requirement is demonstrated by sites having } \\
\text { procedures that require a confirmation of authorization } \\
\text { before releasing waste for transfer, and records } \\
\text { showing that transfers are made in accordance with } \\
\text { written authorizations. }\end{array}$ & See K. above. \\
\hline $\begin{array}{l}\text { (2) Data. Waste characterization data, container } \\
\text { information, and generation, storage, treatment, and } \\
\text { transportation information for low-level waste shall be } \\
\text { transferred with or be traceable to the waste. } \\
\text { From DOE G 435.1-1 Chapter IV: Compliance with } \\
\text { this requirement is demonstrated if there are procedures } \\
\text { requiring that characterization and container data be } \\
\text { provided and maintained for each low-level waste } \\
\text { transfer and documented records of transfers show that } \\
\text { the information is being provided. }\end{array}$ & See K. above. \\
\hline $\begin{array}{l}\text { L. Packaging and Transportation. The following } \\
\text { requirements are in addition to those in Chapter I of } \\
\text { this Manual [DOE M 435.1-1 §I.1.E(11)]. }\end{array}$ & See (1) and (2) below. \\
\hline $\begin{array}{l}\text { (1) Packaging. If containers are used: } \\
\text { From DOE G } 435.1-1 \text { Chapter IV: Compliance with } \\
\text { the packaging requirement is demonstrated by: (1) } \\
\text { procedures which document proper packaging } \\
\text { protocols; and (2) no trends of routine repackaging of } \\
\text { low-level waste that is packaged after issuance of DOE } \\
\text { O } 435.1 \text {. Successful performance of this requirement is } \\
\text { also demonstrated by a record of containers for which } \\
\text { failure has not routinely occurred under management } \\
\text { conditions. It is recognized that there may be failed } \\
\text { containers for waste previously placed in storage. For } \\
\text { those containers, the goal is to only have to repackage } \\
\text { the waste one time after it is retrieved and }\end{array}$ & $\begin{array}{l}\text { MCP-17000 } § 4 \text { addresses packaging requirements. } \\
\text { RSWF-OI-003 } § 4 \\
\text { PER-116, Module II.C and V } \\
\text { PER-116, Attachment } 1 \S \text { D-5 } \\
\text { SD-38.1.1, Appendix A and Appendix E } \\
\text { SAR-407 }\end{array}$ \\
\hline
\end{tabular}


Table 10. (continued).

MFC-771, Radioactive Scrap and Waste Facility

\begin{tabular}{|l|l|}
\hline \multicolumn{1}{|c|}{ Chapter IV, LLW Requirements } \\
\hline $\begin{array}{l}\text { characterized. Further, acceptable performance is } \\
\text { demonstrated by containers of waste having marking } \\
\text { and labeling that allows correlation with waste } \\
\text { characterization data and container information. }\end{array}$ \\
\hline
\end{tabular}

(a) Low-level waste shall be packaged in a manner that provides containment and protection for the duration of the anticipated storage period and until disposal is achieved or until the waste has been removed from the container.

(b) When waste is packaged, vents or other measures shall be provided if the potential exists for pressurizing or generating flammable or explosive concentrations of gases within the waste container.

(c) Containers of low-level waste shall be marked such that their contents can be identified.

(2) Transportation. To the extent practical, the volume of waste and number of low-level waste shipments shall be minimized.

From DOE G 435.1-1 Chapter IV: Compliance with this requirement can be demonstrated by a combination of site procedures directing the efficient use of waste container capacity and documentation showing that low-level waste shipments are systematically planned and optimized to the extent practical.

M. Site Evaluation and Facility Design. The following requirements are in addition to those in Chapter I of this Manual.

(1) Site Evaluation. Proposed locations for low-level waste facilities shall be evaluated to identify relevant features that should be avoided or must be considered in facility design and analyses.

(a) Each site proposed for a new low-level waste facility or expansion of an existing low-level waste facility shall be evaluated considering environmental characteristics, geotechnical characteristics, and human activities, including for a low-level waste disposal facility, the capability of the site to demonstrate, at a minimum, whether it is:

1 Located to accommodate the projected volume of waste to be received;

2 Located in a flood plain, a tectonically active area, or in the zone of water table fluctuation; and

3 Located where radionuclide migration pathways are predictable and erosion and surface runoff can be controlled.

See (1) above.

See (1) above. Facility Compliance Information

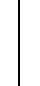
See

Facility Compliance Information

See(1) above.

See (1) above.

NA; waste is not shipped for offsite disposal from this facility.

$\mathrm{NA}$; this requirement addresses new radioactive waste management facilities or modifications to existing facilities.

See M. above.

See M. above.

See M. above.

See M. above.

See M. above. 
Table 10. (continued).

MFC-771, Radioactive Scrap and Waste Facility

\begin{tabular}{|c|c|}
\hline Chapter IV, LLW Requirements & Facility Compliance Information \\
\hline $\begin{array}{l}\text { (b) Proposed sites with environmental characteristics, } \\
\text { geotechnical characteristics, and human activities for } \\
\text { which adequate protection cannot be provided through } \\
\text { facility design shall be deemed unsuitable for the } \\
\text { location of the facility. }\end{array}$ & See M. above. \\
\hline $\begin{array}{l}\text { (c) Low-level waste disposal facilities shall be sited to } \\
\text { achieve long-term stability and to minimize, to the } \\
\text { extent practical, the need for active maintenance } \\
\text { following final closure. }\end{array}$ & See M. above. \\
\hline $\begin{array}{l}\text { (2) Low-Level Waste Treatment and Storage Facility } \\
\text { Design. The following facility requirements and } \\
\text { general design criteria, at a minimum, apply: }\end{array}$ & See M. above. \\
\hline $\begin{array}{l}\text { (a) Confinement. Low-level waste systems and } \\
\text { components shall be designed to maintain waste } \\
\text { confinement. }\end{array}$ & See M. above. \\
\hline (b) Ventilation. & See M. above. \\
\hline $\begin{array}{l}1 \text { Design of low-level waste treatment and storage } \\
\text { facilities shall include ventilation, if applicable, } \\
\text { through an appropriate filtration system to maintain the } \\
\text { release of radioactive material in airborne effluents } \\
\text { within the requirements and guidelines specified in } \\
\text { applicable requirements. }\end{array}$ & See M. above. \\
\hline $\begin{array}{l}2 \text { When conditions exist for generating gases in } \\
\text { flammable or explosive concentrations, ventilation } \\
\text { systems or other measures shall be provided to keep the } \\
\text { gases in a non-flammable and nonexplosive condition. } \\
\text { Where concentrations of explosive or flammable gases } \\
\text { are expected to approach the lower flammability limit, } \\
\text { measures shall be taken to prevent deflagration or } \\
\text { detonation. }\end{array}$ & See M. above. \\
\hline $\begin{array}{l}\text { (c) Consideration of Decontamination and } \\
\text { Decommissioning. Areas in new and modifications to } \\
\text { existing low-level waste management facilities that are } \\
\text { subject to contamination with radioactive or other } \\
\text { hazardous materials shall be designed to facilitate } \\
\text { decontamination. For such facilities a proposed } \\
\text { decommissioning method or a conversion method } \\
\text { leading to reuse shall be described. }\end{array}$ & See M. above. \\
\hline $\begin{array}{l}\text { (d) Instrumentation and Control Systems. Engineering } \\
\text { controls shall be incorporated in the design and } \\
\text { engineering of low-level waste treatment and storage } \\
\text { facilities to provide volume inventory data and to } \\
\text { prevent spills, leaks, and overflows from tanks or } \\
\text { confinement systems. }\end{array}$ & See M. above. \\
\hline
\end{tabular}


Table 10. (continued).

MFC-771, Radioactive Scrap and Waste Facility

\begin{tabular}{|c|c|}
\hline Chapter IV, LLW Requirements & Facility Compliance Information \\
\hline $\begin{array}{l}\text { (e) Monitoring. Monitoring and/or leak detection } \\
\text { capabilities shall be incorporated in the design and } \\
\text { engineering of low-level waste treatment and storage } \\
\text { facilities to provide rapid identification of failed } \\
\text { confinement and/or other abnormal conditions. }\end{array}$ & See M. above. \\
\hline $\begin{array}{l}\text { (3) Low-Level Waste Disposal Facility Design. The } \\
\text { following facility requirements and general design } \\
\text { criteria, at a minimum, apply: }\end{array}$ & See M. above. \\
\hline $\begin{array}{l}\text { (a) Confinement. Low-level waste systems and } \\
\text { components shall be designed to maintain waste } \\
\text { confinement. }\end{array}$ & See M. above. \\
\hline (b) Ventilation. & See M. above. \\
\hline $\begin{array}{l}1 \text { Design of low-level waste disposal facilities shall } \\
\text { include ventilation, if applicable, through an } \\
\text { appropriate filtration system to maintain the release of } \\
\text { radioactive material in airborne effluents within the } \\
\text { requirements and guidelines specified in applicable } \\
\text { requirements. }\end{array}$ & See M. above. \\
\hline $\begin{array}{l}2 \text { When conditions exist for generating gases in } \\
\text { flammable or explosive concentrations, ventilation } \\
\text { systems or other measures shall be provided to keep the } \\
\text { gases in a nonflammable and non-explosive condition. } \\
\text { Where concentrations of explosive or flammable gases } \\
\text { are expected to approach the lower flammability limit, } \\
\text { measures shall be taken to prevent deflagration or } \\
\text { detonation. }\end{array}$ & See M. above. \\
\hline $\begin{array}{l}\text { (c) Stability. Low-level waste disposal facilities shall } \\
\text { be designed to achieve long-term stability and to } \\
\text { minimize to the extent practical, the need for active } \\
\text { maintenance following final closure. }\end{array}$ & See M. above. \\
\hline $\begin{array}{l}\text { (d) Control of Water. Low-level waste disposal } \\
\text { facilities shall be designed to minimize to the extent } \\
\text { practical, the contact of waste with water during and } \\
\text { after disposal. }\end{array}$ & See M. above. \\
\hline $\begin{array}{l}\text { N. Storage and Staging. The following requirements } \\
\text { are in addition to those in Chapter I of this Manual } \\
\text { [DOE M 435.1-1 §I.2.F(13)]. }\end{array}$ & $\begin{array}{l}\text { Not a facility-specific requirement. DOE Manual } \\
435.1-1 \S I .2 . F(13) \text { applies to field element managers. }\end{array}$ \\
\hline \multirow{4}{*}{$\begin{array}{l}\text { (1) Storage Prohibitions. Low-level waste in storage } \\
\text { shall not be readily capable of detonation, explosive } \\
\text { decomposition, reaction at anticipated pressures and } \\
\text { temperatures, or explosive reaction with water. Prior to } \\
\text { storage, pyrophoric materials shall be treated, prepared, } \\
\text { and packaged to be nonflammable. }\end{array}$} & MCP-17000 \\
\hline & RSWF-OI-003 § 4 \\
\hline & PER-116, Module II.C and V \\
\hline & $\begin{array}{l}\text { PER-116, Attachment } 1 \S \text { D-1(a); Attachment } 2 \S \\
\text { C-2(a) }\end{array}$ \\
\hline $\begin{array}{l}\text { From DOE G } 435.1-1 \text { Chapter IV: Compliance with } \\
\text { this requirement is demonstrated by having waste }\end{array}$ & \\
\hline
\end{tabular}


Table 10. (continued).

MFC-771, Radioactive Scrap and Waste Facility

\begin{tabular}{|l|}
\hline \multicolumn{1}{|c|}{ Chapter IV, LLW Requirements } \\
\hline acceptance requirements which prohibit low-level \\
waste that is ignitable or explosive from being accepted \\
for storage unless it has been treated, and procedures \\
for properly preparing such materials for safe storage.
\end{tabular}

(2) Storage Limit. Low-level waste that has an identified path to disposal shall not be stored longer than one year prior to disposal, except for storage for decay, or as otherwise authorized by the Field Element Manager.

From DOE G 435.1-1 Chapter IV: Storage longer than one year can be justified if the conditions for such storage are approved by the Field Element Manager as part of the radioactive waste management basis for the facility.

Storage for radioactive decay for a period greater than 1 year for waste that has an identified path to disposal is allowed. Adequate justification and the supporting information for storage for decay is to be documented in the radioactive waste management basis for the facility in which the storage will take place.

Mixed waste. Under the Federal Facility Compliance Act of 1992, DOE sites were required to develop Site Treatment Plans to bring stored mixed low-level waste into compliance with these requirements. The Site Treatment Plan needs to be consulted and any mixed low-level waste stored for the purpose of accumulation to facilitate treatment must meet Resource

Conservation and Recovery Act storage requirements. There could be several ways within different scenarios that this requirement can be met, as illustrated by the examples below, however, there are basically four ways to show compliance with the requirement and include appropriate provisions in the radioactive waste management basis for the facility in which it is stored.

Legacy waste. As discussed above, the intention of the requirement is not to force malicious compliance or heroic actions which would result in increased risk or safety concerns. Rather, the intention is that waste in storage longer than one year receives additional attention to ensure that the public, the workers, and the environment are protected from the hazards of the waste, and that progress is being made to dispose of the waste. There could be several ways within different scenarios that this requirement can be met, as illustrated by the examples below, however, there are basically four ways to show compliance with the requirement:

\section{Facility Compliance Information}

The HWMA/RCRA permit (PER-116, Module V.B.1) allows ignitable (D001) and reactive (D003) hazardous waste to be stored.

This waste was considered in the safety analysis (SAR-407).

MCP-17000 $\S 4.8 .16$ addresses storage time limits and waste that is to be stored longer than 1 year.

MCP-17000, Appendix F addresses storage time limits.

RSWF-OI-003, Appendix A, "RSWF Material

Acceptance Checksheet," includes a requirement to note whether DOE Idaho Operations Office has approved LLW that is to be stored longer than 1 year and to provide supporting documentation.

Storage longer than 1 year for mixed waste is allowable under the Site Treatment Plan.

\section{COMPLIANCE CONSIDERATION}

DOE approval for storage longer than 1 year will be requested for continued storage of the remote-handled legacy LLW. 
Table 10. (continued).

MFC-771, Radioactive Scrap and Waste Facility

\begin{tabular}{l} 
Chapter IV, LLW Requirements \\
\hline 1) the radioactive waste management basis allows for \\
storage for no more than one year. \\
2) the radioactive waste management basis allows for \\
storage for no more than one year, or for storage for \\
decay only for periods greater than a year, which are \\
specified on a radionuclide basis. \\
3) the radioactive waste management basis allows for \\
storage for more than one year, up to a specified period \\
of time based on a documented technical evaluation \\
that the waste can be stored in a manner that does not \\
cause changes to the waste or waste packages that is \\
detrimental to the safe storage of the waste, the final \\
disposal of the waste or to meeting the disposal \\
performance objectives.
\end{tabular}

4) the radioactive waste management basis allows for storage for decay (with specifics) and for storage for more than one year for other low-level waste, up to a specified period of time based on a documented technical evaluation that the waste can be stored in a manner that does not cause changes to the waste or waste packages that is detrimental to the safe storage of the waste, the final disposal of the waste or to meeting the disposal performance objectives.

Compliance with this requirement is demonstrated by the existence of a radioactive waste management basis for the storage facility approved by the Field Element Manager that includes the time frames that waste are allowed to be stored, the necessary justifications for storage for decay, and the necessary technical evaluations if storage is to extend significantly beyond the one-year time frame.

(3) Storage Integrity. Low-level waste shall be stored in a location and manner that protects the integrity of waste for the expected time of storage and minimizes worker exposure.

From DOE G 435.1-1 Chapter IV: However, in making a decision to use a facility for storage and in developing a radioactive waste management basis for the activity, particular attention to protection of workers is needed.

Compliance with this requirement is demonstrated if sites have storage capabilities for low-level waste that provide protection to waste containers so that their integrity will not be damaged through physical or chemical (corrosion) processes and that keep personnel from spending extended periods of time in the areas where low-level waste is stored.

MCP-17000

RSWF-OI-003 $§ 4$

PER-116, Module V

PER-116, Attachment $1 \S$ D-5

SD-38.1.1, Appendix A and Appendix E.

This waste is considered in the safety analysis (SAR-407). 
Table 10. (continued).

\begin{tabular}{|c|c|}
\hline \multicolumn{2}{|c|}{ MFC-771, Radioactive Scrap and Waste Facility } \\
\hline Chapter IV, LLW Requirements & Facility Compliance Information \\
\hline (4) Waste Characterization for Storage. & See below. \\
\hline $\begin{array}{l}\text { (a) Low-level waste that does not have an identified } \\
\text { path to disposal shall be characterized as necessary to } \\
\text { meet the data quality objectives and minimum } \\
\text { characterization requirements of this Chapter, to ensure } \\
\text { safe storage, and to facilitate disposal. }\end{array}$ & $\begin{array}{l}\text { RSWF-OI- } 003 \S 1 \text { states that "to the extent possible, } \\
\text { the WAC for RSWF complies with the WAC for } \\
\text { various treatment or disposal facilities that could be the } \\
\text { ultimate destination of the waste. Since there is not a } \\
\text { disposal facility with waste acceptance criteria for } \\
\text { some of the types of waste stored at RSWF, } \\
\text { compliance with this procedure does not ensure } \\
\text { compliance with all transport systems or } \\
\text { treatment/disposal facility acceptance criteria." }\end{array}$ \\
\hline \multirow{3}{*}{$\begin{array}{l}\text { (b) Characterization information for all low-level waste } \\
\text { in storage shall be maintained as a record in accordance } \\
\text { with the requirements for Records Management in } \\
\text { Chapter I of this Manual. }\end{array}$} & MCP-17000 \\
\hline & RSWF-OI-003 § 4 \\
\hline & PER-116, Module V.G \\
\hline \multirow[b]{2}{*}{$\begin{array}{l}\text { From DOE G } 435.1-1 \text { Chapter IV: Compliance with } \\
\text { this requirement is demonstrated by documented } \\
\text { procedures for managing waste characterization and } \\
\text { container information on low-level waste as a Federal } \\
\text { record. The records are managed per the applicable } \\
\text { policies and procedures for records management } \\
\text { referenced in DOE O } 200.1 \text { and established at the } \\
\text { applicable Field Element. }\end{array}$} & PER-116, Attachment $1 \S \mathrm{D} ;$ Attachment 2 \\
\hline & SD-38.1.1, Appendix A and Appendix E \\
\hline \multirow{7}{*}{$\begin{array}{l}\text { (5) Container Inspection. A process shall be developed } \\
\text { and implemented for inspecting and maintaining } \\
\text { containers of low-level waste to ensure container } \\
\text { integrity is not compromised. } \\
\text { From DOE G } 435.1-1 \text { Chapter IV: Compliance with } \\
\text { this requirement is demonstrated by: (1) a documented } \\
\text { process for waste container inspection and } \\
\text { maintenance; and (2) documentation for all waste } \\
\text { container inspections and maintenance actions } \\
\text { performed. }\end{array}$} & $\begin{array}{l}\text { LI- } 435 \text { requires quarterly inspections of radioactive } \\
\text { waste containers if waste is stored outdoors or has been } \\
\text { in storage for greater than } 1 \text { year. } \\
\text { MCP- } 17000\end{array}$ \\
\hline & For mixed LLW: \\
\hline & $\begin{array}{l}\text { RSWF-OI- } 006 \S 2.3 \text { requires weekly inspection of } \\
\text { the cathodic protection system. }\end{array}$ \\
\hline & PER-116, Module V.F \\
\hline & $\begin{array}{l}\text { PER-116, Attachment 4, F-2(b)(3); Attachment F- } \\
\text { 3. (this attachment includes examples of facility- } \\
\text { specific inspection forms to be used) }\end{array}$ \\
\hline & SD-38.1.1, Appendix A and Appendix E. \\
\hline & $\begin{array}{l}\text { LWP- } 15011 \text { does not include a requirement for } \\
\text { inspection. }\end{array}$ \\
\hline \multirow[t]{2}{*}{$\begin{array}{l}\text { (6) Storage Management. Low-level waste storage } \\
\text { shall be managed to identify and segregate low-level } \\
\text { waste from mixed low-level waste. }\end{array}$} & $\begin{array}{l}\text { Waste is segregated by container. MCP- } 17000 \S 4.7 \text {, } \\
\text { requires the use of a unique IWTS bar code for each } \\
\text { container. }\end{array}$ \\
\hline & RSWF-OI-003 $\S 4.1 .5$ \\
\hline $\begin{array}{l}\text { (7) Staging. Staging of low-level waste shall be for the } \\
\text { purpose of the accumulation of such quantities of waste } \\
\text { as necessary to facilitate transportation, treatment, and }\end{array}$ & NA; LLW is not staged at this facility. \\
\hline
\end{tabular}


Table 10. (continued).

MFC-771, Radioactive Scrap and Waste Facility

\begin{tabular}{|c|c|}
\hline Chapter IV, LLW Requirements & Facility Compliance Information \\
\hline $\begin{array}{l}\text { disposal. Staging longer than } 90 \text { days shall meet the } \\
\text { requirements for storage above and in Chapter I of this } \\
\text { Manual. }\end{array}$ & \\
\hline $\begin{array}{l}\text { From DOE G 435.1-1 Chapter IV: The staging of low- } \\
\text { level waste needs to be addressed in the radioactive } \\
\text { waste management basis for the facility that is } \\
\text { performing the staging. Generators, treatment facilities, } \\
\text { and disposal facilities that stage waste must ensure that } \\
\text { the action of staging is included and authorized as part } \\
\text { of their radioactive waste management basis for the } \\
\text { affected facilities, operations, or activities. }\end{array}$ & \\
\hline $\begin{array}{l}\text { Staging longer than } 90 \text { days must be justified, the } \\
\text { conditions for such storage met, and these practices } \\
\text { approved by the Field Element Manager as part of the } \\
\text { radioactive waste management basis for the facility. }\end{array}$ & \\
\hline $\begin{array}{l}\text { Compliance with this requirement is demonstrated by a } \\
\text { staging program that limits the temporary storage of } \\
\text { waste to only circumstances allowed in the } \\
\text { requirement, including justifications for any staging } \\
\text { that exceeds the } 90 \text {-day period, which is documented in } \\
\text { the radioactive waste management basis for the facility. }\end{array}$ & \\
\hline $\begin{array}{l}\text { O. Treatment. Low-level waste treatment to provide } \\
\text { more stable waste forms and to improve the long-term } \\
\text { performance of a low-level waste disposal facility shall } \\
\text { be implemented as necessary to meet the performance } \\
\text { objectives of the disposal facility. }\end{array}$ & NA; treatment is not performed at this facility \\
\hline $\begin{array}{l}\text { From DOE G } 435.1-1 \text { Chapter IV: Compliance with } \\
\text { this requirement is demonstrated when a treatment } \\
\text { facility or process ensures that treated waste will meet } \\
\text { the minimum waste form requirements of DOE M } \\
435.1 \text { and meet additional disposal facility-specific } \\
\text { waste acceptance requirements for additional stability } \\
\text { or long-term performance of facilities that will receive } \\
\text { the treated waste. }\end{array}$ & \\
\hline $\begin{array}{l}\text { P. Disposal. Low-level waste disposal facilities shall } \\
\text { meet the following requirements. }\end{array}$ & NA; LLW is not disposed of in this facility. \\
\hline $\begin{array}{l}\text { (1) Performance Objectives. Low-level waste disposal } \\
\text { facilities shall be sited, designed, operated, maintained, } \\
\text { and closed so that a reasonable expectation exists that } \\
\text { the following performance objectives will be met for } \\
\text { waste disposed of after September } 26,1988 \text { : }\end{array}$ & See P. above. \\
\hline $\begin{array}{l}\text { (a) Dose to representative members of the public shall } \\
\text { not exceed } 25 \text { mrem }(0.25 \mathrm{mSv}) \text { in a year total } \\
\text { effective dose equivalent from all exposure pathways, } \\
\text { excluding the dose from radon and its progeny in air. }\end{array}$ & See P. above. \\
\hline $\begin{array}{l}\text { (b) Dose to representative members of the public via } \\
\text { the air pathway shall not exceed } 10 \mathrm{mrem}(0.10 \mathrm{mSv})\end{array}$ & See P. above. \\
\hline
\end{tabular}


Table 10. (continued).

\section{MFC-771, Radioactive Scrap and Waste Facility}

\begin{tabular}{|l|}
\hline \multicolumn{1}{|c|}{ Chapter IV, LLW Requirements } \\
\hline $\begin{array}{l}\text { in a year total effective dose equivalent, excluding the } \\
\text { dose from radon and its progeny. }\end{array}$ \\
\hline $\begin{array}{l}\text { (c) Release of radon shall be less than an average flux } \\
\text { of } 20 \mathrm{pCi} / \mathrm{m}^{2} / \mathrm{s}\left(0.74 \mathrm{~Bq} / \mathrm{m}^{2} / \mathrm{s}\right) \text { at the surface of the } \\
\text { disposal facility. Alternatively, a limit of } 0.5 \mathrm{pCi} / 1 \\
(0.0185 \mathrm{~Bq} / \mathrm{l}) \text { of air may be applied at the boundary of } \\
\text { the facility. }\end{array}$ \\
\hline
\end{tabular}

(2) Performance Assessment. A site-specific radiological performance assessment shall be prepared and maintained for DOE low-level waste disposed of after September 26, 1988. The performance assessment shall include calculations for a 1,000 year period after closure of potential doses to representative future members of the public and potential releases from the facility to provide a reasonable expectation that the performance objectives identified in this Chapter are not exceeded as a result of operation and closure of the facility.

(a) Analyses performed to demonstrate compliance with the performance objectives in this Chapter, and to establish limits on concentrations of radionuclides for disposal based on the performance measures for inadvertent intruders in this Chapter shall be based on reasonable activities in the critical group of exposed individuals. Unless otherwise specified, the assumption of average living habits and exposure conditions in representative critical groups of individuals projected to receive the highest doses is appropriate. The likelihood of inadvertent intruder scenarios may be considered in interpreting the results of the analyses and establishing radionuclide concentrations, if adequate justification is provided.

(b) The point of compliance shall correspond to the point of highest projected dose or concentration beyond a 100 meter buffer zone surrounding the disposed waste. A larger or smaller buffer zone may be used if adequate justification is provided.

(c) Performance assessments shall address reasonably foreseeable natural processes that might disrupt barriers against release and transport of radioactive materials.

(d) Performance assessments shall use DOE-approved dose coefficients (dose conversion factors) for internal and external exposure of reference adults.

(e) The performance assessment shall include a sensitivity/uncertainty analysis.

See P. above.

See P. above.

See P. above.

See P. above.

See P. above.

See P. above.

See P. above. Facility Compliance Information 
Table 10. (continued).

MFC-771, Radioactive Scrap and Waste Facility

\begin{tabular}{|l|l|}
\hline \multicolumn{1}{|c|}{ Chapter IV, LLW Requirements } & \multicolumn{1}{c|}{ Facility Compliance Information } \\
\hline $\begin{array}{l}\text { (f) Performance assessments shall include a } \\
\text { demonstration that projected releases of radionuclides } \\
\text { to the environment shall be maintained as low as } \\
\text { reasonably achievable (ALARA). }\end{array}$ & See P. above. \\
\hline $\begin{array}{l}\text { (g) For purposes of establishing limits on radionuclides } \\
\text { that may be disposed of near-surface, the performance } \\
\begin{array}{l}\text { assessment shall include an assessment of impacts to } \\
\text { water resources. }\end{array}\end{array}$ & See P. above. \\
\hline
\end{tabular}

(h) For purposes of establishing limits on the

See P. above. concentration of radionuclides that may be disposed of near-surface, the performance assessment shall include an assessment of impacts calculated for a hypothetical person assumed to inadvertently intrude for a temporary period into the low-level waste disposal facility. For intruder analyses, institutional controls shall be assumed to be effective in deterring intrusion for at least 100 years following closure. The intruder analyses shall use performance measures for chronic and acute exposure scenarios, respectively, of 100 mrem $(1 \mathrm{mSv})$ in a year and $500 \mathrm{mrem}(5 \mathrm{mSv})$ total effective dose equivalent excluding radon in air.

(3) Composite Analysis. For disposal facilities which See P. above. received waste after September 26, 1988, a site-specific radiological composite analysis shall be prepared and maintained that accounts for all sources of radioactive material that may be left at the DOE site and may interact with the low- level waste disposal facility, contributing to the dose projected to a hypothetical member of the public from the existing or future disposal facilities. Performance measures shall be consistent with DOE requirements for protection of the public and environment and evaluated for a 1,000 year period following disposal facility closure. The composite analysis results shall be used for planning, radiation protection activities, and future use commitments to minimize the likelihood that current low- level waste disposal activities will result in the need for future corrective or remedial actions to adequately protect the public and the environment.

(4) Performance Assessment and Composite Analysis Maintenance. The performance assessment and composite analysis shall be maintained to evaluate changes that could affect the performance, design, and operating bases for the facility. Performance assessment and composite analysis maintenance shall include the conduct of research, field studies, and monitoring needed to address uncertainties or gaps in existing data. The performance assessment shall be updated to support the final facility closure. Additional

See P. above. 
Table 10. (continued).

MFC-771, Radioactive Scrap and Waste Facility

\begin{tabular}{|l|l|}
\hline \multicolumn{1}{|c|}{ Chapter IV, LLW Requirements } & Facility Compliance Information \\
\hline $\begin{array}{l}\text { iterations of the performance assessment and composite } \\
\text { analysis shall be conducted as necessary during the } \\
\text { post-closure period. }\end{array}$ & \\
\hline
\end{tabular}

(a) Performance assessments and composite analyses shall be reviewed and revised when changes in waste forms or containers, radionuclide inventories, facility design and operations, closure concepts, or the improved understanding of the performance of the waste disposal facility in combination with the features of the site on which it is located alter the conclusions or the conceptual model(s) of the existing performance assessment or composite analysis.

(b) A determination of the continued adequacy of the performance assessment and composite analysis shall be made on an annual basis, and shall consider the results of data collection and analysis from research, field studies, and monitoring.

(c) Annual summaries of low-level waste disposal operations shall be prepared with respect to the conclusions and recommendations of the performance assessment and composite analysis and a determination of the need to revise the performance assessment or composite analysis.

(5) Disposal Authorization. A disposal authorization statement shall be obtained prior to construction of a new low-level waste disposal facility. Field Elements with existing low-level waste disposal facilities shall obtain a disposal authorization statement in accordance with the schedule in the Complex-Wide Low-Level Waste Management Program Plan. The disposal authorization statement shall be issued based on a review of the facility's performance assessment, composite analysis, performance assessment and composite analysis maintenance, preliminary closure plan, and preliminary monitoring plan. The disposal authorization statement shall specify the limits and conditions on construction, design, operations, and closure of the low-level waste facility based on these reviews. A disposal authorization statement is a part of the radioactive waste management basis for a disposal facility. Failure to obtain a disposal authorization statement by the implementation date of this Order shall result in shutdown of the disposal facility.

(6) Disposal Facility Operations. The disposal facility design and operation must be consistent with the disposal facility closure plan and lead to disposal facility closure that provides a reasonable expectation that performance objectives will be met. Low-level waste shall be disposed in such a manner that achieves

See P. above.

See P. above.

See P. above.

See P. above.

See P. above. 
Table 10. (continued).

MFC-771, Radioactive Scrap and Waste Facility

\begin{tabular}{l|l|}
\hline \multicolumn{1}{|c|}{ Chapter IV, LLW Requirements } & Facility Compliance Information \\
\hline the performance objectives stated in this Chapter, \\
consistent with the disposal facility radiological \\
performance assessment. Additional requirements \\
include:
\end{tabular}

\begin{abstract}
(a) Operating procedures shall be developed and implemented for low-level waste disposal facilities that protect the public, workers, and the environment; ensure the security of the facility; minimize subsidence during and after waste emplacement; achieve long-term stability and minimize the need for long-term active maintenance; and meet the requirements of the closure/post-closure plan.
\end{abstract}

(b) Permanent identification markers for disposal
excavations and monitoring wells shall be emplaced.

(c) Low-level waste placement into disposal units shall minimize voids between waste containers. Voids within disposal units shall be filled to the extent practical. Uncontainerized bulk waste shall also be placed in a manner that minimizes voids and subsidence.

(d) Operations are to be conducted so that active waste disposal operations will not have an adverse effect on any other disposal units.

(e) Operations shall include a process for tracking and documenting low-level waste placement in the facility by generator source.

(7) Alternate Requirements for Low-Level Waste Disposal Facility Design and Operation. Requirements other than those set forth in this Section for the design and operation of a low-level waste disposal facility may be approved on a specific basis if a reasonable expectation is demonstrated that the disposal performance objectives will be met.

Q. Closure. The following requirements are in addition to those in Chapter I of this Manual.
(1) Disposal Facility Closure Plans. A preliminary closure plan shall be developed and submitted to Headquarters for review with the performance assessment and composite analysis. The closure plan shall be updated following issuance of the disposal authorization statement to incorporate conditions specified in the disposal authorization statement. Closure plans shall:

(a) Be updated as required during the operational life of the facility.

(b) Include a description of how the disposal facility
See P. above.

See P. above.

See P. above.

See P. above.

See P. above.

See P. above.

NA; LLW is not disposed of in this facility.

See Q. above.

See Q. above.

See Q. above. 
Table 10. (continued).

MFC-771, Radioactive Scrap and Waste Facility

\begin{tabular}{|c|}
\hline V, LLW Requirements \\
\hline $\begin{array}{l}\text { will be closed to achieve long-term stability and } \\
\text { minimize the need for active maintenance following } \\
\text { closure and to ensure compliance with the requirements } \\
\text { of DOE 5400.5, Radiation Protection of the Public and } \\
\text { the Environment. }\end{array}$ \\
\hline
\end{tabular}

(c) Include the total expected inventory of wastes to be disposed of at the facility over the operational life of the facility.

(2) Disposal Facility Closure. Closure of a disposal facility shall occur within a five-year period after it is filled to capacity, or after the facility is otherwise determined to be no longer needed.

(a) Prior to facility closure, the final inventory of the low-level waste disposed in the facility shall be prepared and incorporated in the performance assessment and composite analysis which shall be updated to support the closure of the facility.

(b) A final closure plan shall be prepared based on the final inventory of waste disposed in the facility, the plan implemented, and the updated performance assessment and composite analysis prepared in support of the facility closure.

(c) Institutional control measures shall be integrated into land use and stewardship plans and programs, and shall continue until the facility can be released pursuant to DOE 5400.5, Radiation Protection of the Public and the Environment.

(d) The location and use of the facility shall be filed with the local authorities responsible for land use and zoning.

R. Monitoring. The following requirements are in addition to those in Chapter I of this Manual [DOE M 435.1-1 §I.1.E(7)].

(1) All Waste Facilities. Parameters that shall be sampled or monitored, at a minimum, include: temperature, pressure (for closed systems), radioactivity in ventilation exhaust and liquid effluent streams, and flammable or explosive mixtures of gases. Facility monitoring programs shall include verification that passive and active control systems have not failed.

From DOE G 435.1-1 Chapter IV: The minimum parameters specified in the requirement were selected based on their potential significance for anticipating and identifying undesirable conditions at low-level waste management facilities. Each facility's radioactive waste management basis should include an evaluation

See Q. above.

See Q. above. Facility Compliance Information

See Q. above.

See Q. above.

See Q. above.

See Q. above.

See (1), (2), and (3) below.

Monitoring requirements at INL radioactive waste management facilities are tailored for the specific facility to enable timely indication of developing problems. Existing radiological control procedures and assessments are followed/completed to monitor waste facilities.

PER-116, Attachment $1 \S \mathrm{D}$ and Attachment 4 § describe facility monitoring and inspection requirements.

RSWF-OI-006 includes requirements for inspecting the cathodic protection system.

SAR-407 
Table 10. (continued).

MFC-771, Radioactive Scrap and Waste Facility

\begin{tabular}{|c|}
\hline Chapter IV, LLW Requirements \\
\hline $\begin{array}{l}\text { of the applicability and significance of the minimum } \\
\text { parameters. This evaluation also needs to consider } \\
\text { additional parameters to be sampled or monitored to } \\
\text { ensure the protection of the public health, the } \\
\text { environment, and the workers. If a minimum parameter } \\
\text { specified in the requirement is deemed to be not } \\
\text { applicable in any way to the active operation of that } \\
\text { facility, then that justification should be included in the } \\
\text { radioactive waste management basis and when } \\
\text { approved constitutes an exemption to the manual. }\end{array}$ \\
\hline $\begin{array}{l}\text { Verification activities are part of the radioactive waste } \\
\text { management basis as a condition for operation and } \\
\text { documented appropriately. }\end{array}$ \\
\hline $\begin{array}{l}\text { Compliance with this requirement is demonstrated if } \\
\text { monitoring or sampling for the stated parameters is } \\
\text { performed for all facilities with a precision, accuracy, } \\
\text { and frequency consistent with timely identification of } \\
\text { developing problems and a justification exists in the } \\
\text { approved radioactive waste management basis for those } \\
\text { specified parameters which are not monitored or } \\
\text { sampled. }\end{array}$ \\
\hline
\end{tabular}

(2) Liquid Waste Storage Facilities. For facilities storing liquid low-level waste, the following shall also be monitored: liquid level and/or waste volume, and significant waste chemistry parameters.
LRD-15001 and MCP-139 specify methods and frequency of radiological control surveys of all radiological areas. MCP-139 specifies the use of Form 441.A34. This form is referred to as the "routine sheet" and is to be used by facility radiological control foremen to list radiological areas that are to be surveyed, the survey periods, and methods.
These parameters are known for the $\mathrm{NaK}$ liquid waste stored at the facility. Additional waste with free liquids will not be accepted.

The HWMA/RCRA permit (PER-116, Module V.B.4) prohibits storage of waste containing free liquids, other than the NaK described at Module V.B.3.a.

RSWF-OI-003 $\S 4.2 .2$ states that no free liquids (including $\mathrm{NaK}$ or mercury) are allowed in newly received waste.

NA; LLW is not disposed of in this facility.
(3) Disposal Facilities. A preliminary monitoring plan for a low-level waste disposal facility shall be prepared and submitted to Headquarters for review with the performance assessment and composite analysis. The monitoring plan shall be updated within one year following issuance of the disposal authorization statement to incorporate and implement conditions specified in the disposal authorization statement.

(a) The site-specific performance assessment and composite analysis shall be used to determine the media, locations, radionuclides, and other substances to be monitored.

(b) The environmental monitoring program shall be designed to include measuring and evaluating releases, migration of radionuclides, disposal unit subsidence, and changes in disposal facility and disposal site parameters which may affect long-term performance.
See (3) above. 
Table 10. (continued).

\begin{tabular}{|l|l|}
\hline \multicolumn{2}{|c|}{ MFC-771, Radioactive Scrap and Waste Facility } \\
\hline \multicolumn{1}{|c|}{ Chapter IV, LLW Requirements } & \multicolumn{1}{|c|}{ Facility Compliance Information } \\
\hline $\begin{array}{l}\text { (c) The environmental monitoring programs shall be } \\
\text { capable of detecting changing trends in performance to } \\
\text { allow application of any necessary corrective action } \\
\text { prior to exceeding the performance objectives in this } \\
\text { Chapter. }\end{array}$ & See (3) above. \\
\hline
\end{tabular}

\subsection{MFC-774, Electron Microscopy Laboratory}

1. Facility description: MFC-774, Electron Microscopy Laboratory, is a user facility dedicated to materials characterization using as its primary tools, electron and optical microscopy. The Electron Microscopy Laboratory is located within MFC at INL. MFC-774 is a radiological materials area, permitting characterization work to be performed on both radioactive and non-radioactive materials. A limited number of microscopy laboratories in the country provide this unique capability, making the Electron Microscopy Laboratory an enviable laboratory for research (internal and external to the DOE complex) for characterization of radioactive materials. A portion of the laboratory is dedicated to sample preparation, providing the researcher with facilities support, equipment, safety systems, and procedures to prepare samples of diverse materials for analysis.

The three primary instruments in MFC-774 are a JEOL 2010 scanning transmission electron microscope, a JEOL JSM-7000f scanning electron microscope, and a Fixed Ion Beam microscope. The transmission electron microscope is capable of operating at $200 \mathrm{kV}$ and is capable of magnifications from 2,000 to 1,500,000 X. It is equipped with an Oxford Instruments energy dispersive x-ray spectrometer that can be used to gather information about the elemental make-up of a sample. Crystallographic information can be obtained by recording the diffraction patterns formed by electrons as they pass through the sample.

The JEOL scanning electron microscope is a field emission instrument capable of operating at $30 \mathrm{kV}$ and is capable of magnifications from 15 to 500,000 X. It is equipped with Oxford Instruments energy dispersive and wavelength dispersive $\mathrm{x}$-ray spectrometers that can be used to obtain quantitative information about the elemental composition of a sample. It also is equipped with an electron back scattered diffraction camera that can be used to obtain crystallographic information about a sample by recording the diffraction patterns formed by electrons when they tunnel through a sample at glancing angles.

The Zeiss scanning electron microscope is capable of operating at $30 \mathrm{kV}$ and is capable of magnifications from 6 to 200,000 X. It is equipped with Oxford Instruments energy dispersive and wavelength dispersive $\mathrm{x}$-ray spectrometers and an electron back scattered diffraction camera.

The Fixed Ion Beam microscope is similar to a scanning electron microscope except it also uses an ion milling process (internal to the machine) to section samples for further examination.

In addition to the transmission electron microscope and scanning electron microscope, MFC-774 also has several optical microscopes. Some of these are used to support sample preparation and others are used for optical characterization of samples.

Capabilities for sample preparation include cutting, grinding, and polishing, as well as specialized methods such as ultramicrotomy (cutting ultrathin slices of material with a special machine using a diamond knife); chemical and ion milling to produce thin, electron-transparent samples; etching; and coating. Fume hoods (radiological and non-radiological) and a glovebox are available to protect workers and the environment from hazardous materials. 
Activities and projects that have used or are currently using resources in MFC-774 include the Spent Fuel Treatment Project of the Advanced Fuel Cycle Initiative, the Reduced Enrichment Research and Test Reactor project, the Radioisotope Power Source Program, and a variety of other activities that examine irradiated steels, experimental reactor fuels, waste forms, and waste materials. The types of analyses performed include microstructure and chemical analysis, crystallographic analysis, failure analysis, and microhardness and fracture toughness analysis. Since MFC-774 is a user facility, each program defines and manages its own quality assurance requirements. Facility management provides work control and safety oversight to safely and efficiently conduct simultaneous operations.

\section{Hazard category: LTHC3}

3. Radioactive waste managed at this facility: CH LLW and mixed CH LLW are generated and staged at this facility.

\section{RWMB documents/programs:}

a. Safety basis/hazard analysis:

- EDF-7030, "Inventory Analysis of Radiological Facilities at the Materials and Fuels Complex (MFC)"

b. Laboratory-wide:

- Form 435.39, "Waste Determination and Disposition Form (WDDF)"

- Form 435.42, "Radioactive Waste Inventory Sheet"

- Form 441.A34, "INL Radiological Control Required Surveys"

- LI-435, "Waste Management Routine Field Activities"

- LRD-15001, "Radiological Control Manual"

- LWP-13840, "Management of Issues, Observations, and Noteworthy Practices"

- LWP-14002, "Timeout and Stop Work Authority"

- LWP-15011, Radioactive Material Areas and Radioactive Storage Areas"

- LWP-17000, "Waste Management"

- MCP-139, "Radiological Surveys"

- MCP-17000, "Waste Generator Services Waste Management"

- MCP-17410, "Management of Waste Storage Areas"

- MCP-17500, "Waste Generator Services Certification of Waste Shipments to the Nevada Test Site"

- PDD-17000, "Waste Management Program"

- PLN-114, "INL Emergency Plan/RCRA Contingency Plan"

- PLN-522, "Quality Assurance Program Plan for the Waste Management/Waste Certification Program"

c. Facility-specific:

- EML-OI-416, "Circulating, Sampling, and Draining of Suspect Liquid Waste in EML (Bldg. 774) Holding Tanks"

- LI 1219-07-MFC, "Sample Preparation in the Electron Microscopy Laboratory"

- SD-38.1.1, "Treatment, Storage, and Disposal Facilities (TSDF) Environmental Compliance"

- TSD-OI-004, "Waste and Material Acceptance for Storage/Treatment and Radioactive Material Inventory Control." 
LLW is managed at this facility. Table 11 presents the facility compliance information for Chapter IV, "Low-level Waste Requirements."

Table 11. MFC-774, Electron Microscopy Laboratory, DOE Manual 435.1-1 low-level waste requirements and facility compliance information.

\begin{tabular}{|c|c|}
\hline \multicolumn{2}{|c|}{ Facility Name: MFC-774, Electron Microscopy Laboratory } \\
\hline Chapter IV, LLW Requirements & Facility Compliance Information \\
\hline $\begin{array}{l}\text { A. Definition of Low-Level Waste. Low-level } \\
\text { radioactive waste is radioactive waste that is not high- } \\
\text { level radioactive waste, spent nuclear fuel, transuranic } \\
\text { waste, byproduct material (as defined in section 11e.( } 2 \text { ) } \\
\text { of the Atomic Energy Act of 1954, as amended), or } \\
\text { naturally occurring radioactive material. } \\
\text { (From DOE G } 435.1-1 \text { Chapter IV: Low-level } \\
\text { radioactive waste is defined by what it is not. The } \\
\text { guidance on definitions in Chapters II and III should be } \\
\text { consulted first for making a determination on how to } \\
\text { properly manage a suspect waste stream.) }\end{array}$ & $\begin{array}{l}\text { This requirement provides the criteria for determining } \\
\text { which DOE radioactive waste is to be managed as } \\
\text { LLW in accordance with DOE Manaul 435.1-1, } \\
\text { Chapter IV. } \\
\text { Radioactive waste managed at this facility under the } \\
\text { requirements of this chapter is not managed under the } \\
\text { requirements of DOE Manual } 435.1-1 \text {, Chapter II or } \\
\text { Chapter III. }\end{array}$ \\
\hline $\begin{array}{l}\text { B. Management of Specific Wastes. The following } \\
\text { provide for management of specific wastes as low-level } \\
\text { waste in accordance with the requirements in this } \\
\text { Chapter: }\end{array}$ & See below. \\
\hline $\begin{array}{l}\text { (1) Mixed Low-Level Waste. Low-level waste } \\
\text { determined to contain both source, special nuclear, or } \\
\text { byproduct material subject to the Atomic Energy Act of } \\
\text { 1954, as amended, and a hazardous component subject } \\
\text { to the Resource Conservation and Recovery Act } \\
\text { (RCRA), as amended, shall be managed in accordance } \\
\text { with the requirements of RCRA and DOE O } 435.1 \text {, } \\
\text { Radioactive Waste Management, and this Manual. }\end{array}$ & $\begin{array}{l}\text { This facility may manage mixed LLW. } \\
\text { Compliance with RCRA regulations is addressed by } \\
\text { WGS in its waste management services role in } \\
\text { MCP-17000. } \\
\text { LI } 1219-07-\text { MFC } \S 2 \text {, Table } 2.03 \text { and } \S 5 \text { address } \\
\text { generation of mixed LLW and accumulation in an } \\
\text { SAA. } \\
\text { Individual projects also would have project-specific } \\
\text { laboratory instructions that would address the } \\
\text { management of mixed LLW in accordance with RCRA } \\
\text { regulations. }\end{array}$ \\
\hline $\begin{array}{l}\text { (2) TSCA-Regulated Waste. Low-level waste } \\
\text { containing polychlorinated biphenyls, asbestos, or } \\
\text { other such regulated toxic components shall be } \\
\text { managed in accordance with requirements derived from } \\
\text { the Toxic Substances Control Act, as amended, DOE O } \\
\text { 435.1, Radioactive Waste Management, and this } \\
\text { Manual. }\end{array}$ & $\begin{array}{l}\text { NA; this facility does not manage TSCA-regulated } \\
\text { waste. }\end{array}$ \\
\hline $\begin{array}{l}\text { (3) Accelerator-Produced Waste. Radioactive waste } \\
\text { produced as a result of operations of DOE accelerators } \\
\text { is low-level waste and shall be managed in accordance } \\
\text { with DOE O 435.1, Radioactive Waste Management, } \\
\text { and this Manual, and all applicable Federal or State } \\
\text { requirements. }\end{array}$ & $\begin{array}{l}\text { NA; this facility does not manage accelerator-produced } \\
\text { waste. }\end{array}$ \\
\hline $\begin{array}{l}\text { (4) } 11 \mathrm{e} .(2) \text { and Naturally Occurring Radioactive } \\
\text { Material. Small quantities of } 11 \mathrm{e} \text {.(2) byproduct } \\
\text { material and naturally occurring radioactive material }\end{array}$ & $\begin{array}{l}\text { NA; this facility does not manage naturally occurring } \\
\text { radioactive material. }\end{array}$ \\
\hline
\end{tabular}


Table 11. (continued).

Facility Name: MFC-774, Electron Microscopy Laboratory

\begin{tabular}{l}
\hline \multicolumn{1}{|c|}{ Chapter IV, LLW Requirements } \\
\hline $\begin{array}{l}\text { may be managed as low-level waste provided they can } \\
\text { be managed to meet the requirements for low-level } \\
\text { waste disposal in Section IV.P of this Manual. }\end{array}$ \\
\hline $\begin{array}{l}\text { C. } \text { Complex-Wide Low-Level Waste Management } \\
\text { Program. A complex-wide program and plan shall be } \\
\text { developed as described under Responsibilities, } 2 . \text { B and } \\
\text { 2.D, in Chapter I of this Manual. } \\
\text { D. Radioactive Waste Management Basis. Low-level } \\
\text { waste facilities, operations, and activities shall have a } \\
\text { radioactive waste management basis consisting of } \\
\text { physical and administrative controls to ensure the } \\
\text { protection of workers, the public, and the environment. } \\
\text { The following specific waste management controls } \\
\text { shall be part of the radioactive waste management } \\
\text { basis: }\end{array}$
\end{tabular}

(1) Generators. The waste certification program.

From DOE G 435.1-1 Chapter IV: For a facility that generates low-level waste, the radioactive waste management basis is to include the program for certifying that waste meets the waste acceptance requirements of the facility(ies) to which the waste will be sent.

(2) Treatment Facilities. certification program. The waste acceptance requirements and the waste [sic]

From DOE G 435.1-1 Chapter IV: Facilities that store or treat low-level waste are to have approved waste acceptance requirements (see DOE M 435.1-1, Section IV.G) prior to the issuance of a radioactive waste management basis.

A facility that stores or treats waste also is generally expected to have a waste certification program. Waste from these facilities will have to be certified as meeting the waste acceptance requirements of the facility to which it will be transferred, and the facilities have the potential for generating radioactive waste (e.g., secondary processing streams from treatment, monitoring and sampling, radioactive release cleanup). Consequently, storage and treatment facilities should also have an approved waste certification program as part of their radioactive waste management basis.

As part of the radioactive waste management basis, site personnel needs to implement a system or process for tracking the waste inventory at a storage, treatment, or disposal facility.
Not a facility-specific requirement. DOE Manual 435.1-1 §I.2.B and §I.2.D apply to the Assistant Secretary for Environmental Management and the Deputy Assistant Secretary for Waste Management, respectively.

The RWMB provides the regulatory framework for management of radioactive waste at INL. It specifically identifies facility management and implementing documents for the generation, storage, treatment, and disposal of radiological waste.

This facility is a LTHC3 facility (EDF-7030).

See J. below.

NA; LLW is not treated at this facility.

Containerized elementary neutralization is performed at this facility as provided by LWP-8000. As stated in $\S 4.118$, elementary neutralization of corrosive hazardous waste may take place at any location at which the waste is generated or stored, and neither a generator treatment plan nor a permit is required. Solidification of liquid LLW for the purpose of staging (not for treating the radioactive constituents) also may be performed. Therefore, this facility is not considered to be a treatment facility. 
Table 11. (continued).

Facility Name: MFC-774, Electron Microscopy Laboratory

\begin{tabular}{l} 
Chapter IV, LLW Requirements \\
\hline (3) Storage Facilities. The waste acceptance \\
requirements and the waste certification program. \\
From DOE G 435.1-1 Chapter IV: Facilities that store \\
or treat low-level waste are to have approved waste \\
acceptance requirements (see DOE M 435.1-1, Section \\
IV.G) prior to the issuance of a radioactive waste \\
management basis.
\end{tabular}

A facility that stores or treats waste also is generally expected to have a waste certification program. Waste from these facilities will have to be certified as meeting the waste acceptance requirements of the facility to which it will be transferred, and the facilities have the potential for generating radioactive waste (e.g., secondary processing streams from treatment, monitoring and sampling, radioactive release cleanup). Consequently, storage and treatment facilities should also have an approved waste certification program as part of their radioactive waste management basis.

As part of the radioactive waste management basis, site personnel needs to implement a system or process for tracking the waste inventory at a storage, treatment, or disposal facility.

(4) Disposal Facilities. The performance assessment, composite analysis, disposal authorization statement, closure plan, waste acceptance requirements, and monitoring plan.

E. Contingency Actions. The following requirements are in addition to those in Chapter I of this Manual [DOE M 435.1-1 §I.1.E(5)].

(1) Contingency Storage. For off-normal or emergency situations involving high activity or high hazard liquid low-level waste storage or treatment, spare capacity with adequate capabilities shall be maintained to receive the largest volume of liquid contained in any one storage tank or treatment facility. Tanks or other facilities that are designated low-level waste contingency storage shall be maintained in an operational condition when waste is present and shall meet the requirements of DOE O 435.1, Radioactive Waste Management, and this Manual.

From DOE G 435.1-1 Chapter IV: Compliance with these requirements is demonstrated if adequate spare capacity and transfer equipment exists for emergency transfers of all high activity and high hazard liquid low-level waste. In addition, the capability to perform emergency transfers is demonstrated by having waste

\section{Facility Compliance Information}

NA; this facility stages waste in accordance with N.(7) to facilitate treatment or disposal, but does not store LLW.

NA; this facility is not a disposal facility.

Not a facility-specific requirement. DOE Manual 435.1-1 §I.1.E(5) addresses the sitewide emergency management system. The INL plan is provided in PLN-114.

NA; liquid LLW is not stored or treated in a tank system at this facility. 
Table 11. (continued).

Facility Name: MFC-774, Electron Microscopy Laboratory

\begin{tabular}{l} 
Chapter IV, LLW Requirements \\
\hline transfer routings identified, operational procedures to \\
direct transfers, staff trained to the procedures, and \\
records showing that the spare capacity and transfer \\
capability are kept in operating condition. \\
\hline (2) Transfer Equipment. Pipelines and auxiliary \\
facilities necessary for the transfer of high activity or \\
high hazard liquid low-level waste to contingency \\
storage shall be maintained in an operational condition \\
when waste is present and shall meet the requirements \\
of DOE O 435.1, Radioactive Waste Management, and \\
this Manual. \\
From DOE G 435.1-1 Chapter IV: Compliance with \\
these requirements is demonstrated if adequate spare \\
capacity and transfer equipment exists for emergency \\
transfers of all high activity and high hazard liquid \\
low-level waste. In addition, the capability to perform \\
emergency transfers is demonstrated by having waste \\
transfer routings identified, operational procedures to \\
direct transfers, staff trained to the procedures, and \\
records showing that the spare capacity and transfer \\
capability are kept in operating condition.
\end{tabular}

F. Corrective Actions. I of this Manual. The following requirements are in addition to those in Chapter [sic]

From DOE G 435.1-1 Chapter IV: Compliance with DOE M 435.1-1 §I.2.G.(1) is demonstrated by records showing what corrective actions were taken to remedy situations in the radioactive waste management system.

Compliance with DOE M 435.1-1 §I.2.G.(2) is demonstrated by having the necessary procedures, mechanisms, and training in place to effect shutdown or curtailment of activities which pose an imminent danger or other serious hazard to workers or the public, or are not protective of the environment.

(1) Order Compliance. Corrective actions shall be implemented whenever necessary to ensure the requirements of DOE O 435.1, Radioactive Waste Management, and this Manual are met.

From DOE G 435.1-1 Chapter IV: If a facility or activity can be allowed to operate while a noncompliant or hazardous condition exists, the allowance and any associated limitations must be defined as part of the facility or activity's radioactive waste management basis, identified as a configuration controlled item in a configuration management plan or included in a revision or modification to an operating procedure or similar controlled documentation.

Compliance with this requirement is demonstrated if a
NA; liquid LLW is not stored or treated in a tank system at this facility.

The INL-wide procedure addressing problem identification as required by DOE Manual 435.1-1 §I.2.G.(1) is LWP-13840, which implements the laboratory's corrective action system.

The INL-wide procedure addressing shutdown or curtailment of activities as required by DOE Manual 435.1-1 §I.2.G.(2) is LWP-14002.
See F. above. 
Table 11. (continued).

Facility Name: MFC-774, Electron Microscopy Laboratory

\begin{tabular}{l} 
Chapter IV, LLW Requirements \\
\hline $\begin{array}{l}\text { corrective action system addresses noncompliant or } \\
\text { hazardous situations involving low-level waste } \\
\text { management facilities in a systematic fashion, and } \\
\text { allows identification of problems by all personnel. }\end{array}$ \\
(2) Operations Curtailment. Operations shall be \\
curtailed or facilities shut down for failure to establish, \\
maintain, or operate consistent with an approved \\
radioactive waste management basis. \\
From DOE G 435.1-1 Chapter IV: Compliance with \\
this requirement is demonstrated with a documented \\
system of routine assessments to determine whether \\
waste management activities and facilities are \\
operating in accordance with an approved radioactive \\
waste management basis that provides for graded \\
limitations that can be placed on activities and \\
operations that do not have, or are operating outside of, \\
an approved radioactive waste management basis, \\
including shutdown of the facility.
\end{tabular}

G. Waste Acceptance. The following requirements are in addition to those in Chapter I of this Manual [DOE M 435.1-1 §I.2.F(6)].

(1) Technical and Administrative. Waste acceptance requirements for all low-level waste storage, treatment, or disposal facilities, operations, and activities shall specify, at a minimum, the following:

From DOE G 435.1-1 Chapter IV: Compliance with these waste acceptance requirements is demonstrated if they are documented, contain clear and precise criteria specifying the radionuclide limits in the form of contents or concentrations that can be accepted, the limitations and prohibitions on waste forms and packages that can be received, and the limits, prohibitions, or instructions concerning any other technical information so that the waste is compatible with the safety basis of the facility, and which will result in acceptable waste at subsequent steps in managing the low-level waste.

(a) Allowable activities and/or concentrations of specific radionuclides.

(b) Acceptable waste form and/or container requirements that ensure the chemical and physical stability of waste under conditions that might be encountered during transportation, storage, treatment, or disposal.

(c) Restrictions or prohibitions on waste, materials, or containers that may adversely affect waste handlers or compromise facility or waste container performance.
The approved RWMB establishes the current compliance status at each radioactive waste management facility. Facility assessments are scheduled to ensure waste management activities are conducted in accordance with the approved RWMB.

Not a facility-specific requirement. DOE Manual 435.1-1 §I.2.F(6) applies to field element managers.

NA; this facility generates LLW but does not receive radioactive waste from other sources.

See (1) above.

See (1) above.

See (1) above. 
Table 11. (continued).

Facility Name: MFC-774, Electron Microscopy Laboratory

\begin{tabular}{|c|}
\hline Chapter IV, LLW Requirements \\
\hline $\begin{array}{l}\text { (d) The following are additional waste acceptance } \\
\text { requirements that shall be specified in low-level waste } \\
\text { disposal facility waste acceptance requirements: }\end{array}$ \\
\hline $\begin{array}{l}1 \text { Low-level waste must contribute to and not detract } \\
\text { from achieving long-term stability of the facility, } \\
\text { minimizing the need for long-term active maintenance, } \\
\text { minimizing subsidence, and minimizing contact of } \\
\text { water with waste. Void spaces within the waste and, if } \\
\text { containers are used, between the waste and its } \\
\text { container shall be reduced to the extent practical. }\end{array}$ \\
\hline $\begin{array}{l}2 \text { Liquid low-level waste or low-level waste containing } \\
\text { free liquid must be converted into a form that contains } \\
\text { as little freestanding liquid as is reasonably achievable, } \\
\text { but in no case shall the liquid exceed } 1 \text { percent of the } \\
\text { waste volume when the low-level waste is in a disposal } \\
\text { container, or } 0.5 \text { percent of the waste volume after it is } \\
\text { processed to a stable form. }\end{array}$ \\
\hline
\end{tabular}

3 Low-level waste must not be readily capable of detonation or of explosive decomposition or reaction at anticipated pressures and temperatures, or of explosive reaction with water. Pyrophoric materials contained in waste shall be treated, prepared, and packaged to be nonflammable.

4 Low-level waste must not contain, or be capable of generating by radiolysis or biodegradation, quantities of toxic gases, vapors, or fumes harmful to the public or workers or disposal facility personnel, or harmful to the long-term structural stability of the disposal site.

5 Low-level waste in a gaseous form must be packaged such that the pressure does not exceed 1.5 atmospheres absolute at $20 \mathrm{C}$. [ sic $]$

(e) The basis, procedures, and levels of authority required for granting exceptions to the waste acceptance requirements, which shall be contained in each facility's waste acceptance documentation. Each exception request shall be documented, including its disposition as approved or not approved.

From DOE G 435.1-1 Chapter IV: Waste acceptance requirements are acceptable if they are documented and contain a clear description of the procedure and bases for obtaining an exception or deviation to the acceptance criteria for low-level waste to be received at the facility.

(2) Evaluation and Acceptance. The receiving facility shall evaluate waste for acceptance, including confirmation that the technical and administrative requirements have been met. A process for the Facility Compliance Information

NA; this facility is not a LLW disposal facility.

See (d) above.

See (d) above.

See (d) above.

See (d) above.

See (d) above.

NA; this facility does not accept waste from other facilities.
NA; this facility does not accept waste from other facilities. 
Table 11. (continued).

Facility Name: MFC-774, Electron Microscopy Laboratory

\begin{tabular}{l} 
Chapter IV, LLW Requirements \\
\hline disposition of non-conforming wastes shall be \\
established. \\
From DOE G 435.1-1 Chapter IV: Compliance with \\
the waste acceptance requirements for a low-level \\
waste management facility is demonstrated if they \\
include a process for evaluation and acceptance of \\
incoming waste to ensure the acceptance criteria of the \\
facility receiving the waste are met that includes one of \\
or a combination of: (1) testing, sampling, and analysis \\
of representative samples of waste upon receipt; (2) \\
testing, sampling, and analysis of split samples of \\
waste taken at the generator site; (3) evaluation of \\
testing, sampling, and analysis of data provided by the \\
generator, or (4) audits, reviews, surveillance, or \\
observations of generator waste certification programs \\
and characterization activities. Additionally, acceptable \\
waste acceptance requirements for a storage, treatment \\
or disposal facility will have documented procedures \\
and actions to be taken if a waste that does not conform \\
to the waste acceptance criteria is received at the \\
facility.
\end{tabular}

H. Waste Generation Planning. The following requirements are in addition to those in Chapter I of this Manual [DOE M 435.1-1 §I.2.F(7)].

(1) Life-Cycle Planning. Prior to waste generation, planning shall be performed to address the entire life cycle for all low-level waste streams.

From DOE G 435.1-1 Chapter IV: Compliance with this planning requirement is demonstrated by the individual sites establishing a process for evaluating the life-cycle of low-level waste prior to its generation, including the identification of low-level wastes with no path to disposal and appropriate records justifying the newly generated low-level waste stream(s), and site personnel possessing planning information showing the location(s) where low-level waste will be stored, treated, and/or disposed along with a confirmation that the personnel managing the facilities agree that the low-level waste may be managed at those facilities.

(2) Waste with No Identified Path to Disposal. Lowlevel waste streams with no identified path to disposal shall be generated only in accordance with approved conditions which, at a minimum, shall address:

(a) Programmatic need to generate the waste;

(b) Characteristics and issues preventing the disposal of the waste;
Facility Compliance Information

Not a facility-specific requirement. DOE Manual 435.1-1 §I.2.F(7) applies to field element managers.

PDD-17000 and LWP-17000 provide direction to the waste generators for waste generation planning to address the entire life cycle.

LI 1219-07-MFC § 2, Table 2.03 lists the waste anticipated to be generated, the container type, and disposal method.

LI 1219-07-MFC § 2 states that WGS should be contacted if a waste generating process will result in a new radioactive or mixed waste to verify that the waste has an approved path forward.

Laboratory instructions also are prepared for specific tasks and projects. These laboratory instructions would include descriptions of expected waste and disposition plans.

NA; this facility is not generating LLW that does not have an identified path to disposal.

See (2) above.

See (2) above. 
Table 11. (continued).

Facility Name: MFC-774, Electron Microscopy Laboratory

\begin{tabular}{|l|}
\hline \multicolumn{2}{|c}{ Chapter IV, LLW Requirements } \\
\hline \multicolumn{1}{|c|}{ Facility Name: MFC-774, Elect } \\
achieved; and \\
\hline (d) Activities and plans for achieving final disposal of \\
the waste. \\
I. Waste Characterization. Low-level waste shall be \\
characterized using direct or indirect methods, and the \\
characterization documented in sufficient detail to \\
ensure safe management and compliance with the \\
waste acceptance requirements of the facility receiving \\
the waste. \\
From DOE G 435.1-1 Chapter IV: Compliance with \\
this requirement is demonstrated by a program for \\
documenting and the existence of records that \\
document the process for acquiring and verifying the \\
validity of low-level waste characterization data \\
acquired through the use of direct or indirect methods.
\end{tabular}

\section{(1) Data Quality Objectives. The data quality} objectives process, or a comparable process, shall be used for identifying characterization parameters and acceptable uncertainty in characterization data.

From DOE G 435.1-1 Chapter IV: Compliance with this requirement is demonstrated by the documented use of a data quality objectives or a comparable process for determining the type, quantity, and quality of characterization data needed to safely manage lowlevel waste.

\section{(2) Minimum Waste Characterization.}

Characterization data shall, at a minimum, include the following information relevant to the management of the waste:

From DOE G 435.1-1 Chapter IV: Compliance with this requirement is demonstrated by the existence of a program or procedure for determining and records that document characterization of low-level waste consistent with the minimum characterization data requirements.

\begin{tabular}{|l|l|}
\hline (a) Physical and chemical characteristics; & See I. and (2) above. \\
\hline $\begin{array}{l}\text { (b) Volume, including the waste and any stabilization } \\
\text { or absorbent media; }\end{array}$ & See I. and (2) above. \\
\hline $\begin{array}{l}\text { (c) Weight of the container and contents; } \\
\text { (d) Identities, activities, and concentrations of major } \\
\text { radionuclides; }\end{array}$ & See I. and (2) above. \\
\hline \begin{tabular}{l} 
(e) Characterization date; \\
\hline
\end{tabular} & See I. and (2) above. \\
\hline
\end{tabular}


Table 11. (continued).

Facility Name: MFC-774, Electron Microscopy Laboratory

\begin{tabular}{|c|}
\hline Chapter IV, LLW Requirements \\
\hline (f) Generating source; and \\
\hline
\end{tabular}

(g) Any other information which may be needed to prepare and maintain the disposal facility performance assessment, or demonstrate compliance with applicable performance objectives.

J. Waste Certification. A waste certification program shall be developed, documented, and implemented to ensure that the waste acceptance requirements of facilities receiving low-level waste for storage, treatment, and disposal are met.

From DOE G 435.1-1 Chapter IV: Compliance with the development and documentation portion of the certification requirement is demonstrated by a waste certification plan that identifies the organizations involved, assigns responsibilities for implementing the program, and describes or references the quality assurance, training, procurement controls, records management, and procedures to be used by the program. Acceptable performance for implementing the program is demonstrated when appropriate personnel are trained and follow the procedures that govern their part of the waste certification.

Additionally, acceptable performance is demonstrated if the waste certification plan and procedures are current and controlled in accordance with a document controls program, and records related to certification (e.g., certification statements, training records, procurement records, characterization records, container records) are generated and managed in accordance with the established site program.

(1) Certification Program. The waste certification program shall designate the officials who have the authority to certify and release waste for shipment; and specify what documentation is required for waste generation, characterization, shipment, and certification. The program shall provide requirements for auditability, retrievability, and storage of required documentation and specify the records retention period.

From DOE G 435.1-1 Chapter IV: Compliance with this requirement is demonstrated by a program or procedure for record keeping and records showing that low-level waste is certified as having met the waste acceptance criteria of the facility to which it was transferred and that the certification statement is supported by additional records regarding the waste source, characterization, and container.

MCP-17000 cites a waste certification program for LLW destined for NNSS. For waste destined for locations other than NNSS, the waste disposition specialist is responsible for certifying the waste stream by ensuring the waste, as characterized, falls within the limitations of the WAC of the treatment, storage, or disposal facility $(\S 2)$.

Container procurement is addressed in MCP-17000 $\S 4.6$.

MCP-17500 provides the WGS waste certification program for LLW to be shipped to NNSS.

Waste certification is performed and tracked using IWTS. Documentation of the IWTS Program is available electronically only.

PLN-522 requires waste technical specialists and waste disposition specialists to complete the appropriate training/qualification before being granted approval authority for profiles within the IWTS Program. The waste certification official, alternate waste certification official, and NNSS packaging certifiers must complete the appropriate training/qualifications to disposition waste to NNSS.

See J. above. MCP-17500 $\S 2$ and 5 address certification records for shipments to NNSS. 
Table 11. (continued).

Facility Name: MFC-774, Electron Microscopy Laboratory

\begin{tabular}{l} 
Chapter IV, LLW Requirements \\
\hline \multicolumn{1}{c}{ (2) Certification before Transfer. Low-level waste shall } \\
be certified as meeting waste acceptance requirements \\
before it is transferred to the facility receiving the \\
waste. \\
From DOE G 435.1-1 Chapter IV: Compliance with \\
this requirement is demonstrated by the presence of a \\
certification program which includes procedures \\
requiring a signed certification statement prior to the \\
release of waste for transfer, and by dated records \\
showing that waste was certified before being \\
transferred.
\end{tabular}

(3) Maintaining Certification. Low-level waste that has been certified as meeting the waste acceptance requirements for transfer to a storage, treatment, or disposal facility shall be managed in a manner that maintains its certification status.

From DOE G 435.1-1 Chapter IV: Compliance with this requirement is demonstrated by a program or procedure reflecting this requirement is present and site personnel are able to show that the storage of low-level waste containers is in a facility or manner where the containers would not be damaged by normal weather events, and cannot be accessed by unauthorized personnel. Further, each container can be traced to its certification and the information supporting that certification.

K. Waste Transfer. A documented process shall be established and implemented for transferring responsibility for management of low-level waste and for ensuring availability of relevant data. The following requirements are in addition to those in Chapter I of this Manual.

From DOE G 435.1-1 Chapter IV: Compliance with this requirement is demonstrated if facilities have procedures for the receipt of waste and the transfer of waste, as appropriate, which address the acquisition of waste and container data and the transfer of ownership, respectively. Further evidence of acceptable performance is facility records showing that data on the waste containers is available and accurate, and that documented transfer of responsibility occurs.

(1) Authorization. Low-level waste shall not be transferred to a storage, treatment, or disposal facility until personnel responsible for the facility receiving the waste authorize the transfer.

From DOE G 435.1-1 Chapter IV: Compliance with this requirement is demonstrated by sites having

\section{Facility Compliance Information}

See J. above. MCP-17500 $\$ 4.3 .6$ addresses controls for certification before transfer for LLW to be disposed of at NNSS.

See J. above. Pre-certification checklists are cited in MCP-17000 and MCP-17500. Surveillances also are addressed in MCP-17500.

LWP-15011 $\S 5$ provides general radioactive storage area requirements.

MCP-17000 $§ 4.8 .15$ specifies requirements for interfacility transfers.

TSD-OI-004 includes MFC-703 and MFC-797 requirements for receiving transferred waste.

MCP-17500 $\S 4$ addresses LLW to be transferred to NNSS.

See K. above. 
Table 11. (continued).

Facility Name: MFC-774, Electron Microscopy Laboratory

\begin{tabular}{|l|l|}
\hline \multicolumn{1}{|c|}{ Chapter IV, LLW Requirements } & Facility Compliance Information \\
\hline $\begin{array}{l}\text { procedures that require a confirmation of authorization } \\
\text { before releasing waste for transfer, and records } \\
\text { showing that transfers are made in accordance with } \\
\text { written authorizations. }\end{array}$ & \\
\hline
\end{tabular}

(2) Data. Waste characterization data, container information, and generation, storage, treatment, and transportation information for low-level waste shall be transferred with or be traceable to the waste.

From DOE G 435.1-1 Chapter IV: Compliance with this requirement is demonstrated if there are procedures requiring that characterization and container data be provided and maintained for each low-level waste transfer and documented records of transfers show that the information is being provided.

\section{Packaging and Transportation. The following requirements are in addition to those in Chapter I of this Manual [DOE M 435.1-1 §I.1.E(11)].}
(1) Packaging. If containers are used:
From DOE G 435.1-1 Chapter IV: Compliance with the packaging requirement is demonstrated by: (1) procedures which document proper packaging protocols; and (2) no trends of routine repackaging of low-level waste that is packaged after issuance of DOE $\mathrm{O}$ 435.1. Successful performance of this requirement is also demonstrated by a record of containers for which failure has not routinely occurred under management conditions. It is recognized that there may be failed containers for waste previously placed in storage. For those containers, the goal is to only have to repackage the waste one time after it is retrieved and characterized. Further, acceptable performance is demonstrated by containers of waste having marking and labeling that allows correlation with waste characterization data and container information.

(a) Low-level waste shall be packaged in a manner that provides containment and protection for the duration of the anticipated storage period and until disposal is achieved or until the waste has been removed from the container.

(b) When waste is packaged, vents or other measures shall be provided if the potential exists for pressurizing or generating flammable or explosive concentrations of gases within the waste container.

(c) Containers of low-level waste shall be marked such that their contents can be identified.

(2) Transportation. To the extent practical, the volume of waste and number of low-level waste shipments
See K. above.

See (1) and (2) below.

MCP-17000 $§ 4$ addresses packaging requirements.

See (1) above.

See (1) above.

See (1) above.

MCP-17000 $\S 4$ addresses transportation. The waste disposition specialist coordinates with packaging and 
Table 11. (continued).

Facility Name: MFC-774, Electron Microscopy Laboratory

\begin{tabular}{|c|}
\hline Chapter IV, LLW Requirements \\
\hline shall be minimized. \\
\hline $\begin{array}{l}\text { From DOE G } 435.1-1 \text { Chapter IV: Compliance with } \\
\text { this requirement can be demonstrated by a combination } \\
\text { of site procedures directing the efficient use of waste } \\
\text { container capacity and documentation showing that } \\
\text { low-level waste shipments are systematically planned } \\
\text { and optimized to the extent practical. }\end{array}$ \\
\hline $\begin{array}{l}\text { M. Site Evaluation and Facility Design. The following } \\
\text { requirements are in addition to those in Chapter I of } \\
\text { this Manual. }\end{array}$ \\
\hline
\end{tabular}

(1) Site Evaluation. Proposed locations for low-level waste facilities shall be evaluated to identify relevant features that should be avoided or must be considered in facility design and analyses. (a) Each site proposed for a new low-level waste facility or expansion of an existing low-level waste facility shall be evaluated considering environmental characteristics, geotechnical characteristics, and human activities, including for a low-level waste disposal facility, the capability of the site to demonstrate, at a minimum, whether it is:

1 Located to accommodate the projected volume of waste to be received;

2 Located in a flood plain, a tectonically active area, or in the zone of water table fluctuation; and

3 Located where radionuclide migration pathways are predictable and erosion and surface runoff can be controlled.

(b) Proposed sites with environmental characteristics, geotechnical characteristics, and human activities for which adequate protection cannot be provided through facility design shall be deemed unsuitable for the location of the facility.

(c) Low-level waste disposal facilities shall be sited to achieve long-term stability and to minimize, to the extent practical, the need for active maintenance following final closure.

(2) Low-Level Waste Treatment and Storage Facility Design. The following facility requirements and general design criteria, at a minimum, apply:

(a) Confinement. Low-level waste systems and components shall be designed to maintain waste confinement.

(b) Ventilation.

\section{Facility Compliance Information}

transportation personnel for waste shipped offsite from this facility.

Waste is shipped directly to NNSS from this facility. MCP-17500 specifies waste certification official and waste disposition specialist responsibilities and coordination with packaging and transportation personnel.

$\mathrm{NA}$; this requirement addresses new radioactive waste management facilities or modifications to existing facilities.

See M. above.

See M. above.

See M. above.

See M. above.

See M. above.

See M. above.

See M. above.

See M. above.

See M. above.

See M. above. 
Table 11. (continued).

\begin{tabular}{|c|c|}
\hline \multicolumn{2}{|c|}{ Facility Name: MFC-774, Electron Microscopy Laboratory } \\
\hline Chapter IV, LLW Requirements & Facility Compliance Information \\
\hline $\begin{array}{l}1 \text { Design of low-level waste treatment and storage } \\
\text { facilities shall include ventilation, if applicable, } \\
\text { through an appropriate filtration system to maintain the } \\
\text { release of radioactive material in airborne effluents } \\
\text { within the requirements and guidelines specified in } \\
\text { applicable requirements. }\end{array}$ & See M. above. \\
\hline $\begin{array}{l}2 \text { When conditions exist for generating gases in } \\
\text { flammable or explosive concentrations, ventilation } \\
\text { systems or other measures shall be provided to keep the } \\
\text { gases in a non-flammable and nonexplosive condition. } \\
\text { Where concentrations of explosive or flammable gases } \\
\text { are expected to approach the lower flammability limit, } \\
\text { measures shall be taken to prevent deflagration or } \\
\text { detonation. }\end{array}$ & See M. above. \\
\hline $\begin{array}{l}\text { (c) Consideration of Decontamination and } \\
\text { Decommissioning. Areas in new and modifications to } \\
\text { existing low-level waste management facilities that are } \\
\text { subject to contamination with radioactive or other } \\
\text { hazardous materials shall be designed to facilitate } \\
\text { decontamination. For such facilities a proposed } \\
\text { decommissioning method or a conversion method } \\
\text { leading to reuse shall be described. }\end{array}$ & See M. above. \\
\hline $\begin{array}{l}\text { (d) Instrumentation and Control Systems. Engineering } \\
\text { controls shall be incorporated in the design and } \\
\text { engineering of low-level waste treatment and storage } \\
\text { facilities to provide volume inventory data and to } \\
\text { prevent spills, leaks, and overflows from tanks or } \\
\text { confinement systems. }\end{array}$ & See M. above. \\
\hline $\begin{array}{l}\text { (e) Monitoring. Monitoring and/or leak detection } \\
\text { capabilities shall be incorporated in the design and } \\
\text { engineering of low-level waste treatment and storage } \\
\text { facilities to provide rapid identification of failed } \\
\text { confinement and/or other abnormal conditions. }\end{array}$ & See M. above. \\
\hline $\begin{array}{l}\text { (3) Low-Level Waste Disposal Facility Design. The } \\
\text { following facility requirements and general design } \\
\text { criteria, at a minimum, apply: }\end{array}$ & See M. above. \\
\hline $\begin{array}{l}\text { (a) Confinement. Low-level waste systems and } \\
\text { components shall be designed to maintain waste } \\
\text { confinement. }\end{array}$ & See M. above. \\
\hline (b) Ventilation. & See M. above. \\
\hline $\begin{array}{l}1 \text { Design of low-level waste disposal facilities shall } \\
\text { include ventilation, if applicable, through an } \\
\text { appropriate filtration system to maintain the release of } \\
\text { radioactive material in airborne effluents within the } \\
\text { requirements and guidelines specified in applicable } \\
\text { requirements. }\end{array}$ & See M. above. \\
\hline
\end{tabular}


Table 11. (continued).

\begin{tabular}{|c|c|}
\hline \multicolumn{2}{|c|}{ Facility Name: MFC-774, Electron Microscopy Laboratory } \\
\hline Chapter IV, LLW Requirements & Facility Compliance Information \\
\hline $\begin{array}{l}2 \text { When conditions exist for generating gases in } \\
\text { flammable or explosive concentrations, ventilation } \\
\text { systems or other measures shall be provided to keep the } \\
\text { gases in a nonflammable and non-explosive condition. } \\
\text { Where concentrations of explosive or flammable gases } \\
\text { are expected to approach the lower flammability limit, } \\
\text { measures shall be taken to prevent deflagration or } \\
\text { detonation. }\end{array}$ & See M. above. \\
\hline $\begin{array}{l}\text { (c) Stability. Low-level waste disposal facilities shall } \\
\text { be designed to achieve long-term stability and to } \\
\text { minimize to the extent practical, the need for active } \\
\text { maintenance following final closure. }\end{array}$ & See M. above. \\
\hline $\begin{array}{l}\text { (d) Control of Water. Low-level waste disposal } \\
\text { facilities shall be designed to minimize to the extent } \\
\text { practical, the contact of waste with water during and } \\
\text { after disposal. }\end{array}$ & See M. above. \\
\hline $\begin{array}{l}\text { N. Storage and Staging. The following requirements } \\
\text { are in addition to those in Chapter I of this Manual } \\
\text { [DOE M 435.1-1 §I.2.F(13)]. }\end{array}$ & $\begin{array}{l}\text { Not a facility-specific requirement. DOE Manual } \\
435.1-1 \text { §I.2.F(13) applies to field element managers. }\end{array}$ \\
\hline $\begin{array}{l}\text { (1) Storage Prohibitions. Low-level waste in storage } \\
\text { shall not be readily capable of detonation, explosive } \\
\text { decomposition, reaction at anticipated pressures and } \\
\text { temperatures, or explosive reaction with water. Prior to } \\
\text { storage, pyrophoric materials shall be treated, prepared, } \\
\text { and packaged to be nonflammable. }\end{array}$ & NA; LLW is not stored at this facility. \\
\hline $\begin{array}{l}\text { From DOE G } 435.1-1 \text { Chapter IV: Compliance with } \\
\text { this requirement is demonstrated by having waste } \\
\text { acceptance requirements which prohibit low-level } \\
\text { waste that is ignitable or explosive from being accepted } \\
\text { for storage unless it has been treated, and procedures } \\
\text { for properly preparing such materials for safe storage. }\end{array}$ & \\
\hline $\begin{array}{l}\text { (2) Storage Limit. Low-level waste that has an } \\
\text { identified path to disposal shall not be stored longer } \\
\text { than one year prior to disposal, except for storage for } \\
\text { decay, or as otherwise authorized by the Field Element } \\
\text { Manager. }\end{array}$ & NA; LLW is not stored at this facility. \\
\hline $\begin{array}{l}\text { From DOE G } 435.1-1 \text { Chapter IV: Storage longer than } \\
\text { one year can be justified if the conditions for such } \\
\text { storage are approved by the Field Element Manager as } \\
\text { part of the radioactive waste management basis for the } \\
\text { facility. }\end{array}$ & \\
\hline $\begin{array}{l}\text { Storage for radioactive decay for a period greater than } \\
1 \text { year for waste that has an identified path to disposal } \\
\text { is allowed. Adequate justification and the supporting } \\
\text { information for storage for decay is to be documented } \\
\text { in the radioactive waste management basis for the } \\
\text { facility in which the storage will take place. }\end{array}$ & \\
\hline
\end{tabular}


Table 11. (continued).

Facility Name: MFC-774, Electron Microscopy Laboratory

\begin{tabular}{|c|c|}
\hline Chapter IV, LLW Requirements & Facility Compliance Information \\
\hline $\begin{array}{l}\text { Mixed waste. Under the Federal Facility Compliance } \\
\text { Act of 1992, DOE sites were required to develop Site } \\
\text { Treatment Plans to bring stored mixed low-level waste } \\
\text { into compliance with these requirements. The Site } \\
\text { Treatment Plan needs to be consulted and any mixed } \\
\text { low-level waste stored for the purpose of accumulation } \\
\text { to facilitate treatment must meet Resource } \\
\text { Conservation and Recovery Act storage requirements. } \\
\text { There could be several ways within different scenarios } \\
\text { that this requirement can be met, as illustrated by the } \\
\text { examples below, however, there are basically four } \\
\text { ways to show compliance with the requirement and } \\
\text { include appropriate provisions in the radioactive waste } \\
\text { management basis for the facility in which it is stored. }\end{array}$ & \\
\hline $\begin{array}{l}\text { Legacy waste. As discussed above, the intention of the } \\
\text { requirement is not to force malicious compliance or } \\
\text { heroic actions which would result in increased risk or } \\
\text { safety concerns. Rather, the intention is that waste in } \\
\text { storage longer than one year receives additional } \\
\text { attention to ensure that the public, the workers, and the } \\
\text { environment are protected from the hazards of the } \\
\text { waste, and that progress is being made to dispose of the } \\
\text { waste. There could be several ways within different } \\
\text { scenarios that this requirement can be met, as } \\
\text { illustrated by the examples below, however, there are } \\
\text { basically four ways to show compliance with the } \\
\text { requirement: }\end{array}$ & \\
\hline $\begin{array}{l}\text { 1) the radioactive waste management basis allows for } \\
\text { storage for no more than one year. }\end{array}$ & \\
\hline $\begin{array}{l}\text { 2) the radioactive waste management basis allows for } \\
\text { storage for no more than one year, or for storage for } \\
\text { decay only for periods greater than a year, which are } \\
\text { specified on a radionuclide basis. }\end{array}$ & \\
\hline $\begin{array}{l}\text { 3) the radioactive waste management basis allows for } \\
\text { storage for more than one year, up to a specified period } \\
\text { of time based on a documented technical evaluation } \\
\text { that the waste can be stored in a manner that does not } \\
\text { cause changes to the waste or waste packages that is } \\
\text { detrimental to the safe storage of the waste, the final } \\
\text { disposal of the waste or to meeting the disposal } \\
\text { performance objectives. }\end{array}$ & \\
\hline $\begin{array}{l}\text { 4) the radioactive waste management basis allows for } \\
\text { storage for decay (with specifics) and for storage for } \\
\text { more than one year for other low-level waste, up to a } \\
\text { specified period of time based on a documented } \\
\text { technical evaluation that the waste can be stored in a } \\
\text { manner that does not cause changes to the waste or } \\
\text { waste packages that is detrimental to the safe storage of }\end{array}$ & \\
\hline
\end{tabular}


Table 11. (continued).

Facility Name: MFC-774, Electron Microscopy Laboratory

\begin{tabular}{l} 
Chapter IV, LLW Requirements \\
\hline the waste, the final disposal of the waste or to meeting \\
the disposal performance objectives. \\
Compliance with this requirement is demonstrated by \\
the existence of a radioactive waste management basis \\
for the storage facility approved by the Field Element \\
Manager that includes the time frames that waste are \\
allowed to be stored, the necessary justifications for \\
storage for decay, and the necessary technical \\
evaluations if storage is to extend significantly beyond \\
the one-year time frame.
\end{tabular}

(3) Storage Integrity. Low-level waste shall be stored in a location and manner that protects the integrity of waste for the expected time of storage and minimizes worker exposure.

From DOE G 435.1-1 Chapter IV: However, in making a decision to use a facility for storage and in developing a radioactive waste management basis for the activity, particular attention to protection of workers is needed.

Compliance with this requirement is demonstrated if sites have storage capabilities for low-level waste that provide protection to waste containers so that their integrity will not be damaged through physical or chemical (corrosion) processes and that keep personnel from spending extended periods of time in the areas where low-level waste is stored.

(4) Waste Characterization for Storage.

(a) Low-level waste that does not have an identified path to disposal shall be characterized as necessary to meet the data quality objectives and minimum characterization requirements of this Chapter, to ensure safe storage, and to facilitate disposal.

(b) Characterization information for all low-level waste in storage shall be maintained as a record in accordance with the requirements for Records Management in Chapter I of this Manual.

From DOE G 435.1-1 Chapter IV: Compliance with this requirement is demonstrated by documented procedures for managing waste characterization and container information on low-level waste as a Federal record. The records are managed per the applicable policies and procedures for records management referenced in DOE O 200.1 and established at the applicable Field Element.

(5) Container Inspection. A process shall be developed and implemented for inspecting and maintaining containers of low-level waste to ensure container
NA; LLW is not stored at this facility.

NA; LLW is not stored at this facility.

See (4) above.

See (4) above.

LI-435 requires quarterly inspections of radioactive waste containers if waste is stored outdoors or has been in storage for greater than 1 year. 
Table 11. (continued).

Facility Name: MFC-774, Electron Microscopy Laboratory

\begin{tabular}{l}
\multicolumn{1}{|c|}{ Chapter IV, LLW Requirements } \\
\hline integrity is not compromised. \\
From DOE G 435.1-1 Chapter IV: Compliance with \\
this requirement is demonstrated by: (1) a documented \\
process for waste container inspection and \\
maintenance; and (2) documentation for all waste \\
container inspections and maintenance actions \\
performed.
\end{tabular}

(6) Storage Management. Low-level waste storage shall be managed to identify and segregate low-level waste from mixed low-level waste.

(7) Staging. Staging of low-level waste shall be for the purpose of the accumulation of such quantities of waste as necessary to facilitate transportation, treatment, and disposal. Staging longer than 90 days shall meet the requirements for storage above and in Chapter I of this Manual.

From DOE G 435.1-1 Chapter IV: The staging of lowlevel waste needs to be addressed in the radioactive waste management basis for the facility that is performing the staging. Generators, treatment facilities, and disposal facilities that stage waste must ensure that the action of staging is included and authorized as part of their radioactive waste management basis for the affected facilities, operations, or activities.

Staging longer than 90 days must be justified, the conditions for such storage met, and these practices approved by the Field Element Manager as part of the radioactive waste management basis for the facility.

Compliance with this requirement is demonstrated by a staging program that limits the temporary storage of waste to only circumstances allowed in the requirement, including justifications for any staging that exceeds the 90-day period, which is documented in the radioactive waste management basis for the facility.

O. Treatment. Low-level waste treatment to provide more stable waste forms and to improve the long-term performance of a low-level waste disposal facility shall be implemented as necessary to meet the performance objectives of the disposal facility.

From DOE G 435.1-1 Chapter IV: Compliance with this requirement is demonstrated when a treatment facility or process ensures that treated waste will meet the minimum waste form requirements of DOE $\mathrm{M}$ 435.1 and meet additional disposal facility-specific waste acceptance requirements for additional stability or long-term performance of facilities that will receive the treated waste.

\section{Facility Compliance Information}

Inspections are performed for TAAs and SAAs as required by WGS procedures (MCP-17000 and MCP17410).

NA; LLW is not stored at this facility.

LLW and mixed LLW is staged for the purpose of accumulation to facilitate treatment and disposal. Mixed LLW is staged in SAAs in accordance with MCP-17000 and MCP-17410. LLW is staged in TAAs in accordance with MCP-17000and MCP-17410.

MCP-17000, Appendix F restricts staging LLW to 90 days maximum at any generator or treatment facility prior to acceptance by a storage facility.

LI 1219-07-MFC $\S 2$, Table 2.03 states that the facility's mixed LLW is stored in an SAA until the waste is ready for disposition by WGS.

Individual projects also would have project-specific laboratory instructions that would address the management of mixed LLW in accordance with RCRA regulations.

NA; treatment is not performed in this facility.

Containerized elementary neutralization is performed at this facility as provided by LWP-8000. As stated in $\S 4.118$, elementary neutralization of corrosive hazardous waste may take place at any location at which the waste is generated or stored, and neither a generator treatment plan nor a permit is required. Solidification of liquid LLW for the purpose of staging (not for treating the radioactive constituents) also may be performed. Therefore, this facility is not considered to be a treatment facility. 
Table 11. (continued).

Facility Name: MFC-774, Electron Microscopy Laboratory

\begin{tabular}{|l|}
\hline \multicolumn{1}{|c|}{ Chapter IV, LLW Requirements } \\
\hline $\begin{array}{l}\text { P. Disposal. Low-level waste disposal facilities shall } \\
\text { meet the following requirements. }\end{array}$ \\
(1) Performance Objectives. Low-level waste disposal \\
facilities shall be sited, designed, operated, maintained, \\
and closed so that a reasonable expectation exists that \\
the following performance objectives will be met for \\
waste disposed of after September 26, 1988:
\end{tabular}

(a) Dose to representative members of the public shall not exceed $25 \mathrm{mrem}(0.25 \mathrm{mSv})$ in a year total effective dose equivalent from all exposure pathways, excluding the dose from radon and its progeny in air.

(b) Dose to representative members of the public via the air pathway shall not exceed $10 \mathrm{mrem}(0.10 \mathrm{mSv})$ in a year total effective dose equivalent, excluding the dose from radon and its progeny.

(c) Release of radon shall be less than an average flux of $20 \mathrm{pCi} / \mathrm{m}^{2} / \mathrm{s}\left(0.74 \mathrm{~Bq} / \mathrm{m}^{2} / \mathrm{s}\right)$ at the surface of the disposal facility. Alternatively, a limit of $0.5 \mathrm{pCi} / 1$ $(0.0185 \mathrm{~Bq} / \mathrm{l})$ of air may be applied at the boundary of the facility.

(2) Performance Assessment. A site-specific radiological performance assessment shall be prepared and maintained for DOE low-level waste disposed of after September 26, 1988. The performance assessment shall include calculations for a 1,000 year period after closure of potential doses to representative future members of the public and potential releases from the facility to provide a reasonable expectation that the performance objectives identified in this Chapter are not exceeded as a result of operation and closure of the facility.

(a) Analyses performed to demonstrate compliance with the performance objectives in this Chapter, and to establish limits on concentrations of radionuclides for disposal based on the performance measures for inadvertent intruders in this Chapter shall be based on reasonable activities in the critical group of exposed individuals. Unless otherwise specified, the assumption of average living habits and exposure conditions in representative critical groups of individuals projected to receive the highest doses is appropriate. The likelihood of inadvertent intruder scenarios may be considered in interpreting the results of the analyses and establishing radionuclide concentrations, if adequate justification is provided.

(b) The point of compliance shall correspond to the point of highest projected dose or concentration beyond

See P. above. NA; LLW is not disposed of in this facility.

See P. above.

See P. above.

See P. above.

See P. above.

See P. above. Facility Compliance Information 
Table 11. (continued).

Facility Name: MFC-774, Electron Microscopy Laboratory

\begin{tabular}{l} 
Chapter IV, LLW Requirements \\
\hline $\begin{array}{l}\text { a } 100 \text { meter buffer zone surrounding the disposed } \\
\text { waste. A larger or smaller buffer zone may be used if } \\
\text { adequate justification is provided. }\end{array}$ \\
(c) Performance assessments shall address reasonably \\
foreseeable natural processes that might disrupt barrie \\
against release and transport of radioactive materials. \\
\hline $\begin{array}{l}\text { (d) Performance assessments shall use DOE-approved } \\
\text { dose coefficients (dose conversion factors) for internal } \\
\text { and external exposure of reference adults. }\end{array}$ \\
(e) The performance assessment shall include a \\
sensitivity/uncertainty analysis. \\
(f) Performance assessments shall include a \\
demonstration that projected releases of radionuclides \\
to the environment shall be maintained as low as \\
reasonably achievable (ALARA).
\end{tabular}

(g) For purposes of establishing limits on radionuclides that may be disposed of near-surface, the performance assessment shall include an assessment of impacts to water resources.

(h) For purposes of establishing limits on the concentration of radionuclides that may be disposed of near-surface, the performance assessment shall include an assessment of impacts calculated for a hypothetical person assumed to inadvertently intrude for a temporary period into the low-level waste disposal facility. For intruder analyses, institutional controls shall be assumed to be effective in deterring intrusion for at least 100 years following closure. The intruder analyses shall use performance measures for chronic and acute exposure scenarios, respectively, of 100 mrem $(1 \mathrm{mSv})$ in a year and $500 \mathrm{mrem}(5 \mathrm{mSv})$ total effective dose equivalent excluding radon in air.

(3) Composite Analysis. For disposal facilities which received waste after September 26, 1988, a site-specific radiological composite analysis shall be prepared and maintained that accounts for all sources of radioactive material that may be left at the DOE site and may interact with the low- level waste disposal facility, contributing to the dose projected to a hypothetical member of the public from the existing or future disposal facilities. Performance measures shall be consistent with DOE requirements for protection of the public and environment and evaluated for a 1,000 year period following disposal facility closure. The composite analysis results shall be used for planning, radiation protection activities, and future use commitments to minimize the likelihood that current low- level waste disposal activities will result in the
See P. above.

See P. above.

See P. above.

See P. above.

See P. above.

See P. above.

See P. above. 
Table 11. (continued).

Facility Name: MFC-774, Electron Microscopy Laboratory

\begin{tabular}{|l|l|}
\hline \multicolumn{1}{|c|}{ Chapter IV, LLW Requirements } & Facility Compliance Information \\
\hline $\begin{array}{l}\text { need for future corrective or remedial actions to } \\
\text { adequately protect the public and the environment. }\end{array}$ & \\
\hline
\end{tabular}

(4) Performance Assessment and Composite Analysis Maintenance. The performance assessment and composite analysis shall be maintained to evaluate changes that could affect the performance, design, and operating bases for the facility. Performance assessment and composite analysis maintenance shall include the conduct of research, field studies, and monitoring needed to address uncertainties or gaps in existing data. The performance assessment shall be updated to support the final facility closure. Additional iterations of the performance assessment and composite analysis shall be conducted as necessary during the post-closure period.

(a) Performance assessments and composite analyses shall be reviewed and revised when changes in waste forms or containers, radionuclide inventories, facility design and operations, closure concepts, or the improved understanding of the performance of the waste disposal facility in combination with the features of the site on which it is located alter the conclusions or the conceptual model(s) of the existing performance assessment or composite analysis.

(b) A determination of the continued adequacy of the performance assessment and composite analysis shall be made on an annual basis, and shall consider the results of data collection and analysis from research, field studies, and monitoring.

(c) Annual summaries of low-level waste disposal operations shall be prepared with respect to the conclusions and recommendations of the performance assessment and composite analysis and a determination of the need to revise the performance assessment or composite analysis.

(5) Disposal Authorization. A disposal authorization statement shall be obtained prior to construction of a new low-level waste disposal facility. Field Elements with existing low-level waste disposal facilities shall obtain a disposal authorization statement in accordance with the schedule in the Complex-Wide Low-Level Waste Management Program Plan. The disposal authorization statement shall be issued based on a review of the facility's performance assessment, composite analysis, performance assessment and composite analysis maintenance, preliminary closure plan, and preliminary monitoring plan. The disposal authorization statement shall specify the limits and conditions on construction, design, operations, and
See P. above.

See P. above.

See P. above.

See P. above.

See P. above. 
Table 11. (continued).

Facility Name: MFC-774, Electron Microscopy Laboratory

\begin{tabular}{|c|}
\hline Chapter IV, LLW Requirements \\
\hline $\begin{array}{l}\text { closure of the low-level waste facility based on these } \\
\text { reviews. A disposal authorization statement is a part of } \\
\text { the radioactive waste management basis for a disposal } \\
\text { facility. Failure to obtain a disposal authorization } \\
\text { statement by the implementation date of this Order } \\
\text { shall result in shutdown of the disposal facility. }\end{array}$ \\
\hline $\begin{array}{l}\text { (6) Disposal Facility Operations. The disposal facility } \\
\text { design and operation must be consistent with the } \\
\text { disposal facility closure plan and lead to disposal } \\
\text { facility closure that provides a reasonable expectation } \\
\text { that performance objectives will be met. Low-level } \\
\text { waste shall be disposed in such a manner that achieves } \\
\text { the performance objectives stated in this Chapter, } \\
\text { consistent with the disposal facility radiological } \\
\text { performance assessment. Additional requirements } \\
\text { include: }\end{array}$ \\
\hline
\end{tabular}

(a) Operating procedures shall be developed and implemented for low-level waste disposal facilities that protect the public, workers, and the environment; ensure the security of the facility; minimize subsidence during and after waste emplacement; achieve long-term stability and minimize the need for long-term active maintenance; and meet the requirements of the closure/post-closure plan.

(b) Permanent identification markers for disposal excavations and monitoring wells shall be emplaced.

(c) Low-level waste placement into disposal units shall minimize voids between waste containers. Voids within disposal units shall be filled to the extent practical. Uncontainerized bulk waste shall also be placed in a manner that minimizes voids and subsidence.

(d) Operations are to be conducted so that active waste disposal operations will not have an adverse effect on any other disposal units.

(e) Operations shall include a process for tracking and documenting low-level waste placement in the facility by generator source.

(7) Alternate Requirements for Low-Level Waste Disposal Facility Design and Operation. Requirements other than those set forth in this Section for the design and operation of a low-level waste disposal facility may be approved on a specific basis if a reasonable expectation is demonstrated that the disposal performance objectives will be met.

Q. Closure. The following requirements are in addition to those in Chapter I of this Manual.
Facility Compliance Information

See P. above.

See P. above.

See P. above.

See P. above.

See P. above.

See P. above.

See P. above.

NA; LLW is not disposed of in this facility. 
Table 11. (continued).

Facility Name: MFC-774, Electron Microscopy Laboratory

\begin{tabular}{l}
\hline \multicolumn{1}{|c|}{ Chapter IV, LLW Requirements } \\
\hline (1) Disposal Facility Closure Plans. A preliminary \\
closure plan shall be developed and submitted to \\
Headquarters for review with the performance \\
assessment and composite analysis. The closure plan \\
shall be updated following issuance of the disposal \\
authorization statement to incorporate conditions \\
specified in the disposal authorization statement. \\
Closure plans shall:
\end{tabular}

(a) Be updated as required during the operational life of the facility.

(b) Include a description of how the disposal facility will be closed to achieve long-term stability and minimize the need for active maintenance following closure and to ensure compliance with the requirements of DOE 5400.5, Radiation Protection of the Public and the Environment.

(c) Include the total expected inventory of wastes to be disposed of at the facility over the operational life of the facility.

(2) Disposal Facility Closure. Closure of a disposal facility shall occur within a five-year period after it is filled to capacity, or after the facility is otherwise determined to be no longer needed.

(a) Prior to facility closure, the final inventory of the low-level waste disposed in the facility shall be prepared and incorporated in the performance assessment and composite analysis which shall be updated to support the closure of the facility.

(b) A final closure plan shall be prepared based on the final inventory of waste disposed in the facility, the plan implemented, and the updated performance assessment and composite analysis prepared in support of the facility closure.

(c) Institutional control measures shall be integrated into land use and stewardship plans and programs, and shall continue until the facility can be released pursuant to DOE 5400.5, Radiation Protection of the Public and the Environment.

(d) The location and use of the facility shall be filed with the local authorities responsible for land use and zoning.

R. Monitoring. The following requirements are in addition to those in Chapter I of this Manual [DOE M 435.1-1 §I.1.E(7)].

\section{Facility Compliance Information}

See Q. above.

See Q. above.

See Q. above.

See Q. above.

See Q. above.

See Q. above.

See Q. above.

See Q. above.

See Q. above.

See (1), (2), and (3) below. 
Table 11. (continued).

Facility Name: MFC-774, Electron Microscopy Laboratory

\begin{tabular}{|c|c|}
\hline Chapter IV, LLW Requirements & Facility Compliance Information \\
\hline $\begin{array}{l}\text { (1) All Waste Facilities. Parameters that shall be } \\
\text { sampled or monitored, at a minimum, include: } \\
\text { temperature, pressure (for closed systems), } \\
\text { radioactivity in ventilation exhaust and liquid effluent } \\
\text { streams, and flammable or explosive mixtures of gases. } \\
\text { Facility monitoring programs shall include verification } \\
\text { that passive and active control systems have not failed. } \\
\text { From DOE G 435.1-1 Chapter IV: The minimum } \\
\text { parameters specified in the requirement were selected } \\
\text { based on their potential significance for anticipating } \\
\text { and identifying undesirable conditions at low-level } \\
\text { waste management facilities. Each facility's radioactive } \\
\text { waste management basis should include an evaluation } \\
\text { of the applicability and significance of the minimum } \\
\text { parameters. This evaluation also needs to consider } \\
\text { additional parameters to be sampled or monitored to } \\
\text { ensure the protection of the public health, the } \\
\text { environment, and the workers. If a minimum parameter } \\
\text { specified in the requirement is deemed to be not } \\
\text { applicable in any way to the active operation of that } \\
\text { facility, then that justification should be included in the } \\
\text { radioactive waste management basis and when } \\
\text { approved constitutes an exemption to the manual. } \\
\text { Verification activities are part of the radioactive waste } \\
\text { management basis as a condition for operation and } \\
\text { documented appropriately. } \\
\text { Compliance with this requirement is demonstrated if } \\
\text { monitoring or sampling for the stated parameters is } \\
\text { performed for all facilities with a precision, accuracy, } \\
\text { and frequency consistent with timely identification of } \\
\text { developing problems and a justification exists in the } \\
\text { approved radioactive waste management basis for those } \\
\text { specified parameters which are not monitored or } \\
\text { sampled. }\end{array}$ & $\begin{array}{l}\text { Monitoring requirements at INL radioactive waste } \\
\text { management facilities are tailored for the specific } \\
\text { facility to enable timely indication of developing } \\
\text { problems. Existing radiological control procedures and } \\
\text { assessments are followed/completed to monitor waste } \\
\text { facilities. } \\
\text { LRD-15001 and MCP-139 specify methods and } \\
\text { frequency of radiological control surveys of all } \\
\text { radiological areas. MCP-139 specifies the use of } \\
\text { Form } 441 \text {.A34. This form is referred to as the "routine } \\
\text { sheet" and is to be used by facility radiological control } \\
\text { foremen to list radiological areas that are to be } \\
\text { surveyed, the survey periods, and methods. }\end{array}$ \\
\hline $\begin{array}{l}\text { (2) Liquid Waste Storage Facilities. For facilities } \\
\text { storing liquid low-level waste, the following shall also } \\
\text { be monitored: liquid level and/or waste volume, and } \\
\text { significant waste chemistry parameters. }\end{array}$ & NA; liquid waste is not stored at this facility. \\
\hline $\begin{array}{l}\text { (3) Disposal Facilities. A preliminary monitoring plan } \\
\text { for a low-level waste disposal facility shall be prepared } \\
\text { and submitted to Headquarters for review with the } \\
\text { performance assessment and composite analysis. The } \\
\text { monitoring plan shall be updated within one year } \\
\text { following issuance of the disposal authorization } \\
\text { statement to incorporate and implement conditions } \\
\text { specified in the disposal authorization statement. }\end{array}$ & NA; LLW is not disposed of in this facility. \\
\hline
\end{tabular}


Table 11. (continued).

Facility Name: MFC-774, Electron Microscopy Laboratory

\begin{tabular}{|l|l|}
\hline \multicolumn{1}{|c|}{ Chapter IV, LLW Requirements } & \multicolumn{1}{|c|}{ Facility Compliance Information } \\
\hline $\begin{array}{l}\text { (a) The site-specific performance assessment and } \\
\text { composite analysis shall be used to determine the } \\
\text { media, locations, radionuclides, and other substances to } \\
\text { be monitored. }\end{array}$ & See (3) above. \\
\hline $\begin{array}{l}\text { (b) The environmental monitoring program shall be } \\
\text { designed to include measuring and evaluating releases, } \\
\text { migration of radionuclides, disposal unit subsidence, } \\
\text { and changes in disposal facility and disposal site } \\
\text { parameters which may affect long-term performance. }\end{array}$ & See (3) above. \\
\hline $\begin{array}{l}\text { (c) The environmental monitoring programs shall be } \\
\text { capable of detecting changing trends in performance to } \\
\text { allow application of any necessary corrective action } \\
\text { prior to exceeding the performance objectives in this } \\
\text { Chapter. }\end{array}$ & See (3) above. \\
\hline
\end{tabular}

\subsection{MFC-775, Zero Power Physics Reactor Workroom}

1. Facility description: MFC-775, the ZPPR vault/workroom, is a rectangular concrete building that has approximate dimensions of $110-\mathrm{ft}$ long by $42-\mathrm{ft}$ wide by $14-\mathrm{ft}$ high. MFC-775 was constructed in 1968 and consists of a 14-in.-thick concrete-slab floor, 12-in.-thick concrete walls, and a 7-in. concrete-slab roof over precast T-beams. The wall between the fuel storage vault and the workroom is $9 \mathrm{in}$. of reinforced concrete and the floor of the vault is 18 in. of heavily-reinforced concrete. Earth fill is compacted around the walls. The roof is covered by $4 \mathrm{ft}$ of washed and dried sand. Fill materials are protected from the weather by an asphalt membrane. The seismic design of MFC-775 was performed in accordance with the Uniform Building Code Zone-2 requirements. In 1972, a seismic study of MFC-775 was completed. This study used a horizontal zero-period acceleration of $0.2 \mathrm{~g}$ and also a vertical zero period acceleration of $0.2 \mathrm{~g}$. As a result of that study and an additional analysis performed by Argonne National Laboratory-W personnel in March 1973, the connections of the roof beams to the north wall were strengthened to meet the $0.2 \mathrm{~g}$ vertical and horizontal seismic accelerations.

The ZPPR workroom is located adjacent to the vault in MFC-775 and provides a space to inspect fuel material. The workroom has access through seal doors to the outside of the mound area into MFC-784, to the support wing, and to the reactor cell. Seal doors 65 and 66 are protected by fire doors. This area is not protected by an automatic fire sprinkler system. The walls of the workroom are constructed of reinforced concrete and the roof is made of pre-stressed concrete beams with an overlay of $7 \mathrm{in}$. of concrete. An earthen-fill material is compacted around the walls and the roof is covered with washed and dried sand.

Inside the workroom is a barrel-opening hood near the entrance to the vault and two centrally located four-station loading tables. These hoods and tables are treated as suspect contaminated areas and are integrated into the high-efficiency particulate air-filter air-handling system of the mound area. Air is drawn from the room into the hood and is exhausted from the hood to the atmosphere outside of the mound area through high-efficiency particulate air filters.

2. Hazard category: Hazard Category 2 nuclear facility 
3. Radioactive waste managed at this facility: $\mathrm{CH}$ and mixed LLW is generated and staged in this facility subsequent to routine facility operations. The mixed LLW is accumulated in an SAA for disposition.

\section{RWMB documents/programs:}

a. Safety Basis/Hazards Analysis:

- DSA-006-ZPPR, "ZPPR Documented Safety Analysis"

- IAG-265, "INL Authorization Agreement for the Materials and Fuels Complex (MFC) Zero Power Physics Reactor (ZPPR)"

- LST-306, "Safety Basis List for the Materials and Fuels Complex (MFC) Zero Power Physics Reactor (ZPPR)"

b. Laboratory-wide:

- Form 435.39, "Waste Determination and Disposal Form (WDDF)"

- Form 435.42, "Radioactive Waste Inventory Sheet"

- Form 441.A34, "INL Radiological Control Required Surveys"

- LRD-15001, "Radiological Control Manual"

- LWP-13840, "Management of Issues, Observations, and Noteworthy Practices"

- LWP-14002, "Timeout and Stop Work Authority"

- LWP-17000, "Waste Management"

- MCP-139, "Radiological Surveys"

- MCP-17000, "Waste Generator Services Waste Management"

- MCP-17410, "Management of Waste Storage Areas"

- MCP-17500, "Waste Generator Services Certification of Waste Shipments to the Nevada Test Site"

- PDD-17000, "Waste Management Program"

- PLN-114, "INL Emergency Plan/RCRA Contingency Plan"

- PLN-522, "Quality Assurance Program Plan for the Waste Management/Waste Certification Program"

c. Facility-specific:

- TSD-OI-004, "Waste and Material Acceptance for Storage/Treatment and Radioactive Material Inventory Control"

- TSM-OI-003, "Transfer of Hazardous Material in Non-DOT-Certified Packaging between MFC Nuclear Facilities"

- ZPPR-OI-009, “ZPPR General Facility Waste.”

LLW is managed at this facility. Table 12 shows the facility compliance information for DOE Manual 435.1-1, Chapter IV, "Low-level Waste Requirements."

Table 12. MFC-775, Zero Power Physics Reactor Workroom, DOE Manual 435.1-1 low-level waste requirements and facility compliance information.

\begin{tabular}{|c|c|}
\hline \multicolumn{2}{|c|}{ Facility Name: MFC-775, Zero Power Physics Reactor Workroom } \\
\hline Chapter IV, LLW Requirements & Facility Compliance Information \\
\hline A. Definition of Low-Level Waste. Low-level & This requirement proves the criteria for determining \\
\hline
\end{tabular}


Table 12. (continued).

Facility Name: MFC-775, Zero Power Physics Reactor Workroom

Chapter IV, LLW Requirements

radioactive waste is radioactive waste that is not highlevel radioactive waste, spent nuclear fuel, transuranic waste, byproduct material (as defined in section 11e.(2) of the Atomic Energy Act of 1954, as amended), or naturally occurring radioactive material.

From DOE G 435.1-1 Chapter IV: Low-level radioactive waste is defined by what it is not. The guidance on definitions in Chapters II and III should be consulted first for making a determination on how to properly manage a suspect waste stream.)

B. Management of Specific Wastes. The following provide for management of specific wastes as low-level waste in accordance with the requirements in this Chapter:

(1) Mixed Low-Level Waste. Low-level waste determined to contain source, special nuclear, or byproduct material subject to the Atomic Energy Act of 1954, as amended, and a hazardous component subject to the Resource Conservation and Recovery Act (RCRA), as amended, shall be managed in accordance with the requirements of RCRA and DOE O 435.1, Radioactive Waste Management, and this Manual.

(2) TSCA-Regulated Waste. Low-level waste containing polychlorinated biphenyls, asbestos, or other such regulated toxic components shall be managed in accordance with requirements derived from the Toxic Substances Control Act, as amended, DOE O 435.1, Radioactive Waste Management, and this Manual.

(3) Accelerator-Produced Waste. Radioactive waste produced as a result of operations of DOE accelerators is low-level waste and shall be managed in accordance with DOE O 435.1, Radioactive Waste Management, and this Manual, and all applicable Federal or State requirements.

(4) 11e.(2) and Naturally Occurring Radioactive Material. Small quantities of 11e.(2) byproduct material and naturally occurring radioactive material may be managed as low-level waste provided they can be managed to meet the requirements for low-level waste disposal in Section IV.P of this Manual.

C. Complex-Wide Low-Level Waste Management Program. A complex-wide program and plan shall be developed as described under Responsibilities, 2.B and 2.D, in Chapter I of this Manual.

D. Radioactive Waste Management Basis. Low-level waste facilities, operations, and activities shall have a radioactive waste management basis consisting of
Facility Compliance Information

which DOE radioactive waste is to be managed as LLW in accordance with DOE Manaul 435.1-1, Chapter IV.

Radioactive waste managed at this facility under the requirements of this chapter is not managed under the requirements of DOE Manual 435.1-1, Chapter II or Chapter III.

See (1), (2), (3), and (4) below.

This facility manages mixed LLW in SAAs. Management of SAAs is addressed in MCP-17410, and overall management of mixed waste is addressed in MCP-17000.

NA; this facility does not manage TSCA-regulated waste.

NA; this facility does not manage accelerator-produced waste.

NA; this facility does not manage naturally occurring radioactive material.
DOE Manual 435.1-1 §I.2.B and §I.2.D apply to the Assistant Secretary for Environmental Management and the Deputy Assistant Secretary for Waste Management, respectively.

The RWMB provides the regulatory framework for management of radioactive waste at INL. It specifically identifies facility management and implementing 
Table 12. (continued).

Facility Name: MFC-775, Zero Power Physics Reactor Workroom

\begin{tabular}{|l|}
\hline \multicolumn{1}{|c|}{ Chapter IV, LLW Requirements } \\
\hline physical and administrative controls to ensure the \\
protection of workers, the public, and the environment. \\
The following specific waste management controls \\
shall be part of the radioactive waste management \\
basis:
\end{tabular}

(1) Generators. The waste certification program.

From DOE G 435.1-1 Chapter IV: For a facility that generates low-level waste, the radioactive waste management basis is to include the program for certifying that waste meets the waste acceptance requirements of the facility(ies) to which the waste will be sent.

(2) Treatment Facilities. certification program. The waste acceptance requirements and the waste [sic]

From DOE G 435.1-1 Chapter IV: Facilities that store or treat low-level waste are to have approved waste acceptance requirements (see DOE M 435.1-1, Section IV.G) prior to the issuance of a radioactive waste management basis.

A facility that stores or treats waste also is generally expected to have a waste certification program. Waste from these facilities will have to be certified as meeting the waste acceptance requirements of the facility to which it will be transferred, and the facilities have the potential for generating radioactive waste (e.g., secondary processing streams from treatment, monitoring and sampling, radioactive release cleanup). Consequently, storage and treatment facilities should also have an approved waste certification program as part of their radioactive waste management basis.

As part of the radioactive waste management basis, site personnel needs to implement a system or process for tracking the waste inventory at a storage, treatment, or disposal facility.

(3) Storage Facilities. The waste acceptance requirements and the waste certification program.

From DOE G 435.1-1 Chapter IV: Facilities that store or treat low-level waste are to have approved waste acceptance requirements (see DOE M 435.1-1, Section IV.G) prior to the issuance of a radioactive waste management basis.

A facility that stores or treats waste also is generally expected to have a waste certification program. Waste from these facilities will have to be certified as meeting the waste acceptance requirements of the facility to which it will be transferred, and the facilities have the potential for generating radioactive waste (e.g.,

\section{Facility Compliance Information}

documents for the generation, storage, treatment, and disposal of radiological waste.

See J. below for waste certification program requirements.

DSA-006-ZPPR determines and documents the hazard category for this facility as a Hazard Category 2 nuclear facility.

NA; this facility does not treat LLW.
NA; this facility does not store LLW. 
Table 12. (continued).

Facility Name: MFC-775, Zero Power Physics Reactor Workroom

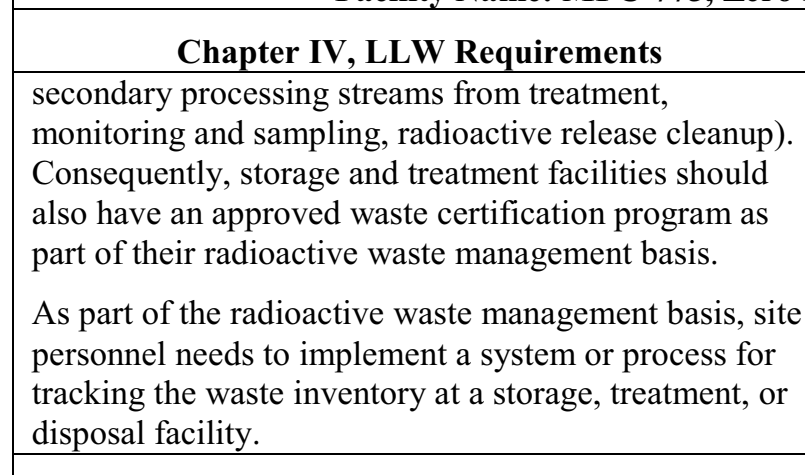

(4) Disposal Facilities. The performance assessment, composite analysis, disposal authorization statement, closure plan, waste acceptance requirements, and monitoring plan.

E. Contingency Actions. The following requirements are in addition to those in Chapter I of this Manual [DOE M 435.1-1 §I.1.E(5)].

(1) Contingency Storage. For off-normal or emergency situations involving high activity or high hazard liquid low-level waste storage or treatment, spare capacity with adequate capabilities shall be maintained to receive the largest volume of liquid contained in any one storage tank or treatment facility. Tanks or other facilities that are designated low-level waste contingency storage shall be maintained in an operational condition when waste is present and shall meet the requirements of DOE O 435.1, Radioactive Waste Management, and this Manual.

From DOE G 435.1-1 Chapter IV: Compliance with these requirements is demonstrated if adequate spare capacity and transfer equipment exists for emergency transfers of all high activity and high hazard liquid lowlevel waste. In addition, the capability to perform emergency transfers is demonstrated by having waste transfer routings identified, operational procedures to direct transfers, staff trained to the procedures, and records showing that the spare capacity and transfer capability are kept in operating condition.

(2) Transfer Equipment. Pipelines and auxiliary facilities necessary for the transfer of high activity or high hazard liquid low-level waste to contingency storage shall be maintained in an operational condition when waste is present and shall meet the requirements of DOE O 435.1, Radioactive Waste Management, and this Manual.

From DOE G 435.1-1 Chapter IV: Compliance with these requirements is demonstrated if adequate spare capacity and transfer equipment exists for emergency transfers of all high activity and high hazard liquid low-
NA; this facility does not dispose of LLW.

DOE Manual 435.1-1 §I.1.E(5) addresses the sitewide emergency management system. The INL plan is provided in PLN-114.

NA; this facility does not store liquid LLW. 
Table 12. (continued).

Facility Name: MFC-775, Zero Power Physics Reactor Workroom

\begin{tabular}{|l|}
\hline \multicolumn{1}{c}{ Chapter IV, LLW Requirements } \\
\hline $\begin{array}{l}\text { level waste. In addition, the capability to perform } \\
\text { emergency transfers is demonstrated by having waste } \\
\text { transfer routings identified, operational procedures to } \\
\text { direct transfers, staff trained to the procedures, and } \\
\text { records showing that the spare capacity and transfer } \\
\text { capability are kept in operating condition. }\end{array}$ \\
$\begin{array}{l}\text { F. Corrective Actions. I of this Manual. The following } \\
\text { requirements are in addition to those in Chapter }[\mathrm{sic}]\end{array}$
\end{tabular}

From DOE G 435.1-1 Chapter IV: Compliance with DOE M 435.1-1 §I.2.G.(1) is demonstrated by records showing what corrective actions were taken to remedy situations in the radioactive waste management system.

Compliance with DOE M 435.1-1 §I.2.G.(2) is demonstrated by having the necessary procedures, mechanisms, and training in place to effect shutdown or curtailment of activities which pose an imminent danger or other serious hazard to workers or the public, or are not protective of the environment.

(1) Order Compliance. Corrective actions shall be implemented whenever necessary to ensure the requirements of DOE O 435.1, Radioactive Waste Management, and this Manual are met.

From DOE G 435.1-1 Chapter IV: If a facility or activity can be allowed to operate while a noncompliant or hazardous condition exists, the allowance and any associated limitations must be defined as part of the facility or activity's radioactive waste management basis, identified as a configuration controlled item in a configuration management plan or included in a revision or modification to an operating procedure or similar controlled documentation.

Compliance with this requirement is demonstrated if a corrective action system addresses noncompliant or hazardous situations involving low-level waste management facilities in a systematic fashion, and allows identification of problems by all personnel.

(2) Operations Curtailment. Operations shall be curtailed or facilities shut down for failure to establish, maintain, or operate consistent with an approved radioactive waste management basis.

From DOE G 435.1-1 Chapter IV: Compliance with this requirement is demonstrated with a documented system of routine assessments to determine whether waste management activities and facilities are operating in accordance with an approved radioactive waste management basis that provides for graded limitations that can be placed on activities and
The INL-wide procedure addressing problem identification as required by DOE Manual 435.1-1 §I.2.G.(1) is LWP-13840, which implements the laboratory's corrective action system.

The INL-wide procedure addressing shutdown or curtailment of activities as required by DOE Manual 435.1-1 §I.2.G.(2) is LWP-14002.

See F. above.

The approved RWMB establishes the current compliance status at each radioactive waste management facility. Facility assessments are scheduled to ensure waste management activities are conducted in accordance with the approved RWMB. 
Table 12. (continued).

Facility Name: MFC-775, Zero Power Physics Reactor Workroom

\begin{tabular}{|c|c|}
\hline Chapter IV, LLW Requirements & Facility Compliance Information \\
\hline $\begin{array}{l}\text { operations that do not have, or are operating outside of, } \\
\text { an approved radioactive waste management basis, } \\
\text { including shutdown of the facility. }\end{array}$ & \\
\hline $\begin{array}{l}\text { G. Waste Acceptance. The following requirements are } \\
\text { in addition to those in Chapter I of this Manual [DOE } \\
\text { M 435.1-1 §I.2.F(6)]. }\end{array}$ & $\begin{array}{l}\text { DOE Manual 435.1-1 } \S \mathrm{I} \cdot 2 . \mathrm{F}(6) \text { applies to field element } \\
\text { managers. }\end{array}$ \\
\hline $\begin{array}{l}\text { (1) Technical and Administrative. Waste acceptance } \\
\text { requirements for all low-level waste storage, treatment, } \\
\text { or disposal facilities, operations, and activities shall } \\
\text { specify, at a minimum, the following: }\end{array}$ & $\begin{array}{l}\text { NA; this facility does not accept LLW from other } \\
\text { facilities. }\end{array}$ \\
\hline $\begin{array}{l}\text { From DOE G 435.1-1 Chapter IV: Compliance with } \\
\text { these waste acceptance requirements is demonstrated if } \\
\text { they are documented, contain clear and precise criteria } \\
\text { specifying the radionuclide limits in the form of } \\
\text { contents or concentrations that can be accepted, the } \\
\text { limitations and prohibitions on waste forms and } \\
\text { packages that can be received, and the limits, } \\
\text { prohibitions, or instructions concerning any other } \\
\text { technical information so that the waste is compatible } \\
\text { with the safety basis of the facility, and which will } \\
\text { result in acceptable waste at subsequent steps in } \\
\text { managing the low-level waste.) }\end{array}$ & \\
\hline $\begin{array}{l}\text { (a) Allowable activities and/or concentrations of } \\
\text { specific radionuclides. }\end{array}$ & See (1) above. \\
\hline $\begin{array}{l}\text { (b) Acceptable waste form and/or container } \\
\text { requirements that ensure the chemical and physical } \\
\text { stability of waste under conditions that might be } \\
\text { encountered during transportation, storage, treatment, } \\
\text { or disposal. }\end{array}$ & See (1) above. \\
\hline $\begin{array}{l}\text { (c) Restrictions or prohibitions on waste, materials, or } \\
\text { containers that may adversely affect waste handlers or } \\
\text { compromise facility or waste container performance. }\end{array}$ & See (1) above. \\
\hline $\begin{array}{l}\text { (d) The following are additional waste acceptance } \\
\text { requirements that shall be specified in low-level waste } \\
\text { disposal facility waste acceptance requirements: }\end{array}$ & See (1) above. \\
\hline $\begin{array}{l}1 \text { Low-level waste must contribute to and not detract } \\
\text { from achieving long-term stability of the facility, } \\
\text { minimizing the need for long-term active maintenance, } \\
\text { minimizing subsidence, and minimizing contact of } \\
\text { water with waste. Void spaces within the waste and, if } \\
\text { containers are used, between the waste and its container } \\
\text { shall be reduced to the extent practical. }\end{array}$ & See (1) above. \\
\hline $\begin{array}{l}2 \text { Liquid low-level waste or low-level waste containing } \\
\text { free liquid must be converted into a form that contains } \\
\text { as little freestanding liquid as is reasonably achievable, } \\
\text { but in no case shall the liquid exceed } 1 \text { percent of the }\end{array}$ & See (1) above. \\
\hline
\end{tabular}


Table 12. (continued).

Facility Name: MFC-775, Zero Power Physics Reactor Workroom

\begin{tabular}{|c|c|}
\hline Chapter IV, LLW Requirements & Facility Compliance Information \\
\hline $\begin{array}{l}\text { waste volume when the low-level waste is in a disposal } \\
\text { container, or } 0.5 \text { percent of the waste volume after it is } \\
\text { processed to a stable form. }\end{array}$ & \\
\hline $\begin{array}{l}3 \text { Low-level waste must not be readily capable of } \\
\text { detonation or of explosive decomposition or reaction at } \\
\text { anticipated pressures and temperatures, or of explosive } \\
\text { reaction with water. Pyrophoric materials contained in } \\
\text { waste shall be treated, prepared, and packaged to be } \\
\text { nonflammable. }\end{array}$ & See (1) above. \\
\hline $\begin{array}{l}4 \text { Low-level waste must not contain, or be capable of } \\
\text { generating by radiolysis or biodegradation, quantities } \\
\text { of toxic gases, vapors, or fumes harmful to the public } \\
\text { or workers or disposal facility personnel, or harmful to } \\
\text { the long-term structural stability of the disposal site. }\end{array}$ & See (1) above. \\
\hline $\begin{array}{l}5 \text { Low-level waste in a gaseous form must be packaged } \\
\text { such that the pressure does not exceed } 1.5 \text { atmospheres } \\
\text { absolute at } 20 \mathrm{C} \text {. }[\text { sic }]\end{array}$ & See (1) above. \\
\hline $\begin{array}{l}\text { (e) The basis, procedures, and levels of authority } \\
\text { required for granting exceptions to the waste } \\
\text { acceptance requirements, which shall be contained in } \\
\text { each facility's waste acceptance documentation. Each } \\
\text { exception request shall be documented, including its } \\
\text { disposition as approved or not approved. } \\
\text { From DOE G 435.1-1 Chapter IV: Waste acceptance } \\
\text { requirements are acceptable if they are documented and } \\
\text { contain a clear description of the procedure and bases } \\
\text { for obtaining an exception or deviation to the } \\
\text { acceptance criteria for low-level waste to be received at } \\
\text { the facility. }\end{array}$ & See (1) above. \\
\hline $\begin{array}{l}\text { (2) Evaluation and Acceptance. The receiving facility } \\
\text { shall evaluate waste for acceptance, including } \\
\text { confirmation that the technical and administrative } \\
\text { requirements have been met. A process for the } \\
\text { disposition of non-conforming wastes shall be } \\
\text { established. } \\
\text { From DOE G } 435.1 \text {-1 Chapter IV: Compliance with the } \\
\text { waste acceptance requirements for a low-level waste } \\
\text { management facility is demonstrated if they include a } \\
\text { process for evaluation and acceptance of incoming } \\
\text { waste to ensure the acceptance criteria of the facility } \\
\text { receiving the waste are met that includes one of or a } \\
\text { combination of: (1) testing, sampling, and analysis of } \\
\text { representative samples of waste upon receipt; ( } 2 \text { ) } \\
\text { testing, sampling, and analysis of split samples of } \\
\text { waste taken at the generator site; ( } 3 \text { ) evaluation of } \\
\text { testing, sampling, and analysis of data provided by the } \\
\text { generator, or (4) audits, reviews, surveillance, or } \\
\text { observations of generator waste certification programs }\end{array}$ & See (1) above. \\
\hline
\end{tabular}


Table 12. (continued).

Facility Name: MFC-775, Zero Power Physics Reactor Workroom

\begin{tabular}{l} 
Chapter IV, LLW Requirements \\
\hline $\begin{array}{l}\text { and characterization activities. Additionally, acceptable } \\
\text { waste acceptance requirements for a storage, treatment } \\
\text { or disposal facility will have documented procedures } \\
\text { and actions to be taken if a waste that does not conform } \\
\text { to the waste acceptance criteria is received at the } \\
\text { facility. }\end{array}$ \\
$\begin{array}{l}\text { H. Waste Generation Planning. The following } \\
\text { requirements are in addition to those in Chapter I of } \\
\text { this Manual [DOE M 435.1-1 §I.2.F(7)]. }\end{array}$ \\
\hline
\end{tabular}

(1) Life-Cycle Planning. Prior to waste generation, planning shall be performed to address the entire life cycle for all low-level waste streams.

From DOE G 435.1-1 Chapter IV: Compliance with this planning requirement is demonstrated by the individual sites establishing a process for evaluating the life-cycle of low-level waste prior to its generation, including the identification of low-level wastes with no path to disposal and appropriate records justifying the newly generated low-level waste stream(s), and site personnel possessing planning information showing the location(s) where low-level waste will be stored, treated, and/or disposed along with a confirmation that the personnel managing the facilities agree that the low-level waste may be managed at those facilities.

(2) Waste with No Identified Path to Disposal. Lowlevel waste streams with no identified path to disposal shall be generated only in accordance with approved conditions which, at a minimum, shall address:

(a) Programmatic need to generate the waste;

(b) Characteristics and issues preventing the disposal of the waste;

(c) Safe storage of the waste until disposal can be achieved; and

(d) Activities and plans for achieving final disposal of the waste.

I. Waste Characterization. Low-level waste shall be characterized using direct or indirect methods, and the characterization documented in sufficient detail to ensure safe management and compliance with the waste acceptance requirements of the facility receiving the waste.

From DOE G 435.1-1 Chapter IV: Compliance with this requirement is demonstrated by a program for documenting and the existence of records that document the process for acquiring and verifying the validity of low-level waste characterization data

DOE Manual 435.1-1 §I.2.F(7) applies to field element managers.

PDD-17000 and LWP-17000 provide direction to the waste generators for waste generation planning to address the entire life cycle.
This facility is not generating radioactive waste that does not have an identified path to disposal.

See (2) above.

See (2) above.

See (2) above.

See (2) above.

MCP-17000 $§ 4$ specifies the requirements for preparing an IWTS profile that captures waste characterization information.

ZPPR-OI-009 $§ 3.2$ provides instructions for the waste generator to characterize the routine LLW generated subsequent to facility operations in cooperation with WGS. This is done using Form 435.39. The facility also uses Form 435.42 to characterize and serve as the characterization record for this waste. 
Table 12. (continued).

Facility Name: MFC-775, Zero Power Physics Reactor Workroom

\begin{tabular}{l} 
Chapter IV, LLW Requirements \\
\hline acquired through the use of direct or indirect methods. \\
\hline $\begin{array}{l}\text { (1) Data Quality Objectives. The data quality } \\
\text { objectives process, or a comparable process, shall be } \\
\text { used for identifying characterization parameters and } \\
\text { acceptable uncertainty in characterization data. } \\
\text { From DOE G 435.1-1 Chapter IV: Compliance with } \\
\text { this requirement is demonstrated by the documented } \\
\text { use of a data quality objectives or a comparable process } \\
\text { for determining the type, quantity, and quality of } \\
\text { characterization data needed to safely manage low- } \\
\text { level waste. } \\
\text { (2) Minimum Waste Characterization. Characterization } \\
\text { data shall, at a minimum, include the following } \\
\text { information relevant to the management of the waste: } \\
\text { From DOE G 435.1-1 Chapter IV: Compliance with } \\
\text { this requirement is demonstrated by the existence of a } \\
\text { program or procedure for determining and records that } \\
\text { document characterization of low-level waste } \\
\text { consistent with the minimum characterization data } \\
\text { requirements.) }\end{array}$ \\
\hline
\end{tabular}

(a) Physical and chemical characteristics;

(b) Volume, including the waste and any stabilization or absorbent media;

(c) Weight of the container and contents;

(d) Identities, activities, and concentrations of major radionuclides;

(e) Characterization date;
(f) Generating source; and

(g) Any other information which may be needed to prepare and maintain the disposal facility performance assessment, or demonstrate compliance with applicable performance objectives.

J. Waste Certification. A waste certification program shall be developed, documented, and implemented to ensure that the waste acceptance requirements of facilities receiving low-level waste for storage, treatment, and disposal are met.

From DOE G 435.1-1 Chapter IV: Compliance with the development and documentation portion of the certification requirement is demonstrated by a waste certification plan that identifies the organizations involved, assigns responsibilities for implementing the program, and describes or references the quality assurance, training, procurement controls, records

\section{Facility Compliance Information}

Radioactive waste management facilities characterize waste in accordance with the requirements of the receiving storage, treatment, or disposal facility. The documented use of a data quality objectives process, or comparable process, was not identified for this facility.

MCP-17000 § 4 specifies the requirements for preparing an IWTS profile that captures waste characterization information.

ZPPR-OI-009 $§ 3.2$ provides instructions for the waste generator to characterize the routine LLW generated subsequent to facility operations.

See (2) above.

See (2) above.

See (2) above.

See (2) above.

See (2) above.

See (2) above.

See (2) above.

MCP-17000 § 4 specifies the requirements for preparing an IWTS profile that captures waste certification information.

MCP-17500 provides the WGS waste certification program for LLW to be shipped to NNSS.

Container procurement is addressed in MCP-17000 $\S 4.6$.

Waste certification is performed and tracked using IWTS. Documentation of the IWTS Program is available electronically only.

PLN-522 requires waste technical specialists and waste 
Table 12. (continued).

Facility Name: MFC-775, Zero Power Physics Reactor Workroom

\begin{tabular}{|l|}
\hline \multicolumn{1}{|c|}{ Chapter IV, LLW Requirements } \\
\hline management, and procedures to be used by the \\
program. Acceptable performance for implementing \\
the program is demonstrated when appropriate \\
personnel are trained and follow the procedures that \\
govern their part of the waste certification. \\
Additionally, acceptable performance is demonstrated \\
if the waste certification plan and procedures are \\
current and controlled in accordance with a document \\
controls program, and records related to certification \\
(e.g., certification statements, training records, \\
procurement records, characterization records, \\
container records) are generated and managed in \\
accordance with the established site program.
\end{tabular}

(1) Certification Program. The waste certification program shall designate the officials who have the authority to certify and release waste for shipment; and specify what documentation is required for waste generation, characterization, shipment, and certification. The program shall provide requirements for auditability, retrievability, and storage of required documentation and specify the records retention period.

From DOE G 435.1-1 Chapter IV: Compliance with this requirement is demonstrated by a program or procedure for record keeping and records showing that low-level waste is certified as having met the waste acceptance criteria of the facility to which it was transferred and that the certification statement is supported by additional records regarding the waste source, characterization, and container.

(2) Certification before Transfer. Low-level waste shall be certified as meeting waste acceptance requirements before it is transferred to the facility receiving the waste.

From DOE G 435.1-1 Chapter IV: Compliance with this requirement is demonstrated by the presence of a certification program which includes procedures requiring a signed certification statement prior to the release of waste for transfer, and by dated records showing that waste was certified before being transferred.

(3) Maintaining Certification. Low-level waste that has been certified as meeting the waste acceptance requirements for transfer to a storage, treatment, or disposal facility shall be managed in a manner that maintains its certification status.

From DOE G 435.1-1 Chapter IV: Compliance with this requirement is demonstrated by a program or procedure reflecting this requirement is present and site

See J. above.

See J. above. Facility Compliance Information disposition specialists to complete the appropriate training/qualification before being granted approval authority for profiles within the IWTS Program. The waste certification official, alternate waste certification official, and NNSS packaging certifiers must complete the appropriate training/qualifications to disposition waste to NNSS.

See J. above.

See J. above.


Table 12. (continued).

Facility Name: MFC-775, Zero Power Physics Reactor Workroom

\begin{tabular}{l} 
Chapter IV, LLW Requirements \\
\hline personnel are able to show that the storage of low-level \\
waste containers is in a facility or manner where the \\
containers would not be damaged by normal weather \\
events, and cannot be accessed by unauthorized \\
personnel. Further, each container can be traced to its \\
certification and the information supporting that \\
certification.
\end{tabular}

K. Waste Transfer. A documented process shall be established and implemented for transferring responsibility for management of low-level waste and for ensuring availability of relevant data. The following requirements are in addition to those in Chapter I of this Manual.

From DOE G 435.1-1 Chapter IV: Compliance with this requirement is demonstrated if facilities have procedures for the receipt of waste and the transfer of waste, as appropriate, which address the acquisition of waste and container data and the transfer of ownership, respectively. Further evidence of acceptable performance is facility records showing that data on the waste containers is available and accurate, and that documented transfer of responsibility occurs.

(1) Authorization. Low-level waste shall not be transferred to a storage, treatment, or disposal facility until personnel responsible for the facility receiving the waste authorize the transfer.

From DOE G 435.1-1 Chapter IV: Compliance with this requirement is demonstrated by sites having procedures that require a confirmation of authorization before releasing waste for transfer, and records showing that transfers are made in accordance with written authorizations.

(2) Data. Waste characterization data, container information, and generation, storage, treatment, and transportation information for low-level waste shall be transferred with or be traceable to the waste.

From DOE G 435.1-1 Chapter IV: Compliance with this requirement is demonstrated if there are procedures requiring that characterization and container data be provided and maintained for each low-level waste transfer and documented records of transfers show that the information is being provided.

L. Packaging and Transportation. The following requirements are in addition to those in Chapter I of this Manual [DOE M 435.1-1 §I.1.E(11)].

(1) Packaging. If containers are used:

MCP-17000 specifies the requirements for preparing an IWTS profile that captures waste certification data, transfer information, and associated authorizations.

MCP-17500 provides the WGS waste certification program for LLW to be shipped to NNSS.

TSD-OI-004 specifies requirements and provides instructions for accepting LLW and mixed LLW at the MFC treatment, storage, and disposal facilities.

See K. above.

See K. above.

DOE Manual 435.1-1 §I.1.E(11) applies to field element managers.

MCP-17000 $§ 4$ addresses packaging requirements.

From DOE G 435.1-1 Chapter IV: Compliance with the 
Table 12. (continued).

Facility Name: MFC-775, Zero Power Physics Reactor Workroom

\begin{tabular}{l} 
Chapter IV, LLW Requirements \\
\hline packaging requirement is demonstrated by: (1) \\
procedures which document proper packaging \\
protocols; and (2) no trends of routine repackaging of \\
low-level waste that is packaged after issuance of DOE \\
O 435.1. Successful performance of this requirement is \\
also demonstrated by a record of containers for which \\
failure has not routinely occurred under management \\
conditions. It is recognized that there may be failed \\
containers for waste previously placed in storage. For \\
those containers, the goal is to only have to repackage \\
the waste one time after it is retrieved and \\
characterized. Further, acceptable performance is \\
demonstrated by containers of waste having marking \\
and labeling that allows correlation with waste \\
characterization data and container information.)
\end{tabular}

(a) Low-level waste shall be packaged in a manner that provides containment and protection for the duration of the anticipated storage period and until disposal is achieved or until the waste has been removed from the container.

(b) When waste is packaged, vents or other measures shall be provided if the potential exists for pressurizing or generating flammable or explosive concentrations of gases within the waste container.

(c) Containers of low-level waste shall be marked such that their contents can be identified.

(2) Transportation. To the extent practical, the volume of waste and number of low-level waste shipments shall be minimized.

From DOE G 435.1-1 Chapter IV: Compliance with this requirement can be demonstrated by a combination of site procedures directing the efficient use of waste container capacity and documentation showing that low-level waste shipments are systematically planned and optimized to the extent practical.

M. Site Evaluation and Facility Design. The following requirements are in addition to those in Chapter I of this Manual.

(1) Site Evaluation. Proposed locations for low-level waste facilities shall be evaluated to identify relevant features that should be avoided or must be considered in facility design and analyses.

(a) Each site proposed for a new low-level waste facility or expansion of an existing low-level waste facility shall be evaluated considering environmental characteristics, geotechnical characteristics, and human activities, including for a low-level waste disposal
See (1) above.

See (1) above.

See (1) above.

NA; waste is not shipped to an offsite facility for final disposition from this facility.
NA; this requirement addresses new radioactive waste management facilities.

See M. above.

See M. above. 
Table 12. (continued).

\begin{tabular}{|c|c|}
\hline \multicolumn{2}{|c|}{ Facility Name: MFC-775, Zero Power Physics Reactor Workroom } \\
\hline Chapter IV, LLW Requirements & Facility Compliance Information \\
\hline $\begin{array}{l}\text { facility, the capability of the site to demonstrate, at a } \\
\text { minimum, whether it is: }\end{array}$ & \\
\hline $\begin{array}{l}1 \text { Located to accommodate the projected volume of } \\
\text { waste to be received; }\end{array}$ & See M. above. \\
\hline $\begin{array}{l}2 \text { Located in a flood plain, a tectonically active area, or } \\
\text { in the zone of water table fluctuation; and }\end{array}$ & See M. above. \\
\hline $\begin{array}{l}3 \text { Located where radionuclide migration pathways are } \\
\text { predictable and erosion and surface runoff can be } \\
\text { controlled. }\end{array}$ & See M. above. \\
\hline $\begin{array}{l}\text { (b) Proposed sites with environmental characteristics, } \\
\text { geotechnical characteristics, and human activities for } \\
\text { which adequate protection cannot be provided through } \\
\text { facility design shall be deemed unsuitable for the } \\
\text { location of the facility. }\end{array}$ & See M. above. \\
\hline $\begin{array}{l}\text { (c) Low-level waste disposal facilities shall be sited to } \\
\text { achieve long-term stability and to minimize, to the } \\
\text { extent practical, the need for active maintenance } \\
\text { following final closure. }\end{array}$ & See M. above. \\
\hline $\begin{array}{l}\text { (2) Low-Level Waste Treatment and Storage Facility } \\
\text { Design. The following facility requirements and } \\
\text { general design criteria, at a minimum, apply: }\end{array}$ & See M. above. \\
\hline $\begin{array}{l}\text { (a) Confinement. Low-level waste systems and } \\
\text { components shall be designed to maintain waste } \\
\text { confinement. }\end{array}$ & See M. above. \\
\hline (b) Ventilation. & See M. above. \\
\hline $\begin{array}{l}1 \text { Design of low-level waste treatment and storage } \\
\text { facilities shall include ventilation, if applicable, } \\
\text { through an appropriate filtration system to maintain the } \\
\text { release of radioactive material in airborne effluents } \\
\text { within the requirements and guidelines specified in } \\
\text { applicable requirements. }\end{array}$ & See M. above. \\
\hline $\begin{array}{l}2 \text { When conditions exist for generating gases in } \\
\text { flammable or explosive concentrations, ventilation } \\
\text { systems or other measures shall be provided to keep the } \\
\text { gases in a non-flammable and nonexplosive condition. } \\
\text { Where concentrations of explosive or flammable gases } \\
\text { are expected to approach the lower flammability limit, } \\
\text { measures shall be taken to prevent deflagration or } \\
\text { detonation. }\end{array}$ & See M. above. \\
\hline $\begin{array}{l}\text { (c) Consideration of Decontamination and } \\
\text { Decommissioning. Areas in new and modifications to } \\
\text { existing low-level waste management facilities that are } \\
\text { subject to contamination with radioactive or other } \\
\text { hazardous materials shall be designed to facilitate } \\
\text { decontamination. For such facilities a proposed }\end{array}$ & See M. above. \\
\hline
\end{tabular}


Table 12. (continued).

Facility Name: MFC-775, Zero Power Physics Reactor Workroom

\begin{tabular}{|c|c|}
\hline Chapter IV, LLW Requirements & Facility Compliance Information \\
\hline $\begin{array}{l}\text { decommissioning method or a conversion method } \\
\text { leading to reuse shall be described. }\end{array}$ & \\
\hline $\begin{array}{l}\text { (d) Instrumentation and Control Systems. Engineering } \\
\text { controls shall be incorporated in the design and } \\
\text { engineering of low-level waste treatment and storage } \\
\text { facilities to provide volume inventory data and to } \\
\text { prevent spills, leaks, and overflows from tanks or } \\
\text { confinement systems. }\end{array}$ & See M. above. \\
\hline $\begin{array}{l}\text { (e) Monitoring. Monitoring and/or leak detection } \\
\text { capabilities shall be incorporated in the design and } \\
\text { engineering of low-level waste treatment and storage } \\
\text { facilities to provide rapid identification of failed } \\
\text { confinement and/or other abnormal conditions. }\end{array}$ & See M. above. \\
\hline $\begin{array}{l}\text { (3) Low-Level Waste Disposal Facility Design. The } \\
\text { following facility requirements and general design } \\
\text { criteria, at a minimum, apply: }\end{array}$ & See M. above. \\
\hline $\begin{array}{l}\text { (a) Confinement. Low-level waste systems and } \\
\text { components shall be designed to maintain waste } \\
\text { confinement. }\end{array}$ & See M. above. \\
\hline \multicolumn{2}{|l|}{ (b) Ventilation. } \\
\hline $\begin{array}{l}1 \text { Design of low-level waste disposal facilities shall } \\
\text { include ventilation, if applicable, through an } \\
\text { appropriate filtration system to maintain the release of } \\
\text { radioactive material in airborne effluents within the } \\
\text { requirements and guidelines specified in applicable } \\
\text { requirements. }\end{array}$ & See M. above. \\
\hline $\begin{array}{l}2 \text { When conditions exist for generating gases in } \\
\text { flammable or explosive concentrations, ventilation } \\
\text { systems or other measures shall be provided to keep the } \\
\text { gases in a nonflammable and non-explosive condition. } \\
\text { Where concentrations of explosive or flammable gases } \\
\text { are expected to approach the lower flammability limit, } \\
\text { measures shall be taken to prevent deflagration or } \\
\text { detonation. }\end{array}$ & See M. above. \\
\hline $\begin{array}{l}\text { (c) Stability. Low-level waste disposal facilities shall } \\
\text { be designed to achieve long-term stability and to } \\
\text { minimize to the extent practical, the need for active } \\
\text { maintenance following final closure. }\end{array}$ & See M. above. \\
\hline $\begin{array}{l}\text { (d) Control of Water. Low-level waste disposal } \\
\text { facilities shall be designed to minimize to the extent } \\
\text { practical, the contact of waste with water during and } \\
\text { after disposal. }\end{array}$ & See M. above. \\
\hline $\begin{array}{l}\text { N. Storage and Staging. The following requirements } \\
\text { are in addition to those in Chapter I of this Manual } \\
\text { [DOE M 435.1-1 §I.2.F(13)]. }\end{array}$ & $\begin{array}{l}\text { DOE Manual 435.1-1 §I.2.F(13) applies to field } \\
\text { element managers. }\end{array}$ \\
\hline
\end{tabular}


Table 12. (continued).

Facility Name: MFC-775, Zero Power Physics Reactor Workroom

\begin{tabular}{l}
\hline Chapter IV, LLW Requirements \\
\hline (1) Storage Prohibitions. Low-level waste in storage \\
shall not be readily capable of detonation, explosive \\
decomposition, reaction at anticipated pressures and \\
temperatures, or explosive reaction with water. Prior to \\
storage, pyrophoric materials shall be treated, prepared, \\
and packaged to be nonflammable.
\end{tabular}

From DOE G 435.1-1 Chapter IV: Compliance with this requirement is demonstrated by having waste acceptance requirements which prohibit low-level waste that is ignitable or explosive from being accepted for storage unless it has been treated, and procedures for properly preparing such materials for safe storage.

(2) Storage Limit. Low-level waste that has an See (1) above. identified path to disposal shall not be stored longer than one year prior to disposal, except for storage for decay, or as otherwise authorized by the Field Element Manager.

From DOE G 435.1-1 Chapter IV: Storage longer than one year can be justified if the conditions for such storage are approved by the Field Element Manager as part of the radioactive waste management basis for the facility.

Storage for radioactive decay for a period greater than 1 year for waste that has an identified path to disposal is allowed. Adequate justification and the supporting information for storage for decay is to be documented in the radioactive waste management basis for the facility in which the storage will take place.

Mixed waste. Under the Federal Facility Compliance Act of 1992, DOE sites were required to develop Site Treatment Plans to bring stored mixed low-level waste into compliance with these requirements. The Site Treatment Plan needs to be consulted and any mixed low-level waste stored for the purpose of accumulation to facilitate treatment must meet Resource Conservation and Recovery Act storage requirements. There could be several ways within different scenarios that this requirement can be met, as illustrated by the examples below, however, there are basically four ways to show compliance with the requirement and include appropriate provisions in the radioactive waste management basis for the facility in which it is stored.

Legacy waste. As discussed above, the intention of the requirement is not to force malicious compliance or heroic actions which would result in increased risk or safety concerns. Rather, the intention is that waste in 
Table 12. (continued).

Facility Name: MFC-775, Zero Power Physics Reactor Workroom

\begin{tabular}{|c|c|}
\hline Chapter IV, LLW Requirements & Facility Compliance Information \\
\hline $\begin{array}{l}\text { storage longer than one year receives additional } \\
\text { attention to ensure that the public, the workers, and the } \\
\text { environment are protected from the hazards of the } \\
\text { waste, and that progress is being made to dispose of the } \\
\text { waste. There could be several ways within different } \\
\text { scenarios that this requirement can be met, as } \\
\text { illustrated by the examples below, however, there are } \\
\text { basically four ways to show compliance with the } \\
\text { requirement: }\end{array}$ & \\
\hline $\begin{array}{l}\text { 1) the radioactive waste management basis allows for } \\
\text { storage for no more than one year. }\end{array}$ & \\
\hline $\begin{array}{l}\text { 2) the radioactive waste management basis allows for } \\
\text { storage for no more than one year, or for storage for } \\
\text { decay only for periods greater than a year, which are } \\
\text { specified on a radionuclide basis. }\end{array}$ & \\
\hline $\begin{array}{l}\text { 3) the radioactive waste management basis allows for } \\
\text { storage for more than one year, up to a specified period } \\
\text { of time based on a documented technical evaluation } \\
\text { that the waste can be stored in a manner that does not } \\
\text { cause changes to the waste or waste packages that is } \\
\text { detrimental to the safe storage of the waste, the final } \\
\text { disposal of the waste or to meeting the disposal } \\
\text { performance objectives. }\end{array}$ & \\
\hline $\begin{array}{l}\text { 4) the radioactive waste management basis allows for } \\
\text { storage for decay (with specifics) and for storage for } \\
\text { more than one year for other low-level waste, up to a } \\
\text { specified period of time based on a documented } \\
\text { technical evaluation that the waste can be stored in a } \\
\text { manner that does not cause changes to the waste or } \\
\text { waste packages that is detrimental to the safe storage of } \\
\text { the waste, the final disposal of the waste or to meeting } \\
\text { the disposal performance objectives. }\end{array}$ & \\
\hline $\begin{array}{l}\text { Compliance with this requirement is demonstrated by } \\
\text { the existence of a radioactive waste management basis } \\
\text { for the storage facility approved by the Field Element } \\
\text { Manager that includes the time frames that waste are } \\
\text { allowed to be stored, the necessary justifications for } \\
\text { storage for decay, and the necessary technical } \\
\text { evaluations if storage is to extend significantly beyond } \\
\text { the one-year time frame. }\end{array}$ & \\
\hline $\begin{array}{l}\text { (3) Storage Integrity. Low-level waste shall be stored in } \\
\text { a location and manner that protects the integrity of } \\
\text { waste for the expected time of storage and minimizes } \\
\text { worker exposure. }\end{array}$ & See (1) above. \\
\hline $\begin{array}{l}\text { However, in making a decision to use a facility for } \\
\text { storage and in developing a radioactive waste } \\
\text { management basis for the activity, particular attention } \\
\text { to protection of workers is needed. }\end{array}$ & \\
\hline
\end{tabular}


Table 12. (continued).

\begin{tabular}{|c|c|}
\hline \multicolumn{2}{|c|}{ Facility Name: MFC-775, Zero Power Physics Reactor Workroom } \\
\hline Chapter IV, LLW Requirements & Facility Compliance Information \\
\hline $\begin{array}{l}\text { From DOE G } 435.1-1 \text { Chapter IV: Compliance with } \\
\text { this requirement is demonstrated if sites have storage } \\
\text { capabilities for low-level waste that provide protection } \\
\text { to waste containers so that their integrity will not be } \\
\text { damaged through physical or chemical (corrosion) } \\
\text { processes and that keep personnel from spending } \\
\text { extended periods of time in the areas where low-level } \\
\text { waste is stored. }\end{array}$ & \\
\hline (4) Waste Characterization for Storage. & See (1) above. \\
\hline $\begin{array}{l}\text { (a) Low-level waste that does not have an identified } \\
\text { path to disposal shall be characterized as necessary to } \\
\text { meet the data quality objectives and minimum } \\
\text { characterization requirements of this Chapter, to ensure } \\
\text { safe storage, and to facilitate disposal. }\end{array}$ & See (1) above. \\
\hline $\begin{array}{l}\text { (b) Characterization information for all low-level waste } \\
\text { in storage shall be maintained as a record in accordance } \\
\text { with the requirements for Records Management in } \\
\text { Chapter I of this Manual. }\end{array}$ & See (1) above. \\
\hline $\begin{array}{l}\text { From DOE G } 435.1-1 \text { Chapter IV: Compliance with } \\
\text { this requirement is demonstrated by documented } \\
\text { procedures for managing waste characterization and } \\
\text { container information on low-level waste as a Federal } \\
\text { record. The records are managed per the applicable } \\
\text { policies and procedures for records management } \\
\text { referenced in DOE O } 200.1 \text { and established at the } \\
\text { applicable Field Element. }\end{array}$ & \\
\hline $\begin{array}{l}\text { (5) Container Inspection. A process shall be developed } \\
\text { and implemented for inspecting and maintaining } \\
\text { containers of low-level waste to ensure container } \\
\text { integrity is not compromised. }\end{array}$ & $\begin{array}{l}\text { LI- } 435 \text { requires quarterly inspections of radioactive } \\
\text { waste containers if waste is stored outdoors or has been } \\
\text { in storage for greater than } 1 \text { year. }\end{array}$ \\
\hline $\begin{array}{l}\text { From DOE G } 435.1-1 \text { Chapter IV: Compliance with } \\
\text { this requirement is demonstrated by: (1) a documented } \\
\text { process for waste container inspection and } \\
\text { maintenance; and (2) documentation for all waste } \\
\text { container inspections and maintenance actions } \\
\text { performed. }\end{array}$ & \\
\hline $\begin{array}{l}\text { (6) Storage Management. Low-level waste storage shall } \\
\text { be managed to identify and segregate low-level waste } \\
\text { from mixed low-level waste. }\end{array}$ & See (1) above. \\
\hline $\begin{array}{l}\text { (7) Staging. Staging of low-level waste shall be for the } \\
\text { purpose of the accumulation of such quantities of waste } \\
\text { as necessary to facilitate transportation, treatment, and } \\
\text { disposal. Staging longer than } 90 \text { days shall meet the } \\
\text { requirements for storage above and in Chapter I of this } \\
\text { Manual. } \\
\text { From DOE G 435.1-1 Chapter IV: The staging of low- }\end{array}$ & $\begin{array}{l}\text { Routine LLW, such as personnel protective equipment, } \\
\text { is accumulated at this facility for disposal. } \\
\text { MCP-17000, Appendix F restricts staging LLW to } \\
90 \text { days maximum at any generator or treatment } \\
\text { facility prior to acceptance by a storage facility. } \\
\text { As stated in DOE Guide } 435.1-1 \text { §IV.N.(7), staging } \\
\text { waste in accordance with this requirement allows waste }\end{array}$ \\
\hline
\end{tabular}


Table 12. (continued).

Facility Name: MFC-775, Zero Power Physics Reactor Workroom

\begin{tabular}{|c|c|}
\hline Chapter IV, LLW Requirements & Facility Compliance Information \\
\hline $\begin{array}{l}\text { level waste needs to be addressed in the radioactive } \\
\text { waste management basis for the facility that is } \\
\text { performing the staging. Generators, treatment facilities, } \\
\text { and disposal facilities that stage waste must ensure that } \\
\text { the action of staging is included and authorized as part } \\
\text { of their radioactive waste management basis for the } \\
\text { affected facilities, operations, or activities. } \\
\text { Staging longer than } 90 \text { days must be justified, the } \\
\text { conditions for such storage met, and these practices } \\
\text { approved by the Field Element Manager as part of the } \\
\text { radioactive waste management basis for the facility. } \\
\text { Compliance with this requirement is demonstrated by a } \\
\text { staging program that limits the temporary storage of } \\
\text { waste to only circumstances allowed in the } \\
\text { requirement, including justifications for any staging } \\
\text { that exceeds the } 90 \text {-day period, which is documented in } \\
\text { the radioactive waste management basis for the facility. }\end{array}$ & $\begin{array}{l}\text { to be accumulated without being considered storage } \\
\text { and being bound by the associated storage } \\
\text { requirements. }\end{array}$ \\
\hline $\begin{array}{l}\text { O. Treatment. Low-level waste treatment to provide } \\
\text { more stable waste forms and to improve the long-term } \\
\text { performance of a low-level waste disposal facility shall } \\
\text { be implemented as necessary to meet the performance } \\
\text { objectives of the disposal facility. } \\
\text { From DOE G } 435.1-1 \text { Chapter IV: Compliance with } \\
\text { this requirement is demonstrated when a treatment } \\
\text { facility or process ensures that treated waste will meet } \\
\text { the minimum waste form requirements of DOE M } \\
435.1 \text { and meet additional disposal facility-specific } \\
\text { waste acceptance requirements for additional stability } \\
\text { or long-term performance of facilities that will receive } \\
\text { the treated waste. }\end{array}$ & NA; this facility does not treat LLW. \\
\hline $\begin{array}{l}\text { P. Disposal. Low-level waste disposal facilities shall } \\
\text { meet the following requirements. }\end{array}$ & NA; this facility does not dispose of LLW. \\
\hline $\begin{array}{l}\text { (1) Performance Objectives. Low-level waste disposal } \\
\text { facilities shall be sited, designed, operated, maintained, } \\
\text { and closed so that a reasonable expectation exists that } \\
\text { the following performance objectives will be met for } \\
\text { waste disposed of after September 26, 1988: }\end{array}$ & See P. above. \\
\hline $\begin{array}{l}\text { (a) Dose to representative members of the public shall } \\
\text { not exceed } 25 \text { mrem }(0.25 \mathrm{mSv}) \text { in a year total effective } \\
\text { dose equivalent from all exposure pathways, excluding } \\
\text { the dose from radon and its progeny in air. }\end{array}$ & See P. above. \\
\hline $\begin{array}{l}\text { (b) Dose to representative members of the public via } \\
\text { the air pathway shall not exceed } 10 \text { mrem }(0.10 \mathrm{mSv}) \\
\text { in a year total effective dose equivalent, excluding the } \\
\text { dose from radon and its progeny. }\end{array}$ & See P. above. \\
\hline $\begin{array}{l}\text { (c) Release of radon shall be less than an average flux } \\
\text { of } 20 \mathrm{pCi} / \mathrm{m}^{2} / \mathrm{s}\left(0.74 \mathrm{~Bq} / \mathrm{m}^{2} / \mathrm{s}\right) \text { at the surface of the }\end{array}$ & See P. above. \\
\hline
\end{tabular}


Table 12. (continued).

Facility Name: MFC-775, Zero Power Physics Reactor Workroom

\begin{tabular}{l} 
Chapter IV, LLW Requirements \\
\hline disposal facility. Alternatively, a limit of $0.5 \mathrm{pCi} / 1$ \\
$(0.0185 \mathrm{~Bq} / \mathrm{l})$ of air may be applied at the boundary of \\
the facility. \\
\hline (2) Performance Assessment. A site-specific \\
radiological performance assessment shall be prepared \\
and maintained for DOE low-level waste disposed of \\
after September 26,1988 . The performance assessment \\
shall include calculations for a 1,000 year period after \\
closure of potential doses to representative future \\
members of the public and potential releases from the \\
facility to provide a reasonable expectation that the \\
performance objectives identified in this Chapter are \\
not exceeded as a result of operation and closure of the \\
facility.
\end{tabular}

(a) Analyses performed to demonstrate compliance with the performance objectives in this Chapter, and to establish limits on concentrations of radionuclides for disposal based on the performance measures for inadvertent intruders in this Chapter shall be based on reasonable activities in the critical group of exposed individuals. Unless otherwise specified, the assumption of average living habits and exposure conditions in representative critical groups of individuals projected to receive the highest doses is appropriate. The likelihood of inadvertent intruder scenarios may be considered in interpreting the results of the analyses and establishing radionuclide concentrations, if adequate justification is provided.

(b) The point of compliance shall correspond to the point of highest projected dose or concentration beyond a 100 meter buffer zone surrounding the disposed waste. A larger or smaller buffer zone may be used if adequate justification is provided.

(c) Performance assessments shall address reasonably foreseeable natural processes that might disrupt barriers against release and transport of radioactive materials.

(d) Performance assessments shall use DOE-approved dose coefficients (dose conversion factors) for internal and external exposure of reference adults.

(e) The performance assessment shall include a sensitivity/uncertainty analysis.

(f) Performance assessments shall include a

See P. above. Facility Compliance Information

See P. above. demonstration that projected releases of radionuclides to the environment shall be maintained as low as reasonably achievable (ALARA).

(g) For purposes of establishing limits on radionuclides that may be disposed of near-surface, the performance

See P. above.

See P. above.

See P. above.

See P. above.

See P. above.

See P. above. 
Table 12. (continued).

Facility Name: MFC-775, Zero Power Physics Reactor Workroom

\begin{tabular}{|c|c|}
\hline Chapter IV, LLW Requirements & Facility Compliance Information \\
\hline $\begin{array}{l}\text { assessment shall include an assessment of impacts to } \\
\text { water resources. }\end{array}$ & \\
\hline $\begin{array}{l}\text { (h) For purposes of establishing limits on the } \\
\text { concentration of radionuclides that may be disposed of } \\
\text { near-surface, the performance assessment shall include } \\
\text { an assessment of impacts calculated for a hypothetical } \\
\text { person assumed to inadvertently intrude for a } \\
\text { temporary period into the low-level waste disposal } \\
\text { facility. For intruder analyses, institutional controls } \\
\text { shall be assumed to be effective in deterring intrusion } \\
\text { for at least } 100 \text { years following closure. The intruder } \\
\text { analyses shall use performance measures for chronic } \\
\text { and acute exposure scenarios, respectively, of } 100 \\
\text { mrem }(1 \mathrm{mSv}) \text { in a year and } 500 \text { mrem }(5 \mathrm{mSv}) \text { total } \\
\text { effective dose equivalent excluding radon in air. }\end{array}$ & See P. above. \\
\hline $\begin{array}{l}\text { (3) Composite Analysis. For disposal facilities which } \\
\text { received waste after September 26, } 1988 \text {, a site-specific } \\
\text { radiological composite analysis shall be prepared and } \\
\text { maintained that accounts for all sources of radioactive } \\
\text { material that may be left at the DOE site and may } \\
\text { interact with the low- level waste disposal facility, } \\
\text { contributing to the dose projected to a hypothetical } \\
\text { member of the public from the existing or future } \\
\text { disposal facilities. Performance measures shall be } \\
\text { consistent with DOE requirements for protection of the } \\
\text { public and environment and evaluated for a } 1,000 \text { year } \\
\text { period following disposal facility closure. The } \\
\text { composite analysis results shall be used for planning, } \\
\text { radiation protection activities, and future use } \\
\text { commitments to minimize the likelihood that current } \\
\text { low- level waste disposal activities will result in the } \\
\text { need for future corrective or remedial actions to } \\
\text { adequately protect the public and the environment. }\end{array}$ & See P. above. \\
\hline $\begin{array}{l}\text { (4) Performance Assessment and Composite Analysis } \\
\text { Maintenance. The performance assessment and } \\
\text { composite analysis shall be maintained to evaluate } \\
\text { changes that could affect the performance, design, and } \\
\text { operating bases for the facility. Performance } \\
\text { assessment and composite analysis maintenance shall } \\
\text { include the conduct of research, field studies, and } \\
\text { monitoring needed to address uncertainties or gaps in } \\
\text { existing data. The performance assessment shall be } \\
\text { updated to support the final facility closure. Additional } \\
\text { iterations of the performance assessment and composite } \\
\text { analysis shall be conducted as necessary during the } \\
\text { post-closure period. }\end{array}$ & See P. above. \\
\hline $\begin{array}{l}\text { (a) Performance assessments and composite analyses } \\
\text { shall be reviewed and revised when changes in waste } \\
\text { forms or containers, radionuclide inventories, facility }\end{array}$ & See P. above. \\
\hline
\end{tabular}


Table 12. (continued).

Facility Name: MFC-775, Zero Power Physics Reactor Workroom

\begin{tabular}{l} 
Chapter IV, LLW Requirements \\
\hline design and operations, closure concepts, or the \\
improved understanding of the performance of the \\
waste disposal facility in combination with the features \\
of the site on which it is located alter the conclusions or \\
the conceptual model(s) of the existing performance \\
assessment or composite analysis.
\end{tabular}

(b) A determination of the continued adequacy of the performance assessment and composite analysis shall be made on an annual basis, and shall consider the results of data collection and analysis from research, field studies, and monitoring.

(c) Annual summaries of low-level waste disposal operations shall be prepared with respect to the conclusions and recommendations of the performance assessment and composite analysis and a determination of the need to revise the performance assessment or composite analysis.

(5) Disposal Authorization. A disposal authorization statement shall be obtained prior to construction of a new low-level waste disposal facility. Field Elements with existing low-level waste disposal facilities shall obtain a disposal authorization statement in accordance with the schedule in the Complex-Wide Low-Level Waste Management Program Plan. The disposal authorization statement shall be issued based on a review of the facility's performance assessment, composite analysis, performance assessment and composite analysis maintenance, preliminary closure plan, and preliminary monitoring plan. The disposal authorization statement shall specify the limits and conditions on construction, design, operations, and closure of the low-level waste facility based on these reviews. A disposal authorization statement is a part of the radioactive waste management basis for a disposal facility. Failure to obtain a disposal authorization statement by the implementation date of this Order shall result in shutdown of the disposal facility.

(6) Disposal Facility Operations. The disposal facility design and operation must be consistent with the disposal facility closure plan and lead to disposal facility closure that provides a reasonable expectation that performance objectives will be met. Low-level waste shall be disposed in such a manner that achieves the performance objectives stated in this Chapter, consistent with the disposal facility radiological performance assessment. Additional requirements include:

(a) Operating procedures shall be developed and implemented for low-level waste disposal facilities that
See P. above. Facility Compliance Information

See P. above.

See P. above.
See P. above.

See P. above. 
Table 12. (continued).

Facility Name: MFC-775, Zero Power Physics Reactor Workroom

\begin{tabular}{l} 
Chapter IV, LLW Requirements \\
\hline protect the public, workers, and the environment; \\
ensure the security of the facility; minimize subsidence \\
during and after waste emplacement; achieve long-term \\
stability and minimize the need for long-term active \\
maintenance; and meet the requirements of the \\
closure/post-closure plan.
\end{tabular}

(b) Permanent identification markers for disposal excavations and monitoring wells shall be emplaced.

(c) Low-level waste placement into disposal units shall minimize voids between waste containers. Voids within disposal units shall be filled to the extent practical. Uncontainerized bulk waste shall also be placed in a manner that minimizes voids and subsidence.

(d) Operations are to be conducted so that active waste disposal operations will not have an adverse effect on any other disposal units.

(e) Operations shall include a process for tracking and documenting low-level waste placement in the facility by generator source.

(7) Alternate Requirements for Low-Level Waste Disposal Facility Design and Operation. Requirements other than those set forth in this Section for the design and operation of a low-level waste disposal facility may be approved on a specific basis if a reasonable expectation is demonstrated that the disposal performance objectives will be met.

Q. Closure. The following requirements are in addition to those in Chapter I of this Manual.

(1) Disposal Facility Closure Plans. A preliminary closure plan shall be developed and submitted to Headquarters for review with the performance assessment and composite analysis. The closure plan shall be updated following issuance of the disposal authorization statement to incorporate conditions specified in the disposal authorization statement. Closure plans shall:

(a) Be updated as required during the operational life of the facility.

(b) Include a description of how the disposal facility will be closed to achieve long-term stability and minimize the need for active maintenance following closure and to ensure compliance with the requirements of DOE 5400.5, Radiation Protection of the Public and the Environment.

(c) Include the total expected inventory of wastes to be disposed of at the facility over the operational life of

NA; this facility does not dispose of LLW.

See Q. above.

See P. above.

See P. above.

See P. above. Facility Compliance Information

See P. above.

See P. above.

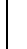

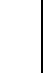


Table 12. (continued).

\begin{tabular}{|c|c|}
\hline \multicolumn{2}{|c|}{ Facility Name: MFC-775, Zero Power Physics Reactor Workroom } \\
\hline Chapter IV, LLW Requirements & Facility Compliance Information \\
\hline the facility. & \\
\hline $\begin{array}{l}\text { (2) Disposal Facility Closure. Closure of a disposal } \\
\text { facility shall occur within a five-year period after it is } \\
\text { filled to capacity, or after the facility is otherwise } \\
\text { determined to be no longer needed. }\end{array}$ & See Q. above. \\
\hline $\begin{array}{l}\text { (a) Prior to facility closure, the final inventory of the } \\
\text { low-level waste disposed in the facility shall be } \\
\text { prepared and incorporated in the performance } \\
\text { assessment and composite analysis which shall be } \\
\text { updated to support the closure of the facility. }\end{array}$ & See Q. above. \\
\hline $\begin{array}{l}\text { (b) A final closure plan shall be prepared based on the } \\
\text { final inventory of waste disposed in the facility, the } \\
\text { plan implemented, and the updated performance } \\
\text { assessment and composite analysis prepared in support } \\
\text { of the facility closure. }\end{array}$ & See Q. above. \\
\hline $\begin{array}{l}\text { (c) Institutional control measures shall be integrated } \\
\text { into land use and stewardship plans and programs, and } \\
\text { shall continue until the facility can be released pursuant } \\
\text { to DOE } 5400.5 \text {, Radiation Protection of the Public and } \\
\text { the Environment. }\end{array}$ & See Q. above. \\
\hline $\begin{array}{l}\text { (d) The location and use of the facility shall be filed } \\
\text { with the local authorities responsible for land use and } \\
\text { zoning. }\end{array}$ & See Q. above. \\
\hline $\begin{array}{l}\text { R. Monitoring. The following requirements are in } \\
\text { addition to those in Chapter I of this Manual [DOE M } \\
435.1-1 \text { §I.1.E(7)]. }\end{array}$ & $\begin{array}{l}\text { DOE Manual 435.1-1 §I.1.E(7) applies to field element } \\
\text { managers. }\end{array}$ \\
\hline $\begin{array}{l}\text { (1) All Waste Facilities. Parameters that shall be } \\
\text { sampled or monitored, at a minimum, include: } \\
\text { temperature, pressure (for closed systems), } \\
\text { radioactivity in ventilation exhaust and liquid effluent } \\
\text { streams, and flammable or explosive mixtures of gases. } \\
\text { Facility monitoring programs shall include verification } \\
\text { that passive and active control systems have not failed. } \\
\text { From DOE G 435.1-1 Chapter IV: The minimum } \\
\text { parameters specified in the requirement were selected } \\
\text { based on their potential significance for anticipating } \\
\text { and identifying undesirable conditions at low-level } \\
\text { waste management facilities. Each facility's radioactive } \\
\text { waste management basis should include an evaluation } \\
\text { of the applicability and significance of the minimum } \\
\text { parameters. This evaluation also needs to consider } \\
\text { additional parameters to be sampled or monitored to } \\
\text { ensure the protection of the public health, the } \\
\text { environment, and the workers. If a minimum parameter } \\
\text { specified in the requirement is deemed to be not } \\
\text { applicable in any way to the active operation of that } \\
\text { facility, then that justification should be included in the }\end{array}$ & $\begin{array}{l}\text { Monitoring requirements at INL radioactive waste } \\
\text { management facilities are tailored for the specific } \\
\text { facility to enable timely indication of developing } \\
\text { problems. Existing radiological control procedures and } \\
\text { assessments are followed/completed to monitor waste } \\
\text { facilities. } \\
\text { LRD-15001 and specifically MCP-139 specify } \\
\text { methods and frequency of radiological control surveys } \\
\text { of all radiological areas. MCP-139 specifies the use of } \\
\text { Form } 441 . \text { A34. This form is referred to as the "routine } \\
\text { sheet" and is to be used by facility radiological control } \\
\text { foremen to list radiological areas that are to be } \\
\text { surveyed, the survey periods, and methods. }\end{array}$ \\
\hline
\end{tabular}


Table 12. (continued).

Facility Name: MFC-775, Zero Power Physics Reactor Workroom

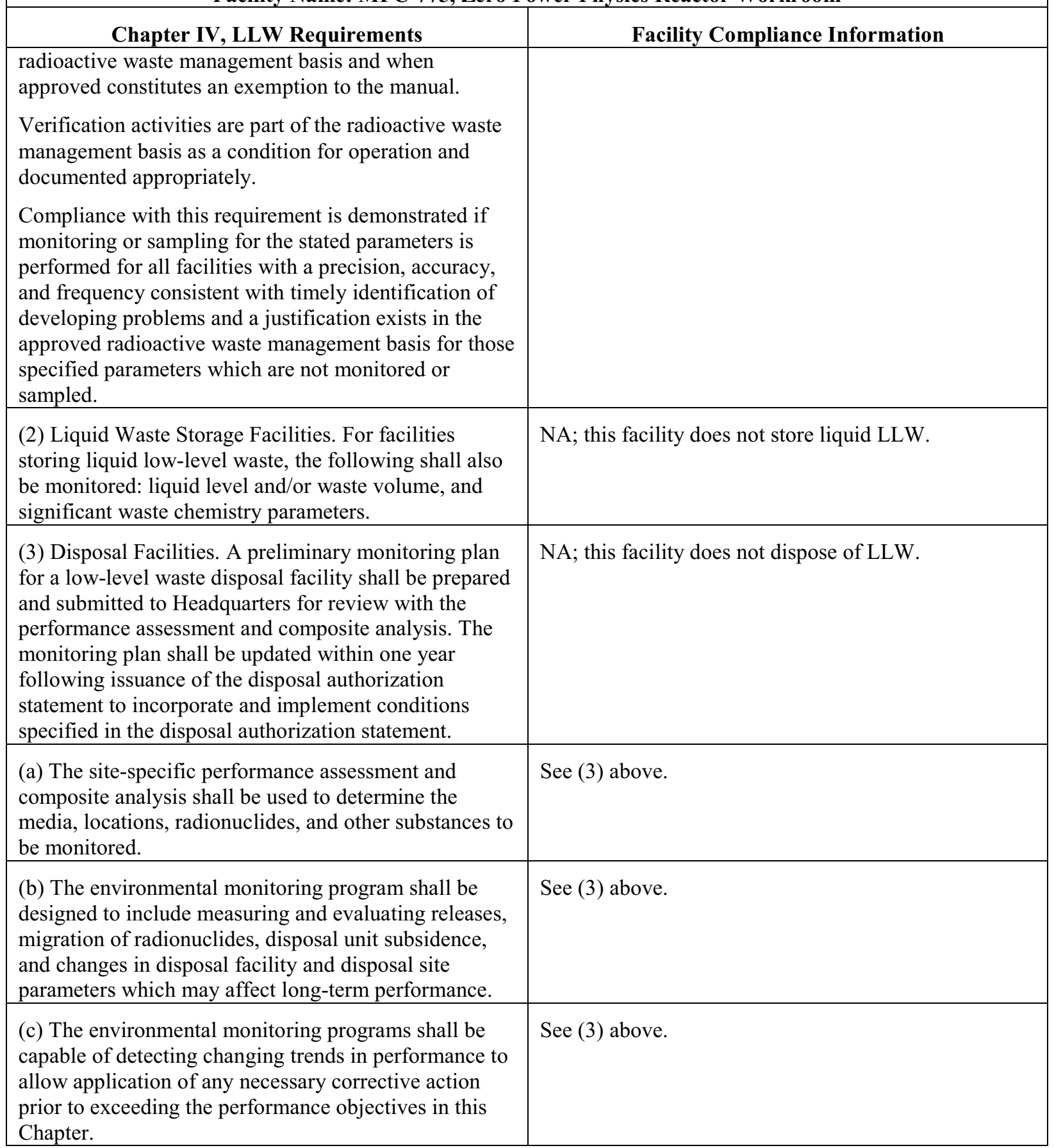

\subsection{MFC-784, Zero Power Physics Reactor Material Control Building}

1. Facility description: The ZPPR materials control building (MFC-784) is a 150 - $\mathrm{ft}$ by 48 -ft by $16-\mathrm{ft}$ high ( $9 \mathrm{ft}$ at eaves) building containing a $20-\mathrm{ft}$ by $60-\mathrm{ft}$ sodium storage room. The building was constructed with steel posts and beams and is covered by corrugated steel panels. This building was relocated from the Test Area North site on the INL to MFC in 1975. The roof also is covered with 
corrugated steel. The sodium storage room (located within MFC-784) is constructed of concrete blocks and is covered with a concrete roof. The facility is used to store nonfissile ZPPR core materials, reactor equipment, experimental apparatus, and structural mockup materials. The facility has an automatic fire-sprinkler system with fire and smoke detectors. The inner sodium storage room is not sprinkler protected; dry chemicals are used in event of a fire.

2. Hazard category: Hazard Category 3 non-reactor nuclear facility

3. Radioactive waste managed at this facility: CH LLW is generated and staged in this facility subsequent to routine facility operations.

4. RWMB documents/programs:

a. Safety Basis/Hazards Analysis:

- DSA-006-ZPPR, "ZPPR Documented Safety Analysis"

b. Laboratory-wide:

- Form 435.39, "Waste Determination and Disposal Form (WDDF)"

- Form 435.42, "Radioactive Waste Inventory Sheet"

- Form 441.A34, "INL Radiological Control Required Surveys"

- LI-435, "Waste Management Routine Field Activities"

- LRD-15001, "Radiological Control Manual"

- LWP-13840, "Management of Issues, Observations, and Noteworthy Practices"

- LWP-14002, "Timeout and Stop Work Authority"

- LWP-17000, "Waste Management"

- MCP-139, "Radiological Surveys"

- MCP-17000, "Waste Generator Services Waste Management"

- MCP-17500, "Waste Generator Services Certification of Waste Shipments to the Nevada Test Site"

- PDD-17000, "Waste Management Program"

- PLN-114, "INL Emergency Plan/RCRA Contingency Plan"

- PLN-522, "Quality Assurance Program Plan for the Waste Management/Waste Certification Program"

c. Facility-specific:

- TSD-OI-004, "Waste and Material Acceptance for Storage/Treatment and Radioactive Material Inventory Control"

- TSM-OI-003, "Transfer of Hazardous Material in Non-DOT-Certified Packaging between MFC Nuclear Facilities"

- ZPPR-OI-009, “ZPPR General Facility Waste.”

LLW is managed at this facility. Table 13 shows the facility compliance information for DOE Manual 435.1-1, Chapter IV, "Low-level Waste Requirements."

Table 13. MFC-784, Zero Power Physics Reactor Material Control Building, DOE Manual 435.1-1 low-level waste requirements and facility compliance information. 
Table 13. (continued).

\begin{tabular}{|c|c|}
\hline \multicolumn{2}{|c|}{ Facility Name: MFC-784, Zero Power Physics Reactor Material Control Building } \\
\hline Chapter IV, LLW Requirements & Facility Compliance Information \\
\hline $\begin{array}{l}\text { A. Definition of Low-Level Waste. Low-level } \\
\text { radioactive waste is radioactive waste that is not high- } \\
\text { level radioactive waste, spent nuclear fuel, transuranic } \\
\text { waste, byproduct material (as defined in section } 11 \mathrm{e} .(2) \\
\text { of the Atomic Energy Act of } 1954 \text {, as amended), or } \\
\text { naturally occurring radioactive material. } \\
\text { From DOE G } 435.1-1 \text { Chapter IV: Low-level } \\
\text { radioactive waste is defined by what it is not. The } \\
\text { guidance on definitions in Chapters II and III should be } \\
\text { consulted first for making a determination on how to } \\
\text { properly manage a suspect waste stream.) }\end{array}$ & $\begin{array}{l}\text { This requirement proves the criteria for determining } \\
\text { which DOE radioactive waste is to be managed as } \\
\text { LLW in accordance with DOE Manaul 435.1-1, } \\
\text { Chapter IV. } \\
\text { Radioactive waste managed at this facility under the } \\
\text { requirements of this chapter is not managed under the } \\
\text { requirements of DOE Manual } 435.1-1 \text {, Chapter II or } \\
\text { Chapter III. }\end{array}$ \\
\hline $\begin{array}{l}\text { B. Management of Specific Wastes. The following } \\
\text { provide for management of specific wastes as low-level } \\
\text { waste in accordance with the requirements in this } \\
\text { Chapter: }\end{array}$ & See (1), (2), (3), and (4) below. \\
\hline $\begin{array}{l}\text { (1) Mixed Low-Level Waste. Low-level waste } \\
\text { determined to contain both source, special nuclear, or } \\
\text { byproduct material subject to the Atomic Energy Act of } \\
1954 \text {, as amended, and a hazardous component subject } \\
\text { to the Resource Conservation and Recovery Act } \\
\text { (RCRA), as amended, shall be managed in accordance } \\
\text { with the requirements of RCRA and DOE O 435.1, } \\
\text { Radioactive Waste Management, and this Manual. }\end{array}$ & NA; this facility does not manage RCRA mixed waste. \\
\hline $\begin{array}{l}\text { (2) TSCA-Regulated Waste. Low-level waste } \\
\text { containing polychlorinated biphenyls, asbestos, or other } \\
\text { such regulated toxic components shall be managed in } \\
\text { accordance with requirements derived from the Toxic } \\
\text { Substances Control Act, as amended, DOE O } 435.1 \text {, } \\
\text { Radioactive Waste Management, and this Manual. }\end{array}$ & $\begin{array}{l}\text { NA; this facility does not manage TSCA-regulated } \\
\text { waste. }\end{array}$ \\
\hline $\begin{array}{l}\text { (3) Accelerator-Produced Waste. Radioactive waste } \\
\text { produced as a result of operations of DOE accelerators } \\
\text { is low-level waste and shall be managed in accordance } \\
\text { with DOE O 435.1, Radioactive Waste Management, } \\
\text { and this Manual, and all applicable Federal or State } \\
\text { requirements. }\end{array}$ & $\begin{array}{l}\text { NA; this facility does not manage accelerator-produced } \\
\text { waste. }\end{array}$ \\
\hline $\begin{array}{l}\text { (4) } 11 \text { e.(2) and Naturally Occurring Radioactive } \\
\text { Material. Small quantities of 11e.(2) byproduct } \\
\text { material and naturally occurring radioactive material } \\
\text { may be managed as low-level waste provided they can } \\
\text { be managed to meet the requirements for low-level } \\
\text { waste disposal in Section IV.P of this Manual. }\end{array}$ & $\begin{array}{l}\text { NA; this facility does not manage naturally occurring } \\
\text { radioactive material. }\end{array}$ \\
\hline $\begin{array}{l}\text { C. Complex-Wide Low-Level Waste Management } \\
\text { Program. A complex-wide program and plan shall be } \\
\text { developed as described under Responsibilities, 2.B and } \\
\text { 2.D, in Chapter I of this Manual. }\end{array}$ & $\begin{array}{l}\text { DOE Manual 435.1-1 §I.2.B and §I.2.D apply to the } \\
\text { Assistant Secretary for Environmental Management } \\
\text { and the Deputy Assistant Secretary for Waste } \\
\text { Management, respectively. }\end{array}$ \\
\hline $\begin{array}{l}\text { D. Radioactive Waste Management Basis. Low-level } \\
\text { waste facilities, operations, and activities shall have a }\end{array}$ & $\begin{array}{l}\text { The RWMB provides the regulatory framework for } \\
\text { management of radioactive waste at INL. It specifically }\end{array}$ \\
\hline
\end{tabular}


Table 13. (continued).

\begin{tabular}{|c|c|}
\hline \multicolumn{2}{|c|}{ Facility Name: MFC-784, Zero Power Physics Reactor Material Control Building } \\
\hline Chapter IV, LLW Requirements & Facility Compliance Information \\
\hline $\begin{array}{l}\text { radioactive waste management basis consisting of } \\
\text { physical and administrative controls to ensure the } \\
\text { protection of workers, the public, and the environment. } \\
\text { The following specific waste management controls } \\
\text { shall be part of the radioactive waste management } \\
\text { basis: }\end{array}$ & $\begin{array}{l}\text { identifies facility management and implementing } \\
\text { documents for the generation, storage, treatment, and } \\
\text { disposal of radiological waste. }\end{array}$ \\
\hline $\begin{array}{l}\text { (1) Generators. The waste certification program. } \\
\text { From DOE G } 435.1-1 \text { Chapter IV: For a facility that } \\
\text { generates low-level waste, the radioactive waste } \\
\text { management basis is to include the program for } \\
\text { certifying that waste meets the waste acceptance } \\
\text { requirements of the facility(ies) to which the waste will } \\
\text { be sent. }\end{array}$ & $\begin{array}{l}\text { See J. below for waste certification program } \\
\text { requirements. } \\
\text { DSA-006-ZPPR determines and documents the hazard } \\
\text { category for this facility as a Hazard Category } 2 \\
\text { nuclear facility. }\end{array}$ \\
\hline $\begin{array}{l}\text { (2) Treatment Facilities. certification program. The } \\
\text { waste acceptance requirements and the waste }[\text { sic }]\end{array}$ & NA; this facility does not treat LLW. \\
\hline $\begin{array}{l}\text { From DOE G 435.1-1 Chapter IV: Facilities that store } \\
\text { or treat low-level waste are to have approved waste } \\
\text { acceptance requirements (see DOE M 435.1-1, Section } \\
\text { IV.G) prior to the issuance of a radioactive waste } \\
\text { management basis. }\end{array}$ & \\
\hline $\begin{array}{l}\text { A facility that stores or treats waste also is generally } \\
\text { expected to have a waste certification program. Waste } \\
\text { from these facilities will have to be certified as meeting } \\
\text { the waste acceptance requirements of the facility to } \\
\text { which it will be transferred, and the facilities have the } \\
\text { potential for generating radioactive waste (e.g., } \\
\text { secondary processing streams from treatment, } \\
\text { monitoring and sampling, radioactive release cleanup). } \\
\text { Consequently, storage and treatment facilities should } \\
\text { also have an approved waste certification program as } \\
\text { part of their radioactive waste management basis. }\end{array}$ & \\
\hline $\begin{array}{l}\text { As part of the radioactive waste management basis, site } \\
\text { personnel needs to implement a system or process for } \\
\text { tracking the waste inventory at a storage, treatment, or } \\
\text { disposal facility. }\end{array}$ & \\
\hline $\begin{array}{l}\text { (3) Storage Facilities. The waste acceptance } \\
\text { requirements and the waste certification program. }\end{array}$ & NA; this facility does not store LLW. \\
\hline $\begin{array}{l}\text { From DOE G } 435.1-1 \text { Chapter IV: Facilities that store } \\
\text { or treat low-level waste are to have approved waste } \\
\text { acceptance requirements (see DOE M 435.1-1, Section } \\
\text { IV.G) prior to the issuance of a radioactive waste } \\
\text { management basis. }\end{array}$ & \\
\hline $\begin{array}{l}\text { A facility that stores or treats waste also is generally } \\
\text { expected to have a waste certification program. Waste } \\
\text { from these facilities will have to be certified as meeting } \\
\text { the waste acceptance requirements of the facility to } \\
\text { which it will be transferred, and the facilities have the } \\
\text { potential for generating radioactive waste (e.g., }\end{array}$ & \\
\hline
\end{tabular}


Table 13. (continued).

\begin{tabular}{|c|c|}
\hline \multicolumn{2}{|c|}{ Facility Name: MFC-784, Zero Power Physics Reactor Material Control Building } \\
\hline Chapter IV, LLW Requirements & Facility Compliance Information \\
\hline $\begin{array}{l}\text { secondary processing streams from treatment, } \\
\text { monitoring and sampling, radioactive release cleanup). } \\
\text { Consequently, storage and treatment facilities should } \\
\text { also have an approved waste certification program as } \\
\text { part of their radioactive waste management basis. }\end{array}$ & \\
\hline $\begin{array}{l}\text { As part of the radioactive waste management basis, site } \\
\text { personnel needs to implement a system or process for } \\
\text { tracking the waste inventory at a storage, treatment, or } \\
\text { disposal facility. }\end{array}$ & \\
\hline $\begin{array}{l}\text { (4) Disposal Facilities. The performance assessment, } \\
\text { composite analysis, disposal authorization statement, } \\
\text { closure plan, waste acceptance requirements, and } \\
\text { monitoring plan. }\end{array}$ & NA; this facility does not dispose of LLW. \\
\hline $\begin{array}{l}\text { E. Contingency Actions. The following requirements } \\
\text { are in addition to those in Chapter I of this Manual } \\
\text { [DOE M 435.1-1 §I.1.E(5)]. }\end{array}$ & $\begin{array}{l}\text { DOE Manual } 435.1-1 \S \mathrm{I} .1 . \mathrm{E}(5) \text { addresses the sitewide } \\
\text { emergency management system. The INL plan is } \\
\text { provided in PLN-114. }\end{array}$ \\
\hline $\begin{array}{l}\text { (1) Contingency Storage. For off-normal or emergency } \\
\text { situations involving high activity or high hazard liquid } \\
\text { low-level waste storage or treatment, spare capacity } \\
\text { with adequate capabilities shall be maintained to } \\
\text { receive the largest volume of liquid contained in any } \\
\text { one storage tank or treatment facility. Tanks or other } \\
\text { facilities that are designated low-level waste } \\
\text { contingency storage shall be maintained in an } \\
\text { operational condition when waste is present and shall } \\
\text { meet the requirements of DOE O } 435.1 \text {, Radioactive } \\
\text { Waste Management, and this Manual. }\end{array}$ & NA; this facility does not store liquid LLW. \\
\hline $\begin{array}{l}\text { From DOE G } 435.1-1 \text { Chapter IV: Compliance with } \\
\text { these requirements is demonstrated if adequate spare } \\
\text { capacity and transfer equipment exists for emergency } \\
\text { transfers of all high activity and high hazard liquid low- } \\
\text { level waste. In addition, the capability to perform } \\
\text { emergency transfers is demonstrated by having waste } \\
\text { transfer routings identified, operational procedures to } \\
\text { direct transfers, staff trained to the procedures, and } \\
\text { records showing that the spare capacity and transfer } \\
\text { capability are kept in operating condition. }\end{array}$ & \\
\hline $\begin{array}{l}\text { (2) Transfer Equipment. Pipelines and auxiliary } \\
\text { facilities necessary for the transfer of high activity or } \\
\text { high hazard liquid low-level waste to contingency } \\
\text { storage shall be maintained in an operational condition } \\
\text { when waste is present and shall meet the requirements } \\
\text { of DOE O } 435.1, \text { Radioactive Waste Management, and } \\
\text { this Manual. }\end{array}$ & NA; this facility does not store liquid LLW. \\
\hline $\begin{array}{l}\text { From DOE G } 435.1-1 \text { Chapter IV: Compliance with } \\
\text { these requirements is demonstrated if adequate spare } \\
\text { capacity and transfer equipment exists for emergency } \\
\text { transfers of all high activity and high hazard liquid low- } \\
\text { level waste. In addition, the capability to perform }\end{array}$ & \\
\hline
\end{tabular}


Table 13. (continued).

\begin{tabular}{|c|c|}
\hline \multicolumn{2}{|c|}{ Facility Name: MFC-784, Zero Power Physics Reactor Material Control Building } \\
\hline Chapter IV, LLW Requirements & Facility Compliance Information \\
\hline $\begin{array}{l}\text { emergency transfers is demonstrated by having waste } \\
\text { transfer routings identified, operational procedures to } \\
\text { direct transfers, staff trained to the procedures, and } \\
\text { records showing that the spare capacity and transfer } \\
\text { capability are kept in operating condition. }\end{array}$ & \\
\hline $\begin{array}{l}\text { F. Corrective Actions. I of this Manual. The following } \\
\text { requirements are in addition to those in Chapter [sic] }\end{array}$ & $\begin{array}{l}\text { The INL-wide procedure addressing problem } \\
\text { identification as required by DOE Manual 435.1-1 }\end{array}$ \\
\hline $\begin{array}{l}\text { From DOE G 435.1-1 Chapter IV: Compliance with } \\
\text { DOE M 435.1-1 §I.2.G.(1) is demonstrated by records }\end{array}$ & $\begin{array}{l}\text { §I.2.G.(1) is LWP-13840, which implements the } \\
\text { laboratory's corrective action system. }\end{array}$ \\
\hline $\begin{array}{l}\text { showing what corrective actions were taken to remedy } \\
\text { situations in the radioactive waste management system. }\end{array}$ & $\begin{array}{l}\text { The INL-wide procedure addressing shutdown or } \\
\text { curtailment of activities as required by DOE Manual }\end{array}$ \\
\hline $\begin{array}{l}\text { Compliance with DOE M 435.1-1 §I.2.G.(2) is } \\
\text { demonstrated by having the necessary procedures, } \\
\text { mechanisms, and training in place to effect shutdown } \\
\text { or curtailment of activities which pose an imminent } \\
\text { danger or other serious hazard to workers or the public, } \\
\text { or are not protective of the environment. }\end{array}$ & 435.1-1 §I.2.G.(2) is LWP-14002. \\
\hline $\begin{array}{l}\text { (1) Order Compliance. Corrective actions shall be } \\
\text { implemented whenever necessary to ensure the } \\
\text { requirements of DOE O 435.1, Radioactive Waste } \\
\text { Management, and this Manual are met. }\end{array}$ & See F. above. \\
\hline $\begin{array}{l}\text { From DOE G 435.1-1 Chapter IV: If a facility or } \\
\text { activity can be allowed to operate while a } \\
\text { noncompliant or hazardous condition exists, the } \\
\text { allowance and any associated limitations must be } \\
\text { defined as part of the facility or activity's radioactive } \\
\text { waste management basis, identified as a configuration } \\
\text { controlled item in a configuration management plan or } \\
\text { included in a revision or modification to an operating } \\
\text { procedure or similar controlled documentation. }\end{array}$ & \\
\hline $\begin{array}{l}\text { Compliance with this requirement is demonstrated if a } \\
\text { corrective action system addresses noncompliant or } \\
\text { hazardous situations involving low-level waste } \\
\text { management facilities in a systematic fashion, and } \\
\text { allows identification of problems by all personnel. }\end{array}$ & \\
\hline $\begin{array}{l}\text { (2) Operations Curtailment. Operations shall be } \\
\text { curtailed or facilities shut down for failure to establish, } \\
\text { maintain, or operate consistent with an approved } \\
\text { radioactive waste management basis. }\end{array}$ & $\begin{array}{l}\text { The approved RWMB establishes the current } \\
\text { compliance status at each radioactive waste } \\
\text { management facility. Facility assessments are } \\
\text { scheduled to ensure waste management activities are }\end{array}$ \\
\hline $\begin{array}{l}\text { From DOE G } 435.1-1 \text { Chapter IV: Compliance with } \\
\text { this requirement is demonstrated with a documented } \\
\text { system of routine assessments to determine whether } \\
\text { waste management activities and facilities are } \\
\text { operating in accordance with an approved radioactive } \\
\text { waste management basis that provides for graded } \\
\text { limitations that can be placed on activities and } \\
\text { operations that do not have, or are operating outside of, } \\
\text { an approved radioactive waste management basis, }\end{array}$ & \\
\hline
\end{tabular}


Table 13. (continued).

\begin{tabular}{|c|c|}
\hline \multicolumn{2}{|c|}{ Facility Name: MFC-784, Zero Power Physics Reactor Material Control Building } \\
\hline Chapter IV, LLW Requirements & Facility Compliance Information \\
\hline including shutdown of the facility. & \\
\hline $\begin{array}{l}\text { G. Waste Acceptance. The following requirements are } \\
\text { in addition to those in Chapter I of this Manual [DOE } \\
\text { M 435.1-1 §I.2.F(6)]. }\end{array}$ & $\begin{array}{l}\text { DOE Manual 435.1-1 §I.2.F(6) applies to field element } \\
\text { managers. }\end{array}$ \\
\hline $\begin{array}{l}\text { (1) Technical and Administrative. Waste acceptance } \\
\text { requirements for all low-level waste storage, treatment, } \\
\text { or disposal facilities, operations, and activities shall } \\
\text { specify, at a minimum, the following: }\end{array}$ & $\begin{array}{l}\text { NA; this facility does not accept LLW from other } \\
\text { facilities. }\end{array}$ \\
\hline $\begin{array}{l}\text { From DOE G 435.1-1 Chapter IV: Compliance with } \\
\text { these waste acceptance requirements is demonstrated if } \\
\text { they are documented, contain clear and precise criteria } \\
\text { specifying the radionuclide limits in the form of } \\
\text { contents or concentrations that can be accepted, the } \\
\text { limitations and prohibitions on waste forms and } \\
\text { packages that can be received, and the limits, } \\
\text { prohibitions, or instructions concerning any other } \\
\text { technical information so that the waste is compatible } \\
\text { with the safety basis of the facility, and which will } \\
\text { result in acceptable waste at subsequent steps in } \\
\text { managing the low-level waste.) }\end{array}$ & \\
\hline $\begin{array}{l}\text { (a) Allowable activities and/or concentrations of } \\
\text { specific radionuclides. }\end{array}$ & See (1) above. \\
\hline $\begin{array}{l}\text { (b) Acceptable waste form and/or container } \\
\text { requirements that ensure the chemical and physical } \\
\text { stability of waste under conditions that might be } \\
\text { encountered during transportation, storage, treatment, } \\
\text { or disposal. }\end{array}$ & See (1) above. \\
\hline $\begin{array}{l}\text { (c) Restrictions or prohibitions on waste, materials, or } \\
\text { containers that may adversely affect waste handlers or } \\
\text { compromise facility or waste container performance. }\end{array}$ & See (1) above. \\
\hline $\begin{array}{l}\text { (d) The following are additional waste acceptance } \\
\text { requirements that shall be specified in low-level waste } \\
\text { disposal facility waste acceptance requirements: }\end{array}$ & See (1) above. \\
\hline $\begin{array}{l}1 \text { Low-level waste must contribute to and not detract } \\
\text { from achieving long-term stability of the facility, } \\
\text { minimizing the need for long-term active maintenance, } \\
\text { minimizing subsidence, and minimizing contact of } \\
\text { water with waste. Void spaces within the waste and, if } \\
\text { containers are used, between the waste and its container } \\
\text { shall be reduced to the extent practical. }\end{array}$ & See (1) above. \\
\hline $\begin{array}{l}2 \text { Liquid low-level waste or low-level waste containing } \\
\text { free liquid must be converted into a form that contains } \\
\text { as little freestanding liquid as is reasonably achievable, } \\
\text { but in no case shall the liquid exceed } 1 \text { percent of the } \\
\text { waste volume when the low-level waste is in a disposal } \\
\text { container, or } 0.5 \text { percent of the waste volume after it is } \\
\text { processed to a stable form. }\end{array}$ & See (1) above. \\
\hline
\end{tabular}


Table 13. (continued).

\begin{tabular}{|c|c|}
\hline \multicolumn{2}{|c|}{ Facility Name: MFC-784, Zero Power Physics Reactor Material Control Building } \\
\hline Chapter IV, LLW Requirements & Facility Compliance Information \\
\hline $\begin{array}{l}3 \text { Low-level waste must not be readily capable of } \\
\text { detonation or of explosive decomposition or reaction at } \\
\text { anticipated pressures and temperatures, or of explosive } \\
\text { reaction with water. Pyrophoric materials contained in } \\
\text { waste shall be treated, prepared, and packaged to be } \\
\text { nonflammable. }\end{array}$ & See (1) above. \\
\hline $\begin{array}{l}4 \text { Low-level waste must not contain, or be capable of } \\
\text { generating by radiolysis or biodegradation, quantities } \\
\text { of toxic gases, vapors, or fumes harmful to the public } \\
\text { or workers or disposal facility personnel, or harmful to } \\
\text { the long-term structural stability of the disposal site. }\end{array}$ & See (1) above. \\
\hline $\begin{array}{l}5 \text { Low-level waste in a gaseous form must be packaged } \\
\text { such that the pressure does not exceed } 1.5 \text { atmospheres } \\
\text { absolute at } 20 \mathrm{C} \text {. [ sic] }\end{array}$ & See (1) above. \\
\hline $\begin{array}{l}\text { (e) The basis, procedures, and levels of authority } \\
\text { required for granting exceptions to the waste } \\
\text { acceptance requirements, which shall be contained in } \\
\text { each facility's waste acceptance documentation. Each } \\
\text { exception request shall be documented, including its } \\
\text { disposition as approved or not approved. }\end{array}$ & See (1) above. \\
\hline $\begin{array}{l}\text { From DOE G } 435.1-1 \text { Chapter IV: Waste acceptance } \\
\text { requirements are acceptable if they are documented and } \\
\text { contain a clear description of the procedure and bases } \\
\text { for obtaining an exception or deviation to the } \\
\text { acceptance criteria for low-level waste to be received at } \\
\text { the facility. }\end{array}$ & \\
\hline $\begin{array}{l}\text { (2) Evaluation and Acceptance. The receiving facility } \\
\text { shall evaluate waste for acceptance, including } \\
\text { confirmation that the technical and administrative } \\
\text { requirements have been met. A process for the } \\
\text { disposition of non-conforming wastes shall be } \\
\text { established. }\end{array}$ & See (1) above. \\
\hline $\begin{array}{l}\text { From DOE G 435.1-1 Chapter IV: Compliance with the } \\
\text { waste acceptance requirements for a low-level waste } \\
\text { management facility is demonstrated if they include a } \\
\text { process for evaluation and acceptance of incoming } \\
\text { waste to ensure the acceptance criteria of the facility } \\
\text { receiving the waste are met that includes one of or a } \\
\text { combination of: (1) testing, sampling, and analysis of } \\
\text { representative samples of waste upon receipt; (2) } \\
\text { testing, sampling, and analysis of split samples of } \\
\text { waste taken at the generator site; ( } 3 \text { ) evaluation of } \\
\text { testing, sampling, and analysis of data provided by the } \\
\text { generator, or (4) audits, reviews, surveillance, or } \\
\text { observations of generator waste certification programs } \\
\text { and characterization activities. Additionally, acceptable } \\
\text { waste acceptance requirements for a storage, treatment } \\
\text { or disposal facility will have documented procedures } \\
\text { and actions to be taken if a waste that does not conform }\end{array}$ & \\
\hline
\end{tabular}


Table 13. (continued).

\begin{tabular}{|c|c|}
\hline \multicolumn{2}{|c|}{ Facility Name: MFC-784, Zero Power Physics Reactor Material Control Building } \\
\hline Chapter IV, LLW Requirements & Facility Compliance Information \\
\hline $\begin{array}{l}\text { to the waste acceptance criteria is received at the } \\
\text { facility. }\end{array}$ & \\
\hline $\begin{array}{l}\text { H. Waste Generation Planning. The following } \\
\text { requirements are in addition to those in Chapter I of } \\
\text { this Manual [DOE M 435.1-1 §I.2.F(7)]. }\end{array}$ & $\begin{array}{l}\text { DOE Manual 435.1-1 §I.2.F(7) applies to field element } \\
\text { managers. }\end{array}$ \\
\hline $\begin{array}{l}\text { (1) Life-Cycle Planning. Prior to waste generation, } \\
\text { planning shall be performed to address the entire life } \\
\text { cycle for all low-level waste streams. }\end{array}$ & $\begin{array}{l}\text { PDD-17000 and LWP- } 17000 \text { provide direction to the } \\
\text { waste generators for waste generation planning to } \\
\text { address the entire life cycle. }\end{array}$ \\
\hline $\begin{array}{l}\text { From DOE G 435.1-1 Chapter IV: Compliance with } \\
\text { this planning requirement is demonstrated by the } \\
\text { individual sites establishing a process for evaluating the } \\
\text { life-cycle of low-level waste prior to its generation, } \\
\text { including the identification of low-level wastes with no } \\
\text { path to disposal and appropriate records justifying the } \\
\text { newly generated low-level waste stream(s), and site } \\
\text { personnel possessing planning information showing the } \\
\text { location(s) where low-level waste will be stored, } \\
\text { treated, and/or disposed along with a confirmation that } \\
\text { the personnel managing the facilities agree that the } \\
\text { low-level waste may be managed at those facilities. }\end{array}$ & \\
\hline $\begin{array}{l}\text { (2) Waste with No Identified Path to Disposal. Low- } \\
\text { level waste streams with no identified path to disposal } \\
\text { shall be generated only in accordance with approved } \\
\text { conditions which, at a minimum, shall address: }\end{array}$ & $\begin{array}{l}\text { This facility is not generating radioactive waste that } \\
\text { does not have an identified path to disposal. }\end{array}$ \\
\hline (a) Programmatic need to generate the waste; & See (2) above. \\
\hline $\begin{array}{l}\text { (b) Characteristics and issues preventing the disposal of } \\
\text { the waste; }\end{array}$ & See (2) above. \\
\hline $\begin{array}{l}\text { (c) Safe storage of the waste until disposal can be } \\
\text { achieved; and }\end{array}$ & See (2) above. \\
\hline $\begin{array}{l}\text { (d) Activities and plans for achieving final disposal of } \\
\text { the waste. }\end{array}$ & See (2) above. \\
\hline $\begin{array}{l}\text { I. Waste Characterization. Low-level waste shall be } \\
\text { characterized using direct or indirect methods, and the } \\
\text { characterization documented in sufficient detail to } \\
\text { ensure safe management and compliance with the } \\
\text { waste acceptance requirements of the facility receiving } \\
\text { the waste. }\end{array}$ & $\begin{array}{l}\text { MCP-17000 } \S 4 \text { specifies the requirements for } \\
\text { preparing an IWTS profile that captures waste } \\
\text { characterization information. } \\
\text { ZPPR-OI-009 } \S 3.2 \text { provides instructions for the waste } \\
\text { generator to characterize the routine LLW generated } \\
\text { subsequent to facility operations in cooperation with }\end{array}$ \\
\hline $\begin{array}{l}\text { From DOE G } 435.1-1 \text { Chapter IV: Compliance with } \\
\text { this requirement is demonstrated by a program for } \\
\text { documenting and the existence of records that } \\
\text { document the process for acquiring and verifying the } \\
\text { validity of low-level waste characterization data } \\
\text { acquired through the use of direct or indirect methods. }\end{array}$ & $\begin{array}{l}\text { WGS. This is done using Form } 435.39 \text {. The facility } \\
\text { also uses Form } 435.42 \text { to characterize and serve as the } \\
\text { characterization record for this waste. }\end{array}$ \\
\hline $\begin{array}{l}\text { (1) Data Quality Objectives. The data quality } \\
\text { objectives process, or a comparable process, shall be } \\
\text { used for identifying characterization parameters and }\end{array}$ & $\begin{array}{l}\text { Radioactive waste management facilities characterize } \\
\text { waste in accordance with the requirements of the } \\
\text { receiving storage, treatment, or disposal facility. The }\end{array}$ \\
\hline
\end{tabular}


Table 13. (continued).

\begin{tabular}{|c|c|}
\hline \multicolumn{2}{|c|}{ Facility Name: MFC-784, Zero Power Physics Reactor Material Control Building } \\
\hline Chapter IV, LLW Requirements & Facility Compliance Information \\
\hline $\begin{array}{l}\text { acceptable uncertainty in characterization data. } \\
\text { From DOE G } 435.1-1 \text { Chapter IV: Compliance with } \\
\text { this requirement is demonstrated by the documented } \\
\text { use of a data quality objectives or a comparable process } \\
\text { for determining the type, quantity, and quality of } \\
\text { characterization data needed to safely manage low- } \\
\text { level waste. }\end{array}$ & $\begin{array}{l}\text { documented use of a data quality objectives process, or } \\
\text { comparable process, was not identified for this facility. }\end{array}$ \\
\hline $\begin{array}{l}\text { (2) Minimum Waste Characterization. Characterization } \\
\text { data shall, at a minimum, include the following } \\
\text { information relevant to the management of the waste: }\end{array}$ & $\begin{array}{l}\text { MCP- } 17000 \S 4 \text { specifies the requirements for } \\
\text { preparing an IWTS profile that captures waste } \\
\text { characterization information. }\end{array}$ \\
\hline $\begin{array}{l}\text { From DOE G } 435.1-1 \text { Chapter IV: Compliance with } \\
\text { this requirement is demonstrated by the existence of a } \\
\text { program or procedure for determining and records that } \\
\text { document characterization of low-level waste } \\
\text { consistent with the minimum characterization data } \\
\text { requirements.) }\end{array}$ & $\begin{array}{l}\text { ZPPR-OI-009 } \$ 3.2 \text { provides instructions for the waste } \\
\text { generator to characterize the routine LLW generated } \\
\text { subsequent to facility operations. }\end{array}$ \\
\hline (a) Physical and chemical characteristics; & See (2) above. \\
\hline $\begin{array}{l}\text { (b) Volume, including the waste and any stabilization } \\
\text { or absorbent media; }\end{array}$ & See (2) above. \\
\hline (c) Weight of the container and contents; & See (2) above. \\
\hline $\begin{array}{l}\text { (d) Identities, activities, and concentrations of major } \\
\text { radionuclides; }\end{array}$ & See (2) above. \\
\hline (e) Characterization date; & See (2) above. \\
\hline (f) Generating source; and & See (2) above. \\
\hline $\begin{array}{l}\text { (g) Any other information which may be needed to } \\
\text { prepare and maintain the disposal facility performance } \\
\text { assessment, or demonstrate compliance with applicable } \\
\text { performance objectives. }\end{array}$ & See (2) above. \\
\hline $\begin{array}{l}\text { J. Waste Certification. A waste certification program } \\
\text { shall be developed, documented, and implemented to } \\
\text { ensure that the waste acceptance requirements of } \\
\text { facilities receiving low-level waste for storage, } \\
\text { treatment, and disposal are met. }\end{array}$ & $\begin{array}{l}\text { MCP-17000 } \S 4 \text { specifies the requirements for } \\
\text { preparing an IWTS profile that captures waste } \\
\text { certification information. } \\
\text { MCP-17500 provides the WGS waste certification } \\
\text { program for LLW to be shipped to NNSS. }\end{array}$ \\
\hline $\begin{array}{l}\text { From DOE G 435.1-1 Chapter IV: Compliance with the } \\
\text { development and documentation portion of the } \\
\text { certification requirement is demonstrated by a waste } \\
\text { certification plan that identifies the organizations } \\
\text { involved, assigns responsibilities for implementing the } \\
\text { program, and describes or references the quality } \\
\text { assurance, training, procurement controls, records } \\
\text { management, and procedures to be used by the } \\
\text { program. Acceptable performance for implementing } \\
\text { the program is demonstrated when appropriate } \\
\text { personnel are trained and follow the procedures that } \\
\text { govern their part of the waste certification. } \\
\text { Additionally, acceptable performance is demonstrated }\end{array}$ & $\begin{array}{l}\text { Container procurement is addressed in MCP-17000 } \\
\S 4.6 \text {. } \\
\text { Waste certification is performed and tracked using } \\
\text { IWTS. Documentation of the IWTS Program is } \\
\text { available electronically only. } \\
\text { PLN-522 requires waste technical specialists and waste } \\
\text { disposition specialists to complete the appropriate } \\
\text { training/qualification before being granted approval } \\
\text { authority for profiles within the IWTS Program. The } \\
\text { waste certification official, alternate waste certification } \\
\text { official, and NNSS packaging certifiers must complete }\end{array}$ \\
\hline
\end{tabular}


Table 13. (continued).

\begin{tabular}{|c|c|}
\hline \multicolumn{2}{|c|}{ Facility Name: MFC-784, Zero Power Physics Reactor Material Control Building } \\
\hline Chapter IV, LLW Requirements & Facility Compliance Information \\
\hline $\begin{array}{l}\text { if the waste certification plan and procedures are } \\
\text { current and controlled in accordance with a document } \\
\text { controls program, and records related to certification } \\
\text { (e.g., certification statements, training records, } \\
\text { procurement records, characterization records, } \\
\text { container records) are generated and managed in } \\
\text { accordance with the established site program. }\end{array}$ & $\begin{array}{l}\text { the appropriate training/qualifications to disposition } \\
\text { waste to NNSS. }\end{array}$ \\
\hline $\begin{array}{l}\text { (1) Certification Program. The waste certification } \\
\text { program shall designate the officials who have the } \\
\text { authority to certify and release waste for shipment; and } \\
\text { specify what documentation is required for waste } \\
\text { generation, characterization, shipment, and } \\
\text { certification. The program shall provide requirements } \\
\text { for auditability, retrievability, and storage of required } \\
\text { documentation and specify the records retention period. }\end{array}$ & See J. above. \\
\hline $\begin{array}{l}\text { From DOE G } 435.1-1 \text { Chapter IV: Compliance with } \\
\text { this requirement is demonstrated by a program or } \\
\text { procedure for record keeping and records showing that } \\
\text { low-level waste is certified as having met the waste } \\
\text { acceptance criteria of the facility to which it was } \\
\text { transferred and that the certification statement is } \\
\text { supported by additional records regarding the waste } \\
\text { source, characterization, and container. }\end{array}$ & \\
\hline $\begin{array}{l}\text { (2) Certification before Transfer. Low-level waste shall } \\
\text { be certified as meeting waste acceptance requirements } \\
\text { before it is transferred to the facility receiving the } \\
\text { waste. }\end{array}$ & See J. above. \\
\hline $\begin{array}{l}\text { From DOE G } 435.1-1 \text { Chapter IV: Compliance with } \\
\text { this requirement is demonstrated by the presence of a } \\
\text { certification program which includes procedures } \\
\text { requiring a signed certification statement prior to the } \\
\text { release of waste for transfer, and by dated records } \\
\text { showing that waste was certified before being } \\
\text { transferred. }\end{array}$ & \\
\hline $\begin{array}{l}\text { (3) Maintaining Certification. Low-level waste that has } \\
\text { been certified as meeting the waste acceptance } \\
\text { requirements for transfer to a storage, treatment, or } \\
\text { disposal facility shall be managed in a manner that } \\
\text { maintains its certification status. }\end{array}$ & See J. above. \\
\hline $\begin{array}{l}\text { From DOE G } 435.1-1 \text { Chapter IV: Compliance with } \\
\text { this requirement is demonstrated by a program or } \\
\text { procedure reflecting this requirement is present and site } \\
\text { personnel are able to show that the storage of low-level } \\
\text { waste containers is in a facility or manner where the } \\
\text { containers would not be damaged by normal weather } \\
\text { events, and cannot be accessed by unauthorized } \\
\text { personnel. Further, each container can be traced to its } \\
\text { certification and the information supporting that } \\
\text { certification. }\end{array}$ & \\
\hline
\end{tabular}


Table 13. (continued).

\begin{tabular}{|c|c|}
\hline \multicolumn{2}{|c|}{ Facility Name: MFC-784, Zero Power Physics Reactor Material Control Building } \\
\hline Chapter IV, LLW Requirements & Facility Compliance Information \\
\hline $\begin{array}{l}\text { K. Waste Transfer. A documented process shall be } \\
\text { established and implemented for transferring } \\
\text { responsibility for management of low-level waste and } \\
\text { for ensuring availability of relevant data. The following } \\
\text { requirements are in addition to those in Chapter I of } \\
\text { this Manual. }\end{array}$ & $\begin{array}{l}\text { MCP-17000 specifies the requirements for preparing } \\
\text { an IWTS profile that captures waste certification data, } \\
\text { transfer information, and associated authorizations. } \\
\text { MCP-17500 provides the WGS waste certification } \\
\text { program for LLW to be shipped to NNSS. }\end{array}$ \\
\hline $\begin{array}{l}\text { From DOE G 435.1-1 Chapter IV: Compliance with } \\
\text { this requirement is demonstrated if facilities have } \\
\text { procedures for the receipt of waste and the transfer of } \\
\text { waste, as appropriate, which address the acquisition of } \\
\text { waste and container data and the transfer of ownership, } \\
\text { respectively. Further evidence of acceptable } \\
\text { performance is facility records showing that data on the } \\
\text { waste containers is available and accurate, and that } \\
\text { documented transfer of responsibility occurs. }\end{array}$ & $\begin{array}{l}\text { TSD-OI-004 specifies requirements and provides } \\
\text { instructions for accepting LLW and mixed LLW at the } \\
\text { MFC treatment, storage, and disposal facilities. }\end{array}$ \\
\hline $\begin{array}{l}\text { (1) Authorization. Low-level waste shall not be } \\
\text { transferred to a storage, treatment, or disposal facility } \\
\text { until personnel responsible for the facility receiving the } \\
\text { waste authorize the transfer. } \\
\text { From DOE G } 435.1-1 \text { Chapter IV: Compliance with } \\
\text { this requirement is demonstrated by sites having } \\
\text { procedures that require a confirmation of authorization } \\
\text { before releasing waste for transfer, and records } \\
\text { showing that transfers are made in accordance with } \\
\text { written authorizations. }\end{array}$ & See K. above. \\
\hline $\begin{array}{l}\text { (2) Data. Waste characterization data, container } \\
\text { information, and generation, storage, treatment, and } \\
\text { transportation information for low-level waste shall be } \\
\text { transferred with or be traceable to the waste. } \\
\text { From DOE G } 435.1-1 \text { Chapter IV: Compliance with } \\
\text { this requirement is demonstrated if there are procedures } \\
\text { requiring that characterization and container data be } \\
\text { provided and maintained for each low-level waste } \\
\text { transfer and documented records of transfers show that } \\
\text { the information is being provided. }\end{array}$ & See K. above. \\
\hline $\begin{array}{l}\text { L. Packaging and Transportation. The following } \\
\text { requirements are in addition to those in Chapter I of } \\
\text { this Manual [DOE M 435.1-1 §I.1.E(11)]. }\end{array}$ & $\begin{array}{l}\text { DOE Manual 435.1-1 §I.1.E(11) applies to field } \\
\text { element managers. }\end{array}$ \\
\hline $\begin{array}{l}\text { (1) Packaging. If containers are used: } \\
\text { From DOE G } 435.1-1 \text { Chapter IV: Compliance with the } \\
\text { packaging requirement is demonstrated by: (1) } \\
\text { procedures which document proper packaging } \\
\text { protocols; and (2) no trends of routine repackaging of } \\
\text { low-level waste that is packaged after issuance of DOE } \\
\text { O } 435.1 \text {. Successful performance of this requirement is } \\
\text { also demonstrated by a record of containers for which } \\
\text { failure has not routinely occurred under management } \\
\text { conditions. It is recognized that there may be failed }\end{array}$ & MCP-17000 $\S 4$ addresses packaging requirements. \\
\hline
\end{tabular}


Table 13. (continued).

\begin{tabular}{|c|c|}
\hline \multicolumn{2}{|c|}{ Facility Name: MFC-784, Zero Power Physics Reactor Material Control Building } \\
\hline Chapter IV, LLW Requirements & Facility Compliance Information \\
\hline $\begin{array}{l}\text { containers for waste previously placed in storage. For } \\
\text { those containers, the goal is to only have to repackage } \\
\text { the waste one time after it is retrieved and } \\
\text { characterized. Further, acceptable performance is } \\
\text { demonstrated by containers of waste having marking } \\
\text { and labeling that allows correlation with waste } \\
\text { characterization data and container information.) }\end{array}$ & \\
\hline $\begin{array}{l}\text { (a) Low-level waste shall be packaged in a manner that } \\
\text { provides containment and protection for the duration of } \\
\text { the anticipated storage period and until disposal is } \\
\text { achieved or until the waste has been removed from the } \\
\text { container. }\end{array}$ & See (1) above. \\
\hline $\begin{array}{l}\text { (b) When waste is packaged, vents or other measures } \\
\text { shall be provided if the potential exists for pressurizing } \\
\text { or generating flammable or explosive concentrations of } \\
\text { gases within the waste container. }\end{array}$ & See (1) above. \\
\hline $\begin{array}{l}\text { (c) Containers of low-level waste shall be marked such } \\
\text { that their contents can be identified. }\end{array}$ & See (1) above. \\
\hline $\begin{array}{l}\text { (2) Transportation. To the extent practical, the volume } \\
\text { of waste and number of low-level waste shipments } \\
\text { shall be minimized. }\end{array}$ & $\begin{array}{l}\text { NA; waste is not shipped to an offsite facility for final } \\
\text { disposition from this facility. }\end{array}$ \\
\hline $\begin{array}{l}\text { From DOE G 435.1-1 Chapter IV: Compliance with } \\
\text { this requirement can be demonstrated by a combination } \\
\text { of site procedures directing the efficient use of waste } \\
\text { container capacity and documentation showing that } \\
\text { low-level waste shipments are systematically planned } \\
\text { and optimized to the extent practical. }\end{array}$ & \\
\hline $\begin{array}{l}\text { M. Site Evaluation and Facility Design. The following } \\
\text { requirements are in addition to those in Chapter I of } \\
\text { this Manual. }\end{array}$ & $\begin{array}{l}\text { NA; this requirement addresses new radioactive waste } \\
\text { management facilities. }\end{array}$ \\
\hline $\begin{array}{l}\text { (1) Site Evaluation. Proposed locations for low-level } \\
\text { waste facilities shall be evaluated to identify relevant } \\
\text { features that should be avoided or must be considered } \\
\text { in facility design and analyses. }\end{array}$ & See M. above. \\
\hline $\begin{array}{l}\text { (a) Each site proposed for a new low-level waste } \\
\text { facility or expansion of an existing low-level waste } \\
\text { facility shall be evaluated considering environmental } \\
\text { characteristics, geotechnical characteristics, and human } \\
\text { activities, including for a low-level waste disposal } \\
\text { facility, the capability of the site to demonstrate, at a } \\
\text { minimum, whether it is: }\end{array}$ & See M. above. \\
\hline $\begin{array}{l}1 \text { Located to accommodate the projected volume of } \\
\text { waste to be received; }\end{array}$ & See M. above. \\
\hline $\begin{array}{l}2 \text { Located in a flood plain, a tectonically active area, or } \\
\text { in the zone of water table fluctuation; and }\end{array}$ & See M. above. \\
\hline 3 Located where radionuclide migration pathways are & See M. above. \\
\hline
\end{tabular}


Table 13. (continued).

\begin{tabular}{|c|c|}
\hline \multicolumn{2}{|c|}{ Facility Name: MFC-784, Zero Power Physics Reactor Material Control Building } \\
\hline Chapter IV, LLW Requirements & Facility Compliance Information \\
\hline $\begin{array}{l}\text { predictable and erosion and surface runoff can be } \\
\text { controlled. }\end{array}$ & \\
\hline $\begin{array}{l}\text { (b) Proposed sites with environmental characteristics, } \\
\text { geotechnical characteristics, and human activities for } \\
\text { which adequate protection cannot be provided through } \\
\text { facility design shall be deemed unsuitable for the } \\
\text { location of the facility. }\end{array}$ & See M. above. \\
\hline $\begin{array}{l}\text { (c) Low-level waste disposal facilities shall be sited to } \\
\text { achieve long-term stability and to minimize, to the } \\
\text { extent practical, the need for active maintenance } \\
\text { following final closure. }\end{array}$ & See M. above. \\
\hline $\begin{array}{l}\text { (2) Low-Level Waste Treatment and Storage Facility } \\
\text { Design. The following facility requirements and } \\
\text { general design criteria, at a minimum, apply: }\end{array}$ & See M. above. \\
\hline $\begin{array}{l}\text { (a) Confinement. Low-level waste systems and } \\
\text { components shall be designed to maintain waste } \\
\text { confinement. }\end{array}$ & See M. above. \\
\hline (b) Ventilation. & See M. above. \\
\hline $\begin{array}{l}1 \text { Design of low-level waste treatment and storage } \\
\text { facilities shall include ventilation, if applicable, } \\
\text { through an appropriate filtration system to maintain the } \\
\text { release of radioactive material in airborne effluents } \\
\text { within the requirements and guidelines specified in } \\
\text { applicable requirements. }\end{array}$ & See M. above. \\
\hline $\begin{array}{l}2 \text { When conditions exist for generating gases in } \\
\text { flammable or explosive concentrations, ventilation } \\
\text { systems or other measures shall be provided to keep the } \\
\text { gases in a non-flammable and nonexplosive condition. } \\
\text { Where concentrations of explosive or flammable gases } \\
\text { are expected to approach the lower flammability limit, } \\
\text { measures shall be taken to prevent deflagration or } \\
\text { detonation. }\end{array}$ & See M. above. \\
\hline $\begin{array}{l}\text { (c) Consideration of Decontamination and } \\
\text { Decommissioning. Areas in new and modifications to } \\
\text { existing low-level waste management facilities that are } \\
\text { subject to contamination with radioactive or other } \\
\text { hazardous materials shall be designed to facilitate } \\
\text { decontamination. For such facilities a proposed } \\
\text { decommissioning method or a conversion method } \\
\text { leading to reuse shall be described. }\end{array}$ & See M. above. \\
\hline $\begin{array}{l}\text { (d) Instrumentation and Control Systems. Engineering } \\
\text { controls shall be incorporated in the design and } \\
\text { engineering of low-level waste treatment and storage } \\
\text { facilities to provide volume inventory data and to } \\
\text { prevent spills, leaks, and overflows from tanks or } \\
\text { confinement systems. }\end{array}$ & See M. above. \\
\hline (e) Monitoring. Monitoring and/or leak detection & See M. above. \\
\hline
\end{tabular}


Table 13. (continued).

\begin{tabular}{|c|c|}
\hline \multicolumn{2}{|c|}{ Facility Name: MFC-784, Zero Power Physics Reactor Material Control Building } \\
\hline Chapter IV, LLW Requirements & Facility Compliance Information \\
\hline $\begin{array}{l}\text { capabilities shall be incorporated in the design and } \\
\text { engineering of low-level waste treatment and storage } \\
\text { facilities to provide rapid identification of failed } \\
\text { confinement and/or other abnormal conditions. }\end{array}$ & \\
\hline $\begin{array}{l}\text { (3) Low-Level Waste Disposal Facility Design. The } \\
\text { following facility requirements and general design } \\
\text { criteria, at a minimum, apply: }\end{array}$ & See M. above. \\
\hline $\begin{array}{l}\text { (a) Confinement. Low-level waste systems and } \\
\text { components shall be designed to maintain waste } \\
\text { confinement. }\end{array}$ & See M. above. \\
\hline \multicolumn{2}{|l|}{ (b) Ventilation. } \\
\hline $\begin{array}{l}1 \text { Design of low-level waste disposal facilities shall } \\
\text { include ventilation, if applicable, through an } \\
\text { appropriate filtration system to maintain the release of } \\
\text { radioactive material in airborne effluents within the } \\
\text { requirements and guidelines specified in applicable } \\
\text { requirements. }\end{array}$ & See M. above. \\
\hline $\begin{array}{l}2 \text { When conditions exist for generating gases in } \\
\text { flammable or explosive concentrations, ventilation } \\
\text { systems or other measures shall be provided to keep the } \\
\text { gases in a nonflammable and non-explosive condition. } \\
\text { Where concentrations of explosive or flammable gases } \\
\text { are expected to approach the lower flammability limit, } \\
\text { measures shall be taken to prevent deflagration or } \\
\text { detonation. }\end{array}$ & See M. above. \\
\hline $\begin{array}{l}\text { (c) Stability. Low-level waste disposal facilities shall } \\
\text { be designed to achieve long-term stability and to } \\
\text { minimize to the extent practical, the need for active } \\
\text { maintenance following final closure. }\end{array}$ & See M. above. \\
\hline $\begin{array}{l}\text { (d) Control of Water. Low-level waste disposal } \\
\text { facilities shall be designed to minimize to the extent } \\
\text { practical, the contact of waste with water during and } \\
\text { after disposal. }\end{array}$ & See M. above. \\
\hline $\begin{array}{l}\text { N. Storage and Staging. The following requirements } \\
\text { are in addition to those in Chapter I of this Manual } \\
\text { [DOE M 435.1-1 §I.2.F(13)]. }\end{array}$ & $\begin{array}{l}\text { DOE Manual 435.1-1 §I.2.F(13) applies to field } \\
\text { element managers. }\end{array}$ \\
\hline $\begin{array}{l}\text { (1) Storage Prohibitions. Low-level waste in storage } \\
\text { shall not be readily capable of detonation, explosive } \\
\text { decomposition, reaction at anticipated pressures and } \\
\text { temperatures, or explosive reaction with water. Prior to } \\
\text { storage, pyrophoric materials shall be treated, prepared, } \\
\text { and packaged to be nonflammable. }\end{array}$ & $\begin{array}{l}\text { NA; this facility does not store LLW. See N. (7) below } \\
\text { for staging requirements. }\end{array}$ \\
\hline $\begin{array}{l}\text { From DOE G } 435.1-1 \text { Chapter IV: Compliance with } \\
\text { this requirement is demonstrated by having waste } \\
\text { acceptance requirements which prohibit low-level }\end{array}$ & \\
\hline
\end{tabular}


Table 13. (continued).

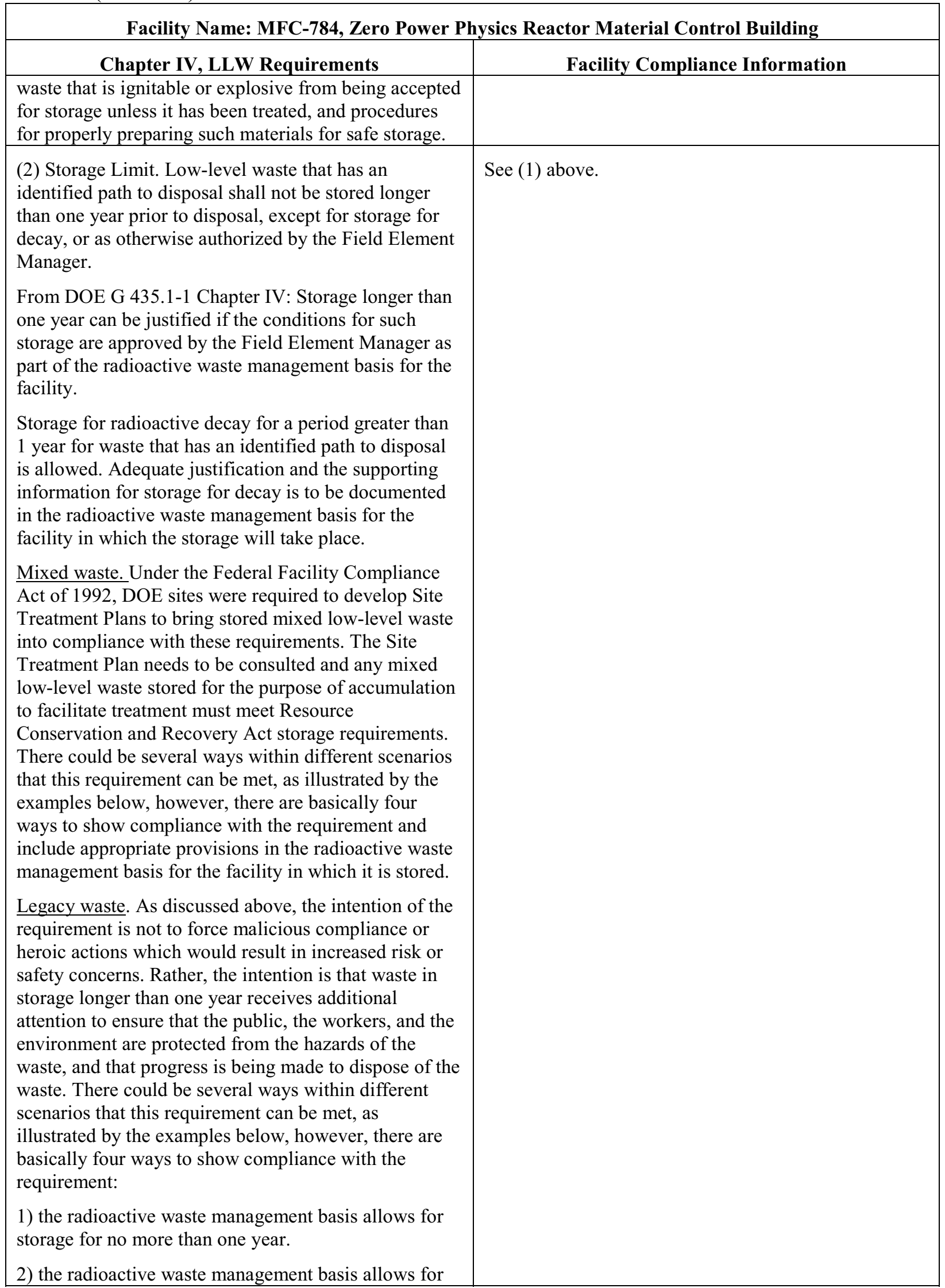


Table 13. (continued).

\begin{tabular}{|c|c|}
\hline \multicolumn{2}{|c|}{ Facility Name: MFC-784, Zero Power Physics Reactor Material Control Building } \\
\hline Chapter IV, LLW Requirements & Facility Compliance Information \\
\hline $\begin{array}{l}\text { storage for no more than one year, or for storage for } \\
\text { decay only for periods greater than a year, which are } \\
\text { specified on a radionuclide basis. }\end{array}$ & \\
\hline $\begin{array}{l}\text { 3) the radioactive waste management basis allows for } \\
\text { storage for more than one year, up to a specified period } \\
\text { of time based on a documented technical evaluation } \\
\text { that the waste can be stored in a manner that does not } \\
\text { cause changes to the waste or waste packages that is } \\
\text { detrimental to the safe storage of the waste, the final } \\
\text { disposal of the waste or to meeting the disposal } \\
\text { performance objectives. }\end{array}$ & \\
\hline $\begin{array}{l}\text { 4) the radioactive waste management basis allows for } \\
\text { storage for decay (with specifics) and for storage for } \\
\text { more than one year for other low-level waste, up to a } \\
\text { specified period of time based on a documented } \\
\text { technical evaluation that the waste can be stored in a } \\
\text { manner that does not cause changes to the waste or } \\
\text { waste packages that is detrimental to the safe storage of } \\
\text { the waste, the final disposal of the waste or to meeting } \\
\text { the disposal performance objectives. }\end{array}$ & \\
\hline $\begin{array}{l}\text { Compliance with this requirement is demonstrated by } \\
\text { the existence of a radioactive waste management basis } \\
\text { for the storage facility approved by the Field Element } \\
\text { Manager that includes the time frames that waste are } \\
\text { allowed to be stored, the necessary justifications for } \\
\text { storage for decay, and the necessary technical } \\
\text { evaluations if storage is to extend significantly beyond } \\
\text { the one-year time frame. }\end{array}$ & \\
\hline $\begin{array}{l}\text { (3) Storage Integrity. Low-level waste shall be stored in } \\
\text { a location and manner that protects the integrity of } \\
\text { waste for the expected time of storage and minimizes } \\
\text { worker exposure. }\end{array}$ & See (1) above. \\
\hline $\begin{array}{l}\text { However, in making a decision to use a facility for } \\
\text { storage and in developing a radioactive waste } \\
\text { management basis for the activity, particular attention } \\
\text { to protection of workers is needed. }\end{array}$ & \\
\hline $\begin{array}{l}\text { From DOE G 435.1-1 Chapter IV: Compliance with } \\
\text { this requirement is demonstrated if sites have storage } \\
\text { capabilities for low-level waste that provide protection } \\
\text { to waste containers so that their integrity will not be } \\
\text { damaged through physical or chemical (corrosion) } \\
\text { processes and that keep personnel from spending } \\
\text { extended periods of time in the areas where low-level } \\
\text { waste is stored. }\end{array}$ & \\
\hline (4) Waste Characterization for Storage. & See (1) above. \\
\hline $\begin{array}{l}\text { (a) Low-level waste that does not have an identified } \\
\text { path to disposal shall be characterized as necessary to } \\
\text { meet the data quality objectives and minimum }\end{array}$ & See (1) above. \\
\hline
\end{tabular}


Table 13. (continued).

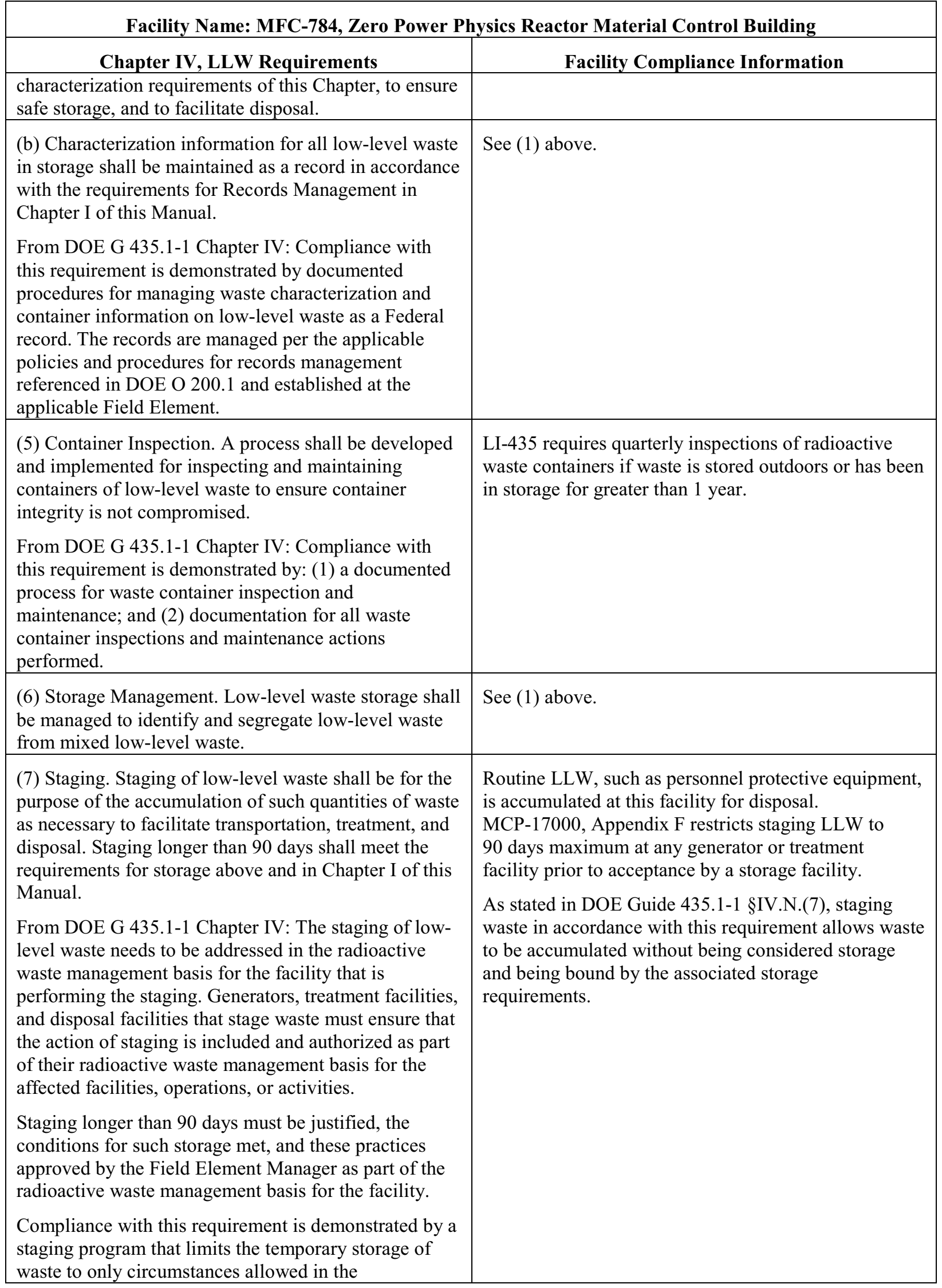


Table 13. (continued).

\begin{tabular}{|c|c|}
\hline \multicolumn{2}{|c|}{ Facility Name: MFC-784, Zero Power Physics Reactor Material Control Building } \\
\hline Chapter IV, LLW Requirements & Facility Compliance Information \\
\hline $\begin{array}{l}\text { requirement, including justifications for any staging } \\
\text { that exceeds the } 90 \text {-day period, which is documented in } \\
\text { the radioactive waste management basis for the facility. }\end{array}$ & \\
\hline $\begin{array}{l}\text { O. Treatment. Low-level waste treatment to provide } \\
\text { more stable waste forms and to improve the long-term } \\
\text { performance of a low-level waste disposal facility shall } \\
\text { be implemented as necessary to meet the performance } \\
\text { objectives of the disposal facility. }\end{array}$ & NA; this facility does not treat LLW. \\
\hline $\begin{array}{l}\text { From DOE G } 435.1-1 \text { Chapter IV: Compliance with } \\
\text { this requirement is demonstrated when a treatment } \\
\text { facility or process ensures that treated waste will meet } \\
\text { the minimum waste form requirements of DOE M } \\
435.1 \text { and meet additional disposal facility-specific } \\
\text { waste acceptance requirements for additional stability } \\
\text { or long-term performance of facilities that will receive } \\
\text { the treated waste. }\end{array}$ & \\
\hline $\begin{array}{l}\text { P. Disposal. Low-level waste disposal facilities shall } \\
\text { meet the following requirements. }\end{array}$ & NA; this facility does not dispose of LLW. \\
\hline $\begin{array}{l}\text { (1) Performance Objectives. Low-level waste disposal } \\
\text { facilities shall be sited, designed, operated, maintained, } \\
\text { and closed so that a reasonable expectation exists that } \\
\text { the following performance objectives will be met for } \\
\text { waste disposed of after September } 26,1988 \text { : }\end{array}$ & See P. above. \\
\hline $\begin{array}{l}\text { (a) Dose to representative members of the public shall } \\
\text { not exceed } 25 \mathrm{mrem}(0.25 \mathrm{mSv}) \text { in a year total effective } \\
\text { dose equivalent from all exposure pathways, excluding } \\
\text { the dose from radon and its progeny in air. }\end{array}$ & See P. above. \\
\hline $\begin{array}{l}\text { (b) Dose to representative members of the public via } \\
\text { the air pathway shall not exceed } 10 \text { mrem }(0.10 \mathrm{mSv}) \\
\text { in a year total effective dose equivalent, excluding the } \\
\text { dose from radon and its progeny. }\end{array}$ & See P. above. \\
\hline $\begin{array}{l}\text { (c) Release of radon shall be less than an average flux } \\
\text { of } 20 \mathrm{pCi} / \mathrm{m}^{2} / \mathrm{s}\left(0.74 \mathrm{~Bq} / \mathrm{m}^{2} / \mathrm{s}\right) \text { at the surface of the } \\
\text { disposal facility. Alternatively, a limit of } 0.5 \mathrm{pCi} / 1 \\
(0.0185 \mathrm{~Bq} / \mathrm{l}) \text { of air may be applied at the boundary of } \\
\text { the facility. }\end{array}$ & See P. above. \\
\hline $\begin{array}{l}\text { (2) Performance Assessment. A site-specific } \\
\text { radiological performance assessment shall be prepared } \\
\text { and maintained for DOE low-level waste disposed of } \\
\text { after September 26, } 1988 \text {. The performance assessment } \\
\text { shall include calculations for a } 1,000 \text { year period after } \\
\text { closure of potential doses to representative future } \\
\text { members of the public and potential releases from the } \\
\text { facility to provide a reasonable expectation that the } \\
\text { performance objectives identified in this Chapter are } \\
\text { not exceeded as a result of operation and closure of the } \\
\text { facility. }\end{array}$ & See P. above. \\
\hline
\end{tabular}


Table 13. (continued).

\begin{tabular}{|c|c|}
\hline \multicolumn{2}{|c|}{ Facility Name: MFC-784, Zero Power Physics Reactor Material Control Building } \\
\hline Chapter IV, LLW Requirements & Facility Compliance Information \\
\hline $\begin{array}{l}\text { (a) Analyses performed to demonstrate compliance } \\
\text { with the performance objectives in this Chapter, and to } \\
\text { establish limits on concentrations of radionuclides for } \\
\text { disposal based on the performance measures for } \\
\text { inadvertent intruders in this Chapter shall be based on } \\
\text { reasonable activities in the critical group of exposed } \\
\text { individuals. Unless otherwise specified, the assumption } \\
\text { of average living habits and exposure conditions in } \\
\text { representative critical groups of individuals projected } \\
\text { to receive the highest doses is appropriate. The } \\
\text { likelihood of inadvertent intruder scenarios may be } \\
\text { considered in interpreting the results of the analyses } \\
\text { and establishing radionuclide concentrations, if } \\
\text { adequate justification is provided. }\end{array}$ & See P. above. \\
\hline $\begin{array}{l}\text { (b) The point of compliance shall correspond to the } \\
\text { point of highest projected dose or concentration beyond } \\
\text { a } 100 \text { meter buffer zone surrounding the disposed } \\
\text { waste. A larger or smaller buffer zone may be used if } \\
\text { adequate justification is provided. }\end{array}$ & See P. above. \\
\hline $\begin{array}{l}\text { (c) Performance assessments shall address reasonably } \\
\text { foreseeable natural processes that might disrupt barriers } \\
\text { against release and transport of radioactive materials. }\end{array}$ & See P. above. \\
\hline $\begin{array}{l}\text { (d) Performance assessments shall use DOE-approved } \\
\text { dose coefficients (dose conversion factors) for internal } \\
\text { and external exposure of reference adults. }\end{array}$ & See P. above. \\
\hline $\begin{array}{l}\text { (e) The performance assessment shall include a } \\
\text { sensitivity/uncertainty analysis. }\end{array}$ & See P. above. \\
\hline $\begin{array}{l}\text { (f) Performance assessments shall include a } \\
\text { demonstration that projected releases of radionuclides } \\
\text { to the environment shall be maintained as low as } \\
\text { reasonably achievable (ALARA). }\end{array}$ & See P. above. \\
\hline $\begin{array}{l}\text { (g) For purposes of establishing limits on radionuclides } \\
\text { that may be disposed of near-surface, the performance } \\
\text { assessment shall include an assessment of impacts to } \\
\text { water resources. }\end{array}$ & See P. above. \\
\hline $\begin{array}{l}\text { (h) For purposes of establishing limits on the } \\
\text { concentration of radionuclides that may be disposed of } \\
\text { near-surface, the performance assessment shall include } \\
\text { an assessment of impacts calculated for a hypothetical } \\
\text { person assumed to inadvertently intrude for a } \\
\text { temporary period into the low-level waste disposal } \\
\text { facility. For intruder analyses, institutional controls } \\
\text { shall be assumed to be effective in deterring intrusion } \\
\text { for at least } 100 \text { years following closure. The intruder } \\
\text { analyses shall use performance measures for chronic } \\
\text { and acute exposure scenarios, respectively, of } 100 \\
\text { mrem ( } 1 \text { mSv) in a year and } 500 \text { mrem ( } 5 \mathrm{mSv}) \text { total } \\
\text { effective dose equivalent excluding radon in air. }\end{array}$ & See P. above. \\
\hline
\end{tabular}


Table 13. (continued).

\begin{tabular}{|c|c|}
\hline \multicolumn{2}{|c|}{ Facility Name: MFC-784, Zero Power Physics Reactor Material Control Building } \\
\hline Chapter IV, LLW Requirements & Facility Compliance Information \\
\hline $\begin{array}{l}\text { (3) Composite Analysis. For disposal facilities which } \\
\text { received waste after September 26, } 1988 \text {, a site-specific } \\
\text { radiological composite analysis shall be prepared and } \\
\text { maintained that accounts for all sources of radioactive } \\
\text { material that may be left at the DOE site and may } \\
\text { interact with the low- level waste disposal facility, } \\
\text { contributing to the dose projected to a hypothetical } \\
\text { member of the public from the existing or future } \\
\text { disposal facilities. Performance measures shall be } \\
\text { consistent with DOE requirements for protection of the } \\
\text { public and environment and evaluated for a } 1,000 \text { year } \\
\text { period following disposal facility closure. The } \\
\text { composite analysis results shall be used for planning, } \\
\text { radiation protection activities, and future use } \\
\text { commitments to minimize the likelihood that current } \\
\text { low- level waste disposal activities will result in the } \\
\text { need for future corrective or remedial actions to } \\
\text { adequately protect the public and the environment. }\end{array}$ & See P. above. \\
\hline $\begin{array}{l}\text { (4) Performance Assessment and Composite Analysis } \\
\text { Maintenance. The performance assessment and } \\
\text { composite analysis shall be maintained to evaluate } \\
\text { changes that could affect the performance, design, and } \\
\text { operating bases for the facility. Performance } \\
\text { assessment and composite analysis maintenance shall } \\
\text { include the conduct of research, field studies, and } \\
\text { monitoring needed to address uncertainties or gaps in } \\
\text { existing data. The performance assessment shall be } \\
\text { updated to support the final facility closure. Additional } \\
\text { iterations of the performance assessment and composite } \\
\text { analysis shall be conducted as necessary during the } \\
\text { post-closure period. }\end{array}$ & See P. above. \\
\hline $\begin{array}{l}\text { (a) Performance assessments and composite analyses } \\
\text { shall be reviewed and revised when changes in waste } \\
\text { forms or containers, radionuclide inventories, facility } \\
\text { design and operations, closure concepts, or the } \\
\text { improved understanding of the performance of the } \\
\text { waste disposal facility in combination with the features } \\
\text { of the site on which it is located alter the conclusions or } \\
\text { the conceptual model(s) of the existing performance } \\
\text { assessment or composite analysis. }\end{array}$ & See P. above. \\
\hline $\begin{array}{l}\text { (b) A determination of the continued adequacy of the } \\
\text { performance assessment and composite analysis shall } \\
\text { be made on an annual basis, and shall consider the } \\
\text { results of data collection and analysis from research, } \\
\text { field studies, and monitoring. }\end{array}$ & See P. above. \\
\hline $\begin{array}{l}\text { (c) Annual summaries of low-level waste disposal } \\
\text { operations shall be prepared with respect to the } \\
\text { conclusions and recommendations of the performance } \\
\text { assessment and composite analysis and a determination } \\
\text { of the need to revise the performance assessment or }\end{array}$ & See P. above. \\
\hline
\end{tabular}


Table 13. (continued).

\begin{tabular}{|c|c|}
\hline \multicolumn{2}{|c|}{ Facility Name: MFC-784, Zero Power Physics Reactor Material Control Building } \\
\hline Chapter IV, LLW Requirements & Facility Compliance Information \\
\hline composite analysis. & \\
\hline $\begin{array}{l}\text { (5) Disposal Authorization. A disposal authorization } \\
\text { statement shall be obtained prior to construction of a } \\
\text { new low-level waste disposal facility. Field Elements } \\
\text { with existing low-level waste disposal facilities shall } \\
\text { obtain a disposal authorization statement in accordance } \\
\text { with the schedule in the Complex-Wide Low-Level } \\
\text { Waste Management Program Plan. The disposal } \\
\text { authorization statement shall be issued based on a } \\
\text { review of the facility's performance assessment, } \\
\text { composite analysis, performance assessment and } \\
\text { composite analysis maintenance, preliminary closure } \\
\text { plan, and preliminary monitoring plan. The disposal } \\
\text { authorization statement shall specify the limits and } \\
\text { conditions on construction, design, operations, and } \\
\text { closure of the low-level waste facility based on these } \\
\text { reviews. A disposal authorization statement is a part of } \\
\text { the radioactive waste management basis for a disposal } \\
\text { facility. Failure to obtain a disposal authorization } \\
\text { statement by the implementation date of this Order } \\
\text { shall result in shutdown of the disposal facility. }\end{array}$ & See P. above. \\
\hline $\begin{array}{l}\text { (6) Disposal Facility Operations. The disposal facility } \\
\text { design and operation must be consistent with the } \\
\text { disposal facility closure plan and lead to disposal } \\
\text { facility closure that provides a reasonable expectation } \\
\text { that performance objectives will be met. Low-level } \\
\text { waste shall be disposed in such a manner that achieves } \\
\text { the performance objectives stated in this Chapter, } \\
\text { consistent with the disposal facility radiological } \\
\text { performance assessment. Additional requirements } \\
\text { include: }\end{array}$ & See P. above. \\
\hline $\begin{array}{l}\text { (a) Operating procedures shall be developed and } \\
\text { implemented for low-level waste disposal facilities that } \\
\text { protect the public, workers, and the environment; } \\
\text { ensure the security of the facility; minimize subsidence } \\
\text { during and after waste emplacement; achieve long-term } \\
\text { stability and minimize the need for long-term active } \\
\text { maintenance; and meet the requirements of the } \\
\text { closure/post-closure plan. }\end{array}$ & See P. above. \\
\hline $\begin{array}{l}\text { (b) Permanent identification markers for disposal } \\
\text { excavations and monitoring wells shall be emplaced. }\end{array}$ & See P. above. \\
\hline $\begin{array}{l}\text { (c) Low-level waste placement into disposal units shall } \\
\text { minimize voids between waste containers. Voids within } \\
\text { disposal units shall be filled to the extent practical. } \\
\text { Uncontainerized bulk waste shall also be placed in a } \\
\text { manner that minimizes voids and subsidence. }\end{array}$ & See P. above. \\
\hline $\begin{array}{l}\text { (d) Operations are to be conducted so that active waste } \\
\text { disposal operations will not have an adverse effect on } \\
\text { any other disposal units. }\end{array}$ & See P. above. \\
\hline
\end{tabular}


Table 13. (continued).

\begin{tabular}{|c|c|}
\hline \multicolumn{2}{|c|}{ Facility Name: MFC-784, Zero Power Physics Reactor Material Control Building } \\
\hline Chapter IV, LLW Requirements & Facility Compliance Information \\
\hline $\begin{array}{l}\text { (e) Operations shall include a process for tracking and } \\
\text { documenting low-level waste placement in the facility } \\
\text { by generator source. }\end{array}$ & See P. above. \\
\hline $\begin{array}{l}\text { (7) Alternate Requirements for Low-Level Waste } \\
\text { Disposal Facility Design and Operation. Requirements } \\
\text { other than those set forth in this Section for the design } \\
\text { and operation of a low-level waste disposal facility } \\
\text { may be approved on a specific basis if a reasonable } \\
\text { expectation is demonstrated that the disposal } \\
\text { performance objectives will be met. }\end{array}$ & See P. above. \\
\hline $\begin{array}{l}\text { Q. Closure. The following requirements are in addition } \\
\text { to those in Chapter I of this Manual. }\end{array}$ & NA; this facility does not dispose of LLW. \\
\hline $\begin{array}{l}\text { (1) Disposal Facility Closure Plans. A preliminary } \\
\text { closure plan shall be developed and submitted to } \\
\text { Headquarters for review with the performance } \\
\text { assessment and composite analysis. The closure plan } \\
\text { shall be updated following issuance of the disposal } \\
\text { authorization statement to incorporate conditions } \\
\text { specified in the disposal authorization statement. } \\
\text { Closure plans shall: }\end{array}$ & See Q. above. \\
\hline $\begin{array}{l}\text { (a) Be updated as required during the operational life of } \\
\text { the facility. }\end{array}$ & See Q. above. \\
\hline $\begin{array}{l}\text { (b) Include a description of how the disposal facility } \\
\text { will be closed to achieve long-term stability and } \\
\text { minimize the need for active maintenance following } \\
\text { closure and to ensure compliance with the requirements } \\
\text { of DOE } 5400.5 \text {, Radiation Protection of the Public and } \\
\text { the Environment. }\end{array}$ & See Q. above. \\
\hline $\begin{array}{l}\text { (c) Include the total expected inventory of wastes to be } \\
\text { disposed of at the facility over the operational life of } \\
\text { the facility. }\end{array}$ & See Q. above. \\
\hline $\begin{array}{l}\text { (2) Disposal Facility Closure. Closure of a disposal } \\
\text { facility shall occur within a five-year period after it is } \\
\text { filled to capacity, or after the facility is otherwise } \\
\text { determined to be no longer needed. }\end{array}$ & See Q. above. \\
\hline $\begin{array}{l}\text { (a) Prior to facility closure, the final inventory of the } \\
\text { low-level waste disposed in the facility shall be } \\
\text { prepared and incorporated in the performance } \\
\text { assessment and composite analysis which shall be } \\
\text { updated to support the closure of the facility. }\end{array}$ & See Q. above. \\
\hline $\begin{array}{l}\text { (b) A final closure plan shall be prepared based on the } \\
\text { final inventory of waste disposed in the facility, the } \\
\text { plan implemented, and the updated performance } \\
\text { assessment and composite analysis prepared in support } \\
\text { of the facility closure. }\end{array}$ & See Q. above. \\
\hline
\end{tabular}


Table 13. (continued).

\begin{tabular}{|c|c|}
\hline \multicolumn{2}{|c|}{ Facility Name: MFC-784, Zero Power Physics Reactor Material Control Building } \\
\hline Chapter IV, LLW Requirements & Facility Compliance Information \\
\hline $\begin{array}{l}\text { (c) Institutional control measures shall be integrated } \\
\text { into land use and stewardship plans and programs, and } \\
\text { shall continue until the facility can be released pursuant } \\
\text { to DOE } 5400.5 \text {, Radiation Protection of the Public and } \\
\text { the Environment. }\end{array}$ & See Q. above. \\
\hline $\begin{array}{l}\text { (d) The location and use of the facility shall be filed } \\
\text { with the local authorities responsible for land use and } \\
\text { zoning. }\end{array}$ & See Q. above. \\
\hline $\begin{array}{l}\text { R. Monitoring. The following requirements are in } \\
\text { addition to those in Chapter I of this Manual [DOE M } \\
\text { 435.1-1 §I.1.E(7)]. }\end{array}$ & $\begin{array}{l}\text { DOE Manual 435.1-1 §I.1.E(7) applies to field element } \\
\text { managers. }\end{array}$ \\
\hline $\begin{array}{l}\text { (1) All Waste Facilities. Parameters that shall be } \\
\text { sampled or monitored, at a minimum, include: } \\
\text { temperature, pressure (for closed systems), } \\
\text { radioactivity in ventilation exhaust and liquid effluent } \\
\text { streams, and flammable or explosive mixtures of gases. } \\
\text { Facility monitoring programs shall include verification } \\
\text { that passive and active control systems have not failed. }\end{array}$ & $\begin{array}{l}\text { Monitoring requirements at INL radioactive waste } \\
\text { management facilities are tailored for the specific } \\
\text { facility to enable timely indication of developing } \\
\text { problems. Existing radiological control procedures and } \\
\text { assessments are followed/completed to monitor waste } \\
\text { facilities. } \\
\text { LRD-15001 and snecifically MCP-139 snecify }\end{array}$ \\
\hline $\begin{array}{l}\text { From DOE G 435.1-1 Chapter IV: The minimum } \\
\text { parameters specified in the requirement were selected } \\
\text { based on their potential significance for anticipating } \\
\text { and identifying undesirable conditions at low-level } \\
\text { waste management facilities. Each facility's radioactive } \\
\text { waste management basis should include an evaluation } \\
\text { of the applicability and significance of the minimum } \\
\text { parameters. This evaluation also needs to consider } \\
\text { additional parameters to be sampled or monitored to } \\
\text { ensure the protection of the public health, the } \\
\text { environment, and the workers. If a minimum parameter } \\
\text { specified in the requirement is deemed to be not } \\
\text { applicable in any way to the active operation of that } \\
\text { facility, then that justification should be included in the } \\
\text { radioactive waste management basis and when } \\
\text { approved constitutes an exemption to the manual. }\end{array}$ & $\begin{array}{l}\text { methods and frequency of radiological control surveys } \\
\text { of all radiological areas. MCP-139 specifies the use of } \\
\text { Form } 441 \text {.A34. This form is referred to as the "routine } \\
\text { sheet" and is to be used by facility radiological control } \\
\text { foremen to list radiological areas that are to be } \\
\text { surveyed, the survey periods, and methods. }\end{array}$ \\
\hline $\begin{array}{l}\text { Verification activities are part of the radioactive waste } \\
\text { management basis as a condition for operation and } \\
\text { documented appropriately. }\end{array}$ & \\
\hline $\begin{array}{l}\text { Compliance with this requirement is demonstrated if } \\
\text { monitoring or sampling for the stated parameters is } \\
\text { performed for all facilities with a precision, accuracy, } \\
\text { and frequency consistent with timely identification of } \\
\text { developing problems and a justification exists in the } \\
\text { approved radioactive waste management basis for those } \\
\text { specified parameters which are not monitored or } \\
\text { sampled. }\end{array}$ & \\
\hline
\end{tabular}


Table 13. (continued).

\begin{tabular}{|l|l|}
\hline \multicolumn{2}{|c|}{ Facility Name: MFC-784, Zero Power Physics Reactor Material Control Building } \\
\hline \multicolumn{1}{|c|}{ Chapter IV, LLW Requirements } & \multicolumn{1}{|c|}{ Facility Compliance Information } \\
\hline $\begin{array}{l}\text { (2) Liquid Waste Storage Facilities. For facilities } \\
\text { storing liquid low-level waste, the following shall also } \\
\text { be monitored: liquid level and/or waste volume, and } \\
\text { significant waste chemistry parameters. }\end{array}$ & NA; this facility does not store liquid LLW. \\
\hline $\begin{array}{l}\text { (3) Disposal Facilities. A preliminary monitoring plan } \\
\text { for a low-level waste disposal facility shall be prepared } \\
\text { and submitted to Headquarters for review with the } \\
\text { performance assessment and composite analysis. The } \\
\text { monitoring plan shall be updated within one year } \\
\text { following issuance of the disposal authorization } \\
\text { statement to incorporate and implement conditions } \\
\text { specified in the disposal authorization statement. }\end{array}$ & NA; this facility does not dispose of LLW. \\
\hline $\begin{array}{l}\text { (a) The site-specific performance assessment and } \\
\text { composite analysis shall be used to determine the } \\
\text { media, locations, radionuclides, and other substances to } \\
\text { be monitored. }\end{array}$ & See (3) above. \\
\hline $\begin{array}{l}\text { (b) The environmental monitoring program shall be } \\
\text { designed to include measuring and evaluating releases, } \\
\text { migration of radionuclides, disposal unit subsidence, } \\
\text { and changes in disposal facility and disposal site } \\
\text { parameters which may affect long-term performance. }\end{array}$ & See (3) above. \\
\hline $\begin{array}{l}\text { (c) The environmental monitoring programs shall be } \\
\text { capable of detecting changing trends in performance to } \\
\text { allow application of any necessary corrective action } \\
\text { prior to exceeding the performance objectives in this } \\
\text { Chapter. }\end{array}$ & See (3) above. \\
\hline
\end{tabular}

\subsection{MFC-785, Hot Fuel Examination Facility}

1. Facility description: MFC-785, HFEF, is a hot cell complex built in the early 1970s for the preparation and examination of irradiation experiments in support of nuclear reactor development programs and process demonstrations. A wide range of remote operations and examinations may be performed in this facility with its shielded cells, support areas, and equipment. Two general types of programs are considered: (1) fuel-related programs that may include metal or oxide fuels and various test trains and test loops, and (2) waste-related programs that include characterization or processing of various waste forms. The dominant near-term program considered in the SAR is the Spent Fuel Treatment Program.

HFEF consists primarily of two adjacent shielded cells, the main cell and the decontamination (decon) cell, in a three-story building. The decon cell contains an air atmosphere. The main cell contains an argon atmosphere for work involving materials such as sodium, plutonium, and other materials that would react chemically with air. Both cells are surrounded by 4-ft thick, high-density concrete to protect workers from the high radiation levels present in the hot cells. There are 21 work stations in HFEF, all equipped with shielded windows and remote manipulators. All in-cell equipment is carefully designed to permit remote operation and maintenance. Offices, laboratories, and other personnel-related areas are located on the operating floor, which is slightly above grade level. A truck lock at the west end of the cell complex also is at this level. The service floor below 
contains the subcell tunnels and most of the building support equipment. The second floor contains additional building support equipment and offices.

A high-bay area covering the entire cell complex and serviced by a 40-ton bridge crane provides access to the tops of the cells for bottom opening casks. This area contains the repair rooms, change room, and access room, and provides space for clean equipment repair and mockup. The Waste Characterization Area also is located in the high-bay area. The Waste Characterization Chamber is an enclosure with a controlled environment that provides the primary confinement for the CH TRU waste during characterization. The characterization operations are performed through sealed glove openings or using robotic manipulators in order to protect personnel, the process, and the environment.

2. Hazard category: Hazard Category 2 nuclear facility

3. Radioactive waste managed at this facility: CH TRU waste, mixed-TRU waste, and RH TRU waste are generated and stored at this facility. CH LLW, mixed LLW, RH LLW, mixed RH-LLW, and liquid LLW are generated and staged at this facility. The mixed LLW is accumulated in an SAA for disposition.

\section{RWMB documents/programs:}

a. Safety Basis/Hazards Analysis:

- DSA-003-HFEF, "Final Safety Analysis Report for the Hot Fuel Examination Facility"

- IAG-266, "INL Authorization Agreement for the Materials and Fuels Complex (MFC) Hot Fuel Examination Facility (HFEF)"

- LST-307, "Safety Basis List for the Materials and Fuels Complex (MFC) Hot Fuel Examination Facility (HFEF)"

b. Laboratory-wide:

- Form 435.83, "Idaho National Laboratory Contact-Handled Transuranic Waste Disposition TSR Related (Checklist - Requirements - Certification)"

- Form 441.A34, "INL Radiological Control Required Surveys"

- LI-435, "Waste Management Routine Field Activities"

- LRD-15001, "Radiological Control Manual"

- LWP-8300, "Transuranic Waste Handling”

- LWP-13840, "Management of Issues, Observations, and Noteworthy Practices"

- LWP-14002, "Timeout and Stop Work Authority"

- LWP-15011, "Radioactive Material Areas and Radioactive Storage Areas"

- LWP-17000, "Waste Management"

- MCP-139, "Radiological Surveys"

- MCP-17000, "Waste Generator Services Waste Management"

- MCP-17410, "Management of Waste Storage Areas"

- MCP-17500, "Waste Generator Services Certification of Waste Shipments to the Nevada Test Site"

- PDD-17000, "Waste Management Program"

- PLN-114, "INL Emergency Plan/RCRA Contingency Plan"

- PLN-522, "Quality Assurance Program Plan for the Waste Management/Waste Certification Program" 
- PLN-8300, "Materials and Fuels Complex Contact-Handled TRU Waste Certification Program Plan"

c. Facility-specific:

- ANL-NT-192, "The Defense Programs Origin of Transuranic Waste at Argonne National Laboratory-West, H. F. McFarlane, 11/1/2001"

- HFEF-OI-1302, "Mass Tracking System"

- HFEF-OI-6601, "Waste Handling”

- HFEF-OI-6602, "Radiological Smearing for Waste Characterization"

- HFEF-OI-6801, "Hazardous Waste/Mixed Waste (HW/MW) Requirements"

- INL/EXT-10-17600, Process Knowledge Summary Report for Materials and Fuels Complex Contact-handled Transuranic Waste

- LST-337, "Approved Container/Payload List for Inter-Facility Transfer Operations at MFC"

- PER-116, "HWMA/RCRA Storage and Treatment Permit for the Materials and Fuels Complex"

- RL-OI-1, "Radioactive Liquid Waste Collection"

- RSWF-OI-003, "Material Acceptance for Storage"

- RSWF-OI-004, "Administrative Requirements/Process for Material Transfers"

- TSD-OI-004, "Waste and Material Acceptance for Storage/Treatment and Radioactive Material Inventory Control"

- TSM-OI-003, "Transfer of Hazardous Material in Non-DOT-Certified Packaging between MFC Nuclear Facilities"

TRU waste and LLW are managed at this facility. Table 14 shows the facility compliance information for DOE Manual 435.1-1 Chapter III, "Transuranic Waste Requirements," and Table 15 presents the facility compliance information for Chapter IV, "Low-level Waste Requirements."

Table 14. MFC-785, Hot Fuel Examination Facility, DOE Manual 435.1-1 transuranic waste requirements and facility compliance information.

\section{Facility Name: MFC-785, Hot Fuel Examination Facility}

\begin{tabular}{|c|c|}
\hline Chapter III, Transuranic Waste Requirements & Facility Compliance Information \\
\hline $\begin{array}{l}\text { A. Definition of Transuranic Waste. Transuranic waste } \\
\text { is radioactive waste containing more than } 100 \\
\text { nanocuries ( } 3700 \text { becquerels) of alpha-emitting } \\
\text { transuranic isotopes per gram of waste, with half-lives } \\
\text { greater than } 20 \text { years, except for: } \\
\text { (From DOE G } 435.1-1 \text { Chapter III: The determination } \\
\text { of transuranic waste should be made at the time of } \\
\text { waste certification, that is, each time the waste is } \\
\text { transferred to another person or facility.) }\end{array}$ & $\begin{array}{l}\text { This requirement proves the criteria for determining } \\
\text { which DOE radioactive waste is to be managed as TRU } \\
\text { waste in accordance with DOE Manual 435.1-1, } \\
\text { Chapter III. } \\
\text { See J. below. }\end{array}$ \\
\hline (1) High-level radioactive waste; & See A. above. \\
\hline $\begin{array}{l}\text { (2) Waste that the Secretary of Energy has determined, } \\
\text { with the concurrence of the Administrator of the } \\
\text { Environmental Protection Agency, does not need the } \\
\text { degree of isolation required by the } 40 \text { CFR Part } 191 \\
\text { disposal regulations; or }\end{array}$ & See A. above. \\
\hline
\end{tabular}


Table 14. (continued).

Facility Name: MFC-785, Hot Fuel Examination Facility

Chapter III, Transuranic Waste Requirements

(3) Waste that the Nuclear Regulatory Commission has approved for disposal on a case-by-case basis in accordance with 10 CFR Part 61.

B. Management of Specific Wastes. The following provide for management of specific wastes as transuranic waste in accordance with the requirements in this Chapter:

From DOE G 435.1-1 Chapter III:

Compliance with these requirements is demonstrated if RCRA, state-hazardous, and TSCA-regulated radioactive wastes are being managed in compliance with applicable requirements and agreements or in accordance with a consent order, and consistent with the Transuranic Waste Requirements of DOE M 435.1-1.)

(1) Mixed Transuranic Waste. Transuranic waste determined to contain both a hazardous component subject to the Resource Conservation and Recovery Act (RCRA), as amended, and a radioactive component subject to the Atomic Energy Act of 1954, as amended, shall be managed in accordance with the requirements of RCRA and DOE O 435.1, Radioactive Waste Management, and this Manual.

(2) TSCA-Regulated Waste. Transuranic waste containing polychlorinated biphenyls, asbestos, or other such regulated toxic components shall be managed in accordance with requirements derived from the Toxic Substances Control Act, as amended, DOE O 435.1, Radioactive Waste Management, and this Manual.

(3) Pre-1970 Transuranic Waste. Transuranic waste disposed of prior to implementation of the 1970 Atomic Energy Commission Immediate Action Directive regarding retrievable storage of transuranic waste is not subject to the requirements of DOE O 435.1, Radioactive Waste Management, and this Manual.

C. Complex-Wide Transuranic Waste Management Program. A complex-wide program and plan shall be developed as described under Responsibilities, 2.B and 2.D, in Chapter I of this Manual.
Facility Compliance Information

See A. above.

See (1), (2), and (3) below.

The documents cited below seem to demonstrate compliance with this requirement.

PER-116 provides RCRA regulation of the hazardous component of the waste managed at this facility.

HFEF-OI-6601 addresses management of mixed TRU waste at this facility.

HFEF-OI-6801 implements the HFEF-specific requirements of PER-116.

LWP-8300 defines the requirements and establishes the process associated with the generation, handling, characterization, and storage of $\mathrm{CH}$, mixed, and $\mathrm{RH}$ mixed TRU waste.

NA; TSCA-regulated TRU waste is not managed at this facility.

NA; pre-1970 TRU waste is not managed at this facility. 
Table 14. (continued).

Facility Name: MFC-785, Hot Fuel Examination Facility

\begin{tabular}{|c|c|}
\hline Chapter III, Transuranic Waste Requirements & Facility Compliance Information \\
\hline $\begin{array}{l}\text { From DOE G 435.1-1 Chapter III: } \\
\text { Compliance with this requirement is demonstrated by } \\
\text { the presence of a Complex-Wide Transuranic Waste } \\
\text { Management Program which includes the appropriate } \\
\text { interfaces, technical information, data inputs, and other } \\
\text { elements described in Chapter I of this Manual. }\end{array}$ & \\
\hline $\begin{array}{l}\text { D. Radioactive Waste Management Basis. Transuranic } \\
\text { waste facilities, operations, and activities shall have a } \\
\text { radioactive waste management basis consisting of } \\
\text { physical and administrative controls to ensure the } \\
\text { protection of workers, the public, and the environment. } \\
\text { The following specific waste management controls } \\
\text { shall be part of the radioactive waste management } \\
\text { basis: } \\
\text { From DOE G 435.1-1 Chapter III: } \\
\text { Compliance with this requirement is demonstrated if, } \\
\text { the radioactive waste management basis is documented } \\
\text { and signed by the Field Element manager or a designee } \\
\text { (see DOE M 435.1-1, Section I.1.A, Delegation of } \\
\text { Authority) for each transuranic waste management } \\
\text { facility, operation, or activity. Using a graded } \\
\text { approach, it may be possible to include multiple } \\
\text { activities under a single radioactive waste management } \\
\text { basis, but it should be possible to objectively identify } \\
\text { which activities are covered. Further, the radioactive } \\
\text { waste management basis includes or references the } \\
\text { controls that are established on a facility-specific basis } \\
\text { to address the unique waste management requirements } \\
\text { and circumstances for each facility, operation, and/or } \\
\text { activity.) }\end{array}$ & $\begin{array}{l}\text { The RWMB provides the regulatory framework for } \\
\text { management of radioactive waste at INL. It specifically } \\
\text { identifies facility management and implementing } \\
\text { documents for the generation, storage, treatment, and } \\
\text { disposal of radiological waste.. }\end{array}$ \\
\hline $\begin{array}{l}\text { (1) Generators. The waste certification program. } \\
\text { From DOE G 435.1-1 Chapter III: } \\
\text { For a facility that generates transuranic waste, the } \\
\text { radioactive waste management basis is to include the } \\
\text { program for certifying that waste meets the waste } \\
\text { acceptance requirements of the facility(ies) to which } \\
\text { the waste will be sent. }\end{array}$ & $\begin{array}{l}\text { See J. below for waste certification program } \\
\text { requirements. } \\
\text { The documentation cited below reflects the best } \\
\text { understanding obtainable at the time of this analysis due } \\
\text { to the pending modifications and revisions being } \\
\text { conducted on the safety basis documentation for this } \\
\text { facility. } \\
\text { DSA-003-HFEF serves as the safety basis } \\
\text { documentation for the facility and establishes it as a } \\
\text { Hazard Category } 2 \text { nuclear facility. } \\
\text { HFEF-OI-1302 specifies material accountability } \\
\text { requirements for managing special nuclear material in } \\
\text { HFEF and provides the instructions necessary to meet } \\
\text { the requirements using the Mass Tracking System } \\
\text { database. }\end{array}$ \\
\hline
\end{tabular}


Table 14. (continued).

Facility Name: MFC-785, Hot Fuel Examination Facility

Chapter III, Transuranic Waste Requirements
(2) Treatment Facilities. certification program. The
waste acceptance requirements and the waste [sic]
From DOE G 435.1-1 Chapter III:
Facilities that store or treat ransuranic waste are to
have approved waste acceptance requirements (see
DOE M 435.1-1, Section III.G) prior to the issuance of
a radioactive waste management basis. The waste
acceptance requirements will usually suffice as
documentation of the radiological, physical, and
chemical limitations on waste that can be safely
received at the facility, provided they are developed
correctly with consideration of the hazards of the
waste to be managed, and are kept up to date. Controls
on the radiological, physical and chemical limitations
need to include considerations of the potential effects
of radiolysis.
A facility that stores or treats waste is generally
expected to have a waste certification program. Waste
from these facilities will have to be certified as
meeting the waste acceptance requirements of the
facility to which it will be transferred and the facilities
have the potential for generating radioactive waste
(e.g., secondary processing streams from treatment,
monitoring and sampling, radioactive release cleanup).
Consequently, storage and treatment facilities should
also have an approved waste certification program as
part of their radioactive waste management basis.

As part of the radioactive waste management basis, site personnel should implement a system or process for tracking the waste inventory at a storage, treatment, or disposal facility.

(3) Storage Facilities. The waste acceptance requirements and the waste certification program.

From DOE G 435.1-1 Chapter III:

Facilities that store or treat transuranic waste are to have approved waste acceptance requirements (see DOE M 435.1-1, Section III.G) prior to the issuance of a radioactive waste management basis. The waste acceptance requirements will usually suffice as documentation of the radiological, physical, and chemical limitations on waste that can be safely received at the facility, provided they are developed correctly with consideration of the hazards of the waste to be managed, and are kept up to date. Controls on the radiological, physical and chemical limitations need to include considerations of the potential effects of radiolysis.
NA; waste is not treated at this facility.
See G. and J. below for waste acceptance and waste certification program requirements.

DSA-003-HFEF serves as the safety basis documentation for the facility and establishes it as a Hazard Category 2 nuclear facility.

HFEF-OI-1302 specifies material accountability requirements for managing special nuclear material in HFEF and provides the instructions necessary to meet the requirements using the Mass Tracking System database. 
Table 14. (continued).

Facility Name: MFC-785, Hot Fuel Examination Facility

Chapter III, Transuranic Waste Requirements
A facility that stores or treats waste is generally
expected to have a waste certification program. Waste
from these facilities will have to be certified as
meeting the waste acceptance requirements of the
facility to which it will be transferred and the facilities
have the potential for generating radioactive waste
(e.g., secondary processing streams from treatment,
monitoring and sampling, radioactive release cleanup).
Consequently, storage and treatment facilities should
also have an approved waste certification program as
part of their radioactive waste management basis.
As part of the radioactive waste management basis,
site personnel should implement a system or process
for tracking the waste inventory at a storage, treatment,
or disposal facility.

(4) Disposal Facilities. The performance assessment, disposal authorization statement, waste acceptance requirements, and monitoring plan.

E. Contingency Actions. The following requirements are in addition to those in Chapter I of this Manual.

From DOE G 435.1-1 Chapter III:

Compliance with these requirements is demonstrated by having adequate spare capacity and transfer equipment exists for emergency transfers of all liquid transuranic waste. In addition, the capability to perform emergency transfers is demonstrated by having waste transfer routings identified, operational procedures to direct transfers, staff trained to the procedures, and records showing that the spare capacity and transfer capability are kept in operating condition.

(1) Contingency Storage. For off-normal or emergency situations involving liquid transuranic waste storage or treatment, spare capacity with adequate capabilities shall be maintained to receive the largest volume of liquid contained in any one storage tank or treatment facility. Tanks or other facilities that are designated transuranic waste contingency storage shall be maintained in an operational condition when waste is present and shall meet the requirements of DOE O 435.1, Radioactive Waste Management, and this Manual.

(2) Transfer Equipment. Pipelines and auxiliary facilities necessary for the transfer of liquid waste to contingency storage shall be maintained in an operational condition when waste is present and shall meet the requirements of DOE O 435.1, Radioactive

NA; this facility does not generate, store, or treat liquid TRU waste.
DOE Manual 435.1-1 §I.1.E(5) addresses the sitewide emergency management system. The INL plan is provided in PLN-114.
NA; this facility is not a disposal facility.

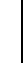
Facility Compliance Information 
Table 14. (continued).

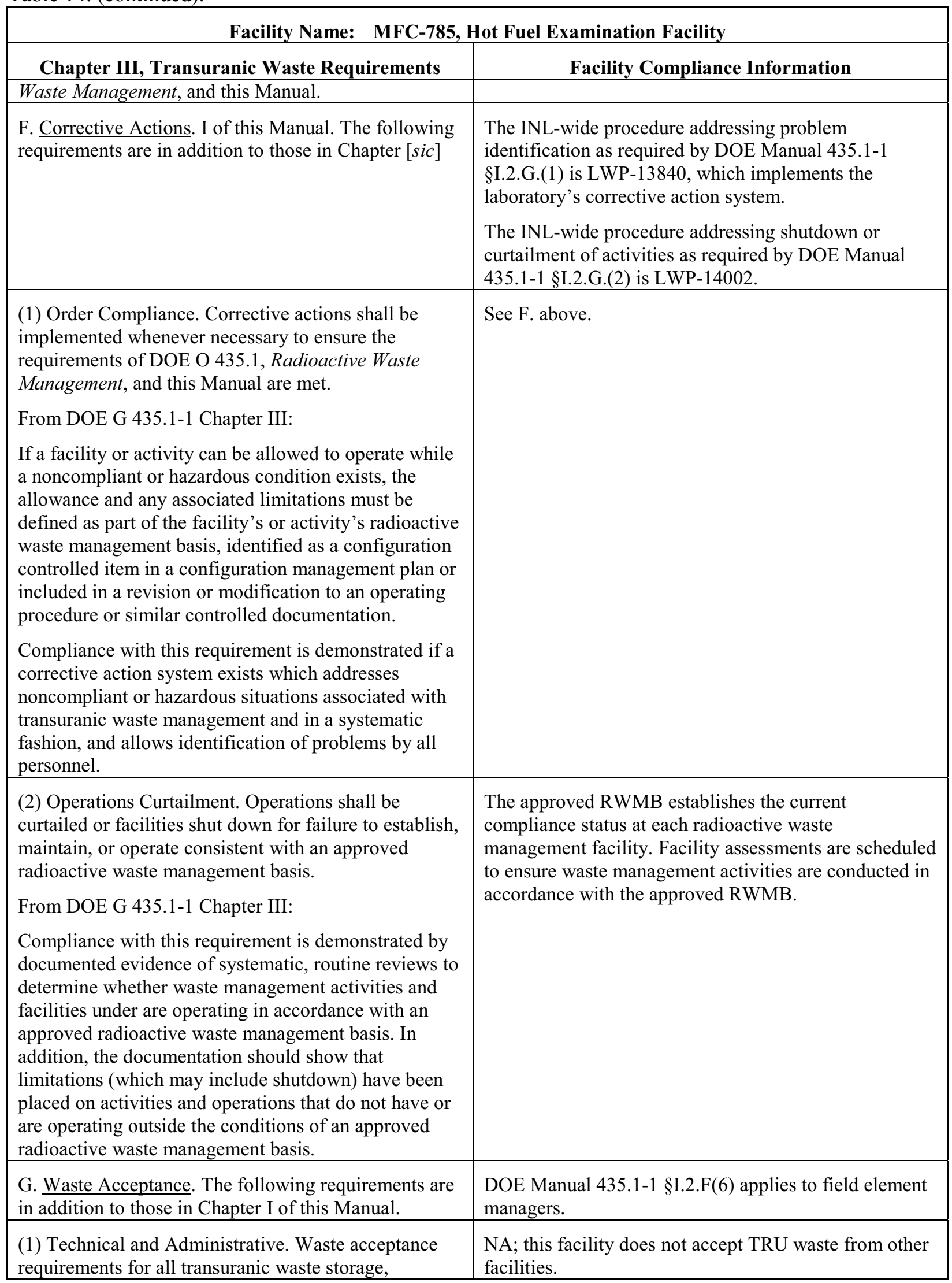


Table 14. (continued).

Facility Name: MFC-785, Hot Fuel Examination Facility

Chapter III, Transuranic Waste Requirements
treatment, or disposal facilities, operations, and
activities shall specify, at a minimum, the following:
From DOE G 435.1-1 Chapter III:
Compliance with these requirements is demonstrated if
waste acceptance requirements are documented,
contain clear and precise criteria specifying the
radionuclide limits in the form of contents or
concentrations that can be accepted, the limitations and
prohibitions on waste forms and packages that can be
received, and the limits, prohibitions, or instructions
concerning any other technical information so that the
waste is compatible with the safety basis of the
facility, and which will result in acceptable waste at
subsequent steps in managing the transuranic waste.
Waste acceptance requirements are to also contain a
clear description of the process and bases for obtaining
an exception or deviation to the acceptance criteria for
transuranic waste to be received
at the facility.

(a) Allowable activities and/or concentrations of specific radionuclides;

(b) Acceptable waste form and/or container requirements that ensure the chemical and physical stability of waste under conditions that might be encountered during transportation, storage, treatment, or disposal;

(c) Restrictions or prohibitions on waste, materials, or containers that may adversely affect waste handlers or compromise facility or waste container performance;

(d) Requirement to identify transuranic waste as defense or non-defense, and limitations on acceptance; and

(e) The basis, procedures, and levels of authority required for granting exceptions to the waste acceptance requirements, which shall be contained in each facility's waste acceptance documentation. Each exception request shall be documented, including its disposition as approved or not approved.

(2) Evaluation and Acceptance. The receiving facility shall evaluate waste for acceptance, including confirmation that technical and administrative requirements have been met. A process for the disposition of non-conforming wastes shall be established.

From DOE G 435.1-1 Chapter III:

Compliance with these requirements is demonstrated if Facility Compliance Information

See (1) above.

See (1) above.

See (1) above.

See (1) above.

See (1) above.

See (1) above. 
Table 14. (continued).

Facility Name: MFC-785, Hot Fuel Examination Facility

\begin{tabular}{|c|c|}
\hline Chapter III, Transuranic Waste Requirements & Facility Compliance Information \\
\hline $\begin{array}{l}\text { there is a procedure or process for evaluating and } \\
\text { accepting incoming waste which ensures the } \\
\text { acceptance criteria of the facility receiving the waste } \\
\text { are met by one or a combination of: (1) testing, } \\
\text { sampling, and analysis of representative samples of } \\
\text { incoming waste upon receipt; (2) testing, sampling, } \\
\text { and analysis of samples of waste taken at the generator } \\
\text { facility; (3) evaluation of testing, sampling, and } \\
\text { analysis of data provided by the generator; or (4) } \\
\text { audits, reviews, or surveillances of generator waste } \\
\text { certification programs and characterization activities. } \\
\text { Additionally, acceptable waste acceptance } \\
\text { requirements for a storage, treatment, or disposal } \\
\text { facility will have documented procedures and actions } \\
\text { to be taken if a waste that does not conform to the } \\
\text { waste acceptance criteria is received at the facility. }\end{array}$ & \\
\hline $\begin{array}{l}\text { H. Waste Generation Planning. The following } \\
\text { requirements are in addition to those in Chapter I of } \\
\text { this Manual. }\end{array}$ & $\begin{array}{l}\text { DOE Manual 435.1-1 §I.2.F(7) applies to field element } \\
\text { managers. }\end{array}$ \\
\hline $\begin{array}{l}\text { (1) Life-Cycle Planning. Prior to waste generation, } \\
\text { planning shall be performed to address the entire life } \\
\text { cycle for all transuranic waste streams. } \\
\text { From DOE G 435.1-1 Chapter III: } \\
\text { Compliance with this planning requirement is } \\
\text { demonstrated by the individual sites establishing a } \\
\text { process for evaluating the life-cycle of [transuranic] } \\
\text { waste prior to its generation, including the } \\
\text { identification of [transuranic] wastes with no path to } \\
\text { disposal and appropriate records justifying the newly } \\
\text { generated [transuranic] waste stream(s), and site } \\
\text { personnel possessing planning information showing } \\
\text { the location(s) where [transuranic] waste will be } \\
\text { stored, treated, and/or disposed along with a } \\
\text { confirmation that the personnel managing the facilities } \\
\text { agree that the [transuranic] waste may be managed at } \\
\text { those facilities. }\end{array}$ & $\begin{array}{l}\text { PDD- } 17000 \text { and LWP- } 17000 \text { provide direction to the } \\
\text { waste generators for waste generation planning to } \\
\text { address the entire life cycle. }\end{array}$ \\
\hline $\begin{array}{l}\text { (2) Waste with No Identified Path to Disposal. } \\
\text { Transuranic waste streams with no identified path to } \\
\text { disposal shall be generated only in accordance with } \\
\text { approved conditions which, at a minimum, shall } \\
\text { address: } \\
\text { From DOE G 435.1-1 Chapter III: } \\
\text { Compliance with requirement is demonstrated by the } \\
\text { waste generation organization having documentation } \\
\text { concerning the decision to generate a transuranic waste } \\
\text { stream that does not have an identified path to } \\
\text { disposal. This documentation needs to include the } \\
\text { cognizant Field Element Manager or designee }\end{array}$ & $\begin{array}{l}\text { NA; this facility does not generate TRU waste with no } \\
\text { identified path to disposal. }\end{array}$ \\
\hline
\end{tabular}


Table 14. (continued).

Facility Name: MFC-785, Hot Fuel Examination Facility

\begin{abstract}
Chapter III, Transuranic Waste Requirements approval to generate the waste, an explanation of the need for the process that generates the transuranic waste, a discussion of the reason it cannot be disposed of, the proposed management plan for the waste, and an up-to-date schedule of activities being pursued to resolve constraints to the disposal of the subject waste. Consistent with the use of a graded approach for applying DOE M 435.1-1 requirements, the schedule and plans for disposing of nondefense waste can defer to the complex-wide resolution of the issue.)
\end{abstract}

(a) Programmatic need to generate the waste;

(b) Characteristics and issues preventing the disposal of the waste;

(c) Safe storage of the waste until disposal can be achieved; and

(d) Activities and plans for achieving final disposal of the waste.

I. Waste Characterization. Transuranic waste shall be characterized using direct or indirect methods, and the characterization documented in sufficient detail to ensure safe management and compliance with the waste acceptance requirements of the facility receiving the waste.

From DOE G 435.1-1 Chapter III:

Compliance with this requirement is demonstrated by a program for documenting and the existence of records that document the process for acquiring and verifying the validity of transuranic waste characterization data acquired through the use of direct or indirect methods.

(1) Data Quality Objectives. The data quality objectives process, or a comparable process, shall be used for identifying characterization parameters and acceptable uncertainty in characterization data. Facility Compliance Information

See (2) above.

See (2) above.

See (2) above.

See (2) above.

LWP-8300 § 4.2 provides general INL-wide requirements for containerization and characterization documentation requirements.

HFEF-OI-6601 addresses characterization requirements for CH TRU, mixed TRU, and RH TRU waste generated in the facility.

HFEF-OI-6602 provides radiological smear analysis characterization instructions for development of characterization data for radiologically-contaminated or mixed TRU waste generated in the facility.

HFEF-OI-6801 specifies the requirements for evaluation and acceptance, storage, treatment, characterization, and shipping preparation of $\mathrm{CH}$ TRU waste. This document complies with the MFC-785 specific sections of PER-116 and the CH TRU WAC for the Waste Isolation Pilot Plant.

TRU waste transferred for onsite storage to MFC-771, RSWF, is characterized in accordance with RSWF-OI003.

When certified in accordance with the RSWF WAC, MFC TRU waste is, to the extent possible, in compliance with the WAC for various treatment or disposal facilities that could be the ultimate destination of the waste (RSWF-OI-003)

Radioactive waste management facilities characterize waste in accordance with the requirements of the receiving storage, treatment, or disposal facility. The documented use of a data quality objectives process, or comparable process, was not identified for this facility. 
Table 14. (continued).

Facility Name: MFC-785, Hot Fuel Examination Facility

Chapter III, Transuranic Waste Requirements
From DOE G 435.1-1 Chapter III:
Compliance with this requirement is demonstrated by
the documented use of a data quality objectives or a
comparable process for determining the type, quantity,
and quality of characterization data needed to safely
manage transuranic waste.
(2) Minimum Waste Characterization. Characterization
data shall, at a minimum, include the following
information relevant to the management of the waste:
From DOE G 435.1-1 Chapter III:
Compliance with this requirement is demonstrated by
the existence of a program or procedures for
determining and records that document
characterization of transuranic waste consistent with
the minimum characterization data requirements.)
Facility Compliance Information

LWP-8300 § 4.2 provides general INL-wide requirements for containerization and characterization documentation requirements.

HFEF-OI-6601 addresses characterization requirements for CH TRU, mixed TRU, and RH TRU waste generated in the facility.

HFEF-OI-6602 provides radiological smear analysis characterization instructions for development of characterization data for radiologically-contaminated or mixed TRU waste generated in the facility.

HFEF-OI-6801 specifies the requirements for evaluation and acceptance, storage, treatment, characterization, and shipping preparation of $\mathrm{CH}$ TRU waste. This document complies with the MFC-785 specific sections of PER-116 and the CH TRU WAC for the Waste Isolation Pilot Plant.

MCP-17000 $\S 4$ specifies the requirements for preparing an IWTS profile that captures waste characterization information.

\begin{tabular}{|l|l|}
\hline (a) Physical and chemical characteristics; & See (2) above. \\
\hline $\begin{array}{l}\text { (b) Volume, including the waste and any stabilization } \\
\text { or absorbent media; }\end{array}$ & See (2) above. \\
\hline (c) Weight of the container and contents; & See (2) above. \\
\hline $\begin{array}{l}\text { (d) Identities, activities, and concentrations of major } \\
\text { radionuclides; }\end{array}$ & See (2) above. \\
\hline $\begin{array}{l}\text { (e) Characterization date; } \\
\text { (f) Generating source; }\end{array}$ & See (2) above. \\
\hline $\begin{array}{l}\text { (g) Packaging date; and } \\
\text { (h) Any other information which may be needed to } \\
\text { prepare and maintain the disposal facility performance } \\
\text { assessment or demonstrate compliance with applicable } \\
\text { performance objectives. }\end{array}$ & See (2) above. \\
\hline $\begin{array}{l}\text { J. Waste Certification. A waste certification program } \\
\text { shall be developed, documented, and implemented to } \\
\text { ensure that the waste acceptance requirements of } \\
\text { facilities receiving transuranic waste for storage, } \\
\text { treatment, or disposal are met. }\end{array}$ & $\begin{array}{l}\text { HFEF-OI-6601 addresses certification requirements for } \\
\text { CH TRU, mixed TRU, and RH TRU waste generated in } \\
\text { the facility. } \\
\text { PLN-8300 provides MFC-wide certification of CH }\end{array}$ \\
\hline
\end{tabular}


Table 14. (continued).

Facility Name: MFC-785, Hot Fuel Examination Facility

\begin{tabular}{l} 
Chapter III, Transuranic Waste Requirements \\
\hline From DOE G 435.1-1 Chapter III: \\
Compliance with the development and documentation \\
portion of the certification requirement is \\
demonstrated by a waste certification plan that \\
identifies the organizations involved, assigns \\
responsibilities for implementing the program, and \\
describes or references the quality assurance, training, \\
procurement controls, records management, and \\
procedures to be used by the program. Acceptable \\
performance for implementing the program is \\
demonstrated when the appropriate personnel are \\
trained, and have and follow the procedures that \\
govern their part of the waste certification process. \\
Acceptable performance also requires that the waste \\
certification plan and procedures are current and \\
controlled in accordance with a document control \\
program, and records related to certification (e.g., \\
certification statements, training records, procurement \\
records, characterization records, container records) \\
are generated and managed in accordance with the \\
established site program. \\
\hline
\end{tabular}

(1) Certification Program. The waste certification program shall designate the officials who have the authority to certify and release waste for shipment; and specify what documentation is required for waste generation, characterization, shipment, and certification. The program shall provide requirements for auditability, retrievability, and storage of required documentation and specify the records retention period.

From DOE G 435.1-1 Chapter III:

Compliance with this requirement is demonstrated by a program or procedure for record keeping and records showing that each container of waste is certified as having met the waste acceptance criteria of the facility to which it was transferred and the certification statement is supported by additional records regarding the waste source, characterization, and container.

(2) Certification before Transfer. Transuranic waste shall be certified as meeting waste acceptance requirements before it is transferred to the facility receiving the waste.

From DOE G 435.1-1 Chapter III:

Compliance with this requirement is demonstrated by the presence of a certification program which includes procedures requiring a signed certification statement prior to the release of waste for transfer, and by dated

TRU waste.

LWP-8300 § 4.2 provides general INL-wide requirements for containerization and characterization documentation requirements.

TRU waste transferred for onsite storage to MFC-771, RSWF, is certified in accordance with RSWF-OI-003 $\S 3.1$.

MCP-17000 specifies the requirements for preparing an IWTS profile that captures waste certification information.

When certified in accordance with the RSWF WAC, MFC TRU waste is, to the extent possible, in compliance with the WAC for various treatment or disposal facilities that could be the ultimate destination of the waste (RSWF-OI-003). Procedural documentation other than this statement regarding certification of TRU waste destined for Waste Isolation Pilot Plant disposition was not found.

See J. above.

See J. above. 
Table 14. (continued).

Facility Name: MFC-785, Hot Fuel Examination Facility

\begin{tabular}{|c|}
\hline $\begin{array}{l}\text { Chapter III, Transuranic Waste Requirements } \\
\text { records showing that waste was certified before being } \\
\text { transferred. }\end{array}$ \\
\hline $\begin{array}{l}\text { (3) Maintaining Certification. Transuranic waste that } \\
\text { has been certified as meeting the waste acceptance } \\
\text { requirements for transfer to a storage, treatment, or } \\
\text { disposal facility shall be managed in a manner that } \\
\text { maintains its certification status. }\end{array}$ \\
\hline From DOE G 435.1-1 Chapter III: \\
\hline $\begin{array}{l}\text { Compliance with this requirement is demonstrated by } \\
\text { the existence of a program or procedure reflecting this } \\
\text { requirement and site personnel able to show that the } \\
\text { storage of containers of waste is in a facility or manner } \\
\text { where the containers are not damaged by normal } \\
\text { weather events, and cannot be accessed by } \\
\text { unauthorized personnel. Further, each container can be } \\
\text { traced to its certification and the information } \\
\text { supporting that certification. }\end{array}$ \\
\hline
\end{tabular}

K. Waste Transfer. A documented process shall be established and implemented for transferring responsibility for management of transuranic waste and for ensuring availability of relevant data. The following requirements are in addition to those in Chapter I of this Manual.

From DOE G 435.1-1 Chapter III:

Compliance with this requirement is demonstrated if facilities have procedures for the receipt of waste and the transfer of waste, as appropriate, which address the acquisition of waste and container data and the transfer of ownership, respectively. Further evidence of acceptable performance is facility records showing that data on the waste containers are available and accurate, and that documented transfer of responsibility occurs.

(1) Authorization. Transuranic waste shall not be transferred to a storage, treatment, or disposal facility until personnel responsible for the facility receiving the waste authorize the transfer.

From DOE G 435.1-1 Chapter III:

Compliance with this requirement is demonstrated by

RSWF-OI-003 specifies requirements and provides instructions for accepting mixed waste, radioactive waste, and radioactive material for storage at RSWF. Appendix A serves as the record document to be maintained for each container going to that facility.

RSWF-OI-004 provides the administrative process used by RSWF management for approval of material transfer activities at RSWF.

TSD-OI-004specifies requirements and provides instructions for accepting $\mathrm{CH}$ TRU and mixed $\mathrm{CH}$ TRU waste at the MFC treatment, storage, and disposal facilities.

LWP-8300 $§ 4.3$ provides instruction on containerization of $\mathrm{CH}$ TRU waste going to the Advanced Mixed Waste Treatment Plant and prescribes the use of Form 435.83 as the documented record of container data and transfer.

PLN-8300 provides MFC-wide certification of $\mathrm{CH}$ TRU waste.

MCP-17000 specifies the requirements for preparing an IWTS profile that captures waste transfer information and associated authorizations.

See K. above. 
Table 14. (continued).

Facility Name: MFC-785, Hot Fuel Examination Facility

\begin{tabular}{l} 
Chapter III, Transuranic Waste Requirements \\
\hline sites having procedures that require a confirmation of \\
authorization before releasing waste for transfer, and \\
records showing that transfers are made in accordance \\
with written authorizations.
\end{tabular}

(2) Data. Waste characterization data, container information, and generation, storage, treatment, and transportation information for transuranic waste shall be transferred with or be traceable to the waste.

From DOE G 435.1-1 Chapter III:

Compliance with this requirement is demonstrated if there are procedures requiring that characterization and container data be provided and maintained for each waste transfer and documented records of transfers show that the information is being provided.

L. Packaging and Transportation. The following requirements are in addition to those in Chapter I of this Manual.

(1) Packaging.

See K. above. Facility Compliance Information

From DOE G 435.1-1 Chapter III:

Compliance with the packaging requirement is demonstrated by procedures which document proper packaging protocols, including documented evidence that, where feasible, non-defense transuranic waste has been packaged separately from defense transuranic waste and by never having to repackage transuranic waste that is packaged after issuance of DOE $\mathrm{O} 435.1$ in order to maintain containment. However, the above protocol may not be satisfied by containers that were placed in storage prior to issuance of the DOE $\mathrm{O}$ 435.1. For those containers, the goal is to only have to repackage the waste one time after it is retrieved and characterized. Further, acceptable performance is demonstrated by containers of waste having marking and labeling that allows correlation with waste characterization data and container information. Successful performance of this requirement is also demonstrated by a record of container performance in which failure has not routinely occurred.

(a) Transuranic waste shall be packaged in a manner that provides containment and protection for the duration of the anticipated storage period and until disposal is achieved or until the waste is removed from the container.

See (1)(a) through (2) below.

See (1)(a) through (2) below.

LWP-8300 and the various documents cited below address packaging requirements for TRU waste managed at this facility.

PLN-8300 addresses this requirement for CH TRU waste generated at this facility.

HFEF-OI-6601 addresses packaging requirements for CH TRU, mixed TRU, RH TRU and mixed RH TRU waste generated in the facility. 
Table 14. (continued).

Facility Name: MFC-785, Hot Fuel Examination Facility

\section{Chapter III, Transuranic Waste Requirements}

(b) Vents or other mechanisms to prevent pressurization of containers or generation of flammable or explosive concentrations of gases shall be installed on containers of newly-generated waste at the time the waste is packaged. Containers of currently stored waste shall meet this requirement as soon as practical unless analyses demonstrate that the waste can otherwise be managed safely.

From DOE G 435.1-1 Chapter III:

In developing the radioactive waste management basis, site personnel need to consider the hazards associated with drums of transuranic waste which have not been provided with vents or been proven to not need vents through an approved safety analysis. For unvented containers in earthen-covered storage, the facility itself may mitigate the hazards associated with the accumulation of gases. For above-grade storage of transuranic waste containers, the radioactive waste management basis needs to include controls which mitigate the hazards associated with the accumulation of gases by restricting access to the storage area and providing equipment to protect against fire or explosion.

(c) When transuranic waste is packaged, defense waste shall be packaged separately from non-defense waste, if feasible.

(d) Containers of transuranic waste shall be marked such that their contents can be identified.

\section{Facility Compliance Information}

HFEF-OI-6801 addresses appropriate container usage for the mixed TRU waste generated in this facility.

LST-337 prescribes the appropriate container as approved by waste type.

RSWF-OI-003 specifies requirements and provides instructions for accepting mixed waste, radioactive waste, and radioactive material for storage at RSWF. Appendix A serves as the record document to be maintained for each container going to that facility.

TSM-OI-003 prescribes the appropriate packaging for intra-facility movements of TRU waste.

LWP-8300 $\S 4.2$ and 4.3 address packaging ventilation requirements for TRU waste.

PLN-8300 addresses this requirement for TRU waste generated at this facility.

HFEF-OI-6601 $\S 5.8 .11$ and 5.10 prescribe the required ventiallation protected packaging as appropriate.

RSWF-OI-003 provides for use of Appendix A as record of the ventilated or other pressurization protection packaging.

HFEF-OI-6801 prescribes the required packaging for both hazardous waste and mixed waste managed at the facility.

TSM-OI-003 prescribes the appropriate packaging for intra-facility movements of TRU waste.

LST-337 prescribes the appropriate container as approved by waste type.

INL/EXT-10-17600 $§ 3$ addresses the defense determination requirement based on ANL-NT-192.

LWP-8300 $\S$ 4.3.1.7 provides instructions on properly marking/labeling TRU waste containers.

PLN-8300 addresses this requirement for TRU waste generated at this facility.

HFEF-OI-6801 prescribes the required packaging for both hazardous wastes and mixed wastes managed at the facility.

RSWF-OI-003 specifies requirements and provides 
Table 14. (continued).

\begin{tabular}{|c|c|}
\hline \multicolumn{2}{|c|}{ Facility Name: MFC-785, Hot Fuel Examination Facility } \\
\hline Chapter III, Transuranic Waste Requirements & Facility Compliance Information \\
\hline & $\begin{array}{l}\text { instructions for accepting mixed waste, radioactive } \\
\text { waste, and radioactive material for storage at RSWF. } \\
\text { Appendix A serves as the record document to be } \\
\text { maintained for each container going to that facility. }\end{array}$ \\
\hline $\begin{array}{l}\text { (2) Transportation. To the extent practical, the volume } \\
\text { of waste and number of transuranic waste shipments } \\
\text { shall be minimized. }\end{array}$ & $\begin{array}{l}\text { NA; waste is not shipped to an offsite facility for final } \\
\text { disposition from this facility. }\end{array}$ \\
\hline From DOE G 435.1-1 Chapter III: & \\
\hline $\begin{array}{l}\text { Compliance with this requirement can be demonstrated } \\
\text { by a combination of site procedures directing the } \\
\text { efficient use of waste container capacity and } \\
\text { documentation showing that transuranic waste } \\
\text { shipments are systematically planned and make } \\
\text { optimal use of the shipment system (e.g., TRUPACT } \\
\text { II) to the extent practical. }\end{array}$ & \\
\hline $\begin{array}{l}\text { M. Site Evaluation and Facility Design. The following } \\
\text { requirements are in addition to those in Chapter I of } \\
\text { this Manual. }\end{array}$ & $\begin{array}{l}\text { NA; this requirement addresses new radioactive waste } \\
\text { management facilities. }\end{array}$ \\
\hline $\begin{array}{l}\text { (1) Site Evaluation. Proposed locations for transuranic } \\
\text { waste facilities shall be evaluated to identify relevant } \\
\text { features that should be avoided or must be considered } \\
\text { in facility design and analyses. }\end{array}$ & See M. above. \\
\hline $\begin{array}{l}\text { (a) Each site proposed for a new transuranic waste } \\
\text { facility or expansion of an existing transuranic waste } \\
\text { facility shall be evaluated considering environmental } \\
\text { characteristics, geotechnical characteristics, and } \\
\text { human activities. }\end{array}$ & See M. above. \\
\hline $\begin{array}{l}\text { (b) Proposed sites with environmental characteristics, } \\
\text { geotechnical characteristics, and human activities for } \\
\text { which adequate protection cannot be provided through } \\
\text { facility design shall be deemed unsuitable for the } \\
\text { location of the facility. }\end{array}$ & See M. above. \\
\hline $\begin{array}{l}\text { (2) Facility Design. The following facility } \\
\text { requirements and general design criteria, at a } \\
\text { minimum, apply: }\end{array}$ & See M. above. \\
\hline $\begin{array}{l}\text { (a) Confinement. Transuranic waste systems and } \\
\text { components shall be designed to maintain waste } \\
\text { confinement. }\end{array}$ & See M. above. \\
\hline \multicolumn{2}{|l|}{ (b) Ventilation. } \\
\hline $\begin{array}{l}1 \text { Design of transuranic waste treatment and storage } \\
\text { facilities shall include ventilation, if applicable, } \\
\text { through an appropriate filtration system to maintain the } \\
\text { release of radioactive material in airborne effluents } \\
\text { within the requirements and guidelines specified in } \\
\text { applicable requirements. }\end{array}$ & See M. above. \\
\hline
\end{tabular}


Table 14. (continued).

Facility Name: MFC-785, Hot Fuel Examination Facility

\begin{tabular}{|c|}
\hline Chapter III, Transuranic Waste Requirements \\
\hline $\begin{array}{l}2 \text { When conditions exist for generating gases in } \\
\text { flammable or explosive concentrations in treatment or } \\
\text { storage facilities, ventilation or other measures shall be } \\
\text { provided to keep the gases in a non-flammable and } \\
\text { non-explosive condition. Where concentrations of } \\
\text { explosive or flammable gases are expected to approach } \\
\text { the lower flammability limit, measures shall be taken } \\
\text { to prevent deflagration or detonation. }\end{array}$ \\
\hline
\end{tabular}

(c) Consideration of Decontamination and

Decommissioning. Areas in new and modifications to existing transuranic waste management facilities that are subject to contamination with radioactive or other hazardous materials shall be designed to facilitate decontamination. For such facilities a proposed decommissioning method or a conversion method leading to reuse shall be described.

(d) Instrumentation and Control Systems. Engineering controls shall be incorporated in the design and engineering of transuranic waste treatment and storage facilities to provide volume inventory data and to prevent spills, leaks, and overflows from tanks or confinement systems.

(e) Monitoring. Monitoring and/or leak detection capabilities shall be incorporated in the design and engineering of transuranic waste storage, treatment, and disposal facilities to provide rapid identification of failed confinement and/or other abnormal conditions.

N. Storage. The following requirements are in addition to those in Chapter I of this Manual.

(1) Storage Prohibitions. Transuranic waste in storage shall not be readily capable of detonation, explosive decomposition, reaction at anticipated pressures and temperatures, or explosive reaction with water. Prior to storage, pyrophoric materials shall be treated, prepared, and packaged to be nonflammable.

From DOE G 435.1-1 Chapter III:

Compliance with this requirement is demonstrated by having waste acceptance requirements which prohibit waste that is ignitable or explosive from being accepted for storage unless it has been treated.

(2) Storage Integrity. Transuranic waste shall be stored in a location and manner that protects the integrity of waste for the expected time of storage and minimizes worker exposure.

From DOE G 435.1-1 Chapter III:
See M. above.

Facility Compliance Information

See M. above.

See M. above.

See M. above.

Not a facility-specific requirement. DOE Manual 435.1$1 \S$ I.2.F(13) applies to field element managers.

LWP-8300 $§ 4.2$, addresses the storage prohibitions for TRU waste managed at INL. The documents cited below provide for proper documentation that this requirement is met upon containerization of this waste.

PLN-8300 provides MFC-wide certification of $\mathrm{CH}$ TRU waste.

HFEF-OI-6601 $\S 5.7$ and Appendix A addresses the prohibition of ignitable waste at MFC-785.

HFEF-OI-6801 $\S 5.1 .2$ addresses the prohibition of explosive contents for hazardous wastes and mixed waste managed at the facility.

LWP-15011 $\S 5$ provides general radioactive storage area requirements.

LWP-8300 $\S 4.2$ addresses the adequate storage requirements for TRU waste managed at INL. 
Table 14. (continued).

Facility Name: MFC-785, Hot Fuel Examination Facility

\begin{tabular}{l}
\hline Chapter III, Transuranic Waste Requirements \\
\hline Compliance with this requirement is demonstrated if \\
sites have storage capabilities for transuranic waste \\
that provide protection of waste containers so that their \\
integrity will not be damaged through physical or \\
chemical (corrosion) processes and that keep personnel \\
from spending extended periods of time in the areas \\
where transuranic waste is stored.
\end{tabular}

(3) Container Inspection. A process shall be developed and implemented for inspecting and maintaining containers of transuranic waste to ensure container integrity is not compromised.

From DOE G 435.1-1 Chapter III:

Compliance with this requirement is demonstrated by a documented process for waste container inspection and maintenance at every facility managing transuranic waste, and documentation for all waste container inspections and maintenance actions performed.

(4) Retrievable Earthen-Covered Storage. Plans for the removal of transuranic waste from retrievable earthencovered storage facilities shall be established and maintained. Prior to commencing waste retrieval activities, each waste storage site shall be evaluated to determine relevant information on types, quantities, and location of radioactive and hazardous chemicals as necessary to protect workers during the retrieval process.

O. Treatment. Transuranic waste shall be treated as necessary to meet the waste acceptance requirements of the facility receiving the waste for storage or disposal.

From DOE G 435.1-1 Chapter III:

Compliance with this requirement is demonstrated by the custodian of transuranic waste maintaining documentation which identifies the plans for treating waste, and maintaining the records that show waste was treated, if necessary, to meet the waste acceptance requirements of the storage or disposal facility to which it was transferred.

P. Disposal. Transuranic waste shall be disposed in accordance with the requirements of 40 CFR Part 191, Environmental Radiation Protection Standards for Management and Disposal of Spent Nuclear Fuel, High-Level and Transuranic Radioactive Wastes.

Q. Monitoring. The following requirements are in addition to those in Chapter I of this Manual.

(1) All Waste Facilities. Parameters that shall be

LI-435 requires quarterly inspections of radioactive waste containers if waste is stored outdoors or has been in storage for greater than 1 year.

HFEF-OI-6801 $\S \S 5.6,8.2$, and 8.3 address the daily and weekly inspection requirements for only hazardous and mixed wastes managed at MFC-785.
NA; this facility is not an earthen-covered storage facility.
NA; this facility is not a TRU waste treatment facility.

NA; this facility is not a TRU waste disposal facility. Facility Compliance Information 
Table 14. (continued).

\section{Facility Name: MFC-785, Hot Fuel Examination Facility}

Chapter III, Transuranic Waste Requirements sampled or monitored, at a minimum, include: temperature, pressure (for closed systems), radioactivity in ventilation exhaust and liquid effluent streams, and flammable or explosive mixtures of gases. Facility monitoring programs shall include verification that passive and active control systems have not failed.

From DOE G 435.1-1 Chapter III:

If a minimum parameter specified in the requirement is deemed to be not applicable in any way to the active operation of that facility, then that justification should be included in the radioactive waste management basis and when approved, constitutes an exemption to the Manual.

Verification activities are part of the radioactive waste management basis and are to be documented appropriately.

Compliance with this requirement is demonstrated if monitoring or sampling for the stated parameters is performed for all facilities with an accuracy, precision, and frequency consistent with timely identification of developing problems and a justification exists in the approved radioactive waste management basis for those specified parameters which are not monitored or sampled.

(2) Stored Wastes. All transuranic wastes in storage shall be monitored, as prescribed by the appropriate facility safety analysis, to ensure the wastes are maintained in safe condition.

From DOE G 435.1-1 Chapter III:

Compliance with this requirement is demonstrated if the monitoring requirements in the facility procedures include, at a minimum, monitoring the systems and parameters as indicated by the safety analysis.

(3) Liquid Waste Storage Facilities. For facilities storing liquid transuranic waste, the following shall also be monitored: liquid level and/or waste volume, and significant waste chemistry parameters.

From DOE G 435.1-1 Chapter III:

Compliance with this requirement is demonstrated by developing operational procedures for monitoring liquid transuranic waste storage tank liquid level, waste volume, and tank chemistry so that waste volume or chemistry changes are detected in a time frame that will allow implementation of corrective measures to limit public and worker doses and to

\section{Facility Compliance Information}

management facilities are tailored for the specific facility to enable timely indication of developing problems. Existing radiological control procedures and assessments are followed/completed to monitor waste facilities.

LRD-15001 and MCP-139 specify methods and frequency of radiological control surveys of all radiological areas. MCP-139 specifies the use of Form 441.A34. This form is referred to as the "routine sheet" and is to be used by facility radiological control foremen to list radiological areas that are to be surveyed, the survey periods, and methods.
The facility's safety basis requirements and implementing documents are identified in DSA-003HFEF. This facility is a Hazard Category 2 Nuclear Facility. 
Table 14. (continued).

Facility Name: MFC-785, Hot Fuel Examination Facility

Chapter III, Transuranic Waste Requirements

Facility Compliance Information

mitigate unplanned releases of stored liquid waste. 
Table 15. MFC-785, Hot Fuel Examination Facility, DOE Manual 435.1-1 low-level waste requirements and facility compliance information.

\begin{tabular}{|c|c|}
\hline \multicolumn{2}{|c|}{ Facility Name: MFC-785, Hot Fuel Examination Facility } \\
\hline Chapter IV, LLW Requirements & Facility Compliance Information \\
\hline $\begin{array}{l}\text { A. Definition of Low-Level Waste. Low-level } \\
\text { radioactive waste is radioactive waste that is not high- } \\
\text { level radioactive waste, spent nuclear fuel, transuranic } \\
\text { waste, byproduct material (as defined in section 11e.(2) } \\
\text { of the Atomic Energy Act of 1954, as amended), or } \\
\text { naturally occurring radioactive material. } \\
\text { From DOE G } 435.1-1 \text { Chapter IV: Low-level } \\
\text { radioactive waste is defined by what it is not. The } \\
\text { guidance on definitions in Chapters II and III should be } \\
\text { consulted first for making a determination on how to } \\
\text { properly manage a suspect waste stream.) }\end{array}$ & $\begin{array}{l}\text { This requirement proves the criteria for determining } \\
\text { which DOE radioactive waste is to be managed as } \\
\text { LLW in accordance with DOE Manual } 435.1-1 \text {, } \\
\text { Chapter IV. } \\
\text { Radioactive waste managed at this facility under the } \\
\text { requirements of this chapter is not managed under the } \\
\text { requirements of DOE Manual } 435.1-1 \text {, Chapter II or } \\
\text { Chapter III. }\end{array}$ \\
\hline $\begin{array}{l}\text { B. Management of Specific Wastes. The following } \\
\text { provide for management of specific wastes as low-level } \\
\text { waste in accordance with the requirements in this } \\
\text { Chapter: }\end{array}$ & See (1), (2), (3), and (4) below. \\
\hline $\begin{array}{l}\text { (1) Mixed Low-Level Waste. Low-level waste } \\
\text { determined to contain both source, special nuclear, or } \\
\text { byproduct material subject to the Atomic Energy Act of } \\
1954 \text {, as amended, and a hazardous component subject } \\
\text { to the Resource Conservation and Recovery Act } \\
\text { (RCRA), as amended, shall be managed in accordance } \\
\text { with the requirements of RCRA and DOE O 435.1, } \\
\text { Radioactive Waste Management, and this Manual. }\end{array}$ & $\begin{array}{l}\text { This facility manages mixed LLW. The documents } \\
\text { cited below seem to demonstrate compliance with this } \\
\text { requirement. } \\
\text { PER-116 provides RCRA regulation of the hazardous } \\
\text { component of the waste managed at this facility. } \\
\text { HFEF-OI- } 6601 \text { addresses management of mixed LLW } \\
\text { at this facility. } \\
\text { HFEF-OI- } 6801 \text { implements the HFEF-specific } \\
\text { requirements of PER-116. } \\
\text { LWP-8300 addresses management of the hazardous } \\
\text { component of TRU waste. } \\
\text { This facility manages mixed LLW in SAAs. } \\
\text { Management of SAAs is addressed in MCP-17410, and } \\
\text { overall management of mixed waste is addressed in } \\
\text { MCP-17000. }\end{array}$ \\
\hline $\begin{array}{l}\text { (2) TSCA-Regulated Waste. Low-level waste } \\
\text { containing polychlorinated biphenyls, asbestos, or other } \\
\text { such regulated toxic components shall be managed in } \\
\text { accordance with requirements derived from the Toxic } \\
\text { Substances Control Act, as amended, DOE O } 435.1 \text {, } \\
\text { Radioactive Waste Management, and this Manual. }\end{array}$ & $\begin{array}{l}\text { NA; this facility does not manage TSCA-regulated } \\
\text { waste. }\end{array}$ \\
\hline $\begin{array}{l}\text { (3) Accelerator-Produced Waste. Radioactive waste } \\
\text { produced as a result of operations of DOE accelerators } \\
\text { is low-level waste and shall be managed in accordance } \\
\text { with DOE O } 435.1 \text {, Radioactive Waste Management, } \\
\text { and this Manual, and all applicable Federal or State } \\
\text { requirements. }\end{array}$ & $\begin{array}{l}\text { NA; this facility does not manage accelerator-produced } \\
\text { waste. }\end{array}$ \\
\hline $\begin{array}{l}\text { (4) } 11 \text { e.(2) and Naturally Occurring Radioactive } \\
\text { Material. Small quantities of } 11 \text { e.(2) byproduct }\end{array}$ & $\begin{array}{l}\text { NA; this facility does not manage naturally occurring } \\
\text { radioactive material. }\end{array}$ \\
\hline
\end{tabular}


Table 15. (continued).

Facility Name: MFC-785, Hot Fuel Examination Facility

\begin{tabular}{|c|}
\hline Chapter IV, LLW Requirements \\
\hline $\begin{array}{l}\text { material and naturally occurring radioactive material } \\
\text { may be managed as low-level waste provided they can } \\
\text { be managed to meet the requirements for low-level } \\
\text { waste disposal in Section IV.P of this Manual. }\end{array}$ \\
\hline $\begin{array}{l}\text { C. Complex-Wide Low-Level Waste Management } \\
\text { Program. A complex-wide program and plan shall be } \\
\text { developed as described under Responsibilities, } 2 . \text { B and } \\
\text { 2.D, in Chapter I of this Manual. }\end{array}$ \\
\hline $\begin{array}{l}\text { D. Radioactive Waste Management Basis. Low-level } \\
\text { waste facilities, operations, and activities shall have a } \\
\text { radioactive waste management basis consisting of } \\
\text { physical and administrative controls to ensure the } \\
\text { protection of workers, the public, and the environment. } \\
\text { The following specific waste management controls } \\
\text { shall be part of the radioactive waste management } \\
\text { basis: }\end{array}$ \\
\hline
\end{tabular}

(1) Generators. The waste certification program.

From DOE G 435.1-1 Chapter IV: For a facility that generates low-level waste, the radioactive waste management basis is to include the program for certifying that waste meets the waste acceptance requirements of the facility(ies) to which the waste will be sent.

(2) Treatment Facilities. certification program. The waste acceptance requirements and the waste [sic]

From DOE G 435.1-1 Chapter IV: Facilities that store or treat low-level waste are to have approved waste acceptance requirements (see DOE M 435.1-1, Section IV.G) prior to the issuance of a radioactive waste management basis.

A facility that stores or treats waste also is generally expected to have a waste certification program. Waste from these facilities will have to be certified as meeting the waste acceptance requirements of the facility to which it will be transferred, and the facilities have the potential for generating radioactive waste (e.g., secondary processing streams from treatment, monitoring and sampling, radioactive release cleanup). Consequently, storage and treatment facilities should also have an approved waste certification program as part of their radioactive waste management basis.

As part of the radioactive waste management basis, site personnel needs to implement a system or process for tracking the waste inventory at a storage, treatment, or
DOE Manual 435.1-1 §I.2.B and §I.2.D apply to the Assistant Secretary for Environmental Management and the Deputy Assistant Secretary for Waste Management, respectively.

The RWMB provides the regulatory framework for management of radioactive waste at INL. It specifically identifies facility management and implementing documents for the generation, storage, treatment, and disposal of radiological waste..

See J. below for waste certification program requirements.

DSA-003-HFEF serves as the safety basis documentation for the facility and establishes it as a Hazard Category 2 nuclear facility.

HFEF-OI-1302 specifies material accountability requirements for managing special nuclear material in HFEF and provides the instructions necessary to meet the requirements using the Mass Tracking System database.

NA; waste is not treated at this facility. 
Table 15. (continued).

\begin{tabular}{|c|c|}
\hline \multicolumn{2}{|c|}{ Facility Name: MFC-785, Hot Fuel Examination Facility } \\
\hline Chapter IV, LLW Requirements & Facility Compliance Information \\
\hline disposal facility. & \\
\hline $\begin{array}{l}\text { (3) Storage Facilities. The waste acceptance } \\
\text { requirements and the waste certification program. }\end{array}$ & NA; this facility does not store LLW. \\
\hline $\begin{array}{l}\text { From DOE G 435.1-1 Chapter IV: Facilities that store } \\
\text { or treat low-level waste are to have approved waste } \\
\text { acceptance requirements (see DOE M 435.1-1, Section } \\
\text { IV.G) prior to the issuance of a radioactive waste } \\
\text { management basis. }\end{array}$ & \\
\hline $\begin{array}{l}\text { A facility that stores or treats waste also is generally } \\
\text { expected to have a waste certification program. Waste } \\
\text { from these facilities will have to be certified as meeting } \\
\text { the waste acceptance requirements of the facility to } \\
\text { which it will be transferred, and the facilities have the } \\
\text { potential for generating radioactive waste (e.g., } \\
\text { secondary processing streams from treatment, } \\
\text { monitoring and sampling, radioactive release cleanup). } \\
\text { Consequently, storage and treatment facilities should } \\
\text { also have an approved waste certification program as } \\
\text { part of their radioactive waste management basis. }\end{array}$ & \\
\hline $\begin{array}{l}\text { As part of the radioactive waste management basis, site } \\
\text { personnel needs to implement a system or process for } \\
\text { tracking the waste inventory at a storage, treatment, or } \\
\text { disposal facility. }\end{array}$ & \\
\hline $\begin{array}{l}\text { (4) Disposal Facilities. The performance assessment, } \\
\text { composite analysis, disposal authorization statement, } \\
\text { closure plan, waste acceptance requirements, and } \\
\text { monitoring plan. }\end{array}$ & NA; this facility is not a disposal facility. \\
\hline $\begin{array}{l}\text { E. Contingency Actions. The following requirements } \\
\text { are in addition to those in Chapter I of this Manual } \\
{[\text { DOE M 435.1-1 } \S \text { I.1.E(5)]. }}\end{array}$ & $\begin{array}{l}\text { DOE Manual } 435.1-1 \S \mathrm{I} .1 . \mathrm{E}(5) \text { addresses the sitewide } \\
\text { emergency management system. The INL plan is } \\
\text { provided in PLN-114. }\end{array}$ \\
\hline $\begin{array}{l}\text { (1) Contingency Storage. For off-normal or emergency } \\
\text { situations involving high activity or high hazard liquid } \\
\text { low-level waste storage or treatment, spare capacity } \\
\text { with adequate capabilities shall be maintained to } \\
\text { receive the largest volume of liquid contained in any } \\
\text { one storage tank or treatment facility. Tanks or other } \\
\text { facilities that are designated low-level waste } \\
\text { contingency storage shall be maintained in an } \\
\text { operational condition when waste is present and shall } \\
\text { meet the requirements of DOE O 435.1, Radioactive } \\
\text { Waste Management, and this Manual. }\end{array}$ & $\begin{array}{l}\text { NA; this facility does not store or treat liquid TRU } \\
\text { waste. }\end{array}$ \\
\hline $\begin{array}{l}\text { From DOE G } 435.1-1 \text { Chapter IV: Compliance with } \\
\text { these requirements is demonstrated if adequate spare } \\
\text { capacity and transfer equipment exists for emergency } \\
\text { transfers of all high activity and high hazard liquid low- } \\
\text { level waste. In addition, the capability to perform } \\
\text { emergency transfers is demonstrated by having waste }\end{array}$ & \\
\hline
\end{tabular}


Table 15. (continued).

Facility Name: MFC-785, Hot Fuel Examination Facility

\begin{tabular}{l} 
Chapter IV, LLW Requirements \\
\hline transfer routings identified, operational procedures to \\
direct transfers, staff trained to the procedures, and \\
records showing that the spare capacity and transfer \\
capability are kept in operating condition.
\end{tabular}

(2) Transfer Equipment. Pipelines and auxiliary facilities necessary for the transfer of high activity or high hazard liquid low-level waste to contingency storage shall be maintained in an operational condition when waste is present and shall meet the requirements of DOE O 435.1, Radioactive Waste Management, and this Manual.

From DOE G 435.1-1 Chapter IV: Compliance with these requirements is demonstrated if adequate spare capacity and transfer equipment exists for emergency transfers of all high activity and high hazard liquid lowlevel waste. In addition, the capability to perform emergency transfers is demonstrated by having waste transfer routings identified, operational procedures to direct transfers, staff trained to the procedures, and records showing that the spare capacity and transfer capability are kept in operating condition.

F. Corrective Actions. I of this Manual. The following requirements are in addition to those in Chapter [sic]

From DOE G 435.1-1 Chapter IV: Compliance with DOE M 435.1-1 §I.2.G.(1) is demonstrated by records showing what corrective actions were taken to remedy situations in the radioactive waste management system.

Compliance with DOE M 435.1-1 §I.2.G.(2) is demonstrated by having the necessary procedures, mechanisms, and training in place to effect shutdown or curtailment of activities which pose an imminent danger or other serious hazard to workers or the public, or are not protective of the environment.

(1) Order Compliance. Corrective actions shall be implemented whenever necessary to ensure the requirements of DOE O 435.1, Radioactive Waste Management, and this Manual are met.

From DOE G 435.1-1 Chapter IV: If a facility or activity can be allowed to operate while a noncompliant or hazardous condition exists, the allowance and any associated limitations must be defined as part of the facility or activity's radioactive waste management basis, identified as a configuration controlled item in a configuration management plan or included in a revision or modification to an operating procedure or similar controlled documentation.

Compliance with this requirement is demonstrated if a 
Table 15. (continued).

Facility Name: MFC-785, Hot Fuel Examination Facility

\begin{tabular}{l} 
Chapter IV, LLW Requirements \\
\hline $\begin{array}{l}\text { corrective action system addresses noncompliant or } \\
\text { hazardous situations involving low-level waste } \\
\text { management facilities in a systematic fashion, and } \\
\text { allows identification of problems by all personnel. }\end{array}$ \\
(2) Operations Curtailment. Operations shall be \\
curtailed or facilities shut down for failure to establish, \\
maintain, or operate consistent with an approved \\
radioactive waste management basis. \\
From DOE G 435.1-1 Chapter IV: Compliance with \\
this requirement is demonstrated with a documented \\
system of routine assessments to determine whether \\
waste management activities and facilities are \\
operating in accordance with an approved radioactive \\
waste management basis that provides for graded \\
limitations that can be placed on activities and \\
operations that do not have, or are operating outside of, \\
an approved radioactive waste management basis, \\
including shutdown of the facility.
\end{tabular}

G. Waste Acceptance. The following requirements are in addition to those in Chapter I of this Manual [DOE M 435.1-1 §I.2.F(6)].

(1) Technical and Administrative. Waste acceptance requirements for all low-level waste storage, treatment, or disposal facilities, operations, and activities shall specify, at a minimum, the following:

From DOE G 435.1-1 Chapter IV: Compliance with these waste acceptance requirements is demonstrated if they are documented, contain clear and precise criteria specifying the radionuclide limits in the form of contents or concentrations that can be accepted, the limitations and prohibitions on waste forms and packages that can be received, and the limits, prohibitions, or instructions concerning any other technical information so that the waste is compatible with the safety basis of the facility, and which will result in acceptable waste at subsequent steps in managing the low-level waste.)

(a) Allowable activities and/or concentrations of specific radionuclides.

(b) Acceptable waste form and/or container requirements that ensure the chemical and physical stability of waste under conditions that might be encountered during transportation, storage, treatment, or disposal.

(c) Restrictions or prohibitions on waste, materials, or containers that may adversely affect waste handlers or compromise facility or waste container performance.
The approved RWMB establishes the current compliance status at each radioactive waste management facility. Facility assessments are scheduled to ensure waste management activities are conducted in accordance with the approved RWMB.

DOE Manual 435.1-1 §I.2.F(6) applies to field element managers.

NA; this facility does not accept LLW from other facilities.
See (1) above.

See (1) above.

See (1) above. 
Table 15. (continued).

Facility Name: MFC-785, Hot Fuel Examination Facility

\begin{tabular}{|c|c|}
\hline Chapter IV, LLW Requirements & Facility Compliance Information \\
\hline $\begin{array}{l}\text { (d) The following are additional waste acceptance } \\
\text { requirements that shall be specified in low-level waste } \\
\text { disposal facility waste acceptance requirements: }\end{array}$ & See (1) above. \\
\hline $\begin{array}{l}1 \text { Low-level waste must contribute to and not detract } \\
\text { from achieving long-term stability of the facility, } \\
\text { minimizing the need for long-term active maintenance, } \\
\text { minimizing subsidence, and minimizing contact of } \\
\text { water with waste. Void spaces within the waste and, if } \\
\text { containers are used, between the waste and its container } \\
\text { shall be reduced to the extent practical. }\end{array}$ & See (1) above. \\
\hline $\begin{array}{l}2 \text { Liquid low-level waste or low-level waste containing } \\
\text { free liquid must be converted into a form that contains } \\
\text { as little freestanding liquid as is reasonably achievable, } \\
\text { but in no case shall the liquid exceed } 1 \text { percent of the } \\
\text { waste volume when the low-level waste is in a disposal } \\
\text { container, or } 0.5 \text { percent of the waste volume after it is } \\
\text { processed to a stable form. }\end{array}$ & See (1) above. \\
\hline $\begin{array}{l}3 \text { Low-level waste must not be readily capable of } \\
\text { detonation or of explosive decomposition or reaction at } \\
\text { anticipated pressures and temperatures, or of explosive } \\
\text { reaction with water. Pyrophoric materials contained in } \\
\text { waste shall be treated, prepared, and packaged to be } \\
\text { nonflammable. }\end{array}$ & See (1) above. \\
\hline $\begin{array}{l}4 \text { Low-level waste must not contain, or be capable of } \\
\text { generating by radiolysis or biodegradation, quantities } \\
\text { of toxic gases, vapors, or fumes harmful to the public } \\
\text { or workers or disposal facility personnel, or harmful to } \\
\text { the long-term structural stability of the disposal site. }\end{array}$ & See (1) above. \\
\hline $\begin{array}{l}5 \text { Low-level waste in a gaseous form must be packaged } \\
\text { such that the pressure does not exceed } 1.5 \text { atmospheres } \\
\text { absolute at } 20 \text { C. }[\text { sic }]\end{array}$ & See (1) above. \\
\hline $\begin{array}{l}\text { (e) The basis, procedures, and levels of authority } \\
\text { required for granting exceptions to the waste } \\
\text { acceptance requirements, which shall be contained in } \\
\text { each facility's waste acceptance documentation. Each } \\
\text { exception request shall be documented, including its } \\
\text { disposition as approved or not approved. } \\
\text { From DOE G 435.1-1 Chapter IV: Waste acceptance } \\
\text { requirements are acceptable if they are documented and } \\
\text { contain a clear description of the procedure and bases } \\
\text { for obtaining an exception or deviation to the } \\
\text { acceptance criteria for low-level waste to be received at } \\
\text { the facility. }\end{array}$ & See (1) above. \\
\hline $\begin{array}{l}\text { (2) Evaluation and Acceptance. The receiving facility } \\
\text { shall evaluate waste for acceptance, including } \\
\text { confirmation that the technical and administrative } \\
\text { requirements have been met. A process for the }\end{array}$ & See (1) above. \\
\hline
\end{tabular}


Table 15. (continued).

Facility Name: MFC-785, Hot Fuel Examination Facility

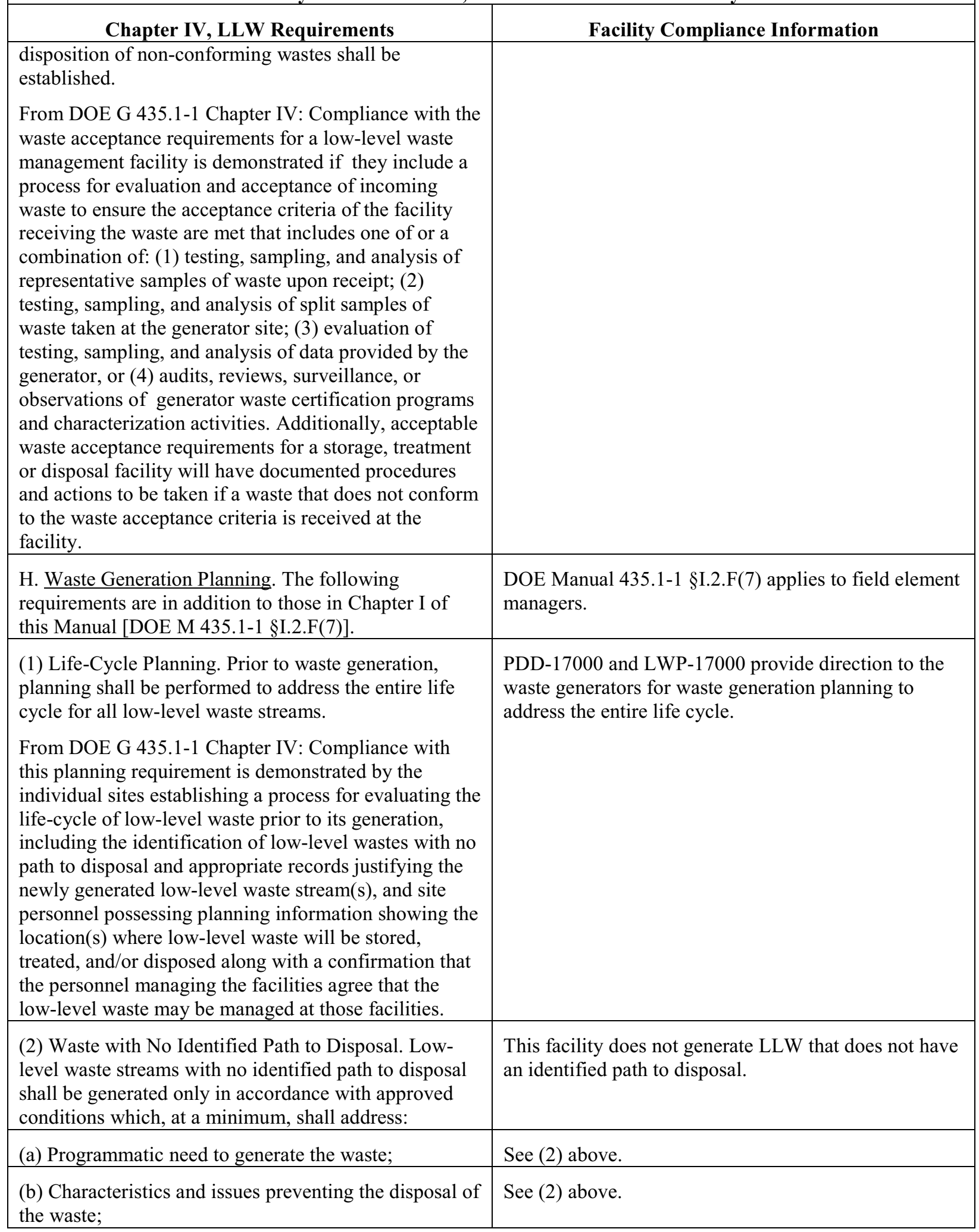


Table 15. (continued).

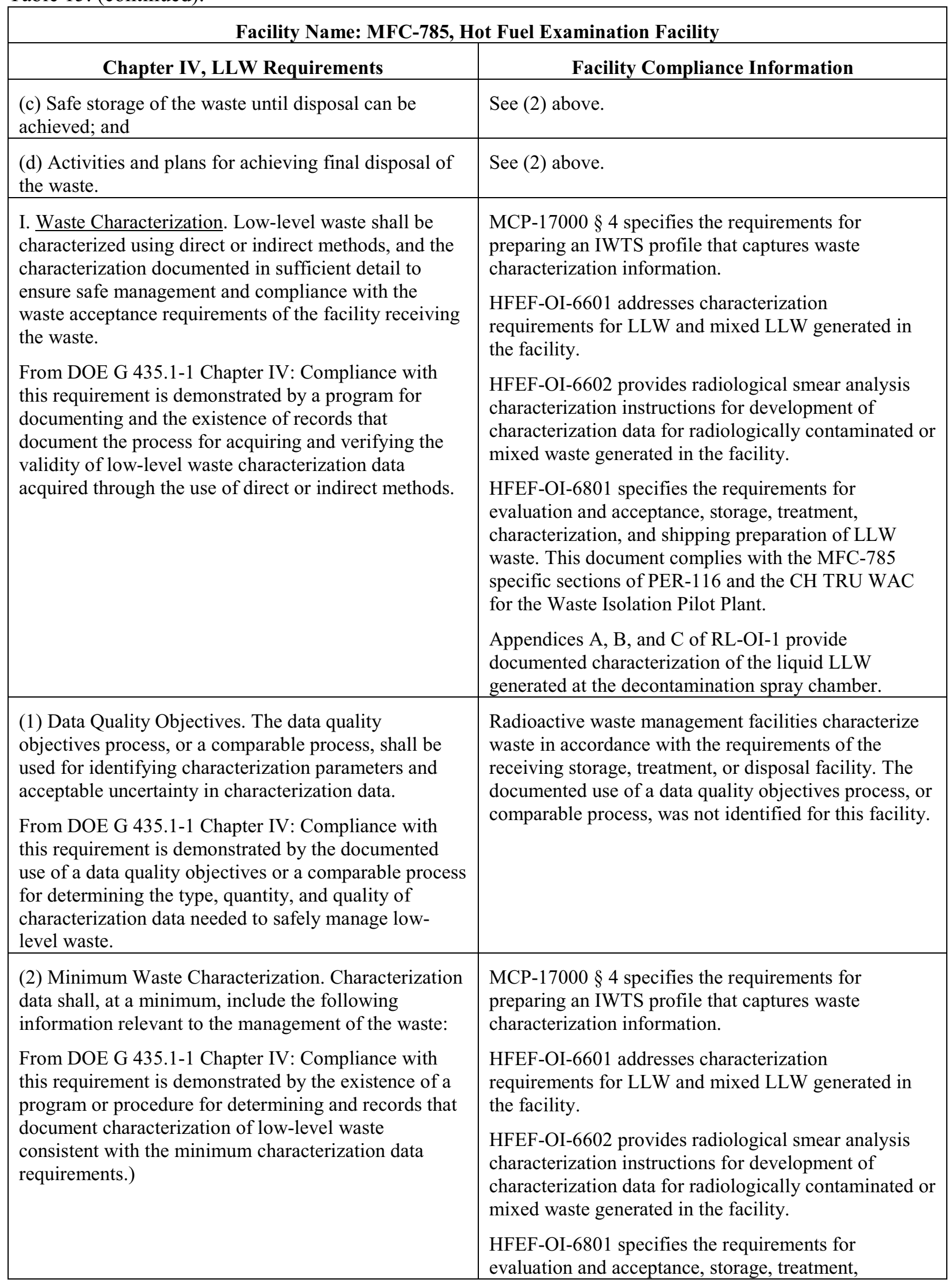


Table 15. (continued).

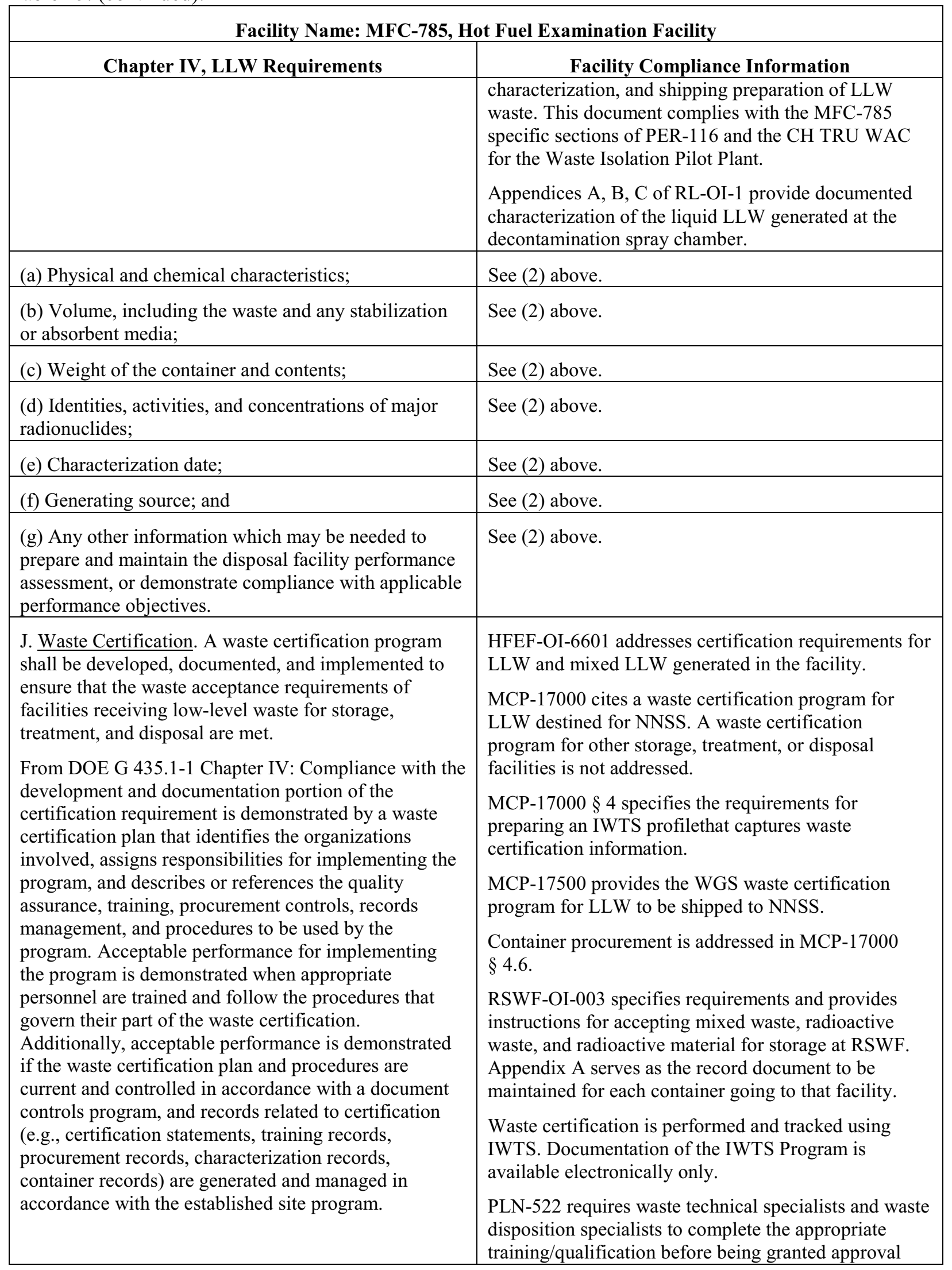


Table 15. (continued).

\begin{tabular}{|c|c|}
\hline \multicolumn{2}{|c|}{ Facility Name: MFC-785, Hot Fuel Examination Facility } \\
\hline Chapter IV, LLW Requirements & Facility Compliance Information \\
\hline & $\begin{array}{l}\text { authority for profiles within the IWTS Program. The } \\
\text { waste certification official, alternate waste certification } \\
\text { official, and NNSS packaging certifiers must complete } \\
\text { the appropriate training/qualifications to disposition } \\
\text { waste to NNSS. } \\
\text { The facility completes a Liquid Waste Generator } \\
\text { Certification Form that is featured as Appendices A } \\
\text { and C of RL-OI-1 to support certification of the liquid } \\
\text { LLW generated their prior to transfer to RLWTF. }\end{array}$ \\
\hline $\begin{array}{l}\text { (1) Certification Program. The waste certification } \\
\text { program shall designate the officials who have the } \\
\text { authority to certify and release waste for shipment; and } \\
\text { specify what documentation is required for waste } \\
\text { generation, characterization, shipment, and } \\
\text { certification. The program shall provide requirements } \\
\text { for auditability, retrievability, and storage of required } \\
\text { documentation and specify the records retention period. }\end{array}$ & See J. above. \\
\hline $\begin{array}{l}\text { From DOE G } 435.1-1 \text { Chapter IV: Compliance with } \\
\text { this requirement is demonstrated by a program or } \\
\text { procedure for record keeping and records showing that } \\
\text { low-level waste is certified as having met the waste } \\
\text { acceptance criteria of the facility to which it was } \\
\text { transferred and that the certification statement is } \\
\text { supported by additional records regarding the waste } \\
\text { source, characterization, and container. }\end{array}$ & \\
\hline $\begin{array}{l}\text { (2) Certification before Transfer. Low-level waste shall } \\
\text { be certified as meeting waste acceptance requirements } \\
\text { before it is transferred to the facility receiving the } \\
\text { waste. }\end{array}$ & See J. above. \\
\hline $\begin{array}{l}\text { From DOE G } 435.1-1 \text { Chapter IV: Compliance with } \\
\text { this requirement is demonstrated by the presence of a } \\
\text { certification program which includes procedures } \\
\text { requiring a signed certification statement prior to the } \\
\text { release of waste for transfer, and by dated records } \\
\text { showing that waste was certified before being } \\
\text { transferred. }\end{array}$ & \\
\hline $\begin{array}{l}\text { (3) Maintaining Certification. Low-level waste that has } \\
\text { been certified as meeting the waste acceptance } \\
\text { requirements for transfer to a storage, treatment, or } \\
\text { disposal facility shall be managed in a manner that } \\
\text { maintains its certification status. }\end{array}$ & See J. above. \\
\hline $\begin{array}{l}\text { From DOE G } 435.1-1 \text { Chapter IV: Compliance with } \\
\text { this requirement is demonstrated by a program or } \\
\text { procedure reflecting this requirement is present and site } \\
\text { personnel are able to show that the storage of low-level } \\
\text { waste containers is in a facility or manner where the } \\
\text { containers would not be damaged by normal weather } \\
\text { events, and cannot be accessed by unauthorized }\end{array}$ & \\
\hline
\end{tabular}


Table 15. (continued).

Facility Name: MFC-785, Hot Fuel Examination Facility

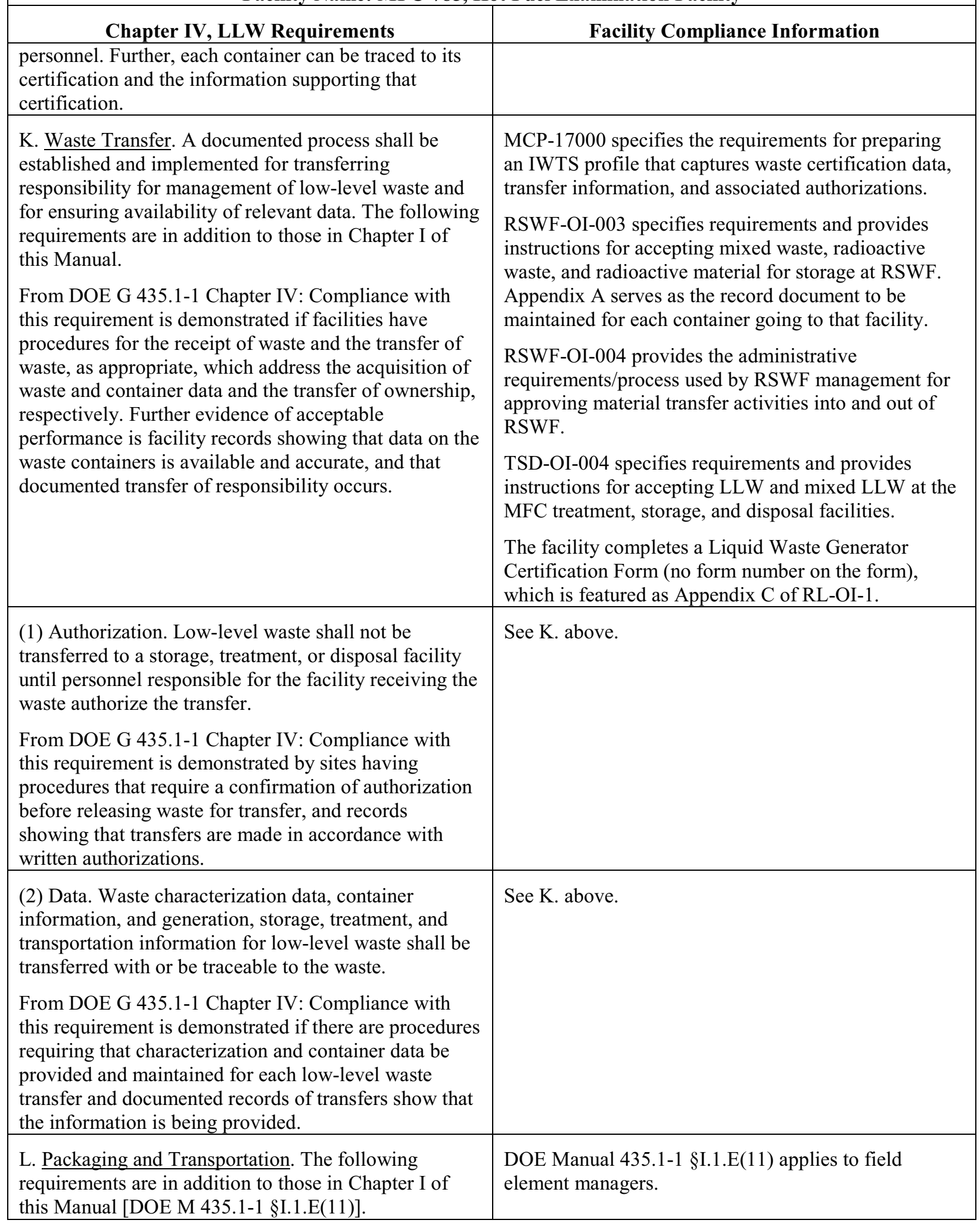


Table 15. (continued).

\begin{tabular}{|c|c|}
\hline \multicolumn{2}{|c|}{ Facility Name: MFC-785, Hot Fuel Examination Facility } \\
\hline Chapter IV, LLW Requirements & Facility Compliance Information \\
\hline $\begin{array}{l}\text { (1) Packaging. If containers are used: } \\
\text { From DOE G } 435.1-1 \text { Chapter IV: Compliance with the } \\
\text { packaging requirement is demonstrated by: (1) } \\
\text { procedures which document proper packaging } \\
\text { protocols; and (2) no trends of routine repackaging of } \\
\text { low-level waste that is packaged after issuance of DOE } \\
\text { O } 435.1 \text {. Successful performance of this requirement is } \\
\text { also demonstrated by a record of containers for which } \\
\text { failure has not routinely occurred under management } \\
\text { conditions. It is recognized that there may be failed } \\
\text { containers for waste previously placed in storage. For } \\
\text { those containers, the goal is to only have to repackage } \\
\text { the waste one time after it is retrieved and } \\
\text { characterized. Further, acceptable performance is } \\
\text { demonstrated by containers of waste having marking } \\
\text { and labeling that allows correlation with waste } \\
\text { characterization data and container information.) }\end{array}$ & MCP-17000 $§ 4$ addresses packaging requirements. \\
\hline $\begin{array}{l}\text { (a) Low-level waste shall be packaged in a manner that } \\
\text { provides containment and protection for the duration of } \\
\text { the anticipated storage period and until disposal is } \\
\text { achieved or until the waste has been removed from the } \\
\text { container. }\end{array}$ & See (1) above. \\
\hline $\begin{array}{l}\text { (b) When waste is packaged, vents or other measures } \\
\text { shall be provided if the potential exists for pressurizing } \\
\text { or generating flammable or explosive concentrations of } \\
\text { gases within the waste container. }\end{array}$ & See (1) above. \\
\hline $\begin{array}{l}\text { (c) Containers of low-level waste shall be marked such } \\
\text { that their contents can be identified. }\end{array}$ & See (1) above. \\
\hline $\begin{array}{l}\text { (2) Transportation. To the extent practical, the volume } \\
\text { of waste and number of low-level waste shipments } \\
\text { shall be minimized. }\end{array}$ & $\begin{array}{l}\text { NA; waste is not shipped to an offsite facility for final } \\
\text { disposition from this facility }\end{array}$ \\
\hline $\begin{array}{l}\text { From DOE G } 435.1-1 \text { Chapter IV: Compliance with } \\
\text { this requirement can be demonstrated by a combination } \\
\text { of site procedures directing the efficient use of waste } \\
\text { container capacity and documentation showing that } \\
\text { low-level waste shipments are systematically planned } \\
\text { and optimized to the extent practical. }\end{array}$ & \\
\hline $\begin{array}{l}\text { M. Site Evaluation and Facility Design. The following } \\
\text { requirements are in addition to those in Chapter I of } \\
\text { this Manual. }\end{array}$ & $\begin{array}{l}\mathrm{NA} \text {; this requirement addresses new radioactive waste } \\
\text { management facilities. }\end{array}$ \\
\hline $\begin{array}{l}\text { (1) Site Evaluation. Proposed locations for low-level } \\
\text { waste facilities shall be evaluated to identify relevant } \\
\text { features that should be avoided or must be considered } \\
\text { in facility design and analyses. }\end{array}$ & See M. above. \\
\hline $\begin{array}{l}\text { (a) Each site proposed for a new low-level waste } \\
\text { facility or expansion of an existing low-level waste }\end{array}$ & See M. above. \\
\hline
\end{tabular}


Table 15. (continued).

Facility Name: MFC-785, Hot Fuel Examination Facility

\begin{tabular}{|c|c|}
\hline Chapter IV, LLW Requirements & Facility Compliance Information \\
\hline $\begin{array}{l}\text { facility shall be evaluated considering environmental } \\
\text { characteristics, geotechnical characteristics, and human } \\
\text { activities, including for a low-level waste disposal } \\
\text { facility, the capability of the site to demonstrate, at a } \\
\text { minimum, whether it is: }\end{array}$ & \\
\hline $\begin{array}{l}1 \text { Located to accommodate the projected volume of } \\
\text { waste to be received; }\end{array}$ & See M. above. \\
\hline $\begin{array}{l}2 \text { Located in a flood plain, a tectonically active area, or } \\
\text { in the zone of water table fluctuation; and }\end{array}$ & See M. above. \\
\hline $\begin{array}{l}3 \text { Located where radionuclide migration pathways are } \\
\text { predictable and erosion and surface runoff can be } \\
\text { controlled. }\end{array}$ & See M. above. \\
\hline $\begin{array}{l}\text { (b) Proposed sites with environmental characteristics, } \\
\text { geotechnical characteristics, and human activities for } \\
\text { which adequate protection cannot be provided through } \\
\text { facility design shall be deemed unsuitable for the } \\
\text { location of the facility. }\end{array}$ & See M. above. \\
\hline $\begin{array}{l}\text { (c) Low-level waste disposal facilities shall be sited to } \\
\text { achieve long-term stability and to minimize, to the } \\
\text { extent practical, the need for active maintenance } \\
\text { following final closure. }\end{array}$ & See M. above. \\
\hline $\begin{array}{l}\text { (2) Low-Level Waste Treatment and Storage Facility } \\
\text { Design. The following facility requirements and } \\
\text { general design criteria, at a minimum, apply: }\end{array}$ & See M. above. \\
\hline $\begin{array}{l}\text { (a) Confinement. Low-level waste systems and } \\
\text { components shall be designed to maintain waste } \\
\text { confinement. }\end{array}$ & See M. above. \\
\hline (b) Ventilation. & See M. above. \\
\hline $\begin{array}{l}1 \text { Design of low-level waste treatment and storage } \\
\text { facilities shall include ventilation, if applicable, } \\
\text { through an appropriate filtration system to maintain the } \\
\text { release of radioactive material in airborne effluents } \\
\text { within the requirements and guidelines specified in } \\
\text { applicable requirements. }\end{array}$ & See M. above. \\
\hline $\begin{array}{l}2 \text { When conditions exist for generating gases in } \\
\text { flammable or explosive concentrations, ventilation } \\
\text { systems or other measures shall be provided to keep the } \\
\text { gases in a non-flammable and nonexplosive condition. } \\
\text { Where concentrations of explosive or flammable gases } \\
\text { are expected to approach the lower flammability limit, } \\
\text { measures shall be taken to prevent deflagration or } \\
\text { detonation. }\end{array}$ & See M. above. \\
\hline $\begin{array}{l}\text { (c) Consideration of Decontamination and } \\
\text { Decommissioning. Areas in new and modifications to } \\
\text { existing low-level waste management facilities that are }\end{array}$ & See M. above. \\
\hline
\end{tabular}


Table 15. (continued).

Facility Name: MFC-785, Hot Fuel Examination Facility

\begin{tabular}{|l|}
\hline \multicolumn{1}{|c|}{ Chapter IV, LLW Requirements } \\
\hline $\begin{array}{l}\text { subject to contamination with radioactive or other } \\
\text { hazardous materials shall be designed to facilitate } \\
\text { decontamination. For such facilities a proposed } \\
\text { decommissioning method or a conversion method } \\
\text { leading to reuse shall be described. }\end{array}$ \\
\hline $\begin{array}{l}\text { (d) Instrumentation and Control Systems. Engineering } \\
\text { controls shall be incorporated in the design and } \\
\text { engineering of low-level waste treatment and storage } \\
\text { facilities to provide volume inventory data and to } \\
\text { prevent spills, leaks, and overflows from tanks or } \\
\text { confinement systems. }\end{array}$ \\
\hline
\end{tabular}

(e) Monitoring. Monitoring and/or leak detection capabilities shall be incorporated in the design and engineering of low-level waste treatment and storage facilities to provide rapid identification of failed confinement and/or other abnormal conditions.

(3) Low-Level Waste Disposal Facility Design. The following facility requirements and general design criteria, at a minimum, apply:

(a) Confinement. Low-level waste systems and components shall be designed to maintain waste confinement.

\section{(b) Ventilation.}

1 Design of low-level waste disposal facilities shall include ventilation, if applicable, through an appropriate filtration system to maintain the release of radioactive material in airborne effluents within the requirements and guidelines specified in applicable requirements.

2 When conditions exist for generating gases in flammable or explosive concentrations, ventilation systems or other measures shall be provided to keep the gases in a nonflammable and non-explosive condition. Where concentrations of explosive or flammable gases are expected to approach the lower flammability limit, measures shall be taken to prevent deflagration or detonation.

(c) Stability. Low-level waste disposal facilities shall be designed to achieve long-term stability and to minimize to the extent practical, the need for active maintenance following final closure.

(d) Control of Water. Low-level waste disposal facilities shall be designed to minimize to the extent practical, the contact of waste with water during and after disposal.
See M. above. Facility Compliance Information

See M. above.

See M. above.

See M. above.

See M. above.

See M. above.

See M. above.

See M. above. 
Table 15. (continued).

Facility Name: MFC-785, Hot Fuel Examination Facility

\begin{tabular}{l}
\hline \multicolumn{1}{c|}{ Chapter IV, LLW Requirements } \\
\hline N. Storage and Staging. The following requirements \\
are in addition to those in Chapter I of this Manual \\
[DOE M 435.1-1 §I.2.F(13)].
\end{tabular}

(1) Storage Prohibitions. Low-level waste in storage shall not be readily capable of detonation, explosive decomposition, reaction at anticipated pressures and temperatures, or explosive reaction with water. Prior to storage, pyrophoric materials shall be treated, prepared, and packaged to be nonflammable.

From DOE G 435.1-1 Chapter IV: Compliance with this requirement is demonstrated by having waste acceptance requirements which prohibit low-level waste that is ignitable or explosive from being accepted for storage unless it has been treated, and procedures for properly preparing such materials for safe storage.

(2) Storage Limit. Low-level waste that has an identified path to disposal shall not be stored longer than one year prior to disposal, except for storage for decay, or as otherwise authorized by the Field Element Manager.

From DOE G 435.1-1 Chapter IV: Storage longer than one year can be justified if the conditions for such storage are approved by the Field Element Manager as part of the radioactive waste management basis for the facility.

Storage for radioactive decay for a period greater than 1 year for waste that has an identified path to disposal is allowed. Adequate justification and the supporting information for storage for decay is to be documented in the radioactive waste management basis for the facility in which the storage will take place.

Mixed waste. Under the Federal Facility Compliance Act of 1992, DOE sites were required to develop Site Treatment Plans to bring stored mixed low-level waste into compliance with these requirements. The Site Treatment Plan needs to be consulted and any mixed low-level waste stored for the purpose of accumulation to facilitate treatment must meet Resource Conservation and Recovery Act storage requirements. There could be several ways within different scenarios that this requirement can be met, as illustrated by the examples below, however, there are basically four ways to show compliance with the requirement and include appropriate provisions in the radioactive waste management basis for the facility in which it is stored.

Legacy waste. As discussed above, the intention of the requirement is not to force malicious compliance or

Facility Compliance Information

Not a facility-specific requirement. DOE Manaul

435.1-1 §I.2.F(13) applies to field element managers.

NA; this facility does not store LLW. See N. (7) below for staging requirements.

NA; this facility does not store LLW. See N. (7) below for staging requirements. 
Table 15. (continued).

Facility Name: MFC-785, Hot Fuel Examination Facility

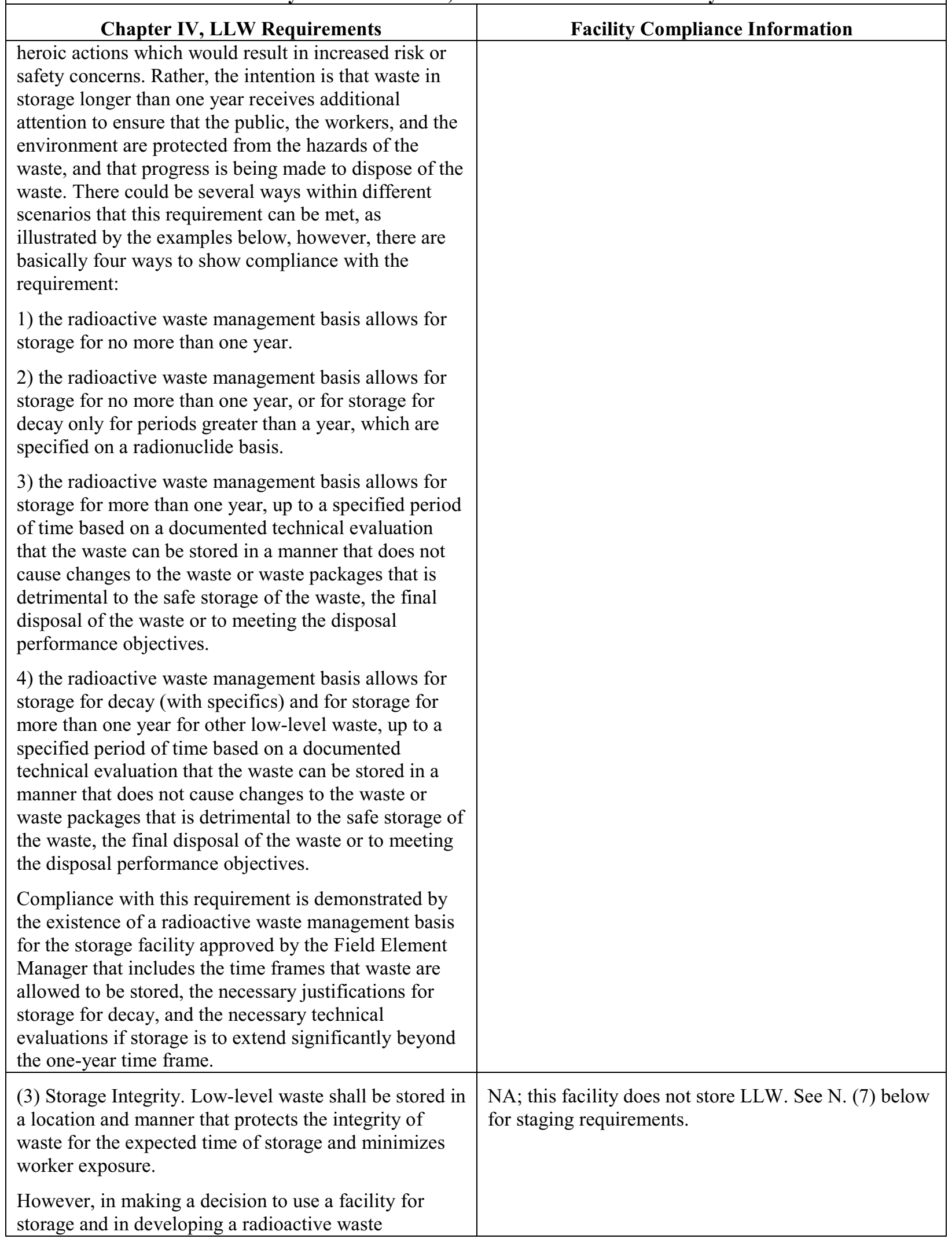


Table 15. (continued).

Facility Name: MFC-785, Hot Fuel Examination Facility

\begin{tabular}{|c|}
\hline Chapter IV, LLW Requirements \\
\hline $\begin{array}{l}\text { management basis for the activity, particular attention } \\
\text { to protection of workers is needed. }\end{array}$ \\
\hline $\begin{array}{l}\text { From DOE G } 435.1-1 \text { Chapter IV: Compliance with } \\
\text { this requirement is demonstrated if sites have storage } \\
\text { capabilities for low-level waste that provide protection } \\
\text { to waste containers so that their integrity will not be } \\
\text { damaged through physical or chemical (corrosion) } \\
\text { processes and that keep personnel from spending } \\
\text { extended periods of time in the areas where low-level } \\
\text { waste is stored. }\end{array}$ \\
\hline
\end{tabular}

(4) Waste Characterization for Storage.

(a) Low-level waste that does not have an identified path to disposal shall be characterized as necessary to meet the data quality objectives and minimum characterization requirements of this Chapter, to ensure safe storage, and to facilitate disposal.

(b) Characterization information for all low-level waste in storage shall be maintained as a record in accordance with the requirements for Records Management in Chapter I of this Manual.

From DOE G 435.1-1 Chapter IV: Compliance with this requirement is demonstrated by documented procedures for managing waste characterization and container information on low-level waste as a Federal record. The records are managed per the applicable policies and procedures for records management referenced in DOE O 200.1 and established at the applicable Field Element.

(5) Container Inspection. A process shall be developed and implemented for inspecting and maintaining containers of low-level waste to ensure container integrity is not compromised.

From DOE G 435.1-1 Chapter IV: Compliance with this requirement is demonstrated by: (1) a documented process for waste container inspection and maintenance; and (2) documentation for all waste container inspections and maintenance actions performed.

(6) Storage Management. Low-level waste storage shall be managed to identify and segregate low-level waste from mixed low-level waste.

(7) Staging. Staging of low-level waste shall be for the purpose of the accumulation of such quantities of waste as necessary to facilitate transportation, treatment, and disposal. Staging longer than 90 days shall meet the requirements for storage above and in Chapter I of this
NA; this facility does not store LLW. See N. (7) below for staging requirements.

NA; this facility does not store LLW. See N. (7) below for staging requirements.

NA; this facility does not store LLW. See N. (7) below for staging requirements.
LI-435 requires quarterly inspections of radioactive waste containers if waste is stored outdoors or has been in storage for greater than 1 year.
NA; this facility does not store LLW. See N. (7) below for staging requirements.

Routine LLW, such as personnel protective equipment, is accumulated at this facility for disposal.

MCP-17000, Appendix F restricts staging LLW to 90 days maximum at any generator or treatment facility prior to acceptance by a storage facility. 
Table 15. (continued).

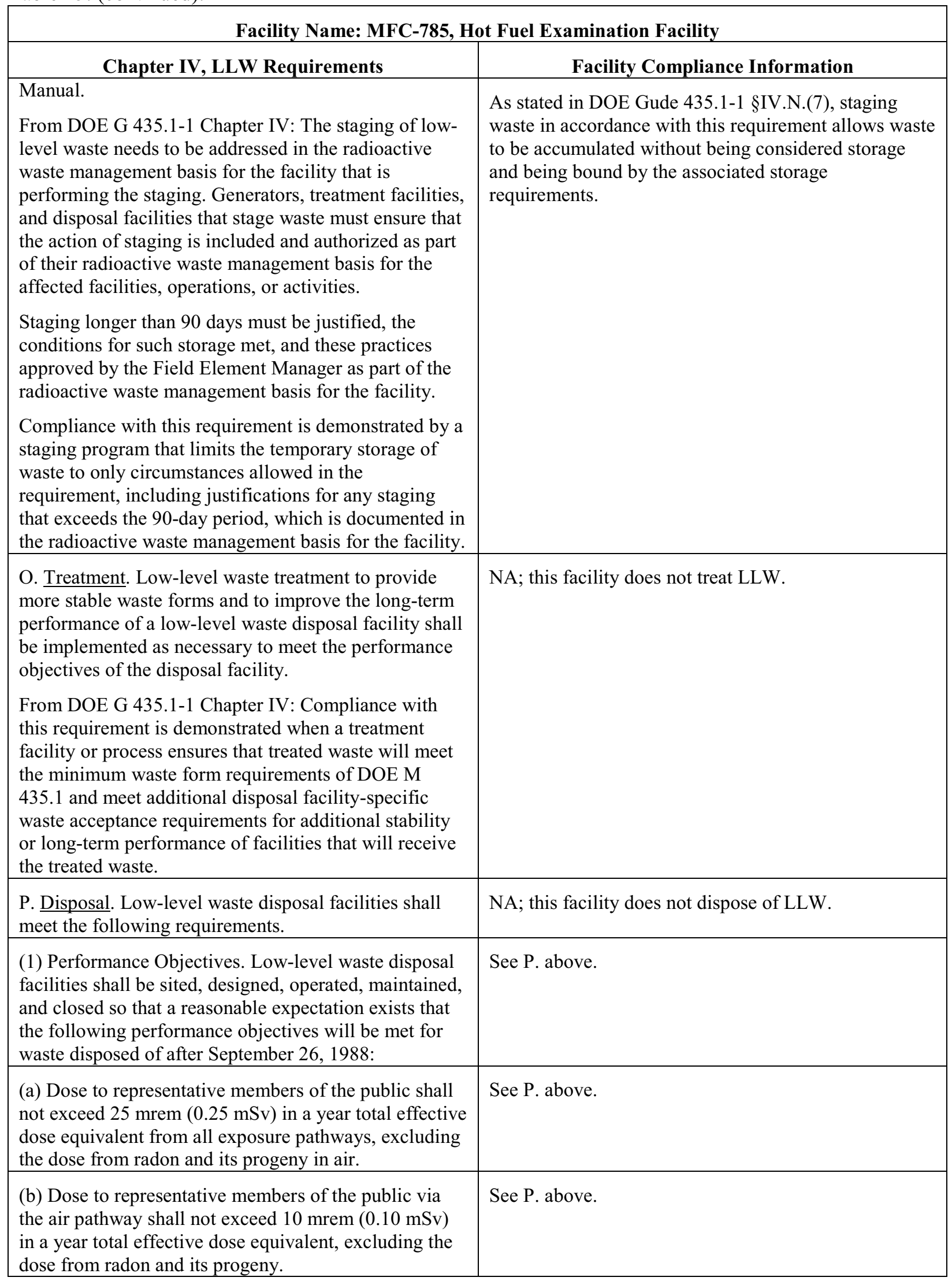


Table 15. (continued).

Facility Name: MFC-785, Hot Fuel Examination Facility

Chapter IV, LLW Requirements

(c) Release of radon shall be less than an average flux of $20 \mathrm{pCi} / \mathrm{m}^{2} / \mathrm{s}\left(0.74 \mathrm{~Bq} / \mathrm{m}^{2} / \mathrm{s}\right)$ at the surface of the disposal facility. Alternatively, a limit of $0.5 \mathrm{pCi} / 1$ $(0.0185 \mathrm{~Bq} / \mathrm{l})$ of air may be applied at the boundary of the facility.

(2) Performance Assessment. A site-specific radiological performance assessment shall be prepared and maintained for DOE low-level waste disposed of after September 26, 1988. The performance assessment shall include calculations for a 1,000 year period after closure of potential doses to representative future members of the public and potential releases from the facility to provide a reasonable expectation that the performance objectives identified in this Chapter are not exceeded as a result of operation and closure of the facility.

(a) Analyses performed to demonstrate compliance with the performance objectives in this Chapter, and to establish limits on concentrations of radionuclides for disposal based on the performance measures for inadvertent intruders in this Chapter shall be based on reasonable activities in the critical group of exposed individuals. Unless otherwise specified, the assumption of average living habits and exposure conditions in representative critical groups of individuals projected to receive the highest doses is appropriate. The likelihood of inadvertent intruder scenarios may be considered in interpreting the results of the analyses and establishing radionuclide concentrations, if adequate justification is provided.

(b) The point of compliance shall correspond to the point of highest projected dose or concentration beyond a 100 meter buffer zone surrounding the disposed waste. A larger or smaller buffer zone may be used if adequate justification is provided.

(c) Performance assessments shall address reasonably foreseeable natural processes that might disrupt barriers against release and transport of radioactive materials.

(d) Performance assessments shall use DOE-approved dose coefficients (dose conversion factors) for internal and external exposure of reference adults.

(e) The performance assessment shall include a sensitivity/uncertainty analysis.

(f) Performance assessments shall include a demonstration that projected releases of radionuclides to the environment shall be maintained as low as reasonably achievable (ALARA).
Facility Compliance Information

See P. above.

See P. above.

See P. above.

See P. above.

See P. above.

See P. above.

See P. above.

See P. above. 
Table 15. (continued).

\begin{tabular}{|c|c|}
\hline \multicolumn{2}{|c|}{ Facility Name: MFC-785, Hot Fuel Examination Facility } \\
\hline Chapter IV, LLW Requirements & Facility Compliance Information \\
\hline $\begin{array}{l}\text { (g) For purposes of establishing limits on radionuclides } \\
\text { that may be disposed of near-surface, the performance } \\
\text { assessment shall include an assessment of impacts to } \\
\text { water resources. }\end{array}$ & See P. above. \\
\hline $\begin{array}{l}\text { (h) For purposes of establishing limits on the } \\
\text { concentration of radionuclides that may be disposed of } \\
\text { near-surface, the performance assessment shall include } \\
\text { an assessment of impacts calculated for a hypothetical } \\
\text { person assumed to inadvertently intrude for a } \\
\text { temporary period into the low-level waste disposal } \\
\text { facility. For intruder analyses, institutional controls } \\
\text { shall be assumed to be effective in deterring intrusion } \\
\text { for at least } 100 \text { years following closure. The intruder } \\
\text { analyses shall use performance measures for chronic } \\
\text { and acute exposure scenarios, respectively, of } 100 \\
\text { mrem }(1 \mathrm{mSv}) \text { in a year and } 500 \text { mrem }(5 \mathrm{mSv}) \text { total } \\
\text { effective dose equivalent excluding radon in air. }\end{array}$ & See P. above. \\
\hline $\begin{array}{l}\text { (3) Composite Analysis. For disposal facilities which } \\
\text { received waste after September } 26,1988 \text {, a site-specific } \\
\text { radiological composite analysis shall be prepared and } \\
\text { maintained that accounts for all sources of radioactive } \\
\text { material that may be left at the DOE site and may } \\
\text { interact with the low- level waste disposal facility, } \\
\text { contributing to the dose projected to a hypothetical } \\
\text { member of the public from the existing or future } \\
\text { disposal facilities. Performance measures shall be } \\
\text { consistent with DOE requirements for protection of the } \\
\text { public and environment and evaluated for a } 1,000 \text { year } \\
\text { period following disposal facility closure. The } \\
\text { composite analysis results shall be used for planning, } \\
\text { radiation protection activities, and future use } \\
\text { commitments to minimize the likelihood that current } \\
\text { low- level waste disposal activities will result in the } \\
\text { need for future corrective or remedial actions to } \\
\text { adequately protect the public and the environment. }\end{array}$ & See P. above. \\
\hline $\begin{array}{l}\text { (4) Performance Assessment and Composite Analysis } \\
\text { Maintenance. The performance assessment and } \\
\text { composite analysis shall be maintained to evaluate } \\
\text { changes that could affect the performance, design, and } \\
\text { operating bases for the facility. Performance } \\
\text { assessment and composite analysis maintenance shall } \\
\text { include the conduct of research, field studies, and } \\
\text { monitoring needed to address uncertainties or gaps in } \\
\text { existing data. The performance assessment shall be } \\
\text { updated to support the final facility closure. Additional } \\
\text { iterations of the performance assessment and composite } \\
\text { analysis shall be conducted as necessary during the } \\
\text { post-closure period. }\end{array}$ & See P. above. \\
\hline
\end{tabular}


Table 15. (continued).

Facility Name: MFC-785, Hot Fuel Examination Facility

Chapter IV, LLW Requirements

(a) Performance assessments and composite analyses shall be reviewed and revised when changes in waste forms or containers, radionuclide inventories, facility design and operations, closure concepts, or the improved understanding of the performance of the waste disposal facility in combination with the features of the site on which it is located alter the conclusions or the conceptual model(s) of the existing performance assessment or composite analysis.

(b) A determination of the continued adequacy of the performance assessment and composite analysis shall be made on an annual basis, and shall consider the results of data collection and analysis from research, field studies, and monitoring.

(c) Annual summaries of low-level waste disposal operations shall be prepared with respect to the conclusions and recommendations of the performance assessment and composite analysis and a determination of the need to revise the performance assessment or composite analysis.

(5) Disposal Authorization. A disposal authorization statement shall be obtained prior to construction of a new low-level waste disposal facility. Field Elements with existing low-level waste disposal facilities shall obtain a disposal authorization statement in accordance with the schedule in the Complex-Wide Low-Level Waste Management Program Plan. The disposal authorization statement shall be issued based on a review of the facility's performance assessment, composite analysis, performance assessment and composite analysis maintenance, preliminary closure plan, and preliminary monitoring plan. The disposal authorization statement shall specify the limits and conditions on construction, design, operations, and closure of the low-level waste facility based on these reviews. A disposal authorization statement is a part of the radioactive waste management basis for a disposal facility. Failure to obtain a disposal authorization statement by the implementation date of this Order shall result in shutdown of the disposal facility.

(6) Disposal Facility Operations. The disposal facility design and operation must be consistent with the disposal facility closure plan and lead to disposal facility closure that provides a reasonable expectation that performance objectives will be met. Low-level waste shall be disposed in such a manner that achieves the performance objectives stated in this Chapter, consistent with the disposal facility radiological performance assessment. Additional requirements
Facility Compliance Information

See P. above.

See P. above.

See P. above.

See P. above.

See P. above. 
Table 15. (continued).

\begin{tabular}{|c|c|}
\hline \multicolumn{2}{|c|}{ Facility Name: MFC-785, Hot Fuel Examination Facility } \\
\hline Chapter IV, LLW Requirements & Facility Compliance Information \\
\hline include: & \\
\hline $\begin{array}{l}\text { (a) Operating procedures shall be developed and } \\
\text { implemented for low-level waste disposal facilities that } \\
\text { protect the public, workers, and the environment; } \\
\text { ensure the security of the facility; minimize subsidence } \\
\text { during and after waste emplacement; achieve long-term } \\
\text { stability and minimize the need for long-term active } \\
\text { maintenance; and meet the requirements of the } \\
\text { closure/post-closure plan. }\end{array}$ & See P. above. \\
\hline $\begin{array}{l}\text { (b) Permanent identification markers for disposal } \\
\text { excavations and monitoring wells shall be emplaced. }\end{array}$ & See P. above. \\
\hline $\begin{array}{l}\text { (c) Low-level waste placement into disposal units shall } \\
\text { minimize voids between waste containers. Voids within } \\
\text { disposal units shall be filled to the extent practical. } \\
\text { Uncontainerized bulk waste shall also be placed in a } \\
\text { manner that minimizes voids and subsidence. }\end{array}$ & See P. above. \\
\hline $\begin{array}{l}\text { (d) Operations are to be conducted so that active waste } \\
\text { disposal operations will not have an adverse effect on } \\
\text { any other disposal units. }\end{array}$ & See P. above. \\
\hline $\begin{array}{l}\text { (e) Operations shall include a process for tracking and } \\
\text { documenting low-level waste placement in the facility } \\
\text { by generator source. }\end{array}$ & See P. above. \\
\hline $\begin{array}{l}\text { (7) Alternate Requirements for Low-Level Waste } \\
\text { Disposal Facility Design and Operation. Requirements } \\
\text { other than those set forth in this Section for the design } \\
\text { and operation of a low-level waste disposal facility } \\
\text { may be approved on a specific basis if a reasonable } \\
\text { expectation is demonstrated that the disposal } \\
\text { performance objectives will be met. }\end{array}$ & See P. above. \\
\hline $\begin{array}{l}\text { Q. Closure. The following requirements are in addition } \\
\text { to those in Chapter I of this Manual. }\end{array}$ & NA; this facility does not dispose of LLW. \\
\hline $\begin{array}{l}\text { (1) Disposal Facility Closure Plans. A preliminary } \\
\text { closure plan shall be developed and submitted to } \\
\text { Headquarters for review with the performance } \\
\text { assessment and composite analysis. The closure plan } \\
\text { shall be updated following issuance of the disposal } \\
\text { authorization statement to incorporate conditions } \\
\text { specified in the disposal authorization statement. } \\
\text { Closure plans shall: }\end{array}$ & See Q. above. \\
\hline $\begin{array}{l}\text { (a) Be updated as required during the operational life of } \\
\text { the facility. }\end{array}$ & See Q. above. \\
\hline $\begin{array}{l}\text { (b) Include a description of how the disposal facility } \\
\text { will be closed to achieve long-term stability and } \\
\text { minimize the need for active maintenance following } \\
\text { closure and to ensure compliance with the requirements } \\
\text { of DOE 5400.5, Radiation Protection of the Public and }\end{array}$ & See Q. above. \\
\hline
\end{tabular}


Table 15. (continued).

\begin{tabular}{|c|c|}
\hline \multicolumn{2}{|c|}{ Facility Name: MFC-785, Hot Fuel Examination Facility } \\
\hline Chapter IV, LLW Requirements & Facility Compliance Information \\
\hline the Environment. & \\
\hline $\begin{array}{l}\text { (c) Include the total expected inventory of wastes to be } \\
\text { disposed of at the facility over the operational life of } \\
\text { the facility. }\end{array}$ & See Q. above. \\
\hline $\begin{array}{l}\text { (2) Disposal Facility Closure. Closure of a disposal } \\
\text { facility shall occur within a five-year period after it is } \\
\text { filled to capacity, or after the facility is otherwise } \\
\text { determined to be no longer needed. }\end{array}$ & See Q. above. \\
\hline $\begin{array}{l}\text { (a) Prior to facility closure, the final inventory of the } \\
\text { low-level waste disposed in the facility shall be } \\
\text { prepared and incorporated in the performance } \\
\text { assessment and composite analysis which shall be } \\
\text { updated to support the closure of the facility. }\end{array}$ & See Q. above. \\
\hline $\begin{array}{l}\text { (b) A final closure plan shall be prepared based on the } \\
\text { final inventory of waste disposed in the facility, the } \\
\text { plan implemented, and the updated performance } \\
\text { assessment and composite analysis prepared in support } \\
\text { of the facility closure. }\end{array}$ & See Q. above. \\
\hline $\begin{array}{l}\text { (c) Institutional control measures shall be integrated } \\
\text { into land use and stewardship plans and programs, and } \\
\text { shall continue until the facility can be released pursuant } \\
\text { to DOE } 5400.5, \text { Radiation Protection of the Public and } \\
\text { the Environment. }\end{array}$ & See Q. above. \\
\hline $\begin{array}{l}\text { (d) The location and use of the facility shall be filed } \\
\text { with the local authorities responsible for land use and } \\
\text { zoning. }\end{array}$ & See Q. above. \\
\hline $\begin{array}{l}\text { R. Monitoring. The following requirements are in } \\
\text { addition to those in Chapter I of this Manual [DOE M } \\
\text { 435.1-1 §I.1.E(7)]. }\end{array}$ & $\begin{array}{l}\text { DOE Manual 435.1-1 §I.1.E(7) applies to field element } \\
\text { managers. }\end{array}$ \\
\hline $\begin{array}{l}\text { (1) All Waste Facilities. Parameters that shall be } \\
\text { sampled or monitored, at a minimum, include: } \\
\text { temperature, pressure (for closed systems), } \\
\text { radioactivity in ventilation exhaust and liquid effluent } \\
\text { streams, and flammable or explosive mixtures of gases. } \\
\text { Facility monitoring programs shall include verification } \\
\text { that passive and active control systems have not failed. } \\
\text { From DOE G 435.1-1 Chapter IV: The minimum } \\
\text { parameters specified in the requirement were selected } \\
\text { based on their potential significance for anticipating } \\
\text { and identifying undesirable conditions at low-level } \\
\text { waste management facilities. Each facility's radioactive } \\
\text { waste management basis should include an evaluation } \\
\text { of the applicability and significance of the minimum } \\
\text { parameters. This evaluation also needs to consider } \\
\text { additional parameters to be sampled or monitored to } \\
\text { ensure the protection of the public health, the }\end{array}$ & $\begin{array}{l}\text { Monitoring requirements at INL radioactive waste } \\
\text { management facilities are tailored for the specific } \\
\text { facility to enable timely indication of developing } \\
\text { problems. Existing radiological control procedures and } \\
\text { assessments are followed/completed to monitor waste } \\
\text { facilities. } \\
\text { LRD-15001 and MCP-139 specify methods and } \\
\text { frequency of radiological control surveys of all } \\
\text { radiological areas. MCP-139 specifies the use of } \\
\text { Form } 441 . \text { A34. This form is referred to as the "routine } \\
\text { sheet" and is to be used by facility radiological control } \\
\text { foremen to list radiological areas that are to be } \\
\text { surveyed, the survey periods, and method. }\end{array}$ \\
\hline
\end{tabular}


Table 15. (continued).

Facility Name: MFC-785, Hot Fuel Examination Facility

\begin{tabular}{|c|c|}
\hline Chapter IV, LLW Requirements & Facility Compliance Information \\
\hline $\begin{array}{l}\text { environment, and the workers. If a minimum parameter } \\
\text { specified in the requirement is deemed to be not } \\
\text { applicable in any way to the active operation of that } \\
\text { facility, then that justification should be included in the } \\
\text { radioactive waste management basis and when } \\
\text { approved constitutes an exemption to the manual. }\end{array}$ & \\
\hline $\begin{array}{l}\text { Verification activities are part of the radioactive waste } \\
\text { management basis as a condition for operation and } \\
\text { documented appropriately. }\end{array}$ & \\
\hline $\begin{array}{l}\text { Compliance with this requirement is demonstrated if } \\
\text { monitoring or sampling for the stated parameters is } \\
\text { performed for all facilities with a precision, accuracy, } \\
\text { and frequency consistent with timely identification of } \\
\text { developing problems and a justification exists in the } \\
\text { approved radioactive waste management basis for those } \\
\text { specified parameters which are not monitored or } \\
\text { sampled. }\end{array}$ & \\
\hline $\begin{array}{l}\text { (2) Liquid Waste Storage Facilities. For facilities } \\
\text { storing liquid low-level waste, the following shall also } \\
\text { be monitored: liquid level and/or waste volume, and } \\
\text { significant waste chemistry parameters. }\end{array}$ & NA; this facility does not store liquid LLW. \\
\hline $\begin{array}{l}\text { (3) Disposal Facilities. A preliminary monitoring plan } \\
\text { for a low-level waste disposal facility shall be prepared } \\
\text { and submitted to Headquarters for review with the } \\
\text { performance assessment and composite analysis. The } \\
\text { monitoring plan shall be updated within one year } \\
\text { following issuance of the disposal authorization } \\
\text { statement to incorporate and implement conditions } \\
\text { specified in the disposal authorization statement. }\end{array}$ & NA; this facility does not dispose of LLW. \\
\hline $\begin{array}{l}\text { (a) The site-specific performance assessment and } \\
\text { composite analysis shall be used to determine the } \\
\text { media, locations, radionuclides, and other substances to } \\
\text { be monitored. }\end{array}$ & See (3) above. \\
\hline $\begin{array}{l}\text { (b) The environmental monitoring program shall be } \\
\text { designed to include measuring and evaluating releases, } \\
\text { migration of radionuclides, disposal unit subsidence, } \\
\text { and changes in disposal facility and disposal site } \\
\text { parameters which may affect long-term performance. }\end{array}$ & See (3) above. \\
\hline $\begin{array}{l}\text { (c) The environmental monitoring programs shall be } \\
\text { capable of detecting changing trends in performance to } \\
\text { allow application of any necessary corrective action } \\
\text { prior to exceeding the performance objectives in this } \\
\text { Chapter. }\end{array}$ & See (3) above. \\
\hline
\end{tabular}




\subsection{MFC-787, Fuels and Applied Sciences Building}

1. Facility description: MFC-787, Fuels and Applied Science Building, is a radiological facility that provides for development of low enriched uranium fuel as an alternative for research reactors, spent fuel treatment, and the conduct of other experimental projects. Equipment and operations in MFC-787 include the following:

- West development glovebox contains a molten salt furnace that is used to perform elementary electrometallurgical research on nuclear materials.

- East development glovebox contains a prototype of a metal waste form furnace that is installed in HFEF. The metal waste form furnace is a passively-cooled, high-temperature induction furnace, which is designed to consolidate cladding hulls resulting from operation of the electrorefiners in FCF. The prototype furnace will be used in the future to resolve any operational issues that may arise in the HFEF furnace during checkout and ingot production.

- Bench-scale casting development system is used for small-scale materials and process development tests, including benchmarking. Recent interest in recycling of minor actinides through scalable remote fuel fabrication processes, with very low material losses, has spurred effort to improve the technology in the areas of (1) elimination of losses of high vapor-pressure minor actinides, (2) elimination of quartz mold waste, and (3) elimination of crucible cleaning, recoating, and associated waste.

- Gamma irradiator contains a large, shielded Co-60 source used for irradiation of samples to evaluate the effects of gamma-ray doses on those samples.

- X-ray diffraction is performed as a nondestructive analytical test to determine information about the crystallographic structure, chemical composition, and physical properties of materials and thin films. This is based on observing the scattered intensity of an x-ray beam hitting a sample as a function of incident and scattered angle, polarization, and wavelength or energy.

- Reduced Enrichment Research and Test Reactors main glovebox operations include (1) uranium alloy atomization (conversion of a solid uranium alloy pin into a powder form), (2) uranium fuel powder handling, processing, and compacting, (3) arc melting metals to produce alloys, (4) hydride/ dehydride processing to form uranium alloy powder.

- Reduced Enrichment Research and Test Reactors small glovebox operations include preparation, fabrication, testing, and sampling of metal or ceramic materials.

- The hot isostatic press is a Reduced Enrichment Research and Test Reactors project that uses high temperature and high pressure to bond metallic fuels and claddings.

- Friction bonding is a Reduced Enrichment Research and Test Reactors fuel fabrication process that is used to clad aluminum with the uranium alloy foils through applying pressure to a tool that generates heat and softens material. The softened material produces a plastic flow that stirs metal from both sides, creating a weld.

- Tensile testing is performed to determine the failure strength of the monolithic foils and fuel plates in fuel development.

- Ultrasonic testing is performed to evaluate/inspect fuel and other materials.

- Newly installed equipment:

- Tribometer - new capability used for mechanical testing of materials (surface friction, in particular); can be used for multiple programs and materials tested will be primarily U/Mo fuels (high priority for the Reduced Enrichment Research and Test Reactors program). 
- Positron Annihilator Spectrometer - new capability used for examining residual stresses of fuels, micro-structural changes to fuels due to irradiation; can examine systems at smaller length scale than a TEM.

- Laser flash analyzer - measures thermal properties of reactor materials.

- Differential scanning calorimeter analyzer - measures thermo-physical material properties of materials and supports reactor experiments nd new reactor designs.

- Dilatometer - measures thermo-physical material properties of materials and supports reactor experiments and new reactor designs.

2. Hazard category: LTHC3

3. Radioactive waste managed at this facility: CH LLW and mixed CH LLW are generated and staged at this facility.

\section{RWMB documents/programs:}

a. Safety basis/hazard analysis:

- EDF-7030, "Inventory Analysis of Radiological Facilities at the Materials and Fuels Complex (MFC)"

b. Laboratory-wide:

- Form 441.A34, "INL Radiological Control Required Surveys"

- LI-435, "Waste Management Routine Field Activities"

- LRD-15001, "Radiological Control Manual"

- LWP-8000, Environmental Instructions for Facilities, Processes, Materials, and Equipment

- LWP-13840, "Management of Issues, Observations, and Noteworthy Practices"

- LWP-14002, "Timeout and Stop Work Authority"

- LWP-15011, "Radioactive Material Areas and Radioactive Storage Areas"

- LWP-17000, "Waste Management"

- MCP-139, "Radiological Surveys"

- MCP-17000, "Waste Generator Services Waste Management"

- MCP-17410, "Management of Waste Storage Areas"

- MCP-17500, "Waste Generator Services Certification of Waste Shipments to the Nevada Test Site"

- PDD-17000, "Waste Management Program"

- PLN-114, "INL Emergency Plan/RCRA Contingency Plan"

- PLN-522, "Quality Assurance Program Plan for the Waste Management/Waste Certification Program"

c. Facility-specific:

- 1356-07-FASB, "FASB General Laboratory Work"

- SD-38.1.1, "Treatment, Storage, and Disposal Facilities (TSDF) Environmental Compliance"

- TSD-OI-004 "Waste and Material Acceptance for Storage/Treatment and Radioactive Material Inventory Control."

LLW is managed at this facility. Table 16 shows the facility compliance information for DOE Manual 435.1-1 Chapter IV, "Low-level Waste Requirements." 
Table 16. MFC-787, Fuels and Applied Sciences Building, DOE Manual 435.1-1 low-level waste requirements and facility compliance information.

\begin{tabular}{|c|c|}
\hline \multicolumn{2}{|c|}{ Facility Name: MFC-787, Fuels and Applied Sciences Building } \\
\hline Chapter IV, LLW Requirements & Facility Compliance Information \\
\hline $\begin{array}{l}\text { A. Definition of Low-Level Waste. Low-level } \\
\text { radioactive waste is radioactive waste that is not high- } \\
\text { level radioactive waste, spent nuclear fuel, transuranic } \\
\text { waste, byproduct material (as defined in section } 11 \mathrm{e} .(2) \\
\text { of the Atomic Energy Act of } 1954 \text {, as amended), or } \\
\text { naturally occurring radioactive material. } \\
\text { (From DOE G } 435.1-1 \text { Chapter IV: Low-level } \\
\text { radioactive waste is defined by what it is not. The } \\
\text { guidance on definitions in Chapters II and III should be } \\
\text { consulted first for making a determination on how to } \\
\text { properly manage a suspect waste stream.) }\end{array}$ & $\begin{array}{l}\text { This requirement provides the criteria for determining } \\
\text { which DOE radioactive waste is to be managed as } \\
\text { LLW in accordance with DOE Manaul } 435.1-1 \text {, } \\
\text { Chapter IV. } \\
\text { Radioactive waste managed at this facility under the } \\
\text { requirements of this chapter is not managed under the } \\
\text { requirements of DOE Manual } 435.1-1 \text {, Chapter II or } \\
\text { Chapter III. }\end{array}$ \\
\hline $\begin{array}{l}\text { B. Management of Specific Wastes. The following } \\
\text { provide for management of specific wastes as low-level } \\
\text { waste in accordance with the requirements in this } \\
\text { Chapter: }\end{array}$ & See below. \\
\hline $\begin{array}{l}\text { (1) Mixed Low-Level Waste. Low-level waste } \\
\text { determined to contain both source, special nuclear, or } \\
\text { byproduct material subject to the Atomic Energy Act of } \\
1954 \text {, as amended, and a hazardous component subject } \\
\text { to the Resource Conservation and Recovery Act } \\
\text { (RCRA), as amended, shall be managed in accordance } \\
\text { with the requirements of RCRA and DOE O 435.1, } \\
\text { Radioactive Waste Management, and this Manual. }\end{array}$ & $\begin{array}{l}\text { This facility may manage mixed LLW. } \\
\text { Compliance with RCRA regulations is addressed by } \\
\text { WGS in its waste management services role in } \\
\text { MCP-17000. } \\
\text { 1356-07-FASB } \S 2 \text {, Table } 2.03 \text { addresses mixed LLW. } \\
\text { Individual projects also would have project-specific } \\
\text { laboratory instructions that would address the } \\
\text { management of mixed LLW in accordance with RCRA } \\
\text { regulations. }\end{array}$ \\
\hline $\begin{array}{l}\text { (2) TSCA-Regulated Waste. Low-level waste } \\
\text { containing polychlorinated biphenyls, asbestos, or } \\
\text { other such regulated toxic components shall be } \\
\text { managed in accordance with requirements derived from } \\
\text { the Toxic Substances Control Act, as amended, DOE O } \\
\text { 435.1, Radioactive Waste Management, and this } \\
\text { Manual. }\end{array}$ & $\begin{array}{l}\text { NA; this facility does not manage TSCA-regulated } \\
\text { waste. }\end{array}$ \\
\hline $\begin{array}{l}\text { (3) Accelerator-Produced Waste. Radioactive waste } \\
\text { produced as a result of operations of DOE accelerators } \\
\text { is low-level waste and shall be managed in accordance } \\
\text { with DOE O } 435.1 \text {, Radioactive Waste Management, } \\
\text { and this Manual, and all applicable Federal or State } \\
\text { requirements. }\end{array}$ & $\begin{array}{l}\text { NA; this facility does not manage accelerator-produced } \\
\text { waste. }\end{array}$ \\
\hline $\begin{array}{l}\text { (4) } 11 \text { e.(2) and Naturally Occurring Radioactive } \\
\text { Material. Small quantities of 11e.(2) byproduct } \\
\text { material and naturally occurring radioactive material } \\
\text { may be managed as low-level waste provided they can } \\
\text { be managed to meet the requirements for low-level } \\
\text { waste disposal in Section IV.P of this Manual. }\end{array}$ & $\begin{array}{l}\text { NA; this facility does not manage naturally occurring } \\
\text { radioactive material. }\end{array}$ \\
\hline $\begin{array}{l}\text { C. Complex-Wide Low-Level Waste Management } \\
\text { Program. A complex-wide program and plan shall be }\end{array}$ & $\begin{array}{l}\text { Not a facility-specific requirement. DOE Manual } \\
435.1-1 \text { §I.2.B and §I.2.D apply to the Assistant }\end{array}$ \\
\hline
\end{tabular}


Table 16. (continued).

Facility Name: MFC-787, Fuels and Applied Sciences Building

\begin{tabular}{|l|}
\hline \multicolumn{1}{|c|}{ Chapter IV, LLW Requirements } \\
\hline $\begin{array}{l}\text { developed as described under Responsibilities, 2.B and } \\
\text { 2.D, in Chapter I of this Manual. }\end{array}$ \\
$\begin{array}{l}\text { D. Radioactive Waste Management Basis. Low-level } \\
\text { waste facilities, operations, and activities shall have a } \\
\text { radioactive waste management basis consisting of } \\
\text { physical and administrative controls to ensure the } \\
\text { protection of workers, the public, and the environment. } \\
\text { The following specific waste management controls } \\
\text { shall be part of the radioactive waste management } \\
\text { basis: }\end{array}$ \\
\hline
\end{tabular}

(1) Generators. The waste certification program.

From DOE G 435.1-1 Chapter IV: For a facility that generates low-level waste, the radioactive waste management basis is to include the program for certifying that waste meets the waste acceptance requirements of the facility(ies) to which the waste will be sent.

(2) Treatment Facilities. certification program. The waste acceptance requirements and the waste [sic]

From DOE G 435.1-1 Chapter IV: Facilities that store or treat low-level waste are to have approved waste acceptance requirements (see DOE M 435.1-1, Section IV.G) prior to the issuance of a radioactive waste management basis.

A facility that stores or treats waste also is generally expected to have a waste certification program. Waste from these facilities will have to be certified as meeting the waste acceptance requirements of the facility to which it will be transferred, and the facilities have the potential for generating radioactive waste (e.g., secondary processing streams from treatment, monitoring and sampling, radioactive release cleanup). Consequently, storage and treatment facilities should also have an approved waste certification program as part of their radioactive waste management basis.

As part of the radioactive waste management basis, site personnel needs to implement a system or process for tracking the waste inventory at a storage, treatment, or disposal facility.

(3) Storage Facilities. The waste acceptance requirements and the waste certification program.

From DOE G 435.1-1 Chapter IV: Facilities that store or treat low-level waste are to have approved waste acceptance requirements (see DOE M 435.1-1, Section IV.G) prior to the issuance of a radioactive waste management basis.

\section{Facility Compliance Information}

Secretary for Environmental Management and the Deputy Assistant Secretary for Waste Management, respectively.

The RWMB provides the regulatory framework for management of radioactive waste at INL. It specifically identifies facility management and implementing documents for the generation, storage, treatment, and disposal of radiological waste..

This facility is a LTHC3 facility (EDF-7030).

See J. below.

NA; LLW is not treated at this facility.

Containerized elementary neutralization is performed at this facility as provided by LWP-8000. As stated in $\S 4.118$, elementary neutralization of corrosive hazardous waste may take place at any location where the waste is generated or stored, and neither a generator treatment plan nor a permit is required. Solidification of liquid LLW for the purpose of staging (not for treating the radioactive constituents) also may be performed. Therefore, this facility is not considered to be a treatment facility.

NA; this facility stages waste in accordance with N.(7) to facilitate treatment or disposal. 
Table 16. (continued).

\begin{tabular}{|c|c|}
\hline \multicolumn{2}{|c|}{ Facility Name: MFC-787, Fuels and Applied Sciences Building } \\
\hline Chapter IV, LLW Requirements & Facility Compliance Information \\
\hline $\begin{array}{l}\text { A facility that stores or treats waste also is generally } \\
\text { expected to have a waste certification program. Waste } \\
\text { from these facilities will have to be certified as meeting } \\
\text { the waste acceptance requirements of the facility to } \\
\text { which it will be transferred, and the facilities have the } \\
\text { potential for generating radioactive waste (e.g., } \\
\text { secondary processing streams from treatment, } \\
\text { monitoring and sampling, radioactive release cleanup). } \\
\text { Consequently, storage and treatment facilities should } \\
\text { also have an approved waste certification program as } \\
\text { part of their radioactive waste management basis. }\end{array}$ & \\
\hline $\begin{array}{l}\text { As part of the radioactive waste management basis, site } \\
\text { personnel needs to implement a system or process for } \\
\text { tracking the waste inventory at a storage, treatment, or } \\
\text { disposal facility. }\end{array}$ & \\
\hline $\begin{array}{l}\text { (4) Disposal Facilities. The performance assessment, } \\
\text { composite analysis, disposal authorization statement, } \\
\text { closure plan, waste acceptance requirements, and } \\
\text { monitoring plan. }\end{array}$ & NA; this facility is not a disposal facility. \\
\hline $\begin{array}{l}\text { E. Contingency Actions. The following requirements } \\
\text { are in addition to those in Chapter I of this Manual } \\
{[\text { DOE M 435.1-1 §I.1.E(5)]. }}\end{array}$ & $\begin{array}{l}\text { Not a facility-specific requirement. DOE Manual } \\
435.1-1 \text { §I.1.E( } 5) \text { addresses the sitewide emergency } \\
\text { management system. The INL plan is provided in } \\
\text { PLN-114. }\end{array}$ \\
\hline $\begin{array}{l}\text { (1) Contingency Storage. For off-normal or emergency } \\
\text { situations involving high activity or high hazard liquid } \\
\text { low-level waste storage or treatment, spare capacity } \\
\text { with adequate capabilities shall be maintained to } \\
\text { receive the largest volume of liquid contained in any } \\
\text { one storage tank or treatment facility. Tanks or other } \\
\text { facilities that are designated low-level waste } \\
\text { contingency storage shall be maintained in an } \\
\text { operational condition when waste is present and shall } \\
\text { meet the requirements of DOE O 435.1, Radioactive } \\
\text { Waste Management, and this Manual. }\end{array}$ & $\begin{array}{l}\text { NA; liquid LLW is not stored or treated in a tank } \\
\text { system at this facility. }\end{array}$ \\
\hline $\begin{array}{l}\text { From DOE G } 435.1-1 \text { Chapter IV: Compliance with } \\
\text { these requirements is demonstrated if adequate spare } \\
\text { capacity and transfer equipment exists for emergency } \\
\text { transfers of all high activity and high hazard liquid } \\
\text { low-level waste. In addition, the capability to perform } \\
\text { emergency transfers is demonstrated by having waste } \\
\text { transfer routings identified, operational procedures to } \\
\text { direct transfers, staff trained to the procedures, and } \\
\text { records showing that the spare capacity and transfer } \\
\text { capability are kept in operating condition. }\end{array}$ & \\
\hline $\begin{array}{l}\text { (2) Transfer Equipment. Pipelines and auxiliary } \\
\text { facilities necessary for the transfer of high activity or } \\
\text { high hazard liquid low-level waste to contingency } \\
\text { storage shall be maintained in an operational condition }\end{array}$ & $\begin{array}{l}\text { NA; liquid LLW is not stored or treated in a tank } \\
\text { system at this facility. }\end{array}$ \\
\hline
\end{tabular}


Table 16. (continued).

Facility Name: MFC-787, Fuels and Applied Sciences Building

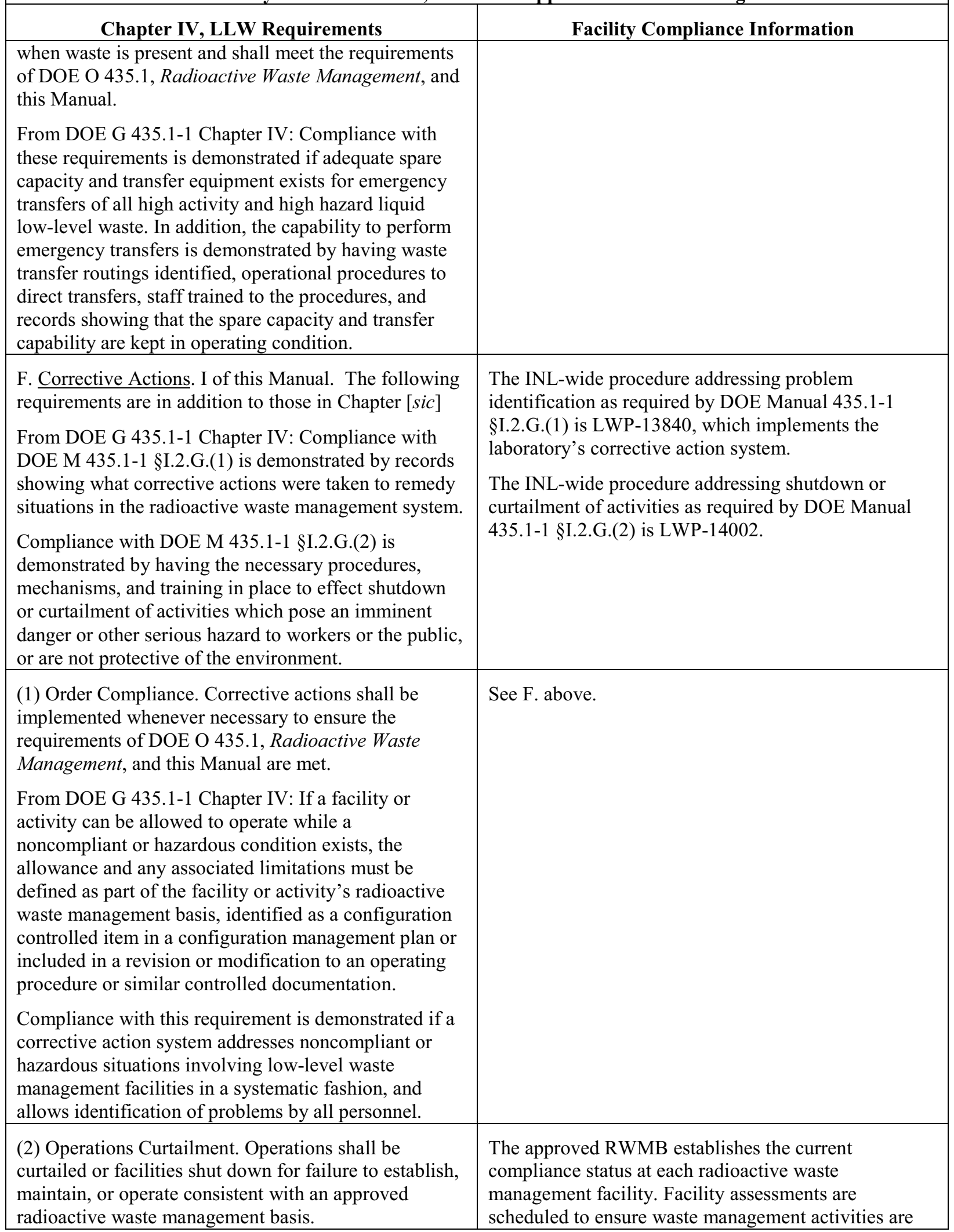


Table 16. (continued).

\begin{tabular}{|c|c|}
\hline \multicolumn{2}{|c|}{ Facility Name: MFC-787, Fuels and Applied Sciences Building } \\
\hline Chapter IV, LLW Requirements & Facility Compliance Information \\
\hline $\begin{array}{l}\text { From DOE G } 435.1-1 \text { Chapter IV: Compliance with } \\
\text { this requirement is demonstrated with a documented } \\
\text { system of routine assessments to determine whether } \\
\text { waste management activities and facilities are } \\
\text { operating in accordance with an approved radioactive } \\
\text { waste management basis that provides for graded } \\
\text { limitations that can be placed on activities and } \\
\text { operations that do not have, or are operating outside of, } \\
\text { an approved radioactive waste management basis, } \\
\text { including shutdown of the facility. }\end{array}$ & conducted in accordance with the approved RWMB. \\
\hline $\begin{array}{l}\text { G. Waste Acceptance. The following requirements are } \\
\text { in addition to those in Chapter I of this Manual [DOE } \\
\text { M 435.1-1 §I.2.F(6)]. }\end{array}$ & $\begin{array}{l}\text { Not a facility-specific requirement. DOE Manual } \\
\text { 435.1-1 §I.2.F(6) applies to field element managers. }\end{array}$ \\
\hline $\begin{array}{l}\text { (1) Technical and Administrative. Waste acceptance } \\
\text { requirements for all low-level waste storage, treatment, } \\
\text { or disposal facilities, operations, and activities shall } \\
\text { specify, at a minimum, the following: }\end{array}$ & $\begin{array}{l}\text { NA; this facility generates LLW but does not receive } \\
\text { radioactive waste from other sources. }\end{array}$ \\
\hline $\begin{array}{l}\text { From DOE G 435.1-1 Chapter IV: Compliance with } \\
\text { these waste acceptance requirements is demonstrated if } \\
\text { they are documented, contain clear and precise criteria } \\
\text { specifying the radionuclide limits in the form of } \\
\text { contents or concentrations that can be accepted, the } \\
\text { limitations and prohibitions on waste forms and } \\
\text { packages that can be received, and the limits, } \\
\text { prohibitions, or instructions concerning any other } \\
\text { technical information so that the waste is compatible } \\
\text { with the safety basis of the facility, and which will } \\
\text { result in acceptable waste at subsequent steps in } \\
\text { managing the low-level waste. }\end{array}$ & \\
\hline $\begin{array}{l}\text { (a) Allowable activities and/or concentrations of } \\
\text { specific radionuclides. }\end{array}$ & See (1) above. \\
\hline $\begin{array}{l}\text { (b) Acceptable waste form and/or container } \\
\text { requirements that ensure the chemical and physical } \\
\text { stability of waste under conditions that might be } \\
\text { encountered during transportation, storage, treatment, } \\
\text { or disposal. }\end{array}$ & See (1) above. \\
\hline $\begin{array}{l}\text { (c) Restrictions or prohibitions on waste, materials, or } \\
\text { containers that may adversely affect waste handlers or } \\
\text { compromise facility or waste container performance. }\end{array}$ & See (1) above. \\
\hline $\begin{array}{l}\text { (d) The following are additional waste acceptance } \\
\text { requirements that shall be specified in low-level waste } \\
\text { disposal facility waste acceptance requirements: }\end{array}$ & NA; this facility is not a LLW disposal facility. \\
\hline $\begin{array}{l}1 \text { Low-level waste must contribute to and not detract } \\
\text { from achieving long-term stability of the facility, } \\
\text { minimizing the need for long-term active maintenance, } \\
\text { minimizing subsidence, and minimizing contact of } \\
\text { water with waste. Void spaces within the waste and, if }\end{array}$ & See (d) above. \\
\hline
\end{tabular}


Table 16. (continued).

Facility Name: MFC-787, Fuels and Applied Sciences Building

\begin{tabular}{|c|c|}
\hline Chapter IV, LLW Requirements & Facility Compliance Information \\
\hline $\begin{array}{l}\text { containers are used, between the waste and its } \\
\text { container shall be reduced to the extent practical. }\end{array}$ & \\
\hline $\begin{array}{l}2 \text { Liquid low-level waste or low-level waste containing } \\
\text { free liquid must be converted into a form that contains } \\
\text { as little freestanding liquid as is reasonably achievable, } \\
\text { but in no case shall the liquid exceed } 1 \text { percent of the } \\
\text { waste volume when the low-level waste is in a disposal } \\
\text { container, or } 0.5 \text { percent of the waste volume after it is } \\
\text { processed to a stable form. }\end{array}$ & See (d) above. \\
\hline $\begin{array}{l}3 \text { Low-level waste must not be readily capable of } \\
\text { detonation or of explosive decomposition or reaction at } \\
\text { anticipated pressures and temperatures, or of explosive } \\
\text { reaction with water. Pyrophoric materials contained in } \\
\text { waste shall be treated, prepared, and packaged to be } \\
\text { nonflammable. }\end{array}$ & See (d) above. \\
\hline $\begin{array}{l}4 \text { Low-level waste must not contain, or be capable of } \\
\text { generating by radiolysis or biodegradation, quantities } \\
\text { of toxic gases, vapors, or fumes harmful to the public } \\
\text { or workers or disposal facility personnel, or harmful to } \\
\text { the long-term structural stability of the disposal site. }\end{array}$ & See (d) above. \\
\hline $\begin{array}{l}5 \text { Low-level waste in a gaseous form must be packaged } \\
\text { such that the pressure does not exceed } 1.5 \text { atmospheres } \\
\text { absolute at } 20 \mathrm{C} \text {. [ } \mathrm{sic}]\end{array}$ & See (d) above. \\
\hline $\begin{array}{l}\text { (e) The basis, procedures, and levels of authority } \\
\text { required for granting exceptions to the waste } \\
\text { acceptance requirements, which shall be contained in } \\
\text { each facility's waste acceptance documentation. Each } \\
\text { exception request shall be documented, including its } \\
\text { disposition as approved or not approved. } \\
\text { From DOE G } 435.1-1 \text { Chapter IV: Waste acceptance } \\
\text { requirements are acceptable if they are documented and } \\
\text { contain a clear description of the procedure and bases } \\
\text { for obtaining an exception or deviation to the } \\
\text { acceptance criteria for low-level waste to be received at } \\
\text { the facility. }\end{array}$ & $\begin{array}{l}\text { NA; this facility does not accept waste from other } \\
\text { facilities. }\end{array}$ \\
\hline $\begin{array}{l}\text { (2) Evaluation and Acceptance. The receiving facility } \\
\text { shall evaluate waste for acceptance, including } \\
\text { confirmation that the technical and administrative } \\
\text { requirements have been met. A process for the } \\
\text { disposition of non-conforming wastes shall be } \\
\text { established. } \\
\text { From DOE G 435.1-1 Chapter IV: Compliance with } \\
\text { the waste acceptance requirements for a low-level } \\
\text { waste management facility is demonstrated if they } \\
\text { include a process for evaluation and acceptance of } \\
\text { incoming waste to ensure the acceptance criteria of the } \\
\text { facility receiving the waste are met that includes one of }\end{array}$ & $\begin{array}{l}\text { NA; this facility does not accept waste from other } \\
\text { facilities. }\end{array}$ \\
\hline
\end{tabular}


Table 16. (continued).

Facility Name: MFC-787, Fuels and Applied Sciences Building

Chapter IV, LLW Requirements Facility Compliance Information

or a combination of: (1) testing, sampling, and analysis of representative samples of waste upon receipt; (2) testing, sampling, and analysis of split samples of waste taken at the generator site; (3) evaluation of testing, sampling, and analysis of data provided by the generator, or (4) audits, reviews, surveillance, or observations of generator waste certification programs and characterization activities. Additionally, acceptable waste acceptance requirements for a storage, treatment or disposal facility will have documented procedures and actions to be taken if a waste that does not conform to the waste acceptance criteria is received at the facility.

H. Waste Generation Planning. The following requirements are in addition to those in Chapter I of this Manual [DOE M 435.1-1 §I.2.F(7)].

(1) Life-Cycle Planning. Prior to waste generation, planning shall be performed to address the entire life cycle for all low-level waste streams.

From DOE G 435.1-1 Chapter IV: Compliance with this planning requirement is demonstrated by the individual sites establishing a process for evaluating the life-cycle of low-level waste prior to its generation, including the identification of low-level wastes with no path to disposal and appropriate records justifying the newly generated low-level waste stream(s), and site personnel possessing planning information showing the location(s) where low-level waste will be stored, treated, and/or disposed along with a confirmation that the personnel managing the facilities agree that the low-level waste may be managed at those facilities.

(2) Waste with No Identified Path to Disposal. Lowlevel waste streams with no identified path to disposal shall be generated only in accordance with approved conditions which, at a minimum, shall address:

(a) Programmatic need to generate the waste;

(b) Characteristics and issues preventing the disposal of the waste;

(c) Safe storage of the waste until disposal can be achieved; and

(d) Activities and plans for achieving final disposal of the waste.

I. Waste Characterization. Low-level waste shall be characterized using direct or indirect methods, and the characterization documented in sufficient detail to ensure safe management and compliance with the

Not a facility-specific requirement. DOE Manual 435.1-1 §I.2.F(7) applies to field element managers.

PDD-17000 and LWP-17000 provide direction to the waste generators for waste generation planning to address the entire life cycle.

1356-07-FASB $\S 2$, Table 2.03 lists the waste expected to be generated, the container type, and notes on treatment and disposal.

1356-07-FASB § 2 states that WGS is responsible for meeting proper storage and disposal requirements of any waste generated that is not identified in Table 2.03 of the procedure.

Laboratory instructions also are prepared for specific tasks and projects. These laboratory instructions would include description of expected waste and disposition plans.

NA; this facility is not generating LLW that does not have an identified path to disposal.

See (2) above.

See (2) above.

See (2) above.

See (2) above.

MCP-17000 addresses waste characterization.

1356-07-FASB § 2, Table 2.03 addresses

characterization of the facility's LLW. 
Table 16. (continued).

Facility Name: MFC-787, Fuels and Applied Sciences Building

Chapter IV, LLW Requirements

waste acceptance requirements of the facility receiving the waste.

From DOE G 435.1-1 Chapter IV: Compliance with this requirement is demonstrated by a program for documenting and the existence of records that document the process for acquiring and verifying the validity of low-level waste characterization data acquired through the use of direct or indirect methods.

(1) Data Quality Objectives. The data quality objectives process, or a comparable process, shall be used for identifying characterization parameters and acceptable uncertainty in characterization data.

From DOE G 435.1-1 Chapter IV: Compliance with this requirement is demonstrated by the documented use of a data quality objectives or a comparable process for determining the type, quantity, and quality of characterization data needed to safely manage lowlevel waste.

(2) Minimum Waste Characterization. Characterization data shall, at a minimum, include the following information relevant to the management of the waste:

From DOE G 435.1-1 Chapter IV: Compliance with this requirement is demonstrated by the existence of a program or procedure for determining and records that document characterization of low-level waste consistent with the minimum characterization data requirements.

(a) Physical and chemical characteristics;
(b) Volume, including the waste and any stabilization
or absorbent media;

(c) Weight of the container and contents;

(d) Identities, activities, and concentrations of major radionuclides;

(e) Characterization date;

(f) Generating source; and

(g) Any other information which may be needed to prepare and maintain the disposal facility performance assessment, or demonstrate compliance with applicable performance objectives.

J. Waste Certification. A waste certification program shall be developed, documented, and implemented to ensure that the waste acceptance requirements of facilities receiving low-level waste for storage, treatment, and disposal are met.

\section{Facility Compliance Information}

1356-07-FASB $\S 2$, Table 2.03 states that disposal of the facility's rinse water generated in the radiological contamination area to industrial waste or to the RLWTF will be based on sampling and analysis.

Radioactive waste management facilities characterize waste in accordance with the requirements of the receiving storage, treatment, or disposal facility. The documented use of a data quality objectives process, or comparable process, was not identified for this facility.

MCP-17000, including $\S \S 4.2,4.3$, and 4.4, provides waste characterization requirements. Information on absorbent media is required in $\S \S 4.5$ and 4.7.

MCP-17000 also specifies the use of IWTS, which documents characterization data in an IWTS profile.

See I. and (2) above.

See I. and (2) above.

See I. and (2) above.

See I. and (2) above.

See I. and (2) above.

See I. and (2) above.

See I. and (2) above.

MCP-17000 cites a waste certification program for LLW destined for NNSS. For waste destined for locations other than NNSS, the waste disposition specialist is responsible for certifying the waste stream by ensuring the waste, as characterized, falls within the 
Table 16. (continued).

Facility Name: MFC-787, Fuels and Applied Sciences Building

\begin{tabular}{|c|}
\hline Chapter IV, LLW Requirements \\
\hline $\begin{array}{l}\text { From DOE G 435.1-1 Chapter IV: Compliance with } \\
\text { the development and documentation portion of the } \\
\text { certification requirement is demonstrated by a waste } \\
\text { certification plan that identifies the organizations } \\
\text { involved, assigns responsibilities for implementing the } \\
\text { program, and describes or references the quality } \\
\text { assurance, training, procurement controls, records } \\
\text { management, and procedures to be used by the } \\
\text { program. Acceptable performance for implementing } \\
\text { the program is demonstrated when appropriate } \\
\text { personnel are trained and follow the procedures that } \\
\text { govern their part of the waste certification. } \\
\text { Additionally, acceptable performance is demonstrated } \\
\text { if the waste certification plan and procedures are } \\
\text { current and controlled in accordance with a document } \\
\text { controls program, and records related to certification } \\
\text { (e.g., certification statements, training records, } \\
\text { procurement records, characterization records, } \\
\text { container records) are generated and managed in } \\
\text { accordance with the established site program. }\end{array}$ \\
\hline
\end{tabular}

(1) Certification Program. The waste certification program shall designate the officials who have the authority to certify and release waste for shipment; and specify what documentation is required for waste generation, characterization, shipment, and certification. The program shall provide requirements for auditability, retrievability, and storage of required documentation and specify the records retention period.

From DOE G 435.1-1 Chapter IV: Compliance with this requirement is demonstrated by a program or procedure for record keeping and records showing that low-level waste is certified as having met the waste acceptance criteria of the facility to which it was transferred and that the certification statement is supported by additional records regarding the waste source, characterization, and container.

(2) Certification before Transfer. Low-level waste shall be certified as meeting waste acceptance requirements before it is transferred to the facility receiving the waste.

From DOE G 435.1-1 Chapter IV: Compliance with this requirement is demonstrated by the presence of a certification program which includes procedures requiring a signed certification statement prior to the release of waste for transfer, and by dated records showing that waste was certified before being transferred.

\section{Facility Compliance Information}

limitations of the WAC of the treatment, storage, or disposal facility $(§ 2)$.

Container procurement is addressed in MCP-17000 $\S 4.6$.

MCP-17500 provides the WGS waste certification program for LLW to be shipped to NNSS.

Waste certification is performed and tracked using IWTS. Documentation of the IWTS Program is available electronically only.

PLN-522 requires waste technical specialists and waste disposition specialists to complete the appropriate training/qualification before being granted approval authority for profiles within the IWTS Program. The waste certification official, alternate waste certification official, and NNSS packaging certifiers must complete the appropriate training/qualifications to disposition waste to NNSS.

See J. above. MCP-17500 $\S 2$ and 5 address certification records for shipments to NNSS.
See J. above. MCP-17500 $§ 4.3 .6$ addresses controls for certification before transfer for LLW to be disposed of at NNSS. 
Table 16. (continued).

\begin{tabular}{|c|c|}
\hline \multicolumn{2}{|c|}{ Facility Name: MFC-787, Fuels and Applied Sciences Building } \\
\hline Chapter IV, LLW Requirements & Facility Compliance Information \\
\hline $\begin{array}{l}\text { (3) Maintaining Certification. Low-level waste that has } \\
\text { been certified as meeting the waste acceptance } \\
\text { requirements for transfer to a storage, treatment, or } \\
\text { disposal facility shall be managed in a manner that } \\
\text { maintains its certification status. } \\
\text { From DOE G } 435.1-1 \text { Chapter IV: Compliance with } \\
\text { this requirement is demonstrated by a program or } \\
\text { procedure reflecting this requirement is present and site } \\
\text { personnel are able to show that the storage of low-level } \\
\text { waste containers is in a facility or manner where the } \\
\text { containers would not be damaged by normal weather } \\
\text { events, and cannot be accessed by unauthorized } \\
\text { personnel. Further, each container can be traced to its } \\
\text { certification and the information supporting that } \\
\text { certification. }\end{array}$ & $\begin{array}{l}\text { See J. above. Pre-certification checklists are cited in } \\
\text { MCP-17000 and MCP-17500. Surveillances are also } \\
\text { addressed in MCP-17500. } \\
\text { LWP- } 15011 \S 5 \text { provides general radioactive storage } \\
\text { area requirements. }\end{array}$ \\
\hline $\begin{array}{l}\text { K. Waste Transfer. A documented process shall be } \\
\text { established and implemented for transferring } \\
\text { responsibility for management of low-level waste and } \\
\text { for ensuring availability of relevant data. The following } \\
\text { requirements are in addition to those in Chapter I of } \\
\text { this Manual. } \\
\text { From DOE G 435.1-1 Chapter IV: Compliance with } \\
\text { this requirement is demonstrated if facilities have } \\
\text { procedures for the receipt of waste and the transfer of } \\
\text { waste, as appropriate, which address the acquisition of } \\
\text { waste and container data and the transfer of ownership, } \\
\text { respectively. Further evidence of acceptable } \\
\text { performance is facility records showing that data on the } \\
\text { waste containers is available and accurate, and that } \\
\text { documented transfer of responsibility occurs. }\end{array}$ & $\begin{array}{l}\text { MCP-17000 } § 4.8 .15 \text { specifies requirements for } \\
\text { interfacility transfers. } \\
\text { TSD-OI-004 includes MFC-703, MFC-793, and } \\
\text { MFC-797 requirements for receiving transferred waste. } \\
\text { MCP-17500 } § 4 \text { addresses LLW to be transferred to } \\
\text { NNSS. }\end{array}$ \\
\hline $\begin{array}{l}\text { (1) Authorization. Low-level waste shall not be } \\
\text { transferred to a storage, treatment, or disposal facility } \\
\text { until personnel responsible for the facility receiving the } \\
\text { waste authorize the transfer. } \\
\text { From DOE G } 435.1-1 \text { Chapter IV: Compliance with } \\
\text { this requirement is demonstrated by sites having } \\
\text { procedures that require a confirmation of authorization } \\
\text { before releasing waste for transfer, and records } \\
\text { showing that transfers are made in accordance with } \\
\text { written authorizations. }\end{array}$ & See K. above. \\
\hline $\begin{array}{l}\text { (2) Data. Waste characterization data, container } \\
\text { information, and generation, storage, treatment, and } \\
\text { transportation information for low-level waste shall be } \\
\text { transferred with or be traceable to the waste. } \\
\text { From DOE G } 435.1-1 \text { Chapter IV: Compliance with } \\
\text { this requirement is demonstrated if there are procedures } \\
\text { requiring that characterization and container data be }\end{array}$ & See K. above. \\
\hline
\end{tabular}


Table 16. (continued).

Facility Name: MFC-787, Fuels and Applied Sciences Building

\begin{tabular}{|c|}
\hline Chapter IV, LLW Requirements \\
\hline $\begin{array}{l}\text { provided and maintained for each low-level waste } \\
\text { transfer and documented records of transfers show the } \\
\text { the information is being provided. }\end{array}$ \\
\hline $\begin{array}{l}\text { L. Packaging and Transportation. The following } \\
\text { requirements are in addition to those in Chapter I of } \\
\text { this Manual [DOE M 435.1-1 §I.1.E(11)]. }\end{array}$ \\
\hline \\
\hline $\begin{array}{l}\text { From DOE G 435.1-1 Chapter IV: Compliance with } \\
\text { the packaging requirement is demonstrated by: (1) } \\
\text { procedures which document proper packaging } \\
\text { protocols; and (2) no trends of routine repackaging of } \\
\text { low-level waste that is packaged after issuance of DOE } \\
\text { O } 435.1 \text {. Successful performance of this requirement is } \\
\text { also demonstrated by a record of containers for which } \\
\text { failure has not routinely occurred under management } \\
\text { conditions. It is recognized that there may be failed } \\
\text { containers for waste previously placed in storage. For } \\
\text { those containers, the goal is to only have to repackage } \\
\text { the waste one time after it is retrieved and } \\
\text { characterized. Further, acceptable performance is } \\
\text { demonstrated by containers of waste having marking } \\
\text { and labeling that allows correlation with waste } \\
\text { characterization data and container information. }\end{array}$ \\
\hline
\end{tabular}

(a) Low-level waste shall be packaged in a manner that provides containment and protection for the duration of the anticipated storage period and until disposal is achieved or until the waste has been removed from the container.

(b) When waste is packaged, vents or other measures shall be provided if the potential exists for pressurizing or generating flammable or explosive concentrations of gases within the waste container.

(c) Containers of low-level waste shall be marked such that their contents can be identified.

(2) Transportation. To the extent practical, the volume of waste and number of low-level waste shipments shall be minimized.

From DOE G 435.1-1 Chapter IV: Compliance with this requirement can be demonstrated by a combination of site procedures directing the efficient use of waste container capacity and documentation showing that low-level waste shipments are systematically planned and optimized to the extent practical.

M. Site Evaluation and Facility Design. The following requirements are in addition to those in Chapter I of this Manual.
Facility Compliance Information

See (1) and (2) below.

MCP-17000 $§ 4$ addresses packaging requirements.
See (1) above.

See (1) above.

See (1) above.

MCP-17000 $§ 4$ addresses transportation. The waste disposition specialist coordinates with packaging and transportation personnel for waste shipped offsite from this facility.

Waste is shipped directly to NNSS from this facility. MCP-17500 specifies waste certification official and waste disposition specialist responsibilities and coordination with packaging and transportation personnel.

NA; this requirement addresses new radioactive waste management facilities or modifications to existing facilities. 
Table 16. (continued).

Facility Name: MFC-787, Fuels and Applied Sciences Building

\section{Chapter IV, LLW Requirements}

(1) Site Evaluation. Proposed locations for low-level waste facilities shall be evaluated to identify relevant features that should be avoided or must be considered in facility design and analyses.

(a) Each site proposed for a new low-level waste facility or expansion of an existing low-level waste facility shall be evaluated considering environmental characteristics, geotechnical characteristics, and human activities, including for a low-level waste disposal facility, the capability of the site to demonstrate, at a minimum, whether it is:

1 Located to accommodate the projected volume of waste to be received;

2 Located in a flood plain, a tectonically active area, or in the zone of water table fluctuation; and

3 Located where radionuclide migration pathways are predictable and erosion and surface runoff can be controlled.

(b) Proposed sites with environmental characteristics, geotechnical characteristics, and human activities for which adequate protection cannot be provided through facility design shall be deemed unsuitable for the location of the facility.

(c) Low-level waste disposal facilities shall be sited to achieve long-term stability and to minimize, to the extent practical, the need for active maintenance following final closure.

(2) Low-Level Waste Treatment and Storage Facility Design. The following facility requirements and general design criteria, at a minimum, apply:

(a) Confinement. Low-level waste systems and components shall be designed to maintain waste confinement.

(b) Ventilation.

1 Design of low-level waste treatment and storage facilities shall include ventilation, if applicable, through an appropriate filtration system to maintain the release of radioactive material in airborne effluents within the requirements and guidelines specified in applicable requirements.

2 When conditions exist for generating gases in flammable or explosive concentrations, ventilation systems or other measures shall be provided to keep the gases in a non-flammable and nonexplosive condition. Where concentrations of explosive or flammable gases

\section{Facility Compliance Information}

See M. above.

See M. above.

See M. above.

See M. above.

See M. above.

See M. above.

See M. above.

See M. above.

See M. above.

See M. above.

See M. above.

See M. above. 
Table 16. (continued).

Facility Name: MFC-787, Fuels and Applied Sciences Building

Chapter IV, LLW Requirements are expected to approach the lower flammability limit, measures shall be taken to prevent deflagration or detonation.

(c) Consideration of Decontamination and Decommissioning. Areas in new and modifications to existing low-level waste management facilities that are subject to contamination with radioactive or other hazardous materials shall be designed to facilitate decontamination. For such facilities a proposed decommissioning method or a conversion method leading to reuse shall be described.

(d) Instrumentation and Control Systems. Engineering controls shall be incorporated in the design and engineering of low-level waste treatment and storage facilities to provide volume inventory data and to prevent spills, leaks, and overflows from tanks or confinement systems.

(e) Monitoring. Monitoring and/or leak detection capabilities shall be incorporated in the design and engineering of low-level waste treatment and storage facilities to provide rapid identification of failed confinement and/or other abnormal conditions.

(3) Low-Level Waste Disposal Facility Design. The following facility requirements and general design criteria, at a minimum, apply:

(a) Confinement. Low-level waste systems and components shall be designed to maintain waste confinement.

\section{(b) Ventilation.}

1 Design of low-level waste disposal facilities shall include ventilation, if applicable, through an appropriate filtration system to maintain the release of radioactive material in airborne effluents within the requirements and guidelines specified in applicable requirements.

2 When conditions exist for generating gases in flammable or explosive concentrations, ventilation systems or other measures shall be provided to keep the gases in a nonflammable and non-explosive condition. Where concentrations of explosive or flammable gases are expected to approach the lower flammability limit, measures shall be taken to prevent deflagration or detonation.
Facility Compliance Information

See M. above.

See M. above.

See M. above.

See M. above.

See M. above.

See M. above.

See M. above.

See M. above. 
Table 16. (continued).

Facility Name: MFC-787, Fuels and Applied Sciences Building

\begin{tabular}{|c|c|}
\hline Chapter IV, LLW Requirements & Facility Compliance Information \\
\hline $\begin{array}{l}\text { (c) Stability. Low-level waste disposal facilities shall } \\
\text { be designed to achieve long-term stability and to } \\
\text { minimize to the extent practical, the need for active } \\
\text { maintenance following final closure. }\end{array}$ & See M. above. \\
\hline $\begin{array}{l}\text { (d) Control of Water. Low-level waste disposal } \\
\text { facilities shall be designed to minimize to the extent } \\
\text { practical, the contact of waste with water during and } \\
\text { after disposal. }\end{array}$ & See M. above. \\
\hline $\begin{array}{l}\text { N. Storage and Staging. The following requirements } \\
\text { are in addition to those in Chapter I of this Manual } \\
{[\text { DOE M 435.1-1 §I.2.F(13)]. }}\end{array}$ & $\begin{array}{l}\text { Not a facility-specific requirement. DOE Manual } \\
435.1-1 \S \text { I.2.F(13) applies to field element managers. }\end{array}$ \\
\hline $\begin{array}{l}\text { (1) Storage Prohibitions. Low-level waste in storage } \\
\text { shall not be readily capable of detonation, explosive } \\
\text { decomposition, reaction at anticipated pressures and } \\
\text { temperatures, or explosive reaction with water. Prior to } \\
\text { storage, pyrophoric materials shall be treated, prepared, } \\
\text { and packaged to be nonflammable. } \\
\text { From DOE G } 435.1-1 \text { Chapter IV: Compliance with } \\
\text { this requirement is demonstrated by having waste } \\
\text { acceptance requirements which prohibit low-level } \\
\text { waste that is ignitable or explosive from being accepted } \\
\text { for storage unless it has been treated, and procedures } \\
\text { for properly preparing such materials for safe storage. }\end{array}$ & NA; LLW is not stored at this facility. \\
\hline $\begin{array}{l}\text { (2) Storage Limit. Low-level waste that has an } \\
\text { identified path to disposal shall not be stored longer } \\
\text { than one year prior to disposal, except for storage for } \\
\text { decay, or as otherwise authorized by the Field Element } \\
\text { Manager. } \\
\text { From DOE G } 435.1-1 \text { Chapter IV: Storage longer than } \\
\text { one year can be justified if the conditions for such } \\
\text { storage are approved by the Field Element Manager as } \\
\text { part of the radioactive waste management basis for the } \\
\text { facility. }\end{array}$ & NA; LLW is not stored at this facility. \\
\hline $\begin{array}{l}\text { Storage for radioactive decay for a period greater than } \\
1 \text { year for waste that has an identified path to disposal } \\
\text { is allowed. Adequate justification and the supporting } \\
\text { information for storage for decay is to be documented } \\
\text { in the radioactive waste management basis for the } \\
\text { facility in which the storage will take place. }\end{array}$ & \\
\hline $\begin{array}{l}\text { Mixed waste. Under the Federal Facility Compliance } \\
\text { Act of 1992, DOE sites were required to develop Site } \\
\text { Treatment Plans to bring stored mixed low-level waste } \\
\text { into compliance with these requirements. The Site } \\
\text { Treatment Plan needs to be consulted and any mixed } \\
\text { low-level waste stored for the purpose of accumulation } \\
\text { to facilitate treatment must meet Resource } \\
\text { Conservation and Recovery Act storage requirements. }\end{array}$ & \\
\hline
\end{tabular}


Table 16. (continued).

Facility Name: MFC-787, Fuels and Applied Sciences Building

There could be several ways within different scenarios that this requirement can be met, as illustrated by the examples below, however, there are basically four ways to show compliance with the requirement and include appropriate provisions in the radioactive waste management basis for the facility in which it is stored.

Legacy waste. As discussed above, the intention of the requirement is not to force malicious compliance or heroic actions which would result in increased risk or safety concerns. Rather, the intention is that waste in storage longer than one year receives additional attention to ensure that the public, the workers, and the environment are protected from the hazards of the waste, and that progress is being made to dispose of the waste. There could be several ways within different scenarios that this requirement can be met, as illustrated by the examples below, however, there are basically four ways to show compliance with the requirement:

1) the radioactive waste management basis allows for storage for no more than one year.

2) the radioactive waste management basis allows for storage for no more than one year, or for storage for decay only for periods greater than a year, which are specified on a radionuclide basis.

3 ) the radioactive waste management basis allows for storage for more than one year, up to a specified period of time based on a documented technical evaluation that the waste can be stored in a manner that does not cause changes to the waste or waste packages that is detrimental to the safe storage of the waste, the final disposal of the waste or to meeting the disposal performance objectives.

4) the radioactive waste management basis allows for storage for decay (with specifics) and for storage for more than one year for other low-level waste, up to a specified period of time based on a documented technical evaluation that the waste can be stored in a manner that does not cause changes to the waste or waste packages that is detrimental to the safe storage of the waste, the final disposal of the waste or to meeting the disposal performance objectives.

Compliance with this requirement is demonstrated by the existence of a radioactive waste management basis for the storage facility approved by the Field Element Manager that includes the time frames that waste are allowed to be stored, the necessary justifications for storage for decay, and the necessary technical 
Table 16. (continued).

Facility Name: MFC-787, Fuels and Applied Sciences Building

\begin{tabular}{|c|c|}
\hline $\begin{array}{l}\text { Chapter IV, LLW Requirements } \\
\text { evaluations if storage is to extend significantly beyond } \\
\text { the one-year time frame. }\end{array}$ & Facility Compliance Information \\
\hline $\begin{array}{l}\text { (3) Storage Integrity. Low-level waste shall be stored } \\
\text { in a location and manner that protects the integrity of } \\
\text { waste for the expected time of storage and minimizes } \\
\text { worker exposure. } \\
\text { From DOE G } 435.1-1 \text { Chapter IV: However, in making } \\
\text { a decision to use a facility for storage and in } \\
\text { developing a radioactive waste management basis for } \\
\text { the activity, particular attention to protection of } \\
\text { workers is needed. } \\
\text { Compliance with this requirement is demonstrated if } \\
\text { sites have storage capabilities for low-level waste that } \\
\text { provide protection to waste containers so that their } \\
\text { integrity will not be damaged through physical or } \\
\text { chemical (corrosion) processes and that keep personnel } \\
\text { from spending extended periods of time in the areas } \\
\text { where low-level waste is stored. }\end{array}$ & NA; LLW is not stored at this facility. \\
\hline (4) Waste Characterization for Storage. & NA; LLW is not stored at this facility. \\
\hline $\begin{array}{l}\text { (a) Low-level waste that does not have an identified } \\
\text { path to disposal shall be characterized as necessary to } \\
\text { meet the data quality objectives and minimum } \\
\text { characterization requirements of this Chapter, to ensure } \\
\text { safe storage, and to facilitate disposal. }\end{array}$ & See (4) above. \\
\hline $\begin{array}{l}\text { (b) Characterization information for all low-level waste } \\
\text { in storage shall be maintained as a record in accordance } \\
\text { with the requirements for Records Management in } \\
\text { Chapter I of this Manual. } \\
\text { From DOE G } 435.1-1 \text { Chapter IV: Compliance with } \\
\text { this requirement is demonstrated by documented } \\
\text { procedures for managing waste characterization and } \\
\text { container information on low-level waste as a Federal } \\
\text { record. The records are managed per the applicable } \\
\text { policies and procedures for records management } \\
\text { referenced in DOE O } 200.1 \text { and established at the } \\
\text { applicable Field Element. }\end{array}$ & See (4) above. \\
\hline $\begin{array}{l}\text { (5) Container Inspection. A process shall be developed } \\
\text { and implemented for inspecting and maintaining } \\
\text { containers of low-level waste to ensure container } \\
\text { integrity is not compromised. } \\
\text { From DOE G } 435.1-1 \text { Chapter IV: Compliance with } \\
\text { this requirement is demonstrated by: (1) a documented } \\
\text { process for waste container inspection and } \\
\text { maintenance; and (2) documentation for all waste } \\
\text { container inspections and maintenance actions } \\
\text { performed. }\end{array}$ & $\begin{array}{l}\text { LI- } 435 \text { requires quarterly inspections of radioactive } \\
\text { waste containers if waste is stored outdoors or has been } \\
\text { in storage for greater than } 1 \text { year. } \\
\text { Inspections are performed for TAAs and SAAs as } \\
\text { required by WGS procedures (MCP-17000 and MCP- } \\
17410 \text { ). }\end{array}$ \\
\hline
\end{tabular}


Table 16. (continued).

Facility Name: MFC-787, Fuels and Applied Sciences Building

\begin{tabular}{l}
\multicolumn{1}{|c|}{ Chapter IV, LLW Requirements } \\
\hline $\begin{array}{l}\text { (6) Storage Management. Low-level waste storage } \\
\text { shall be managed to identify and segregate low-level } \\
\text { waste from mixed low-level waste. }\end{array}$ \\
\hline
\end{tabular}

(7) Staging. Staging of low-level waste shall be for the purpose of the accumulation of such quantities of waste as necessary to facilitate transportation, treatment, and disposal. Staging longer than 90 days shall meet the requirements for storage above and in Chapter I of this Manual.

From DOE G 435.1-1 Chapter IV: The staging of lowlevel waste needs to be addressed in the radioactive waste management basis for the facility that is performing the staging. Generators, treatment facilities, and disposal facilities that stage waste must ensure that the action of staging is included and authorized as part of their radioactive waste management basis for the affected facilities, operations, or activities.

Staging longer than 90 days must be justified, the conditions for such storage met, and these practices approved by the Field Element Manager as part of the radioactive waste management basis for the facility.

Compliance with this requirement is demonstrated by a staging program that limits the temporary storage of waste to only circumstances allowed in the requirement, including justifications for any staging that exceeds the 90-day period, which is documented in the radioactive waste management basis for the facility.

O. Treatment. Low-level waste treatment to provide more stable waste forms and to improve the long-term performance of a low-level waste disposal facility shall be implemented as necessary to meet the performance objectives of the disposal facility.

From DOE G 435.1-1 Chapter IV: Compliance with this requirement is demonstrated when a treatment facility or process ensures that treated waste will meet the minimum waste form requirements of DOE $\mathrm{M}$ 435.1 and meet additional disposal facility-specific waste acceptance requirements for additional stability or long-term performance of facilities that will receive the treated waste.

P. Disposal. Low-level waste disposal facilities shall meet the following requirements.

(1) Performance Objectives. Low-level waste disposal facilities shall be sited, designed, operated, maintained, and closed so that a reasonable expectation exists that the following performance objectives will be met for waste disposed of after September 26, 1988:

Facility Compliance Information

NA; LLW is not stored at this facility.

LLW and mixed LLW is staged for the purpose of accumulation to facilitate treatment and disposal. Mixed LLW is staged in SAAs in accordance with MCP-17000 and MCP-17410. LLW is staged in TAAs in accordance with MCP-17000 and MCP-17410.

MCP-17000, Appendix F restricts staging LLW to 90 days maximum at any generator or treatment facility prior to acceptance by a storage facility.

1356-07-FASB, Table 2.03 addresses LLW and mixed LLW.

Individual projects also would have project-specific laboratory instructions that would address the management of mixed LLW in accordance with RCRA regulations.
NA; treatment is not performed in this facility.

Containerized elementary neutralization is performed at this facility as provided by LWP-8000. As stated in $\S 4.118$, elementary neutralization of corrosive hazardous waste may take place at any location where the waste is generated or stored, and neither a generator treatment plan nor a permit is required. Solidification of liquid LLW for the purpose of staging (not for treating the radioactive constituents) also may be performed. Therefore, this facility is not considered to be a treatment facility.

NA; LLW is not disposed of in this facility. 
Table 16. (continued).

Facility Name: MFC-787, Fuels and Applied Sciences Building

\section{Chapter IV, LLW Requirements}

(a) Dose to representative members of the public shall not exceed $25 \mathrm{mrem}(0.25 \mathrm{mSv})$ in a year total effective dose equivalent from all exposure pathways, excluding the dose from radon and its progeny in air.

(b) Dose to representative members of the public via the air pathway shall not exceed $10 \mathrm{mrem}(0.10 \mathrm{mSv})$ in a year total effective dose equivalent, excluding the dose from radon and its progeny.

(c) Release of radon shall be less than an average flux of $20 \mathrm{pCi} / \mathrm{m}^{2} / \mathrm{s}\left(0.74 \mathrm{~Bq} / \mathrm{m}^{2} / \mathrm{s}\right)$ at the surface of the disposal facility. Alternatively, a limit of $0.5 \mathrm{pCi} / 1$ $(0.0185 \mathrm{~Bq} / \mathrm{l})$ of air may be applied at the boundary of the facility.

(2) Performance Assessment. A site-specific radiological performance assessment shall be prepared and maintained for DOE low-level waste disposed of after September 26, 1988. The performance assessment shall include calculations for a 1,000 year period after closure of potential doses to representative future members of the public and potential releases from the facility to provide a reasonable expectation that the performance objectives identified in this Chapter are not exceeded as a result of operation and closure of the facility.

(a) Analyses performed to demonstrate compliance with the performance objectives in this Chapter, and to establish limits on concentrations of radionuclides for disposal based on the performance measures for inadvertent intruders in this Chapter shall be based on reasonable activities in the critical group of exposed individuals. Unless otherwise specified, the assumption of average living habits and exposure conditions in representative critical groups of individuals projected to receive the highest doses is appropriate. The likelihood of inadvertent intruder scenarios may be considered in interpreting the results of the analyses and establishing radionuclide concentrations, if adequate justification is provided.

(b) The point of compliance shall correspond to the point of highest projected dose or concentration beyond a 100 meter buffer zone surrounding the disposed waste. A larger or smaller buffer zone may be used if adequate justification is provided.

(c) Performance assessments shall address reasonably foreseeable natural processes that might disrupt barriers against release and transport of radioactive materials.

(d) Performance assessments shall use DOE-approved
Facility Compliance Information

See P. above.

See P. above.

See P. above.

See P. above.

See P. above.

See P. above.

See P. above.

See P. above. 
Table 16. (continued).

Facility Name: MFC-787, Fuels and Applied Sciences Building

\begin{tabular}{|l|}
\hline \multicolumn{1}{|c|}{ Chapter IV, LLW Requirements } \\
\hline $\begin{array}{l}\text { dose coefficients (dose conversion factors) for internal } \\
\text { and external exposure of reference adults. }\end{array}$ \\
\hline $\begin{array}{l}\text { (e) The performance assessment shall include a } \\
\text { sensitivity/uncertainty analysis. }\end{array}$ \\
(f) Performance assessments shall include a \\
demonstration that projected releases of radionuclides \\
to the environment shall be maintained as low as \\
reasonably achievable (ALARA).
\end{tabular}

(g) For purposes of establishing limits on radionuclides that may be disposed of near-surface, the performance assessment shall include an assessment of impacts to water resources.

(h) For purposes of establishing limits on the concentration of radionuclides that may be disposed of near-surface, the performance assessment shall include an assessment of impacts calculated for a hypothetical person assumed to inadvertently intrude for a temporary period into the low-level waste disposal facility. For intruder analyses, institutional controls shall be assumed to be effective in deterring intrusion for at least 100 years following closure. The intruder analyses shall use performance measures for chronic and acute exposure scenarios, respectively, of 100 mrem $(1 \mathrm{mSv})$ in a year and $500 \mathrm{mrem}(5 \mathrm{mSv})$ total effective dose equivalent excluding radon in air.

(3) Composite Analysis. For disposal facilities which received waste after September 26, 1988, a site-specific radiological composite analysis shall be prepared and maintained that accounts for all sources of radioactive material that may be left at the DOE site and may interact with the low- level waste disposal facility, contributing to the dose projected to a hypothetical member of the public from the existing or future disposal facilities. Performance measures shall be consistent with DOE requirements for protection of the public and environment and evaluated for a 1,000 year period following disposal facility closure. The composite analysis results shall be used for planning, radiation protection activities, and future use commitments to minimize the likelihood that current low- level waste disposal activities will result in the need for future corrective or remedial actions to adequately protect the public and the environment.

(4) Performance Assessment and Composite Analysis Maintenance. The performance assessment and composite analysis shall be maintained to evaluate changes that could affect the performance, design, and operating bases for the facility. Performance
Facility Compliance Information

See P. above.

See P. above.

See P. above.

See P. above.

See P. above.

See P. above. 
Table 16. (continued).

Facility Name: MFC-787, Fuels and Applied Sciences Building

\begin{tabular}{|l|l|}
\hline \multicolumn{1}{|c|}{ Chapter IV, LLW Requirements } & Facility Compliance Information \\
\hline $\begin{array}{l}\text { assessment and composite analysis maintenance shall } \\
\text { include the conduct of research, field studies, and } \\
\text { monitoring needed to address uncertainties or gaps in } \\
\text { existing data. The performance assessment shall be } \\
\text { updated to support the final facility closure. Additional } \\
\text { iterations of the performance assessment and composite } \\
\text { analysis shall be conducted as necessary during the } \\
\text { post-closure period. }\end{array}$ & \\
\hline
\end{tabular}

(a) Performance assessments and composite analyses shall be reviewed and revised when changes in waste forms or containers, radionuclide inventories, facility design and operations, closure concepts, or the improved understanding of the performance of the waste disposal facility in combination with the features of the site on which it is located alter the conclusions or the conceptual model(s) of the existing performance assessment or composite analysis.

(b) A determination of the continued adequacy of the performance assessment and composite analysis shall be made on an annual basis, and shall consider the results of data collection and analysis from research, field studies, and monitoring.

(c) Annual summaries of low-level waste disposal operations shall be prepared with respect to the conclusions and recommendations of the performance assessment and composite analysis and a determination of the need to revise the performance assessment or composite analysis.

(5) Disposal Authorization. A disposal authorization statement shall be obtained prior to construction of a new low-level waste disposal facility. Field Elements with existing low-level waste disposal facilities shall obtain a disposal authorization statement in accordance with the schedule in the Complex-Wide Low-Level Waste Management Program Plan. The disposal authorization statement shall be issued based on a review of the facility's performance assessment, composite analysis, performance assessment and composite analysis maintenance, preliminary closure plan, and preliminary monitoring plan. The disposal authorization statement shall specify the limits and conditions on construction, design, operations, and closure of the low-level waste facility based on these reviews. A disposal authorization statement is a part of the radioactive waste management basis for a disposal facility. Failure to obtain a disposal authorization statement by the implementation date of this Order shall result in shutdown of the disposal facility.

(6) Disposal Facility Operations. The disposal facility
See P. above.

See P. above.

See P. above.

See P. above.

See P. above. 
Table 16. (continued).

Facility Name: MFC-787, Fuels and Applied Sciences Building

\begin{tabular}{l} 
Chapter IV, LLW Requirements \\
\hline design and operation must be consistent with the \\
disposal facility closure plan and lead to disposal \\
facility closure that provides a reasonable expectation \\
that performance objectives will be met. Low-level \\
waste shall be disposed in such a manner that achieves \\
the performance objectives stated in this Chapter, \\
consistent with the disposal facility radiological \\
performance assessment. Additional requirements \\
include:
\end{tabular}

(a) Operating procedures shall be developed and implemented for low-level waste disposal facilities that protect the public, workers, and the environment; ensure the security of the facility; minimize subsidence during and after waste emplacement; achieve long-term stability and minimize the need for long-term active maintenance; and meet the requirements of the closure/post-closure plan.

(b) Permanent identification markers for disposal excavations and monitoring wells shall be emplaced.

(c) Low-level waste placement into disposal units shall minimize voids between waste containers. Voids within disposal units shall be filled to the extent practical. Uncontainerized bulk waste shall also be placed in a manner that minimizes voids and subsidence.

(d) Operations are to be conducted so that active waste disposal operations will not have an adverse effect on any other disposal units.

(e) Operations shall include a process for tracking and documenting low-level waste placement in the facility by generator source.

(7) Alternate Requirements for Low-Level Waste Disposal Facility Design and Operation. Requirements other than those set forth in this Section for the design and operation of a low-level waste disposal facility may be approved on a specific basis if a reasonable expectation is demonstrated that the disposal performance objectives will be met.

Q. Closure. The following requirements are in addition to those in Chapter I of this Manual.

(1) Disposal Facility Closure Plans. A preliminary closure plan shall be developed and submitted to Headquarters for review with the performance assessment and composite analysis. The closure plan shall be updated following issuance of the disposal authorization statement to incorporate conditions specified in the disposal authorization statement.
Facility Compliance Information

See P. above.

See P. above.

See P. above.

See P. above.

See P. above.

See P. above.

NA; LLW is not disposed of in this facility.

See Q. above. 
Table 16. (continued).

\begin{tabular}{|c|c|}
\hline \multicolumn{2}{|c|}{ Facility Name: MFC-787, Fuels and Applied Sciences Building } \\
\hline Chapter IV, LLW Requirements & Facility Compliance Information \\
\hline Closure plans shall: & \\
\hline $\begin{array}{l}\text { (a) Be updated as required during the operational life of } \\
\text { the facility. }\end{array}$ & See Q. above. \\
\hline $\begin{array}{l}\text { (b) Include a description of how the disposal facility } \\
\text { will be closed to achieve long-term stability and } \\
\text { minimize the need for active maintenance following } \\
\text { closure and to ensure compliance with the requirements } \\
\text { of DOE } 5400.5, \text { Radiation Protection of the Public and } \\
\text { the Environment. }\end{array}$ & See Q. above. \\
\hline $\begin{array}{l}\text { (c) Include the total expected inventory of wastes to be } \\
\text { disposed of at the facility over the operational life of } \\
\text { the facility. }\end{array}$ & See Q. above. \\
\hline $\begin{array}{l}\text { (2) Disposal Facility Closure. Closure of a disposal } \\
\text { facility shall occur within a five-year period after it is } \\
\text { filled to capacity, or after the facility is otherwise } \\
\text { determined to be no longer needed. }\end{array}$ & See Q. above. \\
\hline $\begin{array}{l}\text { (a) Prior to facility closure, the final inventory of the } \\
\text { low-level waste disposed in the facility shall be } \\
\text { prepared and incorporated in the performance } \\
\text { assessment and composite analysis which shall be } \\
\text { updated to support the closure of the facility. }\end{array}$ & See Q. above. \\
\hline $\begin{array}{l}\text { (b) A final closure plan shall be prepared based on the } \\
\text { final inventory of waste disposed in the facility, the } \\
\text { plan implemented, and the updated performance } \\
\text { assessment and composite analysis prepared in support } \\
\text { of the facility closure. }\end{array}$ & See Q. above. \\
\hline $\begin{array}{l}\text { (c) Institutional control measures shall be integrated } \\
\text { into land use and stewardship plans and programs, and } \\
\text { shall continue until the facility can be released pursuant } \\
\text { to DOE } 5400.5, \text { Radiation Protection of the Public and } \\
\text { the Environment. }\end{array}$ & See Q. above. \\
\hline $\begin{array}{l}\text { (d) The location and use of the facility shall be filed } \\
\text { with the local authorities responsible for land use and } \\
\text { zoning. }\end{array}$ & See Q. above. \\
\hline $\begin{array}{l}\text { R. Monitoring. The following requirements are in } \\
\text { addition to those in Chapter I of this Manual [DOE M } \\
435.1-1 \text { §I.1.E(7)]. }\end{array}$ & See (1), (2), and (3) below. \\
\hline $\begin{array}{l}\text { (1) All Waste Facilities. Parameters that shall be } \\
\text { sampled or monitored, at a minimum, include: } \\
\text { temperature, pressure (for closed systems), } \\
\text { radioactivity in ventilation exhaust and liquid effluent } \\
\text { streams, and flammable or explosive mixtures of gases. } \\
\text { Facility monitoring programs shall include verification } \\
\text { that passive and active control systems have not failed. } \\
\text { From DOE G 435.1-1 Chapter IV: The minimum }\end{array}$ & $\begin{array}{l}\text { Monitoring requirements at INL radioactive waste } \\
\text { management facilities are tailored for the specific } \\
\text { facility to enable timely indication of developing } \\
\text { problems. Existing radiological control procedures and } \\
\text { assessments are followed/completed to monitor waste } \\
\text { facilities. } \\
\text { LRD-15001 and MCP-139 specify methods and } \\
\text { frequency of radiological control surveys of all }\end{array}$ \\
\hline
\end{tabular}


Table 16. (continued).

Facility Name: MFC-787, Fuels and Applied Sciences Building

\section{Chapter IV, LLW Requirements}

parameters specified in the requirement were selected based on their potential significance for anticipating and identifying undesirable conditions at low-level waste management facilities. Each facility's radioactive waste management basis should include an evaluation of the applicability and significance of the minimum parameters. This evaluation also needs to consider additional parameters to be sampled or monitored to ensure the protection of the public health, the environment, and the workers. If a minimum parameter specified in the requirement is deemed to be not applicable in any way to the active operation of that facility, then that justification should be included in the radioactive waste management basis and when approved constitutes an exemption to the manual.

Verification activities are part of the radioactive waste management basis as a condition for operation and documented appropriately.

Compliance with this requirement is demonstrated if monitoring or sampling for the stated parameters is performed for all facilities with a precision, accuracy, and frequency consistent with timely identification of developing problems and a justification exists in the approved radioactive waste management basis for those specified parameters which are not monitored or sampled.

(2) Liquid Waste Storage Facilities. For facilities storing liquid low-level waste, the following shall also be monitored: liquid level and/or waste volume, and significant waste chemistry parameters.

(3) Disposal Facilities. A preliminary monitoring plan for a low-level waste disposal facility shall be prepared and submitted to Headquarters for review with the performance assessment and composite analysis. The monitoring plan shall be updated within one year following issuance of the disposal authorization statement to incorporate and implement conditions specified in the disposal authorization statement.

(a) The site-specific performance assessment and composite analysis shall be used to determine the media, locations, radionuclides, and other substances to be monitored.

(b) The environmental monitoring program shall be designed to include measuring and evaluating releases, migration of radionuclides, disposal unit subsidence, and changes in disposal facility and disposal site parameters which may affect long-term performance.

\section{Facility Compliance Information}

radiological areas. MCP-139 specifies the use of Form 441.A34. This form is referred to as the "routine sheet" and is to be used by facility radiological control foremen to list radiological areas that are to be surveyed, the survey periods, and methods.
NA; liquid waste is not stored at this facility.

NA; LLW is not disposed of in this facility.

See (3) above.

See (3) above. 
Table 16. (continued).

\begin{tabular}{|l|l|}
\hline \multicolumn{2}{|c|}{ Facility Name: MFC-787, Fuels and Applied Sciences Building } \\
\hline \multicolumn{1}{|c|}{ Chapter IV, LLW Requirements } & \multicolumn{1}{|c|}{ Facility Compliance Information } \\
\hline $\begin{array}{l}\text { (c) The environmental monitoring programs shall be } \\
\text { capable of detecting changing trends in performance to } \\
\text { allow application of any necessary corrective action } \\
\text { prior to exceeding the performance objectives in this } \\
\text { Chapter. }\end{array}$ & See (3) above. \\
\hline
\end{tabular}

\subsection{MFC-792A, Space and Security Power Systems Facility}

1. Facility description: MFC-792A, Space and Security Power Systems, provides the capability for assembly and acceptance testing of RPSs. The Space and Security Power Systems Facility is comprised of two structures (MFC-792 and 792A). MFC-792 is limited to non-nuclear administrative and support functions. All activities involving handling, assembling, testing, and packaging of fueled RPS components are performed in MFC-792A.

2. Hazard category: Hazard Category 2 non-reactor nuclear facility

3. Radioactive waste managed at this facility: Routine LLW subsequent to facility operations are generated and staged at this facility.

4. RWMB documents/programs:

a. Safety basis/hazard analysis:

- DSA-009-RPSF, "RPSF Documented Safety Analysis"

- LST-302, "Safety Basis List for the Materials and Fuels Complex (MFC) Space and Security Power Systems Facility (SSPSF)"

- IAG-261, "INL Authorization Agreement for the Materials and Fuels Complex (MFC) Space and Security Power Systems Facility (SSPSF)"

b. Laboratory-wide:

- Form 441.A34, "INL Radiological Control Required Surveys"

- LI-435, "Waste Management Routine Field Activities"

- LRD-15001, "Radiological Control Manual"

- LWP-13840, "Management of Issues, Observations, and Noteworthy Practices"

- LWP-14002, "Timeout and Stop Work Authority"

- LWP-15011, "Radioactive Material Areas and Radioactive Storage Areas"

- LWP-17000, "Waste Management"

- MCP-139, "Radiological Surveys"

- MCP-17000, "Waste Generator Services Waste Management"

- MCP-17500, "Waste Generator Services Certification of Waste Shipments to the Nevada Test Site"

- PDD-17000, "Waste Management Program"

- PLN-114, "INL Emergency Plan/RCRA Contingency Plan"

- PLN-522, "Quality Assurance Program Plan for the Waste Management/Waste Certification Program" 


\section{c. Facility-specific:}

- None.

LLW is managed at this facility. Table 17 shows the facility compliance information for DOE Manual 435.1-1 Chapter IV, "Low-level Waste Requirements."

Table 17. MFC-792A, Space and Security Power Systems Facility, DOE Manual 435.1-1 low-level waste requirements and facility compliance information.

\begin{tabular}{|c|c|}
\hline \multicolumn{2}{|c|}{ Facility Name: MFC-792A Space and Security Power Systems Facility } \\
\hline Chapter IV. Low-Level Waste Requirements & Facility Compliance Information \\
\hline $\begin{array}{l}\text { A. Definition of Low-Level Waste. Low-level } \\
\text { radioactive waste is radioactive waste that is not high- } \\
\text { level radioactive waste, spent nuclear fuel, transuranic } \\
\text { waste, byproduct material (as defined in section 11e.(2) } \\
\text { of the Atomic Energy Act of 1954, as amended), or } \\
\text { naturally occurring radioactive material. } \\
\text { (From DOE G } 435.1-1 \text { Chapter IV: Low-level } \\
\text { radioactive waste is defined by what it is not. The } \\
\text { guidance on definitions in Chapters II and III should be } \\
\text { consulted first for making a determination on how to } \\
\text { properly manage a suspect waste stream.) }\end{array}$ & $\begin{array}{l}\text { This requirement provides the criteria for determining } \\
\text { which DOE radioactive waste is to be managed as } \\
\text { LLW in accordance with DOE Manual 435.1-1, } \\
\text { Chapter IV. } \\
\text { Radioactive waste managed at this facility under the } \\
\text { requirements of this chapter is not managed under the } \\
\text { requirements of DOE Manual } 435.1-1 \text { Chapter II or } \\
\text { Chapter III. }\end{array}$ \\
\hline $\begin{array}{l}\text { B. Management of Specific Wastes. The following } \\
\text { provide for management of specific wastes as low-level } \\
\text { waste in accordance with the requirements in this } \\
\text { Chapter: }\end{array}$ & See below. \\
\hline $\begin{array}{l}\text { (1) Mixed Low-Level Waste. Low-level waste } \\
\text { determined to contain both source, special nuclear, or } \\
\text { byproduct material subject to the Atomic Energy Act of } \\
\text { 1954, as amended, and a hazardous component subject } \\
\text { to the Resource Conservation and Recovery Act } \\
\text { (RCRA), as amended, shall be managed in accordance } \\
\text { with the requirements of RCRA and DOE O 435.1, } \\
\text { Radioactive Waste Management, and this Manual. }\end{array}$ & NA; this facility does not manage mixed LLW. \\
\hline $\begin{array}{l}\text { (2) TSCA-Regulated Waste. Low-level waste } \\
\text { containing polychlorinated biphenyls, asbestos, or other } \\
\text { such regulated toxic components shall be managed in } \\
\text { accordance with requirements derived from the Toxic } \\
\text { Substances Control Act, as amended, DOE O 435.1, } \\
\text { Radioactive Waste Management, and this Manual. }\end{array}$ & $\begin{array}{l}\text { NA; this facility does not manage TSCA-regulated } \\
\text { waste. }\end{array}$ \\
\hline $\begin{array}{l}\text { (3) Accelerator-Produced Waste. Radioactive waste } \\
\text { produced as a result of operations of DOE accelerators } \\
\text { is low-level waste and shall be managed in accordance } \\
\text { with DOE O 435.1, Radioactive Waste Management, } \\
\text { and this Manual, and all applicable Federal or State } \\
\text { requirements. }\end{array}$ & $\begin{array}{l}\text { NA; this facility does not manage accelerator-produced } \\
\text { waste. }\end{array}$ \\
\hline $\begin{array}{l}\text { (4) } 11 \text { e.(2) and Naturally Occurring Radioactive } \\
\text { Material. Small quantities of } 11 \text { e.(2) byproduct } \\
\text { material and naturally occurring radioactive material } \\
\text { may be managed as low-level waste provided they can } \\
\text { be managed to meet the requirements for low-level }\end{array}$ & $\begin{array}{l}\text { NA; this facility does not manage naturally occurring } \\
\text { radioactive material. }\end{array}$ \\
\hline
\end{tabular}


Table 17. (continued).

Facility Name: MFC-792A Space and Security Power Systems Facility

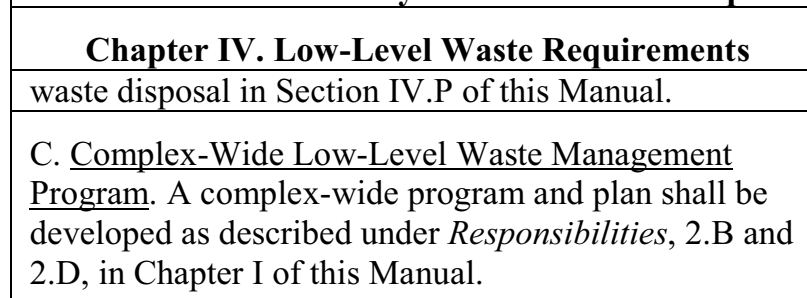

D. Radioactive Waste Management Basis. Low-level waste facilities, operations, and activities shall have a radioactive waste management basis consisting of physical and administrative controls to ensure the protection of workers, the public, and the environment. The following specific waste management controls shall be part of the radioactive waste management basis:

Not a facility-specific requirement. DOE Manual 435.1-1 §I.2.B and §I.2.D apply to the Assistant Secretary for Environmental Management and the Deputy Assistant Secretary for Waste Management, respectively.

The RWMB provides the regulatory framework for management of radioactive waste at INL. It specifically identifies facility management and implementing documents for the generation, storage, treatment, and disposal of radiological waste..

IAG-261 documents DOE's approval of Battelle Energy Alliance's safety basis defined in LST-302.

This facility is a Hazard Category 2 non-reactor nuclear facility (DSA-009-RPSF).

(1) Generators. The waste certification program. See J. below.

From DOE G 435.1-1 Chapter IV: For a facility that generates low-level waste, the radioactive waste management basis is to include the program for certifying that waste meets the waste acceptance requirements of the facility(ies) to which the waste will be sent.

(2) Treatment Facilities. certification program. The waste acceptance requirements and the waste [sic]

From DOE G 435.1-1 Chapter IV: Facilities that store or treat low-level waste are to have approved waste acceptance requirements (see DOE M 435.1-1, Section IV.G) prior to the issuance of a radioactive waste management basis.

A facility that stores or treats waste also is generally expected to have a waste certification program. Waste from these facilities will have to be certified as meeting the waste acceptance requirements of the facility to which it will be transferred, and the facilities have the potential for generating radioactive waste (e.g., secondary processing streams from treatment, monitoring and sampling, radioactive release cleanup). Consequently, storage and treatment facilities should also have an approved waste certification program as part of their radioactive waste management basis.

As part of the radioactive waste management basis, site personnel needs to implement a system or process for tracking the waste inventory at a storage, treatment, or disposal facility.

(3) Storage Facilities. The waste acceptance requirements and the waste certification program.
NA; LLW is not treated at this facility.
NA; this facility stages waste in accordance with N.(7) to facilitate treatment or disposal. 
Table 17. (continued).

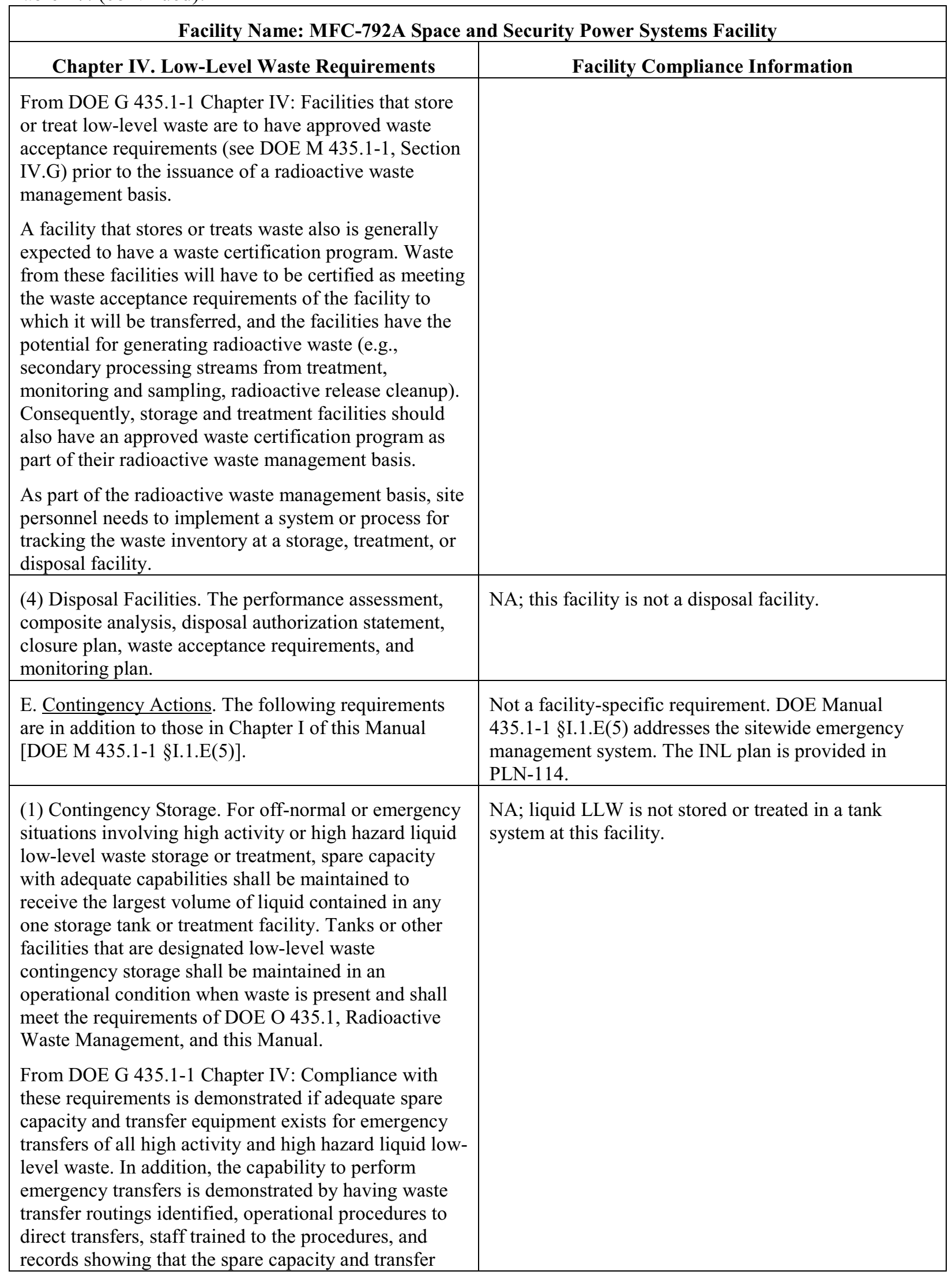


Table 17. (continued).

\begin{tabular}{|c|c|}
\hline \multicolumn{2}{|c|}{ Facility Name: MFC-792A Space and Security Power Systems Facility } \\
\hline Chapter IV. Low-Level Waste Requirements & Facility Compliance Information \\
\hline capability are kept in operating condition. & \\
\hline $\begin{array}{l}\text { (2) Transfer Equipment. Pipelines and auxiliary } \\
\text { facilities necessary for the transfer of high activity or } \\
\text { high hazard liquid low-level waste to contingency } \\
\text { storage shall be maintained in an operational condition } \\
\text { when waste is present and shall meet the requirements } \\
\text { of DOE O } 435.1 \text {, Radioactive Waste Management, and } \\
\text { this Manual. }\end{array}$ & $\begin{array}{l}\text { NA; liquid LLW is not stored or treated in a tank } \\
\text { system at this facility. }\end{array}$ \\
\hline $\begin{array}{l}\text { From DOE G } 435.1-1 \text { Chapter IV: Compliance with } \\
\text { these requirements is demonstrated if adequate spare } \\
\text { capacity and transfer equipment exists for emergency } \\
\text { transfers of all high activity and high hazard liquid low- } \\
\text { level waste. In addition, the capability to perform } \\
\text { emergency transfers is demonstrated by having waste } \\
\text { transfer routings identified, operational procedures to } \\
\text { direct transfers, staff trained to the procedures, and } \\
\text { records showing that the spare capacity and transfer } \\
\text { capability are kept in operating condition. }\end{array}$ & \\
\hline $\begin{array}{l}\text { F. Corrective Actions. I of this Manual. The following } \\
\text { requirements are in addition to those in Chapter [sic] } \\
\text { From DOE G 435.1-1 Chapter IV: Compliance with } \\
\text { DOE M } 435.1-1 \S I .2 . \text { G.(1) is demonstrated by records } \\
\text { showing what corrective actions were taken to remedy } \\
\text { situations in the radioactive waste management system. } \\
\text { Compliance with DOE M 435.1-1 §I.2.G.(2) is } \\
\text { demonstrated by having the necessary procedures, } \\
\text { mechanisms, and training in place to effect shutdown } \\
\text { or curtailment of activities which pose an imminent } \\
\text { danger or other serious hazard to workers or the public, } \\
\text { or are not protective of the environment. }\end{array}$ & $\begin{array}{l}\text { The INL-wide procedure addressing problem } \\
\text { identification as required by DOE Manual } 435.1-1 \\
\text { §I.2.G.(1) is LWP-13840, which implements the } \\
\text { laboratory's corrective action system. } \\
\text { The INL-wide procedure addressing shutdown or } \\
\text { curtailment of activities as required by DOE Manual } \\
\text { 435.1-1 §I.2.G.(2) is LWP-14002. }\end{array}$ \\
\hline $\begin{array}{l}\text { (1) Order Compliance. Corrective actions shall be } \\
\text { implemented whenever necessary to ensure the } \\
\text { requirements of DOE O } 435.1 \text {, Radioactive Waste } \\
\text { Management, and this Manual are met. } \\
\text { From DOE G 435.1-1 Chapter IV: If a facility or } \\
\text { activity can be allowed to operate while a } \\
\text { noncompliant or hazardous condition exists, the } \\
\text { allowance and any associated limitations must be } \\
\text { defined as part of the facility or activity's radioactive } \\
\text { waste management basis, identified as a configuration } \\
\text { controlled item in a configuration management plan or } \\
\text { included in a revision or modification to an operating } \\
\text { procedure or similar controlled documentation. } \\
\text { Compliance with this requirement is demonstrated if a } \\
\text { corrective action system addresses noncompliant or } \\
\text { hazardous situations involving low-level waste } \\
\text { management facilities in a systematic fashion, and }\end{array}$ & See F. above. \\
\hline
\end{tabular}


Table 17. (continued).

Facility Name: MFC-792A Space and Security Power Systems Facility

\begin{tabular}{|l|}
\hline Chapter IV. Low-Level Waste Requirements \\
\hline allows identification of problems by all personnel.
\end{tabular}

(2) Operations Curtailment. Operations shall be curtailed or facilities shut down for failure to establish, maintain, or operate consistent with an approved radioactive waste management basis.

From DOE G 435.1-1 Chapter IV: Compliance with this requirement is demonstrated with a documented system of routine assessments to determine whether waste management activities and facilities are operating in accordance with an approved radioactive waste management basis that provides for graded limitations that can be placed on activities and operations that do not have, or are operating outside of, an approved radioactive waste management basis, including shutdown of the facility.

G. Waste Acceptance. The following requirements are in addition to those in Chapter I of this Manual [DOE M 435.1-1 §I.2.F(6)].

(1) Technical and Administrative. Waste acceptance requirements for all low-level waste storage, treatment, or disposal facilities, operations, and activities shall specify, at a minimum, the following:

From DOE G 435.1-1 Chapter IV: Compliance with these waste acceptance requirements is demonstrated if they are documented, contain clear and precise criteria specifying the radionuclide limits in the form of contents or concentrations that can be accepted, the limitations and prohibitions on waste forms and packages that can be received, and the limits, prohibitions, or instructions concerning any other technical information so that the waste is compatible with the safety basis of the facility, and which will result in acceptable waste at subsequent steps in managing the low-level waste.

(a) Allowable activities and/or concentrations of specific radionuclides.

(b) Acceptable waste form and/or container requirements that ensure the chemical and physical stability of waste under conditions that might be encountered during transportation, storage, treatment, or disposal.

(c) Restrictions or prohibitions on waste, materials, or containers that may adversely affect waste handlers or compromise facility or waste container performance.

(d) The following are additional waste acceptance requirements that shall be specified in low-level waste disposal facility waste acceptance requirements: Facility Compliance Information

The approved RWMB establishes the current compliance status at each radioactive waste management facility. Facility assessments are scheduled to ensure waste management activities are conducted in accordance with the approved RWMB.
Not a facility-specific requirement. DOE Manual 435.1-1 §I.2.F(6) applies to field element managers.

NA; this facility generates LLW but does not receive radioactive waste from other sources.
See (1) above.

See (1) above.

See (1) above.

NA; this facility is not a LLW disposal facility. 
Table 17. (continued).

\begin{tabular}{|c|c|}
\hline \multicolumn{2}{|c|}{ Facility Name: MFC-792A Space and Security Power Systems Facility } \\
\hline Chapter IV. Low-Level Waste Requirements & Facility Compliance Information \\
\hline $\begin{array}{l}1 \text { Low-level waste must contribute to and not detract } \\
\text { from achieving long-term stability of the facility, } \\
\text { minimizing the need for long-term active maintenance, } \\
\text { minimizing subsidence, and minimizing contact of } \\
\text { water with waste. Void spaces within the waste and, if } \\
\text { containers are used, between the waste and its container } \\
\text { shall be reduced to the extent practical. }\end{array}$ & See (d) above. \\
\hline $\begin{array}{l}2 \text { Liquid low-level waste or low-level waste containing } \\
\text { free liquid must be converted into a form that contains } \\
\text { as little freestanding liquid as is reasonably achievable, } \\
\text { but in no case shall the liquid exceed } 1 \text { percent of the } \\
\text { waste volume when the low-level waste is in a disposal } \\
\text { container, or } 0.5 \text { percent of the waste volume after it is } \\
\text { processed to a stable form. }\end{array}$ & See (d) above. \\
\hline $\begin{array}{l}3 \text { Low-level waste must not be readily capable of } \\
\text { detonation or of explosive decomposition or reaction at } \\
\text { anticipated pressures and temperatures, or of explosive } \\
\text { reaction with water. Pyrophoric materials contained in } \\
\text { waste shall be treated, prepared, and packaged to be } \\
\text { nonflammable. }\end{array}$ & See (d) above. \\
\hline $\begin{array}{l}4 \text { Low-level waste must not contain, or be capable of } \\
\text { generating by radiolysis or biodegradation, quantities } \\
\text { of toxic gases, vapors, or fumes harmful to the public } \\
\text { or workers or disposal facility personnel, or harmful to } \\
\text { the long-term structural stability of the disposal site. }\end{array}$ & See (d) above. \\
\hline $\begin{array}{l}5 \text { Low-level waste in a gaseous form must be packaged } \\
\text { such that the pressure does not exceed } 1.5 \text { atmospheres } \\
\text { absolute at } 20 \mathrm{C} \text {. [sic] }\end{array}$ & See (d) above. \\
\hline $\begin{array}{l}\text { (e) The basis, procedures, and levels of authority } \\
\text { required for granting exceptions to the waste } \\
\text { acceptance requirements, which shall be contained in } \\
\text { each facility's waste acceptance documentation. Each } \\
\text { exception request shall be documented, including its } \\
\text { disposition as approved or not approved. }\end{array}$ & $\begin{array}{l}\text { NA; this facility does not accept waste from other } \\
\text { facilities. }\end{array}$ \\
\hline $\begin{array}{l}\text { From DOE G } 435.1-1 \text { Chapter IV: Waste acceptance } \\
\text { requirements are acceptable if they are documented and } \\
\text { contain a clear description of the procedure and bases } \\
\text { for obtaining an exception or deviation to the } \\
\text { acceptance criteria for low-level waste to be received at } \\
\text { the facility. }\end{array}$ & \\
\hline $\begin{array}{l}\text { (2) Evaluation and Acceptance. The receiving facility } \\
\text { shall evaluate waste for acceptance, including } \\
\text { confirmation that the technical and administrative } \\
\text { requirements have been met. A process for the } \\
\text { disposition of non-conforming wastes shall be } \\
\text { established. }\end{array}$ & $\begin{array}{l}\text { NA; this facility does not accept waste from other } \\
\text { facilities. }\end{array}$ \\
\hline
\end{tabular}


Table 17. (continued).

\begin{tabular}{|c|c|}
\hline \multicolumn{2}{|c|}{ Facility Name: MFC-792A Space and Security Power Systems Facility } \\
\hline Chapter IV. Low-Level Waste Requirements & Facility Compliance Information \\
\hline $\begin{array}{l}\text { From DOE G 435.1-1 Chapter IV: Compliance with the } \\
\text { waste acceptance requirements for a low-level waste } \\
\text { management facility is demonstrated if they include a } \\
\text { process for evaluation and acceptance of incoming } \\
\text { waste to ensure the acceptance criteria of the facility } \\
\text { receiving the waste are met that includes one of or a } \\
\text { combination of: (1) testing, sampling, and analysis of } \\
\text { representative samples of waste upon receipt; (2) } \\
\text { testing, sampling, and analysis of split samples of } \\
\text { waste taken at the generator site; ( } 3 \text { ) evaluation of } \\
\text { testing, sampling, and analysis of data provided by the } \\
\text { generator, or (4) audits, reviews, surveillance, or } \\
\text { observations of generator waste certification programs } \\
\text { and characterization activities. Additionally, acceptable } \\
\text { waste acceptance requirements for a storage, treatment } \\
\text { or disposal facility will have documented procedures } \\
\text { and actions to be taken if a waste that does not conform } \\
\text { to the waste acceptance criteria is received at the } \\
\text { facility. }\end{array}$ & \\
\hline $\begin{array}{l}\text { H. Waste Generation Planning. The following } \\
\text { requirements are in addition to those in Chapter I of } \\
\text { this Manual [DOE M 435.1-1 §I.2.F(7)]. }\end{array}$ & $\begin{array}{l}\text { Not a facility-specific requirement. DOE Manual } \\
\text { 435.1-1 §I.2.F(7) applies to field element managers. }\end{array}$ \\
\hline $\begin{array}{l}\text { (1) Life-Cycle Planning. Prior to waste generation, } \\
\text { planning shall be performed to address the entire life } \\
\text { cycle for all low-level waste streams. }\end{array}$ & $\begin{array}{l}\text { PDD- } 17000 \text { and LWP- } 17000 \text { provide direction to the } \\
\text { waste generators for waste generation planning to } \\
\text { address the entire life cycle. }\end{array}$ \\
\hline $\begin{array}{l}\text { From DOE G 435.1-1 Chapter IV: Compliance with } \\
\text { this planning requirement is demonstrated by the } \\
\text { individual sites establishing a process for evaluating the } \\
\text { life-cycle of low-level waste prior to its generation, } \\
\text { including the identification of low-level wastes with no } \\
\text { path to disposal and appropriate records justifying the } \\
\text { newly generated low-level waste stream(s), and site } \\
\text { personnel possessing planning information showing the } \\
\text { location(s) where low-level waste will be stored, } \\
\text { treated, and/or disposed along with a confirmation that } \\
\text { the personnel managing the facilities agree that the } \\
\text { low-level waste may be managed at those facilities. }\end{array}$ & \\
\hline $\begin{array}{l}\text { (2) Waste with No Identified Path to Disposal. Low- } \\
\text { level waste streams with no identified path to disposal } \\
\text { shall be generated only in accordance with approved } \\
\text { conditions which, at a minimum, shall address: }\end{array}$ & $\begin{array}{l}\text { NA; this facility is not generating LLW that does not } \\
\text { have an identified path to disposal. }\end{array}$ \\
\hline (a) Programmatic need to generate the waste; & See (2) above. \\
\hline $\begin{array}{l}\text { (b) Characteristics and issues preventing the disposal of } \\
\text { the waste; }\end{array}$ & See (2) above. \\
\hline $\begin{array}{l}\text { (c) Safe storage of the waste until disposal can be } \\
\text { achieved; and }\end{array}$ & See (2) above. \\
\hline
\end{tabular}


Table 17. (continued).

\begin{tabular}{|c|c|}
\hline \multicolumn{2}{|c|}{ Facility Name: MFC-792A Space and Security Power Systems Facility } \\
\hline Chapter IV. Low-Level Waste Requirements & Facility Compliance Information \\
\hline $\begin{array}{l}\text { (d) Activities and plans for achieving final disposal of } \\
\text { the waste. }\end{array}$ & See (2) above. \\
\hline $\begin{array}{l}\text { I. Waste Characterization. Low-level waste shall be } \\
\text { characterized using direct or indirect methods, and the } \\
\text { characterization documented in sufficient detail to } \\
\text { ensure safe management and compliance with the } \\
\text { waste acceptance requirements of the facility receiving } \\
\text { the waste. }\end{array}$ & MCP-17000 addresses waste characterization. \\
\hline $\begin{array}{l}\text { From DOE G } 435.1-1 \text { Chapter IV: Compliance with } \\
\text { this requirement is demonstrated by a program for } \\
\text { documenting and the existence of records that } \\
\text { document the process for acquiring and verifying the } \\
\text { validity of low-level waste characterization data } \\
\text { acquired through the use of direct or indirect methods. }\end{array}$ & \\
\hline $\begin{array}{l}\text { (1) Data Quality Objectives. The data quality } \\
\text { objectives process, or a comparable process, shall be } \\
\text { used for identifying characterization parameters and } \\
\text { acceptable uncertainty in characterization data. } \\
\text { From DOE G } 435.1-1 \text { Chapter IV: Compliance with } \\
\text { this requirement is demonstrated by the documented } \\
\text { use of a data quality objectives or a comparable process } \\
\text { for determining the type, quantity, and quality of } \\
\text { characterization data needed to safely manage low- } \\
\text { level waste. }\end{array}$ & $\begin{array}{l}\text { Radioactive waste management facilities characterize } \\
\text { waste in accordance with the requirements of the } \\
\text { receiving storage, treatment, or disposal facility. The } \\
\text { documented use of a data quality objectives process, or } \\
\text { comparable process, was not identified for this facility. }\end{array}$ \\
\hline $\begin{array}{l}\text { (2) Minimum Waste Characterization. Characterization } \\
\text { data shall, at a minimum, include the following } \\
\text { information relevant to the management of the waste: } \\
\text { From DOE G } 435.1-1 \text { Chapter IV: Compliance with } \\
\text { this requirement is demonstrated by the existence of a } \\
\text { program or procedure for determining and records that } \\
\text { document characterization of low-level waste } \\
\text { consistent with the minimum characterization data } \\
\text { requirements. }\end{array}$ & $\begin{array}{l}\text { MCP-17000, including } \S \S 4.2,4.3 \text {, and } 4.4 \text {, provides } \\
\text { waste characterization requirements. Information on } \\
\text { absorbent media is required in } \S \S 4.5 \text { and } 4.7 \text {. } \\
\text { MCP-17000 also specifies the use of IWTS that } \\
\text { documents characterization data in an IWTS profile. }\end{array}$ \\
\hline (a) Physical and chemical characteristics; & See (2) above. \\
\hline $\begin{array}{l}\text { (b) Volume, including the waste and any stabilization } \\
\text { or absorbent media; }\end{array}$ & See (2) above. \\
\hline (c) Weight of the container and contents; & See (2) above. \\
\hline $\begin{array}{l}\text { (d) Identities, activities, and concentrations of major } \\
\text { radionuclides; }\end{array}$ & See (2) above. \\
\hline (e) Characterization date; & See (2) above. \\
\hline (f) Generating source; and & See (2) above. \\
\hline
\end{tabular}


Table 17. (continued).

\begin{tabular}{|c|c|}
\hline \multicolumn{2}{|c|}{ Facility Name: MFC-792A Space and Security Power Systems Facility } \\
\hline Chapter IV. Low-Level Waste Requirements & Facility Compliance Information \\
\hline $\begin{array}{l}\text { (g) Any other information which may be needed to } \\
\text { prepare and maintain the disposal facility performance } \\
\text { assessment, or demonstrate compliance with applicable } \\
\text { performance objectives. }\end{array}$ & See (2) above. \\
\hline $\begin{array}{l}\text { J. Waste Certification. A waste certification program } \\
\text { shall be developed, documented, and implemented to } \\
\text { ensure that the waste acceptance requirements of } \\
\text { facilities receiving low-level waste for storage, } \\
\text { treatment, and disposal are met. } \\
\text { From DOE G 435.1-1 Chapter IV: Compliance with the } \\
\text { development and documentation portion of the } \\
\text { certification requirement is demonstrated by a waste } \\
\text { certification plan that identifies the organizations } \\
\text { involved, assigns responsibilities for implementing the } \\
\text { program, and describes or references the quality } \\
\text { assurance, training, procurement controls, records } \\
\text { management, and procedures to be used by the } \\
\text { program. Acceptable performance for implementing } \\
\text { the program is demonstrated when appropriate } \\
\text { personnel are trained and follow the procedures that } \\
\text { govern their part of the waste certification. } \\
\text { Additionally, acceptable performance is demonstrated } \\
\text { if the waste certification plan and procedures are } \\
\text { current and controlled in accordance with a document } \\
\text { controls program, and records related to certification } \\
\text { (e.g., certification statements, training records, } \\
\text { procurement records, characterization records, } \\
\text { container records) are generated and managed in } \\
\text { accordance with the established site program. }\end{array}$ & $\begin{array}{l}\text { MCP-17000 cites a waste certification program for } \\
\text { LLW destined for NNSS. For waste destined for } \\
\text { locations other than NNSS, the waste disposition } \\
\text { specialist is responsible for certifying the waste stream } \\
\text { by ensuring the waste, as characterized, falls within the } \\
\text { limitations of the waste acceptance criteria of the } \\
\text { treatment, storage, or disposal facility (§2). } \\
\text { Container procurement is addressed in MCP-17000 } \\
\S 4.6 \text {. } \\
\text { MCP-17500 provides the WGS waste certification } \\
\text { program for LLW to be shipped to NNSS. } \\
\text { Waste certification is performed and tracked using } \\
\text { IWTS. Documentation of the IWTS Program is } \\
\text { available electronically only. } \\
\text { PLN-522 requires waste technical specialists and waste } \\
\text { disposition specialists to complete the appropriate } \\
\text { training/qualification before being granted approval } \\
\text { authority for profiles within the IWTS Program. The } \\
\text { waste certification official, alternate waste certification } \\
\text { official, and NNSS packaging certifiers must complete } \\
\text { the appropriate training/qualifications to disposition } \\
\text { waste to NNSS. }\end{array}$ \\
\hline $\begin{array}{l}\text { (1) Certification Program. The waste certification } \\
\text { program shall designate the officials who have the } \\
\text { authority to certify and release waste for shipment; and } \\
\text { specify what documentation is required for waste } \\
\text { generation, characterization, shipment, and } \\
\text { certification. The program shall provide requirements } \\
\text { for auditability, retrievability, and storage of required } \\
\text { documentation and specify the records retention period. } \\
\text { From DOE G 435.1-1 Chapter IV: Compliance with } \\
\text { this requirement is demonstrated by a program or } \\
\text { procedure for record keeping and records showing that } \\
\text { low-level waste is certified as having met the waste } \\
\text { acceptance criteria of the facility to which it was } \\
\text { transferred and that the certification statement is } \\
\text { supported by additional records regarding the waste } \\
\text { source, characterization, and container. }\end{array}$ & $\begin{array}{l}\text { See J. above. MCP- } 17500 \S \S 2 \text { and } 5 \text { address } \\
\text { certification records for shipments to NNSS. }\end{array}$ \\
\hline $\begin{array}{l}\text { (2) Certification before Transfer. Low-level waste shall } \\
\text { be certified as meeting waste acceptance requirements } \\
\text { before it is transferred to the facility receiving the }\end{array}$ & $\begin{array}{l}\text { See J. above. MCP- } 17500 \S 4.3 .6 \text { addresses controls } \\
\text { for certification before transfer for LLW to be disposed } \\
\text { of at NNSS. }\end{array}$ \\
\hline
\end{tabular}


Table 17. (continued).

\begin{tabular}{|c|c|}
\hline \multicolumn{2}{|c|}{ Facility Name: MFC-792A Space and Security Power Systems Facility } \\
\hline Chapter IV. Low-Level Waste Requirements & Facility Compliance Information \\
\hline $\begin{array}{l}\text { waste. } \\
\text { From DOE G } 435.1-1 \text { Chapter IV: Compliance with } \\
\text { this requirement is demonstrated by the presence of a } \\
\text { certification program which includes procedures } \\
\text { requiring a signed certification statement prior to the } \\
\text { release of waste for transfer, and by dated records } \\
\text { showing that waste was certified before being } \\
\text { transferred. }\end{array}$ & \\
\hline $\begin{array}{l}\text { (3) Maintaining Certification. Low-level waste that has } \\
\text { been certified as meeting the waste acceptance } \\
\text { requirements for transfer to a storage, treatment, or } \\
\text { disposal facility shall be managed in a manner that } \\
\text { maintains its certification status. } \\
\text { From DOE G } 435.1-1 \text { Chapter IV: Compliance with } \\
\text { this requirement is demonstrated by a program or } \\
\text { procedure reflecting this requirement is present and site } \\
\text { personnel are able to show that the storage of low-level } \\
\text { waste containers is in a facility or manner where the } \\
\text { containers would not be damaged by normal weather } \\
\text { events, and cannot be accessed by unauthorized } \\
\text { personnel. Further, each container can be traced to its } \\
\text { certification and the information supporting that } \\
\text { certification. }\end{array}$ & $\begin{array}{l}\text { See J. above. Pre-certification checklists are cited in } \\
\text { MCP- } 17000 \text { and MCP-17500. Surveillances also are } \\
\text { addressed in MCP-17500. } \\
\text { LWP-15011 } \$ 5 \text { provides general radioactive storage } \\
\text { area requirements. }\end{array}$ \\
\hline $\begin{array}{l}\text { K. Waste Transfer. A documented process shall be } \\
\text { established and implemented for transferring } \\
\text { responsibility for management of low-level waste and } \\
\text { for ensuring availability of relevant data. The following } \\
\text { requirements are in addition to those in Chapter I of } \\
\text { this Manual. } \\
\text { From DOE G } 435.1-1 \text { Chapter IV: Compliance with } \\
\text { this requirement is demonstrated if facilities have } \\
\text { procedures for the receipt of waste and the transfer of } \\
\text { waste, as appropriate, which address the acquisition of } \\
\text { waste and container data and the transfer of ownership, } \\
\text { respectively. Further evidence of acceptable } \\
\text { performance is facility records showing that data on the } \\
\text { waste containers is available and accurate, and that } \\
\text { documented transfer of responsibility occurs. }\end{array}$ & $\begin{array}{l}\text { MCP-17000 } \S 4.8 .15 \text { specifies requirements for } \\
\text { interfacility transfers. } \\
\text { MCP-17500 } \S 4 \text { addresses LLW to be transferred to } \\
\text { NNSS. }\end{array}$ \\
\hline $\begin{array}{l}\text { (1) Authorization. Low-level waste shall not be } \\
\text { transferred to a storage, treatment, or disposal facility } \\
\text { until personnel responsible for the facility receiving the } \\
\text { waste authorize the transfer. } \\
\text { From DOE G } 435.1-1 \text { Chapter IV: Compliance with } \\
\text { this requirement is demonstrated by sites having } \\
\text { procedures that require a confirmation of authorization } \\
\text { before releasing waste for transfer, and records } \\
\text { showing that transfers are made in accordance with } \\
\text { written authorizations. }\end{array}$ & See K. above. \\
\hline
\end{tabular}


Table 17. (continued).

\begin{tabular}{|c|c|}
\hline \multicolumn{2}{|c|}{ Facility Name: MFC-792A Space and Security Power Systems Facility } \\
\hline Chapter IV. Low-Level Waste Requirements & Facility Compliance Information \\
\hline $\begin{array}{l}\text { (2) Data. Waste characterization data, container } \\
\text { information, and generation, storage, treatment, and } \\
\text { transportation information for low-level waste shall be } \\
\text { transferred with or be traceable to the waste. }\end{array}$ & See K. above. \\
\hline $\begin{array}{l}\text { From DOE G } 435.1-1 \text { Chapter IV: Compliance with } \\
\text { this requirement is demonstrated if there are procedures } \\
\text { requiring that characterization and container data be } \\
\text { provided and maintained for each low-level waste } \\
\text { transfer and documented records of transfers show that } \\
\text { the information is being provided. }\end{array}$ & \\
\hline $\begin{array}{l}\text { L. Packaging and Transportation. The following } \\
\text { requirements are in addition to those in Chapter I of } \\
\text { this Manual [DOE M 435.1-1 §I.1.E(11)]. }\end{array}$ & See (1) and (2) below. \\
\hline $\begin{array}{l}\text { (1) Packaging. If containers are used: } \\
\text { From DOE G 435.1-1 Chapter IV: Compliance with the } \\
\text { packaging requirement is demonstrated by: (1) } \\
\text { procedures which document proper packaging } \\
\text { protocols; and (2) no trends of routine repackaging of } \\
\text { low-level waste that is packaged after issuance of DOE } \\
\text { O } 435.1 \text {. Successful performance of this requirement is } \\
\text { also demonstrated by a record of containers for which } \\
\text { failure has not routinely occurred under management } \\
\text { conditions. It is recognized that there may be failed } \\
\text { containers for waste previously placed in storage. For } \\
\text { those containers, the goal is to only have to repackage } \\
\text { the waste one time after it is retrieved and } \\
\text { characterized. Further, acceptable performance is } \\
\text { demonstrated by containers of waste having marking } \\
\text { and labeling that allows correlation with waste } \\
\text { characterization data and container information. }\end{array}$ & MCP-17000 $§ 4$ addresses packaging requirements. \\
\hline $\begin{array}{l}\text { (a) Low-level waste shall be packaged in a manner that } \\
\text { provides containment and protection for the duration of } \\
\text { the anticipated storage period and until disposal is } \\
\text { achieved or until the waste has been removed from the } \\
\text { container. }\end{array}$ & See (1) above. \\
\hline $\begin{array}{l}\text { (b) When waste is packaged, vents or other measures } \\
\text { shall be provided if the potential exists for pressurizing } \\
\text { or generating flammable or explosive concentrations of } \\
\text { gases within the waste container. }\end{array}$ & See (1) above. \\
\hline $\begin{array}{l}\text { (c) Containers of low-level waste shall be marked such } \\
\text { that their contents can be identified. }\end{array}$ & See (1) above. \\
\hline $\begin{array}{l}\text { (2) Transportation. To the extent practical, the volume } \\
\text { of waste and number of low-level waste shipments } \\
\text { shall be minimized. } \\
\text { From DOE G 435.1-1 Chapter IV: Compliance with }\end{array}$ & $\begin{array}{l}\text { MCP- } 17000 \S 4 \text { addresses transportation. The waste } \\
\text { disposition specialist coordinates with packaging and } \\
\text { transportation personnel for waste shipped offsite from } \\
\text { this facility. }\end{array}$ \\
\hline
\end{tabular}


Table 17. (continued).

Facility Name: MFC-792A Space and Security Power Systems Facility

Chapter IV. Low-Level Waste Requirements this requirement can be demonstrated by a combination of site procedures directing the efficient use of waste container capacity and documentation showing that low-level waste shipments are systematically planned and optimized to the extent practical.

M. Site Evaluation and Facility Design. The following requirements are in addition to those in Chapter I of this Manual.

(1) Site Evaluation. Proposed locations for low-level waste facilities shall be evaluated to identify relevant features that should be avoided or must be considered in facility design and analyses.

(a) Each site proposed for a new low-level waste facility or expansion of an existing low-level waste facility shall be evaluated considering environmental characteristics, geotechnical characteristics, and human activities, including for a low-level waste disposal facility, the capability of the site to demonstrate, at a minimum, whether it is:

1 Located to accommodate the projected volume of waste to be received;

2 Located in a flood plain, a tectonically active area, or in the zone of water table fluctuation; and

3 Located where radionuclide migration pathways are predictable and erosion and surface runoff can be controlled.

(b) Proposed sites with environmental characteristics, geotechnical characteristics, and human activities for which adequate protection cannot be provided through facility design shall be deemed unsuitable for the location of the facility.

(c) Low-level waste disposal facilities shall be sited to achieve long-term stability and to minimize, to the extent practical, the need for active maintenance following final closure.

(2) Low-Level Waste Treatment and Storage Facility Design. The following facility requirements and general design criteria, at a minimum, apply:

(a) Confinement. Low-level waste systems and components shall be designed to maintain waste confinement.

(b) Ventilation.

1 Design of low-level waste treatment and storage facilities shall include ventilation, if applicable,

\section{Facility Compliance Information}

Waste may be shipped directly to NNSS from this facility. MCP-17500 specifies waste certification official and waste disposition specialist responsibilities and coordination with packaging and transportation personnel.

NA; this requirement addresses new radioactive waste management facilities or modifications to existing facilities.

See M. above.

See M. above.

See M. above.

See M. above.

See M. above.

See M. above.

See M. above.

See M. above.

See M. above.

See M. above.

See M. above. 
Table 17. (continued).

\begin{tabular}{|c|c|}
\hline \multicolumn{2}{|c|}{ Facility Name: MFC-792A Space and Security Power Systems Facility } \\
\hline Chapter IV. Low-Level Waste Requirements & Facility Compliance Information \\
\hline $\begin{array}{l}\text { through an appropriate filtration system to maintain the } \\
\text { release of radioactive material in airborne effluents } \\
\text { within the requirements and guidelines specified in } \\
\text { applicable requirements. }\end{array}$ & \\
\hline $\begin{array}{l}2 \text { When conditions exist for generating gases in } \\
\text { flammable or explosive concentrations, ventilation } \\
\text { systems or other measures shall be provided to keep the } \\
\text { gases in a non-flammable and nonexplosive condition. } \\
\text { Where concentrations of explosive or flammable gases } \\
\text { are expected to approach the lower flammability limit, } \\
\text { measures shall be taken to prevent deflagration or } \\
\text { detonation. }\end{array}$ & See M. above. \\
\hline $\begin{array}{l}\text { (c) Consideration of Decontamination and } \\
\text { Decommissioning. Areas in new and modifications to } \\
\text { existing low-level waste management facilities that are } \\
\text { subject to contamination with radioactive or other } \\
\text { hazardous materials shall be designed to facilitate } \\
\text { decontamination. For such facilities a proposed } \\
\text { decommissioning method or a conversion method } \\
\text { leading to reuse shall be described. }\end{array}$ & See M. above. \\
\hline $\begin{array}{l}\text { (d) Instrumentation and Control Systems. Engineering } \\
\text { controls shall be incorporated in the design and } \\
\text { engineering of low-level waste treatment and storage } \\
\text { facilities to provide volume inventory data and to } \\
\text { prevent spills, leaks, and overflows from tanks or } \\
\text { confinement systems. }\end{array}$ & See M. above. \\
\hline $\begin{array}{l}\text { (e) Monitoring. Monitoring and/or leak detection } \\
\text { capabilities shall be incorporated in the design and } \\
\text { engineering of low-level waste treatment and storage } \\
\text { facilities to provide rapid identification of failed } \\
\text { confinement and/or other abnormal conditions. }\end{array}$ & See M. above. \\
\hline $\begin{array}{l}\text { (3) Low-Level Waste Disposal Facility Design. The } \\
\text { following facility requirements and general design } \\
\text { criteria, at a minimum, apply: }\end{array}$ & See M. above. \\
\hline $\begin{array}{l}\text { (a) Confinement. Low-level waste systems and } \\
\text { components shall be designed to maintain waste } \\
\text { confinement. }\end{array}$ & See M. above. \\
\hline (b) Ventilation. & See M. above. \\
\hline $\begin{array}{l}1 \text { Design of low-level waste disposal facilities shall } \\
\text { include ventilation, if applicable, through an } \\
\text { appropriate filtration system to maintain the release of } \\
\text { radioactive material in airborne effluents within the } \\
\text { requirements and guidelines specified in applicable } \\
\text { requirements. }\end{array}$ & See M. above. \\
\hline $\begin{array}{l}2 \text { When conditions exist for generating gases in } \\
\text { flammable or explosive concentrations, ventilation }\end{array}$ & See M. above. \\
\hline
\end{tabular}


Table 17. (continued).

Facility Name: MFC-792A Space and Security Power Systems Facility

\begin{tabular}{l}
\hline \multicolumn{1}{|c|}{ Chapter IV. Low-Level Waste Requirements } \\
\hline systems or other measures shall be provided to keep the \\
gases in a nonflammable and non-explosive condition. \\
Where concentrations of explosive or flammable gases \\
are expected to approach the lower flammability limit, \\
measures shall be taken to prevent deflagration or \\
detonation. \\
\hline $\begin{array}{l}\text { (c) Stability. Low-level waste disposal facilities shall } \\
\text { be designed to achieve long-term stability and to } \\
\text { minimize to the extent practical, the need for active } \\
\text { maintenance following final closure. }\end{array}$
\end{tabular}

(d) Control of Water. Low-level waste disposal facilities shall be designed to minimize to the extent practical, the contact of waste with water during and after disposal.

N. Storage and Staging. The following requirements are in addition to those in Chapter I of this Manual [DOE M 435.1-1 §I.2.F(13)].

(1) Storage Prohibitions. Low-level waste in storage shall not be readily capable of detonation, explosive decomposition, reaction at anticipated pressures and temperatures, or explosive reaction with water. Prior to storage, pyrophoric materials shall be treated, prepared, and packaged to be nonflammable.

From DOE G 435.1-1 Chapter IV: Compliance with this requirement is demonstrated by having waste acceptance requirements which prohibit low-level waste that is ignitable or explosive from being accepted for storage unless it has been treated, and procedures for properly preparing such materials for safe storage.

(2) Storage Limit. Low-level waste that has an identified path to disposal shall not be stored longer than one year prior to disposal, except for storage for decay, or as otherwise authorized by the Field Element Manager.

From DOE G 435.1-1 Chapter IV: Storage longer than one year can be justified if the conditions for such storage are approved by the Field Element Manager as part of the radioactive waste management basis for the facility.

Storage for radioactive decay for a period greater than 1 year for waste that has an identified path to disposal is allowed. Adequate justification and the supporting information for storage for decay is to be documented in the radioactive waste management basis for the facility in which the storage will take place.

Mixed waste. Under the Federal Facility Compliance Act of 1992, DOE sites were required to develop Site
See M. above. Facility Compliance Information

S

Facility Compliance Information

\begin{tabular}{|l|}
\hline See M. above. \\
\hline
\end{tabular}

See M. above.

Not a facility-specific requirement. DOE Manual
435.1-1 §I.2.F(13) applies to field element managers.

NA; LLW is not stored at this facility.
$\mathrm{NA}$; LLW is not stored at this facility. 
Table 17. (continued).

Facility Name: MFC-792A Space and Security Power Systems Facility

\begin{tabular}{|c|}
\hline Chapter IV. Low-Level Waste Requirements \\
\hline Treatment Plans to bring stored mixed low-level waste
\end{tabular} into compliance with these requirements. The Site

Treatment Plan needs to be consulted and any mixed low-level waste stored for the purpose of accumulation to facilitate treatment must meet Resource

Conservation and Recovery Act storage requirements.

There could be several ways within different scenarios that this requirement can be met, as illustrated by the examples below, however, there are basically four ways to show compliance with the requirement and include appropriate provisions in the radioactive waste management basis for the facility in which it is stored.

Legacy waste. As discussed above, the intention of the requirement is not to force malicious compliance or heroic actions which would result in increased risk or safety concerns. Rather, the intention is that waste in storage longer than one year receives additional attention to ensure that the public, the workers, and the environment are protected from the hazards of the waste, and that progress is being made to dispose of the waste. There could be several ways within different scenarios that this requirement can be met, as illustrated by the examples below, however, there are basically four ways to show compliance with the requirement:

1) the radioactive waste management basis allows for storage for no more than one year.

2) the radioactive waste management basis allows for storage for no more than one year, or for storage for decay only for periods greater than a year, which are specified on a radionuclide basis.

3) the radioactive waste management basis allows for storage for more than one year, up to a specified period of time based on a documented technical evaluation that the waste can be stored in a manner that does not cause changes to the waste or waste packages that is detrimental to the safe storage of the waste, the final disposal of the waste or to meeting the disposal performance objectives.

4) the radioactive waste management basis allows for storage for decay (with specifics) and for storage for more than one year for other low-level waste, up to a specified period of time based on a documented technical evaluation that the waste can be stored in a manner that does not cause changes to the waste or waste packages that is detrimental to the safe storage of the waste, the final disposal of the waste or to meeting the disposal performance objectives. 
Table 17. (continued).

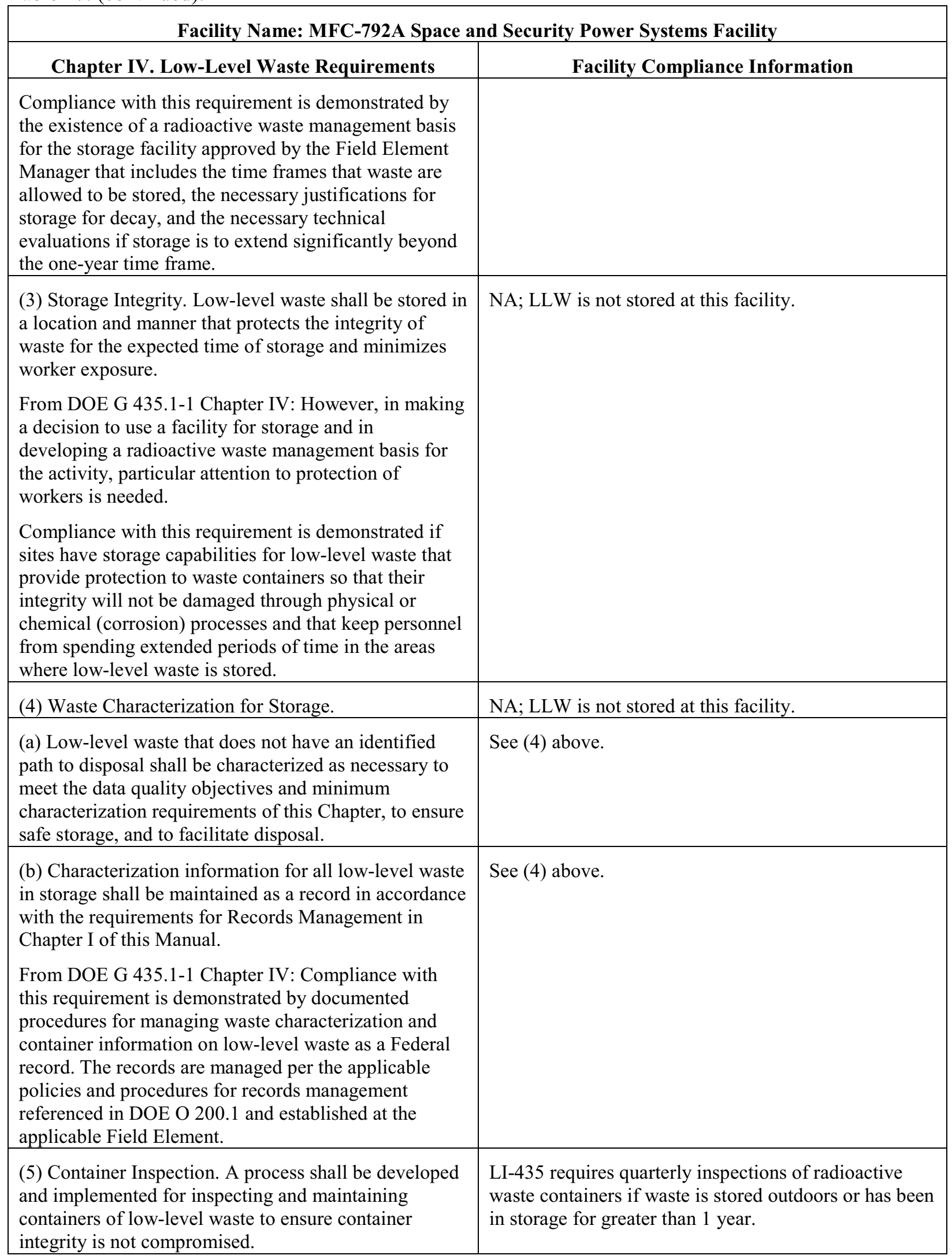


Table 17. (continued).

\begin{tabular}{|c|c|}
\hline \multicolumn{2}{|c|}{ Facility Name: MFC-792A Space and Security Power Systems Facility } \\
\hline Chapter IV. Low-Level Waste Requirements & Facility Compliance Information \\
\hline $\begin{array}{l}\text { From DOE G } 435.1-1 \text { Chapter IV: Compliance with } \\
\text { this requirement is demonstrated by: (1) a documented } \\
\text { process for waste container inspection and } \\
\text { maintenance; and ( } 2 \text { ) documentation for all waste } \\
\text { container inspections and maintenance actions } \\
\text { performed. }\end{array}$ & \\
\hline $\begin{array}{l}\text { (6) Storage Management. Low-level waste storage shall } \\
\text { be managed to identify and segregate low-level waste } \\
\text { from mixed low-level waste. }\end{array}$ & NA; LLW is not stored at this facility. \\
\hline $\begin{array}{l}\text { (7) Staging. Staging of low-level waste shall be for the } \\
\text { purpose of the accumulation of such quantities of waste }\end{array}$ & $\begin{array}{l}\text { LLW is staged for the purpose of accumulation to } \\
\text { facilitate treatment and disposal. }\end{array}$ \\
\hline $\begin{array}{l}\text { as necessary to facilitate transportation, treatment, and } \\
\text { disposal. Staging longer than } 90 \text { days shall meet the } \\
\text { requirements for storage above and in Chapter I of this } \\
\text { Manual. }\end{array}$ & $\begin{array}{l}\text { MCP-17000, Appendix F restricts staging LLW to } \\
90 \text { days maximum at any generator or treatment } \\
\text { facility prior to acceptance by a storage facility. }\end{array}$ \\
\hline $\begin{array}{l}\text { From DOE G } 435.1-1 \text { Chapter IV: The staging of low- } \\
\text { level waste needs to be addressed in the radioactive } \\
\text { waste management basis for the facility that is } \\
\text { performing the staging. Generators, treatment facilities, } \\
\text { and disposal facilities that stage waste must ensure that } \\
\text { the action of staging is included and authorized as part } \\
\text { of their radioactive waste management basis for the } \\
\text { affected facilities, operations, or activities. }\end{array}$ & \\
\hline $\begin{array}{l}\text { Staging longer than } 90 \text { days must be justified, the } \\
\text { conditions for such storage met, and these practices } \\
\text { approved by the Field Element Manager as part of the } \\
\text { radioactive waste management basis for the facility. }\end{array}$ & \\
\hline $\begin{array}{l}\text { Compliance with this requirement is demonstrated by a } \\
\text { staging program that limits the temporary storage of } \\
\text { waste to only circumstances allowed in the } \\
\text { requirement, including justifications for any staging } \\
\text { that exceeds the } 90 \text {-day period, which is documented in } \\
\text { the radioactive waste management basis for the facility. }\end{array}$ & \\
\hline $\begin{array}{l}\text { O. Treatment. Low-level waste treatment to provide } \\
\text { more stable waste forms and to improve the long-term } \\
\text { performance of a low-level waste disposal facility shall } \\
\text { be implemented as necessary to meet the performance } \\
\text { objectives of the disposal facility. }\end{array}$ & NA; treatment is not performed in this facility. \\
\hline $\begin{array}{l}\text { From DOE G } 435.1-1 \text { Chapter IV: Compliance with } \\
\text { this requirement is demonstrated when a treatment } \\
\text { facility or process ensures that treated waste will meet } \\
\text { the minimum waste form requirements of DOE M } \\
435.1 \text { and meet additional disposal facility-specific } \\
\text { waste acceptance requirements for additional stability } \\
\text { or long-term performance of facilities that will receive } \\
\text { the treated waste. }\end{array}$ & \\
\hline
\end{tabular}


Table 17. (continued).

\begin{tabular}{|c|c|}
\hline \multicolumn{2}{|c|}{ Facility Name: MFC-792A Space and Security Power Systems Facility } \\
\hline Chapter IV. Low-Level Waste Requirements & Facility Compliance Information \\
\hline $\begin{array}{l}\text { P. Disposal. Low-level waste disposal facilities shall } \\
\text { meet the following requirements. }\end{array}$ & NA; LLW is not disposed of in this facility. \\
\hline $\begin{array}{l}\text { (1) Performance Objectives. Low-level waste disposal } \\
\text { facilities shall be sited, designed, operated, maintained, } \\
\text { and closed so that a reasonable expectation exists that } \\
\text { the following performance objectives will be met for } \\
\text { waste disposed of after September 26, 1988: }\end{array}$ & See P. above. \\
\hline $\begin{array}{l}\text { (a) Dose to representative members of the public shall } \\
\text { not exceed } 25 \text { mrem }(0.25 \mathrm{mSv}) \text { in a year total effective } \\
\text { dose equivalent from all exposure pathways, excluding } \\
\text { the dose from radon and its progeny in air. }\end{array}$ & See P. above. \\
\hline $\begin{array}{l}\text { (b) Dose to representative members of the public via } \\
\text { the air pathway shall not exceed } 10 \text { mrem }(0.10 \mathrm{mSv}) \\
\text { in a year total effective dose equivalent, excluding the } \\
\text { dose from radon and its progeny. }\end{array}$ & See P. above. \\
\hline $\begin{array}{l}\text { (c) Release of radon shall be less than an average flux } \\
\text { of } 20 \mathrm{pCi} / \mathrm{m}^{2} / \mathrm{s}\left(0.74 \mathrm{~Bq} / \mathrm{m}^{2} / \mathrm{s}\right) \text { at the surface of the } \\
\text { disposal facility. Alternatively, a limit of } 0.5 \mathrm{pCi} / 1 \\
(0.0185 \mathrm{~Bq} / \mathrm{l}) \text { of air may be applied at the boundary of } \\
\text { the facility. }\end{array}$ & See P. above. \\
\hline $\begin{array}{l}\text { (2) Performance Assessment. A site-specific } \\
\text { radiological performance assessment shall be prepared } \\
\text { and maintained for DOE low-level waste disposed of } \\
\text { after September } 26,1988 \text {. The performance assessment } \\
\text { shall include calculations for a } 1,000 \text { year period after } \\
\text { closure of potential doses to representative future } \\
\text { members of the public and potential releases from the } \\
\text { facility to provide a reasonable expectation that the } \\
\text { performance objectives identified in this Chapter are } \\
\text { not exceeded as a result of operation and closure of the } \\
\text { facility. }\end{array}$ & See P. above. \\
\hline $\begin{array}{l}\text { (a) Analyses performed to demonstrate compliance } \\
\text { with the performance objectives in this Chapter, and to } \\
\text { establish limits on concentrations of radionuclides for } \\
\text { disposal based on the performance measures for } \\
\text { inadvertent intruders in this Chapter shall be based on } \\
\text { reasonable activities in the critical group of exposed } \\
\text { individuals. Unless otherwise specified, the assumption } \\
\text { of average living habits and exposure conditions in } \\
\text { representative critical groups of individuals projected } \\
\text { to receive the highest doses is appropriate. The } \\
\text { likelihood of inadvertent intruder scenarios may be } \\
\text { considered in interpreting the results of the analyses } \\
\text { and establishing radionuclide concentrations, if } \\
\text { adequate justification is provided. }\end{array}$ & See P. above. \\
\hline $\begin{array}{l}\text { (b) The point of compliance shall correspond to the } \\
\text { point of highest projected dose or concentration beyond }\end{array}$ & See P. above. \\
\hline
\end{tabular}


Table 17. (continued).

Facility Name: MFC-792A Space and Security Power Systems Facility

\begin{tabular}{l}
\hline \multicolumn{1}{|c|}{ Chapter IV. Low-Level Waste Requirements } \\
\hline $\begin{array}{l}\text { a } 100 \text { meter buffer zone surrounding the disposed } \\
\text { waste. A larger or smaller buffer zone may be used if } \\
\text { adequate justification is provided. }\end{array}$ \\
\hline
\end{tabular}

(c) Performance assessments shall address reasonably foreseeable natural processes that might disrupt barriers against release and transport of radioactive materials.

(d) Performance assessments shall use DOE-approved dose coefficients (dose conversion factors) for internal and external exposure of reference adults.

(e) The performance assessment shall include a
sensitivity/uncertainty analysis.
(f) Performance assessments shall include a
demonstration that projected releases of radionuclides
to the environment shall be maintained as low as
reasonably achievable (ALARA).

(g) For purposes of establishing limits on radionuclides that may be disposed of near-surface, the performance assessment shall include an assessment of impacts to water resources.

(h) For purposes of establishing limits on the concentration of radionuclides that may be disposed of near-surface, the performance assessment shall include an assessment of impacts calculated for a hypothetical person assumed to inadvertently intrude for a temporary period into the low-level waste disposal facility. For intruder analyses, institutional controls shall be assumed to be effective in deterring intrusion for at least 100 years following closure. The intruder analyses shall use performance measures for chronic and acute exposure scenarios, respectively, of 100 mrem $(1 \mathrm{mSv})$ in a year and $500 \mathrm{mrem}(5 \mathrm{mSv})$ total effective dose equivalent excluding radon in air.

(3) Composite Analysis. For disposal facilities which received waste after September 26, 1988, a site-specific radiological composite analysis shall be prepared and maintained that accounts for all sources of radioactive material that may be left at the DOE site and may interact with the low- level waste disposal facility, contributing to the dose projected to a hypothetical member of the public from the existing or future disposal facilities. Performance measures shall be consistent with DOE requirements for protection of the public and environment and evaluated for a 1,000 year period following disposal facility closure. The composite analysis results shall be used for planning, radiation protection activities, and future use commitments to minimize the likelihood that current low- level waste disposal activities will result in the
See P. above.

See P. above.

See P. above.

See P. above.

See P. above.

See P. above.

See P. above. 
Table 17. (continued).

\begin{tabular}{|c|c|}
\hline \multicolumn{2}{|c|}{ Facility Name: MFC-792A Space and Security Power Systems Facility } \\
\hline Chapter IV. Low-Level Waste Requirements & Facility Compliance Information \\
\hline $\begin{array}{l}\text { need for future corrective or remedial actions to } \\
\text { adequately protect the public and the environment. }\end{array}$ & \\
\hline $\begin{array}{l}\text { (4) Performance Assessment and Composite Analysis } \\
\text { Maintenance. The performance assessment and } \\
\text { composite analysis shall be maintained to evaluate } \\
\text { changes that could affect the performance, design, and } \\
\text { operating bases for the facility. Performance } \\
\text { assessment and composite analysis maintenance shall } \\
\text { include the conduct of research, field studies, and } \\
\text { monitoring needed to address uncertainties or gaps in } \\
\text { existing data. The performance assessment shall be } \\
\text { updated to support the final facility closure. Additional } \\
\text { iterations of the performance assessment and composite } \\
\text { analysis shall be conducted as necessary during the } \\
\text { post-closure period. }\end{array}$ & See P. above. \\
\hline $\begin{array}{l}\text { (a) Performance assessments and composite analyses } \\
\text { shall be reviewed and revised when changes in waste } \\
\text { forms or containers, radionuclide inventories, facility } \\
\text { design and operations, closure concepts, or the } \\
\text { improved understanding of the performance of the } \\
\text { waste disposal facility in combination with the features } \\
\text { of the site on which it is located alter the conclusions or } \\
\text { the conceptual model(s) of the existing performance } \\
\text { assessment or composite analysis. }\end{array}$ & See P. above. \\
\hline $\begin{array}{l}\text { (b) A determination of the continued adequacy of the } \\
\text { performance assessment and composite analysis shall } \\
\text { be made on an annual basis, and shall consider the } \\
\text { results of data collection and analysis from research, } \\
\text { field studies, and monitoring. }\end{array}$ & See P. above. \\
\hline $\begin{array}{l}\text { (c) Annual summaries of low-level waste disposal } \\
\text { operations shall be prepared with respect to the } \\
\text { conclusions and recommendations of the performance } \\
\text { assessment and composite analysis and a determination } \\
\text { of the need to revise the performance assessment or } \\
\text { composite analysis. }\end{array}$ & See P. above. \\
\hline $\begin{array}{l}\text { (5) Disposal Authorization. A disposal authorization } \\
\text { statement shall be obtained prior to construction of a } \\
\text { new low-level waste disposal facility. Field Elements } \\
\text { with existing low-level waste disposal facilities shall } \\
\text { obtain a disposal authorization statement in accordance } \\
\text { with the schedule in the Complex-Wide Low-Level } \\
\text { Waste Management Program Plan. The disposal } \\
\text { authorization statement shall be issued based on a } \\
\text { review of the facility's performance assessment, } \\
\text { composite analysis, performance assessment and } \\
\text { composite analysis maintenance, preliminary closure } \\
\text { plan, and preliminary monitoring plan. The disposal } \\
\text { authorization statement shall specify the limits and } \\
\text { conditions on construction, design, operations, and }\end{array}$ & See P. above. \\
\hline
\end{tabular}


Table 17. (continued).

Facility Name: MFC-792A Space and Security Power Systems Facility

\begin{tabular}{|c|}
\hline Chapter IV. Low-Level Waste Requirements \\
\hline $\begin{array}{l}\text { closure of the low-level waste facility based on these } \\
\text { reviews. A disposal authorization statement is a part of } \\
\text { the radioactive waste management basis for a disposal } \\
\text { facility. Failure to obtain a disposal authorization } \\
\text { statement by the implementation date of this Order } \\
\text { shall result in shutdown of the disposal facility. }\end{array}$ \\
\hline $\begin{array}{l}\text { (6) Disposal Facility Operations. The disposal facility } \\
\text { design and operation must be consistent with the } \\
\text { disposal facility closure plan and lead to disposal } \\
\text { facility closure that provides a reasonable expectation } \\
\text { that performance objectives will be met. Low-level } \\
\text { waste shall be disposed in such a manner that achieves } \\
\text { the performance objectives stated in this Chapter, } \\
\text { consistent with the disposal facility radiological } \\
\text { performance assessment. Additional requirements } \\
\text { include: }\end{array}$ \\
\hline
\end{tabular}

(a) Operating procedures shall be developed and implemented for low-level waste disposal facilities that protect the public, workers, and the environment; ensure the security of the facility; minimize subsidence during and after waste emplacement; achieve long-term stability and minimize the need for long-term active maintenance; and meet the requirements of the closure/post-closure plan.

(b) Permanent identification markers for disposal excavations and monitoring wells shall be emplaced.

(c) Low-level waste placement into disposal units shall minimize voids between waste containers. Voids within disposal units shall be filled to the extent practical. Uncontainerized bulk waste shall also be placed in a manner that minimizes voids and subsidence.

(d) Operations are to be conducted so that active waste disposal operations will not have an adverse effect on any other disposal units.

\begin{tabular}{l|l|}
\hline $\begin{array}{l}\text { (e) Operations shall include a process for tracking and } \\
\text { documenting low-level waste placement in the facility } \\
\text { by generator source. }\end{array}$ & See P. above. \\
\hline $\begin{array}{l}\text { (7) Alternate Requirements for Low-Level Waste } \\
\text { Disposal Facility Design and Operation. Requirements } \\
\text { other than those set forth in this Section for the design } \\
\text { and operation of a low-level waste disposal facility } \\
\text { may be approved on a specific basis if a reasonable } \\
\text { expectation is demonstrated that the disposal } \\
\text { performance objectives will be met. }\end{array}$ & See P. above. \\
\hline $\begin{array}{l}\text { Q. Closure. The following requirements are in addition } \\
\text { to those in Chapter I of this Manual. }\end{array}$ & NA; LLW is not disposed of in this facility. \\
\hline
\end{tabular}

See P. above. Facility Compliance Information
See P. above.

See P. above.

See P. above.

See P. above.

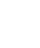


Table 17. (continued).

\begin{tabular}{|c|c|}
\hline \multicolumn{2}{|c|}{ Facility Name: MFC-792A Space and Security Power Systems Facility } \\
\hline Chapter IV. Low-Level Waste Requirements & Facility Compliance Information \\
\hline $\begin{array}{l}\text { (1) Disposal Facility Closure Plans. A preliminary } \\
\text { closure plan shall be developed and submitted to } \\
\text { Headquarters for review with the performance } \\
\text { assessment and composite analysis. The closure plan } \\
\text { shall be updated following issuance of the disposal } \\
\text { authorization statement to incorporate conditions } \\
\text { specified in the disposal authorization statement. } \\
\text { Closure plans shall: }\end{array}$ & See Q. above. \\
\hline $\begin{array}{l}\text { (a) Be updated as required during the operational life of } \\
\text { the facility. }\end{array}$ & See Q. above. \\
\hline $\begin{array}{l}\text { (b) Include a description of how the disposal facility } \\
\text { will be closed to achieve long-term stability and } \\
\text { minimize the need for active maintenance following } \\
\text { closure and to ensure compliance with the requirements } \\
\text { of DOE 5400.5, Radiation Protection of the Public and } \\
\text { the Environment. }\end{array}$ & See Q. above. \\
\hline $\begin{array}{l}\text { (c) Include the total expected inventory of wastes to be } \\
\text { disposed of at the facility over the operational life of } \\
\text { the facility. }\end{array}$ & See Q. above. \\
\hline $\begin{array}{l}\text { (2) Disposal Facility Closure. Closure of a disposal } \\
\text { facility shall occur within a five-year period after it is } \\
\text { filled to capacity, or after the facility is otherwise } \\
\text { determined to be no longer needed. }\end{array}$ & See Q. above. \\
\hline $\begin{array}{l}\text { (a) Prior to facility closure, the final inventory of the } \\
\text { low-level waste disposed in the facility shall be } \\
\text { prepared and incorporated in the performance } \\
\text { assessment and composite analysis which shall be } \\
\text { updated to support the closure of the facility. }\end{array}$ & See Q. above. \\
\hline $\begin{array}{l}\text { (b) A final closure plan shall be prepared based on the } \\
\text { final inventory of waste disposed in the facility, the } \\
\text { plan implemented, and the updated performance } \\
\text { assessment and composite analysis prepared in support } \\
\text { of the facility closure. }\end{array}$ & See Q. above. \\
\hline $\begin{array}{l}\text { (c) Institutional control measures shall be integrated } \\
\text { into land use and stewardship plans and programs, and } \\
\text { shall continue until the facility can be released pursuant } \\
\text { to DOE } 5400.5, \text { Radiation Protection of the Public and } \\
\text { the Environment. }\end{array}$ & See Q. above. \\
\hline $\begin{array}{l}\text { (d) The location and use of the facility shall be filed } \\
\text { with the local authorities responsible for land use and } \\
\text { zoning. }\end{array}$ & See Q. above. \\
\hline $\begin{array}{l}\text { R. Monitoring. The following requirements are in } \\
\text { addition to those in Chapter I of this Manual [DOE M } \\
435.1-1 \S \text { I.1.E(7)]. }\end{array}$ & See (1), (2), and (3) below. \\
\hline
\end{tabular}


Table 17. (continued).

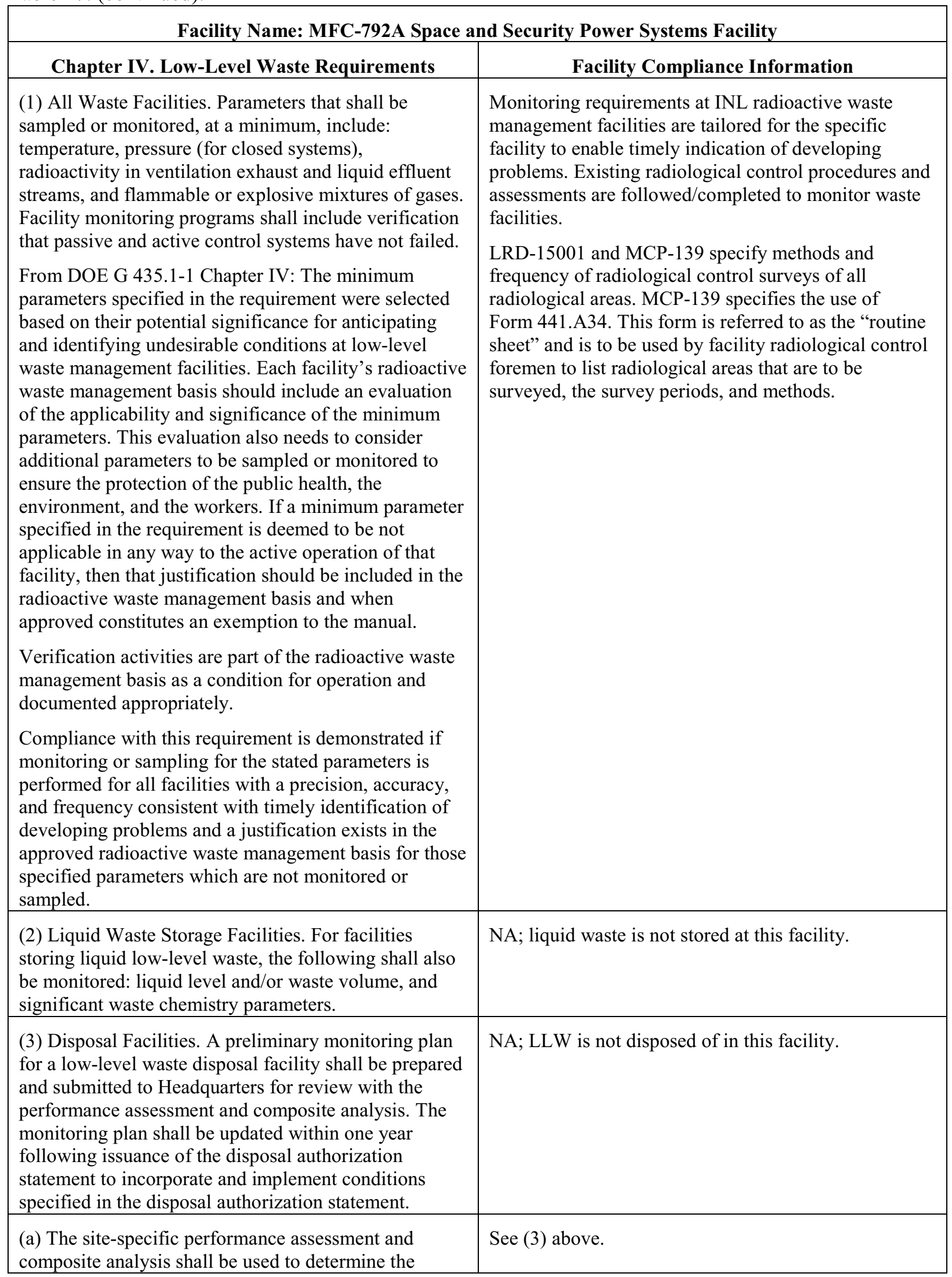


Table 17. (continued).

\begin{tabular}{|l|l|}
\hline \multicolumn{2}{|c|}{ Facility Name: MFC-792A Space and Security Power Systems Facility } \\
\hline \multicolumn{1}{|c|}{ Chapter IV. Low-Level Waste Requirements } & \multicolumn{1}{|c|}{ Facility Compliance Information } \\
\hline $\begin{array}{l}\text { media, locations, radionuclides, and other substances to } \\
\text { be monitored. }\end{array}$ & \\
\hline $\begin{array}{l}\text { (b) The environmental monitoring program shall be } \\
\text { designed to include measuring and evaluating releases, } \\
\text { migration of radionuclides, disposal unit subsidence, } \\
\text { and changes in disposal facility and disposal site } \\
\text { parameters which may affect long-term performance. }\end{array}$ & See (3) above. \\
\hline $\begin{array}{l}\text { (c) The environmental monitoring programs shall be } \\
\text { capable of detecting changing trends in performance to } \\
\text { allow application of any necessary corrective action } \\
\text { prior to exceeding the performance objectives in this } \\
\text { Chapter. }\end{array}$ & See (3) above. \\
\hline
\end{tabular}

\subsection{MFC-793, Sodium Components Maintenance Shop (including Metal RCRA Storage Building MFC-793C and 793G)}

1. Facility description: MFC-793, Sodium Components Maintenance Shop, consists of three buildings used for waste container and tank storage, repackaging, treatment, and bench-scale treatment development work. The three buildings include the following MFC-793, High Bay and Low Bay; MFC-793C, Storage Building; and MFC-793G, Storage Building.

a. Sodium Components Maintenance Shop High Bay

The high bay is used to store, repackage, and treat LLW. The High Bay is a prefabricated steel

frame building with insulated metal siding. It has a reinforced concrete floor that is approximately $39 \times 66 \mathrm{ft}$ with a ceiling height of $38 \mathrm{ft}$. The floor is curbed and sealed with an epoxy coating and is sloped toward floor drains that are routed to the low-bay pit (in the low bay). The high bay houses the 90-gal water wash vessel and its associated ventilation system and change room (provides radioactive contamination control); the water wash scrubber tank; the carbonation vessel; the removable melt, drain, and transfer system; and a work tent (radioactive contamination control).

The high bay is serviced by two 15-ton electrically powered hoists on a single, manually powered 30 -ton bridge and one 5-ton electrically powered bridge crane installed on the building crane rails. The cranes provide the capability to move large components for removal of waste during storage, repackaging, and treatment. Vehicle and component access into the high bay is through a rolling hanger-type steel door that is located at the west end of the building and a steel roll-up door on the east end. Four personnel doors are provided on three sides of the high bay. One door is located on the south end of the high bay, which allows entry into the low bay. Another door is located on the east end, which allows entry into a vestibule and then out of the building. Two additional doors are on the north side of the building. One door is used as an emergency exit and the other door is used as an entry into an adjoining annex. The door leading into the annex is where a fume hood is located, which is used to carry out a bench-scale recipe development in support of Sodium Components Maintenance Shop full-scale solidification/stabilization of waste. When the rolling doors are fully open, a clear opening of $20 \times 32 \mathrm{ft}$ is available. Lighting intensity is a minimum of 50-ft candles at floor level and the bulbs are enclosed in explosion-proof casings. Explosion-proof electrical outlets, 120 volts, are provided at 
approximately 15 -ft intervals around the inside periphery of the building. The high bay is designed to Seismic Zone 3 of the Uniform Building Code.

b. Sodium Components Maintenance Shop Low Bay

The low bay is used to store, repackage, and treat waste. It is a self supporting building with a standard construction reinforced concrete floor $24 \times 48 \mathrm{ft}$ and a 14-ft high ceiling on the low side. The walls of the prefabricated steel frame building are insulated. It contains a bank of highefficiency particulate air filters, an exhaust fan for the ventilation of the high bay, and power and motor controls for the fixed solidification station.

The low bay is serviced by a 1,000-lb rated, electrically powered hoist installed on a monorail in the ceiling. This hoist provides the capability to move containers before and after solidification and to remove large components for maintenance, disassembly, and disposal. The low bay also has a pit that contains the carbonate retention vessel and the scrubber water tank. The floor inside the low bay pit slopes toward a sump in the northeast corner of the pit floor and is painted with a waste-compatible epoxy coating. The floor of the pit is sloped to drain liquids to the $1.5 \times 1.5 \times$ 0.5 -ft deep sump. The sump pump discharges into containers or to the carbonate retention vessel, as appropriate. The exterior pit walls are coated with waterproofing. The pit is covered by metal grating that allows personnel and equipment movement. At floor level there is a sampling station for the carbonate retention vessel and the scrubber water tank. The low bay contains two personnel doors: one going outside on the west end and one into the high bay. The door on the east end of the building is a double door system that has a large door to accommodate the removal of pallets loaded with drums prior to and following solidification. Lighting intensity and electrical outlets, 120 volts, are of standard construction types. The low bay is designed to Seismic Zone 3 of the Uniform Building Code.

c. Sodium Components Maintenance Shop MFC-793C

MFC-793C is located west of the Sodium Components Maintenance Shop building for the storage of waste. The building size is $40 \times 30 \mathrm{ft}$ with a 16-ft eave height. The floor of the storage building is concrete with a design load of $500 \mathrm{psf}$, sloping toward the center with two small concrete sumps designed to remove liquid resulting from precipitation. The floor is painted with an epoxy coating; however, the epoxy floor is not maintained as the secondary containment. Waste containing liquids are stored atop spill pallets and non-liquid HW/mixed waste containers are stored on pallets or secondary containment devices. Two $12 \times 12$-ft roll-up freight doors and two personnel doors are provided. The prefabricated metal building has ridge ventilation and a wall louver to provide gravity ventilation. Two electric heaters with thermostatically controlled fan operation provide heat for the storage building. The building is provided with fluorescent lighting, power outlets (120 volts) for using hand tools and a welding outlet (480 volts). All roof and wall panel joints are self sealing to maintain a weather-tight seal. The building is designed to Seismic Zone 2 of the Uniform Building Code.

An $8 \times 10 \times 20$-ft deep storage pit is located inside the building. The pit is constructed of reinforced concrete and includes a sump in the northeast corner of the pit floor. The floor of the pit is sloping to drain any liquids to the $1.5 \times 1.5 \times 0.5$-ft deep sump. An 8 -mm thick polyethylene vapor barrier is installed under the pit floor and the exterior pit walls are coated with waterproofing.

d. Sodium Components Maintenance Shop MFC-793G

One metal storage building (shed), identified as MFC-793 G is located south of MFC-793C for storage of waste. The metal storage shed was built in the late $1980 \mathrm{~s}$ to house sodium containers. Shed MFC-793 is $13 \times 25.5 \mathrm{ft}$, insulated, and has a personnel door and a large overhead roll-up door. The metal storage shed sits on reinforced concrete and is anchored to ensure the integrity in the wind.

\section{Hazard category: LTHC3}


3. Radioactive waste managed at this facility: CH LLW and liquid mixed CH LLW are generated at this facility. CH LLW and liquid CH mixed LLW are treated at this facility. CH mixed LLW is stored in this facility. TSCA-regulated CH LLW and mixed LLW also are stored in MFC-793C.

4. RWMB documents/programs:

a. Safety basis/hazard analysis:

- EDF-7030, "Inventory Analysis of Radiological Facilities at the Materials and Fuels Complex (MFC)"

b. Laboratory-wide:

- Form 435.39, "Waste Determination and Disposal Form (WDDF)"

- Form 435.42, "Radioactive Waste Inventory Sheet"

- Form 441.A34, "INL Radiological Control Required Surveys"

- FRM-323, "TSD Facilities Material Acceptance Checksheet"

- LI-435, "Waste Management Routine Field Activities"

- LRD-15001, "Radiological Control Manual"

- LWP-13840, "Management of Issues, Observations, and Noteworthy Practices"

- LWP-14002, "Timeout and Stop Work Authority"

- LWP-15011, "Radioactive Material Areas and Radioactive Storage Areas"

- LWP-17000, "Waste Management"

- MCP-139, "Radiological Surveys"

- MCP-17000, "Waste Generator Services Waste Management"

- MCP-17410, "Management of Waste Storage Areas"

- MCP-17500, "Waste Generator Services Certification of Waste Shipments to the Nevada Test Site"

- PDD-17000, "Waste Management Program"

- PLN-114, "INL Emergency Plan/RCRA Contingency Plan"

- PLN-522, "Quality Assurance Program Plan for the Waste Management/Waste Certification Program"

c. Facility-specific:

- PER-116, "HWMA/RCRA Storage and Treatment Permit for the Materials and Fuels Complex"

- SCMS-OI-1, "Facility Information and Administrative Requirements"

- SCMS-OI-6, "Materials Characterization, Segregation, and/or Repackaging in the SCMS Enclosure"

- SCMS-OI-7, "Water Wash System"

- SD-38.1.1, "Treatment, Storage, and Disposal Facilities (TSDF) Environmental Compliance"

- TSD-OI-004, "Waste and Material Acceptance for Storage/Treatment and Radioactive Material Inventory Control."

LLW is managed at this facility. Table 18 shows the facility compliance information for DOE Manual 435.1-1 Chapter IV, "Low-level Waste Requirements."

Table 18. MFC-793, Sodium Components Maintenance Shop, DOE M 435.1-1 low-level waste requirements and facility compliance information. 
Table 18. (continued).

\begin{tabular}{|c|c|}
\hline \multicolumn{2}{|c|}{ MFC-793, Sodium Components Maintenance Shop (including MFC-793C and MFC-793G) } \\
\hline Chapter IV, LLW Requirements & Facility Compliance Information \\
\hline $\begin{array}{l}\text { A. Definition of Low-Level Waste. Low-level } \\
\text { radioactive waste is radioactive waste that is not high- } \\
\text { level radioactive waste, spent nuclear fuel, transuranic } \\
\text { waste, byproduct material (as defined in section 11e.( } 2 \text { ) } \\
\text { of the Atomic Energy Act of 1954, as amended), or } \\
\text { naturally occurring radioactive material. } \\
\text { (From DOE G } 435.1-1 \text { Chapter IV: Low-level } \\
\text { radioactive waste is defined by what it is not. The } \\
\text { guidance on definitions in Chapters II and III should be } \\
\text { consulted first for making a determination on how to } \\
\text { properly manage a suspect waste stream.) }\end{array}$ & $\begin{array}{l}\text { This requirement provides the criteria for determining } \\
\text { which DOE radioactive waste is to be managed as } \\
\text { LLW in accordance with DOE Manual 435.1-1, } \\
\text { Chapter IV. } \\
\text { Radioactive waste managed at this facility under the } \\
\text { requirements of this chapter is not managed under the } \\
\text { requirements of DOE Manual } 435.1-1 \text {, Chapter II or } \\
\text { Chapter III. }\end{array}$ \\
\hline $\begin{array}{l}\text { B. Management of Specific Wastes. The following } \\
\text { provide for management of specific wastes as low-level } \\
\text { waste in accordance with the requirements in this } \\
\text { Chapter: }\end{array}$ & See below. \\
\hline $\begin{array}{l}\text { (1) Mixed Low-Level Waste. Low-level waste } \\
\text { determined to contain both source, special nuclear, or } \\
\text { byproduct material subject to the Atomic Energy Act of } \\
1954 \text {, as amended, and a hazardous component subject } \\
\text { to the Resource Conservation and Recovery Act } \\
\text { (RCRA), as amended, shall be managed in accordance } \\
\text { with the requirements of RCRA and DOE O 435.1, } \\
\text { Radioactive Waste Management, and this Manual. }\end{array}$ & $\begin{array}{l}\text { This facility has a HWMA/RCRA permit to store and } \\
\text { treat mixed waste (PER-116). Mixed LLW is stored in } \\
\text { MFC-793, 793C, and 793G. Mixed LLW is treated in } \\
\text { MFC-793. }\end{array}$ \\
\hline $\begin{array}{l}\text { (2) TSCA-Regulated Waste. Low-level waste } \\
\text { containing polychlorinated biphenyls, asbestos, or } \\
\text { other such regulated toxic components shall be } \\
\text { managed in accordance with requirements derived from } \\
\text { the Toxic Substances Control Act, as amended, DOE O } \\
\text { 435.1, Radioactive Waste Management, and this } \\
\text { Manual. }\end{array}$ & $\begin{array}{l}\text { TSCA-regulated mixed LLW and radioactive waste } \\
\text { may be managed in MFC-793C. Compliance with } \\
\text { TSCA regulations is addressed by WGS in its waste } \\
\text { management services role. Overall management of } \\
\text { mixed waste is addressed in MCP-17000 and } \\
\text { temporary storage of polychlorinated biphenyl waste is } \\
\text { addressed in MCP-17410. }\end{array}$ \\
\hline $\begin{array}{l}\text { (3) Accelerator-Produced Waste. Radioactive waste } \\
\text { produced as a result of operations of DOE accelerators } \\
\text { is low-level waste and shall be managed in accordance } \\
\text { with DOE O } 435.1 \text {, Radioactive Waste Management, } \\
\text { and this Manual, and all applicable Federal or State } \\
\text { requirements. }\end{array}$ & $\begin{array}{l}\text { NA; this facility does not manage accelerator-produced } \\
\text { waste. }\end{array}$ \\
\hline $\begin{array}{l}\text { (4) 11e.(2) and Naturally Occurring Radioactive } \\
\text { Material. Small quantities of } 11 \text { e.(2) byproduct } \\
\text { material and naturally occurring radioactive material } \\
\text { may be managed as low-level waste provided they can } \\
\text { be managed to meet the requirements for low-level } \\
\text { waste disposal in Section IV.P of this Manual. }\end{array}$ & $\begin{array}{l}\text { NA; this facility does not manage naturally occurring } \\
\text { radioactive material. }\end{array}$ \\
\hline $\begin{array}{l}\text { C. Complex-Wide Low-Level Waste Management } \\
\text { Program. A complex-wide program and plan shall be } \\
\text { developed as described under Responsibilities, 2.B and } \\
\text { 2.D, in Chapter I of this Manual. }\end{array}$ & $\begin{array}{l}\text { Not a facility-specific requirement. DOE Manual } \\
435.1-1 \S \text { I.2.B and §I.2.D apply to the Assistant } \\
\text { Secretary for Environmental Management and the } \\
\text { Deputy Assistant Secretary for Waste Management, } \\
\text { respectively. }\end{array}$ \\
\hline
\end{tabular}


Table 18. (continued).

\begin{tabular}{|c|c|}
\hline \multicolumn{2}{|c|}{ MFC-793, Sodium Components Maintenance Shop (including MFC-793C and MFC-793G) } \\
\hline Chapter IV, LLW Requirements & Facility Compliance Information \\
\hline $\begin{array}{l}\text { D. Radioactive Waste Management Basis. Low-level } \\
\text { waste facilities, operations, and activities shall have a } \\
\text { radioactive waste management basis consisting of } \\
\text { physical and administrative controls to ensure the } \\
\text { protection of workers, the public, and the environment. } \\
\text { The following specific waste management controls } \\
\text { shall be part of the radioactive waste management } \\
\text { basis: }\end{array}$ & $\begin{array}{l}\text { The RWMB provides the regulatory framework for } \\
\text { management of radioactive waste at INL. It specifically } \\
\text { identifies facility management and implementing } \\
\text { documents for the generation, storage, treatment, and } \\
\text { disposal of radiological waste.. } \\
\text { This facility is a LTHC3 facility (EDF-7030). }\end{array}$ \\
\hline $\begin{array}{l}\text { (1) Generators. The waste certification program. } \\
\text { From DOE G } 435.1-1 \text { Chapter IV: For a facility that } \\
\text { generates low-level waste, the radioactive waste } \\
\text { management basis is to include the program for } \\
\text { certifying that waste meets the waste acceptance } \\
\text { requirements of the facility(ies) to which the waste will } \\
\text { be sent. }\end{array}$ & See J. below. \\
\hline $\begin{array}{l}\text { (2) Treatment Facilities. certification program. The } \\
\text { waste acceptance requirements and the waste [sic] } \\
\text { From DOE G 435.1-1 Chapter IV: Facilities that store } \\
\text { or treat low-level waste are to have approved waste } \\
\text { acceptance requirements (see DOE M } 435.1-1 \text {, Section } \\
\text { IV.G) prior to the issuance of a radioactive waste } \\
\text { management basis. } \\
\text { A facility that stores or treats waste also is generally } \\
\text { expected to have a waste certification program. Waste } \\
\text { from these facilities will have to be certified as meeting } \\
\text { the waste acceptance requirements of the facility to } \\
\text { which it will be transferred, and the facilities have the } \\
\text { potential for generating radioactive waste (e.g., } \\
\text { secondary processing streams from treatment, } \\
\text { monitoring and sampling, radioactive release cleanup). } \\
\text { Consequently, storage and treatment facilities should } \\
\text { also have an approved waste certification program as } \\
\text { part of their radioactive waste management basis. } \\
\text { As part of the radioactive waste management basis, site } \\
\text { personnel needs to implement a system or process for } \\
\text { tracking the waste inventory at a storage, treatment, or } \\
\text { disposal facility. }\end{array}$ & $\begin{array}{l}\text { See G. and J. below. } \\
\text { Treatment is performed in MFC- } 793 \text {. } \\
\text { MCP- } 17000 \S 4 \text { specifies the use of IWTS, which } \\
\text { tracks the waste inventory. } \\
\text { TSD-OI-004 } § 3.2 .1 \text { addresses the use of IWTS to } \\
\text { track waste inventory. }\end{array}$ \\
\hline $\begin{array}{l}\text { (3) Storage Facilities. The waste acceptance } \\
\text { requirements and the waste certification program. } \\
\text { From DOE G 435.1-1 Chapter IV: Facilities that store } \\
\text { or treat low-level waste are to have approved waste } \\
\text { acceptance requirements (see DOE M } 435.1-1 \text {, Section } \\
\text { IV.G) prior to the issuance of a radioactive waste } \\
\text { management basis. } \\
\text { A facility that stores or treats waste also is generally } \\
\text { expected to have a waste certification program. Waste }\end{array}$ & $\begin{array}{l}\text { See G. and J. below. } \\
\text { MCP- } 17000 \S 4 \text { specifies the use of IWTS, which } \\
\text { tracks the waste inventory. } \\
\text { TSD-OI- } 004 \S 3.2 .1 \text { addresses the use of IWTS to } \\
\text { track waste inventory. }\end{array}$ \\
\hline
\end{tabular}


Table 18. (continued).

\begin{tabular}{|c|c|}
\hline \multicolumn{2}{|c|}{ MFC-793, Sodium Components Maintenance Shop (including MFC-793C and MFC-793G) } \\
\hline Chapter IV, LLW Requirements & Facility Compliance Information \\
\hline $\begin{array}{l}\text { from these facilities will have to be certified as meeting } \\
\text { the waste acceptance requirements of the facility to } \\
\text { which it will be transferred, and the facilities have the } \\
\text { potential for generating radioactive waste (e.g., } \\
\text { secondary processing streams from treatment, } \\
\text { monitoring and sampling, radioactive release cleanup). } \\
\text { Consequently, storage and treatment facilities should } \\
\text { also have an approved waste certification program as } \\
\text { part of their radioactive waste management basis. }\end{array}$ & \\
\hline $\begin{array}{l}\text { As part of the radioactive waste management basis, site } \\
\text { personnel needs to implement a system or process for } \\
\text { tracking the waste inventory at a storage, treatment, or } \\
\text { disposal facility. }\end{array}$ & \\
\hline $\begin{array}{l}\text { (4) Disposal Facilities. The performance assessment, } \\
\text { composite analysis, disposal authorization statement, } \\
\text { closure plan, waste acceptance requirements, and } \\
\text { monitoring plan. }\end{array}$ & NA; this facility is not a disposal facility. \\
\hline $\begin{array}{l}\text { E. Contingency Actions. The following requirements } \\
\text { are in addition to those in Chapter I of this Manual } \\
\text { [DOE M 435.1-1 §I.1.E(5)]. }\end{array}$ & $\begin{array}{l}\text { Not a facility-specific requirement. DOE Manual } \\
435.1-1 \text { §.1.E(5) addresses the sitewide emergency } \\
\text { management system. The INL plan is provided in } \\
\text { PLN-114. }\end{array}$ \\
\hline & $\begin{array}{l}\text { The HWMA/RCRA permit also includes a contingency } \\
\text { plan (PER-116, Attachment } 7, \S \text { G). }\end{array}$ \\
\hline $\begin{array}{l}\text { (1) Contingency Storage. For off-normal or emergency } \\
\text { situations involving high activity or high hazard liquid }\end{array}$ & $\begin{array}{l}\text { This facility is has a HWMA/RCRA permit to store } \\
\text { and treat mixed LLW. }\end{array}$ \\
\hline $\begin{array}{l}\text { low-level waste storage or treatment, spare capacity } \\
\text { with adequate capabilities shall be maintained to } \\
\text { receive the largest volume of liquid contained in any } \\
\text { one storage tank or treatment facility. Tanks or other } \\
\text { facilities that are desionated low-level waste }\end{array}$ & $\begin{array}{l}\text { Contingency storage is addressed as part of the } \\
\text { permit's condition for MFC- } 793 \text { container and tank } \\
\text { system secondary containment and in the permit's } \\
\text { contingency plan. }\end{array}$ \\
\hline contingency storage shall be maintained in an & PER-116 §§ III.F and IV.C \\
\hline $\begin{array}{l}\text { operational condition when waste is present and shall } \\
\text { meet the requirements of DOE O } 435.1 \text {, Radioactive } \\
\text { Waste Management, and this Manual. }\end{array}$ & $\begin{array}{l}\text { PER-116, Attachment } 1 \S \S \text { D-2 and D-4; Attachment } 7 \\
\S \text { G-3(n)(2) }\end{array}$ \\
\hline $\begin{array}{l}\text { From DOE G 435.1-1 Chapter IV: Compliance with } \\
\text { these requirements is demonstrated if adequate spare } \\
\text { capacity and transfer equipment exists for emergency } \\
\text { transfers of all high activity and high hazard liquid } \\
\text { low-level waste. In addition, the capability to perform } \\
\text { emergency transfers is demonstrated by having waste } \\
\text { transfer routings identified, operational procedures to } \\
\text { direct transfers, staff trained to the procedures, and } \\
\text { records showing that the spare capacity and transfer } \\
\text { capability are kept in operating condition. }\end{array}$ & SD-38.1.1, Appendix A and Appendix F \\
\hline $\begin{array}{l}\text { (2) Transfer Equipment. Pipelines and auxiliary } \\
\text { facilities necessary for the transfer of high activity or } \\
\text { high hazard liquid low-level waste to contingency } \\
\text { storage shall be maintained in an operational condition }\end{array}$ & $\begin{array}{l}\text { This facility is has a HWMA/RCRA permit to store } \\
\text { and treat mixed LLW. } \\
\text { Transfer equipment is addressed in the permit's }\end{array}$ \\
\hline
\end{tabular}


Table 18. (continued).

\begin{tabular}{|c|c|}
\hline \multicolumn{2}{|c|}{ MFC-793, Sodium Components Maintenance Shop (including MFC-793C and MFC-793G) } \\
\hline Chapter IV, LLW Requirements & Facility Compliance Information \\
\hline $\begin{array}{l}\text { when waste is present and shall meet the requirements } \\
\text { of DOE O 435.1, Radioactive Waste Management, and } \\
\text { this Manual. }\end{array}$ & $\begin{array}{l}\text { contingency plan for MFC-793 (PER-116, Attachment } \\
7 \S \text { G-3(n)(2)). }\end{array}$ \\
\hline $\begin{array}{l}\text { From DOE G } 435.1-1 \text { Chapter IV: Compliance with } \\
\text { these requirements is demonstrated if adequate spare } \\
\text { capacity and transfer equipment exists for emergency } \\
\text { transfers of all high activity and high hazard liquid } \\
\text { low-level waste. In addition, the capability to perform } \\
\text { emergency transfers is demonstrated by having waste } \\
\text { transfer routings identified, operational procedures to } \\
\text { direct transfers, staff trained to the procedures, and } \\
\text { records showing that the spare capacity and transfer } \\
\text { capability are kept in operating condition. }\end{array}$ & \\
\hline $\begin{array}{l}\text { F. Corrective Actions. I of this Manual. The following } \\
\text { requirements are in addition to those in Chapter [sic] }\end{array}$ & $\begin{array}{l}\text { The INL-wide procedure addressing problem } \\
\text { identification as required by DOE Manual 435.1-1 }\end{array}$ \\
\hline From DOE G 435.1-1 Chapter IV: Compliance with & $\begin{array}{l}\text { §I.2.G.(1) is LWP-13840, which implements the } \\
\text { laboratory's corrective action system. }\end{array}$ \\
\hline $\begin{array}{l}\text { showing what corrective actions were taken to remedy } \\
\text { situations in the radioactive waste management system. }\end{array}$ & $\begin{array}{l}\text { The INL-wide procedure addressing shutdown or } \\
\text { curtailment of activities as required by DOE Manual }\end{array}$ \\
\hline $\begin{array}{l}\text { Compliance with DOE M 435.1-1 §I.2.G.(2) is } \\
\text { demonstrated by having the necessary procedures, } \\
\text { mechanisms, and training in place to effect shutdown } \\
\text { or curtailment of activities which pose an imminent } \\
\text { danger or other serious hazard to workers or the public, } \\
\text { or are not protective of the environment. }\end{array}$ & \\
\hline $\begin{array}{l}\text { (1) Order Compliance. Corrective actions shall be } \\
\text { implemented whenever necessary to ensure the } \\
\text { requirements of DOE O 435.1, Radioactive Waste } \\
\text { Management, and this Manual are met. }\end{array}$ & $\begin{array}{l}\text { See F. above. } \\
\text { This facility is has a HWMA/RCRA permit to store } \\
\text { and treat mixed LLW. }\end{array}$ \\
\hline $\begin{array}{l}\text { From DOE G } 435.1-1 \text { Chapter IV: If a facility or } \\
\text { activity can be allowed to operate while a }\end{array}$ & $\begin{array}{l}\text { Corrective actions for waste regulated under this } \\
\text { permit are addressed as permit conditions. }\end{array}$ \\
\hline noncompliant or hazardous condition exists, the & PER-116, Module VI \\
\hline $\begin{array}{l}\text { allowance and any associated limitations must be } \\
\text { defined as part of the facility or activity's radioactive }\end{array}$ & PER-116, Attachment 4 \\
\hline $\begin{array}{l}\text { waste management basis, identified as a configuration } \\
\text { controlled item in a configuration management plan or } \\
\text { included in a revision or modification to an operating } \\
\text { procedure or similar controlled documentation. }\end{array}$ & SD-38.1.1 $\S 2.4,6$, and Appendix A \\
\hline $\begin{array}{l}\text { Compliance with this requirement is demonstrated if a } \\
\text { corrective action system addresses noncompliant or } \\
\text { hazardous situations involving low-level waste } \\
\text { management facilities in a systematic fashion, and } \\
\text { allows identification of problems by all personnel. }\end{array}$ & \\
\hline $\begin{array}{l}\text { (2) Operations Curtailment. Operations shall be } \\
\text { curtailed or facilities shut down for failure to establish, } \\
\text { maintain, or operate consistent with an approved } \\
\text { radioactive waste management basis. }\end{array}$ & $\begin{array}{l}\text { The approved RWMB establishes the current } \\
\text { compliance status at each radioactive waste } \\
\text { management facility. Facility assessments are } \\
\text { scheduled to ensure waste management activities are }\end{array}$ \\
\hline
\end{tabular}


Table 18. (continued).

\begin{tabular}{|c|c|}
\hline \multicolumn{2}{|c|}{ MFC-793, Sodium Components Maintenance Shop (including MFC-793C and MFC-793G) } \\
\hline Chapter IV, LLW Requirements & Facility Compliance Information \\
\hline $\begin{array}{l}\text { From DOE G 435.1-1 Chapter IV: Compliance with } \\
\text { this requirement is demonstrated with a documented } \\
\text { system of routine assessments to determine whether } \\
\text { waste management activities and facilities are } \\
\text { operating in accordance with an approved radioactive } \\
\text { waste management basis that provides for graded } \\
\text { limitations that can be placed on activities and } \\
\text { operations that do not have, or are operating outside of, } \\
\text { an approved radioactive waste management basis, } \\
\text { including shutdown of the facility. }\end{array}$ & conducted in accordance with the approved RWMB. \\
\hline $\begin{array}{l}\text { G. Waste Acceptance. The following requirements are } \\
\text { in addition to those in Chapter I of this Manual [DOE } \\
\text { M 435.1-1 §I.2.F(6)]. }\end{array}$ & $\begin{array}{l}\text { Not a facility-specific requirement. DOE Manual } \\
435.1-1 \text { §I.2.F(6) applies to field element managers. }\end{array}$ \\
\hline $\begin{array}{l}\text { (1) Technical and Administrative. Waste acceptance } \\
\text { requirements for all low-level waste storage, treatment, } \\
\text { or disposal facilities, operations, and activities shall } \\
\text { specify, at a minimum, the following: }\end{array}$ & See below. \\
\hline $\begin{array}{l}\text { From DOE G 435.1-1 Chapter IV: Compliance with } \\
\text { these waste acceptance requirements is demonstrated if } \\
\text { they are documented, contain clear and precise criteria } \\
\text { specifying the radionuclide limits in the form of } \\
\text { contents or concentrations that can be accepted, the } \\
\text { limitations and prohibitions on waste forms and } \\
\text { packages that can be received, and the limits, } \\
\text { prohibitions, or instructions concerning any other } \\
\text { technical information so that the waste is compatible } \\
\text { with the safety basis of the facility, and which will } \\
\text { result in acceptable waste at subsequent steps in } \\
\text { managing the low-level waste. }\end{array}$ & \\
\hline $\begin{array}{l}\text { (a) Allowable activities and/or concentrations of } \\
\text { specific radionuclides. }\end{array}$ & $\begin{array}{l}\text { MCP-17000 } \\
\text { TSD-OI-004 } 33.2\end{array}$ \\
\hline $\begin{array}{l}\text { (b) Acceptable waste form and/or container } \\
\text { requirements that ensure the chemical and physical } \\
\text { stability of waste under conditions that might be } \\
\text { encountered during transportation, storage, treatment, } \\
\text { or disposal. }\end{array}$ & $\begin{array}{l}\text { MCP-17000 } \\
\text { TSD-OI-004 } \S 3.3 \text { and } 3.4 \\
\text { PER-116, Module II.C and III } \\
\text { PER-116, Attachment } 1 \S \S \text { B-2(a), D-1(a), and } \\
\text { Attachment } 2 \S \text { C-2(a) } \\
\text { SD-38.1.1, Appendix A and Appendix F }\end{array}$ \\
\hline $\begin{array}{l}\text { (c) Restrictions or prohibitions on waste, materials, or } \\
\text { containers that may adversely affect waste handlers or } \\
\text { compromise facility or waste container performance. }\end{array}$ & $\begin{array}{l}\text { MCP-17000 } \\
\text { TSD-OI-004 } \S 3.2 \\
\text { PER-116, Module II.C and III } \\
\text { PER-116, Attachment } 1 \S \S \text { B-2(a), D-1(a) and } \\
\text { Attachment } 2 \S \text { C-2(a) } \\
\text { SD-38.1.1, Appendix A and Appendix F }\end{array}$ \\
\hline
\end{tabular}


Table 18. (continued).

\begin{tabular}{|c|c|}
\hline \multicolumn{2}{|c|}{ MFC-793, Sodium Components Maintenance Shop (including MFC-793C and MFC-793G) } \\
\hline Chapter IV, LLW Requirements & Facility Compliance Information \\
\hline $\begin{array}{l}\text { (d) The following are additional waste acceptance } \\
\text { requirements that shall be specified in low-level waste } \\
\text { disposal facility waste acceptance requirements: }\end{array}$ & NA; this facility is not a LLW disposal facility. \\
\hline $\begin{array}{l}1 \text { Low-level waste must contribute to and not detract } \\
\text { from achieving long-term stability of the facility, } \\
\text { minimizing the need for long-term active maintenance, } \\
\text { minimizing subsidence, and minimizing contact of } \\
\text { water with waste. Void spaces within the waste and, if } \\
\text { containers are used, between the waste and its } \\
\text { container shall be reduced to the extent practical. }\end{array}$ & See (d) above. \\
\hline $\begin{array}{l}2 \text { Liquid low-level waste or low-level waste containing } \\
\text { free liquid must be converted into a form that contains } \\
\text { as little freestanding liquid as is reasonably achievable, } \\
\text { but in no case shall the liquid exceed } 1 \text { percent of the } \\
\text { waste volume when the low-level waste is in a disposal } \\
\text { container, or } 0.5 \text { percent of the waste volume after it is } \\
\text { processed to a stable form. }\end{array}$ & See (d) above. \\
\hline $\begin{array}{l}3 \text { Low-level waste must not be readily capable of } \\
\text { detonation or of explosive decomposition or reaction at } \\
\text { anticipated pressures and temperatures, or of explosive } \\
\text { reaction with water. Pyrophoric materials contained in } \\
\text { waste shall be treated, prepared, and packaged to be } \\
\text { nonflammable. }\end{array}$ & See (d) above. \\
\hline $\begin{array}{l}4 \text { Low-level waste must not contain, or be capable of } \\
\text { generating by radiolysis or biodegradation, quantities } \\
\text { of toxic gases, vapors, or fumes harmful to the public } \\
\text { or workers or disposal facility personnel, or harmful to } \\
\text { the long-term structural stability of the disposal site. }\end{array}$ & See (d) above. \\
\hline $\begin{array}{l}5 \text { Low-level waste in a gaseous form must be packaged } \\
\text { such that the pressure does not exceed } 1.5 \text { atmospheres } \\
\text { absolute at } 20 \text { C. [ sic] }\end{array}$ & See (d) above. \\
\hline $\begin{array}{l}\text { (e) The basis, procedures, and levels of authority } \\
\text { required for granting exceptions to the waste } \\
\text { acceptance requirements, which shall be contained in } \\
\text { each facility's waste acceptance documentation. Each } \\
\text { exception request shall be documented, including its } \\
\text { disposition as approved or not approved. }\end{array}$ & $\begin{array}{l}\text { Exceptions to the waste acceptance requirements are } \\
\text { not permitted. }\end{array}$ \\
\hline $\begin{array}{l}\text { From DOE G } 435.1-1 \text { Chapter IV: Waste acceptance } \\
\text { requirements are acceptable if they are documented and } \\
\text { contain a clear description of the procedure and bases } \\
\text { for obtaining an exception or deviation to the } \\
\text { acceptance criteria for low-level waste to be received at } \\
\text { the facility. }\end{array}$ & \\
\hline $\begin{array}{l}\text { (2) Evaluation and Acceptance. The receiving facility } \\
\text { shall evaluate waste for acceptance, including } \\
\text { confirmation that the technical and administrative } \\
\text { requirements have been met. A process for the }\end{array}$ & $\begin{array}{l}\text { MCP-17000 } \\
\text { TSD-OI-004 § } 3\end{array}$ \\
\hline
\end{tabular}


Table 18. (continued).

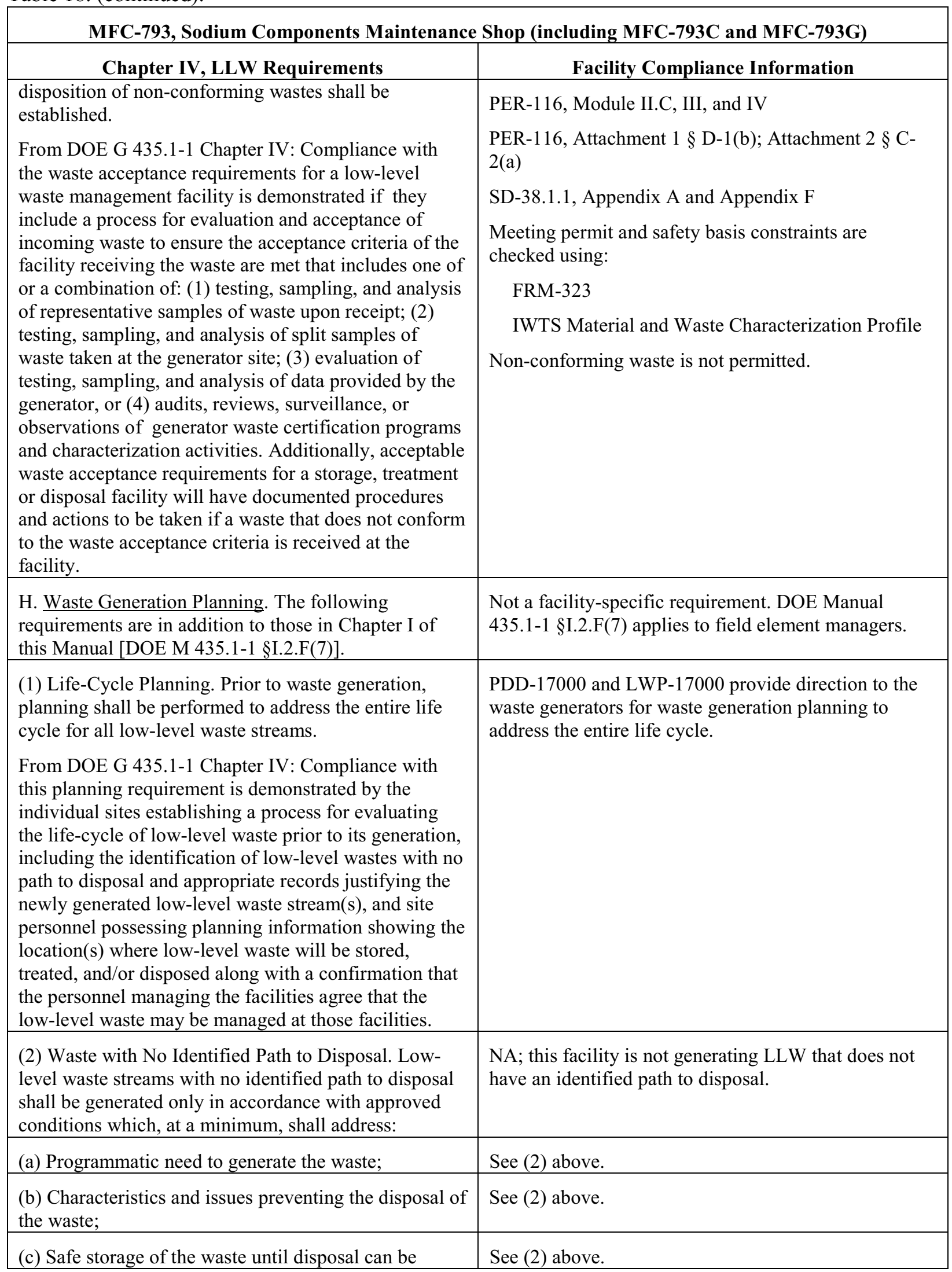


Table 18. (continued).

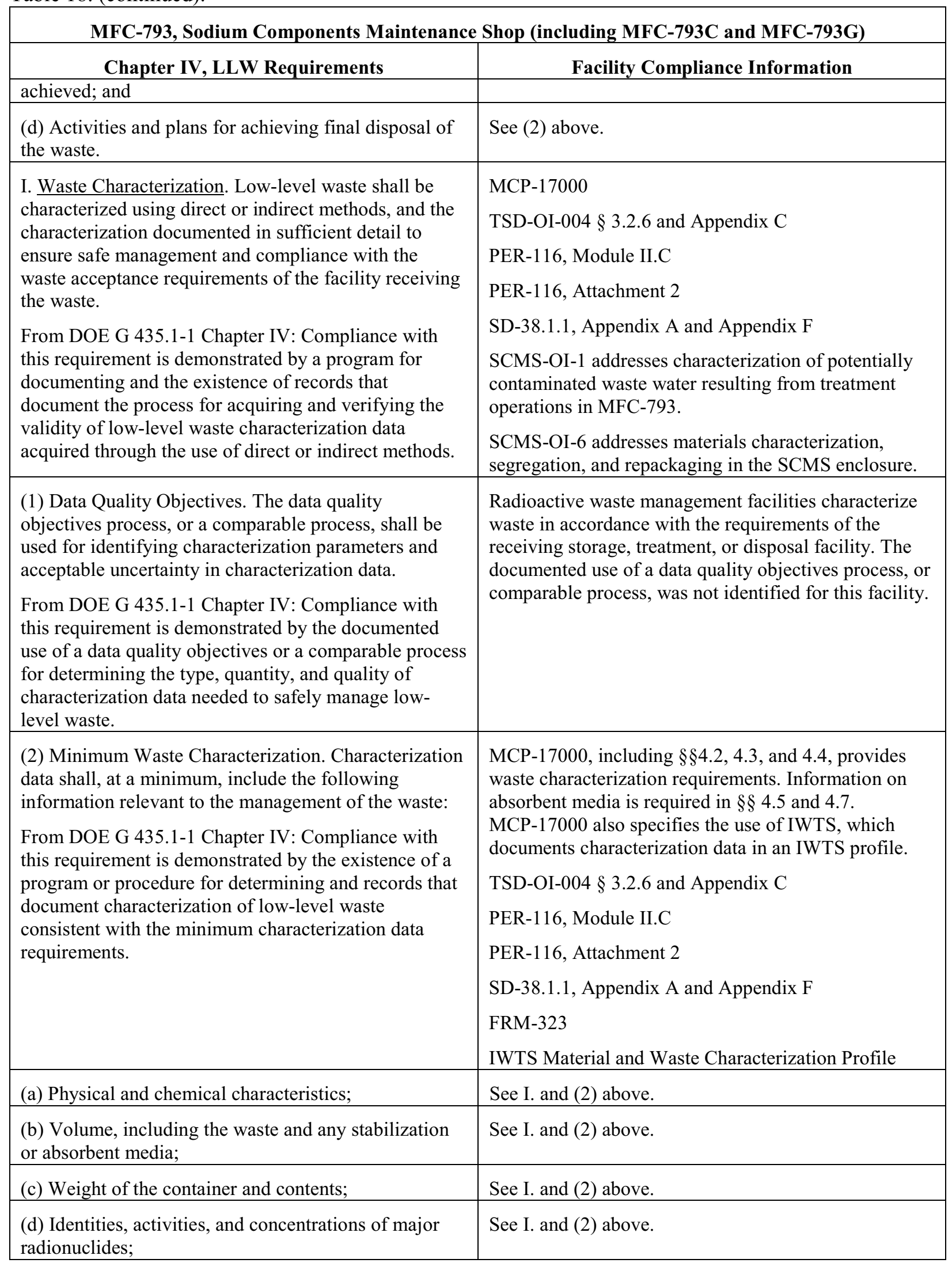


Table 18. (continued).

\begin{tabular}{|c|c|}
\hline \multicolumn{2}{|c|}{ MFC-793, Sodium Components Maintenance Shop (including MFC-793C and MFC-793G) } \\
\hline Chapter IV, LLW Requirements & Facility Compliance Information \\
\hline (e) Characterization date; & See I. and (2) above. \\
\hline (f) Generating source; and & See I. and (2) above. \\
\hline $\begin{array}{l}\text { (g) Any other information which may be needed to } \\
\text { prepare and maintain the disposal facility performance } \\
\text { assessment, or demonstrate compliance with applicable } \\
\text { performance objectives. }\end{array}$ & See I. and (2) above. \\
\hline $\begin{array}{l}\text { J. Waste Certification. A waste certification program } \\
\text { shall be developed, documented, and implemented to } \\
\text { ensure that the waste acceptance requirements of } \\
\text { facilities receiving low-level waste for storage, } \\
\text { treatment, and disposal are met. } \\
\text { From DOE G 435.1-1 Chapter IV: Compliance with } \\
\text { the development and documentation portion of the } \\
\text { certification requirement is demonstrated by a waste } \\
\text { certification plan that identifies the organizations } \\
\text { involved, assigns responsibilities for implementing the } \\
\text { program, and describes or references the quality } \\
\text { assurance, training, procurement controls, records } \\
\text { management, and procedures to be used by the } \\
\text { program. Acceptable performance for implementing } \\
\text { the program is demonstrated when appropriate } \\
\text { personnel are trained and follow the procedures that } \\
\text { govern their part of the waste certification. } \\
\text { Additionally, acceptable performance is demonstrated } \\
\text { if the waste certification plan and procedures are } \\
\text { current and controlled in accordance with a document } \\
\text { controls program, and records related to certification } \\
\text { (e.g., certification statements, training records, } \\
\text { procurement records, characterization records, } \\
\text { container records) are generated and managed in } \\
\text { accordance with the established site program. }\end{array}$ & $\begin{array}{l}\text { MCP-17000 cites a waste certification program for } \\
\text { LLW destined for NNSS. For waste destined for } \\
\text { locations other than NNSS, the waste disposition } \\
\text { specialist is responsible for certifying the waste stream } \\
\text { by ensuring the waste, as characterized, falls within the } \\
\text { limitations of the WAC of the treatment, storage, or } \\
\text { disposal facility ( } \$ 2) \text {. } \\
\text { Container procurement is addressed in MCP-17000 } \\
\S 4.6 \text {. } \\
\text { MCP-17500 provides the WGS waste certification } \\
\text { program for LLW to be shipped to NNSS. } \\
\text { Waste certification is performed and tracked using } \\
\text { IWTS. Documentation of the IWTS Program is } \\
\text { available electronically only. } \\
\text { PLN-522 requires waste technical specialists and waste } \\
\text { disposition specialists to complete the appropriate } \\
\text { training/qualification before being granted approval } \\
\text { authority for profiles within the IWTS Program. The } \\
\text { waste certification official, alternate waste certification } \\
\text { official, and NNSS packaging certifiers must complete } \\
\text { the appropriate training/qualifications to disposition } \\
\text { waste to NNSS. } \\
\text { TSD-OI-004 §§3.2.4, 3.2.5, 3.3, 3.4, 3.6, and } 4 \\
\text { PER-116, Module II.C and III } \\
\text { PER-116, Attachment } 1 \S \S \text { B-2(a) and D-1(a); } \\
\text { Attachment } 2 \S \text { C-2(a) } \\
\text { SD-38.1.1, Appendix A and Appendix F }\end{array}$ \\
\hline $\begin{array}{l}\text { (1) Certification Program. The waste certification } \\
\text { program shall designate the officials who have the } \\
\text { authority to certify and release waste for shipment; and } \\
\text { specify what documentation is required for waste } \\
\text { generation, characterization, shipment, and } \\
\text { certification. The program shall provide requirements } \\
\text { for auditability, retrievability, and storage of required } \\
\text { documentation and specify the records retention period. } \\
\text { From DOE G } 435.1-1 \text { Chapter IV: Compliance with } \\
\text { this requirement is demonstrated by a program or } \\
\text { procedure for record keeping and records showing that }\end{array}$ & $\begin{array}{l}\text { See J. above. MCP- } 17500 \S \S 2 \text { and } 5 \text { address } \\
\text { certification records for shipments to NNSS. }\end{array}$ \\
\hline
\end{tabular}


Table 18. (continued).

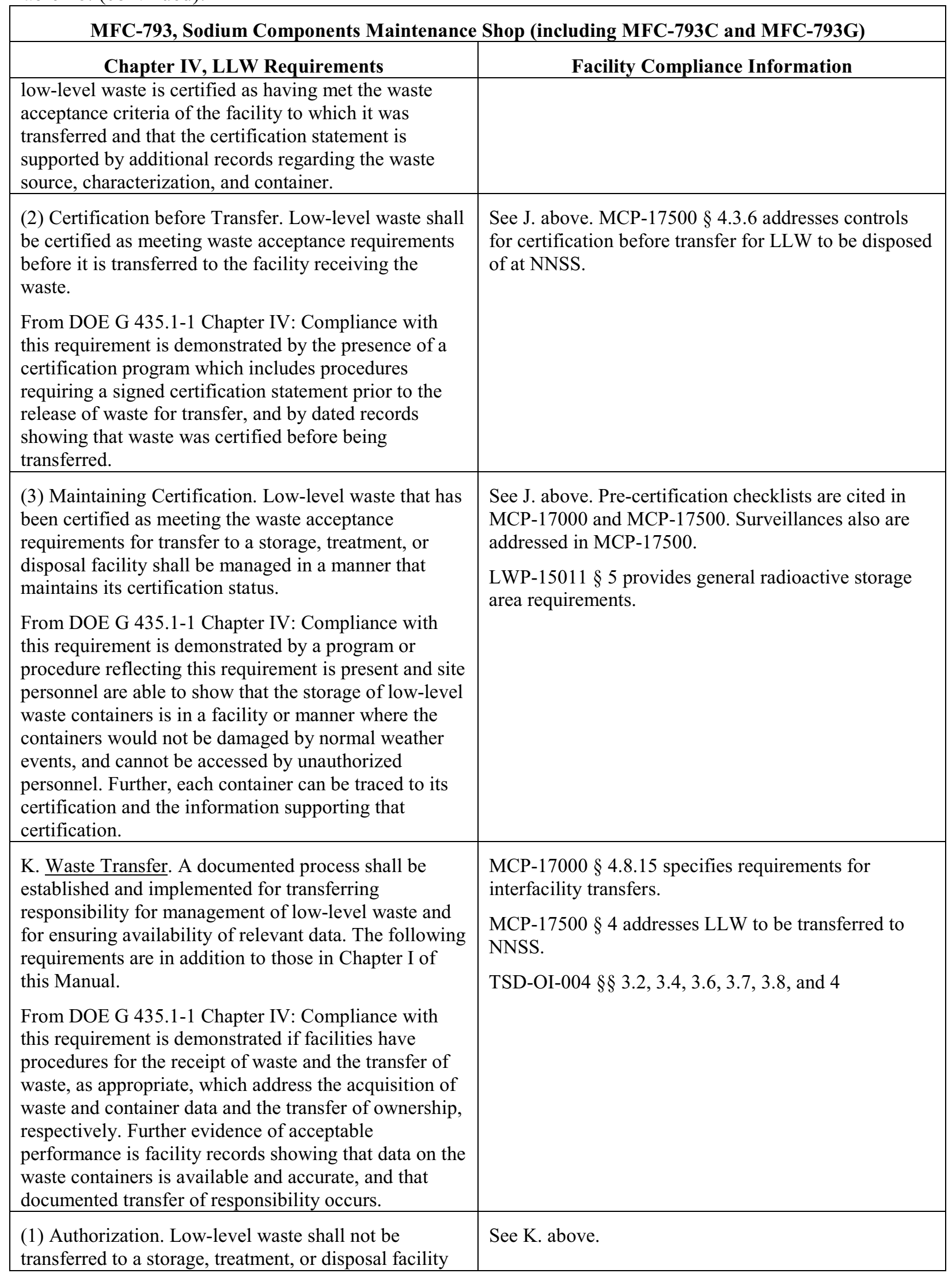


Table 18. (continued).

\begin{tabular}{|c|c|}
\hline \multicolumn{2}{|c|}{ MFC-793, Sodium Components Maintenance Shop (including MFC-793C and MFC-793G) } \\
\hline Chapter IV, LLW Requirements & Facility Compliance Information \\
\hline $\begin{array}{l}\text { until personnel responsible for the facility receiving the } \\
\text { waste authorize the transfer. }\end{array}$ & \\
\hline $\begin{array}{l}\text { From DOE G } 435.1-1 \text { Chapter IV: Compliance with } \\
\text { this requirement is demonstrated by sites having } \\
\text { procedures that require a confirmation of authorization } \\
\text { before releasing waste for transfer, and records } \\
\text { showing that transfers are made in accordance with } \\
\text { written authorizations. }\end{array}$ & \\
\hline $\begin{array}{l}\text { (2) Data. Waste characterization data, container } \\
\text { information, and generation, storage, treatment, and } \\
\text { transportation information for low-level waste shall be } \\
\text { transferred with or be traceable to the waste. }\end{array}$ & See K. above. \\
\hline $\begin{array}{l}\text { From DOE G } 435.1-1 \text { Chapter IV: Compliance with } \\
\text { this requirement is demonstrated if there are procedures } \\
\text { requiring that characterization and container data be } \\
\text { provided and maintained for each low-level waste } \\
\text { transfer and documented records of transfers show that } \\
\text { the information is being provided. }\end{array}$ & \\
\hline $\begin{array}{l}\text { L. Packaging and Transportation. The following } \\
\text { requirements are in addition to those in Chapter I of } \\
\text { this Manual [DOE M 435.1-1 §I.1.E(11)]. }\end{array}$ & See (1) and (2) below. \\
\hline (1) Packaging. If containers are used: & MCP- $17000 \S 4$ addresses packaging requirements. \\
\hline $\begin{array}{l}\text { From DOE G 435.1-1 Chapter IV: Compliance with } \\
\text { the packaging requirement is demonstrated by: (1) } \\
\text { procedures which document proper packaging } \\
\text { protocols; and (2) no trends of routine repackaging of } \\
\text { low-level waste that is packaged after issuance of DOE } \\
\text { O } 435.1 \text {. Successful performance of this requirement is } \\
\text { also demonstrated by a record of containers for which } \\
\text { failure has not routinely occurred under management } \\
\text { conditions. It is recognized that there may be failed } \\
\text { containers for waste previously placed in storage. For } \\
\text { those containers, the goal is to only have to repackage } \\
\text { the waste one time after it is retrieved and } \\
\text { characterized. Further, acceptable performance is } \\
\text { demonstrated by containers of waste having marking } \\
\text { and labeling that allows correlation with waste } \\
\text { characterization data and container information. }\end{array}$ & TSD-OI-004 $§ 3.3$ \\
\hline $\begin{array}{l}\text { (a) Low-level waste shall be packaged in a manner that } \\
\text { provides containment and protection for the duration of } \\
\text { the anticipated storage period and until disposal is } \\
\text { achieved or until the waste has been removed from the } \\
\text { container. }\end{array}$ & See (1) above. \\
\hline $\begin{array}{l}\text { (b) When waste is packaged, vents or other measures } \\
\text { shall be provided if the potential exists for pressurizing } \\
\text { or generating flammable or explosive concentrations of } \\
\text { gases within the waste container. }\end{array}$ & See (1) above. \\
\hline
\end{tabular}


Table 18. (continued).

\begin{tabular}{|c|c|}
\hline \multicolumn{2}{|c|}{ MFC-793, Sodium Components Maintenance Shop (including MFC-793C and MFC-793G) } \\
\hline Chapter IV, LLW Requirements & Facility Compliance Information \\
\hline $\begin{array}{l}\text { (c) Containers of low-level waste shall be marked such } \\
\text { that their contents can be identified. }\end{array}$ & See (1) above. \\
\hline $\begin{array}{l}\text { (2) Transportation. To the extent practical, the volume } \\
\text { of waste and number of low-level waste shipments } \\
\text { shall be minimized. } \\
\text { From DOE G 435.1-1 Chapter IV: Compliance with } \\
\text { this requirement can be demonstrated by a combination } \\
\text { of site procedures directing the efficient use of waste } \\
\text { container capacity and documentation showing that } \\
\text { low-level waste shipments are systematically planned } \\
\text { and optimized to the extent practical. }\end{array}$ & $\begin{array}{l}\text { MCP-17000 } \S 4 \text { addresses transportation. The waste } \\
\text { disposition specialist coordinates with packaging and } \\
\text { transportation personnel for waste shipped offsite from } \\
\text { this facility. } \\
\text { MCP-17500 specifies waste certification official and } \\
\text { waste disposition specialist responsibilities and } \\
\text { coordination with packaging and transportation } \\
\text { personnel for waste shipped directly to NNSS from this } \\
\text { facility. }\end{array}$ \\
\hline $\begin{array}{l}\text { M. Site Evaluation and Facility Design. The following } \\
\text { requirements are in addition to those in Chapter I of } \\
\text { this Manual. }\end{array}$ & $\begin{array}{l}\text { NA; this requirement addresses new radioactive waste } \\
\text { management facilities or modifications to existing } \\
\text { facilities. }\end{array}$ \\
\hline $\begin{array}{l}\text { (1) Site Evaluation. Proposed locations for low-level } \\
\text { waste facilities shall be evaluated to identify relevant } \\
\text { features that should be avoided or must be considered } \\
\text { in facility design and analyses. }\end{array}$ & See M. above. \\
\hline $\begin{array}{l}\text { (a) Each site proposed for a new low-level waste } \\
\text { facility or expansion of an existing low-level waste } \\
\text { facility shall be evaluated considering environmental } \\
\text { characteristics, geotechnical characteristics, and human } \\
\text { activities, including for a low-level waste disposal } \\
\text { facility, the capability of the site to demonstrate, at a } \\
\text { minimum, whether it is: }\end{array}$ & See M. above. \\
\hline $\begin{array}{l}1 \text { Located to accommodate the projected volume of } \\
\text { waste to be received; }\end{array}$ & See M. above. \\
\hline $\begin{array}{l}2 \text { Located in a flood plain, a tectonically active area, or } \\
\text { in the zone of water table fluctuation; and }\end{array}$ & See M. above. \\
\hline $\begin{array}{l}3 \text { Located where radionuclide migration pathways are } \\
\text { predictable and erosion and surface runoff can be } \\
\text { controlled. }\end{array}$ & See M. above. \\
\hline $\begin{array}{l}\text { (b) Proposed sites with environmental characteristics, } \\
\text { geotechnical characteristics, and human activities for } \\
\text { which adequate protection cannot be provided through } \\
\text { facility design shall be deemed unsuitable for the } \\
\text { location of the facility. }\end{array}$ & See M. above. \\
\hline $\begin{array}{l}\text { (c) Low-level waste disposal facilities shall be sited to } \\
\text { achieve long-term stability and to minimize, to the } \\
\text { extent practical, the need for active maintenance } \\
\text { following final closure. }\end{array}$ & See M. above. \\
\hline $\begin{array}{l}\text { (2) Low-Level Waste Treatment and Storage Facility } \\
\text { Design. The following facility requirements and } \\
\text { general design criteria, at a minimum, apply: }\end{array}$ & See M. above. \\
\hline
\end{tabular}


Table 18. (continued).

\begin{tabular}{|c|c|}
\hline \multicolumn{2}{|c|}{ MFC-793, Sodium Components Maintenance Shop (including MFC-793C and MFC-793G) } \\
\hline Chapter IV, LLW Requirements & Facility Compliance Information \\
\hline $\begin{array}{l}\text { (a) Confinement. Low-level waste systems and } \\
\text { components shall be designed to maintain waste } \\
\text { confinement. }\end{array}$ & See M. above. \\
\hline (b) Ventilation. & See M. above. \\
\hline $\begin{array}{l}1 \text { Design of low-level waste treatment and storage } \\
\text { facilities shall include ventilation, if applicable, } \\
\text { through an appropriate filtration system to maintain the } \\
\text { release of radioactive material in airborne effluents } \\
\text { within the requirements and guidelines specified in } \\
\text { applicable requirements. }\end{array}$ & See M. above. \\
\hline $\begin{array}{l}2 \text { When conditions exist for generating gases in } \\
\text { flammable or explosive concentrations, ventilation } \\
\text { systems or other measures shall be provided to keep the } \\
\text { gases in a non-flammable and nonexplosive condition. } \\
\text { Where concentrations of explosive or flammable gases } \\
\text { are expected to approach the lower flammability limit, } \\
\text { measures shall be taken to prevent deflagration or } \\
\text { detonation. }\end{array}$ & See M. above. \\
\hline $\begin{array}{l}\text { (c) Consideration of Decontamination and } \\
\text { Decommissioning. Areas in new and modifications to } \\
\text { existing low-level waste management facilities that are } \\
\text { subject to contamination with radioactive or other } \\
\text { hazardous materials shall be designed to facilitate } \\
\text { decontamination. For such facilities a proposed } \\
\text { decommissioning method or a conversion method } \\
\text { leading to reuse shall be described. }\end{array}$ & See M. above. \\
\hline $\begin{array}{l}\text { (d) Instrumentation and Control Systems. Engineering } \\
\text { controls shall be incorporated in the design and } \\
\text { engineering of low-level waste treatment and storage } \\
\text { facilities to provide volume inventory data and to } \\
\text { prevent spills, leaks, and overflows from tanks or } \\
\text { confinement systems. }\end{array}$ & See M. above. \\
\hline $\begin{array}{l}\text { (e) Monitoring. Monitoring and/or leak detection } \\
\text { capabilities shall be incorporated in the design and } \\
\text { engineering of low-level waste treatment and storage } \\
\text { facilities to provide rapid identification of failed } \\
\text { confinement and/or other abnormal conditions. }\end{array}$ & See M. above. \\
\hline $\begin{array}{l}\text { (3) Low-Level Waste Disposal Facility Design. The } \\
\text { following facility requirements and general design } \\
\text { criteria, at a minimum, apply: }\end{array}$ & See M. above. \\
\hline $\begin{array}{l}\text { (a) Confinement. Low-level waste systems and } \\
\text { components shall be designed to maintain waste } \\
\text { confinement. }\end{array}$ & See M. above. \\
\hline (b) Ventilation. & See M. above. \\
\hline 1 Design of low-level waste disposal facilities shall & See M. above. \\
\hline
\end{tabular}


Table 18. (continued).

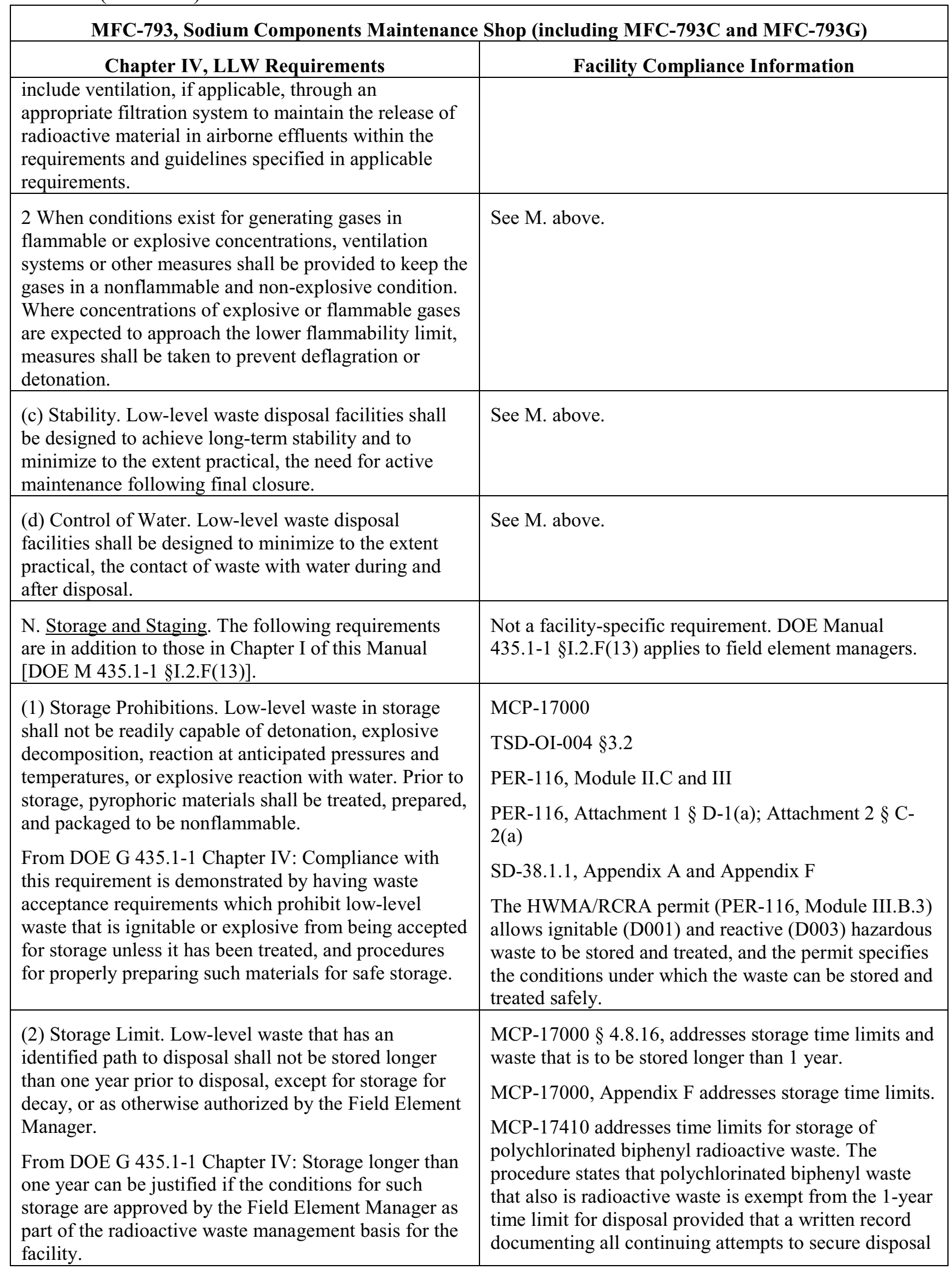


Table 18. (continued).

\begin{tabular}{|c|c|}
\hline \multicolumn{2}{|c|}{ MFC-793, Sodium Components Maintenance Shop (including MFC-793C and MFC-793G) } \\
\hline Chapter IV, LLW Requirements & Facility Compliance Information \\
\hline $\begin{array}{l}\text { Storage for radioactive decay for a period greater than } \\
1 \text { year for waste that has an identified path to disposal } \\
\text { is allowed. Adequate justification and the supporting } \\
\text { information for storage for decay is to be documented } \\
\text { in the radioactive waste management basis for the } \\
\text { facility in which the storage will take place. }\end{array}$ & $\begin{array}{l}\text { is maintained until the waste is disposed of and this } \\
\text { written record is made available for inspection or } \\
\text { submission if requested by the Environental Protection } \\
\text { Agency. } \\
\text { Storage longer than } 1 \text { year for mixed waste is } \\
\text { allowable under the Site Treatment Plan. }\end{array}$ \\
\hline $\begin{array}{l}\text { Mixed waste. Under the Federal Facility Compliance } \\
\text { Act of 1992, DOE sites were required to develop Site } \\
\text { Treatment Plans to bring stored mixed low-level waste } \\
\text { into compliance with these requirements. The Site } \\
\text { Treatment Plan needs to be consulted and any mixed } \\
\text { low-level waste stored for the purpose of accumulation } \\
\text { to facilitate treatment must meet Resource } \\
\text { Conservation and Recovery Act storage requirements. } \\
\text { There could be several ways within different scenarios } \\
\text { that this requirement can be met, as illustrated by the } \\
\text { examples below, however, there are basically four } \\
\text { ways to show compliance with the requirement and } \\
\text { include appropriate provisions in the radioactive waste } \\
\text { management basis for the facility in which it is stored. }\end{array}$ & \\
\hline $\begin{array}{l}\text { Legacy waste. As discussed above, the intention of the } \\
\text { requirement is not to force malicious compliance or } \\
\text { heroic actions which would result in increased risk or } \\
\text { safety concerns. Rather, the intention is that waste in } \\
\text { storage longer than one year receives additional } \\
\text { attention to ensure that the public, the workers, and the } \\
\text { environment are protected from the hazards of the } \\
\text { waste, and that progress is being made to dispose of the } \\
\text { waste. There could be several ways within different } \\
\text { scenarios that this requirement can be met, as } \\
\text { illustrated by the examples below, however, there are } \\
\text { basically four ways to show compliance with the } \\
\text { requirement: }\end{array}$ & \\
\hline $\begin{array}{l}\text { 1) the radioactive waste management basis allows for } \\
\text { storage for no more than one year. }\end{array}$ & \\
\hline $\begin{array}{l}\text { 2) the radioactive waste management basis allows for } \\
\text { storage for no more than one year, or for storage for } \\
\text { decay only for periods greater than a year, which are } \\
\text { specified on a radionuclide basis. }\end{array}$ & \\
\hline $\begin{array}{l}\text { 3) the radioactive waste management basis allows for } \\
\text { storage for more than one year, up to a specified period } \\
\text { of time based on a documented technical evaluation } \\
\text { that the waste can be stored in a manner that does not } \\
\text { cause changes to the waste or waste packages that is } \\
\text { detrimental to the safe storage of the waste, the final } \\
\text { disposal of the waste or to meeting the disposal } \\
\text { performance objectives. }\end{array}$ & \\
\hline 4) the radioactive waste management basis allows for & \\
\hline
\end{tabular}


Table 18. (continued).

\begin{tabular}{|c|c|}
\hline \multicolumn{2}{|c|}{ MFC-793, Sodium Components Maintenance Shop (including MFC-793C and MFC-793G) } \\
\hline Chapter IV, LLW Requirements & Facility Compliance Information \\
\hline $\begin{array}{l}\text { storage for decay (with specifics) and for storage for } \\
\text { more than one year for other low-level waste, up to a } \\
\text { specified period of time based on a documented } \\
\text { technical evaluation that the waste can be stored in a } \\
\text { manner that does not cause changes to the waste or } \\
\text { waste packages that is detrimental to the safe storage of } \\
\text { the waste, the final disposal of the waste or to meeting } \\
\text { the disposal performance objectives. }\end{array}$ & \\
\hline $\begin{array}{l}\text { Compliance with this requirement is demonstrated by } \\
\text { the existence of a radioactive waste management basis } \\
\text { for the storage facility approved by the Field Element } \\
\text { Manager that includes the time frames that waste are } \\
\text { allowed to be stored, the necessary justifications for } \\
\text { storage for decay, and the necessary technical } \\
\text { evaluations if storage is to extend significantly beyond } \\
\text { the one-year time frame. }\end{array}$ & \\
\hline (3) Storage Integrity. Low-level waste shall be stored & MCP-17000 \\
\hline $\begin{array}{l}\text { in a location and manner that protects the integrity of } \\
\text { waste for the expected time of storage and minimizes }\end{array}$ & TSD-OI-004 §§ 3.3 and 3.4 \\
\hline worker exposure. & PER-116, Module III \\
\hline From DOE G 435.1-1 Chapter IV: However, in making & PER-116, Attachment $1 \S$ D-1(a) \\
\hline $\begin{array}{l}\text { a decision to use a facility for storage and in } \\
\text { developing a radioactive waste management basis for } \\
\text { the activity, particular attention to protection of } \\
\text { workers is needed. }\end{array}$ & SD-38.1.1, Appendix A and Appendix F \\
\hline $\begin{array}{l}\text { Compliance with this requirement is demonstrated if } \\
\text { sites have storage capabilities for low-level waste that } \\
\text { provide protection to waste containers so that their } \\
\text { integrity will not be damaged through physical or } \\
\text { chemical (corrosion) processes and that keep personnel } \\
\text { from spending extended periods of time in the areas } \\
\text { where low-level waste is stored. }\end{array}$ & \\
\hline (4) Waste Characterization for Storage. & See below. \\
\hline $\begin{array}{l}\text { (a) Low-level waste that does not have an identified } \\
\text { path to disposal shall be characterized as necessary to } \\
\text { meet the data quality objectives and minimum } \\
\text { characterization requirements of this Chapter, to ensure } \\
\text { safe storage, and to facilitate disposal. }\end{array}$ & $\begin{array}{l}\text { This facility does not store LLW that does not have an } \\
\text { identified path to disposal. }\end{array}$ \\
\hline (b) Characterization information for all low-level waste & MCP-17000 \\
\hline $\begin{array}{l}\text { in storage shall be maintained as a record in accordance } \\
\text { with the requirements for Records Management in }\end{array}$ & TSD-OI-004 $\S \S 3.8$ and 4 \\
\hline Chapter I of this Manual. & PER-116, Module III and IV \\
\hline $\begin{array}{l}\text { From DOE G 435.1-1 Chapter IV: Compliance with } \\
\text { this requirement is demonstrated by documented } \\
\text { procedures for managing waste characterization and } \\
\text { container information on low-level waste as a Federal } \\
\text { record. The records are managed per the applicable }\end{array}$ & $\begin{array}{l}\text { PER-116, Attachment } 1 \S \text { D; Attachment } 2 \\
\text { SD-38.1.1, Appendix A and Appendix F }\end{array}$ \\
\hline
\end{tabular}


Table 18. (continued).

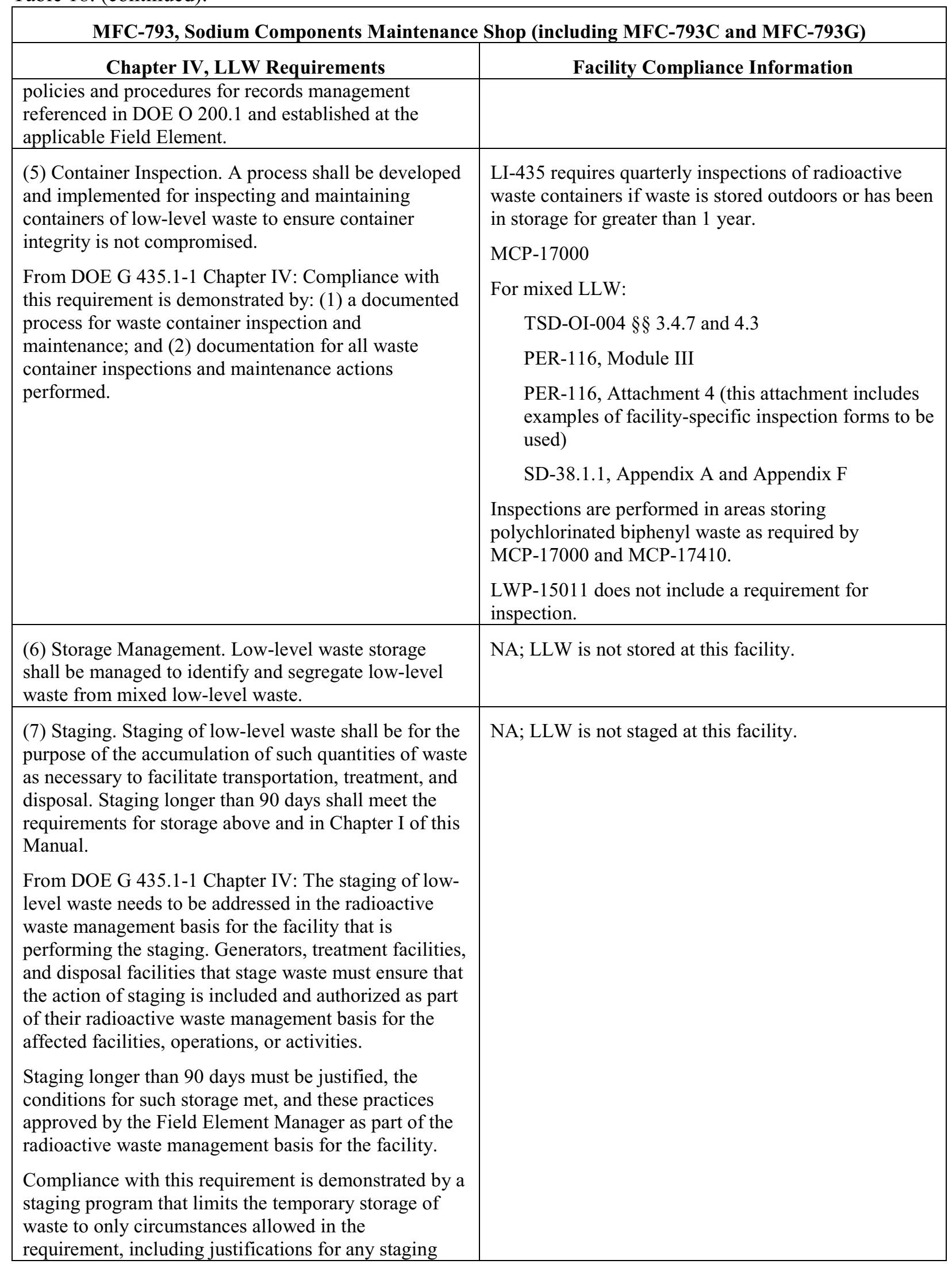


Table 18. (continued).

\begin{tabular}{|c|c|}
\hline \multicolumn{2}{|c|}{ MFC-793, Sodium Components Maintenance Shop (including MFC-793C and MFC-793G) } \\
\hline $\begin{array}{l}\text { Chapter IV, LLW Requirements } \\
\text { that exceeds the } 90 \text {-day period, which is documented in } \\
\text { the radioactive waste management basis for the facility. }\end{array}$ & Facility Compliance Information \\
\hline $\begin{array}{l}\text { O. Treatment. Low-level waste treatment to provide } \\
\text { more stable waste forms and to improve the long-term } \\
\text { performance of a low-level waste disposal facility shall } \\
\text { be implemented as necessary to meet the performance } \\
\text { objectives of the disposal facility. } \\
\text { From DOE G } 435.1-1 \text { Chapter IV: Compliance with } \\
\text { this requirement is demonstrated when a treatment } \\
\text { facility or process ensures that treated waste will meet } \\
\text { the minimum waste form requirements of DOE M } \\
435.1 \text { and meet additional disposal facility-specific } \\
\text { waste acceptance requirements for additional stability } \\
\text { or long-term performance of facilities that will receive } \\
\text { the treated waste. }\end{array}$ & $\begin{array}{l}\text { Treatment is performed in MFC-793. } \\
\text { MCP-17000 } \\
\text { TSD-OI-004 } \S 3.6 \\
\text { PER-116, Module III and IV } \\
\text { PER-116, Attachment } 1 \S \S \text { B-3(d), D-1(a), and D-4(a); } \\
\text { Attachment } 2 \\
\text { SD-38.1.1, Appendix A and Appendix F }\end{array}$ \\
\hline $\begin{array}{l}\text { P. Disposal. Low-level waste disposal facilities shall } \\
\text { meet the following requirements. }\end{array}$ & NA; LLW is not disposed of in this facility. \\
\hline $\begin{array}{l}\text { (1) Performance Objectives. Low-level waste disposal } \\
\text { facilities shall be sited, designed, operated, maintained, } \\
\text { and closed so that a reasonable expectation exists that } \\
\text { the following performance objectives will be met for } \\
\text { waste disposed of after September 26, 1988: }\end{array}$ & See P. above. \\
\hline $\begin{array}{l}\text { (a) Dose to representative members of the public shall } \\
\text { not exceed } 25 \mathrm{mrem}(0.25 \mathrm{mSv}) \text { in a year total } \\
\text { effective dose equivalent from all exposure pathways, } \\
\text { excluding the dose from radon and its progeny in air. }\end{array}$ & See P. above. \\
\hline $\begin{array}{l}\text { (b) Dose to representative members of the public via } \\
\text { the air pathway shall not exceed } 10 \text { mrem }(0.10 \mathrm{mSv}) \\
\text { in a year total effective dose equivalent, excluding the } \\
\text { dose from radon and its progeny. }\end{array}$ & See P. above. \\
\hline $\begin{array}{l}\text { (c) Release of radon shall be less than an average flux } \\
\text { of } 20 \mathrm{pCi} / \mathrm{m}^{2} / \mathrm{s}\left(0.74 \mathrm{~Bq} / \mathrm{m}^{2} / \mathrm{s}\right) \text { at the surface of the } \\
\text { disposal facility. Alternatively, a limit of } 0.5 \mathrm{pCi} / 1 \\
(0.0185 \mathrm{~Bq} / \mathrm{l}) \text { of air may be applied at the boundary of } \\
\text { the facility. }\end{array}$ & See P. above. \\
\hline $\begin{array}{l}\text { (2) Performance Assessment. A site-specific } \\
\text { radiological performance assessment shall be prepared } \\
\text { and maintained for DOE low-level waste disposed of } \\
\text { after September } 26,1988 \text {. The performance assessment } \\
\text { shall include calculations for a } 1,000 \text { year period after } \\
\text { closure of potential doses to representative future } \\
\text { members of the public and potential releases from the } \\
\text { facility to provide a reasonable expectation that the } \\
\text { performance objectives identified in this Chapter are } \\
\text { not exceeded as a result of operation and closure of the } \\
\text { facility. }\end{array}$ & See P. above. \\
\hline
\end{tabular}


Table 18. (continued).

\begin{tabular}{|c|c|}
\hline \multicolumn{2}{|c|}{ MFC-793, Sodium Components Maintenance Shop (including MFC-793C and MFC-793G) } \\
\hline Chapter IV, LLW Requirements & Facility Compliance Information \\
\hline $\begin{array}{l}\text { (a) Analyses performed to demonstrate compliance } \\
\text { with the performance objectives in this Chapter, and to } \\
\text { establish limits on concentrations of radionuclides for } \\
\text { disposal based on the performance measures for } \\
\text { inadvertent intruders in this Chapter shall be based on } \\
\text { reasonable activities in the critical group of exposed } \\
\text { individuals. Unless otherwise specified, the assumption } \\
\text { of average living habits and exposure conditions in } \\
\text { representative critical groups of individuals projected } \\
\text { to receive the highest doses is appropriate. The } \\
\text { likelihood of inadvertent intruder scenarios may be } \\
\text { considered in interpreting the results of the analyses } \\
\text { and establishing radionuclide concentrations, if } \\
\text { adequate justification is provided. }\end{array}$ & See P. above. \\
\hline $\begin{array}{l}\text { (b) The point of compliance shall correspond to the } \\
\text { point of highest projected dose or concentration beyond } \\
\text { a } 100 \text { meter buffer zone surrounding the disposed } \\
\text { waste. A larger or smaller buffer zone may be used if } \\
\text { adequate justification is provided. }\end{array}$ & See P. above. \\
\hline $\begin{array}{l}\text { (c) Performance assessments shall address reasonably } \\
\text { foreseeable natural processes that might disrupt barriers } \\
\text { against release and transport of radioactive materials. }\end{array}$ & See P. above. \\
\hline $\begin{array}{l}\text { (d) Performance assessments shall use DOE-approved } \\
\text { dose coefficients (dose conversion factors) for internal } \\
\text { and external exposure of reference adults. }\end{array}$ & See P. above. \\
\hline $\begin{array}{l}\text { (e) The performance assessment shall include a } \\
\text { sensitivity/uncertainty analysis. }\end{array}$ & See P. above. \\
\hline $\begin{array}{l}\text { (f) Performance assessments shall include a } \\
\text { demonstration that projected releases of radionuclides } \\
\text { to the environment shall be maintained as low as } \\
\text { reasonably achievable (ALARA). }\end{array}$ & See P. above. \\
\hline $\begin{array}{l}\text { (g) For purposes of establishing limits on radionuclides } \\
\text { that may be disposed of near-surface, the performance } \\
\text { assessment shall include an assessment of impacts to } \\
\text { water resources. }\end{array}$ & See P. above. \\
\hline $\begin{array}{l}\text { (h) For purposes of establishing limits on the } \\
\text { concentration of radionuclides that may be disposed of } \\
\text { near-surface, the performance assessment shall include } \\
\text { an assessment of impacts calculated for a hypothetical } \\
\text { person assumed to inadvertently intrude for a } \\
\text { temporary period into the low-level waste disposal } \\
\text { facility. For intruder analyses, institutional controls } \\
\text { shall be assumed to be effective in deterring intrusion } \\
\text { for at least } 100 \text { years following closure. The intruder } \\
\text { analyses shall use performance measures for chronic } \\
\text { and acute exposure scenarios, respectively, of } 100 \\
\text { mrem }(1 \mathrm{mSv}) \text { in a year and } 500 \text { mrem }(5 \mathrm{mSv}) \text { total }\end{array}$ & See P. above. \\
\hline
\end{tabular}


Table 18. (continued).

\begin{tabular}{|c|c|}
\hline \multicolumn{2}{|c|}{ MFC-793, Sodium Components Maintenance Shop (including MFC-793C and MFC-793G) } \\
\hline Chapter IV, LLW Requirements & Facility Compliance Information \\
\hline effective dose equivalent excluding radon in air. & \\
\hline $\begin{array}{l}\text { (3) Composite Analysis. For disposal facilities which } \\
\text { received waste after September 26, } 1988 \text {, a site-specific } \\
\text { radiological composite analysis shall be prepared and } \\
\text { maintained that accounts for all sources of radioactive } \\
\text { material that may be left at the DOE site and may } \\
\text { interact with the low- level waste disposal facility, } \\
\text { contributing to the dose projected to a hypothetical } \\
\text { member of the public from the existing or future } \\
\text { disposal facilities. Performance measures shall be } \\
\text { consistent with DOE requirements for protection of the } \\
\text { public and environment and evaluated for a } 1,000 \text { year } \\
\text { period following disposal facility closure. The } \\
\text { composite analysis results shall be used for planning, } \\
\text { radiation protection activities, and future use } \\
\text { commitments to minimize the likelihood that current } \\
\text { low- level waste disposal activities will result in the } \\
\text { need for future corrective or remedial actions to } \\
\text { adequately protect the public and the environment. }\end{array}$ & See P. above. \\
\hline $\begin{array}{l}\text { (4) Performance Assessment and Composite Analysis } \\
\text { Maintenance. The performance assessment and } \\
\text { composite analysis shall be maintained to evaluate } \\
\text { changes that could affect the performance, design, and } \\
\text { operating bases for the facility. Performance } \\
\text { assessment and composite analysis maintenance shall } \\
\text { include the conduct of research, field studies, and } \\
\text { monitoring needed to address uncertainties or gaps in } \\
\text { existing data. The performance assessment shall be } \\
\text { updated to support the final facility closure. Additional } \\
\text { iterations of the performance assessment and composite } \\
\text { analysis shall be conducted as necessary during the } \\
\text { post-closure period. }\end{array}$ & See P. above. \\
\hline $\begin{array}{l}\text { (a) Performance assessments and composite analyses } \\
\text { shall be reviewed and revised when changes in waste } \\
\text { forms or containers, radionuclide inventories, facility } \\
\text { design and operations, closure concepts, or the } \\
\text { improved understanding of the performance of the } \\
\text { waste disposal facility in combination with the features } \\
\text { of the site on which it is located alter the conclusions or } \\
\text { the conceptual model(s) of the existing performance } \\
\text { assessment or composite analysis. }\end{array}$ & See P. above. \\
\hline $\begin{array}{l}\text { (b) A determination of the continued adequacy of the } \\
\text { performance assessment and composite analysis shall } \\
\text { be made on an annual basis, and shall consider the } \\
\text { results of data collection and analysis from research, } \\
\text { field studies, and monitoring. }\end{array}$ & See P. above. \\
\hline $\begin{array}{l}\text { (c) Annual summaries of low-level waste disposal } \\
\text { operations shall be prepared with respect to the } \\
\text { conclusions and recommendations of the performance }\end{array}$ & See P. above. \\
\hline
\end{tabular}


Table 18. (continued).

\begin{tabular}{|c|c|}
\hline \multicolumn{2}{|c|}{ MFC-793, Sodium Components Maintenance Shop (including MFC-793C and MFC-793G) } \\
\hline Chapter IV, LLW Requirements & Facility Compliance Information \\
\hline $\begin{array}{l}\text { assessment and composite analysis and a determination } \\
\text { of the need to revise the performance assessment or } \\
\text { composite analysis. }\end{array}$ & \\
\hline $\begin{array}{l}\text { (5) Disposal Authorization. A disposal authorization } \\
\text { statement shall be obtained prior to construction of a } \\
\text { new low-level waste disposal facility. Field Elements } \\
\text { with existing low-level waste disposal facilities shall } \\
\text { obtain a disposal authorization statement in accordance } \\
\text { with the schedule in the Complex-Wide Low-Level } \\
\text { Waste Management Program Plan. The disposal } \\
\text { authorization statement shall be issued based on a } \\
\text { review of the facility's performance assessment, } \\
\text { composite analysis, performance assessment and } \\
\text { composite analysis maintenance, preliminary closure } \\
\text { plan, and preliminary monitoring plan. The disposal } \\
\text { authorization statement shall specify the limits and } \\
\text { conditions on construction, design, operations, and } \\
\text { closure of the low-level waste facility based on these } \\
\text { reviews. A disposal authorization statement is a part of } \\
\text { the radioactive waste management basis for a disposal } \\
\text { facility. Failure to obtain a disposal authorization } \\
\text { statement by the implementation date of this Order } \\
\text { shall result in shutdown of the disposal facility. }\end{array}$ & See P. above. \\
\hline $\begin{array}{l}\text { (6) Disposal Facility Operations. The disposal facility } \\
\text { design and operation must be consistent with the } \\
\text { disposal facility closure plan and lead to disposal } \\
\text { facility closure that provides a reasonable expectation } \\
\text { that performance objectives will be met. Low-level } \\
\text { waste shall be disposed in such a manner that achieves } \\
\text { the performance objectives stated in this Chapter, } \\
\text { consistent with the disposal facility radiological } \\
\text { performance assessment. Additional requirements } \\
\text { include: }\end{array}$ & See P. above. \\
\hline $\begin{array}{l}\text { (a) Operating procedures shall be developed and } \\
\text { implemented for low-level waste disposal facilities that } \\
\text { protect the public, workers, and the environment; } \\
\text { ensure the security of the facility; minimize subsidence } \\
\text { during and after waste emplacement; achieve long-term } \\
\text { stability and minimize the need for long-term active } \\
\text { maintenance; and meet the requirements of the } \\
\text { closure/post-closure plan. }\end{array}$ & See P. above. \\
\hline $\begin{array}{l}\text { (b) Permanent identification markers for disposal } \\
\text { excavations and monitoring wells shall be emplaced. }\end{array}$ & See P. above. \\
\hline $\begin{array}{l}\text { (c) Low-level waste placement into disposal units shall } \\
\text { minimize voids between waste containers. Voids } \\
\text { within disposal units shall be filled to the extent } \\
\text { practical. Uncontainerized bulk waste shall also be } \\
\text { placed in a manner that minimizes voids and } \\
\text { subsidence. }\end{array}$ & See P. above. \\
\hline
\end{tabular}


Table 18. (continued).

\begin{tabular}{|c|c|}
\hline \multicolumn{2}{|c|}{ MFC-793, Sodium Components Maintenance Shop (including MFC-793C and MFC-793G) } \\
\hline Chapter IV, LLW Requirements & Facility Compliance Information \\
\hline $\begin{array}{l}\text { (d) Operations are to be conducted so that active waste } \\
\text { disposal operations will not have an adverse effect on } \\
\text { any other disposal units. }\end{array}$ & See P. above. \\
\hline $\begin{array}{l}\text { (e) Operations shall include a process for tracking and } \\
\text { documenting low-level waste placement in the facility } \\
\text { by generator source. }\end{array}$ & See P. above. \\
\hline $\begin{array}{l}\text { (7) Alternate Requirements for Low-Level Waste } \\
\text { Disposal Facility Design and Operation. Requirements } \\
\text { other than those set forth in this Section for the design } \\
\text { and operation of a low-level waste disposal facility } \\
\text { may be approved on a specific basis if a reasonable } \\
\text { expectation is demonstrated that the disposal } \\
\text { performance objectives will be met. }\end{array}$ & See P. above. \\
\hline $\begin{array}{l}\text { Q. Closure. The following requirements are in addition } \\
\text { to those in Chapter I of this Manual. }\end{array}$ & NA; LLW is not disposed of in this facility. \\
\hline $\begin{array}{l}\text { (1) Disposal Facility Closure Plans. A preliminary } \\
\text { closure plan shall be developed and submitted to } \\
\text { Headquarters for review with the performance } \\
\text { assessment and composite analysis. The closure plan } \\
\text { shall be updated following issuance of the disposal } \\
\text { authorization statement to incorporate conditions } \\
\text { specified in the disposal authorization statement. } \\
\text { Closure plans shall: }\end{array}$ & See Q. above. \\
\hline $\begin{array}{l}\text { (a) Be updated as required during the operational life of } \\
\text { the facility. }\end{array}$ & See Q. above. \\
\hline $\begin{array}{l}\text { (b) Include a description of how the disposal facility } \\
\text { will be closed to achieve long-term stability and } \\
\text { minimize the need for active maintenance following } \\
\text { closure and to ensure compliance with the requirements } \\
\text { of DOE 5400.5, Radiation Protection of the Public and } \\
\text { the Environment. }\end{array}$ & See Q. above. \\
\hline $\begin{array}{l}\text { (c) Include the total expected inventory of wastes to be } \\
\text { disposed of at the facility over the operational life of } \\
\text { the facility. }\end{array}$ & See Q. above. \\
\hline $\begin{array}{l}\text { (2) Disposal Facility Closure. Closure of a disposal } \\
\text { facility shall occur within a five-year period after it is } \\
\text { filled to capacity, or after the facility is otherwise } \\
\text { determined to be no longer needed. }\end{array}$ & See Q. above. \\
\hline $\begin{array}{l}\text { (a) Prior to facility closure, the final inventory of the } \\
\text { low-level waste disposed in the facility shall be } \\
\text { prepared and incorporated in the performance } \\
\text { assessment and composite analysis which shall be } \\
\text { updated to support the closure of the facility. }\end{array}$ & See Q. above. \\
\hline $\begin{array}{l}\text { (b) A final closure plan shall be prepared based on the } \\
\text { final inventory of waste disposed in the facility, the }\end{array}$ & See Q. above. \\
\hline
\end{tabular}


Table 18. (continued).

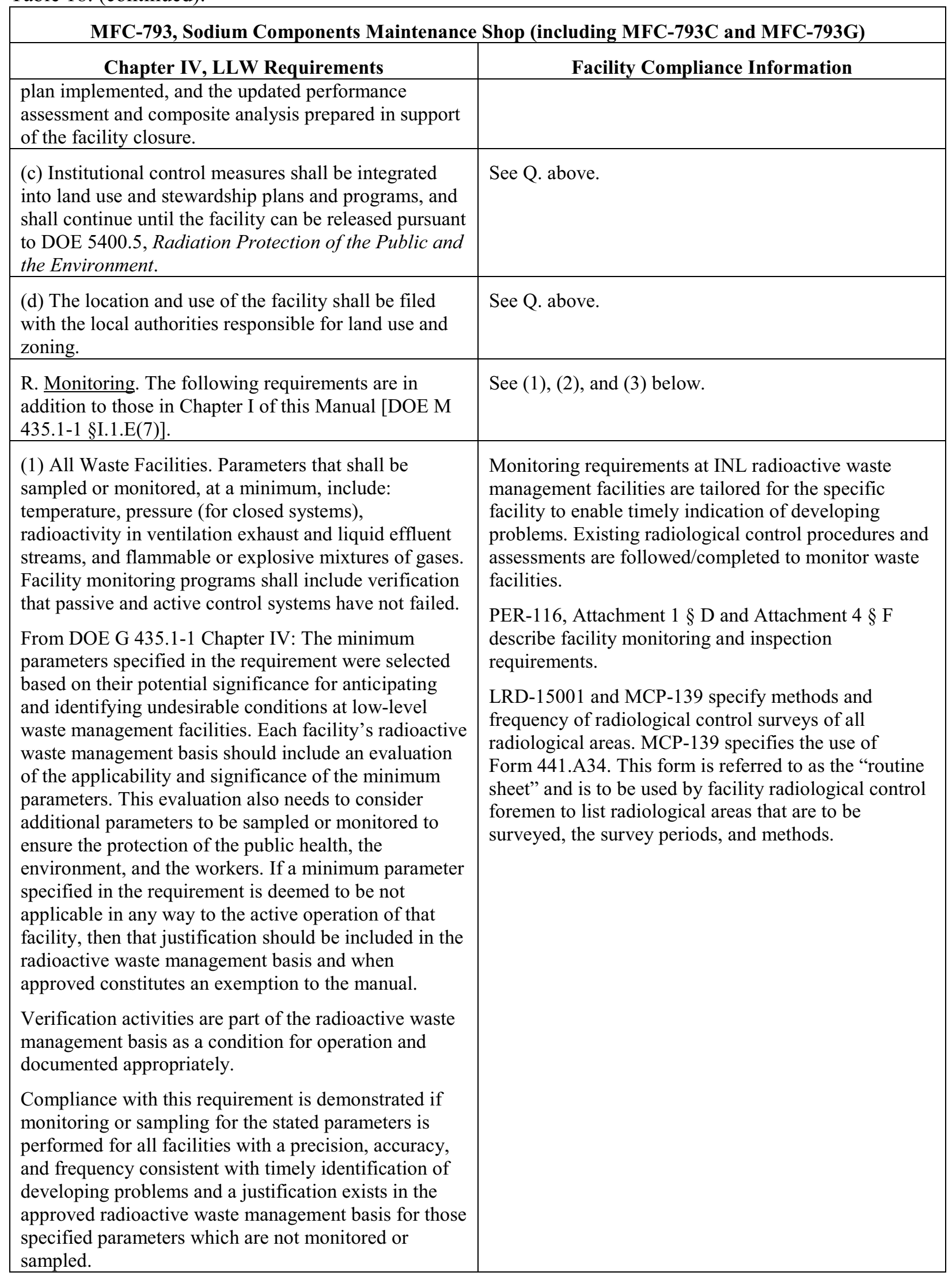


Table 18. (continued).

\begin{tabular}{|l|l|}
\hline \multicolumn{2}{|c|}{ MFC-793, Sodium Components Maintenance Shop (including MFC-793C and MFC-793G) } \\
\hline \multicolumn{1}{|c|}{ Chapter IV, LLW Requirements } & \multicolumn{1}{|c|}{ Facility Compliance Information } \\
\hline $\begin{array}{l}\text { (2) Liquid Waste Storage Facilities. For facilities } \\
\text { storing liquid low-level waste, the following shall also } \\
\text { be monitored: liquid level and/or waste volume, and } \\
\text { significant waste chemistry parameters. }\end{array}$ & See (1) above. \\
\hline $\begin{array}{l}\text { (3) Disposal Facilities. A preliminary monitoring plan } \\
\text { for a low-level waste disposal facility shall be prepared } \\
\text { and submitted to Headquarters for review with the } \\
\text { performance assessment and composite analysis. The } \\
\text { monitoring plan shall be updated within one year } \\
\text { following issuance of the disposal authorization } \\
\text { statement to incorporate and implement conditions } \\
\text { specified in the disposal authorization statement. }\end{array}$ & \\
\hline $\begin{array}{l}\text { (a) The site-specific performance assessment and } \\
\text { composite analysis shall be used to determine the } \\
\text { media, locations, radionuclides, and other substances to } \\
\text { be monitored. }\end{array}$ & See (3) above. \\
\hline $\begin{array}{l}\text { (b) The environmental monitoring program shall be } \\
\text { designed to include measuring and evaluating releases, } \\
\text { migration of radionuclides, disposal unit subsidence, } \\
\text { and changes in disposal facility and disposal site } \\
\text { parameters which may affect long-term performance. }\end{array}$ & See (3) above. \\
\hline $\begin{array}{l}\text { (c) The environmental monitoring programs shall be } \\
\text { capable of detecting changing trends in performance to } \\
\text { allow application of any necessary corrective action } \\
\text { prior to exceeding the performance objectives in this } \\
\text { Chapter. }\end{array}$ & See (3) above. \\
\hline
\end{tabular}

\subsection{MFC-794, Contaminated Equipment Storage Building}

1. Facility Description: MFC-794, Contaminated Equipment Storage Building, located in the northeast corner of the MFC site, is classified as a nonreactor, Less Than Hazard-Category-3 radiological facility. MFC-794 is also a HWMA/RCRA permitted facility that operates in accordance with PER-116. It was originally constructed to provide controlled-access, indoor storage for radiologicallycontaminated equipment. Use of MFC-794 has been expanded to provide a controlled environment for repairing contaminated equipment and characterizing/repackaging/treating waste.

All waste generators must comply with applicable WAC described in activity-specific instructions for waste that will be stored/characterized/repackaged at MFC-794. MFC-794 has received and receives a variety of material from other MFC and DOE facilities.

The Contaminated Equipment Storage Building is a pre-engineered metal building consisting of two large rooms with painted metal wall panels, metal roof panels, and structural-steel support frames. The west side (room) of the building is the original structure. It was designed and constructed in 1975 and can be accessed through a personnel door or a large roll-up door on the west end of the building. An extension to the original building (east room) was completed in 1983. This east side of the building is taller than the west side and can be accessed by a personnel door or a roll-up door on the east side of the building. The most recent modification to MFC-794 included installation of air 
Table 19. (continued).

conditioning units in the east room. The east side of MFC-794 is equipped with a 2-ton bridge crane. The MCCE is equipped with a portable 3-ton, A-frame hoist.

The wall dividing the east and west rooms contains a personnel access door and a large roll-up door.

2. Hazard category: Less Than Hazard Category 3 radiological facility

3. Radioactive waste managed at this facility: Solid and liquid CH LLW and mixed LLW are treated and stored at this facility.

4. RWMB documents/programs:

a. Safety basis/hazard analysis:

- HAD-467, "Contaminated Equipement Storage Building Hazard Categorization”

- ECAR-1545, "Hazard Categorization for the Contaminated Equipment Storage Building (CESB) MFC-794"

b. Laboratory-wide:

- Form 441.A34, "INL Radiological Control Required Surveys"

- FRM-323, "TSD Facilities Material Acceptance Checksheet"

- LI-435, "Waste Management Routine Field Activities"

- LRD-15001, "Radiological Control Manual"

- LWP-13840, "Management of Issues, Observations, and Noteworthy Practices"

- LWP-14002, "Timeout and Stop Work Authority"

- LWP-15011, "Radioactive Material Areas and Radioactive Storage Areas"

- LWP-17000, "Waste Management"

- MCP-139, "Radiological Surveys"

- MCP-17000, "Waste Generator Services Waste Management"

- MCP-17500, "Waste Generator Services Certification of Waste Shipments to the Nevada Test Site"

- PDD-17000, "Waste Management Program"

- PLN-114, "INL Emergency Plan/RCRA Contingency Plan"

- PLN-522, "Quality Assurance Program Plan for the Waste Management/Waste Certification Program"

c. Facility-specific:

- PER-116, "HWMA/RCRA Storage and Treatment Permit for the Materials and Fuels Complex"

- SD-38.1.1, "Treatment, Storage, and Disposal Facilities (TSDF) Environmental Compliance"

- SD-37.1.5, "Waste and Material Acceptance for CESB Storage and Radioactive-Material Inventory Control."

| LLW is managed at this facility. Table 19 shows the facility compliance information for Chapter IV, "Low-level Waste Requirements."

Table 19. MFC-794, Contaminated Equipment Storage Building, DOE Manual 435.1-1 low-level waste requirements and facility compliance information. 
Table 19. (continued).

\section{MFC-794 Contaminated Equipment Storage Building}

\section{Chapter IV. Low-Level Waste Requirements}

A. Definition of Low-Level Waste. Low-level radioactive waste is radioactive waste that is not highlevel radioactive waste, spent nuclear fuel, transuranic waste, byproduct material (as defined in section 11e.(2) of the Atomic Energy Act of 1954, as amended), or naturally occurring radioactive material.

(From DOE G 435.1-1 Chapter IV: Low-level radioactive waste is defined by what it is not. The guidance on definitions in Chapters II and III should be consulted first for making a determination on how to properly manage a suspect waste stream.)

B. Management of Specific Wastes. The following provide for management of specific wastes as low-level waste in accordance with the requirements in this Chapter:

(1) Mixed Low-Level Waste. Low-level waste determined to contain both source, special nuclear, or byproduct material subject to the Atomic Energy Act of 1954, as amended, and a hazardous component subject to the Resource Conservation and Recovery Act (RCRA), as amended, shall be managed in accordance with the requirements of RCRA and DOE O 435.1, Radioactive Waste Management, and this Manual.

(2) TSCA-Regulated Waste. Low-level waste containing polychlorinated biphenyls, asbestos, or other such regulated toxic components shall be managed in accordance with requirements derived from the Toxic Substances Control Act, as amended, DOE O 435.1, Radioactive Waste Management, and this Manual.

(3) Accelerator-Produced Waste. Radioactive waste produced as a result of operations of DOE accelerators is low-level waste and shall be managed in accordance with DOE O 435.1, Radioactive Waste Management, and this Manual, and all applicable Federal or State requirements.

(4) 11e.(2) and Naturally Occurring Radioactive Material. Small quantities of 11e.(2) byproduct material and naturally occurring radioactive material may be managed as low-level waste provided they can be managed to meet the requirements for low-level waste disposal in Section IV.P of this Manual.

C. Complex-Wide Low-Level Waste Management Program. A complex-wide program and plan shall be developed as described under Responsibilities, 2.B and 2.D, in Chapter I of this Manual.

D. Radioactive Waste Management Basis. Low-level

\section{Facility Compliance Information}

This requirement provides the criteria for determining which DOE radioactive waste is to be managed as LLW in accordance with DOE Manual 435.1-1, Chapter IV.

Radioactive waste managed at this facility under the requirements of this chapter is not managed under the requirements of DOE Manual 435.1-1, Chapter II or Chapter III.

See below.

This facility is has a HWMA/RCRA permit to store and treat mixed waste (PER-116).

NA; this facility does not manage TSCA-regulated waste.

NA; this facility does not manage accelerator-produced waste.

NA; this facility does not manage naturally occurring radioactive material.
Not a facility-specific requirement. DOE Manual 435.1-1 §I.2.B and §I.2.D apply to the Assistant Secretary for Environmental Management and the Deputy Assistant Secretary for Waste Management, respectively.

The RWMB provides the regulatory framework for 
Table 19. (continued).

\section{MFC-794 Contaminated Equipment Storage Building}

Chapter IV. Low-Level Waste Requirements

waste facilities, operations, and activities shall have a radioactive waste management basis consisting of physical and administrative controls to ensure the protection of workers, the public, and the environment. The following specific waste management controls shall be part of the radioactive waste management basis:

(1) Generators. The waste certification program.

From DOE G 435.1-1 Chapter IV: For a facility that generates low-level waste, the radioactive waste management basis is to include the program for certifying that waste meets the waste acceptance requirements of the facility(ies) to which the waste will be sent.

(2) Treatment Facilities. certification program. The waste acceptance requirements and the waste [sic]

From DOE G 435.1-1 Chapter IV: Facilities that store or treat low-level waste are to have approved waste acceptance requirements (see DOE M 435.1-1, Section IV.G) prior to the issuance of a radioactive waste management basis.

A facility that stores or treats waste also is generally expected to have a waste certification program. Waste from these facilities will have to be certified as meeting the waste acceptance requirements of the facility to which it will be transferred, and the facilities have the potential for generating radioactive waste (e.g., secondary processing streams from treatment, monitoring and sampling, radioactive release cleanup). Consequently, storage and treatment facilities should also have an approved waste certification program as part of their radioactive waste management basis.

As part of the radioactive waste management basis, site personnel needs to implement a system or process for tracking the waste inventory at a storage, treatment, or disposal facility.

(3) Storage Facilities. The waste acceptance requirements and the waste certification program.

From DOE G 435.1-1 Chapter IV: Facilities that store or treat low-level waste are to have approved waste acceptance requirements (see DOE M 435.1-1, Section IV.G) prior to the issuance of a radioactive waste management basis.

A facility that stores or treats waste also is generally expected to have a waste certification program. Waste
Facility Compliance Information management of radioactive waste at INL. It specifically identifies facility management and implementing documents for the generation, storage, treatment, and disposal of radiological waste.

This facility is a Less Than Hazard Category 3 radiological facility (HAD-467).

ECAR-1545 addresses hazard categorization for CESB.

See J. below.

See G. and J. below.

MCP-17000 § 4 specifies the use of IWTS, which tracks the waste inventory.

SD-37.1.5 addresses the use of IWTS to track waste inventory.
See G. and J. below.

MCP-17000 $§ 4$ specifies the use of IWTS, which tracks the waste inventory.

SD-37.1.5 addresses the use of IWTS to track waste inventory. 
Table 19. (continued).

\section{MFC-794 Contaminated Equipment Storage Building}

\begin{tabular}{|l|}
\hline \multicolumn{1}{|c|}{ Chapter IV. Low-Level Waste Requirements } \\
\hline from these facilities will have to be certified as meeting \\
the waste acceptance requirements of the facility to \\
which it will be transferred, and the facilities have the \\
potential for generating radioactive waste (e.g., \\
secondary processing streams from treatment, \\
monitoring and sampling, radioactive release cleanup). \\
Consequently, storage and treatment facilities should \\
also have an approved waste certification program as \\
part of their radioactive waste management basis. \\
As part of the radioactive waste management basis, site \\
personnel needs to implement a system or process for \\
tracking the waste inventory at a storage, treatment, or \\
disposal facility.
\end{tabular}

(4) Disposal Facilities. The performance assessment, composite analysis, disposal authorization statement, closure plan, waste acceptance requirements, and monitoring plan.

E. Contingency Actions. The following requirements are in addition to those in Chapter I of this Manual [DOE M 435.1-1 §I.1.E(5)].

NA; this facility is not a disposal facility.

Not a facility-specific requirement. DOE Manual 435.1-1 §I.1.E(5) addresses the sitewide emergency management system. The INL plan is provided in PLN-114.

The HWMA/RCRA permit also includes a contingency plan (PER-116, Attachment $7 \S \mathrm{G}$ ).

(1) Contingency Storage. For off-normal or emergency situations involving high activity or high hazard liquid $\mathrm{NA}$; this facility does not store or treat liquid waste in tanks.

low-level waste storage or treatment, spare capacity with adequate capabilities shall be maintained to receive the largest volume of liquid contained in any one storage tank or treatment facility. Tanks or other facilities that are designated low-level waste contingency storage shall be maintained in an operational condition when waste is present and shall meet the requirements of DOE O 435.1, Radioactive Waste Management, and this Manual.

From DOE G 435.1-1 Chapter IV: Compliance with these requirements is demonstrated if adequate spare capacity and transfer equipment exists for emergency transfers of all high activity and high hazard liquid lowlevel waste. In addition, the capability to perform emergency transfers is demonstrated by having waste transfer routings identified, operational procedures to direct transfers, staff trained to the procedures, and records showing that the spare capacity and transfer capability are kept in operating condition.

(2) Transfer Equipment. Pipelines and auxiliary facilities necessary for the transfer of high activity or high hazard liquid low-level waste to contingency storage shall be maintained in an operational condition

$\mathrm{NA}$; this facility does not store or treat liquid waste in tanks. 
Table 19. (continued).

\section{MFC-794 Contaminated Equipment Storage Building}

\begin{tabular}{|c|c|}
\hline Chapter IV. Low-Level Waste Requirements & Facility Compliance Information \\
\hline \multicolumn{2}{|l|}{$\begin{array}{l}\text { when waste is present and shall meet the requirements } \\
\text { of DOE O 435.1, Radioactive Waste Management, and } \\
\text { this Manual. }\end{array}$} \\
\hline \multicolumn{2}{|l|}{$\begin{array}{l}\text { From DOE G } 435.1-1 \text { Chapter IV: Compliance with } \\
\text { these requirements is demonstrated if adequate spare } \\
\text { capacity and transfer equipment exists for emergency } \\
\text { transfers of all high activity and high hazard liquid low- } \\
\text { level waste. In addition, the capability to perform } \\
\text { emergency transfers is demonstrated by having waste } \\
\text { transfer routings identified, operational procedures to } \\
\text { direct transfers, staff trained to the procedures, and } \\
\text { records showing that the spare capacity and transfer } \\
\text { capability are kept in operating condition. }\end{array}$} \\
\hline $\begin{array}{l}\text { F. Corrective Actions. I of this Manual. The following } \\
\text { requirements are in addition to those in Chapter [sic] }\end{array}$ & $\begin{array}{l}\text { The INL-wide procedure addressing problem } \\
\text { identification as required by DOE Manual 435.1-1 }\end{array}$ \\
\hline $\begin{array}{l}\text { From DOE G 435.1-1 Chapter IV: Compliance with } \\
\text { DOE M 435.1-1 §I.2.G.(1) is demonstrated by records }\end{array}$ & $\begin{array}{l}\text { §I.2.G.(1) is LWP-13840, which implements the } \\
\text { laboratory's corrective action system. }\end{array}$ \\
\hline $\begin{array}{l}\text { showing what corrective actions were taken to remedy } \\
\text { situations in the radioactive waste management system. }\end{array}$ & $\begin{array}{l}\text { The INL-wide procedure addressing shutdown or } \\
\text { curtailment of activities as required by DOE Manual }\end{array}$ \\
\hline $\begin{array}{l}\text { Compliance with DOE M 435.1-1 §I.2.G.(2) is } \\
\text { demonstrated by having the necessary procedures, } \\
\text { mechanisms, and training in place to effect shutdown } \\
\text { or curtailment of activities which pose an imminent } \\
\text { danger or other serious hazard to workers or the public, } \\
\text { or are not protective of the environment. }\end{array}$ & 435.1-1 \$1.2.G.(2) is LWP-14002. \\
\hline $\begin{array}{l}\text { (1) Order Compliance. Corrective actions shall be } \\
\text { implemented whenever necessary to ensure the } \\
\text { requirements of DOE O } 435.1 \text {, Radioactive Waste } \\
\text { Management, and this Manual are met. }\end{array}$ & $\begin{array}{l}\text { See F. above. } \\
\text { This facility has a HWMA/RCRA permit to store and } \\
\text { treat mixed LLW. }\end{array}$ \\
\hline $\begin{array}{l}\text { From DOE G } 435.1-1 \text { Chapter IV: If a facility or } \\
\text { activity can be allowed to operate while a }\end{array}$ & $\begin{array}{l}\text { Corrective actions for waste regulated under this } \\
\text { permit are addressed as permit conditions. }\end{array}$ \\
\hline noncompliant or hazardous condition exists, the & PER-116, Module VI \\
\hline $\begin{array}{l}\text { allowance and any associated limitations must be } \\
\text { defined as part of the facility or activity's radioactive }\end{array}$ & PER-116, Attachment 4 \\
\hline $\begin{array}{l}\text { waste management basis, identified as a configuration } \\
\text { controlled item in a configuration management plan or } \\
\text { included in a revision or modification to an operating } \\
\text { procedure or similar controlled documentation. }\end{array}$ & SD-38.1.1 $\S 2.4,6$, and Appendix A \\
\hline $\begin{array}{l}\text { Compliance with this requirement is demonstrated if a } \\
\text { corrective action system addresses noncompliant or } \\
\text { hazardous situations involving low-level waste } \\
\text { management facilities in a systematic fashion, and } \\
\text { allows identification of problems by all personnel. }\end{array}$ & \\
\hline $\begin{array}{l}\text { (2) Operations Curtailment. Operations shall be } \\
\text { curtailed or facilities shut down for failure to establish, } \\
\text { maintain, or operate consistent with an approved } \\
\text { radioactive waste management basis. }\end{array}$ & $\begin{array}{l}\text { The approved RWMB establishes the current } \\
\text { compliance status at each radioactive waste } \\
\text { management facility. Facility assessments are } \\
\text { scheduled to ensure waste management activities are }\end{array}$ \\
\hline
\end{tabular}


Table 19. (continued).

\section{MFC-794 Contaminated Equipment Storage Building}

\section{Chapter IV. Low-Level Waste Requirements}

From DOE G 435.1-1 Chapter IV: Compliance with this requirement is demonstrated with a documented system of routine assessments to determine whether waste management activities and facilities are operating in accordance with an approved radioactive waste management basis that provides for graded limitations that can be placed on activities and operations that do not have, or are operating outside of, an approved radioactive waste management basis, including shutdown of the facility.

G. Waste Acceptance. The following requirements are in addition to those in Chapter I of this Manual [DOE M 435.1-1 §I.2.F(6)].

(1) Technical and Administrative. Waste acceptance requirements for all low-level waste storage, treatment, or disposal facilities, operations, and activities shall specify, at a minimum, the following:

From DOE G 435.1-1 Chapter IV: Compliance with these waste acceptance requirements is demonstrated if they are documented, contain clear and precise criteria specifying the radionuclide limits in the form of contents or concentrations that can be accepted, the limitations and prohibitions on waste forms and packages that can be received, and the limits, prohibitions, or instructions concerning any other technical information so that the waste is compatible with the safety basis of the facility, and which will result in acceptable waste at subsequent steps in managing the low-level waste.

(a) Allowable activities and/or concentrations of specific radionuclides.

(b) Acceptable waste form and/or container requirements that ensure the chemical and physical stability of waste under conditions that might be encountered during transportation, storage, treatment, or disposal.

(c) Restrictions or prohibitions on waste, materials, or containers that may adversely affect waste handlers or compromise facility or waste container performance.
Facility Compliance Information

conducted in accordance with the approved RWMB.

Not a facility-specific requirement. DOE Manual

435.1-1 §I.2.F(6) applies to field element managers.

See below.

MCP-17000

SD-37.1.5

MCP-17000

SD-37.1.5

PER-116, Module II.C and III

PER-116, Attachment $1 \S \S$ B-2(a) and D-1(a); Attachment 2 \& $\mathrm{C}-2(\mathrm{a})$

SD-38.1.1, Appendix A and Appendix C.

MCP-17000

SD-37.1.5

PER-116, Module II.C and III

PER-116, Attachment $1 \S \S$ B-2(a) and D-1(a); Attachment 2 \& -2 (a)

SD-38.1.1, Appendix A and Appendix C. 
Table 19. (continued).

\section{MFC-794 Contaminated Equipment Storage Building}

Chapter IV. Low-Level Waste Requirements

(d) The following are additional waste acceptance requirements that shall be specified in low-level waste disposal facility waste acceptance requirements:

1 Low-level waste must contribute to and not detract from achieving long-term stability of the facility, minimizing the need for long-term active maintenance, minimizing subsidence, and minimizing contact of water with waste. Void spaces within the waste and, if containers are used, between the waste and its container shall be reduced to the extent practical.

2 Liquid low-level waste or low-level waste containing free liquid must be converted into a form that contains as little freestanding liquid as is reasonably achievable, but in no case shall the liquid exceed 1 percent of the waste volume when the low-level waste is in a disposal container, or 0.5 percent of the waste volume after it is processed to a stable form.

3 Low-level waste must not be readily capable of detonation or of explosive decomposition or reaction at anticipated pressures and temperatures, or of explosive reaction with water. Pyrophoric materials contained in waste shall be treated, prepared, and packaged to be nonflammable.

4 Low-level waste must not contain, or be capable of generating by radiolysis or biodegradation, quantities of toxic gases, vapors, or fumes harmful to the public or workers or disposal facility personnel, or harmful to the long-term structural stability of the disposal site.

5 Low-level waste in a gaseous form must be packaged such that the pressure does not exceed 1.5 atmospheres absolute at $20 \mathrm{C}$. [ sic $]$

(e) The basis, procedures, and levels of authority required for granting exceptions to the waste acceptance requirements, which shall be contained in each facility's waste acceptance documentation. Each exception request shall be documented, including its disposition as approved or not approved.

From DOE G 435.1-1 Chapter IV: Waste acceptance requirements are acceptable if they are documented and contain a clear description of the procedure and bases for obtaining an exception or deviation to the acceptance criteria for low-level waste to be received at the facility.

(2) Evaluation and Acceptance. The receiving facility shall evaluate waste for acceptance, including confirmation that the technical and administrative requirements have been met. A process for the

\section{Facility Compliance Information}

NA; this facility is not a LLW disposal facility.

See (d) above.

See (d) above.

See (d) above.

See (d) above.

See (d) above.

Exceptions to the waste acceptance requirements are not permitted.
MCP-17000

SD-37.1.5 
Table 19. (continued).

\section{MFC-794 Contaminated Equipment Storage Building}

\begin{tabular}{|c|c|}
\hline Chapter IV. Low-Level Waste Requirements & Facility Compliance Information \\
\hline $\begin{array}{l}\text { disposition of non-conforming wastes shall be } \\
\text { established. } \\
\text { From DOE G 435.1-1 Chapter IV: Compliance with the } \\
\text { waste acceptance requirements for a low-level waste } \\
\text { management facility is demonstrated if they include a } \\
\text { process for evaluation and acceptance of incoming } \\
\text { waste to ensure the acceptance criteria of the facility } \\
\text { receiving the waste are met that includes one of or a } \\
\text { combination of: (1) testing, sampling, and analysis of } \\
\text { representative samples of waste upon receipt; ( } 2) \\
\text { testing, sampling, and analysis of split samples of } \\
\text { waste taken at the generator site; ( } 3 \text { ) evaluation of } \\
\text { testing, sampling, and analysis of data provided by the } \\
\text { generator, or (4) audits, reviews, surveillance, or } \\
\text { observations of generator waste certification programs } \\
\text { and characterization activities. Additionally, acceptable } \\
\text { waste acceptance requirements for a storage, treatment } \\
\text { or disposal facility will have documented procedures } \\
\text { and actions to be taken if a waste that does not conform } \\
\text { to the waste acceptance criteria is received at the } \\
\text { facility. }\end{array}$ & $\begin{array}{l}\text { PER-116, Module II.C and III } \\
\text { PER-116, Attachment } 1 \S \text { D-1(b); Attachment } 2 \S \text { C- } \\
\text { 2(a) } \\
\text { SD-38.1.1, Appendix A and Appendix C. } \\
\text { Meeting permit and safety basis constraints are } \\
\text { checked using: } \\
\text { FRM-323 } \\
\text { IWTS Material and Waste Characterization Profile } \\
\text { Nonconforming waste is not permitted. }\end{array}$ \\
\hline $\begin{array}{l}\text { H. Waste Generation Planning. The following } \\
\text { requirements are in addition to those in Chapter I of } \\
\text { this Manual [DOE M 435.1-1 §I.2.F(7)]. }\end{array}$ & $\begin{array}{l}\text { Not a facility-specific requirement. DOE Manual } \\
435.1-1 \S \mathrm{I} .2 . \mathrm{F}(7) \text { applies to field element managers. }\end{array}$ \\
\hline $\begin{array}{l}\text { (1) Life-Cycle Planning. Prior to waste generation, } \\
\text { planning shall be performed to address the entire life } \\
\text { cycle for all low-level waste streams. } \\
\text { From DOE G 435.1-1 Chapter IV: Compliance with } \\
\text { this planning requirement is demonstrated by the } \\
\text { individual sites establishing a process for evaluating the } \\
\text { life-cycle of low-level waste prior to its generation, } \\
\text { including the identification of low-level wastes with no } \\
\text { path to disposal and appropriate records justifying the } \\
\text { newly generated low-level waste stream(s), and site } \\
\text { personnel possessing planning information showing the } \\
\text { location(s) where low-level waste will be stored, } \\
\text { treated, and/or disposed along with a confirmation that } \\
\text { the personnel managing the facilities agree that the } \\
\text { low-level waste may be managed at those facilities. }\end{array}$ & $\begin{array}{l}\text { PDD- } 17000 \text { and LWP- } 17000 \text { provide direction to the } \\
\text { waste generators for waste generation planning to } \\
\text { address the entire life cycle. }\end{array}$ \\
\hline $\begin{array}{l}\text { (2) Waste with No Identified Path to Disposal. Low- } \\
\text { level waste streams with no identified path to disposal } \\
\text { shall be generated only in accordance with approved } \\
\text { conditions which, at a minimum, shall address: }\end{array}$ & $\begin{array}{l}\text { NA; this facility is not generating LLW that does not } \\
\text { have an identified path to disposal. }\end{array}$ \\
\hline (a) Programmatic need to generate the waste; & See (2) above. \\
\hline $\begin{array}{l}\text { (b) Characteristics and issues preventing the disposal of } \\
\text { the waste; }\end{array}$ & See (2) above. \\
\hline (c) Safe storage of the waste until disposal can be & See (2) above. \\
\hline
\end{tabular}


Table 19. (continued).

MFC-794 Contaminated Equipment Storage Building

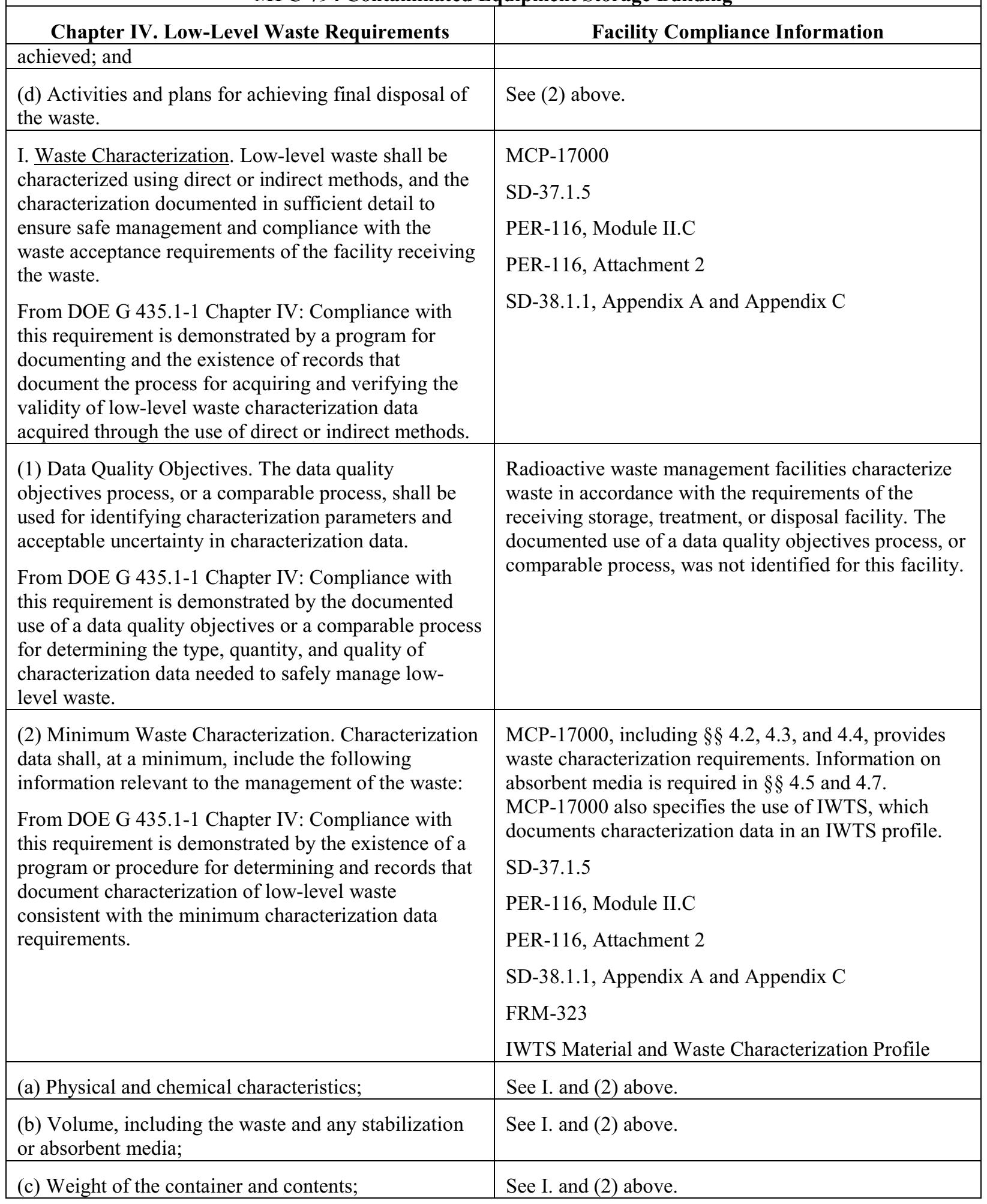


Table 19. (continued).

MFC-794 Contaminated Equipment Storage Building

Chapter IV. Low-Level Waste Requirements

(d) Identities, activities, and concentrations of major radionuclides;

(e) Characterization date;

(f) Generating source; and

(g) Any other information which may be needed to prepare and maintain the disposal facility performance assessment, or demonstrate compliance with applicable performance objectives.

J. Waste Certification. A waste certification program shall be developed, documented, and implemented to ensure that the waste acceptance requirements of facilities receiving low-level waste for storage, treatment, and disposal are met.

From DOE G 435.1-1 Chapter IV: Compliance with the development and documentation portion of the certification requirement is demonstrated by a waste certification plan that identifies the organizations involved, assigns responsibilities for implementing the program, and describes or references the quality assurance, training, procurement controls, records management, and procedures to be used by the program. Acceptable performance for implementing the program is demonstrated when appropriate personnel are trained and follow the procedures that govern their part of the waste certification. Additionally, acceptable performance is demonstrated if the waste certification plan and procedures are current and controlled in accordance with a document controls program, and records related to certification (e.g., certification statements, training records, procurement records, characterization records, container records) are generated and managed in accordance with the established site program.
MCP-17000 cites a waste certification program for LLW destined for NNSS. For waste destined for locations other than NNSS, the waste disposition specialist is responsible for certifying the waste stream by ensuring the waste, as characterized, falls within the limitations of the WAC of the treatment, storage, or disposal facility ( $\$ 2)$.

Container procurement is addressed in MCP-17000 $\S 4.6$.

MCP-17500 provides the WGS waste certification program for LLW to be shipped to NNSS.

Waste certification is performed and tracked using IWTS. Documentation of the IWTS Program is available electronically only.

PLN-522 requires waste technical specialists and waste disposition specialists to complete the appropriate training/qualification before being granted approval authority for profiles within the IWTS Program. The waste certification official, alternate waste certification official, and NNSS packaging certifiers must complete the appropriate training/qualifications to disposition waste to NNSS.

SD-37.1.5

PER-116, Module II.C and III

PER-116, Attachment $1 \S \S \mathrm{B}-2(\mathrm{a})$ and D-1(a); Attachment 2 \& -2 (a)

SD-38.1.1, Appendix A and Appendix C.

See J. above. MCP-17500 $\S 2$ and 5 address certification records for shipments to NNSS.
(1) Certification Program. The waste certification program shall designate the officials who have the authority to certify and release waste for shipment; and specify what documentation is required for waste generation, characterization, shipment, and certification. The program shall provide requirements for auditability, retrievability, and storage of required documentation and specify the records retention period. 
Table 19. (continued).

\section{MFC-794 Contaminated Equipment Storage Building}

\begin{tabular}{|l|}
\hline \multicolumn{1}{|c|}{ Chapter IV. Low-Level Waste Requirements } \\
\hline From DOE G 435.1-1 Chapter IV: Compliance with \\
this requirement is demonstrated by a program or \\
procedure for record keeping and records showing that \\
low-level waste is certified as having met the waste \\
acceptance criteria of the facility to which it was \\
transferred and that the certification statement is \\
supported by additional records regarding the waste \\
source, characterization, and container.
\end{tabular}

(2) Certification before Transfer. Low-level waste shall be certified as meeting waste acceptance requirements before it is transferred to the facility receiving the waste.

From DOE G 435.1-1 Chapter IV: Compliance with this requirement is demonstrated by the presence of a certification program which includes procedures requiring a signed certification statement prior to the release of waste for transfer, and by dated records showing that waste was certified before being transferred.

(3) Maintaining Certification. Low-level waste that has been certified as meeting the waste acceptance requirements for transfer to a storage, treatment, or disposal facility shall be managed in a manner that maintains its certification status.

From DOE G 435.1-1 Chapter IV: Compliance with this requirement is demonstrated by a program or procedure reflecting this requirement is present and site personnel are able to show that the storage of low-level waste containers is in a facility or manner where the containers would not be damaged by normal weather events, and cannot be accessed by unauthorized personnel. Further, each container can be traced to its certification and the information supporting that certification.

K. Waste Transfer. A documented process shall be established and implemented for transferring responsibility for management of low-level waste and for ensuring availability of relevant data. The following requirements are in addition to those in Chapter I of this Manual.

See J. above. MCP-17500 § 4.3.6 addresses controls for certification before transfer for LLW to be disposed of at NNSS. Facility Compliance Information

See J. above. Pre-certification checklists are cited in MCP-17000 and MCP-17500. Surveillances also are addressed in MCP-17500.

LWP-15011 § 5 provides general radioactive storage area requirements.

From DOE G 435.1-1 Chapter IV: Compliance with this requirement is demonstrated if facilities have procedures for the receipt of waste and the transfer of waste, as appropriate, which address the acquisition of waste and container data and the transfer of ownership, respectively. Further evidence of acceptable performance is facility records showing that data on the waste containers is available and accurate, and that

MCP-17000 $§ 4.8 .15$ specifies requirements for interfacility transfers.

MCP-17500 $\S 4$ addresses LLW to be transferred to NNSS.

SD-37.1.5 
Table 19. (continued).

\section{MFC-794 Contaminated Equipment Storage Building}

\begin{tabular}{|c|c|}
\hline Chapter IV. Low-Level Waste Requirements & Facility Compliance Information \\
\hline documented transfer of responsibility occurs. & \\
\hline $\begin{array}{l}\text { (1) Authorization. Low-level waste shall not be } \\
\text { transferred to a storage, treatment, or disposal facility } \\
\text { until personnel responsible for the facility receiving the } \\
\text { waste authorize the transfer. }\end{array}$ & See K. above. \\
\hline $\begin{array}{l}\text { From DOE G } 435.1-1 \text { Chapter IV: Compliance with } \\
\text { this requirement is demonstrated by sites having } \\
\text { procedures that require a confirmation of authorization } \\
\text { before releasing waste for transfer, and records } \\
\text { showing that transfers are made in accordance with } \\
\text { written authorizations. }\end{array}$ & \\
\hline $\begin{array}{l}\text { (2) Data. Waste characterization data, container } \\
\text { information, and generation, storage, treatment, and } \\
\text { transportation information for low-level waste shall be } \\
\text { transferred with or be traceable to the waste. }\end{array}$ & See K. above. \\
\hline $\begin{array}{l}\text { From DOE G } 435.1-1 \text { Chapter IV: Compliance with } \\
\text { this requirement is demonstrated if there are procedures } \\
\text { requiring that characterization and container data be } \\
\text { provided and maintained for each low-level waste } \\
\text { transfer and documented records of transfers show that } \\
\text { the information is being provided. }\end{array}$ & \\
\hline $\begin{array}{l}\text { L. Packaging and Transportation. The following } \\
\text { requirements are in addition to those in Chapter I of } \\
\text { this Manual [DOE M 435.1-1 §I.1.E(11)]. }\end{array}$ & See (1) and (2) below. \\
\hline (1) Packaging. If containers are used: & MCP- $17000 \S 4$ addresses packaging requirements. \\
\hline $\begin{array}{l}\text { From DOE G 435.1-1 Chapter IV: Compliance with the } \\
\text { packaging requirement is demonstrated by: (1) } \\
\text { procedures which document proper packaging } \\
\text { protocols; and (2) no trends of routine repackaging of } \\
\text { low-level waste that is packaged after issuance of DOE } \\
\text { O } 435.1 \text {. Successful performance of this requirement is } \\
\text { also demonstrated by a record of containers for which } \\
\text { failure has not routinely occurred under management } \\
\text { conditions. It is recognized that there may be failed } \\
\text { containers for waste previously placed in storage. For } \\
\text { those containers, the goal is to only have to repackage } \\
\text { the waste one time after it is retrieved and } \\
\text { characterized. Further, acceptable performance is } \\
\text { demonstrated by containers of waste having marking } \\
\text { and labeling that allows correlation with waste } \\
\text { characterization data and container information. }\end{array}$ & SD-37.1.5 \\
\hline $\begin{array}{l}\text { (a) Low-level waste shall be packaged in a manner that } \\
\text { provides containment and protection for the duration of } \\
\text { the anticipated storage period and until disposal is } \\
\text { achieved or until the waste has been removed from the } \\
\text { container. }\end{array}$ & See (1) above. \\
\hline (b) When waste is packaged, vents or other measures & See (1) above. \\
\hline
\end{tabular}


Table 19. (continued).

\section{MFC-794 Contaminated Equipment Storage Building}

Chapter IV. Low-Level Waste Requirements shall be provided if the potential exists for pressurizing or generating flammable or explosive concentrations of gases within the waste container.

(c) Containers of low-level waste shall be marked such that their contents can be identified.

(2) Transportation. To the extent practical, the volume of waste and number of low-level waste shipments shall be minimized.

From DOE G 435.1-1 Chapter IV: Compliance with this requirement can be demonstrated by a combination of site procedures directing the efficient use of waste container capacity and documentation showing that low-level waste shipments are systematically planned and optimized to the extent practical.

M. Site Evaluation and Facility Design. The following requirements are in addition to those in Chapter I of this Manual.

(1) Site Evaluation. Proposed locations for low-level waste facilities shall be evaluated to identify relevant features that should be avoided or must be considered in facility design and analyses.

(a) Each site proposed for a new low-level waste facility or expansion of an existing low-level waste facility shall be evaluated considering environmental characteristics, geotechnical characteristics, and human activities, including for a low-level waste disposal facility, the capability of the site to demonstrate, at a minimum, whether it is:

1 Located to accommodate the projected volume of waste to be received;

2 Located in a flood plain, a tectonically active area, or in the zone of water table fluctuation; and

3 Located where radionuclide migration pathways are predictable and erosion and surface runoff can be controlled.

(b) Proposed sites with environmental characteristics, geotechnical characteristics, and human activities for which adequate protection cannot be provided through facility design shall be deemed unsuitable for the location of the facility.

(c) Low-level waste disposal facilities shall be sited to achieve long-term stability and to minimize, to the extent practical, the need for active maintenance following final closure.

(2) Low-Level Waste Treatment and Storage Facility
Facility Compliance Information

See (1) above.

MCP-17000 § 4 addresses transportation. The waste disposition specialist coordinates with packaging and transportation personnel for waste shipped offsite from this facility.

MCP-17500 specifies waste certification official and waste disposition specialist responsibilities and coordination with packaging and transportation personnel for waste shipped directly to NNSS from this facility.

$\mathrm{NA}$; this requirement addresses new radioactive waste management facilities or modifications to existing facilities.

See M. above.

See M. above.

See M. above.

See M. above.

See M. above.

See M. above.

See M. above.

See M. above. 
Table 19. (continued).

\section{MFC-794 Contaminated Equipment Storage Building}

Chapter IV. Low-Level Waste Requirements Design. The following facility requirements and general design criteria, at a minimum, apply:

(a) Confinement. Low-level waste systems and components shall be designed to maintain waste confinement.

(b) Ventilation.

1 Design of low-level waste treatment and storage facilities shall include ventilation, if applicable, through an appropriate filtration system to maintain the release of radioactive material in airborne effluents within the requirements and guidelines specified in applicable requirements.

2 When conditions exist for generating gases in flammable or explosive concentrations, ventilation systems or other measures shall be provided to keep the gases in a non-flammable and nonexplosive condition. Where concentrations of explosive or flammable gases are expected to approach the lower flammability limit, measures shall be taken to prevent deflagration or detonation.

(c) Consideration of Decontamination and Decommissioning. Areas in new and modifications to existing low-level waste management facilities that are subject to contamination with radioactive or other hazardous materials shall be designed to facilitate decontamination. For such facilities a proposed decommissioning method or a conversion method leading to reuse shall be described.

(d) Instrumentation and Control Systems. Engineering controls shall be incorporated in the design and engineering of low-level waste treatment and storage facilities to provide volume inventory data and to prevent spills, leaks, and overflows from tanks or confinement systems.

(e) Monitoring. Monitoring and/or leak detection capabilities shall be incorporated in the design and engineering of low-level waste treatment and storage facilities to provide rapid identification of failed confinement and/or other abnormal conditions.

(3) Low-Level Waste Disposal Facility Design. The following facility requirements and general design criteria, at a minimum, apply:

(a) Confinement. Low-level waste systems and components shall be designed to maintain waste confinement.

(b) Ventilation.
Facility Compliance Information

See M. above.

See M. above.

See M. above.

See M. above.

See M. above.

See M. above.

See M. above.

See M. above.

See M. above.

See M. above. 
Table 19. (continued).

\section{MFC-794 Contaminated Equipment Storage Building}

\begin{tabular}{|c|}
\hline Chapter IV. Low-Level Waste Requirements \\
\hline $\begin{array}{l}1 \text { Design of low-level waste disposal facilities shall } \\
\text { include ventilation, if applicable, through an } \\
\text { appropriate filtration system to maintain the release of } \\
\text { radioactive material in airborne effluents within the } \\
\text { requirements and guidelines specified in applicable } \\
\text { requirements. }\end{array}$ \\
\hline $\begin{array}{l}2 \text { When conditions exist for generating gases in } \\
\text { flammable or explosive concentrations, ventilation } \\
\text { systems or other measures shall be provided to keep the } \\
\text { gases in a nonflammable and non-explosive condition. } \\
\text { Where concentrations of explosive or flammable gases } \\
\text { are expected to approach the lower flammability limit, } \\
\text { measures shall be taken to prevent deflagration or } \\
\text { detonation. }\end{array}$ \\
\hline
\end{tabular}

(c) Stability. Low-level waste disposal facilities shall be designed to achieve long-term stability and to minimize to the extent practical, the need for active maintenance following final closure.

(d) Control of Water. Low-level waste disposal facilities shall be designed to minimize to the extent practical, the contact of waste with water during and after disposal.

N. Storage and Staging. The following requirements are in addition to those in Chapter I of this Manual [DOE M 435.1-1 §I.2.F(13)].

(1) Storage Prohibitions. Low-level waste in storage shall not be readily capable of detonation, explosive decomposition, reaction at anticipated pressures and temperatures, or explosive reaction with water. Prior to storage, pyrophoric materials shall be treated, prepared, and packaged to be nonflammable.

From DOE G 435.1-1 Chapter IV: Compliance with this requirement is demonstrated by having waste acceptance requirements which prohibit low-level waste that is ignitable or explosive from being accepted for storage unless it has been treated, and procedures for properly preparing such materials for safe storage.

(2) Storage Limit. Low-level waste that has an identified path to disposal shall not be stored longer than one year prior to disposal, except for storage for
Facility Compliance Information

See M. above.

See M. above.

See M. above.

See M. above.

Not a facility-specific requirement. DOE Manual 435.1-1 §I.2.F(13) applies to field element managers.

MCP-17000

SD-37.1.5

PER-116, Module II.C and III

PER-116, Attachment $1 \S$ D-1(a); Attachment $2 \S$ C2(a)

SD-38.1.1, Appendix A and Appendix C

The HWMA/RCRA permit (PER-116, Module III.B.1) allows ignitable (D001) and reactive (D003) hazardous waste to be stored and treated, and the permit specifies the conditions under which the waste can be stored and treated safely.

This waste was considered in the safety analysis (DSA-004-CESB; to be superseded by the implementation of HAD-467 in October 2011)

ECAR-1545 addresses hazard categorization for CESB.

MCP-17000 $§ 4.8 .16$ addresses storage time limits and waste that are to be stored longer than 1 year. 
Table 19. (continued).

\section{MFC-794 Contaminated Equipment Storage Building}

\begin{tabular}{|c|c|}
\hline Chapter IV. Low-Level Waste Requirements & Facility Compliance Information \\
\hline $\begin{array}{l}\text { decay, or as otherwise authorized by the Field Element } \\
\text { Manager. }\end{array}$ & MCP-17000, Appendix F addresses storage time limits. \\
\hline $\begin{array}{l}\text { From DOE G } 435.1-1 \text { Chapter IV: Storage longer than } \\
\text { one year can be justified if the conditions for such } \\
\text { storage are approved by the Field Element Manager as } \\
\text { part of the radioactive waste management basis for the } \\
\text { facility. }\end{array}$ & $\begin{array}{l}\text { Storage longer than } 1 \text { year for mixed waste is } \\
\text { allowable under the Site Treatment Plan. }\end{array}$ \\
\hline $\begin{array}{l}\text { Storage for radioactive decay for a period greater than } \\
1 \text { year for waste that has an identified path to disposal } \\
\text { is allowed. Adequate justification and the supporting } \\
\text { information for storage for decay is to be documented } \\
\text { in the radioactive waste management basis for the } \\
\text { facility in which the storage will take place. }\end{array}$ & \\
\hline $\begin{array}{l}\text { Mixed waste. Under the Federal Facility Compliance } \\
\text { Act of 1992, DOE sites were required to develop Site } \\
\text { Treatment Plans to bring stored mixed low-level waste } \\
\text { into compliance with these requirements. The Site } \\
\text { Treatment Plan needs to be consulted and any mixed } \\
\text { low-level waste stored for the purpose of accumulation } \\
\text { to facilitate treatment must meet Resource } \\
\text { Conservation and Recovery Act storage requirements. } \\
\text { There could be several ways within different scenarios } \\
\text { that this requirement can be met, as illustrated by the } \\
\text { examples below, however, there are basically four } \\
\text { ways to show compliance with the requirement and } \\
\text { include appropriate provisions in the radioactive waste } \\
\text { management basis for the facility in which it is stored. }\end{array}$ & \\
\hline $\begin{array}{l}\text { Legacy waste. As discussed above, the intention of the } \\
\text { requirement is not to force malicious compliance or } \\
\text { heroic actions which would result in increased risk or } \\
\text { safety concerns. Rather, the intention is that waste in } \\
\text { storage longer than one year receives additional } \\
\text { attention to ensure that the public, the workers, and the } \\
\text { environment are protected from the hazards of the } \\
\text { waste, and that progress is being made to dispose of the } \\
\text { waste. There could be several ways within different } \\
\text { scenarios that this requirement can be met, as } \\
\text { illustrated by the examples below, however, there are } \\
\text { basically four ways to show compliance with the } \\
\text { requirement: }\end{array}$ & \\
\hline $\begin{array}{l}\text { 1) the radioactive waste management basis allows for } \\
\text { storage for no more than one year. }\end{array}$ & \\
\hline $\begin{array}{l}\text { 2) the radioactive waste management basis allows for } \\
\text { storage for no more than one year, or for storage for } \\
\text { decay only for periods greater than a year, which are } \\
\text { specified on a radionuclide basis. }\end{array}$ & \\
\hline $\begin{array}{l}\text { 3) the radioactive waste management basis allows for } \\
\text { storage for more than one year, up to a specified period }\end{array}$ & \\
\hline
\end{tabular}


Table 19. (continued).

\section{MFC-794 Contaminated Equipment Storage Building}

Chapter IV. Low-Level Waste Requirements of time based on a documented technical evaluation that the waste can be stored in a manner that does not cause changes to the waste or waste packages that is detrimental to the safe storage of the waste, the final disposal of the waste or to meeting the disposal performance objectives.

4) the radioactive waste management basis allows for storage for decay (with specifics) and for storage for more than one year for other low-level waste, up to a specified period of time based on a documented technical evaluation that the waste can be stored in a manner that does not cause changes to the waste or waste packages that is detrimental to the safe storage of the waste, the final disposal of the waste or to meeting the disposal performance objectives.

Compliance with this requirement is demonstrated by the existence of a radioactive waste management basis for the storage facility approved by the Field Element Manager that includes the time frames that waste are allowed to be stored, the necessary justifications for storage for decay, and the necessary technical evaluations if storage is to extend significantly beyond the one-year time frame.

(3) Storage Integrity. Low-level waste shall be stored in a location and manner that protects the integrity of waste for the expected time of storage and minimizes worker exposure.

From DOE G 435.1-1 Chapter IV: However, in making a decision to use a facility for storage and in developing a radioactive waste management basis for the activity, particular attention to protection of workers is needed.

Compliance with this requirement is demonstrated if sites have storage capabilities for low-level waste that provide protection to waste containers so that their integrity will not be damaged through physical or chemical (corrosion) processes and that keep personnel from spending extended periods of time in the areas where low-level waste is stored.

(4) Waste Characterization for Storage.

(a) Low-level waste that does not have an identified path to disposal shall be characterized as necessary to meet the data quality objectives and minimum characterization requirements of this Chapter, to ensure safe storage, and to facilitate disposal.

(b) Characterization information for all low-level waste in storage shall be maintained as a record in accordance

MCP-17000

SD-37.1.5

PER-116, Module III

PER-116, Attachment 1 § D-1(a)

SD-38.1.1, Appendix A and Appendix C.

This waste was considered in the safety analysis (DSA-004-CESB; to be superseded by the implementation of HAD-467 in October 2011)

ECAR-1545 addresses hazard categorization for CESB.

See below.

This facility does not store LLW that does not have an identified path to disposal.

MCP- 17000

SD-37.1.5 
Table 19. (continued).

\section{MFC-794 Contaminated Equipment Storage Building}

Chapter IV. Low-Level Waste Requirements with the requirements for Records Management in Chapter I of this Manual.

From DOE G 435.1-1 Chapter IV: Compliance with this requirement is demonstrated by documented procedures for managing waste characterization and container information on low-level waste as a Federal record. The records are managed per the applicable policies and procedures for records management referenced in DOE O 200.1 and established at the applicable Field Element.

(5) Container Inspection. A process shall be developed and implemented for inspecting and maintaining containers of low-level waste to ensure container integrity is not compromised.

From DOE G 435.1-1 Chapter IV: Compliance with this requirement is demonstrated by: (1) a documented process for waste container inspection and maintenance; and (2) documentation for all waste container inspections and maintenance actions performed.

(6) Storage Management. Low-level waste storage shall be managed to identify and segregate low-level waste from mixed low-level waste.

(7) Staging. Staging of low-level waste shall be for the purpose of the accumulation of such quantities of waste as necessary to facilitate transportation, treatment, and disposal. Staging longer than 90 days shall meet the requirements for storage above and in Chapter I of this Manual.

From DOE G 435.1-1 Chapter IV: The staging of lowlevel waste needs to be addressed in the radioactive waste management basis for the facility that is performing the staging. Generators, treatment facilities, and disposal facilities that stage waste must ensure that the action of staging is included and authorized as part of their radioactive waste management basis for the affected facilities, operations, or activities.

Staging longer than 90 days must be justified, the conditions for such storage met, and these practices approved by the Field Element Manager as part of the radioactive waste management basis for the facility.
LI-435 requires quarterly inspections of radioactive waste containers if waste is stored outdoors or has been in storage for greater than 1 year.

MCP-17000

For mixed LLW:

SD-37.1.5

PER-116, Module III

PER-116, Attachment 4 (this attachment includes examples of facility-specific inspection forms to be used)

SD-38.1.1, Appendix A and Appendix C.

LWP-15011 does not include a requirement for inspection.

Waste is segregated by container. MCP-17000 $\S 4.7$ requires the use of a unique IWTS bar code for each container.

NA; LLW is not staged at this facility. 
Table 19. (continued).

\section{MFC-794 Contaminated Equipment Storage Building}

Chapter IV. Low-Level Waste Requirements

Compliance with this requirement is demonstrated by a staging program that limits the temporary storage of waste to only circumstances allowed in the requirement, including justifications for any staging that exceeds the 90-day period, which is documented in the radioactive waste management basis for the facility.

O. Treatment. Low-level waste treatment to provide more stable waste forms and to improve the long-term performance of a low-level waste disposal facility shall be implemented as necessary to meet the performance objectives of the disposal facility.

From DOE G 435.1-1 Chapter IV: Compliance with this requirement is demonstrated when a treatment facility or process ensures that treated waste will meet the minimum waste form requirements of DOE M 435.1 and meet additional disposal facility-specific waste acceptance requirements for additional stability or long-term performance of facilities that will receive the treated waste.

P. Disposal. Low-level waste disposal facilities shall meet the following requirements.

(1) Performance Objectives. Low-level waste disposal facilities shall be sited, designed, operated, maintained, and closed so that a reasonable expectation exists that the following performance objectives will be met for waste disposed of after September 26, 1988:

(a) Dose to representative members of the public shall not exceed $25 \mathrm{mrem}(0.25 \mathrm{mSv})$ in a year total effective dose equivalent from all exposure pathways, excluding the dose from radon and its progeny in air.

(b) Dose to representative members of the public via the air pathway shall not exceed $10 \mathrm{mrem}(0.10 \mathrm{mSv})$ in a year total effective dose equivalent, excluding the dose from radon and its progeny.

(c) Release of radon shall be less than an average flux of $20 \mathrm{pCi} / \mathrm{m}^{2} / \mathrm{s}\left(0.74 \mathrm{~Bq} / \mathrm{m}^{2} / \mathrm{s}\right)$ at the surface of the disposal facility. Alternatively, a limit of $0.5 \mathrm{pCi} / 1$ $(0.0185 \mathrm{~Bq} / \mathrm{l})$ of air may be applied at the boundary of the facility.

(2) Performance Assessment. A site-specific radiological performance assessment shall be prepared and maintained for DOE low-level waste disposed of after September 26, 1988. The performance assessment shall include calculations for a 1,000 year period after closure of potential doses to representative future members of the public and potential releases from the facility to provide a reasonable expectation that the
MCP-17000

SD-37.1.5

PER-116, Module III

PER-116, Attachment $1 \S$ D-1(a)

SD-38.1.1, Appendix A and Appendix C

NA; LLW is not disposed of in this facility.

See P. above.

See P. above.

See P. above.

See P. above.

See P. above. 
Table 19. (continued).

\section{MFC-794 Contaminated Equipment Storage Building}

Chapter IV. Low-Level Waste Requirements performance objectives identified in this Chapter are not exceeded as a result of operation and closure of the facility.

(a) Analyses performed to demonstrate compliance with the performance objectives in this Chapter, and to establish limits on concentrations of radionuclides for disposal based on the performance measures for inadvertent intruders in this Chapter shall be based on reasonable activities in the critical group of exposed individuals. Unless otherwise specified, the assumption of average living habits and exposure conditions in representative critical groups of individuals projected to receive the highest doses is appropriate. The likelihood of inadvertent intruder scenarios may be considered in interpreting the results of the analyses and establishing radionuclide concentrations, if adequate justification is provided.

(b) The point of compliance shall correspond to the point of highest projected dose or concentration beyond a 100 meter buffer zone surrounding the disposed waste. A larger or smaller buffer zone may be used if adequate justification is provided.

(c) Performance assessments shall address reasonably foreseeable natural processes that might disrupt barriers against release and transport of radioactive materials.

(d) Performance assessments shall use DOE-approved dose coefficients (dose conversion factors) for internal and external exposure of reference adults.

(e) The performance assessment shall include a sensitivity/uncertainty analysis.

(f) Performance assessments shall include a demonstration that projected releases of radionuclides to the environment shall be maintained as low as reasonably achievable (ALARA).

(g) For purposes of establishing limits on radionuclides that may be disposed of near-surface, the performance assessment shall include an assessment of impacts to water resources.

(h) For purposes of establishing limits on the concentration of radionuclides that may be disposed of near-surface, the performance assessment shall include an assessment of impacts calculated for a hypothetical person assumed to inadvertently intrude for a temporary period into the low-level waste disposal facility. For intruder analyses, institutional controls shall be assumed to be effective in deterring intrusion for at least 100 years following closure. The intruder
See P. above. Facility Compliance Information

See P. above.

See P. above.

See P. above.

See P. above.

See P. above.

See P. above.

See P. above. 
Table 19. (continued).

\section{MFC-794 Contaminated Equipment Storage Building}

\begin{tabular}{|l|l|}
\hline \multicolumn{1}{|c|}{ Chapter IV. Low-Level Waste Requirements } & Facility Compliance Information \\
\hline analyses shall use performance measures for chronic & \\
and acute exposure scenarios, respectively, of 100 & \\
mrem $(1 \mathrm{mSv})$ in a year and $500 \mathrm{mrem}(5 \mathrm{mSv})$ total & \\
effective dose equivalent excluding radon in air. & \\
\hline
\end{tabular}

(3) Composite Analysis. For disposal facilities which

See P. above. received waste after September 26, 1988, a site-specific radiological composite analysis shall be prepared and maintained that accounts for all sources of radioactive material that may be left at the DOE site and may interact with the low- level waste disposal facility, contributing to the dose projected to a hypothetical member of the public from the existing or future disposal facilities. Performance measures shall be consistent with DOE requirements for protection of the public and environment and evaluated for a 1,000 year period following disposal facility closure. The composite analysis results shall be used for planning, radiation protection activities, and future use commitments to minimize the likelihood that current low- level waste disposal activities will result in the need for future corrective or remedial actions to adequately protect the public and the environment.

(4) Performance Assessment and Composite Analysis Maintenance. The performance assessment and composite analysis shall be maintained to evaluate changes that could affect the performance, design, and operating bases for the facility. Performance assessment and composite analysis maintenance shall include the conduct of research, field studies, and monitoring needed to address uncertainties or gaps in existing data. The performance assessment shall be updated to support the final facility closure. Additional iterations of the performance assessment and composite analysis shall be conducted as necessary during the post-closure period.

(a) Performance assessments and composite analyses shall be reviewed and revised when changes in waste forms or containers, radionuclide inventories, facility design and operations, closure concepts, or the improved understanding of the performance of the waste disposal facility in combination with the features of the site on which it is located alter the conclusions or the conceptual model(s) of the existing performance assessment or composite analysis.

(b) A determination of the continued adequacy of the performance assessment and composite analysis shall be made on an annual basis, and shall consider the results of data collection and analysis from research, field studies, and monitoring.

See P. above.

See P. above.
See P. above. 
Table 19. (continued).

MFC-794 Contaminated Equipment Storage Building

Chapter IV. Low-Level Waste Requirements Facility Compliance Information

(c) Annual summaries of low-level waste disposal operations shall be prepared with respect to the conclusions and recommendations of the performance assessment and composite analysis and a determination of the need to revise the performance assessment or composite analysis.

(5) Disposal Authorization. A disposal authorization statement shall be obtained prior to construction of a new low-level waste disposal facility. Field Elements with existing low-level waste disposal facilities shall obtain a disposal authorization statement in accordance with the schedule in the Complex-Wide Low-Level Waste Management Program Plan. The disposal authorization statement shall be issued based on a review of the facility's performance assessment, composite analysis, performance assessment and composite analysis maintenance, preliminary closure plan, and preliminary monitoring plan. The disposal authorization statement shall specify the limits and conditions on construction, design, operations, and closure of the low-level waste facility based on these reviews. A disposal authorization statement is a part of the radioactive waste management basis for a disposal facility. Failure to obtain a disposal authorization statement by the implementation date of this Order shall result in shutdown of the disposal facility.

(6) Disposal Facility Operations. The disposal facility design and operation must be consistent with the disposal facility closure plan and lead to disposal facility closure that provides a reasonable expectation that performance objectives will be met. Low-level waste shall be disposed in such a manner that achieves the performance objectives stated in this Chapter, consistent with the disposal facility radiological performance assessment. Additional requirements include:

(a) Operating procedures shall be developed and implemented for low-level waste disposal facilities that protect the public, workers, and the environment; ensure the security of the facility; minimize subsidence during and after waste emplacement; achieve long-term stability and minimize the need for long-term active maintenance; and meet the requirements of the closure/post-closure plan.

(b) Permanent identification markers for disposal excavations and monitoring wells shall be emplaced.

(c) Low-level waste placement into disposal units shall minimize voids between waste containers. Voids within

See P. above.

See P. above.

See P. above. 
Table 19. (continued).

\section{MFC-794 Contaminated Equipment Storage Building}

Chapter IV. Low-Level Waste Requirements disposal units shall be filled to the extent practical. Uncontainerized bulk waste shall also be placed in a manner that minimizes voids and subsidence.

(d) Operations are to be conducted so that active waste disposal operations will not have an adverse effect on any other disposal units.

(e) Operations shall include a process for tracking and documenting low-level waste placement in the facility by generator source.

(7) Alternate Requirements for Low-Level Waste Disposal Facility Design and Operation. Requirements other than those set forth in this Section for the design and operation of a low-level waste disposal facility may be approved on a specific basis if a reasonable expectation is demonstrated that the disposal performance objectives will be met.

Q. Closure. The following requirements are in addition to those in Chapter I of this Manual.

(1) Disposal Facility Closure Plans. A preliminary closure plan shall be developed and submitted to Headquarters for review with the performance assessment and composite analysis. The closure plan shall be updated following issuance of the disposal authorization statement to incorporate conditions specified in the disposal authorization statement. Closure plans shall:

(a) Be updated as required during the operational life of the facility.

(b) Include a description of how the disposal facility will be closed to achieve long-term stability and minimize the need for active maintenance following closure and to ensure compliance with the requirements of DOE 5400.5, Radiation Protection of the Public and the Environment.

(c) Include the total expected inventory of wastes to be disposed of at the facility over the operational life of the facility.

(2) Disposal Facility Closure. Closure of a disposal facility shall occur within a five-year period after it is filled to capacity, or after the facility is otherwise determined to be no longer needed.

(a) Prior to facility closure, the final inventory of the low-level waste disposed in the facility shall be prepared and incorporated in the performance assessment and composite analysis which shall be updated to support the closure of the facility.

See P. above.

See P. above.

See P. above.

NA; LLW is not disposed of in this facility.

See Q. above.

See Q. above.

See Q. above.

See Q. above.

See Q. above.

See Q. above. acility Compliance Information 
Table 19. (continued).

\section{MFC-794 Contaminated Equipment Storage Building}

Chapter IV. Low-Level Waste Requirements

(b) A final closure plan shall be prepared based on the final inventory of waste disposed in the facility, the plan implemented, and the updated performance assessment and composite analysis prepared in support of the facility closure.

(c) Institutional control measures shall be integrated into land use and stewardship plans and programs, and shall continue until the facility can be released pursuant to DOE 5400.5, Radiation Protection of the Public and the Environment.

(d) The location and use of the facility shall be filed with the local authorities responsible for land use and zoning.

R. Monitoring. The following requirements are in addition to those in Chapter I of this Manual [DOE M 435.1-1 §I.1.E(7)].

(1) All Waste Facilities. Parameters that shall be sampled or monitored, at a minimum, include: temperature, pressure (for closed systems), radioactivity in ventilation exhaust and liquid effluent streams, and flammable or explosive mixtures of gases. Facility monitoring programs shall include verification that passive and active control systems have not failed.

From DOE G 435.1-1 Chapter IV: The minimum parameters specified in the requirement were selected based on their potential significance for anticipating and identifying undesirable conditions at low-level waste management facilities. Each facility's radioactive waste management basis should include an evaluation of the applicability and significance of the minimum parameters. This evaluation also needs to consider additional parameters to be sampled or monitored to ensure the protection of the public health, the environment, and the workers. If a minimum parameter specified in the requirement is deemed to be not applicable in any way to the active operation of that facility, then that justification should be included in the radioactive waste management basis and when approved constitutes an exemption to the manual.

Verification activities are part of the radioactive waste management basis as a condition for operation and documented appropriately.

Compliance with this requirement is demonstrated if monitoring or sampling for the stated parameters is performed for all facilities with a precision, accuracy, and frequency consistent with timely identification of developing problems and a justification exists in the
See Q. above.

See Q. above. Facility Compliance Information

See Q. above.

See Q. above.

See Q. above.

See (1), (2), and (3) below.

Monitoring requirements at INL radioactive waste management facilities are tailored for the specific facility to enable timely indication of developing problems. Existing radiological control procedures and assessments are followed/completed to monitor waste facilities.

PER-116, Attachment 1 § D and Attachment 4 § F describe facility monitoring and inspection requirements.

LRD-15001 and MCP-139 specify methods and frequency of radiological control surveys of all radiological areas. MCP-139 specifies the use of Form 441.A34. This form is referred to as the "routine sheet" and is to be used by facility radiological control foremen to list radiological areas that are to be surveyed, the survey periods, and methods. 
Table 19. (continued).

\section{MFC-794 Contaminated Equipment Storage Building}

\begin{tabular}{|c|c|}
\hline Chapter IV. Low-Level Waste Requirements & Facility Compliance Information \\
\hline $\begin{array}{l}\text { approved radioactive waste management basis for those } \\
\text { specified parameters which are not monitored or } \\
\text { sampled. }\end{array}$ & \\
\hline $\begin{array}{l}\text { (2) Liquid Waste Storage Facilities. For facilities } \\
\text { storing liquid low-level waste, the following shall also } \\
\text { be monitored: liquid level and/or waste volume, and } \\
\text { significant waste chemistry parameters. }\end{array}$ & NA; liquid LLW waste is not stored at this facility. \\
\hline $\begin{array}{l}\text { (3) Disposal Facilities. A preliminary monitoring plan } \\
\text { for a low-level waste disposal facility shall be prepared } \\
\text { and submitted to Headquarters for review with the } \\
\text { performance assessment and composite analysis. The } \\
\text { monitoring plan shall be updated within one year } \\
\text { following issuance of the disposal authorization } \\
\text { statement to incorporate and implement conditions } \\
\text { specified in the disposal authorization statement. }\end{array}$ & NA; LLW is not disposed of in this facility. \\
\hline $\begin{array}{l}\text { (a) The site-specific performance assessment and } \\
\text { composite analysis shall be used to determine the } \\
\text { media, locations, radionuclides, and other substances to } \\
\text { be monitored. }\end{array}$ & See (3) above. \\
\hline $\begin{array}{l}\text { (b) The environmental monitoring program shall be } \\
\text { designed to include measuring and evaluating releases, } \\
\text { migration of radionuclides, disposal unit subsidence, } \\
\text { and changes in disposal facility and disposal site } \\
\text { parameters which may affect long-term performance. }\end{array}$ & See (3) above. \\
\hline $\begin{array}{l}\text { (c) The environmental monitoring programs shall be } \\
\text { capable of detecting changing trends in performance to } \\
\text { allow application of any necessary corrective action } \\
\text { prior to exceeding the performance objectives in this } \\
\text { Chapter. }\end{array}$ & See (3) above. \\
\hline
\end{tabular}

\subsection{MFC-798, Radioactive Liquid Waste Treatment Facility}

1. Facility description: MFC-798, RLWTF, receives low-level radioactive liquid waste water generated by other facilities located at MFC. Waste water is fed via an underground line from HFEF. Waste water from other sources, notably, the TREAT facility (MFC-720, MFC-768, MFC-774, MFC-793), is transported via tank trailer and unloaded from the "truck lock." Waste water is then transferred to one of the four 1,000-gal holding tanks located in the tank room.

Waste is pumped from the holding tanks to one of six shielded hot air drum evaporators located in the evaporator area. Warm air (approximately $220^{\circ} \mathrm{F}$ ) is drawn through the shielded hot air drum evaporators to evaporate the water. The remaining particulate is trapped within the shielded hot air drum evaporator. When the shielded hot air drum evaporators reach a radioactive capacity (for LLW), they are removed and shipped for disposal at NNSS.

The evaporator area also contains a small process vessel referred to as a "surrogate sample cooker." This process vessel is intended for relatively small waste samples to ensure that they meet process specifications. The facility can process approximately 1,000 gallons of waste water at a time and 
operates 24 hours/day seven days a week when in service. The process is highly automatic and controlled from the process control room.

Process air is supplied to the facility from the equipment room. Air is drawn through high-efficiency particulate air filters and exhausted out a stack located atop the facility. This room houses three banks of high-efficiency particulate air filters. One bank (six filters) serves the evaporator process, one bank (two filters) serves the building exhaust system, and one high-efficiency particulate air filter supports the surrogate sample cooker.

The facility is equipped with a $25-\mathrm{kW}$ diesel emergency generator, which is designed to provide emergency power in the event of primary power loss. The generator has a 30-gal diesel fuel tank. Discussions with cognizant personnel indicated that the facility does not meet the threshold of a Hazard Category 3 nonreactor nuclear facility as defined in DOE-STD-3009-94, "Preparation Guide for U.S. Department of Energy Nonreactor Nuclear Facility Safety Analysis Reports" (DOE 1994). Thus, there is no documented safety analysis or safety analysis report for the facility.

2. Hazard category: LTHC3 radiological facility

3. Radioactive waste managed at this facility: Generation of routine LLW subsequent to facility operations, and solid LLW (treatment product). Treatment of liquid LLW.

4. RWMB documents/programs:

a. Safety Basis/Hazards Analysis:

- EDF-7030, "Inventory Analysis of Radiological Facilities at the Materials and Fuels Complex (MFC)"

b. Laboratory-wide:

- Form 441.A34, "INL Radiological Control Required Surveys"

- LI-435, "Waste Management Routine Field Activities"

- LRD-15001, "Radiological Control Manual"

- LWP-13840, "Management of Issues, Observations, and Noteworthy Practices"

- LWP-14002, "Timeout and Stop Work Authority"

- LWP-17000, "Waste Management"

- MCP-139, "Radiological Surveys"

- MCP-17000, "Waste Generator Services Waste Management"

- MCP-17410, "Management of Waste Storage Areas"

- MCP-17500, "Waste Generator Services Certification of Waste Shipments to the Nevada Test Site"

- PDD-17000, "Waste Management Program"

- PLN-114, "INL Emergency Plan/RCRA Contingency Plan"

- PLN-522, "Quality Assurance Program Plan for the Waste Management/Waste Certification Program"

c. Facility-specific:

- RL-OI-1, "Radioactive Liquid Waste Collection"

- RL-OI-2, "Radioactive Liquid Waste Processing"

- TSD-OI-004, "Waste and Material Acceptance for Storage/Treatment and Radioactive Material Inventory Control." 
LLW is managed at this facility. Table 20 shows the facility compliance information for DOE Manual 435.1-1, Chapter IV, "Low-level Waste Requirements."

Table 20. MFC-798, Radioactive Liquid Waste Treatment Facility, DOE Manual 435.1-1 low-level waste requirements and facility compliance information.

\begin{tabular}{|c|c|}
\hline \multicolumn{2}{|c|}{ Facility Name: MFC-798, Radioactive Liquid Waste Treatment Facility } \\
\hline Chapter IV, LLW Requirements & Facility Compliance Information \\
\hline $\begin{array}{l}\text { A. Definition of Low-Level Waste. Low-level } \\
\text { radioactive waste is radioactive waste that is not high- } \\
\text { level radioactive waste, spent nuclear fuel, transuranic } \\
\text { waste, byproduct material (as defined in section 11e.(2) } \\
\text { of the Atomic Energy Act of 1954, as amended), or } \\
\text { naturally occurring radioactive material. } \\
\text { From DOE G } 435.1-1 \text { Chapter IV: Low-level } \\
\text { radioactive waste is defined by what it is not. The } \\
\text { guidance on definitions in Chapters II and III should be } \\
\text { consulted first for making a determination on how to } \\
\text { properly manage a suspect waste stream.) }\end{array}$ & $\begin{array}{l}\text { This requirement proves the criteria for determining } \\
\text { which DOE radioactive waste is to be managed as } \\
\text { low-level waste in accordance with DOE Manual } \\
435.1-1 \text {, Chapter IV. } \\
\text { Radioactive waste managed at this facility under the } \\
\text { requirements of this chapter is not managed under the } \\
\text { requirements of DOE Manual } 435.1-1 \text {, Chapter II or } \\
\text { Chapter III. }\end{array}$ \\
\hline $\begin{array}{l}\text { B. Management of Specific Wastes. The following } \\
\text { provide for management of specific wastes as low-level } \\
\text { waste in accordance with the requirements in this } \\
\text { Chapter: }\end{array}$ & See (1), (2), (3), and (4) below. \\
\hline $\begin{array}{l}\text { (1) Mixed Low-Level Waste. Low-level waste } \\
\text { determined to contain both source, special nuclear, or } \\
\text { byproduct material subject to the Atomic Energy Act of } \\
\text { 1954, as amended, and a hazardous component subject } \\
\text { to the Resource Conservation and Recovery Act } \\
\text { (RCRA), as amended, shall be managed in accordance } \\
\text { with the requirements of RCRA and DOE O 435.1, } \\
\text { Radioactive Waste Management, and this Manual. }\end{array}$ & $\begin{array}{l}\text { This facility manages mixed LLW debris from across } \\
\text { the MFC in TAAs. Management of TAAs is addressed } \\
\text { in MCP- } 17410 \text { and overall management of mixed } \\
\text { waste is addressed in MCP- } 17000 \text {. }\end{array}$ \\
\hline $\begin{array}{l}\text { (2) TSCA-Regulated Waste. Low-level waste } \\
\text { containing polychlorinated biphenyls, asbestos, or other } \\
\text { such regulated toxic components shall be managed in } \\
\text { accordance with requirements derived from the Toxic } \\
\text { Substances Control Act, as amended, DOE O 435.1, } \\
\text { Radioactive Waste Management, and this Manual. }\end{array}$ & $\begin{array}{l}\text { NA; this facility does not manage TSCA-regulated } \\
\text { waste. }\end{array}$ \\
\hline $\begin{array}{l}\text { (3) Accelerator-Produced Waste. Radioactive waste } \\
\text { produced as a result of operations of DOE accelerators } \\
\text { is low-level waste and shall be managed in accordance } \\
\text { with DOE O 435.1, Radioactive Waste Management, } \\
\text { and this Manual, and all applicable Federal or State } \\
\text { requirements. }\end{array}$ & $\begin{array}{l}\mathrm{NA} \text {; this facility does not manage } \\
\text { accelerator-produced waste. }\end{array}$ \\
\hline $\begin{array}{l}\text { (4) } 11 \text { e.(2) and Naturally Occurring Radioactive } \\
\text { Material. Small quantities of } 11 \text { e.(2) byproduct material } \\
\text { and naturally occurring radioactive material may be } \\
\text { managed as low-level waste provided they can be } \\
\text { managed to meet the requirements for low-level waste } \\
\text { disposal in Section IV.P of this Manual. }\end{array}$ & $\begin{array}{l}\text { NA; this facility does not manage naturally occurring } \\
\text { radioactive material. }\end{array}$ \\
\hline $\begin{array}{l}\text { C. Complex-Wide Low-Level Waste Management } \\
\text { Program. A complex-wide program and plan shall be }\end{array}$ & $\begin{array}{l}\text { DOE Manual } 435.1-1 \S \text { I.2.B and } \S I .2 . D \text { apply to the } \\
\text { Assistant Secretary for Environmental Management }\end{array}$ \\
\hline
\end{tabular}


Table 20. (continued).

Facility Name: MFC-798, Radioactive Liquid Waste Treatment Facility

Chapter IV, LLW Requirements

developed as described under Responsibilities, 2.B and 2.D, in Chapter I of this Manual.

D. Radioactive Waste Management Basis. Low-level waste facilities, operations, and activities shall have a radioactive waste management basis consisting of physical and administrative controls to ensure the protection of workers, the public, and the environment. The following specific waste management controls shall be part of the radioactive waste management basis:

(1) Generators. The waste certification program.

From DOE G 435.1-1 Chapter IV: For a facility that generates low-level waste, the radioactive waste management basis is to include the program for certifying that waste meets the waste acceptance requirements of the facility(ies) to which the waste will be sent.

(2) Treatment Facilities. certification program. The waste acceptance requirements and the waste [sic]

From DOE G 435.1-1 Chapter IV: Facilities that store or treat low-level waste are to have approved waste acceptance requirements (see DOE M 435.1-1, Section IV.G) prior to the issuance of a radioactive waste management basis.

A facility that stores or treats waste also is generally expected to have a waste certification program. Waste from these facilities will have to be certified as meeting the waste acceptance requirements of the facility to which it will be transferred, and the facilities have the potential for generating radioactive waste (e.g., secondary processing streams from treatment, monitoring and sampling, radioactive release cleanup). Consequently, storage and treatment facilities should also have an approved waste certification program as part of their radioactive waste management basis.

As part of the radioactive waste management basis, site personnel needs to implement a system or process for tracking the waste inventory at a storage, treatment, or disposal facility.

(3) Storage Facilities. The waste acceptance requirements and the waste certification program.

From DOE G 435.1-1 Chapter IV: Facilities that store or treat low-level waste are to have approved waste acceptance requirements (see DOE M 435.1-1, Section
Facility Compliance Information

and the Deputy Assistant Secretary for Waste Management, respectively.

The RWMB provides the regulatory framework for management of radioactive waste at INL. It specifically identifies facility management and implementing documents for the generation, storage, treatment, and disposal of radiological waste..

See J. below for waste certification program requirements.

EDF-7030 demonstrates that radiological inventory for this facility contains LTHC3 quantities of radiological material. The facility uses IWTS to track the inventory in comparison to the threshold quantities for this hazard classification.

MCP-17000 addresses use of the IWTS to track the radiological inventories for LTHC3 facilities.

See J. below for waste certification program requirements.

See (1) above for safety basis documentation identified. 
Table 20. (continued).

\begin{tabular}{|c|c|}
\hline \multicolumn{2}{|c|}{ Facility Name: MFC-798, Radioactive Liquid Waste Treatment Facility } \\
\hline Chapter IV, LLW Requirements & Facility Compliance Information \\
\hline $\begin{array}{l}\text { IV.G) prior to the issuance of a radioactive waste } \\
\text { management basis. }\end{array}$ & \\
\hline $\begin{array}{l}\text { A facility that stores or treats waste also is generally } \\
\text { expected to have a waste certification program. Waste } \\
\text { from these facilities will have to be certified as meeting } \\
\text { the waste acceptance requirements of the facility to } \\
\text { which it will be transferred, and the facilities have the } \\
\text { potential for generating radioactive waste (e.g., } \\
\text { secondary processing streams from treatment, } \\
\text { monitoring and sampling, radioactive release cleanup). } \\
\text { Consequently, storage and treatment facilities should } \\
\text { also have an approved waste certification program as } \\
\text { part of their radioactive waste management basis. }\end{array}$ & \\
\hline $\begin{array}{l}\text { As part of the radioactive waste management basis, site } \\
\text { personnel needs to implement a system or process for } \\
\text { tracking the waste inventory at a storage, treatment, or } \\
\text { disposal facility. }\end{array}$ & \\
\hline $\begin{array}{l}\text { (4) Disposal Facilities. The performance assessment, } \\
\text { composite analysis, disposal authorization statement, } \\
\text { closure plan, waste acceptance requirements, and } \\
\text { monitoring plan. }\end{array}$ & NA; this facility does not dispose of LLW. \\
\hline $\begin{array}{l}\text { E. Contingency Actions. The following requirements } \\
\text { are in addition to those in Chapter I of this Manual } \\
\text { [DOE M 435.1-1 §I.1.E(5)]. }\end{array}$ & $\begin{array}{l}\text { DOE Manual } 435.1-1 \text { §I.1.E(5) addresses the sitewide } \\
\text { emergency management system. The INL plan is } \\
\text { provided in PLN-114. }\end{array}$ \\
\hline $\begin{array}{l}\text { (1) Contingency Storage. For off-normal or emergency } \\
\text { situations involving high activity or high hazard liquid } \\
\text { low-level waste storage or treatment, spare capacity } \\
\text { with adequate capabilities shall be maintained to } \\
\text { receive the largest volume of liquid contained in any } \\
\text { one storage tank or treatment facility. Tanks or other } \\
\text { facilities that are designated low-level waste } \\
\text { contingency storage shall be maintained in an } \\
\text { operational condition when waste is present and shall } \\
\text { meet the requirements of DOE O 435.1, Radioactive } \\
\text { Waste Management, and this Manual. }\end{array}$ & NA; this facility does not store liquid LLW. \\
\hline $\begin{array}{l}\text { From DOE G 435.1-1 Chapter IV: Compliance with } \\
\text { these requirements is demonstrated if adequate spare } \\
\text { capacity and transfer equipment exists for emergency } \\
\text { transfers of all high activity and high hazard liquid low- } \\
\text { level waste. In addition, the capability to perform } \\
\text { emergency transfers is demonstrated by having waste } \\
\text { transfer routings identified, operational procedures to } \\
\text { direct transfers, staff trained to the procedures, and } \\
\text { records showing that the spare capacity and transfer } \\
\text { capability are kept in operating condition. }\end{array}$ & \\
\hline $\begin{array}{l}\text { (2) Transfer Equipment. Pipelines and auxiliary } \\
\text { facilities necessary for the transfer of high activity or } \\
\text { high hazard liquid low-level waste to contingency }\end{array}$ & NA; this facility does not store liquid LLW. \\
\hline
\end{tabular}


Table 20. (continued).

Facility Name: MFC-798, Radioactive Liquid Waste Treatment Facility

Chapter IV, LLW Requirements

storage shall be maintained in an operational condition when waste is present and shall meet the requirements of DOE O 435.1, Radioactive Waste Management, and this Manual.

From DOE G 435.1-1 Chapter IV: Compliance with these requirements is demonstrated if adequate spare capacity and transfer equipment exists for emergency transfers of all high activity and high hazard liquid lowlevel waste. In addition, the capability to perform emergency transfers is demonstrated by having waste transfer routings identified, operational procedures to direct transfers, staff trained to the procedures, and records showing that the spare capacity and transfer capability are kept in operating condition.

\section{F. Corrective Actions. I of this Manual. The following} requirements are in addition to those in Chapter [sic]

From DOE G 435.1-1 Chapter IV: Compliance with DOE M 435.1-1 §I.2.G.(1) is demonstrated by records showing what corrective actions were taken to remedy situations in the radioactive waste management system.

Compliance with DOE M 435.1-1 §I.2.G.(2) is demonstrated by having the necessary procedures, mechanisms, and training in place to effect shutdown or curtailment of activities which pose an imminent danger or other serious hazard to workers or the public, or are not protective of the environment.

(1) Order Compliance. Corrective actions shall be implemented whenever necessary to ensure the requirements of DOE O 435.1, Radioactive Waste Management, and this Manual are met.

From DOE G 435.1-1 Chapter IV: If a facility or activity can be allowed to operate while a noncompliant or hazardous condition exists, the allowance and any associated limitations must be defined as part of the facility or activity's radioactive waste management basis, identified as a configuration controlled item in a configuration management plan or included in a revision or modification to an operating procedure or similar controlled documentation.

Compliance with this requirement is demonstrated if a corrective action system addresses noncompliant or hazardous situations involving low-level waste management facilities in a systematic fashion, and allows identification of problems by all personnel.

(2) Operations Curtailment. Operations shall be curtailed or facilities shut down for failure to establish, maintain, or operate consistent with an approved
Facility Compliance Information

The INL-wide procedure addressing problem identification as required by DOE Manual 435.1-1 §I.2.G.(1) is LWP-13840, which implements the laboratory's corrective action system.

The INL-wide procedure addressing shutdown or curtailment of activities as required by DOE Manual 435.1-1 §I.2.G.(2) is LWP-14002.

See F. above.
The approved RWMB establishes the current compliance status at each radioactive waste management facility. Facility assessments are 
Table 20. (continued).

Facility Name: MFC-798, Radioactive Liquid Waste Treatment Facility

Chapter IV, LLW Requirements

radioactive waste management basis.

From DOE G 435.1-1 Chapter IV: Compliance with this requirement is demonstrated with a documented system of routine assessments to determine whether waste management activities and facilities are operating in accordance with an approved radioactive waste management basis that provides for graded limitations that can be placed on activities and operations that do not have, or are operating outside of, an approved radioactive waste management basis, including shutdown of the facility.

G. Waste Acceptance. The following requirements are in addition to those in Chapter I of this Manual [DOE M 435.1-1 §I.2.F(6)].

(1) Technical and Administrative. Waste acceptance requirements for all low-level waste storage, treatment, or disposal facilities, operations, and activities shall specify, at a minimum, the following:

From DOE G 435.1-1 Chapter IV: Compliance with these waste acceptance requirements is demonstrated if they are documented, contain clear and precise criteria specifying the radionuclide limits in the form of contents or concentrations that can be accepted, the limitations and prohibitions on waste forms and packages that can be received, and the limits, prohibitions, or instructions concerning any other technical information so that the waste is compatible with the safety basis of the facility, and which will result in acceptable waste at subsequent steps in managing the low-level waste.)

(a) Allowable activities and/or concentrations of specific radionuclides.

(b) Acceptable waste form and/or container requirements that ensure the chemical and physical stability of waste under conditions that might be encountered during transportation, storage, treatment, or disposal.

(c) Restrictions or prohibitions on waste, materials, or containers that may adversely affect waste handlers or compromise facility or waste container performance.

(d) The following are additional waste acceptance requirements that shall be specified in low-level waste disposal facility waste acceptance requirements:

1 Low-level waste must contribute to and not detract from achieving long-term stability of the facility, minimizing the need for long-term active maintenance, minimizing subsidence, and minimizing contact of

\section{Facility Compliance Information}

scheduled to ensure waste management activities are conducted in accordance with the approved RWMB.

DOE Manual 435.1-1 §I.2.F(6) applies to field element managers.

RL-OI-1 provides the WAC specifying the

radionuclide limits in the form of contents or concentrations that can be accepted, the limitations, and prohibitions of the liquid LLW forms the facility can receive. This document also addresses the limits and prohibitions that ensure the waste is compatible with the safety basis of the facility.

EDF-7030 demonstrates that radiological inventory for this facility contains LTHC3 quantities of radiological material. The facility uses IWTS to track the inventory in comparison to the threshold quantities for this hazard classification.
See (1) above.

See (1) above.
See (1) above.

See (1) above.

See (1) above. 
Table 20. (continued).

Facility Name: MFC-798, Radioactive Liquid Waste Treatment Facility

Chapter IV, LLW Requirements Facility Compliance Information

water with waste. Void spaces within the waste and, if containers are used, between the waste and its container shall be reduced to the extent practical.

2 Liquid low-level waste or low-level waste containing free liquid must be converted into a form that contains as little freestanding liquid as is reasonably achievable, but in no case shall the liquid exceed 1 percent of the waste volume when the low-level waste is in a disposal container, or 0.5 percent of the waste volume after it is processed to a stable form.

3 Low-level waste must not be readily capable of detonation or of explosive decomposition or reaction at anticipated pressures and temperatures, or of explosive reaction with water. Pyrophoric materials contained in waste shall be treated, prepared, and packaged to be nonflammable.

4 Low-level waste must not contain, or be capable of generating by radiolysis or biodegradation, quantities of toxic gases, vapors, or fumes harmful to the public or workers or disposal facility personnel, or harmful to the long-term structural stability of the disposal site.

5 Low-level waste in a gaseous form must be packaged such that the pressure does not exceed 1.5 atmospheres absolute at $20 \mathrm{C}$. [sic]

(e) The basis, procedures, and levels of authority required for granting exceptions to the waste acceptance requirements, which shall be contained in each facility's waste acceptance documentation. Each exception request shall be documented, including its disposition as approved or not approved.

From DOE G 435.1-1 Chapter IV: Waste acceptance requirements are acceptable if they are documented and contain a clear description of the procedure and bases for obtaining an exception or deviation to the acceptance criteria for low-level waste to be received at the facility.

(2) Evaluation and Acceptance. The receiving facility shall evaluate waste for acceptance, including confirmation that the technical and administrative requirements have been met. A process for the disposition of non-conforming wastes shall be established.

From DOE G 435.1-1 Chapter IV: Compliance with the waste acceptance requirements for a low-level waste management facility is demonstrated if they include a process for evaluation and acceptance of incoming waste to ensure the acceptance criteria of the facility

See (1) above.

See (1) above.

NA; this facility does not manage LLW in gaseous form.

See (1) above.

See (1) above. 
Table 20. (continued).

Facility Name: MFC-798, Radioactive Liquid Waste Treatment Facility

Chapter IV, LLW Requirements Facility Compliance Information

receiving the waste are met that includes one of or a combination of: (1) testing, sampling, and analysis of representative samples of waste upon receipt; (2) testing, sampling, and analysis of split samples of waste taken at the generator site; (3) evaluation of testing, sampling, and analysis of data provided by the generator, or (4) audits, reviews, surveillance, or observations of generator waste certification programs and characterization activities. Additionally, acceptable waste acceptance requirements for a storage, treatment or disposal facility will have documented procedures and actions to be taken if a waste that does not conform to the waste acceptance criteria is received at the facility.

H. Waste Generation Planning. The following requirements are in addition to those in Chapter I of this Manual [DOE M 435.1-1 §I.2.F(7)].

(1) Life-Cycle Planning. Prior to waste generation, planning shall be performed to address the entire life cycle for all low-level waste streams.

From DOE G 435.1-1 Chapter IV: Compliance with this planning requirement is demonstrated by the individual sites establishing a process for evaluating the life-cycle of low-level waste prior to its generation, including the identification of low-level wastes with no path to disposal and appropriate records justifying the newly generated low-level waste stream(s), and site personnel possessing planning information showing the location(s) where low-level waste will be stored, treated, and/or disposed along with a confirmation that the personnel managing the facilities agree that the lowlevel waste may be managed at those facilities.

(2) Waste with No Identified Path to Disposal. Lowlevel waste streams with no identified path to disposal shall be generated only in accordance with approved conditions which, at a minimum, shall address:

(a) Programmatic need to generate the waste;

(b) Characteristics and issues preventing the disposal of the waste;

(c) Safe storage of the waste until disposal can be achieved; and

(d) Activities and plans for achieving final disposal of the waste.

I. Waste Characterization. Low-level waste shall be characterized using direct or indirect methods, and the characterization documented in sufficient detail to

DOE Manual 435.1-1 §I.2.F(7) applies to field element managers.

PDD-17000 and LWP-17000 provide direction to the waste generators for waste generation planning to address the entire life cycle.
This facility is not generating radioactive waste that does not have an identified path to disposal.
See (2) above.

See (2) above.

See (2) above.

See (2) above.

Regarding the liquid LLW sent to MFC-798 for treatment, RL-OI-1 provides the WAC specifying the radionuclide limits in the form of contents or 
Table 20. (continued).

Facility Name: MFC-798, Radioactive Liquid Waste Treatment Facility

Chapter IV, LLW Requirements

ensure safe management and compliance with the waste acceptance requirements of the facility receiving the waste.

From DOE G 435.1-1 Chapter IV: Compliance with this requirement is demonstrated by a program for documenting and the existence of records that document the process for acquiring and verifying the validity of low-level waste characterization data acquired through the use of direct or indirect methods.
(1) Data Quality Objectives. The data quality objectives process, or a comparable process, shall be used for identifying characterization parameters and acceptable uncertainty in characterization data.

From DOE G 435.1-1 Chapter IV: Compliance with this requirement is demonstrated by the documented use of a data quality objectives or a comparable process for determining the type, quantity, and quality of characterization data needed to safely manage low-level waste.

(2) Minimum Waste Characterization. Characterization data shall, at a minimum, include the following information relevant to the management of the waste:

From DOE G 435.1-1 Chapter IV: Compliance with this requirement is demonstrated by the existence of a program or procedure for determining and records that document characterization of low-level waste consistent with the minimum characterization data requirements.)

(a) Physical and chemical characteristics;
Facility Compliance Information concentrations that can be accepted, the limitations, and prohibitions of the liquid LLW forms the facility can receive. This document also addresses the limits and prohibitions that ensure the waste is compatible with the safety basis of the facility.

RL-OI-1 $\S 3$ provides the prerequisite process for acquiring and verifying the validity of the characterization data prior to waste acceptance.

RL-OI- $2 \S 5$ provides confirmatory characterization sampling of all liquid LLW being transferred to this facility.

Regarding the routine solid LLW stream generated subsequent to MFC-798 operations, MCP-17000 § 4 specifies the requirements for preparing an IWTS profile that captures waste characterization information.

Radioactive waste management facilities characterize waste in accordance with the requirements of the receiving storage, treatment, or disposal facility. The documented use of a data quality objectives process, or comparable process, was not identified for this facility.

Regarding the liquid LLW sent to MFC-798 for treatment, RL-OI-1 provides the WAC specifying the radionuclide limits in the form of contents or concentrations that can be accepted, the limitations, and prohibitions of the liquid LLW forms the facility can receive. This document also addresses the limits and prohibitions that ensure the waste is compatible with the safety basis of the facility.

RL-OI-1 $\S 3$ provides the prerequisite process for acquiring and verifying the validity of the characterization data prior to waste acceptance.

RL-OI-2 § 5 provides confirmatory characterization sampling of all liquid LLW being transferred to this facility.

Regarding the routine solid LLW stream generated subsequent to MFC- 798 operations, MCP- $17000 \S 4$ specifies the requirements for preparing an IWTS profile that captures waste characterization information.

See (2) above. 
Table 20. (continued).

\begin{tabular}{|c|c|}
\hline \multicolumn{2}{|c|}{ Facility Name: MFC-798, Radioactive Liquid Waste Treatment Facility } \\
\hline Chapter IV, LLW Requirements & Facility Compliance Information \\
\hline $\begin{array}{l}\text { (b) Volume, including the waste and any stabilization or } \\
\text { absorbent media; }\end{array}$ & See (2) above. \\
\hline (c) Weight of the container and contents; & See (2) above. \\
\hline $\begin{array}{l}\text { (d) Identities, activities, and concentrations of major } \\
\text { radionuclides; }\end{array}$ & See (2) above. \\
\hline (e) Characterization date; & See (2) above. \\
\hline (f) Generating source; and & See (2) above. \\
\hline $\begin{array}{l}\text { (g) Any other information which may be needed to } \\
\text { prepare and maintain the disposal facility performance } \\
\text { assessment, or demonstrate compliance with applicable } \\
\text { performance objectives. }\end{array}$ & See (2) above. \\
\hline $\begin{array}{l}\text { J. Waste Certification. A waste certification program } \\
\text { shall be developed, documented, and implemented to } \\
\text { ensure that the waste acceptance requirements of } \\
\text { facilities receiving low-level waste for storage, } \\
\text { treatment, and disposal are met. } \\
\text { From DOE G 435.1-1 Chapter IV: Compliance with the } \\
\text { development and documentation portion of the } \\
\text { certification requirement is demonstrated by a waste } \\
\text { certification plan that identifies the organizations } \\
\text { involved, assigns responsibilities for implementing the } \\
\text { program, and describes or references the quality } \\
\text { assurance, training, procurement controls, records } \\
\text { management, and procedures to be used by the } \\
\text { program. Acceptable performance for implementing the } \\
\text { program is demonstrated when appropriate personnel } \\
\text { are trained and follow the procedures that govern their } \\
\text { part of the waste certification. Additionally, acceptable } \\
\text { performance is demonstrated if the waste certification } \\
\text { plan and procedures are current and controlled in } \\
\text { accordance with a document controls program, and } \\
\text { records related to certification (e.g., certification } \\
\text { statements, training records, procurement records, } \\
\text { characterization records, container records) are } \\
\text { generated and managed in accordance with the } \\
\text { established site program. }\end{array}$ & $\begin{array}{l}\text { Regarding the liquid LLW sent to MFC-798 for } \\
\text { treatment, RL-OI-1 provides the WAC to be } \\
\text { "certified" to by those facilities sending liquid LLW to } \\
\text { MFC-798 for treatment. } \\
\text { Regarding the treated waste form generated } \\
\text { subsequent to MFC-798 liquid LLW treatment, which } \\
\text { is sent to NNSS for ultimate disposition, MCP-17000 } \\
\text { cites a waste certification program for LLW destined } \\
\text { for NNSS. A waste certification program for other } \\
\text { storage, treatment, or disposal facilities is not } \\
\text { addressed. } \\
\text { Regarding the routine solid LLW stream generated } \\
\text { subsequent to MFC-798 operations, MCP-17000 cites } \\
\text { a waste certification program for LLW destined for } \\
\text { NNSS. A waste certification program for other } \\
\text { storage, treatment, or disposal facilities is not } \\
\text { addressed. } \\
\text { MCP-17000 } \$ 4 \text { specifies the requirements for } \\
\text { preparing an IWTS profile that captures waste } \\
\text { certification information. } \\
\text { MCP-17500 provides the WGS waste certification } \\
\text { program for LLW to be shipped to NNSS. } \\
\text { Procurement controls do not appear to be addressed. } \\
\text { Also, how the procedure is maintained within the site's } \\
\text { document control system is not addressed in the } \\
\text { procedure and has not been determined. }\end{array}$ \\
\hline $\begin{array}{l}\text { (1) Certification Program. The waste certification } \\
\text { program shall designate the officials who have the } \\
\text { authority to certify and release waste for shipment; and } \\
\text { specify what documentation is required for waste } \\
\text { generation, characterization, shipment, and } \\
\text { certification. The program shall provide requirements } \\
\text { for auditability, retrievability, and storage of required } \\
\text { documentation and specify the records retention period. }\end{array}$ & See J. above. \\
\hline
\end{tabular}


Table 20. (continued).

\begin{tabular}{|c|c|}
\hline \multicolumn{2}{|c|}{ Facility Name: MFC-798, Radioactive Liquid Waste Treatment Facility } \\
\hline Chapter IV, LLW Requirements & Facility Compliance Information \\
\hline $\begin{array}{l}\text { From DOE G } 435.1-1 \text { Chapter IV: Compliance with } \\
\text { this requirement is demonstrated by a program or } \\
\text { procedure for record keeping and records showing that } \\
\text { low-level waste is certified as having met the waste } \\
\text { acceptance criteria of the facility to which it was } \\
\text { transferred and that the certification statement is } \\
\text { supported by additional records regarding the waste } \\
\text { source, characterization, and container. }\end{array}$ & \\
\hline $\begin{array}{l}\text { (2) Certification before Transfer. Low-level waste shall } \\
\text { be certified as meeting waste acceptance requirements } \\
\text { before it is transferred to the facility receiving the } \\
\text { waste. } \\
\text { From DOE G 435.1-1 Chapter IV: Compliance with } \\
\text { this requirement is demonstrated by the presence of a } \\
\text { certification program which includes procedures } \\
\text { requiring a signed certification statement prior to the } \\
\text { release of waste for transfer, and by dated records } \\
\text { showing that waste was certified before being } \\
\text { transferred. }\end{array}$ & See J. above. \\
\hline $\begin{array}{l}\text { (3) Maintaining Certification. Low-level waste that has } \\
\text { been certified as meeting the waste acceptance } \\
\text { requirements for transfer to a storage, treatment, or } \\
\text { disposal facility shall be managed in a manner that } \\
\text { maintains its certification status. } \\
\text { From DOE G } 435.1-1 \text { Chapter IV: Compliance with } \\
\text { this requirement is demonstrated by a program or } \\
\text { procedure reflecting this requirement is present and site } \\
\text { personnel are able to show that the storage of low-level } \\
\text { waste containers is in a facility or manner where the } \\
\text { containers would not be damaged by normal weather } \\
\text { events, and cannot be accessed by unauthorized } \\
\text { personnel. Further, each container can be traced to its } \\
\text { certification and the information supporting that } \\
\text { certification. }\end{array}$ & See J. above. \\
\hline $\begin{array}{l}\text { K. Waste Transfer. A documented process shall be } \\
\text { established and implemented for transferring } \\
\text { responsibility for management of low-level waste and } \\
\text { for ensuring availability of relevant data. The following } \\
\text { requirements are in addition to those in Chapter I of this } \\
\text { Manual. } \\
\text { From DOE G 435.1-1 Chapter IV: Compliance with } \\
\text { this requirement is demonstrated if facilities have } \\
\text { procedures for the receipt of waste and the transfer of } \\
\text { waste, as appropriate, which address the acquisition of } \\
\text { waste and container data and the transfer of ownership, } \\
\text { respectively. Further evidence of acceptable } \\
\text { performance is facility records showing that data on the } \\
\text { waste containers is available and accurate, and that }\end{array}$ & $\begin{array}{l}\text { Regarding the liquid LLW sent to MFC- } 798 \text { for } \\
\text { treatment, RL-OI-1, Appendices A, B, and C all } \\
\text { require recording of signatures by personnel } \\
\text { authorized for transfer of waste ownership. } \\
\text { Regarding the treated waste form generated } \\
\text { subsequent to MFC-798 liquid LLW treatment, which } \\
\text { is sent to NNSS for ultimate disposition, MCP-17000 } \\
\S 4 \text { specifies the requirements for preparing an IWTS } \\
\text { profile that captures waste transfer authorization } \\
\text { information. } \\
\text { Regarding the routine solid LLW stream generated } \\
\text { subsequent to MFC-798 operations, MCP-17000 } § 4 \\
\text { specifies the requirements for preparing an IWTS }\end{array}$ \\
\hline
\end{tabular}


Table 20. (continued).

\begin{tabular}{|c|c|}
\hline \multicolumn{2}{|c|}{ Facility Name: MFC-798, Radioactive Liquid Waste Treatment Facility } \\
\hline Chapter IV, LLW Requirements & Facility Compliance Information \\
\hline documented transfer of responsibility occurs. & $\begin{array}{l}\text { profile that captures waste transfer authorization } \\
\text { information. } \\
\text { MCP- } 17500 \text { provides the WGS waste certification } \\
\text { program for LLW to be shipped to NNSS. } \\
\text { TSD-OI- } 004 \text { specifies requirements and provides } \\
\text { instructions for accepting LLW and mixed LLW at the } \\
\text { MFC treatment, storage, and disposal facilities. }\end{array}$ \\
\hline $\begin{array}{l}\text { (1) Authorization. Low-level waste shall not be } \\
\text { transferred to a storage, treatment, or disposal facility } \\
\text { until personnel responsible for the facility receiving the } \\
\text { waste authorize the transfer. } \\
\text { From DOE G } 435.1-1 \text { Chapter IV: Compliance with } \\
\text { this requirement is demonstrated by sites having } \\
\text { procedures that require a confirmation of authorization } \\
\text { before releasing waste for transfer, and records showing } \\
\text { that transfers are made in accordance with written } \\
\text { authorizations. }\end{array}$ & See K. above. \\
\hline $\begin{array}{l}\text { (2) Data. Waste characterization data, container } \\
\text { information, and generation, storage, treatment, and } \\
\text { transportation information for low-level waste shall be } \\
\text { transferred with or be traceable to the waste. } \\
\text { From DOE G 435.1-1 Chapter IV: Compliance with } \\
\text { this requirement is demonstrated if there are procedures } \\
\text { requiring that characterization and container data be } \\
\text { provided and maintained for each low-level waste } \\
\text { transfer and documented records of transfers show that } \\
\text { the information is being provided. }\end{array}$ & See K. above. \\
\hline $\begin{array}{l}\text { L. Packaging and Transportation. The following } \\
\text { requirements are in addition to those in Chapter I of this } \\
\text { Manual [DOE M 435.1-1 §I.1.E(11)]. }\end{array}$ & $\begin{array}{l}\text { DOE Manual 435.1-1 §I.1.E(11) applies to field } \\
\text { element managers }\end{array}$ \\
\hline $\begin{array}{l}\text { (1) Packaging. If containers are used: } \\
\text { From DOE G 435.1-1 Chapter IV: Compliance with the } \\
\text { packaging requirement is demonstrated by: (1) } \\
\text { procedures which document proper packaging } \\
\text { protocols; and (2) no trends of routine repackaging of } \\
\text { low-level waste that is packaged after issuance of DOE } \\
\text { O } 435.1 \text {. Successful performance of this requirement is } \\
\text { also demonstrated by a record of containers for which } \\
\text { failure has not routinely occurred under management } \\
\text { conditions. It is recognized that there may be failed } \\
\text { containers for waste previously placed in storage. For } \\
\text { those containers, the goal is to only have to repackage } \\
\text { the waste one time after it is retrieved and } \\
\text { characterized. Further, acceptable performance is } \\
\text { demonstrated by containers of waste having marking } \\
\text { and labeling that allows correlation with waste } \\
\text { characterization data and container information.) }\end{array}$ & $\begin{array}{l}\text { MCP- } 17000 \S 4 \text { addresses packaging requirements for } \\
\text { the routine LLW generated at this facility. } \\
\text { MCP- } 17500 \text { provides the WGS waste packaging } \\
\text { requirements for the treated LLW to be shipped to } \\
\text { NNSS. }\end{array}$ \\
\hline
\end{tabular}


Table 20. (continued).

Facility Name: MFC-798, Radioactive Liquid Waste Treatment Facility

Chapter IV, LLW Requirements

(a) Low-level waste shall be packaged in a manner that provides containment and protection for the duration of the anticipated storage period and until disposal is achieved or until the waste has been removed from the container.

(b) When waste is packaged, vents or other measures shall be provided if the potential exists for pressurizing or generating flammable or explosive concentrations of gases within the waste container.

(c) Containers of low-level waste shall be marked such that their contents can be identified.

(2) Transportation. To the extent practical, the volume of waste and number of low-level waste shipments shall be minimized.

From DOE G 435.1-1 Chapter IV: Compliance with this requirement can be demonstrated by a combination of site procedures directing the efficient use of waste container capacity and documentation showing that low-level waste shipments are systematically planned and optimized to the extent practical.

M. Site Evaluation and Facility Design. The following requirements are in addition to those in Chapter I of this Manual.

(1) Site Evaluation. Proposed locations for low-level waste facilities shall be evaluated to identify relevant features that should be avoided or must be considered in facility design and analyses.
(a) Each site proposed for a new low-level waste facility or expansion of an existing low-level waste facility shall be evaluated considering environmental characteristics, geotechnical characteristics, and human activities, including for a low-level waste disposal facility, the capability of the site to demonstrate, at a minimum, whether it is:

1 Located to accommodate the projected volume of waste to be received;

2 Located in a flood plain, a tectonically active area, or in the zone of water table fluctuation; and

3 Located where radionuclide migration pathways are predictable and erosion and surface runoff can be controlled.

(b) Proposed sites with environmental characteristics, geotechnical characteristics, and human activities for which adequate protection cannot be provided through facility design shall be deemed unsuitable for the

\section{Facility Compliance Information}

See (1) above.

See (1) above.

See (1) above.

NA; waste is not shipped to an offsite facility for final disposition from this facility.

$\mathrm{NA}$; this requirement addresses new radioactive waste management facilities.

See M. above.

See M. above.

See M. above.

See M. above.

See M. above.

See M. above. 
Table 20. (continued).

Facility Name: MFC-798, Radioactive Liquid Waste Treatment Facility

Chapter IV, LLW Requirements location of the facility.

(c) Low-level waste disposal facilities shall be sited to achieve long-term stability and to minimize, to the extent practical, the need for active maintenance following final closure.

(2) Low-Level Waste Treatment and Storage Facility Design. The following facility requirements and general design criteria, at a minimum, apply:

(a) Confinement. Low-level waste systems and components shall be designed to maintain waste confinement.

(b) Ventilation.

1 Design of low-level waste treatment and storage facilities shall include ventilation, if applicable, through an appropriate filtration system to maintain the release of radioactive material in airborne effluents within the requirements and guidelines specified in applicable requirements.

2 When conditions exist for generating gases in flammable or explosive concentrations, ventilation systems or other measures shall be provided to keep the gases in a non-flammable and nonexplosive condition. Where concentrations of explosive or flammable gases are expected to approach the lower flammability limit, measures shall be taken to prevent deflagration or detonation.

(c) Consideration of Decontamination and Decommissioning. Areas in new and modifications to existing low-level waste management facilities that are subject to contamination with radioactive or other hazardous materials shall be designed to facilitate decontamination. For such facilities a proposed decommissioning method or a conversion method leading to reuse shall be described.

(d) Instrumentation and Control Systems. Engineering controls shall be incorporated in the design and engineering of low-level waste treatment and storage facilities to provide volume inventory data and to prevent spills, leaks, and overflows from tanks or confinement systems.

(e) Monitoring. Monitoring and/or leak detection capabilities shall be incorporated in the design and engineering of low-level waste treatment and storage facilities to provide rapid identification of failed confinement and/or other abnormal conditions.

(3) Low-Level Waste Disposal Facility Design. The
Facility Compliance Information

See M. above.

See M. above.

See M. above.

See M. above.

See M. above.

See M. above.

See M. above

See M. above.

See M. above.

See M. above. 
Table 20. (continued).

Facility Name: MFC-798, Radioactive Liquid Waste Treatment Facility

\begin{tabular}{|l|l|}
\hline \multicolumn{1}{|c|}{ Chapter IV, LLW Requirements } & Facility Compliance Information \\
\hline $\begin{array}{l}\text { following facility requirements and general design } \\
\text { criteria, at a minimum, apply: }\end{array}$ & \\
\hline
\end{tabular}

(a) Confinement. Low-level waste systems and components shall be designed to maintain waste confinement.

(b) Ventilation.

1 Design of low-level waste disposal facilities shall include ventilation, if applicable, through an appropriate filtration system to maintain the release of radioactive material in airborne effluents within the requirements and guidelines specified in applicable requirements.

2 When conditions exist for generating gases in flammable or explosive concentrations, ventilation systems or other measures shall be provided to keep the gases in a nonflammable and non-explosive condition. Where concentrations of explosive or flammable gases are expected to approach the lower flammability limit, measures shall be taken to prevent deflagration or detonation.

(c) Stability. Low-level waste disposal facilities shall be designed to achieve long-term stability and to minimize to the extent practical, the need for active maintenance following final closure.

(d) Control of Water. Low-level waste disposal facilities shall be designed to minimize to the extent practical, the contact of waste with water during and after disposal.

N. Storage and Staging. The following requirements are in addition to those in Chapter I of this Manual [DOE M 435.1-1 §I.2.F(13)].

See M. above.

See M. above.

See M. above.

(1) Storage Prohibitions. Low-level waste in storage shall not be readily capable of detonation, explosive decomposition, reaction at anticipated pressures and temperatures, or explosive reaction with water. Prior to storage, pyrophoric materials shall be treated, prepared, and packaged to be nonflammable.

From DOE G 435.1-1 Chapter IV: Compliance with this requirement is demonstrated by having waste acceptance requirements which prohibit low-level waste that is ignitable or explosive from being accepted for storage unless it has been treated, and procedures for properly preparing such materials for safe storage.

(2) Storage Limit. Low-level waste that has an identified path to disposal shall not be stored longer than one year prior to disposal, except for storage for

DOE Manual 435.1-1 §I.2.F(13) applies to field element managers.
NA; this facility does not store LLW.

See M. above.
NA; this facility does not store LLW. See N. (7) below for staging requirements. 
Table 20. (continued).

Facility Name: MFC-798, Radioactive Liquid Waste Treatment Facility

\begin{tabular}{|c|c|}
\hline Chapter IV, LLW Requirements & Facility Compliance Information \\
\hline $\begin{array}{l}\text { decay, or as otherwise authorized by the Field Element } \\
\text { Manager. }\end{array}$ & \\
\hline $\begin{array}{l}\text { From DOE G } 435.1-1 \text { Chapter IV: Storage longer than } \\
\text { one year can be justified if the conditions for such } \\
\text { storage are approved by the Field Element Manager as } \\
\text { part of the radioactive waste management basis for the } \\
\text { facility. }\end{array}$ & \\
\hline $\begin{array}{l}\text { Storage for radioactive decay for a period greater than } 1 \\
\text { year for waste that has an identified path to disposal is } \\
\text { allowed. Adequate justification and the supporting } \\
\text { information for storage for decay is to be documented } \\
\text { in the radioactive waste management basis for the } \\
\text { facility in which the storage will take place. }\end{array}$ & \\
\hline $\begin{array}{l}\text { Mixed waste. Under the Federal Facility Compliance } \\
\text { Act of 1992, DOE sites were required to develop Site } \\
\text { Treatment Plans to bring stored mixed low-level waste } \\
\text { into compliance with these requirements. The Site } \\
\text { Treatment Plan needs to be consulted and any mixed } \\
\text { low-level waste stored for the purpose of accumulation } \\
\text { to facilitate treatment must meet Resource Conservation } \\
\text { and Recovery Act storage requirements. There could be } \\
\text { several ways within different scenarios that this } \\
\text { requirement can be met, as illustrated by the examples } \\
\text { below, however, there are basically four ways to show } \\
\text { compliance with the requirement and include } \\
\text { appropriate provisions in the radioactive waste } \\
\text { management basis for the facility in which it is stored. }\end{array}$ & \\
\hline $\begin{array}{l}\text { Legacy waste. As discussed above, the intention of the } \\
\text { requirement is not to force malicious compliance or } \\
\text { heroic actions which would result in increased risk or } \\
\text { safety concerns. Rather, the intention is that waste in } \\
\text { storage longer than one year receives additional } \\
\text { attention to ensure that the public, the workers, and the } \\
\text { environment are protected from the hazards of the } \\
\text { waste, and that progress is being made to dispose of the } \\
\text { waste. There could be several ways within different } \\
\text { scenarios that this requirement can be met, as illustrated } \\
\text { by the examples below, however, there are basically } \\
\text { four ways to show compliance with the requirement: }\end{array}$ & \\
\hline $\begin{array}{l}\text { 1) the radioactive waste management basis allows for } \\
\text { storage for no more than one year. }\end{array}$ & \\
\hline $\begin{array}{l}\text { 2) the radioactive waste management basis allows for } \\
\text { storage for no more than one year, or for storage for } \\
\text { decay only for periods greater than a year, which are } \\
\text { specified on a radionuclide basis. }\end{array}$ & \\
\hline $\begin{array}{l}\text { 3) the radioactive waste management basis allows for } \\
\text { storage for more than one year, up to a specified period } \\
\text { of time based on a documented technical evaluation that }\end{array}$ & \\
\hline
\end{tabular}


Table 20. (continued).

Facility Name: MFC-798, Radioactive Liquid Waste Treatment Facility

\begin{tabular}{l} 
Chapter IV, LLW Requirements \\
\hline the waste can be stored in a manner that does not cause \\
changes to the waste or waste packages that is \\
detrimental to the safe storage of the waste, the final \\
disposal of the waste or to meeting the disposal \\
performance objectives. \\
4) the radioactive waste management basis allows for \\
storage for decay (with specifics) and for storage for \\
more than one year for other low-level waste, up to a \\
specified period of time based on a documented \\
technical evaluation that the waste can be stored in a \\
manner that does not cause changes to the waste or \\
waste packages that is detrimental to the safe storage of \\
the waste, the final disposal of the waste or to meeting \\
the disposal performance objectives. \\
Compliance with this requirement is demonstrated by \\
the existence of a radioactive waste management basis \\
for the storage facility approved by the Field Element \\
Manager that includes the time frames that waste are \\
allowed to be stored, the necessary justifications for \\
storage for decay, and the necessary technical \\
evaluations if storage is to extend significantly beyond \\
the one-year time frame.
\end{tabular}

(3) Storage Integrity. Low-level waste shall be stored in a location and manner that protects the integrity of waste for the expected time of storage and minimizes worker exposure.

However, in making a decision to use a facility for storage and in developing a radioactive waste management basis for the activity, particular attention to protection of workers is needed.

From DOE G 435.1-1 Chapter IV: Compliance with this requirement is demonstrated if sites have storage capabilities for low-level waste that provide protection to waste containers so that their integrity will not be damaged through physical or chemical (corrosion) processes and that keep personnel from spending extended periods of time in the areas where low-level waste is stored.

(4) Waste Characterization for Storage.

(a) Low-level waste that does not have an identified path to disposal shall be characterized as necessary to meet the data quality objectives and minimum characterization requirements of this Chapter, to ensure safe storage, and to facilitate disposal.

(b) Characterization information for all low-level waste in storage shall be maintained as a record in accordance
NA; this facility does not store LLW. See N. (7) below for staging requirements.
NA; this facility does not store LLW. See N. (7) below for staging requirements.

NA; this facility does not store LLW. See N. (7) below for staging requirements.
NA; this facility does not store LLW. See N. (7) below for staging requirements. 
Table 20. (continued).

Facility Name: MFC-798, Radioactive Liquid Waste Treatment Facility

\begin{tabular}{l} 
Chapter IV, LLW Requirements \\
\hline with the requirements for Records Management in \\
Chapter I of this Manual. \\
From DOE G 435.1-1 Chapter IV: Compliance with \\
this requirement is demonstrated by documented \\
procedures for managing waste characterization and \\
container information on low-level waste as a Federal \\
record. The records are managed per the applicable \\
policies and procedures for records management \\
referenced in DOE O 200.1 and established at the \\
applicable Field Element.
\end{tabular}

(5) Container Inspection. A process shall be developed and implemented for inspecting and maintaining containers of low-level waste to ensure container integrity is not compromised.

From DOE G 435.1-1 Chapter IV: Compliance with this requirement is demonstrated by: (1) a documented process for waste container inspection and maintenance; and (2) documentation for all waste container inspections and maintenance actions performed.

(6) Storage Management. Low-level waste storage shall be managed to identify and segregate low-level waste from mixed low-level waste.

(7) Staging. Staging of low-level waste shall be for the purpose of the accumulation of such quantities of waste as necessary to facilitate transportation, treatment, and disposal. Staging longer than 90 days shall meet the requirements for storage above and in Chapter I of this Manual.

From DOE G 435.1-1 Chapter IV: The staging of lowlevel waste needs to be addressed in the radioactive waste management basis for the facility that is performing the staging. Generators, treatment facilities, and disposal facilities that stage waste must ensure that the action of staging is included and authorized as part of their radioactive waste management basis for the affected facilities, operations, or activities.

Staging longer than 90 days must be justified, the conditions for such storage met, and these practices approved by the Field Element Manager as part of the radioactive waste management basis for the facility.

Compliance with this requirement is demonstrated by a staging program that limits the temporary storage of waste to only circumstances allowed in the requirement, including justifications for any staging that exceeds the 90-day period, which is documented in the radioactive waste management basis for the facility.
LI-435 requires quarterly inspections of radioactive waste containers if waste is stored outdoors or has been in storage for greater than 1 year.
NA; this facility does not store LLW. See N. (7) below for staging requirements.

Routine LLW, such as personnel protective equipment, is accumulated at this facility for disposal.

MCP-17000, Appendix F restricts staging LLW to 90 days maximum at any generator or treatment facility prior to acceptance by a storage facility.

As stated in DOE Guide 435.1-1 §IV.N.(7), staging waste in accordance with this requirement allows waste to be accumulated without being considered storage and being bound by the associated storage requirements 
Table 20. (continued).

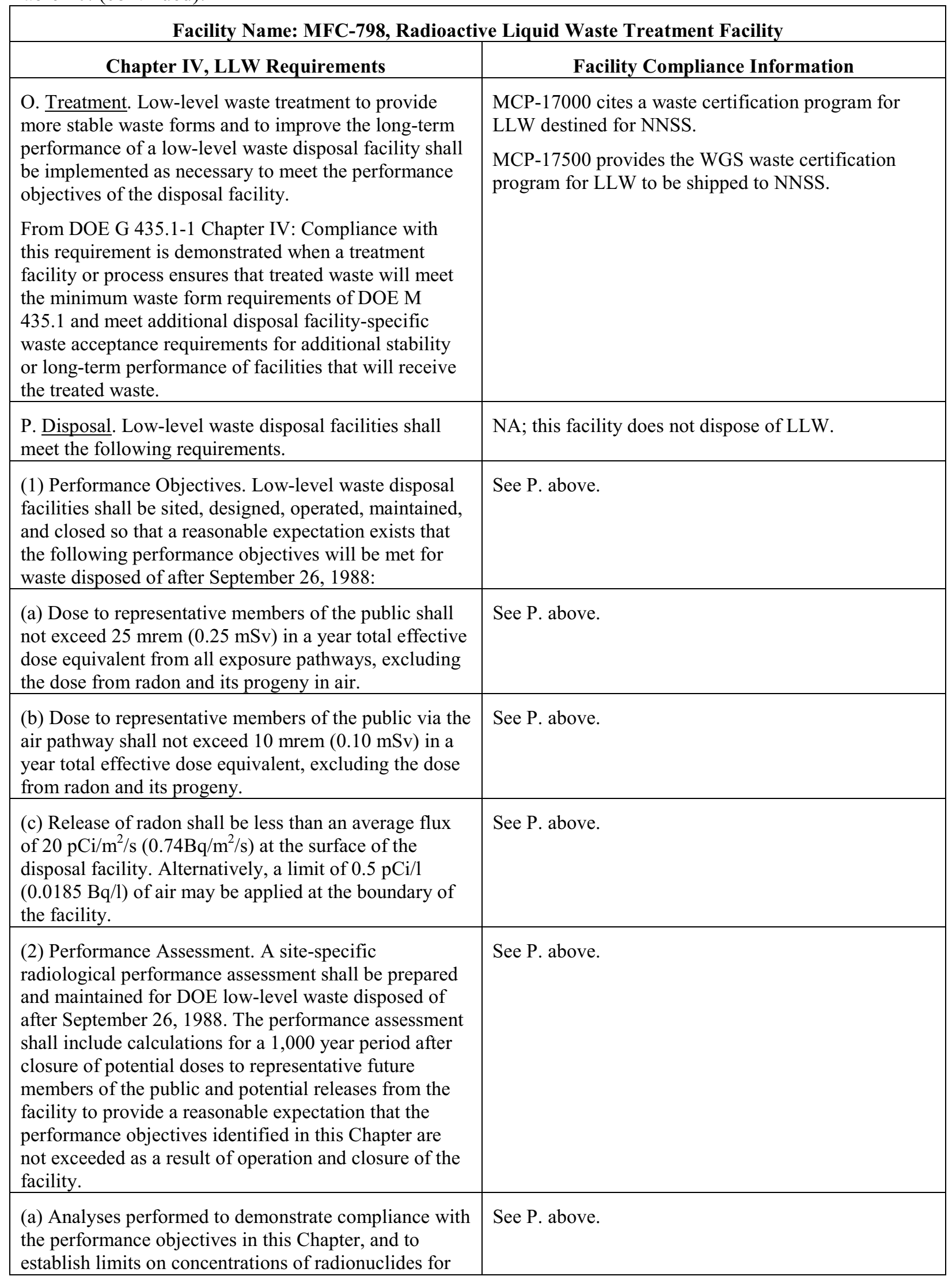


Table 20. (continued).

Facility Name: MFC-798, Radioactive Liquid Waste Treatment Facility

Chapter IV, LLW Requirements Facility Compliance Information

disposal based on the performance measures for inadvertent intruders in this Chapter shall be based on reasonable activities in the critical group of exposed individuals. Unless otherwise specified, the assumption of average living habits and exposure conditions in representative critical groups of individuals projected to receive the highest doses is appropriate. The likelihood of inadvertent intruder scenarios may be considered in interpreting the results of the analyses and establishing radionuclide concentrations, if adequate justification is provided.

(b) The point of compliance shall correspond to the point of highest projected dose or concentration beyond a 100 meter buffer zone surrounding the disposed waste. A larger or smaller buffer zone may be used if adequate justification is provided.

(c) Performance assessments shall address reasonably foreseeable natural processes that might disrupt barriers against release and transport of radioactive materials.

(d) Performance assessments shall use DOE-approved dose coefficients (dose conversion factors) for internal and external exposure of reference adults.

(e) The performance assessment shall include a sensitivity/uncertainty analysis.

(f) Performance assessments shall include a demonstration that projected releases of radionuclides to the environment shall be maintained as low as reasonably achievable (ALARA).

(g) For purposes of establishing limits on radionuclides that may be disposed of near-surface, the performance assessment shall include an assessment of impacts to water resources.

(h) For purposes of establishing limits on the See P. above. concentration of radionuclides that may be disposed of near-surface, the performance assessment shall include an assessment of impacts calculated for a hypothetical person assumed to inadvertently intrude for a temporary period into the low-level waste disposal facility. For intruder analyses, institutional controls shall be assumed to be effective in deterring intrusion for at least 100 years following closure. The intruder analyses shall use performance measures for chronic and acute exposure scenarios, respectively, of $100 \mathrm{mrem}(1 \mathrm{mSv})$ in a year and $500 \mathrm{mrem}(5 \mathrm{mSv})$ total effective dose equivalent excluding radon in air.

(3) Composite Analysis. For disposal facilities which received waste after September 26, 1988, a site-specific

See P. above.

See P. above.

See P. above.

See P. above.

See P. above.

See P. above. 
Table 20. (continued).

Facility Name: MFC-798, Radioactive Liquid Waste Treatment Facility

\begin{tabular}{|l|l|}
\hline \multicolumn{1}{|c|}{ Chapter IV, LLW Requirements } & Facility Compliance Information \\
\hline radiological composite analysis shall be prepared and & \\
maintained that accounts for all sources of radioactive & \\
material that may be left at the DOE site and may & \\
interact with the low- level waste disposal facility, & \\
contributing to the dose projected to a hypothetical & \\
member of the public from the existing or future & \\
disposal facilities. Performance measures shall be & \\
consistent with DOE requirements for protection of the & \\
public and environment and evaluated for a 1,000 year & \\
period following disposal facility closure. The & \\
composite analysis results shall be used for planning, & \\
radiation protection activities, and future use & \\
commitments to minimize the likelihood that current & \\
low- level waste disposal activities will result in the & \\
need for future corrective or remedial actions to & \\
adequately protect the public and the environment. & \\
\hline
\end{tabular}

(4) Performance Assessment and Composite Analysis Maintenance. The performance assessment and composite analysis shall be maintained to evaluate changes that could affect the performance, design, and operating bases for the facility. Performance assessment and composite analysis maintenance shall include the conduct of research, field studies, and monitoring needed to address uncertainties or gaps in existing data.

The performance assessment shall be updated to support the final facility closure. Additional iterations of the performance assessment and composite analysis shall be conducted as necessary during the post-closure period.

(a) Performance assessments and composite analyses shall be reviewed and revised when changes in waste forms or containers, radionuclide inventories, facility design and operations, closure concepts, or the improved understanding of the performance of the waste disposal facility in combination with the features of the site on which it is located alter the conclusions or the conceptual model(s) of the existing performance assessment or composite analysis.

(b) A determination of the continued adequacy of the performance assessment and composite analysis shall be made on an annual basis, and shall consider the results of data collection and analysis from research, field studies, and monitoring.

(c) Annual summaries of low-level waste disposal operations shall be prepared with respect to the conclusions and recommendations of the performance assessment and composite analysis and a determination of the need to revise the performance assessment or composite analysis.

See P. above.

See P. above.

See P. above.

See P. above. 
Table 20. (continued).

\begin{tabular}{|c|c|}
\hline \multicolumn{2}{|c|}{ Facility Name: MFC-798, Radioactive Liquid Waste Treatment Facility } \\
\hline Chapter IV, LLW Requirements & Facility Compliance Information \\
\hline $\begin{array}{l}\text { (5) Disposal Authorization. A disposal authorization } \\
\text { statement shall be obtained prior to construction of a } \\
\text { new low-level waste disposal facility. Field Elements } \\
\text { with existing low-level waste disposal facilities shall } \\
\text { obtain a disposal authorization statement in accordance } \\
\text { with the schedule in the Complex-Wide Low-Level } \\
\text { Waste Management Program Plan. The disposal } \\
\text { authorization statement shall be issued based on a } \\
\text { review of the facility's performance assessment, } \\
\text { composite analysis, performance assessment and } \\
\text { composite analysis maintenance, preliminary closure } \\
\text { plan, and preliminary monitoring plan. The disposal } \\
\text { authorization statement shall specify the limits and } \\
\text { conditions on construction, design, operations, and } \\
\text { closure of the low-level waste facility based on these } \\
\text { reviews. A disposal authorization statement is a part of } \\
\text { the radioactive waste management basis for a disposal } \\
\text { facility. Failure to obtain a disposal authorization } \\
\text { statement by the implementation date of this Order shall } \\
\text { result in shutdown of the disposal facility. }\end{array}$ & See P. above. \\
\hline $\begin{array}{l}\text { (6) Disposal Facility Operations. The disposal facility } \\
\text { design and operation must be consistent with the } \\
\text { disposal facility closure plan and lead to disposal } \\
\text { facility closure that provides a reasonable expectation } \\
\text { that performance objectives will be met. Low-level } \\
\text { waste shall be disposed in such a manner that achieves } \\
\text { the performance objectives stated in this Chapter, } \\
\text { consistent with the disposal facility radiological } \\
\text { performance assessment. Additional requirements } \\
\text { include: }\end{array}$ & See P. above. \\
\hline $\begin{array}{l}\text { (a) Operating procedures shall be developed and } \\
\text { implemented for low-level waste disposal facilities that } \\
\text { protect the public, workers, and the environment; } \\
\text { ensure the security of the facility; minimize subsidence } \\
\text { during and after waste emplacement; achieve long-term } \\
\text { stability and minimize the need for long-term active } \\
\text { maintenance; and meet the requirements of the } \\
\text { closure/post-closure plan. }\end{array}$ & See P. above. \\
\hline $\begin{array}{l}\text { (b) Permanent identification markers for disposal } \\
\text { excavations and monitoring wells shall be emplaced. }\end{array}$ & See P. above. \\
\hline $\begin{array}{l}\text { (c) Low-level waste placement into disposal units shall } \\
\text { minimize voids between waste containers. Voids within } \\
\text { disposal units shall be filled to the extent practical. } \\
\text { Uncontainerized bulk waste shall also be placed in a } \\
\text { manner that minimizes voids and subsidence. }\end{array}$ & See P. above. \\
\hline $\begin{array}{l}\text { (d) Operations are to be conducted so that active waste } \\
\text { disposal operations will not have an adverse effect on } \\
\text { any other disposal units. }\end{array}$ & See P. above. \\
\hline
\end{tabular}


Table 20. (continued).

Facility Name: MFC-798, Radioactive Liquid Waste Treatment Facility

Chapter IV, LLW Requirements Facility Compliance Information

(e) Operations shall include a process for tracking and documenting low-level waste placement in the facility by generator source.

(7) Alternate Requirements for Low-Level Waste Disposal Facility Design and Operation. Requirements other than those set forth in this Section for the design and operation of a low-level waste disposal facility may be approved on a specific basis if a reasonable expectation is demonstrated that the disposal performance objectives will be met.

Q. Closure. The following requirements are in addition to those in Chapter I of this Manual.

(1) Disposal Facility Closure Plans. A preliminary closure plan shall be developed and submitted to Headquarters for review with the performance assessment and composite analysis. The closure plan shall be updated following issuance of the disposal authorization statement to incorporate conditions specified in the disposal authorization statement. Closure plans shall:

(a) Be updated as required during the operational life of the facility.

(b) Include a description of how the disposal facility will be closed to achieve long-term stability and minimize the need for active maintenance following closure and to ensure compliance with the requirements of DOE 5400.5, Radiation Protection of the Public and the Environment.

(c) Include the total expected inventory of wastes to be disposed of at the facility over the operational life of the facility.

(2) Disposal Facility Closure. Closure of a disposal facility shall occur within a five-year period after it is filled to capacity, or after the facility is otherwise determined to be no longer needed.

(a) Prior to facility closure, the final inventory of the low-level waste disposed in the facility shall be prepared and incorporated in the performance assessment and composite analysis which shall be updated to support the closure of the facility.

(b) A final closure plan shall be prepared based on the final inventory of waste disposed in the facility, the plan implemented, and the updated performance assessment and composite analysis prepared in support of the facility closure.

NA; this facility does not dispose of LLW.

See Q. above.

See P. above.

See P. above.

See Q

See Q. above.

See Q. above.

See Q. above.

See Q. above.

See Q. above.

See Q. above. 
Table 20. (continued).

\begin{tabular}{|c|c|}
\hline \multicolumn{2}{|c|}{ Facility Name: MFC-798, Radioactive Liquid Waste Treatment Facility } \\
\hline Chapter IV, LLW Requirements & Facility Compliance Information \\
\hline $\begin{array}{l}\text { (c) Institutional control measures shall be integrated } \\
\text { into land use and stewardship plans and programs, and } \\
\text { shall continue until the facility can be released pursuant } \\
\text { to DOE } 5400.5 \text {, Radiation Protection of the Public and } \\
\text { the Environment. }\end{array}$ & See Q. above. \\
\hline $\begin{array}{l}\text { (d) The location and use of the facility shall be filed } \\
\text { with the local authorities responsible for land use and } \\
\text { zoning. }\end{array}$ & See Q. above. \\
\hline $\begin{array}{l}\text { R. Monitoring. The following requirements are in } \\
\text { addition to those in Chapter I of this Manual [DOE M } \\
435.1-1 \text { §I.1.E(7)]. }\end{array}$ & $\begin{array}{l}\text { Not a facility-specific requirement. DOE Manual } \\
435.1-1 \S I .1 . E(7) \text { applies to field element managers. }\end{array}$ \\
\hline $\begin{array}{l}\text { (1) All Waste Facilities. Parameters that shall be } \\
\text { sampled or monitored, at a minimum, include: } \\
\text { temperature, pressure (for closed systems), radioactivity } \\
\text { in ventilation exhaust and liquid effluent streams, and } \\
\text { flammable or explosive mixtures of gases. Facility } \\
\text { monitoring programs shall include verification that } \\
\text { passive and active control systems have not failed. } \\
\text { From DOE G 435.1-1 Chapter IV: The minimum } \\
\text { parameters specified in the requirement were selected } \\
\text { based on their potential significance for anticipating and } \\
\text { identifying undesirable conditions at low-level waste } \\
\text { management facilities. Each facility's radioactive waste } \\
\text { management basis should include an evaluation of the } \\
\text { applicability and significance of the minimum } \\
\text { parameters. This evaluation also needs to consider } \\
\text { additional parameters to be sampled or monitored to } \\
\text { ensure the protection of the public health, the } \\
\text { environment, and the workers. If a minimum parameter } \\
\text { specified in the requirement is deemed to be not } \\
\text { applicable in any way to the active operation of that } \\
\text { facility, then that justification should be included in the } \\
\text { radioactive waste management basis and when } \\
\text { approved constitutes an exemption to the manual. }\end{array}$ & $\begin{array}{l}\text { Monitoring requirements at INL radioactive waste } \\
\text { management facilities are tailored for the specific } \\
\text { facility to enable timely indication of developing } \\
\text { problems. Existing radiological control procedures and } \\
\text { assessments are followed/completed to monitor waste } \\
\text { facilities. } \\
\text { LRD-15001 and MCP-139 specify methods and } \\
\text { frequency of radiological control surveys of all } \\
\text { radiological areas. MCP-139 specifies the use of } \\
\text { Form } 441 . \text { A34. This form is referred to as the "routine } \\
\text { sheet" and is to be used by facility radiological control } \\
\text { foremen to list radiological areas that are to be } \\
\text { surveyed, the survey periods, and methods. }\end{array}$ \\
\hline $\begin{array}{l}\text { Verification activities are part of the radioactive waste } \\
\text { management basis as a condition for operation and } \\
\text { documented appropriately. }\end{array}$ & \\
\hline $\begin{array}{l}\text { Compliance with this requirement is demonstrated if } \\
\text { monitoring or sampling for the stated parameters is } \\
\text { performed for all facilities with a precision, accuracy, } \\
\text { and frequency consistent with timely identification of } \\
\text { developing problems and a justification exists in the } \\
\text { approved radioactive waste management basis for those } \\
\text { specified parameters which are not monitored or } \\
\text { sampled. }\end{array}$ & \\
\hline $\begin{array}{l}\text { (2) Liquid Waste Storage Facilities. For facilities } \\
\text { storing liquid low-level waste, the following shall also }\end{array}$ & NA; this facility is not a liquid LLW storage facility. \\
\hline
\end{tabular}


Table 20. (continued).

Facility Name: MFC-798, Radioactive Liquid Waste Treatment Facility

\begin{tabular}{|c|c|}
\hline Chapter IV, LLW Requirements & Facility Compliance Information \\
\hline $\begin{array}{l}\text { be monitored: liquid level and/or waste volume, and } \\
\text { significant waste chemistry parameters. }\end{array}$ & \\
\hline $\begin{array}{l}\text { (3) Disposal Facilities. A preliminary monitoring plan } \\
\text { for a low-level waste disposal facility shall be prepared } \\
\text { and submitted to Headquarters for review with the } \\
\text { performance assessment and composite analysis. The } \\
\text { monitoring plan shall be updated within one year } \\
\text { following issuance of the disposal authorization } \\
\text { statement to incorporate and implement conditions } \\
\text { specified in the disposal authorization statement. }\end{array}$ & NA; this facility is not a LLW disposal facility. \\
\hline $\begin{array}{l}\text { (a) The site-specific performance assessment and } \\
\text { composite analysis shall be used to determine the } \\
\text { media, locations, radionuclides, and other substances to } \\
\text { be monitored. }\end{array}$ & See (3) above. \\
\hline $\begin{array}{l}\text { (b) The environmental monitoring program shall be } \\
\text { designed to include measuring and evaluating releases, } \\
\text { migration of radionuclides, disposal unit subsidence, } \\
\text { and changes in disposal facility and disposal site } \\
\text { parameters which may affect long-term performance. }\end{array}$ & See (3) above. \\
\hline $\begin{array}{l}\text { (c) The environmental monitoring programs shall be } \\
\text { capable of detecting changing trends in performance to } \\
\text { allow application of any necessary corrective action } \\
\text { prior to exceeding the performance objectives in this } \\
\text { Chapter. }\end{array}$ & See (3) above. \\
\hline
\end{tabular}

\subsection{MFC-797, Outside Radioactive Storage Area}

1. Facility description: Outdoor radioactive waste storage area.

2. Hazard category: LTHC3

3. Radioactive waste managed at this facility: CH LLW and mixed CH LLW are stored at this facility. The mixed LLW is accumulated in an SAA for disposition.

4. RWMB documents/programs:

a. Safety basis/hazard analysis:

- EDF-7030, "Inventory Analysis of Radiological Facilities at the Materials and Fuels Complex (MFC)"

b. Laboratory-wide:

- Form 441.A34, "INL Radiological Control Required Surveys"

- FRM-323, "TSD Facilities Material Acceptance Checksheet"

- LI-435, "Waste Management Routine Field Activities"

- LRD-15001, "Radiological Control Manual"

- LWP-13840, "Management of Issues, Observations, and Noteworthy Practices"

- LWP-14002, "Timeout and Stop Work Authority" 
- LWP-15011, "Radioactive Material Areas and Radioactive Storage Areas"

- MCP-139, "Radiological Surveys"

- MCP-17000, "Waste Generator Services Waste Management"

- MCP-17410, "Management of Waste Storage Areas"

- MCP-17500, "Waste Generator Services Certification of Waste Shipments to the Nevada Test Site"

- PDD-17000, "Waste Management Program"

- PLN-114, "INL Emergency Plan/RCRA Contingency Plan"

- PLN-522, "Quality Assurance Program Plan for the Waste Management/Waste Certification Program"

c. Facility-specific:

- SD-38.1.1, "Treatment, Storage, and Disposal Facilities (TSDF) Environmental Compliance"

- TSD-OI-004, "Waste and Material Acceptance for Storage/Treatment and Radioactive Material Inventory Control."

LLW is managed at this facility. Table 21 shows the facility compliance information for DOE Manual 435.1-1, Chapter IV, "Low-level Waste Requirements."

Table 21. MFC-797, Outside Radioactive Storage Area, DOE Manual 435.1-1 low-level waste requirements and facility compliance information.

\begin{tabular}{|c|c|}
\hline \multicolumn{2}{|c|}{ MFC-797 Outside Radioactive Storage Area } \\
\hline Chapter IV. Low-Level Waste Requirements & Facility Compliance Information \\
\hline $\begin{array}{l}\text { A. Definition of Low-Level Waste. Low-level } \\
\text { radioactive waste is radioactive waste that is not high- } \\
\text { level radioactive waste, spent nuclear fuel, transuranic } \\
\text { waste, byproduct material (as defined in section 11e.(2) } \\
\text { of the Atomic Energy Act of 1954, as amended), or } \\
\text { naturally occurring radioactive material. } \\
\text { (From DOE G } 435.1-1 \text { Chapter IV: Low-level } \\
\text { radioactive waste is defined by what it is not. The } \\
\text { guidance on definitions in Chapters II and III should be } \\
\text { consulted first for making a determination on how to } \\
\text { properly manage a suspect waste stream.) }\end{array}$ & $\begin{array}{l}\text { This requirement provides the criteria for determining } \\
\text { which DOE radioactive waste is to be managed as } \\
\text { LLW in accordance with DOE Manual } 435.1-1 \text {, } \\
\text { Chapter IV. } \\
\text { Radioactive waste managed at this facility under the } \\
\text { requirements of this chapter is not managed under the } \\
\text { requirements of DOE Manual } 435.1-1 \text {, Chapter II or } \\
\text { Chapter III. }\end{array}$ \\
\hline $\begin{array}{l}\text { B. Management of Specific Wastes. The following } \\
\text { provide for management of specific wastes as low-level } \\
\text { waste in accordance with the requirements in this } \\
\text { Chapter: }\end{array}$ & See below. \\
\hline $\begin{array}{l}\text { (1) Mixed Low-Level Waste. Low-level waste } \\
\text { determined to contain both source, special nuclear, or } \\
\text { byproduct material subject to the Atomic Energy Act of } \\
\text { 1954, as amended, and a hazardous component subject } \\
\text { to the Resource Conservation and Recovery Act } \\
\text { (RCRA), as amended, shall be managed in accordance } \\
\text { with the requirements of RCRA and DOE O 435.1, } \\
\text { Radioactive Waste Management, and this Manual. }\end{array}$ & $\begin{array}{l}\text { This facility manages mixed LLW in SAAs. } \\
\text { Management of SAAs is addressed in MCP-17410, and } \\
\text { overall management of mixed waste is addressed in } \\
\text { MCP-17000. }\end{array}$ \\
\hline $\begin{array}{l}\text { (2) TSCA-Regulated Waste. Low-level waste } \\
\text { containing polychlorinated biphenyls, asbestos, or other }\end{array}$ & $\begin{array}{l}\text { NA; this facility does not manage TSCA-regulated } \\
\text { waste. }\end{array}$ \\
\hline
\end{tabular}


Table 21. (continued).

\section{MFC-797 Outside Radioactive Storage Area}

Chapter IV. Low-Level Waste Requirements such regulated toxic components shall be managed in accordance with requirements derived from the Toxic Substances Control Act, as amended, DOE O 435.1, Radioactive Waste Management, and this Manual.

(3) Accelerator-Produced Waste. Radioactive waste produced as a result of operations of DOE accelerators is low-level waste and shall be managed in accordance with DOE O 435.1, Radioactive Waste Management, and this Manual, and all applicable Federal or State requirements.

(4) 11e.(2) and Naturally Occurring Radioactive Material. Small quantities of 11e.(2) byproduct material and naturally occurring radioactive material may be managed as low-level waste provided they can be managed to meet the requirements for low-level waste disposal in Section IV.P of this Manual.

C. Complex-Wide Low-Level Waste Management Program. A complex-wide program and plan shall be developed as described under Responsibilities, 2.B and 2.D, in Chapter I of this Manual.

D. Radioactive Waste Management Basis. Low-level waste facilities, operations, and activities shall have a radioactive waste management basis consisting of physical and administrative controls to ensure the protection of workers, the public, and the environment. The following specific waste management controls shall be part of the radioactive waste management basis:

(1) Generators. The waste certification program.

From DOE G 435.1-1 Chapter IV: For a facility that generates low-level waste, the radioactive waste management basis is to include the program for certifying that waste meets the waste acceptance requirements of the facility(ies) to which the waste will be sent.

(2) Treatment Facilities. certification program. The waste acceptance requirements and the waste [sic]

From DOE G 435.1-1 Chapter IV: Facilities that store or treat low-level waste are to have approved waste acceptance requirements (see DOE M 435.1-1, Section IV.G) prior to the issuance of a radioactive waste management basis.

A facility that stores or treats waste also is generally expected to have a waste certification program. Waste from these facilities will have to be certified as meeting the waste acceptance requirements of the facility to

NA; this facility does not manage accelerator-produced waste. Facility Compliance Information

NA; this facility does not manage naturally occurring radioactive material.

Not a facility-specific requirement. DOE Manual 435.1-1 §I.2.B and §I.2.D apply to the Assistant Secretary for Environmental Management and the Deputy Assistant Secretary for Waste Management, respectively.

The RWMB provides the regulatory framework for management of radioactive waste at INL. It specifically identifies facility management and implementing documents for the generation, storage, treatment, and disposal of radiological waste..

This facility is a LTHC3 facility (EDF-7030).

NA; this facility does not generate LLW.

NA; this facility does not treat LLW. 
Table 21. (continued).

\section{MFC-797 Outside Radioactive Storage Area}

Chapter IV. Low-Level Waste Requirements which it will be transferred, and the facilities have the potential for generating radioactive waste (e.g., secondary processing streams from treatment, monitoring and sampling, radioactive release cleanup). Consequently, storage and treatment facilities should also have an approved waste certification program as part of their radioactive waste management basis.

As part of the radioactive waste management basis, site personnel needs to implement a system or process for tracking the waste inventory at a storage, treatment, or disposal facility.

(3) Storage Facilities. The waste acceptance requirements and the waste certification program.

From DOE G 435.1-1 Chapter IV: Facilities that store or treat low-level waste are to have approved waste acceptance requirements (see DOE M 435.1-1, Section IV.G) prior to the issuance of a radioactive waste management basis.

A facility that stores or treats waste also is generally expected to have a waste certification program. Waste from these facilities will have to be certified as meeting the waste acceptance requirements of the facility to which it will be transferred, and the facilities have the potential for generating radioactive waste (e.g., secondary processing streams from treatment, monitoring and sampling, radioactive release cleanup). Consequently, storage and treatment facilities should also have an approved waste certification program as part of their radioactive waste management basis.

As part of the radioactive waste management basis, site personnel needs to implement a system or process for tracking the waste inventory at a storage, treatment, or disposal facility.

(4) Disposal Facilities. The performance assessment, composite analysis, disposal authorization statement, closure plan, waste acceptance requirements, and monitoring plan.

E. Contingency Actions. The following requirements are in addition to those in Chapter I of this Manual [DOE M 435.1-1 §I.1.E(5)].

(1) Contingency Storage. For off-normal or emergency situations involving high activity or high hazard liquid low-level waste storage or treatment, spare capacity with adequate capabilities shall be maintained to receive the largest volume of liquid contained in any one storage tank or treatment facility. Tanks or other
See G. and J. below.

MCP-17000 § 4 specifies the use of IWTS, which tracks the waste inventory.

TSD-OI-004 § 3.2.1 addresses the use IWTS to track waste inventory.
NA; this facility is not a disposal facility.

Not a facility-specific requirement. DOE Manual 435.1-1 §I.1.E(5) addresses the sitewide emergency management system. The INL plan is provided in PLN-114.

NA; this facility does not store liquid waste in tanks. 
Table 21. (continued).

\section{MFC-797 Outside Radioactive Storage Area}

\begin{tabular}{|c|c|}
\hline Chapter IV. Low-Level Waste Requirements & Facility Compliance Information \\
\hline \multicolumn{2}{|l|}{$\begin{array}{l}\text { facilities that are designated low-level waste } \\
\text { contingency storage shall be maintained in an } \\
\text { operational condition when waste is present and shall } \\
\text { meet the requirements of DOE O 435.1, Radioactive } \\
\text { Waste Management, and this Manual. }\end{array}$} \\
\hline \multicolumn{2}{|l|}{$\begin{array}{l}\text { From DOE G 435.1-1 Chapter IV: Compliance with } \\
\text { these requirements is demonstrated if adequate spare } \\
\text { capacity and transfer equipment exists for emergency } \\
\text { transfers of all high activity and high hazard liquid low- } \\
\text { level waste. In addition, the capability to perform } \\
\text { emergency transfers is demonstrated by having waste } \\
\text { transfer routings identified, operational procedures to } \\
\text { direct transfers, staff trained to the procedures, and } \\
\text { records showing that the spare capacity and transfer } \\
\text { capability are kept in operating condition. }\end{array}$} \\
\hline $\begin{array}{l}\text { (2) Transfer Equipment. Pipelines and auxiliary } \\
\text { facilities necessary for the transfer of high activity or } \\
\text { high hazard liquid low-level waste to contingency } \\
\text { storage shall be maintained in an operational condition } \\
\text { when waste is present and shall meet the requirements } \\
\text { of DOE O } 435.1 \text {, Radioactive Waste Management, and } \\
\text { this Manual. }\end{array}$ & NA; this facility does not store liquid waste in tanks. \\
\hline \multicolumn{2}{|l|}{$\begin{array}{l}\text { From DOE G 435.1-1 Chapter IV: Compliance with } \\
\text { these requirements is demonstrated if adequate spare } \\
\text { capacity and transfer equipment exists for emergency } \\
\text { transfers of all high activity and high hazard liquid low- } \\
\text { level waste. In addition, the capability to perform } \\
\text { emergency transfers is demonstrated by having waste } \\
\text { transfer routings identified, operational procedures to } \\
\text { direct transfers, staff trained to the procedures, and } \\
\text { records showing that the spare capacity and transfer } \\
\text { capability are kept in operating condition. }\end{array}$} \\
\hline $\begin{array}{l}\text { F. Corrective Actions. I of this Manual. The following } \\
\text { requirements are in addition to those in Chapter [sic] }\end{array}$ & $\begin{array}{l}\text { The INL-wide procedure addressing problem } \\
\text { identification as required by DOE Manual 435.1-1 }\end{array}$ \\
\hline $\begin{array}{l}\text { From DOE G } 435.1-1 \text { Chapter IV: Compliance with } \\
\text { DOE M 435.1-1 §I.2.G.(1) is demonstrated by records }\end{array}$ & $\begin{array}{l}\text { §I.2.G.(1) is LWP-13840, which implements the } \\
\text { laboratory's corrective action system. }\end{array}$ \\
\hline $\begin{array}{l}\text { showing what corrective actions were taken to remedy } \\
\text { situations in the radioactive waste management system. }\end{array}$ & \\
\hline $\begin{array}{l}\text { Compliance with DOE M 435.1-1 §I.2.G.(2) is } \\
\text { demonstrated by having the necessary procedures, } \\
\text { mechanisms, and training in place to effect shutdown } \\
\text { or curtailment of activities which pose an imminent } \\
\text { danger or other serious hazard to workers or the public, } \\
\text { or are not protective of the environment. }\end{array}$ & 435.1-1 §I.2.G.(2) is LWP-14002. \\
\hline $\begin{array}{l}\text { (1) Order Compliance. Corrective actions shall be } \\
\text { implemented whenever necessary to ensure the } \\
\text { requirements of DOE O } 435.1 \text {, Radioactive Waste } \\
\text { Management, and this Manual are met. }\end{array}$ & See F. above. \\
\hline
\end{tabular}


Table 21. (continued).

\section{MFC-797 Outside Radioactive Storage Area}

\begin{tabular}{l}
\hline \multicolumn{1}{|c|}{ Chapter IV. Low-Level Waste Requirements } \\
\hline $\begin{array}{l}\text { From DOE G 435.1-1 Chapter IV: If a facility or } \\
\text { activity can be allowed to operate while a } \\
\text { noncompliant or hazardous condition exists, the } \\
\text { allowance and any associated limitations must be } \\
\text { defined as part of the facility or activity's radioactive } \\
\text { waste management basis, identified as a configuration } \\
\text { controlled item in a configuration management plan or } \\
\text { included in a revision or modification to an operating } \\
\text { procedure or similar controlled documentation. } \\
\text { Compliance with this requirement is demonstrated if a } \\
\text { corrective action system addresses noncompliant or } \\
\text { hazardous situations involving low-level waste } \\
\text { management facilities in a systematic fashion, and } \\
\text { allows identification of problems by all personnel. }\end{array}$ \\
\hline
\end{tabular}

(2) Operations Curtailment. Operations shall be curtailed or facilities shut down for failure to establish, maintain, or operate consistent with an approved radioactive waste management basis.

From DOE G 435.1-1 Chapter IV: Compliance with this requirement is demonstrated with a documented system of routine assessments to determine whether waste management activities and facilities are operating in accordance with an approved radioactive waste management basis that provides for graded limitations that can be placed on activities and operations that do not have, or are operating outside of, an approved radioactive waste management basis, including shutdown of the facility.

G. Waste Acceptance. The following requirements are in addition to those in Chapter I of this Manual [DOE $\mathrm{M} 435.1-1 \S \mathrm{I} .2 . \mathrm{F}(6)]$.

(1) Technical and Administrative. Waste acceptance requirements for all low-level waste storage, treatment, or disposal facilities, operations, and activities shall specify, at a minimum, the following:

From DOE G 435.1-1 Chapter IV: Compliance with these waste acceptance requirements is demonstrated if they are documented, contain clear and precise criteria specifying the radionuclide limits in the form of contents or concentrations that can be accepted, the limitations and prohibitions on waste forms and packages that can be received, and the limits, prohibitions, or instructions concerning any other technical information so that the waste is compatible with the safety basis of the facility, and which will result in acceptable waste at subsequent steps in managing the low-level waste.
The approved RWMB establishes the current compliance status at each radioactive waste management facility. Facility assessments are scheduled to ensure waste management activities are conducted in accordance with the approved RWMB.

Not a facility-specific requirement. DOE Manual 435.1-1 §I.2.F(6) applies to field element managers.

WGS manages LLW in accordance with MCP-17000.

SAAs are managed under MCP-17410

TSD-OI-004 $\S 2.2,3.2,3.3$, and 3.4

This facility is used primarily for storage of radioactive waste or material that does not contain any hazardous or mixed waste. Mixed waste is placed in the SAA located in the facility. 
Table 21. (continued).

\section{MFC-797 Outside Radioactive Storage Area}

Chapter IV. Low-Level Waste Requirements

(a) Allowable activities and/or concentrations of specific radionuclides.

(b) Acceptable waste form and/or container requirements that ensure the chemical and physical stability of waste under conditions that might be encountered during transportation, storage, treatment, or disposal.

(c) Restrictions or prohibitions on waste, materials, or containers that may adversely affect waste handlers or compromise facility or waste container performance.

(d) The following are additional waste acceptance requirements that shall be specified in low-level waste disposal facility waste acceptance requirements:

1 Low-level waste must contribute to and not detract from achieving long-term stability of the facility, minimizing the need for long-term active maintenance, minimizing subsidence, and minimizing contact of water with waste. Void spaces within the waste and, if containers are used, between the waste and its container shall be reduced to the extent practical.

2 Liquid low-level waste or low-level waste containing free liquid must be converted into a form that contains as little freestanding liquid as is reasonably achievable, but in no case shall the liquid exceed 1 percent of the waste volume when the low-level waste is in a disposal container, or 0.5 percent of the waste volume after it is processed to a stable form.

3 Low-level waste must not be readily capable of detonation or of explosive decomposition or reaction at anticipated pressures and temperatures, or of explosive reaction with water. Pyrophoric materials contained in waste shall be treated, prepared, and packaged to be nonflammable.

4 Low-level waste must not contain, or be capable of generating by radiolysis or biodegradation, quantities of toxic gases, vapors, or fumes harmful to the public or workers or disposal facility personnel, or harmful to the long-term structural stability of the disposal site.

5 Low-level waste in a gaseous form must be packaged such that the pressure does not exceed 1.5 atmospheres absolute at $20 \mathrm{C}$. [sic]

(e) The basis, procedures, and levels of authority required for granting exceptions to the waste acceptance requirements, which shall be contained in each facility's waste acceptance documentation. Each exception request shall be documented, including its
Facility Compliance Information

See (1) above.

See (1) above.

See (1) above.

NA; this facility is not a LLW disposal facility.

See (d) above.

See (d) above.

See (d) above.

See (d) above.

See (d) above.

Exceptions to the waste acceptance requirements are not permitted. 
Table 21. (continued).

\section{MFC-797 Outside Radioactive Storage Area}

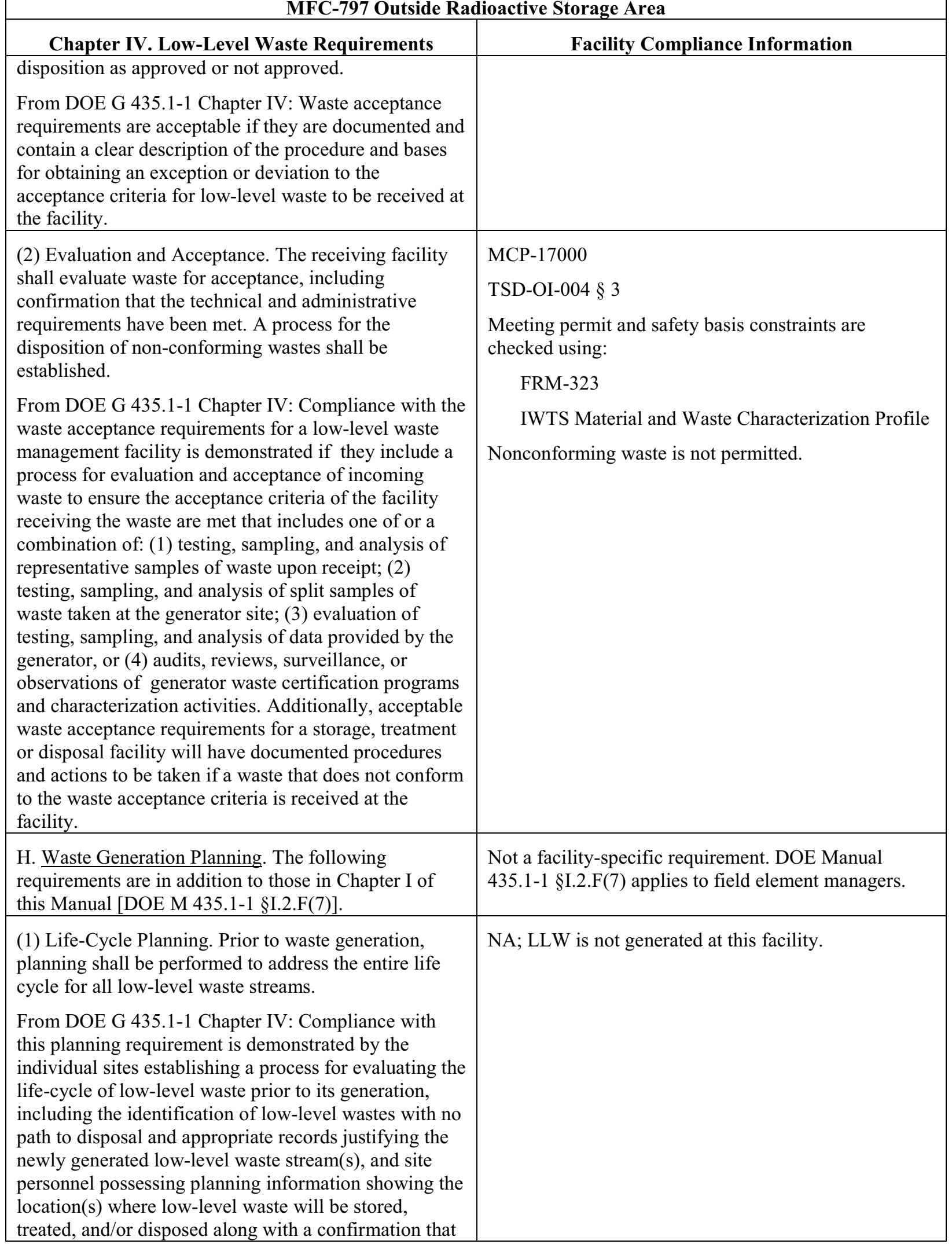


Table 21. (continued).

\section{MFC-797 Outside Radioactive Storage Area}

Chapter IV. Low-Level Waste Requirements the personnel managing the facilities agree that the low-level waste may be managed at those facilities.

(2) Waste with No Identified Path to Disposal. Lowlevel waste streams with no identified path to disposal shall be generated only in accordance with approved conditions which, at a minimum, shall address:

(a) Programmatic need to generate the waste;
(b) Characteristics and issues preventing the disposal of
the waste;

(c) Safe storage of the waste until disposal can be achieved; and

(d) Activities and plans for achieving final disposal of the waste.

I. Waste Characterization. Low-level waste shall be characterized using direct or indirect methods, and the characterization documented in sufficient detail to ensure safe management and compliance with the waste acceptance requirements of the facility receiving the waste.

From DOE G 435.1-1 Chapter IV: Compliance with this requirement is demonstrated by a program for documenting and the existence of records that document the process for acquiring and verifying the validity of low-level waste characterization data acquired through the use of direct or indirect methods.

(1) Data Quality Objectives. The data quality objectives process, or a comparable process, shall be used for identifying characterization parameters and acceptable uncertainty in characterization data.

From DOE G 435.1-1 Chapter IV: Compliance with this requirement is demonstrated by the documented use of a data quality objectives or a comparable process for determining the type, quantity, and quality of characterization data needed to safely manage lowlevel waste.

(2) Minimum Waste Characterization. Characterization data shall, at a minimum, include the following information relevant to the management of the waste:

From DOE G 435.1-1 Chapter IV: Compliance with this requirement is demonstrated by the existence of a program or procedure for determining and records that document characterization of low-level waste consistent with the minimum characterization data requirements.

(a) Physical and chemical characteristics;
Facility Compliance Information

NA; this facility is not generating LLW that does not have an identified path to disposal.

See (2) above.

See (2) above.

See (2) above.

See (2) above.

MCP-17000

TSD-OI-004 $§ 3.2 .6$ and Appendix C
Radioactive waste management facilities characterize waste in accordance with the requirements of the receiving storage, treatment, or disposal facility. The documented use of a data quality objectives process, or comparable process, was not identified for this facility.
MCP-17000, including $\S \S 4.2,4.3$, and 4.4, provides waste characterization requirements. Information on absorbent media is required in $\S \S 4.5$ and 4.7. MCP-17000 also specifies the use of IWTS, which documents characterization data in an IWTS profile.

TSD-OI-004 § 3.2.6 and Appendix C

FRM-323

IWTS Material and Waste Characterization Profile

See I. and (2) above. 
Table 21. (continued).

\section{MFC-797 Outside Radioactive Storage Area}

Chapter IV. Low-Level Waste Requirements

(b) Volume, including the waste and any stabilization or absorbent media;

(c) Weight of the container and contents;

(d) Identities, activities, and concentrations of major radionuclides;

(e) Characterization date;

(f) Generating source; and

(g) Any other information which may be needed to prepare and maintain the disposal facility performance assessment, or demonstrate compliance with applicable performance objectives.

J. Waste Certification. A waste certification program shall be developed, documented, and implemented to ensure that the waste acceptance requirements of facilities receiving low-level waste for storage, treatment, and disposal are met.

From DOE G 435.1-1 Chapter IV: Compliance with the development and documentation portion of the certification requirement is demonstrated by a waste certification plan that identifies the organizations involved, assigns responsibilities for implementing the program, and describes or references the quality assurance, training, procurement controls, records management, and procedures to be used by the program. Acceptable performance for implementing the program is demonstrated when appropriate personnel are trained and follow the procedures that govern their part of the waste certification.

Additionally, acceptable performance is demonstrated if the waste certification plan and procedures are current and controlled in accordance with a document controls program, and records related to certification (e.g., certification statements, training records, procurement records, characterization records, container records) are generated and managed in accordance with the established site program.

(1) Certification Program. The waste certification program shall designate the officials who have the authority to certify and release waste for shipment; and specify what documentation is required for waste generation, characterization, shipment, and certification. The program shall provide requirements for auditability, retrievability, and storage of required documentation and specify the records retention period.

From DOE G 435.1-1 Chapter IV: Compliance with this requirement is demonstrated by a program or

\section{Facility Compliance Information}

See I. and (2) above. See I. and (2) above.

See I. and (2) above. See I. and (2) above.

See I. and (2) above.

See I. and (2) above.

MCP-17000 cites a waste certification program for LLW destined for NNSS. For waste destined for locations other than NNSS, the waste disposition specialist is responsible for certifying the waste stream by ensuring the waste, as characterized, falls within the limitations of the WAC of the treatment, storage, or disposal facility $(\S 2)$.

Container procurement is addressed in MCP- 17000 $\S 4.6$.

MCP-17500 provides the WGS waste certification program for LLW to be shipped to NNSS.

Waste certification is performed and tracked using IWTS. Documentation of the IWTS Program is available electronically only.

PLN-522 requires waste technical specialists and waste disposition specialists to complete the appropriate training/qualification before being granted approval authority for profiles within the IWTS Program. The waste certification official, alternate waste certification official, and NNSS packaging certifiers must complete the appropriate training/qualifications to disposition waste to NNSS.

TSD-OI-004 $\S \S 3.2 .4,3.2 .5,3.3,3.4$, and 4 .

See J. above. MCP- $17500 \S \S 2$ and 5 address certification records for shipments to NNSS. 
Table 21. (continued).

\section{MFC-797 Outside Radioactive Storage Area}

\section{Chapter IV. Low-Level Waste Requirements procedure for record keeping and records showing that low-level waste is certified as having met the waste acceptance criteria of the facility to which it was transferred and that the certification statement is supported by additional records regarding the waste source, characterization, and container. \\ (2) Certification before Transfer. Low-level waste shall be certified as meeting waste acceptance requirements before it is transferred to the facility receiving the waste. \\ From DOE G 435.1-1 Chapter IV: Compliance with this requirement is demonstrated by the presence of a certification program which includes procedures requiring a signed certification statement prior to the release of waste for transfer, and by dated records showing that waste was certified before being transferred.}

(3) Maintaining Certification. Low-level waste that has been certified as meeting the waste acceptance requirements for transfer to a storage, treatment, or disposal facility shall be managed in a manner that maintains its certification status.

From DOE G 435.1-1 Chapter IV: Compliance with this requirement is demonstrated by a program or procedure reflecting this requirement is present and site personnel are able to show that the storage of low-level waste containers is in a facility or manner where the containers would not be damaged by normal weather events, and cannot be accessed by unauthorized personnel. Further, each container can be traced to its certification and the information supporting that certification.

K. Waste Transfer. A documented process shall be established and implemented for transferring responsibility for management of low-level waste and for ensuring availability of relevant data. The following requirements are in addition to those in Chapter I of this Manual.

From DOE G 435.1-1 Chapter IV: Compliance with this requirement is demonstrated if facilities have procedures for the receipt of waste and the transfer of waste, as appropriate, which address the acquisition of waste and container data and the transfer of ownership, respectively. Further evidence of acceptable performance is facility records showing that data on the waste containers is available and accurate, and that documented transfer of responsibility occurs.

(1) Authorization. Low-level waste shall not be
Facility Compliance Information

See J. above. MCP-17500 § 4.3.6 addresses controls for certification before transfer for LLW to be disposed of at NNSS.
See J. above. Pre-certification checklists are cited in MCP-17000 and MCP-17500. Surveillances also are addressed in MCP-17500.

LWP-15011 $\$ 5$ provides general radioactive storage area requirements.
MCP-17000 $§ 4.8 .15$ specifies requirements for interfacility transfers.

MCP-17500 $\S 4$ addresses LLW to be transferred to NNSS.

TSD-OI-004 $\S \S 3.2,3.4,3.7,3.8$, and 4 
Table 21. (continued).

\section{MFC-797 Outside Radioactive Storage Area}

\begin{tabular}{l}
\hline \multicolumn{1}{c|}{ Chapter IV. Low-Level Waste Requirements } \\
\hline transferred to a storage, treatment, or disposal facility \\
until personnel responsible for the facility receiving the \\
waste authorize the transfer. \\
From DOE G 435.1-1 Chapter IV: Compliance with \\
this requirement is demonstrated by sites having \\
procedures that require a confirmation of authorization \\
before releasing waste for transfer, and records \\
showing that transfers are made in accordance with \\
written authorizations.
\end{tabular}

(2) Data. Waste characterization data, container information, and generation, storage, treatment, and transportation information for low-level waste shall be transferred with or be traceable to the waste.

From DOE G 435.1-1 Chapter IV: Compliance with this requirement is demonstrated if there are procedures requiring that characterization and container data be provided and maintained for each low-level waste transfer and documented records of transfers show that the information is being provided.

\section{Packaging and Transportation. The following requirements are in addition to those in Chapter I of this Manual [DOE M 435.1-1 §I.1.E(11)].}

(1) Packaging. If containers are used:

From DOE G 435.1-1 Chapter IV: Compliance with the packaging requirement is demonstrated by: (1) procedures which document proper packaging protocols; and (2) no trends of routine repackaging of low-level waste that is packaged after issuance of DOE O 435.1. Successful performance of this requirement is also demonstrated by a record of containers for which failure has not routinely occurred under management conditions. It is recognized that there may be failed containers for waste previously placed in storage. For those containers, the goal is to only have to repackage the waste one time after it is retrieved and characterized. Further, acceptable performance is demonstrated by containers of waste having marking and labeling that allows correlation with waste characterization data and container information.

(a) Low-level waste shall be packaged in a manner that provides containment and protection for the duration of the anticipated storage period and until disposal is achieved or until the waste has been removed from the container.

(b) When waste is packaged, vents or other measures shall be provided if the potential exists for pressurizing
See K. above. Facility Compliance Information
See (1) and (2) below.

MCP-17000 § 4 addresses packaging requirements.

TSD-OI-004 § 3.3

See (1) above.

See (1) above. 
Table 21. (continued).

\section{MFC-797 Outside Radioactive Storage Area}

\begin{tabular}{|c|}
\hline Chapter IV. Low-Level Waste Requirements \\
\hline $\begin{array}{l}\text { or generating flammable or explosive concentrations of } \\
\text { gases within the waste container. }\end{array}$ \\
\hline $\begin{array}{l}\text { (c) Containers of low-level waste shall be marked such } \\
\text { that their contents can be identified. }\end{array}$ \\
\hline $\begin{array}{l}\text { (2) Transportation. To the extent practical, the volume } \\
\text { of waste and number of low-level waste shipments } \\
\text { shall be minimized. }\end{array}$ \\
\hline $\begin{array}{l}\text { From DOE G } 435.1-1 \text { Chapter IV: Compliance with } \\
\text { this requirement can be demonstrated by a combination } \\
\text { of site procedures directing the efficient use of waste } \\
\text { container capacity and documentation showing that } \\
\text { low-level waste shipments are systematically planned } \\
\text { and optimized to the extent practical. }\end{array}$ \\
\hline $\begin{array}{l}\text { M. Site Evaluation and Facility Design. The following } \\
\text { requirements are in addition to those in Chapter I of } \\
\text { this Manual. }\end{array}$ \\
\hline
\end{tabular}

(1) Site Evaluation. Proposed locations for low-level waste facilities shall be evaluated to identify relevant features that should be avoided or must be considered in facility design and analyses.
(a) Each site proposed for a new low-level waste facility or expansion of an existing low-level waste facility shall be evaluated considering environmental characteristics, geotechnical characteristics, and human activities, including for a low-level waste disposal facility, the capability of the site to demonstrate, at a minimum, whether it is:

1 Located to accommodate the projected volume of
waste to be received;
2 Located in a flood plain, a tectonically active area, or
in the zone of water table fluctuation; and

3 Located where radionuclide migration pathways are predictable and erosion and surface runoff can be controlled.

(b) Proposed sites with environmental characteristics, geotechnical characteristics, and human activities for which adequate protection cannot be provided through facility design shall be deemed unsuitable for the location of the facility.

(c) Low-level waste disposal facilities shall be sited to achieve long-term stability and to minimize, to the extent practical, the need for active maintenance following final closure.

(2) Low-Level Waste Treatment and Storage Facility Design. The following facility requirements and
Facility Compliance Information

See (1) above.

MCP-17000 $\S 4$ addresses transportation. The waste disposition specialist coordinates with packaging and transportation personnel for waste shipped offsite from this facility.

MCP-17500 specifies waste certification official and waste disposition specialist responsibilities and coordination with packaging and transportation personnel for waste shipped directly to NNSS from this facility.

$\mathrm{NA}$; this requirement addresses new radioactive waste management facilities or modifications to existing facilities.

See M. above.

See M. above.

See M. above.

See M. above.

See M. above.

See M. above.

See M. above.

See M. above. 
Table 21. (continued).

MFC-797 Outside Radioactive Storage Area

\begin{tabular}{l} 
Chapter IV. Low-Level Waste Requirements \\
\hline general design criteria, at a minimum, apply: \\
\hline $\begin{array}{l}\text { (a) Confinement. Low-level waste systems and } \\
\text { components shall be designed to maintain waste } \\
\text { confinement. }\end{array}$ \\
(b) Ventilation. \\
$\begin{array}{l}1 \text { Design of low-level waste treatment and storage } \\
\text { facilities shall include ventilation, if applicable, } \\
\text { through an appropriate filtration system to maintain the } \\
\text { release of radioactive material in airborne effluents } \\
\text { within the requirements and guidelines specified in } \\
\text { applicable requirements. }\end{array}$ \\
\hline
\end{tabular}

2 When conditions exist for generating gases in flammable or explosive concentrations, ventilation systems or other measures shall be provided to keep the gases in a non-flammable and nonexplosive condition. Where concentrations of explosive or flammable gases are expected to approach the lower flammability limit, measures shall be taken to prevent deflagration or detonation.

\section{(c) Consideration of Decontamination and}

Decommissioning. Areas in new and modifications to existing low-level waste management facilities that are subject to contamination with radioactive or other hazardous materials shall be designed to facilitate decontamination. For such facilities a proposed decommissioning method or a conversion method leading to reuse shall be described.

(d) Instrumentation and Control Systems. Engineering controls shall be incorporated in the design and engineering of low-level waste treatment and storage facilities to provide volume inventory data and to prevent spills, leaks, and overflows from tanks or confinement systems.

(e) Monitoring. Monitoring and/or leak detection capabilities shall be incorporated in the design and engineering of low-level waste treatment and storage facilities to provide rapid identification of failed confinement and/or other abnormal conditions.

(3) Low-Level Waste Disposal Facility Design. The following facility requirements and general design criteria, at a minimum, apply:

\begin{tabular}{|l|l|}
\hline $\begin{array}{l}\text { (a) Confinement. Low-level waste systems and } \\
\text { components shall be designed to maintain waste } \\
\text { confinement. }\end{array}$ & See M. above. \\
\hline (b) Ventilation. & See M. above. \\
\hline
\end{tabular}


Table 21. (continued).

\section{MFC-797 Outside Radioactive Storage Area}

\begin{tabular}{l}
\hline \multicolumn{1}{|c|}{ Chapter IV. Low-Level Waste Requirements } \\
$\begin{array}{l}1 \text { Design of low-level waste disposal facilities shall } \\
\text { include ventilation, if applicable, through an } \\
\text { appropriate filtration system to maintain the release of } \\
\text { radioactive material in airborne effluents within the } \\
\text { requirements and guidelines specified in applicable } \\
\text { requirements. }\end{array}$ \\
$\begin{array}{l}2 \text { When conditions exist for generating gases in } \\
\text { flammable or explosive concentrations, ventilation } \\
\text { systems or other measures shall be provided to keep the } \\
\text { gases in a nonflammable and non-explosive condition. } \\
\text { Where concentrations of explosive or flammable gases } \\
\text { are expected to approach the lower flammability limit, } \\
\text { measures shall be taken to prevent deflagration or } \\
\text { detonation. }\end{array}$ \\
\hline
\end{tabular}

(c) Stability. Low-level waste disposal facilities shall be designed to achieve long-term stability and to minimize to the extent practical, the need for active maintenance following final closure.

(d) Control of Water. Low-level waste disposal facilities shall be designed to minimize to the extent practical, the contact of waste with water during and after disposal.

N. Storage and Staging. The following requirements are in addition to those in Chapter I of this Manual [DOE M 435.1-1 §I.2.F(13)].

(1) Storage Prohibitions. Low-level waste in storage shall not be readily capable of detonation, explosive decomposition, reaction at anticipated pressures and temperatures, or explosive reaction with water. Prior to storage, pyrophoric materials shall be treated, prepared, and packaged to be nonflammable.

From DOE G 435.1-1 Chapter IV: Compliance with this requirement is demonstrated by having waste acceptance requirements which prohibit low-level waste that is ignitable or explosive from being accepted for storage unless it has been treated, and procedures for properly preparing such materials for safe storage.

(2) Storage Limit. Low-level waste that has an identified path to disposal shall not be stored longer than one year prior to disposal, except for storage for decay, or as otherwise authorized by the Field Element Manager.

From DOE G 435.1-1 Chapter IV: Storage longer than one year can be justified if the conditions for such storage are approved by the Field Element Manager as part of the radioactive waste management basis for the facility.
See M. above. Facility Compliance Information

See M. above.

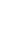

See M. above.

See M. above.

Not a facility-specific requirement. DOE Manual

435.1-1 §I.2.F(13) applies to field element managers.

MCP-17000

TSD-OI-004 $\S 3.2$

Also, NNSS WAC does not allow ignitable or explosive waste (MCP-17500).

MCP-17000 $\S 4.8 .16$ addresses storage time limits and waste that is to be stored longer than 1 year.

MCP-17000, Appendix F addresses storage time limits.

Storage longer than 1 year for mixed waste is allowable under the Site Treatment Plan.

MCP-17410 addresses storage for SAAs and TAAs. 
Table 21. (continued).

\section{MFC-797 Outside Radioactive Storage Area}

\begin{tabular}{|c|c|}
\hline Chapter IV. Low-Level Waste Requirements & Facility Compliance Information \\
\hline $\begin{array}{l}\text { Storage for radioactive decay for a period greater than } \\
1 \text { year for waste that has an identified path to disposal } \\
\text { is allowed. Adequate justification and the supporting } \\
\text { information for storage for decay is to be documented } \\
\text { in the radioactive waste management basis for the } \\
\text { facility in which the storage will take place. }\end{array}$ & \\
\hline $\begin{array}{l}\text { Mixed waste. Under the Federal Facility Compliance } \\
\text { Act of } 1992 \text {, DOE sites were required to develop Site } \\
\text { Treatment Plans to bring stored mixed low-level waste } \\
\text { into compliance with these requirements. The Site } \\
\text { Treatment Plan needs to be consulted and any mixed } \\
\text { low-level waste stored for the purpose of accumulation } \\
\text { to facilitate treatment must meet Resource } \\
\text { Conservation and Recovery Act storage requirements. } \\
\text { There could be several ways within different scenarios } \\
\text { that this requirement can be met, as illustrated by the } \\
\text { examples below, however, there are basically four } \\
\text { ways to show compliance with the requirement and } \\
\text { include appropriate provisions in the radioactive waste } \\
\text { management basis for the facility in which it is stored. }\end{array}$ & \\
\hline $\begin{array}{l}\text { Legacy waste. As discussed above, the intention of the } \\
\text { requirement is not to force malicious compliance or } \\
\text { heroic actions which would result in increased risk or } \\
\text { safety concerns. Rather, the intention is that waste in } \\
\text { storage longer than one year receives additional } \\
\text { attention to ensure that the public, the workers, and the } \\
\text { environment are protected from the hazards of the } \\
\text { waste, and that progress is being made to dispose of the } \\
\text { waste. There could be several ways within different } \\
\text { scenarios that this requirement can be met, as } \\
\text { illustrated by the examples below, however, there are } \\
\text { basically four ways to show compliance with the } \\
\text { requirement: }\end{array}$ & \\
\hline $\begin{array}{l}\text { 1) the radioactive waste management basis allows for } \\
\text { storage for no more than one year. }\end{array}$ & \\
\hline $\begin{array}{l}\text { 2) the radioactive waste management basis allows for } \\
\text { storage for no more than one year, or for storage for } \\
\text { decay only for periods greater than a year, which are } \\
\text { specified on a radionuclide basis. }\end{array}$ & \\
\hline $\begin{array}{l}\text { 3) the radioactive waste management basis allows for } \\
\text { storage for more than one year, up to a specified period } \\
\text { of time based on a documented technical evaluation } \\
\text { that the waste can be stored in a manner that does not } \\
\text { cause changes to the waste or waste packages that is } \\
\text { detrimental to the safe storage of the waste, the final } \\
\text { disposal of the waste or to meeting the disposal } \\
\text { performance objectives. }\end{array}$ & \\
\hline 4) the radioactive waste management basis allows for & \\
\hline
\end{tabular}


Table 21. (continued).

\section{MFC-797 Outside Radioactive Storage Area}

\begin{abstract}
Chapter IV. Low-Level Waste Requirements storage for decay (with specifics) and for storage for more than one year for other low-level waste, up to a specified period of time based on a documented technical evaluation that the waste can be stored in a manner that does not cause changes to the waste or waste packages that is detrimental to the safe storage of the waste, the final disposal of the waste or to meeting the disposal performance objectives.

Compliance with this requirement is demonstrated by the existence of a radioactive waste management basis for the storage facility approved by the Field Element Manager that includes the time frames that waste are allowed to be stored, the necessary justifications for storage for decay, and the necessary technical evaluations if storage is to extend significantly beyond the one-year time frame.
\end{abstract}

(3) Storage Integrity. Low-level waste shall be stored in a location and manner that protects the integrity of waste for the expected time of storage and minimizes worker exposure.

From DOE G 435.1-1 Chapter IV: However, in making a decision to use a facility for storage and in developing a radioactive waste management basis for the activity, particular attention to protection of workers is needed.

Compliance with this requirement is demonstrated if sites have storage capabilities for low-level waste that provide protection to waste containers so that their integrity will not be damaged through physical or chemical (corrosion) processes and that keep personnel from spending extended periods of time in the areas where low-level waste is stored.

\begin{tabular}{|l|l} 
(4) Waste Characterization for Storage. & Se \\
\hline
\end{tabular}

(a) Low-level waste that does not have an identified path to disposal shall be characterized as necessary to meet the data quality objectives and minimum characterization requirements of this Chapter, to ensure safe storage, and to facilitate disposal.

(b) Characterization information for all low-level waste in storage shall be maintained as a record in accordance with the requirements for Records Management in Chapter I of this Manual.

From DOE G 435.1-1 Chapter IV: Compliance with this requirement is demonstrated by documented procedures for managing waste characterization and container information on low-level waste as a Federal record. The records are managed per the applicable
MCP- 17000

TSD-OI-004 $\S \S 3.3$ and 3.4
See below.

This facility does not store LLW that does not have an identified path to disposal.

MCP-17000

TSD-OI-004 $\S 3.8$ and 4 
Table 21. (continued).

\section{MFC-797 Outside Radioactive Storage Area}

Chapter IV. Low-Level Waste Requirements Facility Compliance Information

policies and procedures for records management referenced in DOE O 200.1 and established at the applicable Field Element.

(5) Container Inspection. A process shall be developed and implemented for inspecting and maintaining containers of low-level waste to ensure container integrity is not compromised.

From DOE G 435.1-1 Chapter IV: Compliance with this requirement is demonstrated by: (1) a documented process for waste container inspection and maintenance; and (2) documentation for all waste container inspections and maintenance actions performed.

(6) Storage Management. Low-level waste storage shall be managed to identify and segregate low-level waste from mixed low-level waste.

(7) Staging. Staging of low-level waste shall be for the purpose of the accumulation of such quantities of waste as necessary to facilitate transportation, treatment, and disposal. Staging longer than 90 days shall meet the requirements for storage above and in Chapter I of this Manual.

From DOE G 435.1-1 Chapter IV: The staging of lowlevel waste needs to be addressed in the radioactive waste management basis for the facility that is performing the staging. Generators, treatment facilities, and disposal facilities that stage waste must ensure that the action of staging is included and authorized as part of their radioactive waste management basis for the affected facilities, operations, or activities.

Staging longer than 90 days must be justified, the conditions for such storage met, and these practices approved by the Field Element Manager as part of the radioactive waste management basis for the facility.

Compliance with this requirement is demonstrated by a staging program that limits the temporary storage of waste to only circumstances allowed in the requirement, including justifications for any staging that exceeds the 90-day period, which is documented in the radioactive waste management basis for the facility.

$\mathrm{O}$. Treatment. Low-level waste treatment to provide more stable waste forms and to improve the long-term performance of a low-level waste disposal facility shall be implemented as necessary to meet the performance objectives of the disposal facility.

From DOE G 435.1-1 Chapter IV: Compliance with

LI-435 requires quarterly inspections of radioactive waste containers if waste is stored outdoors or has been in storage for greater than 1 year.

LWP-15011 does not include a requirement for inspection.

MCP-17000

For mixed LLW, TSD-OI-004 $\S \S 3.4 .7$ and 4.3

Inspections are performed for SAAs as required by WGS procedures (MCP-17000 and MCP-17410).

MCP-17000 $\S 4.7$ requires the use of a unique IWTS bar code for each container

TSD-OI-004 $\S 2.2$

NA; LLW is not staged at this facility.

NA; treatment is not performed in this facility. 
Table 21. (continued).

\section{MFC-797 Outside Radioactive Storage Area}

\begin{tabular}{|l|}
\hline \multicolumn{1}{|c|}{ Chapter IV. Low-Level Waste Requirements } \\
\hline this requirement is demonstrated when a treatment \\
facility or process ensures that treated waste will meet \\
the minimum waste form requirements of DOE M \\
435.1 and meet additional disposal facility-specific \\
waste acceptance requirements for additional stability \\
or long-term performance of facilities that will receive \\
the treated waste. \\
\hline $\begin{array}{l}\text { P. Disposal. Low-level waste disposal facilities shall } \\
\text { meet the following requirements. }\end{array}$ \\
(1) Performance Objectives. Low-level waste disposal \\
facilities shall be sited, designed, operated, maintained, \\
and closed so that a reasonable expectation exists that \\
the following performance objectives will be met for \\
waste disposed of after September 26, 1988:
\end{tabular}

(a) Dose to representative members of the public shall not exceed $25 \mathrm{mrem}(0.25 \mathrm{mSv})$ in a year total effective dose equivalent from all exposure pathways, excluding the dose from radon and its progeny in air.

(b) Dose to representative members of the public via the air pathway shall not exceed $10 \mathrm{mrem}(0.10 \mathrm{mSv})$ in a year total effective dose equivalent, excluding the dose from radon and its progeny.

(c) Release of radon shall be less than an average flux of $20 \mathrm{pCi} / \mathrm{m}^{2} / \mathrm{s}\left(0.74 \mathrm{~Bq} / \mathrm{m}^{2} / \mathrm{s}\right)$ at the surface of the disposal facility. Alternatively, a limit of $0.5 \mathrm{pCi} / 1$ $(0.0185 \mathrm{~Bq} / \mathrm{l})$ of air may be applied at the boundary of the facility.

(2) Performance Assessment. A site-specific radiological performance assessment shall be prepared and maintained for DOE low-level waste disposed of after September 26, 1988. The performance assessment shall include calculations for a 1,000 year period after closure of potential doses to representative future members of the public and potential releases from the facility to provide a reasonable expectation that the performance objectives identified in this Chapter are not exceeded as a result of operation and closure of the facility.

(a) Analyses performed to demonstrate compliance with the performance objectives in this Chapter, and to establish limits on concentrations of radionuclides for disposal based on the performance measures for inadvertent intruders in this Chapter shall be based on reasonable activities in the critical group of exposed individuals. Unless otherwise specified, the assumption of average living habits and exposure conditions in representative critical groups of individuals projected to receive the highest doses is appropriate. The

NA; LLW is not disposed of in this facility.

See P. above.

See P. above.

See P. above.

See P. above.

See P. above.

See P. above. 
Table 21. (continued).

\section{MFC-797 Outside Radioactive Storage Area}

\section{Chapter IV. Low-Level Waste Requirements likelihood of inadvertent intruder scenarios may be considered in interpreting the results of the analyses and establishing radionuclide concentrations, if adequate justification is provided. \\ (b) The point of compliance shall correspond to the point of highest projected dose or concentration beyond a 100 meter buffer zone surrounding the disposed waste. A larger or smaller buffer zone may be used if adequate justification is provided.}

(c) Performance assessments shall address reasonably foreseeable natural processes that might disrupt barriers against release and transport of radioactive materials.

(d) Performance assessments shall use DOE-approved dose coefficients (dose conversion factors) for internal and external exposure of reference adults.

(e) The performance assessment shall include a sensitivity/uncertainty analysis.

(f) Performance assessments shall include a demonstration that projected releases of radionuclides to the environment shall be maintained as low as reasonably achievable (ALARA).

(g) For purposes of establishing limits on radionuclides that may be disposed of near-surface, the performance assessment shall include an assessment of impacts to water resources.

(h) For purposes of establishing limits on the concentration of radionuclides that may be disposed of near-surface, the performance assessment shall include an assessment of impacts calculated for a hypothetical person assumed to inadvertently intrude for a temporary period into the low-level waste disposal facility. For intruder analyses, institutional controls shall be assumed to be effective in deterring intrusion for at least 100 years following closure. The intruder analyses shall use performance measures for chronic and acute exposure scenarios, respectively, of 100 mrem $(1 \mathrm{mSv})$ in a year and $500 \mathrm{mrem}(5 \mathrm{mSv})$ total effective dose equivalent excluding radon in air.

(3) Composite Analysis. For disposal facilities which received waste after September 26, 1988, a site-specific radiological composite analysis shall be prepared and maintained that accounts for all sources of radioactive material that may be left at the DOE site and may interact with the low- level waste disposal facility, contributing to the dose projected to a hypothetical member of the public from the existing or future disposal facilities. Performance measures shall be
See P. above.

See P. above.

See P. above.

See P. above.

See P. above.

See P. above.

See P. above. Facility Compliance Information 
Table 21. (continued).

\section{MFC-797 Outside Radioactive Storage Area}

\begin{abstract}
Chapter IV. Low-Level Waste Requirements consistent with DOE requirements for protection of the public and environment and evaluated for a 1,000 year period following disposal facility closure. The composite analysis results shall be used for planning, radiation protection activities, and future use commitments to minimize the likelihood that current low- level waste disposal activities will result in the need for future corrective or remedial actions to adequately protect the public and the environment.
\end{abstract}

(4) Performance Assessment and Composite Analysis Maintenance. The performance assessment and composite analysis shall be maintained to evaluate changes that could affect the performance, design, and operating bases for the facility. Performance assessment and composite analysis maintenance shall include the conduct of research, field studies, and monitoring needed to address uncertainties or gaps in existing data. The performance assessment shall be updated to support the final facility closure. Additional iterations of the performance assessment and composite analysis shall be conducted as necessary during the post-closure period.

(a) Performance assessments and composite analyses shall be reviewed and revised when changes in waste forms or containers, radionuclide inventories, facility design and operations, closure concepts, or the improved understanding of the performance of the waste disposal facility in combination with the features of the site on which it is located alter the conclusions or the conceptual model(s) of the existing performance assessment or composite analysis.

(b) A determination of the continued adequacy of the performance assessment and composite analysis shall be made on an annual basis, and shall consider the results of data collection and analysis from research, field studies, and monitoring.

(c) Annual summaries of low-level waste disposal operations shall be prepared with respect to the conclusions and recommendations of the performance assessment and composite analysis and a determination of the need to revise the performance assessment or composite analysis.

(5) Disposal Authorization. A disposal authorization statement shall be obtained prior to construction of a new low-level waste disposal facility. Field Elements with existing low-level waste disposal facilities shall obtain a disposal authorization statement in accordance with the schedule in the Complex-Wide Low-Level Waste Management Program Plan. The disposal
See P. above.

See P. above.

See P. above.

See P. above.

See P. above. Facility Compliance Information 
Table 21. (continued).

\section{MFC-797 Outside Radioactive Storage Area}

\begin{tabular}{l} 
Chapter IV. Low-Level Waste Requirements \\
\hline authorization statement shall be issued based on a \\
review of the facility's performance assessment, \\
composite analysis, performance assessment and \\
composite analysis maintenance, preliminary closure \\
plan, and preliminary monitoring plan. The disposal \\
authorization statement shall specify the limits and \\
conditions on construction, design, operations, and \\
closure of the low-level waste facility based on these \\
reviews. A disposal authorization statement is a part of \\
the radioactive waste management basis for a disposal \\
facility. Failure to obtain a disposal authorization \\
statement by the implementation date of this Order \\
shall result in shutdown of the disposal facility. \\
(6) Disposal Facility Operations. The disposal facility \\
design and operation must be consistent with the \\
disposal facility closure plan and lead to disposal \\
facility closure that provides a reasonable expectation \\
that performance objectives will be met. Low-level \\
waste shall be disposed in such a manner that achieves \\
the performance objectives stated in this Chapter, \\
consistent with the disposal facility radiological \\
performance assessment. Additional requirements \\
include:
\end{tabular}

(a) Operating procedures shall be developed and implemented for low-level waste disposal facilities that protect the public, workers, and the environment; ensure the security of the facility; minimize subsidence during and after waste emplacement; achieve long-term stability and minimize the need for long-term active maintenance; and meet the requirements of the closure/post-closure plan.

(b) Permanent identification markers for disposal excavations and monitoring wells shall be emplaced.

(c) Low-level waste placement into disposal units shall minimize voids between waste containers. Voids within disposal units shall be filled to the extent practical. Uncontainerized bulk waste shall also be placed in a manner that minimizes voids and subsidence.

(d) Operations are to be conducted so that active waste disposal operations will not have an adverse effect on any other disposal units.

(e) Operations shall include a process for tracking and documenting low-level waste placement in the facility by generator source.

(7) Alternate Requirements for Low-Level Waste Disposal Facility Design and Operation. Requirements other than those set forth in this Section for the design and operation of a low-level waste disposal facility
See P. above. Facility Compliance Information
See P. above.

See P. above.

See P. above.

See P. above.

See P. above.

See P. above. 
Table 21. (continued).

\section{MFC-797 Outside Radioactive Storage Area}

Chapter IV. Low-Level Waste Requirements may be approved on a specific basis if a reasonable expectation is demonstrated that the disposal performance objectives will be met.

Q. Closure. The following requirements are in addition to those in Chapter I of this Manual.

(1) Disposal Facility Closure Plans. A preliminary closure plan shall be developed and submitted to Headquarters for review with the performance assessment and composite analysis. The closure plan shall be updated following issuance of the disposal authorization statement to incorporate conditions specified in the disposal authorization statement. Closure plans shall:

(a) Be updated as required during the operational life of the facility.

(b) Include a description of how the disposal facility will be closed to achieve long-term stability and minimize the need for active maintenance following closure and to ensure compliance with the requirements of DOE 5400.5, Radiation Protection of the Public and the Environment.

(c) Include the total expected inventory of wastes to be disposed of at the facility over the operational life of the facility.

(2) Disposal Facility Closure. Closure of a disposal facility shall occur within a five-year period after it is filled to capacity, or after the facility is otherwise determined to be no longer needed.

(a) Prior to facility closure, the final inventory of the low-level waste disposed in the facility shall be prepared and incorporated in the performance assessment and composite analysis which shall be updated to support the closure of the facility.

(b) A final closure plan shall be prepared based on the final inventory of waste disposed in the facility, the plan implemented, and the updated performance assessment and composite analysis prepared in support of the facility closure.

(c) Institutional control measures shall be integrated into land use and stewardship plans and programs, and shall continue until the facility can be released pursuant to DOE 5400.5, Radiation Protection of the Public and the Environment.

(d) The location and use of the facility shall be filed with the local authorities responsible for land use and zoning.

NA; LLW is not disposed of in this facility.

See Q. above. Facility Compliance Information

See Q. above.

See Q. above.

See Q. above.

See Q. above.

See Q. above.

See Q. above.

See Q. above.

See Q. above. 
Table 21. (continued).

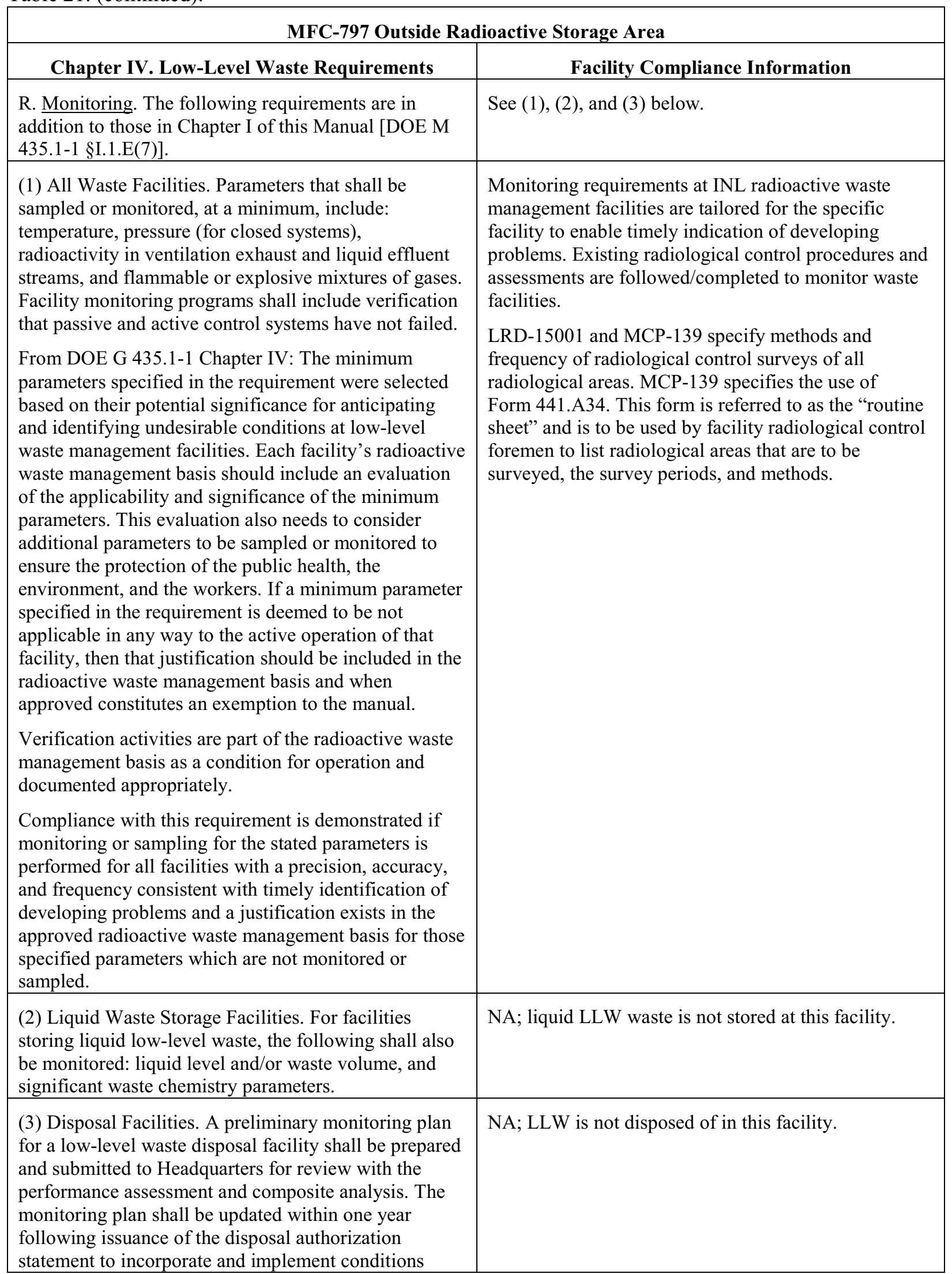


Table 21. (continued).

MFC-797 Outside Radioactive Storage Area

Chapter IV. Low-Level Waste Requirements Facility Compliance Information

specified in the disposal authorization statement.

(a) The site-specific performance assessment and composite analysis shall be used to determine the media, locations, radionuclides, and other substances to be monitored.

(b) The environmental monitoring program shall be designed to include measuring and evaluating releases, migration of radionuclides, disposal unit subsidence, and changes in disposal facility and disposal site parameters which may affect long-term performance.

(c) The environmental monitoring programs shall be capable of detecting changing trends in performance to allow application of any necessary corrective action prior to exceeding the performance objectives in this Chapter.

\subsection{MFC-799 and 799A, Sodium Process Facility}

1. Facility description: SD-38.1.1, "Treatment, Storage, and Disposal Facilities (TSDF) Environmental Compliance," includes MFC-799A as part of the Sodium Process Facility. NOTE: This facility is scheduled for transfer of ownership to the DOE Office of Environmental Management.

MFC-799, Sodium Processing Facility, consists of the following process areas in one building:

a. Sodium Process Area

The Sodium Process Area is used for the storage and treatment of HW/mixed waste in both containers and tanks. This area consists of an original four-roomed, L-shaped structure and a later-constructed enclosed, covered, carbon steel-lined concrete pad upon which process equipment is located. The building is supported on a thickened-edge, reinforced-concrete pad. There are three rooms in the Sodium Process Area used for HW/mixed waste storage or treatment: the Barrel Holding Room, Sodium Melting and Draining Room, and Sodium Process Equipment Room. The fourth room is the Sodium Processing Facility Control Room. Each of these rooms is described briefly below. The approximate overall dimensions of the present enclosed Sodium Process Area area are $65 \times 57 \mathrm{ft}$. Most of the exterior of the Sodium Processing Facility is constructed of galvanized-steel siding and roof panels on a structural-steel frame. However, the Sodium Melting and Draining Room (the central room along the north wall) has 12-in. thick reinforced concrete block walls and an 8-in. thick reinforced-concrete slab roof.

b. Barrel Holding Room

The Barrel Holding Room is used to receive (store up to) 32 drums of HW/mixed waste. The dimensions of the room are $20 \mathrm{ft} 6 \mathrm{in} . \times 25 \mathrm{ft}$. The $\mathrm{HW} /$ mixed waste is brought into this area through a $10 \times 10$-ft sliding service door (east exterior wall), removed from the skid on which they were received, and placed onto individual barrel dollies. Once placed on the dollies, the drums are moved into the Sodium Melting and Draining Room (Sodium Processing Facility typically processes sodium and sodium-potassium alloy waste, but may process other alkali metals) through a $6 \times 6$-ft sliding door on the west wall of the Barrel Holding Room. In addition, the Barrel Holding Room also is the pathway for removal of the drained drums from the Sodium 
Melting and Draining Room as discussed below. A 1,000-lb lift capacity jib crane is available for moving full drums (as needed) for sodium processing activities and maintenance support.

c. Sodium Melting and Draining Room

The Sodium Melting and Draining Room is used to melt and drain drums of alkali metal $\mathrm{HW} /$ mixed waste. The dimensions of the room are $25 \times 22 \mathrm{ft}$. There are eight barrel container assemblies used to hold the drums of HW/mixed waste (typically sodium and sodium-potassium alloy) while they are melted and drained. There is a bridge crane used to transfer the drums into the barrel container assemblies. The crane has a capacity of $1,000 \mathrm{lb}$ and coverage of $15 \mathrm{ft}$ laterally and $18 \mathrm{ft}$ along the rail. The barrel container assemblies are arranged in two banks of four A barrel draining manifold, which is insulated and serves each of the two banks of four barrel assemblies. A flexible, stainless-steel line is provided at each barrel container assembly to connect the drum to the manifold. Each manifold is constructed of 3/4-in. Series-300 stainless-steel pipe. A nitrogen purge is provided for each of the flexible barrel drain lines. The two barrel draining manifolds are combined into an insulated 1-in. Series-300 stainless-steel pipe, and in turn, connected to the 5,000-gal sodium storage tank. The manifolds and 1-in. pipe are all sloped to drain into the 5,000-gal sodium storage tank. One drum can be drained through each manifold simultaneously.

d. Sodium Process Equipment Area

The Sodium Process Equipment Area is used to store and treat alkali metal HW/mixed waste. The are several major components in the sodium process are, including a 5,000-gal sodium storage tank, two 730-gal sodium day tanks, sodium reaction vessel, 1,000-gal caustic cooling tank, 4,000-gal caustic storage tank, and the caustic off-gas system. The dimensions of the area are approximately $20 \times 57 \mathrm{ft}$ in an L-shaped configuration. The process area floor is a concrete pad and the process area secondary containment pits are lined with welded carbon-steel plate. The building is supported on a thickened-edge, reinforced concrete pad.

The sodium storage tank is a carbon-steel tank that receives alkali metal from the barrel drain stations. The storage tank fills the day tanks, which feeds the alkali metal to the reaction vessel at a rate of approximately 0.75 to $1.0 \mathrm{gal} / \mathrm{min}$. The reaction vessel converts the alkali metal to a liquid hydroxide waste form, which is then loaded into drums and allowed to cool to solidify. The caustic cooling tank and the caustic storage tank allow for storage of caustic during reaction vessel shutdowns. The caustic storage tank is used for backup storage only. The caustic storage tank is located in a separate building, just west of the Sodium Process Equipment Area.

The caustic off-gas system is composed of several components designed to remove moisture, entrained caustic vapor and provides a vent path for hydrogen from the reaction vessel. The caustic off-gas system is located on the wall, in the southwest corner of the Sodium Process Equipment Area.

e. Control Room

The dimensions of the Control Room are approximately $20 \times 10 \mathrm{ft}$. The Sodium Processing Facility Control Room houses the control computer and input/output front-end computer. An operator is in attendance whenever the process system is in operation. he control computer is programmed to provide the control and operator interface for the Sodium Processing Facility that will allow control of system pressures, valves, and temperatures.

f. Carbonate Process Area

The Carbonate Process Area is an addition to the Sodium Processing Facility and is adjoined to the original structure to the south. Doors allow access between the original Sodium Processing Facility and the Carbonate Process Area. The Carbonate Process Area accommodates equipment for filling drums and provides storage of the hydroxide solution while it solidifies. The Carbonate Process Area includes the following: 
- Approximately $23 \times 25 \mathrm{ft}$ of main processing area, with an associated upper mezzanine level

- A shielded staging area of approximately $17 \times 16 \mathrm{ft}$.

The building height in the main processing and staging areas is approximately $31 \mathrm{ft}$. The other wing of the L-shaped structure adds approximately $30 \times 72 \mathrm{ft}$ of drum storage and handling area with room for forklift operations. There are two 5-ton trolley cranes in this area that are used for supporting maintenance operations. The building height in this second wing is approximately $12 \mathrm{ft}$. The building is placed on a reinforced-concrete pad capable of supporting a uniform live load of $500 \mathrm{lb} / \mathrm{ft}^{2}$. All sections of the Sodium Processing Facility meet the requirements of the Uniform Building Code and Seismic Zone 2 or 2B.

Storage of filled hydroxide drums is provided by two storage bays in the southeast area of the Carbonate Process Area. The storage bays are placed on a reinforced concrete pad with cinder block walls. Roll-up doors provide access to the Carbonate Process Area side of each bay, and an external roll-up door is available on the west bay. Permanent carbon-steel pans provide secondary containment for the liquid caustic drums stored in the bays. Poly platforms are placed inside the pans to allow forklift operation in the secondary containment areas and to elevate the caustic drums off the floor.

2. Hazard category: LTHC3

3. Radioactive waste managed at this facility: Solid and liquid $\mathrm{CH}$ mixed LLW are stored at this facility.

\section{RWMB documents/programs:}

a. Safety basis/hazard analysis:

- EDF-7030, "Inventory Analysis of Radiological Facilities at the Materials and Fuels Complex (MFC)"

b. Laboratory-wide:

- Form 441.A34, "INL Radiological Control Required Surveys"

- FRM-323, "TSD Facilities Material Acceptance Checksheet"

- LI-435, "Waste Management Routine Field Activities"

- LRD-15001, "Radiological Control Manual"

- LWP-13840, "Management of Issues, Observations, and Noteworthy Practices"

- LWP-14002, "Timeout and Stop Work Authority"

- LWP-15011, "Radioactive Material Areas and Radioactive Storage Areas"

- LWP-17000, "Waste Management"

- MCP-139, "Radiological Surveys"

- MCP-17000, "Waste Generator Services Waste Management"

- MCP-17500, "Waste Generator Services Certification of Waste Shipments to the Nevada Test Site"

- PDD-17000, "Waste Management Program"

- PLN-114, "INL Emergency Plan/RCRA Contingency Plan"

- PLN-522, "Quality Assurance Program Plan for the Waste Management/Waste Certification Program"

c. Facility-specific:

- PER-116, "HWMA/RCRA Storage and Treatment Permit for the Materials and Fuels Complex" 
- SD-38.1.1, "Treatment, Storage, and Disposal Facilities (TSDF) Environmental Compliance"

- SPF-OI-1-B, "Environmental Compliance"

- TSD-OI-004, "Waste and Material Acceptance for Storage/Treatment and Radioactive Material Inventory Control"

LLW is managed at this facility. Table 22 shows the facility compliance information for DOE Manual 435.1-1, Chapter IV, "Low-level Waste Requirements."

Table 22. MFC-799 and MFC-799A, Sodium Process Facility, DOE Manual 435.1-1 low-level waste requirements and facility compliance information.

\begin{tabular}{|c|c|}
\hline \multicolumn{2}{|c|}{$\begin{array}{l}\text { MFC-799 and MFC-799A, Sodium Process Facility } \\
\text { [Note: SD-38.1.1 includes MFC-799A as part of the Sodium Process Facility.] }\end{array}$} \\
\hline Chapter IV. Low-Level Waste Requirements & Facility Compliance Information \\
\hline $\begin{array}{l}\text { A. Definition of Low-Level Waste. Low-level radioactive } \\
\text { waste is radioactive waste that is not high-level radioactive } \\
\text { waste, spent nuclear fuel, transuranic waste, byproduct } \\
\text { material (as defined in section 11e.(2) of the Atomic Energy } \\
\text { Act of } 1954 \text {, as amended), or naturally occurring radioactive } \\
\text { material. } \\
\text { (From DOE G } 435.1-1 \text { Chapter IV: Low-level radioactive } \\
\text { waste is defined by what it is not. The guidance on } \\
\text { definitions in Chapters II and III should be consulted first for } \\
\text { making a determination on how to properly manage a } \\
\text { suspect waste stream.) }\end{array}$ & $\begin{array}{l}\text { This requirement provides the criteria for } \\
\text { determining which DOE radioactive waste is to } \\
\text { be managed as LLW in accordance with DOE } \\
\text { Manual } 435.1-1 \text {, Chapter IV. } \\
\text { Radioactive waste managed at this facility under } \\
\text { the requirements of this chapter is not managed } \\
\text { under the requirements of DOE Manual } 435.1-1 \text {, } \\
\text { Chapter II or Chapter III. }\end{array}$ \\
\hline $\begin{array}{l}\text { B. Management of Specific Wastes. The following provide } \\
\text { for management of specific wastes as low-level waste in } \\
\text { accordance with the requirements in this Chapter: }\end{array}$ & See below. \\
\hline $\begin{array}{l}\text { (1) Mixed Low-Level Waste. Low-level waste determined to } \\
\text { contain both source, special nuclear, or byproduct material } \\
\text { subject to the Atomic Energy Act of 1954, as amended, and a } \\
\text { hazardous component subject to the Resource Conservation } \\
\text { and Recovery Act (RCRA), as amended, shall be managed in } \\
\text { accordance with the requirements of RCRA and DOE O } \\
\text { 435.1, Radioactive Waste Management, and this Manual. }\end{array}$ & $\begin{array}{l}\text { This facility has an HWMA/RCRA permit to } \\
\text { store and treat mixed waste (PER-116). }\end{array}$ \\
\hline $\begin{array}{l}\text { (2) TSCA-Regulated Waste. Low-level waste containing } \\
\text { polychlorinated biphenyls, asbestos, or other such regulated } \\
\text { toxic components shall be managed in accordance with } \\
\text { requirements derived from the Toxic Substances Control Act, } \\
\text { as amended, DOE O 435.1, Radioactive Waste Management, } \\
\text { and this Manual. }\end{array}$ & $\begin{array}{l}\text { NA; this facility does not manage } \\
\text { TSCA-regulated waste. }\end{array}$ \\
\hline $\begin{array}{l}\text { (3) Accelerator-Produced Waste. Radioactive waste } \\
\text { produced as a result of operations of DOE accelerators is } \\
\text { low-level waste and shall be managed in accordance with } \\
\text { DOE O 435.1, Radioactive Waste Management, and this } \\
\text { Manual, and all applicable Federal or State requirements. }\end{array}$ & $\begin{array}{l}\mathrm{NA} \text {; this facility does not manage } \\
\text { accelerator-produced waste. }\end{array}$ \\
\hline $\begin{array}{l}\text { (4) } 11 \text { e.(2) and Naturally Occurring Radioactive Material. } \\
\text { Small quantities of 11e.(2) byproduct material and naturally } \\
\text { occurring radioactive material may be managed as low-level } \\
\text { waste provided they can be managed to meet the } \\
\text { requirements for low-level waste disposal in Section IV.P of }\end{array}$ & $\begin{array}{l}\text { NA; this facility does not manage naturally } \\
\text { occurring radioactive material. }\end{array}$ \\
\hline
\end{tabular}


Table 22. (continued).

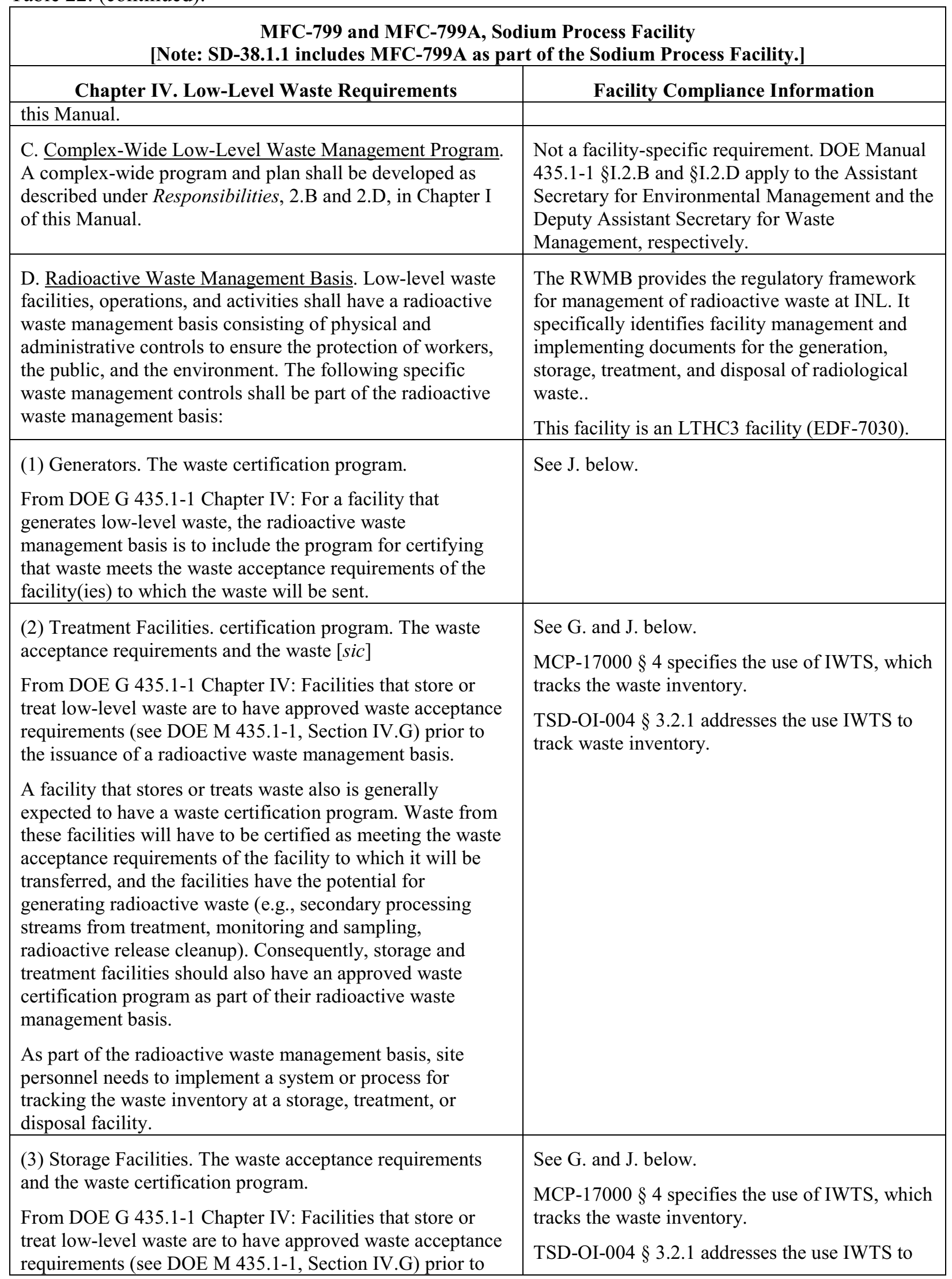


Table 22. (continued).

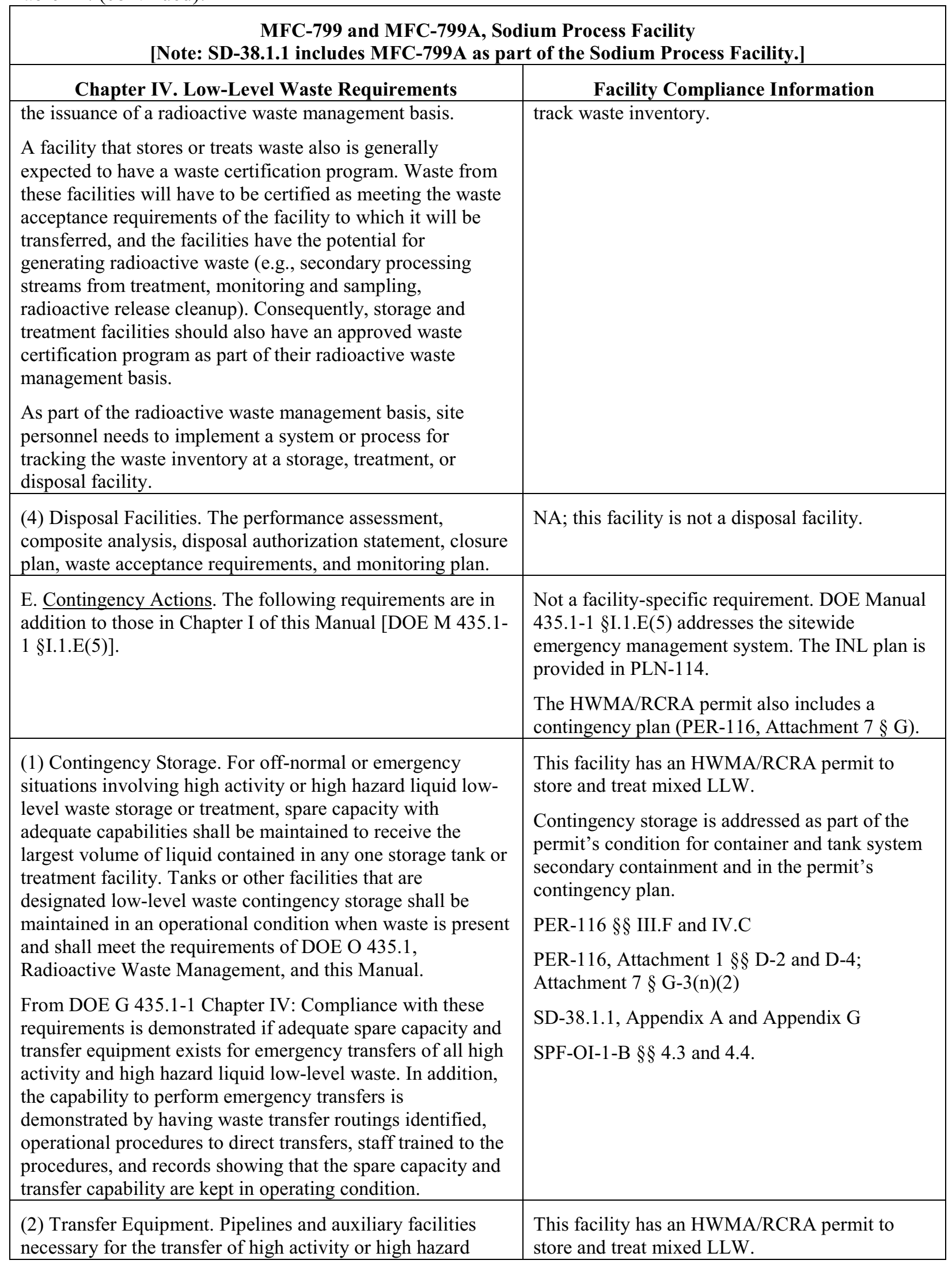


Table 22. (continued).

\begin{tabular}{|c|c|}
\hline \multicolumn{2}{|c|}{$\begin{array}{l}\text { MFC-799 and MFC-799A, Sodium Process Facility } \\
\text { [Note: SD-38.1.1 includes MFC-799A as part of the Sodium Process Facility.] }\end{array}$} \\
\hline Chapter IV. Low-Level Waste Requirements & Facility Compliance Information \\
\hline $\begin{array}{l}\text { liquid low-level waste to contingency storage shall be } \\
\text { maintained in an operational condition when waste is present } \\
\text { and shall meet the requirements of DOE O } 435.1 \text {, } \\
\text { Radioactive Waste Management, and this Manual. } \\
\text { From DOE G 435.1-1 Chapter IV: Compliance with these } \\
\text { requirements is demonstrated if adequate spare capacity and } \\
\text { transfer equipment exists for emergency transfers of all high } \\
\text { activity and high hazard liquid low-level waste. In addition, } \\
\text { the capability to perform emergency transfers is } \\
\text { demonstrated by having waste transfer routings identified, } \\
\text { operational procedures to direct transfers, staff trained to the } \\
\text { procedures, and records showing that the spare capacity and } \\
\text { transfer capability are kept in operating condition. }\end{array}$ & $\begin{array}{l}\text { Transfer equipment is addressed in the permit's } \\
\text { contingency plan (PER-116, Attachment } 7 \\
\S \text { G-3(n)(2)). }\end{array}$ \\
\hline $\begin{array}{l}\text { F. Corrective Actions. I of this Manual. The following } \\
\text { requirements are in addition to those in Chapter [sic] } \\
\text { From DOE G 435.1-1 Chapter IV: Compliance with DOE M } \\
\text { 435.1-1 §I.2.G.(1) is demonstrated by records showing what } \\
\text { corrective actions were taken to remedy situations in the } \\
\text { radioactive waste management system. } \\
\text { Compliance with DOE M 435.1-1 §I.2.G.(2) is demonstrated } \\
\text { by having the necessary procedures, mechanisms, and } \\
\text { training in place to effect shutdown or curtailment of } \\
\text { activities which pose an imminent danger or other serious } \\
\text { hazard to workers or the public, or are not protective of the } \\
\text { environment. }\end{array}$ & $\begin{array}{l}\text { The INL-wide procedure addressing problem } \\
\text { identification as required by DOE Manual } 435.1 \text { - } \\
1 \text { §I.2.G.(1) is LWP-13840, which implements } \\
\text { the laboratory's corrective action system. } \\
\text { The INL-wide procedure addressing shutdown or } \\
\text { curtailment of activities as required by DOE } \\
\text { Manual 435.1-1 §I.2.G.(2) is LWP-14002. }\end{array}$ \\
\hline $\begin{array}{l}\text { (1) Order Compliance. Corrective actions shall be } \\
\text { implemented whenever necessary to ensure the requirements } \\
\text { of DOE O 435.1, Radioactive Waste Management, and this } \\
\text { Manual are met. } \\
\text { From DOE G 435.1-1 Chapter IV: If a facility or activity can } \\
\text { be allowed to operate while a noncompliant or hazardous } \\
\text { condition exists, the allowance and any associated } \\
\text { limitations must be defined as part of the facility or activity's } \\
\text { radioactive waste management basis, identified as a } \\
\text { configuration controlled item in a configuration management } \\
\text { plan or included in a revision or modification to an operating } \\
\text { procedure or similar controlled documentation. } \\
\text { Compliance with this requirement is demonstrated if a } \\
\text { corrective action system addresses noncompliant or } \\
\text { hazardous situations involving low-level waste management } \\
\text { facilities in a systematic fashion, and allows identification of } \\
\text { problems by all personnel. }\end{array}$ & $\begin{array}{l}\text { See F. above. } \\
\text { This facility has an HWMA/RCRA permit to } \\
\text { store and treat mixed LLW. } \\
\text { Corrective actions for waste regulated under this } \\
\text { permit are addressed as permit conditions. } \\
\text { PER-116, Module VI } \\
\text { PER-116, Attachment } 4 \\
\text { SD-38.1.1 } § 2.4,6 \text { and Appendix A }\end{array}$ \\
\hline $\begin{array}{l}\text { (2) Operations Curtailment. Operations shall be curtailed or } \\
\text { facilities shut down for failure to establish, maintain, or } \\
\text { operate consistent with an approved radioactive waste } \\
\text { management basis. }\end{array}$ & $\begin{array}{l}\text { The approved RWMB establishes the current } \\
\text { compliance status at each radioactive waste } \\
\text { management facility. Facility assessments are } \\
\text { scheduled to ensure waste management activities }\end{array}$ \\
\hline
\end{tabular}


Table 22. (continued).

\begin{tabular}{|c|c|}
\hline \multicolumn{2}{|c|}{$\begin{array}{l}\text { MFC-799 and MFC-799A, Sodium Process Facility } \\
\text { [Note: SD-38.1.1 includes MFC-799A as part of the Sodium Process Facility.] }\end{array}$} \\
\hline Chapter IV. Low-Level Waste Requirements & Facility Compliance Information \\
\hline $\begin{array}{l}\text { From DOE G 435.1-1 Chapter IV: Compliance with this } \\
\text { requirement is demonstrated with a documented system of } \\
\text { routine assessments to determine whether waste management } \\
\text { activities and facilities are operating in accordance with an } \\
\text { approved radioactive waste management basis that provides } \\
\text { for graded limitations that can be placed on activities and } \\
\text { operations that do not have, or are operating outside of, an } \\
\text { approved radioactive waste management basis, including } \\
\text { shutdown of the facility. }\end{array}$ & $\begin{array}{l}\text { are conducted in accordance with the approved } \\
\text { RWMB. }\end{array}$ \\
\hline $\begin{array}{l}\text { G. Waste Acceptance. The following requirements are in } \\
\text { addition to those in Chapter I of this Manual [DOE M 435.1- } \\
1 \text { §I.2.F(6)]. }\end{array}$ & $\begin{array}{l}\text { Not a facility-specific requirement. DOE Manual } \\
435.1-1 \S \text { I.2.F(6) applies to field element } \\
\text { managers. }\end{array}$ \\
\hline $\begin{array}{l}\text { (1) Technical and Administrative. Waste acceptance } \\
\text { requirements for all low-level waste storage, treatment, or } \\
\text { disposal facilities, operations, and activities shall specify, at } \\
\text { a minimum, the following: }\end{array}$ & $\begin{array}{l}\text { WGS manages LLW in accordance with } \\
\text { MCP- } 17000 . \\
\text { See below. }\end{array}$ \\
\hline $\begin{array}{l}\text { From DOE G } 435.1-1 \text { Chapter IV: Compliance with these } \\
\text { waste acceptance requirements is demonstrated if they are } \\
\text { documented, contain clear and precise criteria specifying the } \\
\text { radionuclide limits in the form of contents or concentrations } \\
\text { that can be accepted, the limitations and prohibitions on } \\
\text { waste forms and packages that can be received, and the } \\
\text { limits, prohibitions, or instructions concerning any other } \\
\text { technical information so that the waste is compatible with } \\
\text { the safety basis of the facility, and which will result in } \\
\text { acceptable waste at subsequent steps in managing the low- } \\
\text { level waste. }\end{array}$ & \\
\hline $\begin{array}{l}\text { (a) Allowable activities and/or concentrations of specific } \\
\text { radionuclides. }\end{array}$ & $\begin{array}{l}\text { MCP-17000 } \\
\text { TSD-OI-004 } \S 3.2\end{array}$ \\
\hline $\begin{array}{l}\text { (b) Acceptable waste form and/or container requirements } \\
\text { that ensure the chemical and physical stability of waste } \\
\text { under conditions that might be encountered during } \\
\text { transportation, storage, treatment, or disposal. }\end{array}$ & $\begin{array}{l}\text { MCP-17000 } \\
\text { TSD-OI-004 } \S 3.3 \text { and } 3.4 \\
\text { PER-116, Module II.C and III } \\
\text { PER-116, Attachment } 1 \S \S \text { B-2(a) and D-1(a); } \\
\text { Attachment } 2 \S \text { C-2(a) } \\
\text { SD-38.1.1, Appendix A and Appendix G }\end{array}$ \\
\hline $\begin{array}{l}\text { (c) Restrictions or prohibitions on waste, materials, or } \\
\text { containers that may adversely affect waste handlers or } \\
\text { compromise facility or waste container performance. }\end{array}$ & $\begin{array}{l}\text { MCP-17000 } \\
\text { TSD-OI-004 } \S 3.2 \\
\text { PER-116, Module II.C. and III } \\
\text { PER-116, Attachment } 1 \S \S \text { B-2(a) and D-1(a); } \\
\text { Attachment } 2 \S \text { C-2(a) } \\
\text { SD-38.1.1, Appendix A and Appendix G }\end{array}$ \\
\hline
\end{tabular}


Table 22. (continued).

\begin{tabular}{|c|c|}
\hline \multicolumn{2}{|c|}{$\begin{array}{l}\text { MFC-799 and MFC-799A, Sodium Process Facility } \\
\text { [Note: SD-38.1.1 includes MFC-799A as part of the Sodium Process Facility.] }\end{array}$} \\
\hline Chapter IV. Low-Level Waste Requirements & Facility Compliance Information \\
\hline $\begin{array}{l}\text { (d) The following are additional waste acceptance } \\
\text { requirements that shall be specified in low-level waste } \\
\text { disposal facility waste acceptance requirements: }\end{array}$ & NA; this facility is not a LLW disposal facility. \\
\hline $\begin{array}{l}1 \text { Low-level waste must contribute to and not detract from } \\
\text { achieving long-term stability of the facility, minimizing the } \\
\text { need for long-term active maintenance, minimizing } \\
\text { subsidence, and minimizing contact of water with waste. } \\
\text { Void spaces within the waste and, if containers are used, } \\
\text { between the waste and its container shall be reduced to the } \\
\text { extent practical. }\end{array}$ & See (d) above. \\
\hline $\begin{array}{l}2 \text { Liquid low-level waste or low-level waste containing free } \\
\text { liquid must be converted into a form that contains as little } \\
\text { freestanding liquid as is reasonably achievable, but in no } \\
\text { case shall the liquid exceed } 1 \text { percent of the waste volume } \\
\text { when the low-level waste is in a disposal container, or } 0.5 \\
\text { percent of the waste volume after it is processed to a stable } \\
\text { form. }\end{array}$ & See (d) above. \\
\hline $\begin{array}{l}3 \text { Low-level waste must not be readily capable of detonation } \\
\text { or of explosive decomposition or reaction at anticipated } \\
\text { pressures and temperatures, or of explosive reaction with } \\
\text { water. Pyrophoric materials contained in waste shall be } \\
\text { treated, prepared, and packaged to be nonflammable. }\end{array}$ & See (d) above. \\
\hline $\begin{array}{l}4 \text { Low-level waste must not contain, or be capable of } \\
\text { generating by radiolysis or biodegradation, quantities of } \\
\text { toxic gases, vapors, or fumes harmful to the public or } \\
\text { workers or disposal facility personnel, or harmful to the } \\
\text { long-term structural stability of the disposal site. }\end{array}$ & See (d) above. \\
\hline $\begin{array}{l}5 \text { Low-level waste in a gaseous form must be packaged such } \\
\text { that the pressure does not exceed } 1.5 \text { atmospheres absolute at } \\
20 \text { C. [sic] }\end{array}$ & See (d) above. \\
\hline $\begin{array}{l}\text { (e) The basis, procedures, and levels of authority required for } \\
\text { granting exceptions to the waste acceptance requirements, } \\
\text { which shall be contained in each facility's waste acceptance } \\
\text { documentation. Each exception request shall be documented, } \\
\text { including its disposition as approved or not approved. }\end{array}$ & $\begin{array}{l}\text { Exceptions to the waste acceptance requirements } \\
\text { are not permitted. }\end{array}$ \\
\hline $\begin{array}{l}\text { From DOE G } 435.1-1 \text { Chapter IV: Waste acceptance } \\
\text { requirements are acceptable if they are documented and } \\
\text { contain a clear description of the procedure and bases for } \\
\text { obtaining an exception or deviation to the acceptance criteria } \\
\text { for low-level waste to be received at the facility. }\end{array}$ & \\
\hline (2) Evaluation and Acceptance. The receiving facility shall & MCP-17000 \\
\hline $\begin{array}{l}\text { evaluate waste for acceptance, including confirmation that } \\
\text { the technical and administrative requirements have been met. }\end{array}$ & TSD-OI-004 § 3 \\
\hline A process for the disposition of non-conforming wastes shall & PER-116, Module II.C., III, and IV \\
\hline be established. & PER-116, Attachment $1 \S$ D-1(b); Attachment 2 \\
\hline
\end{tabular}


Table 22. (continued).

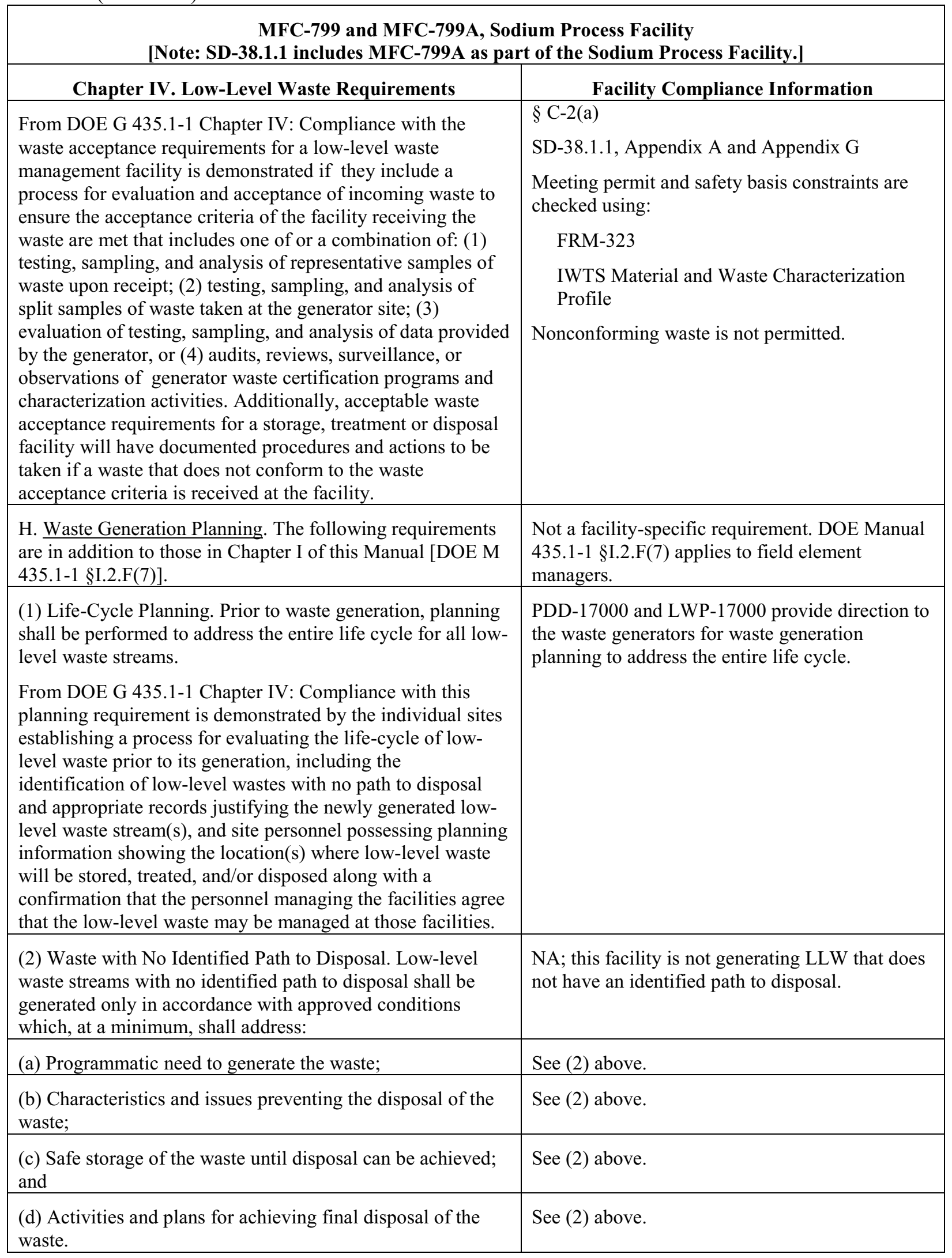


Table 22. (continued).

\begin{tabular}{|c|c|}
\hline \multicolumn{2}{|c|}{$\begin{array}{l}\text { MFC-799 and MFC-799A, Sodium Process Facility } \\
\text { [Note: SD-38.1.1 includes MFC-799A as part of the Sodium Process Facility.] }\end{array}$} \\
\hline Chapter IV. Low-Level Waste Requirements & Facility Compliance Information \\
\hline $\begin{array}{l}\text { I. Waste Characterization. Low-level waste shall be } \\
\text { characterized using direct or indirect methods, and the } \\
\text { characterization documented in sufficient detail to ensure } \\
\text { safe management and compliance with the waste acceptance } \\
\text { requirements of the facility receiving the waste. } \\
\text { From DOE G 435.1-1 Chapter IV: Compliance with this } \\
\text { requirement is demonstrated by a program for documenting } \\
\text { and the existence of records that document the process for } \\
\text { acquiring and verifying the validity of low-level waste } \\
\text { characterization data acquired through the use of direct or } \\
\text { indirect methods. }\end{array}$ & $\begin{array}{l}\text { TSD-OI-004 } \S 3.2 .6 \text { and Appendix C } \\
\text { PER-116, Module II.C } \\
\text { PER-116, Attachment } 2 \\
\text { SD-38.1.1, Appendix A and Appendix G } \\
\text { MCP-17000 }\end{array}$ \\
\hline $\begin{array}{l}\text { (1) Data Quality Objectives. The data quality objectives } \\
\text { process, or a comparable process, shall be used for } \\
\text { identifying characterization parameters and acceptable } \\
\text { uncertainty in characterization data. } \\
\text { From DOE G } 435.1-1 \text { Chapter IV: Compliance with this } \\
\text { requirement is demonstrated by the documented use of a data } \\
\text { quality objectives or a comparable process for determining } \\
\text { the type, quantity, and quality of characterization data } \\
\text { needed to safely manage low-level waste. }\end{array}$ & $\begin{array}{l}\text { Radioactive waste management facilities } \\
\text { characterize waste in accordance with the } \\
\text { requirements of the receiving storage, treatment, } \\
\text { or disposal facility. The documented use of a data } \\
\text { quality objectives process, or comparable } \\
\text { process, was not identified for this facility. }\end{array}$ \\
\hline $\begin{array}{l}\text { (2) Minimum Waste Characterization. Characterization data } \\
\text { shall, at a minimum, include the following information } \\
\text { relevant to the management of the waste: } \\
\text { From DOE G } 435.1-1 \text { Chapter IV: Compliance with this } \\
\text { requirement is demonstrated by the existence of a program } \\
\text { or procedure for determining and records that document } \\
\text { characterization of low-level waste consistent with the } \\
\text { minimum characterization data requirements. }\end{array}$ & $\begin{array}{l}\text { MCP-17000, including } \S \S 4.2,4.3 \text {, and } 4.4 \text {, } \\
\text { provides waste characterization requirements. } \\
\text { Information on absorbent media is required in } \\
\S \S 4.5 \text { and } 4.7 \text {. MCP-17000 also specifies the use } \\
\text { of IWTS, which documents characterization data } \\
\text { in an IWTS profile. } \\
\text { TSD-OI-004 } \S 3.2 .6 \text { and Appendix C } \\
\text { PER-116, Module II.C } \\
\text { PER-116, Attachment } 2 \\
\text { SD-38.1.1, Appendix A and Appendix G } \\
\text { FRM-323 } \\
\text { IWTS Material and Waste Characterization } \\
\text { Profile }\end{array}$ \\
\hline (a) Physical and chemical characteristics; & See I. and (2) above. \\
\hline $\begin{array}{l}\text { (b) Volume, including the waste and any stabilization or } \\
\text { absorbent media; }\end{array}$ & See I. and (2) above. \\
\hline (c) Weight of the container and contents; & See I. and (2) above. \\
\hline $\begin{array}{l}\text { (d) Identities, activities, and concentrations of major } \\
\text { radionuclides; }\end{array}$ & See I. and (2) above. \\
\hline (e) Characterization date; & See I. and (2) above. \\
\hline (f) Generating source; and & See I. and (2) above. \\
\hline
\end{tabular}


Table 22. (continued).

\begin{tabular}{|c|c|}
\hline \multicolumn{2}{|c|}{$\begin{array}{l}\text { MFC-799 and MFC-799A, Sodium Process Facility } \\
\text { [Note: SD-38.1.1 includes MFC-799A as part of the Sodium Process Facility.] }\end{array}$} \\
\hline Chapter IV. Low-Level Waste Requirements & Facility Compliance Information \\
\hline $\begin{array}{l}\text { (g) Any other information which may be needed to prepare } \\
\text { and maintain the disposal facility performance assessment, } \\
\text { or demonstrate compliance with applicable performance } \\
\text { objectives. }\end{array}$ & See I. and (2) above. \\
\hline $\begin{array}{l}\text { J. Waste Certification. A waste certification program shall be } \\
\text { developed, documented, and implemented to ensure that the } \\
\text { waste acceptance requirements of facilities receiving low- } \\
\text { level waste for storage, treatment, and disposal are met. } \\
\text { From DOE G 435.1-1 Chapter IV: Compliance with the } \\
\text { development and documentation portion of the certification } \\
\text { requirement is demonstrated by a waste certification plan } \\
\text { that identifies the organizations involved, assigns } \\
\text { responsibilities for implementing the program, and describes } \\
\text { or references the quality assurance, training, procurement } \\
\text { controls, records management, and procedures to be used by } \\
\text { the program. Acceptable performance for implementing the } \\
\text { program is demonstrated when appropriate personnel are } \\
\text { trained and follow the procedures that govern their part of } \\
\text { the waste certification. Additionally, acceptable performance } \\
\text { is demonstrated if the waste certification plan and procedures } \\
\text { are current and controlled in accordance with a document } \\
\text { controls program, and records related to certification (e.g., } \\
\text { certification statements, training records, procurement } \\
\text { records, characterization records, container records) are } \\
\text { generated and managed in accordance with the established } \\
\text { site program. }\end{array}$ & $\begin{array}{l}\text { MCP-17000 cites a waste certification program } \\
\text { for LLW destined for NNSS. For waste destined } \\
\text { for locations other than NNSS, the waste } \\
\text { disposition specialist is responsible for certifying } \\
\text { the waste stream by ensuring the waste, as } \\
\text { characterized, falls within the limitations of the } \\
\text { WAC of the treatment, storage, or disposal } \\
\text { facility ( } \$ 2 \text { ). } \\
\text { Container procurement is addressed in MCP- } \\
17000 \S 4.6 \text {. } \\
\text { MCP-17500 provides the WGS waste } \\
\text { certification program for LLW to be shipped to } \\
\text { NNSS. } \\
\text { Waste certification is performed and tracked } \\
\text { using IWTS. Documentation of the IWTS } \\
\text { Program is available electronically only. } \\
\text { PLN-522 requires waste technical specialists and } \\
\text { waste disposition specialists to complete the } \\
\text { appropriate training/qualification before being } \\
\text { granted approval authority for profiles within the } \\
\text { IWTS Program. The waste certification official, } \\
\text { alternate waste certification official, and NNSS } \\
\text { packaging certifiers must complete the } \\
\text { appropriate training/qualifications to disposition } \\
\text { waste to NNSS. } \\
\text { TSD-OI-004 } \S ~ 3.2 .4,3.2 .5,3.3,3.4,3.6 \text {, and } 4 \\
\text { PER-116, Module II.C and III } \\
\text { PER-116, Attachment } 1 \text { } \S \text { B-2(a) and D-1(a); } \\
\text { Attachment } 2 \S \text { C-2(a) } \\
\text { SD-38.1.1, Appendix A and Appendix G }\end{array}$ \\
\hline $\begin{array}{l}\text { (1) Certification Program. The waste certification program } \\
\text { shall designate the officials who have the authority to certify } \\
\text { and release waste for shipment; and specify what } \\
\text { documentation is required for waste generation, } \\
\text { characterization, shipment, and certification. The program } \\
\text { shall provide requirements for auditability, retrievability, and } \\
\text { storage of required documentation and specify the records } \\
\text { retention period. } \\
\text { From DOE G } 435.1-1 \text { Chapter IV: Compliance with this } \\
\text { requirement is demonstrated by a program or procedure for }\end{array}$ & $\begin{array}{l}\text { See J. above. MCP- } 17500 \S \S 2 \text { and } 5 \text { address } \\
\text { certification records for shipments to NNSS. }\end{array}$ \\
\hline
\end{tabular}


Table 22. (continued).

\begin{tabular}{|c|c|}
\hline \multicolumn{2}{|c|}{$\begin{array}{l}\text { MFC-799 and MFC-799A, Sodium Process Facility } \\
\text { [Note: SD-38.1.1 includes MFC-799A as part of the Sodium Process Facility.] }\end{array}$} \\
\hline Chapter IV. Low-Level Waste Requirements & Facility Compliance Information \\
\hline $\begin{array}{l}\text { record keeping and records showing that low-level waste is } \\
\text { certified as having met the waste acceptance criteria of the } \\
\text { facility to which it was transferred and that the certification } \\
\text { statement is supported by additional records regarding the } \\
\text { waste source, characterization, and container. }\end{array}$ & \\
\hline $\begin{array}{l}\text { (2) Certification before Transfer. Low-level waste shall be } \\
\text { certified as meeting waste acceptance requirements before it } \\
\text { is transferred to the facility receiving the waste. }\end{array}$ & $\begin{array}{l}\text { See J. above. MCP- } 17500 \S 4.3 .6 \text { addresses } \\
\text { controls for certification before transfer for LLW } \\
\text { to be disposed of at NNSS. }\end{array}$ \\
\hline $\begin{array}{l}\text { From DOE G 435.1-1 Chapter IV: Compliance with this } \\
\text { requirement is demonstrated by the presence of a } \\
\text { certification program which includes procedures requiring a } \\
\text { signed certification statement prior to the release of waste for } \\
\text { transfer, and by dated records showing that waste was } \\
\text { certified before being transferred. }\end{array}$ & \\
\hline $\begin{array}{l}\text { (3) Maintaining Certification. Low-level waste that has been } \\
\text { certified as meeting the waste acceptance requirements for } \\
\text { transfer to a storage, treatment, or disposal facility shall be }\end{array}$ & $\begin{array}{l}\text { See J. above. Pre-certification checklists are cited } \\
\text { in MCP-17000 and MCP-17500. Surveillances } \\
\text { also are addressed in MCP-17500. }\end{array}$ \\
\hline $\begin{array}{l}\text { managed in a manner that maintains its certification status. } \\
\text { requirement is demonstrated by a program or procedure } \\
\text { reflecting this requirement is present and site personnel are } \\
\text { able to show that the storage of low-level waste containers is } \\
\text { in a facility or manner where the containers would not be } \\
\text { damaged by normal weather events, and cannot be accessed } \\
\text { by unauthorized personnel. Further, each container can be } \\
\text { traced to its certification and the information supporting that } \\
\text { certification. }\end{array}$ & $\begin{array}{l}\text { LWP- } 15011 \S 5 \text { provides general radioactive } \\
\text { storage area requirements. }\end{array}$ \\
\hline $\begin{array}{l}\text { K. Waste Transfer. A documented process shall be } \\
\text { established and implemented for transferring responsibility } \\
\text { for management of low-level waste and for ensuring } \\
\text { availability of relevant data. The following requirements are } \\
\text { in addition to those in Chapter I of this Manual. }\end{array}$ & $\begin{array}{l}\text { MCP- } 17000 \S 4.8 .15 \text { specifies requirements for } \\
\text { interfacility transfers. } \\
\text { MCP-17500 } § 4 \text { addresses LLW to be transferred } \\
\text { to NNSS. }\end{array}$ \\
\hline $\begin{array}{l}\text { From DOE G 435.1-1 Chapter IV: Compliance with this } \\
\text { requirement is demonstrated if facilities have procedures for } \\
\text { the receipt of waste and the transfer of waste, as appropriate, } \\
\text { which address the acquisition of waste and container data } \\
\text { and the transfer of ownership, respectively. Further evidence } \\
\text { of acceptable performance is facility records showing that } \\
\text { data on the waste containers is available and accurate, and } \\
\text { that documented transfer of responsibility occurs. }\end{array}$ & TSD-OI-004 $\S \S 3.2,3.4,3.6,3.7,3.8$, and 4 \\
\hline $\begin{array}{l}\text { (1) Authorization. Low-level waste shall not be transferred } \\
\text { to a storage, treatment, or disposal facility until personnel } \\
\text { responsible for the facility receiving the waste authorize the } \\
\text { transfer. }\end{array}$ & See K. above. \\
\hline $\begin{array}{l}\text { From DOE G } 435.1-1 \text { Chapter IV: Compliance with this } \\
\text { requirement is demonstrated by sites having procedures that }\end{array}$ & \\
\hline
\end{tabular}


Table 22. (continued).

\begin{tabular}{|c|c|}
\hline \multicolumn{2}{|c|}{$\begin{array}{l}\text { MFC-799 and MFC-799A, Sodium Process Facility } \\
\text { [Note: SD-38.1.1 includes MFC-799A as part of the Sodium Process Facility.] }\end{array}$} \\
\hline Chapter IV. Low-Level Waste Requirements & Facility Compliance Information \\
\hline $\begin{array}{l}\text { require a confirmation of authorization before releasing } \\
\text { waste for transfer, and records showing that transfers are } \\
\text { made in accordance with written authorizations. }\end{array}$ & \\
\hline $\begin{array}{l}\text { (2) Data. Waste characterization data, container information, } \\
\text { and generation, storage, treatment, and transportation } \\
\text { information for low-level waste shall be transferred with or } \\
\text { be traceable to the waste. }\end{array}$ & See K. above. \\
\hline $\begin{array}{l}\text { From DOE G } 435.1-1 \text { Chapter IV: Compliance with this } \\
\text { requirement is demonstrated if there are procedures requiring } \\
\text { that characterization and container data be provided and } \\
\text { maintained for each low-level waste transfer and } \\
\text { documented records of transfers show that the information is } \\
\text { being provided. }\end{array}$ & \\
\hline $\begin{array}{l}\text { L. Packaging and Transportation. The following } \\
\text { requirements are in addition to those in Chapter I of this } \\
\text { Manual [DOE M 435.1-1 §I.1.E(11)]. }\end{array}$ & See (1) and (2) below. \\
\hline $\begin{array}{l}\text { (1) Packaging. If containers are used: } \\
\text { From DOE G 435.1-1 Chapter IV: Compliance with the } \\
\text { packaging requirement is demonstrated by: (1) procedures } \\
\text { which document proper packaging protocols; and (2) no } \\
\text { trends of routine repackaging of low-level waste that is } \\
\text { packaged after issuance of DOE O } 435.1 \text {. Successful } \\
\text { performance of this requirement is also demonstrated by a } \\
\text { record of containers for which failure has not routinely } \\
\text { occurred under management conditions. It is recognized that } \\
\text { there may be failed containers for waste previously placed in } \\
\text { storage. For those containers, the goal is to only have to } \\
\text { repackage the waste one time after it is retrieved and } \\
\text { characterized. Further, acceptable performance is } \\
\text { demonstrated by containers of waste having marking and } \\
\text { labeling that allows correlation with waste characterization } \\
\text { data and container information. }\end{array}$ & $\begin{array}{l}\text { MCP-17000 } \S 4 \text { addresses packaging } \\
\text { requirements. } \\
\text { TSD-OI-004 } \S 3.3\end{array}$ \\
\hline $\begin{array}{l}\text { (a) Low-level waste shall be packaged in a manner that } \\
\text { provides containment and protection for the duration of the } \\
\text { anticipated storage period and until disposal is achieved or } \\
\text { until the waste has been removed from the container. }\end{array}$ & See (1) above. \\
\hline $\begin{array}{l}\text { (b) When waste is packaged, vents or other measures shall } \\
\text { be provided if the potential exists for pressurizing or } \\
\text { generating flammable or explosive concentrations of gases } \\
\text { within the waste container. }\end{array}$ & See (1) above. \\
\hline $\begin{array}{l}\text { (c) Containers of low-level waste shall be marked such that } \\
\text { their contents can be identified. }\end{array}$ & See (1) above. \\
\hline $\begin{array}{l}\text { (2) Transportation. To the extent practical, the volume of } \\
\text { waste and number of low-level waste shipments shall be } \\
\text { minimized. }\end{array}$ & $\begin{array}{l}\text { MCP-17000 } \S 4 \text { addresses transportation. The } \\
\text { waste disposition specialist coordinates with } \\
\text { packaging and transportation personnel for waste } \\
\text { shipped offsite from this facility. }\end{array}$ \\
\hline
\end{tabular}


Table 22. (continued).

\begin{tabular}{|c|c|}
\hline \multicolumn{2}{|c|}{$\begin{array}{l}\text { MFC-799 and MFC-799A, Sodium Process Facility } \\
\text { [Note: SD-38.1.1 includes MFC-799A as part of the Sodium Process Facility.] }\end{array}$} \\
\hline Chapter IV. Low-Level Waste Requirements & Facility Compliance Information \\
\hline $\begin{array}{l}\text { From DOE G } 435.1-1 \text { Chapter IV: Compliance with this } \\
\text { requirement can be demonstrated by a combination of site } \\
\text { procedures directing the efficient use of waste container } \\
\text { capacity and documentation showing that low-level waste } \\
\text { shipments are systematically planned and optimized to the } \\
\text { extent practical. }\end{array}$ & $\begin{array}{l}\text { MCP-17500 specifies waste certification official } \\
\text { and waste disposition specialist responsibilities } \\
\text { and coordination with packaging and } \\
\text { transportation personnel for waste shipped } \\
\text { directly to NNNS from this facility. }\end{array}$ \\
\hline $\begin{array}{l}\text { M. Site Evaluation and Facility Design. The following } \\
\text { requirements are in addition to those in Chapter I of this } \\
\text { Manual. }\end{array}$ & $\begin{array}{l}\text { NA; this requirement addresses new radioactive } \\
\text { waste management facilities or modifications to } \\
\text { existing facilities. }\end{array}$ \\
\hline $\begin{array}{l}\text { (1) Site Evaluation. Proposed locations for low-level waste } \\
\text { facilities shall be evaluated to identify relevant features that } \\
\text { should be avoided or must be considered in facility design } \\
\text { and analyses. }\end{array}$ & See M. above. \\
\hline $\begin{array}{l}\text { (a) Each site proposed for a new low-level waste facility or } \\
\text { expansion of an existing low-level waste facility shall be } \\
\text { evaluated considering environmental characteristics, } \\
\text { geotechnical characteristics, and human activities, including } \\
\text { for a low-level waste disposal facility, the capability of the } \\
\text { site to demonstrate, at a minimum, whether it is: }\end{array}$ & See M. above. \\
\hline $\begin{array}{l}1 \text { Located to accommodate the projected volume of waste to } \\
\text { be received; }\end{array}$ & See M. above. \\
\hline $\begin{array}{l}2 \text { Located in a flood plain, a tectonically active area, or in the } \\
\text { zone of water table fluctuation; and }\end{array}$ & See M. above. \\
\hline $\begin{array}{l}3 \text { Located where radionuclide migration pathways are } \\
\text { predictable and erosion and surface runoff can be controlled. }\end{array}$ & See M. above. \\
\hline $\begin{array}{l}\text { (b) Proposed sites with environmental characteristics, } \\
\text { geotechnical characteristics, and human activities for which } \\
\text { adequate protection cannot be provided through facility } \\
\text { design shall be deemed unsuitable for the location of the } \\
\text { facility. }\end{array}$ & See M. above. \\
\hline $\begin{array}{l}\text { (c) Low-level waste disposal facilities shall be sited to } \\
\text { achieve long-term stability and to minimize, to the extent } \\
\text { practical, the need for active maintenance following final } \\
\text { closure. }\end{array}$ & See M. above. \\
\hline $\begin{array}{l}\text { (2) Low-Level Waste Treatment and Storage Facility } \\
\text { Design. The following facility requirements and general } \\
\text { design criteria, at a minimum, apply: }\end{array}$ & See M. above. \\
\hline $\begin{array}{l}\text { (a) Confinement. Low-level waste systems and components } \\
\text { shall be designed to maintain waste confinement. }\end{array}$ & See M. above. \\
\hline (b) Ventilation. & See M. above. \\
\hline $\begin{array}{l}1 \text { Design of low-level waste treatment and storage facilities } \\
\text { shall include ventilation, if applicable, through an } \\
\text { appropriate filtration system to maintain the release of }\end{array}$ & See M. above. \\
\hline
\end{tabular}


Table 22. (continued).

\begin{tabular}{|c|c|}
\hline \multicolumn{2}{|c|}{$\begin{array}{l}\text { MFC-799 and MFC-799A, Sodium Process Facility } \\
\text { [Note: SD-38.1.1 includes MFC-799A as part of the Sodium Process Facility.] }\end{array}$} \\
\hline Chapter IV. Low-Level Waste Requirements & Facility Compliance Information \\
\hline $\begin{array}{l}\text { radioactive material in airborne effluents within the } \\
\text { requirements and guidelines specified in applicable } \\
\text { requirements. }\end{array}$ & \\
\hline $\begin{array}{l}2 \text { When conditions exist for generating gases in flammable } \\
\text { or explosive concentrations, ventilation systems or other } \\
\text { measures shall be provided to keep the gases in a non- } \\
\text { flammable and nonexplosive condition. Where } \\
\text { concentrations of explosive or flammable gases are expected } \\
\text { to approach the lower flammability limit, measures shall be } \\
\text { taken to prevent deflagration or detonation. }\end{array}$ & See M. above. \\
\hline $\begin{array}{l}\text { (c) Consideration of Decontamination and } \\
\text { Decommissioning. Areas in new and modifications to } \\
\text { existing low-level waste management facilities that are } \\
\text { subject to contamination with radioactive or other hazardous } \\
\text { materials shall be designed to facilitate decontamination. For } \\
\text { such facilities a proposed decommissioning method or a } \\
\text { conversion method leading to reuse shall be described. }\end{array}$ & See M. above. \\
\hline $\begin{array}{l}\text { (d) Instrumentation and Control Systems. Engineering } \\
\text { controls shall be incorporated in the design and engineering } \\
\text { of low-level waste treatment and storage facilities to provide } \\
\text { volume inventory data and to prevent spills, leaks, and } \\
\text { overflows from tanks or confinement systems. }\end{array}$ & See M. above. \\
\hline $\begin{array}{l}\text { (e) Monitoring. Monitoring and/or leak detection capabilities } \\
\text { shall be incorporated in the design and engineering of low- } \\
\text { level waste treatment and storage facilities to provide rapid } \\
\text { identification of failed confinement and/or other abnormal } \\
\text { conditions. }\end{array}$ & See M. above. \\
\hline $\begin{array}{l}\text { (3) Low-Level Waste Disposal Facility Design. The } \\
\text { following facility requirements and general design criteria, at } \\
\text { a minimum, apply: }\end{array}$ & See M. above. \\
\hline $\begin{array}{l}\text { (a) Confinement. Low-level waste systems and components } \\
\text { shall be designed to maintain waste confinement. }\end{array}$ & See M. above. \\
\hline (b) Ventilation. & See M. above. \\
\hline $\begin{array}{l}1 \text { Design of low-level waste disposal facilities shall include } \\
\text { ventilation, if applicable, through an appropriate filtration } \\
\text { system to maintain the release of radioactive material in } \\
\text { airborne effluents within the requirements and guidelines } \\
\text { specified in applicable requirements. }\end{array}$ & See M. above. \\
\hline $\begin{array}{l}2 \text { When conditions exist for generating gases in flammable } \\
\text { or explosive concentrations, ventilation systems or other } \\
\text { measures shall be provided to keep the gases in a non- } \\
\text { flammable and non-explosive condition. Where } \\
\text { concentrations of explosive or flammable gases are expected } \\
\text { to approach the lower flammability limit, measures shall be } \\
\text { taken to prevent deflagration or detonation. }\end{array}$ & See M. above. \\
\hline
\end{tabular}


Table 22. (continued).

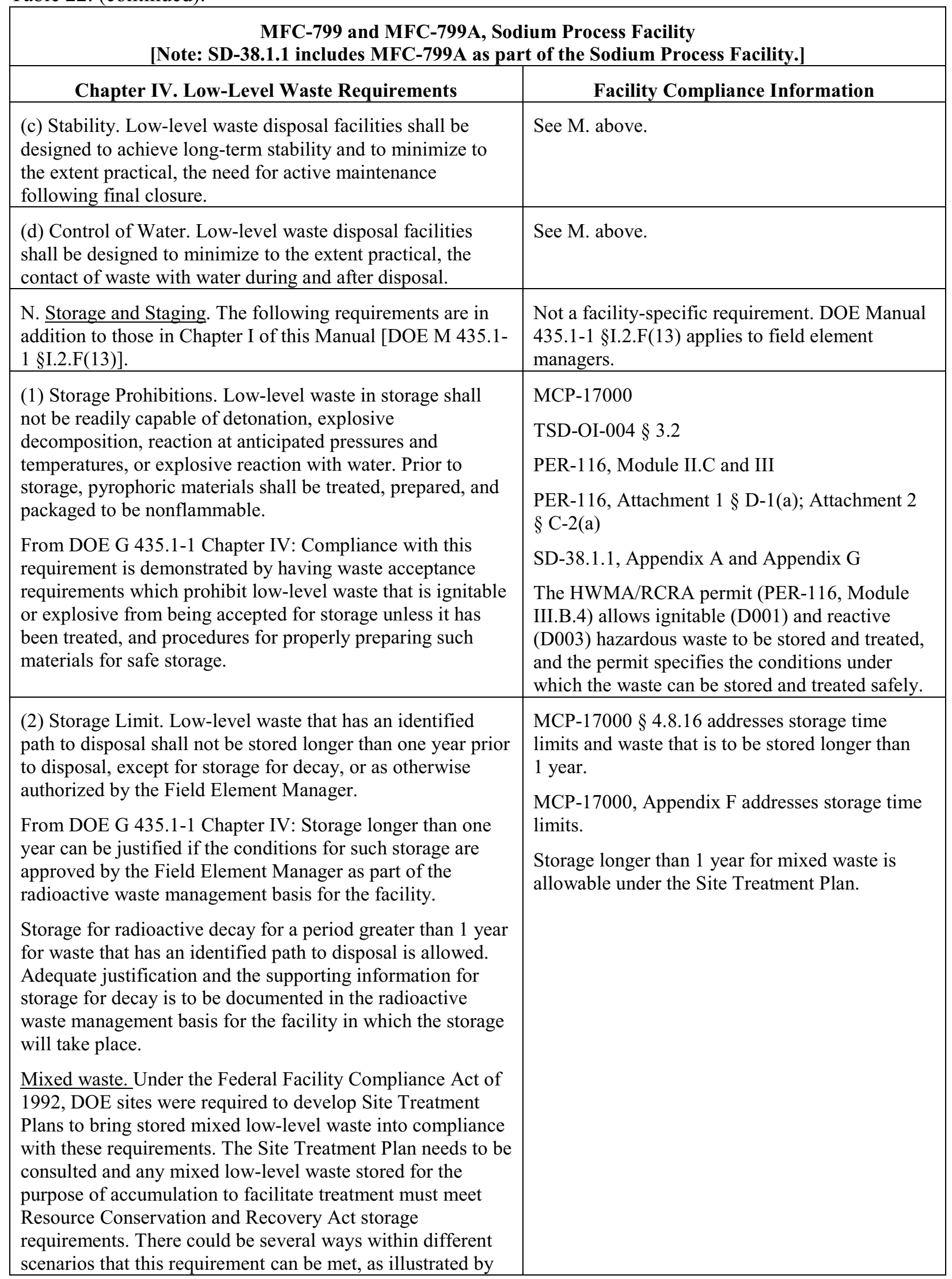


Table 22. (continued).

MFC-799 and MFC-799A, Sodium Process Facility

[Note: SD-38.1.1 includes MFC-799A as part of the Sodium Process Facility.]

Chapter IV. Low-Level Waste Requirements
the examples below, however, there are basically four ways
to show compliance with the requirement and include
appropriate provisions in the radioactive waste management
basis for the facility in which it is stored.
Legacy waste. As discussed above, the intention of the
requirement is not to force malicious compliance or heroic
actions which would result in increased risk or safety
concerns. Rather, the intention is that waste in storage longer
than one year receives additional attention to ensure that the
public, the workers, and the environment are protected from
the hazards of the waste, and that progress is being made to
dispose of the waste. There could be several ways within
different scenarios that this requirement can be met, as
illustrated by the examples below, however, there are
basically four ways to show compliance with the
requirement:

1) the radioactive waste management basis allows for storage for no more than one year.

2) the radioactive waste management basis allows for storage for no more than one year, or for storage for decay only for periods greater than a year, which are specified on a radionuclide basis.

3 ) the radioactive waste management basis allows for storage for more than one year, up to a specified period of time based on a documented technical evaluation that the waste can be stored in a manner that does not cause changes to the waste or waste packages that is detrimental to the safe storage of the waste, the final disposal of the waste or to meeting the disposal performance objectives.

4) the radioactive waste management basis allows for storage for decay (with specifics) and for storage for more than one year for other low-level waste, up to a specified period of time based on a documented technical evaluation that the waste can be stored in a manner that does not cause changes to the waste or waste packages that is detrimental to the safe storage of the waste, the final disposal of the waste or to meeting the disposal performance objectives.

Compliance with this requirement is demonstrated by the existence of a radioactive waste management basis for the storage facility approved by the Field Element Manager that includes the time frames that waste are allowed to be stored, the necessary justifications for storage for decay, and the necessary technical evaluations if storage is to extend significantly beyond the one-year time frame.

(3) Storage Integrity. Low-level waste shall be stored in a location and manner that protects the integrity of waste for the expected time of storage and minimizes worker

MCP-17000

TSD-OI-004 $\S 3.3$ and 3.4 
Table 22. (continued).

\begin{tabular}{|c|c|}
\hline \multicolumn{2}{|c|}{$\begin{array}{l}\text { MFC-799 and MFC-799A, Sodium Process Facility } \\
\text { [Note: SD-38.1.1 includes MFC-799A as part of the Sodium Process Facility.] }\end{array}$} \\
\hline Chapter IV. Low-Level Waste Requirements & Facility Compliance Information \\
\hline $\begin{array}{l}\text { exposure. } \\
\text { From DOE G 435.1-1 Chapter IV: However, in making a } \\
\text { decision to use a facility for storage and in developing a } \\
\text { radioactive waste management basis for the activity, } \\
\text { particular attention to protection of workers is needed. } \\
\text { Compliance with this requirement is demonstrated if sites } \\
\text { have storage capabilities for low-level waste that provide } \\
\text { protection to waste containers so that their integrity will not } \\
\text { be damaged through physical or chemical (corrosion) } \\
\text { processes and that keep personnel from spending extended } \\
\text { periods of time in the areas where low-level waste is stored. }\end{array}$ & $\begin{array}{l}\text { PER-116, Module III } \\
\text { PER-116, Attachment } 1 \S \text { D-1(a) } \\
\text { SD-38.1.1, Appendix A and Appendix G }\end{array}$ \\
\hline (4) Waste Characterization for Storage. & See below. \\
\hline $\begin{array}{l}\text { (a) Low-level waste that does not have an identified path to } \\
\text { disposal shall be characterized as necessary to meet the data } \\
\text { quality objectives and minimum characterization } \\
\text { requirements of this Chapter, to ensure safe storage, and to } \\
\text { facilitate disposal. }\end{array}$ & $\begin{array}{l}\text { This facility does not store LLW that does not } \\
\text { have an identified path to disposal. }\end{array}$ \\
\hline $\begin{array}{l}\text { (b) Characterization information for all low-level waste in } \\
\text { storage shall be maintained as a record in accordance with } \\
\text { the requirements for Records Management in Chapter I of } \\
\text { this Manual. }\end{array}$ & $\begin{array}{l}\text { MCP-17000 } \\
\text { TSD-OI-004 } \S 3.8 \text { and } 4 \\
\text { PER-116, Module III and IV }\end{array}$ \\
\hline $\begin{array}{l}\text { From DOE G 435.1-1 Chapter IV: Compliance with this } \\
\text { requirement is demonstrated by documented procedures for } \\
\text { managing waste characterization and container information } \\
\text { on low-level waste as a Federal record. The records are } \\
\text { managed per the applicable policies and procedures for } \\
\text { records management referenced in DOE O } 200.1 \text { and } \\
\text { established at the applicable Field Element. }\end{array}$ & $\begin{array}{l}\text { PER-116, Attachment } 1 \S \text { D; Attachment } 2 \\
\text { SD-38.1.1, Appendix A and Appendix G }\end{array}$ \\
\hline $\begin{array}{l}\text { (5) Container Inspection. A process shall be developed and } \\
\text { implemented for inspecting and maintaining containers of } \\
\text { low-level waste to ensure container integrity is not } \\
\text { compromised. }\end{array}$ & $\begin{array}{l}\text { LI- } 435 \text { requires quarterly inspections of } \\
\text { radioactive waste containers if waste is stored } \\
\text { outdoors or has been in storage for greater than } \\
1 \text { year. }\end{array}$ \\
\hline From DOE G 435.1-1 Chapter IV: Compliance with this & MCP-17000 \\
\hline $\begin{array}{l}\text { requirement is demonstrated by: (1) a documented process } \\
\text { for waste container inspection and maintenance; and ( } 2 \text { ) }\end{array}$ & For mixed LLW: \\
\hline documentation for all waste container inspections and & TSD-OI-004 $\S \S 3.4 .7$ and 4.3 \\
\hline maintenance actions performed. & PER-116, Module III \\
\hline & $\begin{array}{l}\text { PER-116, Attachment } 4 \text { (this attachment } \\
\text { includes examples of facility-specific } \\
\text { inspection forms to be used) }\end{array}$ \\
\hline & SD-38.1.1, Appendix A and Appendix G \\
\hline & $\begin{array}{l}\text { LWP-15011 does not include a requirement for } \\
\text { inspection. }\end{array}$ \\
\hline
\end{tabular}


Table 22. (continued).

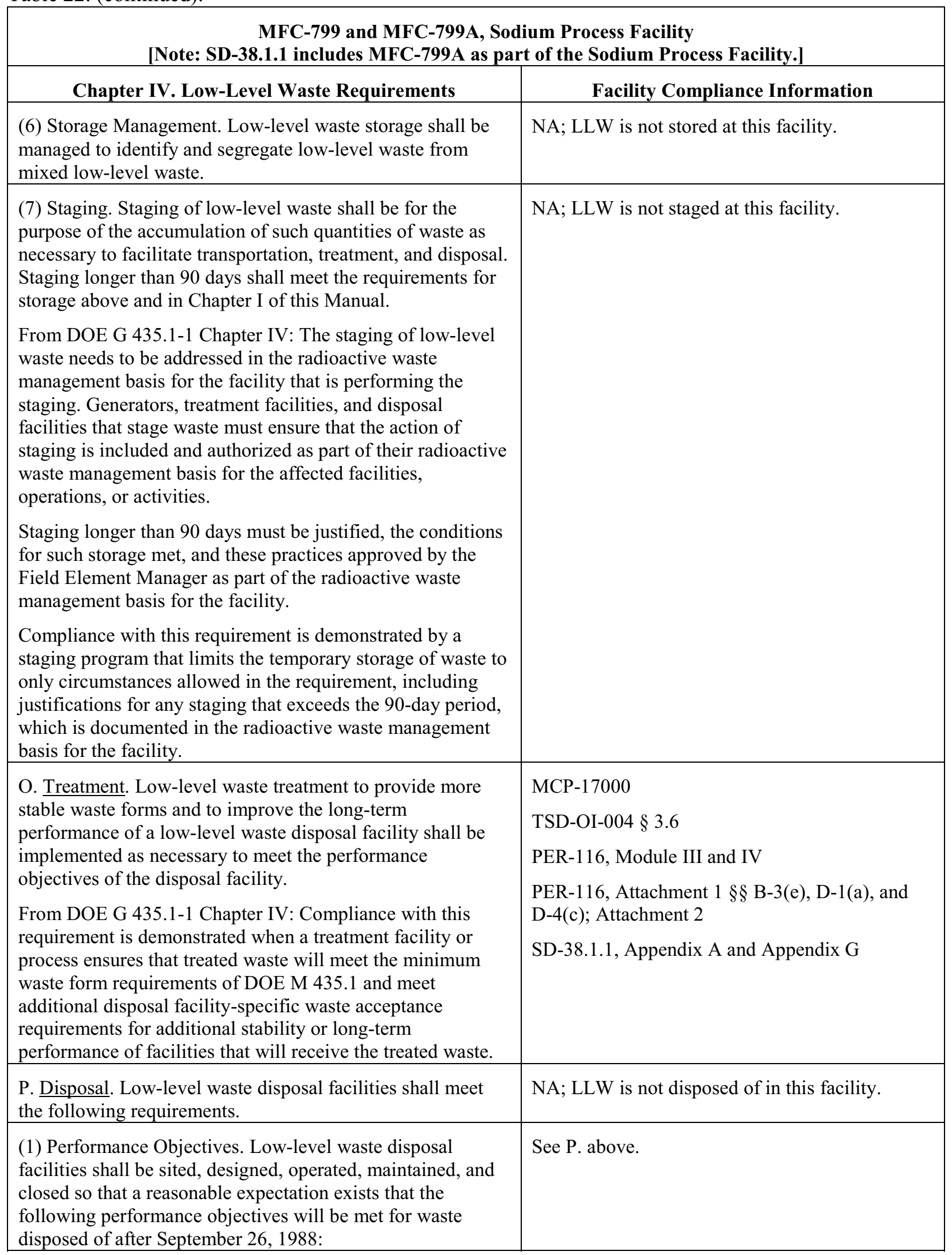


Table 22. (continued).

\begin{tabular}{|c|c|}
\hline \multicolumn{2}{|c|}{$\begin{array}{l}\text { MFC-799 and MFC-799A, Sodium Process Facility } \\
\text { [Note: SD-38.1.1 includes MFC-799A as part of the Sodium Process Facility.] }\end{array}$} \\
\hline Chapter IV. Low-Level Waste Requirements & Facility Compliance Information \\
\hline $\begin{array}{l}\text { (a) Dose to representative members of the public shall not } \\
\text { exceed } 25 \mathrm{mrem}(0.25 \mathrm{mSv}) \text { in a year total effective dose } \\
\text { equivalent from all exposure pathways, excluding the dose } \\
\text { from radon and its progeny in air. }\end{array}$ & See P. above. \\
\hline $\begin{array}{l}\text { (b) Dose to representative members of the public via the air } \\
\text { pathway shall not exceed } 10 \text { mrem }(0.10 \mathrm{mSv}) \text { in a year total } \\
\text { effective dose equivalent, excluding the dose from radon and } \\
\text { its progeny. }\end{array}$ & See P. above. \\
\hline $\begin{array}{l}\text { (c) Release of radon shall be less than an average flux of } 20 \\
\mathrm{pCi} / \mathrm{m}^{2} / \mathrm{s}\left(0.74 \mathrm{~Bq} / \mathrm{m}^{2} / \mathrm{s}\right) \text { at the surface of the disposal facility. } \\
\text { Alternatively, a limit of } 0.5 \mathrm{pCi} / 1(0.0185 \mathrm{~Bq} / \mathrm{l}) \text { of air may be } \\
\text { applied at the boundary of the facility. }\end{array}$ & See P. above. \\
\hline $\begin{array}{l}\text { (2) Performance Assessment. A site-specific radiological } \\
\text { performance assessment shall be prepared and maintained } \\
\text { for DOE low-level waste disposed of after September } 26 \text {, } \\
\text { 1988. The performance assessment shall include calculations } \\
\text { for a } 1,000 \text { year period after closure of potential doses to } \\
\text { representative future members of the public and potential } \\
\text { releases from the facility to provide a reasonable expectation } \\
\text { that the performance objectives identified in this Chapter are } \\
\text { not exceeded as a result of operation and closure of the } \\
\text { facility. }\end{array}$ & See P. above. \\
\hline $\begin{array}{l}\text { (a) Analyses performed to demonstrate compliance with the } \\
\text { performance objectives in this Chapter, and to establish } \\
\text { limits on concentrations of radionuclides for disposal based } \\
\text { on the performance measures for inadvertent intruders in this } \\
\text { Chapter shall be based on reasonable activities in the critical } \\
\text { group of exposed individuals. Unless otherwise specified, } \\
\text { the assumption of average living habits and exposure } \\
\text { conditions in representative critical groups of individuals } \\
\text { projected to receive the highest doses is appropriate. The } \\
\text { likelihood of inadvertent intruder scenarios may be } \\
\text { considered in interpreting the results of the analyses and } \\
\text { establishing radionuclide concentrations, if adequate } \\
\text { justification is provided. }\end{array}$ & See P. above. \\
\hline $\begin{array}{l}\text { (b) The point of compliance shall correspond to the point of } \\
\text { highest projected dose or concentration beyond a } 100 \text { meter } \\
\text { buffer zone surrounding the disposed waste. A larger or } \\
\text { smaller buffer zone may be used if adequate justification is } \\
\text { provided. }\end{array}$ & See P. above. \\
\hline $\begin{array}{l}\text { (c) Performance assessments shall address reasonably } \\
\text { foreseeable natural processes that might disrupt barriers } \\
\text { against release and transport of radioactive materials. }\end{array}$ & See P. above. \\
\hline $\begin{array}{l}\text { (d) Performance assessments shall use DOE-approved dose } \\
\text { coefficients (dose conversion factors) for internal and } \\
\text { external exposure of reference adults. }\end{array}$ & See P. above. \\
\hline
\end{tabular}


Table 22. (continued).

\begin{tabular}{|c|c|}
\hline \multicolumn{2}{|c|}{$\begin{array}{l}\text { MFC-799 and MFC-799A, Sodium Process Facility } \\
\text { [Note: SD-38.1.1 includes MFC-799A as part of the Sodium Process Facility.] }\end{array}$} \\
\hline Chapter IV. Low-Level Waste Requirements & Facility Compliance Information \\
\hline $\begin{array}{l}\text { (e) The performance assessment shall include a } \\
\text { sensitivity/uncertainty analysis. }\end{array}$ & See P. above. \\
\hline $\begin{array}{l}\text { (f) Performance assessments shall include a demonstration } \\
\text { that projected releases of radionuclides to the environment } \\
\text { shall be maintained as low as reasonably achievable } \\
\text { (ALARA). }\end{array}$ & See P. above. \\
\hline $\begin{array}{l}\text { (g) For purposes of establishing limits on radionuclides that } \\
\text { may be disposed of near-surface, the performance } \\
\text { assessment shall include an assessment of impacts to water } \\
\text { resources. }\end{array}$ & See P. above. \\
\hline $\begin{array}{l}\text { (h) For purposes of establishing limits on the concentration } \\
\text { of radionuclides that may be disposed of near-surface, the } \\
\text { performance assessment shall include an assessment of } \\
\text { impacts calculated for a hypothetical person assumed to } \\
\text { inadvertently intrude for a temporary period into the low- } \\
\text { level waste disposal facility. For intruder analyses, } \\
\text { institutional controls shall be assumed to be effective in } \\
\text { deterring intrusion for at least } 100 \text { years following closure. } \\
\text { The intruder analyses shall use performance measures for } \\
\text { chronic and acute exposure scenarios, respectively, of } 100 \\
\text { mrem }(1 \mathrm{mSv}) \text { in a year and } 500 \text { mrem }(5 \mathrm{mSv}) \text { total } \\
\text { effective dose equivalent excluding radon in air. }\end{array}$ & See P. above. \\
\hline $\begin{array}{l}\text { (3) Composite Analysis. For disposal facilities which } \\
\text { received waste after September 26, 1988, a site-specific } \\
\text { radiological composite analysis shall be prepared and } \\
\text { maintained that accounts for all sources of radioactive } \\
\text { material that may be left at the DOE site and may interact } \\
\text { with the low- level waste disposal facility, contributing to the } \\
\text { dose projected to a hypothetical member of the public from } \\
\text { the existing or future disposal facilities. Performance } \\
\text { measures shall be consistent with DOE requirements for } \\
\text { protection of the public and environment and evaluated for a } \\
1,000 \text { year period following disposal facility closure. The } \\
\text { composite analysis results shall be used for planning, } \\
\text { radiation protection activities, and future use commitments } \\
\text { to minimize the likelihood that current low- level waste } \\
\text { disposal activities will result in the need for future corrective } \\
\text { or remedial actions to adequately protect the public and the } \\
\text { environment. }\end{array}$ & See P. above. \\
\hline $\begin{array}{l}\text { (4) Performance Assessment and Composite Analysis } \\
\text { Maintenance. The performance assessment and composite } \\
\text { analysis shall be maintained to evaluate changes that could } \\
\text { affect the performance, design, and operating bases for the } \\
\text { facility. Performance assessment and composite analysis } \\
\text { maintenance shall include the conduct of research, field } \\
\text { studies, and monitoring needed to address uncertainties or } \\
\text { gaps in existing data. The performance assessment shall be }\end{array}$ & See P. above. \\
\hline
\end{tabular}


Table 22. (continued).

\begin{tabular}{|c|c|}
\hline \multicolumn{2}{|c|}{$\begin{array}{l}\text { MFC-799 and MFC-799A, Sodium Process Facility } \\
\text { [Note: SD-38.1.1 includes MFC-799A as part of the Sodium Process Facility.] }\end{array}$} \\
\hline Chapter IV. Low-Level Waste Requirements & Facility Compliance Information \\
\hline $\begin{array}{l}\text { updated to support the final facility closure. Additional } \\
\text { iterations of the performance assessment and composite } \\
\text { analysis shall be conducted as necessary during the post- } \\
\text { closure period. }\end{array}$ & \\
\hline $\begin{array}{l}\text { (a) Performance assessments and composite analyses shall } \\
\text { be reviewed and revised when changes in waste forms or } \\
\text { containers, radionuclide inventories, facility design and } \\
\text { operations, closure concepts, or the improved understanding } \\
\text { of the performance of the waste disposal facility in } \\
\text { combination with the features of the site on which it is } \\
\text { located alter the conclusions or the conceptual model(s) of } \\
\text { the existing performance assessment or composite analysis. }\end{array}$ & See P. above. \\
\hline $\begin{array}{l}\text { (b) A determination of the continued adequacy of the } \\
\text { performance assessment and composite analysis shall be } \\
\text { made on an annual basis, and shall consider the results of } \\
\text { data collection and analysis from research, field studies, and } \\
\text { monitoring. }\end{array}$ & See P. above. \\
\hline $\begin{array}{l}\text { (c) Annual summaries of low-level waste disposal operations } \\
\text { shall be prepared with respect to the conclusions and } \\
\text { recommendations of the performance assessment and } \\
\text { composite analysis and a determination of the need to revise } \\
\text { the performance assessment or composite analysis. }\end{array}$ & See P. above. \\
\hline $\begin{array}{l}\text { (5) Disposal Authorization. A disposal authorization } \\
\text { statement shall be obtained prior to construction of a new } \\
\text { low-level waste disposal facility. Field Elements with } \\
\text { existing low-level waste disposal facilities shall obtain a } \\
\text { disposal authorization statement in accordance with the } \\
\text { schedule in the Complex-Wide Low-Level Waste } \\
\text { Management Program Plan. The disposal authorization } \\
\text { statement shall be issued based on a review of the facility's } \\
\text { performance assessment, composite analysis, performance } \\
\text { assessment and composite analysis maintenance, preliminary } \\
\text { closure plan, and preliminary monitoring plan. The disposal } \\
\text { authorization statement shall specify the limits and } \\
\text { conditions on construction, design, operations, and closure of } \\
\text { the low-level waste facility based on these reviews. A } \\
\text { disposal authorization statement is a part of the radioactive } \\
\text { waste management basis for a disposal facility. Failure to } \\
\text { obtain a disposal authorization statement by the } \\
\text { implementation date of this Order shall result in shutdown of } \\
\text { the disposal facility. }\end{array}$ & See P. above. \\
\hline $\begin{array}{l}\text { (6) Disposal Facility Operations. The disposal facility design } \\
\text { and operation must be consistent with the disposal facility } \\
\text { closure plan and lead to disposal facility closure that } \\
\text { provides a reasonable expectation that performance } \\
\text { objectives will be met. Low-level waste shall be disposed in } \\
\text { such a manner that achieves the performance objectives } \\
\text { stated in this Chapter, consistent with the disposal facility }\end{array}$ & See P. above. \\
\hline
\end{tabular}


Table 22. (continued).

\begin{tabular}{|c|c|}
\hline \multicolumn{2}{|c|}{$\begin{array}{l}\text { MFC-799 and MFC-799A, Sodium Process Facility } \\
\text { [Note: SD-38.1.1 includes MFC-799A as part of the Sodium Process Facility.] }\end{array}$} \\
\hline Chapter IV. Low-Level Waste Requirements & Facility Compliance Information \\
\hline $\begin{array}{l}\text { radiological performance assessment. Additional } \\
\text { requirements include: }\end{array}$ & \\
\hline $\begin{array}{l}\text { (a) Operating procedures shall be developed and } \\
\text { implemented for low-level waste disposal facilities that } \\
\text { protect the public, workers, and the environment; ensure the } \\
\text { security of the facility; minimize subsidence during and after } \\
\text { waste emplacement; achieve long-term stability and } \\
\text { minimize the need for long-term active maintenance; and } \\
\text { meet the requirements of the closure/post-closure plan. }\end{array}$ & See P. above. \\
\hline $\begin{array}{l}\text { (b) Permanent identification markers for disposal } \\
\text { excavations and monitoring wells shall be emplaced. }\end{array}$ & See P. above. \\
\hline $\begin{array}{l}\text { (c) Low-level waste placement into disposal units shall } \\
\text { minimize voids between waste containers. Voids within } \\
\text { disposal units shall be filled to the extent practical. } \\
\text { Uncontainerized bulk waste shall also be placed in a manner } \\
\text { that minimizes voids and subsidence. }\end{array}$ & See P. above. \\
\hline $\begin{array}{l}\text { (d) Operations are to be conducted so that active waste } \\
\text { disposal operations will not have an adverse effect on any } \\
\text { other disposal units. }\end{array}$ & See P. above. \\
\hline $\begin{array}{l}\text { (e) Operations shall include a process for tracking and } \\
\text { documenting low-level waste placement in the facility by } \\
\text { generator source. }\end{array}$ & See P. above. \\
\hline $\begin{array}{l}\text { (7) Alternate Requirements for Low-Level Waste Disposal } \\
\text { Facility Design and Operation. Requirements other than } \\
\text { those set forth in this Section for the design and operation of } \\
\text { a low-level waste disposal facility may be approved on a } \\
\text { specific basis if a reasonable expectation is demonstrated } \\
\text { that the disposal performance objectives will be met. }\end{array}$ & See P. above. \\
\hline $\begin{array}{l}\text { Q. Closure. The following requirements are in addition to } \\
\text { those in Chapter I of this Manual. }\end{array}$ & NA; LLW is not disposed of in this facility. \\
\hline $\begin{array}{l}\text { (1) Disposal Facility Closure Plans. A preliminary closure } \\
\text { plan shall be developed and submitted to Headquarters for } \\
\text { review with the performance assessment and composite } \\
\text { analysis. The closure plan shall be updated following } \\
\text { issuance of the disposal authorization statement to } \\
\text { incorporate conditions specified in the disposal authorization } \\
\text { statement. Closure plans shall: }\end{array}$ & See Q. above. \\
\hline $\begin{array}{l}\text { (a) Be updated as required during the operational life of the } \\
\text { facility. }\end{array}$ & See Q. above. \\
\hline $\begin{array}{l}\text { (b) Include a description of how the disposal facility will be } \\
\text { closed to achieve long-term stability and minimize the need } \\
\text { for active maintenance following closure and to ensure } \\
\text { compliance with the requirements of DOE } 5400.5 \text {, Radiation } \\
\text { Protection of the Public and the Environment. }\end{array}$ & See Q. above. \\
\hline
\end{tabular}


Table 22. (continued).

\begin{tabular}{|c|c|}
\hline \multicolumn{2}{|c|}{$\begin{array}{l}\text { MFC-799 and MFC-799A, Sodium Process Facility } \\
\text { [Note: SD-38.1.1 includes MFC-799A as part of the Sodium Process Facility.] }\end{array}$} \\
\hline Chapter IV. Low-Level Waste Requirements & Facility Compliance Information \\
\hline $\begin{array}{l}\text { (c) Include the total expected inventory of wastes to be } \\
\text { disposed of at the facility over the operational life of the } \\
\text { facility. }\end{array}$ & See Q. above. \\
\hline $\begin{array}{l}\text { (2) Disposal Facility Closure. Closure of a disposal facility } \\
\text { shall occur within a five-year period after it is filled to } \\
\text { capacity, or after the facility is otherwise determined to be } \\
\text { no longer needed. }\end{array}$ & See Q. above. \\
\hline $\begin{array}{l}\text { (a) Prior to facility closure, the final inventory of the low- } \\
\text { level waste disposed in the facility shall be prepared and } \\
\text { incorporated in the performance assessment and composite } \\
\text { analysis which shall be updated to support the closure of the } \\
\text { facility. }\end{array}$ & See Q. above. \\
\hline $\begin{array}{l}\text { (b) A final closure plan shall be prepared based on the final } \\
\text { inventory of waste disposed in the facility, the plan } \\
\text { implemented, and the updated performance assessment and } \\
\text { composite analysis prepared in support of the facility } \\
\text { closure. }\end{array}$ & See Q. above. \\
\hline $\begin{array}{l}\text { (c) Institutional control measures shall be integrated into } \\
\text { land use and stewardship plans and programs, and shall } \\
\text { continue until the facility can be released pursuant to DOE } \\
\text { 5400.5, Radiation Protection of the Public and the } \\
\text { Environment. }\end{array}$ & See Q. above. \\
\hline $\begin{array}{l}\text { (d) The location and use of the facility shall be filed with the } \\
\text { local authorities responsible for land use and zoning. }\end{array}$ & See Q. above. \\
\hline $\begin{array}{l}\text { R. Monitoring. The following requirements are in addition to } \\
\text { those in Chapter I of this Manual [DOE M 435.1-1 } \\
\S I .1 . E(7)] \text {. }\end{array}$ & See (1), (2), and (3) below. \\
\hline $\begin{array}{l}\text { (1) All Waste Facilities. Parameters that shall be sampled or } \\
\text { monitored, at a minimum, include: temperature, pressure (for } \\
\text { closed systems), radioactivity in ventilation exhaust and } \\
\text { liquid effluent streams, and flammable or explosive mixtures } \\
\text { of gases. Facility monitoring programs shall include } \\
\text { verification that passive and active control systems have not } \\
\text { failed. }\end{array}$ & $\begin{array}{l}\text { Monitoring requirements at INL radioactive } \\
\text { waste management facilities are tailored for the } \\
\text { specific facility to enable timely indication of } \\
\text { developing problems. Existing radiological } \\
\text { control procedures and assessments are } \\
\text { followed/completed to monitor waste facilities. } \\
\text { PER-116. Attachment } 1 \text { \& D and Attachment } 4\end{array}$ \\
\hline $\begin{array}{l}\text { From DOE G } 435.1-1 \text { Chapter IV: The minimum parameters } \\
\text { specified in the requirement were selected based on their }\end{array}$ & $\begin{array}{l}\S \mathrm{F} \text { describe facility monitoring and inspection } \\
\text { requirements. }\end{array}$ \\
\hline $\begin{array}{l}\text { potential significance for anticipating and identifying } \\
\text { undesirable conditions at low-level waste management } \\
\text { facilities. Each facility's radioactive waste management } \\
\text { basis should include an evaluation of the applicability and } \\
\text { significance of the minimum parameters. This evaluation } \\
\text { also needs to consider additional parameters to be sampled } \\
\text { or monitored to ensure the protection of the public health, } \\
\text { the environment, and the workers. If a minimum parameter } \\
\text { specified in the requirement is deemed to be not applicable } \\
\text { in any way to the active operation of that facility, then that }\end{array}$ & $\begin{array}{l}\text { LRD-15001 and MCP-139 specify methods and } \\
\text { frequency of radiological control surveys of all } \\
\text { radiological areas. MCP-139 specifies the use of } \\
\text { Form } 441 \text {.A34. This form is referred to as the } \\
\text { "routine sheet" and is to be used by facility } \\
\text { radiological control foremen to list radiological } \\
\text { areas that are to be surveyed, the survey periods, } \\
\text { and methods. }\end{array}$ \\
\hline
\end{tabular}


Table 22. (continued).

\begin{tabular}{|c|c|}
\hline \multicolumn{2}{|c|}{$\begin{array}{l}\text { MFC-799 and MFC-799A, Sodium Process Facility } \\
\text { [Note: SD-38.1.1 includes MFC-799A as part of the Sodium Process Facility.] }\end{array}$} \\
\hline Chapter IV. Low-Level Waste Requirements & Facility Compliance Information \\
\hline $\begin{array}{l}\text { justification should be included in the radioactive waste } \\
\text { management basis and when approved constitutes an } \\
\text { exemption to the manual. }\end{array}$ & \\
\hline $\begin{array}{l}\text { Verification activities are part of the radioactive waste } \\
\text { management basis as a condition for operation and } \\
\text { documented appropriately. }\end{array}$ & \\
\hline $\begin{array}{l}\text { Compliance with this requirement is demonstrated if } \\
\text { monitoring or sampling for the stated parameters is } \\
\text { performed for all facilities with a precision, accuracy, and } \\
\text { frequency consistent with timely identification of developing } \\
\text { problems and a justification exists in the approved } \\
\text { radioactive waste management basis for those specified } \\
\text { parameters which are not monitored or sampled. }\end{array}$ & \\
\hline $\begin{array}{l}\text { (2) Liquid Waste Storage Facilities. For facilities storing } \\
\text { liquid low-level waste, the following shall also be } \\
\text { monitored: liquid level and/or waste volume, and significant } \\
\text { waste chemistry parameters. }\end{array}$ & See (1) above. \\
\hline $\begin{array}{l}\text { (3) Disposal Facilities. A preliminary monitoring plan for a } \\
\text { low-level waste disposal facility shall be prepared and } \\
\text { submitted to Headquarters for review with the performance } \\
\text { assessment and composite analysis. The monitoring plan } \\
\text { shall be updated within one year following issuance of the } \\
\text { disposal authorization statement to incorporate and } \\
\text { implement conditions specified in the disposal authorization } \\
\text { statement. }\end{array}$ & NA; LLW is not disposed of in this facility \\
\hline $\begin{array}{l}\text { (a) The site-specific performance assessment and composite } \\
\text { analysis shall be used to determine the media, locations, } \\
\text { radionuclides, and other substances to be monitored. }\end{array}$ & See (3) above. \\
\hline $\begin{array}{l}\text { (b) The environmental monitoring program shall be designed } \\
\text { to include measuring and evaluating releases, migration of } \\
\text { radionuclides, disposal unit subsidence, and changes in } \\
\text { disposal facility and disposal site parameters which may } \\
\text { affect long-term performance. }\end{array}$ & See (3) above. \\
\hline $\begin{array}{l}\text { (c) The environmental monitoring programs shall be capable } \\
\text { of detecting changing trends in performance to allow } \\
\text { application of any necessary corrective action prior to } \\
\text { exceeding the performance objectives in this Chapter. }\end{array}$ & See (3) above. \\
\hline
\end{tabular}

\subsection{MFC-1702, Radiochemistry Laboratory}

1. Facility description: Information regarding a general facility description for MFC-1702, Radiochemistry Laboratory, was not identified at the time of publication of this document. Per a phone conversation with Richard Gunderson and Robert Gomez held on July 17, 2010, facility description information for this facility is yet to be developed pending the facility status change to operational. 


\section{Hazard category: LTHC3}

3. Radioactive waste managed at this facility: CH LLW and mixed CH LLW are generated and staged at this facility.

4. RWMB documents/programs:

a. Safety basis/hazard analysis:

- ECAR-671, "Hazard Catergorization Document for the Radiochemistry Laboratory (MFC-1702) at MFC"

- EDF-7030, "Inventory Analysis of Radiological Facilities at the Materials and Fuels Complex (MFC)"

b. Laboratory-wide:

- Form 441.A34, "INL Radiological Control Required Surveys"

- LI-435, "Waste Management Routine Field Activities"

- LRD-15001, "Radiological Control Manual"

- LWP-8000, Environmental Instructions for Facilities, Processes, Materials, and Equipment

- LWP-13840, "Management of Issues, Observations, and Noteworthy Practices"

- LWP-14002, "Timeout and Stop Work Authority"

- LWP-15011, "Radioactive Material Areas and Radioactive Storage Areas"

- LWP-17000, "Waste Management"

- MCP-139, "Radiological Surveys"

- MCP-17000, "Waste Generator Services Waste Management"

- MCP-17410, "Management of Waste Storage Areas"

- MCP-17500, "Waste Generator Services Certification of Waste Shipments to the Nevada Test Site"

- PDD-17000, "Waste Management Program"

- PLN-114, "INL Emergency Plan/RCRA Contingency Plan"

- PLN-522, "Quality Assurance Program Plan for the Waste Management/Waste Certification Program"

c. Facility-specific:

- TSD-OI-004, "Waste and Material Acceptance for Storage/Treatment and Radioactive Material Inventory Control"

LLW is managed at this facility. Table 23 shows the facility compliance information for DOE Manual 435.1-1, Chapter IV, "Low-level Waste Requirements."

Table 23. MFC-1702, Radiochemistry Laboratory, DOE Manual 435.1-1 low-level waste requirements and facility compliance information.

\begin{tabular}{|l|l|}
\hline \multicolumn{2}{|c|}{ Facility Name: MFC-1702, Radiochemistry Laboratory } \\
\hline \multicolumn{1}{|c|}{ Chapter IV, LLW Requirements } & \multicolumn{1}{c|}{ Facility Compliance Information } \\
\hline $\begin{array}{l}\text { A. Definition of Low-Level Waste. Low-level } \\
\text { radioactive waste is radioactive waste that is not high- } \\
\text { level radioactive waste, spent nuclear fuel, transuranic } \\
\text { waste, byproduct material (as defined in section 11e.(2) } \\
\text { of the Atomic Energy Act of 1954, as amended), or }\end{array}$ & $\begin{array}{l}\text { This requirement provides the criteria for determining } \\
\text { which DOE radioactive waste is to be managed as LLW in } \\
\text { accordance with DOE Manual 435.1-1, Chapter IV. } \\
\text { Radioactive waste managed at this facility under the } \\
\text { requirements of this chapter is not managed under the }\end{array}$ \\
\hline
\end{tabular}


Table 23. (continued).

Facility Name: MFC-1702, Radiochemistry Laboratory

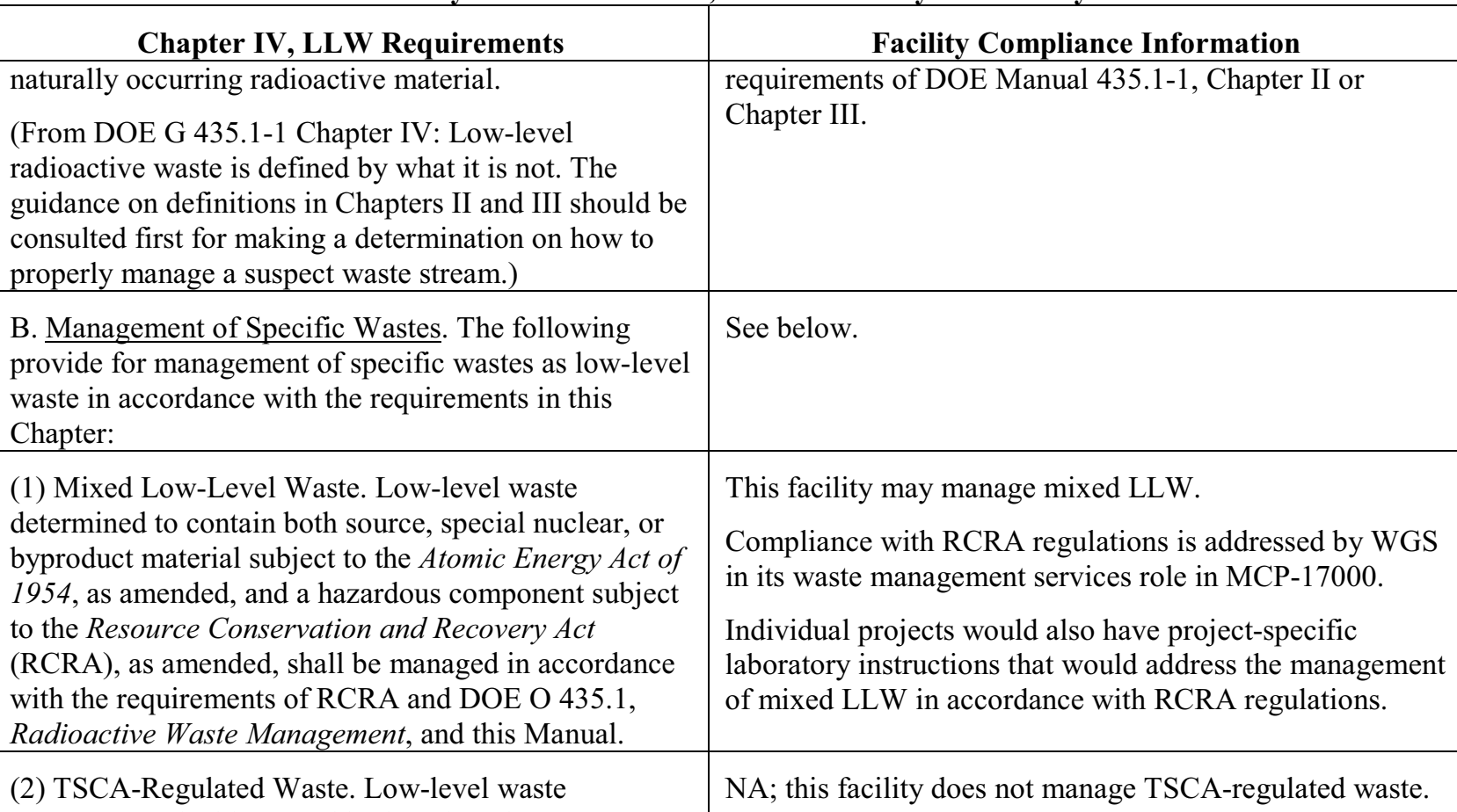

containing polychlorinated biphenyls, asbestos, or other such regulated toxic components shall be managed in accordance with requirements derived from the Toxic Substances Control Act, as amended, DOE O 435.1, Radioactive Waste Management, and this Manual.

(3) Accelerator-Produced Waste. Radioactive waste produced as a result of operations of DOE accelerators is low-level waste and shall be managed in accordance with DOE O 435.1, Radioactive Waste Management, and this Manual, and all applicable Federal or State requirements.

(4) 11e.(2) and Naturally Occurring Radioactive Material. Small quantities of 11e.(2) byproduct material and naturally occurring radioactive material may be managed as low-level waste provided they can be managed to meet the requirements for low-level waste disposal in Section IV.P of this Manual.

\section{Complex-Wide Low-Level Waste Management} Program. A complex-wide program and plan shall be developed as described under Responsibilities, 2.B and 2.D, in Chapter I of this Manual.

D. Radioactive Waste Management Basis. Low-level waste facilities, operations, and activities shall have a radioactive waste management basis consisting of physical and administrative controls to ensure the protection of workers, the public, and the environment. The following specific waste management controls
NA; this facility does not manage accelerator-produced waste.
NA; this facility does not manage naturally occurring radioactive material.
Not a facility-specific requirement. DOE Manual 435.1-1 §I.2.B and §I.2.D apply to the Assistant Secretary for Environmental Management and the Deputy Assistant Secretary for Waste Management, respectively.

The RWMB provides the regulatory framework for management of radioactive waste at INL. It specifically identifies facility management and implementing documents for the generation, storage, treatment, and disposal of radiological waste..

This facility is an LTHC3 facility (ECAR-671). 
Table 23. (continued).

Facility Name: MFC-1702, Radiochemistry Laboratory

\begin{tabular}{l} 
Chapter IV, LLW Requirements \\
\hline $\begin{array}{l}\text { shall be part of the radioactive waste management } \\
\text { basis: }\end{array}$ \\
(1) Generators. The waste certification program. \\
From DOE G 435.1 -1 Chapter IV: For a facility that \\
generates low-level waste, the radioactive waste \\
management basis is to include the program for \\
certifying that waste meets the waste acceptance \\
requirements of the facility(ies) to which the waste will \\
be sent.
\end{tabular}

(2) Treatment Facilities. certification program. The waste acceptance requirements and the waste [sic]

From DOE G 435.1-1 Chapter IV: Facilities that store or treat low-level waste are to have approved waste acceptance requirements (see DOE M 435.1-1, Section IV.G) prior to the issuance of a radioactive waste management basis.

A facility that stores or treats waste also is generally expected to have a waste certification program. Waste from these facilities will have to be certified as meeting the waste acceptance requirements of the facility to which it will be transferred, and the facilities have the potential for generating radioactive waste (e.g., secondary processing streams from treatment, monitoring and sampling, radioactive release cleanup). Consequently, storage and treatment facilities should also have an approved waste certification program as part of their radioactive waste management basis.

As part of the radioactive waste management basis, site personnel needs to implement a system or process for tracking the waste inventory at a storage, treatment, or disposal facility.

(3) Storage Facilities. The waste acceptance requirements and the waste certification program.

See J. below. Facility Compliance Information

NA; LLW is not treated at this facility.

Containerized elementary neutralization is performed at this facility as provided by LWP-8000. As stated in $\S 4.118$, elementary neutralization of corrosive hazardous waste may take place at any location at which the waste is generated or stored, and neither a generator treatment plan nor a permit is required. Solidification of liquid LLW for the purpose of staging (not for treating the radioactive constituents) also may be performed. Therefore, this facility is not considered to be a treatment facility.

From DOE G 435.1-1 Chapter IV: Facilities that store or treat low-level waste are to have approved waste acceptance requirements (see DOE M 435.1-1, Section IV.G) prior to the issuance of a radioactive waste management basis.

A facility that stores or treats waste also is generally expected to have a waste certification program. Waste from these facilities will have to be certified as meeting the waste acceptance requirements of the facility to which it will be transferred, and the facilities have the potential for generating radioactive waste (e.g., secondary processing streams from treatment, monitoring and sampling, radioactive release cleanup). Consequently, storage and treatment facilities should

NA; this facility stages waste in accordance with N.(7) to facilitate treatment or disposal. 
Table 23. (continued).

Facility Name: MFC-1702, Radiochemistry Laboratory

\begin{tabular}{l} 
Chapter IV, LLW Requirements \\
\hline $\begin{array}{l}\text { also have an approved waste certification program as } \\
\text { part of their radioactive waste management basis. } \\
\text { As part of the radioactive waste management basis, site } \\
\text { personnel needs to implement a system or process for } \\
\text { tracking the waste inventory at a storage, treatment, or } \\
\text { disposal facility. }\end{array}$ \\
\hline
\end{tabular}

(4) Disposal Facilities. The performance assessment, composite analysis, disposal authorization statement, closure plan, waste acceptance requirements, and monitoring plan.

E. Contingency Actions. The following requirements are in addition to those in Chapter I of this Manual [DOE M 435.1-1 §I.1.E(5)].

(1) Contingency Storage. For off-normal or emergency situations involving high activity or high hazard liquid low-level waste storage or treatment, spare capacity with adequate capabilities shall be maintained to receive the largest volume of liquid contained in any one storage tank or treatment facility. Tanks or other facilities that are designated low-level waste contingency storage shall be maintained in an operational condition when waste is present and shall meet the requirements of DOE O 435.1, Radioactive Waste Management, and this Manual.

From DOE G 435.1-1 Chapter IV: Compliance with these requirements is demonstrated if adequate spare capacity and transfer equipment exists for emergency transfers of all high activity and high hazard liquid low-level waste. In addition, the capability to perform emergency transfers is demonstrated by having waste transfer routings identified, operational procedures to direct transfers, staff trained to the procedures, and records showing that the spare capacity and transfer capability are kept in operating condition.

(2) Transfer Equipment. Pipelines and auxiliary facilities necessary for the transfer of high activity or high hazard liquid low-level waste to contingency storage shall be maintained in an operational condition when waste is present and shall meet the requirements of DOE O 435.1, Radioactive Waste Management, and this Manual.

From DOE G 435.1-1 Chapter IV: Compliance with these requirements is demonstrated if adequate spare capacity and transfer equipment exists for emergency transfers of all high activity and high hazard liquid low-level waste. In addition, the capability to perform emergency transfers is demonstrated by having waste transfer routings identified, operational procedures to
NA; this facility is not a disposal facility.

Not a facility-specific requirement. DOE Manual 435.1-1 $\S$ I.1.E(5) addresses the sitewide emergency management system. The INL plan is provided in PLN-114.

$\mathrm{NA}$; liquid LLW is not stored or treated in a tank system at this facility.
NA; liquid LLW is not stored or treated in a tank system at this facility. 
Table 23. (continued).

Facility Name: MFC-1702, Radiochemistry Laboratory

\begin{tabular}{l} 
Chapter IV, LLW Requirements \\
\hline $\begin{array}{l}\text { direct transfers, staff trained to the procedures, and } \\
\text { records showing that the spare capacity and transfer } \\
\text { capability are kept in operating condition. }\end{array}$ \\
F. Corrective Actions. I of this Manual. The following \\
requirements are in addition to those in Chapter [sic] \\
From DOE G 435.1-1 Chapter IV: Compliance with \\
DOE M 435.1-1 §I.2.G.(1) is demonstrated by records \\
showing what corrective actions were taken to remedy \\
situations in the radioactive waste management system. \\
Compliance with DOE M 435.1-1 §I.2.G.(2) is \\
demonstrated by having the necessary procedures, \\
mechanisms, and training in place to effect shutdown \\
or curtailment of activities which pose an imminent \\
danger or other serious hazard to workers or the public, \\
or are not protective of the environment.
\end{tabular}

(1) Order Compliance. Corrective actions shall be implemented whenever necessary to ensure the requirements of DOE O 435.1, Radioactive Waste Management, and this Manual are met.

From DOE G 435.1-1 Chapter IV: If a facility or activity can be allowed to operate while a noncompliant or hazardous condition exists, the allowance and any associated limitations must be defined as part of the facility or activity's radioactive waste management basis, identified as a configuration controlled item in a configuration management plan or included in a revision or modification to an operating procedure or similar controlled documentation.

Compliance with this requirement is demonstrated if a corrective action system addresses noncompliant or hazardous situations involving low-level waste management facilities in a systematic fashion, and allows identification of problems by all personnel.

(2) Operations Curtailment. Operations shall be curtailed or facilities shut down for failure to establish, maintain, or operate consistent with an approved radioactive waste management basis.

From DOE G 435.1-1 Chapter IV: Compliance with this requirement is demonstrated with a documented system of routine assessments to determine whether waste management activities and facilities are operating in accordance with an approved radioactive waste management basis that provides for graded limitations that can be placed on activities and operations that do not have, or are operating outside of, an approved radioactive waste management basis, including shutdown of the facility.
The INL-wide procedure addressing problem identification as required by DOE Manual 435.1-1 §I.2.G.(1) is LWP-13840, which implements the laboratory's corrective action system.

The INL-wide procedure addressing shutdown or curtailment of activities as required by DOE Manual 435.1-1 §I.2.G.(2) is LWP-14002.

See F. above.

The approved RWMB establishes the current compliance status at each radioactive waste management facility. Facility assessments are scheduled to ensure waste management activities are conducted in accordance with the approved RWMB. 
Table 23. (continued).

Facility Name: MFC-1702, Radiochemistry Laboratory

Chapter IV, LLW Requirements
Facility Compliance Information

G. Waste Acceptance. The following requirements are in addition to those in Chapter I of this Manual [DOE M 435.1-1 §I.2.F(6)].

(1) Technical and Administrative. Waste acceptance requirements for all low-level waste storage, treatment, or disposal facilities, operations, and activities shall specify, at a minimum, the following:

From DOE G 435.1-1 Chapter IV: Compliance with these waste acceptance requirements is demonstrated if they are documented, contain clear and precise criteria specifying the radionuclide limits in the form of contents or concentrations that can be accepted, the limitations and prohibitions on waste forms and packages that can be received, and the limits, prohibitions, or instructions concerning any other technical information so that the waste is compatible with the safety basis of the facility, and which will result in acceptable waste at subsequent steps in managing the low-level waste.

(a) Allowable activities and/or concentrations of
specific radionuclides.
(b) Acceptable waste form and/or container
requirements that ensure the chemical and physical
stability of waste under conditions that might be
encountered during transportation, storage, treatment,
or disposal.

(c) Restrictions or prohibitions on waste, materials, or containers that may adversely affect waste handlers or compromise facility or waste container performance.

(d) The following are additional waste acceptance requirements that shall be specified in low-level waste disposal facility waste acceptance requirements:

1 Low-level waste must contribute to and not detract from achieving long-term stability of the facility, minimizing the need for long-term active maintenance, minimizing subsidence, and minimizing contact of water with waste. Void spaces within the waste and, if containers are used, between the waste and its container shall be reduced to the extent practical.

2 Liquid low-level waste or low-level waste containing free liquid must be converted into a form that contains as little freestanding liquid as is reasonably achievable, but in no case shall the liquid exceed 1 percent of the waste volume when the low-level waste is in a disposal container, or 0.5 percent of the waste volume after it is processed to a stable form.
See (1) above.

See (1) above.

See (1) above.

NA; this facility is not a LLW disposal facility.

See (d) above.

See (d) above. 
Table 23. (continued).

Facility Name: MFC-1702, Radiochemistry Laboratory

\begin{tabular}{|c|c|}
\hline Chapter IV, LLW Requirements & Facility Compliance Information \\
\hline $\begin{array}{l}3 \text { Low-level waste must not be readily capable of } \\
\text { detonation or of explosive decomposition or reaction at } \\
\text { anticipated pressures and temperatures, or of explosive } \\
\text { reaction with water. Pyrophoric materials contained in } \\
\text { waste shall be treated, prepared, and packaged to be } \\
\text { nonflammable. }\end{array}$ & See (d) above. \\
\hline $\begin{array}{l}4 \text { Low-level waste must not contain, or be capable of } \\
\text { generating by radiolysis or biodegradation, quantities } \\
\text { of toxic gases, vapors, or fumes harmful to the public } \\
\text { or workers or disposal facility personnel, or harmful to } \\
\text { the long-term structural stability of the disposal site. }\end{array}$ & See (d) above. \\
\hline $\begin{array}{l}5 \text { Low-level waste in a gaseous form must be packaged } \\
\text { such that the pressure does not exceed } 1.5 \text { atmospheres } \\
\text { absolute at } 20 \text { C. [ sic] }\end{array}$ & See (d) above. \\
\hline $\begin{array}{l}\text { (e) The basis, procedures, and levels of authority } \\
\text { required for granting exceptions to the waste } \\
\text { acceptance requirements, which shall be contained in } \\
\text { each facility's waste acceptance documentation. Each } \\
\text { exception request shall be documented, including its } \\
\text { disposition as approved or not approved. }\end{array}$ & $\begin{array}{l}\text { NA; this facility does not accept waste from other } \\
\text { facilities. }\end{array}$ \\
\hline $\begin{array}{l}\text { From DOE G } 435.1-1 \text { Chapter IV: Waste acceptance } \\
\text { requirements are acceptable if they are documented and } \\
\text { contain a clear description of the procedure and bases } \\
\text { for obtaining an exception or deviation to the } \\
\text { acceptance criteria for low-level waste to be received at } \\
\text { the facility. }\end{array}$ & \\
\hline $\begin{array}{l}\text { (2) Evaluation and Acceptance. The receiving facility } \\
\text { shall evaluate waste for acceptance, including } \\
\text { confirmation that the technical and administrative } \\
\text { requirements have been met. A process for the } \\
\text { disposition of non-conforming wastes shall be } \\
\text { established. }\end{array}$ & $\begin{array}{l}\text { NA; this facility does not accept waste from other } \\
\text { facilities. }\end{array}$ \\
\hline $\begin{array}{l}\text { From DOE G 435.1-1 Chapter IV: Compliance with } \\
\text { the waste acceptance requirements for a low-level } \\
\text { waste management facility is demonstrated if they } \\
\text { include a process for evaluation and acceptance of } \\
\text { incoming waste to ensure the acceptance criteria of the } \\
\text { facility receiving the waste are met that includes one of } \\
\text { or a combination of: (1) testing, sampling, and analysis } \\
\text { of representative samples of waste upon receipt; (2) } \\
\text { testing, sampling, and analysis of split samples of } \\
\text { waste taken at the generator site; (3) evaluation of } \\
\text { testing, sampling, and analysis of data provided by the } \\
\text { generator, or (4) audits, reviews, surveillance, or } \\
\text { observations of generator waste certification programs } \\
\text { and characterization activities. Additionally, acceptable } \\
\text { waste acceptance requirements for a storage, treatment } \\
\text { or disposal facility will have documented procedures }\end{array}$ & \\
\hline
\end{tabular}


Table 23. (continued).

Facility Name: MFC-1702, Radiochemistry Laboratory

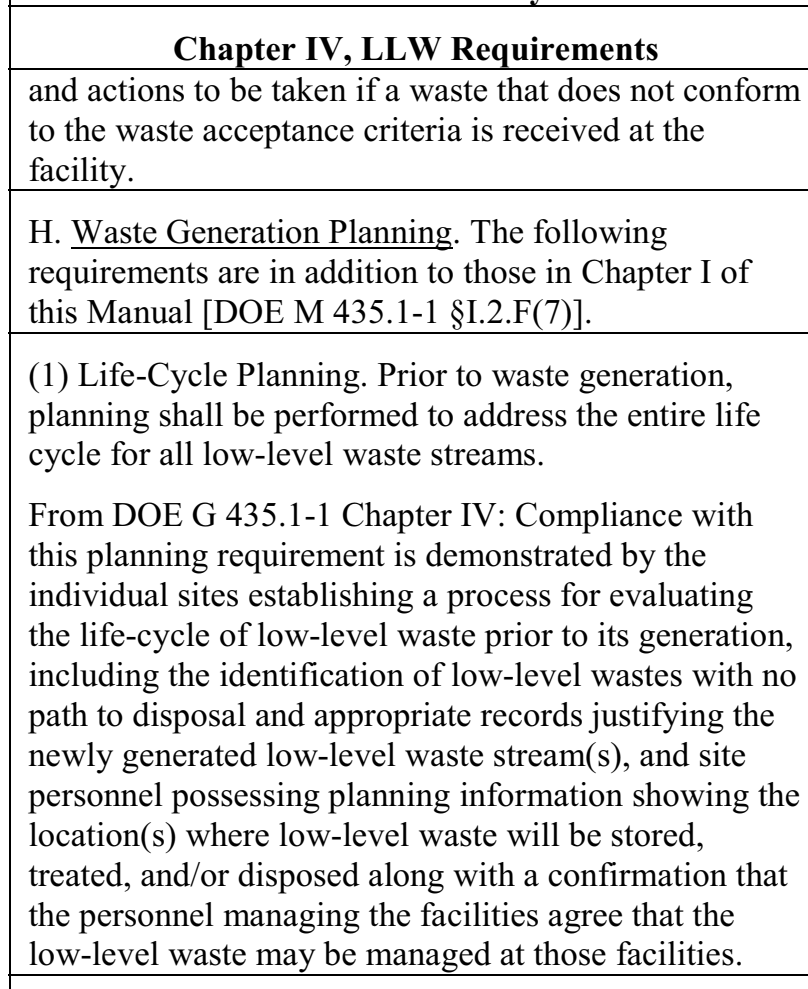

(2) Waste with No Identified Path to Disposal. Lowlevel waste streams with no identified path to disposal shall be generated only in accordance with approved conditions which, at a minimum, shall address:

(a) Programmatic need to generate the waste;
(b) Characteristics and issues preventing the disposal of
the waste;

(c) Safe storage of the waste until disposal can be achieved; and

(d) Activities and plans for achieving final disposal of the waste.

I. Waste Characterization. Low-level waste shall be characterized using direct or indirect methods, and the characterization documented in sufficient detail to ensure safe management and compliance with the waste acceptance requirements of the facility receiving the waste.

From DOE G 435.1-1 Chapter IV: Compliance with this requirement is demonstrated by a program for documenting and the existence of records that document the process for acquiring and verifying the validity of low-level waste characterization data acquired through the use of direct or indirect methods.

Not a facility-specific requirement. DOE Manual 435.1-1 $\S I .2 . F(7)$ applies to field element managers.

PDD-17000 and LWP-17000 provide direction to the waste generators for waste generation planning to address the entire life cycle.
NA; this facility is not generating LLW that does not have an identified path to disposal.

See (2) above.

See (2) above.

See (2) above.

See (2) above.

MCP-17000 addresses waste characterization.

A procedure addressing all liquid waste (including characterization) at this facility is being developed. Disposal of the facility's rinse water generated in the radiological contamination area to Industrial Waste or to RLWTF will be based on sampling and analysis. 
Table 23. (continued).

Facility Name: MFC-1702, Radiochemistry Laboratory

\begin{tabular}{l}
\hline \multicolumn{1}{|c|}{ Chapter IV, LLW Requirements } \\
\hline (1) Data Quality Objectives. The data quality \\
objectives process, or a comparable process, shall be \\
used for identifying characterization parameters and \\
acceptable uncertainty in characterization data. \\
From DOE G 435.1-1 Chapter IV: Compliance with \\
this requirement is demonstrated by the documented \\
use of a data quality objectives or a comparable process \\
for determining the type, quantity, and quality of \\
characterization data needed to safely manage low- \\
level waste.
\end{tabular}

(2) Minimum Waste Characterization. Characterization data shall, at a minimum, include the following information relevant to the management of the waste:

From DOE G 435.1-1 Chapter IV: Compliance with this requirement is demonstrated by the existence of a program or procedure for determining and records that document characterization of low-level waste consistent with the minimum characterization data requirements.

(a) Physical and chemical characteristics;
(b) Volume, including the waste and any stabilization
or absorbent media;

(c) Weight of the container and contents;

(d) Identities, activities, and concentrations of major radionuclides;

(e) Characterization date;
(f) Generating source; and

(g) Any other information which may be needed to prepare and maintain the disposal facility performance assessment, or demonstrate compliance with applicable performance objectives.

\section{J. Waste Certification. A waste certification program} shall be developed, documented, and implemented to ensure that the waste acceptance requirements of facilities receiving low-level waste for storage, treatment, and disposal are met.

From DOE G 435.1-1 Chapter IV: Compliance with the development and documentation portion of the certification requirement is demonstrated by a waste certification plan that identifies the organizations involved, assigns responsibilities for implementing the program, and describes or references the quality assurance, training, procurement controls, records management, and procedures to be used by the

\section{Facility Compliance Information}

Radioactive waste management facilities characterize waste in accordance with the requirements of the receiving storage, treatment, or disposal facility. The documented use of a data quality objectives process, or comparable process, was not identified for this facility.

MCP-17000, including $\S \S 4.2,4.3$, and 4.4, provides waste characterization requirements. Information on absorbent media is required in $\S \S 4.5$ and 4.7. MCP-17000 also specifies the use of IWTS, which documents characterization data in an IWTS profile.
See I. and (2) above.

See I. and (2) above.

See I. and (2) above.

See I. and (2) above. See I. and (2) above.

See I. and (2) above.

See I. and (2) above.

MCP-17000cites a waste certification program for LLW destined for NNSS. For waste destined for locations other than NNSS, the waste disposition specialist is responsible for certifying the waste stream by ensuring the waste, as characterized, falls within the limitations of the WAC of the treatment, storage, or disposal facility $(\$ 2)$.

Container procurement is addressed in MCP-17000 $\S 4.6$.

MCP-17500 provides the WGS waste certification program for LLW to be shipped to NNSS.

Waste certification is performed and tracked using IWTS. Documentation of the IWTS Program is available electronically only. 
Table 23. (continued).

Facility Name: MFC-1702, Radiochemistry Laboratory

Chapter IV, LLW Requirements
program. Acceptable performance for implementing
the program is demonstrated when appropriate
personnel are trained and follow the procedures that
govern their part of the waste certification.
Additionally, acceptable performance is demonstrated
if the waste certification plan and procedures are
current and controlled in accordance with a document
controls program, and records related to certification
(e.g., certification statements, training records,
procurement records, characterization records,
container records) are generated and managed in
accordance with the established site program.

(1) Certification Program. The waste certification program shall designate the officials who have the authority to certify and release waste for shipment; and specify what documentation is required for waste generation, characterization, shipment, and certification. The program shall provide requirements for auditability, retrievability, and storage of required documentation and specify the records retention period.

From DOE G 435.1-1 Chapter IV: Compliance with this requirement is demonstrated by a program or procedure for record keeping and records showing that low-level waste is certified as having met the waste acceptance criteria of the facility to which it was transferred and that the certification statement is supported by additional records regarding the waste source, characterization, and container.

(2) Certification before Transfer. Low-level waste shall be certified as meeting waste acceptance requirements before it is transferred to the facility receiving the waste.

From DOE G 435.1-1 Chapter IV: Compliance with this requirement is demonstrated by the presence of a certification program which includes procedures requiring a signed certification statement prior to the release of waste for transfer, and by dated records showing that waste was certified before being transferred.

(3) Maintaining Certification. Low-level waste that has been certified as meeting the waste acceptance requirements for transfer to a storage, treatment, or disposal facility shall be managed in a manner that maintains its certification status.

From DOE G 435.1-1 Chapter IV: Compliance with this requirement is demonstrated by a program or procedure reflecting this requirement is present and site personnel are able to show that the storage of low-level

See J. above. MCP-17500 $§ \S 2$ and 5 address certification records for shipments to NNSS.
See J. above. MCP-17500 $§ 4.3 .6$ addresses controls for certification before transfer for LLW to be disposed of at NNSS.
See J. above. Pre-certification checklists are cited in MCP-17000 and MCP-17500. Surveillances also are addressed in MCP-17500.

LWP-15011 $\S 5$ provides general radioactive storage area requirements. 
Table 23. (continued).

Facility Name: MFC-1702, Radiochemistry Laboratory

\begin{tabular}{|c|c|}
\hline Chapter IV, LLW Requirements & Facility Compliance Information \\
\hline $\begin{array}{l}\text { waste containers is in a facility or manner where the } \\
\text { containers would not be damaged by normal weather } \\
\text { events, and cannot be accessed by unauthorized } \\
\text { personnel. Further, each container can be traced to its } \\
\text { certification and the information supporting that } \\
\text { certification. }\end{array}$ & \\
\hline $\begin{array}{l}\text { K. Waste Transfer. A documented process shall be } \\
\text { established and implemented for transferring } \\
\text { responsibility for management of low-level waste and } \\
\text { for ensuring availability of relevant data. The following } \\
\text { requirements are in addition to those in Chapter I of } \\
\text { this Manual. } \\
\text { From DOE G } 435.1-1 \text { Chapter IV: Compliance with } \\
\text { this requirement is demonstrated if facilities have } \\
\text { procedures for the receipt of waste and the transfer of } \\
\text { waste, as appropriate, which address the acquisition of } \\
\text { waste and container data and the transfer of ownership, } \\
\text { respectively. Further evidence of acceptable } \\
\text { performance is facility records showing that data on the } \\
\text { waste containers is available and accurate, and that } \\
\text { documented transfer of responsibility occurs. }\end{array}$ & $\begin{array}{l}\text { MCP-17000 } § 4.8 .15 \text { specifies requirements for } \\
\text { interfacility transfers. } \\
\text { TSD-OI-004 includes the MFC-703, MFC-793, and } \\
\text { MFC-797 requirements for receiving transferred waste. } \\
\text { MCP-17500 } § 4 \text { addresses LLW to be transferred to } \\
\text { NNSS. }\end{array}$ \\
\hline $\begin{array}{l}\text { (1) Authorization. Low-level waste shall not be } \\
\text { transferred to a storage, treatment, or disposal facility } \\
\text { until personnel responsible for the facility receiving the } \\
\text { waste authorize the transfer. } \\
\text { From DOE G } 435.1-1 \text { Chapter IV: Compliance with } \\
\text { this requirement is demonstrated by sites having } \\
\text { procedures that require a confirmation of authorization } \\
\text { before releasing waste for transfer, and records } \\
\text { showing that transfers are made in accordance with } \\
\text { written authorizations. }\end{array}$ & See K. above. \\
\hline $\begin{array}{l}\text { (2) Data. Waste characterization data, container } \\
\text { information, and generation, storage, treatment, and } \\
\text { transportation information for low-level waste shall be } \\
\text { transferred with or be traceable to the waste. } \\
\text { From DOE G } 435.1-1 \text { Chapter IV: Compliance with } \\
\text { this requirement is demonstrated if there are procedures } \\
\text { requiring that characterization and container data be } \\
\text { provided and maintained for each low-level waste } \\
\text { transfer and documented records of transfers show that } \\
\text { the information is being provided. }\end{array}$ & See K. above. \\
\hline $\begin{array}{l}\text { L. Packaging and Transportation. The following } \\
\text { requirements are in addition to those in Chapter I of } \\
\text { this Manual [DOE M 435.1-1 §I.1.E(11)]. }\end{array}$ & See (1) and (2) below. \\
\hline $\begin{array}{l}\text { (1) Packaging. If containers are used: } \\
\text { From DOE G } 435.1-1 \text { Chapter IV: Compliance with } \\
\text { the packaging requirement is demonstrated by: (1) }\end{array}$ & MCP- $17000 \S 4$ addresses packaging requirements. \\
\hline
\end{tabular}


Table 23. (continued).

Facility Name: MFC-1702, Radiochemistry Laboratory

\begin{tabular}{|l|}
\hline \multicolumn{1}{|c|}{ Chapter IV, LLW Requirements } \\
\hline procedures which document proper packaging \\
protocols; and (2) no trends of routine repackaging of \\
low-level waste that is packaged after issuance of DOE \\
O 435.1. Successful performance of this requirement is \\
also demonstrated by a record of containers for which \\
failure has not routinely occurred under management \\
conditions. It is recognized that there may be failed \\
containers for waste previously placed in storage. For \\
those containers, the goal is to only have to repackage \\
the waste one time after it is retrieved and \\
characterized. Further, acceptable performance is \\
demonstrated by containers of waste having marking \\
and labeling that allows correlation with waste \\
characterization data and container information.
\end{tabular}

(a) Low-level waste shall be packaged in a manner that provides containment and protection for the duration of the anticipated storage period and until disposal is achieved or until the waste has been removed from the container.

(b) When waste is packaged, vents or other measures shall be provided if the potential exists for pressurizing or generating flammable or explosive concentrations of gases within the waste container.

(c) Containers of low-level waste shall be marked such that their contents can be identified.

(2) Transportation. To the extent practical, the volume of waste and number of low-level waste shipments shall be minimized.

From DOE G 435.1-1 Chapter IV: Compliance with this requirement can be demonstrated by a combination of site procedures directing the efficient use of waste container capacity and documentation showing that low-level waste shipments are systematically planned and optimized to the extent practical.

M. Site Evaluation and Facility Design. The following requirements are in addition to those in Chapter I of this Manual.

(1) Site Evaluation. Proposed locations for low-level waste facilities shall be evaluated to identify relevant features that should be avoided or must be considered in facility design and analyses.

(a) Each site proposed for a new low-level waste facility or expansion of an existing low-level waste facility shall be evaluated considering environmental characteristics, geotechnical characteristics, and human activities, including for a low-level waste disposal facility, the capability of the site to demonstrate, at a

See (1) above.

See (1) above.

See (1) above.

MCP-17000 $§ 4$ addresses transportation. The waste disposition specialist coordinates with packaging and transportation personnel for waste shipped offsite from this facility.

Waste is shipped directly to NNSS from this facility. MCP-17500 specifies waste certification official and waste disposition specialist responsibilities and coordination with packaging and transportation personnel.

$\mathrm{NA}$; this requirement addresses new radioactive waste management facilities or modifications to existing facilities.

See M. above.

See M. above. 
Table 23. (continued).

Facility Name: MFC-1702, Radiochemistry Laboratory

\begin{tabular}{|c|c|}
\hline Chapter IV, LLW Requirements & Facility Compliance Information \\
\hline minimum, whether it is: & \\
\hline $\begin{array}{l}1 \text { Located to accommodate the projected volume of } \\
\text { waste to be received; }\end{array}$ & See M. above. \\
\hline $\begin{array}{l}2 \text { Located in a flood plain, a tectonically active area, or } \\
\text { in the zone of water table fluctuation; and }\end{array}$ & See M. above. \\
\hline $\begin{array}{l}3 \text { Located where radionuclide migration pathways are } \\
\text { predictable and erosion and surface runoff can be } \\
\text { controlled. }\end{array}$ & See M. above. \\
\hline $\begin{array}{l}\text { (b) Proposed sites with environmental characteristics, } \\
\text { geotechnical characteristics, and human activities for } \\
\text { which adequate protection cannot be provided through } \\
\text { facility design shall be deemed unsuitable for the } \\
\text { location of the facility. }\end{array}$ & See M. above. \\
\hline $\begin{array}{l}\text { (c) Low-level waste disposal facilities shall be sited to } \\
\text { achieve long-term stability and to minimize, to the } \\
\text { extent practical, the need for active maintenance } \\
\text { following final closure. }\end{array}$ & See M. above. \\
\hline $\begin{array}{l}\text { (2) Low-Level Waste Treatment and Storage Facility } \\
\text { Design. The following facility requirements and } \\
\text { general design criteria, at a minimum, apply: }\end{array}$ & See M. above. \\
\hline $\begin{array}{l}\text { (a) Confinement. Low-level waste systems and } \\
\text { components shall be designed to maintain waste } \\
\text { confinement. }\end{array}$ & See M. above. \\
\hline (b) Ventilation. & See M. above. \\
\hline $\begin{array}{l}1 \text { Design of low-level waste treatment and storage } \\
\text { facilities shall include ventilation, if applicable, } \\
\text { through an appropriate filtration system to maintain the } \\
\text { release of radioactive material in airborne effluents } \\
\text { within the requirements and guidelines specified in } \\
\text { applicable requirements. }\end{array}$ & See M. above. \\
\hline $\begin{array}{l}2 \text { When conditions exist for generating gases in } \\
\text { flammable or explosive concentrations, ventilation } \\
\text { systems or other measures shall be provided to keep the } \\
\text { gases in a non-flammable and nonexplosive condition. } \\
\text { Where concentrations of explosive or flammable gases } \\
\text { are expected to approach the lower flammability limit, } \\
\text { measures shall be taken to prevent deflagration or } \\
\text { detonation. }\end{array}$ & See M. above. \\
\hline $\begin{array}{l}\text { (c) Consideration of Decontamination and } \\
\text { Decommissioning. Areas in new and modifications to } \\
\text { existing low-level waste management facilities that are } \\
\text { subject to contamination with radioactive or other } \\
\text { hazardous materials shall be designed to facilitate } \\
\text { decontamination. For such facilities a proposed } \\
\text { decommissioning method or a conversion method }\end{array}$ & See M. above. \\
\hline
\end{tabular}


Table 23. (continued).

Facility Name: MFC-1702, Radiochemistry Laboratory

\begin{tabular}{l}
\hline \multicolumn{1}{|c|}{ Chapter IV, LLW Requirements } \\
\hline leading to reuse shall be described. \\
\hline $\begin{array}{l}\text { (d) Instrumentation and Control Systems. Engineering } \\
\text { controls shall be incorporated in the design and } \\
\text { engineering of low-level waste treatment and storage } \\
\text { facilities to provide volume inventory data and to } \\
\text { prevent spills, leaks, and overflows from tanks or } \\
\text { confinement systems. }\end{array}$ \\
\hline
\end{tabular}

(e) Monitoring. Monitoring and/or leak detection capabilities shall be incorporated in the design and engineering of low-level waste treatment and storage facilities to provide rapid identification of failed confinement and/or other abnormal conditions.

(3) Low-Level Waste Disposal Facility Design. The following facility requirements and general design criteria, at a minimum, apply:

\begin{abstract}
(a) Confinement. Low-level waste systems and components shall be designed to maintain waste confinement.
\end{abstract}

(b) Ventilation.

1 Design of low-level waste disposal facilities shall include ventilation, if applicable, through an appropriate filtration system to maintain the release of radioactive material in airborne effluents within the requirements and guidelines specified in applicable requirements.

2 When conditions exist for generating gases in flammable or explosive concentrations, ventilation systems or other measures shall be provided to keep the gases in a nonflammable and non-explosive condition. Where concentrations of explosive or flammable gases are expected to approach the lower flammability limit, measures shall be taken to prevent deflagration or detonation.

(c) Stability. Low-level waste disposal facilities shall be designed to achieve long-term stability and to minimize to the extent practical, the need for active maintenance following final closure.

(d) Control of Water. Low-level waste disposal facilities shall be designed to minimize to the extent practical, the contact of waste with water during and after disposal.

N. Storage and Staging. The following requirements are in addition to those in Chapter I of this Manual [DOE M 435.1-1 §I.2.F(13)].

\section{Facility Compliance Information}

See M. above.

See M. above.

See M. above.

See M. above.

See M. above.

See M. above.

See M. above.

See M. above.

See M. above.

Not a facility-specific requirement. DOE Manual 435.1-1 $\S$ I.2.F(13) applies to field element managers. 
Table 23. (continued).

Facility Name: MFC-1702, Radiochemistry Laboratory

\begin{tabular}{|c|c|}
\hline Chapter IV, LLW Requirements & Facility Compliance Information \\
\hline $\begin{array}{l}\text { (1) Storage Prohibitions. Low-level waste in storage } \\
\text { shall not be readily capable of detonation, explosive } \\
\text { decomposition, reaction at anticipated pressures and } \\
\text { temperatures, or explosive reaction with water. Prior to } \\
\text { storage, pyrophoric materials shall be treated, prepared, } \\
\text { and packaged to be nonflammable. }\end{array}$ & NA; LLW is not stored at this facility. \\
\hline $\begin{array}{l}\text { From DOE G 435.1-1 Chapter IV: Compliance with } \\
\text { this requirement is demonstrated by having waste } \\
\text { acceptance requirements which prohibit low-level } \\
\text { waste that is ignitable or explosive from being accepted } \\
\text { for storage unless it has been treated, and procedures } \\
\text { for properly preparing such materials for safe storage. }\end{array}$ & \\
\hline (2) Storage Limit. Low-level waste that has an & NA; LLW is not stored at this facility. \\
\hline
\end{tabular}
identified path to disposal shall not be stored longer than one year prior to disposal, except for storage for decay, or as otherwise authorized by the Field Element Manager.

From DOE G 435.1-1 Chapter IV: Storage longer than one year can be justified if the conditions for such storage are approved by the Field Element Manager as part of the radioactive waste management basis for the facility.

Storage for radioactive decay for a period greater than 1 year for waste that has an identified path to disposal is allowed. Adequate justification and the supporting information for storage for decay is to be documented in the radioactive waste management basis for the facility in which the storage will take place.

Mixed waste. Under the Federal Facility Compliance Act of 1992, DOE sites were required to develop Site Treatment Plans to bring stored mixed low-level waste into compliance with these requirements. The Site Treatment Plan needs to be consulted and any mixed low-level waste stored for the purpose of accumulation to facilitate treatment must meet Resource Conservation and Recovery Act storage requirements. There could be several ways within different scenarios that this requirement can be met, as illustrated by the examples below, however, there are basically four ways to show compliance with the requirement and include appropriate provisions in the radioactive waste management basis for the facility in which it is stored.

Legacy waste. As discussed above, the intention of the requirement is not to force malicious compliance or heroic actions which would result in increased risk or safety concerns. Rather, the intention is that waste in storage longer than one year receives additional attention to ensure that the public, the workers, and the 
Table 23. (continued).

Facility Name: MFC-1702, Radiochemistry Laboratory

Chapter IV, LLW Requirements

Facility Compliance Information

environment are protected from the hazards of the waste, and that progress is being made to dispose of the waste. There could be several ways within different scenarios that this requirement can be met, as illustrated by the examples below, however, there are basically four ways to show compliance with the requirement:

1) the radioactive waste management basis allows for storage for no more than one year.

2) the radioactive waste management basis allows for storage for no more than one year, or for storage for decay only for periods greater than a year, which are specified on a radionuclide basis.

3 ) the radioactive waste management basis allows for storage for more than one year, up to a specified period of time based on a documented technical evaluation that the waste can be stored in a manner that does not cause changes to the waste or waste packages that is detrimental to the safe storage of the waste, the final disposal of the waste or to meeting the disposal performance objectives.

4) the radioactive waste management basis allows for storage for decay (with specifics) and for storage for more than one year for other low-level waste, up to a specified period of time based on a documented technical evaluation that the waste can be stored in a manner that does not cause changes to the waste or waste packages that is detrimental to the safe storage of the waste, the final disposal of the waste or to meeting the disposal performance objectives.

Compliance with this requirement is demonstrated by the existence of a radioactive waste management basis for the storage facility approved by the Field Element Manager that includes the time frames that waste are allowed to be stored, the necessary justifications for storage for decay, and the necessary technical evaluations if storage is to extend significantly beyond the one-year time frame.

(3) Storage Integrity. Low-level waste shall be stored in a location and manner that protects the integrity of waste for the expected time of storage and minimizes worker exposure.

From DOE G 435.1-1 Chapter IV: However, in making a decision to use a facility for storage and in developing a radioactive waste management basis for the activity, particular attention to protection of workers is needed. 
Table 23. (continued).

Facility Name: MFC-1702, Radiochemistry Laboratory

\begin{tabular}{|l|}
\hline \multicolumn{1}{|c|}{ Chapter IV, LLW Requirements } \\
\hline Compliance with this requirement is demonstrated if \\
sites have storage capabilities for low-level waste that \\
provide protection to waste containers so that their \\
integrity will not be damaged through physical or \\
chemical (corrosion) processes and that keep personnel \\
from spending extended periods of time in the areas \\
where low-level waste is stored.
\end{tabular}

(4) Waste Characterization for Storage.

NA; LLW is not stored at this facility.

(a) Low-level waste that does not have an identified

See (4) above. path to disposal shall be characterized as necessary to meet the data quality objectives and minimum characterization requirements of this Chapter, to ensure safe storage, and to facilitate disposal.

(b) Characterization information for all low-level waste in storage shall be maintained as a record in accordance with the requirements for Records Management in Chapter I of this Manual.

From DOE G 435.1-1 Chapter IV: Compliance with this requirement is demonstrated by documented procedures for managing waste characterization and container information on low-level waste as a Federal record. The records are managed per the applicable policies and procedures for records management referenced in DOE O 200.1 and established at the applicable Field Element.

(5) Container Inspection. A process shall be developed and implemented for inspecting and maintaining containers of low-level waste to ensure container integrity is not compromised.

From DOE G 435.1-1 Chapter IV: Compliance with this requirement is demonstrated by: (1) a documented process for waste container inspection and maintenance; and (2) documentation for all waste container inspections and maintenance actions performed.

(6) Storage Management. Low-level waste storage shall be managed to identify and segregate low-level waste from mixed low-level waste.

(7) Staging. Staging of low-level waste shall be for the purpose of the accumulation of such quantities of waste as necessary to facilitate transportation, treatment, and disposal. Staging longer than 90 days shall meet the requirements for storage above and in Chapter I of this Manual.

From DOE G 435.1-1 Chapter IV: The staging of lowlevel waste needs to be addressed in the radioactive

See (4) above. Facility Compliance Information

LI-435 requires quarterly inspections of radioactive waste containers if waste is stored outdoors or has been in storage for greater than 1 year.

Inspections are performed for TAAs and SAAs as required by WGS procedures (MCP-17000 and MCP-17410).

NA; LLW is not stored at this facility.

LLW and mixed LLW is staged for the purpose of accumulation to facilitate treatment and disposal. Mixed LLW is staged in SAAs in accordance with MCP-17000 and MCP-17410. LLW is staged in TAAs in accordance with MCP-17000 and MCP-17410.

MCP-17000, Appendix F restricts staging LLW to 90 days maximum at any generator or treatment facility prior to acceptance by a storage facility. 
Table 23. (continued).

Facility Name: MFC-1702, Radiochemistry Laboratory

Chapter IV, LLW Requirements
waste management basis for the facility that is
performing the staging. Generators, treatment facilities,
and disposal facilities that stage waste must ensure that
the action of staging is included and authorized as part
of their radioactive waste management basis for the
affected facilities, operations, or activities.
Staging longer than 90 days must be justified, the
conditions for such storage met, and these practices
approved by the Field Element Manager as part of the
radioactive waste management basis for the facility.
Compliance with this requirement is demonstrated by a
staging program that limits the temporary storage of
waste to only circumstances allowed in the
requirement, including justifications for any staging
that exceeds the 90 -day period, which is documented in
the radioactive waste management basis for the facility.

O. Treatment. Low-level waste treatment to provide more stable waste forms and to improve the long-term performance of a low-level waste disposal facility shall be implemented as necessary to meet the performance objectives of the disposal facility.

From DOE G 435.1-1 Chapter IV: Compliance with this requirement is demonstrated when a treatment facility or process ensures that treated waste will meet the minimum waste form requirements of DOE M 435.1 and meet additional disposal facility-specific waste acceptance requirements for additional stability or long-term performance of facilities that will receive the treated waste.

P. Disposal. Low-level waste disposal facilities shall meet the following requirements.

(1) Performance Objectives. Low-level waste disposal facilities shall be sited, designed, operated, maintained, and closed so that a reasonable expectation exists that the following performance objectives will be met for waste disposed of after September 26, 1988:

(a) Dose to representative members of the public shall not exceed 25 mrem $(0.25 \mathrm{mSv})$ in a year total effective dose equivalent from all exposure pathways, excluding the dose from radon and its progeny in air.

(b) Dose to representative members of the public via the air pathway shall not exceed $10 \mathrm{mrem}(0.10 \mathrm{mSv})$ in a year total effective dose equivalent, excluding the dose from radon and its progeny.

(c) Release of radon shall be less than an average flux of $20 \mathrm{pCi} / \mathrm{m}^{2} / \mathrm{s}\left(0.74 \mathrm{~Bq} / \mathrm{m}^{2} / \mathrm{s}\right)$ at the surface of the disposal facility. Alternatively, a limit of $0.5 \mathrm{pCi} / 1$

NA; treatment is not performed in this facility.

Containerized elementary neutralization is performed at this facility as provided by LWP-8000. As stated in $\S 4.118$, elementary neutralization of corrosive hazardous waste may take place at any location at which the waste is generated or stored, and neither a generator treatment plan nor a permit is required. Solidification of liquid LLW for the purpose of staging (not for treating the radioactive constituents) also may be performed. Therefore, this facility is not considered to be a treatment facility.

NA; LLW is not disposed of in this facility.

See P. above.

See P. above.

See P. above.

See P. above. 
Table 23. (continued).

Facility Name: MFC-1702, Radiochemistry Laboratory

\begin{tabular}{l}
\hline \multicolumn{1}{|c|}{ Chapter IV, LLW Requirements } \\
\hline $\begin{array}{l}\text { (0.0185 Bq/1) of air may be applied at the boundary of } \\
\text { the facility. }\end{array}$ \\
(2) Performance Assessment. A site-specific \\
radiological performance assessment shall be prepared \\
and maintained for DOE low-level waste disposed of \\
after September 26, 1988. The performance assessment \\
shall include calculations for a 1,000 year period after \\
closure of potential doses to representative future \\
members of the public and potential releases from the \\
facility to provide a reasonable expectation that the \\
performance objectives identified in this Chapter are \\
not exceeded as a result of operation and closure of the \\
facility.
\end{tabular}

(a) Analyses performed to demonstrate compliance with the performance objectives in this Chapter, and to establish limits on concentrations of radionuclides for disposal based on the performance measures for inadvertent intruders in this Chapter shall be based on reasonable activities in the critical group of exposed individuals. Unless otherwise specified, the assumption of average living habits and exposure conditions in representative critical groups of individuals projected to receive the highest doses is appropriate. The likelihood of inadvertent intruder scenarios may be considered in interpreting the results of the analyses and establishing radionuclide concentrations, if adequate justification is provided.

(b) The point of compliance shall correspond to the See P. above. point of highest projected dose or concentration beyond a 100 meter buffer zone surrounding the disposed waste. A larger or smaller buffer zone may be used if adequate justification is provided.

(c) Performance assessments shall address reasonably foreseeable natural processes that might disrupt barriers against release and transport of radioactive materials.

(d) Performance assessments shall use DOE-approved dose coefficients (dose conversion factors) for internal and external exposure of reference adults.

(e) The performance assessment shall include a sensitivity/uncertainty analysis.

(f) Performance assessments shall include a demonstration that projected releases of radionuclides to the environment shall be maintained as low as reasonably achievable (ALARA).

See P. above. Facility Compliance Information

See P. above.

See P. above.

See P. above.

See P. above.

See P. above. 
Table 23. (continued).

Facility Name: MFC-1702, Radiochemistry Laboratory

\begin{tabular}{|l|}
\hline \multicolumn{1}{|c|}{ Chapter IV, LLW Requirements } \\
\hline (g) For purposes of establishing limits on radionuclides \\
that may be disposed of near-surface, the performance \\
assessment shall include an assessment of impacts to \\
water resources.
\end{tabular}

(h) For purposes of establishing limits on the concentration of radionuclides that may be disposed of near-surface, the performance assessment shall include an assessment of impacts calculated for a hypothetical person assumed to inadvertently intrude for a temporary period into the low-level waste disposal facility. For intruder analyses, institutional controls shall be assumed to be effective in deterring intrusion for at least 100 years following closure. The intruder analyses shall use performance measures for chronic and acute exposure scenarios, respectively, of 100 mrem $(1 \mathrm{mSv})$ in a year and $500 \mathrm{mrem}(5 \mathrm{mSv})$ total effective dose equivalent excluding radon in air.

(3) Composite Analysis. For disposal facilities which received waste after September 26, 1988, a site-specific radiological composite analysis shall be prepared and maintained that accounts for all sources of radioactive material that may be left at the DOE site and may interact with the low- level waste disposal facility, contributing to the dose projected to a hypothetical member of the public from the existing or future disposal facilities. Performance measures shall be consistent with DOE requirements for protection of the public and environment and evaluated for a 1,000 year period following disposal facility closure. The composite analysis results shall be used for planning, radiation protection activities, and future use commitments to minimize the likelihood that current low- level waste disposal activities will result in the need for future corrective or remedial actions to adequately protect the public and the environment.

(4) Performance Assessment and Composite Analysis Maintenance. The performance assessment and composite analysis shall be maintained to evaluate changes that could affect the performance, design, and operating bases for the facility. Performance assessment and composite analysis maintenance shall include the conduct of research, field studies, and monitoring needed to address uncertainties or gaps in existing data. The performance assessment shall be updated to support the final facility closure. Additional iterations of the performance assessment and composite analysis shall be conducted as necessary during the post-closure period. 
Table 23. (continued).

Facility Name: MFC-1702, Radiochemistry Laboratory

Chapter IV, LLW Requirements

(a) Performance assessments and composite analyses shall be reviewed and revised when changes in waste forms or containers, radionuclide inventories, facility design and operations, closure concepts, or the improved understanding of the performance of the waste disposal facility in combination with the features of the site on which it is located alter the conclusions or the conceptual model(s) of the existing performance assessment or composite analysis.

(b) A determination of the continued adequacy of the performance assessment and composite analysis shall be made on an annual basis, and shall consider the results of data collection and analysis from research, field studies, and monitoring.

(c) Annual summaries of low-level waste disposal operations shall be prepared with respect to the conclusions and recommendations of the performance assessment and composite analysis and a determination of the need to revise the performance assessment or composite analysis.

(5) Disposal Authorization. A disposal authorization statement shall be obtained prior to construction of a new low-level waste disposal facility. Field Elements with existing low-level waste disposal facilities shall obtain a disposal authorization statement in accordance with the schedule in the Complex-Wide Low-Level Waste Management Program Plan. The disposal authorization statement shall be issued based on a review of the facility's performance assessment, composite analysis, performance assessment and composite analysis maintenance, preliminary closure plan, and preliminary monitoring plan. The disposal authorization statement shall specify the limits and conditions on construction, design, operations, and closure of the low-level waste facility based on these reviews. A disposal authorization statement is a part of the radioactive waste management basis for a disposal facility. Failure to obtain a disposal authorization statement by the implementation date of this Order shall result in shutdown of the disposal facility.

(6) Disposal Facility Operations. The disposal facility design and operation must be consistent with the disposal facility closure plan and lead to disposal facility closure that provides a reasonable expectation that performance objectives will be met. Low-level waste shall be disposed in such a manner that achieves the performance objectives stated in this Chapter, consistent with the disposal facility radiological performance assessment. Additional requirements

\section{Facility Compliance Information}

See P. above.

See P. above.

See P. above.

See P. above.

See P. above. 
Table 23. (continued).

Facility Name: MFC-1702, Radiochemistry Laboratory

\begin{tabular}{l} 
Chapter IV, LLW Requirements \\
\hline include: \\
\hline (a) Operating procedures shall be developed and \\
implemented for low-level waste disposal facilities that \\
protect the public, workers, and the environment; \\
ensure the security of the facility; minimize subsidence \\
during and after waste emplacement; achieve long-term \\
stability and minimize the need for long-term active \\
maintenance; and meet the requirements of the \\
closure/post-closure plan.
\end{tabular}

(b) Permanent identification markers for disposal excavations and monitoring wells shall be emplaced.

(c) Low-level waste placement into disposal units shall minimize voids between waste containers. Voids within disposal units shall be filled to the extent practical. Uncontainerized bulk waste shall also be placed in a manner that minimizes voids and subsidence.

(d) Operations are to be conducted so that active waste disposal operations will not have an adverse effect on any other disposal units.

(e) Operations shall include a process for tracking and documenting low-level waste placement in the facility by generator source.

(7) Alternate Requirements for Low-Level Waste Disposal Facility Design and Operation. Requirements other than those set forth in this Section for the design and operation of a low-level waste disposal facility may be approved on a specific basis if a reasonable expectation is demonstrated that the disposal performance objectives will be met.

Q. Closure. The following requirements are in addition to those in Chapter I of this Manual.

(1) Disposal Facility Closure Plans. A preliminary closure plan shall be developed and submitted to Headquarters for review with the performance assessment and composite analysis. The closure plan shall be updated following issuance of the disposal authorization statement to incorporate conditions specified in the disposal authorization statement. Closure plans shall:

(a) Be updated as required during the operational life of the facility.

(b) Include a description of how the disposal facility will be closed to achieve long-term stability and minimize the need for active maintenance following closure and to ensure compliance with the requirements

See P. above.

See P. above.

See P. above. Facility Compliance Information

See P. above.

See P. above.

See P. above.

P. above.

NA; LLW is not disposed of in this facility. See Q. above. n 
Table 23. (continued).

Facility Name: MFC-1702, Radiochemistry Laboratory

\begin{tabular}{|l|l|}
\hline \multicolumn{1}{|c|}{ Chapter IV, LLW Requirements } & Facility Compliance Information \\
\hline $\begin{array}{l}\text { of DOE 5400.5, Radiation Protection of the Public and } \\
\text { the Environment. }\end{array}$ & \\
\hline
\end{tabular}

(c) Include the total expected inventory of wastes to be disposed of at the facility over the operational life of the facility.

(2) Disposal Facility Closure. Closure of a disposal facility shall occur within a five-year period after it is filled to capacity, or after the facility is otherwise determined to be no longer needed.

(a) Prior to facility closure, the final inventory of the low-level waste disposed in the facility shall be prepared and incorporated in the performance assessment and composite analysis which shall be updated to support the closure of the facility.

(b) A final closure plan shall be prepared based on the final inventory of waste disposed in the facility, the plan implemented, and the updated performance assessment and composite analysis prepared in support of the facility closure.

(c) Institutional control measures shall be integrated into land use and stewardship plans and programs, and shall continue until the facility can be released pursuant to DOE 5400.5, Radiation Protection of the Public and the Environment.

(d) The location and use of the facility shall be filed with the local authorities responsible for land use and zoning.

R. Monitoring. The following requirements are in addition to those in Chapter I of this Manual [DOE M 435.1-1 §I.1.E(7)].

(1) All Waste Facilities. Parameters that shall be sampled or monitored, at a minimum, include: temperature, pressure (for closed systems), radioactivity in ventilation exhaust and liquid effluent streams, and flammable or explosive mixtures of gases. Facility monitoring programs shall include verification that passive and active control systems have not failed.

From DOE G 435.1-1 Chapter IV: The minimum parameters specified in the requirement were selected based on their potential significance for anticipating and identifying undesirable conditions at low-level waste management facilities. Each facility's radioactive waste management basis should include an evaluation of the applicability and significance of the minimum parameters. This evaluation also needs to consider additional parameters to be sampled or monitored to
See Q. above.

See Q. above.

See Q. above.

See Q. above.

See Q. above.

See Q. above.

See (1), (2), and (3) below.

Monitoring requirements at INL radioactive waste management facilities are tailored for the specific facility to enable timely indication of developing problems. Existing radiological control procedures and assessments are followed/completed to monitor waste facilities.

LRD-15001 and MCP-139 specify methods and frequency of radiological control surveys of all radiological areas. MCP-139 specifies the use of Form 441.A34. This form is referred to as the "routine sheet" and is to be used by facility radiological control foremen to list radiological areas that are to be surveyed, the survey periods, and methods. 
Table 23. (continued).

Facility Name: MFC-1702, Radiochemistry Laboratory

Chapter IV, LLW Requirements
ensure the protection of the public health, the

environment, and the workers. If a minimum parameter

specified in the requirement is deemed to be not

applicable in any way to the active operation of that

facility, then that justification should be included in the

radioactive waste management basis and when

approved constitutes an exemption to the manual.

Verification activities are part of the radioactive waste management basis as a condition for operation and documented appropriately.

Compliance with this requirement is demonstrated if monitoring or sampling for the stated parameters is performed for all facilities with a precision, accuracy, and frequency consistent with timely identification of developing problems and a justification exists in the approved radioactive waste management basis for those specified parameters which are not monitored or sampled.

(2) Liquid Waste Storage Facilities. For facilities storing liquid low-level waste, the following shall also be monitored: liquid level and/or waste volume, and significant waste chemistry parameters.

(3) Disposal Facilities. A preliminary monitoring plan for a low-level waste disposal facility shall be prepared and submitted to Headquarters for review with the performance assessment and composite analysis. The monitoring plan shall be updated within one year following issuance of the disposal authorization statement to incorporate and implement conditions specified in the disposal authorization statement.

(a) The site-specific performance assessment and composite analysis shall be used to determine the media, locations, radionuclides, and other substances to be monitored.

(b) The environmental monitoring program shall be See (3) above. designed to include measuring and evaluating releases, migration of radionuclides, disposal unit subsidence, and changes in disposal facility and disposal site parameters which may affect long-term performance.

(c) The environmental monitoring programs shall be capable of detecting changing trends in performance to allow application of any necessary corrective action prior to exceeding the performance objectives in this Chapter. 


\section{REFERENCES}

AL-0634-OI-001, "Radioactive Liquid Waste System"

AL-5000-LI-003, "Contact-Handled Transuranic Waste Handling”

AL-7000-OI-001, "Facility Conditions"

AWP-2.13, "Radiological Material Inventory Control and Facility Hazard Categorization"

CCN 210728, August 8, 2007, Mr. Brian R. Monson to Mr. David L. Wessman, "Manufacturing Process Unit Exemption for the Fuel Conditioning Facility at the Materials and Fuels Complex, Idaho National Laboratory"

DSA-003-HFEF, "Final Safety Analysis Report for the Hot Fuel Examination Facility"

DSA-004-CESB, "CESB Documented Safety Analysis"

DSA-009-RPSF, "RPSF Documented Safety Analysis"

ECAR-671, "Hazard Catergorization Document for the Radiochemistry Laboratory (MFC-1702) at MFC"

ECAR-789, "Hazard Categorization of the Materials and Fuels Complex Laundry Facility MFC-702"

ECAR-1545, "Hazard Categorization for the Contaminated Equipment Storage Building (CESB) MFC794"

EDF-7030, "Inventory Analysis of Radiological Facilities at the Materials and Fuels Complex (MFC)"

EDF-7234, "Evaluation of Source Terms in MFC-Building 702"

EML-OI-416, "Circulating, Sampling, and Draining of Suspect Liquid Waste in EML (Bldg. 774)

Holding Tanks"

FCF-OI-1302, "Material Control and Accountability"

FCF-OI-6523, "Radioactive Liquid Waste System"

FCF-OI-6605, "In-Cell Waste Tracking and Logging"

FCF-OI-6606, "In-Cell Radiological Smear Data Logging"

FCF-OI-6614, "Contact-Handled Low-Level Waste Handling"

FCF-OI-6620, "In Cell Indirect Waste Handling”

FMF-OI-015, "General Facility Waste"

F0000-0018-AK, "Final Safety Analysis Report for the Fuel Conditioning Facility"

F0000-0026-ES, "Criticality Hazard Control Statement for the Fuel Conditioning Facility"

Form 435.39, "Waste Determination and Disposal Form (WDDF)"

Form 435.42, "Radioactive Waste Inventory Sheet"

Form 435.83, "Idaho National Laboratory Contact-Handled Transuranic Waste Disposition - TSR Related

(Checklist - Requirements - Certification)"

Form 441.A34, "INL Radiological Control Required Surveys"

FRM-323, "TSD Facilities Material Acceptance Checksheet"

HFEF-OI-1302, "Mass Tracking System"

HFEF-OI-6601, "Waste Handling" 
HFEF-OI-6602, "Radiological Smearing for Waste Characterization”

HFEF-OI-6801, "Hazardous Waste/Mixed Waste (HW/MW) Requirements"

IAG-261, "INL Authorization Agreement for the Materials and Fuels Complex (MFC) Space and Security Power Systems Facility (SSPSF)"

IAG-264, "INL Authorization Agreement for the Materials and Fuels Complex (MFC) Radioactive Scrap and Waste Facility (RSWF)"

INL/EXT-10-17600, Process Knowledge Summary Report for Materials and Fuels Complex Contacthandled Transuranic Waste

LI-435, "Waste Management Routine Field Activities"

LI 1219-07-MFC, "Sample Preparation in the Electron Microscopy Laboratory"

LI 1356-07-FASB, "FASB General Laboratory Work"

LRD-15001, "Radiological Control Manual”

LST-302, "Safety Basis List for the Materials and Fuels Complex (MFC) Space and Security Power Systems Facility (SSPSF)"

LST-305, "Safety Basis List for the Materials and Fuels Complex (MFC) Radioactive Scrap and Waste Facility (RSWF)"

LST-329, "Analytical Laboratory Nuclear Safety Basis Implementation Matrix"

LST-337, "Approved Container/Payload List for Inter-Facility Transfer Operations at MFC"

LWP-8000, Environmental Instructions for Facilities, Processes, Materials, and Equipment

LWP-8300, "Transuranic Waste Handling"

LWP-13840, "Management of Issues, Observations, and Noteworthy Practices"

LWP-14002, "Timeout and Stop Work Authority"

LWP-15011, "Radioactive Material Areas and Radioactive Storage Areas"

LWP-17000, "Waste Management"

MCP-139, "Radiological Surveys"

MCP-17000, "Waste Generator Services Waste Management"

MCP-17410, "Management of Waste Storage Areas"

MCP-17500, "Waste Generator Services Certification of Waste Shipments to the Nevada Test Site"

PDD-17000, "Waste Management Program"

PER-116, "HWMA/RCRA Storage and Treatment Permit for the Materials and Fuels Complex"

PLN-114, "INL Emergency Plan/RCRA Contingency Plan"

PLN-522, "Quality Assurance Program Plan for the Waste Management/Waste Certification Program"

PLN-8300, "Materials and Fuels Complex Contact-Handled TRU Waste Certification Program Plan"

PLN-2495, "Waste Analysis Plan for the Idaho National Laboratory Materials and Fuels Complex Analytical Laboratory Elementary Neutralization Unit"

RL-OI-1, "Radioactive-Liquid-Waste Collection" 
RL-OI-2, "Radioactive Liquid Waste Processing"

RSWF-OI-003, "Material Acceptance for Storage"

RSWF-OI-004, "Administrative Requirements/Process for Material Transfers"

RSWF-OI-006, "Maintenance and Surveillance Requirements"

SAR-404, "Safety Analysis Report for the Fuel Manufacturing Facility"

SAR-407, "Safety Analysis Report for the Radioactive Scrap and Waste Facility (MFC-771)"SD-38.1.1,

"Treatment, Storage, and Disposal Facilities (TSDF) Environmental Compliance"

SCMS-OI-1, "Facility Information and Administrative Requirements"

SD-38.1.1, "Treatment, Storage, and Disposal Facilities (TSDF) Environmental Compliance"

SPF-OI-1-B, "Environmental Compliance"

STM-PS-52, Circulating, Sampling, And Draining Of Suspect Liquid Waste In EML (Bldg. 774) Holding Tanks"

TSD-OI-004, "Waste and Material Acceptance for Storage/Treatment and Radioactive Material Inventory Control"

TSM-OI-003, Transfer of Hazardous Material in Non-DOT-Certified Packaging between MFC Nuclear Facilities."

W0640-0047-KP, "Hot Cell Waste Preparation and Sample Collection for Disposal/Return”

W0660-0035-AP, "General Laboratory Waste”

W0660-0055-KH, “Analytical Laboratory Safety Analysis Report” 